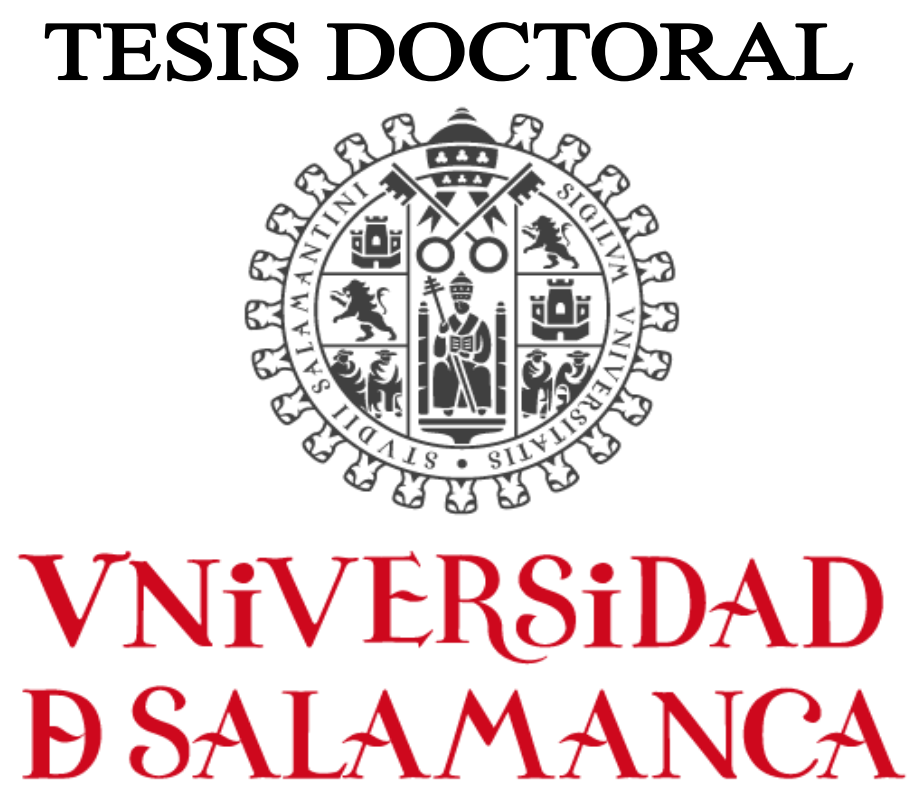

CAMPUS DE EXCELENCIA INTERNACIONAL

FACULTAD DE CIENCIAS SOCIALES DEPARTAMENTO DE SOCIOLOGÍA Y COMUNICACIÓN

El sexismo en el Estado de Michoacán de Ocampo. Materiales educativos y percepciones del Aumnado de Pimer Grado de Secundaria.

Tesis para optar por el título de doctora presentada por:

Elva Morales Robles

Director: Doctor FERNANDO GIL VILLA

Salamanca, 2017 



\title{
Tesis titulada
}

\section{El sexismo en el Estado de Michoacán de Ocampo. Materiales educativos y percepciones del Alumnado de Pimer Grado de Secundaria.}

\author{
Por: Elva Morales Robles
}

El Dr. D. Fernando Gil Villa, CATEDRÁTICO DEL DEPARTAMENTO DE SOCIOLOGÍA Y COMUNICACIÓN DE LA UNIVERSIDAD DE SALAMANCA,

\section{CERTIFICA}

Que la tesis titulada: "El sexismo en el Estado Michoacán de Ocampo. Materiales educativos y percepciones del alumnado de primer grado de secundaria", realizada por Dña. Elva Morales Robles para optar al grado de Doctora por la Universidad de Salamanca, cumple todos los requisitos necesarios para su presentación y defensa ante el Tribunal que legalmente procede.

Y para que conste donde proceda y surta los efectos oportunos, expido este certificado en Salamanca, a treinta de junio de dos mil diecisiete.

Director de Tesis Doctoral

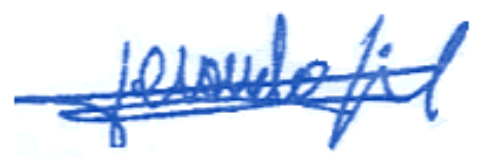

Fdo.: Director: Dr. D. Fernando Gil Villa

Catedrático de Universidad 



\section{A Bruno y a Samuel}

Con amor, por ser y estar 



\section{Agradecimientos}

Durante el largo recorrido que me ha supuesto la entrega de este trabajo, quiero agradecer por todo el apoyo que he recibido tanto en el aspecto profesional como en lo personal a las instituciones, profesores/as, familia y amigos/as que han contribuido de una u otra forma en la elaboración de mi tesis doctoral.

\section{A la Universidad de Salamanca:}

Por recibirme y brindarme la oportunidad de ser una alumna más en cursar los Posgrados en Sociología.

\section{A la Secretaria de la Mujer de Michoacán de Ocampo}

Por permitirme poner en práctica los conocimientos aprendidos y despertar mi ambición de aprender más sobre las desigualdades de género. Por contribuir en mi formación y sobre todo por facilitarme la recogida de los datos.

\section{A la Universidad Politécnica de Castelo Branco}

Por acogerme y apoyarme durante la estancia de investigación, especialmente a la Dra. Cristina Pereira y a la Dra. Maria da Natividade Pires, por su hospitalidad, asesoría y cercanía.

\section{Al Dr. D. Fernando Gil Villa, director de mi trabajo}

Gracias infinitas por su apoyo y comprensión, por siempre encontrar en usted a un amigo que estaba ahí para tenderme la mano, orientarme, corregirme... pero sobre todo por animarme a concluir este proyecto.

\section{A la Dra. $\mathrm{D}^{\mathrm{a}}$. Rosalba Robles Ortega}

Gracias, por ser una de las primeras personas en trasmitirme el amor por este campo del conocimiento, por enseñarme que con las gafas de género un mundo mejor es posible. Gracias también por ser un referente en mis estudios y en mi vida personal.

\section{A la Dra. Ma Eugenia Salinas Muñoz}

Por su ser referente académico y moral, gracias.

\section{Al Dr. D. Luis Vicente Gómez García}

Le agradezco la pertinencia en sus correcciones, a pesar de no ser experto en mi tema de estudio, y sobre todo por el apoyo personal y por la amistad que nos une.

\section{Al Dr. Javier Chapado Sánchez}

Por el acompañamiento académico y personal.

\section{A todos los profesores y profesoras del Doctorado en Sociología}

Por trasmitirnos la pasión por investigar, especialmente quiero agradecer al Dr. Alberto del Rey, por su buena disposición, profesionalidad y su tiempo. 



\section{A toda mi familia}

Especialmente a mi madre Elizabeth y a mi padre Trinidad, por su lucha y entrega por conseguir un mundo mejor, por apoyarme en cada paso que doy y alentarme a continuar mi camino de manera libre.

A mis hermanas Liliana y Avelina por su apoyo incondicional, por protegerme, por mimarme y por acompañarme sin soltarme de la mano, aún a pesar de la distancia. Y por supuesto a mis cuñados Jorge y Javier que se han convertido en parte de esta hermosa familia.

A mi sobrina, Valeria y a mi sobrino Oliver por llegar a la familia para inyectar amor y alegría.

A los amores de mi vida. A mi hijo Samuel, por inyectarme fortaleza... por existir. A ti "Bruno" por ser mi refugio, mi soporte y mi impulso, por potenciar lo mejor de mí... como dice Mario Benedetti "con tu puedo y con mi quiero, vamos juntos compañero".

A Magdalena y Ángel por tratarme como a una hija más, por apoyarnos en el día a día con las tareas de casa, y la crianza de nuestro pequeño Samuel. Sin ustedes esto no sería posible... Gracias.

A la familia extensiva de los Morales y las Robles: Mis tíos/as, primas/os, sobrinos/as y demás familia de México que siempre han sabido mantener la unidad, tejiendo redes de amor, solidaridad, comprensión y apoyo.

\section{A los amigos y a las amigas}

Por las mañanas de parque, las tardes de conversación y por las noches de cafés... En México y en España, siempre me han apoyado, incentivado y alentado a concluir con esté trabajo.

\section{iiiInfinitas Gracias!!!}

Fragmento de un poema de Benedetti con tu puedo y con mi quiero vamos juntos compañero la historia tañe sonora su lección como campana para gozar el mañana hay que pelear el ahora 

Aunque en este trabajo se ha intentado no usar un lenguaje sexista, para facilitar su lectura, en ocasiones se han empleado términos masculinos que, no obstante, incluyen a ambos sexos. 



\section{Índice de contenido}

Índice de esquemas $\quad$ xvii

Índice de figuras $\quad$ xviii

Índice de gráficas $\quad$ xxi

Índice de tablas $\quad$ xxiii

Introducción $\quad$ xxix

Introdução $\quad$ xxxiv

PARTE I. LA CONSTRUCCIÓN DE LA DESIGUALDAD A

TRAVÉS DEL GÉNERO EN LAS RELACIONES ESCOLARES 41

1. Teorías explicativas 43

1.1. Teoría feminista 46

1.1.1. La primera ola $\quad 53$

1.1.2. La segunda ola $\quad 59$

1.1.3. La tercera ola 67

1.2. El movimiento feminista en México 75

1.2.1. Etapa previa al surgimiento del movimiento feminista en México 76

1.2.2. Nuevos feminismos en México 82

1.3. Las categorías de análisis de la teoría feminista 91

1.3.1. El Patriarcado $\quad 92$

1.3.2. El Género

1.4. Resumen 114

2. Género y educación 117

2.1. El proceso de socialización en la etapa adolescente 125

2.1.1. Identidad sexual y de género 132

2.1.2. Estereotipos sexuales y roles sociales 139

2.2. La escuela secundaria en México 144

2.2.1. El sexismo en la educación 160 
2.2.2. Los libros de texto en educación secundaria

2.3. Estudios que preceden a esta investigación $\quad 170$

2.3.1. Estudios sobre estereotipos de género en adolescentes 172

2.3.2. El análisis del sexismo a través de los libros de texto 178

2.4. Resumen 194

3. Igualdad entre hombres y mujeres. Marco normativo actual 197

3.1. La Constitución y los Instrumentos internacionales firmados y ratificados por México en materia de igualdad

3.2. Leyes Nacionales. Igualdad de género 206

3.3. Leyes estatales 211

3.4. Resumen 215

PARTE II. LOS LIBROS DE TEXTO 217

Y LAS PERCEPCIONES DEL ALUMNADO DE PRIMER GRADO

DE SECUNDARIA DEL ESTADO DE MICHOACÁN DE OCAMPO 217

4. Contextualización 219

4.1. Justificación de la relevancia de la investigación 219

4.2. Situación política y social del Estado de Michoacán 226

4.3. Resumen 257

5. El problema de la percepción en la mejora de la igualdad a través de la educación

5.1. Objetivos generales: 260

5.2. Objetivos específicos: 260

5.3. Hipótesis 261

6. Método y Técnica de análisis 263

6.1. Técnica de recolección de información 267

$\begin{array}{ll}\text { 6.2. Muestra } & 270\end{array}$

6.3. Procedimientos 273

6.4. Financiación y recursos empleados 286 
7. Percepciones del alumnado 291

7.1. Percepciones sobre la sexualidad 292

7.1.1. Resumen 312

7.2. Percepciones sobre el género 313

7.2.1. Resumen $\quad 335$

7.3. Sexismo en las relaciones afectivo-sexuales descritas por los y las adolescentes 337

7.3.1. Resumen 354

8. Los libros de texto $\quad 357$

8.1. Los personajes en las imágenes 358

8.1.1. Presencia de los personajes en los libros de texto 359

8.1.2. Personajes históricos o representativos 361

8.1.3. Estereotipos sexistas en los modelos sociales 372

8.1.4. Promoción de la igualdad/equidad de género a través de las imágenes 388

8.1.5. Resumen 393

8.2. Los personajes en el texto 395

8.2.1. La presencia de los personajes en los libros de texto 395

8.2.2. Personajes históricos o representativos 398

8.2.3. Estereotipos sexistas en los modelos sociales 407

8.2.4. Resumen 416

8.3. Los personajes en los contenidos 418

8.3.1. Estereotipos sexistas en los textos 419

8.3.2. Promoción de la igualdad/equidad de género 431

8.3.3. Resumen 438

PARTE IV. DEBATIÉNDONOS ENTRE EL SEXISMO Y LA IGUALDAD 
9. Conclusiones y reflexiones finales

9.1. Discusión 443

9.2. Constatación de hipótesis 455

9.3. Fortalezas y debilidades del estudio $\quad 460$

9.4. Recomendaciones y futuras líneas de investigación. 463

9. Reflexões e conclusões 4464

$\begin{array}{ll}\text { Referencias } & 487\end{array}$

Anexos 1. Parte teórica y metodológica 525

Anexos 2. Parte de análisis de resultados grupos de discusión ${ }^{1} \quad 537$

$\begin{array}{ll}\text { Transcripciones } & 537\end{array}$

Reporte de consulta categoría de sexualidad por zona 684

$\begin{array}{ll}\text { Reporte de consulta categoría género por zona } & 719\end{array}$

Anexos 3. Parte de análisis de resultados libros de texto 748

$\begin{array}{ll}\text { Imágenes } & 748\end{array}$

$\begin{array}{ll}\text { Texto } & 754\end{array}$

${ }^{1}$ A partir de este punto el trabajo se presenta únicamente en formato digital. 


\section{Índice de esquemas}

Esquema 1.1. Modelo determinista del sexo y de la identidad sexual 98

Esquema 1.2. Modelo sexo-género basado en Gayle Rubin (1975) 100

Esquema 1.3. Elementos sobre la categoría de género: coincidencias y divergencias de las tres propuestas

Esquema 2.1. Proceso de socialización en el sujeto

Esquema 2.2. Reforma para la articulación de la educación básica $\quad 150$

Esquema 2.3. Modelo de sexismo ambivalente 162

Esquema 2.4. Actitudes sexistas presentes en el contexto educativo 164

Esquema 3.1. Marco jurídico sobre igualdad de género 216

Esquema 6.1. Técnicas de recolección de información 270

Esquema 6.2. Categorías y sub-categorías de análisis de grupos de discusión y auto-descripción breve

Esquema 6.3. Resumen sobre el diseño metodológico llevado a cabo en la investigación

Esquema 7.1. Referencia de citas seleccionadas

Esquema 7.2. Categoría de sexualidad y las relaciones entre sus subcategorías

Esquema 7.3. Categoría de género y las relaciones entre sus subcategorías 


\section{Índice de figuras}

Figura 3.1. Jerarquía normativa en México

Figura 3.2. Leyes nacionales vinculadas a la igualdad de género 209

Figura 4.1. Mapa del Estado de Michoacán de Ocampo 227

Figura 4.2. Conceptos claves para la investigación 257

Figura 4.3. Figura de la situación político-social de Michoacán 258

Figura 6.1. Mapa de las Regiones del Estado de Michoacán de Ocampo 272

Figura 8.1. Personajes representativos en las imágenes del libro de Ciencias

Figura 8.2. Personajes representativos en las imágenes del libro de Ciencias

Figura 8.3. Personajes representativos en las imágenes del libro de Ciencias

Figura 8.4. Personajes representativos en las imágenes del libro de Ciencias

Figura 8.5. Personajes representativos en las imágenes del libro de Español

Figura 8.6. Personajes representativos en las imágenes del libro de Español

Figura 8.7. Personajes representativos en las imágenes del libro de Español

Figura 8.8. Personajes representativos en las imágenes del libro de Geografía

Figura 8.9. Personajes representativos en las imágenes del libro de Matemáticas

Figura 8.10. Personajes representativos en las imágenes del libro de Matemáticas

Figura 8.11. Personajes representativos en las imágenes del libro de Matemáticas

Figura 8.12. Personajes representativos en las imágenes del libro de Matemáticas 
Figura 8.13. Estereotipo masculino en el ámbito profesional, libro de Matemáticas

Figura 8.14. Estereotipo masculino en el ámbito profesional, libro de Español

Figura 8.15. Estereotipo masculino en el ámbito profesional, libro de Español

Figura 8.16. Estereotipo masculino en el ámbito profesional, libro de Geografía

Figura 8.17. Estereotipo masculino en el ámbito profesional, libro de Geografía

Figura 8.18. Estereotipo masculino en el ámbito profesional, libro de Ciencias

Figura 8.19. Estereotipo masculino en el ámbito profesional, libro de Ciencias

Figura 8.20. Estereotipo femenino en el ámbito profesional, libro de Ciencias

Figura 8.21. Conductas estereotipadas, libros de Ciencias y de Matemáticas

Figura 8.22. Conductas estereotipadas, libros de Ciencias y de Español

Figura 8.23. Actitudes hacia el medio ambiente, libros de Ciencias y de Geografía

Figura 8.24. La familia, libros de Ciencias y de Geografía

Figura 8.25. Las relaciones afectivas, libros de Ciencias y de Geografía

Figura 8.26. Promoción de la igualdad, libro de Geografía

Figura 8.27. Promoción de la igualdad, libro de Ciencias

Figura 8.28. Promoción de la igualdad, libro de Ciencias

Figura 8.29. Promoción de la igualdad, libro de Ciencias

Figura 8.30. Promoción de la igualdad, libro de Geografía

Figura 8.31. Promoción de la igualdad, libro de Geografía 
Figura 8.33. Presencia de personajes históricos y representativos en el libro de Ciencias

Figura 8.34. Presencia de personajes históricos y representativos en el libro de Español

Figura 8.35. Presencia de personajes históricos y representativos en el libro de Geografía

Figura 8.36. Presencia de personajes históricos y representativos en el libro de Matemáticas

Figura 8.37. Nube de palabras sobre las profesiones referidas en masculino

Figura 8.38. Nube de palabras sobre las profesiones referidas en femenino 


\section{Índice de gráficas}

Gráfica 2.1. Estudios sobre estereotipos de género en la población adolescente por año

Gráfica 2.2. Estudios sobre estereotipos de género en la población adolescente por ámbito de estudio

Gráfica 2.3. Investigaciones desarrolladas en España y en América Latina por nivel educativo

Gráfica 4.1. Pirámide de la población michoacana, 2010

Gráfica 4.2. Grado promedio de escolaridad de la población de 15 años y más

Gráfica 4.3. Evolución del IDG y comparación con los mejores y peores resultados

Gráfica 4.4. IDG en las entidades federativas, año 2012

Gráfica 4.5. Índice de Desigualdad de Género por dimensión, año 2012

Gráfica 4.6. Dimensión de empoderamiento del IGD, año 2012

Gráfica 4.7. Dimensión de salud reproductiva del IDG, año 2012

Gráfica 4.8. Tasa de fecundidad Adolescente, Nacional y Estatal

Gráfica 4.9. Dimensión de mercado laboral del IDG, año 2012

Gráfica 7.1. Sub-categorías de sexualidad según el sexo del alumnado

Gráfica 7.2. Sub-categorías de sexualidad según la zona de ubicación escolar

Gráfica 7.3. Sub-categorías de género según el sexo del alumnado

Gráfica 7.4. Sub-categorías de género según la zona de ubicación escolar 
Gráfica 8.1. Distribución de la presencia de varones y mujeres en las imágenes

Gráfica 8.2. Conductas de los personajes según el sexo

Gráfica 8.3. Espacios en los que aparecen los personajes según el sexo

Gráfica 8.4. Presencia de mujeres y hombres en el texto

Gráfica 8.5. Personajes representativos según el ámbito de actividad

Gráfica 8.6. Distribución de los personajes en el texto

Gráfica 8.7. Ámbitos de actividad/ocupación en los que aparecen los personajes en el texto

Gráfica 8.8. Conductas de los personajes según el sexo en el texto

Gráfica 8.9. Espacios en los que aparecen los personajes en el texto

Gráfica 8.10. Espacios en los que aparecen hombres y mujeres en el texto 


\section{Índice de tablas}

Tabla 1.1. Postulados feministas desde la década de los 60 hasta principios de los 80

Tabla 1.2. Corrientes feministas a partir de la década de los 80

Tabla 1.3. Género, dicotomías atribuidas a lo femenino y a lo masculino 113

Tabla 2.1. Características específicas de la etapa de la adolescencia temprana

Tabla 2.2. Análisis comparativo de los tres enfoques clásicos

Tabla 2.3. Modelo evolutivo de tipificación sexual y de género

Tabla 2.4. Estereotipos y roles sexistas

Tabla 2.5. Sistema Educativo Nacional en México

148

Tabla 2.6. Mapa curricular de primer grado de secundaria en escuelas a tiempo completo

Tabla 2.7. Objetivos y estrategias planteados por PND 2013-2018

Tabla 2.8. Objetivos y estrategias planteados por PROIGUALDAD 2013-2018

Tabla 2.9. Objetivos y estrategias planteadas por el Programa Sectorial de Educación 2013-2018

Tabla 2.10. Resumen de los resultados derivados de las investigaciones en España

Tabla 2.11. Resumen de los resultados derivados de las investigaciones en América Latina

Tabla 2.12. Investigaciones sobre la presencia de sexismo en los libros de texto, en el contexto Español

Tabla 2.13. Investigaciones sobre la presencia de sexismo en los libros de texto, en el contexto Español a partir del año 2000 a la fecha

Tabla 2.14. Investigaciones sobre la presencia de sexismo en los libros de texto, en el contexto de América Latina

Tabla 3.1. Artículos reformados en la Constitución Política de los Estados Unidos Mexicanos 
Tabla 3.2. Convenciones firmadas y ratificadas por México en el ámbito de la ONU

Tabla 3.3. Convenciones firmadas y ratificadas por México en el ámbito de la OIT y de la OEA

Tabla 3.4. Protocolos firmados y ratificados por México en el ámbito de la ONU y de la OEA

Tabla 3.5. Pactos firmados y ratificados por México en el ámbito de la ONU

Tabla 4.1. Datos sociodemográficos de la población michoacana y la nacional, 2010

Tabla 4.2. Población en edad de trabajar por sexo según condición de actividad económica, segundo trimestre 2012

Tabla 4.3. Características educativas de la población michoacana según sexo, año 2012

Tabla 4.4. Participación político-parlamentaria Estatal, año 2012

Tabla 4.5. Tasa de participación económica y de desocupación de la población de 15 y más años, años 2010 y 2012

Tabla 4.6. Población ocupada por sexo, según nivel de ingresos, año 2012

Tabla 5.1. Objetivos específicos e hipótesis

Tabla 6.1. Escuelas secundarias Generales y Técnicas en las que se aplicaron los instrumentos para la investigación

Tabla 6.2. Muestra de los libros de texto

Tabla 6.3. Resumen de los instrumentos y las técnicas de empleadas

Tabla 6.4. Sub-categorías de la categoría de sexualidad

Tabla 6.5. Sub-categorías de la categoría de género

Tabla 6.6. Indicadores establecidos para la elaboración del análisis de los libros de texto

Tabla 6.7. Recursos materiales empleados en la primera y segunda fases

Tabla 7.1. Cómo se informan los adolescentes sobre sexualidad

Tabla 7.2. Cómo se informan las adolescentes sobre sexualidad 
Tabla 7.3. Rol de los hombres en el cortejo inicial, percepción de los chicos

Tabla 7.4. Rol de las mujeres en el cortejo inicial, percepción de las chicas

Tabla 7.5. Cualidades y características que gustan a los chicos

Tabla 7.6. Cualidades y características que gustan a las chicas

Tabla 7.7. Estrategias empleadas por los chicos para atraer a la persona que le gusta

Tabla 7.8. Estrategias empleadas por las chicas para atraer a la persona que le gusta

Tabla 7.9. Percepciones del sexo opuesto sobre el cortejo inicial

Tabla 8.1. Distribución de la presencia de personajes en las imágenes

Tabla 8.2. Distribución de la presencia de hombres y mujeres en las imágenes según asignatura

Tabla 8.3. Personajes representativos en las imágenes por ámbitos de actividad según la asignatura

Tabla 8.4. Presencia de hombres y mujeres en las imágenes según la actividad desarrollada

Tabla 8.5. Características psicosociales con diez porcentajes más elevados

Tabla 8.6. Distribución de la presencia de los personajes en el texto

Tabla 8.7. Distribución de la presencia de hombres y de mujeres en el texto según asignatura

Tabla 8.8. Personajes representativos según asignatura

Tabla 8.9. Personajes representativos por asignatura según ámbitos de actividad en el texto

Tabla 8.10. Asociación entre la variable personajes y la variable nombre propio

Tabla 8.11. Personajes en el texto con nombres propios por asignatura 409

Tabla 8.12. Ámbitos de actividad y/o ocupación según personajes en el texto 
Tabla 8.13. Características psicosociales con diez porcentajes más elevados en el texto

Tabla 9.1. Conclusiones en función de las hipótesis 


\section{Acrónimos}

APF

CEAMEG

CIDE

CINVESTAV

CNEGYSR

CENSIDA

CSW

CEPAL

CIM

$\mathrm{CNDH}$

CDI

CIMAC

COMMCA

CONAPO

CONAPRED

CPEUM

CEDAW

DEL

DOF

COLMEX

FLACSO

UNIFEM

IDG

IMOP

IMJUVE

INEGI

INMUJERES

LAMVLVEMO

LFPED

LGAMVLV

LGIMH

LIMHEMO

LPEDVEMO

LPAETPPAVEMO

LTG

MI
Administración Pública Federal

Centro de Estudios para el Adelanto de las Mujeres y la Equidad de Género

Centro de Investigación y Docencia Económicas

Centro de Investigaciones y Estudios Avanzados del Instituto Politécnico Nacional

Centro Nacional de Equidad de Género y Salud Reproductiva

Centro Nacional para la Prevención y Control del VIH/Sida

Comisión de la Condición Jurídica y Social de la Mujer

Comisión Económica para América Latina y el Caribe

Comisión Interamericana de Mujeres

Comisión Nacional de los Derechos Humanos

Comisión Nacional para el Desarrollo de los Pueblos Indígenas

Comunicación e Información de la Mujer

Consejo de Ministras de la Mujer de Centroamérica

Consejo Nacional de Población

Consejo Nacional para Prevenir la Discriminación

Constitución de los Estados Unidos Mexicanos

Convención sobre la Eliminación de todas las Formas de Discriminación contra la Mujer

Diccionario de la Lengua Española

Diario Oficial de la Federación

El Colegio de México

Facultad Latinoamericana de Ciencias Sociales

Fondo de las Naciones Unidas para la Mujer

Índice de Desarrollo de Género

Instituto de Marketing y Opinión Pública

Instituto Mexicano de la Juventud

Instituto Nacional de Estadística y Geografía

Instituto Nacional de las Mujeres

Ley de Acceso de las Mujeres a una Vida Libre de Violencia del Estado de Michoacán de Ocampo

Ley Federal para Prevenir y Eliminar la Discriminación

Ley General de Acceso de las Mujeres a una Vida Libre de Violencia

Ley General para la Igualdad entre Mujeres y Hombres

Ley para la Igualdad entre Mujeres y Hombres en el Estado de Michoacán de Ocampo

Ley para Prevenir y Eliminar la Discriminación y la Violencia en el Estado de Michoacán de Ocampo

Ley para Prevenir, Atender y Erradicar la Trata de Personas y para la Protección y Asistencia de las Víctimas en el Estado de Michoacán de Ocampo

Libro de Texto Gratuito

Michoacán 
OEA

ONU

OIT

OMS

PO

PND

PNUD

PUEG

RMM

SAGARPA

SEDESOL

SE

SEP

SEGOB

SEMUJER

SER

TMM

UNAM
Organización de los Estados Americanos

Organización de Naciones Unidas

Organización Internacional del Trabajo

Organización Mundial de la Salud

Periódico Oficial del Gobierno Constitucional del Estado de Michoacán de Ocampo

Plan Nacional de Desarrollo 2007-2012

Programa de las Naciones Unidas para el Desarrollo

Programa Universitario de Estudios de Género

Razón de mortalidad materna

Secretaría de Agricultura, Ganadería, Desarrollo Rural, Pesca y Alimentación

Secretaría de Desarrollo Social

Secretaría de Economía

Secretaría de Educación Pública

Secretaría de Gobernación

Secretaría de la Mujer (Michoacán)

Secretaría de Relaciones Exteriores

Tasa de Mortalidad Materna

Universidad Nacional Autónoma de México 


\section{Introducción}

Esta tesis doctoral tiene su génesis en mi despertar, en mi toma de conciencia de una realidad social que me ubica como mujer en un plano inferior al de mis congéneres varones. Responde a una doble necesidad vital. En primer lugar la de comprender los mecanismos sociales por los que desde mi infancia he experimentado que la mujer está supeditada al hombre. En segundo lugar, la de actuar para cambiar esta realidad empleando la educación, la herramienta más poderosa y efectiva, para conseguir que la igualdad entre varones y mujeres deje de ser la utopía que persigo sin descanso.

Desde que era pequeña cuestionaba el por qué las mujeres y los hombres no podíamos participar en las mismas actividades y de manera conjunta. No entendía por qué mis amigas preferían pasar sus horas de receso sentadas mientras mis amigos jugaban en las canchas. Tampoco comprendía por qué si yo quería y podía jugar al fútbol con ellos, tenía que aguantar entradas fuertes o balonazos que, cuando ellos jugaban solos, no se propinaban.

Conforme avanzaba mi formación, me iba dando cuenta de lo injusto que podía ser para las mujeres tener relaciones afectivas. Muchas de mis amigas se iban a vivir con sus parejas y para hacerse cargo de las tareas del hogar se veían obligadas a dejar sus estudios. En otros casos era para hacer frente a embarazos no deseados, mientras que sus novios continuaban con sus vidas como si no fueran también responsables de ellos. Aunque no alcanzaba a comprender estas situaciones, las consideraba injustas.

Emprendí mi formación universitaria en psicología educativa convencida de que una buena educación es la única herramienta capaz de cambiar el rumbo de la sociedad. Por ello, decidí cursar un máster en servicios públicos y políticas sociales. El paso por esta especialidad fue la llave que abrió las puertas que hasta entonces para mí eran muros. Al finalizar este periodo de formación regresé a México y empecé mi trayectoria profesional en la Secretaría de la 
Mujer en el Estado de Michoacán. La experiencia vivida en esta institución supuso una sacudida intelectual que hizo que me replanteara mi visión de la realidad, del papel que yo, como mujer, ocupaba en este mundo. Desde entonces, nunca he dejado de cuestionarme acerca del papel que desempeñamos las mujeres en una sociedad que nos presentan como universal e igualitaria pero que raras veces lo es.

Los proyectos emprendidos en coordinación con la Secretaría de Educación me permitieron iniciar mi tesis sobre el tema del sexismo en secundaria. En los inicios me di cuenta de que el tema de investigación no era nuevo. Existe una extensa tradición académica dedicada a estudiar los estereotipos y roles de género que se trasmiten, legitiman y promueven en los contextos escolares. A pesar de eso, decidimos continuar con esta línea de trabajo con la intencionalidad de abordarlo desde una perspectiva metodológica y de análisis distinta.

Un primer acercamiento a la bibliografía existente relacionada con nuestro tema de estudio nos permitió establecer un panorama general tanto de la producción académica, como de las estrategias metodológicas empleadas.

Muchas de las investigaciones se han dedicado a analizar la interiorización de los estereotipos de género en los y las adolescentes (Amurrio Velez, Larrinaga, Usategui, \& Del Valle, 2012; Colás Bravo \& Villaciervos, 2007; García Pérez et al., 2010; Lameiras \& Rodríguez, 2002; Quesada Jiménez, 2014; Quesada Jiménez \& López, 2011; Ruiz Palomino et al., 2010; Ruiz Pinto, García, \& Rebollo, 2013). Estos estudios en su mayoría han optado por realizar un análisis cuantitativo de los datos mediante la aplicación de inventarios ya validados o adaptados.

Otra línea de investigación que estudia los estereotipos de género persistentes en el contexto escolar se ha enfocado en el análisis de los libros de texto. En estos estudios, desarrollados principalmente en países anglosajones y europeos, 
se ha optado por describir la presencia de hombres y mujeres cuantitativa y/o cualitativamente (Blanco, 2000, 2003, 2007; Espigado, 2004; I.M.O.P. Encuestas, 2000; López-Navajas, 2010, 2015; Manassero \& Vázquez, 2002; Michel, 2001).

Al indagar en la temática del sexismo, advertimos que no se habían realizado trabajos en los que se analizaran de manera conjunta ambas líneas de investigación. Además, respecto al análisis de los libros de texto no encontramos ningún estudio desarrollado a nivel de secundaria en México.

Mi motivación personal y experiencia profesional, junto con el escaso avance hacia la igualdad observado en las investigaciones consultadas sobre la interiorización de los estereotipos de género en los y las adolescentes y la exigua investigación sobre el sexismo en los libros de texto de secundaria en México, motivaron la realización de este estudio.

Nuestra investigación gira en torno a dos cuestiones. En primer lugar, descubrir cuáles son las percepciones que tienen las y los adolescentes que permiten que se legitime la desigualdad entre hombres y mujeres. En segundo lugar, averiguar si a través de los libros de texto se promueve la igualdad de oportunidades, derechos, recursos, etc. entre ambos sexos.

En consecuencia, la finalidad de esta investigación es doble. Por un lado, hemos planteado el objetivo de describir y analizar las percepciones que llevan al alumnado a legitimar las desigualdades entre hombres y mujeres, y, por otro lado, pretendemos analizar si los libros de texto de primer grado de secundaria contienen información visual o textual sexista, o si por el contrario promueven una cultura de la igualdad entre hombres y mujeres.

Esperamos que nuestra investigación contribuya a enriquecer el necesario debate, iniciado hace más de tres siglos y aun vigente en la actualidad, acerca de las desigualdades por razón de sexo. Así mismo, consideramos que la 
información que se derive de este análisis puede resultar relevante para los/as interesados/as en desarrollar planes y programas en materia de políticas educativas tendientes a incluir en sus iniciativas un modelo basado en la igualdad entre hombres y mujeres.

Teniendo en cuenta tanto la literatura consultada como los objetivos planteados, hemos optado por utilizar una estrategia metodológica que combina técnicas cualitativas y cuantitativas que nos permiten obtener una visión más amplia sobre la temática estudiada. Autores como Stephen Gorard y Chris Taylor (2004) han referido la utilidad de emplear este tipo de estrategias en la investigación tanto en Ciencias Sociales como en Educación.

Con relación a las técnicas de recogida de información, organizamos grupos de discusión formados por tres mujeres y tres varones cada uno. Además, analizamos cuatro libros de texto de las asignaturas correspondientes a Español, Matemáticas, Geografía y Ciencias. Por otra parte, para llevar a cabo el análisis de la información empleamos los paquetes informáticos ATLAS.ti versión 7.5 y el SPSS versión 18 para Windows.

El estudio que aquí presentamos se ha organizado en cuatro partes. La primera, "La construcción de la desigualdad a través del género", está dividida a su vez en tres capítulos. Comenzamos elaborando una revisión sobre los movimientos feministas que se dieron a nivel internacional, haciendo especial hincapié en los que se desarrollaron en México. Explicamos las teorías feministas y las categorías que fueron acuñadas por esta corriente de pensamiento para explicar la desigualdad existente entre varones y mujeres. Este apartado nos ha proporcionado el soporte teórico que sustenta el análisis de esta investigación, pues permite explicar las barreras establecidas socioculturalmente que impiden a las personas ejercer sus derechos y libertades bajo condiciones y oportunidades de igualdad. 
En el segundo capítulo, "Género y educación", abordamos tanto el papel que ha jugado la educación en la conformación de las asimetrías establecidas en función del sexo, como los conceptos fundamentales para el desarrollo de este trabajo: procesos de socialización, identidad sexual, identidad de género, estereotipos sexuales, roles sociales... Por otra parte se tratan las especificidades del sistema educativo mexicano en el nivel de secundaria. También se examina el concepto de sexismo en educación y cómo este constructo teórico ha ido evolucionando con el paso de los años. Seguidamente situamos nuestro estudio dentro de un conjunto más amplio de investigaciones, con la finalidad de apreciar cuáles han sido las aportaciones de este trabajo con respecto a otros.

Finalizamos el primer apartado abordando, en el capítulo tres, el análisis de la normativa y regulación legislativa sobre igualdad y equidad de género que se ha desarrollado a nivel internacional, nacional y estatal. Este capítulo se elabora con el propósito de exponer las prescripciones establecidas para garantizar la igualdad y la vigilancia de la no discriminación por razón de sexo.

La segunda parte de esta tesis doctoral, titulada "Los libros de texto y las percepciones del alumnado de primer grado de secundaria del Estado de Michoacán de Ocampo" está conformada también por tres capítulos. En el primero (capítulo 4 de la tesis), analizamos tanto la situación de desigualdad entre hombres y mujeres en México, - particularmente en el Estado de Michoacán de Ocampo- como las características sociales y políticas propias de esta región.

En el capítulo 5 presentamos los objetivos e hipótesis que conforman esta investigación, mientras que en el 6 desarrollamos el diseño metodológico, explicamos la técnica de recolección de información por la que hemos optado, especificamos las características de la muestra y exponemos los procedimientos que seguimos en cada una de las fases de este estudio. 
La tercera parte de esta tesis doctoral, el "Análisis de resultados" está dividida en dos capítulos. En el capítulo 7 se exponen los resultados obtenidos de los grupos de discusión. La presentación de los mismos se realiza conforme a las categorías establecidas, es decir, primero se muestra la información sobre sexualidad que puede ubicarse en distintas tonalidades de color amarillo. A continuación se muestra la información sobre la categoría género en distintas tonalidades de color azul. Finalmente se realiza la integración de las dos categorías, cuya representación llevamos a cabo con el resultado de la adicción de ambos en verde.

En el capítulo 8 se presentan los resultados del análisis de los libros de texto. Comenzamos exponiendo los datos sobre la presencia de hombres y mujeres en las imágenes contenidas en los materiales didácticos. Posteriormente, mostramos la información correspondiente al análisis del texto y concluimos con el análisis del contenido.

La cuarta y última parte de esta investigación, titulada "Debatiéndonos entre el sexismo y la igualdad", se desarrolla a lo largo del capítulo 9, "Conclusiones y reflexiones finales". Confrontamos nuestros resultados con los obtenidos por otras investigaciones consultadas para llevar a cabo esta obra. Además realizamos la constatación de los objetivos e hipótesis planteados en esta investigación, así como sus limitaciones y fortalezas. Terminamos con las recomendaciones y futuras líneas de investigación.

\section{Introdução}

Esta tese tem a sua génese no meu despertar, na minha compreensão de uma realidade social que me coloca, enquanto mulher, num plano inferior face aos homens. Responde a duas necessidades vitais. A primeira, a de compreender os mecanismos sociais pelos quais desde a minha infância experienciei que a mulher está sujeita ao homem. Em segundo lugar, a de agir de maneira a mudar essa realidade através da educação, a ferramenta mais poderosa e eficaz, para 
conseguir que a igualdade entre homens e mulheres deixe de ser a utopia que persigo sem descanso.

Desde pequena me questionava sobre a razão pela qual homens e mulheres não podiam participar nas mesmas atividades juntos. Não compreendia porque é que as minhas amigas preferiam passar os intervalos sentadas, enquanto os rapazes jogavam nos campos de futebol. Também não compreendia, se eu queria e podia jogar futebol com eles, porque tinha de aguentar rasteiras e fortes boladas que, quando jogavam apenas os rapazes, não eram frequentes.

À medida que a minha formação avançava, reparava o quão injusto era para as mulheres ter relacionamentos. Muitas das minhas amigas foram viver com os seus companheiros e, para ficarem responsáveis das tarefas domésticas, eram forçadas a deixar os seus estudos. Noutros casos, abandonaram a sua formação para lidar com uma gravidez indesejada, enquanto os seus namorados continuaram as suas vidas, sem assumir a responsabilidade que lhes correspondia. Apesar de não conseguir compreender estas situações, considerava-as injustas.

Comecei a minha formação universitária em Psicologia Educacional convicta de que uma boa educação é a única ferramenta capaz de mudar o rumo da sociedade. Por isso, decidi tirar um mestrado em serviços públicos e políticas sociais. Estes estudos foram essenciais para ultrapassar as barreiras que até então não tinha sequer imaginado quebrar. Ao concluir este mestrado, retornei ao México e comecei a trabalhar na Secretaria da Mulher do Estado de Michoacan. A experiência vivida nesta instituição significou um choque intelectual que me fez repensar a minha visão da realidade, do papel que eu, enquanto mulher, ocupo neste mundo. Desde então, nunca mais parei de me questionar sobre o papel que as mulheres têm numa sociedade que nos é apresentada como universal e igualitária, mas que poucas vezes o é. 
Os projetos desenvolvidos em coordenação com o Ministério da Educação permitiram-me começar a minha tese de doutoramento sobre o tema do sexismo no ensino secundário. No início, percebi que o tema de investigação não era novo. Existe uma extensa tradição académica dedicada a estudar os estereótipos e os papéis de género que são transmitidos, legitimados e promovidos nos contextos escolares. Apesar disso, decidimos continuar esta linha de trabalho, com a intenção de o abordar a partir de uma perspetiva metodológica diferente.

A primeira abordagem à literatura relacionada com o nosso tema de estudo permitiu-nos estabelecer uma visão geral tanto da produção académica, como das estratégias metodológicas empregadas.

Muitos dos estudos têm-se centrado na análise da interiorização dos estereótipos de género nos adolescentes (Amurrio Velez, Larrinaga, Usategui, e Del Valle 2012, Colás Bravo \& Villaciervos, 2007;. García Pérez et al, 2010; Lameiras \& Rodriguez, 2002; Jimenez Quesada, 2014; Jimenez Quesada \& Lopez, 2011; Ruiz Palomino et al, 2010 ;. Ruiz Pinto, García, \& Rebollo, 2013). A maioria destes estudos têm realizado uma análise quantitativa dos dados recolhidos através da aplicação de inventários já validados ou adaptados.

Outra linha de investigação, que estuda os estereótipos de género persistentes no contexto escolar, tem-se centrado na análise dos manuais escolares. Nestes estudos, desenvolvidos principalmente em países anglo-saxónicos e europeus, analisa-se, qualitativa e/ou quantitativamente, a presença de homens e mulheres nos materiais didáticos (Blanco, 2000, 2003, 2007, Espigado, 2004; I.M.O.P. Encuestas, 2000; López-Navajas, 2010, 2015, Manassero e Vázquez, 2002; Michel, 2001).

$\mathrm{Na}$ rigorosa análise da bibliografia que realizamos, reparamos que não se tinham realizado estudos que desenvolvessem de maneira conjunta as duas linhas de investigação referidas. Além disso, não encontramos no México nenhum estudo que se focasse ao nível do ensino secundário. 
Assim, a minha motivação pessoal e experiência profissional, juntamente com a falta de progressos no sentido da promoção da igualdade, observada nas investigações examinadas sobre a interiorização dos estereótipos de género em adolescentes, e a inexistência de estudos sobre o sexismo em manuais escolares do ensino secundário no México, motivaram a realização desta tese de doutoramento.

A nossa investigação tenta responder a duas questões. Em primeiro lugar, descobrir quais são as perceções dos adolescentes que lhes permitem legitimar a desigualdade entre homens e mulheres. Em segundo lugar, verificar se é promovida, através dos manuais escolares, a igualdade de oportunidades, direitos e recursos entre homens e mulheres.

Por conseguinte, o objetivo desta investigação é duplo. Por um lado, descrever e analisar as perceções que levam os alunos a justificar as desigualdades entre homens e mulheres. Por outro lado, analisar se os manuais do primeiro ano do ensino secundário contêm informação visual ou textual sexista, ou se pelo contrário promovem uma cultura da igualdade entre homens e mulheres.

Esperamos que a nossa pesquisa contribua para o enriquecimento do necessário debate, começado há mais de três séculos e atualmente ainda em vigor, sobre as desigualdades de género. Também consideramos que podem ser relevantes as informações obtidas neste estudo para os/as interessados/as na criação e implementação de programas de políticas educativas baseadas na igualdade entre homens e mulheres.

Tendo em conta tanto a literatura consultada como os objetivos a atingir, optamos por utilizar uma estratégia metodológica que combina técnicas qualitativas e quantitativas, o que nos permite obter uma visão mais ampla do assunto estudado. Autores como Stephen Gorard e Chris Taylor (2004) 
demostraram, tanto nas Ciências Sociais como na Educação, a utilidade de empregar este tipo de estratégias metodológicas mistas.

Em relação às técnicas de recolha de informação, organizamos grupos de discussão formados, cada um deles, por três mulheres e três homens. Além disso, foram analisados quatro manuais escolares das disciplinas de Espanhol, Matemática, Geografia e Ciências. Para efetuar a análise dos dados recolhidos, usamos os softwares ATLAS.ti versão 7.5 e SPSS versão 18 para Windows.

O estudo aqui apresentado é organizado em quatro partes. A primeira, "A construção da desigualdade através do género", é dividida em três capítulos. Começamos por efetuar uma revisão dos movimentos feministas que ocorreram a nível internacional, com particular ênfase naqueles que aconteceram no México. Explicamos as teorias e categorias feministas que foram criadas para explicar a desigualdade entre homens e mulheres. Esta primeira parte da tese proporciona o suporte teórico que sustenta a análise desta investigação, dado que permite explicar as barreiras socioculturais estabelecidas para impedir as pessoas de exercerem os seus direitos e liberdades em igualdade de condições e oportunidades.

No segundo capítulo, "Género e educação", abordamos tanto o papel desempenhado pela educação na formação de assimetrias estabelecidas em função do sexo, como os conceitos fundamentais para o desenvolvimento deste trabalho: processos de socialização, identidade sexual, identidade de género, estereótipos sexuais, papéis sociais... Além disso, são analisadas as especificidades do sistema educativo mexicano no nível secundário. Examinamos o conceito de sexismo na educação, e a forma como esta construção teórica tem evoluído ao longo dos anos. Finalmente, colocamos o nosso estudo dentro de um conjunto mais amplo de investigação, por forma a avaliar as contribuições deste trabalho em comparação com outros. 
Concluímos a primeira parte da tese com a análise, no capítulo três, da regulamentação legislativa sobre a igualdade e equidade de género que tem sido desenvolvida a nível internacional, nacional e estadual. Este capítulo pretende explicar os requisitos estabelecidos para assegurar a igualdade e nãodiscriminação por razão de género.

A segunda parte desta tese, intitulada "Os manuais escolares e as perceções dos alunos do primeiro ano do ensino secundário do estado de Michoacán de Ocampo", também é composta por três capítulos. No primeiro (capítulo 4 da tese), analisamos tanto a situação de desigualdade entre homens e mulheres no México, particularmente no Estado de Michoacán de Ocampo, como as características sociais e políticas desta região.

No Capítulo 5 apresentamos os objetivos e hipóteses que compõem esta investigação, enquanto no 6 desenvolvemos o desenho metodológico, explicamos a técnica de recolha de dados escolhida, especificamos as características da amostra e, por último, definimos os procedimentos que seguimos em cada uma das fases deste estudo.

A terceira parte desta tese, a "Análise dos resultados", é dividida em dois capítulos. No capítulo 7 apresentamos os resultados dos grupos de discussão de acordo com as categorias estabelecidas. Assim, primeiro mostramos informações sobre a sexualidade em diferentes tons de amarelo. Depois, apresentamos a informação obtida sobre a categoria de género em diferentes tons de azul. Finalmente, realizamos a integração de ambas as categorias, que são representadas com o resultado da adição de ambas as cores, o verde.

No capítulo 8, são apresentados os resultados da análise de manuais escolares. Começamos por expor os dados sobre a presença de homens e mulheres nas imagens contidas nos materiais didáticos. Posteriormente, mostramos a informação que corresponde à análise do texto e concluímos com a análise de conteúdo. 
A quarta e última parte desta tese de doutoramento, intitulada "Debatendonos entre o sexismo e a igualdade" desenvolve-se ao longo de todo o capítulo 9, "Conclusões e reflexões finais". Confrontamos os nossos resultados com os obtidos por outras investigações consultadas para realizar este estudo. Além disso, analisamos se os objetivos e as hipóteses desta tese de doutoramento foram alcançados, e em que medida. Para finalizar, referimos os seus pontos fortes e fracos e apontamos futuras linhas de investigação que surgem a partir deste estudo. 
PARTE I. LA CONSTRUCCIÓN DE LA DESIGUALDAD A TRAVÉS DEL GÉNERO EN LAS RELACIONES ESCOLARES 



\section{Teorías explicativas}

Kofi Annan: «La igualdad de los sexos no es un objetivo en sí mismo, sino que es indispensable para alcanzar los otros objetivos, y ninguna estrategia de desarrollo será

eficaz, si no concede a las mujeres un papel de primer plano» (Citado por Fraisse, 2005, p. 21)

Las transformaciones políticas y socioeconómicas que se han producido en las últimas décadas impulsadas por los movimientos y los estudios feministas han sido consideradas como uno de los cambios más relevantes de los últimos tiempos (Cobo Bedia, 2004; Fernández Poncela, 1998; Lagarde, 1996; Larrañaga Sarriegui, s/f; Larrañaga Sarriegui \& Jubeto Ruiz, 2012; Puleo, 2000; Valcárcel, 2010, 2013).

Los movimientos feministas han contribuido a una serie de transformaciones culturales y sociales que hasta hace tres siglos eran impensables. Entre estos cambios se encuentran: la incorporación de la mujer al mercado laboral, la incorporación de la mujer a la educación, el descenso de la tasa de fecundidad, la aceptación de nuevas estructuras familiares y la aparición de nuevos tipos de familias, las nuevas formas de relación entre los sexos... (Larrañaga S., s/f). Rosa Cobo describe al feminismo como "uno de los efectos reflexivos de la modernidad que más ha contribuido en los dos últimos siglos al progreso social y político" (2004, p. 14).

Estos avances, como bien menciona M. Teresa López de la Vieja, no han conseguido que exista una igualdad plena y efectiva en ninguna parte del mundo, pues hombres y mujeres continúan sin gozar de las mismas condiciones y tampoco tienen acceso a las mismas libertades y derechos (2015, p. 132). No obstante, actualmente existe una idea muy extendida, que sintetiza perfectamente Valcárcel con la definición de "el espejismo de la igualdad". Según esta autora, la población, sobre todo las mujeres jóvenes, no percibe los escenarios de desigualdad; cree que ya está todo conseguido. Sin embargo, esta 
situación no es así en ningún lugar del mundo, ${ }^{2}$ no podemos negar que ha habido logros importantes, pero esto lo hace aún más peligroso, ya que como reitera Valcárcel, "en los tiempos que corren la desigualdad que sufren las mujeres es muy sutil y se requiere de un bagaje teórico mínimo para poder percatarse y exigir la igualdad y la libertad en condiciones equitativas a los varones" (Valcárcel, 2013, p. 162).

La teoría feminista — como los marcos conceptuales que de ella se desprenden - es hoy como fue ayer, un referente teórico oportuno para explicar los fenómenos sociales y culturales que imposibilitan que hombres y mujeres puedan acceder a los derechos, oportunidades y recursos de manera equitativa y justa. La propuesta feminista consiste, de acuerdo con Silvia Tubert, en "concebir la diferencia sin recurrir a oposiciones binarias; pensarla sin confrontarla con la norma; reconocerla pero no en términos jerárquicos" (2003, p. 387). Es por ello que hemos considerado que este referente teórico nos ofrece, por un lado, la posibilidad de visibilizar las desigualdades que se esconden en una normalidad regida por un grupo dominante androcéntrico, donde las mujeres y los hombres no son valoradas/os de manera equitativa, $\mathrm{y}$, por otro lado, nos proporciona las herramientas metodológicas adecuadas para evidenciar, explicar y analizar lo que se encubre en los materiales escolares y las percepciones del alumnado de primer grado de segundaria.

Para tales fines, hemos dividido este epígrafe en tres partes. La primera la dedicamos a realizar una aproximación a la teoría feminista, haciendo un breve recorrido histórico de cómo lo que se inicia como un movimiento social va tomando fuerza hasta llegar a convertirse en referente académico multidisciplinar (antropología, historia, filosofía, psicología, sociología...) todas

\footnotetext{
${ }^{2}$ Algunos estudios que muestran algunas cifras a nivel nacional y estatal sobre la situación de desigualdad que viven las mujeres son los siguientes: Chapado Sánchez, 2012; CONAPO, 2013; CONAPO \& UNFPA, 2009; Freyermuth-Enciso \& Luna, 2014; INEGI, 2012; INEGI \& INMUJERES, 2013; López de la Vieja, 2015; PNUD, 2014).
} 
estas disciplinas han estudiado, descubierto y denunciado las inequidades y subordinación que sufren las mujeres en todo el mundo solo por el mero hecho de ser mujeres (Maldonado Barahona, 2013). En esta primera parte abordamos las tres olas del feminismo haciendo referencia al desarrollo y evolución de este movimiento teórico y práctico.

En el punto 1.2. analizaremos de manera breve cómo se inician las primeras vindicaciones sobre la emancipación de la mujer en México. En primer lugar, señalaremos la participación política de las mujeres hasta la obtención del voto, así como las negativas y la ocultación de las demandas de las primeras mujeres que alzaron la voz para exigir un mundo más equitativo. En segundo lugar abordamos los movimientos feministas que se reavivan en los años setenta —al cobijo de los movimientos sociales que tienen lugar a nivel internacional- y cómo estos movimientos van adquiriendo a través de los años características particulares y además expondremos los movimientos desarrollados en otras altitudes. Todo ello, será realizado con el fin de proporcionar el contexto en el cual se desarrollan los movimientos feministas en México.

Por su parte, en el punto 1.3. haremos referencia a las principales categorías de análisis acuñadas por el feminismo, para explicar las situaciones de subordinación y opresión a las que han estado sujetas las mujeres a lo largo de la historia en todas las sociedades, que son, según Rosa Cobo, patriarcado y género $(2005,2008,2014)$. Así pues, en el apartado 1.3.1. desarrollaremos los principales debates que se han generado en torno al patriarcado, mientras que en punto 1.3.2. abordaremos la perspectiva de género con el afán de reflexionar en torno a lo que ha venido aconteciendo alrededor de este constructo teórico como parte del creciente "uso y abuso" de este concepto dentro de las ciencias sociales (Izquierdo, 1998, p. 18), con el propósito final de adentrarnos en la categoría de análisis que fundamenta a esta investigación. 


\subsection{Teoría feminista}

Harriett Taylor 1850: «Negamos el derecho de que cualquier porción de la especie decida por la otra porción, o cualquier individuo por otro individuo, qué es y qué no es la "esfera propia" de cada uno. La esfera propia es, para todos los seres humanos, la más ancha y la más alta que pueden conseguir. Y esto no se puede averiguar sin una completa libertad de escoger» (Citada por Blanco, 2003, p. 45)

Antes de abrir el debate de lo que es el feminismo y lo que aporta la teoría feminista, vamos a explicar la organización que seguimos en este apartado. Así pues, este capítulo está dividió en tres partes. En la parte primera abordamos el surgimiento del movimiento feminista como protesta al discurso naturalistabiologicista que mantenía a las mujeres en una situación de subordinación en relación con el varón y las consecuencias, tanto políticas como morales, que se desencadenaron del pensamiento moderno que se produjo en el periodo de la Ilustración. En el segundo epígrafe, analizamos lo ocurrido con el movimiento feminista-sufragista y las aportaciones teóricas derivadas de la acción social emprendida por hombres y por mujeres que exigían la igualdad entre los sexos. Finalmente, en el sub-apartado tres, hacemos referencia a la tercera ola del feminismo las demandas y las acciones promovidas para establecer una agenda pública con perspectiva de género, factor primordial para el desarrollo de una sociedad regida por los principios de igualdad, libertad y justicia.

El feminismo se inició hace tres siglos como un movimiento político crítico e interpretativo de la realidad social que denuncia, construye y vindica la situación y la condición de subordinación y desigualdad que viven las mujeres (Amorós, 1985, 2010b; Arizpe, 2002; Cobo Bedia, 2004, 2014; De las Heras Aguilera, 2009; Flores Espínola, 2016; Freedman, 2004a; Maldonado Barahona, 2013b; Méndez Pérez, 2008; Montero, 2006; Radl Philipp, 2001; Sau, 1990; Stuven, 2013; Valcárcel, 2013).

El feminismo, desde entonces hasta ahora, se ha nutrido de un mosaico multidisciplinar (filosofía, sociología, psicología, antropología...), lo que ha 
derivado en un entramado de discursos intelectuales diversos y nuevos enfoques teóricos. ${ }^{3}$ Es por ello que en esta investigación realizamos una selección de las conceptualizaciones feministas que abogan por la vindicación de la igualdad, la justicia y la libertad.

Una vez dicho esto, vamos a iniciar por definir feminismo. Recurriremos primero a la definición de la Real Academia Española, para posteriormente realizar un análisis teniendo en cuenta lo señalado por diversas autoras.

El diccionario de la Real Academia Española (DLE) tiene dos acepciones para definir esta palabra: I. "ideología que defiende que las mujeres deben tener los mismos derechos que los hombres; II. "el movimiento que se apoya en el feminismo".

La definición que se da en el Diccionario ideológico feminista de Sau (1990) es la siguiente:

Un movimiento social y político que se inicia formalmente a finales del siglo XVIII - aunque sin adoptar todavía esta denominación - y que supone la toma de conciencia de las mujeres como grupo o colectivo humano, de la opresión, dominación y explotación de que han sido y son objeto por parte del colectivo de varones en el seno del patriarcado bajo sus distintas fases históricas de modelo de producción, lo cual las mueve a la acción para la liberación de su sexo con todas las transformaciones de la sociedad que aquélla requiera (pp. 121-122).

Teniendo en cuenta las dos definiciones enunciadas en los párrafos anteriores, podemos decir que la primera definición (DLE) no es, ni mucho

\footnotetext{
${ }^{3}$ Lourdes Méndez, menciona las siguientes: universalista o de la igualdad, de la diferencia, posestructuralista y posmoderna (2008, p. 99-100). La corriente de la igualdad o universalista se basa en las ideas del racionalismo instrumental y concibe su pensamiento sobre las relaciones sociales de dominación y de explotación, exigiendo la aplicación de presupuestos ético-universales para las mujeres. Algunos referentes teóricos de este enfoque son Amorós, 1985, 2010b; Cobo Bedia, 2007; Valcárcel, 2013. La corriente de la diferencia tiene el objetivo de reivindicar la genealogía femenina donde las mujeres son poseedoras de virtudes vinculadas a la maternidad y a su conexión con la naturaleza, siendo su principal referente teórico es Luces Irigaray. En la corriente posestructuralista se cuestiona la existencia de categorías de "mujer" y de "hombre", porque se considera que el sexo tiene un carácter social en el que interviene el psicoanálisis, el lenguaje y el poder; Lacan, Derrida y Foucault son los miembros más sobresalientes de este grupo. Por último, la corriente posmoderna pretende escapar de la lógica de las oposiciones binarias sobre la que se ha construido el saber sobre el hombre, argumentando que lo femenino o lo masculino pueden asumirse indistintamente por hombres y mujeres; los autores/as que abogan por esta corriente son Derrida, Deleuze, entre otros/as.
} 
menos, suficiente. El feminismo va más allá de una ideología, es un paradigma teórico-práctico tendiente a analizar el mundo, describirlo, explicarlo, saber cómo funciona... para poder proponer nuevas formas de organización social, política, cultural... (Maldonado Barahona, 2013b, p. 16). Atendiendo a lo descrito por la autora Sau, consideramos relevante resaltar que el movimiento empieza a tener mayor incidencia en lo político, lo social y lo cultural cuando un determinado número de mujeres se reunieron en "función del reconocimiento de su semejanza sexual" y se nombraron a sí mismas, formando con ello un colectivo (Izquierdo, 1998a p. 15).

El feminismo es, pues, un movimiento social históricamente constituido. Ya en el siglo XV se encuentran documentos que hacen referencia a la desigualdad que viven las mujeres. Autoras como Christine de Pisan, con su obra "La ciudad de las damas" en 1405, abren un debate literario en torno a la situación de las mujeres, pero no se pretende con ello acabar con la situación de desigualdad, ni cuestionar el poder de los varones. Sus escritos son más bien una queja respecto a los abusos que vivían las mujeres, que un referente teórico. No es hasta el siglo XVIII — bajo la influencia de la tradición científica moderna - cuando se producen los primeros esbozos de la vindicación de los derechos de las mujeres para ser tratadas como ciudadanas.

A partir de este periodo, los movimientos feministas inician una lucha teórica y práctica para conseguir que las mujeres sean reconocidas como seres humanos y valoradas en igualdad de condiciones que los hombres, una lucha que va ser pausada y silenciada por el poder patriarcal. Sin embargo, en la década de los setenta, tanto en Europa como en Estados Unidos, se incrementa el corpus científico sobre los temas relacionados con las mujeres como colectivo y el género (Méndez Pérez, 2008).

Cabe destacar que la academia también puso trabas al paradigma feminista. Las investigadoras feministas tuvieron que incursionar en la investigación de las 
ciencias sociales para desarrollar sus aproximaciones bajo unos criterios científicos androcéntricos. Las autoras Sandra Harding y Kathryn Norberg, explican que los y las investigadores/as feministas han estudiado y denunciado que las exigencias investigativas (androcéntricas) discriminan y dificultan el estudio de grupos sociales vulnerables dentro de la práctica cotidiana. Es por ello que la propuesta feminista se ha dado a la tarea de transformar el uso de las metodologías y epistemologías — analizando sí los paradigmas generadores de conocimiento promueven o impiden el desarrollo de las relaciones sociales basadas en los principios democráticos - para abrirse camino dentro de la investigación social (Harding \& Norberg, 2005).

Así pues, las investigadoras feministas recurrieron a diversos postulados teórico-metodológicos (la teoría crítica, la ética del discurso, la fenomenología, la desconstrucción, la genealogía, el psicoanálisis, la semiótica, los estudios culturales, el análisis del lenguaje, el pragmatismo...) provenientes de diversas áreas del conocimiento, como la sociología, la economía, la psicología... Y la elección de estos postulados teórico-metodológicos llevó a las feministas por caminos distintos. Ahora bien, estos caminos convergían tanto en la finalidad: intentar desarrollar modelos de análisis que reflejen la subordinación/opresión de las mujeres con relación a los varones, como en la asunción de que la subordinación no obedece a causas naturales, sino a la forma en que cada cultura o sociedad establece las normas de ser hombre o ser mujer (Méndez Pérez, 2008).

En la actualidad es impensable considerar que el feminismo puede referirse a una sola manera de hacer investigación o que sus posturas se reúnan en una categoría unitaria. ${ }^{4}$ Todo lo contrario, la teoría feminista refleja e incluye múltiples aproximaciones, de ahí que existan distintos tipos de feminismo distintas corrientes teóricas - cada una de las cuales ha contribuido al desarrollo

\footnotetext{
${ }^{4}$ Isabel Torres en "Prologo a la edición española" en Freedman, 2004, p. 10.
} 
de contextos sociales determinados. A pesar de las variaciones de este paradigma teórico-metodológico, ${ }^{5}$ existen diversos puntos de encuentro que resumimos a continuación: ${ }^{6}$

- Posee el objetivo de liberar a la mujer de cualquier forma de subordinación o dependencia.

- Plantea la existencia de un sujeto (mujeres) subordinado.

- Identifica un problema (la subordinación y la desigualdad de las mujeres a partir de la relaciones de género).

- Expresa varias intenciones:

- acabar con las relaciones de dominación,

○ terminar con la discriminación por razón de sexo,

- asegurar la liberación sexual de las mujeres,

- luchar a favor de sus derechos e intereses,

○ crear "conciencia",

○ transformar las estructuras institucionales y legales, e

o introducir una perspectiva de género en la concepción de la democracia.

- Se rige por principios específicos:

- la igualdad, el respeto, el reconocimiento, la dignidad, la justicia, la libertad, la autonomía, la solidaridad, la democracia y la modernidad.

Podemos decir, pues, que la teoría feminista se ha nutrido de la acción social. Celia Amorós considera que es un paradigma, teórico y práctico de marco

\footnotetext{
${ }^{5}$ Harding, (1987) explica que se tiene que distinguir entre método, metodología y epistemológica. Por la primera, la autora considera las técnicas para recabar información. Por metodología se entiende la teoría sobre los procedimientos que sigue o debería seguir la investigación y una manera de analizarlos. Finalmente, epistemología refiere teoría del conocimiento que se emplea. También nos menciona como este paradigma ha tenido que trasformar las herramientas metodológicas, puesto que la investigación social se basa en métodos fundamentados en una visión androcéntrica.

${ }^{6}$ Tomamos en cuenta lo descrito por diversos/as autores/as Amorós, 1985, p. 143; Cobo Bedia, 2005, p. 251; Dietz \& Olivares Mansuy, 2005, p. 179; Valcárcel, 2013, p. 47.
} 
interpretativo y crítico de la realidad social que hace visible, nombra, define y cuestiona los hechos, los fenómenos y los aconteceres que no son perceptibles ni oportunos desde otras orientaciones de la atención (Amorós, 1985, p. 143, 2010b p. 98-99). Es, también, un referente metodológico en la medida en que acuña categorías nuevas y sus teorizaciones tienen implicaciones políticas, en tanto enfoque que promueve la coordinación de acciones para procurar la transformación social (Dietz \& Olivares Mansuy, 2005).

El pensamiento feminista está en constante transformación, en una evolución que se tiñe de colores diversos y que es dependiente de un contexto histórico, social y cultural determinado. En este sentido, el feminismo, como cualquier otra teoría del conocimiento, ha desarrollado en palabras de Rosa Cobo, "una mirada intelectual y política sobre ciertas dimensiones de la realidad que otras teorías no habían sido capaces de conceptualizar" (Cobo Bedia, 2014, p. 9). Se evidencia así la existencia de un sistema social hegemónico en el que los varones ocupan una posición social superior a las mujeres.

El corpus teórico que se ha construido sobre este paradigma se basa en la distinción analítica entre sexo, género y patriarcado (entre otras nociones/categorías acuñadas). El sistema sexo-género es una matriz sobre la que se configuran las formas de organización jerárquica de las relaciones entre hombres y mujeres en determinados contextos socioculturales. Desde este paradigma (crítico e interpretativo) se cuestiona el sistema normativo de estas relaciones como estructura de poder hegemónica masculina que divide la sociedad en dos partes asimétricas, "una de ellas marcada por la subordinación y otra por la dominación, una con exceso de recursos y otra con déficit de los mismos, una con sobrecarga de derechos y otra con un déficit significativo de los mismos" (Cobo Bedia, 2008, p. 5).

A modo de recapitulación, en este apartado hemos visto que el feminismo es un movimiento social que se inició hace tres siglos. Durante este periodo de 
tiempo ha habido avances y retrocesos, protestas y silencios, rebeldía y opresión. Aun cuando han existido oleadas en las que el movimiento teóricopráctico ha tenido mayor activismo social y producción académica, siempre han existido mujeres que han levantado la voz por conseguir la igualdad y la libertad que les fue negada por el mero hecho de ser mujeres (Gutiérrez Esteban \& Luengo González, 2011 citando a Freedman, 2004). La teoría feminista ha contribuido, entonces, a visibilizar escenarios caracterizados por el sexismo, la desigualdad, la subordinación y la opresión de mujeres (principalmente) y de hombres que no se ajustan a las normativas establecidas en las sociedades patriarcales, mediante el análisis de categorías y conceptualizaciones que no habían sido cuestionadas desde otras áreas del conocimiento (Amorós \& Miguel Álvarez, 2007).

En los apartados que presentamos a continuación especificaremos algunos de los pormenores protagonizados por el movimiento feminista desde su surgimiento en el periodo de la Ilustración hasta su dilación — la considerada primera ola—. ${ }^{7}$ Es así como el movimiento feminista inicia y continúa su lucha por conseguir la igualdad de derechos educativos y políticos en una primera instancia — segunda ola—, para posteriormente abogar por el reconocimiento de los derechos reproductivos y sexuales, la representación y la participación de las mujeres en ámbitos de toma de decisiones, así como la eliminación de los techos de cristal, el trabajo doméstica compartido, la eliminación de las brechas salariales... - tercera ola-.

\footnotetext{
${ }^{7}$ Periodo en el cual las ideas revolucionarias cuestionaban el sistema normativo del Estado y se genera una tendencia intelectual renovadora que utiliza la razón para elaborar una revisión crítica de las creencias religiosas, el obscurantismo y las cuestiones éticas imperantes hasta entonces (Carrillo Prieto, 1981). Se exigen condiciones igualitarias para todos los "hombres" — pronto las mujeres se dan cuenta de que la palabra "hombre" no se refiere en sentido universal del ser humano, es decir se les excluye del nuevo proyecto político fundado en los principios de libertad, justicia e igualdad. Es por ello que autoras como A. Valcárcel y C. Amorós consideran que el feminismo es el hijo no querido de la Ilustración (Amorós, 2010b; Valcárcel, 2013).
} 


\subsubsection{La primera ola}

En este apartado analizaremos cómo surgieron las primeras aspiraciones feministas y los problemas que se encontraron al vindicar el derecho a ser tratadas como ciudadanas. Para ello, vamos a analizar algunos de los referentes teóricos que se remontan al periodo Ilustrado.

Durante siglos las mujeres han sido invisibilizadas y subordinadas bajo el discurso de la legitimación de la desigualdad entre los sexo, en donde filósofos, clérigos, políticos... han discurrido sobre lo qué es ser mujer y los contextos en dónde podían desempeñar las funciones que ellos consideraban oportunas para su sexo.

Los discursos legitimadores de la desigualdad han empleado para ello tres argumentos principales. El primero está relacionado con los supuestos morales, donde los discursos mitológicos y religiosos reflejan a la mujer como un ser sin alma y por tanto inferior al hombre - modelos como los de Eva-. El segundo argumento se basa en cuestiones biológicas. En él la idea central dominante era que la fisiología, y la biología de la mujer (humores corporales, la estructura cerebral, la estructura ósea, los embarazos, las menstruaciones, los partos, la menopausia, etc.) las situaba en un estado permanente de enfermedad física, lo cual demostraba la "superioridad" de los varones. El tercer argumento está relacionado con cuestiones intelectuales, que podrían resumirse en la supuesta menor capacidad racional de las mujeres frente a su mayor capacidad intuitiva y emocional, lo que la incapacitaría para el desempeño de muchas actividades intelectuales (Bosch Fiol \& Ferrer Pérez, 2003a, 2003b).

Los discursos que legitimaban la desigualdad de los sexos estaban fundados en una justificación biologicista-naturalista, anclada en creencias y costumbres que no eran cuestionadas, lo cual tuvo como consecuencia el establecimiento de un orden político, social, jurídico y económico caracterizado por otorgarle 
supremacía a los varones y a lo masculino (patriarcado), relegando a la mujer al ámbito de lo natural y lo privado (Puleo, 2000; Radl Philipp, 2001).

Ante estos discursos mujeres, como Christine de Pisan plantean los prejuicios con los que los hombres discurren sobre las mujeres en su obra $L a$ ciudad de las damas, en el siglo XV. Durante trescientos años, del siglo XV al XVIII, se sostuvo como elemento nodal el cuestionamiento a la "naturalidad" de la supuesta inferioridad femenina (Riquer \& Tepichín, 2001). Aunque la obra de C. Pisan describe las injustas condiciones de las mujeres de esa época, estos relatos solo representan "quejas" ante las situaciones que viven las mujeres, pues en esta obra no se cuestionaba la situación de subordinación de las mujeres, ni el sistema de poder establecido que las relega al ámbito privado.

No es hasta finales del siglo XVII y comienzos del XVIII en que, aprovechando la coyuntura político-social, se produce la trasformación del Humanismo Renacentista para dar origen al pensamiento moderno (definido por la razón, la libertad y el progreso). Autores como François Poullain de la Barre (1673) sientan las bases teóricas del feminismo, argumentando (con base en la razón) que la desigualdad de los sexos no tiene fundamento natural, sino que procede de un prejuicio cultural. Este autor somete el mundo de las costumbres y el prejuicio a la contrastación, empleando la desigualdad de los sexos para realizar su crítica (Amorós, 2010b, pp. 23-24; Valcárcel, 2013, p. 48).

El periodo de la Ilustración es un movimiento político-intelectual que exalta los principios de la razón, la igualdad, la libertad y la universalidad. Bajo estos principios se formulan los nuevos códigos que han de regir a la nueva sociedad moderna. Sus principales defensores cuestionan los sistemas totalizadores y optan por un discurso filosófico más directo y libre, un discurso que se extiende y se populariza gracias a las transformaciones político-sociales propias de esta 
etapa. $^{8}$ Durante este periodo se planteaban ideas para cambiar las formas de gobierno y con ello mejorar la condición social de los "ciudadanos".

El día 7 de octubre de 1789 se promulga la Declaración de los Derechos del Hombre y del Ciudadano, adoptada por la Asamblea Constituyen en Francia, hecho que significó el fin de un estado de servidumbre y el acceso a la ciudadanía, ${ }^{9}$ reconociéndose algunos derechos humanos como el de la igualdad. Sin embargo, esta no fue aplicada de manera universalista, todo lo contrario, se otorgan beneficios económicos a la burguesía y por supuesto se deja fuera de este proyecto político a las mujeres. ${ }^{10}$

La negativa a la ciudadanía de las mujeres desató diversas críticas. Condorcet, en julio de 1790, escribió un ensayo titulado Sobre la admisión de las mujeres en la ciudadanía, en el cual plantea por vez primera que la exclusión de las mujeres a ejercer su derecho como ciudadanas es un acto discriminatorio y de tiranía. A continuación reproducimos lo descrito por este autor en $1790:^{11}$

¿no han violado todos los principios de igualdad de los derechos al privar tranquilamente a la mitad del género humano del derecho de concurrir a la formación de las leyes, al excluir a las mujeres del derecho de ciudadanía?[...]

Para que esta exclusión no fuera un acto de tiranía, habría que probar que los derechos naturales de las mujeres no son en absoluto los mimos que los de los hombres, o mostrar que no son capaces de ejercerlos.

Ahora bien, los derechos de los hombres se derivan únicamente de que son seres sensibles susceptibles de adquirir ideas morales y de razonar con esas ideas. De esta

\footnotetext{
${ }^{8}$ Aumenta el número de imprentas y el mercado cultural se extiende propiciando la emergencia de productos como los libros, los periódicos, las revistas, los panfletos, las obras eruditas o de consulta encuentran un eco y una demanda impensables sólo un siglo antes (Mestre Chust \& Mayos Solsona, 2007).

${ }^{9}$ Ruiz Carbonell, 2010, p. 71

${ }^{10}$ Las mujeres comprendieron rápidamente que el término de "hombre" y "ciudadanía" no hacía referencia al universalismo del ser humano fundado en los principios de la Ilustración, sino que se continuaba considerando la definición dada por la Enciclopedia de Diderot y de D'Alembert, (1765): Ciudadano: "aquel miembro de una sociedad libre de varias familias que comparte los derechos de esta sociedad y se beneficia de esas franquicias" y que "sólo se otorga este título a las mujeres, a los niños y a los sirvientes como miembros de la familia de un ciudadano propiamente dicho. Mujeres, niños y sirvientes no son verdaderos ciudadanos". citado por Alicia Puleo, (1993, p. 23).

${ }^{11}$ Retomado de Alicia Puleo (1993, p.101).
} 
manera, puesto que las mujeres tienen estas mismas cualidades, tienen necesariamente iguales derechos. ${ }^{12}$

Olympe de Gouges es otro referente feminista de la Ilustración que, tras su descontento con la Declaración de los Derechos del Hombre y del Ciudadano, basó su trabajo en establecer la universalización que se pretendía con esta Declaración. Es así como en 1791 redacta la Declaración de los derechos de la mujer y de la ciudadana, si bien fue guillotinada dos años después tanto por vindicar sus ideas sobre igualdad y libertad, como por criticar la dictadura de Robespierr (Puleo, 1993, p. 155; Valcárcel, 2013, p. 54).

Los políticos argumentaban que esta exclusión de las mujeres no era una negación a sus derechos, ya que no "podrían ser acordados a quien no los necesita porque es la propia naturaleza la que se los ha negado". "No son ciudadanas porque son madres y esposas". "Y lo que se podría entender como una exclusión injusta, no lo es, sino que, muy al contrario, la separación de esferas conviene que sea nítida para el propio bien de las excluidas"(Valcárcel, 2013, pp. 54-55). Políticos de la época, como Charles Maurice de TalleyrandPérigord, Rousseau y E. Kant, muestran su negativa a conceder a la mujer los mismos derechos que a los varones basando sus argumentaciones en cuestiones morales y naturalista. Sin lugar a dudas, estos discursos legitimadores de la desigualdad de los sexos son insostenibles a la luz de la razón. A continuación mostramos las palabras que dedica Rousseau en su "Discurso sobre el origen y los fundamentos de la desigualdad entre los hombres, la división de tareas entre los sexos aparece en la dedicatoria" citado por A. Valcárcel (2013, p. 56):

¿Podría yo olvidar a esta preciosa mitad de la república que hace la felicidad de la otra, cuya dulzura y sabiduría mantienen la paz y las buenas costumbres? Amables y

\footnotetext{
${ }^{12}$ A. Puleo, menciona que Condorcet escribió otros documentos en los que exalta la tarea de la razón y la crítica ante la desigualdad y los prejuicios, considerando que la abolición de los mismo "hará posible el desarrollo de una conciencia moral más plena y el goce de una felicidad hasta el momento desconocida". Este autor fue un defensor de la educación de las mujeres en las mismas condiciones que la de los hombres, pues consideraba que era la única forma de avanzar hacia el progreso (Puleo, 1993, pp. 93-94)
} 
virtuosas ciudadanas, la suerte de vuestro sexo siempre será gobernar al nuestro... Sed siempre, pues lo que sois, las castas guardianas de las costumbres y de los dulces vínculos de la paz; y continuad haciendo valer en toda ocasión los derechos del corazón y de la naturaleza en beneficio del deber y de la virtud.

Estos argumentos, carentes de toda racionalidad, llevan a la autora Mary Wollstoncraft (referente del feminismo) a dedicar parte de su trabajo a la vindicación de los derechos de las mujeres y a dilucidar las incoherencias que persisten en los discursos que intentan dejar fuera a las mujeres de su participación como ciudadanas. Conocedora de las obras de Poullain de la Barre cuestiona el abuso de poder de los varones sobres las mujeres:

Ver una mitad de la raza humana excluida por la otra de toda participación en el gobierno era un fenómeno político que, según los principios abstractos, era imposible explicar. Si es así ¿en qué se apoya su constitución? Si los derechos abstractos del hombre sostienen la discusión y explicación, los de la mujer, por un razonamiento parejo, no rehuirían el mismo examen; aun así, en este país prevalece una opinión diferente, basada en los mismos argumentos que utilizan para justificar la opresión de la mujer: el precepto. [...]

¿Quién hizo al hombre el juez exclusivo, si la mujer comparte con él el don de la razón?"13

La crítica que realiza la autora muestra la incongruencia que existe entre los discursos dados por esos varones que pretenden, a través de la razón, la igualdad y la libertad entre los hombres, acabar con los privilegios de las castas y de la monarquía y sin embargo no plantean los mismos derechos para ellas. Wollstoncraft, al escribir la Vindicación de los derechos de la mujer, (1792), elabora una crítica pormenorizada contra la exclusión de las mujeres y con ella se desata la polémica de la Ilustración, pues evidencia que el poder que los varones ejercen sobre las mujeres no tiene un fundamento racional, sino que este se basa en los prejuicios.

Su obra la basa en el hecho de que las mujeres nacen como seres humanos, pero la "educación descuidada de sus semejantes" es la que provoca que las

${ }^{13}$ Vindicación de los derechos de la Mujer. A.M. Talleyrand-Périgod, antiguo obispo de Autun.(Wollstonecraft, 1994, p. 110). 
mujeres carezcan de las virtudes de la razón y, por tanto, sean inferiores a los hombres, razón por la cual Wollstonecraft apela al Estado educación para las mujeres, alegando que la virtud de la razón ha de ser común a todas las personas para que surta efectos en el progreso general (Wollstonecraft, 1994, pp. 108109).

Su mérito, pues, es doble: por un lado, elabora una vindicación de los derechos políticos y civiles de las mujeres, y, por otro lado, sus aportaciones muestran por primera vez la naturaleza del problema, los varones gozaban de privilegios injustos sustentados en preceptos inmemoriales (Postigo Asenjo, 2006).

Las vindicaciones generadas por estos/as autores/as: Poullain de la Barre, Condorcet, Gouges y Wollstonecraft sientan las bases del feminismo como movimiento y como teoría, al evidenciar que los cambios políticos exigidos para conseguir mayor libertad ciudadana, no "pretendían alterar la jerarquía ancestral de los sexos", cuestión que carecía de fundamento crítico y racional (Amorós, 2010b, p. 116). Estas obras reflejan cómo el feminismo fue, en palabras de C. Amorós, el "Pepito Grillo y la Cenicienta" de la Ilustración (Amorós, 2010b, p. 26). "Pepito Grillo" porque las obras citadas con anterioridad dan cuenta de la primera corrección fuerte y significativa al democratísimo Ilustrado. "Cenicienta", debido a que se muestra con claridad cómo este periodo convulso de transformaciones político sociales es deudor de extrapolar los principios de igualdad, libertad y justicia a las mujeres, basándose en discursos que eran incongruentes.

Así pues, en la Ilustración las mujeres se apropian de las ideas de igualdad. Como bien menciona Valcárcel, por vez primera se cuestionó el hecho de que las mujeres fueran el sexo dominado por designio de la naturaleza, orden inalterable (2013, p. 16). No obstante, esto no fue suficiente para que las cosas se tornaran distintas para las mujeres de esa época. Una vez pasados los albores 
de la Revolución, las mujeres quedan relegadas al ámbito doméstico y sus derechos son postergados de nueva cuenta, pues con la nueva legislación civil y penal las mujeres quedaban consagradas a la minoría de edad perpetua, consideradas hijas o madres en poder de sus padres, esposos e incluso de sus hijos. No tenían tampoco derecho a administrar su propiedad, fijar o abandonar su domicilio, ejercer la patria potestad, mantener una profesión o emplearse sin permiso. La obediencia, el respeto, la abnegación y el sacrificio quedaban fijados como sus virtudes obligatorias. Se crearon delitos específicos para ellas, como el adulterio y el aborto. El modelo educativo que también tuvo trasformaciones fundamentales, ${ }^{14}$ igualmente dejaba fuera a las mujeres (Valcárcel, 2013, pp. 59-60).

Es así como esta primera ola del feminismo, aunque no consigue formar parte de la agenda política de la época, sí que sienta las bases conceptuales para continuar con la lucha por los derechos y libertades de las mujeres.

A modo de síntesis, en este apartado hemos podido constatar que la primera ola del feminismo dura más de un siglo, su primer gran referente es Poullain de la Barre. La vindicación de los derechos de las mujeres desata la polémica feminista ilustrada, por ello se convierte en el primer referente teórico feminista, pues se denuncia la discriminación que sufren las mujeres y se genera una crítica de cómo lo que se consideraba inferioridad moral, intelectual y bilógica no tenía más fundamento que la irracionalidad: las mujeres no es que careciesen de las virtudes de la razón, sino que estás eran domesticadas para ocupar una posición social y civil de subordinación con relación a los varones.

\subsubsection{La segunda ola}

El movimiento feminista organizado teje sus redes de acción tras el incumplimiento de las demandas de igualdad generadas en la primera ola -

\footnotetext{
${ }^{14}$ Se establecen los niveles educativos que hasta la fecha conocemos: educación primaria, media y superior; el Estado se vuelve el garante de los programas y proyectos educativos y la educación se convierte en el medio a través del cual se puede acceder a una profesión.
} 
periodo de las luces - y favorecido por los cambios sociales, políticos, económicos y científicos que se estaban instaurando en el mundo "moderno" del siglo XIX (Amorós, 2010b; Amorós \& Miguel Álvarez, 2007; Astelarra, 2005; Maldonado Barahona, 2013b).

Al inicio de este siglo las mujeres, conocedoras de las obras que vindicaban la igualdad entre hombres y mujeres en el periodo ilustrado (Poullain de la Barre, Gouges, Condorcet, Wollstonecraft), reclamaban derechos para ser tratadas como seres humanos. Sin embargo, en la mayor parte de los países occidentales estas demandas son rechazadas y se prohíbe que las mujeres realicen actividades que no se ciñan al espacio privado. A este respecto, A. Valcárcel menciona que en este siglo se edifica una "misoginia romántica" con la que se pretende mantener la exclusión de las mujeres, basándose en la conceptualización rousseauniana y que tuvo como "fin (re)argumentar la exclusión". La retórica religiosa y moral sobre la inferioridad de la mujer es sustituida por las teorizaciones construidas por filósofos de gran calado social y político del siglo XIX, entre los que podemos ubicar a autores como "Hegel, Shopenhauer, Kierkegaard, Nietzche". ${ }^{15}$ En este siglo se redefine el sistema patriarcal de Rousseau, atribuyendo la exclusión de la mujer a cuestiones biológicas (Miyares, 2007; Valcárcel, 2013, p. 66).

Lo que llamamos misoginia romántica[...] es un complejo ideológico que se despliega en varios registros, desde la idealización de la Mujer en una versión del amor cortés adaptada a una nueva tópica de la sensibilidad y a una peculiar reelaboración simbólica de referentes sociohistóricos perdidos [...] hasta su descripción en los términos naturalistas más peyorativos [...] (Amorós, 2000, p. 205).

Ante estas condiciones de sujeción y exclusión a las que estaban sometidas por parte de los sectores conservadores, las mujeres tuvieron que abrirse paso para reclamar los derechos de los que habían sido excluidas (Astelarra, 2005).

${ }^{15}$ En "La misoginia romántica" se pueden conocer los argumentos que elaboran los autores citados para mantener a las mujeres fuera de toda participación política y ciudadana (Valcárcel, 2013, pp.66-68). Alicia Miyares en "El sufragismo" también hace referencia a algunas teorizaciones que elaboran los autores citados (Miyares, 2007, p. 262) 
Pero no fueron las únicas, este periodo fue el escenario político de distintas pugnas sociales: libertad, derecho a la propiedad, sufragio..., de las cuales se derivan tres teorías políticas: el liberalismo por medio de las revoluciones burguesas, el marxismo mediante el movimiento obrero, el feminismo a través del movimiento sufragista, que van a tener mayor repercusión en las trasformaciones sociales, políticas, económicas y culturales establecidas en la actualidad (Miyares, 2007).

Vamos a analizar el desarrollo del movimiento sufragista dividiéndolo en las acciones que se llevaron a cabo en los dos países donde tuvo mayor fuerza el movimiento sufragista: en Estados Unidos de América (EUA) y en el Reino Unido (Amorós, 2010b; Astelarra, 2005; Maldonado Barahona, 2013b; Miyares, 2007; Valcárcel, 2013; Varela, 2008). También vamos a retomar los periodos propuestos por Alicia Miyares para ubicar la temporalidad de los acontecimientos de emancipación de la mujer que se emprendieron durante el siglo XIX. Así pues la autora propone tres periodos: el primero va de 1848 a 1871, el segundo de 1871 a 1900 y finalmente el periodo de 1900 hasta el periodo de entre guerras (Miyares, 2007, p.251).

- Movimiento sufragista en Estados Unidos de América

Los años treinta y cincuenta del siglo XIX están marcados por distintas protestas y manifestaciones de grupos de personas que abogan por los derechos de libertad de los esclavos en EUA. Este movimiento es apoyado por colectivos de mujeres, las cuales, tras su participación en este movimiento, se concienciaron de la desigualdad de las mujeres y plantearon la necesidad de luchar de manera global para establecer un nuevo orden político donde todos los seres humanos tuvieran los mismos derechos. En este contexto, en 1848 se comienzan a gestar las reivindicaciones de los derechos de las mujeres. Por primera vez, un grupo de alrededor de setenta mujeres y de treinta varones de diversos movimientos y asociaciones políticas de talante liberal, lideradas por 
Elizabeth Cady Stanton y Lucretia Mott, se reunieron en el Hall de Seneca y firmaron lo que llamaron la "Declaración de Sentimientos". En ella se perseguían dos propósitos fundamentales: 1. Alcanzar la ciudadanía civil; 2. Modificar las costumbres y la moral. No obstante, más tarde, en los sesenta del siglo XIX, Cady Stanton junto a Susana Anthony, llegan a la conclusión de que la lucha por los derechos de las mujeres debe ser definida por la capacidad de las mismas para asociarse. Llegaron a esta reflexión tras decretarse el derecho al voto de los esclavos varones, en 1866, que si bien fue definido como sufragio universal, excluyó nuevamente a las mujeres (Miyares, 2007; Varela, 2008).

A finales de los sesenta, Cady Stanton y Susana Anthony habían formado un grupo de mujeres organizadas cuyo objetivo central era conseguir el voto, ya que consideraban que con él podían asegurar la igualdad entre los sexos. De todos modos, solo en 1920 las mujeres estadounidenses consiguen el voto (Miyares, 2007; Varela, 2008).

- Movimiento sufragista en Reino Unido

En este país el movimiento sufragista se articularía más tarde que en EUA, y tuvo como principales referentes a Harriet Taylor y John Stuart Mill, que sentaron las bases de la teoría política en que el sufragismo se movió no solo en este país, pues sus obras fueron publicadas en diversos países convirtiéndose en referentes teóricos globales del feminismo.

Las obras de Harriet Taylor y John Stuart Mill, se encuadran en la corriente utilitarista, en esta corriente se afirma que la felicidad es "el único valor que es un fin en sí mismo, a partir de ahí cualquier medida legal o política, cualquier acción humana será considerada justa y buena si contribuye a aumentar la mayor felicidad del mayor número de personas" (De Miguel Álvarez, 2007a, p. 179). Este principio es retomado para formular las demandas del sufragio universal. Harriet Taylor influye de manera significativa en las obras de S. Mill, 
llegando a reconocer este ultimo que Taylor es prácticamente coautora de algunas de sus obras.

La obra principal de Mill es "La sujeción de la mujer" fue publicada en 1869 y en ella los principios de felicidad, justicia y libertad son cruciales para desarrollar su filosofía moral. A. Miyares especifica que esta obra constituye una denuncia contra la esclavitud legal, la educación deficitaria y la opresiva moral que se ejerce sobre las esposas (Miyares, 2007). Para Mill la subordinación de las mujeres es injustificada a la par que perjudicial para el progreso de la humanidad en el nuevo orden liberal.

Ana De Miguel (2007) nos explica que el objetivo del trabajo de Mill fue desarticular los prejuicios con relación a la idea de la "naturaleza diferente y complementaria de la mujer", las concepciones que justificaban las diferencias que existían entre varones y mujeres en el desempeño de tareas y funciones se basaban en dos nociones. Por un lado se consideraba que la desigualdad o la complementariedad de la mujer era producto de su inferioridad: carencia de cualidades físicas, morales o intelectuales. Por otro lado existía un discurso que exaltaba la superioridad de la mujer: cualidades femeninas: virtud, abnegación, intuición intelectual... Mill consideró que tanto los discursos de inferioridad como los de superioridad dejaban a la mujer en una posición de subordinación pues el mero hecho de alabarlas no les otorgaba igualdad. Para romper con estas nociones Mill emplea tres argumentos principales: 1. Argumento agnóstico, con este argumento Mill expresa que si bien es cierto que existen diferencias intelectuales y morales entre hombres y mujeres - hasta ese momento-, estas diferencias son producto de una educación que tiende a anularlas como personas autónomas, así como educarlas para ser siervas. También manifiesta cómo la sociedad relega a la mujer del espacio privado; 2. Argumento empírico, lo construye tomando en cuenta tanto los ejemplos de mujeres que han desempeñado de manera adecuada funciones tradicionalmente de varones, como 
defendiendo que los rasgos propios de las mujeres serian útiles para el resto de la humanidad; 3. Argumento de universalización, todos los discursos sobre la felicidad y la libertad para los varones, lo son también para las mujeres, "no existen recortes a la universalidad" (De Miguel Álvarez, 2007a, pp. 187-194).

Así pues, en el periodo (1865-1868) que Mill funge como parlamentario, el movimiento sufragista elabora una petición firmada por 1499 mujeres para exigir el voto de las mujeres que eran contribuyentes, que fue rechazada. Debido a este rechazo, durante los años siguientes, de 1867 a 1897, se constituyó un movimiento sufragista que exigiría, en repetidas ocasiones, el derecho al voto y el derecho a la educación de las mujeres, pero nuevamente estas demandas fueron denegadas, hasta en tres ocasiones, en el parlamento. En 1880 se hace extensivo el voto a varones de clases menos favorecidas, provocando varios desacuerdos entre el movimiento sufragista. El hecho que provoca que se dividan las opiniones fue que una parte de este movimiento defendía que se hiciera extensible el voto a todas las mujeres solteras, viudas y casadas, mientras que otra facción exigía el voto solo para las mujeres con estatus de contribuyentes. De cualquier forma, no es hasta 1897 que las asociaciones sufragistas conforman un solo movimiento, liderado por Millicent Garret Fawcett, que tiene la característica de ser más reivindicativo políticamente, asumiendo por lo tanto la reivindicación del sufragio para todas las mujeres, contribuyentes o no.

Los métodos empleados por este movimiento fueron cambiando en el trascurso del tiempo. A partir de 1905 — periodo en que el Partido Liberal entra al poder y el derecho al voto de las mujeres es nuevamente negado - otra de las dirigentes del movimiento sufragista, Emmeline Pankhurst organiza manifestaciones, ataques directos a la propiedad y desobediencia civil. ${ }^{16}$ Estos

\footnotetext{
${ }^{16}$ Las palabras de E. Pankhurstn reflejan la situación de efervescencia que vivía el movimiento feminista por esos años: "nos tienen sin cuidado vuestras leyes, caballeros, nosotras situamos la libertad y la dignidad de la mujer por encima de todas esas consideraciones, y vamos a continuar esa
} 
métodos fueron sancionados por el Gobierno, llevándolas a prisión. Incluso encarceladas continuaron reivindicando el sufragio para las mujeres, hasta que en el año 1913 se desarticuló este movimiento. No obstante, cuatro años después, en 1917, las británicas de 30 años obtienen el derecho al voto. Pasaron, pues, 11 años más para que el sufragio de la mujeres se equiparase con el de los varones (Miyares, 2007, pp. 285-288).

Después de describir las acciones que emprendió el movimiento feminista en estos dos países, vamos a resumir los logros conseguidos durante los periodos en los que se desarrolla el movimiento sufragista:

- En el periodo de 1848 a 1871 mujeres y hombres se reúnen para formar un colectivo que aboga por la igualdad de los sexos. Es decir, se concreta el asociacionismo principalmente de mujeres de manera organizada, sobre todo en EUA y en Reino Unido, aunque no va a tener repercusiones a nivel global.

- En el período de 1871 a 1900 se cristalizan algunas de las demandas civiles que reivindican las mujeres. Así pues, se comienza a admitir a las mujeres en educación media y superior en algunas partes de Europa y de EUA. Sin embargo lo que motivó esta incursión era la conveniencia de contratarlas posteriormente como maestras, pues su contratación suponía una menor remuneración. En algunos lugares de EUA se otorga el derecho a las mujeres de cobrar sus propias rentas, heredar propiedades y entablar acciones judiciales.

- De 1900 hasta el periodo entreguerras las mujeres consiguen su derecho al voto en la mayor parte de países europeos y en EUA. Solo en sociedades autoritarias o en donde la iglesia tenía mayor poder,

guerra como lo hicimos en el pasado; pero no seremos responsables de la propiedad que sacrifiquemos, o del perjuicio que la propiedad sufra como resultado. De todo ello será culpable el Gobierno, que, a pesar de admitir que nuestras peticiones son justas, se niegan a satisfacérnoslas..." Miyares citando a E. Pankhurstn (2007, p. 287). 
estas conquistas fueron más tardías. En contraposición a los derechos conseguidos, se despliega una nueva radicalización de la misoginia fundada en teorías emergentes (psicoanálisis, psicología), cuyos postulados discurrían sobre la anomalía mental del sexo femenino.

Cabe destacar que en el periodo entreguerras, con la llegada del capitalismo y la falta de mano de obra, las mujeres se incorporan al mercado laboral de manera masiva, lo que les permite ser conscientes de que realmente podían mantener un país a flote y que las cuestiones por las cuales eran excluidas del mundo público no se podían sostener con argumentos naturalistas-biologicistas. $\mathrm{Al}$ retornar los varones de la guerra las mujeres son despojadas de sus puestos de trabajo, pues lo hombres los reclaman. Esta vez las mujeres poseían derechos y educación, lo cual les otorgaban las facultades para poder continuar en ellos, de ahí que las medidas que se ponen en marcha para dejarlas fuera del ámbito público sean realmente ruines. Se crea todo un entramado de estrategias para "reconducir a las mujeres al hogar", que consistieron en construir un modelo de mujeres "libres y competentes" (Valcárcel, 2013, p. 77). "Libres" para tomar la sabia decisión de construir un hogar - mujeres que teniendo los derechos para poder acceder al ámbito laboral, optaban por renunciar a ellos por el "bien de la familia"-. "Competentes" para realizar el trabajo doméstico como si de una empresa se tratara, y velar por la unidad familiar, imagen de la mujer que se promovió a través de los diversos medios de comunicación: revistas, televisión, radio, cine. Así trascurren las décadas de los 20 a los 50.

A modo de recapitulación, podemos decir que el movimiento feminista en este periodo fue orientado mayoritariamente hacia el sufragismo, que se basa en los principios del derecho natural, la justicia, la libertad y la felicidad. ${ }^{17} \mathrm{El}$

17 Prudencia Gutiérrez y $\mathrm{M}^{\mathrm{a}}$ Rosa Luengo nos explican cómo las mujeres defienden estos principios en conexión con las nuevas corrientes del individualismo liberal y de la Ilustración, dando lugar al feminismo liberal que se ocupa de ampliar los derechos legales, políticos y laborales de las mujeres de la clase media. (Gutiérrez Esteban \& Luengo González, 2011). 
derecho al voto y a la educación fueron el eje en el que centraron sus demandas, pues consideraban que consiguiendo estas dos demandas se podrían obtener objetivos más significativos: acceso a la cultura, a la política, al mercado laboral... Este movimiento tuvo especial fuerza en Estados Unidos y en Reino Unido, ejemplos que sirven para mostrar que el movimiento feminista tuvo que luchar abierta y decididamente para conseguir el derecho al voto, empleando para ello diversos métodos: la manifestación pacífica, la interrupción de oradores mediante preguntas sistemáticas, la huelga de hambre, el auto encadenamiento, la tirada de panfletos vindicativos. ${ }^{18}$ Los logros (el voto y la educación) que se plantearon desde el movimiento sufragista fueron conseguidos en un lapso de más de 80 años en la mayor parte de los países occidentales. ${ }^{19}$ Sin embargo, los derechos conquistados demostraron al movimiento feminista que la desigualdad de los sexos no sería desarticulada solo por tener participación a nivel parlamentario y por el acceso a la educación (Astelarra, 2005).

\subsubsection{La tercera ola}

El siglo XX es posiblemente el periodo de mayores transformaciones sociales y políticas. Por primera vez en la historia las mujeres obtienen derechos civiles que les permiten tener capacidad de decisión política y acceso a la educación. Sin embargo, el sistema patriarcal no es tan fácil de desarticular, esto lo podemos corroborar las mujeres incluso en la actualidad.

En las primeras décadas del siglo XX, las mujeres tienen nuevas expectativas para soñar, dibujar y configurar realidades distintas para ser personasciudadanas. Aunque la lucha por los derechos civiles fue lenta, por fin las mujeres entraban al siglo XX con los derechos que les permitían formarse y

\footnotetext{
${ }^{18}$ A. Valcárcel considera que estos métodos (lucha pacífica y la agitación cívica) son unas de las aportaciones propuestas y puestas en marcha por el sufragismo (Valcárcel, 2013, p. 74).

${ }^{19}$ A excepción de los países en los que la iglesia católica o los gobiernos autoritarios pusieron trabas para que se concedieran estos derechos a las mujeres.
} 
participar en la política. El asociacionismo de las mujeres se había desintegrado prácticamente pues consideraban que una vez conseguidas las demandas formuladas, la desigualdad desaparecería. ${ }^{20}$ Pronto se dieron cuenta de que la opresión de las mujeres no se iba a desmantelar solo por el reconocimiento de los derechos, esta vez las estrategias que entraron en juego por parte de las autoridades no fueron negarles los derechos, sino construir un conjunto de estereotipos para que las "mujeres modernas" con formación y derechos se convencieran de que el trabajo más importante que podían y debían desempeñar era el de amas de casa.

Nuria Varela nos explica que en el periodo de posguerra se reanuda la domesticación de la mujer, debido a que el gobierno precisa que las mujeres regresen al ámbito doméstico por tres cuestiones principalmente. La primera está relacionada con alejar a las mujeres del mercado laboral para reubicar a los varones que habían regresado del frente; la segunda está asociada a incrementar la natalidad de los países que estuvieron en conflicto bélico -pues la pérdida de vidas tras la guerra fue incalculable-; y finalmente se pretendía reactivar la economía, por lo cual se desarrollaron bienes de consumo y electrodomésticos, y en consecuencia se pretendía conseguir que las mujeres estuvieran dispuestas a consumir y regresar al hogar aceptando la división de funciones tradicionales.

Las exigencias llevadas a cabo por las autoridades y la sociedad patriarcal tuvieron consecuencias para las mujeres de clases medias. Pronto se comenzó a generalizar un mal que "no tenía nombre" en palabras de la autora Betty Friedan (1993). En esa época, que coincide con la emergencia de nuevas corrientes psicológicas, las mujeres presentan síntomas de desgana y fatiga, "enfermedades mentales" que los psicoanalistas rápidamente atribuyeron a las

\footnotetext{
${ }^{20}$ También influyó el desgaste y cansancio de la principales líderes de feminismo, no olvidemos que su lucha duró más de ochenta años. Cabe señalar que de las dirigentes que iniciaron el movimiento de sufragio en los Estados Unidos de América, solo una de ellas (Charlotte Woodward) consiguió ser partícipe de unas elecciones presidenciales en 1920 (Varela, 2008).
} 
mujeres. Es aquí donde entra en juego la figura de la feminista estadounidense Betty Friedan, (1963) con su obra "La Mística de la Feminidad” que será clave "para el resurgimiento del movimiento y la teoría feminista en los años siguientes" (Trimiño Velásquez, 2010, p. 291). En su obra analiza el "problema de la identidad femenina", afirmando que el origen del "mal de las mujeres" no se deriva de cuestiones patológicas propias de las mujeres, sino que las exigencias sociales-culturales crean estereotipos femeninos que no se corresponden con las mujeres reales.

Es así como se inicia el movimiento feminista de la tercera ola. Las mujeres que se estaban formando en la Universidad de los últimos sesenta y los primeros setenta fueron las protagonistas de ser ciudadanas con derechos, pero sin ellos, día a día fueron enfrentando situaciones que las excluían de la participación en el ámbito público y las relegaba al ámbito doméstico. Pero esta vez algo había cambiando, las mujeres ya no solo se movilizaban sino que también teorizaban. A este nuevo estado de cosas lo llamaron patriarcado. Valcárcel (2013, p. 80) nos explica que este término fue acuñado por las feministas de la tercera ola para significar el orden político-social que mantenía la jerarquía masculina inamovible independientemente de los derechos conseguidos.

Así fueron surgiendo los análisis, datos y aportaciones desde diversas disciplinas (psicología, antropología, sociología...), de autoras como Kate Millet, S. Firestone, Simone de Beauvoir que fueron configurando las obras de cabecera para este periodo de trasformaciones donde las mujeres reclamaban sus derechos y sus libertades.

En este primer periodo del siglo $\mathrm{XX}$, el feminismo comienza a dibujar una teoría que retoma diversos postulados del conocimiento para posteriormente apropiárselos y construir nuevas formar de visibilizar la desigualdad entre los sexos. Sheila Rowbotham menciona que en esta década se crea una política que cuestiona lo "femenino como destino": 
In the 1970's women's liberation developed a politics which starts from questioning the given in what is seen as female destiny in the dominant culture and then moves outwards to look at the social structures and relationships in which women learn to be women $(1985$, p. 661).

Así pues, en la siguiente tabla podemos observar las corrientes feministas en el primer periodo del siglo XX.

Tabla 1.1. Postulados feministas desde la década de los 60 hasta principios de los 80

\begin{tabular}{|c|c|c|c|}
\hline \multirow{2}{*}{ Postulado } & \multicolumn{2}{|r|}{ Principales obras } & \multirow{2}{*}{ Objetivo } \\
\hline & Autoras/es & Obras & \\
\hline Radical & $\begin{array}{l}\text { Sulamith } \\
\text { Firestone }\end{array}$ & $\begin{array}{l}\text { "La dialéctica de la } \\
\text { sexualidad" }\end{array}$ & $\begin{array}{l}\text { Control sexual y reproductivo; } \\
\text { Poder económico, social y } \\
\text { cultural; Organizaciones no } \\
\text { jerárquicas, solidarias y } \\
\text { horizontales; } \\
\text { Independencia total de los } \\
\text { partidos políticos y los sindicatos. }\end{array}$ \\
\hline \multirow[b]{2}{*}{$\begin{array}{l}\text { Socialista } \\
\text { y marxista }\end{array}$} & $\begin{array}{l}\text { August } \\
\text { Bebel }\end{array}$ & "Mujer y socialismo" & \multirow{2}{*}{$\begin{array}{l}\text { Nueva visón del origen de la } \\
\text { opresión de las mujeres. } \\
\text { Vindica la abolición del } \\
\text { capitalismo como la disolución } \\
\text { del sistema patriarcal (Las clases } \\
\text { sociales y la diferencias de género } \\
\text { han de ser erradicadas para que las } \\
\text { mujeres determinen libremente las } \\
\text { condiciones de su vida). }\end{array}$} \\
\hline & $\begin{array}{l}\text { Alejandra } \\
\text { Kollontain }\end{array}$ & $\begin{array}{l}\text { Activista -Impulsa la OMI* } \\
\text { Escribió conferencias, } \\
\text { panfletos... } \\
\text { "La mujer nuevay la moral } \\
\text { sexual y otros escritos" } \\
\text { "Marxismo y revolución } \\
\text { sexual" } \\
\text { "La opresión obrera" }\end{array}$ & \\
\hline Liberal & $\begin{array}{l}\text { Betty } \\
\text { Friedan }\end{array}$ & $\begin{array}{l}\text { "La mística de la } \\
\text { feminidad" }\end{array}$ & $\begin{array}{l}\text { Reformar el sistema para lograr la } \\
\text { igualdad entre los sexos: } \\
\text { Mayor participación en la vida } \\
\text { pública, en el mercado laboraly } \\
\text { en acceso a cargos políticos. }\end{array}$ \\
\hline
\end{tabular}

Fuente: elaboración propia con base en: Bodelón, 1998; De las Heras Aguilera, 2009; Gamba, 2008; Varela, 2008.

Nota: OMI= Organización de Mujeres a nivel Internacional.

Los movimientos feministas —establecidos a finales de los sesenta y principios de los ochenta, como se puede observar en la tabla-, derivan sus acciones en tres perspectivas que marcan distintas visiones sobre la situación de las mujeres: el feminismo liberal, el feminismo socialista y el feminismo radical. En este periodo se construyen nuevas vindicaciones, "abolir y cambiar 
las leyes", "lo personal es político" y "mi cuerpo es mío" (De las Heras Aguilera, 2009; Valcárcel, 2013, p. 110; Varela, 2008).

Nuria Varela menciona que, después de la década de los setenta, los movimientos feministas, sobre todo el movimiento feminista radical, consiguieron calar hondo en todas las formas de hacer política y práctica feminista (2008). ${ }^{21}$ Desde los 70 hasta la actualidad el feminismo no ha cesado en su labor de evidenciar la desigualdad que sufren mujeres y hombres por no ajustarse a los modelos tradicionales socialmente establecidos (Casado Aparicio, 1999).

En cuanto a la vindicación de "abolir el patriarcado y cambiar las leyes", las feministas de los años setenta realizaron un trabajo minucioso en el terreno legislativo, intentando erradicar todas aquellas partes en las que existieran desigualdades por razón de sexo y se añadieron un conjunto nuevo de libertades. En este periodo se realizaron también revisiones y reformas legales que permitieran a las mujeres el efectivo uso de su libertad, lo que coincidió con la emergencia de la internacionalización de los derechos humanos y de las mujeres.

Con relación a la vindicación "lo personal es privado" y "mi cuerpo es mío", lo que se persigue es tanto posicionarse en el ámbito público (igualdad de derechos civiles y políticos: educativos, laborales, representación política), como transformar el espacio privado (analizar las relaciones de poder dentro del ámbito familiar y sexual). Estas demandas tienen efecto a nivel internacional: miles de mujeres en Estados Unidos, Francia, Inglaterra... salen a las calles para manifestar su desacuerdo ante la falta de igualdad de oportunidades (Varela, 2008). Con ello se consigue que temas como los derechos sexuales y reproductivos, los anticonceptivos, el aborto, el trabajo doméstico...

\footnotetext{
${ }^{21}$ Se acuñan las categorías de análisis principales de los feminismos: "patriarcado", "género" y "casta sexual".
} 
incursionaran en la agenda pública de algunas regiones de occidente. El feminismo de este periodo no solo exigía la igualdad formal (derechos legales), también se demandaba la igualdad social y cultural que las dejaba en permanente desventaja con relación a los varones (Valcárcel, 2013, p. 110).

Entrada la década de los ochenta el feminismo ya no podía seguir siendo visto desde un único frente — como se hizo con el movimiento sufragista-, dado que tanto su praxis como su producción teórica se expandieron a nivel mundial, originando características, tiempos y necesidades diversas. Por consiguiente, a partir de este momento resulta más adecuado hablar de feminismos. Sobre esto Isabel Torres, en el prologo del libro de Jane Freedman señala lo siguiente:

No se ha manifestado de forma monolítica y universal, sino muy diversificado en sus métodos de actuación, en sus prioridades, e incluso, en sus fundamentaciones teóricas previas, que hunden su raíces ya en el marxismo o el psicoanálisis, en el estructuralismo o el pensamiento postmoderno (Freedman, 2004b, p. 9).

A continuación presentamos una tabla en la que se muestran algunas de las corrientes feministas (lésbica, psicoanálitica, posmoderna, posestructuralista, de la diferencia y de la igualdad) que se consolidaron a partir de la década de los ochenta.

Tabla 1.2. Corrientes feministas a partir de la década de los 80

\begin{tabular}{|c|c|c|c|}
\hline Corriente & $\begin{array}{r}\text { Princ } \\
\text { Autoras/es }\end{array}$ & $\begin{array}{c}\text { pales obras } \\
\text { Obras }\end{array}$ & Objetivo \\
\hline 疋 & $\begin{array}{l}\text { Sheila } \\
\text { Jeffries } \\
\text { Adrienne } \\
\text { Rich } \\
\text { Monique } \\
\text { Wittig }\end{array}$ & $\begin{array}{l}\text { "Lesbians in } \\
\text { Revolt" } \\
\text { "The lesbian } \\
\text { heresy. A } \\
\text { feminist } \\
\text { perspective on } \\
\text { the lesbian } \\
\text { sexual } \\
\text { revolution" } \\
\text { "La } \\
\text { heterosexualida } \\
\text { dobligatoria } y \\
\text { la existencia } \\
\text { lesbiana" } \\
\text { "La categoria } \\
\text { de sexo en el } \\
\text { pensamiento } \\
\text { heterosexual } y \\
\text { otros ensavos" }\end{array}$ & $\begin{array}{l}\text { Transgresión } \\
\text { de los géneros. } \\
\text { Denunciar la } \\
\text { violencia } \\
\text { contra las } \\
\text { mujeres; } \\
\text { Proponer la } \\
\text { creación de } \\
\text { centros de } \\
\text { acogida. }\end{array}$ \\
\hline
\end{tabular}




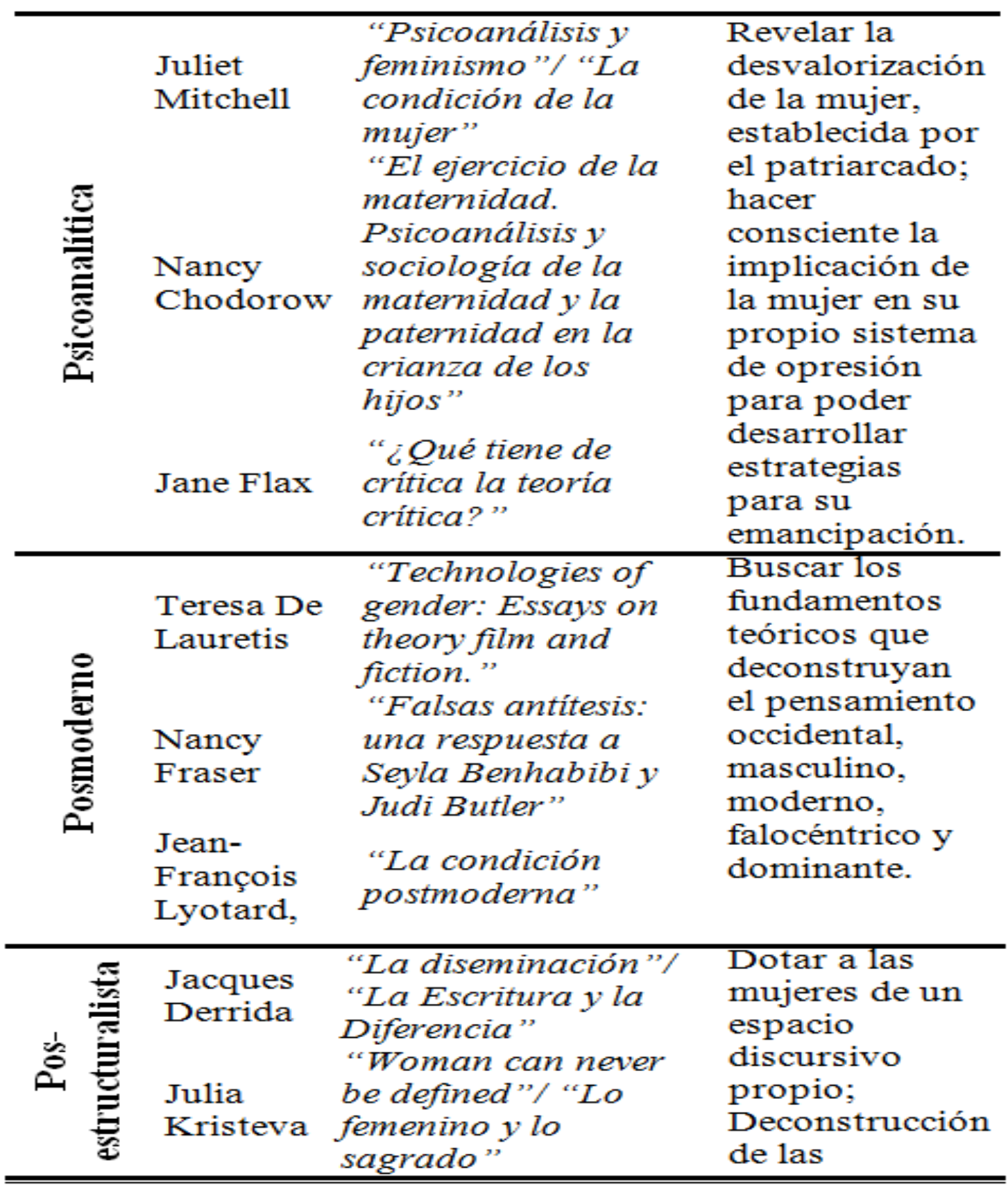

Fuente: elaboración propia basándome principalmente en De las Heras Aguilera, 2009; Gamba, 2008; Gutiérrez Esteban \& Luengo González, 2011; Méndez Pérez, 2008. ${ }^{22}$

${ }^{22}$ Para cada una de las corrientes hemos buscamos documentos que nos permitieran tener una visión más amplia. Los documentos consultados para desarrollar el cuadro se mencionan a continuación. Corriente lésbica: Castellanos Llanos, (2011); corriente psicoanalítica: Izquierdo, en "El malestar en la desigualdad" (1998a) y Rohr, en "Feminismo y psicoanálisis" (1993); corriente posmoderna: Piedra Guillén, en "Feminismo y postmodernidad: entre el ser para sí o el ser para los otros" (2003) y finalmente la corriente pos-estructuralista: Rifá Valls, en "Michel Foucault y el giro postestructuralista crítico feminista en la investigación educativa" (2009) y Zambrini y Iadevito, en "Feminismo filosófico y pensamiento post-estructuralista: teorías y reflexiones acerca de las nociones de sujeto e identidad femenin" (2009); corriente de la igualdad: Puleo, en "Igualdad y androcentrismo" (1995). Las corrientes de la diferencia y la institucional, se elaboraron con la información de los documentos base enunciados en la fuente. 
Como se puede observar en la tabla 1.2. la diversificación de propuestas que analizan y denuncian la desigualdad de las mujeres se ha ido incrementando a través de los años. Con esto se logró colocar la cuestión de la emancipación de las mujeres en la agenda pública y la producción académica no solo aumentó sino que se expandió a otras áreas del conocimiento. No obstante, el movimiento social en la práctica fue perdiendo fuerza, diversas autoras así lo manifiestan (Lamas, 2002; Méndez Pérez, 2008; Valcárcel, 2013; Varela, 2008). ${ }^{23}$ No es que se haya desarticulado el movimiento, sino que las feministas encontraron cabida en el ámbito institucional: universidades, organismos internacionales, ONGs y espacios gubernamentales.

Los feminismos de los últimos años encontraron las vías para conseguir que el tema de la desigualdad de género fuera una cuestión de Estado. Cada corriente, desde su entorno más cercano, formuló e hizo visibles temas que seguían sin estar resueltos a pesar de los años que habían trascurrido desde las primeras vindicaciones, como las deficiencias de los sistemas de salud reproductiva, el aborto, las relaciones de poder, las diferencias salariales, la doble jornada, los techos de cristal, la violencia de género, los feminicidios, el sexismo en la educación, el sexismo en los medios de comunicación, la invisibilización de la participación de las mujeres en el trascurrir de la historia,... Se pusieron sobre la mesa cuestiones que atañen a mujeres y a hombres que abogan por una sociedad libre, justa y equitativa.

Otro aspecto que debemos señalar, es que en la tabla 1.2 no fue posible incluir el total de corrientes feministas que existen en la actualidad, pues, como se mencionó en párrafos anteriores, la producción académica que toma como base las teorías feministas se ha diversificado dando lugar a un sin número de propuestas. El artículo elaborado por Gutiérrez Esteban y Luengo González, (2011) hace una recapitulación amplia de los feminismos que existen en la actualidad: las corrientes, obras y autoras/es.

${ }^{23}$ Estas autoras consideran que es necesario no olvidar que los feminismos tienen que seguir en las calles, si bien es cierto que muchas de ella opinan que la institucionalización del feminismo es favorable. Sin embargo no comulgan con la idea de hacer teoría sin tener en cuenta lo que sucede en el día a día con las mujeres y los hombres. El movimiento tiene que seguir vivo. 
Haciendo una recapitalización de este apartado, podemos destacar que el feminismo de la tercera ola acuña dos categorías, género y patriarcado, que van a ser claves para la construcción de argumentos críticos que promuevan la emancipación de la mujer. Los análisis y reflexiones derivadas de la categoría "género" van a tomar caminos muy distintos dependiendo de la corriente que las estudie. La corriente de la diferencia, por ejemplo, considera que es necesaria la revalorización de la identidad femenina para lograr que la mujer sea libre y autónoma. Las corrientes posmoderna y posestructuralista plantean que las categorías binarias (hombre/mujer, femenina/masculino) han de desaparecer para poder establecer una sociedad regida por la igualdad. En cambio, la corriente de la igualdad cree que a través de la deconstrucción de los estereotipos de género se puede desarticular el sistema de dominación patriarcal. Aunque estas corrientes tienen objetivos distintos y en ocasiones opuestos, todas ellas comparten el propósito principal de trasformar la situación de desigualdad que lleva a las mujeres (principalmente) y a los hombres a no tener las mismas oportunidades para conseguir un desarrollo pleno.

La diferencia principal entre la segunda y la tercera ola, es el cambio de estrategia para conseguir la igualdad: mientras que en la segunda ola las feministas apuestan por formaciones horizontales y sin líderes, en la tercera ola se decantan por institucionalizar las vindicaciones sobre la emancipación de las mujeres.

\subsection{El movimiento feminista en México}

Rosario Castellanos (1950): «Ellos holgadamente atraviesan para desembocar en un mundo luminoso, sereno, altísimo. Incomparablemente mejor que el que yo habito [...] El mundo que para mí está cerrado tiene un nombre; se llama cultura.

Sus habitantes son todos ellos del sexo masculino» (Citada por Hierro, 2002, p. 32)

Con este apartado pretendemos elaborar una breve reflexión sobre el surgimiento y los motivos por los que se inició la lucha feminista en México y 
cómo ha ido evolucionando con el pasar de los años. Durante este breve recorrido podremos constatar que la historia de este movimiento en México se corresponde con los emprendidos en otras regiones del mundo, aunque no en el tiempo ni en la forma, sí en las trabas y en los discursos que se han generado para evitar atender las demandas de igualdad. ${ }^{24}$

Este apartado está organizado en dos secciones. En la primera analizamos el surgimiento del feminismo en México en el siglo XIX y a principios del siglo $\mathrm{XX}$ y cómo las demandas derivadas de estos movimientos fueron silenciadas durante más de medio siglo. En la segunda sección, a partir de la década de los 70 , se origina lo que han denominado algunas autoras ${ }^{25}$ como nuevos feminismos. Con ellos se estructuran las primeras organizaciones de mujeres feministas formalmente, abordaremos cómo el movimiento durante estas cuatro décadas ha establecido sus propias líneas de acción.

\subsubsection{Etapa previa al surgimiento del movimiento feminista en México}

En este apartado haremos referencia a las primeras mujeres que alzaron la voz para dar cuenta de la situación de desigualdad a la que estaban sujetas por el mero hecho de ser mujeres. Para ello analizaremos la participación política de las mujeres hasta la obtención del voto, las restricciones civiles, religiosas y familiares a las que se enfrentaban y cómo los movimientos sociales, tanto el de independencia como el revolucionario, son deudores de expandir los derechos de igualdad, justicia y libertad que proclamaban.

\section{Etapa previa al voto}

\footnotetext{
${ }^{24}$ Es preciso aclarar que el objetivo de este apartado no es profundizar en la historia del movimiento feminista, sino elaborar un marco de contextualización sobre el feminismo en México. De todas formas, las siguientes referencias pueden servir para aquellas personas que estén interesadas en profundizar más sobre el tema: Ana Lau "La nueva ola del feminismo en México" México: Grupo Editorial Planeta, UNAM, 1987; Esperanza Tuñón "Mujeres en escena: de la tramoya al protagonismo (1982-1994): el quehacer político del movimiento amplio de mujeres de México (19821994)". México: UNAM, 1997; Griselda Gutiérrez (Coord.) "Feminismo en México. Revisión histórico-crítica del siglo que termina" México, UNAM-PUEG, 2002.

${ }^{25}$ Álvarez Enríquez, (2004); Lau Jaiven, (1987, 2006); Serret, (2000).
} 
El proceso de emancipación de las mujeres mexicanas se ha caracterizado por sus tímidos avances y un sinfín de retrocesos. Así, en el país han existido mujeres que han desafiado las normas que el sistema patriarcal les ha impuesto y con ello han mostrado que las situaciones de subordinación pueden ser transformadas. Algunas autoras ${ }^{26}$ ven a Sor Juana Inés de la Cruz (siglo XVII) como una de las pioneras del feminismo en México, puesto que en su trabajo reflejó que la mujer podía y debía tener otras aspiraciones más que ser una ama de casa (Dufort, 2011).

Durante la lucha de Independencia (1807-1823) la participación de las mujeres es igualmente relevante, sin embargo sus aportaciones van a ser invisibiliazadas por la historia, así lo manifiesta la autora Martha Del Palacio (2015, pp. 78-80). ${ }^{27}$

El periodo de Reforma (1857-1860) es un proceso de transición política y social que tiene por objetivo establecer un nuevo orden social, restando poder al clero y al Estado y otorgando a los ciudadanos (excluyendo a las ciudadanas) derechos políticos y libertades, es decir, es un periodo en el que se intenta avanzar hacia la modernidad (Girón, González Marín, \& Jiménez, 2008a). Girón y otras también comentan que, aunque hubo participación de las mujeres en este periodo, su actividad en este proceso de transformación política es la menos documentada. Ricardo Ruiz señala que los avances acaecidos en materia de igualdad entre mujeres y hombres en México en este periodo son prácticamente inexistentes De todos modos, destaca que en esta época de

\footnotetext{
${ }^{26}$ Entre ellas podemos destacar a Martha Del Palacio, (2015); a Alicia Girón, et al., (2008); y a Griselda Gutiérrez, (2002).

${ }^{27}$ Esta autora menciona cómo mujeres de elite apoyaron con recursos económicos la lucha por la independencia, entre las que destaca a Sor Juan Inés de la Cruz, Leona Vicario, Doña María Ignacia (Güera Rodríguez). Otras mujeres prestaron servicios de reunión. Así María Teresa Medina de la Sota Riva, que reunía en su casa a los simpatizantes de la insurgencia. Por su parte, la señorita Avilés, María Catalina Gómez de Larrondo, Las hermanas González y Getrudis Bocanegra prestaron servicios de informantes y propagandismo. Como combatientes en el frente se pueden mencionar a Manuela Medina, la Capitana, María Fermina Rivera y Antonia Nava, la Generala, que no solo prestó sus servicios sino que entregó a sus hijos para que sirvieran en el frente. Esto son solo algunos ejemplos, para profundizar más consultar a Marta Del Palacio (2015, pp. 78-89).
} 
Reforma, durante el periodo de discusiones de la Constitución, "Ignacio Ramírez, el Nigromante", propuso conferir a la mujer los mismos derechos que a los hombres, pero fue desestimado (Ruiz Carbonell, 2010, p. 76).

El periodo revolucionario va de 1910 a $1920,{ }^{28}$ a partir de este momento se encuentran más registros de la participación política que tuvieron las mujeres. Así pues, durante esta época se emprende un nuevo proyecto que pretende renovar las estructuras políticas, sociales y económicas que frenaban el desarrollo de la sociedad mexicana. Gabriela Cano recoge cómo en 1913 el movimiento constitucionalista, encabezado por Venustiano Carranza, inició la creación de un nuevo orden político (1992). Las reformas sociales emprendidas pretendían estabilizar el país, educar al pueblo y así alcanzar el progreso. Algunos de los dirigentes estaban convencidos de que el espíritu de regeneración social de la Revolución tendría que abarcar, también, la condición de las mujeres (Cano, 1996).

Es así como se inician las primeras pinceladas de los temas de emancipación de la mujer en México. Sin embargo, es preciso aclarar que la condición y la situación de las mujeres no fueron abordadas de igual manera en todo el país. Los proyectos políticos que promovían cuestiones relacionadas con la igualdad entre hombres y mujeres estuvieron sujetos a los promotores de cada región. En este sentido, diversos autores (Acevedo, 2002; Cano, 1992; Cano, 1996; Girón et al., 2008; Ruiz Carbonell, 2010; Villegas Morales, 2001) consideran que el

\footnotetext{
${ }^{28}$ Gladys Villegas explica que al iniciarse la Revolución Mexicana se encontraba en el poder el dictador Porfirio Díaz cuyo gobierno duró 34 años. Durante esta época el curso del país estaba en manos de un grupo de abogados, contadores e intelectuales conocidos como los "científicos" (la mayoría de esos hombres eran discípulos de la filosofía positivista de Auguste Comte). Este grupo pretendía seguir los modelos culturales y económicos de la Europa "moderna", por lo que colocaron una gran parte de la industria mexicana, así como la explotación de sus recursos naturales, en manos de potencias extranjeras, norteamericanas o europeas. La cultura indígena de México era despreciada. Una vez derrocado Porfirio Días, en 1911, el movimiento revolucionario va a conseguir tres objetivos principales: libertad política, reforma agraria y organización obrera. En los veinte, se empezaron a consolidar los logros de la larga batalla de este movimiento armado (Villegas Morales, 2001, p. 170).
} 
mandato que emprende Gral. Salvador Alvarado en el Estado de Yucatán (19151918) contemplaba una gestión feminista.

Marta Acevedo (2002) señala que este Gobernador impulsa decretos que rompen con las formas tradicionales, impulsando cambios en la vida privada (sexualidad, matrimonio, familia), en el contexto educativo y en el ámbito laboral. Alvarado consideraba imprescindible el dotar a todas las personas de una educación basada en la racionalidad para conseguir el progreso del país.

Durante el mandato de Alvarado se convocan los primeros Congresos Feministas Estatales, empezando los preparativos para su realización en 1915, con la formación de un comité organizador integrado por siete mujeres. Estos dos congresos tuvieron lugar en el Estado de Yucatán. Girón y otras (2008, pp. 41-42) destacan cinco resoluciones derivadas de los congresos:

1. Modificación de la legislación civil, dotando a las mujeres de mayores libertades para desarrollar sus aspiraciones;

2. el derecho a tener un oficio o una profesión para ganarse la vida;

3. educar a la mujer racionalmente;

4. que se fomentara el ejercicio de nuevas profesiones; y

5. el fomento de la literatura y escritura.

Gabriela Cano menciona que la Constitución de 1917 sentó las bases de la renovación política. En ella se incorporaron demandas de campesinos y obreros, ${ }^{29}$ sin embargo las demandas al sufragio — derecho a votar y ser votadas-, llevadas al Congreso Constituyente por Hermila Galindo, fueron nuevamente desestimadas (Cano, 1996). Los argumentos que emplearon los varones constituyentes se fundamentaron otra vez en prejuicios relacionados

\footnotetext{
${ }^{29}$ En la constitución también se incorporan algunos derechos para las mujeres, derechos que, manifiesta Cano (1992) fortalecen la separación por géneros de las esferas pública y privada, puesto que se decretan leyes que regulan de manera estricta la participación de la mujer en el ámbito privado, mientras que la participación en el ámbito público queda reservada para los varones.
} 
con la incapacidad de las mujeres y su falta de educación, motivo por el cual serían fácilmente influenciadas por el clero (Cano, 1992).

Marta Acevedo señala que el gobierno de Carrillo Puerto (1922-1924) avanzó en los derechos educativos de las mujeres, promulgó la ley del divorcio, impulsó las ligas femeninas, y otorgó a las mujeres el derecho a votar y ser votadas en el Estado

Dentro de la época del gobierno de Carrillo Puerto, destacan Rosa Torres y Elvia Carrillo Puerto como participantes activas en la vida política del Estado. Estas dos mujeres van a emprender candidaturas resultando ganadoras. Sin embargo esto va a durar poco tiempo, pues Carrillo Puerto es asesinado y las reformas a favor de las mujeres se echaron para atrás, entre ellas el derecho a votar y ser votada. (Girón et al. 2008). No obstante, este avance sirvió como referente para que otros Estados otorgaran - aunque fuera por un tiempo breve- el sufragio a las mujeres. Las entidades que extendieron este derecho a las mujeres fueron San Luis Potosí (1924-1925) y Chiapas (1925).

Cabe destacar que en el periodo que va de 1920 a 1935 se llevan a cabo varios encuentros feministas: en 1923 tuvo lugar el Primer Congreso Feminista de la Liga Panamericana de Mujeres; en 1925 se celebró el Congreso Liga de Mujeres Ibéricas e Hispanoamericanas; en los años 1931, 1933 y 1934 tuvieron lugar tres Congresos Nacionales de Obreras y Campesinas; y en 1935 se crea el Frente Único Pro-Derechos de las Mujeres (FUPDM) (Cano, 1992; Girón et al. 2008).

Con la llegada de Lázaro Cárdenas (1934-1940) al gobierno, se esperaba que durante su gestión se atendieran cuestiones de igualdad, libertad y justicia social y que las mujeres formaran parte de este nuevo proyecto político. Así pues, aunque este Presidente logró ampliar y reestructurar la educación pública, otorgó derechos y tierras a las personas de zonas rurales, brindó apoyo económico al campo, expropió recursos naturales a empresas extranjeras y las 
nacionalizó... En resumidas cuentas, desarrolló un proyecto político y social que atendía las necesidades de la población más vulnerable, no extendió los derechos políticos a las mujeres. Durante su gestión se envía en 1937 una iniciativa de reforma al artículo 34 de la Constitución para otorgarles el derecho a votar y ser votadas. Aunque tanto la Cámara de Senadores como la de Diputados la aprueba, no se publica en el Diario Oficial, lo que deja nuevamente a las mujeres sin poder ejercer los derechos del sufragio (Girón et al., 2008a; Montes de Oca Navas, 2015; Ruiz Carbonell, 2010). Este hecho reafirma la escasa importancia que los líderes políticos otorgan a las demandas promovidas por las mujeres.

No podemos negar que en el mandato de Lázaro Cárdenas se muestra un cambio a favor de la igualdad entre hombres y mujeres, sobre todo en el terreno educativo y en el ámbito laboral, pero no se cumple con las expectativas y exigencias que los colectivos de mujeres habían formulado durante este periodo. Elvira Montes (2015, p. 151) señala al respecto lo siguiente:

Las mujeres del siglo $\mathrm{XX}$, especialmente las de las primeras décadas, vivieron y padecieron las ambigüedades de un nuevo régimen social que no terminaba por nacer $\mathrm{y}$ otro que no terminaba por desaparecer, un sistema que hablaba de libertad, igualdad, ciudadanía, pero donde las mujeres seguían bajo la tutela de los varones, lo que daba por resultado una inequidad social contraria a los supuestos del liberalismo y la democracia que se dijo serían las ideas que guiarían al nuevo México del siglo XX.

Cano (1996) reseña cómo el sufragio femenino no fue un tema de interés para la población durante los años cuarenta, pues para ese momento el movimiento feminista había perdido fuerza hasta prácticamente desaparecer. A finales de la década de los 40 del siglo XX (1947) se reconoce parcialmente el derecho al voto de las mujeres en el nivel municipal; pero este logro fue más "un símbolo de la imagen de modernidad política" que una "reivindicación política sostenida por una movilización" (Cano, 1996, p. 353). No es hasta 1953, al iniciarse el periodo presidencial de Adolfo Ruiz Cortines - bajo las protestas realizadas por la organización Alianza Nacional Femenina creada 1952 - que se aprobará la 
iniciativa de Cárdenas y se otorga el derecho de ciudadanía a las mujeres (Alonso, 2004; Gabierla Cano, 1992; Gabriela Cano, 1996; Girón et al., 2008a; Ochoa Avalos, 2004; Ruiz Carbonell, 2010; Villegas Morales, 2001).

Hasta aquí hemos podido constatar cómo las mujeres mexicanas denunciaron y vindicaron su posición de subordinación de una manera distinta a la que emplearon las mujeres británicas y norteamericanas. Optaron, así, por demostrar que se podían conseguir derechos haciendo práctica de ellos sin tenerlos. De este modo, cuando no les era permitido votar, encabezaban listas para ser candidatas - hacían y ganaban candidaturas-. Estas mujeres demostraban con su actuación, vindicando los derechos civiles, políticos, educativos y sobre todo económicos, que, aunque sus triunfos no fueran reconocidos por la Cámara de Diputados, su participación política era necesaria además de posible. En resumen, las reformas legislativas no solo fueron dilatadas sino que fortalecían las desigualdades entre hombres y mujeres. $\mathrm{M}^{\mathrm{a}}$ Candelaria lo expresa de la siguiente manera:

El resultado fue el reforzamiento de un tipo ideal de las mujeres mexicanas: esposa, madre y ama de casa. La legislación se tradujo en acciones "proteccionistas" para las mujeres dependientes de los hombres como madres, esposas e hijas, y para las mujeres trabajadoras - que valga decir, eran sólo unas cuantas - un conjunto de derechos vinculados a la maternidad, [...] Estas leyes proteccionistas tuvieron como eje tres elementos: la fuerza física, la moral y el rol familiar. Las mujeres no son consideradas sujetos de derecho, sino entes vulnerables y necesitados de protección (Ochoa Avalos, 2004, pp. 183-184).

\subsubsection{Nuevos feminismos en México}

Diversas autoras, entre ellas Teresita De Barbieri, (1990); Griselda Gutiérrez (2002a); Ana Lau, (1987, 2006) y Estela Serret, (2000) consideran que el movimiento feminista en México se inicia de manera formal en los años setenta. $^{30}$ En este periodo la situación social, económica y política a nivel

\footnotetext{
${ }^{30}$ Cabe destacar que autoras como Ana Lau y Silvia Lopéz elaboran tipologías distintas para el abordaje del movimiento feminista en México, en la tesis elaborada por Janet García se hace referencia a estas dos propuestas (2016, pp. 29-31).
} 
mundial y a nivel nacional avanzaba de manera vertiginosa. El desarrollo industrial y económico se contraponía a las inconformidades y protestas sociales a nivel internacional, las cuales se extendieron en nuestro país con características propias. La descendencia de una generación que durante décadas lucho por obtener derechos educativos y civiles mostraba su inconformidad ante las acciones de sus gobernantes. La represión política promovió, en vez apaciguar, la movilización social: movimientos de estudiantes, movimiento feminista, movimientos sindicales... Al cobijo de este conjunto de sucesos se aviva nuevamente el feminismo en nuestro país.

Siguiendo lo descrito por diversas autoras: (Girón et al., 2008a; Lau Jaiven, 2006; Serret, 2000; Villegas Morales, 2001) podemos decir que la formación de movimientos feministas en México estuvo asociado a los siguientes factores:

- conciencia ciudadana a partir de las demandas de democratización generadas por los movimientos estudiantiles del 68;

- la influencia progresiva del feminismo estadounidense;

- mayor número de mujeres con formación media superior;

- el incremento de la participación de las mujeres en el ámbito laboral, y

- la influencia de la Internacionalización de los Derechos Humanos, (Conferencia del Año Internacional de la Mujer por parte de las Naciones Unidas, 1975).

Todos estos factores contribuyeron a que las mujeres tomaran conciencia de la opresión de que eran objeto y a través de la asociación buscaron transformar sus realidades y mejorar sus condiciones (Lau Jaiven, 2006, p. 152). Gabriela Cano (1996) señala que los nuevos feminismos en México vindican las limitaciones de la igualdad jurídica que formalmente establecía igualdad salarial. No obstante, en la práctica no se llevaba a cabo. Además, los derechos decretados no eliminaban las constantes discriminaciones que vivían las mujeres tanto en el ámbito público como en la vida privada. Rosario Castellanos 
en 1971 pronuncia un discurso en un acto público en el que denuncia de manera elocuente las consecuencias sociales y morales de la desigualdad femenina (Cano, 1996, p. 354).

Así pues, en la década de los setenta las mujeres empiezan a denunciar, a través de artículos en revistas, las situaciones de desigualdad a las que estaban sujetas. ${ }^{31}$ Hacia 1976 existían cuatro organizaciones conformadas: Mujeres en Acción Solidaria (MAS), el Movimiento Nacional de Mujeres (MNM), ${ }^{32}$ el Movimiento de Liberación de la Mujer $(\mathrm{MLM})^{33}$ y el Colectivo Revuelta (Villegas Morales, 2001).

Estos movimientos surgieron de las reflexiones y polémicas que se generaban en pequeños grupos de autoconciencia, en los que se iban entretejiendo y analizando los aconteceres de la vida social y política de las mujeres que participaban en ellos (Álvarez Enríquez, 2004; Arizpe, 2002; Bartra, 1999; Cano, 1996; Girón et al., 2008; Serret, 2000). A partir de este proceso de análisis, las mujeres consiguen, por un lado, mostrar que su experiencia personal de opresión y subordinación no es única, y, por otro, que esta experiencia puede ser explicada desde lo social y por lo tanto se puede transformar a través de la acción y la movilización (Bartra, 1999; Serret, 2000).

Estela Serret nos explica cómo estos grupos fueron conformados por mujeres universitarias de clase media que buscaban, en un primer momento, construir una conciencia feminista, y que, aunque estaban influenciadas por el feminismo de otras altitudes, no tenían muy claro cómo enfrentarse a las situaciones de

\footnotetext{
${ }^{31}$ Rosario Castellanos y Martha Acevedo, escriben artículos en revistas de opinión distintas. Cabe destacar que se hace alusión a estas dos autoras ya que son consideradas por Graciela Hierro como las madres del feminismo en México (Hierro, 2002).

${ }^{32}$ El MAS fue creado en 1971 con la finalidad de organizar una protesta para desmitificar el día de las madres. En 1973 se crea el MNM que tiene como ejes prioritarios acabar con los prejuicios existentes en la educación y las costumbres de las mujeres. Reclama que se respeten las leyes laborales existentes y que se de reconocimiento y apoyo a la maternidad (mediante la construcción de guarderías y facilidades para la doble función de la mujer trabajadora y madre) (Girón et al., 2008a).

${ }^{33}$ Bartra menciona que el MLM fue el grupo más importante, pues este movimiento fue el que sentó las bases para "la nueva conciencia feminista en el país" (1999, 216).
} 
desigualdad que se vivían en su entorno, lo que les llevó a hacer política sobre la marcha. Bartra afirma que el objetivo del movimiento en esta década es el de "despertar la conciencia feminista":

La década de los setenta es, pues, la época del despertar, de la toma de conciencia, de la búsqueda, a veces a tientas, y el periodo de más efervescencia, sin lugar a dudas. Las acciones, sin embargo, se limitaban a la expresión, al grito: "romper el silencio" era una consigna más que socorrida. Lo que importaba ante todo era manifestarse; poder hablar en público en distintos foros; escribir y publicar donde se pudiera; salir a la calle. Y la verdad es que pocas mujeres hacían mucho ruido (Bartra, 1999, p. 217).

Otro aspecto que caracterizó al movimiento feminista de nuestro país fue la escasez de movilización de masas, ${ }^{34}$ pues las demandas que planteaban (la legalización del aborto, la penalización de las violaciones y el apoyo a mujeres violadas), ${ }^{35}$ chocaban con las nociones y costumbres arraigadas en una sociedad fuertemente patriarcal. Martha Zapata manifiesta que el movimiento feminista de esta época se obcecó con determinadas vindicaciones y no percibió otras que afectaban a las mujeres en su día a día (trabajo doméstico):

A partir de este momento se aprecia una cierta miopía del movimiento al concentrar todas sus acciones preferentemente en la demanda del aborto -en una sociedad con fuerte influencia conservadora por parte de la Iglesia Católica y con estructuras de dominación masculina caracterizada por una hipermasculinidad hegemónica, que también es asumida, reproducida y defendida por muchas mujeres, que predomina en todos los ámbitos de la sociedad y que rechaza violentamente los esfuerzos por transformar el orden de los géneros-descuidando otros conflictos sociales importantes que también afectan existencialmente a las mujeres[...] (Zapata, 2005, p. 1).

La falta de apoyo social intentó solventarse estableciendo alianzas con otros actores sociales y políticos. Para la década de los ochenta se dan algunas divergencias en el interior de los movimientos feministas, pues algunas de las participantes consideran oportuno reestructurar su formas de participación

\footnotetext{
${ }^{34}$ Martha Zapata, menciona que la falta de apoyo social de movimiento feminista en México se debe en parte a que las mujeres de sectores populares no se han sentido identificadas con las demandas que han elaborado los grupos de mujeres de clase media y media-alta.

${ }^{35}$ Álvarez Enríquez, 2004, p. 97
} 
(autónoma e independiente del Estado) ${ }^{36}$ y dar un paso hacia la institucionalización. Tal cambio les permitiría obtener financiamiento para continuar innovando formas de trabajo y llevar a cabo acciones con sectores populares de la población (Álvarez Enríquez, 2004). Así es como muchos de los grupos feministas se constituyen en organizaciones no gubernamentales (ONG) que fueron denominadas populáricas (Girón et al., 2008a).

Las demandas de las feministas se fueron insertando cada vez más dentro del ámbito institucional. En 1989 se crea la Coordinadora Feminista, con el objetivo de aglutinar las fuerzas del feminismo, y dar una organicidad política al movimiento, a la vez que media como interlocutora de éste ante el Estado y otras instancias institucionales. No obstante se produjo una división entre las feministas, visto que algunas consideraban necesario establecer relaciones con las instituciones oficiales, al tiempo que otras consideraban que la lucha del movimiento consistía precisamente en oponerse a las relaciones verticales que se promueven en los sistemas institucionales. En los años venideros, estas posturas contrapuestas debilitaron el movimiento, sin embargo las demandas fueron encontrando válvulas de concreción en las instancias institucionales y en el sistema de partidos (Álvarez Enríquez, 2004).

En la década de los noventa el feminismo en México incrementa su campo se acción dentro del sistema institucional. Menciona Bartra (1999) que las feministas de los años setenta vivían por la lucha feminista y a partir de los noventa se vive de ella, pues institucionalmente se exige a los profesionales que planteen nuevos rumbos para abordar las desigualdades entre mujeres y varones. En esta década existe una mayor retroalimentación entre el trabajo académico y los movimientos feministas, pero los movimientos feministas en este periodo

\footnotetext{
${ }^{36}$ Eli Bartra menciona que en la década de los 70 el movimiento feminista en México rechazaba deliberadamente el acercamiento con las instituciones, así el MLM se manifiesta totalmente en contra de la celebración de la Conferencia Internacional de la Mujer que tuvo lugar en México en 1975 (Bartra, 1997, p. 202).
} 
enfrentan el desafío de conseguir la regeneración generacional, debido a que la participación de personas jóvenes en el movimiento es cada vez más escasa.

Con relación a la producción académica feminista, Estela Serret señala que durante la década de los 70 tenía más carácter difusivo que de crítica sistemática. Algunas autoras, entre ellas Gabriela Cano (1996) y Eli Bartra (1999), mencionan que a partir de la década de los noventa las publicaciones de los estudios académicos de género se incrementaron en el país y adquirieron una mayor especialización. ${ }^{37}$ Aparecieron las revistas en las que se debatían los avances de la teoría crítica feminista y las que se centraban solo en los estudios de género. ${ }^{38}$ Cano comenta que el feminismo aumenta su legitimidad sobre todo en zonas urbanas, gracias a los espacios públicos en los que empiezan a incursionar las feministas, así como mediante su participación en foros y encuentros internacionales y nacionales (Cano, 1996; Lau Jaiven, 2006).

Diversas autoras (Arizpe, 2002; Bartra, 1999; Cano, 1996; Gutiérrez Castañeda, 2002a; Zapata, 2005) señalan que aún cuando el feminismo en México (siglo XX) no logró ser un movimiento social masificado y que sus demandas no tuvieron una aceptación generalizada por la población, sí que se ha conseguido que los temas de igualdad entre hombres y mujeres formen parte de las políticas públicas. Entre los logros de las demandas que iniciaron las feministas en los años setenta se pueden destacar los siguientes:

- Aprobación el 12 de julio de 1990 de las reformas al Código Civil en lo relativo a delitos sexuales.

\footnotetext{
${ }^{37}$ Se inicia la creación de centros de investigación y docencia cuyo eje de estudio eran las temáticas relacionadas con el feminismo. Eli Bartra menciona que "se puede decir que siempre ha existido un vínculo bastante estrecho entre el movimiento feminista y la academia, así como una retroalimentación mutua" (Bartra, 1997, p. 203).

38 "La primera en su tipo fue la revista semestral debate feminista aparecida en 1990 bajo la dirección de Marta Lamas, con la intención de ser un puente entre los aspectos políticos y teóricos del feminismo. Centrada en los estudios de género, apareció en 1995 La ventana, editada por la Universidad de Guadalajara bajo la dirección de Cristina Palomar" (Cano, 1996, p. 358).
} 
- Despenalización de aborto antes de las semana 12 de gestación (en Ciudad de México). ${ }^{39}$

- Ganan espacios de participación política, a través incorporar acciones afirmativas en las leyes de electorales.

- Se crea el Instituto Nacional de las Mujeres (IMUJERES). ${ }^{40}$

- Se decretan leyes para salvaguardar la vida de las mujeres, evitar la discriminación y la violencia. ${ }^{41}$

El feminismo a finales del siglo XX y en lo que va del siglo XXI se ha institucionalizado plenamente, ya sea en organismos gubernamentales, ONGs o en instituciones académicas (Bartra, 1999; Lau Jaiven, 2006). ${ }^{42}$ Esto ha traído muchas ventajas, pero también ha generado desventajas. En cuanto a las ventajas de la institucionalización del feminismo, vamos a mencionar cuatro de ellas, teniendo en cuenta los apuntes que hace Zapata al respecto (2005):

- Se incrementa su presencia en espacios públicos: incorporación los temas de desigualdad entre hombres y mujeres en el ámbito político a través de proyectos, reformas a la legislación, implementación de políticas públicas con perspectiva de género.

- Legitimación y reconocimiento de las vindicaciones de igualdad entre hombres y mujeres a nivel local, nacional e internacional.

- Mayor aceptación social al establecimiento de políticas públicas con perspectiva de género.

${ }^{39}$ (Lagarde, 2013, p. 362)

${ }^{40}$ Instituto creado para "identificar, sistematizar y evaluar en el ámbito nacional y ante los foros internacionales, las acciones y estrategias desarrolladas en beneficio de la equidad entre hombres y mujeres" (Inmujeres 2002, citado por Lau J. 2006, p. 190).

${ }^{41}$ Se detallan en el apartado cuatro de esta investigación.

${ }^{42}$ A pesar de los numerosos cambios que se han vivido en las últimas décadas en el país - la adopción del modelo neoliberal, la reforma de instituciones y el relevo político que tuvo lugar en 2000 que desbanco al partido que había gobernado el país por más de de 70 años, la criminalidad instaurada en el país, la impunidad y la corrupción - el feminismo ha conseguido establecer una cultura política con perspectiva de género en una democracia que aun esta por construirse (Tarrés, 2006). 
- Introducción en la agenda pública de la justicia de género y con ello ampliación de los derechos políticos, sociales y civiles de las mujeres.

Con relación a las desventajas, las misma autora (Zapata, 2005) señala que esto repercute sobre todo en el aspecto crítico de la perspectiva feminista, pues al estar institucionalizada solo se hace referencia a los temas que son políticamente correctos y no se abordan las problemáticas sociales que realmente aquejan a la población. Esta autora, además de considerar que se ha establecido una ruptura entre las feministas profesionalizadas y los movimientos autónomos, manifiesta que hacen falta espacios "de concienciación en los que se planten nuevas formas para lograr la emancipación de las mujeres y la trasformación social, económica y cultural en donde las mujeres puedan participar bajo las mismas condiciones que los hombres" (p. 5). Por otro lado, Ana Lau (2006, p. 191) hace referencia a que el discurso feminista ha logrado incidir en el Estado, pero "éste lo ha tomado y cooptado para explotarlo a su antojo y conveniencia".

Por su parte, Bartra (2010) señala que uno de los retos de feminismo en décadas anteriores era el lograr un relevo generacional, que en el presente siglo se está efectivamente produciendo. Ahora bien, la autora manifiesta que queda mucho por hacer, si bien enfatiza que lo más importante es que la población juvenil participe y se creen espacios de acción en el que se reivindiquen sus necesidades. Resulta evidente que sin la participación del movimiento feminista las luchas conseguidas pueden desaparecer.

Haciendo una recapitulación de este apartado podemos destacar que el feminismo en México tiene más de un siglo de historia. Desde las primeras vindicaciones que realizan las mujeres mexicanas para tener derechos políticos y civiles fundamentales, hasta que llega su consecución tienen que pasar más de 37 años. Durante este periodo las mujeres que participaron en la construcción y el desarrollo del país fueron borradas de la historia, sus denuncias fueron 
postergadas durante más de tres décadas, hasta que en el año 1953 se les otorga el voto. No obstante, este avance no significó romper con el sistema patriarcal que relegaba a las mujeres al ámbito de lo privado.

En los años setenta las mujeres comprobaron que el elegir y ser electas no era suficiente, la carencia de ciudadanía las llevó a organizarse para reclamar derechos que les eran vedados solo por el hecho de ser mujeres. La conformación de grupos y demandas no fue fácil, pues en un primer momento se intenta rehuir de cualquier forma de organización que denote verticalidad. Se dificultó, de este modo, la puesta en marcha de acciones, visto que cualquier tipo de debate requería de muchas horas de trabajo. Las características propias de nuestro país también dificultaban las acciones emprendidas por los movimientos, sin embargo las feministas fueron encontrando canales de participación y colaboración (partidos políticos de izquierdas, entidades institucionales, instituciones no gubernamentales) que les permitirá ir trasformando las relaciones de opresión y sujeción que les impedían desarrollar sus potencialidades como seres humanos.

Los avances con relación a la igualdad entre mujeres y varones a finales del siglo XX y a principios del XXI son muchos, debido a que el movimiento ha conseguido institucionalizarse tanto a nivel gubernamental como en la academia. Con la institucionalización gubernamental y de las ONG's se ha conseguido legitimidad, reconocimiento y ampliación de derechos civiles, educativos y político. En cuanto a la institucionalización académica, no solo se ha conseguido aumentar la producción científica, sino que se han ampliado las disciplinas que hacen uso de las teorías feministas para explicar los aconteceres sociales. No obstante, quedan muchos retos por delante, uno de ellos es conseguir que la movilización ciudadana continué atenta a las nuevas formas de opresión y de subordinación, y que se generen espacios desde los cuales poder 
analizar los valores culturales que han de ser promovidos para conseguir la igualdad de oportunidades, recursos, libertades...

Muchas son las mujeres que han luchado para que hoy nosotras podamos tener una conciencia feminista, ${ }^{43}$ acceder a la educación, al trabajo remunerado, podamos participar en la política, tengamos derecho a decidir sobre nuestro cuerpo..., en fin el feminismo nos ha dado la posibilidad de vivir en un mundo mejor. No obstante, en nuestra sociedad como en muchas otras, aun cuando las condiciones han mejorado, todavía persiste y reaparecen nuevas brechas de género que afectan y repercuten no solo a las mujeres sino a la sociedad en general. Bartra (2010), menciona que queda mucho por recorrer porque los temas de emancipación de las mujeres nunca pueden considerarse como un logro definitivo, pues el trascurrir de la historia nos ha demostrado que nuestras conquistas siempre se pueden revertir.

\subsection{Las categorías de análisis de la teoría feminista}

Carlos Lomas: «Soy un hombre al que no le gusta lo que observa a su alrededor, al que no le agrada que el lujo de una minoría se sustente en las miserias de una mayoría, al que le indigna la sinrazón masculina que excluye, menosprecia y maltrata a las mujeres en nombre de un (des)orden cultural que le otorga todo tipo de privilegios simbólicos y materiales, al que le escandalizan las estrategias de manipulación del poder que intenta justificar el expolio de las culturas y de los pueblos, el asesinato indiscriminado de inocentes y la ocupación de territorios ajenos en nombre del progreso y la libertad, al que le gustaría que en verdad otro mundo fuera posible» (Lomas, 2008, p. 30)

El feminismo, tras más de tres siglos de historia, ha puesto en evidencia la estructura de poder y los mecanismos ideológicos que sitúan a las mujeres en una posición de permanente desventaja respecto a los varones. Rosa Cobo manifiesta que desde el feminismo se ha "desarrollado una mirada intelectual y política sobre determinadas dimensiones de la realidad que otras teorías no

\footnotetext{
${ }^{43}$ Marta Lamas menciona que la conciencia feminista "no requiere de un acervo intelectual de feminismo, ni de aceptar la etiqueta de "feminista" sino de compartir la idea de que estar subordinada, por el hecho de ser mujer, entraña una injusticia" (2016, p. 412).
} 
habían sido capaces de realizar" (2008, p. 6). En los años setenta se observa un despunte de la producción académica que intenta explicar la división asimétrica existente en todas las sociedades, donde las mujeres son excluidas y discriminadas en los diferentes ámbitos en los que participan. A partir de este momento el feminismo acuña varias categorías de análisis, las cuales, como bien menciona $\mathrm{M}^{\mathrm{a}}$ Rosa Luengo y Florentino Blázquez (2004, p. 23), han funcionado como auténticos "armazones conceptuales" que "permiten sustentar las construcciones mentales de la realidad y los modelos de interpretación" y que, en definitiva, permiten explicar las barreras que impiden que mujeres y hombres puedan conseguir la igualdad sustantiva tanto en el ámbito privado como en el público.

Las categorías de análisis a las que haremos referencia en este apartado son las consideradas por Rosa Cobo como las fundamentales en las teorías feministas: patriarcado y género (2005, 2008, 2014; Cobo Bedia \& Sánchez Bello, 2004). Así pues, en el epígrafe 1.3.1. abordaremos los debates que se han generado en torno al patriarcado, mientras que en punto 1.3.2. elaboramos una aproximación teórica con relación a las discusiones, a los usos y a los abusos que se han construido a partir del empleo de la categoría género.

\subsubsection{El Patriarcado}

Celina de Jesús Trimiño (2010) afirma que los primeros debates realizados sobre este concepto se realizan en el siglo XIX. ${ }^{44}$ Sin embargo no es hasta la década de los setenta del siglo XX que se desarrolló este constructo, con el

${ }^{44}$ Esta investigadora, citando a Z. Eisenstein, menciona que las autoras, M. Wollstonecraft, E. Cady Stanton y H. Taylor Mill avanzaron algunas ideas sobre la política sexual, pero no llegaron a establecieron las conexiones necesarias entre la opresión sexual, la división sexual del trabajo y la estructura económica de clase que son desarrolladas con posterioridad y que son fundamentales para la construcción de la categoría patriarcado (Trimiño Velásquez, 2010, p. 315).

Por otro lado la autora Patricia García señala que en 1893 la autora Joslyn Gages elabora una crítica bajo el título de "patriarchante". En ella discurre sobre las leyes restrictivas hacia las mujeres, además de documentar cómo la inferioridad de la mujer era predicada desde el púlpito de la Iglesia y cómo ésta institución se oponía a la educación de las mujeres, esto ha tenido como resultado la exclusión de las mujeres a poder ocupar un lugar en la Iglesia y en el Estado (2004, p. 31). 
resurgir de la teoría feminista contemporánea (Bryson, 1999; Cobo Bedia, 2014; Fernández Domingo, 2013; García Guevara, 2004; Trimiño Velásquez, 2010). Rosa Cobo (2014) nos cuenta que en el año 1969, Kate Millett, en su obra Política sexual, acuña el concepto de patriarcado, dotándole de un bagaje feminista y dándole un carácter global. En estos términos, patriarcado hace referencia al sistema de dominación masculino que emplean los varones para tener subordinadas a las mujeres. Además, recuerda esta autora que aunque el patriarcado se fundamenta sobre la institución de la familia, es una institución firmemente arraigada en la sociedad, que, por lo tanto, se refuerza y se manifiesta en todos los ámbitos y dimensiones de la vida: políticas, sociales y económicas...

A partir de esta nueva reformulación se suscitan diversos análisis sobre cómo operaba/opera ese entramado de estrategias y mecanismos que mantenía/ mantienen oprimida a la mujer, estableciendo conexiones entre patriarcado y diferentes temáticas (sistemas económicos, cambios históricos, variaciones de clase, etnia, cultura, sexualidad...) (García Guevara, 2004, p. 33). La ampliación de estos debates y la adquisición de derechos en la mayor parte de los países occidentales no solo generó estas conexiones, sino que también propició que algunas feministas - Luisa Muraro y Anna Maria Piussi, por nombrar algunas - se plantearan tanto la utilidad como el abandono de este concepto. ${ }^{45}$

Ante las críticas sobre abandonar esta categoría, la autora Carol Pateman manifiesta que hacer tal cosa significaría despojar al feminismo del "único concepto" que se refiere a "la sujeción de las mujeres" y que define el "derecho político que todos los varones ejercen en tanto que varones" (Pateman, 1995, p. 32). Para Carol Pateman el patriarcado es un constructo legítimo, pues la

\footnotetext{
${ }^{45}$ Carlos Lomas hace referencia a varias de las autoras que consideran que la aplicación de este constructo ya no es oportuno, por tanto lo dan por muerto (2008, pp. 126-129).
} 
sociedad civil es patriarcal, lo que provoca que las mujeres estén subyugadas a los varones tanto en el ámbito público como en el privado:

Las mujeres están sometidas a los varones tanto en la esfera privada corno en la pública; por cierto, el derecho patriarcal de los varones es el mayor soporte estructural que une ambas esferas en un todo social. El derecho de los hombres a acceder al cuerpo de las mujeres se ejerce en el mercado público tanto como en el matrimonio privado, [...] (Pateman, 1995, p. 159).

Por su parte, Patricia García responde a las críticas que se hacen sobre esta categoría indicando que el patriarcado es un fenómeno social de "estructura variable y compleja", dado que está conectado a otras dimensiones, "a la economía - mucho antes que al capitalismo-, a la política y a la historia, etc. Tales estructuras guardan una relación con la clase, etnia, [...]", lo cual hace que este constructo sea aplicable en contextos particulares (García Guevara, 2004, p. 42).

Cristina Molina (2003, p. 140), también menciona que el patriarcado es un constructo oportuno, pues éste tiene "el poder de nombrar" y "el poder de asignar espacios":

El patriarcado es entonces el poder de negar la palabra a las mujeres y asignarles límites, construcciones, de manera que no pueda hacer «grandes hechos» ni decir «grandes palabras». Es el poder de naturalizar los sitios de género y de mantener estos límites de lo femenino a fuerza de ideología, de discursos de su Palabra (mística de la feminidad [...]) y de negar o desautorizar la palabra de ellas con la fuerza del pacto de fratría entre ellos [...] (2013, p. 142).

Carlos Lomas, considera que es verdad que el patriarcado no afecta de igual manera a todas las mujeres, sobre todo a las de los países occidentales, dado que estas por "su situación académica, su estatus económico y su poder político, evitan los efectos de la dominación masculina”. No obstante, Lomas señala que aún estamos lejos de dar por muerto al patriarcado, pues la dominación y la opresión masculina continúan afectando a la mayoría de las mujeres en este mundo (2008, p. 128). 
Haciendo una recapitulación de este apartado, podemos decir que el patriarcado continúa siendo una categoría útil para el análisis de los estudios feministas. Sin embargo es preciso contemplar otras variables (sociales, políticas, culturales...) para explicar las estructuras de poder masculino que están arraigadas en las sociedad y que (nos)impide a las mujeres escapar de las situaciones de dominación que se ejerce sobre (nosotras) ellas, debido a que este sistema se perpetúa de generación en generación, arrastrando modelos hegemónicos que son asumidos por ambos sexos y que, en la mayoría de los países, son ratificados y promovidos por diversas instituciones: la familia, la escuela, la sociedad y los medios de comunicación. Es por ello que consideramos que este concepto es imprescindible para plantear la deconstrucción del sistema de valores que resta valor, discrimina y subordina a las mujeres u hombres que no cumplen con los estereotipos y roles que se promueven en el orden social establecido en la mayoría de los países del mundo.

\subsubsection{El Género}

El objetivo de este apartado es abrir una reflexión sobre el origen y la utilización del concepto género, pues a partir de este concepto se han construido una serie de estudios que tienen un recorrido histórico y teórico amplio y solido, especialmente durante las últimas décadas (Puleo, 2000).

La inserción de concepto "género" en las teorizaciones feministas se introduce en la década de los setenta en las universidades de países industrializados (González Jiménez, 2009, Tubert, 2003). A partir de allí y sobre todo en los últimos años el término "género" se ha extendido de una manera abrumadora en diversos ámbitos (académico, político, social, 
educativo), a tal punto que algunas autoras consideran que se ha hecho un uso indiscriminado del término. ${ }^{46}$

Los estudios desde esta perspectiva han permitido visibilizar las condiciones socioculturales arraigadas en los sistemas patriarcales, donde lo masculino es el modelo hegemónico, y por tanto la división social entre hombres y mujeres (re)produce desigualdades (Barberá Heredia, 2004; Cobo Bedia, 2005, 2014; De Barbieri, 1998; Facio \& Fries, 2005; Fernández Poncela, 1998; Hernández García, 2006; Lagarde, 1996; Lamas, 1999; Puleo, 2000). Respecto a esto Capitolina Díaz y Sandra Dema indican lo siguiente:

La inclusión de la perspectiva de género no solo revela la dinámica de producción de identidades de género diferenciadas, sino el hecho de que las relaciones entre mujeres y hombres se traducen en relaciones de desigualdad, poder, exclusión, dominación. Las teorías feministas aunque diversas, todas coinciden en considerar que la situación social de las mujeres, tanto en el ámbito público como en el privado, es fruto de un orden social injusto que privilegia a los varones sobre las mujeres (Díaz Martínez \& Dema Moreno, 2013, p. 73).

Por estas razones, la reflexión sobre el concepto, las teorías y las perspectivas de género - producto de las teorías feministas-, se vuelve indispensable para el análisis y la transformación de los actuales modelos sexuales, sociales, económicos y políticos hacia una convivencia humana basada en la comprensión y el respeto a la diversidad, donde hombres y mujeres puedan desarrollar sus potencialidades como seres humanos (Facio \& Fries, 2005).

Así pues, en este epígrafe procuraremos dar cuenta de la utilidad de esta categoría como herramienta para explicar las desigualdades derivadas de la estratificación sexual, para lo cual planteamos tres puntos. En el primero presentaremos de manera sintética el surgimiento del concepto como legado de las teorías feministas; en el segundo abordaremos algunas de las controversias que se han derivado de la popularización, ampliación e irrupción de dicho

\footnotetext{
${ }^{46}$ Se puede consultar para una información más detallada (González Jiménez, 2009, p. 681; Izquierdo, 1998, p. 18; Tubert, 2003, p. 7).
} 
concepto en diversas aéreas del conocimiento; y finalmente, en el tercer punto, señalamos el por qué la categoría género continua siendo legitima para el análisis de las relaciones entre hombres y mujeres.

\section{Construyendo senderos hacia la igualdad}

El surgimiento del concepto género como instrumento para el análisis de la desigualdad entre varones y mujeres planteado por las feministas, que ya se había anticipado en este apartado, data de los años setenta. Sin embargo, Rosa $\mathrm{M}^{\mathrm{a}}$ González señala que tanto el libro de la filósofa Simone de Beauvoir, " $E l$ segundo sexo” (1949), como los trabajos de la antropóloga Margaret Mead "Sex and temperament in three primitive societies" (1935) y los del profesor de psiquiatría Robert Stoller "Sex and gender: On the development of masculinity and femininity" (1968), se consideran antecedentes del concepto de género. Añade esta autora que "género" va a representar para el feminismo de los años setenta una herramienta tanto teórica como política destinada a cuestionar que "la biología sea destino" (González Jiménez, 2009, p. 683).

Los trabajos que se consideran antecesores del concepto de género tienen raíces en diversas disciplinas. Así, Simone de Beauvoir, desde la filosofía, explica de manera profunda, sencilla y resumida que no hay nada en la biología de los seres humanos que explique la discriminación de las mujeres, con su frase célebre «No se nace mujer: llega una a serlo» (citada por Amorós, 2010a, p. 67). La filósofa elabora una separación entre la naturaleza y la cultura, explicando cómo las características consideradas "propias de las mujeres" no tienen una base biológica, sino que son adquiridas a través de un proceso complejo tanto individual como social (Amorós, 2010a; González Jiménez, 2009; Varela, 2008). Margaret Mead, desde la antropología, intenta explicar que las diferencias conductuales (hombre-productivo, mujer-reproductivo) de los seres humanos "son creaciones culturales y que la naturaleza humana es maleable" (Lamas, 1986, p. 176). Estos trabajos, como bien menciona Rosa $\mathrm{M}^{\mathrm{a}}$ 
González (2009), van a ser la base de muchos de los postulados feministas. Finalmente, el trabajo desarrollado por el psiquiatra Robert Stoller es considerado el primero en emplear el término género atribuyéndole una connotación social.

Marta Lamas señala que desde la psicología en su vertiente médica se empieza a utilizar el concepto género para establecer una diferenciación entre el sexo biológico y el social. Robert Stoller, a partir de un estudio sobre trastornos de la identidad sexual de niños y niñas que no se identifican con sus caracteres biológico-anatómicos, concluye que "lo que determina la identidad y el comportamiento de género no es el sexo biológico, sino el hecho de haber vivido desde el nacimiento las experiencias, ritos y costumbres atribuidos a cierto género" (Lamas, 1986, p. 188).

En el esquema 1.1. mostramos el planteamiento propuesto por Robert Stoler (1968), el cual implicaría "dividir a la mujer y al hombre en dos componentes, ser mujer u hombre sería el resultado de una adición" (Izquierdo, 2013).

Esquema 1.1. Modelo determinista del sexo y de la identidad sexual Connotaciones

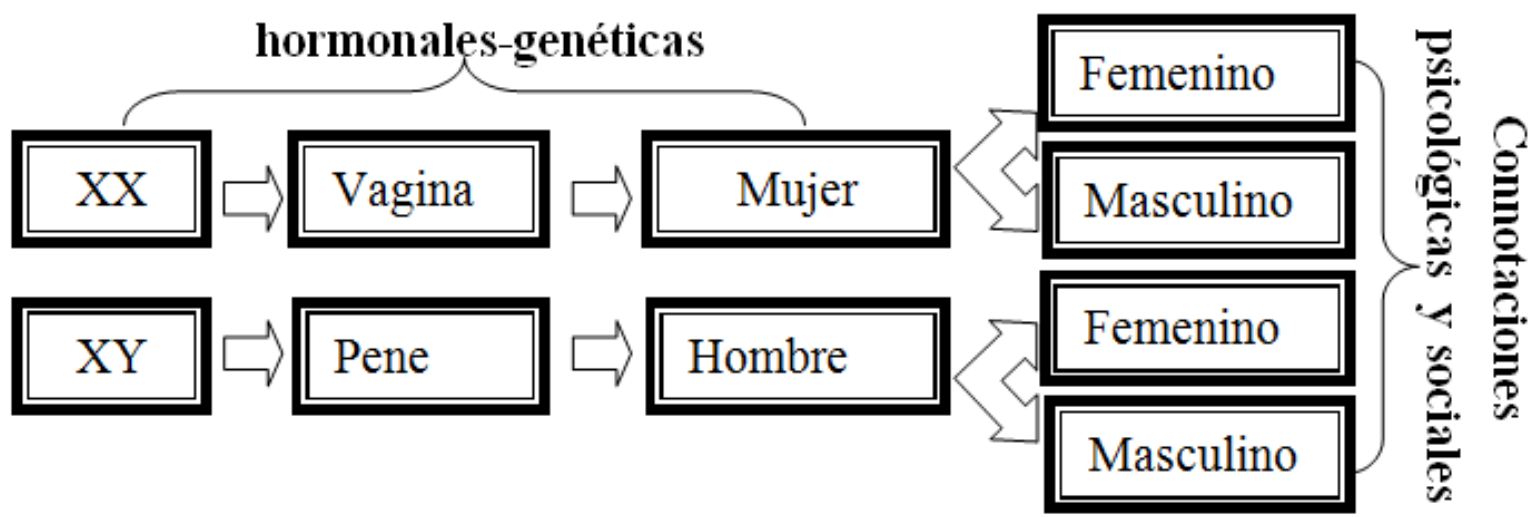

Fuente: elaboración propia con base en Aranda Friz, (2015, p. 27); González Jiménez, (2009, p. 684), (2013, p. 12); Lamas, (1986, p. 188).

El carácter multidisciplinar en el que se fundamenta el concepto género favoreció el abordaje de éste en diversas áreas del conocimiento. La psicología, la filosofía, la antropología y más tarde la sociología y otras ciencias humanas fueron, poco a poco, introduciendo el género en sus investigaciones. Las 
primeras investigaciones se enfocaban en comparar las capacidades, los valores o los comportamientos de hombres y de mujeres, utilizando el análisis estadístico para identificar diferencias entre varones y mujeres (González Jiménez, 2009). Es decir, solo se estudiaba la diferenciación de los géneros, puesto que únicamente en la década de los setenta las académicas feministas comprenden que esa diferenciación conlleva una jerarquización.

Se considera a Gayle Rubin (1975), con su obra El tráfico de mujeres: notas sobre la «economía política» del sexo, como la pionera en conceptualizar el género con sentido feminista (Casado Aparicio, 1999, p. 76; Cobo Bedia, 2005, p. 249, 2014, p. 9; Fernández Domingo, 2013, p. 16; González Jiménez, 2013, p. 13; Izquierdo, 2013, p. 110; Lamas, 1986, p. 191; Oliva Portolés, 2007, p. 22). Rubin define el género como "una división de los sexos socialmente impuesta. Es un producto de las relaciones sociales de sexualidad" (1986, p. 114). A partir de este momento el género se va a convertir en una de las categorías principales para la teoría feminista.

Gayle Rubin, acuña el término sistema sexo-género a partir de la crítica feminista a las doctrinas formuladas por Lévi-Strauss y Freud (Oliva Portolés, 2007, p. 26). La lectura que realiza la autora sobre la estructura del parentesco descrita por Levys-Strauss, la lleva a concluir que "los sistemas de parentesco se basan en el matrimonio; por lo tanto, trasforman a machos y hembras en «hombres» $\mathrm{y}$ «mujeres»" [...]. A través de ésta institución se establecen reglas que "gobiernan la sexualidad", con tres cometidos principales. El primero es el "tabú del incesto", mediante este se evita la endogamia; el segundo sería la heterosexualidad obligatoria, donde el deseo sexual tiene que ser dirigido hacia el otro sexo, si no se tacha como una conducta "anormal" o patológica; y finalmente la división asimétrica de los sexos, basada en otorgar derechos diferenciados a hombres y a mujeres. En cuanto a la teoría de la femineidad elaborada por Freud, la autora menciona que el orden social hace que las niñas 
enfrenten una crisis edípica, pues "el complejo de Edipo confiere al varón los derechos masculinos, y obliga a las mujeres a acomodarse a sus menores deseos" (Rubin, 1986, pp. 114-130).

La propuesta de Gayle Rubin es un sistema sexo-género, que ella misma define como "neutro", el cual muestra que la "opresión no es inevitable", dado que es "producto de las relaciones sociales". Con estas palabras la autora refleja su intención de conocer la realidad para plantear un nuevo orden social sin jerarquías de género (1986, p. 105). Para la autora Silvia Gil las aportaciones de Rubin significan una profundización en el alcance de los efectos perversos de la producción del género, y que posicionaron el debate de la heterosexualidad:

El sistema sexo/género no se refiere a la identidad femenina, sino a un conjunto de relaciones específicas: es el modo en que una sociedad transforma la sexualidad humana, convirtiéndola en un producto determinado. Las aportaciones de Rubin profundizaron en el alcance de los efectos perversos de la producción del género, y situaron el régimen heterosexual en el epicentro del debate (Gil, 2013, p. 53).

A continuación presentamos a modo de resumen un esquema sobre el sistema sexo- género.

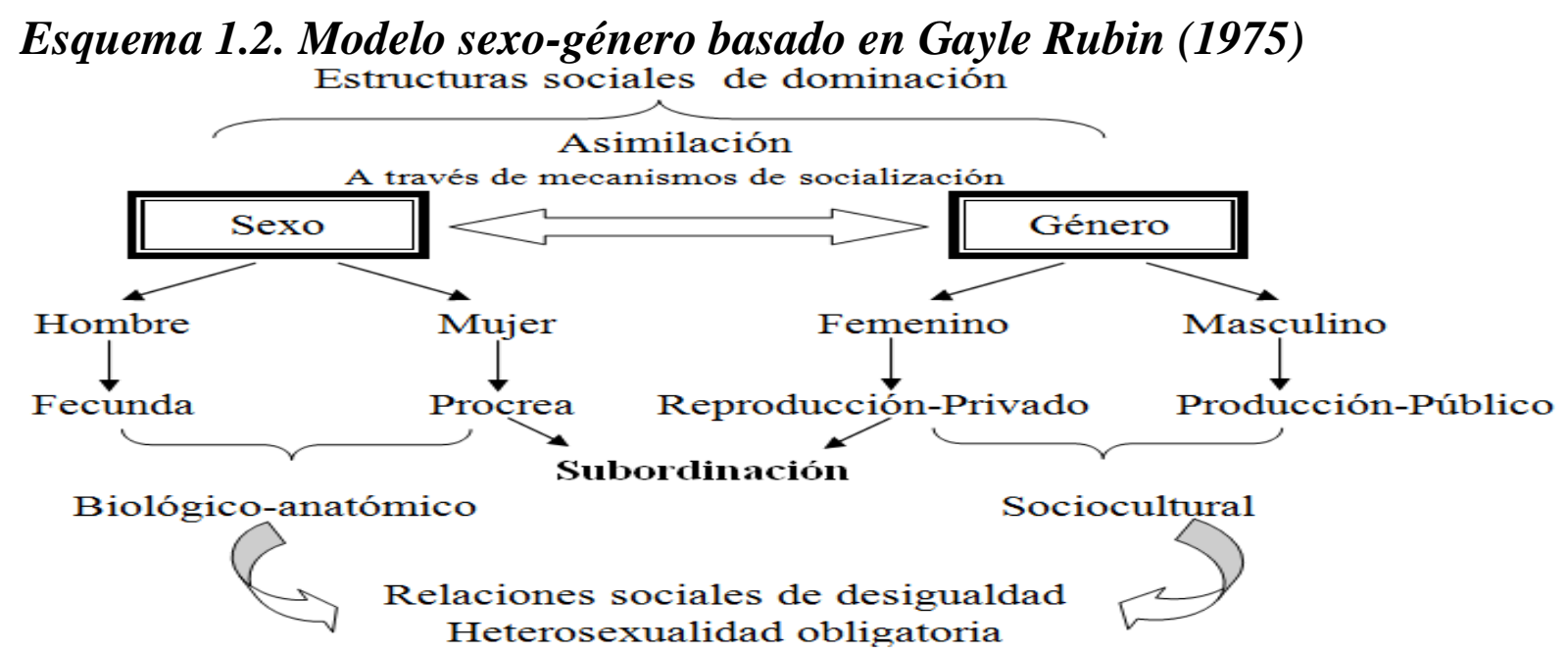

Fuente: elaboración propia, con base en Rubin, (1986).

Así pues, el sistema sexo-genero hace referencia a la existencia de una normatividad femenina edificada sobre la diferencia sexual biológica-anatómica (Cobo Bedia, 2014). Los estudios que toman como referente este sistema sexo- 
género han de contemplar la distinción entre dos conceptos: sexo y género. Eva Espinar señala que el sexo hace referencia a "la base biológica de las diferencias entre hombres y mujeres; es decir, diferencias hormonales, genitales y fenotípicas", mientras que el género hace alusión a la "interpretación cultural del sexo, es decir, el conjunto de expectativas sociales depositadas sobre los roles a desempeñar por hombres y mujeres: lo que se espera de ambos" (S. Murillo (2000) citada por Espinar-Ruiz 2003, p. 27). Por su parte Marta Lamas (2000, p. 2) señala que el concepto género engloba el "conjunto de ideas, representaciones, prácticas y prescripciones sociales que una cultura desarrolla desde la diferencia anatómica entre mujeres y hombres, para simbolizar y construir socialmente lo que es "propio" de los hombres (lo masculino) y "propio" de las mujeres (lo femenino)". Por tanto el género implica los roles, estereotipos, identidades, actitudes, valores, comportamientos, derechos, responsabilidades... que la sociedad atribuye a uno y otro sexo.

Respecto a la distinción entre los conceptos sexo-género, coincidimos con el autor José Ignacio Pichardo, cuando señala que en numerosos estudios se han "obviado" componentes elementales (heteronormatividad) de la propuesta realizada por Gayle Rubin, debido a que el planteamiento del concepto sexo no se refiere exclusivamente a la dicotomía hombre mujer, sino a la sexualidad y a las relaciones sexuales en su conjunto. Pichardo rescata las siguientes citas de Gayle Rubin para fundamentar sus aseveraciones: "el género no es sólo una identificación con un sexo: además implica el deseo sexual hacia el otro sexo" (1996: 60) y "la organización social del sexo se basa en el género, la heterosexualidad obligatoria y la construcción de la sexualidad femenina (1996: 58)". Este autor resalta que Gayle Rubin en su propuesta no solo sitúa la sede de la opresión en las mujeres, sino también de las minorías sexuales (Pichardo, 2013, p. 274). 
El sistema sexo-género también permite evidenciar que existe una distribución simbólica del espacio asociada a la diferencia sexual, donde a las mujeres se les relega al ámbito reproductivo (privado/devaluado socialmente/no remunerado), mientras que a los hombres se les designan espacios productivos (público/prestigio social/remunerado).

Rosa Cobo elabora un análisis del sistema sexo-género a partir de las definiciones propuestas por Gayle Rubin y por Seyla Benhabid, que la lleva a concluir que en el núcleo de la sociedad existe un mecanismo distribuidor de los recursos (políticos, económicos, culturales o de autoridad, entre otros) en función del género. Añade Rosa Cobo que ese mecanismo sobrecarga los recursos a los varones y los sustrae de los que les corresponden a las mujeres (Cobo Bedia, 2004, pp. 15-19).

Por otro lado, Izquierdo menciona que este sistema ha permitido visibilizar que las diferencias sexuales han sido la base para justificar infinidad de prácticas culturales que continúan siendo un problema común en las sociedades actuales: "la feminidad, la división del trabajo, la diferenciación y la separación de las tareas femeninas y las masculina" (Izquierdo, 2013, p. 109).

Elena Casado (1999, p. 76) nos explica que el sistema sexo-género fue bien recibido por las académicas feministas, sobre todo durante las primeras décadas después de su incursión. Así, afirma que "el término corrió como la pólvora convirtiéndose en un instrumento fundamental de teorización y orientación práctica". Sin embargo, en los años noventa la ampliación y la popularización del término propiciaron que se abriera un nuevo debate sobre la pertinencia de su empleo.

\section{Uso y abusos del concepto género}

En las últimas cuatro décadas los estudios que han incorporado el concepto de género no solo se han incrementado, sino que también se ha diversificado el 
empleo del mismo. Recordemos que la década en la cual se teoriza sobre este concepto coincide con el resurgir del movimiento feminista tanto a nivel teórico como práctico. Así pues, este concepto desde sus orígenes es complejo y difícil de delimitar, dado que se ha utilizado con distintas acepciones y en diversos marcos teóricos (Martín Bardera, 2015). A este respecto, Izquierdo indica que la pluralidad de significados que ha caracterizado el empleo de éste concepto obedece a que es un constructo con origen en la lucha de las mujeres contra la discriminación sexual y no derivado de postulados científicos, "la política se anticipa a la ciencia" (Izquierdo, 1998, p. 18),

El uso del término género irrumpe en las academias como una herramienta analítica que cuestiona que la biología sea destino. Así, el género es utilizado como una categoría crítica de la realidad social cuyas bases se fundamentan en las teorías feministas. A partir de esta perspectiva se reinterpreta el estudio de diversas disciplinas del saber, incluyendo una mirada crítica de las relaciones de poder establecidas en un orden social que justifica las desigualdades entre hombres y mujeres basándose en las diferencias biológicas. Joan Scott (1986), manifiesta que las feministas consideraron que este término, además de evidenciar temas nuevos, revolucionaría las normas y premisas en el ámbito académico (Scott, 1986). ${ }^{47}$

Los cambios acaecidos en las sociedades occidentales a partir de la década de los ochenta, ${ }^{48}$ exigían a los Estados la puesta en marcha de acciones que favorecieran la igualdad de oportunidades entre hombres y mujeres. Esto propició que la situación de desigualdad que denunciaban las mujeres lograra entrar en las agendas públicas. Sin embargo, Scott nos explica cómo poco a poco el término "género", debido a su mayor acogida política, fue sustituyendo

\footnotetext{
${ }^{47}$ Versión traducida: "El género: una categoría útil para el análisis histórico", en Lamas, M. (comp.) (1996). "El género: la construcción cultural de la diferencia sexual”. México: PUEG, p. 265302. Disponible en pdf en: http://www.cholonautas.edu.pe/modulo/upload/scott.pdf

${ }^{48}$ Mayor participación de las mujeres en ámbitos académicos, laborales; movimientos sociales; compromisos internacionales asumidos por las naciones sobre derechos humanos, entre otros.
} 
al de "mujer". En el ámbito académico también hubo repercusiones, así pronto los "estudios de las mujeres" fueron sustituidos por "estudios de género". Scott, manifiesta que el concepto género fue una búsqueda de legitimidad científica, pues el empleo de "género" parecía ajustarse mejor a las exigencias de la terminología científica de las ciencias sociales. El sentido y el uso del término fue interpretado de diferentes maneras, lo cual provocó que alrededor de este constructo se establecieran vaguedades y nociones inciertas (Botello Lonngi, 2005; González Jiménez, 2009; Lamas, 1999, 2000; Scott, 1986; UNFPA, 2006). Todo este conjunto de ambigüedades en torno al concepto género produce permanentes líneas de tensión con otros postulados feministas, puesto que la realidad a investigar no son entidades esenciales e inmutables, sino elementos de la realidad social en proceso de cambio (UNFPA, 2006).

Las líneas de tensión, críticas o cuestionamientos que se generaron con relación al concepto género giraron en torno a los siguientes puntos:

- Argumentos deterministas y monocausales: Sobre este punto la autora Elena Casado indica que desde esta perspectiva se vuelve nuevamente a oposiciones binarias arraigadas en la tradicional separación entre el individuo y la sociedad (Casado Aparicio, 1999, p. 77).

- Limitación del concepto a la diferencia sexual. Marta Lamas (2000, p. 5) menciona que algunas feministas "al ignorar un sistema total de relaciones que incluye la subjetividad y la sexualidad, no rebasaron los límites de la interrogante de los papeles sociales". Izquierdo (Izquierdo, 1998, p. 19) señala que la perversión más generalizada de este concepto ha sido la de usarlo para sustituir mecánicamente el término sexo.

- Dicotomía sexo-género/naturaleza-cultura: los movimientos feminista surgidos en la década de los ochenta (posestructuralistas, posmoderno, psicoanalista) van a elaborar una crítica sobre el carácter determinista 
de este concepto. Así, autoras como Butler (1990) debaten el establecimiento de las categorías hombre/mujer por considerarlas como rígidas y excluyentes, argumentando que a través de estas categorías se ocultaba la diferenciación entre las personas. Marta Lamas (2000) explica cómo en los años noventa existe una aceptación sobre la importancia de comprender el género para analizar la situación de mujeres y hombres. Sin embargo existe una fuerte crítica sobre la identidad adquirida, pues gana terreno la idea de tomar en cuenta el papel que juega en el ser humano la subjetividad. Con base en las obras de Foucault (1987), se argumenta que el sexo tiene una historicidad y también es construido socio-culturalmente. El cuerpo no es una superficie plana y neutra a partir de la que levantar el edificio cultural, sino una instancia del conocimiento socialmente investida (Gil, 2013, p. 54).

- Despolitización del género. Se elimina cualquier referencia al poder, María Jesús Izquierdo, citando a Nighat Khan, señala que los análisis de género forma parte de un discurso tecnocrático, utilizado por profesionales para el diseño de políticas sociales pero que carece de sentido crítico y trasformador. El empleo de este concepto deja de ser analítico para convertirse en un modelo descriptivo sobre el cual se obscurece el conflicto o las relaciones de género (Izquierdo, 1998, pp. 28-29). Rosa Cobo, plantea que durante los últimos años diversas instituciones (gubernamentales, institucionales...) han empleado este término sustrayendo su contenido feminista, provocando que el "género se convierta en un eufemismo para invisibilizar un marco de interpretación de la realidad que nos muestra la sociedad en clave de sistema de dominación" (Cobo Bedia, 2005, p. 256). La autora afirma, así mismo, que la perdida de la vinculación entre género y feminismo nos priva de la brújula que nos indique la senda político-social que hay 
que seguir para conseguir la igualdad, la justicia y la libertad. Silvia Tubert también aborda esta temática, al mencionar que cuando se habla de "perspectiva de género en vez de perspectiva feminista, "se establece un campo académico despojado de toda proyección crítica y reivindicativa de los movimientos sociales" (2003, p. 13).

Todas estas críticas, derivadas de la pluralidad, la generalización y el abuso del concepto "género" en las que se cuestiona el estudio aislado de las mujeres, su supuesta homogeneidad, el determinismo naturaleza/cultura y la despolitización, no restan importancia a la categoría del genero como herramienta de análisis, sino que la enriquecen. Como bien menciona Rosa Cobo, "los conceptos son útiles en la medida en que iluminan la realidad que designan y aportan elementos para comprenderla" (Cobo Bedia (2005, p. 250) citando a Berger y Kellner, 1985). Teniendo en cuenta estas consideraciones es que retomamos este concepto como eje para elaborar el análisis de esta investigación.

\section{El género como categoría de análisis}

Desde tiempos remotos se nos ha negado a las mujeres el derecho de participar en igualdad de condiciones con relación a los varones en el ámbito social, cultural, político, económico. Los argumentos ontológicos que han servido para justificarlo han sido una y otra vez la "naturaleza" de unos y otras. Rosa Cobo manifiesta que ninguna otra dominación/opresión ejercida en el pasado o en el presente ha sido revestida por la insignia de la naturaleza como lo ha sido y lo es la subordinación de la mujer. Marta Lamas (1986) citó a Sullerot, haciendo referencia a que era más fácil cambiar la naturaleza que la cultura, "es más fácil librar a la mujer de la necesidad "natural" de amamantar, que conseguir que el marido se encargue de dar el biberón" (p. 183). María Jesús Izquierdo también hace algunas consideraciones en relación a la difícil tarea que conlleva el intento de modificar el orden social: 
[...] las evidencias nos permiten afirmar que es más fácil modificar las características naturales que la organización de la sociedad. Solo hay que considerar el espectacular incremento de la esperanza de vida que se ha producido en el último siglo, el hecho de que la carencia de alas no nos impida volar [...] En cambio, el pasmoso incremento de la productividad no ha contribuido a eliminar el hambre en el mundo, así como los conocimientos sobre el tratamiento de las principales enfermedades no se ha traducido en la erradicación de las mismas entre una buena parte de la población mundial (Izquierdo, 2013, p. 96).

Es evidente que el trasformar el sistema patriarcal no es tarea fácil. Tres siglos de lucha feminista dan cuenta de ello. No obstante, consideramos que se han conseguido grandes cosas, si bien el trabajo no está terminado y es preciso continuar evidenciando las formas en las que opera el sistema patriarcal. El género como categoría analítica es una "estrategia conveniente y necesaria para documentar y comprender los roles, las responsabilidades y las identidades de mujeres y hombres en un contexto económico, político, social y cultural dado" (Quintero (2007) citado por Costa Aguirre, 2016, p. 46). Utilizar la categoría crítica del género significa no solo analizar la realidad social de la relaciones de poder entre los sexos, sino que también conlleva una "voluntad ética y política de denuncia de las deformaciones conceptuales de un discurso hegemónico basado en la exclusión e inferiorizacion de la mitad de la especie humana" (Puleo, 2000, p. 19).

En la actualidad, aun cuando el término género no está exento de cuestionamiento, sigue siendo un referente académico reconocido por diversos autores (Cabral \& García, 2003; Cabral \& Samudio, 2005; Casado Aparicio, 1999; Cobo Bedia, 2005, 2008, 2014; De Barbieri, 1990; Gabriela Delgado Ballesteros, 2003a; Facio \& Fries, 2005; Gil, 2013; González Jiménez, 2009; Hernández García, 2006; Izquierdo, 1998, 2013; Lagarde, 1996; Lamas, 2000; Maquieira, 2013; Martínez \& Egido, 2009; Oliva Portolés, 2007; Postigo Asenjo, 2006; Puleo, 2000; Radl Philipp, 2001; Scott, 1986, 2011). 
Los planteamientos son muy diversos, por esta razón en este estudio vamos analizar cuatro propuestas. Tres de ellas que consideran la categoría género adecuada para el estudio de las relaciones sociales (Joan Scott, 1986; Rosa Cobo, 2005 y 2014; y Marcela Lagarde, 1996). La otra sobre la dominación masculina, a partir de Pierre Bourdieu, (2000). En su conjunto, estos cuatro planteamientos pueden enriquecer considerablemente nuestra investigación.

Joan Scott (1986) propone una definición de género que reposa sobre dos núcleos principales, y donde uno de ellos se compone por cuatro elementos que han de ser tomados en cuenta:

1. El género es un elemento constitutivo de las relaciones sociales basadas en las diferencias que distinguen los sexos.

a. Los símbolos y los mitos culturalmente disponibles que evocan representaciones múltiples y estas pueden ser contradictorias.

b. Los conceptos normativos que manifiestan las interpretaciones de los significados de los símbolos. Es decir, las características, principios, valores, conceptos... que afirman categórica y unívocamente el significado de varón y mujer, masculino y femenino.

c. Las instituciones y organizaciones sociales de las relaciones de género: el sistema de parentesco, la familia, el mercado de trabajo segregado por sexos, las instituciones educativas, la política.

d. La identidad subjetiva. En este punto la autora señala que si bien es cierto que la identidad es algo subjetivo y personal, también es posible elaborar tratamientos colectivos que estudien la construcción de la identidad genérica en grupos. Marta Lamas (1999) ve en este punto una debilidad en la propuesta de la autora, pues señala que se mezcla "identidad subjetiva con identidad genérica”. 
2. El género es una forma primaria de relaciones significantes de poder. Con este punto Scott elabora una la teorización donde señala que el género de forma persistente y recurrente ha implicado en la concepción y en la construcción al propio poder, al punto de contribuir a la distribución y al control diferencial sobre los recursos materiales y simbólicos, o al acceso de los mismos.

En su planteamiento, Scott explica que las dos ideas principales que giran en torno al género están interrelacionadas entre sí, sin embargo son analíticamente distintas, pues aunque existe una conexión integral entre ellas, estas nociones se retroalimentan entre sí, no operan de manera simultánea.

Por su parte Rosa Cobo (2005, 2014), plantea que la categoría de género evidencia la subordinación de las mujeres, explica la causa de la misma y elabora acciones políticas orientadas a desactivar los mecanismos de esa discriminación. También indica que este concepto no es algo estático sino todo lo contrario, es dinámico en tanto que puede ser modificado con el trascurrir y el hacer de las personas. Esta autora hace referencia a tres directrices:

1. Existe una normatividad femenina edificada sobre el sexo como hecho anatómico. Es decir, las prescripciones que las sociedades atribuyen a las mujeres: desarrollarse en el ámbito privado, ejercer la procreación, los cuidados de los otros/as, el trabajo doméstico, la heterosexualidad y la ausencia de poder... varían de una sociedad a otra. No obstante, en la mayoría de los países industrializados recae en las mujeres el desempeño de estas funciones.

2. Sistema social jerarquizado. Distribución de espacios y de recursos diferenciados para varones y mujeres, con las connotaciones que de ellos se derivan. Así pues, el espacio destinado para los hombres es el público/prestigio/remuneración, mientras que el espacio privado/ignominia/no remunerado está configurado para las mujeres. 
3. Estructuras sociales de dominación. Las instituciones y doctrinas religiosas, educativas, políticas, económicas, (re)producen argumentos impregnados con la idea de "naturaleza" que dotan de una estabilidad legitimadora que pareciera es inmutable.

La propuesta de Rosa Cobo, a diferencia de la de Scott, puntualiza en la subordinación de la mujer, además de hacer mayor referencia a cómo la construcción social con base en la biología ha legitimado durante milenios la dominación que se ha ejercido sobre más de la mitad de la población (mujeres).

Comienza Marcela Lagarde por definir el género como una "categoría del orden sociocultural configurado sobre la base de la sexualidad: la sexualidad a su vez definida y significada históricamente por el orden genérico" (1996, p. 26).

Para Lagarde, la asignación de género se inicia con el ritual de la procreación y el nacimiento: al nacer la criatura, o incluso antes, al conocer los genitales de la criatura, se dice y nombra a la vez: "es niña" o es "niño". "La palabra, el lenguaje es la marca que significa el sexo e inaugura el género". A partir de ese momento (ser nombrado), el cuerpo recibe una significación sexual, sobre la cual existe una predeterminación normativa que va a condicionar las posibilidades y potencialidades vitales de las personas. Para Lagarde están implicados seis elementos:

- Las actividades y las creaciones del sujeto: el hacer del sujeto en el mundo.

- La intelectualidad y la afectividad, los lenguajes, las concepciones, los valores, el imaginario y las fantasías, el deseo del sujeto, la subjetividad del sujeto.

- La identidad del sujeto o autoidentidad en tanto ser de género: percepción de sí, de su corporalidad, de sus acciones, sentido del Yo, 
sentido de pertenencia, de semejanza, de diferencia, de unicidad y estado de la existencia en el mundo.

- Los bienes del sujeto: materiales y simbólicos, recursos vitales, espacio y lugar en el mundo.

- El poder del sujeto (capacidad para vivir, relación con otros, posición jerárquica: prestigio y estatus) condición política, estado de las relaciones de poder del sujeto, oportunidades.

- El sentido de la vida del sujeto.

En la propuesta que realiza Lagarde juega un papel primordial la sexualidad, dado que la considera como "el conjunto de experiencias humanas atribuidas al sexo y definidas por la diferencia sexual y la significación que de ella se hace" (Lagarde, 1996, p. 28). Manifiesta también que el orden fundado sobre la sexualidad es un orden de poder, en el cual las personas han de ajustarse a ciertas normativas y asignaciones genéricas. Así mismo, considera que se puede intervenir activamente en la trasformación de estas asignaciones, de acuerdo a las posibilidades opresivo/emancipadoras que tengan las personas.

Lagarde insiste en que la categoría género ofrece la posibilidad de comprender y explicar a cualquier sujeto social a través de la significación social de su cuerpo sexuado (cargado de deberes y prohibiciones asignadas).

Hasta aquí hemos abordado una aproximación a los tres planteamientos sobre la categoría género. Si bien cada uno de ellos pone el acento en cuestiones distintas, todos coinciden en que es una categoría útil para evidenciar que la diferencia de sexo se ha traducido en desigualdad social. Las propuestas de estas autoras convergen también en desafiar el orden sociocultural, cuestionando y desmontando los argumentos ontológicos que intentan legitimar las relaciones de poder que generan discriminación entre las personas.

En el esquema que presentamos a continuación se muestran las coincidencias y las divergencias entre las propuestas abordadas sobre la categoría de género. 
En la parte central se pueden observar los aspectos en los que consideramos que existen encuentros entre las autoras. En la parte exterior de los círculos se pueden observar las particularidades que aportan cada uno de los planteamientos explicados.

Esquema 1.3. Elementos sobre la categoría de género: coincidencias y divergencias de las tres propuestas

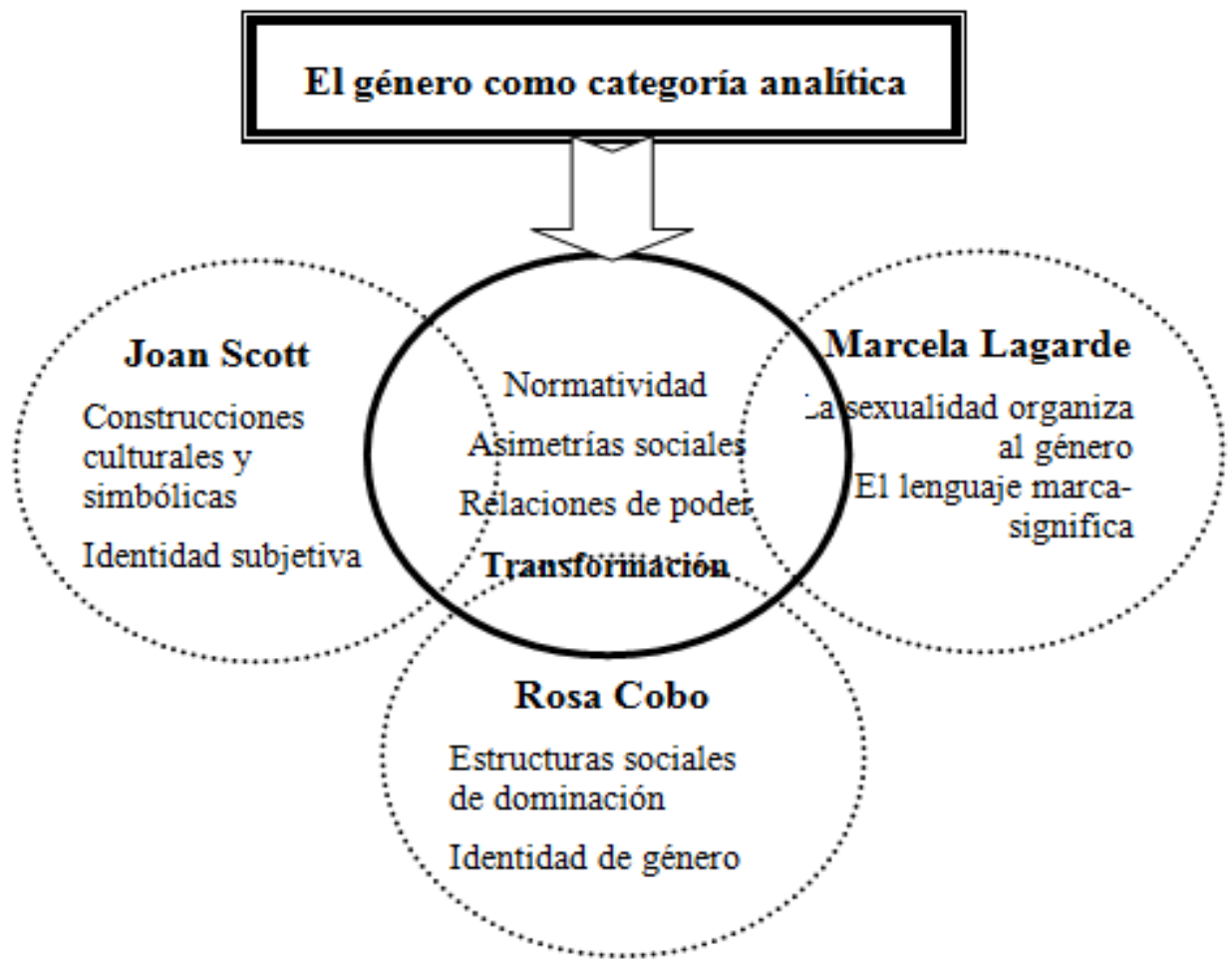

Fuente: elaboración propia con base en Cobo Bedia, (2005, pp. 252-256), (2014, pp. 8-10); Lagarde, (1996, pp. 26-34); Scott, (1986).

La propuesta elaborada por Pierre Bourdieu (2000), —aun cuando no hace referencia de manera directa al concepto género-, investiga cómo la división de las cosas y las actividades, incluidas las diferencias sexuales, permanecen inmersas en un "sistema de oposiciones homólogas" (alto/bajo, arriba/abajo, delante/detrás, derecha/izquierda, público/privado) (Bourdieu, 2000, p. 20). En todas ellas, lo que representa el polo positivo está siempre asociado a lo masculino, ocurriendo lo inverso con lo femenino (UNFPA, 2006, p. 30). Bourdieu explica que la división sexual al presentarse en un "orden" de lo normal y lo natural, se inscribe en un esquema de pensamiento universal de las 
divisiones preexistentes, lo cual consagra, reconoce y justifica el orden establecido de dominación (Bourdieu, 2000, pp. 20-22).

Teniendo en cuenta estos planteamientos, podemos decir que la categoría de género resulta adecuada como marco de referencia para esta investigación, puesto que nos permite abordar tanto el acontecer de los sujetos (las relaciones de género entre el alumnado), como las construcciones sociales-culturales que les son atribuidos a uno y otro sexo desde la organización social de un contexto determinado (en nuestro caso hemos elegido el ámbito educativo).

Así pues, la elección de este referente analítico nos permitirá evidenciar las desigualdades que persisten en un contexto socio-cultural determinado (Michoacán de Ocampo), con un grupo de estudiantes específico (adolescentes de primer grado de secundaria), los cuales están inmersos en estructuras sociales de orden público (institución educativa). Pretendemos comprender como operan los elementos planteados por estas autoras a nivel individual, colectivo e institucional.

En la siguiente tabla se reflejan los elementos en los que coinciden las tres propuestas referenciadas, también se muestra cómo en el orden social establecido lo masculino ha ocupado y ocupa un lugar de privilegio con relación a lo femenino. Este entramado de relaciones de poder ha sido aceptado como algo natural, durante siglos, a través de fuerzas de coerción, y, además, en los procesos de socialización se configuran los comportamientos, acciones, experiencias, representaciones mentales y corporales con los que "las personas pueden o no hacer, decir o pensar" (Lagarde, 1996, p. 27).

Tabla 1.3. Género, dicotomías atribuidas a lo femenino y a lo masculino

\begin{tabular}{|c|c|c|c|}
\hline \multirow{2}{*}{ Elementos } & \multirow{2}{*}{$\begin{array}{l}\text { Códigos } \\
\text { prescriptivos }\end{array}$} & \multicolumn{2}{|c|}{$\begin{array}{c}\text { Género. Dicotomías atribuidas } \\
\text { socialmente }\end{array}$} \\
\hline & & Femenino & Masculino \\
\hline Normatividad & Estereotipos & $\begin{array}{l}\text { Emoción } \\
\text { Sensibilidad } \\
\text { Intuición } \\
\text { Vacilación } \\
\text { Dependencia }\end{array}$ & $\begin{array}{l}\text { Razón } \\
\text { Análisis } \\
\text { Pensamiento } \\
\text { Decisión } \\
\text { Independencia }\end{array}$ \\
\hline
\end{tabular}




\begin{tabular}{|c|c|c|c|}
\hline & Roles & $\begin{array}{l}\text { Asociados a la } \\
\text { procreación }\end{array}$ & $\begin{array}{l}\text { Asociados a la } \\
\text { producción }\end{array}$ \\
\hline \multirow{2}{*}{$\begin{array}{c}\text { Relaciones de } \\
\text { poder }\end{array}$} & Atributos & $\begin{array}{l}\text { Inferior } \\
\text { Opresión } \\
\text { Exclusión }\end{array}$ & $\begin{array}{l}\text { Superior } \\
\text { Dominio } \\
\text { Oportunidad }\end{array}$ \\
\hline & Espacios & $\begin{array}{l}\text { Privado } \\
\text { Cerrado } \\
\text { Invisible } \\
\text { Victima }\end{array}$ & $\begin{array}{l}\text { Público } \\
\text { Abierto } \\
\text { Visible } \\
\text { Violencia }\end{array}$ \\
\hline $\begin{array}{l}\text { Asimetrías } \\
\text { sociales }\end{array}$ & $\begin{array}{c}\text { Valoración } \\
\text { social }\end{array}$ & $\begin{array}{l}\text { Invisilidad } \\
\text { No valoración } \\
\text { social }\end{array}$ & $\begin{array}{l}\text { Reconocimiento } \\
\text { Prestigio social }\end{array}$ \\
\hline
\end{tabular}

Se requiere la trasformación social

Fuente: elaboración propia con base en Aranda Friz, (2015, p. 41); Bourdieu, (2000, pp. 20-22); INMUJERES, (2009, pp. 41-42).

Haciendo una recapitulación de este apartado, podemos decir que hasta aquí hemos tratado de exponer que el género forma parte de los mecanismos que organizan lo social. Ahora bien, como categoría de análisis es una herramienta útil para estudiar las relaciones de poder y dominación que están inscritas tanto en los individuos, como en las instituciones sociales. Con este instrumento analítico no solo intentamos evidenciar las relaciones de desigualdad existentes en el Estado de Michoacán de Ocampo, sino que también nos permitirá proponer acciones encaminadas a favorecer la igualdad entre los y las adolescentes. Coincidimos así con Alicia Puleo (2000) cuando manifiesta que el empleo de esta categoría implica una mirada crítica y una voluntad ética y moral para proponer alternativas que sirvan para la transformación social.

\subsection{Resumen}

El repaso de la historia del feminismo nos ayuda a mirar al futuro con otros ojos y a recordar que tiempo atrás (tres siglos) la vida para las mujeres era pensada solo desde la otredad. Este repaso nos lleva, también, a reflexionar sobre los avances que se han alcanzado gracias a la fortaleza de unas cuantas 
que no se conformaron con "ser" lo que "otros" decían que "debían ser". Gracias a la valentía, a la rabia, a las ilusiones... de muchas mujeres de estas y otras altitudes (y unos cuantos hombres) por pensar que un mundo con nuestra participación sería mejor, hoy podemos "manejar nuestros propios bienes, heredar, tener la tutela de nuestros hijos e hijas, votar y ser votadas, elegir una profesión y ejercerla, figurar como sujetos jurídicos, asociarnos y expresarnos públicamente" (UNAM, 2013, p. 148).

Estudiar la historia del feminismo internacional y del feminismo mexicano, nos da la posibilidad de comprender que el cuestionar estructuras sociales de dominación favorece el desarrollo y el progreso de las naciones. Queda mucho por mejorar y los logros conseguidos nunca pueden ser considerados como fijos. Amelia Valcárcel nos recuerda que la libertad es una condición civil y política que en algunas regiones se ha alcanzado recientemente, pero que esta es difícil de obtener y aun más complicado de practicar, pues exige de un buen sistema de gobierno democrático “[...] leyes, gobiernos, magistraturas, pero también estados de opinión, limitación de prejuicios y decisión"[...] "La libertad no es un derecho natural que todos traigamos escrito en la frente al venir al mundo, es por el contrario un bien, el mayor, y nada fácil. El sistema debería garantizar su equitativo reparto, pero la riqueza, el desmedido poder de algunos y las costumbres dejan a muchos sin él” (Valcárcel, 2013, p. 25).

El feminismo no solo ha logrado movilizar a las personas a nivel internacional para vindicar sus derechos, también ha logrado dar una vuelta de tuerca a las ciencias sociales, acuñando categorías que han permitido/permiten visibilizar que la situación social de las mujeres, en todos los ámbitos (público/privado), está determinada por un orden social-cultural injusto que privilegia a los varones sobre las mujeres La categoría género es, en resumidas cuentas, una herramienta analítica que permite descubrir las diferencias construidas socialmente entre hombres y mujeres, así como averiguar cómo 
estas diferencias se traducen en relaciones de desigualdad, poder, exclusión, dominación (Díaz Martínez \& Dema Moreno, 2013). 


\section{Género y educación}

Marcela Lagarde 1997 «Transitar al próximo siglo y al nuevo milenio y desentendernos de lo que hemos sido y aún somos, significaría para mujeres y para hombres no sólo intercambiar cualidades de género y hacerlas indistintas según el sexo, sino desmontar lo que cada género contiene de oprobioso» (Citada por Subirats i Martori \& Tomé, 2010)

Es fundamental plantearnos el tema de la desigualdad entre hombres y mujeres en el contexto educativo, dado que esta institución juega un papel crucial en el proceso de socialización del alumnado y, por tanto, de la ciudadanía en general. Tal como han destacado varios autores, la articulación entre los estudios de género y la educación es una de las condiciones necesarias para lograr mayor justicia e igualdad y para el ejercicio de la democracia, (Arnot, 1995; Gabriela Delgado Ballesteros, 2003b; González Jiménez, 2009; González Ramírez \& Villaseñor García, 2010; Guzmán, 1997; Rebollo Catalán, García Pérez, Piedra, \& Vega, 2011; Tarabini \& Bonal, 2012; Valdés E., 2013). También los organismos internacionales han considerado fundamental la vinculación de estas dos áreas del conocimiento (UNESCO, 2001; UNFPA, 2006).

Diversos autores han destacado la relevancia de los estudios de género en el campo educativo y la actualidad científica de esta temática, puesto que se considera que la articulación entre estos dos campos es una de las condiciones necesarias para lograr mayor justicia e igualdad, además de un instrumento oportuno para el ejercicio de la democracia, (Arnot, 1995; Gabriela Delgado Ballesteros, 2003b; González Jiménez, 2009; González Ramírez \& Villaseñor García, 2010; Guzmán, 1997; Rebollo Catalán et al., 2011; Tarabini \& Bonal, 2012; Valdés E., 2013). También los organismos internacionales han considerado fundamental el articular estas dos áreas del conocimiento (UNESCO, 2001; UNFPA, 2006). 
El presente capítulo nos permitirá adentrarnos en el papel que ha jugado la educación en la conformación de las asimetrías establecidas en función de la diferencia sexual. Buscamos analizar el contexto educativo desde una perspectiva de género para visibilizar situaciones socioculturales que perpetúan las desigualdades entre hombres y mujeres y para reflexionar sobre la función que realiza esta institución con la finalidad de procurar el desarrollo social, político, económico, cultural...

Para tal efecto, iniciaremos este capítulo haciendo una breve introducción de cómo se gestó la educación institucionalizada, con la finalidad de ilustrar que el modelo educativo ha estado permeado desde su origen por la diferenciación y discriminación en función de la diferencia sexual entre las personas (Goetschel, 2007).

En el capítulo anterior abordamos cómo la Ilustración significó un antes y un después en la concepción y configuración del ser humano y de la sociedad en general. En este periodo se desafió el orden social y político poniendo en entredicho el régimen monárquico y la teoría iusnaturalista, recurriendo para ello a los principios liberadores de la razón, la igualdad y la justicia. Bajo estos principios se formulan los nuevos códigos que han de regir a la nueva sociedad moderna. Amelia Valcárcel explica que en este periodo (en Francia) se plantean ideas para cambiar las formas de gobierno y brindar más soberanía a los ciudadanos (recordemos que las mujeres fueron excluidas de este proyecto político). La educación a partir de este momento va a adquirir un nuevo sentido, pues el Estado se volvía "juez y garante" de lo que un individuo debía o no saber. En este periodo se establecieron los tramos educativos que conocemos hasta la fecha, quedando divididos en: educación primaria, media y superior (Álvarez de Morales, 2011; Paladines Escudero, 1996; Valcárcel, 2013).

Es así como la institucionalización de la educación comienza en Francia a finales del siglo XVIII y primeras décadas del XIX, ligada al ascenso de la 
nueva clase burguesa. Carlos Paladines, manifiesta que es a partir de este momento que se dan las condiciones para que la educación "[...] se convierta en condición sine qua non del progreso y ella fuera reclamada tanto por el Estado como por la Sociedad Civil [...]". El nacimiento de "la escuela" es utilizado por el Estado como una estrategia insoslayable para la consolidación de las transformaciones sociales (1996, p. 76-77). Dicha idea estará avalada por políticos como Mirabeau, Talleyrand o Condorcet (1791) (Pérez, 2011). Paladines cita a los siguientes autores para ejemplificar el alto valor asignado a la educación en ese periodo:

Mirabeau en la convención de 1791:

Los que quieren que el hombre del pueblo no sepa leer ni escribir, sin duda han formado un patrimonio con su ignorancia y sus motivos no son difíciles de estimar. Pero no saben que cuando se ha hecho del hombre un animal bravío se expone uno a verlo a cada instante transformado en bestia feroz. Sin luz no hay moral

[...] Talleyrand, quien decía:

A fin de que la voluntad general sea recta es preciso que sea esclarecida e instruida... Después de haber dado al pueblo el poder debéis enseñarle la sabiduría... La instrucción es el contrapeso necesario de la libertad. La ley, que de hoy en adelante es obra del pueblo, no debe estar a merced de las opiniones tumultuosas de una multitud ignorante (Paladines Escudero, 1996, p. 76).

Por su parte, José Antonio Souto señala que aunque es Talleyrand quien elabora el Informe sobre la Instrucción Pública (1791), Condorcet va a tener mayor influencia sobre la misma. Para Condorcet la educación debía abarcar "[...]lo físico, lo intelectual y lo moral y debe tener un profundo significado social" y también debía ser universal, gratuita y obligatoria (Souto Paz, 2011, p. 21).

La escuela comenzó a adquirir mayor relevancia debido principalmente a las trasformaciones derivadas de la primera revolución industrial y al desarrollo del nuevo orden político (Souto Paz, 2011, p. 19; Valcárcel, 2013, p. 49). En esta época surgieron también las primeras vindicaciones respecto a hacer extensivo el derecho a la educación a las mujeres, pues, aunque se abrieron nuevos centros educativos para ellas, el objetivo seguía siendo mantenerlas alejadas del 
conocimiento (Valcárcel, 2013, p. 49). El cometido de la educación era pues distinto para hombres y para mujeres. Para los hombres la formación educativa se convirtió en la llave para acceder al campo profesional y al conocimiento, mientras que la de las mujeres (burguesas principalmente) tenía como finalidad que estuvieran preparadas para encargarse de la educación de sus hijos e hijas, pero se mantenía la división de papeles entre hombres (público) y mujeres (privado) (Quesada Jiménez, 2014; Serrano Barquín \& Serrano Barquín, 2006).

Por tanto, la educación fue el medio a través del cual el Estado procuró trasmitir y fomentar tanto los conocimientos y saberes, como los valores y hábitos que se consideren oportunos para el progreso de la Nación. Es ahí donde radica la importancia de esta institución, pues mediante ésta se configuran los modelos, los valores, las creencias, los saberes que han de regir la vida de las ciudadanas y los ciudadanos de una sociedad determinada.

Francesc López menciona cómo históricamente el varón ha utilizado la educación entre otros instrumentos y estrategias para perpetuar las desigualdades sociales entre hombres y mujeres (2002). Durante siglos el sistema patriarcal otorgó lugares distintos a hombres y a mujeres. La educación no fue la excepción, ellas eran relegadas al ámbito doméstico argumentando que no poseían las características morales, intelectuales y anatómicas que se requerían para alcanzar la ciudadanía plena (Bosch Fiol \& Ferrer Pérez, 2003a, 2003b). Los discurso biologicistas-naturalistas, perpetuados durante miles de años, las colocaban "[...] al margen del conocimiento y del saber, al margen de la razón" (Buquet Corleto \& Moreno, 2013).

Frente a estos supuestos siempre han existido mujeres que se han pronunciado, denunciando y/o reivindicando que otro mundo era/es posible (López Rodríguez, 2002). El movimiento sufragista también vindicó el derecho a la educación de las mujeres. Sin embargo, tanto el acceso al conocimiento como la incorporación a la educación fueron procesos complejos y dilatados 
cuyo comienzo tuvo lugar en el siglo XIX en Europa y en otras regiones de los países occidentales.

En México, Patricia García indica que la educación vista como bien público separada del clero fue definida por primera vez en 1833, no obstante, no es hasta 1867 que se establece "en su artículo $3^{\circ}$ de la Constitución que la enseñanza será gratuita y obligatoria" (García Guevara, 2004, p. 94). ${ }^{49}$ Por su parte, Roberto Zárate manifiesta que los cimientos de la educación actual se pueden ubicar en los años que van de 1876 a 1910, dado que en este periodo en México se establece la pedagogía moderna, se crean y expanden las escuelas normales, se instauran las primeras carreras técnicas para los obreros y la educación superior se propaga por todos los Estados de la Nación (Zárate Rosas, 2003).

Rocha (1991), citada por Dulce C. Montero y Landy Esquivel, señala que a partir de 1880 se crean instituciones educativas dedicadas a la preparación de las mujeres en México. Ese mismo año se establecen las escuelas vocacionales femeninas, las cuales instruían a las mujeres en actividades "propias de su sexo" para evitar que la prostitución fuera la única opción de las mujeres sin recursos. También se instauran las escuelas municipales para obreras en el año 1887. En 1896 se funda la escuela Teórico Práctica de Obstetricia para mujeres en un hospital de la ciudad de México. Era destinada para "señoritas mayores de veinte años que hubieran terminado la primaria y que tuvieran certificado de buena conducta” (Montero Moguel \& Esquivel Alcocer, 2000, pp. 53-54).

\footnotetext{
${ }^{49}$ Cabe destacar que a lo largo de los siglos XIX y XX la educación entendida como servicio público y tutelada por el Estado se generaliza en la mayor parte de los países occidentales (Pérez, 2011). Lucila Parga explica de manera detallada cómo se da el proceso de institucionalización de la educación en México (2008). Así pues, esta autora señala que en la época de la colonia, la instrucción estaba fuertemente influenciada por la religión católica y el pensamiento dogmático, con el tránsito a una sociedad independiente, la educación cobró importancia, y en 1834 se materializan las Leyes y reglamento para el arreglo de la Instrucción Pública en el Distrito Federal. En 1910 con la Revolución se generaron una serie de iniciativas que orientaron el futuro de la educación nacional. La instrucción se convirtió en un proceso fundamental para conseguir la cohesión social y la unidad nacional (Parga Romero, 2008, pp. 95-99).
} 
A finales del siglo XIX la incorporación de las mujeres a la educación superior era mínima, pues, aunque no se les negaba el acceso de manera reglamentaria, la educación recibida en el nivel medio era diferenciada por sexos. Ellas, instruidas en bordado, tejido y corte y confección entre otros, no cumplían con los requisitos para entrar a una educación superior que requería de la formación científica, cálculo, moral, física, entre otras que recibían los varones en la educación media (Montero Moguel \& Esquivel Alcocer, 2000 citando a Velásquez). A principios del siglo $\mathrm{XX}$, las mujeres que ingresan a estudios superiores continúan siendo mínimas. En 1921 se funda la Secretaría de Educación Pública y ésta institución promueve la incorporación de la mujer a los estudios superiores de magisterio (Rocha citada por Montero Moguel \& Esquivel Alcocer, 2000).

Ana Buquet y Hortensia Moreno indican que la incorporación de la mujer a la educación superior en México "ha tenido que transitar de la exclusión absoluta a la incorporación paulatina, con casos muy excepcionales -en el siglo XIX y principios del XX [...]" (2013, p. 89).

Elvira Montes de Oca señala que durante el gobierno cardenista (1934-1940) la educación adquiere un sentido más social. Se planteaba que la nueva educación debía orientarse a formar a niños y niñas para que estos pudieran liberarse de los prejuicios que les condenaban a ser excluidos:

La educación impartida por el Estado sería la misma tanto en el medio urbano como en el rural, orientada una hacia las actividades productivas desarrolladas en las ciudades y otra hacia las actividades del campo. También sería igual para niños que para niñas, para hombres que para mujeres; por eso todas las escuelas serían mixtas (Montes de Oca Navas, 2015, p. 156).

Este proyecto educativo iba más allá de la educación mixta, se planteaba que niños y niñas debían colaborar para contribuir al progreso de la Nación. Este proyecto de educación socialista se vio postergado con el arribo de un nuevo gobierno que cambió el rumbo de la educación. Además fue severamente 
criticado por los grupos conservadores y la Iglesia católica (Parga Romero, 2008).

Las políticas educativas implementadas con posterioridad promovían ideas conservadoras. La instrucción educativa debía basarse en prepararlas para cuidar del bienestar de la familia. El eje rector de su enseñanza era el cuidado del "otro". Lucila Parga indica que "las mujeres se convertían en un instrumento del Estado para legitimar el proyecto político con fronteras sexistas estructuradas" (Parga Romero, 2008, p. 143).

Las trasformaciones suscitadas en las sociedades industrializadas durante el siglo XX y el XXI han generado profundos cambios, ${ }^{50}$ la educación no ha permanecido al margen. Durante los años setenta y ochenta, la expansión de la educación secundaria y superior obligó al Estado a reorganizar los planes y programas establecidos. ${ }^{51}$ Las movilizaciones feministas, las presiones jurídicas internacionales y nacionales cuestionaron la escasa participación de las mujeres en el sistema educativo, es decir, las primeras vindicaciones fueron la búsqueda de cobertura cuantitativa, cuestión que ha sido superada en el presente siglo (DOF, 2013b). Sin embargo, el acceso a la educación no significó que se planteara una estrategia coeducativa, simplemente se incorporó a las mujeres a un sistema educativo androcéntrico (Zapata-Martelo \& Ayala-Carrillo, 2014).

Diversas autoras manifiestan que en la década de los noventa se abre la discusión en términos de políticas públicas en materia de género y educación (Gabriela Delgado Ballesteros, 2003b; González Jiménez, 2009; Parga Romero, 2008). Desde entonces hasta la fecha se han puesto en marcha diversas acciones encaminadas a transformar la cultura escolar bajo los principios de justicia y

\footnotetext{
${ }^{50}$ Tomás Calvo refiere ya en 1995 que "nunca como ahora formamos parte toda la humanidad de una aldea global, el universalismo y la globalización; el mundo se ha convertido en un gran mercado, en el que libremente transitan capital, tecnología, recursos, empresas y productos" (Calvo Buezas, 1995, p. 255).

${ }^{51}$ Recordemos que en este periodo resurge el movimiento feminista mexicano que se implica en la lucha por lograr la igualdad real con los varones, y vindican el derecho a la educación en igualdad de condiciones que los hombres.
} 
equidad, pues la igualdad de género continúa siendo una tarea pendiente para el contexto educativo. Parga menciona que lograr la igualdad exige principalmente tres cuestiones:

1. Romper con los estereotipos, perjuicios y roles que limiten las potencialidades de las mujeres,

2. Procurar una distribución justa y equitativa de la participación de las mujeres en el proceso de enseñanza-aprendizaje, y

3. Brindar oportunidades reales que apunten a una nueva distribución de poder en los espacios físicos y simbólicos en el escenario educativo.

Con esta breve introducción damos cuenta de cómo la educación institucionalizada ha sido un escenario que ha brindado a las mujeres oportunidades para acceder a la autonomía personal, pero su incorporación ha estado llena de tensiones, conflictos, desigualdades y discriminaciones en función de las diferencias de sexo, que se han ido fraguando históricamente y que siguen repercutiendo en el momento actual. Los movimientos feministas, tanto prácticos como académicos, se han tenido que enfrentar a un acérrimo sistema patriarcal y androcéntrico que se ha resistido y que se resiste a trasformar las normatividades de género existentes.

Teniendo estas cuestiones en consideración presentamos este capítulo que consta de tres subapartados.

En el primero mostramos el proceso de socialización en la etapa adolescente que se encuentra dividido en dos partes interrelacionadas. Primero veremos cómo intervienen los procesos de socialización en la construcción de la identidad sexual y de género. En segundo lugar abordaremos cómo las diferencias establecidas en función del sexo generan asimetrías entre hombres y mujeres. 
En el segundo subapartado veremos cómo está estructurada la escuela secundaria en México prestando atención, por un lado, a la temática del sexismo en la educación y, por otro, a la importancia de los libros de texto.

Por último, profundizamos en las investigaciones que preceden a esta en el contexto español y latinoamericano: tanto las relacionadas con los estereotipos de género como las generadas en torno al análisis del sexismo en los libros de texto.

\subsection{El proceso de socialización en la etapa adolescente}

"Más allá de los estereotipos y de los iconos, todos y todas tenemos en alguna medida y, sin duda, deberíamos tener tanto referentes de identidad como dimensiones de subjetividad. Sin raíces, desde luego, nos secamos. Pero, demasiado apegados a nuestras raíces, no crecemos. Las identidades ni son ni deberían ser costras: están atravesadas por mediaciones crítico-reflexivas que deben producir permanentemente aportaciones y rechazos selectivos"

(Amorós, 2007, p. 231)

La socialización es el proceso a través del cual las personas aprendemos, interiorizamos, construimos y reconstruimos los valores, normas y comportamientos que son considerados adecuados dentro de un contexto sociocultural determinado (Cánovas Leonhardt \& Sahuquillo Mateo, 2008; Quesada Jiménez, 2014; Simkin \& Becerra, 2013). En este sentido, Irene Silva afirma que "el proceso de socialización propiamente dicho, sería entonces la manera con que los miembros de una colectividad aprenden los modelos culturales de su sociedad, los asimilan y los convierten en sus propias reglas personales de vida" (2007, p. 14).

Hugo Simkin y Gastón Becerra (2013), mencionan que el proceso de socialización se inicia en el nacimiento y trascurre y evoluciona durante todas las etapas de la vida. Las personas entran en contacto con el mundo social mediante diversos agentes socializadores. Hugo Simkin y Gastón Becerra, citando a Berger y Luckmann (1968), manifiestan que pueden distinguirse tres tipos de socialización: 
1. La socialización primaria. Tiene lugar en la infancia y el agente socializador principal es la familia. Es aquí donde se inicia el proceso de aprendizaje e interiorización del mundo social, por ello estos autores consideran que es la más importante y trascendente para el desarrollo de las personas.

2. La socialización secundaria. Es una prolongación del primer tipo, mediante cuyo proceso se puede acceder a conocimientos, valores, roles distintos a los adquiridos en el seno familiar. Se desarrolla dentro de los grupos secundarios: amigos, escuela, medios de comunicación, asociaciones, grupos de ocio, comunidades religiosas, etc., y posee un carácter menos afectivo.

3. La socialización terciaria. Hace referencia a los procesos de socialización que se producen cuando el individuo establece relación con personas de otras culturas.

Los agentes de socialización mencionados van a jugar un papel de mayor o menor importancia según las características propias de la sociedad, de la etapa vital de las personas y de su posición en la estructura social (Silva, 2007). A través de estos agentes se van a transmitir las normas, creencias, valores y pautas de comportamiento que son consideradas oportunas para un contexto determinado. Los principales agentes de socialización en los países occidentales son la familia, la escuela, los medios de comunicación... Durante la adolescencia, cobran especial importancia como agentes de socialización, la escuela, el grupo de pares y las relaciones amorosas (Fuertes, Carpintero, Martínez, Soriano, \& Hernández, 1997).

A continuación presentamos un esquema propuesto por Silva 2002 retomado en el trabajo realizado en 2007- para resumir lo expuesto anteriormente, en el cual aparece enfatizado el contexto elegido para el desarrollo de este trabajo de investigación: 


\section{Esquema 2.1. Proceso de socialización en el sujeto}

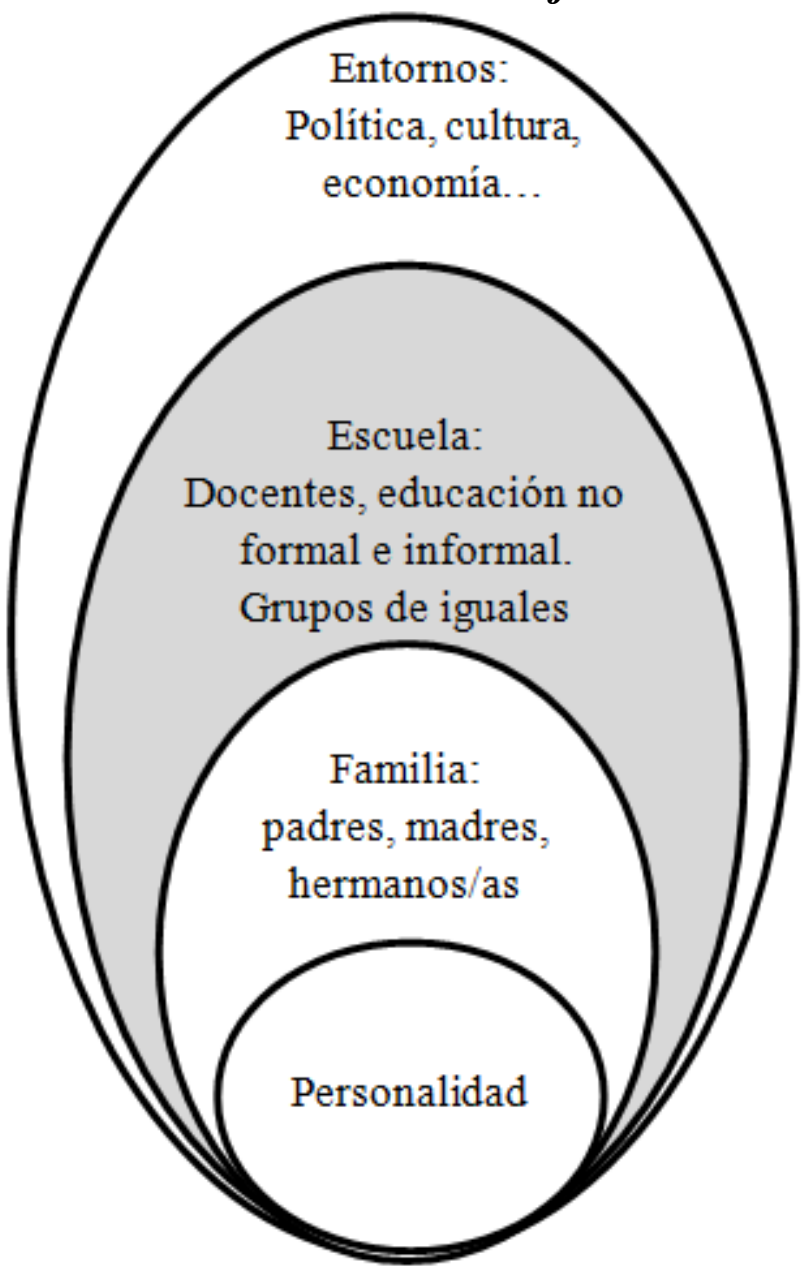

Fuente: adaptado de Silva Diveiro, (2007, p. 15).

Tal como manifiestan diversos autores, la escuela en todos sus ámbitos (espacio, profesorado, alumnado, currículo, aprendizajes, enseñanzas...) resulta ser un importante eje regulador del proceso de socialización (Blanco, 2003, 2007; Lomas, 2008; Luengo González \& Blázquez Entonado, 2004). Es en este entorno donde se transmiten los modelos y pautas de comportamiento que promueven los gobiernos para fomentar el conocimiento y las normas de convivencia que han de perdurar para que se produzca efectivamente el desarrollo social. En este sentido, Carlos Lomas (2008, p. 179) señala que la escuela es "[...] ese lugar en el que trascurre el tiempo de nuestra infancia, adolescencia y juventud y en el que no sólo se aprenden cosas sino también maneras de ser y de estar en el mundo". Por tanto nos vamos a centrar en la influencia del proceso de socialización en la escuela. 
Estos agentes socializadores no han permanecido inamovibles a lo largo del tiempo, sin embargo en todas las sociedades han afectado de forma distinta a hombres y a mujeres. Isabel Guibourg (1992) hace referencia a que la diferenciación comienza incluso antes del nacimiento. En el momento que los progenitores conocen el sexo del bebé ya empiezan a configurarse las representaciones simbólicas alrededor de lo que es ser mujer y ser hombre. Nos convertimos en mujeres y varones no porque tengamos diferente sexo, sino porque hemos aprendido a serlo a través de los diversos agentes socializadores: la familia, la escuela, los medios de comunicación, el grupo de iguales (Llorca Llinares, 2007; Quesada Jiménez, 2014).

A través de la familia se van a empezar a fraguar las desigualdades en función de las diferencias anatómicas, a través de los juegos-juguetes, los cuentos, los premios o los castigos, los modelos de representación que observan del padre y de la madre en la distribución de las funciones tanto laborales como domésticas... Mediante todo este entramado de representaciones simbólicas, niños y niñas irán recibiendo mensajes que van a incidir en la construcción de su propia identidad (Quesada Jiménez, 2014). Posteriormente la escuela, como agente socializador, tiene la posibilidad de perpetuar o trasformar la desigualdades entre hombres y mujeres. No obstante, el proceso del desarrollo social no solo se verá influenciado por los agentes externos, sino que las estructuras mentales del individuo adquieren una vital importancia, ya que se produce una interacción, una adaptación y una reconstrucción que les van a permitir - a los sujetos-, apropiarse y adaptarse al entorno social en el que deben vivir (Llorca Llinares, 2007).

En la etapa de la adolescencia, ${ }^{52}$ que es la que más concretamente nos interesa, el proceso de socialización cobra relevancia, pues en ella se adquiere

\footnotetext{
${ }^{52} \mathrm{La}$ adolescencia es una etapa de transición peculiar, pues las personas se encuentran en una fase de tensiones y ambivalencias donde no se es niño/a pero tampoco se ha alcanzado la etapa adulta. Una de las señas propias de esta etapa es la diversidad de cambios que se presentan a nivel biológico,
} 
un conocimiento más preciso de los estereotipos de género. Ahora bien, al mismo tiempo los individuos cuentan con estructuras de pensamiento formales que les permiten pensar más allá de lo sensible, inmediato y perceptible, es decir, no sólo en lo real sino en lo posible. (Costa Aguirre, 2016; Llorca Llinares, 2007; Parga Romero, 2008). A continuación presentamos una tabla que muestra algunas de las características específicas de este periodo.

Tabla 2.1. Características específicas de la etapa de la adolescencia temprana

\begin{tabular}{ll}
\hline $\begin{array}{l}\text { Características } \\
\text { Peculiaridades }\end{array}$ & Adolescencia temprana (10-14) \\
\hline Maduración somática & $\begin{array}{l}\text { Aparición de caracteres sexuales secundarios. } \\
\text { Crecimiento corporal. }\end{array}$ \\
\hline Imagen y cuerpo & $\begin{array}{l}\text { Preocupación por los cambios corporales y del } \\
\text { propio yo. Comparación con los del mismo sexo. } \\
\text { Conciencia de sensaciones eróticas. Necesidad de } \\
\text { intimidad. }\end{array}$ \\
\hline Independencia & $\begin{array}{l}\text { Ambivalencia entre necesidad de independencia y } \\
\text { dependencia. Desacuerdo y enfrentamiento con los } \\
\text { padres. }\end{array}$ \\
\hline Amigos & $\begin{array}{l}\text { Mayor contacto con amigos del mismo sexo. } \\
\text { Inseguridad y necesidad de reafirmación a través del } \\
\text { grupo de iguales. }\end{array}$ \\
\hline Identidad & $\begin{array}{l}\text { Evolución al pensamiento abstracto. Menor control } \\
\text { de impulsos. Mayor mundo de fantasías. Se define } \\
\text { la identidad de género. Inestabilidad emocional. }\end{array}$ \\
\hline
\end{tabular}

Fuente: extracto de la tabla elaborada por Valdivielso Alba, $(2015, p .16)$ a partir de la adaptación de la propuesta de Ros et al. (2001, p. 34.).

La tabla que presentamos muestra algunas de las especificidades sobre el periodo de edad que hemos elegido para esta investigación. En cualquier caso es importante destacar que coincidimos con Lucila Parga en relación a su definición de esta etapa: "Las adolescencias son múltiples y diversas; el

social, intrapersonal y emocional (Cardona Duque, Ariza-Gerena, Gaona-Restrepo, \& Medina-Pérez, 2015). Se justifica así la pertinencia de elegir esta población como muestra para nuestro estudio. "Durante la adolescencia, la definición de la identidad sexual y la ubicación del género son clave en el desarrollo psicosocial" (Parga Romero, 2008, p. 68).

El estudio de esta etapa ha llevado a diversos autores a entrar en contradicción. Algunos autores como Hall (1904), refieren que es una etapa evolutiva del desarrollo. En cambio, otros —entre ellos Zazzo (1982) - consideran que esta etapa se ha originado en las sociedades capitalistas e industrializadas, por lo cual entienden que su estudio ha de abarcar las significaciones socioculturales generadas en los contextos particulares (Valdivielso Alba, 2015). 
mosaico es plural y abierto; se despliega en direcciones distintas donde los sujetos construyen sus identidades con diferentes culturas, pautas, códigos y lenguaje" (2008, p. 79).

Ahora mencionaremos algunas de las influencias que tiene el proceso de socialización en los adolescentes dentro del contexto educativo, tomando en cuenta diversos agentes en él involucrados:

- Influencia del profesorado. Diversos estudios han constatado que el trato, la disciplina, la atención, las exigencias y las expectativas con relación a la tarea académica varían en función del sexo del alumnado (Itatí, 1995; López Valero \& Encabo Fernández, 1999; Nava Saucedo \& López Álvarez, 2010). Estas y otras investigaciones han documentado cómo dentro de los espacios escolares se esconden diversos códigos de género que programan una acérrima enseñanza de prácticas culturales sexistas.

- Influencias de los materiales educativos. Nieves Blanco (2003, p.32) indica que "los libros de texto constituyen la herramienta creada para recoger y presentar a los escolares la cultura seleccionada para ser trasmitida", de ahí que se consideren un agente socializador de gran importancia. Los estudios que evidencian que los materiales didácticos empleados por el alumnado trasmiten estereotipos de género son numerosos (ver apartado 2.3.2).

- Influencias entre el grupo de iguales. Como se había comentado en párrafos anteriores, este agente socializador cobra relevancia en la etapa adolescente. Las personas en esta etapa construyen con sus iguales redes de apoyo y confianza. $\mathrm{M}^{\mathrm{a}}$ Rosa Luengo y Florentino Blázquez (2004) señalan que estas redes les permiten expresar sus sentimientos, compartir sus conflictos y adquirir autoestima: “[...] tienen la posibilidad de ensayar y aprender otro tipo de relaciones 
nuevas, la amistad íntima y los vínculos amorosos" (p. 33). Por otro lado, Josefa Quesada (2014, p. 43), citando el trabajo de Coleman y Hendry (2003), señala que el grupo de iguales da la posibilidad de experimentar "relaciones horizontales", en las que no están tan presentes las jerarquías y que son más equitativas. En estos grupos los y las estudiantes también van a reforzar y consolidar la identidad de género.

Marina Subirats nos explica cómo estos procesos socializadores diferenciados tienen repercusiones sobre todo en las niñas. En este sentido, la autora refiere que, a nivel individual, el modo de socialización típico occidental conlleva en la mujer características de comportamiento subordinado y escaso nivel de toma de posesión del entorno social. Juan Fernández agrega: [...] "falta de competencia, insatisfacción en el rol femenino y un sentimiento de inferioridad adicional al del hombre, que viene adscrito socialmente" (Fernández, 1987, p. 53; Subirats i Martori, 2007, pp. 139-141). En cuanto a los niños, Marina Subirats señala que ellos tienden a apropiarse del espacio, del tiempo y de la acción, en definitiva tienen una posición de jerarquía con respecto a las niñas (Subirats i Martori, 2007).

Haciendo una recapitulación de la temática abordada en este apartado, destacamos que la socialización es un proceso a través del cual las personas aprenden, integran y adaptan, a lo largo de todo su ciclo vital, los elementos/normas establecidos en determinados contextos socioculturales, para ser un integrante más de la comunidad social.

Estos procesos de socialización se han desarrollado en la mayor parte del mundo de manera diferenciada para hombres y para mujeres. La socialización diferenciada por sexo se ha traducido en discriminación y opresión para las personas que no cumplen con las atribuciones requeridas para uno u otro sexo. Estas distintas formas de socialización han sido trasmitidas y reproducidas por 
los distintos agentes socializadores: la familia, la escuela, los medios de comunicación..., cobrando en la adolescencia mayor importancia.

Ahora bien, se vuelve necesario delimitar algunos conceptos que han ido surgiendo conforme avanzábamos en el tema. Para ello, organizamos este apartado en dos puntos. En el punto 2.1.1. haremos referencia al constructo de la identidad y en el punto 2.1.2. definiremos el concepto de estereotipos de género y roles sociales.

\subsubsection{Identidad sexual y de género}

En el presente apartado elaboramos una aproximación teórica sobre la identidad sexual y la identidad de género, dado que consideramos que estos conceptos explican en cierta media las desigualdades existentes entre hombres y mujeres. El abordar la identidad nos permite tener una mirada crítica de los idearios que se configuran sobre la feminidad y la masculinidad.

Una vez dicho esto, vamos a iniciar por definir el concepto de identidad. Desde el punto de vista antropológico, hace referencia a un proceso social que lleva a los sujetos a construir un sentido de pertenencia a un colectivo o a un grupo. Así pues, este concepto no es ni mucho menos una esencia fija e inalterable, puesto que su conformación va a depender de un proceso psicosocial en el que intervienen tanto la autopercepción (subjetividad), como la heteropercepción (prácticas sociales y culturales que organizan el self) (Lara Flores, 1991).

Las autoras Rosa Pastor y Amparo Bonilla consideran que la identidad está relacionada con la toma de conciencia de uno mismo, con el lugar que ha de ocupar en el mundo y con la relación que ha de establecer con los demás. Por eso manifiestan que los procesos identitarios son centrales para el desarrollo humano a lo largo de toda la vida (Pastor Carballo \& Bonilla Campos, 2000). Por su parte, Pilar Colás, nos explica que la identidad implica "la asunción de determinados valores, culturas, ideas, etc." , y que este concepto se construye de 
forma dinámica, cambiando según las circunstancias temporales (Colás Bravo, 2007).

Es preciso aclarar que en este trabajo la identidad adquiere un énfasis especial, pues los y las adolescentes buscan una identificación, adscripción y diferenciación que les permitan configurar su Yo, pero teniendo como referente a "los otros" que les marquen el "deber" social, el cual se encuentra estructurado por un orden político, social y cultural que brinda más valor, prestigio y reconocimiento a lo masculino y por tanto a los varones (Matamala Sáez \& Rodríguez Torres, 2010). No obstante, estas estructuras de poder son la mayor parte de las veces muy sutiles, de ahí que su identificación requiera de unos conocimientos de las teorías feministas y de género ${ }^{53}$ que permitan desvelar las desigualdades ocultas bajo los modelos de identificación que se presentan a la población juvenil.

Marina Subirats y Amparo Tomé (2010) señalan que la primera información que se da cuando nace una persona es su sexo. Esta característica derivada de la dotación genética va a marcar el devenir de las personas en todos los ámbitos en los que se desenvuelva. Así pues, la identidad sexual ${ }^{54}$ de las personas no es un folio en blanco en el cual los individuos al nacer puedan escribir sus experiencias. Marta Lamas refiere que en cada sociedad-cultura se signa a “[...]los seres humanos con el género y éste marca la percepción de todo lo demás: lo social, lo político, lo religioso, lo cotidiano" (Lamas, 1999). Es decir, la sociedad y la cultura ya tienen establecido un orden para los/as recién llegados/as.

Ahora bien, llegados a este punto cabe preguntarnos cómo llega un ser humano a adquirir esta identidad. Interrogante que han intentado responder diversos autores (Horney, 1973; Block, 1973; Pleck, 1975; entre otros citados

\footnotetext{
${ }^{53}$ Celia Amorós, 2010

${ }^{54}$ Entendida como el conjunto de características anatómicas-corporales básicas, especialmente genitales (López, 1988a).
} 
por Juan Fernández, 1987). Juan Fernández menciona que son tres las teorías clásicas que han intentado resolver esta cuestión: la teoría conductista, el psicoanálisis y la teoría cognitiva. A continuación se presenta una tabla en la que se pueden observar las tres propuestas:

\section{Tabla 2.2. Análisis comparativo de los tres enfoques clásicos}

\begin{tabular}{|c|c|c|c|c|}
\hline \multirow{2}{*}{ Enfoque } & \multirow{2}{*}{$\begin{array}{c}\text { Nivel descriptivo } \\
\text { Objetivo }\end{array}$} & \multicolumn{2}{|c|}{ Nivel explicativo } & \multirow{2}{*}{$\begin{array}{c}\text { Metodología } \\
\text { Técnica }\end{array}$} \\
\hline & & Mecanismo & Fuente & \\
\hline Psicoanalítico & $\begin{array}{l}\text { Desarrollo de la } \\
\text { identidad sexual }\end{array}$ & $\begin{array}{l}\text { Identificación } \\
\text { sexual a posteriori }\end{array}$ & La libido & $\begin{array}{l}\text { Tratamiento } \\
\text { psicoanalítico de } \\
\text { pacientes y } \\
\text { autoanálisis }\end{array}$ \\
\hline Conductista & $\begin{array}{l}\text { Desarrollo de la } \\
\text { conducta tipificada } \\
\text { sexualmente }\end{array}$ & $\begin{array}{l}\text { Imitación- } \\
\text { identificación } \\
\text { conductual a } \\
\text { posteriori }\end{array}$ & El ambiente & Método experimental \\
\hline Cognitivo & $\begin{array}{l}\text { Desarrollo } \\
\text { cognitivo de la } \\
\text { identidad- } \\
\text { constancia de } \\
\text { género }\end{array}$ & $\begin{array}{l}\text { Imitación- } \\
\text { identificación } \\
\text { cognitiva a priori }\end{array}$ & $\begin{array}{l}\text { La } \\
\text { maduración } \\
\text { cognitiva }\end{array}$ & $\begin{array}{l}\text { Clínico-crítico } \\
\text { piagetano }\end{array}$ \\
\hline
\end{tabular}

Fuente: Juan Fernández (1987, p. 51).

Para Juan Fernández estas tres teorías no pueden ser comparadas pues persiguen objetivos distintos. Para el psicoanálisis es imprescindible el estudio sexológico de la identidad, mientras que para el enfoque conductista lo que es motivo de estudio son las semejanzas y diferencias de las conductas tipificadas como femeninas o masculinas. Finalmente, la teoría cognitiva se va a interesar por explicar cómo se genera en el sujeto el sentido de pertenencia a uno y otro sexo.

En cambio, Félix López (1988), aun cuando manifiesta que estos constructos teóricos son distintos, considera que estas tres corrientes pueden ser complementarias a la hora de explicar la adquisición y formación de la identidad sexual y de género (p. 69).

López explica que las teorías cognitivas aportan el término de identidad, que hace referencia a la conciencia que una persona tiene de ser ella misma y distinta a las demás (DLE), es decir la auto clasificación. El psicoanálisis pone de manifiesto en sus estudios el concepto de identificación -implica 
sentimientos de deseo por llegar a tener las mismas creencias, propósitos, etc., que otra persona-; y las teorías de aprendizaje social hacen referencia a la tipificación, que se refiere a la asimilación del rol que la sociedad atribuye a cada sexo. Así pues estas tres corrientes ayudarían a explicar de manera más global la adquisición y formación de la identidad sexual y de género (1988, pp. 68-69).

La adquisición de la identidad sexual y de género se inicia en la infancia, ${ }^{55}$ en el último trimestre del primer año, cuando el infante muestra habilidades para reconocerse a sí mismo y a diferenciarse de los demás.

Félix López explica que en la primera infancia se desarrolla más la identidad de género —basándose en características como: vestido, peinado, adornos, actividades - mientras que el desarrollo de la identidad sexual se inicia en la edad escolar, entre los seis y los nueve años, cuando anteponen las diferencias biológicas a las culturales.

Thompson (1975), citado por Félix López (1988, p. 51), explica que durante el período de cero a seis años la adquisición de la identidad sexual y de género sigue un triple proceso:

1. El conocimiento conductual de la existencia de dos tipos de vestidos, adornos, actividades... donde los/as infantes de uno a dos años muestran preferencias tipificadas.

2. La auto clasificación dentro de una de las categorías sexuales. Se da alrededor de los tres años, las personas asimilan lo que desde el nacimiento ha sido asignado y aceptado socialmente como propio de su sexo.

3. A partir de los tres años usan el conocimiento de la identidad sexual y de género para definir con claridad sus preferencias y valoraciones.

\footnotetext{
${ }^{55}$ Existen algunas limitaciones, pues los estudios sobre esta temática comienzan cuando los infantes adquieren la capacidad lingüística.
} 
Posteriormente, durante la niñez intermedia y la adolescencia, Félix López explica que existe mayor conciencia y conocimiento de los estereotipos de género, se dan cuenta de que la identidad sexual y de género es estable ${ }^{56} \mathrm{y}$, además, perciben la distinción entre la identidad sexual y la de género.

En la tabla que se presenta a continuación se muestra una aproximación a cómo se adquiere la identidad sexual y de género teniendo en cuenta tanto el desarrollo evolutivo como el contexto sociocultural:

\section{Tabla 2.3. Modelo evolutivo de tipificación sexual y de género}

\begin{tabular}{ccll}
\hline \hline Núcleos teóricos & Edad & Tareas de investigación & Fuentes de tipificación \\
\hline $\begin{array}{c}\text { Asignación sexual y de } \\
\text { género }\end{array}$ & $0-2$ & $\begin{array}{l}\text { Comportamientos } \\
\text { determinados por tales } \\
\text { asignaciones }\end{array}$ & Adultos-Familia. \\
\hline $\begin{array}{c}\text { Discriminación de sexo } \\
\text { y género }\end{array}$ & $2-3$ & $\begin{array}{l}\text { Discriminación sexual y de } \\
\text { género. Categorización propia } \\
\text { y de los demás }\end{array}$ & $\begin{array}{l}\text { Adultos (familia, cuidadores), } \\
\text { otros niños/as. } \\
\text { Medios de comunicación. }\end{array}$ \\
\hline $\begin{array}{c}\text { Identificación sexul y } \\
\text { de género }\end{array}$ & $3-7$ & $\begin{array}{l}\text { Identificación, preferencia y } \\
\text { adopción sexual y de género }\end{array}$ & $\begin{array}{l}\text { Adultos (familia, cuidadores), } \\
\text { otros niños/as. Escuela. Medios } \\
\text { de comunicación. }\end{array}$ \\
\hline $\begin{array}{c}\text { Constancia sexual y } \\
\text { flexibilidad de género }\end{array}$ & $7-11$ & $\begin{array}{l}\text { Afianzamiento en la } \\
\text { conservación sexual. Rigidez- } \\
\text { flexibilidad en la identidad de } \\
\text { género. }\end{array}$ & $\begin{array}{l}\text { Escuela, grupo de pares del } \\
\text { mismo sexo, medios de } \\
\text { comunicación, libros, docentes, } \\
\text { familia. }\end{array}$ \\
\hline $\begin{array}{c}\text { Redefinición sexuly y } \\
\text { de género }\end{array}$ & $11-20$ & $\begin{array}{l}\text { Ajuste a los cambios } \\
\text { corporales. Ajuste a los } \\
\text { papeles de género }\end{array}$ & $\begin{array}{l}\text { Factores biológicos, } \\
\text { compañeros de uno y otro } \\
\text { sexo, medios de comunicación, } \\
\text { libros, escuela, familia. }\end{array}$ \\
\hline \hline
\end{tabular}

Fuente: adaptado de la propuesta de Juan Fernández (1987, p. 66).

Las etapas de adquisición de la identidad que realizan tanto Félix López como Juan Fernández nos ayudan a clarificar, en cierta medida, el desarrollo evolutivo de la identidad sexual y de género en el sujeto. Sin embargo, lo que a nosotros nos interesa es saber cómo la construcción de la identidad de género formulada con base en la diferencia sexual, constituye el punto de partida que marca el transitar de los seres humanos a priori por caminos distintos $\mathrm{y}$ desiguales. En este sentido, Pilar Colás refiere:

\footnotetext{
${ }^{56}$ Recordemos que esta rigidez en cuanto a la permanencia y constancia de género ha recibido fuertes críticas por parte de los movimientos feministas posestructuralista y posmoderno, pues plantean que las identidades son variables y estas se modifican mediante la interacción sujeto/sociedad/cultura.
} 
"La identidad de género se trasmite culturalmente a través de expectativas, normas, roles, valores, creencias, actitudes y comportamientos que les son trasmitidos a sus miembros en función de que nazcan hembras o machos".

[...]"Ser mujer y ser hombre, implica tener posiciones y roles diferenciados en el espacio cultural que comparten como grupo de sujetos"(Colás Bravo, 2007, p. 155).

Diversas/os autoras/es coinciden en que la identidad de género implica la transmisión cultural de pautas de comportamiento, valores, creencias, deseos y normas (entre otros) diferenciadas para uno y otro sexo. Esta diferenciación condiciona las potencialidades y las posibilidades de desarrollo de las personas, y además conlleva relaciones asimétricas entre mujeres y varones (Cobo Bedia, 2004; Lagarde, 1996; Lamas, 1999; Llorca Llinares, 2007; Subirats i Martori \& Tomé, 2010).

En el año 2006 la UNFPA, citando a Lagarde (1992), menciona que los modelos de género operan como un sistema de referencia a partir del cual el sujeto asume elementos de una "identidad asignada y elementos optados". Los aspectos asignados son su cuerpo y el conjunto de actividades que constituyen el "deber ser". Los elementos optados constituyen la auto identidad, (integrada por la estructura psíquica que refiere a las formas de pensamiento y afectividad y a la confluencia de ambas en la configuración del Yo) (p. 32).

Otro aspecto sobre el que se ha debatido académicamente es si la identidad de género como construcción sociocultural genera modelos descriptivos o prescriptivos. ${ }^{57}$ Marina Subirats y Amparo Tomé señalan al respecto que en la mayor parte de los países occidentales lo "propio de hombres" y lo "propio de mujeres", continúa siendo prescriptivo $(2010$, p. 31$)$.

Los modelos de identidad de género no han permanecido inalterados. Si bien en los países occidentales se puede observar que se han flexibilizado muchas de

\footnotetext{
${ }^{57}$ Los modelos descriptivos son los comportamientos, actitudes y valores que son adoptados por las personas de manera libre, es decir, que no son impuestos. Se habla de modelos prescriptivos cuando la sociedad impone a los seres humanos pautas de comportamiento y exige mediante sanciones que los transgresores cumplan con ellas (Subirats i Martori \& Tomé, 2010, p. 29).
} 
las imposiciones sobre el "deber ser" en función del sexo, — sobre todo para las mujeres-, sin embargo persisten representaciones simbólicas en las cuales opera una "lógica de oposición binaria". Esta oposición se organiza con una lógica de inclusión y exclusión basada en principios antagónicos y complementarios (Lamas, 1999).

En este modelo ideal de lo femenino y lo masculino, a los seres humanos se les asignan diferentes roles, funciones, espacios, rasgos de personalidad, etc. que no son valorados de manera equitativa, pues lo masculino en la mayor parte de las sociedades occidentales es el referente universal (Colás Bravo, 2007; Costa Aguirre, 2016; Lagarde, 1996; Lamas, 1999; Subirats i Martori \& Tomé, 2010; UNFPA, 2006). En este sentido, Celia Amorós (2010b), citando a Molina, indica que la identidad de género para las mujeres hace referencia al conflicto que tienen que enfrentar en "ese proyectar el proyecto del otro para ellas". En palabras de Beauvoir "es tener que vivir como elección propia lo que ya han elegido para nosotras" (pp. 77-78).

El varón, como afirma Beauvoir, "toma su cuerpo como una relación directa y normal con el mundo al cual cree aprehender en su objetividad, mientras que considera que el cuerpo de la mujer se encuentra como entorpecido por cuanto lo especifica: un obstáculo, una prisión” (Amorós, 2010b, p. 77).

La identidad de género constituye pues un proceso dinámico, inacabado, en el cual las redes y las representaciones simbólicas se encuentran en constante transformación. Los seres humanos en el trascurso de su ciclo vital van entretejiendo y reelaborando su identidad de acuerdo a las interrelaciones generadas con su entorno más próximo (UNFPA, 2006, p. 32). La categoría de análisis de género nos brinda la posibilidad de estudiar en qué medida estas prescripciones limitan el desarrollo de las capacidades, las potencialidades, las posibilidades y los deseos de las personas (Cobo Bedia, 2004, 2005; Colás Bravo, 2007; De Barbieri, 1990; Izquierdo, 2013; Lagarde, 1996; UNFPA, 2006). 
Hasta aquí hemos intentado presentar una aproximación respecto al debate académico existente en torno al constructo teórico sobre identidad/identidad sexual/identidad de género. En el apartado que se muestra a continuación se abordaran los estereotipos de género.

\subsubsection{Estereotipos sexuales y roles sociales}

El abordaje de los estereotipos de género y de los roles sociales ha ocupado un lugar importante en los estudios de género, debido a que este instrumento permite analizar si las prescripciones impuestas a los sexos en contextos determinados han ido acompañando las trasformaciones sociales producidas en la mayor parte de los países occidentales (Martínez Sánchez, Navarro Olivas, \& Yubero Jiménez, 2009). Así pues, en este apartado presentamos cómo este constructo (estereotipo) se introdujo en el ámbito académico con el sentido que se emplea en la actualidad. Posteriormente plantearemos diversas definiciones que se han formulado respecto a los estereotipos, los estereotipos de género y los roles sociales y de género. Finalmente vamos a presentar una tabla en la que se muestran algunos de los estereotipos de género que persisten en la mayoría de los países occidentales.

El concepto de estereotipos fue utilizado por primera vez por Walter Lippman 1922. Para este autor nuestras representaciones del mundo están determinadas por esquemas culturales preexistentes que sirven para orientarnos dentro del mundo social. Los estereotipos son imágenes mentales tendientes a simplificar la realidad sobre colectivos, grupos (Lippman, 1922; citado por Parga Romero, 2008, p. 63).

El ajuste del hombre a su ambiente tiene lugar a través de la mediación de ficciones. Por ficciones no quiero decir mentiras. Me refiero a una representación que está en mayor o menor grado hecha por el hombre mismo. El alcance de la ficción se extiende sin interrupción desde la alucinación completa hasta el uso perfectamente consciente por parte de los científicos de un modelo esquemático (Lippman, 1922, pp. 15-16; citado por (Reyes Bueno Moreno \& Garrido Torres, 2012, p. 100). 
Walter Lippman hace referencia a los estereotipos con una connotación un tanto negativa al relacionarla con prejuicios que las personas adoptan para describir a grupos. $\mathrm{M}^{\mathrm{a}}$ Reyes y Miguel A. Garrido (2012) afirman que a partir de 1922 la producción académica alrededor de este concepto ha sido cuantiosa. Sin embargo en este trabajo nos limitaremos a mencionar algunos de los conceptos que consideramos oportunos para el desarrollo de esta tesis. Tajfel en 1977 hace referencia a los estereotipos señalando lo siguiente:

[...] es una imagen mental muy simplificada (por lo general) de alguna categoría de personas, institución o acontecimientos que es compartida, en sus características esenciales, por gran número de personas. Los estereotipos van frecuentemente acompañados de prejuicios, es decir, de una predisposición favorable o desfavorable hacia cualquier miembro de la categoría en cuestión (Escartí, Musitu, \& Garcia, 1988, p. 207).

La definición de Tajfel introduce que los estereotipos pueden ir o no acompañados de prejuicios, lo cual elimina en cierta medida la carga negativa con la que se había formulado en un principio. No obstante, se continúa manteniendo el carácter simplificador de este constructo.

Más adelante, en 1988, Amparo Encartí y col. (p. 208) manifiestan que los estereotipos son "generalizaciones a las que llegan los individuos", tendientes a simplificar, categorizar o sistematizar la realidad, con la finalidad de lograr una adaptación cognoscitiva y conductual. Estos autores refieren que los estereotipos cumplen una doble función. Por un lado, están las funciones individuales "[...] ayudan a los individuos a defender, o preservar, su sistema de valores"; y por otro, están las funciones sociales, las cuales "[ ...] contribuyen a la creación y mantenimiento de ideologías de grupos que explican y justifican una serie de acciones sociales, y ayudan a conservar y a crear diferenciaciones positivamente valoradas de un grupo respecto de otros [...]". Esta definición aporta la doble funcionalidad de los estereotipos y explica cómo estos son aceptados y validados culturalmente. 
$\mathrm{M}^{\mathrm{a}}$ Reyes y Miguel A. Garrido (2012) señalan que diversos teóricos han aceptado la siguiente definición de estereotipo: "conjunto de creencias compartidas sobre las características personales, generalmente rasgos de personalidad, pero también los comportamientos propios de un grupo de personas (Leyens, Yzerbyt y Schadron, 1994 citados por Reyes Bueno Moreno \& Garrido Torres, 2012, p. 100). $\mathrm{M}^{\mathrm{a}}$ Reyes y Miguel A. Garrido consideran que los estereotipos, al ser culturalmente validados y determinados, están sujetos a los cambios y/o transformaciones "sociales, ideológicos y culturales" (2012, p. 102).

Finalmente queremos citar a Josefa Quesada, dado que hace referencia al carácter "emocional" y "subjetivo" de los estereotipos, lo cual conlleva la experiencia vivida del sujeto en interacción con su medio social y cultural (Quesada Jiménez, 2014, p. 91). Las autoras Esperanza Bosch y Victoria Ferrer también hacen alusión al carácter subjetivo del estereotipo, señalando que este "[...] descansa en ideas preconcebidas, condiciona las opiniones de las personas y dirige las expectativas de los miembros del grupo social [...]" $(2003,140)$.

Tras esta revisión podemos concluir que los estereotipos son un conjunto de ideas preconcebidas sobre los rasgos de personalidad, comportamientos y atributos que se consideran propios de grupos o colectivos. Estos estereotipos están valorados, aceptados y arraigados culturalmente, y tienen la función de establecer generalizaciones simplistas y clasificatorias sobre un grupo determinado. Los estereotipos condicionan nuestras opiniones y nuestras expectativas respecto a los grupos sociales; y no son inmutables, pues dependen del entorno social, ideológico y cultural.

Ahora bien, a qué nos referimos cuando hablamos de estereotipos de género. Lucila Parga (2008, p. 65) menciona que este término hace alusión a “[...] las creencias sobre las actividades, los roles, rasgos, características o atributos que caracterizan y distinguen a hombres y mujeres [...]". La autora Josefina Caro 
menciona que son construcciones socioculturales que van a condicionar las actitudes y características de cada sexo, y añade que estos estereotipos van a crear modelos rígidos de "ser hombre" y "ser mujer" (2008, p. 226).

Son muchas las aportaciones que se han formulado alrededor de este término, por ello hemos optado por hacer referencia a algunos de los puntos en los que coinciden diversas autoras/es (Barberá, 2004; Bosch Fiol \& Ferrer Pérez, 2003a; Calero \& Santana, 2001; Caro Blanco, 2008, 2008; Colás Bravo, 2007; Colás Bravo \& Villaciervos Moreno, 2007; Izquierdo, 2013; Martínez Benlloch, Bonilla Campos, Gómez Sánchez, \& Bayot, 2008; Parga Romero, 2008; Quesada Jiménez, 2014). Los mencionados autores consideran que los estereotipos:

- Agrupan un conjunto de creencias sobre los rasgos de personalidad, las conductas correspondientes al rol y los espacios que se consideran característicos de alguno de los sexos.

- Crean modelos de lo que es "propio de hombres" y lo que es "propio de mujeres".

- Valoran de manera desigual. Lo masculino ha sido utilizado como el referente universal.

- Establecen sanciones sociales para los y las trasgresores/as

Teniendo estos puntos en consideración, podemos decir que los estereotipos de género son construcciones socioculturales que marcan las pautas de comportamiento, las relaciones y los espacios que han de ocupar unos y otras. La socialización es el proceso a través del cual se van a reproducir y trasmitir estos estereotipos de género. A partir del nacimiento se van a ir configurando las lógicas del género.

La autora Gloria Poal (1993), citada por Esperanza Bosch y Victoria Ferrer (2003, p. 143), afirma que haber nacido varón tiene ventajas y desventajas, mientras que haber nacido mujer solo tiene desventajas. Las autoras señalan que 
el educar a las mujeres bajo el modelo ideal femenino implica "enseñarles también a infravalorarse, a sentirse dependientes e inseguras, y, por tanto, a convertirse en más vulnerables ante la depresión".

Cada cultura y cada sociedad marcan pautas de comportamiento que llevan a las personas a adecuarse a determinadas funciones, papeles, valores y a renunciar a otros por el mero hecho de haber nacido de uno u otro sexo. Renuncia que limita las posibilidades, opciones y potencialidades de los seres humanos. Los roles sociales son la función y/o tarea que desempeña cada persona. Más específicamente, con el concepto "roles de género" nos referimos a las tareas, papeles y funciones que se asignan a mujeres y varones. Varones y mujeres han de desempeñar funciones y tareas distintas. Cortina (1998) explica cómo los roles asignados a los hombres y a las mujeres van a servir de justificación para continuar con el mantenimiento de una situación que privilegia lo masculino.

En la tabla que presentamos a continuación mostramos algunos de los estereotipos de género y los roles que se atribuyen a lo femenino y a lo masculino:

Tabla 2.4. Estereotipos y roles sexistas

\begin{tabular}{|c|c|c|}
\hline \multirow[b]{2}{*}{$\begin{array}{l}\text { Prescripciones } \\
\text { sociales }\end{array}$} & \multicolumn{2}{|l|}{ Estereotipos sexistas } \\
\hline & Femeninos & Masculinos \\
\hline $\begin{array}{l}\text { Ligados a } \\
\text { características de } \\
\text { personalidad }\end{array}$ & $\begin{array}{l}\text { Pasividad, ternura, } \\
\text { sumisión, obediencia, } \\
\text { docilidad, miedo, } \\
\text { solidaridad, timidez, } \\
\text { falta de iniciativa, } \\
\text { curiosidad, } \\
\text { seguridad, soñadora, } \\
\text { dudosa, inestabilidad } \\
\text { emocional, falta de, } \\
\text { control, dependencia, } \\
\text { afectividad marcada, } \\
\text { frivolidad, } \\
\text { incoherencia, } \\
\text { debilidad, } \\
\text { subjetividad. }\end{array}$ & $\begin{array}{l}\text { Actividad, } \\
\text { agresividad, } \\
\text { autoridad, valentía, } \\
\text { competitividad, } \\
\text { ambición, protección, } \\
\text { riesgo, creatividad, } \\
\text { inteligencia, } \\
\text { asertividad, } \\
\text { autocontrol, dominio, } \\
\text { dinamismo, } \\
\text { autoafirmación, } \\
\text { racionalidad, } \\
\text { franqueza, eficacia, } \\
\text { amor al riesgo, } \\
\text { objetividad, } \\
\text { ingenioso, atlético. }\end{array}$ \\
\hline
\end{tabular}




\begin{tabular}{|c|c|c|}
\hline \multicolumn{3}{|c|}{ Roles sexistas } \\
\hline Roles sociales & $\begin{array}{l}\text { Actividades de } \\
\text { procreación. } \\
\text { La mujer como un } \\
\text { valor estético y/o } \\
\text { sexual. }\end{array}$ & $\begin{array}{l}\text { Actividades } \\
\text { deportivas y } \\
\text { productivas. } \\
\text { E1 hombre como un } \\
\text { mero valor estético } \\
\text { y/o sexual. }\end{array}$ \\
\hline Roles politicos & $\begin{array}{l}\text { No apta, demasiado } \\
\text { Emocional. } \\
\text { Aparece en grupos. }\end{array}$ & $\begin{array}{l}\text { Puestos de mando, } \\
\text { gestión y poder. }\end{array}$ \\
\hline Roles familiares & $\begin{array}{l}\text { Actividades } \\
\text { domésticas y } \\
\text { culinarias. } \\
\text { Actividades ligadas } \\
\text { al cuidado y } \\
\text { educación de los } \\
\text { hijos. }\end{array}$ & $\begin{array}{l}\text { Autoridad y } \\
\text { actividades de } \\
\text { estudio. } \\
\text { Arreglando } \\
\text { desperfectos del } \\
\text { hogar. }\end{array}$ \\
\hline Roles profesionales & $\begin{array}{l}\text { Actividades de } \\
\text { profesora, enfermera, } \\
\text { cuidadora. }\end{array}$ & $\begin{array}{l}\text { Actividades de } \\
\text { investigación, } \\
\text { técnicas y de } \\
\text { responsabilidad } \\
\text { social. }\end{array}$ \\
\hline
\end{tabular}

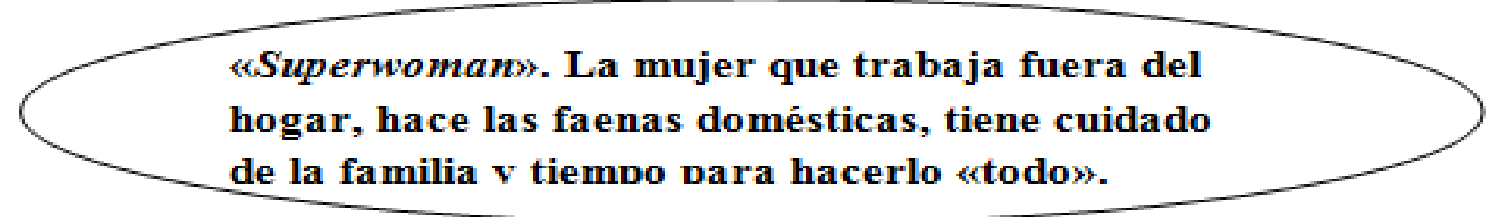

Fuente: elaboración adaptada con base en Espín López, Marín Gracia, \& Rodríguez Lajo, (2004, p. 210); Parga Romero, (2008, p. 67) y Luengo González \& Blázquez Entonado, (2004, p. 79).

No queremos concluir este apartado sin mencionar que en esta investigación los estereotipos de género son considerados como algo dinámico y variable. A través de su estudio pretendemos identificar sus rupturas y continuidades por medio del análisis de las percepciones del alumnado. Intentamos, en definitiva, descubrir si los estereotipos de género pueden llegar a legitimar la desigualdad en las relaciones entre varones y mujeres.

\subsection{La escuela secundaria en México}

«La educación es el terreno, entre lo público y lo privado, entre la sociedad y la familia, en el que asumimos la responsabilidad de establecer la continuidad del mundo, 
conservándolo a través de la protección de la novedad que introducen los nuevos seres humanos que llegan a él» (Blanco, 2008, p. 12)

Con este apartado pretendemos mostrar a grandes rasgos las características generales de este nivel educativo, la enseñanza secundaria, ya que es el contexto elegido para desarrollar nuestro tema de investigación. Para ello, en un primer momento haremos referencia a cómo se encuentra estructurado el Sistema Educativo Nacional (SEN). En segundo lugar definiremos los objetivos que persigue la educación secundaria. En tercer lugar abordaremos cómo se han ido incorporando planes y programas que tienen la finalidad de transversalizar la perspectiva de género en educación. Y finalmente plantearemos la organización de este apartado.

El Sistema Educativo Nacional (SEN) actualmente enfrenta grandes retos. Los cambios sociales acaecidos sobre todo en el último siglo - los cambios demográficos, la incorporación de las mujeres al sistema educativo y al mercado laboral, el aumento de la esperanza de vida, el desarrollo de las telecomunicaciones, la globalización, la desigualdad social en México, etc., han provocado cambios en los planes y programas del SEN para poder afrontar los desafíos que se plantean en la actualidad. Cabe destacar que algunos de los fines por los cuales se creó la Secretaría de Educación Pública (SEP) en 1921 se han ido alcanzando durante este siglo. Así pues, la alfabetización y la cobertura que hasta hace relativamente poco tiempo (50 años) era inimaginable, actualmente es casi un hecho. ${ }^{58}$ No obstante, aun quedan pendientes otros fines, entre ellos podemos mencionar el diseño y operación de un proyecto educativo integrador que permita "anclar y proyectar al país en materia de prosperidad,

\footnotetext{
${ }^{58}$ Como plantean diversos documentos: el "Informe del Programa Nacional para la Igualdad de Oportunidades y no Discriminación contra las Mujeres 2013-2018” (DOF, 2013b); el libro en línea "Plan de diez años para desarrollar el Sistema Educativo Nacional" (Narro Robles, Martuscelli Quintana, \& Barzana García, 2012); el proyecto "El modelo educativo 2016. El planteamiento pedagógico de la Reforma Educativa" (SEP, 2016a); el artículo "Políticas de equidad de género: educación para una escuela libre de violencia" (Zapata-Martelo \& Ayala-Carrillo, 2014); y el artículo "La educación secundaria en México: al filo de su reforma" (Zorrilla, 2004).
} 
calidad de vida y participación ciudadana en lo individual y en lo colectivo" (Narro Robles, Martuscelli Quintana, \& Barzana García, 2012).

En México, el Sistema Educativo Nacional (SEN) se ha ido ampliando gradualmente en materia de obligatoriedad y calidad educativa. En un primer momento este sistema se orientó a establecer garantías y derechos individuales y en la actualidad se ha adoptado un enfoque que contempla los derechos humanos (INEE, 2016).

El derecho a la educación recogido en el artículo $3^{\circ}$. de la Constitución Política de los Estados Unidos Mexicanos (CPEUM), ha tenido que ser replanteado $^{59}$ en diversos momentos, con la finalidad de responder a las transformaciones acaecidas en la sociedad.

En la actualidad el artículo tercero ${ }^{60}$ establece lo siguiente:

Todo individuo tiene derecho a recibir educación. El Estado — Federación, Estados, Ciudad de México y Municipios-, impartirá educación preescolar, primaria, secundaria y media superior. La educación preescolar, primaria y secundaria conforman la educación básica; ésta y la media superior serán obligatorias.

La educación que imparta el Estado tenderá a desarrollar armónicamente, todas las facultades del ser humano y fomentará en él, a la vez, el amor a la Patria, el respeto a los derechos humanos y la conciencia de la solidaridad internacional, en la independencia y en la justicia. ${ }^{61}$

A este respecto, Margarita Zorrilla (2004) indica que en un primer momento se estableció la obligatoriedad y laicidad de la educación primaria. ${ }^{62}$ Posteriormente, en 1993, se amplía la obligatoriedad de la educación secundaria

${ }^{59}$ José Narro y col. (2012) mencionan que las modificaciones que se han realizado tanto al artículo tercero como a su reglamentación - Ley Federal de Educación (1973) y la vigente Ley General de Educación (1993) - no han transformado en esencia los ideales educativos que se plantearon en el periodo revolucionario.

${ }^{60}$ La reforma al artículo $3^{\circ}$ de la Constitución Política de los Estados Unidos Mexicanos, realizada el 26 de febrero de 2013, estableció explícitamente la obligación del Estado de garantizar una educación de calidad para todos.

${ }^{61}$ Retomado de la página web de la Unidad General de Asuntos Jurídicos (SEGOB \& UGAJ, 2013a) disponible en: http://www.ordenjuridico.gob.mx/Constitucion/articulos.php

${ }^{62}$ Lucila Parga afirma que el 5 de febrero de 1917 se promulgó la actual Constitución Política de los Estados Unidos Mexicanos, y en su artículo $3^{\circ}$ se establece el derecho de todo mexicano a recibir educación laica y gratuita en las escuelas primarias oficiales (Parga Romero, 2008, p. 128). 
y se establece la descentralización ${ }^{63}$ de la educación básica. En 2002 se reforma nuevamente el artículo tercero para expandir la obligatoriedad de la educación preescolar, estableciéndose los siguientes plazos: el tercer año de preescolar, a partir del ciclo 2004 a 2005; el segundo año de preescolar, a partir del ciclo 2005 a 2006; el primer año de preescolar, a partir del ciclo 2008 a 2009. Finalmente, en el año 2012, una nueva restructuración del artículo tercero marca la obligatoriedad de la educación media superior, cuyo objetivo es conseguir la cobertura de este nivel educativo a más tardar para el ciclo escolar 2021 a $2022 .{ }^{64}$

En la Ley General de Educación se establecen tres tipos de educación: básica, media superior y superior. La educación básica se cursa a lo largo de 12 grados, distribuidos en tres niveles educativos: tres grados de educación preescolar, seis grados de educación primaria y tres grados de educación secundaria (SEP, 2016b).

En la tabla que presentamos a continuación mostramos cómo se encuentra estructurado el SEN actualmente. Es importante destacar que la edad enfatizada, 12 y 13 , se refiere a la muestra que se ha escogido para ser investigada en este estudio.

${ }^{63}$ La federación quedaba a cargo de la determinación de los planes y programas de estudio de la educación primaria, secundaria y normal para toda la República, y se transfieren a los Estados las competencias que se encargan de administrar el servicio educativo, las plazas de los maestros, los puestos de los empleados...Por otra parte la federación se comprometió a canalizar recursos financieros crecientes a la educación nacional. (Ornelas, 1995:307 citado por Parga Romero, 2008, p. 112).

Cabe destacar que en esta reforma constitucional se introduce "el término de derechos humanos en los grandes lineamientos de la política educativa en la Ley General de Educación" (Parga Romero, 2008, p. 132).

${ }^{64}$ Esta información fue extraída de la página web de la Unidad General de Asuntos Jurídicos: http://www.ordenjuridico.gob.mx/Constitucion/reformas.php 
Tabla 2.5. Sistema Educativo Nacional en México

\begin{tabular}{|c|c|c|c|c|c|}
\hline Edad & Carácter & Tipo & & Nivel & $\overline{\text { Edad }}$ \\
\hline 3 & \multirow{17}{*}{ 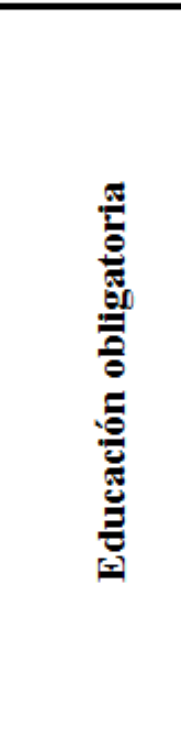 } & \multirow{13}{*}{ 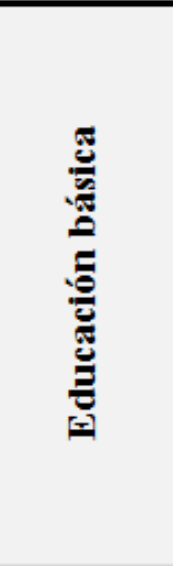 } & \multirow{3}{*}{\multicolumn{2}{|c|}{ Educación Pre-escolar }} & 3 \\
\hline 4 & & & & & 4 \\
\hline 5 & & & & & 5 \\
\hline 6 & & & \multirow{6}{*}{\multicolumn{2}{|c|}{ Educación Primaria }} & 6 \\
\hline 7 & & & & & 7 \\
\hline 8 & & & & & 8 \\
\hline 9 & & & & & 9 \\
\hline 10 & & & & & 10 \\
\hline 11 & & & & & 11 \\
\hline 12 & & & \multirow{4}{*}{\multicolumn{2}{|c|}{ Educación secundaria }} & 12 \\
\hline 13 & & & & & 13 \\
\hline 14 & & & & & 14 \\
\hline 15 & & & & & 15 \\
\hline 16 & & \multirow{4}{*}{ 必突总 } & \multirow{4}{*}{$\begin{array}{l}\text { Educación } \\
\text { profesional } \\
\text { técnica }\end{array}$} & \multirow[t]{4}{*}{ Bachillerato } & 16 \\
\hline 17 & & & & & 17 \\
\hline 18 & & & & & 18 \\
\hline 19 & & & & & 19 \\
\hline 20 & \multirow{7}{*}{ 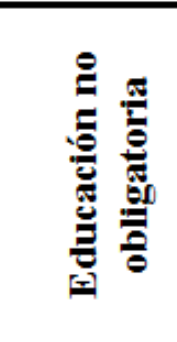 } & \multirow{7}{*}{ 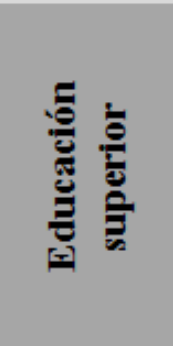 } & Técnico & \multirow[t]{5}{*}{ Licenciatura } & 20 \\
\hline 21 & & & superior & & 21 \\
\hline 22 & & & & & 22 \\
\hline 23 & & & & & 23 \\
\hline 24 & & & & & 24 \\
\hline 25 & & & & \multirow[t]{2}{*}{ Posgrado } & 25 \\
\hline 26 y más & & & & & 26 y más \\
\hline
\end{tabular}

Fuente: elaboración propia a partir de la (DOF, 2011a; Narro Robles et al., 2012).

El sistema educativo nacional exige un certificado o acreditación oficial para acceder a los niveles de estudio más elevados, a partir de primaria. Es decir, la primaria se cursa en seis grados y se finaliza con la acreditación oficial (certificado) que constituye un requisito indispensable para ingresar a la secundaria. La educación secundaria se imparte en tres grados, siendo también necesaria la acreditación oficial al concluir este periodo para poder ingresar a la educación media superior.

La educación media superior comprende el nivel de educación técnica profesional y el bachillerato. En la educación profesional técnica ${ }^{65}$ existen varios programas. Están los que se cursan en dos años, los que se concluyen en tres años (la mayor parte) y los que se programan para cuatro y cinco años

\footnotetext{
${ }^{65}$ Se orienta a la formación para el trabajo técnico y casi todos los programas son de carácter terminal.
} 
lectivos. El bachillerato se imparte generalmente en tres grados, aunque existen programas de estudio de dos y de cuatro años. El certificado de bachillerato es obligatorio para ingresar a la educación de tipo superior.

La educación superior también contempla varias modalidades: técnico superior, licenciatura y posgrado. El primero está orientado a una formación de profesionales capacitados para el trabajo técnico/profesional, que suele ser de carácter terminal y no alcanza el nivel de licenciatura. El segundo tipo (licenciatura) va dirigido a personas que están interesadas en realizar estudios profesionales en una determinada área de conocimiento, y suele durar cuatro o más años. Se imparten en instituciones universitarias, tecnológicas y de formación de maestros y es de carácter terminal. El último tipo, la educación de posgrado, va dirigida a profesionistas que quieren continuar con su formación realizando estudios de especialización, maestría y/o doctorado. Para acceder a estos estudios se requiere de un certificado.

Hasta aquí hemos intentado mostrar a grandes rasgos como está organizado el SEN. A continuación vamos a mostrar cómo se ha desarrollado la educación secundaria en México.

A partir de 1993 la educación secundaria se plantea como el último tramo de la educación básica, esto va a exigir "la redefinición profunda de su identidad" (Parga Romero, 2008, p. 112). El cambio se inicia en el año 2004 y culmina en el año 2011. Durante este periodo se pone en marcha la Reforma Integral de Educación Básica (RIEB), con la cual se pretenden adecuar los planes y programas de estos tres niveles educativos para alcanzar los objetivos y finalidades pretendidos en la educación básica (ver esquema 2.2.). En el 2006 se pone en marcha la Reforma Integral de Educación Secundaria (RIES), sin embargo esta no va a ser bien acogida por el cuerpo de docentes, como veremos más adelante. 


\section{Esquema 2.2. Reforma para la articulación de la educación básica}

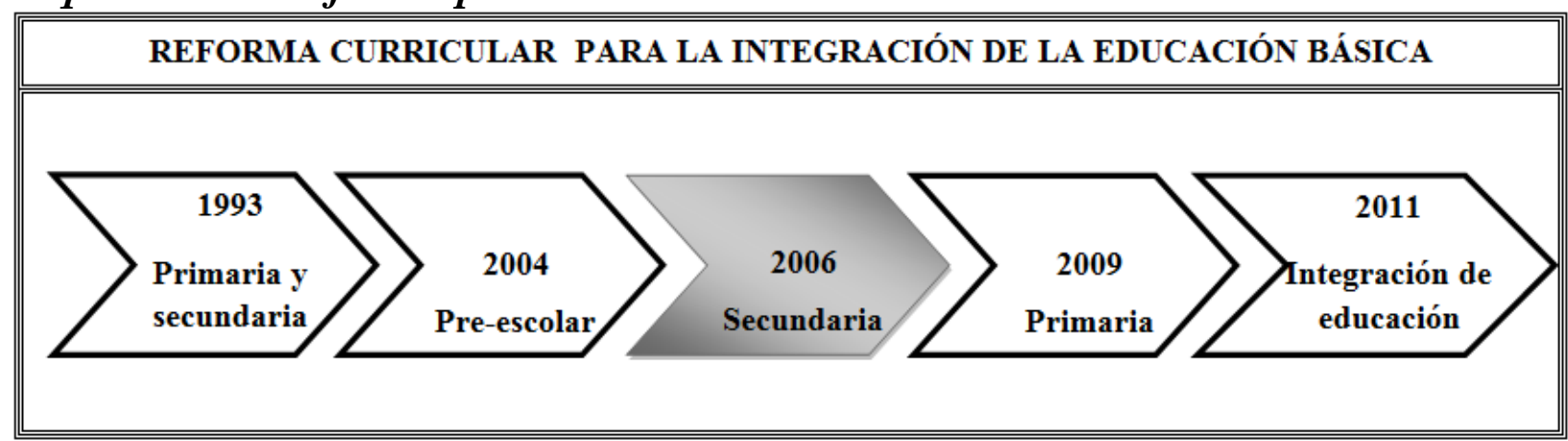

Fuente: elaboración propia a partir de Rosalina Morales, (2014, p. 8).

La educación secundaria en México se define como el último tramo de la enseñanza básica obligatoria. En este nivel educativo se atiende al alumnado con edades comprendidas entre los 12 y los 15 años. Este servicio educativo tiene seis modalidades:

1. Educación secundaria general

2. Educación secundaria técnica

3. Educación telesecundaria

4. Educación para trabajadores

5. Educación para adultos

6. Educación comunitaria/indígena

Cada modalidad posee una estructuración distinta. Así pues, las secundarias generales, técnicas ${ }^{66}$ y para trabajadores tienen una organización que considera la existencia de docentes por asignaturas. En las telesecundarias ${ }^{67}$ y las secundarias comunitarias ${ }^{68}$ sólo se contempla la presencia de un/a docente por grado o grupo. Finalmente, la educación secundaria para adultos promueve la adquisición de las competencias académicas básicas y las destrezas laborales

${ }^{66}$ El INEE (2016) señala que las secundarias que tienen mayor presencia en el país son las modalidades general y técnica. Estás modalidades fueron las elegidas para el desarrollo de esta investigación.

${ }^{67}$ En estos centros se atiende principalmente a la población de comunidades rurales de alta marginación. Para acompañar el proceso de enseñanza-aprendizaje se utilizan medios electrónicos y de comunicación (televisión, señal satelital y videos).

${ }^{68}$ Los centros educativos de esta modalidad están destinados a personas que habitan en pequeñas comunidades rurales e indígenas. 
que permitirán a las personas una mejor integración al mercado laboral. Esta última modalidad está orientada a proporcionar una formación educativa extraescolar que se basa en el autodidactismo y en la solidaridad social (Narro Robles et al., 2012).

Los planes y programas de la educación secundaria en México van encaminados a proporcionar los conocimientos y habilidades que la población adolescente requiere para desenvolverse y participar activamente en la construcción de una sociedad democrática (Acuerdo 384, 2006).

Así pues, el objetivo principal de la Secretaría de Educación Pública, a partir del año 2006, ha sido integrar la educación secundaria dentro del plan de estudios de educación básica. En esta propuesta curricular se establecieron cuatro campos de formación que organizan las asignaturas.

En la tabla que se presenta a continuación se muestra el mapa curricular de primer grado de secundaria, en el se muestran los campos de formación propuestos, las asignaturas correspondientes a cada campo y la distribución por horas lectivas en las escuelas secundarias a tiempo completo.

Tabla 2.6. Mapa curricular de primer grado de secundaria en escuelas a tiempo completo

\begin{tabular}{|c|c|c|c|}
\hline \multirow[b]{2}{*}{ Campos de formación } & \multirow[b]{2}{*}{ Áreas disciplinarias } & \multicolumn{2}{|c|}{ Horas } \\
\hline & & $\begin{array}{c}\text { Secundarias } \\
\text { generales }\end{array}$ & $\begin{array}{c}\text { Secundarias } \\
\text { técnicas }\end{array}$ \\
\hline \multirow{2}{*}{ Lenguaje y comunicación } & Español I & 7 & 7 \\
\hline & Segunda Lengua: Inglés I & 5 & 4 \\
\hline Pensamiento matemático & Matemáticas I & 7 & 6 \\
\hline \multirow{4}{*}{$\begin{array}{l}\text { Exploración y comprensión } \\
\text { del mundo natural y social }\end{array}$} & $\begin{array}{l}\text { Ciencias I (énfasis en } \\
\text { Biología) }\end{array}$ & 7 & 6 \\
\hline & $\begin{array}{l}\text { Geografía de México y el } \\
\text { mundo }\end{array}$ & 5 & 5 \\
\hline & Tecnología I & 3 & $8 *$ \\
\hline & Asignatura Estatal & 3 & - \\
\hline \multirow{4}{*}{$\begin{array}{l}\text { Desarrollo personal y para la } \\
\text { convivencia }\end{array}$} & Educación Física I & 3 & 2 \\
\hline & $\begin{array}{l}\text { Artes I (Música, Danza, } \\
\text { Teatro o Artes Visuales) }\end{array}$ & 3 & 2 \\
\hline & Tutoría & 2 & 2 \\
\hline & Total & 45 & $\mathbf{5 0}$ \\
\hline
\end{tabular}

Fuente: elaboración propia a partir de los datos publicados en el Diario Oficial de la Federación (DOF, 2011a).

Nota: *Para las secundarias técnicas, la carga horaria de esta asignatura no podrá ser menor a ocho horas. 
La reforma educativa de este nivel educativo fue denominada Reforma Integral de Educación Secundaria (RIES). Lucila Parga (2008) explica que el proyecto de articular la educación secundaria con los niveles que le anteceden fue malogrado debido a que no se establecieron las redes oportunas para lograr esta integración de manera favorable:

La reforma por "Acuerdo" no podrá romper con las tradiciones heredadas del pasado, menos aún de ser un proyecto integral ahora fallido terminó en una más de las reformas curriculares a lo largo de la historia. Los cuestionamientos por parte de algunos grupos de maestros, la CNTE y grupos de académicos son diversos, la RES será combatida, pero la imposición está consagrada (Parga Romero, 2008, p. 118) ${ }^{69}$

Desde su creación la educación secundaria ha sido replanteada en diversas ocasiones. Margarita Zorrilla (2004) y Lucila Parga (2008) hacen un recorrido histórico de cómo surge y cómo ha evolucionado este nivel educativo en México. Sin embargo, nuestro objetivo es mostrar a partir de qué momento se inicia el camino para promover la transversalidad de la perspectiva de género en educación secundaria.

A este respecto, Gabriela Delgado (2003) manifiesta que los estudios de género en educación son una línea de reciente creación, ya que solo en la década de los noventa surgen los ejes transversales en educación. Por su parte, Ruiz Cuéllar, (2012, p. 52) refiere que en el año 1993 se incluyen unas directrices en el marco de una política educativa que obtienen mayor alcance en el país (Acuerdo Nacional para la Modernización de la Educación Básica, ANMEB)—. Estas directrices o ejes transversales educativos contemplan la incorporación al sistema educativo de los derechos humanos, la perspectiva de género, el medio ambiente, la construcción de ciudadanía, y la no violencia, entre otros (Delgado Ballesteros, 2003, p. 485).

${ }^{69}$ El CNTE significa Coordinación Nacional de Trabajadores de la Educación. Y la autora hace referencia a la RES en lugar de la RIES, porque manifiesta que la I de integración nuevamente se queda en meras intenciones. 
Las reformas educativas establecidas con posterioridad han de tener siempre en cuenta estos ejes trasversales, los compromisos asumidos a nivel internacional (que se detallan en el capítulo 3) y las normas jurídicas e instrumentos marco de la política pública mexicana (el Plan Nacional de Desarrollo (PND) 2013-1018, el Programa Nacional para la Igualdad entre Mujeres y Hombres (PROIGUALDAD) 2013-2018 y el Programa Sectorial de Educación). En su conjunto, estos instrumentos han establecido objetivos y directrices para combatir las desigualdades entre hombres y mujeres perpetuadas por el sistema educativo en nuestro país.

Así pues, los instrumentos internacionales que han establecido pautas específicas para promover la igualdad entre los sexos han sido los siguientes:

- La Convención sobre la Eliminación de todas las formas de Discriminación contra la Mujer (CEDAW, por sus siglas en ingles) en su artículo 10 hace referencia a que "los Estados Parte deberán tomar las medidas oportunas para eliminar la discriminación contra la mujer, a fin de asegurarle la igualdad de derechos con el hombre en la esfera de la educación y en particular para asegurar, en condiciones de igualdad entre hombres y mujeres $[\ldots] "$

c) La eliminación de todo concepto estereotipado de los papeles masculino y femenino en todos los niveles y en todas las formas de enseñanza, mediante el estímulo de la educación mixta y de otros tipos de educación que contribuyan a lograr este objetivo y, en particular, mediante la modificación de los libros y programas escolares y la adaptación de los métodos en enseñanza: ${ }^{70}$

- La IV Conferencia Mundial de las Mujeres (realizada en Beijing, China, en 1995) establece diversos objetivos estratégicos en el ámbito educativo que tienen como finalidad "lograr la igualdad, el desarrollo y la paz, que deben ser accesibles por igual a mujeres y hombres, de tal manera que las mujeres

\footnotetext{
${ }^{70}$ Retomado de la página web de la Unidad General de Asuntos Jurídicos "Tratados y declaraciones sobre Derechos Humanos". http://www.ordenjuridico.gob.mx/derechos_humanos.php.
} 
se conviertan en agentes de cambio": ${ }^{71}$ Para ello, se establece una plataforma de acción con doce objetivos estratégicos, el correspondiente a la educación es el "B. Educación y capacitación de la mujer". De este objetivo se derivan otros seis: ${ }^{72}$

○ B.1. Asegurar la igualdad de acceso a la educación;

- B.2. Eliminar el analfabetismo entre las mujeres;

- B.3. Aumentar el acceso de las mujeres a la formación profesional, a la ciencia y la tecnología y a la educación permanente;

- B.4. Establecer sistemas de educación y capacitación no discriminatorios; entre las medidas que se han de adoptar para conseguir este objetivo se hace referencia, en el inciso a, a los planes de estudio y los libros de texto:

Formular recomendaciones y elaborar planes de estudio, libros de texto y material didáctico libres de estereotipos basados en el género para todos los niveles de enseñanza, [...]

○ B.5. Asignar recursos suficientes para las reformas de la educación y vigilar la aplicación de esas reformas; y

○ B.6. Promover la educación y la capacitación permanentes de las niñas y las mujeres.

Hasta aquí hemos mencionado algunos de los instrumentos internacionales tendentes a procurar relaciones entre hombres y mujeres más igualitarias en el terreno educativo. Ahora vamos a hacer referencia a algunas de las acciones que se han llevado a cabo en el país.

\footnotetext{
${ }^{71}$ Información retomada del trabajo realizado por María D. Rodríguez y Elena Tapia (2011, pp. 89).

${ }^{72}$ La información que presentamos ha sido extraída de la "Compilación de los principales instrumentos internacionales sobre derechos humanos de las mujeres" (Instituto Nacional de las Mujeres, 2008, pp. 190-197).
} 
En México se han reformulado y establecido diversas normativas jurídicas para mejorar la situación y condición de las mujeres y los hombres en términos de igualdad y equidad de género en el ámbito educativo.

Así pues, en la Constitución Política de los Estados Unidos Mexicanos se recogen varios artículos que establecen la igualdad entre hombres y mujeres (ver capítulo 3). Uno de ellos es el artículo $3^{\circ}$. que fue reformado para incluir que la educación:

c) Contribuirá a la mejor convivencia humana, a fin de fortalecer el aprecio y respeto por la diversidad cultural, la dignidad de la persona, la integridad de la familia, la convicción del interés general de la sociedad, los ideales de fraternidad e igualdad de derechos de todos, evitando los privilegios de razas, de religión, de grupos, de sexos o de individuos. ${ }^{73}$

La Ley General de Educación también hace referencia a la igualdad entre hombres y mujeres en su artículo $8^{\circ}$, reformado el 11 de septiembre de 2013:

El criterio que orientará a la educación que el Estado y sus organismos descentralizados impartan —así como toda la educación preescolar, la primaria, la secundaria, media superior, la normal y demás para la formación de maestros de educación básica que los particulares impartan — se basará en los resultados del progreso científico; luchará contra la ignorancia y sus causas y efectos, las servidumbres, los fanatismos, los prejuicios, la formación de estereotipos, la discriminación y la violencia especialmente la que se ejerce contra las mujeres y niños, debiendo implementar políticas públicas de Estado orientadas a la transversalidad de criterios en los tres órdenes de gobierno. ${ }^{74}$

En México también se cuenta con varias leyes y políticas públicas destinadas a promover una cultura de igualdad y no discriminación en función de sexo dentro de las instituciones educativas, entre ellas la Ley General para Igualdad entre Mujeres y Hombres, aprobada en 2006, que establece en su artículo 34, párrafo II, que hay que: "Fomentar la incorporación a la educación y formación de las personas que en razón de su sexo están relegadas". Además, en su

\footnotetext{
${ }^{73}$ Inciso reformado DOF 09/02/2012, 26/02/2013

${ }^{74}$ Artículo reformado, información extraída de la Unidad General de Asuntos Jurídicos (SEGOB \& UGAJ, 2013b), disponible en http://www.ordenjuridico.gob.mx/Documentos/Federal/pdf/wo39036.pdf
} 
artículo 36, fracción II, mandata que las autoridades correspondientes "garantizarán que la educación en todos sus niveles se realice en el marco de la igualdad entre mujeres y hombres y se cree conciencia de la necesidad de eliminar toda forma de discriminación" (DOF, 2006).

Un año después, la Ley General de Acceso de las Mujeres a una Vida Libre de Violencia, aprobada en 2007, indica, en su quinta sección, en el artículo 45 ., que la Secretaría de Educación Pública debe:

"II. Desarrollar programas educativos, en todos los niveles de escolaridad, que fomenten la cultura de una vida libre de violencia contra las mujeres y el respeto a su dignidad; así como la comprensión adecuada al ejercicio del derecho a una paternidad y maternidad libre, responsable e informada, como función social y el reconocimiento de la responsabilidad compartida de hombres y mujeres en cuanto a la educación y el desarrollo de sus hijos" (DOF, 2007b). ${ }^{75}$

En cuanto a las políticas públicas que sirven de marco de referencia para la igualdad entre hombres y mujeres, como ya habíamos adelantado, son: el Plan Nacional de Desarrollo (PND) 2013- 2018, el Programa Nacional para la Igualdad entre Mujeres y Hombres (PROIGUALDAD) 2013-2018 y el Programa Sectorial de Educación 2013-2018.

El PND es un documento que guía la programación y presupuestación de toda la Administración Pública Federal. En él se establecen cinco metas nacionales: un México en paz, un México incluyente, un México con educación de calidad, un México próspero y un México con responsabilidad global. Además, estas metas han de atender tres estrategias transversales, una de ellas es la perspectiva de género. A continuación se señalan algunos de los objetivos que plantea el PND en materia educativa y perspectiva de género:

\footnotetext{
75 Fracción reformada el 28 de enero de 2011, disponible en http://mail.uteq.edu.ec/handle/43000/174
} 
Tabla 2.7. Objetivos y estrategias planteados por PND 2013-2018

\begin{tabular}{ll}
\hline \hline Objetivos & Plan Nacional de Desarrollo 2013-2018 \\
\hline & Estrategias \\
& $\begin{array}{l}\text { 3.1.3 Garantizar que los planes y programas de estudio } \\
\text { sean pertinentes y contribuyan a que los estudiantes } \\
\text { puedan avanzar exitosamente en su trayectoria educativa, } \\
\text { al tiempo que desarrollen aprendizajes significativos y } \\
\text { competencias que les sirvan a lo largo de la vida. }\end{array}$ \\
$\begin{array}{l}\text { Objetivo 3: } \\
\text { México con educación } \\
\text { de calidad. }\end{array}$ & Fortalecer dentro de los planes y programas de \\
& estudio, la enseñanza sobre derechos humanos en \\
& la educación básica y media superior. \\
& Fomentar que los planes de estudio de todos los \\
& niveles incorporen una perspectiva de género. \\
& Robustecer la participación de las niñas y mujeres \\
& en actividades deportivas, para mejorar su salud \\
& y su desarrollo humano. \\
\hline \hline
\end{tabular}

Fuente: elaboración propia a partir de la página web del Gobierno de la República, (2013b), disponible en: http://pnd.gob.mx/wp-content/uploads/2013/05/PND.pdf

El Programa Nacional para la Igualdad entre Mujeres y Hombres (PROIGUALDAD) 2013-2018, tiene el propósito de "alcanzar la igualdad sustantiva entre mujeres y hombres, en un marco de respeto irrestricto a los derechos humanos de las mujeres y las niñas, y en un contexto de democracia participativa, utilizando para ello la planeación, programación y presupuesto con perspectiva de género,[...]” (Gobierno de la República, 2013a). Este programa contempla siete objetivos: 1). Alcanzar la igualdad sustantiva entre mujeres y hombres y propiciar un cambio cultural respetuoso de los derechos de las mujeres; 2). Prevenir, atender, sancionar y erradicar la violencia contra mujeres y niñas, y garantizarles acceso a una justicia efectiva; 3). Promover el acceso de las mujeres al trabajo remunerado, empleo decente y recursos productivos, en un marco de igualdad; 4). Fortalecer las capacidades de las mujeres para participar activamente en el desarrollo social y alcanzar el bienestar; 5). Generar entornos seguros y amigables de convivencia familiar y social, actividades de tiempo libre y movilidad segura para las mujeres y las niñas y 6). Incorporar las políticas de igualdad de género en los tres órdenes de gobierno y fortalecer su institucionalización en la cultura organizacional. En la siguiente tabla se podrán consultar los objetivos y las estrategias de acción más 
relevantes que se proponen en este plan nacional para impulsar la igualdad en el campo educativo.

Tabla 2.8. Objetivos y estrategias planteados por PROIGUALDAD 2013-2018 PROIGUALDAD 2013-2018

\section{Objetivo}

Objetivo 1:

Alcanzar la sustantiva entre mujeres y hombres y propiciar un cambio cultural respetuoso de los derechos de las mujeres.

\section{Estrategias}

1.2 Promover acciones afirmativas para garantizar el ejercicio de los derechos de las mujeres y evitar la discriminación de género.

1.2.3 Difundir los derechos y adoptar acciones afirmativas para garantizar el goce de los derechos de niñas, adolescentes y jóvenes. 1.5 Promover valores que contribuyan al cambio social y cultural a favor de la igualdad y el respeto de los derechos humanos.

1.5.1 Promover la inclusión de los temas de derechos humanos de las mujeres en los planes de estudio de todos los niveles educativos.

2.1 Incrementar, promover y fortalecer la prevención integral y eficaz de la violencia contra mujeres y niñas.

2.1.4. Eliminar cualquier imagen, contenido o estereotipo sexista y/o

Objetivo 2:

Prevenir, atender, misógino de libros de texto en educación básica, media y media

sancionar y erradicar la 2.2 Promover conductas y prácticas no violentas, respecto a las mujeres y violencia contra mujeres y resolución pacífica de conflictos en escuelas y familias.

niñas, y garantizarles acceso a una justicia efectiva.
2.2.1. Establecer códigos de conducta en las escuelas para eliminar la violencia entre varones, mujeres, niñas y adolescentes.

2.2.5 Incorporar talleres y materiales pedagógicos auxiliares para educar en la no violencia, la tolerancia, las nuevas masculinidades.

2.2.6 Incorporar en los planes de estudio el tema de la igualdad sustantiva entre mujeres y hombres.

4.4 Desarrollar acciones afirma para las mujeres en todos los niveles del sistema educativo, áreas del conocimiento e investigación.

4.5 Fortalecer las actividades artísticas, culturales y deportivas con acciones afirmativas hacia las mujeres y niñas.

4.5.1 Procurar la construcción y adecuación de espacios escolares deportivos con infraestructura y servicios que contemplen las necesidades de las mujeres.
Objetivo 4:

Fortalecer las capacidades de las mujeres para participar activamente en el desarrollo social y alcanzar el bienestar.

Fuente: elaboración propia a partir del Programa Nacional para la Igualdad entre Mujeres y Hombres (Gobierno de la República, 2013c), disponible en http://dof.gob.mx/nota_detalle.php?codigo=5312418\&fecha=30/08/2013.

Finalmente vamos a mostrar los objetivos y estrategias que se establecen en el Programa Sectorial de Educación. Este programa contempla, al igual que su antecesor, seis objetivos. Sin embargo, nosotros solo haremos alusión a los que consideramos que plasman la intencionalidad de trabajar en pro de la no discriminación y el no sexismo en el campo educativo, más específicamente en 
lo relacionado a trasformar la cultura escolar con base en la igualdad y la equidad de género.

Tabla 2.9. Objetivos y estrategias planteadas por el Programa Sectorial de Educación 2013-2018

\begin{tabular}{|c|c|}
\hline \multicolumn{2}{|r|}{ Programa Sectorial de Educación } \\
\hline Objetivo & Estrategias \\
\hline $\begin{array}{l}\text { Objetivo } 1 . \\
\text { Asegurar la calidad de los } \\
\text { aprendizajes en la } \\
\text { educación básica y la } \\
\text { formación integral de } \\
\text { todos los grupos de la } \\
\text { población }\end{array}$ & $\begin{array}{l}\text { 1.3. Garantizar la pertinencia de los planes y programas de estudio, así } \\
\text { como los materiales educativos. } \\
\text { 1.7. Fortalecer la relación de la escuela con su entrono para favorecer la } \\
\text { educación integral. } \\
\text { 1.7.3. Impulsar la coordinación de escuelas y familias para construir una } \\
\text { convivencia respetuosa de los derechos humanos y la perspectiva de } \\
\text { género. } \\
\text { 17.4. Promover, junto con las familias, ambientes libres de violencia que } \\
\text { favorezcan una educación integral de niñas, niños y jóvenes. } \\
\text { 1.7.8. Coordinar acciones con el sector salud para las campañas de } \\
\text { vacunación, de prevención del embarazo en edad temprana e ITS. }\end{array}$ \\
\hline $\begin{array}{l}\text { Objetivo } 3 . \\
\text { Asegurar mayor } \\
\text { cobertura, inclusión y } \\
\text { equidad educativa entre } \\
\text { todos los grupos de la } \\
\text { población para la } \\
\text { construcción de una } \\
\text { sociedad más justa }\end{array}$ & $\begin{array}{l}\text { Líneas de acción transversales: } \\
\text { 3. Promover la inclusión de los temas de derechos humanos de las } \\
\text { mujeres en los planes de estudio de todos los niveles educativos. } \\
\text { 4. Eliminar cualquier imagen, contenido o estereotipo sexista y/o } \\
\text { misógino en los planes de estudio de todos los niveles educativos. } \\
\text { 5. Incorporar talleres y materiales pedagógicos auxiliares para educar } \\
\text { en la no violencia, la tolerancia, las nuevas masculinidades. } \\
\text { 6. Incorporar en los planes de estudio el tema de la igualdad sustantiva } \\
\text { entre mujeres y hombres. } \\
\text { 18. Fortalecer la educación sexual con enfoque de derechos humanos, } \\
\text { perspectiva de género y competencias para la vida en todos los } \\
\text { niveles educativos. }\end{array}$ \\
\hline
\end{tabular}

Fuente: elaboración propia a partir del Programa Sectorial de Educación (Gobierno de la República, 2013b) disponible en http://www.dof.gob.mx/nota_detalle_popup.php?codigo=5326569

Este breve recorrido nos muestra el esfuerzo que a nivel institucional se está realizando con el fin de mejorar las situaciones de desigualdad en función de sexo que aquejan a México. La política pública nacional refleja una clara intención de articular los objetivos en materia de igualdad de género. Y en los tres marcos se hace referencia a la intencionalidad de combatir los estereotipos y roles de género perpetuados a través del proceso de enseñanza-aprendizaje. ${ }^{76}$

En este tema hemos abordado cómo se encuentra estructurada la educación en México, las reformas curriculares que se han llevado a cabo en los últimos

\footnotetext{
${ }^{76}$ Esta declaración de intenciones no es algo nuevo en el país, ya en el marco de políticas públicas planteadas años atrás (PND 2007-2012; PROIGUALDAD 2008-2012 y PSE 2007-2012) se establecen objetivos tendientes a incorporar la transversalidad de la perspectiva de género en educación (ver Cámara de Diputados LX Legislatura, s. f.; Rodríguez Huacuz \& Tapia Fonllem, 2011).
} 
años, y los planes y programas que se han puesto en marcha con la finalidad de transversalizar ${ }^{77}$ la perspectiva de género en educación.

En los siguientes puntos analizaremos, por un lado, el sexismo como constructo teórico y su repercusión en el campo educativo. Dicho sexismo hace referencia a las actitudes que son consideradas tanto positivas como negativas y que afectan o limitan a los individuos en función de su sexo al encasillarlos en un determinado rol. Por otro lado, los libros de texto profundizando en su importancia en la enseñanza.

\subsubsection{El sexismo en la educación}

En este punto abordaremos cómo las aportaciones teóricas que se han ido desarrollando en torno al sexismo han ido evolucionando conforme han pasado los años. También haremos referencia a las actitudes sexistas que se pueden presentar en el contexto educativo y, finalmente, cerraremos este apartado haciendo hincapié en la necesidad de seguir contribuyendo al debate sobre el sexismo en el terreno educativo.

El sexismo, tal y como se había referido en el capítulo primero, es un término acuñado por el movimiento feminista durante los años setenta para evidenciar la desigualdad, la subordinación y las asimetrías existentes en función del sexo (Varela, 2008). Victoria Sau (1990) lo define como:

Conjunto de todos y cada uno de los métodos empleados en el seno del patriarcado para poder mantener en situación de inferioridad, subordinación y explotación al sexo dominado: el femenino. El sexismo abarca todos los ámbitos de la vida y las relaciones humanas, de modo que es imposible hacer una relación, no exhaustiva, sino ni tan siquiera aproximada de sus formas de expresión y puntos de incidencia, de modo que

77 La transversalidad es un método de gestión pública que permite aplicar recursos de distintas esferas a un mismo propósito, que en este caso es a la igualdad entre mujeres y varones. Este método obliga a para explicar el impacto de la acción pública en hombres y mujeres; y por tanto, a transformar los planes con los que se enfocan tradicionalmente los problemas y sus soluciones. Se trata de cambiar el enfoque de un supuesto individuo neutro-universal sin diferencias sexuales, para reconocer las diferencias entre mujeres y hombres; identificar las brechas de desigualdad y diseñar acciones que permitan eliminarlas (Gobierno de la República, 2013a). 
los que se citan a continuación deben tomarse sólo como ejemplos o referencias (p. 257).

Las primeras aportaciones teóricas hacen referencia al sexismo como una actitud de prejuicio hacia las mujeres. Las conceptualizaciones sobre el sexismo se dirigían a evidenciar actitudes de hostilidad manifiesta hacia lo femenino o las mujeres, a las cuales se les otorgaba un estatus de inferioridad y de subordinación (Allport, 1954, citado por Malonda Vidal, 2014).

Con la expansión de las investigaciones que toman como referente las teorías feministas y la categoría de análisis del sistema sexo-género, las conceptualizaciones sobre sexismo se fueron complejizando. Diversos estudios han mostrado que las actitudes sexistas hostiles/ negativas estaban menos presentes en el mundo occidental, sin embargo, esto no es debido a una trasformación hacia la igualdad, como demuestran diversas investigaciones (Expósito, Moya, \& Glick, 1998; Glick \& Fiske, 1996; Lameiras \& Rodríguez, 2002; Padilla Carmona, Sánchez García, Martín Berrido, \& Moreno Sánchez, 1999; Rodríguez Otero \& Mancinas Espinoza, 2016). Los estudios emprendidos por los autores citados ponen de manifiesto que el sexismo ha ido evolucionando con el paso del tiempo. En la actualidad el sexismo es coloreado con tintes positivos, en donde se enaltecen las cualidades del sexo subordinado, sin que ello modifique el rechazo o predisposición a adoptar un comportamiento hostil y discriminatorio hacia el colectivo considerado diferente. Los autores/as hacen hincapié en lo perjudicial que puede ser para el grupo subordinado el considerar las actitudes sexistas como cualidades positivas para su colectivo.

En el estudio realizado por Peter Glick y Susan Fiske (1996) se señala que existen dos tipos de sexismo - hostil y benévolo- y la combinación de estos genera un tercer tipo de sexismo, el ambivalente. Por un lado, el sexismo hostil, hace referencia a las actitudes prejuiciosas basadas en la supuesta inferioridad 
de la diferencia biológica de las mujeres. Por otro lado se encuentra el sexismo benévolo, el cual es definido por los autores como:

[...] as a set of interrelated attitudes toward women that are sexist in terms of viewing women stereotypitally and in restricted roles but that are subjectively positive in feeling tone (for the perceiver) and also tend to elicit behaviors typically categorized as prosocial (e.g., helping) or intimacyseeking (e.g., self-disclosure) (Glick \& Fiske, 1996, p. 491).

Finalmente, el sexismo ambivalente hace referencia a una concepción más amplia que incluye tanto las actitudes hostiles como las benévolas (Glick \& Fiske, 1996). En él se pueden identificar tres aspectos: el paternalismo protector (el hombre cuida y protege a la mujer porque ésta es débil), la diferenciación de género complementaria ${ }^{78}$ (las mujeres tienen unas cualidades biológicas que las hace que puedan complementarse con los varones) y la intimidad heterosexual (la dependencia intima de los hombres respecto a las mujeres) (ver esquema propuesto por Glick \& Fiske, 1996).

\section{Esquema 2.3. Modelo de sexismo ambivalente}

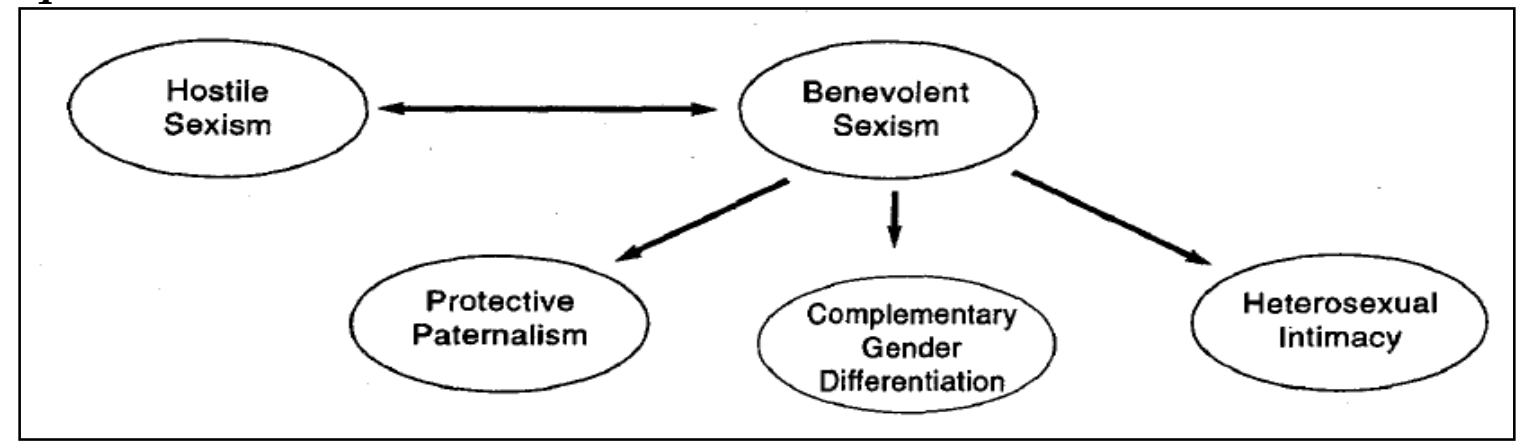

Fuente: Glick y Fiske, (1996, p. 498).

Francisca Expósito y col. (1998, p. 161) señalan que mediante el sexismo ambivalente se justifica "el poder estructural del varón” que caracteriza, con base en la diferencia sexual, las relaciones de desigualdad entre varones y mujeres. Así, los individuos establecen una serie de supuestos (inconscientes) en los que se encasilla a las mujeres en dos grupos: "buenas" o "malas"

\footnotetext{
${ }^{78}$ Recordemos que ya en 1869 John Stuart Mill intentó combatir los prejuicios basados en la "naturaleza diferente y complementaria de la mujer" argumentando que tanto los discursos de inferioridad como los de superioridad dejaban a la mujer en una posición de subordinación, pues el mero hecho de alabarlas no les otorgaba igualdad (De Miguel Álvarez, 2007b).
} 
(Malonda Vidal, 2014 citando a Glick \& Fiske, 1997). El componente negativo de la ambivalencia, el sexismo hostil, es utilizado para castigar a las mujeres "malas" — ej. profesionistas - que no cumplen con los estereotipos de género que se han atribuido socialmente a su sexo. Por su parte, el componente subjetivamente positivo/benévolo de la ambivalencia, recompensa o premia a las mujeres que asumen las atribuciones y roles de género que les son impuestos por la sociedad — amas de casa y madres — (Espinoza Ornelas, Moya, \& Willis, 2015; Expósito et al., 1998; Malonda Vidal, 2014).

Esperanza Espinoza y col., (2015) indican que el sexismo benévolo es tan sexista como el sexismo hostil, ya que los dos tipos de sexismo asignan a las mujeres características y rasgos de personalidad menoscabados en la sociedad y en la familia, fundamentándose en los estereotipos de género tradicionales (hombre-dominador/mujer-dependiente). Por tanto, "esta teoría postula que las relaciones entre los géneros están caracterizadas por la coexistencia de la dominación masculina en la sociedad y la interdependencia íntima” (p. 73).

Ahora bien, ¿qué puede hacer la escuela para evitar que se den estas situaciones dentro y fuera del contexto educativo? Como veíamos en el apartado anterior, la escuela es uno de los agentes socializadores más importantes pero no el único. Así, los alumnos entran a la escuela influenciados por un bagaje social y cultural trasmitido por la familia, los medios de comunicación y la sociedad, que reconstruyen y adaptan a sus propias necesidades e intereses. Es indudable que la escuela es la institución legitimada para formar a las personas bajo los principios de igualdad, justicia y libertad, pero ¿realmente se promueven estos principios en las instituciones escolares? Hemos demostrado en los apartados expuestos con anterioridad que actualmente este objetivo dista mucho de ser una realidad.

En consecuencia, cabe preguntarnos: ¿cuáles son las actitudes sexistas que pueden presentarse en el ámbito educativo? Intentando dar contestación a esta 
interrogante, la autora Mirta González (2005) señala un total de 15 formas de sexismo que se presentan en este contexto. Nosotros hemos agrupado once de ellas en cinco categorías (ver esquema). En la primera, denominada "normalización", señalamos las formas de sexismo que hacen referencia a cómo dentro de los contextos escolares se asume a lo masculino como norma universal, lo cual lleva a obviar situaciones de desigualdad y de discriminación presentes en las prácticas educativas (materiales didácticos que promueven estereotipos sexistas, docentes que hacen diferenciación de manera inconsciente, etc.). En la segunda categoría, “diferenciación”, se hace referencia a cómo las personas son recompensadas o sancionadas según los estereotipos de género atribuidos a uno y a otro sexo. En la tercera categoría, "minimización", se señalan las formas de sexismo que menoscaban lo considerado propio de mujeres en las prácticas académicas. Por su parte, la cuarta categoría, “exclusión", pone de manifiesto que el sexismo tiende a separar las actividades y espacios que realizan hombres y mujeres, otorgando a ellos supremacía tanto en el espacio como en las competiciones y actividades deportivas. Finalmente, en la categoría cinco "violencia", se indica cómo las mujeres están sujetas de manera verbal (bromas hirientes con respecto al cuerpo) y física (tocamientos) a situaciones de riesgo en la escuela.

\section{Esquema 2.4. Actitudes sexistas presentes en el contexto educativo}

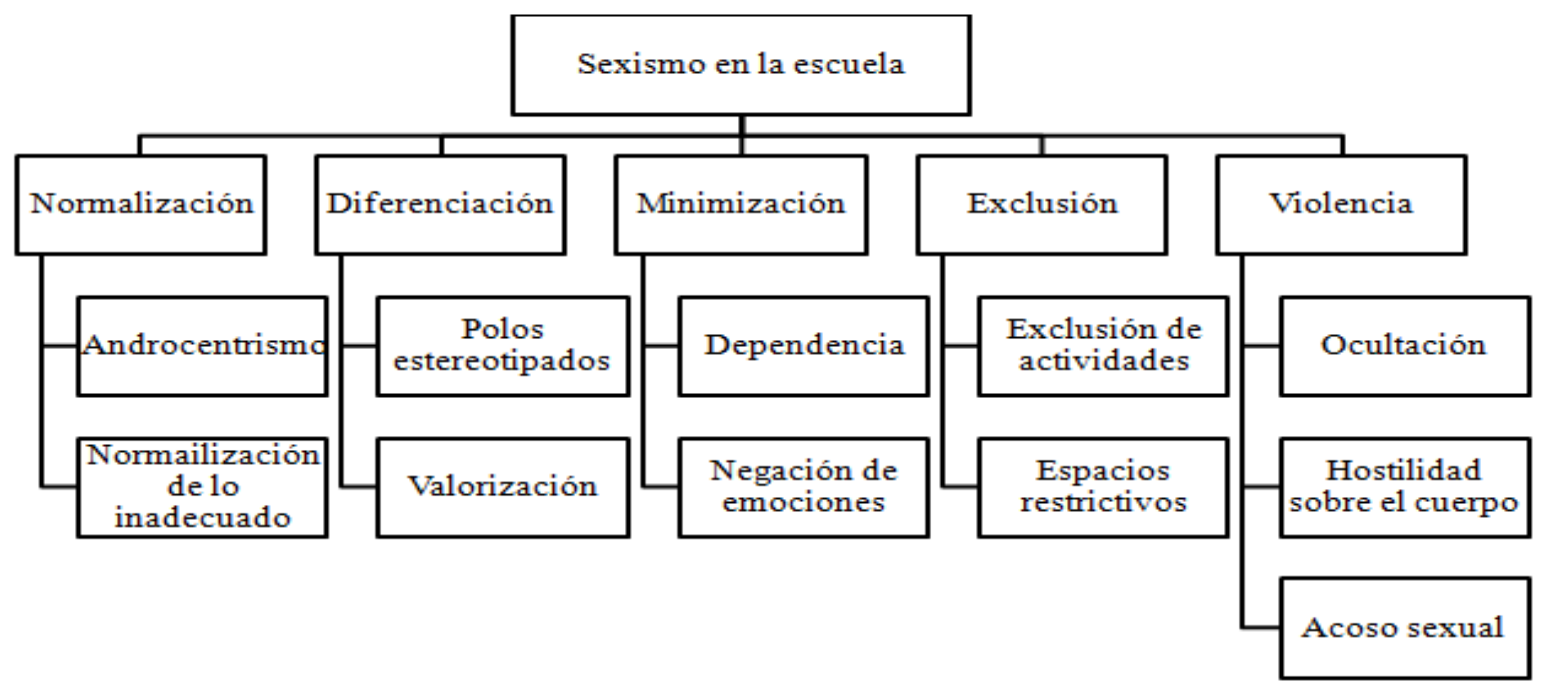

Fuente: Mirta González, (2005, pp. 78-79). 
Nieves Blanco resalta la importancia que tiene la institución educativa como agente de socialización, señalando que la escuela tiene la función de trasmitir la cultura, los conocimientos, las habilidades y las actitudes que se consideran fundamentales tanto para el "completo desarrollo personal como para la supervivencia de la sociedad" (2007, p. 106). Esta autora destaca la función doble, socializadora y educativa, que tiene la escuela, cuyo objetivo fundamental debería ser la preparación para la libertad, “[...] Educarle será despertarle o ayudarle a que se despierte a la realidad en modo tal que la realidad no sumerja su ser, el que le es propio, ni lo oprima, ni se derrumbe sobre el” Nieves Blanco (2007, p. 107; 2008, p. 65) citando a María Zambrano (1965).

Queremos cerrar este apartado haciendo referencia a que la institución educativa es, en definitiva, un ámbito que ha de estar en permanente análisis, dado que las relaciones sociales no son entes fijos y permanentes, sino dinámicos y cambiantes. Las sociedades evolucionan y las personas junto a ellas. Lo que anteriormente era visto como algo natural (subordinación de la mujer) hoy, al menos en el discurso, pierde sentido y es mal visto. No obstante, la igualdad entre varones y mujeres aún no es un hecho en ninguna parte del mundo. La educación es, sin lugar a dudas, la institución que más cambios ha introducido para lograr la equidad de género (Subirats \& González, 2010), pero los datos muestran que estos esfuerzos no han sido suficientes. ${ }^{79}$ Se justifica, de este modo, la importancia de continuar analizando desde las teorías feministas y la perspectiva de género el papel que juega el sexismo en la cultura escolar.

\footnotetext{
${ }^{79}$ Los diagnósticos realizados por el PND y PROIGUALDAD muestran que aún persisten las desigualdades entre hombres y mujeres, lo cual refleja que es menos complicado establecer reformas normativas que lograr trasformaciones sociales.

Se puede consultar estos documentos en http://pnd.gob.mx/wp-content/uploads/2013/05/PND.pdf y en http://dof.gob.mx/nota_detalle.php?codigo=5312418\&fecha=30/08/2013.

En el informe que elabora el Instituto Nacional para la Evaluación de la Educación (INEE, 2016) sobre la educación obligatoria en México, se muestra un panorama general de situación del sistema educativo nacional, disponible en http://publicaciones.inee.edu.mx/buscadorPub/P1/I/241/P1I241.pdf
} 


\subsubsection{Los libros de texto en educación secundaria}

En el presente apartado vamos a poner de manifiesto la importancia que los libros de texto tienen en la educación. Para ello repasaremos lo expuesto por distintos autores e instituciones.

Desde los inicios de la educación obligatoria hasta nuestros días, se ha producido de forma generalizada la implementación y utilización del libro de texto (LT) en el aula, siendo este el material que más emplean él y la docente (González A. \& Sierra V., 2004, p. 389). Tanto para el alumnado como para los y las docentes, los libros de texto continúan desempeñando en la actualidad un papel preponderante (Solé 2014, p. 43). Según Morgado (2004, p. 37), los manuales de texto son, por un lado, un soporte de conocimiento y producto de consumo, y por otro, una herramienta de transmisión de valores, ideología y cultura. En paralelismo con lo referido por Morgado, para la Secretaría de Educación Pública de México (SEP, 2001, p. 2) los libros de texto son tanto un vehículo de transferencia de valores y referentes como un soporte textual y teórico primordial para la transmisión de los conocimientos.

Por su parte, Nieves Blanco (1995) afirma que los libros de texto son un recurso "privilegiado" para analizar el conocimiento, las creencias y los modelos que quiere trasmitir el gobierno a las generaciones más jóvenes: "En un sentido muy real representan y materializan "el conocimiento", hasta el punto de que nos resulta imposible pensar en la enseñanza sin el libro de texto". Agrega esta autora que el libro de texto (LT) representa "el conocimiento legítimo dentro de las escuelas y se ha convertido en un instrumento necesario y a veces imprescindible - entre las prescripciones oficiales derivadas de las decisiones políticas y los docentes, por un lado, y entre los docentes y los estudiantes por otro" (Blanco García, 1995, p. 199). 
Los libros de texto, en opinión de Nieves Blanco, son la selección de contenidos, saberes, y valores que una sociedad legitimada elige y/o excluye, promociona y/o rechaza, sobrevalora y/u oculta (1995).

Tonatiuh Anzures menciona que las evidencias sobre la relevancia de los libros de texto en el proceso de enseñanza-aprendizaje y su contribución a la calidad de la educación existen hace décadas, tal y como han demostrado, entre otros Verspoor, (1989); Villa Lever, (2009) (citados por Azures, 2011).

Celis García, (2011, p. 2) citando a Choppin (1998), menciona que el libro de texto tiene multiplicidad de funciones. Entre ellas destaca tres: a) como herramienta pedagógica porque facilita el aprendizaje; b) como soporte de la verdad que la sociedad cree necesario transmitir a las jóvenes generaciones, por lo que cambia considerablemente según lugar, época y régimen político; y c) como medio de comunicación que tiende a uniformar el discurso que desde él se promueve. La autora menciona que estas funciones convierten al libro de texto en un proceso de socialización, aculturación y adoctrinamiento. Estas ideas son compartidas también por otros/as autores/as, entre ellos/as: Blanco, (2003, 2007); García Gracia, Troiano i Gomà, \& Zaldívar Sancho, (1993); Garreta \& Careaga, (1987); I.M.O.P. Encuestas, (2000); Lomas, C., (2002); LópezNavajas, (2014); Luengo González \& Blázquez Entonado, (2004); Peñalver, (2003); Pérez, (2011).

En México, los libros de texto son prioritarios para el logro de los fines educativos de la mayoría de instituciones escolares que atienden la enseñanza básica. ${ }^{80}$ Gabriela Delgado señala que los libros de texto en México son una parte fundamental del contenido temático que se presenta al alumnado, además

\footnotetext{
${ }^{80}$ Margarita Zorrilla, señala que gracias a la gestión de Torres Bodet, — Secretario de Educación Pública por dos ocasiones: la primera de 1943 a 1946 y la segunda entre 1958 y 1964- se estableció en México la gratuidad del libro de texto en educación primaria (2004). La SEP indica que en 1959 la sociedad tuvo acceso a los libros de texto, lo que sirvió no solo para reforzar los contenidos sino también como elemento de apoyo para las familias que no tenían recursos para adquirirlos (SEP, 2016).
} 
de ser el único logro palpable de equidad, puesto que se distribuyen gratuitamente en el nivel de primaria. ${ }^{81}$ La autora menciona que este recurso didáctico no solo beneficia/perjudica a los y las estudiantes, pues al ser donados pueden quedarse los alumnos con ellos, extendiendo el beneficio de su empleo a sus propias familias, amigos, etc... (2003).

Tonatiuh Anzures nos explica que en México existen dos modalidades de los libros de texto gratuitos (LTG): los de "textos únicos (para preescolar y primaria) y los títulos diversos (para educación secundaria)" (2011, p. 370-371). Los primeros son editados y producidos por la SEP, lo cual significa que tienen mayor cobertura y menor costo, mientras que los segundos pueden ser editados por las autoridades educativas estatales, por diversas editoriales privadas y por algunos autores independientes. Todas las editoriales que se presenten a la convocatoria han de seguir unas normas establecidas por la Secretaría de Educación Pública (SEP), a través de la Dirección General de Materiales Educativos (DGME), dado que es ésta institución pública la encargada de valorar la calidad y la pertinencia de dichos contenidos.

En el acuerdo número 592 por el que se establece la Articulación de la Educación Básica, se menciona, en su fracción XVII, que el sistema de autorización de libros de texto de secundaria tiene más de 10 años. Este proceso ha tenido que ir incorporando nuevas estrategias de actuación para dar respuesta a los desafíos actuales, como se recoge en la fracción XVIII:

Se construyó un proceso de revisión y mejora continua de los materiales para vigilar su concordancia con el programa (enfoque y contenidos), su calidad (veracidad), la pertinencia de las actividades, del lenguaje, de las imágenes, la secuencia lógica de la propuesta didáctica y la transversalidad de tópicos de preponderancia nacional, como la equidad de género, productividad, educación financiera, seguridad y salud, y educación ambiental, entre otros (DOF, 2011a).

${ }^{81}$ La autora Tonatiuh Anzues, señala la pertinencia actual de la gratuidad de los libros de texto, aseverando que en México la gran mayoría de las personas no tienen las condiciones socialeseconómicas necesarias para hacer frente a los gastos que implicaría la compra de los libros y materiales educativos. Lo explica así: "los educandos reciben un apoyo material fundamental que les permite acceder a los servicios educativos en condiciones más igualitarias" (Anzures, 2011, p. 369). 
En este sentido, en el año 2013, la SEP, a través de la DGME, establece el acuerdo número 689. En él se declaran los lineamientos y procedimientos de evaluación para autorizar el uso de obras destinadas a servir como libros de texto en las escuelas secundarias del Sistema Educativo Nacional. El punto IV del artículo 5 indica que los contenidos deben:

Fortalecer el tratamiento transversal de temas de relevancia social como la diversidad cultural, la equidad de género, la educación para la salud, la educación sexual, la educación ambiental para la sustentabilidad, la educación financiera y la educación del consumidor, la prevención de la violencia escolar, la educación para la paz, los derechos humanos así como la perspectiva inclusiva de personas con discapacidad;(DOF, 2013a).

Estos principios orientadores nos señalan la intención de programar cambios en los materiales para tener una cultura escolar más igualitaria. No hemos encontrado ningún estudio que obtenga resultados sobre la situación real del sexismo en los libros de texto de secundaria de México, motivo por el cual nos parece fundamental llevar a cabo este trabajo.

Uno de los puntos más fuertes que tiene la modalidad de secundaria, según Tonatiuh Anzures, es "la posibilidad de que sean las/os docentes -y no las autoridades educativas desde el centro del país- quienes elijan los textos que les parezcan más adecuados para su estilo y método de enseñanza”. La autora explica que los y las docentes pueden elegir y seleccionar el título del libro de texto que consideren más oportuno entre la lista de aprobados por la SEP. Sin embargo, esta riqueza puede verse mermada si el profesorado no cuenta con los recursos oportunos para detectar que exista sexismo en los materiales. Sobre este punto sí se han formulado algunas propuestas, entre las cuales destaca el trabajo coordinado entre la SEP y el Programa Universitario de Estudios de Genero (PUEG). Este proyecto conjunto, que se desarrolló en cuatro fases, durante los años 2008 y 2011, persiguió estos objetivos:

- Elaborar un diagnóstico sobre el sexismo en los libros de texto de educación primaria; 
- Capacitar al personal docente de los tres niveles de enseñanza básica, a través de talleres de capacitación;

- Elaborar materiales de apoyo para los niveles de educación básica dirigidos a docentes para coadyuvar en la transformación de los patrones socioculturales y difundir el respeto a los derechos de todas las personas, la cultura de la equidad y no violencia.

- El recurso para el profesorado de educación secundaria estuvo coordinado por Martha Leñero y se tituló "Equidad de género y prevención de la violencia en secundaria” (2011).

Hemos evidenciado que el libro de texto continúa siendo un recurso preponderante en el proceso de enseñanza-aprendizaje. Además, en México las especiales características sociales de desigualdad hacen que el empleo del libro de texto adquiera una mayor relevancia, puesto que para muchos infantes y jóvenes el acceso a otros libros y a otros medios de comunicación es inexistente (Anzures, 2011; Gabriela Delgado Ballesteros, 2003b). Por consiguiente, consideramos relevante analizar estos materiales. Aunque coincidimos con Schmelkes (1999) en que "El texto solo no basta. El texto interactúa con otros factores; de manera muy importante el maestro, los métodos de enseñanza, la organización de la escuela, entre otros.[...]" (citado por Anzures, 2011, p. 383), consideramos que los contenidos, cultura y valores, etc. que aparecen en los libros de texto, han de ser analizados con rigor, para que en ellos se promueva una cultura de la igualdad, el respeto y la comprensión entre seres humanos. En un apartado posterior abordaremos los estudios realizados en diversos países sobre el sexismo en los libros de texto.

\subsection{Estudios que preceden a esta investigación}

Paulo Freire (1996) «La existencia humana no puede trascurrir en silencio ni tampoco ser alimentada con palabras falsas... existir humanamente es ponerle nombre al mundo, cambiarlo... los hombres [y las mujeres] no se construyen en silencio, 
Vamos a iniciar este apartado haciendo referencia al título del artículo "Cómo hemos cambiado... ¿o no?” de Marina Moreno (2016) porque nuestro objetivo es evidenciar, mediante investigaciones pasadas y presentes, que, aunque hemos avanzado, la desigualdad aún forma parte del día a día en los contextos escolares.

En México, tal como se muestra en el capítulo anterior, los estudios en el contexto educativo desde la perspectiva de género han irrumpido en el ámbito académico recientemente (Gabriela Delgado Ballesteros, 2003b; González Jiménez, 2009), de ahí la importancia de seguir contribuyendo al debate de la desigualdad en la educación institucionalizada. Diversos autores/as (Arcos, Figueroa, Miranda, \& Ramos, 2007; Castro Sandúa, Duque, \& Villarejo Carballido, 2016; González Jiménez, 2009, 2013; Subirats i Martori \& Tomé, 2010) consideran la necesidad de elaborar investigaciones científicas para poder proponer formas de actuación que atiendan realmente las necesidades y problemáticas encontradas en dichos estudios.

En la investigación realizada por Gabriela Delgado (2003), se recogen un total de 257 estudios de género en educación en el periodo 1992-2002. Para realizar el análisis de los mismos, los dividió en varios campos: políticas públicas, sujetos, currículo, acceso y permanencia en los diferentes niveles del sistema educativo, nuevas tecnologías y materiales didácticos, entre otros. También contempló el nivel educativo en el que se desarrollaron los estudios.

Con su estudio, Delgado señala cuáles son las líneas de investigación menos abordadas en el periodo 1992-2002. Respecto a los niveles educativos, indica que la educación secundaria y el bachillerato son los menos estudiados. También menciona que la temática elegida en esta tesis ha sido escasamente abordada en el país. La autora invita a seguir contribuyendo a la generación de estudios con perspectiva de género desde el ámbito educativo (2003). Por ello, consideramos viable la elaboración de esta investigación. Con ella podemos 
contribuir al debate sobre el sexismo a través de la información real y proveniente de las vicisitudes de las y los estudiantes. Además, analizamos los modelos, creencias y valores que el gobierno quiere transmitir a las generaciones jóvenes mediante los libros de texto, para hacer de ellos y de ellas personas deseosas de transformar las desigualdades y de construir una sociedad más digna, igualitaria y justa.

Así pues, con este apartado pretendemos mostrar algunas de las investigaciones que se han realizado en otras latitudes, con la finalidad de proporcionar al lector una referencia global sobre el tema que vamos a abordar en esta investigación. Para ello, dividimos este epígrafe en dos partes. En la primera presentamos las investigaciones sobre las actitudes y expectativas que tienen los y las adolescentes para comprobar si los cambios/trasformaciones sociales han modificado los estereotipos de género. En la segunda, mostramos lo que se ha trabajado en distintos países para evidenciar que los materiales didácticos pasados y actuales tienen sesgos androcéntricos y patriarcales, pues se trasmiten modelos sociales hegemónicos donde lo masculino continúa siendo el referente universal.

\subsubsection{Estudios sobre estereotipos de género en adolescentes}

Los estereotipos y los roles nos muestran los avances y lo que queda por hacer para superar las asimetrías entre los sexos (Subirats i Martori \& Tomé, 2010). Tanto unos como otros han tenido una especial relevancia dentro de la investigación sobre género. ${ }^{82}$ El estudio de dichos estereotipos y roles aporta información fundamental sobre las actitudes, creencias, valores en cuanto al "deber ser" de hombres y mujeres (tanto de lo que opinan sobre sí mismos, como de los otros).

El recorrido académico que hemos enunciado en los apartados anteriores refleja que los logros en materia de igualdad de género han estado impregnados

\footnotetext{
${ }^{82}$ Cuadrados (2007), citado por Martínez Sánchez, Navarro Olivas, y Yubero Jiménez, (2009).
} 
de ahogos y avatares. La lucha por conseguir que hombres y mujeres puedan disfrutar de los rasgos característicos de los seres humanos (sensibilidad, fortaleza, intuición, objetividad...) sin recurrir al determinismo biológico no ha sido ni es tarea fácil (Cortina, 1998). Es por ello que muchas investigadoras/es se han interesado en explicar si las trasformaciones sociales, acaecidas principalmente en los países occidentales, han modificado los estereotipos de género. Se construyeron instrumentos como: Sex-Role Inventory (BSRI) de Sandra Bem, (1974); ${ }^{83}$ el Ambivalent Sexism Inventory (ASI) desarrollado por Peter Glick y Susan Fiske (1996), ${ }^{84}$ y el Inventario de Masculinidad y Feminidad IMAFE de Lara-Cantú (1993), ${ }^{85}$ entre muchos otros, para medir y explicar en qué medida se han trasformado tanto las expectativas como las actitudes personales de los individuos en la actualidad. Cabe destacar que la mayoría de las investigaciones que se han desarrollado han optado por emplear este tipo de instrumentos.

Nosotros hemos podido comprobar que se ha incrementado en los últimos años el interés en conocer y explicar lo que ocurre con las percepciones que tienen los y las adolescentes sobre lo que es "propio de hombres" y lo que es "propio de mujeres" y si estas percepciones coinciden con las trasformaciones sociales actuales (gráfica 2.1.).

${ }^{83}$ Este inventario es innovador en su tiempo, ya que mide los rasgos de personalidad que encajan en el rol sexual. Por lo tanto, su puntuación indica si las expectativas y las autopercepciones han cambiado o si persisten los estereotipos de género. Sandra Bem desarrolla un inventario de autoevaluación con una lista de rasgos de personalidad, donde las personas encuestadas eligen entre cuatro grupos: masculino, femenino, andrógino o indiferenciada.

${ }^{84}$ Este inventario se compone de una serie de frases donde las personas encuestadas han de responder 22 ítems (formato likert). 11 ítems hacen referencia al sexismo hostil y 11 al sexismo benévolo. Las personas encuestadas han de elegir entre seis opciones (van desde totalmente en desacuerdo = 0 hasta "totalmente de acuerdo" $=6$ ): Mayores puntuaciones en la escala indican mayores niveles de prejuicio hacia las mujeres.

${ }^{85}$ Este inventario fue diseñado en México, con el objetivo de medir roles de género (masculino, femenino, machismo y sumisión). Está compuesto por 60 ítems y las personas encuestadas han de responder en qué medida tienen o no los rasgos descritos (en formato likert). Tienen siete opciones para elegir: de nunca o casi nunca soy así $=1$, a siempre o casi siempre soy así $=7$. La puntuación se calcula sumando el promedio de las puntuaciones por ítem, lo que da como resultado una puntuación mínima de 1 y máxima de 7. 
Gráfica 2.1. Estudios sobre estereotipos de género en la población adolescente por año
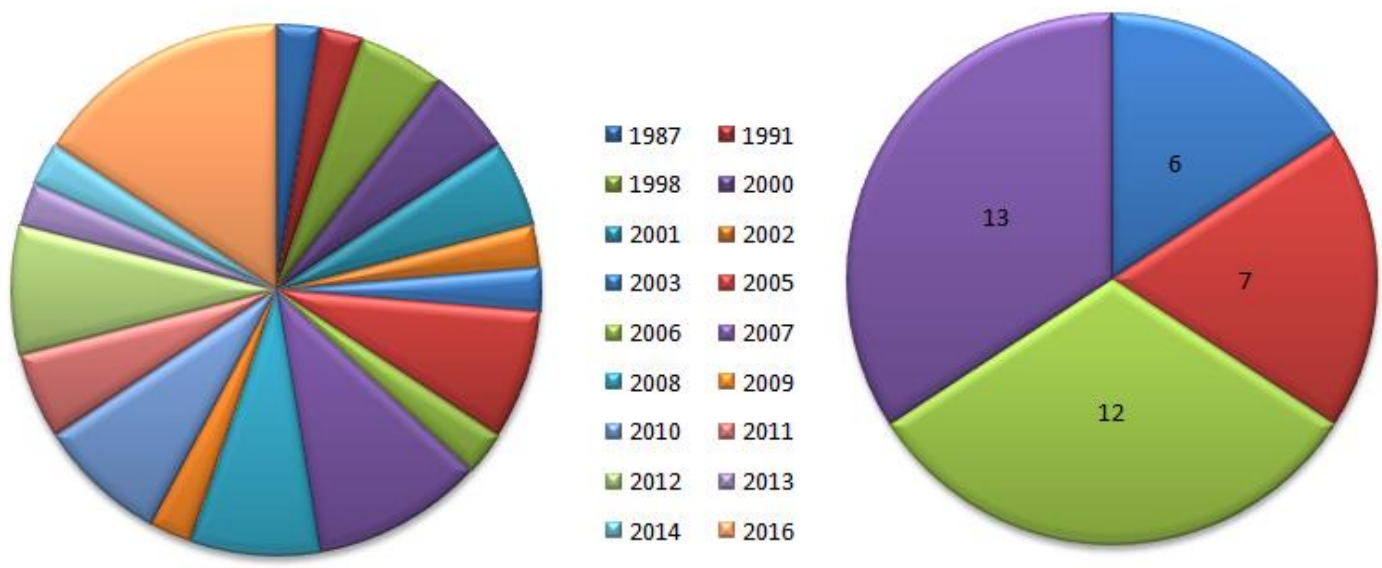

1987-2000

2001-2005

2006-2010

2011-2016

Fuente: elaboración propia basada en los documentos investigados.

Durante los últimos treinta años los estudios sobre las representaciones culturales de género (estereotipos) se han incrementado, contribuyendo con ello a proporcionar una base teórica y de conocimiento cada vez más sólida y que, además, nos sirve como referente para esta investigación. La producción académica que hemos revisado está contextualizada mayoritariamente en el nivel educativo de secundaria, ya que es el ámbito elegido para esta investigación. No obstante se han tenido en cuenta trabajos que se han desarrollado en otros ámbitos (gráfica 2.2.).

Gráfica 2.2. Estudios sobre estereotipos de género en la población adolescente por ámbito de estudio
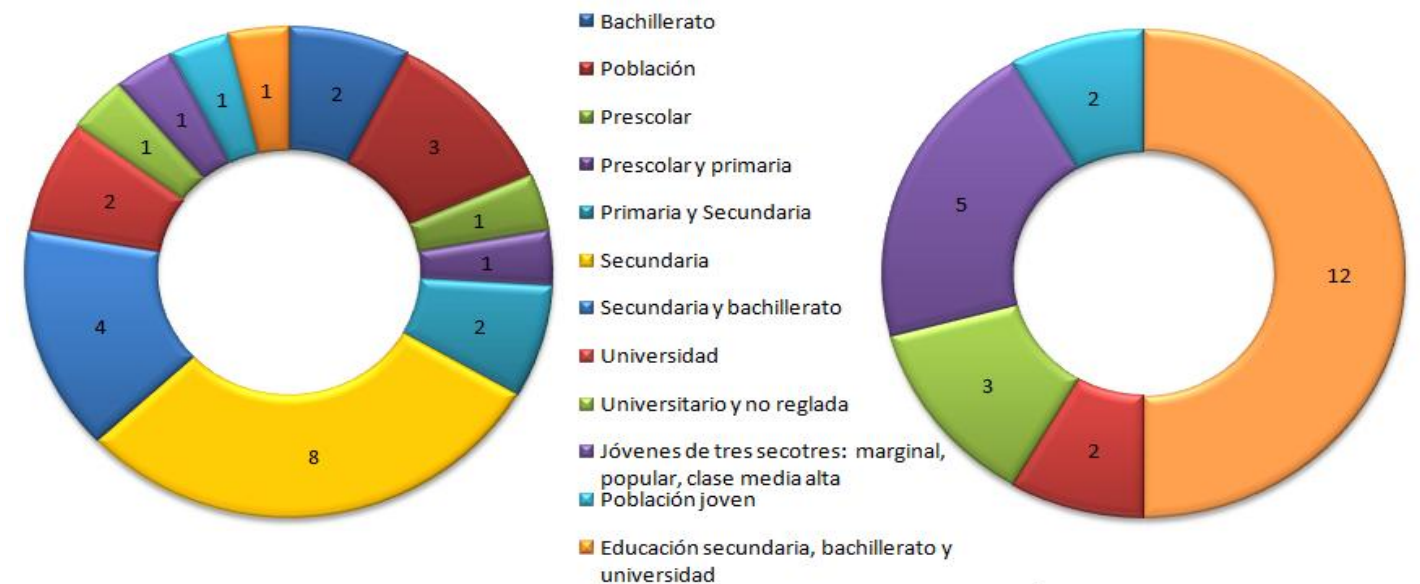

Educación básica - Educación media ⿶ Universidad Mixta $\square$ Población joven

Fuente: elaboración propia basada en la documentación analizada. 
Así pues, las investigaciones que se han revisado para el desarrollo de este apartado son mayoritariamente artículos de investigadores/as españoles/as (Amurrio Velez, Larrinaga Renteria, Usategui Basozabal, \& Del Valle Loroño, 2012; Caro Blanco, 2008; Colás Bravo \& Villaciervos Moreno, 2007; García Pérez et al., 2010; García Vega, Menéndez Robledo, Fernández García, \& Cuesta Izquierdo, 2012; García-Vega, Menéndez Robledo, García Fernández, \& Rico Fernández, 2010; Lameiras \& Rodríguez, 2002; Martínez Benlloch et al., 2008; Martínez Sánchez et al., 2009; Muñoz Tinoco, Jiménez Lagares, \& Moreno Rodríguez, 2008; Quesada Jiménez \& López López, 2011; Rodríguez Marín, 2016; Ruiz Pinto, García Pérez, \& Rebollo, 2013; Sáez, Valor-Segura, \& Expósito, 2012). Hemos revisado, además, tres tesis doctorales (Bascón Díaz, 2007; Quesada Jiménez, 2014; Rodríguez Marín, 2016) y una de Máster (Blanco Belver, 2011).

También hemos accedido, aunque en menor medida, a estudios desarrollados en América Latina (Costa Aguirre, 2016 (tesis doctoral); Cubillas Rodríguez et al., 2016; Nehring, 2005; Parga Romero, 2008; Pires, Fonseca, \& Padilla, 2016; Rodríguez Otero \& Mancinas Espinoza, 2016; Stern, 2007; Tuñón Pablos \& Eroza Solana, 2001).

Todos estos estudios se han desarrollado con metodologías, objetivos, contextos, procedimientos... muy diversos. Sin embargo, todos ellos coinciden en que intentan mostrar de qué manera los estereotipos de género repercuten en las relaciones asimétricas entre hombres y mujeres. Así pues, a continuación resumiremos (tabla 2.10. y tabla 2.11.) brevemente los resultados que han arrojado los estudios realizados tanto en España como en América Latina - la mayoría de estas investigaciones no desvelan resultados muy halagüeños-. 
Tabla 2.10. Resumen de los resultados derivados de las investigaciones en España

Autoras/es $\quad$ Principales resultados de las investigaciones en España

Amurio Velez et al., 2012; Colás

Bravo \& Villaciervos Moreno, 2007;

García Pérez et al., 2010; Lameiras \&

Rodríguez, 2002; Quesada Jiménez,

Prevalecen los estereotipos de género tradicionales en las personas,

2014; Quesada Jiménez \& López respecto a cualidades 0 características, roles o funciones vinculadas

López, 2011; Rodríguez Marín, 2016; al espacio público/privado y a las creencias legitimadoras de la

Ruiz Palomino et al., 2010; Ruiz Pinto autoridad, el dominio y el control masculino.

et al., 2013; Sáez et al., 2012

Barberá, 2004; Martínez Sánchez et al., La imagen que tienen sobre sí mismos es menos estereotipada que la 2009 que tienen respecto a otros.

Colás Bravo \& Villaciervos Moreno,

2007; García Pérez et al., 2010;

Lameiras \& Rodríguez, 2002; Mosteiro

García \& Porto Castro, 2016; Ruiz

Los chicos tienen más arraigados los estereotipos de género que las chicas.

Palomino et al., 2010

Blanco Belver, 2011; Caro Blanco,

El sexismo y los estereotipos de género pueden convertirse en un

2008; García-Vega et al., 2010 precursor de la violencia de pareja al normalizar las relaciones de poder y dominio de los varones sobre las mujeres en el mundo de los afectos y del amor.

Amurio Velez et al., 2012 Los hombres y las mujeres aspiran a mantener relaciones afectivas basadas en estereotipos de género sexistas.

Cala Carrillo \& Mata Benítez, 2005; García Pérez et al., 2010; Mosteiro García \& Porto Castro, 2016

Las mujeres muestran más actitudes favorables hacia la igualdad que los hombres.

Los estereotipos asignados a las mujeres están cambiando, aparecen García Pérez et al., 2010; Osuna, 2003; para las mujeres términos tradicionalmente relacionados con el Quesada Jiménez, 2014 varón como el trabajo, la valentía o la inteligencia, sin embargo los estereotipos de género en hombres siguen siendo los mismos.

Las mujeres de niveles educativos más elevados tienen un ideal de pareja más igualitario, expectativas para sus hijas/os más corresponsables, y son más críticas con las desigualdades entre hombres y mujeres en diversos contextos.

García Pérez et al., 2010; Mosteiro García \& Porto Castro, 2016 Actitudes del alumnado favorables hacia la igualdad.

Fuente: elaboración propia a partir de la bibliografía consultada. 
Tabla 2.11. Resumen de los resultados derivados de las investigaciones en América Latina

\begin{tabular}{|c|c|}
\hline Autoras/es & Principales resultados de las investigaciones en América \\
\hline $\begin{array}{l}\text { Parga Romero, 2008; Rodríguez Otero } \\
\text { \& Mancinas Espinoza, 2016; Szasz, } \\
1998\end{array}$ & $\begin{array}{l}\text { Prevalecen los estereotipos de género tradicionales en las personas, } \\
\text { respecto a cualidades o características, roles o funciones vinculadas } \\
\text { al espacio público/privado. }\end{array}$ \\
\hline Pires et al., 2016 & $\begin{array}{l}\text { Las creencias religiosas y las funciones de cuidado inciden en la } \\
\text { sumisión de las mujeres con respeto a los varones }\end{array}$ \\
\hline Nehring, 2005 & $\begin{array}{l}\text { Existe una pluralidad contradictoria sobre las relaciones de género } \\
\text { en personas de clase media, por un lado se promueven ideas } \\
\text { individualistas (capacidad de decisión) y por otro deterministas } \\
\text { (sumisión "natural de la mujer"). }\end{array}$ \\
\hline Szasz, 1998 & $\begin{array}{l}\text { El sexismo y los estereotipos de género pueden convertirse en un } \\
\text { precursor de la violencia de pareja al normalizar las relaciones de } \\
\text { poder y dominio de los varones sobre las mujeres en el mundo de } \\
\text { los afectos y del amor. }\end{array}$ \\
\hline Stem, 2007; Szasz, 1998 & $\begin{array}{l}\text { La divergencia existente entre la moral sexual para varones y la } \\
\text { moral sexual para las mujeres representa uno de los mayores riesgos } \\
\text { tanto sociales como de salud. }\end{array}$ \\
\hline \multirow{3}{*}{ Cubillas Rodríguez et al., 2016} & $\begin{array}{l}\text { Las mujeres muestran más actitudes favorables hacia la igualdad } \\
\text { que los hombres. }\end{array}$ \\
\hline & $\begin{array}{l}\text { Los estereotipos asignados a las mujeres están cambiando, aparecen } \\
\text { para las mujeres términos tradicionalmente relacionados con el } \\
\text { varón como el trabajo, la valentía o la inteligencia, sin embargo los } \\
\text { estereotipos de género en hombres siguen siendo los mismos. }\end{array}$ \\
\hline & $\begin{array}{l}\text { Las expectativas de las relaciones de pareja para los hombres siguen } \\
\text { siendo que las mujeres realicen la doble jornada. }\end{array}$ \\
\hline Costa Aguirre, 2016 & $\begin{array}{l}\text { Están cambiando las percepciones en cuanto a masculinidad y } \\
\text { feminidad pues tanto hombres como mujeres se atribuyen } \\
\text { características que no eran vistas anteriormente como propias de su } \\
\text { sexo. }\end{array}$ \\
\hline Parga Romero, 2008 & $\begin{array}{l}\text { Cuando los padres cuentan con menores niveles de escolaridad y } \\
\text { pertenecen a los sectores populares las concepciones respecto al } \\
\text { género son más tradicionales y presentan más resistencia al cambio. }\end{array}$ \\
\hline
\end{tabular}

Fuente: elaboración propia a partir de la bibliografía consultada.

Hasta aquí hemos intentado mostrar al lector el panorama consultado sobre los trabajos que se han desarrollado tanto en España como en América Latina sobre los estereotipos de género en los y las adolescentes. Las aportaciones de estos y otras autoras desvelan que los estereotipos de género forman parte tanto de lo subjetivo como de lo cotidiano; de cómo a través de juegos, deportes, 
lecturas, amores,... se van entretejiendo y enraizando las diferencias entre unas y otros. Amparo Tomé manifiesta a este respecto que "los estereotipos modifican nuestras formas de pensar, de hablar, de sentir y de vivir, es decir, condicionan nuestra racionalidad, nuestra emotividad y nuestros comportamientos" (2007, p. 119). Los estudios que hemos abordado dan cuenta de ello, pues a pesar de que cada vez existe más participación de las mujeres en diversos espacios públicos, la mayoría de los y las adolescentes que han estado sujetos a investigación no la reconocen. Y lo que es más preocupante aun, las investigaciones muestran que la mayoría de los chicos no están trasformando sus expectativas ni sus percepciones sobre sí mismos en cuanto a los roles y funciones sociales.

En resumen, en este apartado hemos condensado las ideas principales derivadas de las investigaciones consultadas sobre los estereotipos de género en los adolescentes - algunas de las cuales son retomadas en el punto de contextualización y otras en el epígrafe de justificación. En el apartado siguiente vamos a presentar los resultados de investigaciones que han analizado cómo la escuela intenta promover el sexismo entre hombres y mujeres a través de los libros de texto.

\subsubsection{El análisis del sexismo a través de los libros de texto}

En la década de los setenta el corpus de las investigaciones que, mediante los libros de texto, ponen en evidencia las diversas formas de discriminación en razón del sexo, va a empezar a germinar. Su estudio se inicia en el ámbito anglosajón y se expande por Europa y posteriormente por América, Asía y África - teniendo menor producción académica fuera del contexto europeo y anglosajón- - ${ }^{86}$ No obstante en esta investigación hemos hecho una revisión de

\footnotetext{
${ }^{86}$ La tesis doctoral elaborada por María Vaíllo muestra un recorrido geográfico y cronológico sobre el surgimiento y el desarrollo del análisis del sexismo en los libros de texto (Vaíllo Rodríguez, 2013, pp. 45-86).
} 
los estudios que se han desarrollado a partir de la década de los noventa, en España y en América Latina, con la intención de seguir el mismo hilo conductor del apartado anterior.

Con la finalidad de ilustrar el amplio desarrollo de la línea de investigación sobre género y libros de texto en el contexto español, presentamos a continuación una tabla que condensa los trabajos que, desde finales de la década de los ochenta, han abordado la temática del sexismo en los libros de texto.

Los trabajos desarrollados en la década de los noventa, como veremos a continuación, destacaron por profundizar en los sesgos androcéntricos que se ocultaban en los libros de texto bajo el masculino universal.

Tabla 2.12. Investigaciones sobre la presencia de sexismo en los libros de texto, en el contexto Español

\begin{tabular}{|c|c|c|}
\hline $\begin{array}{l}\text { Año y } \\
\text { tipos de } \\
\text { doc. }\end{array}$ & Autoras/es & Presencia de sexismo en los libros de texto \\
\hline $\begin{array}{l}1987 \\
\text { Libro }\end{array}$ & $\begin{array}{l}\text { Garreta y } \\
\text { Careaga }\end{array}$ & $\begin{array}{l}\text { Esta investigación fue encargada por el Instituto de la } \\
\text { Mujer y el antiguo Centro de Investigación y } \\
\text { Documentación Educativa (CIDE), con la finalidad de } \\
\text { averiguar los modelos que se presentaban para uno y otro } \\
\text { sexo en los libros de texto. Estas autoras, fueron las } \\
\text { primeras, en España, en seleccionar libros de texto de } \\
\text { varias asignaturas - } 18 \text { de Lenguaje y } 18 \text { de Ciencias } \\
\text { Sociales-y editoriales (catorce) de toda la etapa de la } \\
\text { EGB. Analizaron tanto las ilustraciones como los textos, } \\
\text { concluyendo que la presencia femenina esta } \\
\text { infrarrepresentada: } 25 \% \text { frente al } 74 \% \text { de la masculina. }\end{array}$ \\
\hline $\begin{array}{l}1990 \\
\text { Artícul } \\
\text { o }\end{array}$ & $\begin{array}{l}\text { Cerezal } \\
\text { Jiménez }\end{array}$ & $\begin{array}{l}\text { Elabora un análisis de los libros de texto de Lengua } \\
\text { Extranjera (LE) en la EGB, en el cual introdujo como } \\
\text { variable la nacionalidad de las editoriales analizadas. } \\
\text { Utilizaron como guía metodológica los estudios de Garreta } \\
\text { y Careaga. Sus resultados cuantitativos en el libro de LE } \\
\text { Francés no reflejan grandes diferencias porcentuales: de } \\
1330 \text { personajes } 40,3 \% \text { son mujeres y } 59,6 \% \text { son hombres. } \\
\text { En cuanto al libro de LE de Ingles, de los } 1,290 \text { personajes } \\
\text { analizados en las ilustraciones, el } 34 \% \text { son mujeres y el }\end{array}$ \\
\hline
\end{tabular}

Por su parte, el artículo elaborado por Hazir Ullah y otros también hacen referencia a diversas investigaciones desarrolladas en el contexto anglosajón sobre la persistencia de perjuicios de género en los libros de textos en educación (Ullah, Ali, \& Naz, 2014). 
$65,8 \%$ son varones. Concluye que tanto los libros de Inglés como los de Francés presentan un modelo discriminatorio y sexista para las mujeres, así como un modelo de superioridad para los hombres. Las actividades, el protagonismo y la autonomía continúan estando representadas por hombres.

Analiza el sexismo existente en contenidos sociohistóricos de los libros de texto de $5^{\circ}, 7^{\circ}$ de EGB y de $1^{\circ}$ de BUP (en total se analizaron 1,120 páginas de 15 editoriales distintas), mediante el análisis de las 1993 Subirats ilustraciones, el texto, las lecturas de citas y las Libro (Coord.) actividades. Concluye que existe un insignificante porcentaje de referencias a las mujeres. Con relación al lenguaje manifiesta que "se constata que el discurso de las Ciencias Sociales se articula en torno al uso mayoritario del genérico" (p. 262) y evidencia que el conjunto de personajes analizados reafirman el discurso androcéntrico.

Fuente: elaboración propia a partir de la documentación investigada.

En el periodo de tiempo que transcurre del 2000 a la actualidad, lejos de abandonarse la línea de investigación sobre el sexismo en los libros de texto, se ha continuado la revisión crítica de los materiales, ampliándose las temáticas analizadas, las asignaturas y los niveles educativos. El corpus de investigaciones que se han venido desarrollando ha permitido también trazar una evolución de la persistencia del sexismo en distintos momentos, ya que se han obtenido resultados similares empleando metodologías y técnicas de análisis distintas a lo largo del tiempo. Los resultados aportados por otras investigaciones permiten también ilustrar el grado en el que se han incorporado los temas de igualdad entre hombres y mujeres en los distintos materiales. A continuación presentamos una tabla en la que se condensa la información de las investigaciones del año dos mil hasta la actualidad.

Tabla 2.13. Investigaciones sobre la presencia de sexismo en los libros de texto, en el contexto Español a partir del año 2000 a la fecha

Año y Autoras/es Presencia de sexismo en los libros de texto

$2000 \quad$ Blanco
Libro

Se analizan los materiales de texto de secundaria, de las asignaturas de Ciencias Sociales, Lengua y Literatura, Ciencias Naturales, Matemáticas y Educación Física. En 
total se analizaron más de 16,000 personajes. Los resultados arrojados en esta investigación constatan que la mujer esta infrarrepresentada alrededor del $23 \%$ frente a la sobrerrepresentación de los varones, que superan el $76 \%$. También se precisa que los hombres tienen una mayor diversidad de ocupaciones, siendo contabilizadas más de 300 , cifra que se reduce a 94 en el caso de las mujeres. La autonomía también es otro rasgo en el que aparecen mayoritariamente los varones, con un $47,5 \%$ frente al $16 \%$ de las mujeres. Tras el análisis de resultados, la autora concluye que el contenido de los libros de texto no refleja la realidad social actual, que los libros de texto trasmiten modelos estereotipados a hombres y a mujeres, que existe una invisibilidad de la mujer en cuanto a su participación en el desarrollo social, cultural, económico..., y que, además, no se explica la ausencia de las mujeres en periodos pasados y no se enfatizan sus aportaciones en el presente.

El Instituto de Marketing y Opinión Pública (IMOP encuestas) elabora un análisis sobre el texto y las ilustraciones, realizando un inventario (frecuencia de aparición de personajes) y contextualizando lo que hacen los personajes (sentido con el que aparecen). Se analizaron, bajo estas pautas, 5 asignaturas de primaria: Conocimiento del medio, Lengua castellana, Lengua autonómica y Matemáticas. Y 7 de secundaria: Ciencias de la naturaleza, Ciencias sociales, Educación plástica y visual, Lengua Castellana, Lengua autonómica, Matemáticas y Tecnología. También se analizaron los 2000 I.M.O.P. cuadernos de trabajo en primaria. En este estudio se Libro Encuestas constata la supeditación de las mujeres: su presencia global fue del 33,8\%, frente al 66,2\% de los varones. En cuanto a las ilustraciones de secundaria, de 9.049 ilustraciones analizadas, el $48 \%$ corresponde a figuras masculinas, un $23 \%$ a figuras femeninas y un $28 \%$ a grupos compuestos por personajes de ambos sexos. El análisis del texto tampoco dista mucho de los resultados en las ilustraciones, ya que de 15.771 denominaciones analizadas en secundaria, los hombres representan el $66 \%$ y las mujeres el 34\%. Esta investigación concluye que las mujeres no solo aparecen menos representadas, sino que aparecen de manera distinta a cómo lo hacen los varones.

$2002 \&$

Artículo Vázquez, 2002a)
(Manassero Analiza los estereotipos de género observados en el lenguaje de treinta y dos libros de texto de Ciencias y Tecnología. Las autoras comprueban la escasa o nula presencia de las mujeres, y describen que las chicas 
aparecen con actitudes negativas hacia la Ciencia y la Tecnología.

Las mujeres aparecen menos representadas, más

2003

Capítulo de Blanco libro dependientes, poco proactivas y con menor repertorio profesional. La realidad que se plantea en los libros es sexista porque plantea una visión distorsionada de la realidad, al ocultar el trascurrir de la vida de las mujeres, y al no proporcionar una explicación de las ausencias.

En esta investigación se analizan un total de veinticuatro libros de varias asignaturas (Lengua y Literatura y Ciencias Sociales). La autora concluye que los textos escolares se debaten entre la presión que la normativa demanda, la inercia cultural y el androcentrismo que existe 2003 Peñalver en la sociedad. El empleo del doble género es utilizado de Libro manera impropia e inconsistente. Se evidencia que los textos trasmiten estereotipos de género, mostrando mayoritariamente a mujeres en entornos familiares. Además aparecen menos individualizadas y ejerciendo profesiones tradicionalmente "femeninas".

Instituto de Es un proyecto para medir el grado de sexismo de las

2004

Proyecto la Mujer $\mathrm{y}$ escuelas primarias y secundarias. En el capítulo II abordan Red2Red Consultore $\mathrm{s}$ la temática sobre análisis del sexismo. En ella, proponen una estrategia metodológica para detectar/medir el sexismo en los libros de texto.

Elaboran un análisis cuantitativo y cualitativo de las imágenes (5131 imágenes en total, de los libros de Lengua y Literatura de 9 editoriales), basándose en Subirats y col. (1993) y López Valero (1992). Los resultados de su estudio muestran que en la iconografía la presencia del varón es del 67,04\% frente al 32,95\% de las mujeres. Este estudio analiza, también, cómo las imágenes presentan Luengo sesgos estereotipados en el uso de las Tecnologías de la 2004 González y Comunicación y la Información, desvelando que los Libro Blázquez Entonado personajes femeninos aparecen asociados a la incapacidad para manejar estos recursos tecnológicos, en contraste con la autosuficiencia con la que los chicos los utilizan. Por tanto, concluyen que a través de los libros de texto se trasmite un modelo sociocultural que tiene forma y figura de varón, cuestión que dista de la realidad social actual. Los autores develan que los libros de texto mantienen una deuda con las mujeres, pues la evolución de los libros de texto continúa estando claramente sesgada por el sexismo.

2007 Elabora una propuesta de indicadores para la detección del

Capítulo de Blanco libro

2007 López
sexismo, a la vez que realiza una divulgación de los datos recabados en las publicaciones anteriores (2000-2001). Se lleva a cabo el análisis de un libro de texto de Lengua 
Artículo Ojeda

Castellana y Literatura de la editorial Oxford para cuarto de la ESO. Con su análisis indagan sobre el sexismo en los libros de texto de secundaria, encontrando que las estrategias que vienen empleando las editoriales para evitar el sexismo son: la sustitución de genéricos universales masculinos que incluyen a ambos sexos por sustantivos colectivos; la predominancia de la segunda persona del singular en los verbos y el uso del infinitivo; $y$ la omisión del uso estereotipado de adjetivos calificativos. Concluyen que cada vez es más difícil encontrar el sexismo en los libros de texto porque son redactados desde lo políticamente correcto. Elaboran, para finalizar, una lista de propuestas para eliminar el lenguaje sexista.

En este trabajo, la autora hace una crítica respecto a cómo la investigación bajo el paraguas de considerarse neutra 2008 excluye los saberes de las mujeres. Hace referencia a sus Artículo Blanco investigaciones y las de otras/os para proponer la incorporación de los saberes de las mujeres al conocimiento escolar.

El objetivo de estas autoras es indagar sobre el papel otorgado a la mujer a través de las ilustraciones. Para ello, analizaron los textos correspondientes a las áreas disciplinares de Conocimiento del medio natural, social y cultural; Lengua castellana y Literatura y Matemáticas, de

$\begin{array}{cl} & \text { Terrón } \\ 2008 & \text { Caro y } \\ \text { Artículo } & \text { Cobano- } \\ & \text { Delgado } \\ & \text { Palma }\end{array}$
tres editoriales distintas. Se analizaron en total 1062 imágenes. Los resultados muestran que los hombres aparecen en el $44 \%$ de ellas, frente al 35,6\% de las mujeres. Concluyen que, si bien es cierto que encontraron mayoritariamente a mujeres en entornos privados, la representación de las mismas con relación a las profesiones es más equilibrada. Un dato que destacan las autoras, es la presencia de más hombres realizando tareas domésticas que de mujeres trabajando en puestos de un mayor rango.

El libro consta de seis capítulos en los que, partiendo de la coeducación en las ciencias experimentales, se hace un 2010 Álvarez $\begin{aligned} & \text { recorrido por la historia de las ciencias a través de la } \\ & \text { presencia de las mujeres en su construcción y producción, }\end{aligned}$ Libro Lires no solo en la ciencia oficial, sino también en aquellas tareas encomendadas a ellas desde hace siglos, tales como la alimentación o el cuidado de las personas.

En este artículo se presentan los avances de la primera fase

2010 López-

Artículo Navajas de un proyecto financiado por el Ministerio de Ciencia e Innovación y el Instituto de la Mujer del Ministerio de Igualdad, del cual la autora es la coordinadora. En esta primera fase se presenta el análisis de la presencia de los 
personajes femeninos y masculinos. Los contenidos estudiados son los correspondientes a todas las asignaturas de la ESO (19), de los cuatro niveles educativos y de tres editoriales distintas. Mediante el estudio de un doble indicador - el de la presencia de personajes y el de recuento de apariciones- se constató que la aparición de las mujeres en los libros de texto está supeditada a la de los hombres: del total de 5527 personajes analizados, las mujeres representan el 12\% (692 mujeres / 4716 hombres). Además, la cifra disminuye del $12 \%$ al $7 \%$ cuando se toma como referencia el segundo indicador. Otro de los resultados que desvela este estudio es que, conforme avanza el nivel educativo, la presencia y aparición de las mujeres pierde peso. La autora añade que en cuarto de la ESO en la asignatura de Literatura e Historia, durante el periodo que va del siglo XIX al XX, la presencia femenina es exigua, siendo esta etapa el momento histórico en el que deberían estar más presentes por las luchas emprendidas y por los resultados obtenidos.

La finalidad de esta investigación es describir cómo se abordan los contenidos de educación sexual en la Comunidad de Navarra. Para ello, se analizaron los conceptos de sexo y género y la caracterización que se da a hombres y a mujeres tanto en las imágenes como en el contenido verbal. Los libros de texto examinados fueron los de Matemáticas y Conocimiento del Medio (euskera y castellano). Concluyen que existe una escasa representación de la mujer $(37,2 \%)$. Se comprueba, así

Pellejero

2011 Goñi y Artículo Torres Iglesias mismo, que se trasmiten expectativas diferenciadas en función del sexo y que existen reticencias a incorporar el tema de la sexualidad como algo natural. Con su estudio estos autores desvelan la falta de claridad con la que los libros hacen referencia a la sexualidad humana. En este sentido, muestran cómo el cuerpo es abordado con ambigüedad y los únicos signos que permiten su identificación son los estereotipos de género (adornos, ropas...). Con relación a la familia, en los libros se presenta una imagen de familia tradicional, excluyéndose, por tanto, las familias mixtas, las homosexuales... Finalmente, en cuanto al género, destacan la falta de imágenes que enriquezcan la corresponsabilidad en las tareas domésticas y la autonomía.

El objetivo de esta investigación fue analizar cuatro

2011

Tesis de Pérez

Máster unidades didácticas de los libros de texto de Ciencias Sociales, Geografía e Historia, para comprobar si con la llegada de la LOE y el I Plan de Igualdad la presencia de 
sexismo en imágenes, texto y lecturas se había modificado. Los resultados arrojados de su estudio, muestran que, en el lenguaje, el uso del masculino genérico representa el 32,6\%, con relación a los personajes protagonistas. Así mismo, destaca el hecho de que de un total de 386 personajes, $187(48 \%)$ son varones y 16 $(4,1 \%)$ son mujeres. El análisis de las ilustraciones refleja que los varones aparecen en un $55,10 \%$ y las mujeres en un $12,30 \%$. Finalmente, en cuanto a los resultados de las lecturas, se observa que casi la totalidad de estas son documentadas y escritas por varones. Concluye Pérez que los cambios legislativos no han conseguido modificar el sexismo en los manuales analizados, puesto que las mujeres siguen sin aparecer en los libros de Historia como protagonistas de la misma.

En esta investigación se realiza una revisión detallada de la producción académica existente sobre el análisis del sexismo en los libros de texto. Además se plantea como

$\begin{array}{cl}2013 & \text { Vaíllo } \\ \text { Tesis de } & \text { Rodríguez } \\ \text { Doctorado } & \end{array}$
objetivo principal cambiar el foco de atención. Para ello, elabora un instrumento con la finalidad de indagar en las normas de elaboración y revisión en las que se basan las editoriales para introducir el principio de igualdad en los libros de texto.

En este trabajo se expone la metodología que se siguió para analizar los materiales educativos de secundaria. Se analizaron un total de 115 libros de tres editoriales distintas. Su propuesta metodológica consistió en diseñar $2014 \quad$ López- un fichero electrónico en el que se realizaría el vaciado de Artículo Navajas los datos. Este fichero se construyó a partir de dos indicadores: 1, la presencia (cuántos personajes aparecen) y 2, la aparición (las veces en que han sido citados). También se tuvieron en cuenta algunos filtros de jerarquización (modo y lugar en el que aparecen los personajes).

Se analizan los libros de texto de Historia y Filosofía (8 en total) de Bachillerato de dos editoriales distintas. El análisis se centra en estudiar la presencia de mujeres y Llorent-

2014 Bedmar y hombres tanto en los equipos de editores de los libros, como del corpus textual mediante el análisis de las Artículo Cobanoimágenes y las lecturas de los mensajes de las imágenes. Así pues, en cuanto a la edición del libro se concluye que la presencia de hombres tanto en la redacción como en la ilustración es mayoritariamente masculina. En cuanto al análisis del corpus textual, encuentran que los hombres aparecen: con profesiones más variadas, más autónomos, con mayor protagonismo y representados con mayor 
frecuencia con relación a las mujeres. Con su estudio constatan que perdura el sexismo en los materiales analizados, si bien es cierto que gracias al esfuerzo realizado por las editoriales esta discriminación ya no es tan lacerante como antaño.

En este trabajo se presentan de manera ampliada los

2015

Capítulo de libro Navajas resultados mostrados en el artículo de 2010. Concluye que en el análisis de todas las asignaturas se constata que la ausencia de las mujeres es sistemática en todos los contenidos educativos, en menor o mayor medida.

Esta investigación fue realizada en educación secundaria, con la finalidad de estudiar el sexismo en los libros de texto de Ciencias Sociales de cuarto año de la ESO de tres editoriales, así como las percepciones del alumnado. En cuanto a los libros de texto, mediante el análisis de las imágenes (128 en total), se constata que la representación femenina continúa siendo escasa. Además, la actitud y los ámbitos en los que aparecen hombres y mujeres también tienen sesgos en función del sexo. Ellos aparecen con actitudes de actividad, liderazgo, pasividad, valentía y

Gómez- poder, mientras que las mujeres solo reflejan una actitud 2016 Carrasco y de actividad cuando aparecen junto a los hombres. Tras el Artículo Gallego- análisis tanto de los libros como de las percepciones del Herrera alumnado, los autores concluyen que se observa un avance en materia de igualdad de género, pero se siguen reflejando sesgos sexistas en los manuales escolares de historia, que representan un mundo y una historia mayoritariamente masculina. Con relación a las percepciones del alumnado, se constata que existe una doble realidad: por un lado se mantienen estereotipos relacionados con la personalidad: hombres $=$ fuertes, valientes... mujeres $=$ sensibles, dóciles, $\mathrm{y}$, por otro lado, los roles sociales asociados al mundo productivo/varónreproductivo-mujer han ido perdiendo nitidez.

Este proyecto se establece con la finalidad de elaborar un diagnóstico general sobre la realidad educativa en cuanto a

Ministerio

de

$\mathrm{s} / \mathrm{f}$ Proyecto Educación, Cultura y Deporte la igualdad de género tanto en el contexto español como en el noruego. Nosotros estudiamos para la realización de esta tesis el apartado en el que abordan el análisis de los materiales didácticos donde se muestran algunas estrategias metodológicas para el análisis de los mismos (p. 176-208).

\footnotetext{
Fuente: elaboración propia a partir de la documentación analizada.
}

En América Latina también se ha contribuido a la producción académica del análisis del sexismo a través de los libros de texto. En la década de los noventa 
es cuando se observa una mayor producción, debido a la financiación de proyectos por parte de los gobiernos nacionales e internacionales (Ritter, Luján, Monti Carvalho, \& Nieto, 2011; Vaíllo Rodríguez, 2013). Sin embargo, no hemos podido acceder a varias de las investigaciones citadas por otras autoras. A continuación, presentamos una tabla en la que se muestran algunos trabajos que han servido también como fuentes para esta investigación.

Tabla 2.14. Investigaciones sobre la presencia de sexismo en los libros de texto, en el contexto de América Latina

\begin{tabular}{|c|c|c|c|}
\hline $\begin{array}{c}\text { Año y tipos } \\
\text { de doc. }\end{array}$ & Autoras/es & País & Presencia de sexismo en los libros de texto \\
\hline $\begin{array}{l}1992 \\
\text { Libro }\end{array}$ & $\begin{array}{l}\text { Robalino, } \\
\text { Villarruel A. } \\
\text { y Isch L }\end{array}$ & Ecuador & $\begin{array}{l}\text { Estas autoras/es elaboran un análisis del } \\
\text { contenido presente en los libros de texto, } \\
\text { agregando una descripción de las actitudes } \\
\text { sexistas del personal docente }\end{array}$ \\
\hline $\begin{array}{c}1994 \\
\text { Capítulo de } \\
\text { libro }\end{array}$ & $\begin{array}{l}\text { Delgado } \\
\text { Ballesteros }\end{array}$ & México & $\begin{array}{l}\text { Se analizaron imágenes, lenguaje y mensajes } \\
\text { contenidos en los libros de texto gratuitos de } \\
\text { primero a sexto de primaria. Su investigación } \\
\text { evidencia la existencia de sexismo tanto en las } \\
\text { ilustraciones utilizadas como en el uso de } \\
\text { adjetivos calificativos al referirse a un hombre } \\
\text { o a una mujer en el texto escrito (libros de } 1^{\text {er }} \text { y } \\
2^{\circ} \text { año). También muestra que en las } \\
\text { ilustraciones las niñas aparecen en una posición } \\
\text { pasiva en comparación con el hombre. Se } \\
\text { comprobó, así mismo, que la aparición de las } \\
\text { mujeres va perdiendo representatividad } \\
\text { conforme aumenta el nivel educativo, llegando } \\
\text { a representar tan solo el 16.6\% de las } \\
\text { ilustraciones que se refieren a las mujeres en } \\
\text { sexto de primaria. Además, la mayoría de estas } \\
\text { ilustraciones presentaban una imagen } \\
\text { estereotipada de la mujer: madre, maestra, } \\
\text { enfermera... }\end{array}$ \\
\hline $\begin{array}{l}2001 \\
\text { Libro }\end{array}$ & $\begin{array}{l}\text { SEP } \\
\text { PUEG }\end{array}$ & México & $\begin{array}{l}\text { Estamos ante un informe de resultados de un } \\
\text { proyecto emprendido de manera conjunta por la } \\
\text { SEP y el PUEG. Este estudio plantea una doble } \\
\text { finalidad: por un lado, indagar sobre los roles, } \\
\text { los espacios de acción y los atributos que se } \\
\text { asignan a hombres y a mujeres en educación } \\
\text { primaria; por otro, proponer alternativas para } \\
\text { contribuir a la identificación /eliminación del } \\
\text { sexismo en los libros de texto gratuitos (LTG). }\end{array}$ \\
\hline
\end{tabular}


Para ello, se establecieron cuatro fases.

La primera, iniciada en 2008, consistió en analizar libros de texto gratuitos de educación primaria. Se analizaron 30 libros de cuatro áreas disciplinares: Libros integrados, Español, Matemáticas y Ciencias Naturales. Las conclusiones, tras el análisis, ponen de manifiesto que en los LTG prevalecen modelos que favorecen, fomentan, y/o justifican la inequidad, la discriminación y la violencia contra las niñas y mujeres.

En la fase II (2009) se analizaron 24 LTG de cinco asignaturas: Español, Exploración de la Naturaleza y la Sociedad, Ciencias Naturales, Historia y Geografía. En el análisis de estos materiales se añadieron indicadores de inequidad, discriminación y violencia. El informe de resultados indica que, aunque se constatan avances relacionados con la inclusión de mujeres desempeñando actividades tradicionalmente de varones, tanto en el texto como en las imágenes continuaron apareciendo formas de violencia simbólica contra las mujeres.

En la fase III (2010) se analizaron 42 LTG de nueve áreas disciplinares: Español, Matemáticas, Exploración de la Naturaleza y la Sociedad, Ciencias Naturales, Historia, Geografía, Educación Artística, Educación Física y Formación Cívica y Ética de todos los cursos de primaria. Los resultados obtenidos fueron más halagüeños que sus antecesores, pues evidencian que en la inmensa mayoría de los libros de texto analizados, tanto en las narrativas visuales como en las textuales, existe mayor sensibilidad a la igualdad y a la no discriminación entre uno y otro sexo. No obstante, se recuerda que es necesario continuar trabajando para que los libros de texto sean un recurso que permita a los y las adolescentes ser críticos con las situaciones de desigualdad entre mujeres y hombres.

En la fase IV, la finalidad de esta es detectar en qué medida los LTG que se utilizan en Telesecundaria, en tres áreas disciplinarias de tercer grado (Español, Formación Cívica y 


\begin{tabular}{|c|c|c|c|}
\hline & & & $\begin{array}{l}\text { Ética e Historia), contienen o no elementos que } \\
\text { favorecen, fomentan, justifican o toleran la } \\
\text { violencia contra las mujeres y las niñas, no } \\
\text { obstante no pudimos acceder a los resultados. }\end{array}$ \\
\hline $\begin{array}{l}2009 \\
\text { Tesis de } \\
\text { Máster }\end{array}$ & $\begin{array}{l}\text { Ladrón De } \\
\text { Guevara } \\
\text { Benítez }\end{array}$ & México & $\begin{array}{l}\text { En este trabajo de investigación se analizan los } \\
\text { LTG de primaria, con la finalidad de identificar } \\
\text { la presencia de la violencia simbólica en las } \\
\text { imágenes. Para ello, se indaga tanto sobre la } \\
\text { presencia cuantitativa y cualitativa de las } \\
\text { mujeres y los hombres, como en lo referido a } \\
\text { las formas en las que están caracterizados. Se } \\
\text { tuvieron en cuenta los libros de tercer año de } \\
\text { primaria de las distintas áreas del } \\
\text { conocimiento: Español, Matemáticas, Historia, } \\
\text { Ciencias Naturales y Geografía. Los resultados } \\
\text { de esta investigación muestran que el } 80 \% \text { de } \\
\text { las veces se nombra en masculino genérico, al } \\
\text { tiempo que el nombrar a uno y a otro sexo solo } \\
\text { representa el 20\%. De los } 1500 \text { personajes } \\
\text { contabilizados solo el } 34 \% \text { eran mujeres, frente } \\
\text { al 66\% de varones. Con relación a las } \\
\text { imágenes, la representación de los personajes } \\
\text { femeninos es de } 32 \% \text {, frente al } 43 \% \text { de los } \\
\text { personajes masculinos y el } 25 \% \text { para grupos } \\
\text { mixtos. También se menciona que las mujeres } \\
\text { aparecen representadas mayoritariamente en los } \\
\text { roles familiares, y los hombres en el ámbito } \\
\text { laboral. Se concluye que "los libros de texto se } \\
\text { pueden concebir como un acto de violencia } \\
\text { simbólica" (p. 144), lo que obedece a la } \\
\text { exclusión de las mujeres, que convierte en } \\
\text { natural un acto impuesto. }\end{array}$ \\
\hline
\end{tabular}

La autora hace una crítica a los libros de texto escolares de Historia en Chile, denunciando que se ha ignorado casi por completo el aporte realizado por las mujeres al desarrollo económico, político, artístico, social... El

2010

Artículo en Minte

conferencia análisis contempló una muestra de veintiséis Chile textos escolares del nivel de educación básica y media de diferentes editoriales (publicaciones de 1990-2010). La autora constata que la presencia de la mujer en los libros analizados es sesgada: se presenta en función de los estereotipos de género, principalmente en el ámbito privado y destaca, así mismo, que su rol 
social está muy ligado a los cánones de la iglesia católica.

El propósito de este proyecto es identificar la vigencia del sexismo y los estereotipos de género en los libros de texto de lectura de primer grado. Los resultados muestran que, de

2011
Proyecto

Rodríguez

2011 Huacuz y

Proyecto Tapia

Fonllem
Argentin un total de 3620 figuras analizadas, el 60,47\% corresponden a hombres y el 39,53 a mujeres. Tras el análisis se concluye que prevalecen los estereotipos de género, pues existe mayor representación de las figuras masculinas, las profesiones se muestran diferenciadas por sexo $\mathrm{y}$ aparece un modelo de familia tradicional.

Este proyecto, encargado por el Instituto de las Mujeres del Estado de San Luis Potosí, fue coordinado por María Dolores Rodríguez y Margarita Elena Tapia, con la finalidad de proponer acciones en materia de igualdad y equidad en la escuela. Para ello, las autoras elaboraron una investigación respecto a diversos tópicos -nosotros vamos a obtener información de lo referente al análisis de los libros de texto. Así pues, analizaron los libros de todas las áreas de conocimiento de quinto y sexto de primaria, tomando como indicadores para el análisis el sexismo, la violencia y la discriminación. Los resultados reflejan que el lenguaje utilizado en la mayoría de las asignaturas (Español, Matemáticas, Ciencias,

México Educación física y Geografía, a excepción de Formación cívica y ética) es un lenguaje masculinizado. En cuanto a la imagen mencionan que existe una escasa representación de las mujeres, desvelando que el porcentaje de aparición de los hombres oscila entre el $75 \%$ y el $80 \%$ con respecto al total de imágenes, y se incrementa particularmente en los textos de Historia, en los que alcanza el $91 \%$. En el análisis del contenido destacan que en algunos libros se refleja el esfuerzo de las instituciones educativas por incorporar los temas de igualdad de género. En este sentido, los libros de Formación cívica y ética han incorporado contenido sobre igualdad de género y derechos humanos, y el libro de Historia ha incorporado información respecto a 
la situación educativa de las mujeres en diversas culturas. No obstante, se concluye que en los libros de texto analizados persiste el sexismo y la discriminación hacia las mujeres.

Muestra cómo el libro de texto gratuito de

2013

Libro

Capistran México

tercer grado de primaria, continúa revelando una visión patriarcal y androcéntrica.

La autora realiza un análisis de los libros de texto que se emplearon durante la época del gobierno cardenista, con la finalidad de evidenciar que este proyecto político es deudor de trasladar las ideas de igualdad hacia las mujeres. Elvira Montes de Oca indica que en este periodo se abrieron nuevos espacios de participación para las mujeres (en lo laboral, en lo educativo y en lo político). Durante el gobierno cardenista se pone en práctica la educación socialista, se editan nuevos libros de texto, los cuales han de elaborarse bajo los lineamientos de la estrenada reforma educativa. En los nuevos libros se daba voz a colectivos y sujetos sociales que hasta ese momento habían permanecido silenciados: niños, obreros, campesinos, indígenas, mujeres. Los libros contenían imágenes sencillas, en colores blanco

2015 Montes de Artículo Oca Navas

\section{México}

y negro. En ellas se presentaban imágenes donde niños y niñas convivían juntos y se nombraban entre sí como "camaradas". A través de los libros se fomentaban valores considerados fundamentales para la formación del buen ciudadano: respeto a los mayores, a los padres, a los maestros y a los animales, amor al trabajo, participación en las tareas familiares... Se refiere que en estos libros se muestran imágenes en donde las mujeres desarrollan actividades laborales, sin abandonar las tareas del hogar. También se manifiesta que en los libros de esta época se "ensalza" la labor doméstica que realizan las mujeres (p. 159). A través de los contenidos se intenta mostrar que niños y niñas pueden integrarse por igual a las distintas labores sociales, pero que han de participar desde las funciones "propias de cada sexo" (p. 162). En este artículo se concluye que, si bien en este periodo se abrieron nuevos espacios de participación para las mujeres 
(donde destaca el trabajo asalariado), las políticas públicas desarrollas mantuvieron la separación de los roles masculinos y femeninos, como constatan los libros de texto analizados.

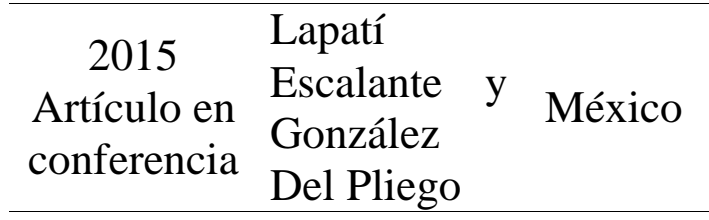

Es un proyecto en el que se pone de relieve la escasa investigación que se ha realizado en México sobre el análisis del sexismo en los LTG de historia en educación secundaria.

En este artículo se elabora un análisis de quince libros de texto de Historia (10 chilenos y 5 cubanos), con la intención de caracterizar a las mujeres en las imágenes y en el discurso. La presencia de las mujeres en los libros de historia chilenos es entendida como no protagonista de hechos o procesos históricos: en las imágenes aparecen en ámbitos sociales y familiares, mientras que los hombres vienen caracterizados como protagonistas $y$ productores. No obstante, en estos libros de texto chilenos, durante el periodo de finales del siglo XIX y parte del XX, se hace referencia tanto a mujeres que lucharon por ingresar a la

2015 Münzenmay ChileArtículo er y Cuba González educación superior, como a las que exigían el derecho a sufragio -si bien estas alusiones son relegadas a notas de pie de fotografías o a actividades didácticas sugeridas. En cambio, los libros de texto de Cuba no refieren el movimiento que emprendieron las mujeres en esta época. Las autoras concluyen que la invisibilización de las mujeres, tanto en Chile como en Cuba, es una constante en los libros de Historia. Destacan, además, que los libros de texto no responden a la realidad social contemporánea en la que mujeres y hombres desempeñan todo tipo de actividades, profesiones... Constatan, por último, que "en el discurso oficial las mujeres no están presentes"(p. 329).

Fuente: elaboración propia a partir de la documentación analizada.

Las investigaciones revisadas en este apartado dan cuenta de las características particulares con las que los distintos países han procurado 
atender el problema de la desigualdad, la discriminación y el androcentrismo que prevalecen en los materiales educativos.

Un rasgo que diferencia a los estudios realizados en España y en América Latina, es que la mayor parte las investigaciones desarrolladas en el primer contexto pueden ubicarse en el último tramo de educación obligatoria (secundaria), mientras que en América Latina las investigaciones se han emprendido mayoritariamente en educación primaria (gráfico 2.3.).

Gráfica 2.3. Investigaciones desarrolladas en España y en América Latina por nivel educativo

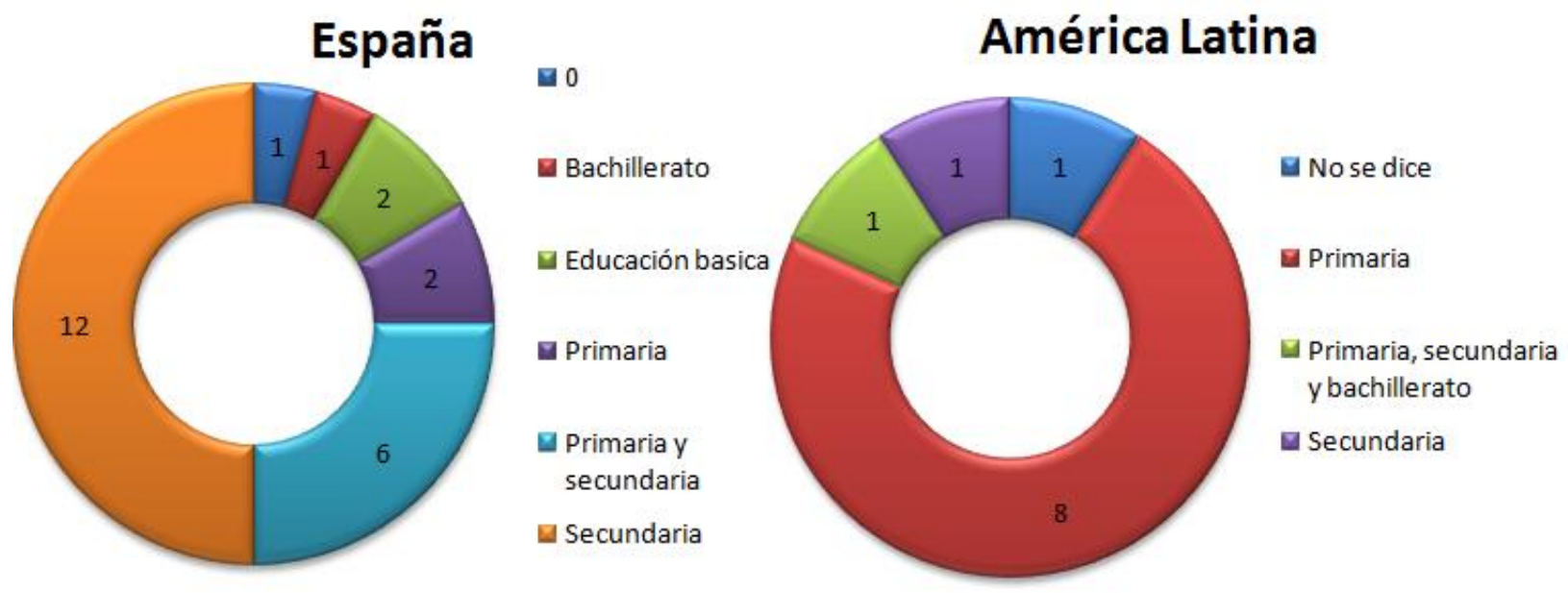

Fuente: elaboración propia a partir de la documentación analizada.

Otro de los rasgos que se ha identificado como diferenciadores es que en América Latina se abordan indicadores de violencia simbólica, mientras que en el contexto español no se hace referencia a este indicador.

De cualquier manera, cabe destacar que todas las investigaciones citadas han evidenciado, en menor o mayor medida, la situación de discriminación y sexismo que se sigue manteniendo en los libros de texto. Así pues, de la revisión bibliográfica concluimos los siguientes aspectos:

- La investigación sobre el sexismo en los libros de texto continúa siendo una línea de investigación adecuada para evidenciar los sesgos androcéntricos y patriarcales que perviven en los materiales. 
- Los resultados de los análisis del contenido, de los textos, de las ilustraciones pasadas y presentes, tanto en México como en resto de países revisados, no han hecho sino constatar la difícil tarea de eliminar los estereotipos sexistas de los libros de texto.

- Las acciones emprendidas en materia jurídica no han conseguido que los libros de textos trasformen suficientemente sus contenidos.

- Hemos corroborado que en México existe una exigua investigación sobre el análisis del sexismo en los LTG en educación secundaria.

En los estudios analizados sobre los estereotipos de género de las tres últimas décadas, tanto en los sujetos como en los materiales educativos, pueden identificarse líneas de investigación que nos sirven de puntales para la elaboración de este trabajo, pues como bien mencionan Esperanza Tuñón y Enrique Eroza: "El conocimiento y aprendizaje no habrán de agotarse, pues la realidad social será siempre cambiante y fascinante" (2001, p. 223).

\subsection{Resumen}

Teniendo en cuenta las aportaciones teóricas revisadas, cabe preguntarnos: ¿es realmente la diferencia entre sexos tal, que no permita que los seres humanos, ya sean hombres o mujeres, puedan desarrollar plenamente sus potencialidades como consecuencia de los roles de género que se les atribuyen? Y si esto es así, ¿es inevitable que se sigan reproduciendo los prejuicios sobre mujeres y hombres que no encajan en las normatividades culturales establecidas para uno y otro sexo? Históricamente se han articulado asimetrías que han perjudicado a mujeres (principalmente) y a hombres, encasillándolos en el desempeño de determinadas funciones, expectativas, responsabilidades, profesiones, actividades laborales,... (Costa Aguirre, 2016; Subirats i Martori \& Tomé, 2010). Esta distribución no ha tenido en cuenta las características de los seres humanos, y se ha colocado lo masculino como eje rector universal, con lo 
cual tanto mujeres como hombres hemos perdido. $\mathrm{M}^{\mathrm{a}}$ José Arena (1997) lo expresa así:

Por cada mujer fuerte cansada de aparentar debilidad, hay un hombre débil, cansado de parecer fuerte.

Por cada mujer cansada de tener que actuar como una tonta, hay un hombre agobiado por tener que aparentar saberlo todo.

Por cada mujer cansada de ser calificada como una «hembra emocional», hay un hombre a quien se le ha negado el derecho a llorar y a ser delicado.

Por cada mujer catalogada como poco femenina cuando compite, hay un hombre obligado a competir para que no se dude de su masculinidad.

Por cada mujer cansada de ser un objeto sexual, hay un hombre preocupado por su potencia sexual. (...) (Citada por Cortina, 1998, p. 35). 



\section{Igualdad entre hombres y mujeres. Marco normativo actual}

Hastrup, 2001a. p. 21: «El deseo común de vivir libres de los horrores de la violencia, el hambre, la tortura, la enfermedad y la discriminación es indicación de la humanidad compartida y, a la vez, fundamentación y aspiración de los derechos humanos. El lenguaje de los derechos humanos supone la ambición de universalizar la justicia y la igualdad [...], plantea un modo de imaginar el mundo y así gradualmente hacerlo real [...] y en este sentido forman parte de la complejidad del mundo actual y de las posibilidades de su transformación» (citado por Maquieira, 2013, p. 45)

La lucha por la igualdad entre hombres y mujeres ha sido una constante desde el siglo VIII hasta nuestros días. ${ }^{87}$ El resultado de las reivindicaciones por la igualdad entre hombres y mujeres se ha plasmado, de manera institucional, a través de la creación de diversos instrumentos, mecanismos y compromisos, tanto nacionales como internacionales, que, en forma de leyes, tratados, convenciones, protocolos, pactos... conforman un marco regulador para impulsar el desarrollo en igualdad de condiciones de hombres y mujeres y garantiza que sus derechos sean respetados en los distintos ámbitos en los que se desenvuelven (CEAMEG, 2007; SECMUJER, 2008; Secretaría de Relaciones, UNIFEM, \& PNUD, 2005).

\section{La Constitución Política de los Estados Unidos Mexicanos ${ }^{88}$ (CPEUM), en el} artículo 133, indica la jerarquía normativa, la cual señala que la "Ley Suprema de la Unión" es la Constitución, seguida de los Tratados internacionales ratificados por el Senado, y finalmente las leyes federales y locales (SCJN, 2006). Sin embargo, la reforma en materia de derechos humanos hecha al

\footnotetext{
${ }^{87}$ Las mujeres que se han revelado en contra de la situación de desigualdad han estado presentes desde tiempos remotos. Ya en el siglo XV, Christine de Piasan plasma en sus escritos lo injustas que eran las opiniones que los hombres tenían de las mujeres. Sin embargo, el feminismo entendido como movimiento político y teórico nace vinculado a las ideas de la ilustración, con escritoras como Condorcet, Olympe de Gouges y Mary Wollstonecraft, entre otras (Maldonado Barahona, 2013a; Ruiz Carbonell, 2010). En la actualidad son muchas las personas que reivindican la igualdad entre hombres y mujeres en el mundo y desde muy distintas perspectivas, entre ellas/os están Amorós, Cobo Bedia, Dio Bleichmar, Ferguson, Lagarde y de los Ríos, Lamas, Oliva Portolés, Puleo, Tubert, entre muchas/os otras/as.

${ }^{88}$ Por economía lingüística me referiré a la Constitución Política de los Estados Unidos Mexicanos como CPEUM o bien como la Constitución.
} 
artículo $1^{\circ}$ del 10 de junio de 2011, indica que "Las normas relativas a los derechos humanos se interpretarán de conformidad con esta Constitución y con los tratados internacionales de la materia favoreciendo en todo tiempo a las personas la protección más amplia" (DOF, 2011b). Para algunos constitucionalistas (Becerra Ramírez, Carpizo, Corzo Sosa, \& López-Ayllón, 2000; M. Carbonell, 2012; De Silva Gutiérrez, 2012; Orozco Henríquez, 2011) este principio pro homine pone en igual rango, o por encima de la Constitución, a los tratados internacionales ratificados en materia de derechos humanos.

Éste epígrafe contiene los instrumentos, mecanismos y compromisos que México ha asumido, firmado y ratificado para garantizar a la ciudadanía una vida digna. Hemos tomado en cuenta la jerarquía normativa aprobada por el sistema jurídico mexicano para organizar este apartado.

La jerarquización por la que ha optado el país ha sido discutida por diversos autores (Becerra Ramírez et al., 2000; Carpizo, 2012; CEAMEG, 2007; FixZamudio, 2006; SCJN, 2006), los cuales coinciden al afirmar que existe una inconsistencia debida a la indeterminación contenida en el artículo 133 constitucional. Tal falta de precisión da lugar a interpretaciones muy distintas, dejando a las leyes federales, e incluso a la CPEUM, en un lugar de menor rango frente a los tratados internacionales.

A fin de tener una idea más clara de cómo está establecida la jerarquía normativa en México, presentamos la figura 3.1. En ella se puede observar el porqué del debate sobre la ubicación de los tratados internacionales por encima de las leyes federales e incluso de la CPEUM: 
Figura 3.1. Jerarquía normativa en México

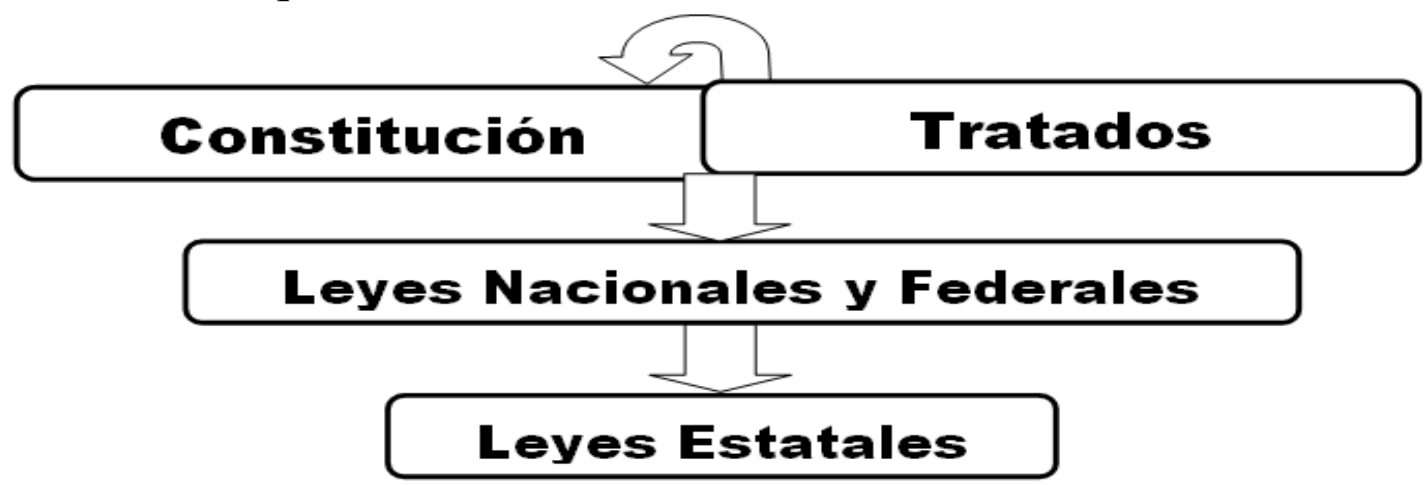

Fuente: elaborado con base en (Cámara de Diputados, 2012; M. Carbonell, 2012; Consejo Nacional de Población, 2012; De Silva Gutiérrez, 2012; DOF, 2011b, 2015; Saldaña, 2007; SCJN, 2006).

Tomando en cuenta lo descrito anteriormente, presentamos el orden y la forma que vamos a seguir para describir la normativa jurídica en materia de igualdad y equidad de género. En la primera parte mencionamos los artículos que hacen referencia a la igualdad de género en la Constitución Política de los Estados Unidos Mexicanos, seguido de los tratados internacionales firmados y ratificados por México en esta materia. ${ }^{89}$

A continuación, en el apartado 3.2., presentamos un marco jurídico nacional muy breve y específico sobre las herramientas jurídicas básicas relacionadas con la igualdad entre hombres y mujeres. En el punto 3.3., hacemos referencia a las leyes federales y estatales. Finalmente presentamos un resumen sobre este apartado

\subsection{La Constitución y los Instrumentos internacionales firmados y ratificados por México en materia de igualdad}

Haciendo un recuento general sobre la integración de los derechos de las mujeres, y por consiguiente de la igualdad, encontramos la primera gran reforma constitucional publicada el 17 de octubre de 1953. Con ella se reformó el Artículo 34 Constitucional de modo a reconocer la ciudadanía de las mujeres (Girón et al., 2008a, p. 34; Ruiz Carbonell, 2010, p. 82). En febrero de 1965, la

\footnotetext{
${ }^{89}$ Nos basamos en la clasificación que presentan CEAMEG, 2007, agregando información que proporciona SEGOB, s. f.
} 
reforma al Artículo 18 Constitucional reconoció las necesidades específicas de las mujeres en prisión, al permitir que éstas compurguen sus penas en lugares separados de los destinados a los hombres. Posteriormente, en 1969, se reformó el Artículo 30 constitucional, a fin de beneficiar a las madres mexicanas cuyos hijos nacieron en el extranjero, siendo estos considerados mexicanos por nacimiento, sin que importe la nacionalidad o la identidad del padre (Ruiz Carbonell, 2010).

Los autores Fabián Castillo y Carolina Viveros, nos explican que en México la igualdad de género se reconoció, como derecho fundamental, por primera vez en 1974, mediante la reforma del artículo 4o. de la CPEUM de 1917. Posteriormente se han realizado otras dos reformas, una que tiene que ver con la paridad laboral, realizada en 1986 (artículo 123), y la segunda reforma establecida en el artículo 1o. sobre la equidad de género en el año 2001 (2013, p. 412).

Cabe destacar que agregaremos artículos de la CPEUM que hemos considerado que se han enmendado en pro de la igualdad de derechos entre mujeres y hombres. Entre ellos se encuentran el artículo $2^{\circ}$, en él se reconoce y garantiza el derecho de los pueblos indígenas a la autodeterminación y a la autonomía. Esta reforma fue de gran importancia para las mujeres indígenas, puesto que con ella se garantiza su participación en condiciones de equidad frente a los varones. El artículo $3^{\circ}$ se reformó en 2013 para garantizar una educación en igualdad de condiciones para hombres y mujeres.

Por otro lado, vamos a referir algunos artículos que amplían la visión del trabajo que se ha realizado en México en materia jurídica de igualdad de género. Así, los Artículos Constitucionales 14, 16, 19 y 90, contienen varias disposiciones que reglamentan el Código Penal Federal. En 1997 se tipificó por primera vez en nuestro país la violencia familiar del siguiente modo: 
"se considera el uso de la fuerza física o moral, así como las omisiones graves, que de manera reiterada ejerza un miembro de la familia en contra de otro integrante de la misma, que atente contra su integridad física, psíquica o ambas, independientemente de que pueda producir o no lesiones; siempre y cuando el agresor y el agredido habiten en el mismo domicilio y exista una relación de parentesco, matrimonio o concubinato". 90

A continuación mencionaremos los artículos que se han reformado en la Constitución para incorporar en sus estatutos la igualdad entre hombres y mujeres (tabla 3.1). Cabe destacar que la aparición de los artículos la realizaremos en orden numérico y solo se hará referencia a las reformas que se han establecido posteriormente, con la finalidad conseguir la igualdad entre hombres y mujeres en México: ${ }^{91}$ Tabla 3.1. Artículos reformados en la Constitución Política de los Estados
Unidos Mexicanos

\begin{tabular}{|c|c|c|}
\hline Artículos & Fecha de reforma & Texto que reformado \\
\hline Artículo $1^{\circ}$. & DOF 10/06/2011 & $\begin{array}{l}\text { Queda prohibida toda discriminación motivada por origen étnico } \\
\text { o nacional, el género, la edad, las discapacidades, la condición } \\
\text { social, las condiciones de salud, la religión, las opiniones, las } \\
\text { preferencias sexuales, el estado civil o cualquier otra que atente } \\
\text { contra la dignidad humana y tenga por objeto anular o } \\
\text { menoscabar los derechos y libertades de las personas. }\end{array}$ \\
\hline \multirow[t]{2}{*}{ Artículo $2^{\circ}$. } & DOF 14/08/2001 & $\begin{array}{l}\text { II. Aplicar sus propios sistemas normativos en la regulación y } \\
\text { solución de sus conflictos internos, sujetándose a los principios } \\
\text { generales de esta Constitución, respetando las garantías } \\
\text { individuales, los derechos humanos y, de manera relevante, la } \\
\text { dignidad e integridad de las mujeres. }\end{array}$ \\
\hline & DOF 29/01/2016 & $\begin{array}{l}\text { También se reforma la fracción III el apartado B que hacen } \\
\text { referencia a los derechos de hombres y de mujeres indígenas a } \\
\text { ejercer su derecho al sufragio y gozar de los derechos humanos } \\
\text { en igualdad de condiciones. }\end{array}$ \\
\hline Artículo $3^{\circ}$. & DOF $26 / 02 / 2013$ & $\begin{array}{l}\text { c) Contribuirá a la mejor convivencia humana, a fin de fortalecer } \\
\text { el aprecio y respeto por la diversidad cultural, la dignidad de la } \\
\text { persona, la integridad de la familia, la convicción del interés } \\
\text { general de la sociedad, los ideales de fraternidad e igualdad de } \\
\text { derechos de todos, evitando los privilegios de razas, de religión, } \\
\text { de grupos, de sexos o de individuos, }\end{array}$ \\
\hline
\end{tabular}

${ }^{90}$ El capítulo octavo del Código Penal entonces vigente para el Distrito Federal, en el artículo 343 bis es tipificada la violencia familiar por primera vez en México, así lo describe (Morales Hernández, 2002, p. 136).

${ }^{91}$ Con base en los documentos publicados en el Diario Oficial de la Federación (DOF, 2015). Algunos de estos artículos los presentaremos de manera parcial.

En los anexos se pueden consultar de manera más ampliada los artículos a los que hacemos alusión en esta tabla. 


\begin{tabular}{lll}
\hline Artículo $4^{\circ}$. & DOF 31/12/1974 & $\begin{array}{l}\text { El varón y la mujer son iguales ante la ley. Ésta protegerá la } \\
\text { organización y el desarrollo de la familia. }\end{array}$ \\
\hline Artículo 123. & DOF 23/12/1986 & $\begin{array}{l}\text { VII. Para trabajo igual debe corresponder salario igual, sin tener } \\
\text { en cuenta sexo ni nacionalidad. }\end{array}$ \\
\hline \hline
\end{tabular}

Fuente: elaboración propia a partir de la Constitución Política de los Estados Unidos Mexicanos (SEGOB \& UGAJ, 2016). Disponible en http://www.ordenjuridico.gob.mx/constitucion.php

Estos artículos son las únicas referencias constitucionales, a nivel federal, que hacen algún señalamiento sobre la igualdad entre hombres y mujeres. No obstante, el Plan Nacional de Desarrollo y la Ley del Instituto Nacional de las Mujeres contienen disposiciones generales establecidas para salvaguardar los objetivos y planes en materia de igualdad y equidad de género.

Una vez descritos los artículos de la Constitución Mexicana que abordan los temas sobre igualdad, pasamos a mencionar los instrumentos internacionales que contienen los principios básicos sobre los cuales los gobiernos de los países miembros deben formular políticas e impulsar acciones para lograr el desarrollo humano, pues como bien manifiesta Lucero Saldaña, (2007, p. 29) aunque la tendencia mundial ha sido la democratización y la igualdad entre hombres y mujeres, la participación de las mujeres en la adopción de decisiones fundamentales como partícipes plenas y en condiciones de igualdad, aún no se ha logrado.

Así pues, los derechos consagrados en los instrumentos internacionales constituyen una base para impulsar el desarrollo de las mujeres y garantizar sus derechos en su integración en los ámbitos político, económico, cultural y social. En ese sentido, conforman un marco para la incorporación de sus demandas y necesidades en las agendas nacionales.

Convencido de ello, México ha firmado y ratificado los principales instrumentos internacionales en materia de derechos humanos de las mujeres con la Organización de las Naciones Unidas (ONU), la Organización Internacional del Trabajo (OIT) y con la Organización de los Estados Americanos (OEA) - , y ha asumido responsabilidades morales y políticas que 
promueven e impulsan los derechos humanos y las ibertades fundamentales en igualdad de condiciones que el hombre.

Dada la relevancia de su difusión, en este apartado se mencionan algunos de estos instrumentos, con el propósito de elaborar un marco de referencia sobre mecanismos y herramientas jurídicas internacionales en pro de la igualdad, la justicia, la libertad y la dignidad social entre mujeres y hombres.

Los instrumentos internacionales firmados y ratificados por México, tanto en el ámbito mundial (ONU y OIT), como en el ámbito regional (OEA), se pueden clasificar por su obligatoriedad en vinculantes y no vinculantes. En este apartado solo se hará mención a los instrumentos vinculantes: Convenciones, Protocolos, Pactos y Convenios.

Cabe destacar que la información se presentará a través de tablas donde se podrá observar el instrumento, ámbito o sistema (S) en el que están circunscritos (ONU, OIT y OEA), la fecha de ratificación (R. o A.), la fecha de entrada en vigor (E.V.) a nivel internacional, la fecha de Publicación en Diario Oficial (PDO) y el objetivo del instrumento.

Tabla 3.2. Convenciones firmadas y ratificadas por México en el ámbito de la ONU

\begin{tabular}{|c|c|c|c|c|c|}
\hline CONVENCIÓN & $\mathbf{S}$ & R. A. & $\begin{array}{l}\text { E. } \\
\text { V. }\end{array}$ & PDO & OBJETIVOS \\
\hline CISTMM & ONU & $\begin{array}{c}26 / 12 / \\
1932\end{array}$ & 1921 & $\begin{array}{c}25 / 01 / \\
1936\end{array}$ & $\begin{array}{l}\text { Prohíbe la trata de menores de edad de uno y otro sexo. } \\
\text { Los Estados parte se comprometen a tomar medidas } \\
\text { administrativas y legislativas para a combatir la trata de } \\
\text { mujeres y menores de edad. }\end{array}$ \\
\hline CIRRTMME & ONU & $\begin{array}{l}3 / 05 / \\
1938\end{array}$ & 1933 & $\begin{array}{c}21 / 06 / \\
1938\end{array}$ & $\begin{array}{l}\text { Sanciona la trata de mujeres mayores de edad, aún } \\
\text { cuando los actos constitutivos del delinto se hayan } \\
\text { realizado en distintos países. }\end{array}$ \\
\hline CRTPEA & ONU & $\begin{array}{c}21 / 02 / \\
1956\end{array}$ & 1950 & $\begin{array}{c}19 / 06 / \\
1956\end{array}$ & $\begin{array}{l}\text { Sanciona la trata de personas y la explotación de la } \\
\text { prostitución ajena. Además, prohíbe el mantenimiento } \\
\text { de casas de prostitución. }\end{array}$ \\
\hline CDPM & ONU & $\begin{array}{c}23 / 03 / \\
1981\end{array}$ & 1954 & $\begin{array}{c}28 / 04 / \\
1981\end{array}$ & $\begin{array}{l}\text { Establece el derecho de las mujeres a ejercer el voto en } \\
\text { cualquier proceso electoral en igualdad de términos que } \\
\text { los hombres. Además, Establece el derecho de las } \\
\text { mujeres a participar como candidatas en procesos de } \\
\text { elección y ser nombradas a cargos públicos, en } \\
\text { conformidad con las leyes nacionales y en igualdad de } \\
\text { términos respecto a los hombres. }\end{array}$ \\
\hline
\end{tabular}




\begin{tabular}{|c|c|c|c|c|c|}
\hline CCMEMCMRM & ONU & $\begin{array}{c}22 / 02 / \\
1983\end{array}$ & 1964 & $\begin{array}{c}19 / 04 / \\
1983\end{array}$ & $\begin{array}{l}\text { Establece la obligatoriedad de consentimiento de ambas } \\
\text { partes para la celebración del matrimonio, la edad } \\
\text { mínima para contraerlo y el registro para asegurar los } \\
\text { derechos sociales a las mujeres casadas. }\end{array}$ \\
\hline CEDAW & $\mathrm{ONU}$ & $\begin{array}{c}23 / 03 / \\
1981\end{array}$ & 1981 & $\begin{array}{c}22 / 06 / \\
1981\end{array}$ & $\begin{array}{l}\text { Promulga derechos universales y medidas para } \\
\text { conseguir que las mujeres gocen de igualdad de derechos } \\
\text { independientemente de su estado civil, en las esferas } \\
\text { política, económica, social, cultura, etc. }\end{array}$ \\
\hline
\end{tabular}

Fuente: elaboración propia con base en la información publicada por las siguientes instituciones: CEAMEG, 2007; Instituto Nacional de las Mujeres, 2008; SEGOB, s. f.

En la tabla 3.2. podemos observar las convenciones que fueron aprobadas por México. Cabe señalar que la que se refiere a la Eliminación de Todas las Formas de Discriminación Contra las Mujeres (CEDAW) es considerada clave y fundamental para el reconocimiento de los derechos humanos de las mujeres constituyendo el principio de un proceso de afirmación de la igualdad y de la instrumentalización de la equidad.

A continuación presentamos la tabla 3.3. En ella se muestran los instrumentos internacionales y regionales que han servido para la construcción de un marco normativo tendiente a proteger los derechos humanos y a conseguir el principio de igualdad (UNFPA, 2006).

Tabla 3.3. Convenciones firmadas y ratificadas por México en el ámbito de la OIT y de la OEA

\begin{tabular}{|c|c|c|c|c|c|}
\hline CONVENCIÓN & S. & R. A. & $\begin{array}{l}\text { E. } \\
\text { v. }\end{array}$ & PDO & OBJETIVOS \\
\hline $\begin{array}{l}\text { Convenio Internacional del } \\
\text { Trabajo No. } 100\end{array}$ & OIT & $\begin{array}{c}23 / 08 / \\
1952\end{array}$ & 1951 & $\begin{array}{l}9 / 10 / \\
1952\end{array}$ & $\begin{array}{l}\text { Los Estados Parte se comprometen a garantizar } \\
\text { la igualdad de remuneración entre la mano de } \\
\text { obra masculina y la mano de obra femenina por } \\
\text { un trabajo de igual valor. }\end{array}$ \\
\hline $\begin{array}{l}\text { Convenio } 111 \text { sobre la } \\
\text { Discriminación Empleo y } \\
\text { Ocupación }\end{array}$ & OIT & $\begin{array}{c}11 / 09 / \\
1961\end{array}$ & 1960 & $\begin{array}{c}11 / 08 / \\
1962\end{array}$ & $\begin{array}{l}\text { La finalidad es promover la igualdad de } \\
\text { oportunidades y de trato en materia de empleo } \\
\text { y ocupación. }\end{array}$ \\
\hline $\begin{array}{l}\text { Convención sobre la } \\
\text { Nacionalidad de la Mujer }\end{array}$ & $\mathrm{OEA}$ & $\begin{array}{c}27 / 01 / \\
1936\end{array}$ & 1934 & $\begin{array}{l}7 / 04 / \\
1936\end{array}$ & $\begin{array}{l}\text { Establece que ni la celebración ni la anulación } \\
\text { del matrimonio podrán afectar a las mujeres en } \\
\text { sus derechos fundamentales como el derecho a } \\
\text { la nacionalidad. }\end{array}$ \\
\hline $\begin{array}{l}\text { Convención Interamericana } \\
\text { sobre Concesión de los } \\
\text { Derechos Políticos de la } \\
\text { Mujer }\end{array}$ & $\mathrm{OEA}$ & $\begin{array}{c}24 / 03 / \\
1981\end{array}$ & 1981 & $\begin{array}{c}29 / 04 / \\
1981\end{array}$ & $\begin{array}{l}\text { La comunidad americana establece el derecho al } \\
\text { igual tratamiento político entre mujeres y } \\
\text { hombres. }\end{array}$ \\
\hline $\begin{array}{l}\text { Convención Interamericana } \\
\text { sobre Concesión de los } \\
\text { Derechos Civiles de la Mujer }\end{array}$ & OEA & $\begin{array}{c}24 / 03 / \\
1981\end{array}$ & 1981 & $\begin{array}{c}29 / 04 / \\
1981\end{array}$ & $\begin{array}{l}\text { Reconoce la igualdad de derechos civiles entre } \\
\text { mujeres y hombres. }\end{array}$ \\
\hline
\end{tabular}


Convención Americana sobre Derechos Humanos "Pacto de San José de Costa Rica"

OEA $\begin{array}{ccc}24 / 03 / & & \\ 1981 & 1978 & 7 / 05 / \\ & & \end{array}$

$\mathrm{Su}$ finalidad es instruir los mecanismos para garantizar los derechos esenciales, que tienen como fundamento los atributos de la persona humana, por lo que hace énfasis en la igualdad y la no discriminación.

Convención Interamericana para Prevenir Sancionar y Erradicar la Violencia contra la Mujer (Belem do Pará) OEA $\begin{array}{ccc}12 / 11 / & & 19 / 01 / \\ 1998 & 1994 & 1999\end{array}$ Señala el deber de los Estados parte para proteger el derecho de las mujeres a una vida libre de violencia, física, sexual y psicológica; mediante la adopción, en forma progresiva de medidas específicas.

Fuente: elaboración propia con base en la información publicada por las siguientes instituciones: CEAMEG, 2007; Instituto Nacional de las Mujeres, 2008; SEGOB, s.f.

En la siguiente tabla 3.4. se pueden observar las enmiendas o acuerdos que se han elaborado con el fin de adecuar las normas y principios derivados de las convenciones internacionales o regionales en materia de igualdad.

\section{Tabla 3.4. Protocolos firmados y ratificados por México en el ámbito de la ONU y de la OEA}

\begin{tabular}{|c|c|c|c|c|c|}
\hline PROTOCOLOS & S. & R. A. & E. V. & PDO & OBJETIVOS \\
\hline $\begin{array}{l}\text { P. Enmienda la Convención para la } \\
\text { Represión para la Trata de Mujeres y } \\
\text { Menores y la Convención para la } \\
\text { Supresión del Tráfico de Mujeres } \\
\text { Mayores de Edad. }\end{array}$ & ONU & $\begin{array}{c}17 / 08 / \\
1949\end{array}$ & 1947 & $\begin{array}{c}19 / 10 / \\
1949\end{array}$ & $\begin{array}{l}\text { Las dos convenciones a las que se hace alusión } \\
\text { fueron formuladas cuando existía la Sociedad de las } \\
\text { Naciones. Como consecuencia de su disolución fue } \\
\text { necesario, mediante el Protocolo, tomar las } \\
\text { disposiciones para asegurar la continuidad del } \\
\text { ejercicio de los poderes y funciones. }\end{array}$ \\
\hline $\begin{array}{l}\text { P. facultativo de la Convención sobre } \\
\text { la Eliminación de Todas las Formas } \\
\text { de Discriminación Contra la Mujer }\end{array}$ & ONU & $\begin{array}{c}15 / 03 / \\
2002\end{array}$ & 1999 & $\begin{array}{c}03 / 05 / \\
2002\end{array}$ & $\begin{array}{l}\text { Los Estados parte en el presente Protocolo } \\
\text { reconocen la competencia del Comité de la } \\
\text { CEDAW para establecer procedimientos de } \\
\text { comunicacióny un procedimiento de investigación, } \\
\text { que permite ejercer el derecho de petición respecto } \\
\text { de la aplicación de la Convención. }\end{array}$ \\
\hline $\begin{array}{l}\text { P. para Prevenir, Reprimiry } \\
\text { Sancionar la Trata de Personas, } \\
\text { Especialmente Mujeres y Niños, que } \\
\text { Complementa la Convención de las } \\
\text { Naciones Unidas Contra la } \\
\text { Delincuencia Organizada } \\
\text { Trasnacional }\end{array}$ & ONU & $\begin{array}{c}04 / 03 / \\
2003\end{array}$ & 2001 & $\begin{array}{c}10 / 04 / \\
2003\end{array}$ & $\begin{array}{l}\text { Los fines del protocolo son prevenir y combatir la } \\
\text { trata de personas, presentando especial atención a } \\
\text { las mujeres y a la infancia; proteger y ayudar a las } \\
\text { víctimas de dicha trata, respetando plenamente sus } \\
\text { derechos humanos; y promover la cooperación } \\
\text { entre los Estados Parte para lograr esos fines. }\end{array}$ \\
\hline $\begin{array}{l}\text { P. adicional a la Convención } \\
\text { Americana sobre Derechos Humanos } \\
\text { en Materia de Derechos Económicos, } \\
\text { Sociales y Culturales "Protocolo de } \\
\text { San Salvador" }\end{array}$ & OEA & $\begin{array}{c}16 / 04 / \\
1996\end{array}$ & 1988 & $\begin{array}{c}01 / 09 / \\
1998\end{array}$ & $\begin{array}{l}\text { Los Estados parte se comprometen a ejecutar y a } \\
\text { fortalecer programas que coadyuven a una } \\
\text { adecuada atención familiar. }\end{array}$ \\
\hline
\end{tabular}

Fuente: elaboración propia con base en información publicada por las siguientes instituciones: CEAMEG, 2007; Instituto Nacional de las Mujeres, 2008; SEGOB, s. f. 
La tabla que presentamos a continuación contiene los pactos de los tratados internacionales sobre los derechos civiles y políticos y los derechos económicos, sociales y culturales.

\section{Tabla 3.5. Pactos firmados y ratificados por México en el ámbito de la ONU}

\begin{tabular}{|c|c|c|c|c|c|}
\hline PACTOS & SISTEMA & R.0A. & E.V. & PD0 & OBJETIVOS \\
\hline $\begin{array}{l}\text { Pacto Intemacional de } \\
\text { Derechos Económicos, } \\
\text { Sociales y Culturales }\end{array}$ & ONU & $23 / 03 / 1981$ & 1976 & $\begin{array}{l}1205 / \\
1981\end{array}$ & $\begin{array}{l}\text { Los Estados parte se comprometen a garantizar el ejercicio de los derechos } \\
\text { que en él se enuncian. Sin discriminación alguna por motivos de raza, color, } \\
\text { sexo, idioma, religión, opinión politica o de otra indole, origen nacional o } \\
\text { social, posición económica, nacimiento o cualquier otra condición social. } \\
\text { También busca garantizar a las mujeres condiciones de trabajo no infeniores } \\
\text { a las de los hombres. }\end{array}$ \\
\hline $\begin{array}{l}\text { Pacto Intemacional de } \\
\text { Derechos Civiles y } \\
\text { Politicos. }\end{array}$ & ONU & $23 / 03 / 1981$ & 1976 & $\begin{array}{r}2005 / \\
1981\end{array}$ & $\begin{array}{l}\text { Garantiza a hombres y mujeres el disfrute de las libertades civiles y } \\
\text { politicas. }\end{array}$ \\
\hline
\end{tabular}

Fuente: elaboración propia con base en información publicada por las siguientes instituciones: CEAMEG, 2007; Instituto Nacional de las Mujeres, 2008; SEGOB, s. f.

\subsection{Leyes Nacionales. Igualdad de género}

Con este apartado pretendemos plasmar el contenido que tienen las leyes nacionales pensadas y elaboradas para que las mujeres y los hombres puedan vivir en un mundo regido por la igualdad, no solo formal, sino sustantiva. ${ }^{92}$

El tema de la igualdad formal ha tenido una historia relativamente reciente en nuestro país, pues como se vio en el apartado del feminismo en México, la situación y condición de las mujeres en nuestro país ha estado caracterizado por la segregación, el control, la discriminación, la desigualdad y la postergación. Javier Chapado S. (2012), citando a Sandoval (2001), menciona que Sor Juan Inés de la Cruz (siglo XVII) es una de las primeras mujeres que se manifestó en contra de esta situación a través de sus escritos. En 1912-1924 documentamos en nuestro país registros que muestran la exigencia, la apertura y la demandas por parte de las mujeres a ser tratadas como ciudadanas, a tener, en definitiva,

\footnotetext{
${ }^{92}$ Por igualdad formal entendemos aquella que se establece jurídicamente a través de las leyes y normas, mientras que por igualdad sustantiva consideramos lo descrito por Saldaña, "la ausencia de toda distinción, exclusión o restricción basada en el sexo que tenga por objeto o resultado menoscabar o anular el reconocimiento, goce o ejercicio de los derechos humanos y las libertades fundamentales en las esferas política, económica, social y civil o en cualquier otra" (2007, p. 28).
} 
igualdad de derechos. ${ }^{93}$ Sin embargo, no es hasta el 17 de octubre de 1953 cuando se reconoce su derecho a sufragio. Con esto se consuma un logro en pro de la igualdad y se da inicio a una nueva etapa para conseguir, proteger e incorporar en el plano legislativo leyes que velaran por la igualdad de derechos entre mujeres y hombres.

Ricardo Ruiz menciona que en 1975 comienza un momento histórico, a nivel mundial, donde se abre camino la idea de que la igualdad entre mujeres y hombres puede ser reconocida y establecida, "siendo de vital importancia las convenciones, tratados, pactos, cumbres, declaraciones, etcétera" (Ruiz Carbonell, 2010, p. 83). Ruiz continúa señalando que durante los años siguientes se obtienen logros en materia de igualdad en el país, derivados de estos compromisos internacionales y se asientan las bases para la aprobación de un plan de acción mundial en el que se establecen las directrices que debían seguir tanto los gobiernos como la comunidad internacional para alcanzar los objetivos de institucionalizar la igualdad de género.

La institucionalización de la igualdad de género en nuestro país, México, como se mencionaba en párrafos anteriores, ha estado detenida/controlada por decisiones políticas que no veían la pertinencia de establecer la igualdad de género en el marco jurídico mexicano. Las transformaciones jurídicas sobre los derechos humanos de las mujeres en México se conforman como un proceso de avances y retrocesos hasta mediados de los años setenta.

Ricardo Ruiz (2010) menciona cómo las trasformaciones jurídicas en materia de igualdad fueron impulsadas de manera más "motorizada" durante el corto tramo que se lleva del presente siglo. Esto se consiguió tanto a través de la demandas de las organizaciones no gubernamentales (movimiento feminista),

\footnotetext{
${ }^{93}$ Bajo el mandato del Salvador Álvarez y el de Carrillo Puerto se consiguen algunos derechos para las mujeres, en relación con la educación, el trabajo, el divorcio y el control de la natalidad. También tuvo lugar el primer con Congreso Feminista (1915-1916). Sin embargo, con la muerte de Carrillo Puerto los derechos de las mujeres se ven postergados (Girón et al., 2008a, pp. 43-44).
} 
como por los acuerdos, tratados y compromisos internacionales que México ha firmado y ratificado. Producto de ello, y con el esfuerzo conjunto de las legisladoras de los diferentes partidos políticos, en 2001 se fundó por ley el Instituto Nacional de las Mujeres (INMUJERES). Su creación significó un paso importante en la consolidación a nivel nacional de los mecanismos institucionales, ya que se le otorgó a esta institución estatus administrativo, patrimonio propio y presupuesto, para ejercer dentro del marco legal atribuciones en materia de la política nacional de género (CONAPO \& UNFPA, 2009, p. 43; IMUJERES, 2012, p. 6).

Otra gran conquista para la institucionalización de la igualdad de género ha sido la promulgación de leyes que vigilen y promueven la igualdad entre los sexos, la no discriminación y la no violencia en el ámbito nacional así como en las entidades federativas. Estas leyes se inscriben en el ámbito de una serie de trasformaciones jurídicas, constituyendo en su conjunto un cimiento fundamental del marco jurídico mexicano para la vigencia de los derechos humanos permanentemente violentados de las mujeres, los pueblos... (Lagarde, 2013, p. 362).

El 11 de agosto de 2003 se avanza en el camino hacia la consolidación entre los géneros, mediante la Ley Federal para Prevenir y Eliminar la Discriminación (LFPED), cuya finalidad es doble. Por un lado, se pretende elaborar un diagnóstico sobre la situación del fenómeno de la discriminación en México, y por otro, se formuló la redacción de un proyecto de ley para combatir todas las formas de discriminación en el país (Ruiz Carbonell, 2010, p. 127).

El 2 de agosto de 2006 se promulgó la Ley General para la Igualdad entre Mujeres y Hombres (LGIMH). En ella se establece como objetivos prioritarios regular y garantizar la igualdad entre mujeres y hombres, y proponer los lineamientos y mecanismos institucionales que orienten a la Nación hacia el cumplimiento de la igualdad sustantiva. La ley del 2 de agosto de 2006 enfatiza, 
además, la obligatoriedad de transversalizar los programas y políticas, de modo que aseguren una planeación presupuestal tomando en cuenta las necesidades diferenciadas de mujeres y hombres; fomentar la participación y representación política equilibrada; promover el acceso a los derechos sociales e igualdad en la vida civil, así como eliminar estereotipos en función del sexo (IMUJERES, 2012, pp. 6-7).

Poco después, en febrero de 2007, se emitió la Ley General de Acceso de las Mujeres a una Vida Libre de Violencia (LGAMVLV), Marcela Lagarde (2013) menciona que esta ley garantiza y protege el derecho de las mujeres a vivir una vida libre de violencia, pues en ella se establecen las condiciones jurídicas destinadas a proteger y velar por la seguridad de las mujeres que sufren violencia de género en cualquiera de sus modalidades. Esta autora nos dice que la LGAMVLV es aplicable a todo el territorio nacional, así como obligatoria para los tres órdenes de gobierno (p. 358).

A modo de resumen, presentamos, en la figura 3.2., una panorámica general de las leyes nacionales y federales vinculadas a la igualdad de género:

Figura 3.2. Leyes nacionales vinculadas a la igualdad de género

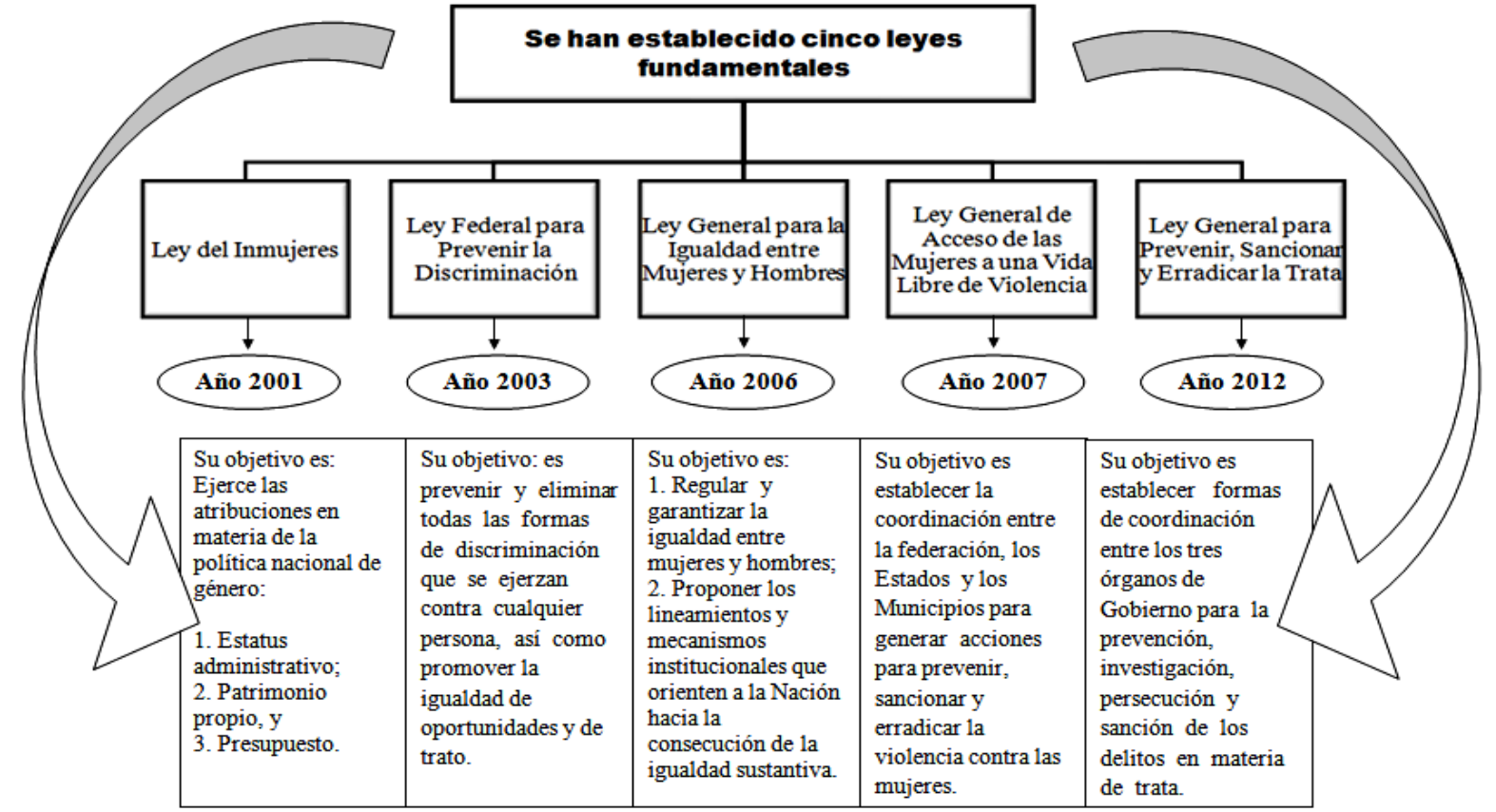

Fuente: elaboración propia con base en (Consejo Nacional de Población, 2012; DOF, 2001, 2006, 2007a, 2012). 
Algunas cuestiones en entredicho:

La autora María L. Christiansen (2014) considera que existen algunas incongruencias sobre la LGAMVLV, puesto que en sus objetivos no enfrenta realmente el problema, “[...]sin ánimo de demeritar las buenas intenciones de quienes siguen pensando que la violencia social se aborda y se resuelve promulgando nuevas leyes, solo cabe señalar que dicha maniobra cambia lo superficial solo para mantener intacto lo profundo". Para la autora es importante revisar el concepto de violencia, debido a que se inscribe en el plano social interdisciplinar y transdisciplinar.

Por otro lado, legisladores/as y personas expertas manifiestan que, si bien es cierto que México ha realizado importantes esfuerzos para garantizar la protección de los derechos humanos de las mujeres, como por ejemplo la "Ley General de Acceso de las Mujeres a una Vida Libre de Violencia", tales medidas no están siendo suficientes. ${ }^{94}$

En los siguientes puntos se resumen algunas de las cuestiones para perfeccionar dicha Ley:

- Órdenes de protección a víctimas, tardías e inaccesibles (Fiscal Nelly Montealegre Díaz).

- No hay un registro real de feminicidios en el país (M. de la Paz López Barajas). ${ }^{95}$

- Armonización con otras normativas en las Leyes de las entidades federativas, la reformulación actual de la ley y el comienzo de la revisión de las alertas de género de todo el país (Diputada: María del Rocío García Olmedo).

\footnotetext{
${ }^{94}$ Información retomada de la página web del H. Congreso de la Unión, (2014), boletín No 4620 .

${ }^{95}$ Especialista en Estadística y Políticas de Igualdad de Género de ONU Mujeres
} 
- Ampliar las órdenes de protección a otros ámbitos y no sólo a la violencia familiar o de pareja (Diputada: M. de las Nieves García Fernández; Mayela García Ramírez). ${ }^{96}$

- Diseñar un sistema de rehabilitación de victimarios en donde haya mecanismos para que esas personas asistan a terapia después de su trabajo y convivan con personal especializado (Julia Pérez Cervera). ${ }^{97}$

- Redefinir el concepto de violencia familiar (Perla Gómez Gallardo). ${ }^{98}$

\subsection{Leyes estatales}

Atendiendo a los compromisos internacionales - derivados principalmente de la Convención sobre la Eliminación de todas las Formas de Discriminación contra la Mujer (CEDAW) y de la Convención Interamericana para Prevenir, Sancionar y Erradicar la Violencia contra la Mujer (Convención Belém do Pará)_, a las presiones de movimientos feministas, y a los esfuerzos institucionales del INMUJERES, se decretan, a partir del 2003, diversas Leyes Federales con la intención de otorgar a las ciudadanas una vida más igualitaria, libre de discriminación y de violencia.

Estos compromisos en materia de igualdad asumidos por la Nación, obligan a los Estados Federales a establecer acciones de coordinación entre los distintos niveles de Gobierno en lo referente a las políticas públicas destinadas a garantizar "la igualdad de derechos, oportunidades, recurso y libertades" (INMUJERES, 2009, p. 12).

El Estado de Michoacán de Ocampo, ${ }^{99}$ con el afán de cumplir con estas disposiciones Internacionales y Nacionales y teniendo en cuenta las demandas de movimientos sociales (principalmente feministas), decreta cuatro Leyes en pro de la igualdad.

\footnotetext{
${ }^{96}$ Directora del Colectivo de Investigación, Desarrollo y Educación entre Mujeres

${ }^{97}$ Directora de Vereda Themis

${ }^{98}$ Presidenta Comisión de Derechos Humanos del Distrito Federal

${ }^{99}$ Durante la lectura de los capítulos siguientes, con el propósito de economizar el lenguaje, nos referiremos a Michoacán de Ocampo como Michoacán o bien como MI.
} 
1. Ley de Acceso de las Mujeres a una Vida Libre de Violencia del Estado de Michoacán de Ocampo (LAMVLVEMO), publicada el miércoles 31 de Diciembre del 2008;

2. Ley para la Igualdad entre Mujeres y Hombres en el Estado de Michoacán de Ocampo (LIMHEMO), publicada el jueves 1 de enero de 2009;

3. Ley para Prevenir y Eliminar la Discriminación y la Violencia en el Estado de Michoacán de Ocampo (LPEDVEMO), publicada el viernes 2 de enero de 2009; y

4. Finalmente, la Ley para Prevenir, Atender y Erradicar la Trata de Personas y para la Protección y Asistencia de las Víctimas en el Estado de Michoacán de Ocampo (LPAETPPAVEMO), entró en vigor el martes 25 de agosto de $2015 .^{100}$

Con la Ley LAMVLVEMO, ${ }^{101}$ se pretende combatir legalmente el problema de violencia de género en el ámbito privado y en el público, las medidas previstas de atención a la violencia no se limitan a la asistencia, prevención y atención a las mujeres, sino que intenta prevenir, promover, sancionar y erradicar la violencia ejercida hacia las mujeres. Esto requiere que se lleven a cabo trasformaciones estructurales a nivel institución, a nivel público, y a nivel privado.

Los principios rectores que se deben tomar en cuenta para establecer políticas públicas a favor de la no violencia son: la igualdad jurídica, la dignidad, la no discriminación, y la libertad. La SECMUJER menciona que el hecho de establecer esta Ley tanto a nivel Nacional como a nivel Estatal es una apuesta

\footnotetext{
${ }^{100}$ Información retomada de la página web de la Secretaría de Gobernación (SEGOB, 2015): "Orden Jurídico Nacional-Ámbito Local y Municipal". En el siguiente link se puede acceder a las Leyes mencionadas en su íntegra: http://www.ordenjuridico.gob.mx/estatal.php?liberado=si\&edo=16.

${ }^{101}$ Información retomada del Periódico Oficial del Gobierno del Estado de Michoacán de Ocampo (PO, 2008).
} 
política ética (SECMUJER, 2008, p. 229). Estamos de acuerdo con este ideario, ya que los estatutos contenidos en esta ley procuran salvaguardar la vida de las mujeres, así como establecer las políticas públicas y las acciones gubernamentales que garanticen el acceso de las mujeres a una vida libre de violencia, que a su vez favorezca su desarrollo y bienestar conforme a los principios de igualdad y de no discriminación.

La LIMHEMO establece los mecanismos legales para institucionalizar la perspectiva de género bajo tres principios: la igualdad, la no discriminación y la equidad $^{102}$.En ella se asignan funciones y responsabilidades específicas que son conducentes a la transversalidad de la perspectiva de género. Su estatuto legal proporciona un conjunto de disposiciones, normas, procedimientos y métodos — tanto a las instituciones públicas como a los órganos de gobierno Municipal y Estatal- con los cuales efectuar acciones destinadas a la promoción y procuración de la igualdad entre mujeres y hombres, respetando los diferentes niveles de competencia. A continuación retomaremos las disposiciones que se establecen en el artículo 17 de esta Ley, lo que obedece al hecho de que específica cuestiones relacionadas con nuestro tema de estudio:

Artículo 17. La política estatal en materia de Igualdad entre mujeres y hombres deberá establecer las acciones conducentes para lograr la igualdad de oportunidades en los ámbitos económico, político, social y cultural.

La política estatal que desarrolle el Ejecutivo del Estado deberá considerar los siguientes lineamientos:

I. Fomenta y establece la igualdad entre mujeres y hombres en todos los ámbitos de la vida;

II. Garantiza la planeación presupuestal del gasto público, incorpore la perspectiva de género, apoye la transversalidad y prevea el

${ }^{102}$ Artículo $5_{\text {o. }}$ de la LIMHEM. La información que presentamos sobre esta Ley es retomada de PO, (2009). 
cumplimiento de los programas, proyectos y acciones orientadas a impulsar la igualdad entre mujeres y hombres;

III. Fomenta la participación y representación política equilibrada entre mujeres y hombres;

\section{Promueve las condiciones para la igualdad de acceso y pleno} disfrute de los derechos sociales para las mujeres y los hombres; y,

\section{Erradica los estereotipos establecidos en función del sexo}

Por otro lado, la LPEDVEMO, ${ }^{103}$ se fundamenta en cuatro principios rectores: la libertad, la igualdad, la no discriminación y el desarrollo integral sustentable. Esta Ley, al igual que las referidas en los párrafos anteriores, tiene el objetivo de implementar las estrategias y acciones oportunas para garantizar a la ciudadanía una vida libre de discriminación y de violencia, pero, a diferencia de las otras, promueve estos principios favoreciendo el desarrollo integral de las personas.

Finalmente, y después de seis años de expedirse las Leyes enunciadas en párrafos anteriores, se decreta la LPAETPPAVEMO, que tiene como finalidad prevenir, atender y erradicar la trata de personas ${ }^{104}$, así como brindar protección y asistencia a las víctimas, ofendidos y testigos, de conformidad con la Ley General. Los principios rectores que dan fundamento a esta Ley son: la debida diligencia, el derecho a la reparación del daño, las garantías de que no se repitan los agravios a las víctimas, los derechos de la niñez, laicidad y libertad de religión, las medidas de protección a la dignidad, libertad, seguridad y demás derechos humanos.

\footnotetext{
${ }^{103}$ La información que presentamos sobre esta Ley es retomada de PO, (2009b).

${ }^{104}$ Entendiendo por trata de personas: "toda acción u omisión dolosa para captar, enganchar, transportar, transferir, retener, entregar, recibir o alojar a una o varias personas con fines de esclavitud, servidumbre, prostitución ajena u otras formas de explotación sexual, explotación laboral, trabajo o servicios forzados, mendicidad forzada, actividades delictivas, adopción ilegal, matrimonio forzoso o servil, tráfico de órganos, tejidos y células de seres humanos vivos y experimentación biomédica ilícita en seres humanos" Artículo $1_{\mathrm{o}}$. PO, (2015).
} 
La emisión de estas Leyes ha significado, sin lugar a dudas, un paso más para conseguir la emancipación de la mujer en el Estado. Sin embargo, no podemos pensar, tal y como señala Christiansen, (2014), que el establecer una normativa jurídica va a solucionar el problema. Se trata solo de un primer paso para conseguir la igualdad, ya que se requiere de un esfuerzo conjunto que implica la puesta en marcha de acciones que incorporen efectivamente la perspectiva de género en las políticas públicas. Políticas que, así mismo, han de estar encaminadas a transformar las barreras que invisibilizan y segregan a un colectivo que representa a más del cincuenta por ciento del total de la población.

\subsection{Resumen}

En este apartado hemos intentado ofrecer un panorama general sobre el proceso histórico-legislativo que se ha puesto en marcha para que las mujeres mexicanas puedan tener una vida libre de subordinación y opresión.

Los tres sub-apartados dan cuenta de cómo los avances jurídicos en materia de igualdad entre hombres y mujeres han sido tímidos. No obstante, los logros conseguidos han sido dilatados en el tiempo y siempre está al acecho la posibilidad del retroceso, Celia Amorós acierta al recordarnos que no podemos dar vacaciones a la igualdad, pues "las mujeres siempre corremos el riesgo de que nos hagan retroceder hasta en logros cuya estabilidad parecía pertenecer al dominio de lo obvio" (Amorós, 2010b, p. 29).

A continuación presentamos en un esquema el panorama jurídico en México relacionado con la igualdad de género. En él podemos observar cómo los compromisos internacionales asumidos por México se han traducido en avances legislativos de gran calado para el país. Además, las acciones emprendidas a nivel Federal han otorgado a los Estados referentes para decretar estatutos que promuevan una vida libre de violencia y discriminación. La elaboración de mecanismos jurídicos que velen por una participación justa y equitativa tanto en 
la vida privada como en la pública es un primer paso para conseguir la igualdad entre hombres y mujeres. Sin embargo esto no es suficiente, se requiere de la implementación de acciones y proyectos públicos destinados a deconstruir los estereotipos y roles de género que limitan las potencialidades de desarrollo tanto de hombres como de mujeres

\section{Esquema 3.1. Marco jurídico sobre igualdad de género}

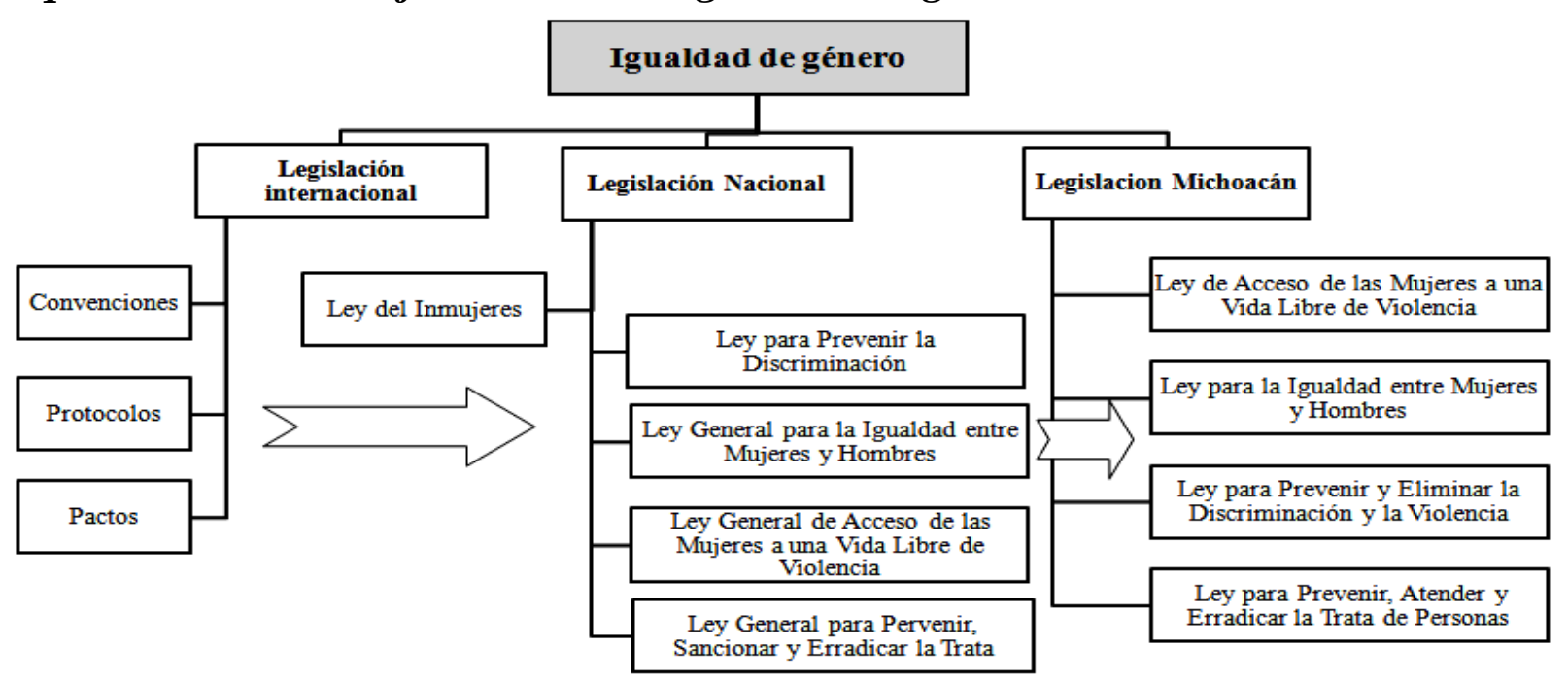

Fuente: elaboración propia con base en figuras y tablas anteriores. 


\section{PARTE II. LOS LIBROS DE TEXTO Y LAS PERCEPCIONES DEL}

ALUMNADO DE PRIMER GRADO DE SECUNDARIA DEL ESTADO DE MICHOACÁN DE OCAMPO 



\section{Contextualización}

Marcela Lagarde «Una humanidad diversa y democrática requiere que mujeres y hombres seamos diferentes de quienes hemos sido, para ser reconocidos en la diversidad de vivir en la democracia genérica» (Lagarde, 1996, p. 14)

Este capítulo lo estructuramos en dos apartados. En el punto 4.1. elaboramos una justificación de la relevancia que tiene nuestro tema de estudio. Por un lado, destacamos algunos de los conceptos que hemos analizado en la parte de fundamentación teórica, y por otro lado, hacemos referencia a los estudios que nos han servido de base teórica para elaborar el diseño metodológico de nuestra investigación. Por su parte, en el epígrafe 4.2. realizamos una descripción sobre la situación política y social del Estado de Michoacán.

\subsection{Justificación de la relevancia de la investigación}

Amelia Valcárcel: «Conocer qué lugar ocupa el sexo en la imagen del mundo es tener en las manos una de las claves interpretativas fuertes de un autor o una época, porque las reflexiones que produce la dimorfia sexual forman muy a menudo la trama invisible pero no menos verdadera sobre la que se pinta la ontología que se exhibe» (Valcárcel, 1991, p. 10)

La situación de desigualdad entre hombres y mujeres es una problemática que afecta a nivel mundial. Aunque en la actualidad ha mejorado mucho la condición de las mujeres, aún hoy en día ellas tienen menos posibilidades de desarrollarse en condiciones de igualdad en todos los ámbitos en los que se desenvuelven. Por eso, en este trabajo nos planteamos, por una parte, identificar cuáles son las percepciones que provocan que los y las adolescentes del Estado de Michoacán legitimen las relaciones de desigualdad $\mathrm{y}$, por otra, averiguar de qué manera se promueven en los libros de texto las relaciones de igualdad/desigualdad. 
Para ello se vuelve necesario, primeramente, definir algunos conceptos tales como percepción, género, estereotipos, estereotipos de género, roles, roles de género, ya que todos ellos constituyen la base sobre la cual se ha configurado esta investigación. En segundo lugar, analizaremos algunas de las investigaciones que se han retomado para la elaboración de estudio. ${ }^{105}$

Para definir lo que entendemos por percepción retomamos lo descrito por Vania Álvarez, "proceso mental a través del cual se comprende o interpreta el medio circundante, y que genera conocimientos, ideas, conceptos o emociones. Depende en gran medida de la cultura, la memoria y el conocimiento previo" (Álvarez Olivas, 2015, p. 94).

En esta investigación el género es considerado como una categoría de estudio que hace referencia a las construcciones socioculturales elaboradas alrededor de los sexos hombre y mujer, para atribuirles ciertos rasgos, valores y patrones de comportamiento propios de cada género (femenino/masculino). Estas construcciones socioculturales se traducen en la mayor parte de los países en desventajas sociales, subordinación y/o dominación para las personas, principalmente mujeres, que no cumplen con los roles/estereotipos que se promueven en las sociedades patriarcales (Barberá Heredia, 2004; Blanco, 2006; Chávez Carpia, 2004; Checa, 2005; Delgado Ballesteros, 2003; González Ramírez \& Villaseñor G., 2010; Izquierdo, 2013; Lagarde, 1996; Lamas, 1995, 1999; Puleo, 2000; Szasz, 1998; Valcárcel, 2010).

Los estereotipos y los roles han tenido una especial relevancia dentro de la investigación sobre género, puesto que su estudio arroja descriptores en cuanto a los juicios que tienen varones y mujeres sobre sí mismos y sobre

\footnotetext{
${ }^{105}$ En el apartado 2.3 de esta tesis hacemos una referencia más global de las investigaciones que han abordado de alguna manera la temática propuesta en esta investigación.
} 
las demás personas. ${ }^{106}$ Por ello consideramos oportuno aclarar lo que entendemos por estos dos conceptos.

Así, cuando hablamos de estereotipos nos referimos a las ideas preconcebidas y simplistas tendientes a crear generalizaciones sobre personas y colectivos que están socialmente arraigadas y aceptadas (Colás Bravo \& Villaciervos M., 2007; Martínez Sánchez, Navarro O., \& Yubero J., 2009; Quesada Jiménez, 2014). Pero al referimos a los estereotipos de género retomamos lo descrito por Josefina Caro:

Son construcciones culturales que determinan una visión de las características y actitudes de cada sexo. Crean modelos rígidos en los que tienen que encajar para ser socialmente aceptado, fijan un modelo de ser chico y un modelo de ser chica $\mathrm{y}$, a partir de una visión tópica construida, establecen un sistema desigual de relaciones entre los dos sexos y cada uno de ellos hacia el mundo (Caro Blanco, 2008, p. 226).

Por rol, consideramos la función y/o tarea que desempeña cada persona. Más específicamente, con el concepto "roles de género" nos referimos a las tareas, papeles y funciones que se asignan a mujeres y varones. Varones y mujeres han de desempeñar funciones y tareas distintas. Cortina (1998) explica cómo los roles asignados a hombres y a mujeres van a servir de justificación para continuar con el mantenimiento de una situación que privilegia lo masculino.

Hasta aquí hemos clarificado los conceptos, ahora enunciaremos algunos estudios que se han llevado a cabo en estas áreas, con la finalidad de evidenciar la relevancia que tiene la temática que en esta investigación se propone.

La investigación realizada por Gabriela Delgado (2003), que analiza una gran variedad de estudios existentes en México sobre género y educación, evidencia la necesidad de seguir contribuyendo a la generación de estudios

${ }^{106}$ Cuadrados (2007), citado por Martínez Sánchez et al., (2009). 
con perspectiva de género desde el ámbito académico. Los 257 estudios sobre género y educación realizados en el periodo 1992-2002, reflejan que existe una tendencia a que el sistema escolar reproduzca patrones de comportamiento estereotipados, donde el género masculino recibe mayor valor que el femenino. Delgado (2003) también revela en su estudio la escasez de investigaciones que analicen los libros de texto y los discursos que tienen las y los adolescentes sobre esta temática a nivel de secundaria y de bachillerato.

En cuanto a los libros de texto en Europa, sobre todo en España, hemos encontrado diversas/os autoras/es que han elaborado análisis sobre los materiales escolares desde una perspectiva de género, empleando para ello una variedad de métodos (Alvarez N., 2009; Blanco, s/f, 2000, 2003; Espigado, 2004; García G., Troiano i Gomà, \& Zaldívar S., 1993; Garreta \& Careaga, 1987; Gómez-Carrasco \& Gallego-Herrera, 2016; I.M.O.P. Encuestas, 2000; Lomas, C., 2002; López Ojeda, 2007; López-Navajas, 2014; Luengo G. \& Blázquez E., 2004; Mínguez \& Beas, 1995; Morgado, 2004; Pellejero Goñi \& Torres I., 2011; Peñalver, 2003; Pérez, 2011; Sánchez, 2012; Solé, 2014; Subirats, 1991). En México, cabe destacar que solo hemos podido acceder a dos artículos en los que se hace referencia a este tipo de estudios: el realizado por SEP y PUEG, (2001), Metodología del análisis de los libros de texto gratuitos de telesecundaria desde la perspectiva de la equidad de género, y el elaborado por Elvira Montes de Oca, (2015). Las mujeres mexicanas durante el gobierno de Lázaro Cárdenas, 1934-1940. Revista Historia de la Educación Latinoamericana, (17), 149-166.

En cuanto a la percepción sobre igualdad/desigualdad de género, existe una multiplicidad de estudios en diversas aéreas del conocimiento 
(psicología, sociología, educación). Para una mejor comprensión de los mismos, los vamos a ubicar por temáticas.

Primero podemos mencionar diversos estudios que confirman la persistencia de estereotipos de género tradicionales. A las mujeres se les define como sensibles, guapas, cariñosas y relacionadas con las tareas del hogar, o bien con el cuidado a los otros/as (ámbito privado). Por su parte, los varones son vistos como fuertes, valientes y trabajadores (ámbito público) (Amurrio Velez et al., 2012; Colás Bravo \& Villaciervos Moreno, 2007; Martínez Sánchez et al., 2009; Morin-Messabel, Ferrière, Lainé, Mieyaa, \& Rouyer, 2016; Quesada Jiménez, 2014; Ruiz Pinto et al., 2013; Stern, 2007).

En segundo lugar aparecen los estudios que evidencian que la autopercepción de hombres y/o de mujeres es menos estereotipada, pues ambos sexos reconocen en sí mismos/as estereotipos que eran atribuidos generalmente al sexo contrario. Sin embargo concluyen que esta autopercepción de rasgos, de actitudes o de roles menos estereotipada no se ha visto acompañada con la evolución y el desarrollo que han caracterizado a la mayoría de las sociedades (Auster \& Ohm, 2000; Barberá, 2004; Costa Aguirre, 2016; Martínez Sánchez et al., 2009).

En tercer lugar, vamos a referir algunos estudios sobre actitudes del alumnado hacia la igualdad de género. García Pérez et al., (2010) destacan cuatro cuestiones. La primera es que los y las adolescentes tienen disposición hacia la cultura de igualdad. Destaca, además, que las chicas tienen las puntaciones más elevadas al ser medida esta actitud. En segundo lugar, el alumnado obtiene mejores puntuaciones en aspectos relacionados con la actividad profesional y social de la mujer. En tercer lugar, a nivel sociocultural y personal el alumnado continúa mostrando creencias estereotipadas y expectativas basadas en la diferenciación de rol de género, 
sobre todo en cuanto a la repartición de tareas domésticas o asociadas al cuidado de otros/as. En cuarto y último lugar sobresale que los chicos obtienen puntaciones elevadas en indicadores relativos a la justificación de la violencia hacia las mujeres.

El estudio de Lameiras \& Rodríguez, (2002) muestra que el alumnado continúa perpetuando una visión estereotipada de la mujer y de los hombres. En cuanto a la mujer existe una evaluación negativa (hostil) en la que es valorada como "inferior", y otra en un tono más benevolente en la que es evaluada positivamente como "diferente". En lo referido a los hombres, la valoración estereotipada negativa atribuida a ellos es la de "agresor", al tiempo que la evaluación positiva es la de "protector". Estas autoras concluyen que, para conseguir la igualdad, se deben superar los estereotipos referidos tanto a las mujeres como a los hombres.

Finalmente, indicaremos dos estudios que han utilizado una metodología parecida a la nuestra (grupos de discusión en contextos educativos) para analizar las actitudes que tienen hombres y mujeres hacia la igualdad de género. Ahora bien, difieren en la conformación y análisis del mismo. Así pues, en el estudio realizado por Cala Carrillo \& Mata B. (2005) se analizan las diferencias entre hombres y mujeres de distintos niveles educativos. Las personas que participaron fueron agrupadas en función del nivel educativo (alfabetización, graduado y universitario) y del sexo (hombre/mujer). El análisis se realizó en función del discurso y los resultados mostraron que el grupo compuesto por hombres de nivel educativo alfabetización fue el menos igualitario. En este grupo persistieron los estereotipos tradicionales sobre género, de acuerdo con los cuales ellos son los que trabajan fuera y ellas las que se quedan a cargo de las tareas domésticas y del cuidado de los hijos e hijas. Concluyen estos investigadores que conforme aumenta el nivel educativo la postura de las 
actitudes y creencias es más igualitaria. Otro aspecto que se destaca en este estudio es que las opiniones y percepciones en los grupos de discusión masculinos son menos igualitarias que en los femeninos.

El otro estudio que revisamos fue el elaborado por Amurrio Velez, Larrinaga R., Usategui B., \& Del Valle, (2012). En él se realiza un análisis sobre los estereotipos de género en jóvenes y adolescentes en cuanto a las relaciones afectivas, empleando para ello herramientas cuantitativas (encuesta) y cualitativas (GD). La conclusión a la que llegaron estas autoras es que existe una fuerte interiorización de los estereotipos de género entre los y las adolescentes, hecho que se traduce en relaciones afectivas y sexuales marcadas por la desigualdad y el dominio de los chicos sobre las chicas. En las relaciones amorosas/afectivas aparecen de este modo rasgos asociados al abuso, la prepotencia, la manipulación, el chantaje del varón sobre la mujer, $\mathrm{y}$, por tanto, la justificación, en ocasiones, de la propia violencia de género.

Los estudios a los que hemos aludido más arriba evidencian que las transformaciones sociales ocurridas en los contextos en los que se han desarrollado las diferentes investigaciones no han modificado los estereotipos de género arraigados en hombres y mujeres - de menor o mayor edad- . Aunque algunas investigaciones muestran cierto optimismo al afirmar que hemos avanzado bastante en la lucha por erradicar los estereotipos, estos todavía continúan presentes, si bien muchas veces no somos conscientes de ello. Por ello se justifica plenamente la pertinencia de estudiar y analizar las situaciones de desigualdad que siguen instauradas en las opiniones que tienen los adolescentes y la manera en que los materiales didácticos las promueven. 


\subsection{Situación política y social del Estado de Michoacán}

Jaume Carbonell: «[...] La democracia no es una puerta abierta a la tolerancia y al relativismo sino un acceso que conduce al respeto crítico y activo. La única manera de poder cuestionar algunas verdades y reconocer otras» (Carbonell, 2001, p. 93)

La situación y condición actual de mujeres y hombres en el Estado de Michoacán ha sufrido importantes transformaciones sociales, políticas y económicas que pueden servir de referencia para comprender el análisis que realizamos en esta investigación. Por eso, en este apartado mostramos el panorama sociodemográfico del Estado de Michoacán de Ocampo, incluyendo datos relevantes para conocer algunas de las características demográficas, económicas, políticas y sociales básicas de la población.

A continuación presentamos la secuencia seguida en este apartado.

1. Información general sobre el Estado;

2. Datos demográficos de la población;

3. Características económicas de la región;

4. Rasgos de la situación política y social de la región;

5. Analizando la desigualdad entre hombres y mujeres en el Estado.

\section{Información general sobre el Estado}

El Estado de Michoacán de Ocampo es un estado libre y soberano, cuyo nombre procede del náhualt "michihuacán", que quiere decir "lugar de pescadores" (Secretaría de Relaciones Exteriores SRE, s. f.). Su ubicación se encuentra en el extremo sur occidental del territorio nacional (ver mapa), gracias a la cual es un estado con gran riqueza natural, con bosques, praderas y lagunas, con montañas y volcanes que descienden hacia el mar y que hacen de él un lugar mágico. Limita con los estados de Colima y Jalisco al noroeste, al norte con Guanajuato y Querétaro, al este con el Estado de México, al sur con Guerrero y el Océano Pacífico, y al oeste con 
el Océano Pacífico y Colima (Gobierno del Estado de Michoacán \& INEGI, 2012).

Michoacán de Ocampo cuenta con 113 municipios y su capital es Morelia. Tiene una extensión territorial de 59,864 km2, ocupando el 16 lugar a nivel nacional (SRE, s. f.). La entidad cuenta con 213 kilómetros de litoral y $1,490 \mathrm{~km}^{2}$ de aguas marítimas (INEGI, 2014).

\section{Figura 4.1. Mapa del Estado de Michoacán de Ocampo}

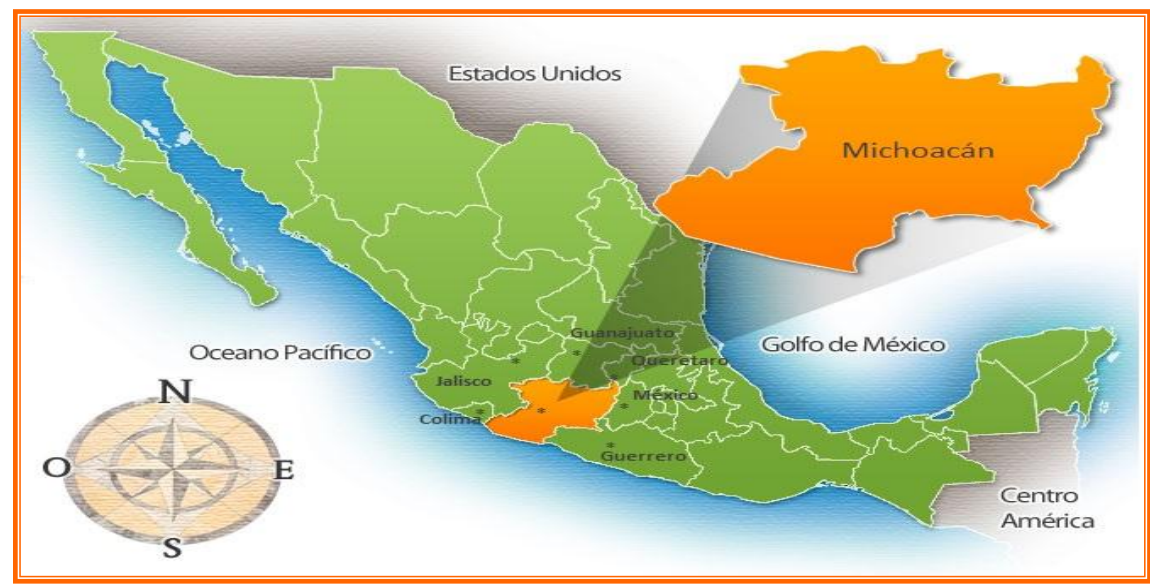

Fuente: http://www.travelbymexico.com/estados/michoacan,

Nota: se agregaron los nombres de los Estados colindantes.

Cabe decir que uno de los aspectos más destacables de Michoacán es la diversidad natural contenida en su territorio, estando su orografía compuesta por mesetas y valles. La Sierra Madre Occidental forma parte de su territorio, lo que sitúa a Michoacán como uno de los estados con mayores recursos forestales. Está ubicado entre el eje Volcánico Transversal y la Sierra Madre del Sur (Mercado Vargas \& Palmerín Cerna, 2012).

A nivel Nacional el Estado de Michoacán es el que cuenta con mayor cantidad de aguas interiores. Los principales lagos son el de Pátzcuaro, el de Zirahuén y el de Cuitzeo, así como parte del lago de Chapala. El río más importante es el Lerma, que nace en el Estado de México y abastece la presa de Tepuxtec. Otros ríos en el estado son el Balsas y el Cupatitzio. En 
el río Balsas están construidas las presas Hidroeléctricas, el Infiernillo, que es la tercera hidroeléctrica más importante del país, y la presa José Ma. Morelos (Mercado V. \& Palmerín C., 2012).

En cuanto a la climatología, el estado cuenta con una gran variedad de climas: frio en su región oriente, templado en el centro, y caluroso en tierra caliente y la costa, lo cual es debido a que se encuentran diversas altitudes que van desde el nivel del mar en la costa, hasta los 3 mil 840 metros en el pico de Tancítaro.

Estadísticamente, Michoacán tiene una precipitación media anual de 806 mm, y su temperatura promedio es de $22,2^{\circ} \mathrm{C}$, con extremos mínimos anuales de $14,7^{\circ} \mathrm{C}$ y de $29,6^{\circ} \mathrm{C}$. De manera general sus climas son cálido sub-húmedo en el sureste y suroeste, templado-sub-húmedo en la región noreste, semi cálido con lluvias en verano en el noroeste, semi seco en la región centro sur. ${ }^{107}$

\section{Datos demográficos de la población}

La población total del Estado en 2010 fue de 4,351,037 personas, lo cual representó el 3,87\% de la población a nivel nacional. ${ }^{108}$ En el año 2015 podemos observar un ligero incremento pues la población llega a $4,584,471$. De este total, las mujeres representan más del $51 \%$, y los hombres el 48,2\%. ${ }^{109} \mathrm{Si}$ comparamos el porcentaje de hombres y de mujeres del año 2010 al 2015, vemos que no se muestran diferencias (ver gráfica 4.1.).

Si analizamos la pirámide de población, lo primero que se puede observar es que existe poca diferencia entre la simetría de las barras

\footnotetext{
${ }^{107}$ La información sobre el clima se extrajo de la página web del Gobierno del Estado de Michoacán, 2013.

${ }^{108}$ Según los datos del Censo General de Población y Vivienda, 2010. El censo se realiza cada diez años (INEGI, 2012c).

${ }^{109}$ Los datos que aquí presentamos se derivan del INEGI. Encuesta Intercensal 2015, (INMUJERES, SEGOB, \& SIG, 2017).
} 
correspondiente a hombres y a mujeres. No obstante, conforme van aumentando los años se muestra un mayor porcentaje de mujeres que de hombres. La relación es que de cada 100 mujeres hay 93,47 hombres (INEGI, 2011). Cabe destacar que existe un mayor predominio de mujeres entre los rangos de edad de 15-30 años. ${ }^{110}$

Otro aspecto que se muestra en la gráfica 4.1. es que la mayor parte de la población michoacana se concentra en grupos de edad infantil y adulta, estando la media de edad en 25 años (INEGI, 2011). También
Gráfica 4.1. Pirámide de la población michoacana, 2010

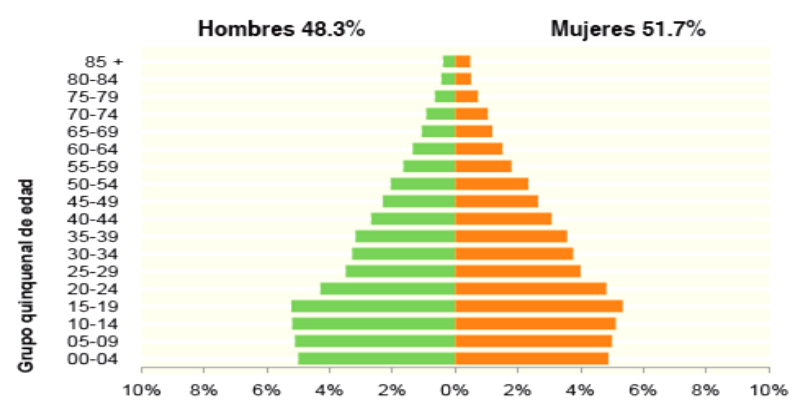

Fuente: INEGI, 2011.

podemos observar que en los grupos de edad adulta y adultos mayores la gráfica se va estrechando, lo que indica que en Michoacán de Ocampo existe una población mayoritariamente joven, o bien económicamente activa.

En la siguiente tabla se pueden observar datos sobre la población del estado en su relación con el resto de la población nacional.

\footnotetext{
${ }^{110}$ Esto puede ser debido a que en el Estado la tasa de emigración en 2009 a Estados Unidos de América fue del 39,6\% (INEGI, s. f.). No fue posible encontrar datos desagregados por sexo en este año, sin embargo en la Coordinación de planeación y desarrollo del SEIM se encontraron datos desagregados por sexo del año 2010, donde se muestra que más del más $77 \%$ de los que emigraron a Estados Unidos de América fueron hombres, al tiempo que las mujeres no alcanzan el $23 \%$.
} 
Tabla 4.1. Datos sociodemográficos de la población michoacana y la nacional, 2010

\begin{tabular}{lrr}
\hline Indicador & Michoacán & Nacional \\
Hogares, 2010 & 1066630 & 28159373 \\
\hline Porcentaje de hogares con jefatura femenina & 24,01 & 24,56 \\
\hline Tamaño promedio de los hogares, 2010 & 4,02 & 3,93 \\
\hline Tasa de fecundidad de las adolescentes de 15 a 19 años, 2010 & 54,48 & 56,86 \\
\hline Porcentaje de nacimientos registrados de madres adolecentes* & 18,90 & 18,80 \\
\hline Grado promedio de escolaridad de la población de 15 y más años, 2010 & 7,42 & 8,63 \\
\hline Porcentaje de analfabetas, 2010 & 10,18 & 6,88 \\
\hline \hline
\end{tabular}

Fuente: elaboración propia con información de México en Cifras INEGI, s. f. y con estadísticas de natalidad en INEGI, 2012

* Madres adolescentes menores de 20 años, 2010.

En el año 2010 había en el estado 1,066,630 hogares (3,8\% del total de hogares a nivel nacional), de los cuales el $24 \%$ estaban encabezados por jefas de familia, lo cual representa el $0,91 \%$ a nivel nacional.

Algunos datos sociodemográficos de la población michoacana muestran que el tamaño promedio de los hogares en el estado (2010) fue de 4.0 integrantes, y que la tasa de fecundidad en las adolescentes (TFA) de 15 a 19 años es del 54,48\%, para el año 2016 hubo un incremento de más de 5 puntos porcentuales. ${ }^{111}$

En 2010 el grado promedio de escolaridad de la población de 15 o más años en el Estado era de 7,4\%, — esto significa que se encuentran cursando primer año de secundaria - frente al grado promedio de escolaridad del 8,6\% a nivel nacional (gráfica 4.2.). Ese mismo año, más de un $10 \%$ de la población michoacana no sabían ni leer ni escribir, mientras que a nivel nacional el porcentaje era de 6,8\% (Gobierno del Estado de Michoacán \& INEGI, 2012). Para el año 2015 aumenta el promedio de escolaridad en el Estado a 7,9\%, las cifras no varían con relación al sexo (INMUJERES, SEGOB, \& SIG, 2017)

\footnotetext{
${ }^{111}$ La TFA se refiere al número de hijos nacidos vivos por cada 1000 mujeres que tienen entre 15 y 19 años de edad. Los datos del año 2016 son retomados de la información generada por INMUJERES et al., 2017.
} 
Gráfica 4.2. Grado promedio de escolaridad de la población de 15 años y más

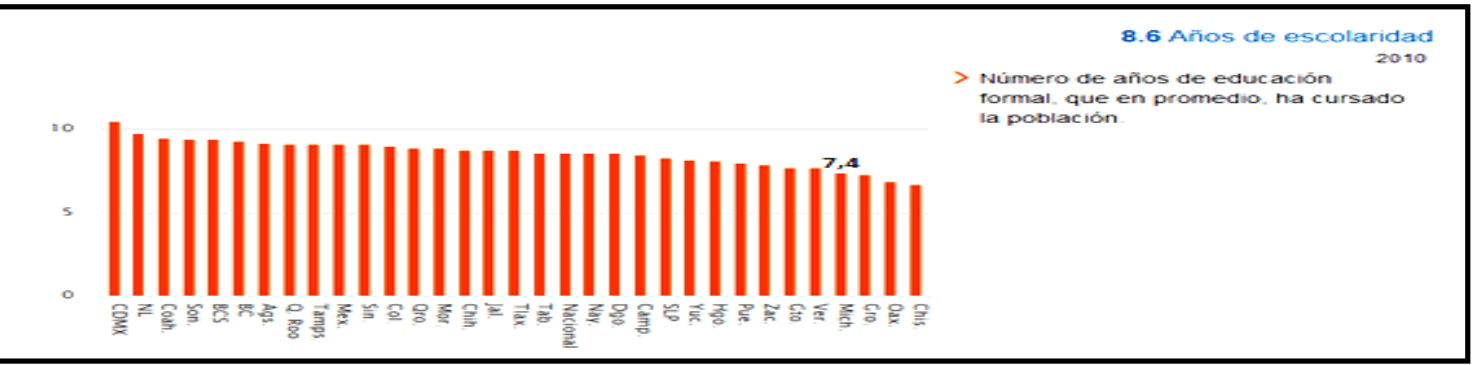

Fuente: México en Cifras INEGI, s. f. Censos y Conteos de Población y Vivienda.

\section{Características económicas de la región}

El Producto Interno Bruto (PIB) de Michoacán en 2012 representó el $2,27 \%$ con respecto al total nacional (INEGI, s. f.).

En el segundo trimestre de 2012 la Población Económicamente Activa (PEA) representó el 58,89\% de la población en edad de trabajar (14 años y más). Del total de la PEA el 96,86\% está ocupada y el 3,14\% desocupada. Analizando los datos desagregados por sexo, observamos que el porcentaje de PEA en hombre asciende al 64,32\%, mientras que la PEA en mujeres baja al 35,67\% (Gobierno del Estado de Michoacán \& INEGI, 2012).

Por grupo de actividad económica, en el segundo trimestre de 2012 los datos muestran que las principales actividades económicas están ubicadas en el sector terciario, con un porcentaje de 57,62\%. El 21,22\% de la población ocupada realiza actividades en el sector primario, mientras que las actividades económicas que corresponde al sector secundario representan el $20,95 \%$.

Si observamos los porcentajes de población ocupada en los distintos sectores desagregados por sexo, se puede observar que en el sector primario y secundario existe una marcada diferencia porcentual de los hombres con respecto a las mujeres que están ocupadas. En el sector terciario, aun cuando los hombres siguen obteniendo un mayor porcentaje, 
la diferencia entre hombres y mujeres ocupados en este sector no llega al $3 \%$ (Observar tabla).

Tabla 4.2. Población en edad de trabajar por sexo según condición de actividad económica, segundo trimestre 2012

\begin{tabular}{llc} 
Indicadores & Mujeres & Hombres \\
\hline Porcentaje de población ocupada en el sector primario & 2,97 & 18,25 \\
\hline Porcentaje de población ocupada en el sector secundario & 5,20 & 15,77 \\
\hline Porcentaje de población ocupada en el sector terciario & 27,48 & 30,144 \\
\hline \hline
\end{tabular}

Fuente: elaboración propia con datos de Gobierno del Estado de Michoacán \& INEGI, 2012.

La economía de Michoacán en el segundo trimestre de 2012 tuvo como pilar fundamental el comercio, con un 19,53\%, la agricultura, la ganadería, la silvicultura, la caza y la pesca obtuvieron el $21,22 \%$, la industria manufacturera el 11,99\% y los servicios sociales el 8,57 (Gobierno del Estado de Michoacán \& INEGI, 2012). En el rubro de la infraestructura productiva, el Estado cuenta con cinco parques industriales y/o tecnológicos (SE, s. f.). Cabe mencionar que Michoacán lidera a nivel Nacional la producción de vegetales como el aguacate, el limón, la guayaba, la fresa o la zarzamora. Además sus valles son propicios para la ganadería, tal y como confirman las estadísticas del Gobierno Federal.

\section{Rasgos de la situación política y social de la región}

Michoacán de Ocampo es un Estado caracterizado por un tejido social en el que han existido y continúan existiendo dos tendencias muy contrapuestas: por un lado, históricamente ha sido cuna de corrientes político-ideológicas reivindicativas - puede verse la participación activa de personajes representativos de la región en movimientos sociales de calado 
nacional- ${ }^{112} \mathrm{y}$, por otro, ha sido escenario de movimientos con tendencias conservadoras y religiosas (movimiento cristero), lo que obedece al hecho de que la mayor parte de la población es católica (Nava Hernández, 1987; Pérez Prado, 1995).

Otro aspecto que caracteriza a este Estado mexicano es la diversidad de culturas que lo conforman, - el caso del Bajío, la Meseta Tarasca, la Costa y Tierra Caliente- con presencia de grupos étnicos con costumbres e incluso lenguas diferentes (purhépecha, náhuatl, otomí-mazahuas).

Todos estos componentes asociados a una política económica neoliberal y a las estrategias de crecimiento/desarrollo por las que se ha apostado, tanto en el País como en Michoacán, están siendo determinantes en los conflictos y problemáticas que se vienen arrastrando desde hace ya varias décadas, y que se han recrudecido en la actualidad, con un nivel de violencia tal que ha puesto en tela de juicio la actuación de las instituciones públicas y del gobierno, fracturando así cada vez más nuestra democracia (Guerrero Gutiérrez, 2010, 2014; Maldonado A., 2012; Nava H., 1987; Pereyra, 2012; Pérez P., 1995).

Las desigualdades sociales que aquejan a esta población están relacionadas principalmente con problemáticas asociadas a la transnacionalización del narcotráfico, la militarización de la seguridad interna y las migraciones de la población tanto a nivel nacional como extranjero (Oikión Solano, 2012, p. 331). ${ }^{113}$ Estas problemáticas no se han originado de manera aislada, sino todo lo contrario. Como se demuestra a continuación, las desigualdades existentes han sido consecuencia de dos

\footnotetext{
${ }^{112}$ Por mencionar algunos, José María Morelos y Pavón y Josefa Ortiz de Domínguez en la Independencia de México, Melchor Ocampo participó en las Leyes de Reforma y Lázaro Cárdenas del Río fue Presidente de la República y elaboró la reforma agraria y del petróleo.

113 Nosotros agregaríamos algunas condicionantes más, a parte de las que contempla Oikión S., (2012): el abandono del campo, así como la discriminación y la pobreza también han ocasionado esta fracturación social.
} 
aspectos fundamentales: a) las estrategias político-económicas que se han seguido y la identidad propia de la región — con un fuerte arraigo a la tierra-; y b) las respuestas del gobierno ante los desafíos que vive el Estado.

\section{a). Estrategias político-económicas}

Salvador Maldonado explica cómo el sur de Michoacán se ha considerado históricamente una "zona periférica, indomable e indolente", debido en gran medida a su posición geográfica. Así, las dificultades de acceso y el relativo aislamiento son una constante para muchos de los pueblos - por la serranía — lo que aunado a la fertilidad de las tierras — en la planicie - y a la abundancia de agua, han convertido a Michaocán en una región atractiva para los narcotraficantes (2012, p. 11).

Durante la administración de Lázaro de Cárdenas (1934-1940) y posteriormente, cuando fungió como vocal ejecutivo de dos comisiones para el desarrollo (1947-1970), se apostó por una política y una economía más igualitaria (Malkin, 2001; Pérez P. 1995). Montes de Oca afirmas que: "Cárdenas se anunció a sí mismo como un presidente liberal y demócrata, que iba a encabezar un gobierno a favor de los más necesitados, incluidas las mujeres" (2015, p. 151).

Con relación a la política igualitaria, ${ }^{114}$ Montes de Oca nos explica que en este periodo se propuso mejorar las condiciones de la población mediante el establecimiento de políticas más justas y equitativas socialmente. Una de ellas fue mejorar las relaciones sociales entre hombres y mujeres, de tal manera que las condiciones de subordinación de las mujeres fueran menos duras y difíciles, sin establecer el cambio de manera estructural. Muestra de ello es que el voto universal de las mujeres se

\footnotetext{
${ }^{114}$ Estás políticas se llevaron a cabo a nivel nacional, ahora bien no fue posible encontrar información exclusivamente referente al Estado de Michoacán.
} 
aprobó en 1937 desde el Ejecutivo federal y se reformó el artículo 24 de la constitución para reconocer y registrar este derecho. No obstante, dicha reforma quedó en suspenso, puesto que no se publicó en el Diario Oficial ${ }^{15}$ (Gutiérrez C., 2002; Montes de Oca N., 2015). Cabe destacar que durante el mandato de Lázaro de Cárdenas se otorgan derechos a las mujeres que no eran reconocidos hasta ese momento, como la libre reunión, los espacios de participación política y laboral, la educación mixta, etc... Nos detendremos un poco en especificar los cambios que se pretendían instaurar en la educación pública. De acuerdo con Montes de Oca, está "nueva" educación era vista como un servicio social que tenía el objetivo de preparar a las nuevas generaciones en la lucha para conseguir una sociedad más libre e igualitaria:

La educación impartida por el Estado sería la misma tanto en el medio urbano como en el rural, orientada una hacia las actividades productivas desarrolladas en las ciudades y otra hacia las actividades del campo. También sería igual para niños que para niñas, para hombres que para mujeres; por eso todas las escuelas serían mixtas (Montes de Oca N., 2015, p. 156).

En cuanto a la estrategia económica, se estableció un programa de desarrollo regional. En este periodo se abrieron cientos de kilómetros de carreteras, se repartieron miles de hectáreas a campesinos (con la reforma agraria), se otorgaron créditos para el campo, y se regularon los precios de los productos agrícolas. Se llevaron a cabo proyectos hidráulicos, minerometalúrgicos e hidroeléctricos, con la finalidad de "integrar" la región en la economía y política nacionales (Maldonado A., 2012, p. 12; Malkin, 2001, pp. 549-553; Pérez P., 1995, p. 203). En su conjunto, estas obras abrieron las puertas a una economía basada en el comercio agrícola y el minero, y

115 "La Alianza Nacional Femenina y el Grupo Leona Vicario realizaron protestas solicitando que se aprobara la iniciativa de Cárdenas y tras varios años de lucha consiguen que en 1946 la Cámara de Diputados apruebe la adición al artículo 158 que concede el derecho a votar a las mujeres, se vota sólo para las presidencias municipales. Todavía pasaron siete años más (1953) para que estas modificaciones fueran publicadas en el Diario Oficial de la Federación y el derecho fuera ejercido" (Cimac, 2003 citada por Gutiérrez C., 2002, p. 45). 
relacionadas con el mercado de Estados Unidos de América. No obstante, las reformas apenas trajeron consigo beneficios a la población, dado que grandes empresarios, caciques y narcotraficantes acabaron apropiándose de tierras comunales para invertir en proyectos turísticos, fomentar el tráfico de drogas o implantar explotaciones mineras. Además, utilizaron tanto las infraestructuras (terrestre, aérea y marítima) como las redes del comercio para ampliar el negocio de la producción y tráfico de droga (Maldonado A., 2012, p. 13).

Las políticas de crecimiento social y económico por las que se apostó en ese periodo fueron aplazadas en los años venideros. Las mujeres, como menciona Arizpe (2002), que durante el primer periodo del régimen revolucionario habían tenido una participación activa en la vida pública, ${ }^{116}$ después fueron nuevamente relegadas a la vida privada. El proceso en el que las mujeres fueron/fuimos adquiriendo derechos, libertades $\mathrm{y}$ reconocimiento fue y sigue siendo lento. Los conflictos sociales y económicos que se explican a continuación han servido de excusa para postergar los temas de igualdad de las mujeres. Aun así, los años setenta fueron un caldo de cultivo para el movimiento feminista (Girón, González M., \& Jiménez, 2008).

Durante los años setenta y ochenta, la crisis económica hace que se abandonen las políticas productivas y de apoyo al campo y se sustituyan por políticas económicas neoliberales. A finales de los ochenta, México se enfrenta también a un cambio de descentralización política, lo que trajo consigo varias consecuencias. Por un lado, expandió el mercado de drogas - al encontrarse con un sistema político más abierto y con menores limitaciones del gobierno federal hacia los estados y los municipios-; por

\footnotetext{
${ }^{116}$ Una participación que, a través de la historia, ha quedado invisibilizada y olvidada. Sobre esto (Girón, González Marín, \& Jiménez, 2008b, p. 33) menciona que las mujeres que han participado en los distintos movimientos sociales que han tenido lugar en México son "las invisibles", "porque han transitado la historia sin haber sido percibidas" (2008, p. 33).
} 
otro lado, se colapsó la economía de las familias, ${ }^{117}$ donde los recursos obtenidos difícilmente les permitían pasar el día a día, por lo que el dinero "ilícito"118 compensaba la falta de intervención de las instituciones públicas en las situaciones de precariedad que dejaron a su paso estás medidas (Maldonado A., 2012; Pereyra, 2012).

Maldonado (2012) y Pereya (2012) explican cómo, ante la falta de oportunidades para mejorar, las condiciones de vida muchas personas se ven en la necesidad de emigrar, principalmente hacia Estados Unidos. Sin embargo, con la entrada en vigor de la ley Simpson-Rodino se restringe el flujo de migrantes indocumentados, la cual provoca que muchas de las personas que anteriormente emigraban para mejorar sus condiciones de vida de manera legal, se enfrascaran en proyectos ilegales, de los que obtenían grandes ganancias. Estos flujos migratorios se van asentando con el cultivo de droga, gracias a las redes familiares y de paisanaje. Tales situaciones provocaron que las personas consideraran factible realizar actividades ilegales, pues les otorgaban prestigio social y les permitía ascender en la escala social de manera rápida y fácil.

Otro condicionante que contribuyó al fortalecimiento del narcotráfico en México, y en Michoacán en particular, fue el golpe que sufrieron en la década de los años noventa los cárteles de Medellín y de Cali con la implementación de políticas antidroga en Colombia, Bolivia y Perú, aunado al cierre de la ruta del Caribe, la liberación financiera y la aprobación del Tratado de Libre Comercio de América del Norte (TLCAN). Estos sucesos abrieron una ventana de oportunidad a los cárteles mexicanos,

${ }^{117}$ Con el recorte presupuestal de los apoyos al campo, hubo una caída de precios de productos agrícolas a nivel internacional. De este modo, empresas y comercios se fueron a la ruina y la rentabilidad de las tierras para producción agrícola quedaron muy dañadas por la utilización inadecuada de plaguicidas y fertilizantes.

${ }^{118}$ La situación de desprotección económica y la falta de opciones laborales, lleva a la población rural a incursionar en algunos actos delictivos, como el de plantar droga en las tierras que habían quedado abandonadas ante los recortes al campo (Oikión Solano, 2012). 
convirtiéndose México en el territorio más importante para el tránsito de drogas a Estados Unidos (Chabat, 2010; Guerrero G., 2010; Maldonado A., 2012; Malkin, 2001; Moloeznik, 2008; Pereyra, 2012; Pérez P., 1995).

Debido tanto a los flujos migratorios, como al negocio ilícito de las drogas, y a la llegada de la "modernidad", como bien menciona Pérez P., "la identidad de hombres y mujeres en el estado se fue reconstruyendo" (p. 201). Se estableció un sistema de símbolos, valores, creencias, normas, definiciones, usos y costumbres íntimamente ligado al mundo del narco. Un narcotráfico con raíces profundamente rurales. Se desarrollaron entre la población complejas redes económicas, políticas y familiares, donde cada vez era más borrosa la franja que diferenciaba a políticos de narcotraficantes. Maldonado (2012) describe la existencia de una narco cultura que se caracteriza por una modernidad de lujos y bienes efímeros observados por los grandes capos en sus viajes fuera del país.

Jiménez Valdez (2014), también hace referencia a esa vida de derroche que llevan los narcotraficantes. Sin embargo, explica que los motivos y la manera en que incursionan en el crimen organizado hombres y mujeres es diferente. Explica la existencia de motivación en la inserción a los cárteles según la clase social. Así, para los hombres de clase obrera los elementos que determinan su inserción son la pobreza, el olvido de las instituciones, el desempleo, la exclusión del sistema escolar, el pertenecer a pandillas y la reclusión en penales por infracciones menores. En cuanto a los hombres de clase media y alta, manifiesta que lo que buscan es adrenalina, dinero, poder y pertenencia a un grupo poderoso. Por su parte, los elementos que determinan que las mujeres incursionen en el narcotráfico son los relacionados con los vínculos de dependencia emocional que establecen con sus parejas (principalmente), la pobreza, la baja escolaridad, o el desempleo (p. 112). 
En su conjunto, esta diversidad de factores muestra cómo en el narcotráfico se siguen patrones de comportamiento anclados a una concepción de desigualdad que, como explica Robles Ortega (2014, p.4), supone para las mujeres un "trato bajo, menoscabado y de subordinación, un trato no igual". Así pues, la construcción social de los capos se relaciona con actitudes "masculinas" como valentía, control, fortaleza, poder, superioridad. En cambio, la construcción social de las mujeres en el narco es la de persona subordinada, mero artículos decorativos para exhibirse, y para las más jóvenes compañía, diversión y sexo (Turati, 2011). Para las mujeres el pertenecer al narco es conseguir lujos, viajes, coches y artículos que les proporcionan una vida de derroche. También buscan sentirse poderosas y protegidas por sus parejas. Es verdad que hay mujeres que han conseguido ser representativas en el crimen organizado, pero son pocas: la mayoría de ellas cumple funciones de traslado de mercancía, narcomenudeo e ingreso de drogas en los penales (Jiménez Valdez, 2014, p. 112).

Es importante destacar que en Michoacán los cárteles han implementado estrategias de violencia e intimidación a la población, con actos tan violentos como las decapitaciones masivas, acompañadas de pancartas que exponen los motivos por los que cometieron tales crímenes. Otro aspecto que caracteriza a estos cárteles es el de realizar "mejoras" en las comunidades de la región, como reparto de dinero a personas de escasos recursos, grandes inversiones en comunidades para el cultivo, la producción y la exportación de productos agrícolas — como el aguacate, la fresa, productos vegetales en los que Michoacán es líder a nivel nacional-, restablecer la "seguridad" de la ciudadanía, etc... Como señala Pereya (2012, p. 440), "se trata de una violencia que asume al mismo tiempo una estructura de soberanía arborescente, con un centro de mando definido y 
fuertes relaciones jerárquicas”. El narcotráfico produce, entendido así, más beneficios en sus comunidades de origen que las mismas instituciones oficiales. Este sistema de actuación ha permitido a los carteles expandir su negocio, estableciendo mecanismos de protección y respaldo que las mismas comunidades les proporcionan.

\section{b). Las respuestas del gobierno ante los desafíos que vive el Estado}

Durante las décadas de los años ochenta y noventa, los jefes de gobierno Miguel de la Madrid y Carlos Salinas de Gortari impusieron leyes de control de la droga más estrictas a las antes implementadas, consistentes sobre todo en introducir a militares en las regiones donde se producía la droga (Chabat, 2010, p. 22; Maldonado A., 2012, p. 22; Pereyra, 2012). Maldonado (2012) explica que esta estrategia de combate al narcotráfico mediante intervención militar, en especial durante el mandato de Carlos Salinas de Gortari, estaba relacionada con un intento por opacar el movimiento opositor neo cardenista, pues Michoacán fue una de las regiones donde hubo mayor movilización y plantones por el fraude electoral (1988-1994). Ahora bien, la implementación de estas estrategias extremistas de combate a las drogas produjeron efectos contrarios a los esperados. Así, frente a leyes más severas y prohibicionistas, los traficantes mejoraron sus capacidades administrativas, expandieron y diversificaron sus actividades delictivas, reorganizaron la producción y optimizaron los métodos de transporte, todo ello financiado por una enorme capacidad económica. ${ }^{119}$

Durante los años ochenta y noventa en Michoacán, el auge del narcotráfico regional dio cabida a la creación de cárteles como fueron "Los Valencia" o "Milenio", pero en este periodo la violencia que se empleaba

\footnotetext{
119 El dinero del narco corrompió, de una forma nunca antes vista, a las autoridades mexicanas.
} 
no se vivía de manera generalizada. Estos cárteles se regían por códigos que eran respetados por el resto de los integrantes (generalmente parte de la familia), y se decía de estas familias que eran personas de respeto, honor y disciplina. Sin embargo, en el año 2000 este cártel ya no era predomínate en la región.

El grado de competencia y conflicto entre los cárteles se intensifica de manera dramática durante la transición política del año 2000, en gran medida por la nueva creación de cárteles - con estrategias militares más sanguinarias y violentas, como "los Zetas"-, la disolución de pactos políticos, la reorganización de las agencias policiales, el auge del pluralismo político y, también, los efectos desestabilizadores de la lucha contra el narcotráfico, como evidencian Astorga y Shirk, citados por Maldonado (2012, p. 28).

Pereya (2012) explica que la utilización de la violencia como factor de presión social y política no es una estrategia nueva. Sin embargo, la situación que se vive en México tras la intervención federal se ha vuelto insostenible: los cárteles aumentaron las matanzas internas y los ataques contra sedes policiales, soldados, funcionarios de seguridad y centros de drogodependientes. Las maneras de ejercer violencia se vuelven cada vez más atroces y con mayor impacto mediático, siendo frecuentes las decapitaciones entre los narcotraficantes rivales, los ajustes de cuentas con las policías corruptas y entre los propios distribuidores.

El año 2006 fue un año de diversos conflictos sociales, entre los que destacan las problemáticas del narcotráfico y la división del país en dos posturas políticas totalmente contrarias: la del PAN y la del PRD. Ganó las elecciones de manera muy ajustada Felipe Calderón (PAN), que, con el descontento de las personas que no optaron por esa opción política reciente, decide - bajo ese escenario y apenas a tres días de haber asumido el 
cargo- - iniciar en su estado natal, Michoacán, su estrategia de combate frontal al crimen organizado, ${ }^{120}$ que consistió en llevar policías federales y militares a las calles para encargarse de las tareas de seguridad. El desplazamiento terrestre y aéreo de militares y policías fue realmente espectacular (Chabat, 2010; Guerrero Gutiérrez, 2010; Maldonado A., 2012; Rábago Vital \& Vergara, 2011). ${ }^{121}$

A partir de este momento, en el Estado de Michaocán los actos delictivos se vuelven más frecuentes. Uno de los que tuvo más impacto mediático fue el ataque que, en la ciudad de Morelia, se vivió el día 15 de septiembre de 2008, en pleno festejo por el aniversario de la Independencia Nacional, cuando se lanzaron dos granadas de fragmentación contra la población civil, causando la muerte de tres personas e hiriendo a un centenar (El País, 2008). Después de esto se inicia un combate directo entre el gobierno federal y el cártel de la "Familia Michoacana", en el cual el gobierno federal acusa al gobierno estatal de tener nexos con este grupo de crimen organizado, mientras que el gobierno estatal acusa al gobierno federal de apoyar al cártel del Golfo (Maldonado, 2012, p. 32).

En 2009 se lleva a cabo la encarcelación de políticos de primera y de segunda línea por nexos con el narcotráfico (el michoacanazo), la mayoría de ellos pertenecientes al Partido de la Revolución Democrática (PRD). Este acto es criticado por el gobierno estatal quien pone una queja por realizar los arrestos sin haber recibido ninguna notificación. Esto dio paso a una serie de descalificaciones políticas. Un año y medio después todos los funcionarios arraigados fueron puestos en libertad por falta de pruebas. Pero los conflictos sociales no disminuyeron sino todo lo contrario.

\footnotetext{
${ }^{120}$ Hizo el combate al narcotráfico el eje de su acción gubernamental. Un tanto motivada por la intención de dar una imagen de control frente a las problemáticas que se vislumbraban.

${ }^{121}$ Las estrategias elegidas por el gobierno, como bien mencionan Illades y Santiago, no han dado resultados efectivos para abatir el narcotráfico, pues el mercado consumidor es superior y de carácter internacional, de tal manera que los recursos que destina el gobierno a este efecto resultan totalmente insuficientes.
} 
Durante el sexenio de Felipe Calderón hubo numerosos enfrentamientos entre "La Familia Michoacana" y otros cárteles como "Los Zetas", y los cuerpos policiales y los militares, que dejaron una siniestra cantidad de crímenes realizados tanto por las fuerzas del estado como por el crimen organizado.

Durante los enfrentamientos "La Familia Michoacana" desplegó un combate estratégico-militar, de días de mucha violencia entre estos y las fuerzas armadas, con graves repercusiones en la ciudadanía. Un ejemplo de ello se observó en diciembre de 2010, cuando este cártel realizó "narcobloqueos" en varias poblaciones del Estado incluyendo la capital (Morelia). En estos días de "guerra" se incendiaron gasolineras y camiones, colocados en cada una de las salidas de esta ciudad, obstruyendo la entrada y salida por vía terrestre.

Lo que llama la atención de este grupo de narcos es que reivindica cierta identidad regional que pareciera estar amenazada por fuerzas externas, utiliza la violencia física con un tono de fanatismo religioso, y su forma de organización se asemeja a células paramilitares o guerrilleras con ideas de justicia social. En continuas ocasiones sacaban comunicados reiterando que no mataban a personas inocentes, sino solo a aquellas que estaban involucradas en actos delictivos e ilegales. Pereya (2012, p. 440) menciona que "La Familia Michoacana" nace como un grupo de vigilancia para atacar los crímenes locales, donde sus miembros se relacionan con fuertes sentimientos de lealtad y sus sicarios ejecutan actos públicos de violencia sobre los infractores del denominado "orden", invocando una "justicia divina". Sin embargo, la población civil se ve sometida a actos delictivos de toda clase: secuestros, extorsiones, cuotas a comercios a cambio de permitirles trabajar, cuotas de seguridad a grandes empresarios y tráfico de personas, entre otros. La situación de violencia que se vivió en ese sexenio 
dejó tanto al Gobierno Federal como al Estatal sin un plan claro para mejorar las condiciones de vida de la población. Fernando Gil realiza un análisis sobre violencia y corrupción en México y explica cómo tanto los gobiernos como la ciudadanía han normalizado las problemáticas y conflictos sociales:

Gobernantes, intelectuales y medios de comunicación, tienden a definir la corrupción como un concepto extraordinario, actual, público y económico. Por otra parte, la comparación con el cáncer y la asociación indiscriminada con otros problemas sociales, especialmente la pobreza y la inseguridad, permite extraer de los discursos un mensaje final pesimista que exigiría un cambio social radical. Sin embargo, la ciudadanía parece inclinarse por una concepción opuesta en la que la corrupción es el estado normal de los sistemas individuales y sociales (Gil Villa, 2013, p. 259).

Por lo tanto, consideramos que estas problemáticas no son una tarea única de los representantes políticos. La ciudadanía ha de exigir y proponer estrategias con el objetivo de mejorar la situación de los/as michoacanos/as.

\section{Analizando la desigualdad entre hombres y mujeres en el Estado.}

El trato desigual entre hombres y mujeres en Michoacán es, como en el resto del mundo, un lastre para el desarrollo de las personas en nuestra sociedad. Las estadísticas que describimos a continuación pueden servirnos como ejemplo para destacar algunas diferencias que existen actualmente entre hombres y mujeres en cuanto a sus libertades, derechos, oportunidades...

El Índice de Desarrollo relativo al Género (IDG) ${ }^{122}$ ubica al Estado, en 2006, en el lugar número 29 con relación al conjunto de entidades del país, tan solo por arriba de Guerrero, Oaxaca y Chiapas (INEGI, 2008, p. 29). En la gráfica que se muestra a continuación se puede observar la evolución del

122 Índice de desigualdad de género: "refleja la desventaja que pueden experimentar las mujeres respecto de los hombres en tres dimensiones: salud reproductiva, empoderamiento y mercado laboral"(PNUD, 2014a, p. 18). "El IDG posee un valor cercano a cero cuando el panorama de desarrollo es igualitario, y se aproxima a uno cuando las desventajas de las mujeres frente a los hombres son amplias" (PNUD, 2014, p. 113). 
IDG en Michoacán del 2008 al 2012, tomando como referencia los Estados en los que se presentan las mejores condiciones de igualdad y los que presentan peores condiciones.

Gráfica 4.3. Evolución del IDG y comparación con los mejores y peores resultados

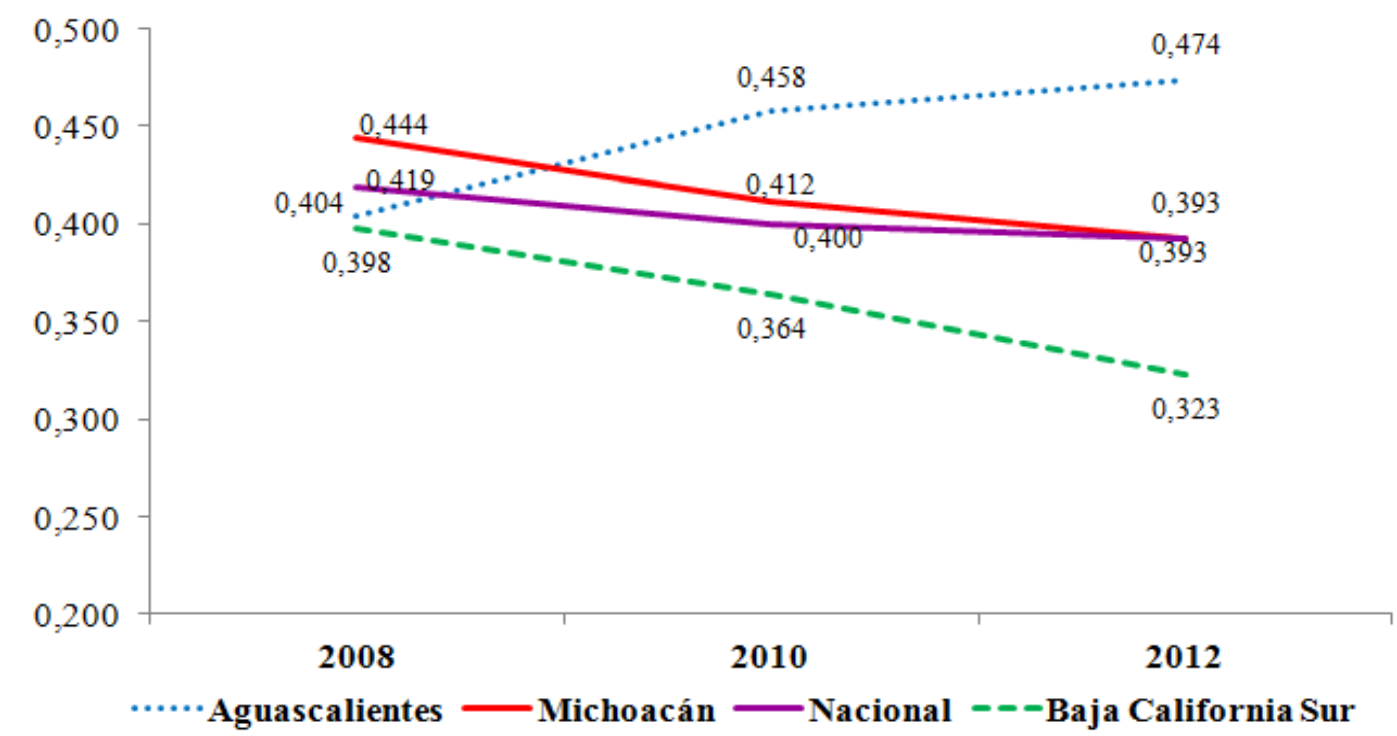

Fuente: elaboración propia con información del PNUD 2014b. ${ }^{123}$

En el 2012 las cifras del IDG mejoran sustancialmente con respecto al 2006, colocando al Estado de Michoacán en el lugar número 17 (PNUD, 2014a, p. 113). Llega así a obtener la misma puntuación que la media nacional, 0,393, como se puede observar en la gráfica 4.4. En está gráfica, además, se destacan las entidades federativas que en el año 2012 presentan mayor desigualdad de género (Aguascalientes), así como las mujeres que tienen menores desventajas sociales por el hecho de ser mujeres como es el caso de Baja california Sur.

\footnotetext{
${ }^{123}$ Es importante destacar que se manipularon los datos (el eje del IDG inicia en el 0,2 en vez del 0), con el objetivo de que se pudieran observar las diferencias entre unos años y otros.
} 
Gráfica 4.4. IDG en las entidades federativas, año 2012

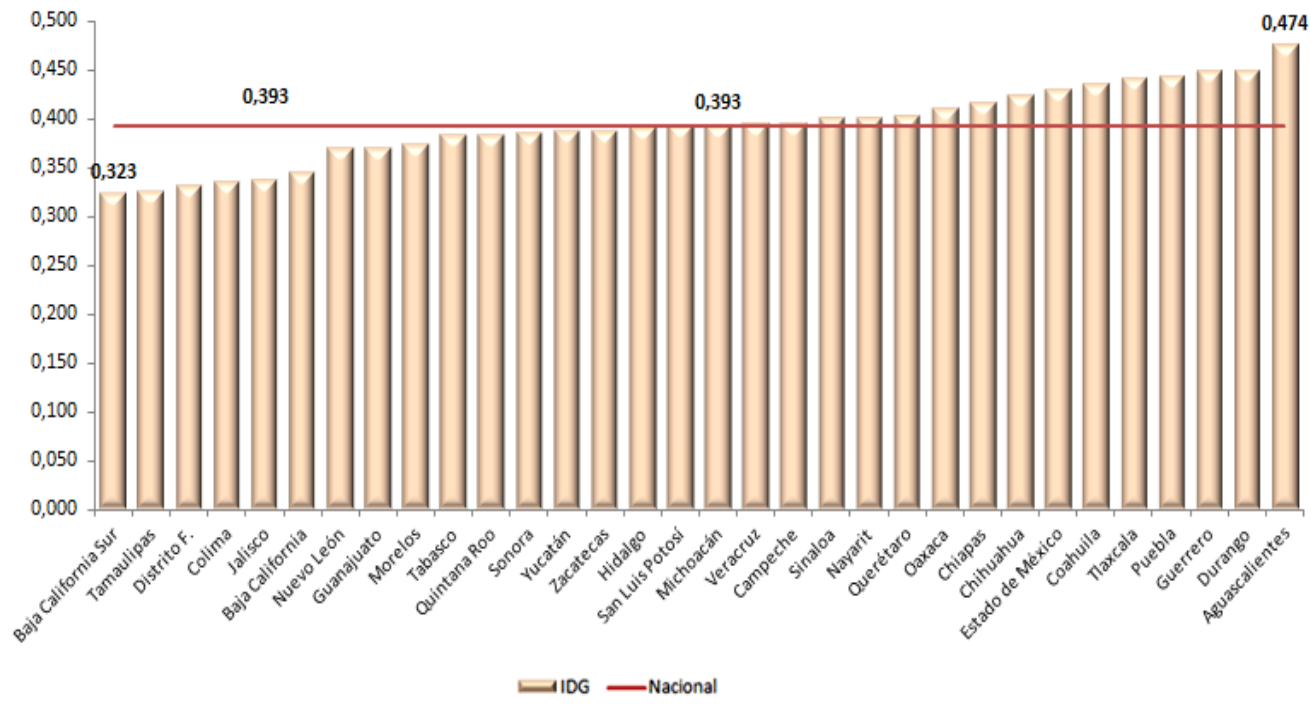

Fuente: elaboración propia con datos de PNUD, $2014 b$.

Estas cifras revelan que, aunque se ha mejorado, las mujeres en Michoacán continúan tenido menores oportunidades que los hombres en los tres rubros que analiza el IDG, a saber: empoderamiento, salud reproductiva y mercado laboral. El PNUD elabora estas tres dimensiones para realizar un diagnóstico general de la situación de las mujeres a nivel internacional. La dimensión de empoderamiento contempla tanto la representación parlamentaria como el logro en educación secundaria y superior. En la dimensión salud reproductiva se tienen en cuenta los indicadores relacionados con la tasa de mortalidad materna y la tasa de fecundidad adolescente. Finalmente, para el rubro de mercado laboral se tienen en cuenta la ${ }_{\text {PEA. }}{ }^{124}$

A continuación presentamos la gráfica 4.5., donde podemos comparar los datos obtenidos en el Estado con los alcanzados a nivel Nacional. Cabe destacar que las dimensiones se manejan de manera contraria al IDG, es decir, el cero representa mayor desigualdad y el uno mejores condiciones. La gráfica nos muestra cómo Michoacán obtiene condiciones de mayor

${ }^{124}$ PEA= Población Económicamente Activa. 
desigualdad que a nivel Nacional en los rubros de empoderamiento y en los de mercado laboral.

Gráfica 4.5. Índice de Desigualdad de Género por dimensión, año 2012

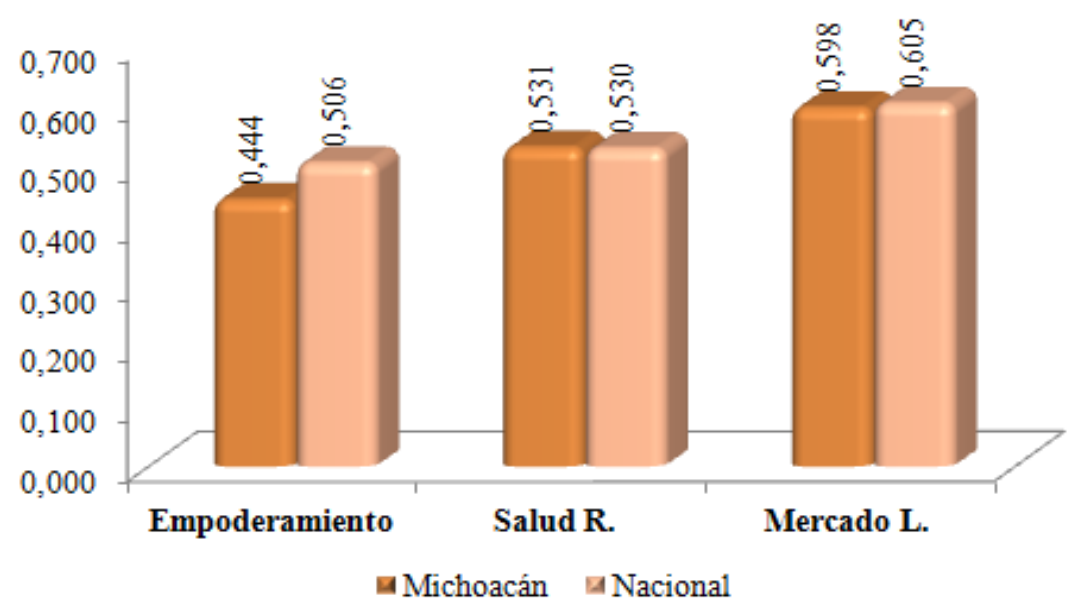

Fuente: elaboración propia con base en datos del PNUD (2014b).

Si analizamos uno a uno los rubros del IDG podemos decir que en la dimensión de empoderamiento ${ }^{125}$ Michoacán ocupa el lugar número 28 (ver gráfica 4.6) con relación al resto de los estados del país. Esto significa que las mujeres tienen mayores dificultades para acceder a escaños parlamentarios y a niveles secundarios y terciarios de educación.

Gráfica 4.6. Dimensión de empoderamiento del IGD, año 2012

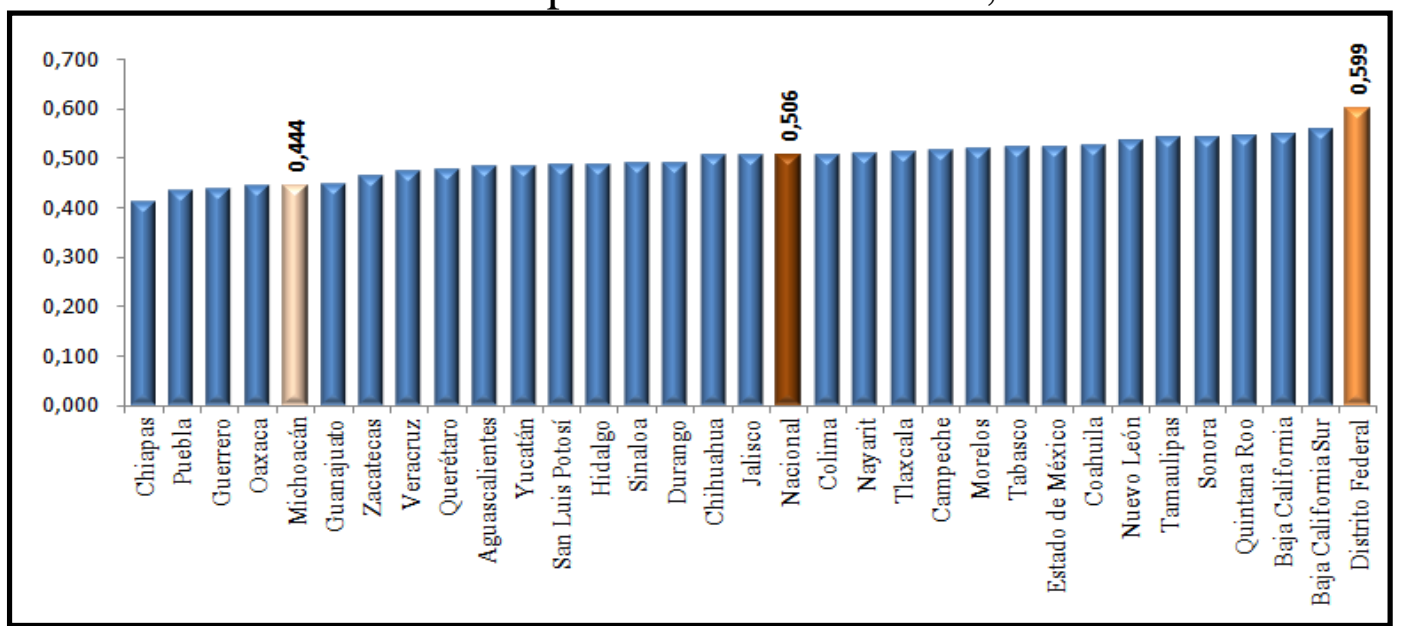

Fuente: elaboración propia con base en datos del PNUD $2014 b$.

${ }^{125}$ En esta dimensión se combina el porcentaje de escaños parlamentarios ocupados por mujeres y el nivel de educación alcanzado por las mujeres. Con el primero se intentan medir las desigualdades en los puestos de toma de decisiones en todos los niveles de gobierno; con el segundo se incluye a la población femenina que al menos concluye la educación secundaria (PNUD, 2014, p. 21). 
Analizando los datos correspondientes a los indicadores educativos y a los indicadores correspondientes a la participación parlamentaria de hombres y de mujeres en el Estado para el año 2012, tenemos los siguientes resultados (tabla 4.3.):

Tabla 4.3. Características educativas de la población michoacana según sexo, año 2012

\begin{tabular}{lrrrr}
\hline \hline \multirow{2}{*}{ Nivel educativo } & \multicolumn{2}{c}{ Hombre } & \multicolumn{2}{c}{ Mujeres } \\
\cline { 5 - 6 } & \multicolumn{1}{c}{ Total } & Porcentaje & \multicolumn{1}{c}{ Total } & Porcentaje \\
\hline Educación básica & 495624 & 50,6 & 483271 & 49,4 \\
Educación media superior & 69687 & 48,0 & 75467 & 52,0 \\
Educación superior & 45612 & 50,0 & 45636 & 50,0 \\
Total & 610923 & 50,3 & 604374 & 49,7 \\
\hline \hline
\end{tabular}

Fuente: elaboración propia con información retomada de SEP, 2012. ${ }^{126}$

Las cifras que presentamos reflejan que en el terreno educativo Michoacán ha logrado revertir las desigualdades por razón de sexo en todos los niveles educativos. Así, en educación básica el porcentaje de hombres es un poco mayor, sin embargo en educación media el porcentaje de mujeres es dos puntos porcentuales más elevado que el de los hombres. En educación superior se iguala nuevamente el porcentaje de alumnado.

Las asimetrías entre hombres y mujeres aumentan en la esfera políticoparlamentaria. La participación de las mujeres en puestos de trabajo que impliquen tomas de decisiones es mínima, tal como se muestra en la tabla 4.4. En los puestos de presidencia municipal las mujeres apenas tienen representación $(7,5 \%) .{ }^{127}$ En cuanto a las regidurías, los hombres continúan siendo mayoría, con más del $65 \%$. La participación de mujeres síndicas es

\footnotetext{
${ }^{126}$ Nota: los datos de educación básica presentados los obtuvimos de la SEP, 2012, p. 39. Las cifras de educación media superior fueron retomadas de SEP, 2012, p. 103 y finalmente los datos de educación superior se calcularon de la información de SEP, 2012, p. 146.

${ }^{127}$ En las cifras que se dan en la web del INEGI están 20 presidentes municipales sin especificar.
} 
prácticamente nula $8,8 \%$, y finalmente podemos observar cómo de un total de 40 diputados y diputadas locales, solo 11 son mujeres.

Tabla 4.4. Participación político-parlamentaria Estatal, año 2012

\begin{tabular}{|c|c|c|c|c|}
\hline \multirow{2}{*}{ Indicador } & \multicolumn{2}{|c|}{ Hombres } & \multicolumn{2}{|c|}{ Mujeres } \\
\hline & Total & Porcentaje & Total & Porcentaje \\
\hline Presidencia & 86 & 92,5 & 7 & 7,5 \\
\hline Regidurías & 572 & 65,7 & 299 & 34,3 \\
\hline Síndicos & 103 & 91,2 & 10 & 8,8 \\
\hline Diputados/as & 29 & 72,5 & 11 & 27,5 \\
\hline
\end{tabular}

Fuente: elaboración propia basada en datos del H. Congreso del Estado de Michoacán de Ocampo, 2012.

Cotejando las cifras obtenidas en la dimensión de empoderamiento, destaca que no existe una coincidencia entre los logros alcanzados en el terreno educativo y la participación de las mujeres en la esfera política. Los cargos políticos, y por tanto las decisiones que afectan a la ciudadanía, siguen estando mayoritariamente sustentados por hombres.

El segundo rubro que vamos a analizar es el de salud reproductiva, indicador que se mide a través de la tasa de mortalidad materna (TMM $^{128} \mathrm{y}$ de la tasa de fecundidad adolescente (TFA $).^{129}$ Cabe destacar que en este rubro se ha mejorado del 2006 al 2012, como confirman algunos informes desarrollados por fuentes oficiales (INEGI, 2008, pp. 2-3; PNUD, 2014a, p. 113). La gráfica que presentamos a continuación refleja la situación del estado de Michoacán a nivel nacional. En ella destacan algunos datos en los que Michoacán supera, si bien por poco, la media obtenida a nivel nacional.

128 "La TMM mide el riesgo obstétrico y la frecuencia con que las mujeres están expuestas a dicho riesgo. Se calcula con el número de muertes maternas por 100 mil mujeres en edad reproductiva, usualmente de 15-49 años, durante un periodo estipulado" (Freyermuth-Enciso, 2014, p. 25).

129 "La tasa específica de fecundidad de mujeres de 15 a 19 años de edad se refiere al número de nacimientos ocurridos en mujeres de entre 15 y 19 años, que tiene lugar en un determinado año, por cada 100 mujeres de 15 a 19 años a mitad de ese año" (Freyermuth-Enciso \& Luna, 2014, p. 26). 
Gráfica 4.7. Dimensión de salud reproductiva del IDG, año 2012

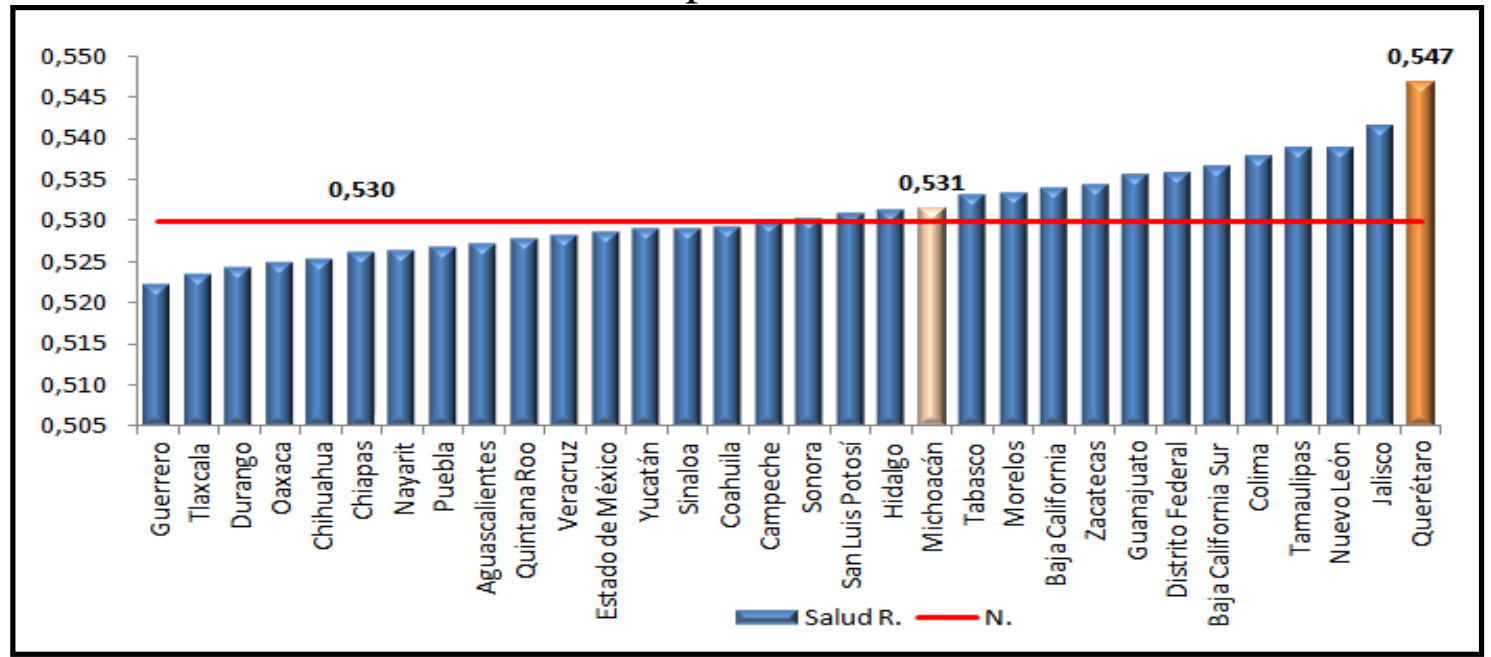

Fuente: elaboración propia con base en datos del PNUD $2014 b$.

El análisis de estos dos indicadores ( porque hace evidente la problemática que se origina de la desigualdad de acceso a los servicios de salud y de la falta de atención/prevención oportuna en situaciones que pueden ser revertidas (Freyermuth-Enciso, 2014; INEGI \& INMUJERES, 2013).

A continuación realizaremos un desglose de los indicadores que se contemplan en salud reproductiva, con la intención de proporcionar una visión estadística general de las dificultades y de las desigualdades que se derivan de la falta de acceso a los servicios de salud pública, así como de la escasa prevención/formación que existe respecto a la educación sexual.

Así pues, antes de comenzar a analizar la muerte materna (мм $),{ }^{130}$ debemos aclarar que analizaremos las dos principales formas de medición de la мM: la razón de muerte materna $\left.{ }_{(\mathrm{RMM}}\right)^{131}$ y la tasa de mortalidad materna (TMм).

${ }^{130}$ Freyermuth-Enciso (2014) citando a la OMS (2003: 139) definida como el número de defunciones de mujeres mientras se encuentren embarazadas o dentro de los 42 días siguientes a la terminación del embarazo y debida a cualquier causa relacionada con, o agravada por, el embarazo mismo o su atención.

${ }^{131}$ La RMM representa el riesgo obstétrico asociado con cada embarazo y se obtiene al dividir el número de defunciones por complicaciones del embarazo, parto o puerperio durante un año por 100 mil nacidos vivos durante el mismo periodo (Freyermuth-Enciso, 2014, p. 24). 
La muerte prematura de las mujeres durante la maternidad a nivel Nacional en el año 2010 fue de 992 y para el 2012 el total de ${ }_{\text {MM }}$ fue de 960. En Michoacán (MI) el número de defunciones totales por maternidad fue de 49 en el 2010, mientras que en el 2012 bajó a 40. Si comparamos la RMM que se obtiene en el ámbito Nacional y en MI para este periodo 2010 y 2012, tenemos que en 2010, en el ámbito Nacional, por cada 100 mil nacidos vivos fallecieron 44,1 mujeres por causas relacionadas con el embarazo, el parto o el puerperio, mientras que en MI, el número asciende 53,9. En año 2012 los resultados continúan siendo más elevados en el Estado de Michoacán RMm, con un 44,1 frente al 42,7 a nivel Nacional. Sin embargo, en este Estado se muestra una mayor reducción de las мм (9,8 puntos) con relación a la evolución que se ha observado a nivel Nacional $(1,4$ puntos $) .{ }^{132}$

Consideramos oportuno retomar la RMM en adolescentes, dadas las características de nuestra investigación. En el ámbito Nacional, en el 2010, el 10 por ciento de las defunciones por maternidad eran mujeres adolescentes, en el año 2012 se incrementan 2,8 puntos porcentuales los

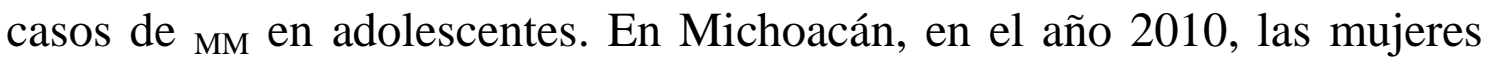
adolescentes fallecidas por causas relacionadas al embarazo, el parto o el posparto representan el 6,1 por ciento, al tiempo que en el año 2012, la MM en mujeres adolescentes se incrementó a un 15 por ciento. Estas cifras dan cuenta de la desigualdad y el incumplimiento del derecho de las mujeres a acceder y a recibir a una atención de calidad y oportuna. Sobre todo destaca el aumento de la мм en adolescentes en el Estado de Michoacán, lo que refleja la falta de políticas públicas destinadas a la población juvenil y, por tanto, la escasez de acciones a favor de mejorar y de dotar de herramientas oportunas para que se transformen estas situaciones. En cuanto a la tasa de

\footnotetext{
${ }^{132}$ Análisis elaborado con base en Freyermuth-Enciso \& Luna, 2011, 2013, 2014.
} 
muerte materna ( año 2010, por cada 100 mil mujeres en edad fértil mueren 3,6 mujeres por causas relacionadas con la maternidad, el parto o puerperio. En MI, esta cifra aumenta hasta el 4,1. En el año 2012, la TMM se reduce tanto a nivel Nacional, al 3, como a nivel Estatal, al 3,2.

Por otro lado, el análisis de la tasa de fecundidad adolescente (TFA $_{\text {, }}$, es un tema que preocupa a las Instituciones Públicas del Estado. Está claro que el desarrollo de mujeres y hombres cuando se es madre o padre en la adolescencia se ve mermado, pues esta condición dificulta las posibilidades que tienen para transitar de mejor manera hacia la vida adulta, al reducirse las opciones de conseguir estudios universitarios y acceder a puestos de trabajo con mejores condiciones laborales (INEGI \& INMUJERES, 2013, pp. 21-22).

Según los datos retomados de la CONAPO la situación no ha mejorado en el estado de Michoacán del 2009 al 2014, pues la tFA Nacional fue del 77 mientras que las cifras del Estado fueron del 83,5 por ciento en 2014, es decir, la cifra aumento más de 6 puntos. Los resultados de este indicador son desalentadores, pues reflejan que tanto a nivel Nacional como Estatal la tendencia de la TFA se ha incrementado en los dos niveles de gobierno, sin olvidar que el Estado obtiene peores resultados. A continuación se muestra una gráfica en la que se observan los datos de la TFA.

Gráfica 4.8. Tasa de fecundidad Adolescente, Nacional y Estatal

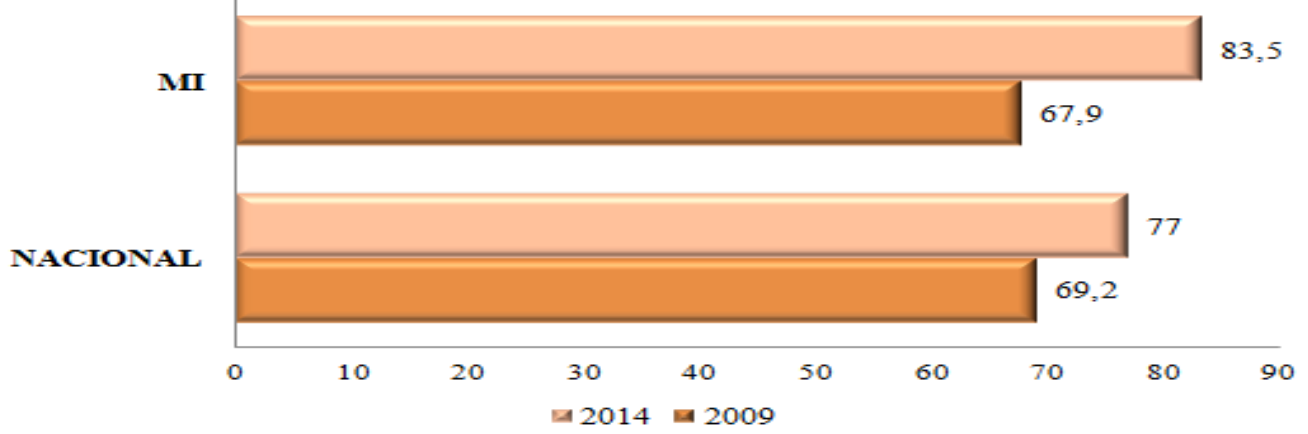

Fuente: elaboración propia con base en estimaciones de CONAPO, 
“Estimaciones de Población, 1990-2010 y Proyecciones de Población, 2010-2050”." ${ }^{133}$

*Hijos por cada 1000 mujeres.

En los datos que manejan Freyermuth-Enciso y Luna (2014, p. 26) se muestra la evolución de la TFA a nivel Nacional y Estatal. La lectura que podemos hacer es que, en el año 2010, en el ámbito Nacional ocurrieron aproximadamente 7 nacimientos por cada 100 mujeres entre 15 y 19 años de edad, mientras que en Michoacán ese mismo año la cifra fue de 6 nacimientos. ${ }^{134}$ En el año 2012 Michoacán tiene condiciones superiores a las del país en salud reproductiva (PNUD, 2014a), lo cual no significa que el trabajo esté concluido; es necesaria la puesta en marcha de políticas públicas que atiendan de manera integral los embarazos adolescentes, la cobertura de métodos anticonceptivos y que se promueva una sexualidad libre y responsable entre la población juvenil. La importancia de combatir los embarazos en esta etapa de la vida radica en que es un momento de suma importancia para desarrollar el capital humano de las personas: "La postergación de la edad al matrimonio, además del inicio de la paternidad o maternidad, permite a nivel individual aumentar la posibilidad de contar con una mayor preparación y maduración, lo que brindará a este grupo de población ventajas en etapas posteriores de su ciclo de vida" (CONAPO, 2013, p. 18).

Los estudios elaborados por Calero y Santana, (2001) y Stern, (2007), muestran que las relaciones sexuales en adolescentes están condicionadas por fuertes estereotipos de género, donde los hombres intentan reafirmar su "hombría" y las mujeres demuestran su "amor". Por ello, los y las adolescentes que participan en los estudios manifiestan que se inician sexualmente sin precaución y sin protección. Concretamente el estudio de

\footnotetext{
${ }^{133}$ Página web donde se puede consultar la información a nivel Nacional y por Estados: http://www.conapo.gob.mx/es/CONAPO/Tasa_Global_de_Fecundidad_y_Tasa_de_Fecundidad _Adolescente_2009_y_2014

${ }^{134}$ Estas autoras no nos proporcionan datos del 2012.
} 
Stern refleja que, independientemente de la clase social a la que pertenezcan, los y las adolescentes emprenden relaciones sexuales sin protección, situación que los/as llevan a transitar por realidades riesgosas que terminan desencadenado una serie de problemas y/o consecuencias que les obligan a tomar decisiones apresuradas y sin meditación, sobre todo para las mujeres de contextos más vulnerables.

El tercer rubro que contempla el IDG es el Mercado laboral. El informe del PNUD (2014) indica que Michoacán en este rubro está por debajo del promedio nacional. Como se puede observar en la gráfica que presentamos a continuación, este estado ocupa el puesto 19 a nivel nacional. Los Estados con mayor igualdad en cuanto a la participación de hombres y mujeres en el ámbito laboral son Quintana Roo, Colima y Yucatán, mientras que las entidades federales en las que las mujeres tienen mayores desventajas laborales respecto a los hombres son Chihuahua, Querétaro y Durando.

Gráfica 4.9. Dimensión de mercado laboral del IDG, año 2012

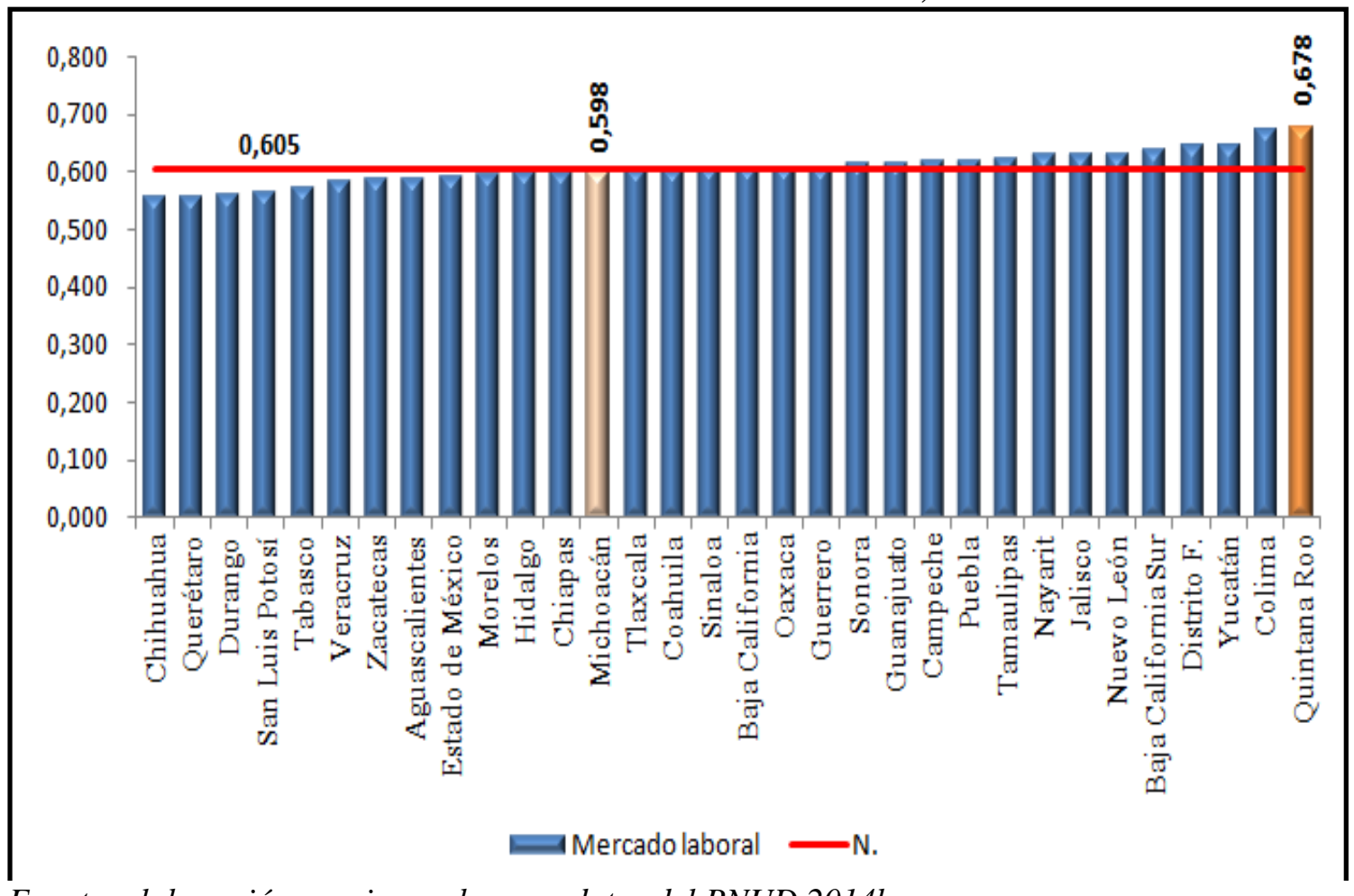

Fuente: elaboración propia con base en datos del PNUD $2014 b$. 
Ahora vamos a efectuar un análisis del panorama que existe a nivel del estado de Michoacán y a nivel nacional sobre la situación de hombres y de mujeres en el mercado laborar. Para ello, vamos a tener en cuenta el indicador que se proponen en el IDG, "la tasa de participación económica (TPE)" y vamos a agregar información sobre el acceso a recursos económicos (nivel de ingresos).

Como se puede ver en la tabla 4.5., en el año 2012 la tasa de participación económica de las mujeres en Michoacán es del 40,4 por ciento, mientras que en el ámbito nacional alcanza una cifra de 42,6 puntos porcentuales. En la tabla también podemos observar que en Michoacán la participación de los hombres en el mercado laboral aumentó 4,7 puntos del año 2010 al 2012, al tiempo que el incremento de la participación de las mujeres ha sido de un escaso 0,7 porciento.

Tabla 4.5. Tasa de participación económica y de desocupación de la población de 15 y más años, años 2010 y 2012

\begin{tabular}{lcccr}
\hline \multirow{2}{*}{ Indicador } & \multicolumn{2}{c}{ Nacional } & & \multicolumn{2}{c}{ Michoacán } \\
\cline { 2 - 3 } \cline { 5 - 5 } & 2010 & 2012 & 2010 & 2012 \\
\hline Tasa de participación económica & 59,2 & 59,7 & 56,0 & 58,9 \\
$\quad$ Hombres & 77,6 & 77,5 & 74,3 & 79,0 \\
Mujeres & 42,6 & 43,5 & 39,7 & 40,4 \\
\hline Tasa de desempleo & 5,3 & 4,8 & 4,0 & 3,1 \\
$\quad$ Hombres & 5,3 & 4,8 & 4,8 & 3,2 \\
Mujeres & 5,2 & 4,9 & 2,7 & 3,0 \\
\hline
\end{tabular}

Fuente elaboración propia con base en INEGI, 2012b, 2013, 2014.

Por otro lado, la tasa de desocupación es del 3\% para las mujeres y del $3,2 \%$ para los hombres. La incorporación de la mujer en el campo laboral — resultado de distintos procesos económicos y sociales (las reivindicaciones sociales, las crisis económicas y los cambios tecnológicos, las transformaciones demográficas: en la salud y la educación, la disminución de la mortalidad y la fecundidad, la esperanza de vida y el nivel educativo de la población, entre otros)—, ha sido un proceso condicionado por las desigualdades existentes entre hombres y mujeres. La 
tabla que presentamos a continuación muestra que, a pesar de que se ha avanzado en cuanto de derechos y oportunidades, las desventajas tanto salariales como de participación económica son peores para ellas (INEGI \& INMUJERES, 2013).

Tabla 4.6. Población ocupada por sexo, según nivel de ingresos, año 2012

\begin{tabular}{|c|c|c|c|c|c|c|c|c|c|c|c|c|}
\hline \multirow[t]{2}{*}{ Ámbito } & \multirow{2}{*}{$\begin{array}{c}\begin{array}{c}\text { Población } \\
\text { ocupada }\end{array} \\
\text { Frecuencia }\end{array}$} & \multirow{2}{*}{$\begin{array}{c}\text { Hasta un salario } \\
\text { mínimo }\end{array}$} & \multicolumn{2}{|c|}{$\begin{array}{l}0 \text { Más de } 1 \text { hasta } 2 \\
\text { salarios mínimos }\end{array}$} & \multicolumn{2}{|c|}{$\begin{array}{l}\text { Más de } 2 \text { hasta } 3 \\
\text { salarios mínimos }\end{array}$} & \multicolumn{2}{|c|}{$\begin{array}{l}\text { Más de } 3 \text { hasta } 5 \\
\text { salarios mínimos }\end{array}$} & \multicolumn{2}{|c|}{$\begin{array}{c}\text { Más de } 5 \text { salarios } \\
\text { mínimos }\end{array}$} & \multicolumn{2}{|c|}{$\begin{array}{l}\text { No recibe } \\
\text { ingreso }\end{array}$} \\
\hline & & & 6 Frecuencia & & riecuencla & & iecuencia & $\%$ & recuencia & & & $\%$ \\
\hline Nacional & 48437762100,0 & $6745626 \quad 13,9$ & 911330968 & 23,4 & 10556010 & 21,8 & 7287852 & 15,0 & 3820727 & 7,9 & 4016660 & 8,3 \\
\hline Hombres & $29913613 \quad 61,8$ & $3181829 \quad 6,6$ & 6348642 & 13,1 & 7304939 & 15,1 & 5141556 & 10,6 & 2658904 & 5,5 & 2260473 & 4,7 \\
\hline Mujeres & $18524149 \quad 38,2$ & $\begin{array}{ll}3563797 & 7,4 \\
\end{array}$ & $4 \quad 4982326$ & 10,3 & 3251071 & 6,7 & 2146296 & 4,4 & 1161823 & 2,4 & 1756187 & 3,6 \\
\hline Michoacán & 1824456100,0 & 292745 & 461741 & 25,3 & 399513 & 21,9 & 327634 & 18,0 & 140001 & 7,7 & 179145 & 9,8 \\
\hline Hombres & $1172593 \quad 64,3$ & $135932 \quad 7,5$ & 279050 & 15,3 & 297020 & 16,3 & 237014 & 13,0 & 108855 & 6,0 & 98537 & 5,4 \\
\hline Mujeres & $651863 \quad 35,7$ & $156813 \quad 8,6$ & 182691 & 10,0 & 102493 & 5,6 & 90620 & 5,0 & 31146 & 1,7 & 80608 & 4,4 \\
\hline
\end{tabular}

Fuente: elaboración propia con base en datos extraídos del INEGI, 2012b, pp. 344-345.

En la tabla 4.6. se evidencian las asimetrías que persisten en nuestra sociedad. En la entidad de Michoacán solo el 1,7\% de las mujeres perciben más de cinco salarios mínimos, frente al 6 por ciento de los hombres. En la tabla también se refleja que existe mayor equidad entre hombres y mujeres en los niveles de salarios más bajos, pero a partir de dos o más salarios mínimos el porcentaje de mujeres va disminuyendo y la brecha entre unos y otras se acrecienta. Estas dos tablas ilustran cómo la incorporación y participación de la mujer en el mercado laboral continúa estando sujetada a situaciones y condiciones que ellas/nosotras no pueden/podemos contralar - condiciones parecidas a las que pasaron durante la guerra y la posguerra, cuando miles de mujeres tuvieron que salir de sus hogares para insertarse al mercado laboral porque los hombres estaban en combate y cuando regresaron las mujeres fueron despojadas de sus trabajos-, analogía que viene dada porque, aunque ya han pasado más de tres décadas de esos hechos, las cifras continúan demostrando que las mujeres no tienen las 
mismas oportunidades de acceso, de recursos y de tiempo que los hombres en el campo laboral.

\subsection{Resumen}

En este capítulo presentamos una serie de informaciones y de datos sobre la situación política y social del Estado de Michoacán, con la finalidad de hacer visibles las principales problemáticas que tiene la ciudadanía y a las que tiene que hacer frente el Gobierno mediante políticas públicas oportunas.

En el primer sub-apartado del capítulo rescatamos algunos de los conceptos claves para la investigación, que aparecen resumidos en la siguiente figura, compendio de las ideas principales de los conceptos analizados:

Figura 4.2. Conceptos claves para la investigación

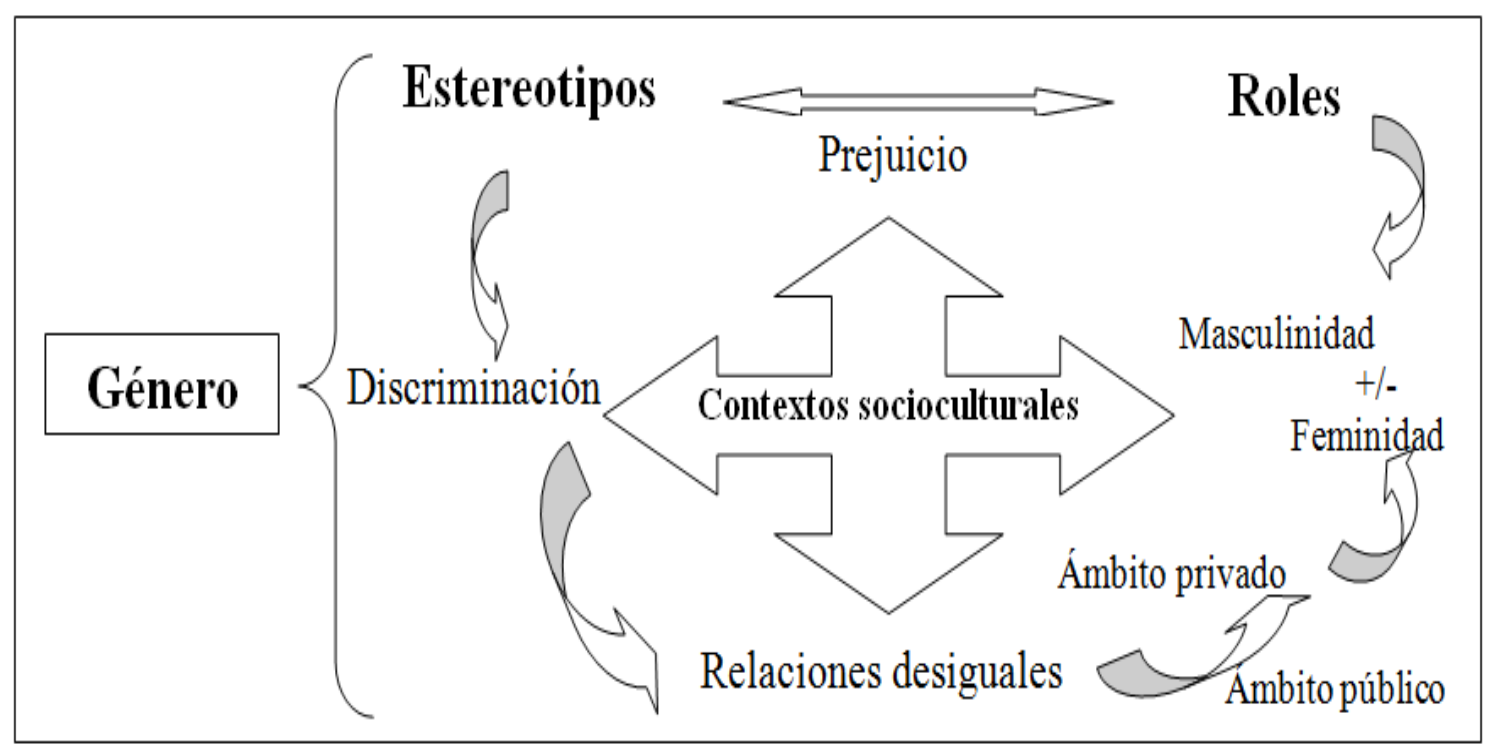

Fuente: elaboración propia.

En cuanto al punto 4.2., se analizaron distintos aspectos de la vida política, social, educativa, económica de la población michoacana desde una perspectiva de género. Con ello pretendemos que el lector tenga una referencia general de lo que acontece con las mujeres y los hombres en el Estado de Michoacán. 
Figura 4.3. Figura de la situación político-social de Michoacán

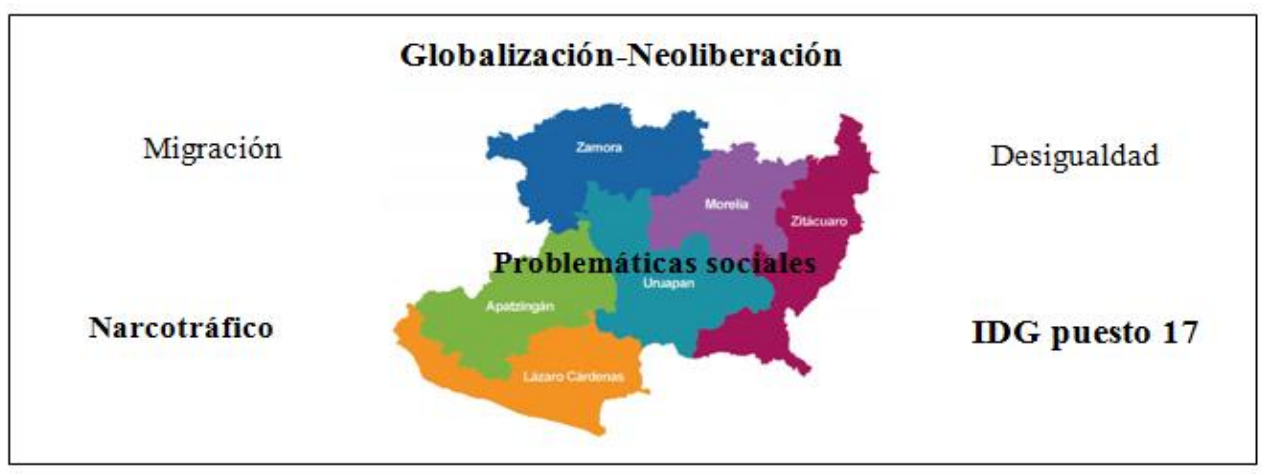

Fuente: elaboración propia, imagen del Estado retomada de la página web del Gobierno del Estado de Michoacán, 2015. 


\section{El problema de la percepción en la mejora de la igualdad a través}

\section{de la educación}

Considerando, por un lado, que la desigualdad de género es un proceso dinámico y complejo en el que intervienen cuestiones sociales, políticas, económicas, culturales... y, por otro, la situación que hemos mostrado en el caso específico de Michoacán, hemos podido constatar que en la actualidad las asimetrías entre hombres y mujeres son menores que hace tres décadas. Sin embargo, la situación analizada a este respecto tanto en México como en Michoacán evidencia que aún falta mucho por hacer para alcanzar el objetivo de conseguir que hombres y mujeres tengan las mismas oportunidades, derechos, libertades...

La brecha de género entre hombres y mujeres en el Estado de Michoacán de Ocampo ha hecho que el Gobierno, en especial la Secretaría de La Mujer y la de Educación Pública, ponga en marcha una serie de estrategias para intentar contrarrestar estas relaciones de subordinación y desigualdad.

Derivada de estas estrategias nace este proyecto de investigación. En un primer momento recabamos información sobre las concepciones fundamentales: feminismo, género y educación, igualdad, justicia social, entre otras; luego proseguimos a investigar la realidad de la entidad en la actualidad; finalmente nos planteamos el cómo abordar las relaciones de género y que está haciendo el gobierno para mejorar la situación y condición de igualdad de la población michoacana en los contextos educativos. De estas reflexiones es que surgieron las dos interrogantes que presentamos en esta investigación. En la primera nos cuestionamos sobre cuáles son las percepciones que tienen las y los adolescentes que permiten que se legitime la desigualdad entre hombres y mujeres. En la segunda nos preguntamos si la educación secundaria en el Estado promueve la igualdad 
de oportunidades, derechos, recursos... entre hombres y mujeres a través de los libros de texto.

Con la finalidad de responder a estos dos fundamentales interrogantes establecemos los siguientes objetivos generales y específicos:

\subsection{Objetivos generales:}

1. Describir y analizar las percepciones que legitiman la desigualdad entre hombres y mujeres con el alumnado de primer grado de secundaria.

2. Analizar si los libros de texto de primer grado de secundaria promueven o no la educación sexual y la igualdad de género.

\subsection{Objetivos específicos:}

1. Describir y explicar si el alumnado del Estado de Michoacán atribuye a varones o a mujeres pautas de comportamiento "propias" de cada sexo.

2. Describir y analizar las diferencias que existen en el contenido del discurso sobre la sexualidad y la equidad de género entre el alumnado que vive en zonas urbanas, rurales e indígenas.

3. Describir las diferencias entre hombres y mujeres respecto a la percepción sobre educación sexual y equidad de género.

4. Describir y examinar la presencia/ausencia de hombres y mujeres en los contenidos, el texto, y las imágenes/ilustraciones de los libros de texto de primer grado de secundaria.

5. Comparar el papel y la relevancia que se da a los hombres y a las mujeres en los libros de texto de primer grado de secundaria.

6. Analizar las conductas, las actividades, y las ocupaciones que desempeñan hombres y mujeres en los manuales escolares. 


\subsection{Hipótesis}

Con el fin de establecer algunas conjeturas o supuestos iniciales a las preguntas de investigación: ¿cuáles son las creencias que tienen las y los adolescentes que permiten que se legitime la desigualdad entre hombres y mujeres?, y ¿la educación secundaria en el Estado está promoviendo la igualdad de oportunidades, derechos, recursos... entre hombres y mujeres a través de los libros de texto?, se establecen las siguientes hipótesis.

Suponemos que las percepciones que el alumnado tiene sobre la sexualidad y la equidad de género estarán influenciadas por dos variables.

- Sexo

- Zona territorial

Por tanto se consideraron las siguientes hipótesis.

- Las y los adolescentes reconocen situaciones que legitiman la desigualdad de género en los distintos ámbitos en los que se desenvuelven.

- La población juvenil de centros educativos que se ubican en zona urbana percibe que existen relaciones más equitativas entre hombres y mujeres que la población de la zona rural e indígena.

- El sexo del alumnado determina la percepción sobre sexualidad y equidad de género.

- Existe mayor representación de hombres que de mujeres en los libros de texto de primer grado de secundaria.

- Los hombres aparecen en los libros de texto en mayor medida que las mujeres representado funciones de prestigio social, cultural, científico... 
- Los personajes que aparecen en los libros de texto no rompen con los estereotipos de género tradicionalmente asignados a hombres y a mujeres.

A continuación presentamos una tabla resumen con los objetivos específicos y las hipótesis derivadas de ellos:

\section{Tabla 5.1. Objetivos específicos e hipótesis}

\begin{tabular}{|c|c|c|}
\hline \multirow{6}{*}{$\begin{array}{l}\overline{0} \\
0 \\
0 \\
0 \\
0 \\
0 \\
0 \\
0 \\
0\end{array}$} & \multirow[t]{2}{*}{ Objetivo 1} & $\begin{array}{l}\text { Describiry explicar si el alumnado del Estado de Michoacán atribuye a varones } \\
\text { o a mujeres pautas de comportamiento "propias" de cada sexo. }\end{array}$ \\
\hline & & $\begin{array}{ll}\text { Hipótesis } 1 \text { El alumnado reconoce situaciones que legitiman la desigualdad } \\
\text { entre hombres y mujeres. }\end{array}$ \\
\hline & \multirow[t]{2}{*}{ Objetivo 2} & $\begin{array}{l}\text { Describir las percepciones del alumnado teniendo en cuenta el contexto donde se } \\
\text { encuentra el centro educativo: zona urbana, rural e indígena. }\end{array}$ \\
\hline & & $\begin{array}{ll}\text { Hipótesis } 2 & \begin{array}{l}\text { La pob } \\
\text { relacio1 }\end{array} \\
\end{array}$ \\
\hline & \multirow[t]{2}{*}{ Objetivo 3} & $\begin{array}{l}\text { Describir las diferencias entre hombres y mujeres respecto a la percepción sobre } \\
\text { educación sexual y equidad de género. }\end{array}$ \\
\hline & & $\begin{array}{l}\text { nado determina la percepción sobre sexualidad y } \\
\text { rro. }\end{array}$ \\
\hline \multirow{6}{*}{$\begin{array}{l}\overline{0} \\
0 \\
0 \\
0 \\
0 \\
0 \\
0 \\
0 \\
0 \\
0 \\
0 \\
0\end{array}$} & \multirow[t]{2}{*}{ Objetivo 4} & $\begin{array}{l}\text { escribir y examir } \\
\text { e texto. }\end{array}$ \\
\hline & & $\begin{array}{ll}\text { tesis } 4 & \begin{array}{l}\text { Existe mayor representación de hombres que de mu } \\
\text { libros de texto de primer grado de secundaria. }\end{array}\end{array}$ \\
\hline & \multirow[t]{2}{*}{ Objetivo 5} & $\begin{array}{l}\text { Comparar el papel y la relevancia que se da a los hombres y a las mujeres en los } \\
\text { materiales. }\end{array}$ \\
\hline & & $\begin{array}{ll}\text { Hipótesis } 5 & \begin{array}{l}\text { En los manuales los hombres aparecen desempeñando papeles } \\
\text { más representativos que las mujeres. }\end{array} \\
\end{array}$ \\
\hline & \multirow[t]{2}{*}{ tivo 6} & $\begin{array}{l}\text { Analizar las conductas y las actividades que desempeñan hombres y mujeres en } \\
\text { los libros de texto. }\end{array}$ \\
\hline & & $\begin{array}{ll}\text { ótesis } 6 & \begin{array}{l}\text { Los libros de texto no rompen con los estereotipos } \\
\text { tradicionalmente asignados a hombres y a mujeres. }\end{array}\end{array}$ \\
\hline
\end{tabular}

Fuente: elaboración propia basada en Álvarez Olivas, 2015, p. 96. 


\section{Método y Técnica de análisis}

Existe un reconocimiento creciente en la comunidad científica acerca de la necesidad de utilizar métodos combinados en investigación, puesto que han sido identificados como elementos claves para mejorar la investigación tanto en Ciencias Sociales como en Educación (Gorard \& Taylor, 2004). Así mismo, y dado que los fenómenos sociales suelen ser multifacéticos, el uso de perspectivas mixtas aquí adoptado es realmente apropiado para evitar fragmentaciones innecesarias (Faber \& Scheper, 2003; Sánchez Gómez, 2015). La combinación metodológica consiste, pues, en utilizar varios tipos y fuentes de datos, lo que fortalece las conclusiones y a su vez nos permite plantear nuevas líneas de investigación (Bericat Alastuey, 1998).

En consecuencia con estas premisas, y teniendo en cuenta los objetivos generales y específicos que se plantean en este estudio, hemos optado por un diseño que contempla un modelo mixto, combinando así estrategias metodológicas cuantitativas y cualitativas, lo que nos permitirá obtener una visión más amplia sobre la temática estudiada. Por ello se realiza en esta investigación una combinación de datos derivados de las entrevistas realizadas a los grupos de discusión y del análisis de los libros de textos.

Empleamos un modelo mixto con técnicas cualitativas y cuantitativas. La combinación de técnicas nos va a permitir describir, explicar y contrastar la información recabada para este estudio. Así pues, por un lado, se realiza un análisis detallado de las percepciones que tienen los y las estudiantes respecto al tema estudiado, por otro lado, se analiza la presencia/ausencia de hombres y mujeres en los libros de texto de primer grado de secundaria del Estado de Michoacán de Ocampo, con la finalidad de comprobar si el Gobierno del Estado promueve una cultura de igualdad o, por el contrario, perpetúa el sistema patriarcal que existe en la sociedad. 
La estrategia seguida en un primer momento es de corte cualitativo, empleando para ello técnicas de recogidas de información, tanto orales como escritas. Para el caso de las fuentes orales, se optó por la técnica de grupos de discusión.

Los grupos de discusión son una herramienta oportuna para la investigación social cualitativa, pues a través de esta técnica se recogen las representaciones y los mapas de significados que entran en juego en la acción social (Mena \& Murillo, 2006). Está herramienta permite, según Lunt y Livingstone (1996), ${ }^{135}$ tomar al grupo como un mecanismo a través del cual se obtiene una doble ventaja. Por una parte, se genera un debate en el cual se revelan significados y percepciones que las personas participantes tienen respecto al tema a discutir. Por otra, se originan representaciones o conocimientos sociales que surgen en el grupo por la diversidad y diferencia de las personas que participan. Algunos autores como Flick (2004) y Suárez Ortega (2005) manifiestan que una de las limitaciones de esta técnica de recogida de datos es identificar a los oradores de manera individual, cuestión a la que nos enfrentamos en esta investigación.

En cuanto a la coordinación de la técnica, se elaboró un guión previo ${ }^{136}$ para orientar las discusiones grupales y con ello generar un análisis reflexivo en y desde la interacción que se estableciera en los grupos. ${ }^{137}$ Además, con la ayuda de la teoría feminista y la categoría analítica de género podremos clarificar, explicar y analizar la percepción del alumnado de primer grado de secundaria en cuanto a la sexualidad y a la equidad de género.

En el caso de las fuentes escritas establecimos contacto con la SEP (Michoacán, México), que proporcionó los libros de texto de primer grado de

\footnotetext{
${ }^{135}$ Citado por Flick 2004 [2007] p. 135.

${ }^{136}$ Se puede observar en el Anexo 1.

${ }^{137}$ Algunos autores como Flick 2004 [2007];Nava Balcázar, et al. 2005; Picado, (2006) hacen referencia a esto.
} 
secundaria (alumnado de entre 12-14 años) de cuatro asignaturas de áreas troncales del curso académico 2010/2011.

El método de análisis utilizado para las dos fuentes de recogida de información es de corte descriptivo y explicativo. Este diseño ofrece la posibilidad de indagar y reflexionar sobre el fenómeno estudiado básicamente a través del análisis de contenido (AC de aquí en adelante). Tanto con los grupos de discusión como con los libros de texto se establecen algunas categorías previas. Para la categorización de la información recabada tendremos en cuenta los criterios de saturación, ${ }^{138}$ considerando también la información más significativa que brindaron las y los alumnas/os (caso de grupos de discusión de aquí en adelante GD) y las fuentes documentales (base teórica). En el caso de GD, las categorías seleccionadas, al igual que el diseño y el guión, fueron validadas por dos personas expertas en género, una en sexología y dos en educación. $^{139}$

El paquete estadístico que empleamos para realizar el análisis de la información es el ATLAS.ti. Está herramienta informática fue desarrollada para favorecer la sistematización y análisis de la información procedente de diversas fuentes: orales, escritas, iconográficas, entre otras (Flick, 2004, p. 273). Su diseño es oportuno para la investigación cualitativa, debido a que opera con un sistema de información macro llamado unidad hermenéutica, en la que se organizan los documentos ya transcritos, editados y organizados. ATLAS.ti ofrece un depósito de documentos, textos, imágenes, entre otros (Salinas Muños, 2016, p. 386). Una vez guardados los documentos se procede a realizar

\footnotetext{
${ }^{138}$ Picado, (2006), citando a Glaser y Strauss (1967), menciona que el concepto de "saturación teórica" se refiere a que en el análisis el evaluador reagrupa y estructura las informaciones en categorías, con el fin de volver estas categorías de análisis lo más densas y ricas posibles. Es por ello que en esta investigación se consideró la utilización de este criterio, dado que permite crear unas categorías de análisis basadas en la información más recurrente que proporciona el alumnado.

${ }^{139}$ Mtra. Georgina Pérez Coeto Mateos (Universidad Autónoma de Michoacán de Ocampo), Mtra. Ma. de Jesús Soto Campos (Universidad Autónoma de Michoacán de Ocampo), Dra. María Elena Rivera Heredia (Facultad de Medicina de la Universidad de Salamanca), Mtra. Elena Hasuko y Mtro. Juan Miguel Guerrero (Jefes de Estudios de la SEP).
} 
el análisis con una serie de funciones que ofrece este software como son las citas, los códigos y los memos.

La técnica de análisis para la interpretación de resultados es el AC. Este es descrito por Bardin como una técnica que permite obtener indicadores por medio de procedimientos sistemáticos y también realizar inferencias sobre los mensajes teniendo en cuenta condiciones de producción/recepción del mensaje (1991, p. 32). Los resultados obtenidos los presentaremos mediante citas textuales que contengan las ideas claves, tanto de las conversaciones generadas en los GD como de los contenidos provenientes de los libros de texto.

Como hemos anticipado, en esta investigación se optó por la utilización de métodos combinados (cuantitativos y cualitativos). Una vez explicada la estrategia de corte cualitativo, pasamos a describir el modelo cuantitativo que vamos a emplear en esta investigación. Esté método se basa en el desglose de los datos obtenidos. Las técnicas de recogida de información serán las mismas, sin embargo se realizará un tratamiento de la información distinta.

El análisis de la información será de tipo descriptivo, ${ }^{140}$ por lo que hacemos referencia a las frecuencias y/o a los porcentajes de una serie de códigos/categorías establecidos. Para ello emplearemos el paquete estadístico SPSS versión 18 para Windows.

El SPSS versión 18 para Windows es un programa que da la posibilidad de organizar y presentar la información recabada mediante tablas y gráficas, lo que nos permiten describir y comparar los datos con base en los objetivos y las hipótesis planteados en este estudio.

Los resultados obtenidos desde ambas perspectivas, cuantitativa y cualitativa, se integrarán para obtener una visión más amplia sobre las percepciones del alumnado en lo que concierne a la equidad de género y a la

\footnotetext{
${ }^{140}$ Se emplea la técnica de análisis de contenido descrita por (Bardin, 1991)
} 
educación sexual, así como en lo referido a la promoción que se realiza en los libros de textos acerca de estos aspectos (Bericat, 1998; Hernández et al., 2006; Sánchez, 2015).

\subsection{Técnica de recolección de información}

Basándonos en el problema y los objetivos de estudio, definimos como técnicas para la recolección de información los grupos de discusión y el análisis de libros de texto. La primera de ellas permitirá recabar información oral sobre la percepción, opinión... que tienen las y los adolescentes con relación a la sexualidad y la igualdad de género. Por su parte, con los libros de texto se recaba y analiza información escrita sobre las imágenes, el texto y el contenido relacionada con la temática de sexualidad y equidad de género.

El empleo de estas técnicas de recolección de información permite desarrollar una investigación con métodos combinados (cuantitativos y cualitativos), puesto que, como manifiestan diversos autores (Sánchez, 2015; Gorard \& Taylor, 2004; Faber \& Scheper, 2003; Bericat A., 1998), su empleo aporta elementos enriquecedores para la investigación tanto en Ciencias Sociales como en Educación.

Grupos de discusión

El empleo de esta técnica ha sido introducida en la investigación de marketing, si bien diversos autores reconocen en esta técnica potencialidades para la investigación social (Mena \& Murillo, 2006), para la investigación educativa (Flick, 2004; Gil Flores, 1992) y para la investigación feminista (Wilkinson,1999b citado por Barbour \& Amo, 2013, p. 27). Los grupos de discusión, en palabras de Krueger (1991), "constituyen una técnica de recogida de datos de naturaleza cualitativa que reúne a un número limitado de personas (generalmente entre siete y diez) desconocidas entre sí y con características homogéneas en relación al tema investigado, con la finalidad de mantener una 
discusión guiada en un clima permisivo, no directivo" (Gil Flores, 1992, p. 201).

A partir de varios autores (Flick, 2004; Gil Flores, 1992; Kruger, 1991; Mena \& Murillo, 2006; Valles Martínez, 1999) se tomaron las siguientes decisiones en lo referido al diseño de los grupos de discusión:

- Construcción de un guión previo. Las preguntas y/o temáticas incluidas en el guión previo elaborado para los grupos de discusión pretenden identificar las percepciones y las experiencias que tiene el alumnado de primer grado de secundaria sobre la sexualidad y la equidad de género.

- El guión contempla así tres rubros en los que se abordan cuestiones sobre la sexualidad y la equidad/desigualdad de género: 1) Conceptos, 2) Percepciones, 3) Experiencias. ${ }^{141}$

- Establecimos grupos de discusión de contextos educativos diversos, con la finalidad de reunir en grupos a sujetos capaces de reproducir posicionamientos diferentes relacionados con nuestro tema de estudio. Contactamos con los Jefes de Enseñanza de la SEP, para que ellos/as se ocuparan de cuestiones logísticas con los centros educativos.

- El tiempo de duración de los grupos de discusión osciló entre 40 y 90 minutos.

- El lugar para llevar a cabo el trabajo con los grupos de discusión era asignado por la institución escolar.

- Se optó por establecer grupos de seis participantes.

Libros de texto

Diversos autores/as, como se vio en apartados anteriores, consideran que el libro de texto es el recurso educativo más utilizado de todos los tiempos y en

\footnotetext{
${ }^{141}$ El guión fue revisado y corregido por elementos de SEP y de la SMUJER, siendo concedida la aprobación del mismo para su posterior aplicación.
} 
todos los países (Alvarez Nunes, 2009; J. Carbonell, 2001; Garreta \& Careaga, 1987a; Peñalver, 2003; J. Sánchez, 2012). Carbonell menciona que "no es el programa o el currículum sino el manual escolar el que determina lo que realmente se enseña en la aulas" (2001, p. 76).

García Gracia et al (1993) consideran que el libro de texto, aparte de ser un recurso global, tiene la función de unificar y trasmitir modelos de comportamiento propuestos por grupos dominantes androcéntricos. En consecuencia, estos/as autores/as consideran relevante el análisis de estos documentos, puesto que solo "leyendo entre líneas" o "entre imágenes" se pueden dilucidar las verdaderas referencias que se están intentando trasmitir (Subirats, 1993, pp. 26-27).

A partir de lo descrito por estos y otros autores/as nos decantamos por esta técnica de recolección de información como la más oportuna para conseguir los objetivos planteados en esta investigación. Así, en el siguiente punto explicamos cómo accedimos a los libros de texto que sirvieron para el análisis.

- Solicitamos a la SEP los manuales que se entregan de manera gratuita al alumnado de primer grado de educación secundaria en el Estado. La institución proporcionó un total de cuatro ejemplares. ${ }^{142}$

En el esquema que se presenta a continuación mostramos las técnicas de recogida de información que se contemplaron para esta investigación.

\footnotetext{
${ }^{142}$ La persona que atendió la solicitud, nos informó que la institución brinda libros de asignaturas troncales a los centros de educación secundaria pública, tanto a técnicas como a generales, de manera gratuita, sin embargo los centros tienen la potestad para decidir si los emplean o no.
} 


\section{Esquema 6.1. Técnicas de recolección de información}

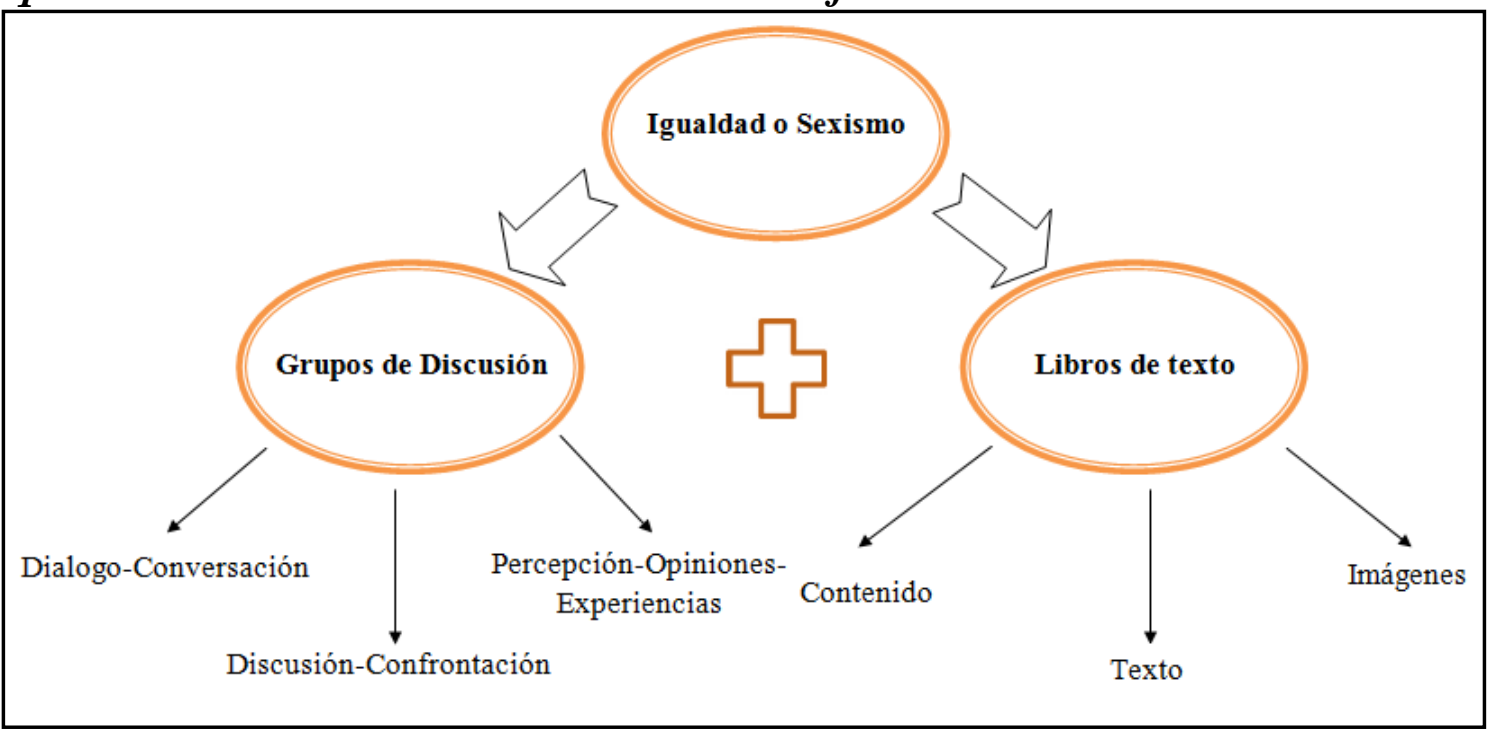

Fuente: elaboración propia.

\subsection{Muestra}

En la recogida de información de grupos de discusión organizamos diez grupos de seis estudiantes cada uno, de los centros educativos de secundaria ubicados en distintos municipios del Estado de Michoacán, en sus dos modalidades: técnicas y generales. Participaron en total 60 adolescentes del primer grado de secundaria, 30 hombres y 30 mujeres. La muestra correspondiente a los libros de texto es de cuatro.

Para la elección de la muestra de grupos de discusión tomamos en cuenta los criterios de homogeneidad-heterogeneidad, de accesibilidad, y de economía descritos por Valles (1999).

La homogeneidad se traduce en la selección de personas de primer grado de secundaria de centros educativos incorporados a la reforma educativa 2006. Por su parte, la heterogeneidad se observa en varios sentidos: en primer lugar, se seleccionan centros educativos de secundaria, en sus dos modalidades, que se encuentran en contextos geográficos distintos (urbano, rural, indígena); en segundo lugar, la composición de cada uno de los grupos de discusión se realiza 
por cuota de sexo, 3 hombres y 3 mujeres; por último, las personas son seleccionadas de distintos grupos de primer grado de secundaria. ${ }^{143}$

La elección de los centros educativos se llevó a cabo con el apoyo económico y la información facilitada por la SEP seleccionando aquellos centros que ofrecían mejores condiciones de seguridad y accesibilidad.

Las escuelas se seleccionaron también teniendo intentando que estuvieran representadas las diferentes condiciones contextuales, basándose en:

- Las escuelas que están incorporadas al plan de estudios 2006.

- La zona geográfica, establecida por el (INEGI): urbana, rural y hablantes de lengua indígena.

- En este rubro se incluyó también un internado mixto por contemplar en su estructura educativa características específicas.

- Participaron 4 de 7 regiones del estado de Michoacán de Ocampo: Morelia, Zamora, Lázaro Cárdenas, Apatzingán.

Cabe destacar que para la elección de escuelas se programaron reuniones con jefes de estudios de las distintas zonas de secundaria en el Estado. Los profesores/as que aceptaron colaborar en la investigación fueron los centros seleccionados para la aplicación del instrumento, lo que obedece a que se necesitaba la colaboración tanto administrativa como financiera para facilitar la recogida de información. Los jefes/as de estudios fueron los encargados de gestionar los permisos con las instituciones educativas, así como de conseguir los espacios para llevar a cabo la aplicación de los instrumentos.

A continuación se muestra el mapa del Estado, con la finalidad de ilustrar la ubicación de las zonas donde se llevó a cabo la investigación.

\footnotetext{
${ }^{143}$ En el caso de que la institución no contara con varios grupos de primer grado, la selección del alumnado se realizó con personas del mismo grupo.
} 
Figura 6.1. Mapa de las Regiones del Estado de Michoacán de Ocampo

Fuente: imagen retomada de la página del Gobierno del Estado: http://michoacan.gob.mx/index.php/temas/cultura-ocio-y-deporte/regiones.

En la siguiente tabla se pueden observar las escuelas secundarias que colaboraron para la elaboración de esta investigación:

Tabla 6.1. Escuelas secundarias Generales y Técnicas en las que se aplicaron los instrumentos para la investigación

\begin{tabular}{lccccc}
\hline \multirow{2}{*}{ Modalidad } & \multicolumn{3}{c}{ ESCUELAS SECUNDARIAS TÉCNICAS (EST) Y GENERALES (ESG) } & Total \\
\cline { 2 - 5 } & R. costa & R. Morelia & R. Zamora & R. Apatzingán & \\
\hline Urbana & EST. 65 Morelia & EST. 23 Tanganciuaro & $\begin{array}{c}\text { EST. 05 Apatzingán } \\
\text { ESG. 02 Apatzingán }\end{array}$ & 4 \\
\hline Rural & EST. 33 Playa azul & $\begin{array}{c}\text { EST.71 Nuevo progreso } \\
\text { Internado:CECADEJDis. San } \\
\text { Antonio Corrales }\end{array}$ & & 3 \\
\hline Habla indigena & 1 & & $\begin{array}{c}\text { EST. 112 Carapan } \\
\text { EST.72 Patamban }\end{array}$ & ESG. San Felipe de los Alzati & 3 \\
\hline Total & 1 & 3 & 3 & 3 & 10 \\
\hline
\end{tabular}

Fuente: elaboración propia.

Respecto a los libros de textos, contactamos a la SEP y le solicitamos los manuales que se entregan de manera gratuita al alumnado de primer grado de educación secundaria en el Estado. La institución proporcionó un total de cuatro ejemplares: Ciencias 1, con énfasis en biología; Geografía de México y el mundo; Español 1, y Matemáticas 1. En la tabla que se muestra a continuación se pueden observar los libros proporcionados y sus características: 


\section{Tabla 6.2. Muestra de los libros de texto}

\begin{tabular}{llc}
\hline \multicolumn{1}{c}{$\begin{array}{c}\text { Libros } \\
\text { México }\end{array}$} & $\mathbf{N}^{\circ}$ de bloques analizados & Paginas \\
\hline Ciencias (con énfasis en Biología) & 5 Bloques & 259 \\
Español I & 5 Bloques & 229 \\
Geografia de México y el mundo & 5 Bloques & 309 \\
Matemáticas I & 5 Bloques & 262 \\
\hline
\end{tabular}

Fuente: elaboración propia.

Por su parte, en la tabla que presentamos a continuación se muestra un resumen de los instrumentos de recolección utilizados, además de la información que pretendemos recabar.

\section{Tabla 6.3. Resumen de los instrumentos y las técnicas de empleadas}

\begin{tabular}{ccll}
\hline Instrumento & Técnica de análisis & Muestra & Tipo de información recabada \\
\hline $\begin{array}{c}\text { Grupos de } \\
\text { discusión }\end{array}$ & Análisis de contenido & $\begin{array}{l}30 \text { alumnas } \\
30 \text { alumnos }\end{array}$ & $\begin{array}{l}\text { Percepciones, creencias, } \\
\text { opiniones en cuanto a la } \\
\text { sexualidad y la equidad de género }\end{array}$ \\
\hline & $\begin{array}{l}\text { Análisis de contenido } \\
\text { de tres unidades: }\end{array}$ & 4 libros de & $\begin{array}{l}\text { Promoción o no de la sexualidad y } \\
\text { la equidad de género. }\end{array}$ \\
Libros de texto & - imagen & texto & \\
& - texto & & \\
\hline
\end{tabular}

Fuente: elaboración adaptada con base en Álvarez Olivas, $(2015$, p. 111).

\subsection{Procedimientos}

Establecimos cuatro fases en la investigación. La primera la consideramos como fase teórica/preparatoria; la segunda como trabajo de campo; la tercera como analítica/ interpretativa; y la última correspondiente a las conclusiones y reflexiones finales. A continuación explicamos cada una de ellas.

\section{Fase 1. Teórica/preparatoria}

En la primera establecimos dos momentos de actuación. El primero consistió en indagar en diversas fuentes impresas y electrónicas que nos sirvieran como base para dar sustento a nuestra investigación. Para ello, realizamos un análisis de datos secundarios básicamente mediante información documental de libros, 
revistas, documentos webs,... ${ }^{144}$ Tras este primer acercamiento con investigaciones y estudios relacionados con la igualdad, la justicia y la libertad entre hombres y mujeres, generamos las primeras preguntas de investigación, los objetivos, y las hipótesis. En el segundo momento, nos centramos en establecer un marco teórico que nos permitiera abordar los temas de igualdad entre mujeres y hombres desde una posición crítica. La revisión de la literatura, nos permitió decantarnos por la teoría feminista de la igualdad y la categoría analítica de género, estos referentes teóricos nos proporcionan un sustento coherente y ordenado en el que apoyar la investigación.

\section{Fase 2. Trabajo de campo}

En esta segunda fase nos planteamos abordar el tema de la investigación, combinando la metodología cualitativa con la cuantitativa, lo cual nos permite enriquecer los resultados. Por ello, tuvimos que diseñar instrumentos y técnicas de recolección de información y/o análisis que pudieran ser abordados desde estos dos modelos.

Recurriendo a la revisión de la literatura, encontramos que la técnica de recogida de información oral y escrita podía servirnos para llevar a cabo análisis cuantitativos y cualitativos. Por ello, optamos por la técnica de grupos de discusión (fuente oral) y análisis de libros de texto (fuente escrita). A continuación explicamos el proceso seguido con cada una de las técnicas seleccionadas y diseñadas, así como la aplicación del instrumento:

\section{Selección y construcción de técnicas de recogida de información}

- Grupos de discusión. Realizamos la construcción de un guión previo, que posteriormente fue sometido a revisión y validación por un grupo interdisciplinario. Planteamos la conformación de los grupos basándonos

\footnotetext{
${ }^{144}$ Bases de datos y recursos bibliográficos que proporciona la universidad como: scopus, eric, scielo, cisc, dialnet, entre otros.
} 
en características propuestas por diversos autores (Flick, 2004; Gil Flores, 1992; Kruger, 1991; Mena \& Murillo, 2006; Valles Martínez, 1999).

- Libros de texto. Concertamos una cita con la SEP para solicitar los manuales que se entregan de manera gratuita al alumnado de primer grado de educación secundaria en el Estado. La institución proporcionó un total de cuatro ejemplares: Ciencias 1, con énfasis en biología; Geografía de México y el mundo; Español 1, y Matemáticas $1 .{ }^{145}$

\section{Aplicación de la técnica de recogida de información}

- Grupos de discusión. Para llevar a cabo la aplicación de este instrumento seguimos los siguientes pasos:

1. Solicitamos apoyo logístico y económico a la SEP.

2. Programamos reuniones con los jefes de estudios de las distintas zonas de los centros educativos de secundaria en el Estado.

3. Los jefes de estudio indicaron los centros educativos que tenían mejores condiciones en cuanto a accesibilidad y a seguridad. Finalmente se encargaron de los trámites, tanto administrativos como financieros, para facilitar la recogida de información.

4. Dentro de los centros educativos tuvimos el apoyo de los prefectos/as. ${ }^{146}$ Ellos/as tenían la tarea de llevar a los/as participantes al punto de encuentro (despacho o gabinete cedido por las autoridades de la escuela secundaria).

5. Antes de iniciar con la discusión, se explicó a los y las participantes la temática sobre la que iban a dialogar. Además, se les preguntó si querían participar, y se les informó respecto a la

\footnotetext{
${ }^{145} \mathrm{El}$ interés de incluir este análisis es que en éstos se presentan más frecuentemente modelos y hechos de la vida cotidiana y tienen, por tanto, una mayor influencia en el desarrollo de estereotipos relacionados con el sexo de las personas y su función social.

${ }^{146}$ Son docentes encargados de gestionar cada nivel académico.
} 
grabación de la sesión y a la confidencialidad de los datos proporcionados.

6. Finalmente, la duración de la sesión osciló entre 40 y 90 minutos. Trabajamos en círculo, en un espacio privado y confortable, y se incluyeron tres momentos:

- El establecimiento del encuadre; el desarrollo del dialogodiscusión; y el cierre.

- Libros de texto: El análisis y la construcción de indicadores los creamos basándonos principalmente en cuatro investigaciones (I.M.O.P. Encuestas, 2000; Lomas, C., 2002; Luengo González \& Blázquez Entonado, 2004; Subirats, 1993).

\section{Fase 3. Analítica/interpretativa}

En esta tercera fase se establecen tres momentos: 1. Sistematización de la información; 2. Construcción del análisis mediante los paquetes informáticos; 3. Análisis e integración de resultados.

1. La sistematización de la información.

Una vez que disponemos de la información recabada con los grupos de discusión y de los libros de texto, pasamos tanto a la trascripción de las grabaciones de audio, ${ }^{147}$ como al escaneado de los libros de texto, con la finalidad de organizar y preparar los datos para pasarlos al paquete informático ATLAS.ti, versión 7.5 para Windows y al SPSS versión 18 para Windows. Las transcripciones se incorporaron al software para realizar la reducción de los datos, que se llevó a cabo siguiendo un método deductivo/inductivo, en donde dos categorías, sexualidad y género, son establecidas previamente, mientras que el resto de categorías se establecieron en base a la información obtenida (método inductivo).

\footnotetext{
${ }^{147}$ Nueve de las diez entrevistas (un grupo de discusión se negó a ser grabado) fueron grabadas en formato de audio y posteriormente transcritas.
} 
2. Construcción del análisis mediante los paquetes informáticos.

Realizadas las transcripciones (pre análisis) ${ }^{148}$ y teniendo los documentos en formato $P D F$ introducidos en las unidades hermenéuticas del software ATLAS.ti, versión 7.5 para Windows, iniciamos con el proceso de codificación de las unidades de análisis, categorías previas y subcategorías. Cabe destacar que las categorías derivadas del preanálisis de GD son, posteriormente, sometidas a validación por dos personas expertas en género, una en sexualidad y dos en educación.

En cuanto a las unidades de análisis y categorías creadas para los libros de textos, fueron construidas basándonos en investigaciones y estudios relacionados con el nuestro (Espigado, 2004; Garreta \& Careaga, 1987a; López Ojeda, 2007; López-Navajas, 2014, 2015; Manassero \& Vázquez, 2002b; Mínguez \& Beas, 1995; Montes de Oca Navas, 2015; Morgado, 2004; Pérez, 2011; Salinas Villanueva, 1996; Solé, 2014; Vaíllo Rodríguez, 2013). En total se revisaron treinta y seis estudios relacionados con el análisis de libros de texto enfocados a los temas de igualdad. Para guiarnos en la metodología retomamos los estudios de Alvarez Nunes, (2009); Gobierno de España, s/f; I.M.O.P. Encuestas, (2000); y Luengo González \& Blázquez Entonado, (2004). Y para la elaboración de la base de datos tomamos en cuenta los indicadores propuestos por las siguientes investigadoras: Blanco, (2000, 2003); Miranda Santana, (2004); Subirats, (1993).

En cuanto a las categorías y sub-categorías validadas para los GD, los podemos observar en el siguiente esquema: ${ }^{149}$

\footnotetext{
${ }^{148}$ Se realiza una lectura superficial del material, con ello se elabora una primera aproximación a las categorías y subcategorías que se desarrollarán en la investigación, también se realiza una revisión de la formulación de las hipótesis y de los objetivos.

${ }^{149}$ Cabe destacar que durante el proceso de análisis con el programa ATLAS.ti podrían surgir subcategorías que no hayan sido contempladas en un primer momento. Sin embargo, al enfrentarnos con los textos vemos que es necesaria su incorporación. A estas sub-categorías se les llamará emergentes.
} 
Esquema 6.2. Categorías y sub-categorías de análisis de grupos de discusión y auto-descripción breve
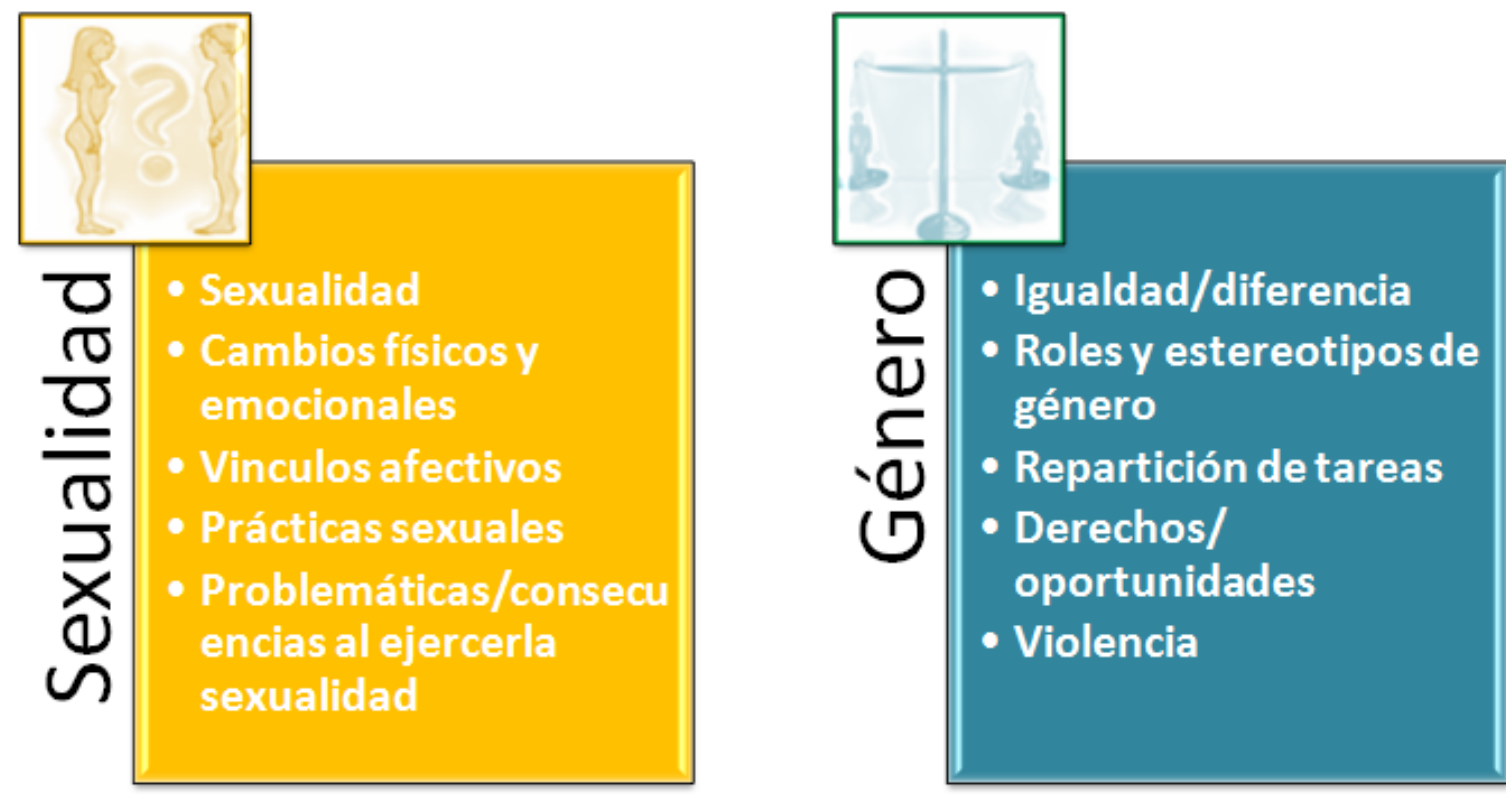

Fuente: elaboración propia.

La división de las categorías de análisis se realiza tomando en cuenta el pre análisis derivado de los GD y lo descrito por diversos autores en el apartado teórico, como Barberá Heredia, 2004; Bascón Díaz, 2007; Calero \& Santana, 2001; Fernández, 1988; Lameiras \& Rodríguez, 2002; F. L. Sánchez, Rouco, González, Kilani, \& Blázquez, 2010; Stern, 2007; Vance, 1989. De acuerdo con estos autores, la sexualidad y el género, aun cuando existen algunos paralelismos entre estos dos constructos planteados por la teoría de la construcción social, son territorios, separados o bien como los llama Gayle Rubin (1975) son vectores de opresión distintos.

En la categoría de análisis sobre sexualidad se hace referencia a las tres esferas de interacción inseparable del ser humano: la biológica (cuerpo), la psicológica (sentimientos/emociones) y la social (contexto sociocultural).

Si bien es cierto que cada persona tiene una manera de expresar/ejercer su sexualidad, esta se rige por un contexto social determinado por condiciones culturales, políticas, ideológicas, económicas, religiosas,... que regulan y 
reglamentan, a través de prohibiciones y sanciones, las formas de vivir la sexualidad (Grajales Valdespino, 2004; Monroy, 2002; Vance, 1989).

Resulta de crucial importancia que recabemos datos sobre las percepciones y experiencias que los y las adolescentes michoacanos/as tienen acerca de las relaciones de igualdad entre sexos, para así poder descubrir cómo justifican la desigualdad, y generar políticas que se adecuen a las necesidades que experimentan. Debemos, así mismo, atender de manera especial al hecho de que la población que participa en este estudio se encuentra en una etapa vital, la adolescencia, en la que el ser humano experimenta cambios físicos, psicológicos y sociales, y en la que se inicia un proceso de maduración moral y sexual que demanda más obligaciones, derechos y libertades.

La sexualidad en esta etapa de la vida cobra crucial importancia, ya que, a lo largo de la misma, la experiencia sexual adquiere una gran significación vinculada a diversos aspectos como son las transformaciones físicas $\mathrm{y}$ hormonales que obran sobre el cuerpo, los deseos, fantasías, erotismo, el placer... sin olvidar los condicionamientos sociales, culturales, religiosos,... que operan de manera decisiva en la iniciación, asunción y expresión de la sexualidad (Checa, 2005).

En esta categoría se intenta recopilar información dada por el alumnado respecto a cinco sub-categorías previas que se definen en la tabla 6.4.

\section{Tabla 6.4. Sub-categorías de la categoría de sexualidad}

1. Sexualidad

2. Cambios físicos y emocionales

3. Vínculos afectivos
En esta sub-categoría se van a analizar tanto los conceptos como las conductas que el alumnado identifique como sexualidad.

Se analizan todos aquellos cambios percibidos por los y las adolecentes en esta etapa del desarrollo. Algunos de ellos relacionados con la maduración corporal y otros con las variaciones emocionales.

En esta categoría se hará referencia a la capacidad de tener sentimientos de amor, tanto con ellos/as mismos/as como con los otros/as. Se analizarán aspectos relacionados con la amistad, la confianza, el noviazgo... 
4. Prácticas sexuales

5. Problemáticas/conflictos al ejercer la sexualidad
Se refiere a las expresiones y ejercicio de la sexualidad destinados a producir placer, deseo y gozo en las y los jóvenes.

Se analizan aquellos aspectos negativos o no deseados derivados de mantener relaciones sexuales o sexo-genitales.

Fuente: elaboración propia.

En cuanto a la categoría género, se analiza el conjunto de percepciones y patrones de comportamiento que el alumnado identifica como "propias" de lo "masculino y lo femenino" — identidad de género- y cómo estas influyen afectan/benefician - en los diversos aspectos de la vida del alumnado (personal, social, educativo...). Se analizarán, también, las posiciones que tomen los y las adolescentes con respecto a las situaciones de discriminación de género. Finalmente, se considerará la información que tienen sobre los derechos de igualdad que existen tanto a nivel nacional como estatal, además de las consideraciones que ellos y ellas tienen respecto a lo establecido por ley (Ver tabla 6.5.).

\section{Tabla 6.5. Sub-categorías de la categoría de género}

1. Igualdad diferencia

Se recoge todo aquello que las y los jóvenes identifiquen y reconozcan como igualdad/diferencia entre hombres y mujeres. En esta sub-categoría se realiza un análisis respecto a las generalizaciones de determinados prejuicios 0 ideas

2. Roles y estereotipos de género preconcebidas que tiene el alumnado en cuanto a lo que corresponde hacer a mujeres y hombres de manera discriminatoria, concediendo a uno $\mathrm{u}$ otro determinados privilegios en cuanto a unas supuestas capacidades, logros y actitudes.

Se realiza un análisis respecto a la concepción, identificación o

3. Repartición de tareas reconocimiento de la división de tareas en cuanto al sexo, en los diversos contextos en los que ellos y ellas se desenvuelven.

En esta sub-categoría se recoge la información que tiene el

4. Derechos y oportunidades alumnado en cuanto a los derechos y oportunidades que tienen hombres y mujeres relacionados con la igualdad tanto a nivel nacional como estatal y si estos son respetados por la sociedad.

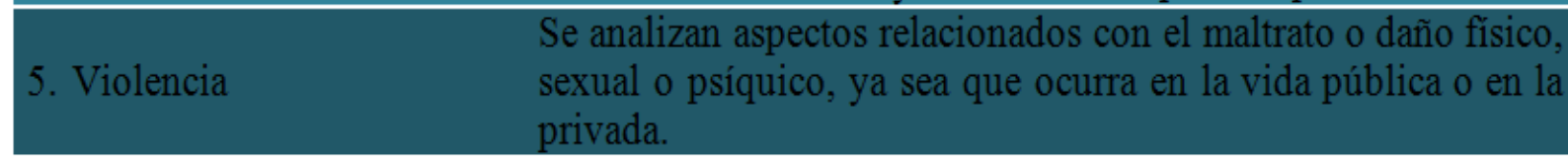

Fuente: elaboración propia. 
Con relación al análisis de los libros de texto, se considera al personaje como la unidad de análisis, y se tuvieron en cuenta tres contextos para el análisis: las imágenes, el texto y el contenido:

1. Imágenes o ilustraciones: Se centra en la presencia de mujeres y hombres, estableciendo algunas categorías previas sobre la construcción simbólica de cada uno de los personajes, analizando los roles, y los estereotipos de género en el ámbito social, familiar y profesional. ${ }^{150}$

2. Texto: Se codifican hombres y mujeres en texto para realizar un análisis sobre el uso sexista o no sexista del lenguaje, y la presencia/relevancia de aparición de unos y otras, tomando en cuenta algunos indicadores como son la ocupación, la actividad, el lugar o el protagonismo.

3. Contenido: Se analiza la información contenida en los libros de texto, tanto respecto a los estereotipos o roles sexistas como a la promoción de la cultura de igualdad entre hombres y mujeres.

Cabe destacar que para el punto uno se establecieron cuatro categorías previas, validadas por medio del contraste con otras investigaciones (LópezNavajas, 2014; Sánchez, 2012; Pérez, 2011; Alvarez N., 2009; Luengo G. \& Blázquez E., 2004; Espigado, 2004; Blanco N., 2000; IMOP Encuestas, S.A., 2000; Subirats, 1991; Garreta \& Careaga, 1987; Blanco N., s/f;). Para el punto dos únicamente se analizan las tres primeras categorías establecidas. Por su parte, el análisis sobre el contenido se realizará tomando en cuenta las categorías tres y cuatro.

1. Presencia/ausencia de hombres y mujeres en los libros de texto. Codificación del personaje: hombres, mujeres, genéricos, colectivos de mujeres, colectivos de hombres, colectivos mixto y masculino genérico. Con esta categoría se pretende corroborar si la información (texto y

\footnotetext{
${ }^{150} \mathrm{Si}$ aparecen más de cinco personas en la misma imagen se contabiliza como colectivo. El colectivo puede, a su vez, ser femenino, masculino o mixto.
} 
contenido) y las imágenes que se presentan en los libros de texto de primer grado de secundaria tienen una distribución equitativa o no de los personajes.

2. Personajes históricos o representativos: Se codifican los personajes, si son nombrados/as, el lugar en el que se desarrolla, el ámbito en el que se lleva a cabo la actividad y la importancia del mismo. Con esta categoría se pretenden recoger las aportaciones que, para el desarrollo social, político y científico, realizan los personajes de los libros de texto.

3. Estereotipos sexistas en ocupaciones y/o actividades que desempeñan los personajes: Se codifican los personajes, las actividades laborales y ocupaciones cotidianas, el lugar donde se desarrolla la actividad u ocupación, y el nombre del personaje. Con esta categoría se pretende indagar sobre los modelos sociales androcéntricos que se promueven a través del texto, de las imágenes y del contenido de los libros de texto.

4. Promoción de la igualdad/equidad de género: Se codifica al personaje que desempeñe actividades contrarias a lo esperado según su rol de género. Con esta categoría pretendemos evidenciar la promoción que, en los libros de texto, se hace de la igualdad y la equidad de género.

Los indicadores que se tuvieron en cuenta para cuantificar y codificar tanto las imágenes como el texto de los libros se presentan la siguiente tabla:

Tabla 6.6. Indicadores establecidos para la elaboración del análisis de los libros de texto

\begin{tabular}{cll}
\hline \hline Indicador & \multicolumn{1}{c}{ Código } & \multicolumn{1}{c}{ Significado } \\
\hline \hline \multirow{2}{*}{ Nombre } & $\mathrm{Si}$ & \multirow{2}{*}{ Personajes que vienen nombrados } \\
& $\mathrm{No}$ & \\
\hline \multirow{2}{*}{} & Mujer & Cada uno de los seres humanos reales o ficticios que figuran en los \\
& Hombre & libros de texto analizados \\
Genérico & \\
\hline \multirow{2}{*}{} &
\end{tabular}




\begin{tabular}{|c|c|c|}
\hline \multirow{4}{*}{ 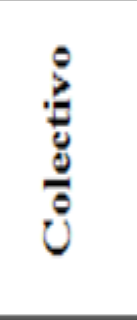 } & Hombres & Conjunto de personas formadas exclusivamente por varones \\
\hline & Mujeres & Conjunto de personas formadas exclusivamente por mujeres \\
\hline & Mixto & Para distinguir personajes en los que participaban hombres y mujeres \\
\hline & $\begin{array}{l}\text { Masc. } \\
\text { genérico }\end{array}$ & $\begin{array}{l}\text { Uso universal masculino en el discurso lingüístico para refenire a } \\
\text { hombres o a mujeres al unísono. }\end{array}$ \\
\hline \multirow{4}{*}{ 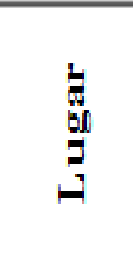 } & Abierto & Espacio al aire libre \\
\hline & Cerrado & Espacios cerrados: Colegios, muros, aulas \\
\hline & Público & Espacio donde se realizan actividades de carácter laboral o profesional \\
\hline & Privado & Espacios que están relacionados con el ámbito individual o doméstico. \\
\hline \multirow{5}{*}{ 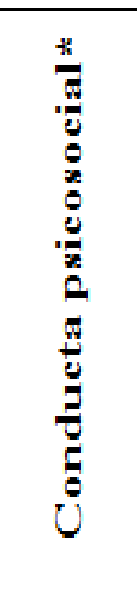 } & Pasiva & $\begin{array}{l}\text { Se entiende por esta cuando el personaje está inmóvil, impávido, sin } \\
\text { gesto facial/corporal. }\end{array}$ \\
\hline & Activa & $\begin{array}{l}\text { Se considera siempre que el personaje esté realizando alguna actividad } \\
\text { o implique una acción. }\end{array}$ \\
\hline & Agresiva & Se muestra agitación, extenuación, toda acción que denote violencia. \\
\hline & Felicidad & $\begin{array}{l}\text { Se contabiliza los rasgos de personalidad que denoten o citen alegría, } \\
\text { amor, dicha, bienestar, suerte, prosperidad, ventura, ... }\end{array}$ \\
\hline & Tristeza & $\begin{array}{l}\text { Se contabilizan los rasgos de personalidad relacionados con } \\
\text { preocupación, compasión, lástima, pena, desconsuelo, aflicción... }\end{array}$ \\
\hline \multirow{11}{*}{ 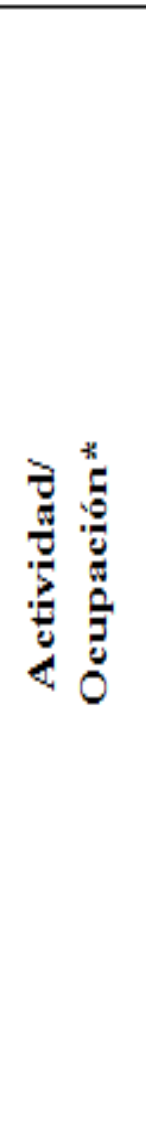 } & Político & $\begin{array}{l}\text { Act. relacionadas con actos diplomáticos y de toma de decisiones, } \\
\text { Reyes, Reinas, diplomáticos/as, presidentes/as, senadores/as... }\end{array}$ \\
\hline & Militar & Act. relacionadas con actos bélicos: militares, soldados, generales... \\
\hline & Religioso & $\begin{array}{l}\text { Act. relacionadas con actos religiosos. Dioses, Diosas, sacerdotes, } \\
\text { rabinos, monjas,... }\end{array}$ \\
\hline & $\begin{array}{l}\text { Cultural- } \\
\text { Artístico }\end{array}$ & $\begin{array}{l}\text { Act. relacionadas al arte y la cultura: artistas, pintores/as, magos/as, } \\
\text { poetas, poetisas... }\end{array}$ \\
\hline & Científico & $\begin{array}{l}\text { Act. relacionadas con al trabajo intelectual e investigativo en las } \\
\text { distintas áreas del conocimiento, sociología, biología, letras... }\end{array}$ \\
\hline & Técnico-P. & Act. relacionadas con oficios manuales: obreros/as, meseros/as... \\
\hline & Económico & $\begin{array}{l}\text { Act. relacionadas con el trabajo remunerado o con actividades } \\
\text { productivas. }\end{array}$ \\
\hline & Lúdico & Toda actividad que implique juego, deporte, ocio o recreación. \\
\hline & Educativo & Act. relacionadas con los procesos de enseñanza aprendizaje. \\
\hline & Salud & Act. relacionadas con el área de la salud, médicos/as, enfermeros/as... \\
\hline & Doméstico & doméstico, la crianza, las tareas de casa. \\
\hline
\end{tabular}




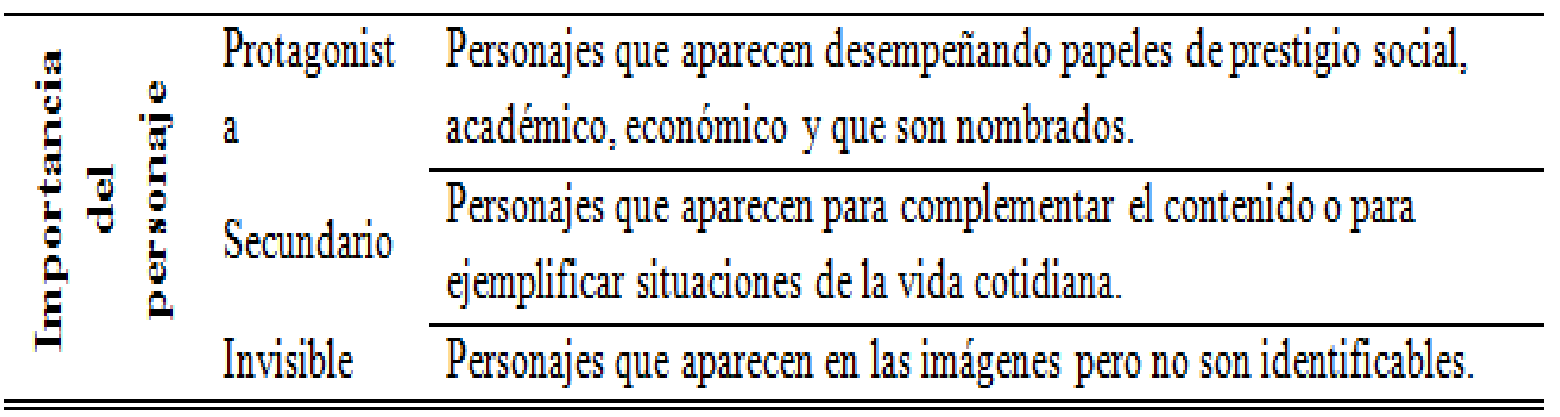

Fuente: elaboración propia con base en IMOP Encuestas, S.A., (2000) García, García et al. (1993) Lomas (2000) y Luengo G. \& Blázquez E., (2004).

*Al emplear los dos paquetes informáticos obtenemos estos indicadores con dos modalidades 1. Abierto se recogen los indicadores tal cual se presentan en los/as personajes en el texto, y 2. Cerrado al establecer un código para facilitar el análisis.

3. Análisis e integración de los resultados.

En este apartado llevamos a cabo una integración de los resultados, siguiendo el procesamiento y el análisis sugerido por Porta \& Silva (2003), en el cual se plantean tres momentos:

En un primer momento, se realiza un análisis descriptivo de los instrumentos utilizados, a través del software ATLAS.ti, versión 7.5 para Windows y del programa estadístico SPSS versión 18 para Windows. Mediante estos dos programas se numeran las características de la información obtenida, en relación a la frecuencia de aparición de las distintas categorías.

En segundo lugar, se elabora un contraste entre los datos, midiendo el grado de asociación y relación entre las variables (tablas de contingencia).

En tercer lugar elaboramos el análisis, la interpretación y la integración de los resultados, con el objetivo de, primero, obtener una perspectiva más amplia sobre las percepciones que tiene el alumnado acerca de la temática abordada, $\mathrm{y}$, además, comprobar si desde la sociedad (a través de los libros de texto) se contribuye o no a reforzar la equidad entre los sexos y la educación sexual.

Cabe destacar que la información generada tanto de los GD como de los libros de texto la presentaremos diferenciada por colores. Así, a la categoría de sexualidad y a sus sub-categorías las ubicaremos en diversas tonalidades de 
color amarillo. En cambio, la categoría de análisis sobre género y las subcategorías que se deriven de ella serán presentadas en distintas tonalidades de color azul. La integración de estas categorías la presentaremos en distintas tonalidades de color verde. Por su parte, los colores empleados para los resultados de libros de texto serán tonalidades de color morado. Esta organización por colores facilita la integración, comprensión y análisis de la información. También ayuda a una rápida localización de la información que sea requerida. Recordemos que la presentación de los datos pretende sobre todo establecer los contrastes, semejanzas y diferencias que el alumnado de primer grado de secundaria en el Estado menciona en sus discursos sobre género, así como averiguar si desde los manuales escolares se promueve una cultura de igualdad entre hombres y mujeres.

\section{Fase 4. Conclusiones y reflexiones finales}

El apartado de conclusiones y reflexiones finales lo dividimos en cuatro secciones:

En primer lugar, desarrollamos una discusión a partir de las preguntas generadas al inicio de la investigación, presentamos la interpretación de los resultados analizados y los comparamos con los resultados obtenidos por otras investigaciones. En segundo lugar, elaboramos la constatación de objetivos e hipótesis con base en la interpretación del análisis de los resultados derivados de los grupos de discusión y del análisis de los libros de texto. En tercer lugar, enunciaremos las fortalezas y las debilidades de este trabajo. Finalmente describiremos las posibles líneas futuras de investigación.

A continuación presentamos un esquema en que el que resumimos las cuatro fases que se establecieron en este trabajo de investigación: fase 1. Teórica/preparatoria; fase 2. Trabajo de campo; fase 3. Analítica/interpretativa; fase 4. Conclusiones y reflexiones finales: 
Esquema 6.3. Resumen sobre el diseño metodológico llevado a cabo en la investigación

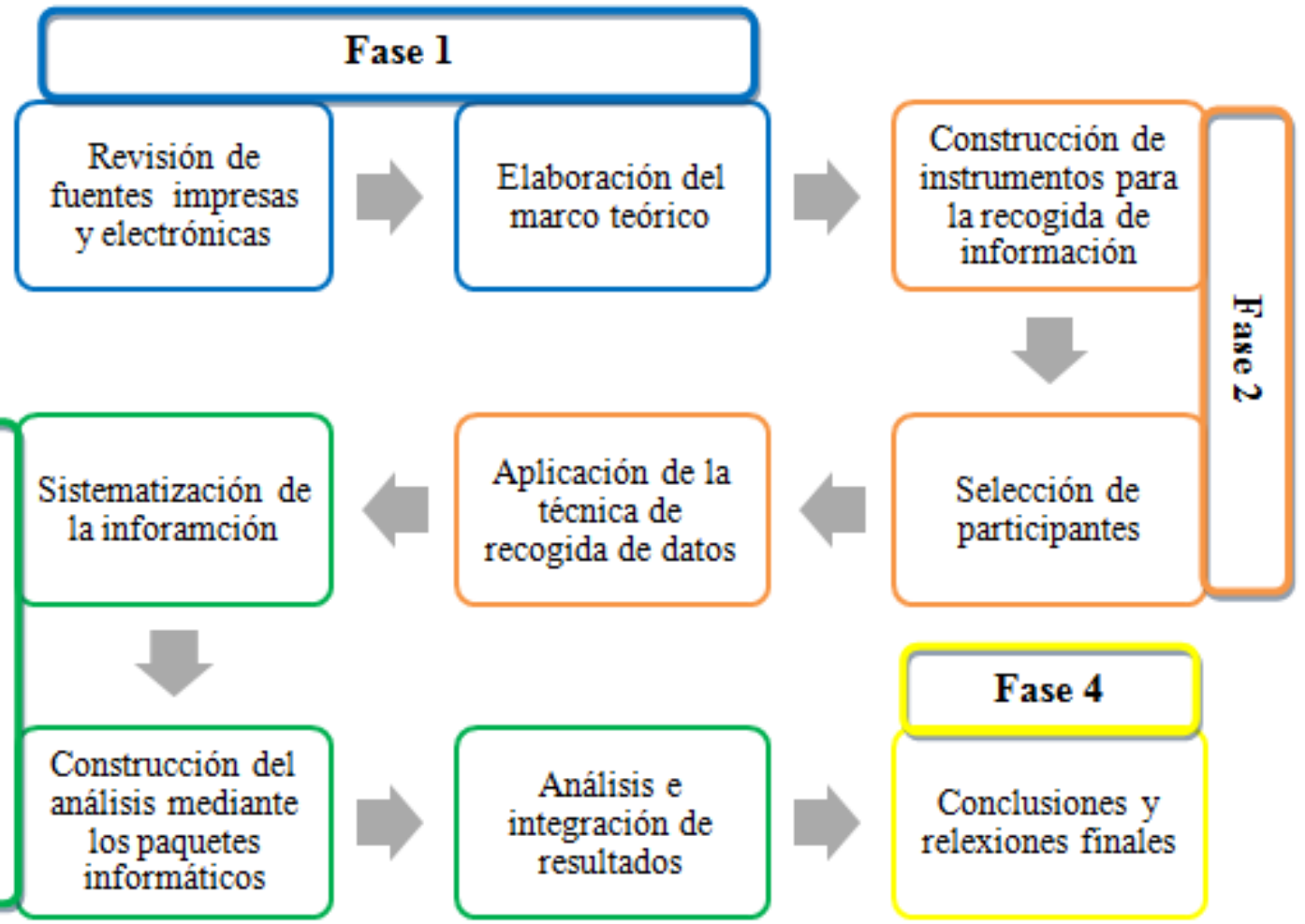

Fuente: elaboración propia.

\subsection{Financiación y recursos empleados}

En este apartado se muestra la viabilidad o factibilidad respecto a la disponibilidad de los recursos financieros, humanos y materiales que, en última instancia, determinarán los alcances de esta investigación.

Es importante mencionar que el trabajo inicial de esta investigación fue financiado y apoyado por dos secretarias públicas en el Estado de Michoacán de Ocampo. De este modo, las titulares de la Secretaria de la Mujer (SEMUJER) ${ }^{151}$ y de la Secretaría de Educación en el Estado (SEE) ${ }^{152}$ firman un convenio de colaboración, en un claro esfuerzo de coadyuvar en las acciones que desde sus dependencias realizan para garantizar la equidad de género. En el marco de este acuerdo surge el presente estudio, que contiene información referente a la percepción que tiene el alumnado de primer grado de secundaria respecto a la

\footnotetext{
${ }^{151}$ Cristina Portillo Ayala

${ }^{152}$ Graciela Andrade García Peláez
} 
sexualidad y la equidad de género. Considerando, así mismo, que la educación representa un instrumento indispensable para lograr una convivencia social caracterizada por la equidad, la libertad, la justicia y la igualdad social, entendida esta última no sólo en "relación a la distribución de los bienes, de los derechos y de las obligaciones, sino también en relación a la participación de los sujetos sociales en la determinación de las reglas que norman la sociedad...”(Guzmán, 1997).

Con el apoyo financiero que proporcionaron estas dos instituciones públicas se formó un grupo interdisciplinario que se encargaba de corregir y validar los instrumentos de investigación que se presentan en esta tesis.

Además, nos brindaron apoyo logístico y profesional para la aplicación de los instrumentos. Con el apoyo logístico, se constituyó un equipo de trabajo encargado de facilitar la tarea para la aplicación de instrumentos. Su trabajo consistía en:

- Los traslados a las distintas zonas en las que se aplicó el instrumento. Proporcionar coches, personal conductor.

- Tener la papelería y material informático para el desarrollo de la investigación.

- Obtener la autorización para la aplicación de los instrumentos en los distintos centros

- Conseguir gabinetes o cubículos para que se llevaran a cabo los grupos de discusión.

- Proporcionar los libros sujetos a análisis.

Con el apoyo profesional que brindaron las dos secretarías, además del grupo interdisciplinario, se creó un equipo para llevar a cabo tareas con los grupos de discusión, cuya principal función fue la siguiente:

- Realizar grabación, relatoría y observación con los grupos de discusión. 
Tabla 6.7. Recursos materiales empleados en la primera y segunda fases

\begin{tabular}{ll}
\hline \hline Productos & Descripción \\
\hline Alimentacióny hospedaje & Gastos de estancia en el destino donde se aplicaron los instrumentos. \\
\hline $\begin{array}{l}\text { Coche, gasolina, cuotas de } \\
\text { autovías }\end{array}$ & Traslados a las distintas regiones donde se aplicaron los instrumentos. \\
\hline Despacho & Lugar para la aplicación de instrumentos. \\
\hline Grabadora de audio & $\begin{array}{l}\text { En caso de estar de acuerdo el alumnado se realizaba una grabación de audio de los } \\
\text { grupos de discusión. }\end{array}$ \\
\hline Folios & Folios para realizar anotaciones. \\
\hline Boligrafos & Un paquete de bolígrafos para realizar las anotaciones pertinentes. \\
\hline libros de texto & $\begin{array}{l}\text { Los libros de textos de las asignaturas de Ciencias (con énfasis en Biología), Español I, } \\
\text { Geografia de Méxicoy el Mundo y Matemáticas I. }\end{array}$ \\
\hline Ordenador & $\begin{array}{l}\text { Para realizar la sistematización de los datos } \\
\text { Programa estadístico }\end{array}$ \\
\hline \hline
\end{tabular}

Fuente: elaboración propia. 


\section{PARTE III. ANÁLISIS DE RESULTADOS}





\section{Percepciones del alumnado}

En este apartado presentamos los resultado que se han obtenido tras el estudio empírico, siguiendo los pasos descritos por Porta \& Silva (2003). Primero realizaremos una descripción de los resultados, posteriormente haremos un contraste entre los datos obtenidos y finalmente los integraremos haciendo una interpretación de los mismos. Para ello, hemos dividido este apartado en tres puntos. En el primero se hará referencia a las percepciones que tiene el alumnado sobre la sexualidad. En el segundo epígrafe se muestran las percepciones que tiene la población estudiantil con respecto a la igualdad/diferencia de género. Por su parte, en el tercer punto haremos una integración de ambas categorías. Cabe destacar que durante todo el análisis prestaremos atención a las semejanzas y diferencias entre las percepciones de chicas (M.) y de chicos (H.) y a las características relacionadas con la zona territorial en la que se encuentra la escuela, con la finalidad de explicar si el contenido del discurso de los sujetos que participan en esta investigación se ve influenciado por estas dos variables.

Es importante destacar que el análisis de la información que se muestra en este capítulo se realizó con el programa informático ATLAS.ti versión 7.5 para windows. Así pues, en la presentación de las citas seleccionadas se podrá identificar: la modalidad de secundaria (escuela secundaria general: "ESG", escuela secundaria técnica: "EST"), el número de identificación de la escuela, el lugar de ubicación, el número de documento primario y el número de cita. A continuación mostramos un ejemplo:

\section{Esquema 7.1. Referencia de citas seleccionadas}

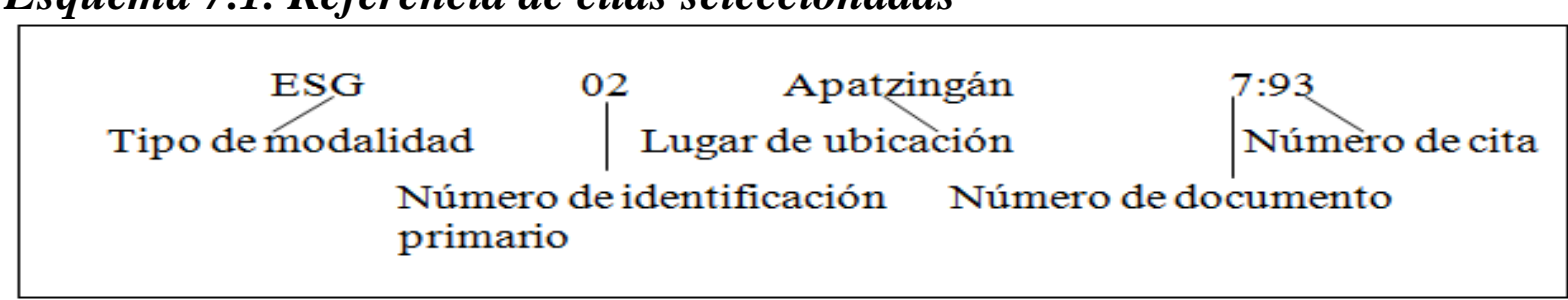

Fuente: elaboración propia. 


\subsection{Percepciones sobre la sexualidad}

En este epígrafe mostramos las percepciones, inquietudes y expectativas que tienen los y las adolescentes en torno a la categoría denominada sexualidad, la cual está conformada por siete sub-categorías, cinco de ellas fueron establecidas a priori y dos de ellas se establecieron durante el trabajo de análisis (esquema 7.2.).

La categoría analizada en este apartado es un tema sensible y de interés para las y los adolescentes. En ella convergen un sinfín de dimensiones: cambios físicos y emocionales, vínculos afectivos, prácticas sexuales, problemáticas y conflictos al ejercer la sexualidad (embarazo adolescente e infecciones de transmisión sexual, entre otras), todas ellas mediadas por la identidad, los estereotipos de género y las normas socioculturales propias de cada región.

El siguiente esquema 7.2., mostramos la relación existente entre las subcategorías y el número de citas que se han asociado a cada una de ellas. Haciendo una rápida lectura de los datos vemos que la sub-categoría con más citas asociadas es la de "vínculos afectivos" —más adelante veremos que los y las adolescentes hicieron referencia a vínculos afectivos relacionados con la familia, con los amigos y con el noviazgo o pareja-. Las siguientes subcategorías en función del número de citas son: prácticas sexuales (162), problemáticas y/o conflictos al ejercer la sexualidad (97), cambios físicos y emocionales (77), sexualidad (73), embarazo adolescente (62), e infecciones de trasmisión sexual (31).

Cabe destacar que el número de citas que aparecen corresponden al total de las referidas, lo cual significa que muchas de ellas están relacionadas con la categoría de género (como era de esperarse), razón por la cual en este apartado solo haremos referencia a las citas que aparecen de manera exclusiva en esta categoría. 
Esquema 7.2. Categoría de sexualidad y las relaciones entre sus subcategorías

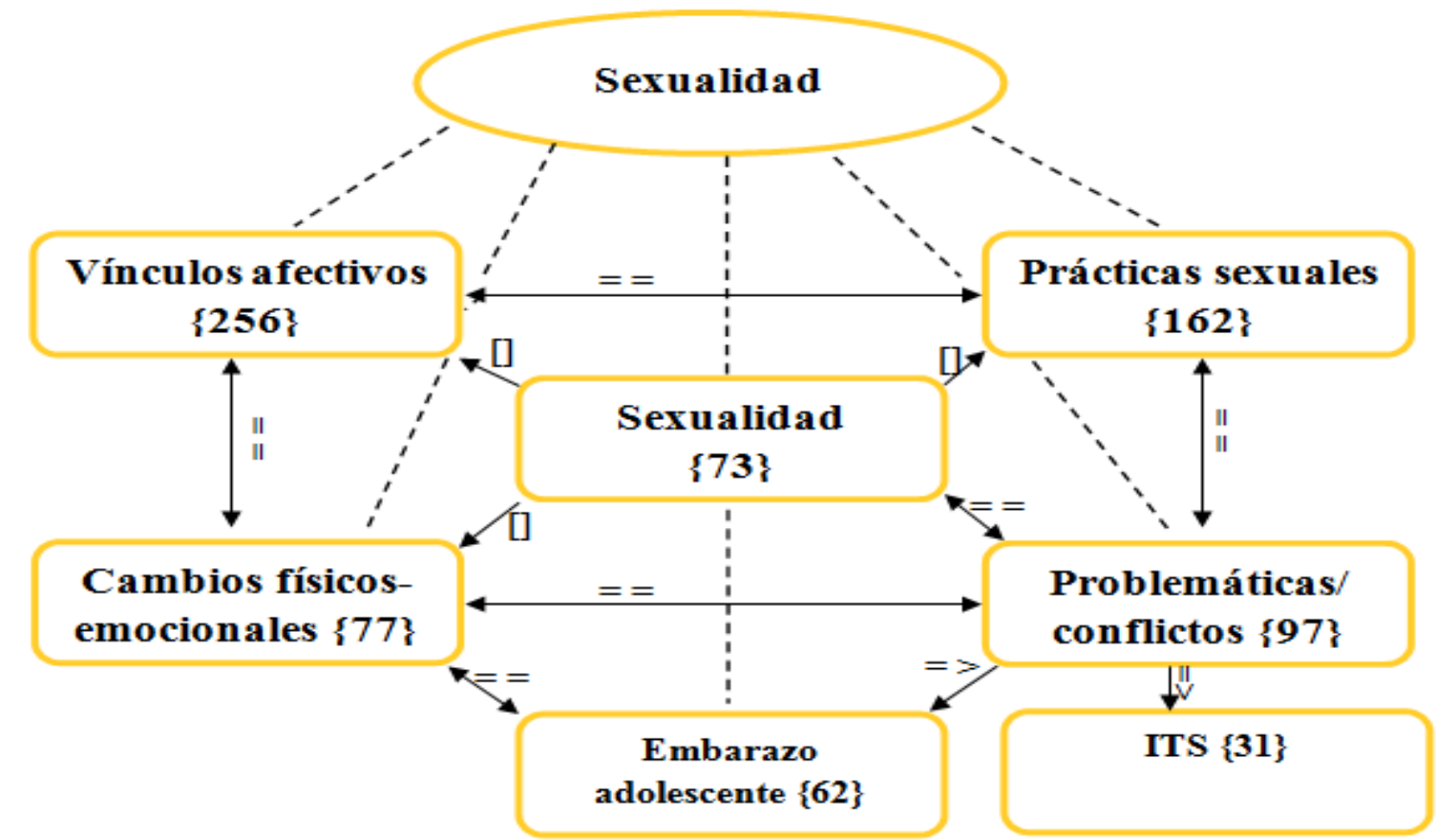

Nota: simbología de las relaciones: $==$ asociada con; [] parte de; => causa de.

La información que brindaron los y las alumnas sobre esta categoría refleja que esta temática continua siendo atendida desde una perspectiva restrictiva y fundada en el miedo y la prohibición. La actitud de los y las adolescentes en los grupos de discusión era de nerviosismo, vergüenza y pudor; sobre todo por parte de las adolescentes. Estas actitudes ya manifiestan que no están acostumbrados/as a abordar los contenidos sobre los afectos y las relaciones sexuales desde una perspectiva integral que englobe todas las dimensiones humanas: cuerpo-emociones-sentimientos.

En la siguiente gráfica mostramos el número de intervenciones que tuvieron hombres y mujeres en cada sub-categoría. En ella se refleja que la participación de unos y otras estuvo bastante equilibrada, del cien por ciento de las citas de esta categoría las mujeres obtienen el 51,7 y los hombres el 48,3. Las mujeres tienen mayor número de citas asociadas en las sub-categorías de conflictos al ejercer la sexualidad, en la de cambios físicos y emocionales y en la de prácticas sexuales. En donde se observa una mayor equiparación en cuanto a las citas 
asociadas a unos y a otras es en vínculos afectivos, sexualidad e infecciones de transmisión sexual.

Gráfica 7.1. Sub-categorías de sexualidad según el sexo del alumnado

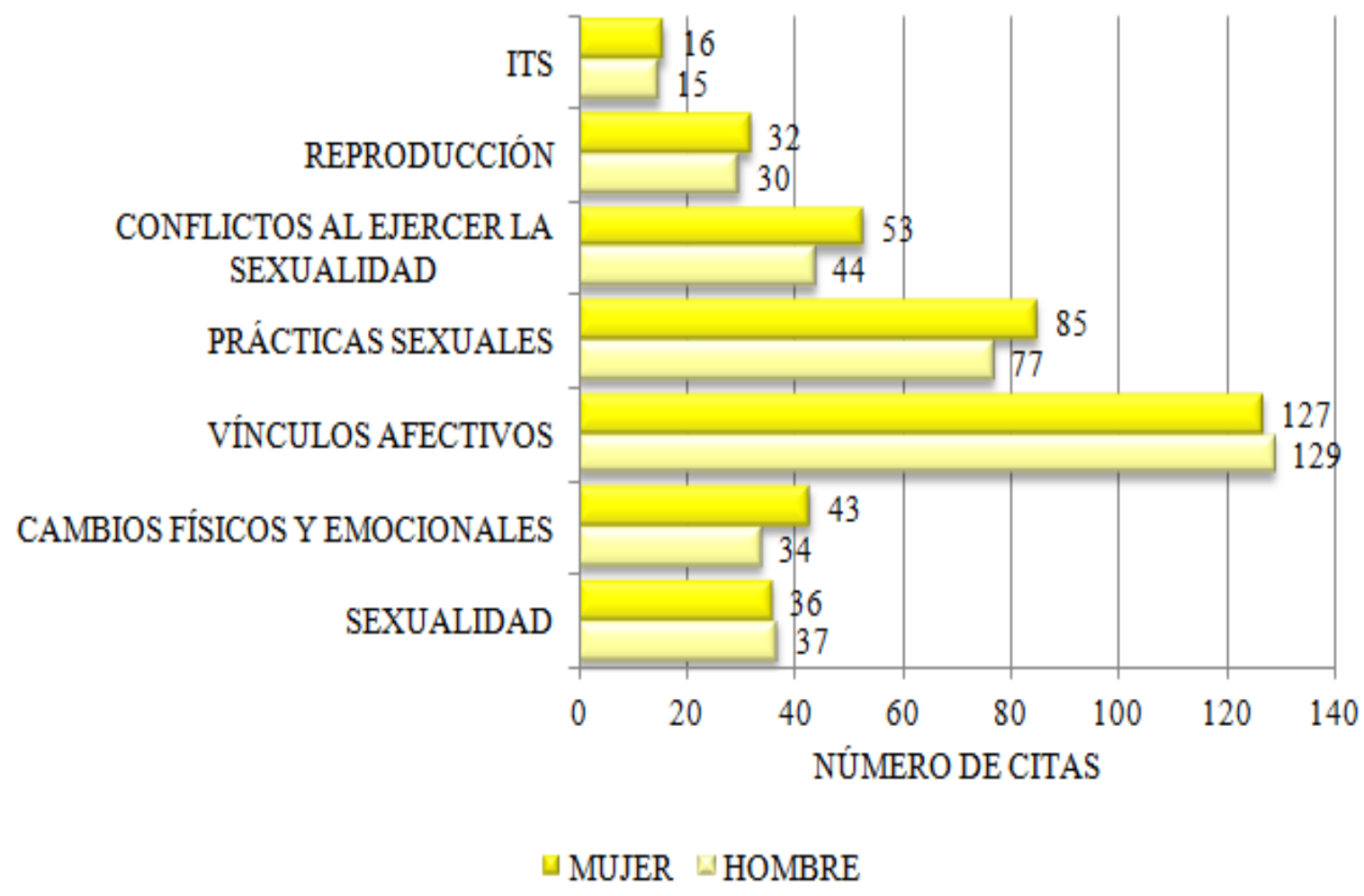

Teniendo en cuenta la zona de ubicación de las escuelas analizadas, los datos reflejan que las escuelas con mayor porcentaje de citas se encuentran en la zona urbana $(40,6 \%)$, seguida de la zona indígena $(38,9 \%)$ y finalmente la zona rural $(20,5 \%)$.

En la gráfica que se presenta a continuación podemos observar el porcentaje de citas asociadas a cada una de las sub-categorías analizadas, según la zona de ubicación. La sub-categoría con mayor porcentaje de citas en las tres zonas es la de vínculos afectivos, siendo más elevado el porcentaje de las intervenciones de la zona indígena. En cuanto a las sub-categorías de prácticas sexuales, las de conflictos al ejercer la sexualidad y los cambios físicos y emocionales, la zona urbana es la que presenta un porcentaje mayor con respecto a las otras zonas estudiadas. En la sub-categoría de reproducción se observa un porcentaje similar en las regiones donde se llevó a cabo esta investigación. 
Gráfica 7.2. Sub-categorías de sexualidad según la zona de ubicación escolar

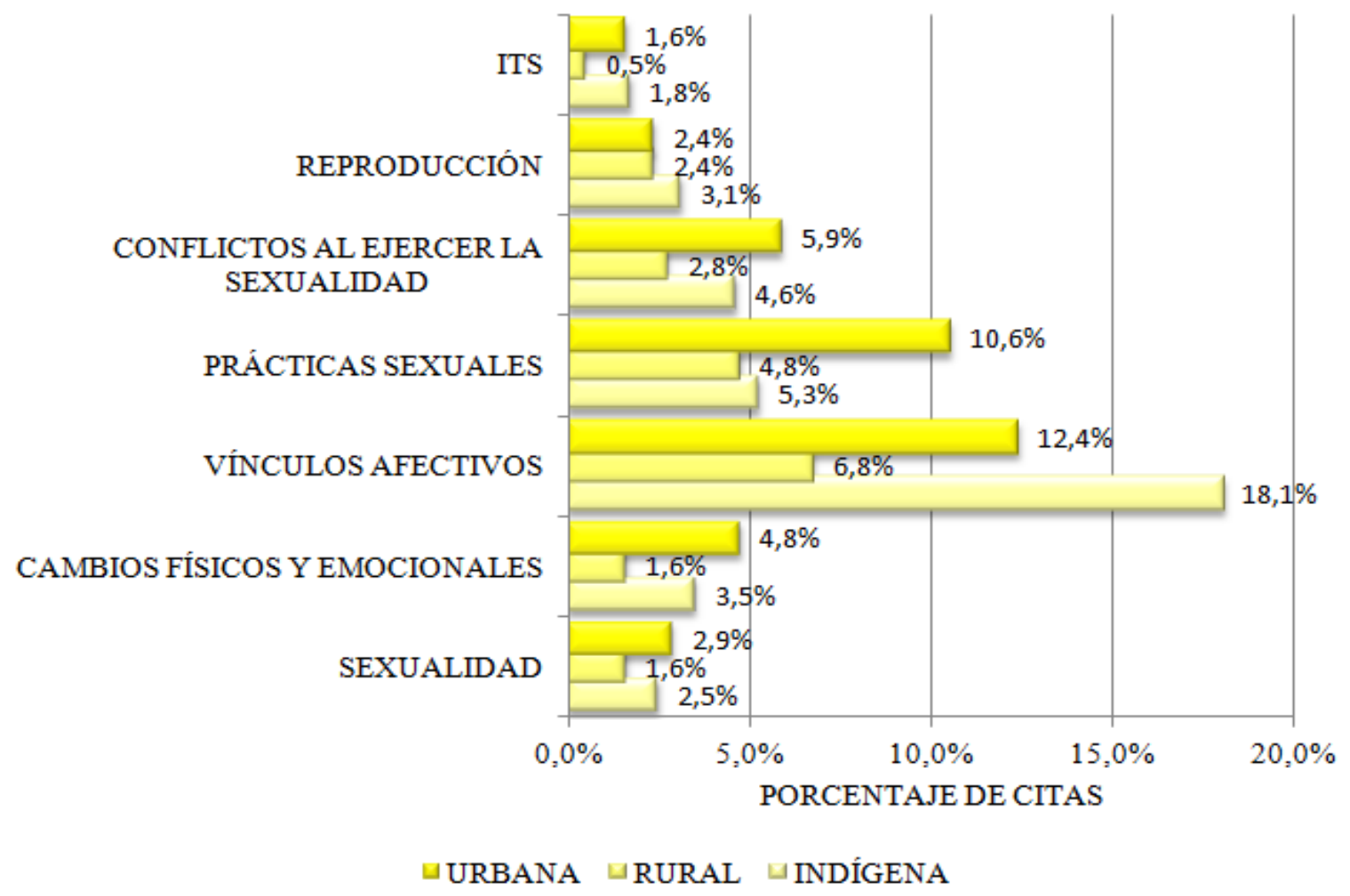

Los datos que se muestran en el esquema y en las gráficas nos ilustran de manera general cómo trascurrieron las intervenciones en los grupos de discusión. Ahora bien, como lo que pretendemos es hacer un análisis del contenido del discurso de los y las estudiantes, en los párrafos siguientes vamos a presentar la información que fueron aportando los y las jóvenes en cada una de las sub-categorías. Tras el análisis se comprobará que la educación sexual que recibe el alumnado está caracterizada por los silencios y por las restricciones.

El contenido del discurso elaborado por los y las adolescentes respecto a la sub-categoría de sexualidad refleja que este tema continúa siendo un tabú, tanto en el seno familiar como en el educativo, así lo señalan las y los adolescentes (tabla 7.1. y 7.2.).

En la tabla 7.1., que se muestra a continuación presentamos el contenido del discurso de los varones respecto a cómo obtienen información sobre la sexualidad. Los chicos de las escuelas ubicadas en zona indígena señalan que la 
información sobre sexualidad la obtienen principalmente de sus familias, de la escuela y del grupo de pares. Los chicos de las escuelas ubicadas en zona rural indican que la información sobre esta temática la obtienen de libros, de internet, de los familiares e incluso uno de ellos menciona que buscan información en videos pornográficos. Los adolescentes de zonas urbanas comentan que la información la obtienen de sus familiares, medios de comunicación (internet, tv), así como en la escuela, con los amigos y la sociedad en general.

\section{Tabla 7.1. Cómo se informan los adolescentes sobre sexualidad}

\section{Zona de}

ubicación

\section{Contenido del discurso}

escolar

$H$. De repente a unos todavía sus papás ni les explican y ya lo están diciendo sin saber.

H. Por eso cuando uno le pregunta a su mamá, que le dice "oye má, por qué esto, por qué aquello" y su mamá le dice, "no que eso no es así, que eso es bien cochino, eso no debes de escucharlo", ya entonces su hijo le pregunta a otra persona, y la otra persona le contesta pero le contesta algo malo, algo que no es. Muchas mamás tienen vergüenza de contarles pues y les dicen "no, tú no andes hablando de eso, que eso es bien cochino, a ti te trajo un avión.

(EST 112 Carapan - 4:127)

Indígena $\quad H$. Preguntamos al profe ---... de un libro.

H. Pero él no explica bien

H. Yo le pregunto a mi papá.

H. Yo a mi hermano mayor... o en la clínica.

(EST 72 Patambán - 5:22)

H. En internet, es algo que ahorita se está haciendo necesario para todo, porque aqui en San Felipe no hay bibliotecas... de las revistas, de la tv.

H. Con los padres

H. En la clínica

H. Podría ser con los maestros

(ESG San Felipe de los Alzatis - 9:207)

H: De los libros, de internet, de los papás y familiares.

H. De los videos porno

Rural

(EST 71 Nuevo Progreso - 1:22)

H. Leyendo un libro, estudiando

(EST 33 Playa azul - 8:33)

Urbana

H. De los libros de biología, de internet y de nuestros papás.

H. De la sociedad 
(ESG 02 Apatzingán - 7:28)

H. De los papás, de internet, de los amigos...

H. También podría ser de la escuela, en la asignatura de ciencias a veces el profe nos dice de la sexualidad y que debemos de cuidarnos para no tener enfermedades que pueden ser fatales.

(EST 23 Tangancícuaro - 3:102)

H. (Una chica había hecho referencia al uso de internet), También de la escuela, de los papás y de los amigos.

(EST 65 Morelia - 2:36)

H. Pues todos los comerciales que pasan sobre condones y los programas que pasan en la noche.

H. O que los mismos maestros hablen más de esas protecciones, como deben de cuidarse porque algunos maestros les da vergüenza hablar de esos temas.

H. Yo siento que a los que les debemos tener confianza es a los papás porque un amigo luego se pelean y anda diciendo todo $y$ hasta lo que no y por eso empiezan a salir mal.

(EST 05 Apatzingán - 6:128)

Nota: La simbología utilizada significa: $H .=$ hombre; $M .=$ Mujer. Es importante destacar que a partir de este momento la información por zonas territoriales se presentará en las tonalidades que se muestran en esta tabla. La zona indígena se muestra en la tonalidad más suave, la zona rural el tonalidad media y la zona urbana en tonalidad fuerte.

En la tabla 7.2. mostramos los discursos referidos por ellas. En sus discursos existen más coincidencias. Así, en las tres zonas analizadas las jóvenes señalan que su madre es a quien le tienen más confianza para hablar e informarse sobre estas temáticas. Otra coincidencia es que las madres no consideran el internet como una herramienta segura para que las adolescentes se informen (EST 71 Nuevo Progreso, EST 23 Tangancícuaro). En la información recogida en una de las escuelas de zona indígena se reitera que en ocasiones hablar sobre sexualidad con la familia resulta imposible porque a los padres y a las madres les da "vergüenza" abordarlos.

Tabla 7.2. Cómo se informan las adolescentes sobre sexualidad Zona de ubicación escolar

\section{Contenido del discurso}

M. De nuestras mamás.

M. Sí, de nuestros padres.

Indígena M. Algunas, porque a muchas les da vergüenza hablar de eso. M. A mí no me da vergüenza porque mi mamá desde la otra vez ya me dijo eso... 
M. Yo a mi mamá.

(EST 112 Carapan - 4:155)

M. También en la clínica,... [Quién las da] una la doctora... [cada cuando las reciben] Una vez al mes.

M. Sí, de las enfermedades, de la violencia, la drogadicción.

(EST 72 Patambán 5:23-29)

M. Con nuestros padres, si porque mi mamá es doctora... El Ciber

M. Con nuestros padres

M. Yo con mi mamá... en periódico y la tv.

(ESG San Felipe de los Alzatis 9:207)

M. Del internet, aunque el internet ha traído cosas buenas y malas, porque no todo ha sido bueno. Las cosas malas serían los delitos cibernéticos porque hay personas que se hacen

Rural pasar por otras y pueden llegar a hacerte mucho daño.

M. Yo creo que de los videos porno no sacan nada bueno, más bien de la información, puedes platicar con tus padres.

M. Yo me expreso mejor con mi mamá.

(EST 71 Nuevo Progreso - 1:148)

M. De los libros de biología, de internet y de nuestros papás.

M. Yo iba a decir de la comunicación con mi mamá.

(ESG 02 Apatzingán 7:29)

M. Más de los amigos porque a veces a los papás no les gusta hablar de ese tema porque les da vergüenza [...]

M. En internet dice mi mamá que no ande buscando porque hay cosas buenas, pero casi siempre hay cosas malas.

(EST 23 Tangancícuaro - 3:106)

M. En la asignatura de ciencias.

M. Algunos obtienen información de internet.

Urbana

(EST 65 Morelia - 2:36)

$M$. [Discute con un chico que hay algunos maestros que si podrían informarlos] Sobre todo porque si hay algunos maestro que tienen la capacidad y nos explican lo de sexualidad y métodos anticonceptivos, que nos dejen en claro las responsabilidades que nos va dejar tener un acto sexual y sobre todo si queda embarazada la muchacha porque hay algunas que dicen "no pues no pasa nada” y no nos dejan en claro las causas y consecuencias y todo.

M. Como también yo les tengo mucha confianza a mis tías y a mi mamá también. [...]

(EST 05 Apatzingán - 6:128-137)

En la mayor parte de los grupos de discusión, los y las estudiantes coincidieron en que los temas que se han abordado en las asignaturas 
correspondientes a Ciencias (con énfasis en biología) y de Orientación y Tutoría están relacionados principalmente con las problemáticas y conflictos que pueden producirse al ejercer la sexualidad, como es el caso de la infecciones de trasmisión sexual, el embarazo adolescente y los métodos anticonceptivos. Incluso un comentario relatado por un estudiante constata los prejuicios con los que el/la docente abordan estos temas. Refiere este alumno que les aconsejan no entablar relaciones sexo-genitales con personas que ya las hayan experimentado, como si el hecho de tener mayor experiencia en estas prácticas les restara valor como seres humanos (tercer comentario de un chico de EST 112 Carapan - 4:6).

H. Y en Biología nos explican para que ya no tomemos tanto porque de repente hay nomás formamos las relaciones sexuales y de repente cuando algunos tienen alguna enfermedad y hacen relaciones sexuales y después rápido contagian a alguien y ya tienen enfermedades.

M. Y nos explican las enfermedades de transmisión sexual, no nos prohíben que las tengamos [habla de las relaciones sexuales] pero ya cuando estemos grandes.

H. Y tampoco hacer relaciones sexuales con una mujer que ya ha tenido con otro hombre porque qué tal si ya esa mujer tiene ya alguna enfermedad y puede causar a un hombre, o un hombre puede causarle a una mujer.

(EST 112 Carapan - 4:6)

H. Pues no han dicho muchas cosas, principalmente cómo se trasmiten las enfermedades.

M. Que debemos cuidarnos mejor.

$H$. De métodos anticonceptivos.

(ESG San Felipe de los Alzatis 9:21-22-23)

M. Que cambien la materia de tutoría porque nada más entramos y no hablamos de nada.

M. Y que nos den otra materia en la que de verdad nos pongan a hacer algo.

(EST 33 Playa Azul - 8:29)

M. En Biología hemos visto la reproducción y los cambios de la adolescencia.

H y M. Y las enfermedades de transmisión sexual.

(EST 23 Tangancícuaro - 3:103)

Solo una estudiante hizo referencia a que la estrategia didáctica empleada por su docente le resulto significativa para aprender sobre sexualidad. No obstante, en su discurso se muestra una inconsistencia pues considera que la reproducción se corresponde con sexualidad: 
M: En Biología hicimos un proyecto sobre la reproducción o sexualidad, yo aprendí sobre los métodos anticonceptivos, sobre las enfermedades por contacto sexual, cómo estar preparados, porque algún día vas a tener sexo, pero no a temprana edad, porque las consecuencias van a ser fatales como un embarazo no deseado o enfermedades como VH sida.

(EST 71 Nuevo Progreso - 1:149).

En cuanto a la sub-categoría de cambios físicos y emocionales, los y las adolescentes manifiestan que esta fase de trasformación la comienzan a percibir a partir de quinto o sexto grado de primaria. Los y las estudiantes nos explican que en esta etapa tienen más conflictos familiares, pues tienden a mostrar mayor independencia y autonomía en la toma de decisiones sobre la elección de sus grupos de amigos y de sus relaciones afectivas.

M. Que nuestros papás ya nos regañan más, ya nos dan más consejos, ya no nos dejan salir tanto.

H. Ya nos regañan más porque ahorita que es la adolescencia se revelan muchos, muy feo, se salen, toman...

(EST 112 Carapan - 4:124)

H. En mí caso mi familia no comprenden muy bien, pero si por la edad, al menos me dicen que no que primero tengo que estudiar y luego tener un tiempo de vida y ya después tener esposa.

(ESG San Felipe de los Alzatis - 9:103)

M. Mi papá me dice que apenas soy como un pajarito que están creciendo mis alas y yo ya quiero volar y entiendo que todavía no estoy preparada para vivir.

(CECADEJ Internado Mixto - 10:103)

M. Mi papá ni siquiera se da cuenta, es de los que nunca tiene el detalle ni la obligación de preguntar ni donde estoy ni en mis calificaciones, y mi mamá pues no estoy con ella y la esposa de mi papá ella si se interesa por mí y lo que hace es darme consejos y apoyarme en los problemas que tengo, porque siempre que entras en la adolescencia hay más problemas tanto entre nosotros como con los demás.

M. Cuando vamos creciendo los problemas crecen con los papás por los permisos que no nos dejan salir con los amigos o por el novio.

$H$. $O$ a veces piensan que puedes agarrar vicios se vuelven más estrictos porque pues como ya estas más grande piensan que van a agarrar cosas malas.

(EST 05 Apatzingán - 6:94)

Las chicas y los chicos perciben que su apariencia física ha cambiado, que tanto su cuerpo como sus emociones se están adaptando a nuevas situaciones y 
experiencias. Los amigos/as y las relaciones afectivas empiezan a ganar importancia en esta etapa.

H. Ya no somos los mismos de antes... En nuestros cuerpos, en nuestros pensamientos

M. Pues diferente ha como pensaba antes, antes jugaba con las barbis, y ahorita ya a otra cosa, andar con las amigas.

(EST 72 Patambán - 5:20-21)

H. Comienza la sudoración del cuerpo, sale vello axilar y púbico. En el caso de las mujeres es la menstruación, el aumento de los senos...

(ESG San Felipe de los Alzatis - 9:50)

H. Los cambios físicos es cuando están en sus días las mujeres.

H. Y también a las mujeres les van creciendo los senos y a los hombres le va creciendo... ya saben (risas).

M. Nos salen espinillas, cambia la voz.

M. Los cambios de humor son como por ejemplo cuando me siento muy feliz y de repente ya estoy triste.

H. También puede ser como cuando antes les gustaba jugar algunas cosas y después ya no.

H. Los cambios depende de con quién te juntes, por ejemplo si te juntas con personas que son buenas vas a hacer bueno. Como dice el dicho el que con lobos anda a aullar se enseña. Porque si andas con gente mala que fuma y se drogan pues eso te causa mal.

(CECADEJ Internado Mixto - 10:45-46-47)

H. Que a las niñas les tiene que pasar su menstruación y a los niños los sueños húmedos.

(EST 23 Tangancícuaro - 3:17)

H. Es una nueva experiencia, una nueva etapa, conocer a nuevas personas, amigos que conoces en la escuela, este... en este mismo tiempo llegan también los cambios hormonales y emocionales, empiezas a ver las cosas de diferentes maneras, desde un punto de vista que no lo veías de chico.

(ESG 02 Apatzingán - 7:16)

Otro aspecto que nos parece importante destacar es que una de las alumnas de zona indígena manifiesta que muchas veces el desconocer lo que sucede con los cambios físicos puede resultar desconcertante:

M. [...] A nosotros el maestro de Biología nos dijo que hubo un caso de una chava que nunca le habían hablado de la menstruación y el día que le bajó se espantó mucho, pero porque no le habían hablado de eso.

(EST 112 Carapan - 4:130) 
En la zona urbana, algunas chicas manifiestan que las temáticas relacionadas con los cambios propios de las mujeres en esta etapa vienen acompañadas de faltas de respeto por parte de sus compañeros. Las chicas les preguntan directamente a los chicos por qué razón interrumpen y realizan bromas que a ellas les incomodan cuando lo que están tratando es algo que debería preocuparles también a ellos (ESG 02 Apatzingán- 7:82- 7:92).

M. Si... que los niños puedan entender que es algo serio, no es de juego. Porque siempre que intentamos hablar en el salón... cuando la maestra está hablando... por decir el día que vimos los aparatos reproductores, cuando nos tocó de mujer, todos los niños se la pasaban riéndose de nosotros. (Hablan a la vez).

M. Y también cuando se vio lo de la menstruación, ¿Y por qué piensan que es un chiste?

H. Prácticamente porque los niños desde muy temprano empiezan a hablar de eso, y empiezan a jugar.

M. No es un juego, es algo que pasa.

H. Ustedes hacen que seamos así.

M. [...] tal vez solo lo hacen por seguir la corriente.

H. Si, o por aparentar... que saben mucho y que ya lo hicieron [se refiere a las prácticas sexuales].

M. Tal vez porque les da pena el tema y quieren evadirlo.

(ESG 02 Apatzingán- 7:82- 7:92)

El prototipo de sexualidad que les es impuesto a los varones en las sociedades patriarcales influye de forma determinante en los argumentos que estos emplean para justificar las faltas de respeto a sus compañeras, al tener que aparentar que ellos son dominadores en todas las cuestiones relacionadas con el sexo. Por otra parte, restan valor a los cambios que experimentan las adolescentes. Según las chicas, sus compañeros bromean para enmascarar su falta de conocimiento.

La construcción de las relaciones afectivas es un proceso que la población juvenil va descubriendo conforme va definiendo sus gustos, intereses y aficiones. En esta etapa los vínculos afectivos adquieren mayor relevancia: la familia, los amigos y las relaciones de pareja se vuelven determinantes en la conformación de la identidad de los y las adolescentes. En esta sub-categoría 
convergen un sinfín de emociones, sensaciones y experiencias que estarán marcadas por el amor y la protección, pero también por la tensión y el conflicto.

La información que proporciona el alumnado está relacionada, pues, con sus intereses, actitudes, experiencias y puntos de vista en el terreno afectivo. No obstante, en este apartado solo vamos a hacer algunas señalizaciones, puesto que la mayoría de las intervenciones las vamos a analizar en el punto 7.3. Así pues, a continuación enunciaremos los discursos que proporcionan los y las adolescentes sobre los vínculos afectivos en la familia, con los amigos y finalmente en el noviazgo.

Con relación a la familia, como ya veíamos en párrafos anteriores (subcategoría cambios físicos y emocionales), los y las adolescente señalan que existen algunos desencuentros y tensiones ocasionadas por intentar ganar autonomía e independencia en la elección y preferencia sobre sus amistades y sus relaciones de noviazgo. No obstante, también señalan que los/as padres/madres actúan así pensando en su bienestar y para protegerlos/as (EST 05; ESG 02; EST 65; EST 23). Por otra parte, los jóvenes de las zonas indígenas manifiestan que uno de los motivos por los que toman alcohol es para llamar la atención de sus progenitores que en ocasiones reaccionan ante ese hecho (EST 112 Carapan 4:124).

M. Como también lo más común es que creemos que siempre tenemos la razón y si alguien nos reprende o no hace ver que estamos mal empezamos a creer que no nos quieren o que están en nuestra contra o simplemente quieren manejarnos sin darnos cuenta que lo hacen por nuestro bien, especialmente con nuestros papás.

M. O el problema del novio, que no llegues tan tarde, que no nos quieren dejar salir por todo lo que sale de lo que le hacen pues a las mujeres.

(EST 05 Apatzingán - 6:99)

M. Mi mamá siempre me dice que yo le cuente todo, [...] y cuando le platico algo siempre me trata de explicar bien... También de lo que pasa en la escuela me dicen que les platique

M. Mi mamá siempre me dice que no la vea solo como mamá, que a veces en ocasiones hay que verla más como mi amiga.

(ESG 02 Apatzingán - 7:221) 
M. Sentimos que nuestros papás no nos entienden. Dicen que las amistades son mal influencia.

(EST 65 Morelia - 2:38)

M. Mis papás, me dejan juntarme con algunas personas siempre y cuando no nos den mal ejemplo.

H. A veces nos dejan juntarnos con personas que sean conocidas o sean de confianza porque a veces los papás tienen sospechas con las personas que ellos no conocen.

H. Cuando una persona anda en malos pasos mejor me retiro porque mi mamá me dice que esa persona no me conviene como amistad.

H. También cuando quiero salir de viaje, una vez que invitaron no me dejó mi mamá que porque no conocía al señor y que porque era muy lejos. ¿Cómo se le llama a eso?

H. Protección.

H. También algunos alumnos no quieren dejar su amistad y se ponen rebeldes, pero los papás lo hacen por nosotros mismos, nos regañan o nos pegan para que dejemos malas amistades o andemos en malos pasos.

(EST 23 Tangancícuaro - 3:1)

H. Y los papás también nos ponen más atención... porque así se forman las redes de que se emborrachan, porque a unos sus papás no les ponen atención, que por qué no me escucha, que por qué será que no me quiere, o por qué será que me trata así. Ya por eso los papás escuchan, les ponen más atención. ¡Unos verdad, porque otros no!

(EST 112 Carapan 4:124)

En cuanto a la amistad sobre todo las chicas de los grupos de discusión, sin observar diferencias entre las zonas territoriales analizadas, señalan que las amistades son las personas que les escuchan y en quienes ellas depositan sentimientos de confianza y amor. Las relaciones de pares adquieren mayor relevancia porque según sus discursos éstas son duraderas, pueden abordar cualquier temática sin vergüenza y comparten juegos y aficiones.

M. Porque cuando hay amistad hay confianza.

M. Porque dura más una amistad que un noviazgo.

M. Un amigo te cuenta todo y a un novio no le puedes contar todo... hablamos de nuestras cosas, de lo que nos pasa.

(EST 72 Patambán - 5:63)

H. A los amigos es a quien les tenemos más confianza.

M. Sí, porque hay papás que ni siquiera quieren conversar.

M. Que ni siquiera los quieren escuchar.

(EST 112 Carapan - 4:140) 
H. A veces se juntan en bolita, 5-6 y andan en grupos relajeando, caminando, saludando a los demás [...] Me gusta mucho jugar con ellos porque a veces me divierten.

M. Las mujeres a veces nos juntamos en bolitas y al chisme, de nuestras experiencias, de los niños que nos gustan. Al menos yo sí platico de eso con mis amigas, de la moda, de la ropa.

(EST 71 Nuevo Progreso1:92)

M. Desde la primaria expresan sentimientos, emociones a los amigos.

M. Conocí a mis amigos aquí, coincidimos y nos llevamos bien.

M. Se divierten mojándose, saliendo a pasear, platicando, en internet (Messenger, facebook).

(EST 65 Morelia - 2:24-26)

M. Tenemos más confianza con los amigos porque a veces a los papás no les gusta hablar de ese tema porque les da vergüenza y hasta no nos dejan tener novio.

(EST 23 Tangancícuaro - 3:2)

M. Con sus amigos, no especialmente con sus amigos sino con la persona que más confianza le tienes, puede ser un amigo, una hermana, un tío, una mamá, porque no muchas veces los confidentes son los papás porque muchas veces se ocupan de darnos lo material y nunca se molestan en preguntarnos lo que nos pasa, lo que sentimos y a veces buscamos la confianza que no tengamos con ellos con otras personas.

M. También platicamos cosas de nosotras de lo que nos pasa porque uno a veces confia más en los amigos que en los papás... aunque hay unos amigos que les cuenta algo y se lo cuentan a otros y empiezan los chismes. Al igual con ella nos platicamos todo pero como ninguna de las dos cuenta nada de la otra, pues como nos tenemos confianza nos platicamos todo, a veces estamos mal pero al ratito estamos juntas otra vez.

H. Pero también hay amigos a los que les tienes demasiada confianza, ellos son los amigos que nunca se separan de ti, a esos son a los que debes de confiar como a los papás o alguien especial a quien le queras contar a un amigo

(EST 05 Apatzingán - 6:68-71)

El análisis del contenido de los grupos de discusión refleja que las y los adolescentes vinculan la construcción de las relaciones afectivo-sexuales exclusivamente con la heterosexualidad; refieren, de este modo, que en esta etapa se inicia la atracción por el sexo opuesto, negando con ello otras opciones de atracción (homosexualidad, bisexualidad) existentes en la sociedad:

H. En esta etapa se da la atracción por el sexo opuesto

(ESG San Felipe de los Alzatis - 9:52) 
En la mayoría de los grupos de discusión investigados los y las adolescentes refieren que los sentimientos de atracción por otra persona surgen en la parte final de la educación primaria, 10-11 años (EST 23). Sin embargo, en sus discursos - sobre todo las chicas - el iniciar una relación de noviazgo en esta etapa tiene una connotación negativa. Padres, madres y docentes les aconsejan evitarlas y esperar hasta que sean maduros para iniciar con este tipo de relaciones. Estas recomendaciones no se realizan, entonces, bajo una perspectiva de cuidado, de respeto y de amor, sino desde los silencios, la prohibición y la descalificación o menosprecio de aquellas personas (principalmente mujeres) que hayan decidido ejercer su sexualidad.

M. En algunos casos se da desde que se ingresa a la secundaria o en algunos casos desde antes.

H. Yo en la primaria tenía una compañera que ya tenía novio.

M. Algunos padres les dicen a sus hijos que no pueden tener novio porque todavía no tienen su mente madura y ellos tampoco son maduros.

M. Luego a algunos los aconsejan y les dicen que es muy divertido y los aconsejan para que tengan novios, y luego los llevan a tener problemas.

M: En la primaria nos decía la maestra que para poder tener relaciones sexuales, tenemos que tener una edad madura, casa y trabajo, para poder mantener a su familia.

(EST 23 Tangancícuaro - 3:7-83)

H. Tener novio ha repercutido en la novia de mi amigo, tenía 10 y ahora reprueba.

(EST 65 Morelia - 2:37)

M. Mis amigas siempre dicen que sus mamás nunca las entienden, porque por decir ellas les dicen a sus mamás que les gusta un niño y el niño ya le pidió que fuera su novia ... y entonces este... las mamás les dicen... No tienes permiso de tener novio... Si, mis amigas les dicen a sus mamás, y sus mamás no las dejan tener novio, eso las hace que ellas tengan novio a escondidas y que cuando se enteran las regañan.

M. Sí, es mejor que les den permiso, para que ella, la niña... tenga la seguridad...

H. Mi papá es normal. Ellos me platicaron sobre eso... yo ya tengo una educación sexual hecha, o sea me compraron una enciclopedia...

M. Mis papas desde que yo entre a la secundaria me hablaron de todo eso, porque dijeron que hay muchos niños malditos que... te quieren invitar a hacer cosas malas que no debes de hacer.

(ESG 02 Apatzingán - 7:93-:74)

En los grupos de discusión también hubo coincidencias en cuanto a las percepciones que tiene el alumnado respecto a quién ha de iniciar el cortejo en 
una relación amorosa. En todos los grupos se indicó que los hombres han de tomar la iniciativa en los rituales amorosos. Hubo únicamente dos excepciones de la misma escuela en las que se expuso que los dos podrían empezar la relación afectiva:

H. Los dos pueden pedirse ser novios.

M. Yo sí, si me gusta porque no voy a poder pedírselo.

(CECADEJ Internado Mixto -10:71-73)

En cuanto a las relaciones de noviazgo, en las escuelas de la zona indígena, la mayor parte de las chicas refirió que en sus hogares no les es permitido tener novio; en cambio, todos los chicos admitieron que les dejan tener pareja.

M. Me gustaría que me dejen tener novio.

M. Tampoco me dejan tener novio.

M. A mí tampoco me dejan.

(ESG San Felipe de los Alzatis - 9:171)

Otro aspecto en el que encontramos algunas diferencias entre los grupos de discusión según la zona de ubicación de las escuelas, es el de las expectativas con las que consideran que se inicia el noviazgo en esta etapa. Así, mientras que el alumnado de zona urbana manifiesta que las relaciones amorosas las inician como un juego o para sentirse mayores y maduros (EST 65; EST 23), los y las jóvenes de zona indígena (EST 112; ESG) indican que las inician con la intención de establecer una relación de amor, apoyo y confianza.

M. No lo toman en serio, es puro juego, no se enamoran.

$H$. Un amigo le ayuda a un chavo en algunas cosas a cambio de que le lleve recados a su novia, pero es puro juego.

M. Se presentan y se van conociendo y luego es como se hacen novios, es un juego.

M. Solo se tiene novio por decir que se tiene novio.

(EST 65 Morelia - 2:4)

H. Que un novio es para comunicar ideas y eso y no nada más por tener novia y creerte más.

M. A veces es por moda y por presumir... porque ya se sienten maduros cuando no lo están.

(EST 23 Tangancícuaro - 3:7-3:99)

H. Hablando de eso... aquí las personas solo tienen novios por tener...

M. Si, simplemente... nada más... somos novios y ya... 
(ESG 02 Apatzingán - 7:173)

M. Para poder expresar los sentimientos hacia la otra persona.

H. O conocernos.

M. Conocer muchachos.

H. Que fuera duradera y amistosa.

(EST 112 Carapan - 4:142)

M. Sincera, que no hubiera mentiras.

H. Que confiaran en ellos mismos, que tuvieran confianza porque para eso es una pareja ¿no?

(ESG San Felipe de los Alzatis - 9:8)

En la sub-categoría de prácticas sexuales se analizó principalmente lo relacionado con la iniciación sexo-genital y todas aquellas experiencias, conocimientos y opiniones que estuvieran asociados a generar placer, deseo, gozo entre las personas que se relacionan afectivamente. Ellos y ellas comentan que se inician en prácticas sexo-genitales durante su paso por la secundaria: en la mayoría de los grupos de discusión (siete de diez) hombres y mujeres coinciden en que es alrededor de los 12-13 años que inician los chicos y las mujeres 13-15.

Los discursos de los y las adolescentes reflejan que tienen un desconocimiento sobre estas temáticas, así en uno de los grupos de discusión (zona indígena) algunos alumnos ni siquiera han escuchado hablar de los condones femeninos:

H. Que quedó embarazada por no usar condón el hombre o la mujer.

H. ¿Cómo va haber condones femeninos?

H. También hay condones para mujeres, ¡no sabían o qué!

(EST 72 Patambán - 5:92)

Con relación a las motivaciones que llevan a los y las adolescentes a iniciarse sexualmente encontramos más divergencias con relación a la variable sexo que respecto a la zona de ubicación.

Entre las motivaciones que hacen que los chicos se inicien sexualmente se comentó lo siguiente:

H. Pues una atracción entre ellos, sus sentimientos que se quieren. 
H. La excitación (risas y murmullos).

H. Los vínculos afectivos, el erotismo.

(ESG San Felipe de los Alzatis - 9:73).

H. La provocación.

H. La excitación (risas y nerviosismo).

H. Empezar a usar los condones [...] También cuando se quieren burlar de ellas y dejarles un hijo y dejarlas ahí.

(EST 72 Patambán - 5:43)

H. A veces solo por curiosidad [...] O también porque algunos que ya tuvieron relaciones les dicen ¡no está bien chido! y ellos por tentación lo hacen.

H. Tal vez por lo que oyen o lo que pasa en la tele [...] Pues todos los comerciales que pasan sobre condones y los programas que pasan en la noche.

H. O también por drogas. Las drogan y ya las llevan a eso [prácticas sexuales].

(EST 05 Apatzingán - 6:46)

Las chicas refieren que lo que las motiva a iniciarse sexualmente es tener sentimientos de amor o porque se dejan llevar.

M. Porque se dejan llevar.

M. Tal vez porque el muchacho le gusta.

(EST 72 Patambán - 5:46)

M. Por los sentimientos.

M. El quererse.

M. El que se quiera la pareja.

(ESG San Felipe de los Alzatis - 9:55 - 76)

M. Que si los quieren... que les den una prueba de amor.

(ESG 02 Apatzingán - 7:93)

También el alumnado, sobre todo los de escuelas ubicadas en zona indígena y rural, señala que es más conveniente postergar las relaciones sexo-genitales hasta el matrimonio, debido a que así pueden evitar las consecuencias o problemáticas derivadas de las prácticas sexuales (ITS y embarazo no deseado). En vez de preparar al alumnado para establecer prácticas sexuales seguras y responsables, solo se promueve el postergar las relaciones afectivo-sexuales, estrategia que, por lo que comentan los y las adolescentes, no ha surtido el efecto esperado:

H: No hacer el sexo a temprana edad...

H: Y esperarse hasta el matrimonio, porque se puede contagiar de enfermedades.

M: A no tener relaciones sexuales. 
M: [...] mejor, es que te esperes, nos esperemos hasta el matrimonio.

(EST 71 Nuevo Progreso - 1:153)

H. Dicen [se refiere a los/as docentes] que no hay que correr el riesgo de contagiarnos de alguna enfermedad.

M. De esperarnos a tener relaciones sexuales a ya cuando estemos mayores.

H. Más grandes.

M. Los hombres ya que se desarrollen bien, y yo cuando ya me desarrolle bien entonces ya voy a hacer una relación sexual.

(EST 112 Carapan - 4:157)

Las problemáticas y conflictos al ejercer la sexualidad fue una de las subcategorías más recurrentes. Los discursos del alumnado de las tres zonas analizadas señalan principalmente tres consecuencias o problemáticas al ejercer la sexualidad en edades tempranas: el fugarse con el novio, el embarazo adolescente y las infecciones de transmisión sexual (ITS). A continuación iremos detallando los discursos que han referido los y las alumnos/as que participaron en esta investigación acerca de estos tres aspectos:

La primera consecuencia, fugarse con el novio o "se la robó el novio", alude al establecimiento de relaciones afectivas formales que fracasan al poco tiempo de iniciarse, acarreando, sobre todo en las mujeres, problemáticas de prestigio y falta de oportunidades educativas y laborales:

M. Se creen ya las muy grandes para poder hacerse cargo de un hijo, aquí a veces se casan a los 12 años.

M: Aquí se han casado dos niñas de segundo de esta escuela.

$H$. [Y chicos] de tercero, puro de tercero ¿verdad?

H. Sí

(EST 112 Carapan - 4:43-46)

H. Cuando se roban a la novia luego ellos las tienen que mantener.

H. Cuando se casan muy chicos los papás dicen que el novio todavía va a ir a la escuela, y la novia pues ya se queda a hacer el quehacer [...]

M. Sí, se van a trabajar, los mandan a trabajar sus papás, o algunos nada más están ahí y sus mamás los cuidan, o ellos se van a la escuela y su esposa nada más ahí se queda.

(EST 112 Carapan- 4:80-83)

H. Sí, ya después no las quieren porque se les quito lo virgen (risas).

(EST 33 Playa Azul - 8:10)

M. Se van con ellos y al final termina hasta peleados que porque ya no se quieren. 
(CECADEJ Internado Mixto -10:57)

La segunda, la referida al embarazo adolescente, conlleva dependencia económica y obligación de ejercer las tareas domésticas en el ámbito privado. Sobre esta problemática las que más comentan son las mujeres, como se puede observar a continuación.

M. Pues se dejan embarazar por descuido. Tal vez se dejan llevar y caen en la tentación.

(EST 72 Patambán - 5:86)

M. Nos platicaron de una chica... que se quedo embarazada y se tuvo que salir de la escuela.

(EST 65 Morelia - 2:30)

M. [...] tengo una vecina que tiene apenas 13 años y ya tiene un niño de un año $y$ pues se ve mal, porque en vez de estar estudiando se ponen a cuidar niños, pero por qué lo hacen, porque no van a la escuela, no platican con sus padres.

M. También en la noche que pasan las películas de porno los alumnos en vez de ponerse hacer tarea se ponen a ver eso y pues muchas muchachas salen embarazadas y también por falta de dinero y les dicen que vente para acá y pues ellas que saben por dinero va a hacer lo que les dicen.

H. Hubo una compañera que iba con nosotros y ella no quiso medir las consecuencias y quedó embarazada.

H. En mi salón también hubo una que se tuvo que salir en el tercer bimestre porque se quedó embarazada.

(EST 05 Apatzingán - 6:39 - 45 - 47)

Respecto a la tercera consecuencia al ejercer la sexualidad a edades tempranas, la concerniente al riesgo de contagiarse de alguna infección por trasmisión sexual, destaca la mayor participación de los hombres, que expresan su temor ante la promiscuidad como elemento favorecedor de las ITS.

M. Que es muy mal porque si tuvo relaciones con alguien más grande que ella, le puede pegar una enfermedad que no se quita y a la mejor no más lo hace por curiosidad.

(EST 72 Patambán - 5:88)

H. Hay hombres que ya se metieron con las de las cantinas pues, y ya tienen una enfermedad como, por ejemplo la gonorrea y como les gustó ya lo quieren hacer con otras mujeres y a veces no miden las precauciones pues y ya lo hacen con las mujeres y las mujeres sin darse cuenta de lo que ya había hecho.

$H$. O lo del sida, que en venganza quieren contagiar a otras personas. 
H. O a la mejor o los hombres que ya están casados se van a las cantinas se meten con otras mujeres que están infectadas de alguna enfermedad, se van a su casa se meten con la mujer y le pegan la enfermedad.

H. Y ya nacen los hijos infectados o a veces cuando ya están bien... (No se entiende) $y$ dicen de todas formas me voy a morir se ponen una jeringa y se sacan sangre $y$ empiezan a infectar a las otras personas, eso paso en África.

(EST 05 Apatzingán - 6:46)

H. Yo tenía una amiga que se fue de su casa a los 13 años... [Interviene otro adolescente ise la robaron!... I y como al año le llegó la noticia que su hija se había muerto de Sida... se contagió...

(ESG 02 Apatzingán 7:93)

H. [Los adolescentes que se infectan] podría ser que [actuaran] muy desesperadamente porque no saben qué hacer a tan corta edad.

(EST 23 Tangancícuaro - 3:20)

\subsubsection{Resumen}

El análisis del contenido del discurso nos permite constatar que la información que respecto a la sexualidad recibe el alumnado de las tres zonas estudiadas está basada en prejuicios y estereotipos de género. A continuación mencionaremos los puntos que consideramos que resumen los discursos proporcionados por el alumnado:

- Hombres y mujeres sienten interés por el tema de la sexualidad, sin embargo la información que reciben propicia que no lo aborden de manera natural. Eso se muestra, además de en cómo evitan decir la palabra sexo en sus discursos, en sus risas y murmullos.

- Existe una doble moral basada en el sexo: se espera y se juzga que el comportamiento en el terreno sexual y afectivo sea distinto en los hombres y en las mujeres.

- Los chicos, cuando hacen referencia a la sexualidad, intentan mostrar dominio y conocimiento llevando la iniciativa, mostrándose atrevidos, sarcásticos y confiados. Las chicas, por su parte, hablan en tono más 
bajo, se muestran interesadas y sobre todo preocupadas por evitar las consecuencias o problemáticas al ejercer la sexualidad.

- Los chicos y las chicas en sus discursos hacen referencia continuamente a casos de personas de su entorno más próximo que han sufrido las consecuencias de haber mantenido relaciones sexuales sin responsabilidad.

- Encontramos diferencias en cuanto a las expectativas al iniciar el noviazgo entre las zonas territoriales analizadas. Así, mientras que hombres y mujeres de zona indígena y rural manifiestan que les gustaría emprender un noviazgo duradero basado en la confianza y el cariño, los/as de zona urbana señalan que el noviazgo en esta etapa es un juego que les permite sentirse más mayores y maduros.

\subsection{Percepciones sobre el género}

En este apartado vamos a analizar el contenido del discurso sobre la categoría género, que engloba siete sub-categorías: cinco de las cuales fueron creadas $a$ priori y dos se elaboraron durante el análisis. A continuación mostramos un esquema, el 7.3., en el que se pueden observar las relaciones que se establecieron entre las sub-categorías analizadas y las citas que se recopilaron de los discursos del alumnado que participó en esta investigación.

Haciendo una lectura de los datos analizado con el programa ATLAS.ti versión 7.5, y que aparecen en el esquema 7.3., observamos que la sub-categoría con más citas es la de roles y estereotipos de género, debido a que en ella se recogen todos los discursos que proporcionan los y las jóvenes que denotan prejuicios o ideas preconcebidas en cuanto a lo que es "propio de las mujeres" y lo que es "propio de los hombres". Las que, en cambio, tienen un menor 
número de citas asociadas son las sub-categorías de desigualdad (47), ${ }^{153}$ derechos y oportunidades $(47)^{154} \mathrm{y}$ acceso al poder (53). ${ }^{155}$

\section{Esquema 7.3. Categoría de género y las relaciones entre sus sub-categorías}

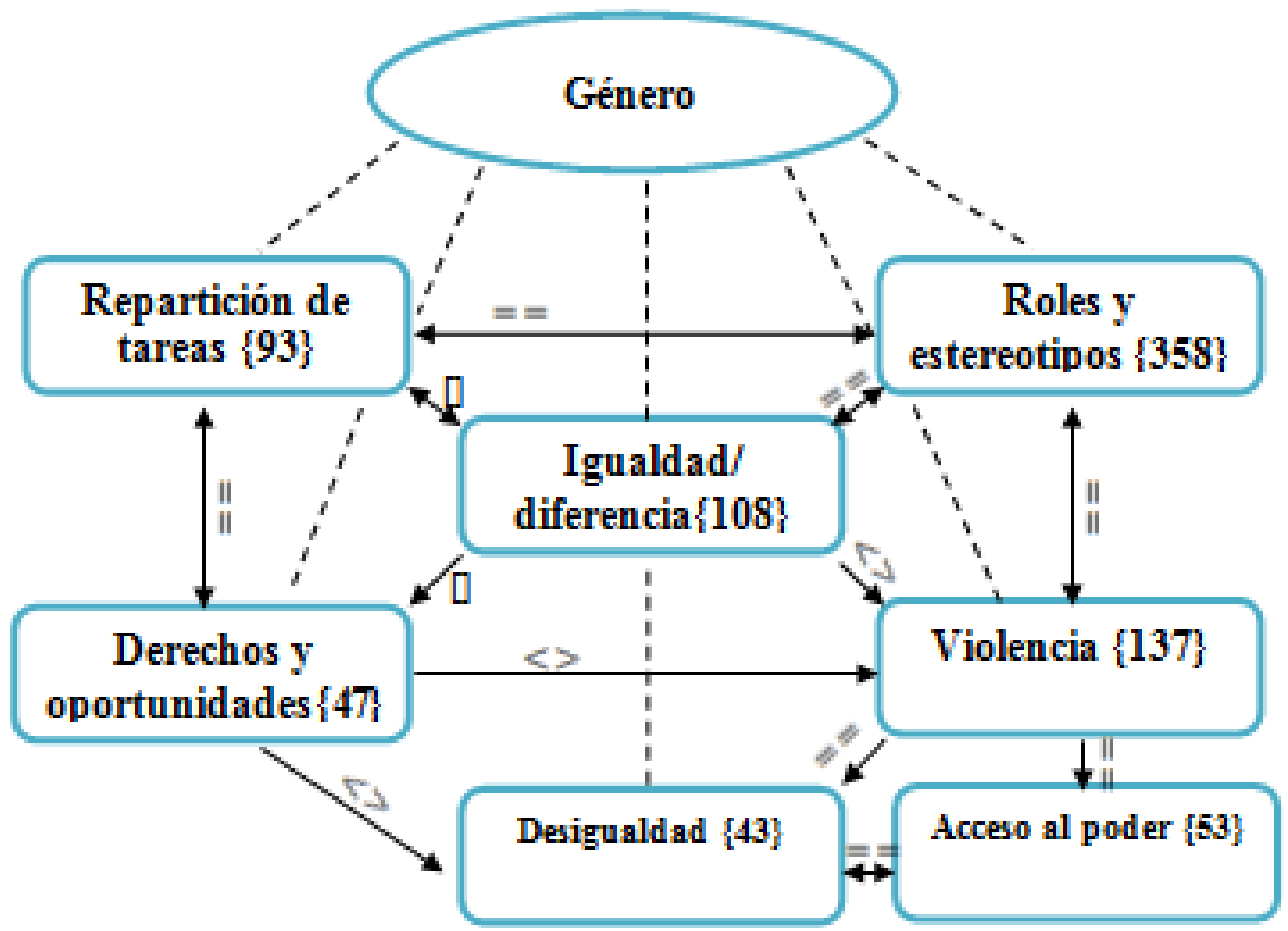

Nota: simbología de las relaciones: $==$ asociada con; [] parte de; $\left\langle>\right.$ contradice $a^{156}$

La información que proporcionan los y las alumnos/as sobre esta categoría refleja que esta temática es escasamente abordada dentro de las aulas. La igualdad entre hombres y mujeres en el discurso de las y los estudiantes aparece como un objetivo ya cumplido. No obstante, al indagar sobre la repartición de tareas en los distintos ámbitos en los que se desenvuelven (familiar, relaciones

${ }^{153}$ En la sub-categoría de desigualdad se recogen las percepciones del alumnado sobre las situaciones asimétricas que reconozcan en su hacer cotidiano.

${ }^{154} \mathrm{La}$ segunda sub-categoría menos referida recoge la información que tiene el alumnado sobre los derechos y obligaciones en materia de igualdad y equidad de género.

${ }^{155}$ Finalmente, en la tercera sub-categoría menos citada, se analizan los discursos que hacen referencia al empleo de la violencia o la coerción para acceder al poder.

${ }^{156}$ Como se refería en el aparatado anterior el número de citas corresponde al total. En el análisis que se lleva a cabo en este apartado solo se hará referencia a las citas que aparezcan de manera exclusiva en la categoría género y que no se correspondan con la categoría de sexualidad. 
afectiva entre pares, escolar) las chicas muestran mayor percepción respecto a las desigualdades existentes entre los sexos.

En la gráfica que presentamos a continuación se pueden observar las intervenciones que tuvieron hombres y mujeres en esta categoría. Los datos muestran que los hombres tienen más citas asociadas en las sub-categorías de estereotipos de género (tres por ciento más que las mujeres), repartición de tareas, violencia y acceso al poder (con menos de dos punto porcentuales). Por su parte, las mujeres tienen más citas asociadas en las sub-categorías de desigualdad y en derechos y oportunidades.

Gráfica 7.3. Sub-categorías de género según el sexo del alumnado

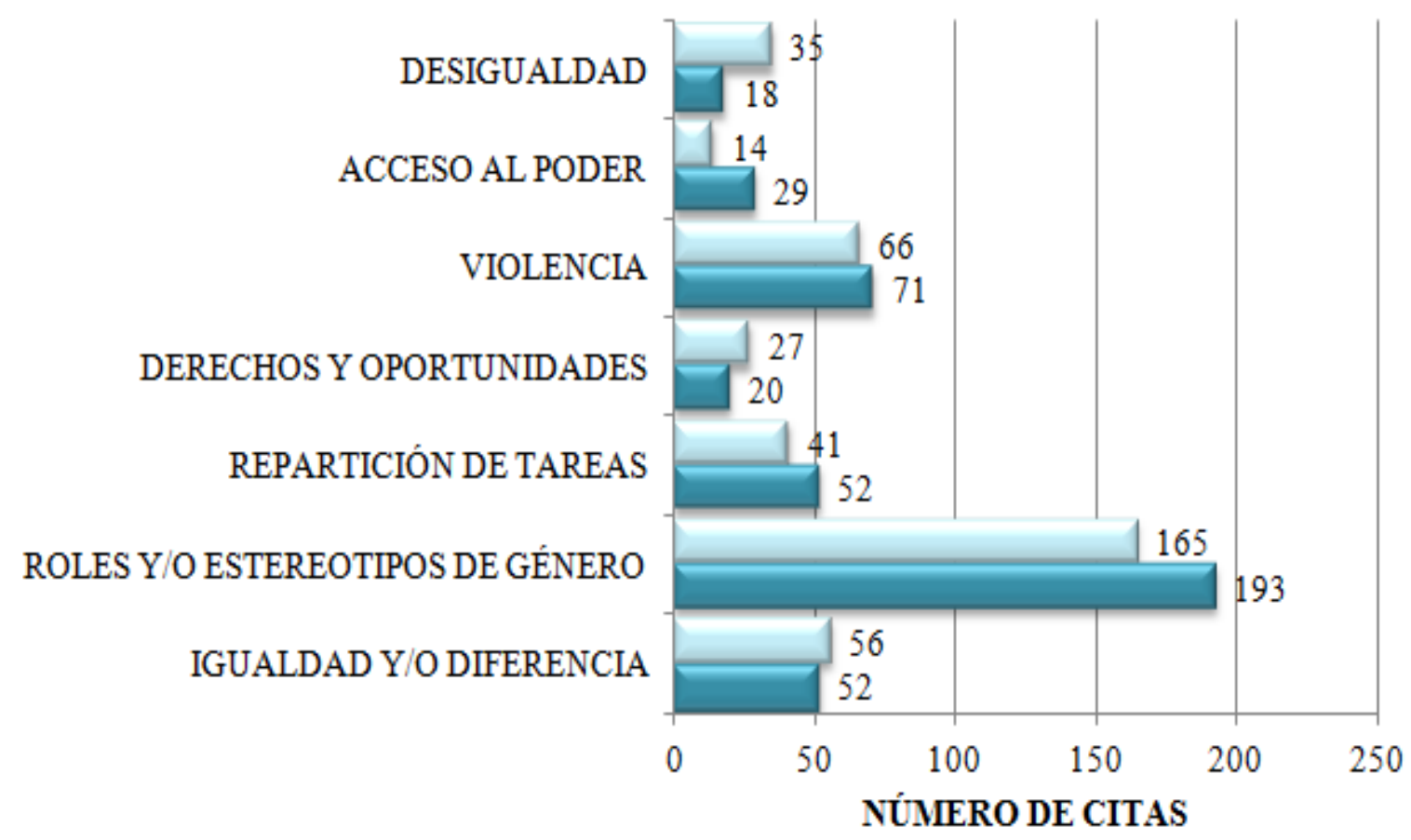

\section{$\triangle$ MUJER $\square$ HOMBRE}

En cuanto a la distribución de citas que se generaron en los distintos contextos analizados, tenemos que en la zona indígena están la mayor parte de las citas asociadas (cuarenta por ciento), seguida de la zona urbana (33 por ciento) y finalmente la rural (27 por ciento). A continuación presentamos una gráfica, 7.4., en la que se puede observar el porcentaje de citas asociadas a cada sub-categoría. 
Gráfica 7.4. Sub-categorías de género según la zona de ubicación escolar

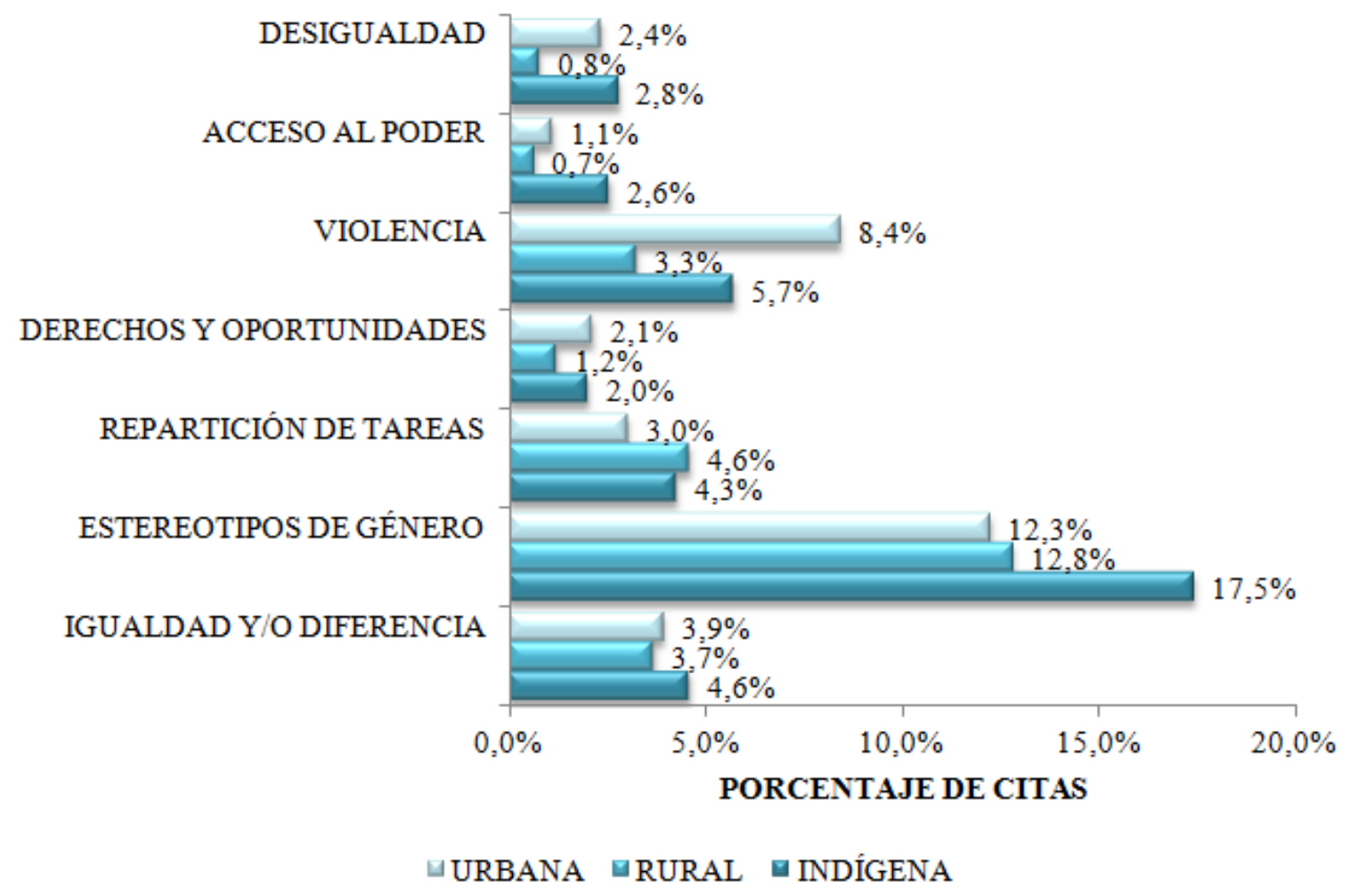

En la gráfica 7.4. se muestra que el alumnado de zona indígena tiene un mayor porcentaje de citas asociadas a la sub-categoría estereotipos de género y a la de igualdad/diferencia. La zona rural tiene un mayor porcentaje de citas asociadas a la sub-categoría repartición de tareas, mientras que la zona urbana obtiene mayores puntuaciones en violencia.

Una vez obtenido el panorama general de cómo se dieron las intervenciones en los grupos de discusión, pasamos a detallar el contenido del discurso que proporcionaron los y las adolescentes sobre esta categoría. Para ello, iremos seleccionando los discursos que consideramos que reflejan las percepciones y opiniones del alumnado, siguiendo el orden de presentación de las subcategorías propuestas en el marco metodológico.

- Igualdad diferencia

- Roles y estereotipos de género

- Repartición de tareas

- Derechos y oportunidades 
- Violencia

- Acceso al poder

- Desigualdad

La presentación del contenido del discurso, al igual que en apartado anterior, se realiza por colores. En este epígrafe utilizaremos distintas tonalidades de color azul, siendo el tono más suave para la zona indígena, el medio para la zona rural y el tono fuerte para la zona urbana.

Vamos a iniciar por destacar que el alumnado de la mitad de los grupos de discusión (5) manifestó que en la asignatura de Ciencias (con énfasis en biología) y en la de orientación y tutoría no han abordado la temática de igualdad y equidad de género. Solamente en cinco grupos refirieron que habían tratado en clase el tema.

M. Que en tutoría nos explica la maestra cómo nos debemos de respetar o cómo debemos de entender bien las cosas.

(EST 112 Carapan - 4:157)

M. En la materia de ciencias nos hablan sobre todo de eso, [...] así como de la equidad de género entre hombres y mujeres, que tenían los mismos derechos.

M. Nada más la de biología [...]

(ESG San Felipe de los Alzatis - 9:206)

M. Que tenemos los mismos derechos entre hombre y mujer.

(EST 33 Playa Azul - 8:29)

M. En biología hemos visto los estereotipos.

H. Sí, los estereotipos del hombre y de la mujer.

(CECADEJ Internado Mixto - 10:114)

H. En biología nos han enseñado sobre eso.

M. Vienen los derechos de hombres y mujeres, la igualdad de género.

(EST 65 Morelia - 2:2)

Los y las estudiantes que refirieron que habían abordado la igualdad y equidad de género en sus clases, no muestran tener mayor información que el resto de compañeros/as que no la habían recibido. Tal como se refleja a continuación, los y las adolescentes no tienen claro qué es la igualdad, la equidad, y la no discriminación por razón de sexo. Los/as alumnos/as hacen 
referencia a que todos/as tenemos los mismos derechos, pero nunca citan ejemplos concretos que tengan que ver con la igualdad de género.

M. Que ahora las mujeres valemos tanto como valen los hombres.

(EST 112 Carapan 4:90)

H. A no ser discriminados.

M. A no ser discriminados, por decir si tiene una enfermedad como el SIDA no discriminar a la persona que lo tiene.

M. A que todos somos iguales.

$H$. A que todos somos equivalentes a lo mismo.

H. Que nadie vale más que otro, sea porque alguien tiene más dinero, sea pobre o rico, como sea valemos lo mismo.

H. Que no hay distinción de clases sociales.

(ESG San Felipe de los Alzatis - 9:32 -206)

M. Creo que debes tratar a hombres y a mujeres por igual [...]

(EST 71 Nuevo Progreso - 1:19)

H. [a qué se refieren los estereotipos de género] como la manera de pensar de cada quien, como una señora que esta delgadita y se siente gorda porque su esposo lo dice.

(CECADEJ Internado Mixto - 10:114)

M. Que las niñas y los niños tenemos los mismos derechos aunque diferentes cosas, que se nos tiene que tratar igual [...]

(EST 23 Tangancícuaro - 3:31)

M. La discriminación entre los dos... los flaquitos, los chaparritos...

(ESG 02 Apatzingán - 7:14)

Solo dos intervenciones por parte del alumnado se aproximan al significado del concepto de igualdad de género.

M. Tener los mismos derechos para todas las cosas, por ejemplo, los talleres de cocina que sean para hombres y para mujeres porque también hay muchos hombres que pueden ser chefs.

H. Como si en una balanza pusieran a un hombre a una mujer y estuvieran los dos igual.

(ESG San Felipe de los Alzatis - 9:32)

Otro aspecto que queremos destacar es que en la mayor parte de los grupos de discusión (9 de 10) los y las adolescentes, ante la pregunta ¿Ustedes creen que hay igualdad entre hombres y mujeres aquí en la escuela?, manifestaron que la igualdad de género es un derecho ya conseguido en el terreno educativo. Vamos

a retomar los argumentos que dan mujeres y hombres de la EST 23 de Tangancícuaro para ejemplificar que cuando ellos/as hacen referencia a la 
igualdad, no se están refiriendo a una cultura escolar que promueva los derechos humanos desde el respeto y potenciación del desarrollo de las personas, sino a una igualdad de acceso a la educación.

\footnotetext{
M y H. Aquí en la escuela nos tratan por igual.

M. [...] No me gusta que antes a las niñas les daban poquito de comer porque los niños tenían que salir a trabajar y las niñas se quedaban en la casa.

M. Niños y niñas tienen las mismas oportunidades. Antes nada más a los niños los mandaba a la escuela y a las niñas no les permitian estudiar... y también, lei en un libro que una mujer hizo una cosa para ser tratada como hombre pero la sacaron de la cárcel porque no la juzgaron como hombre y ella quería que sí lo hicieran.

$H$. Antes también el voto, sólo los hombres iban a votar y ahora también las mujeres pueden ir a votar.

H. Antes iban nada más los hombres a la escuela pero ahora en las escuelas hay más mujeres que hombres.
}

(EST 23 Tangancícuaro - 3:31 - :41)

Como mencionábamos con anterioridad, solo en un grupo de discusión una de las alumnas refirió que en su escuela no existe igualdad de género, pues ellas están sujetas a continuas faltas de respeto por el hecho de ser mujeres.

M. Yo diría que es muy poca [la igualdad] porque de hecho ya ni nosotras respetamos a los hombres, ni mucho menos ellos nos respetan a nosotras, se ponen a decirnos cosas, nos avientan, a veces nos faltan al respeto, nos levantan la falda o así.

(EST 05 Apatzingán - 6:46)

En esta sub-categoría se muestra cómo el orden social — basado tanto en el ejercicio diferenciado como en la desigual de las relaciones entre los sexos-, determina las percepciones de los y las adolescentes. Sus discursos neutralizan y normalizan las desigualdades entre hombres y mujeres y, aunque indagando sobre otras cuestiones pueden reconocer la carencia de equidad entre unos y otras, la percepción sobre la consecución de la igualdad en el campo educativo es compartida por la mayoría de los participantes de este estudio.

Asimismo, las atribuciones, expectativas, funciones, creencias sobre lo que un hombres o una mujer "deben de" ser y/o hacer están claramente diferenciadas en los discursos de los y las adolescentes. Las informaciones 
proporcionadas por el alumnado respecto a la sub-categoría de roles y estereotipos de género muestran, sin apenas diferencia entre las distintas zonas analizadas, que las relaciones entre varones y mujeres están marcadas por patrones de comportamiento socioculturales diferenciados y asimétricos. Los estereotipos de género atribuidos a los chicos están relacionadas con la fortaleza, el dinamismo, la valentía, la protección, el riesgo y la inteligencia, entre otros. Los estereotipos de género que se atribuyen a las chicas son la pasividad, la dependencia, la afectividad, el orden, la empatía y la comunicación. A continuación, y separando las percepciones de ellos y de ellas, referimos algunos de los discursos que constatan los estereotipos que hemos enunciado.

\section{Percepciones de los adolescentes hombres sobre sí mismos}

H. [...] los hombres desarrollan más los músculos y pues los puños.

H. A pesar de todo, los hombres tienen más fuerza.

H. Pues que pueden hacer trabajos más duros como en el campo, que las mujeres no podrían hacer.

(ESG San Felipe de los Alzatis -9:148)

H. Entre hombres [hablamos] de futbol, de deporte, de música.

(ESG San Felipe de los Alzatis -9:123

H. [Entre hombres hablamos] del mundial... de que ya va ganando México, y que va con Francia.

(EST 72 Patambán - 5:69)

H. Que somos más fuertes.

H. Que somos más inteligentes.

(EST 72 Patambán - 5:135)

H. Platicamos de cuando vamos a la fiesta de sus experiencias. Cuando vamos a la casa de un amigo nos ponemos a platicar de una fiesta, o así... Cuando se van a tocar mi primo platica sobre cosas que sucede, cuántas horas trabajan, y así.

H. De experiencias de cuando andamos en caballo.

H. De futbol, voleibol y de básquetbol.

(EST 71 Nuevo Progreso -1:96)

H. [...] los hombres no [están tranquilos], siempre nos estamos pegando zapes entre nosotros.

(CECADEJ Internado Mixto - 10:7)

H. [Los hombres hablan] de deportes, de las materias.

H. De todo.

(EST 65 Morelia -2:26) 
H: Las ventajas de ser hombre podría ser que puedes tener un trabajo mejor pagado que las mujeres.

H. Que tienen más oportunidades de trabajo que las mujeres.

(EST 23 Tangancícuaro - 3:13)

H. Físicamente somos mejores de naturaleza...

(ESG 02 Apatzingán - 7:14)

\section{Percepciones de ellos respecto a ellas}

H. [Ellas hablan] de qué me voy a poner, del maquillaje, de la ropa que van a usar.

EST 72 Patambán -5:72

H. Las chicas platican de las telenovelas... de sus novios.

$H$. De cuales películas vieron, de sus viajes y sus aventuras.

$H$. [Ventajas de las mujeres] que da vida a otra vida.

(ESG San Felipe de los Alzatis-9:121)

H. [Ir de fiesta] ... es más peligroso [para una mujer], porque entre más tarde llegue la niña ahí en la calle nunca falta que pueda pasar, podrían abusar de ella o [...] podrían agredirle, pero hay más riesgo en las mujeres.

H. Pero hay más riesgo por si hay un loco o un violador.

$H$. [...] un hombre cuando toma alcohol no se ve tan mal como una mujer porque el ser humano ya está acostumbrado a que las mujeres no deben de hacer eso. O sea póngale que ellas dicen que sí se controlan, pero pues si se ven mal con una cuba [copa] en la mano o una cerveza.

(ESG San Felipe de los Alzatis - 9:11)

H. [Ventajas de las mujeres] que las mujeres pasan primero, apoco no ha visto la película de Titanic primero pasan a las mujeres y a los niños (risas).

$H$. Es que las mujeres siempre están bien tranquilas en el chisme.

(CECADEJ Internado Mixto - 10:7)

\section{Percepciones de las adolescentes mujeres sobre sí mismas}

M. [Ventajas de las mujeres] son más ordenadas.

M. [Las mujeres hablan] de ropa, de chicos, de zapatos...

M. O también de sus chismes.

(ESG San Felipe de los Alzatis 9:122)

M. [Las mujeres hablan] de los muchachos que nos gustan

M. De lo que nos pasa, de nuestros sentimientos y de los muchachos que nos gustan.

(EST 72 Patambán -5:70)

M. Las mujeres a veces nos juntamos en bolitas y al chisme, de nuestras experiencias, de los niños que nos gustan. Al menos yo sí platico de eso con mis amigas, de la moda, de la ropa.

M. De las novelas.

(EST 71 Nuevo Progreso -1:92)

M. [Ventajas] Las mujeres podemos pensar en más cosas a la vez y ellos no. 
M. [Las mujeres hablan] de las materias.

(CECADEJ Internado Mixto - 10:7)

M. De lo que pasa con los papás.

M. De lo del novio.

(EST 65 Morelia -2:26)

M. Que las mujeres también tienen oportunidades de trabajo, por ejemplo que una vecina trabaja en un camión.

(EST 23 Tangancícuaro - 3:13)

\section{Percepciones de ellas respecto a ellos}

M. De futbol, nada más están diciendo: que la abrace, que la bese.

$M$. Ellos platican que si tienen novia platican de lo que hacen con las novias.

M. Pues de las muchachas, de que ha soñado con la novia y de eso [se refiere a las prácticas sexuales].

(EST 72 Patambán - 5:76)

M. De deportes o de alguna persona ... pues de chicas.

(ESG San Felipe de los Alzatis 9:126)

Lo que llama más la atención de estos discursos es que las percepciones de unos y otras respecto al otro sexo coinciden en cómo se perciben a sí mismos. Esto muestra que los y las adolescentes se asumen en estereotipos y roles de género tradicionales sobre la feminidad y la masculinidad. Solo en uno de los grupos (de zona urbana) las mujeres discutieron con los varones por encasillarlas en estereotipos de género que ellas consideran no "propios de las mujeres", como mostramos a continuación:

M. Los hombres se creen superiores que las mujeres.

$H$. Es que fisicamente somos mejores...

M. Claro que no... una mujer puede ser mejor que un hombre fisicamente (varias responden a la vez).

H. ¿Por qué, a ver?

M. Pero también podemos ser mejores...

H. ¿Pueden?...

M. Los hombres no pueden... bueno si pueden pero no quieren o no sé... barrer, trapear, hacer el aseo de la casa...

H. Yo si lo hago...

M. Sí, pero por que la mamá los pone...

H. Pero los hombres trabajamos más que las mujeres.

H. Que trabajamos para darles a ellas de comer y todo...

M. Y qué... también las mujeres trabajan... 


\section{Las mujeres también pueden trabajar... \\ H. Pero no igual... \\ M. Claro que sí... Y hasta más que ustedes...}

(ESG 02 Apatzingán - 7:14)

Pasando ahora a la sub-categoría de repartición de tareas, comprobamos que también está asociada a los estereotipos de género. Ello se debe a que el asumir un rol femenino o masculino no solo significa actuar bajo ciertas normas, sino que además guarda relación con las funciones, los espacios y las tareas que vamos a desempeñar en los diversos ámbitos en los que nos desenvolvemos.

Los discursos aportados por las y los adolescentes nos muestran que la separación de espacios, actividades y funciones en razón de sexo continúan persistiendo no solo en el hogar, sino también en el ámbito educativo.

Existe una percepción rígida (sobre todo en los varones) en cuanto a considerar que los hombres han de ocupar los espacios públicos y exteriores, mientras que los espacios considerados apropiados para ellas son los privados/domésticos. Como veíamos en la discusión anteriormente presentada del alumnado de Apatzingán $\mathrm{N}^{\circ} 2$, hombres y mujeres reconocen que las mujeres se han incorporado al mercado laboral. Sin embargo las tareas del hogar (el cuidado de los/as hijos/as y el quehacer doméstico, entre otros) continúan recayendo sobre las mujeres. Asimismo, un hombre puede ser criticado/sancionado socialmente por desempeñar funciones que son atribuidas como "propias de mujeres". En cuanto a la repartición de tareas en el hogar los y las adolescentes refirieron lo siguiente:

M. [...] los hombres ya no hacen cosas en su casa, por decir los niños, llegan de la escuela, se salen y a jugar.

H. Pero no todos.

M. Y los señores se van a trabajar, llegan y comen y ya no hacen lo que las mujeres hacen.

H. Pero la mayoría lo hace, porque la mayoría trabajan tanto hombres como mujeres y descansan igual.

M. Porque dice la gente que un hombre que no tiene el mismo cuerpo que una mujer ¿qué no tiene manos o qué no tiene pies para hacer lo mismo que hace una mujer? Y a 
la mujer le dicen lo mismo, ¿qué no puedes tú hacer eso mismo que hacen los hombres? O que no dejan que hagas tú eso.

H. O también cuando el esposo se emborracha manda a la señora a traer leña y el esposo nada más ahí se queda tomando.

H. Y deja que la muchacha haga todo en la casa y que el hombre no haga nada.

M. Que se quede acostado en la cama.

H. Pero a mí no me parece eso bien, porque cualquier cosita que hagan los hombres que le toca a la mujer luego, luego le dicen eso que es ijoto!, y a mí no me parece porque no porque el hombre haga algo que le "pertenece a la mujer" se va a morir o le va a pasar algo.

(EST 112 Carapan - 4:8)

H. Hasta ahorita yo veo que ya las mujeres trabajan también en el campo.

H. Sí, ya hay muchas señoras de Carapan que van a Tangancícuaro a trabajar en la fresa.

(EST 112 Carapan - 4:26)

H. Como a mis hermanas las ponen a barrer y a trapear y a mí no. Yo le ayudo a mi papá a trabajar.

(EST 72 Patambán - 5:141)

H. Porque a veces no está mi mamá y nada más nos quedamos mi hermano y yo y cocinamos y a veces se nos quema la comida. [El alumno señala que le gustaría que hubiese cursos de cocina para que les enseñaran cosas básicas, porque su madre que es quien se ocupa de esas tareas algunas veces no está].

(ESG San Felipe de los Alzatis - 9:20)

H. [Cosas que no le permiten por ser hombre] ayudarle a hacer el quehacer de la casa a mi mamá. Sí, sí me dejan pero si hay amigos que son machistas, si te ven te empiezan a decir "tú que no sé qué" y te empiezan a discriminar.

(ESG San Felipe de los Alzatis - 9:11)

H. Que las mamás trajeran recetas, si se pudiera. [Hace referencia a que le gustaría que su mamá pudiera pasar sus recetas al comedor escolar].

(EST 71 Nuevo Progreso - 1:24)

M. A algunos hombres les gusta quedarse en la casa y que sea la mujer la que salga a trabajar y cuando llega a la casa le toca hacer todo el quehacer.

M. Yo escuché al novio de una amiga que decía que se iban al cerro para el otro día a sembrar, su mamá, su hermana... todas. Y no hacían nada en la casa. En la noche que regresaban los hombres se iban a descansar y ellas se ponían a hacer el quehacer.

H. Yo si le ayudo a mi mamá. Cuando sale me dice que espera que cuando regrese ya tenga barrido y trapeado, y sí. [El alumno refiere que él ayuda a su mamá, atribuyendo que es a ella a quién le corresponde desempeñar estas tareas].

H. Pero yo no entiendo cómo los hombres que se van al norte [Estados Unidos] allá, no se van con su mujer, y trapean, barren, cocinan, lavan su ropa y todo lo que hacen las mujeres aquí y cuando regresan no les ayudan a hacer nada de eso aquí.

M. A lo mejor porque dicen que para eso se casaron, pero se casaron porque las querían, no para traerlas así.

(EST 71 Nuevo Progreso - 1:19) 
M. [...] en algunas casas las niñas nada más están para hacer quehacer y los niños se la pasan viendo tele, aunque pueden hacer las mismas cosas.

(EST 23 Tangancícuaro - 3:38)

M. También las personas mayores a veces, los hombres más que nada... dicen... "ahí no pongas al niño a barrer... porque es niño... como va a hacer eso... luego se hace niña”... pues si también tienen manos, también pueden ... no porque sean niños...

(ESG 02 Apatzingán -7:188)

Un par de chicos manifiesta que estudia en el Internado mixto porque sus mamás trabajan mucho y no pueden estar pendientes del ellos. Con estos comentarios nuevamente se reafirma que son las mujeres las que desempeñan las tareas de cuidado.

H. Mi mamá trabaja mucho y no puede estar todo el día en la casa me aburro.

H. [...] a parte mi mamá trabaja mucho y mi papá nunca se la pasa en la casa.

(CECADEJ Internado Mixto - 10:9)

En cuanto a la repartición de espacios y actividades en el contexto educativo se hace referencia principalmente a cuatro cuestiones. En primer lugar, los chicos defienden que el espacio de las canchas les pertenece y se quejan de que algunas chicas les perturban cuando están jugando, al tiempo que las mujeres reclaman que el espacio debe ser compartido (EST 112 Carapan - 4:109-114). En segundo lugar, en varios grupos de discusión chicos y chicas señalan que los y las docentes suelen ser más condescendientes con las mujeres y con ellos más estrictos (EST 71 Nuevo Progreso - 1:21; CECADEJ Internado Mixto - 10:107113). En tercer lugar, sobre todo el alumnado de secundarias técnicas manifiesta que la elección del taller se hace en función del sexo, debido a que se considera que algunas disciplinas son más apropiadas para hombres o para mujeres (EST 65 Morelia - 2:2 EST 23 Tangancícuaro - 3:32). Finalmente indican que, en la repartición de las tareas, los/as docentes encomiendan a los hombres las que requieren fuerza, mientras que a las mujeres les encargan realizar tareas de limpieza en las aulas (EST 72 Patambán - 5:142).

H. Y que las mujeres no molesten a los hombres cuando estén jugando fútbol. 
H. Les quitan el balón.

H. Y las niñas, cuando se llevan con los niños [...]

H. O sea, no se aguantan, porque cuando los niños ya les pegan también, luego, luego van y reportan.

(EST 112 Carapan - 4:109)

M. Y que los hombres para que no los molestemos que se vayan a la cancha de fútbol porque juegan en la de basquetbol y ahí no es para jugar fútbol.

$M$. [cuando juegan al futbol con ellos], a propósito les pegan con el balón para que le tengan miedo y se salgan.

M. Y a veces los hombres agarran el balón de nosotras y lo avientan.

M. O lo ponchan.

M. ¡Que porque el fútbol sólo es de hombres!

M. Y en las dos canchas juegan los hombres y las mujeres no sabemos dónde jugar.

M. Nada más sentadotas ahí. Como ahora sí jugamos, pero nos tiraban el balón, nos pegaban bien feo.

(EST 112 Carapan - 4:114)

H. Cuando hay trabajo a nosotros nos ponen hacer todo el trabajo pesado.

M. A las niñas nos ponen a barrer o a trapear.

(EST 72 Patambán - 5:142)

H. Las chiquillas no hacen nada, en la tecnología de agricultura, que también participen.

H. Que hagan algo las chiquillas [...] Nosotros sembramos...

H. Cosechar.

H. [Y ellas] Nada más se la pasan jugando.

H. Nada más se la pasan jugando. Y a ellas no las reprueba.

M. Pero es que también él se lo busca porque casi no lleva las tareas, no hace los trabajos que le dice el maestro.

H. Lo que califica el maestro son las actividades que hacemos aquí.

H. Pero no se compara una mujer con un hombre. Las mujeres pueden hacer trabajos menos pesados y los hombres los más pesados.

H. Es que el maestro les dice "pónganse a hacer esto" y no lo hacen. Podrían ayudar en la cosecha.

M. El maestro nos tendría que tratar a todos por igual, quizá en trabajos no tan pesados pero que sí las ponga.

(EST 71 Nuevo Progreso - 1:21)

M. A veces les ponen más atención a las mujeres los maestros.

M. A un amigo no hizo algo y no le dieron ni una oportunidad lo dejaron externo y a las mujeres les dan cinco oportunidades y aquí las dejan.

H. Los maestros son más tolerantes con las niñas.

(CECADEJ Internado Mixto - 10:107-113)

M. Aquí en industria del vestido hay hombres que quieren entrar pero no lo hacen porque se burlan, y en carpintería no entran mujeres.

(EST 65 Morelia - 2:2) 
H. Podría ser en el taller, que dicen que es sólo para hombres aunque en realidad van dos mujeres y puede que sean mejor que yo en esa materia, no tienen que estar a fuerzas en talleres como contabilidad $u$... otros talleres.

(EST 23 Tangancícuaro - 3:32)

La sub-categoría denominada derechos y oportunidades fue de las menos citadas. Además, las referencias que hace el alumnado sobre ambos aspectos son superficiales: señalan que hombres y mujeres tienen los mismos derechos y oportunidades, pero no citan nada que demuestre que conocen los mecanismos jurídicos o las instancias oportunas para denunciar y/o atender la falta de equidad entre hombres y mujeres. Únicamente un chico hace referencia a ello, mostrando su enfado ante la "falta de igualdad" porque a su parecer los hombres quedan desprotegidos en casos de abusos o violencia de las mujeres hacia los hombres. Las respuestas de las chicas muestran que carecen totalmente de información tanto sobre los derechos de hombres y mujeres, como acerca de las instancias públicas en las que pueden recibir información y atención tanto hombres como mujeres.

H. Este... si violan a una mujer, a los hombres los culpan... o si les pegamos... pero ¿si las mujeres nos pegan también hay una ley?...

M. Nooo...

M. Pero siempre te dicen que los hombres son más fuertes...

H. Pero no todos los hombres les quieren pegar a las mujeres.

M. Pero aun asi lo hacen...

H. Y luego andan diciendo "me pegó”...

(ESG 02 Apatzingán - 7:206)

La sub-categoría que abordaremos a partir de este momento es la correspondiente a la violencia. Nos sorprendió observar en los discursos de las y los adolescentes que el ejercicio de la violencia es cotidiano y que, además, no solo toleran su uso, sino que es aprobado, justificado e incluso exaltado en sus intervenciones.

H. Que el otro día también se agarraron los cuarentas con los policías y bien feo se habian agarrado, tiraban piedras...

M. ¡Y no les tenían miedo a los policías! [Su comentario denota admiración]. 
(EST 112 Carapan - 4:64)

M. Y aparte los hombres se emocionan más [cuando se pelean].

(EST 71 Nuevo Progreso - 1:139)

M. Cuando yo no me puedo desquitar de mi coraje lloro y cuando ven a alguien llorando la empiezan a criticar y cuando me pasa a mí la verdad ya no me puedo controlar si me voy a los golpes pocas veces he llegado a hacerlo pero si lo he hecho.

(EST 05 Apatzingán - 6:78)

M. Se dio algo en mi salón muy chistoso, estábamos en mi salón y unas amigas mías, se pelearon, asi del pelo por un shampoo, porque una le dijo a la otra... - huele mi shampoo... y le dice la otra, no el mío huele mejor que el tuyo-y se agarraron del pelo y se hicieron decir... - dime de cuál compras... no dime tu del cuál comprasasí... y luego el maestro va y les dice suéltense... y —no hasta que tú me sueltes y yo de ahi no te voy a soltar... ah yo tampoco-y se agarraron media hora de las greñas... y como una está más alta que otra, la más alta la tenía en el piso... jajaja... iyo tengo el video en You Tube!

(ESG 02 Apatzingán - 7:137)

H. [...] este... las peleas de los niños es muy común ver sangre...

H. Moretones... golpes... a veces hasta agarran piedras y cadenas... (Hablan todos/as a la vez).

(ESG 02 Apatzingán - 7:137)

M. [relato de una pelea] Una niña de por mi casa este... que le decía cosas a mi mamá y un día pues... yo ya no me aguante y pues... me la agarre... y gane...

H. [relato de una pelea] Ah... les platico... se puso chido... Ah, no pues no más por defender a otros amigos... Estábamos ahi en mi casa... y llego uno que se llama Axel, que vivía por ahí.. y empezó a dar zapes y zapes a mi hermano... y yo lo estaba dejando... y ya hasta que le di un trancazo y que le saco la sangre... vámonos... que primero le di dos en la boca, luego dos en la panza y se quedó llorando... y que "vas a ver mañana te voy a pegar"... y que se va llorando [...] [me sentí como] Súper héroe...

H. Yo la primera vez o la última vez que me peleé... Me sentí bien, porque traía ganas de pelear...

(ESG 02 Apatzingán - 7:154)

Cabe señalar que los y las jóvenes que participaron en esta investigación refirieron varios tipos de violencia directa y en diversos ámbitos. Así pues, con respecto al medio en el que incurren los actos de violencia señalaron principalmente tres: el contexto educativo, la comunidad y el familiar o de pareja (este último se abordara en el siguiente apartado). El uso de la violencia referido por las y los adolescentes en los tres ámbitos es ejercido con la finalidad de acceder al poder (categoría emergente tras el análisis), y de ganar prestigio mediante la intimidación y la sumisión del agredido/a. 
H. Por el barrio... por creerse más chingón.

H. Por sentirse los valientes.

(EST 72 Patambán - 5:127)

$H$. [se pelean] porque tratan de ganar un lugar más alto en ese grupo. Es como tener un lugar socialmente en su grupo.

H. Porque, como en el caso de los animales, dicen que el león es el rey, es el animal más sobresaliente de todos los demás, el más fuerte, el más agresivo... [Los chocos se pelean] porque dan con los puños cerrados y así ya no le buscan más porque saben que sabe pelear.

H. Ellos pelean por ser el león alfa... O para que le tengan miedo.

(ESG San Felipe de los Alzatis - 9:130)

H. Las peleas se dan coraje, por envidia, por celos de las cosas.

M. También para lucirse y decir que yo si se pelear.

(CECADEJ Internado Mixto - 10:93)

M. Porque se sienten superiores a los demás, sienten que pueden hacer lo que quieran o porque tratan de llamar la atención de los demás.

(EST 23 Tangancícuaro - 3:66)

M. O simplemente por molestar o porque creen que el respeto de los demás se lo van a ganar formado una imagen agresiva y ser el más fuerte, dicen "yo soy la mejor en las peleas" y lo voy a demostrar por ganar esa imagen que a veces es verdadera y otras veces es solo una imagen.

M. O hay unos que según andan en eso de la mafia y si tienen problemas con alguien ya nada más llaman a los que ellos conocen [narcotraficantes] y si los llegan a matar.

H. Y hay algunos que dicen -yo soy de la mafia-y como piensan que sí es cierto, pues ya le hacen caso y va a ser como su mandadero. Para que no le hagan nada.

(EST 05 Apatzingán - 6:82)

En el primer contexto se hace referencia tanto a la violencia ejercida en el grupo de pares como la violencia entre el docente y las alumnas. En el grupo de pares se relatan anécdotas de uso de violencia tanto verbal (insultos, notas en baños) como física (peleas con o sin objetos, golpes) (EST 72 Patambán 5:120, EST 112 Carapan - 4:36; EST 23 Tangancicuaro - 3:47; EST 05 Apatzingán - 6:10; ESG 02 Apatzingán - 7:154). En cuanto a la violencia ejercida por los docentes, las alumnas señalan que algunos profesores les hacen insinuaciones y propuestas que van desde miradas inapropiadas o peticiones de fotos en las que les muestren su cuerpo, hasta tocamientos en contra de su voluntad (EST 72 Patambán - 5:154; EST 05 Apatzingán - 6:64). 
H. [Relata una pelea con un compañero de la escuela] Yo sí sentí lástima... sí le pegue bien feo. Después me arrepentí de haberle pegado, no era para tanto. Había quebrado una lámpara y no quería que le dijera al profe.

H. Porque aquí en la escuela los primeros días se pelearon los de tercero " $A$ " se pelearon con los de tercero " $B$ " todos contra todos.

$H$. Sí se pelearon como una semana, casi puros hombres.

H. Pero también las chiquillas se estuvieron peleando.

H. Ah sí Norma con Selena.

H. Y Grecia con Brenda.

(EST 72 Patambán - 5:120)

M. La otra vez veníamos de comprar el desayuno íbamos por aquel lado y paso el prefecto y me hizo así y me pego y yo me quede así como... [Explica con ademanes que intento darle una nalgada, también manifiesta que no se quejó con las autoridades de la escuela].

(EST 72 Patambán - 5:154)

H: Muchos se van de la escuela porque los molestan, porque hay muchos niños maldosos, les pican o les pegan a los demás.

H. Por ejemplo ella, tiene buenas calificaciones y yo le pego, le pego para que me haga mis tareas porque yo no puedo... es un ejemplo.

(EST 112 Carapan - 4:36)

M. Algunos le ponen mensajes en las butacas y rayan los baños y eso no debe de ser $[\ldots]$

(EST 23 Tangancícuaro - 3:47)

M. Los alumnos entre ellos se golpean, por decir uno empoja a otro le dicen cosas, y ya pues empiezan a darse golpes.

(EST 05 Apatzingán - 6:10)

M. Bueno, un maestro de aquí le pidió a una alumna de aquí una foto de ella en trapos menores por ejemplo cuando andamos mal en esa materia nos ofrece pasarnos a cambio de otras cosas.

M. Por esa misma falta de respeto, muchas alumnas, que las aferran, [el maestro] pues que les den, que les den lo que les esté pidiendo y muchas que no entran [se refiere a que no entran a clases] o se la salan [hacen novillos] y las bajan de calificación o las reprueban y con eso tienes para reprobar la escuela y quedarte sin estudiar, por eso mismo es que te da miedo que te sigan molestando los maestros.

M. Si no hace lo que él dice te reprueban aunque cumplas con tareas y trabajos.

M. Aunque uno hable con la directora o con el director, les hacen más caso a los maestros que a los alumnos. Porque eso también paso en la mañana, mi tía vino a hablar con el maestro y el director por lo mismo y le dijeron que lo iban a correr a él, porque ese maestro sí era muy malito pues decía muchas cosas a las alumnas, si se agachaba una alumna por algo y les empezaba a decir - se te vio esto se te ve lo otro o les decía "desabróchate la blusa se te ve bonita la que traes abajo"-y pues ellas van y se las desabrochan o les dicen algo y los maestros no les hacen caso y dicen que los alumnos ya no tienen ni que decir y les hacen más caso a los maestros que a uno.

(EST 05 Apatzingán - 6:64) 
H. La primera vez que me peleé estaba en quinto ya estaba muy grande... pero yo siempre había sido calmado... fue con un niño del salón y empezó a decirme cosas, durante todo el año... era nuevo, me había cambiado de salón para acá... este me empezó a decir cosas y un día me empezó a decir maldiciones sobre mi mamá, o sea me empezó a mentar la madre... y para mí eso no era común, porque casi no conocía las tradiciones entonces, fue cuando me enoje, sentí ira, adrenalina y lo empecé a golpear, lo ahorque hasta que llegó la directora... y me separó y asi me empecé a llevar a trancazos con él. Otro día y ya a ese niño ya lo estuvieron a punto de expulsar...

M. A mi una vez que estábamos en la primaria, una niña este... cuando yo iba en tercero ella era mi mejor amiga, pero ella, me sobornaba... me decía que si no le pasaba las tareas, me iba a dejar de hablar... y pues yo sentía feo, porque ella era la única con la que me hablaba del salón y siempre le pasaba todo... y un día le platique a mi mamá y me dijo que estaba mal, y cuando yo le dije me dijo jestás pendeja! y quien sabe que... me empezó a decir un montón de cosas ... y yo aguanto que me digan a mí, pero que se metan con mi familia no... me cae mal... me prende eso... y empezó a decirme... me mentó la madre... empezó a decirme que mi papá y que mis hermanos... uy pues yo me puse bien enojada y que la agarro de las greñas, y que la boto en el piso... hasta que no me pidas perdón te voy a soltar, asi que empiézale... (risas) y no quería... hasta que la jale más que me dijo... ya ya, discúlpame... y le dije, te vuelves a meter conmigo y te va a ir peor... y ya nunca más me volvió a decir nada...

(ESG 02 Apatzingán - 7:154)

El segundo ámbito en el que hay violencia es la comunidad. Los y las adolescentes manifiestan que la violencia física y verbal se ejerce como un mecanismo para resolver conflictos, demostrar valentía y ganar poder y prestigio.

H. Hasta una vez hubo una pelea, y yo me salí de mi casa porque había mucho ruido, y me fijé y habían hasta niños chiquitos como de $6^{\circ}$, de $5^{\circ}$ o hasta de $4^{\circ}$ peleando y pues así se defienden, no con las manos porque no han de estar fuertes, y se defienden con palos, con botellas, con cadenas.

$H$. $Y$ de repente, como aquí dicen que hay barrios, y se juntan muchos hombres, y ahí van con otra y se agarran bien feo.

H. Cuando se cruzan pues.

H. Porque aquí hay cuarteles [la división del pueblo es en cuatro cuarteles], hay cuatro cuarteles y no se llevan. Por ejemplo, yo soy del segundo cuartel y...

H. Por ejemplo vienen las fiestas y cada cuartel saca algo. Y acá, por ejemplo yo soy del segundo cuartel y no se llevan con los del tercer cuartel... Y nosotros del segundo somos los Quésicuas. 
H. Cada quien tiene nombre, nosotros somos los Cuarenta... El cuartel de nosotros es el que sí... se cree, el cuartel de los Cuarenta son los que más problemas provocan en el pueblo.

H. Y los del tercer cuartel los 05.

H. Y los del cuarto cuartel son los Santa Cruz.

M. [Razones por las que pelean] que defienden su cuartel, que dicen "mi cuartel es el más grande" o "mi cuartel si sabe pelear".

M. Sí, acá nosotros no porque... bueno sí también.

M. Acá los de nosotros no nos peleamos tanto, nada más cuando empiezan a decirnos, por ejemplo que van a la fiesta y empiezan a decirnos y a presumir, no que nosotros trajimos la mejor banda, no que la de ustedes no fue tan mejor, y ahi es cuando empiezan.

(EST 112 Carapan - 4:64)

H. Es que aquí hay barrios, cada quien tiene sus nombres y aquí se pelean mucho por eso por defender al barrio.

H. Que porque yo soy de la izquierda y yo de la derecha, que porque soy de arriba y tú de abajo...

(EST 72 Patambán - 5:120)

H. Una vez me peleé. Estábamos jugando y no me alcanzó, me aventó una pedrada y yo me le aventé para golpearlo, y yo creo que si no llega su mamá sí lo mato.

H. O a veces se agarran a decirse palabrotas.

(EST 71 Nuevo Progreso - 1:139)

El análisis de esta sub-categoría constata que para el alumnado el uso y ejercicio de la violencia es habitual en los diversos contextos en los que se desenvuelve. La influencia del sistema patriarcal favorece que hombres y mujeres consideren que la violencia forma parte de la naturaleza de las personas, impidiéndoles juzgar de manera razonada el alcance de las consecuencias producto de los actos violentos, incluso para quién agrede. Los hombres, en aras de confirmar su masculinidad, han de demostrar su valentía, fuerza, virilidad y poder mediante el uso de la violencia. En cuanto a las chicas, se muestra como ellas también hacen uso de la violencia, aunque en menor medida, para intimidar y ganarse el respeto de sus iguales, dado que cuando se es "débil" puedes resultar agredida. Así lo expresa una adolescente "cuando ven a alguien llorando la empiezan a criticar y cuando me pasa a mí, la verdad ya no me puedo controlar" (EST 05 Apatzingán - 6:78). 
En cuanto a las diferencias encontradas entre las zonas analizadas, podemos destacar que el alumnado de zonas rurales habla más de la violencia en el contexto comunitario mientras que el alumnado de zona urbana hace más referencia a la violencia en el contexto educativo. En uno de los grupos de discusión (zona urbana) que pertenece a la región de Lázaro Cárdenas se hace referencia a la problemática del narcotráfico que ha irrumpido en el Estado y de manera más contundente en esta región. Los y las alumnas manifiestan que hay adolescentes que les intimidan señalando que pertenecen a bandas criminales $y$, por temor, ellos y ellas se someten a sus abusos. Un chico expresa lo siguiente "hay algunos que dicen - yo soy de la mafia-y como piensan que sí es cierto, pues ya le hacen caso y va a ser como su mandadero. Para que no le hagan nada” (EST 05 Apatzingán - 6:82).

Finalmente analizaremos la sub-categoría de desigualdad. En ella se muestra cómo las mujeres son más conscientes de las desigualdades por razón de sexo que los varones. En esta sub-categoría también se habla de dos ámbitos principalmente, el familiar y el escolar.

Con relación al primero las adolescentes, sobre todo, manifiestan que en sus hogares las mujeres no tienen los mismos derechos y las mismas libertades que los hombres, pues ellas tienen permisos más restrictivos que los varones. Mientras tanto con los hombres, los progenitores, son menos afectivos que con las mujeres. También manifiestan que ellos no tienen encomendadas tareas en el hogar mientras que ellas sí.

M. A mí no me dejan salir... Que porque como soy mujer no debo de salir, que solamente que los hombres.

H. Menos mal que soy hombre (risas y murmullos).

M. Pues me salgo, me voy a casa de mi abuela, llego como antes de las nueve y media. No me regañan. Y cuando me salgo con las chiquillas por ahí, si me tardo me regañan también. [...] No, ellos [sus hermanos] se salen en la tarde a la plaza con sus amigos y ya luego le van a ayudar a mi tía a trabajar, ya llegan pasadas las doce. Y a ellos no los regañan. 
[¿Y eso, consideran que es equitativo? ¿Qué hay equidad entre hombres y mujeres con ese tipo de situaciones?]

H. Sí

M. No. Porque tanto hombres como mujeres tenemos los mismos derechos y si los hombres se saben cuidar y por qué las mujeres no.

(EST 72 Patambán - 5:107)

M. Por ejemplo, en mi casa a mi hermana y a mí nos cuidan y nos hacen más caricias que a mis hermanos.

(EST 72 Patambán - 5:138)

H. Por decir en el caso del quehacer de la casa hay veces que el padre no deja a los hijos que le ayuden a su madre, por el machismo, no permiten nada porque dicen "no que te pasa esto o que te pasa lo otro".

(ESG San Felipe de los Alzatis - 9:11 9:162)

M. Hay hombres machistas que quieren que la mujer se quede nada más en la casa, que les lave y les planche, creen que como ellos traen el dinero a la casa ellas tienen que hacerles todo lo que ellos les piden.

(EST 71 Nuevo Progreso - 1:19)

M. Las mujeres no sólo son para estar en la casa, pueden estar en cualquier trabajo, tienen las mismas oportunidades que los hombres para estudiar y trabajar.

(EST 71 Nuevo Progreso - 1:124)

M. Se me permite, lo más tarde que puedo llegar es a las 9 de la noche cuando salgo con mis amigas y cuando salgo a bailes mi mamá me trae a la 1 o 1.30 a.m.

H. Cuando salgo con mis amigos puedo llegar a mi casa a las 11:30 y en los bailes a las 3:30 a.m.

M. Mira la diferencia, tú eres hombre, y las mujeres creo que somos más puritanas.

(EST 71 Nuevo Progreso - 1:15)

M. En la vida real no es así [se refiere a que no hay igualdad], que lo que se ve que hacen los hombres las mujeres no y lo que hacen las mujeres los hombres no.

(EST 65 Morelia - 2:2)

En la escuela los y las alumnas manifiestan que a la hora de elegir talleres lo hacen en función del sexo. Las mujeres suelen entrar a talleres "propios para chicas" (contabilidad, industria del vestido) y los chicos a los "propios para chicos" (carpintería, tecnología de la agricultura). Cuando las y los adolescentes deciden romper con la norma se enfrentan a críticas y burlas por parte del grupo de pares, e incluso algunos padres/madres les restringen la entrada a estos talleres. También comentan que en las actividades deportivas suelen participar más los varones que las mujeres. 
H. Como a mí mis amigos me dicen que contabilidad es para mujeres, pero hasta ahorita llevo buenas calificaciones y les digo que a mí me gusta y no me importa si es para mujeres o no. O sea que a veces les gusta un taller y no entran porque les dicen que ese no es para hombres y mujeres.

(EST 23 Tangancícuaro - 3:33)

M. Algunas veces, no porque luego que se meten en talleres y otros se empiezan a burlar, otras veces que se juntan a fumar se burlan de los que no quieren y les dicen que son mandilones o mujeres.

M. Aquí [en la escuela] una vez hicieron un torneo pero a las mujeres no las dejaron entrar.

(EST 23 Tangancícuaro - 3:36)

M. Yo también me metí a otro [taller "propio para hombres"] para que algo me dijera a mí, pero a mí sí me dejaron meterme, a otras les dicen que no, que no van a aprender.

(EST 23 Tangancícuaro - 3:97)

H. En el deporte hay más equipos de hombres.

(EST 65 Morelia - 2:2)

Tras el análisis de esta última sub-categoría pudimos constatar que, independientemente de la zona territorial analizada, las prescripciones de comportamiento atribuidos a uno y otro sexo son rígidas y tan sutiles que son pocos/as los que perciben sus consecuencias. No obstante, en los grupos de discusión analizados las mujeres suelen identificar y reflexionar más sobre las desigualdades por razón de sexo que los hombres.

\subsubsection{Resumen}

En este apartado hemos analizado los discursos de los y las adolescentes respecto a la categoría género. En sus discursos hemos podido identificar que sus percepciones están modeladas por comportamientos, actitudes y expectativas fundadas en estereotipos y roles de género tradicionales. A continuación mencionaremos los puntos que consideramos que resumen los discursos proporcionados por el alumnado.

- El alumnado que participó en este trabajo de investigación no cuenta con información básica sobre el tema de igualdad y equidad de género. 
- En los discursos de las y los adolescentes, principalmente en los argumentos de los chicos de zona indígena y rural, se refleja un fuerte arraigo a los estereotipos y roles de género tradicionales.

- Los y las adolescentes atribuyen estereotipos de género a las mujeres que anteriormente eran asignados a los hombres, como el hecho de participar en el ámbito laboral. Sin embargo no reconocen que los hombres tengan una corresponsabilidad en las tareas domésticas.

- Los y las adolescentes carecen de información sobre los derechos humanos relacionados con la igualdad y la equidad de género. Tampoco identifican las instituciones públicas en donde pueden ser atendidos/as e informados en caso de querer denunciar los casos de desigualdad de género.

- El uso de la violencia es justificada y en ocasiones exaltada por el alumnado. La violencia es el mecanismo a través del cual los y las adolescentes acceden al poder, ganan prestigio y demuestran valentía. Aunque continúa primando el estereotipo de agresor/trasgresor en los hombres, pudimos identificar en sus discursos que las mujeres también están ejerciendo la violencia como estrategia para ganar poder.

- Algunas alumnas que participaron en el estudio refieren casos graves de violencia escolar de tipo sexual (denuncian que algunos profesores les solicitan favores sexuales a cambio de unos mejores resultados académicos). También manifiestan que en las secundarias ellas son blanco de acoso por parte de sus compañeros (tocamientos, miradas) y manifiestan que no existen instancias dentro del centro educativo en las que puedan interponer una queja o denuncia. No obstante, no podemos hablar de acoso escolar, pues la metodología utilizada no nos permite conocer la frecuencia y el motivo con las que se llevan a cabo este tipo de abusos. 
- Las alumnas tienden a identificar y a reflexionar más sobre las diferencias de género, sobre todo en el contexto familiar y educativo.

\subsection{Sexismo en las relaciones afectivo-sexuales descritas por los y las adolescentes}

La sexualidad y los estereotipos de género están íntimamente interrelacionados, así se refleja en los discursos pronunciados por los y las adolescentes. Al ser cuestionados sobre las relaciones afectivo-sexuales, los y las jóvenes reproducen creencias, actitudes, valores y expectativas claramente influenciadas por los estereotipos y roles de género. Así pues, en este apartado se pretende mostrar que las percepciones de los y las adolescentes respecto a las relaciones de pareja están fuertemente relacionadas con los estereotipos de género. Para ello vamos a analizar tres puntos. En primer lugar examinaremos cómo se da el inicio del cortejo y cómo hacen los hombres y las mujeres para atraer a las personas que les gustan. En segundo lugar vamos a mostrar las funciones y roles que adoptan los hombres y las mujeres en las relaciones amorosas. Y finalmente vamos a analizar si las consecuencias derivadas de ejercer la sexualidad tienen las mismas connotaciones para mujeres que para hombres.

En los inicios del cortejo, sin apenas diferencias entre las zonas analizadas, predomina el relato de un varón atrevido, conquistador, fuerte, valiente, agresivo y experimentado. En esta fase inicial son ellos los que han de desempeñar el rol activo dando el primer paso (tabla 7.3.). Por su parte, las chicas aceptan su rol pasivo en el inicio del cortejo (tabla 7.4.).

Tabla 7.3. Rol de los hombres en el cortejo inicial, percepción de los chicos

\begin{tabular}{ll}
\hline \hline Zona & Cómo y quién inicia el cortejo en las relaciones amorosas \\
\hline & H. Pues te acercas y les dices que si quiere ser tu novia. \\
& H. Yo nada más le regalé una caja de chocolates, y luego ya le dije y me dijo que lo \\
iba a pensar y luego ya me dijo que sí, fue muy corto el tiempo. & (ESG San Felipe de los Alzatis - 9:8) \\
Indígena & H. Haciendo pequeños obsequios, regalándole rosas, chocolates. \\
(ESG San Felipe de los Alzatis - 9:57)
\end{tabular}


H. Diciéndole si quiere ser su novia.

H. O con una carta.

(EST 112 Carapan - 4:118)

H. [...] yo creo que los chicos tenemos más iniciativa para pedir ser novios, pero Rural las chicas toman la iniciativa en otras cosas.

(CECADEJInternado Mixto - 10:74)

H. Un amigo le ayuda a un chavo en algunas cosas a cambio de que le lleve

Urbana recados a su novia, pero es puro juego.

EST 65 Morelia - 2:4

En la tabla que mostramos a continuación se puede observar que las adolescentes manifiestan que esperan a que sean ellos quienes den el primer paso en las relaciones afectivas. En sus discursos predomina el relato de una mujer dependiente, afectiva, pasiva, insegura, ingenua, seductora. Únicamente una alumna señala que ella no tendría problema por pedirle a un chico iniciar una relación. Otra alumna manifiesta que en ocasiones las chicas optan por no aceptar la relación de manera inmediata y prolongar la respuesta unas cuantas semanas.

Tabla 7.4. Rol de las mujeres en el cortejo inicial, percepción de las chicas

\begin{tabular}{|c|c|}
\hline Zona & Cómo y quién inicia el cortejo en las relaciones amorosas \\
\hline Indígena & $\begin{array}{l}\text { M. [Cuando les preguntan si quieren iniciaruna relación] Algunas dicen que lo van } \\
\text { a pensar. } \\
\text { M. Bueno yo le dije que sí, pero ya luego le dije que no, duramos muy poquito. } \\
\text { (ESG San Felipe de los Alzatis - 9:99) }\end{array}$ \\
\hline Rural & $\begin{array}{l}\text { M. Se gustan-ella o él le pide que sean novios-, más los hombres piden que sea } \\
\text { la novia. } \\
\text { (CECADEJInternado Mixto - 10:70) } \\
\text { M. [pediría salir con un chico] Yo no, porque los niños son los que tienen que tener } \\
\text { la iniciativa. } \\
\text { M. Yo tampoco se los pediría. } \\
\text { M. Yo sí, si me gusta porque no voy a poder pedírselo. } \\
\text { (CECADEJInternado Mixto-10:72) }\end{array}$ \\
\hline Urbana & $\begin{array}{r}\text { M. Se presentany se van conociendo y luego es como se hacen novios, es un juego. } \\
\text { (EST } 65 \text { Morelia - 2:4) }\end{array}$ \\
\hline & $\begin{array}{l}\text { M. }[\ldots] \text { el hombre empieza a llevarle una rosa a la muchacha que le gusta y la } \\
\text { muchacha que le gusta le empieza a mandar mensajes. } \\
\text { M. O empiezan como amigos. } \\
\text { (EST 05 Apatzingán - 6:89) }\end{array}$ \\
\hline
\end{tabular}

Los chicos confiesan dar prioridad, en la aproximación inicial, tanto al físico (buen cuerpo, cara bonita), como a las características y cualidades de una "chica buena", por ejemplo que sean amables, nobles, simpáticas y hacendosas (tabla 
7.5.). Mientras, las chicas indican que para ellas lo importante es la personalidad, por ejemplo detallistas, románticos, sinceros y que las protejan (tabla 7.6.).

\section{Tabla 7.5. Cualidades y características que gustan a los chicos}

\begin{tabular}{|c|c|}
\hline Zona & Qué te atrae de una persona \\
\hline \multirow[t]{2}{*}{ Indígena } & $\begin{array}{l}\text { H. [...] que estén bonitas [...] Son muy pocos también que se fijan en cómo es por } \\
\text { dentro porque siempre tienes que fijarte cómo es por dentro o cómo actúa o cómo } \\
\text { es y sólo se fija en lo que es y cómo se viste y no se fijan de lo que es por dentro y } \\
\text { por eso a veces cuando se casan hay problemas, que "yo no te conocía que } \\
\text { andabas así. } \\
\text { (EST } 112 \text { Carapan-4.52) }\end{array}$ \\
\hline & $\begin{array}{l}\text { H. De que estén bien bonitas. } \\
\text { H. Se las llevan al rinconcito. } \\
\text { H. Ya la hicieron. Y ya pueden hablar de todo. (Risas y bromas). } \\
\text { (EST } 72 \text { Patambán - 5:39) }\end{array}$ \\
\hline \multirow[t]{2}{*}{ Rural } & $\begin{array}{l}\text { H. Una mujer por su escultura, su belleza, su carácter: amable, noble. } \\
\text { H. Por su fisico, por su carácter: noble, liviana, pues activa: que haga quehacer en } \\
\text { la casa, cuando llegue el hombre de trabajar que le tenga su comida preparada. } \\
\text { H. La princesa rosa: amable, generosa, guapa, comprensiva, de ojos verdes... } \\
\text { H: Trabajadora, que haga todo el quehacer. } \\
\text { (EST } 71 \text { Nuevo Progreso-1:47-54) }\end{array}$ \\
\hline & $\begin{array}{l}\text { H. Su forma de ser, amable, que respete. } \\
\text { H. Pues una mujer que no se venda } \\
\text { H. Que no sea materialista }\end{array}$ \\
\hline Urbana & $\begin{array}{l}\text { (CECADEJ Internado Mixto-10:80) } \\
\text { H. Prefieren a las que son delgadas o tienen una cara bonita. } \\
\text { (EST } 23 \text { Tangancicuaro-3:107) }\end{array}$ \\
\hline
\end{tabular}

A continuación presentamos una tabla en la que se muestran las opiniones de las chicas. Sus intervenciones están mediadas por el estereotipo de género, puesto que evitan hablar del deseo o de la atracción física al iniciar las relaciones afectivas. Manifiestan que lo que a ellas les interesa es que las traten bien, que sean detallistas, e incluso llegan a mencionar que es importante que muestren agresividad, porque eso significa que las pueden proteger. También aparecen referencias al sexismo hostil, pues manifiestan que las mujeres utilizan a los hombres para beneficiarse económica o socialmente. Así pues, una alumna de zona rural señala que algunas mujeres se interesan por hombres que tienen documentación legal para vivir en Estados Unidos, pues es una zona en la que muchas personas emigran en busca de opciones laborales. 
Tabla 7.6. Cualidades y características que gustan a las chicas

\begin{tabular}{|c|c|}
\hline Zona & Qué te atrae de una persona \\
\hline \multirow{5}{*}{ Indígena } & $\begin{array}{l}\text { M. De los hombres nos gusta cómo piensan o cómo son por dentro, o a algunas les } \\
\text { gusta cómo se visten, cómo se peinan. }\end{array}$ \\
\hline & (EST 112 Carapan - 4:47) \\
\hline & M. Para poder sacar más los sentimientos, para protección. \\
\hline & (EST 112 Carapan - 4:140) \\
\hline & $\begin{array}{l}\text { M. Que no solamente sea bello por fuera sino también por dentro. } \\
\text { (ESG San Felipe de los Alzatis - 9:60) }\end{array}$ \\
\hline \multirow{6}{*}{ Rural } & $\begin{array}{l}\text { M: Las mujeres nos enamoramos de los hombres por su modo de ser, depende } \\
\text { como sean de detallistas. } \\
\text { M. [Que sea] ¿Romántico?, sincero. } \\
\text { M. Aparte que los dos nos entendamos bien. }\end{array}$ \\
\hline & (EST 71 Nuevo Progreso - 1:9) \\
\hline & $\begin{array}{l}\text { M. O porque tienen papeles y se las pueden llevar para el norte [Estados Unidos] } \\
\text { M. Algunas en verdad sí los quieren. }\end{array}$ \\
\hline & $\begin{array}{l}\text { M. Por detalles, los dos. (Todos dicen: sí con cariño). } \\
\text { (EST } 71 \text { Nuevo Progreso - 1:46) }\end{array}$ \\
\hline & $\begin{array}{l}\text { M. En los hombres que no sean sangrones los hombres. } \\
\text { M. Que no sean presumidos los hombres. }\end{array}$ \\
\hline & (CECADEJInternado Mixto - 10:80) \\
\hline \multirow{3}{*}{ Urbana } & $\begin{array}{r}\text { M: Que sea respetuoso, responsable, que no ande en pandillas. } \\
\text { (EST } 23 \text { Tangancícuaro-3:59) }\end{array}$ \\
\hline & $\begin{array}{l}\text { M. Y a veces que cuando pelean, el que gana, asíya todas las niñas ya quieren con } \\
\text { él, solamente porque gana... }\end{array}$ \\
\hline & (ESG 02 Apatzingán - 7:98) \\
\hline
\end{tabular}

En cuanto a las estrategias que emplean para atraer a las personas que les gustan, también identificamos algunas diferencias entre lo que ellos y ellas afirman hacer. Así, los chicos manifiestan que realizan un conjunto de rituales que van desde el aseo personal y los pequeños detalles/obsequios, hasta la participación en peleas para demostrar fortaleza y valentía (tabla 7.7.). Mientras, ellas indican que sus estrategias son más sutiles, discretas e indirectas (7.8.).

Tabla 7.7. Estrategias empleadas por los chicos para atraer a la persona que le gusta

\begin{tabular}{ll}
\hline \hline Zona & Cómo atraen a las personas que les gustan \\
\hline & H. Se perfuman... \\
& H. Se portan decentes con ellas. \\
& H. No toman. \\
& H. [...] como cuando se pelean por la novia y siente que así los van a elegir más. \\
Indigena & (EST 72 Patambán - 129) \\
\cline { 2 - 3 } & H. Por la higiene, pues por si llega bien bañado, perfumado, les gusta a las niñas. \\
& (ESG San Felipe de los Alzatis - 9:56) \\
\hline
\end{tabular}


H. Las peleas se generan por muchas cosas, como por ejemplo... por los novios...

(EST 112 Carapan - 4:37)

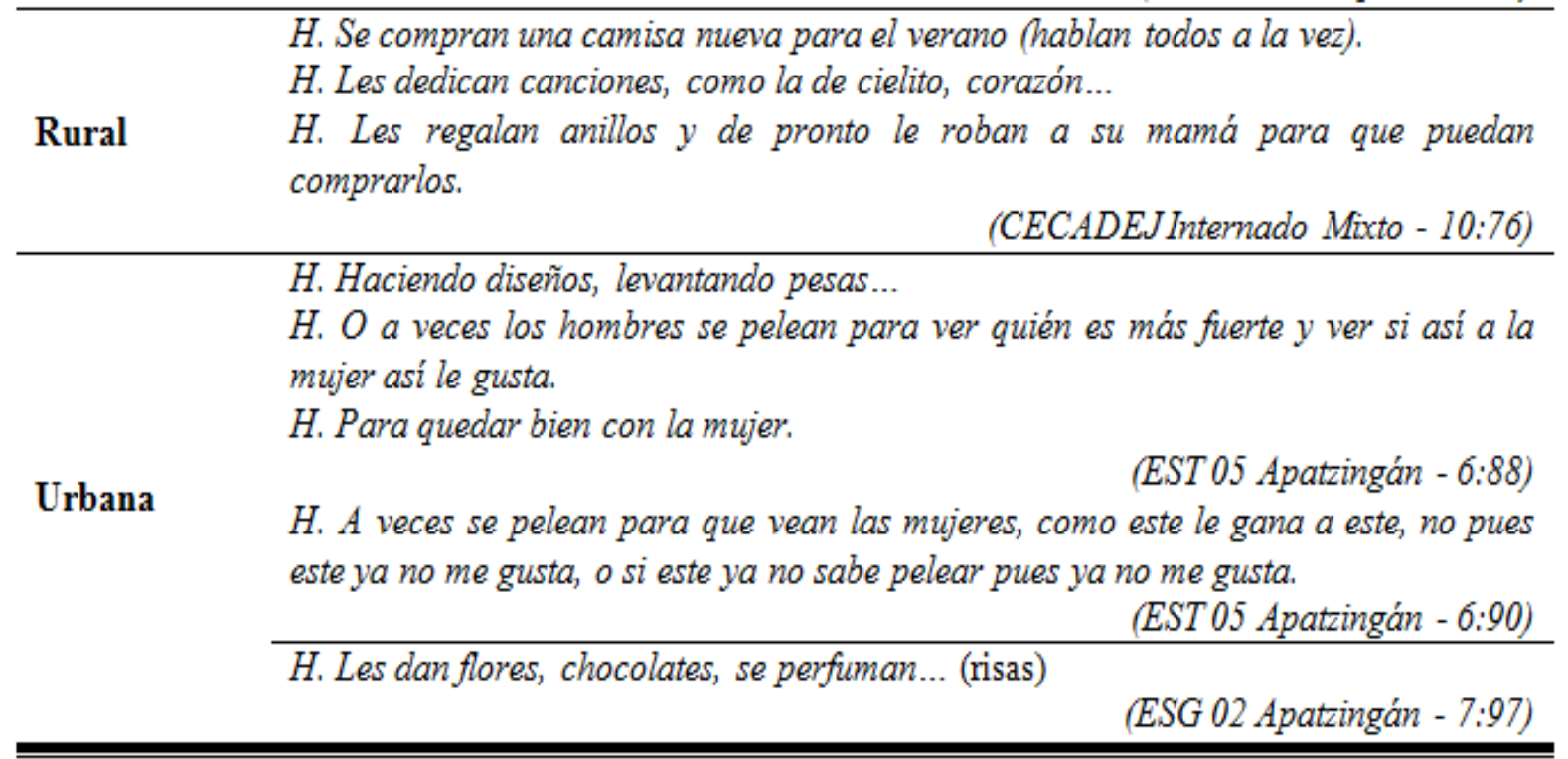

Las chicas elaboran un juego de seducción más discreto e indirecto: señalan que a través de cartas, prestando atención a lo que ellos dicen y hacen, utilizando ropa más entallada y maquillándose, logran atraer a los chicos. Nos sorprendió, así mismo, que una de ellas afirmó que hay chicas que utilizan la violencia como estrategia para conquistar a los chicos (EST 23 Tangancícuaro $3: 44)$.

Tabla 7.8. Estrategias empleadas por las chicas para atraer a la persona que le gusta

\begin{tabular}{|c|c|}
\hline Zona & Cómo atraen a las personas que les gustan \\
\hline \multirow{4}{*}{ Indígena } & M. Platicando... Qué hace en sus tiempos libres. \\
\hline & (ESG San Felipe de los Alzatis - 9:58) \\
\hline & $\begin{array}{l}\text { M. Las mujeres [también hacen cartas], las hacen y las empiezan a mandar, porque } \\
\text { como que las mujeres tienen más sentimientos que los hombres. }\end{array}$ \\
\hline & (EST 112 Carapan - 4:119) \\
\hline \multirow{5}{*}{ Rural } & $\begin{array}{l}\text { M. Vestirse entallada llamando la atención (risas). } \\
\text { M. Habla mal de él para que nadie se fije en él. }\end{array}$ \\
\hline & (CECADEJInternado Mixto - 10:70) \\
\hline & $\begin{array}{l}\text { M. Una mujer pintarse los labios, la cara, vestirse bien, perfumarse, bañarse bien. } \\
\text { Oue sea resnetuosa. }\end{array}$ \\
\hline & M. [Que sea] No tan cursi, que sea chistosa y que sea amable. \\
\hline & (CECADEJInternado Mixto - 10:80) \\
\hline
\end{tabular}


M. Coqueteando.

M. La mujer se empieza a arreglar para llamar la atención del hombre [...]

Urbana

(EST 05 Apatzingán - 6:89)

M. Yo soy como soy siempre... estén niños o no estén niños... no hay que cambiar de forma de ser, si alguien se enamora de ti es porque te quiere como eres.

M. Sí, con tus defectos y cualidades.

(ESG02 Apatzingán - 7:100)

En cuanto a las percepciones que tienen los chicos sobre lo que han de hacer las chicas en el inicio de los rituales amorosos, se observa, por un lado, que existen opiniones que denotan un sexismo hostil (estereotipos de mujer fatal seductora y maliciosa). Así calificamos estas afirmaciones, ya que muchos chicos afirman que las chicas los buscan por interés, para aprovecharse de ellos tanto económica como afectivamente. Por otro lado, encontramos alumnos que consideran que las mujeres se acercan a los chicos porque tienen sentimientos de amor, mezclándose en estos casos el sexismo hostil con el benévolo.

H. Son pocas las que se fijan en los sentimientos, las demás que porque está guapo o porque no sé qué tanto.

H. O por el dinero.

(EST 112 Carapan - 4:4)

H. Por interés, hay hombres que traen carros y tienen dinero.

H. O porque de verdad sí los quieren.

(EST 71 Nuevo Progreso -1:45)

También identificamos que las percepciones que tienen chicas y chicos respecto al otro sexo - con relación a los rituales amorosos-, coinciden mucho con cómo se perciben a sí mismos/as. Así pues, ellos señalan que ellas emplean estrategias de seducción más indirectas, como por ejemplo utilizar ropa entallada, maquillarse y coquetear a través de miradas y conversaciones. Y ellas manifiestan que ellos han de adoptar una actitud complaciente hacia ellas (darles regalos, detalles...) y demostrar su interés siendo arriesgados y activos. 
Tabla 7.9. Percepciones del sexo opuesto sobre el cortejo inicial

Sexo

Percepciones sobre qué hace el sexo opuesto en el cortejo inicial de las relaciones amorosas

H. Se visten escotadas

H. Como dijeron en la clínica que se ponen como las faldas cortas [...] blusas hasta aquí así [señala el abdomen por encima del ombligo].

H. O las minifaldas y los pantalones bien pegaditos.

Percepciones

de los

hombres

respecto a

las mujeres

H. Platicando con uno de cómo se la pasa, qué hace

(EST 72 Patambán - 5:37)

H. Qué le gusta.

H. También apoyar a la persona pues.

(ESG San Felipe de los Alzatis - 9:60)

H. Maquillarse o ponerse ropa muy corta, o blusas que no les tapen la panza.

H. También a veces hacen dieta para estar delgadas. Por decir una familia come y la niña en el baño se vomita. Como la anorexia o la bulimia.

(EST 23 Tangancícuaro - 3:54)

M. [...] diciéndole, dile que le mando un saludo, que si quiere andar conmigo.

M. [diciéndole] Cosas de amor [...] Por ejemplo, "hola, cómo estás, espero que estés bien. Solo te mando esta carta para decirte que te quiero mucho, que si quieres andar conmigo, me gustas desde el primer día que te conocí." Y así, poemas y cosas.

Percepciones

de las

M. Pues primero te hablan bien, se ganan tu amistad.

mujeres $\quad M$. Se visten bien, se arreglan, se echan perfume... (Risas y respecto a nerviosismo).

los hombres $M$. Hablan decente, no se portan groseros en frente de nosotras.

(EST 72 Patambán - 5:40)

M. Si una amiga te pide no tomar, y si la quiere pues no toma y si no la quiere pues sigue tomando.

(EST 72 Patambán - 5:42)

M. Se comportan románticos.

(CECADEJ Internado Mixto - 10:70)

Los discursos de los y las jóvenes ilustran que unos y otras tienen muy interiorizados los estereotipos de género atribuidos a uno y otro sexo. Las relaciones amorosas, como vimos tras el análisis sobre el inicio del cortejo y como se mostrará con los otros dos puntos que quedan por abordar, no tienen las mismas connotaciones para mujeres que para hombres. 
Las funciones y roles que adoptan los hombres y las mujeres en las relaciones amorosas — segundo punto que se va analizar—, están claramente diferenciadas en los discursos de los y las adolescentes. Así pues, las mujeres han de demostrar su integridad y formalidad mostrando resistencia, respetabilidad y recato en las relaciones amorosas. Estas actitudes van a suponer una prueba que diferencia a las chicas "llevadas" o "putas" (desprestigio social) de las chicas "buenas" o "formales" (valoración positiva).

M. También es importante, es conveniente que no te andes metiendo con uno y con otro, porque después vas a salir perjudicada, mejor, es que te esperes, nos esperemos hasta el matrimonio.

(EST 71 Nuevo Progreso - 1:13)

M. Yo estoy en una red del metro blog donde suben fotos y hay unas páginas que tienen pornografía, que suben a las muchachas casi desnudas ahí cuando no se dan cuenta y les puede ocasionar un problema, como muchas cosas que han subido de alguien... [Se jactan de alguien que conocen].

M. Aparte yo creo que ellas solas están haciendo saber que son ... muy... "malas". [Su intencionalidad es decir "putas"].

(ESG 02 Apatzingán - 7:1)

M. También hay una niña en mi salón, que aquí en la escuela se ha creado fama de que es... todos le dicen que es puta... este porque... (Risas) ha andado con todos los de tercero y siempre la descubren los prefectos besándose con ellos atrás de los salones de segundo, porque ya han venido muchas veces a reportarla los policías cuando se suben arriba... (No se le entiende) los prefectos la regañan y le dicen, pero nunca entiende y nosotras hemos hablado con ella y le decimos que por qué hace eso, pero nos dice que nomás porque ella quiere...

(ESG 02 Apatzingán - 7:73)

M. Y eso que nos ponemos a platicar porque son compañeros de la escuela, no venimos a echar novio ni nada, venimos como compañeros, están más grandes pero siguen siendo compañeros de una misma escuela, y una cosas es platicar y otra es estar abrazándonos, besándonos, como unos que hacen esas cosas aquí, pero pues la gente ya no halla ni qué decir.

(EST 05 Apatzingán - 6:29)

Para los hombres, en contraposición con las mujeres, el mostrar desparpajo y habilidad en las relaciones amorosas y en las prácticas sexuales supone desmarcarse de aquello que les resta valor, "la homosexualidad", se asocia la hombría con triunfo amoroso-sexual. De hecho, algunos mencionan que el grupo de amigos puede llegar a convertirse en una presión, pues el iniciarse en 
el terreno sexual y afectivo con las chicas, y adquirir experiencia les hace reafirmarse en su hombría y, por tanto, ganar prestigio social.

H. Porque un amigo me llevó con una mujer para tener sexo con ella, pero yo no quise porque no sé qué enfermedades pueda tener ella y con cuántos hombres se ha metido, puede tener un hijo y a mis papás no les gusta tener... "hijos".

M. A lo mejor porque la mayoría de los hombres ya han tenido sexo, son más aventados. Como por ejemplo los amigos de Poncho que ya han tenido sexo pero él no y a lo mejor se siente presionado.

(EST 71 Nuevo Progreso - 1:14)

M. Antier que estábamos en nuestro salón, estábamos nosotras así platicando con un maestro y entonces llegaron los chiquillos y empezaron a hablar de que -yo a esa ya me la eché-, que quién sabe qué cosas estaban diciendo... (Risas).

M. Sí eso dicen siempre.

M. Y nosotras estábamos diciendo... si van a hacer eso [relaciones sexo-genitales] o si van a hablar de eso mejor cállense, porque hacen que se quemen los demás... mejor guárdenlo en secreto y ya cállense la boca, pero como que les gusta mucho presumir esas cosas...

(ESG 02 Apatzingán - 7:61)

M. Los niños normalmente lo hacen... siempre [tener prácticas sexuales] ... o dicen que lo hacen... (Risas).

(ESG 02 Apatzingán - 7:1)

Tanto hombres como mujeres manifiestan que el incumplimiento de estas normas sociales les pueden ocasionar sanciones que van desde la burla, el desprecio, el rechazo... hasta la discriminación. En los discursos que presentamos a continuación se reflejan algunas sanciones que pueden recibir las mujeres por desviarse de las normas de comportamiento que se atribuyen a su rol en las relaciones amorosas. El primer comentario que presentamos ilustra cómo los hombres se creen con la potestad de corregir a las mujeres y llevarlas por el camino que ellos han decido como adecuado (EST 112 Carapan 4:55). Las mujeres son, de este modo, la otredad definida y enjuiciada desde la mirada de los otros, y no desde unos parámetros propios.

H. Ya hay algunos compañeros que las regañan, porque así tiene que ser, que las regañen. Un compañero que regañaba a una niña, no porque era bonita o así, sino porque la quería y no quería que anduviera así, que no actuara así, y le decía: "tú no vas a andar dejándote que te traten así, que te agarren en todas partes, porque si 
andas así espera a que tengas como 18 o 19 años y verás que ya ningún niño te va a hacer caso".

(EST 112 Carapan 4:55)

H. Pues pienso bien porque es verdad, si alguna niña se deja y ya, los niños se fijan o las señoras se fijan y algunas señoras les dicen a sus hijos: “'te estás fijando en esa niña, cómo anda, cómo es de loca, cómo se "lleva"? Tú no vas a andar con esa niña".

$H$. Aquí la gente critica mucho, por ejemplo las que quieren andar a la moda, que se ponen sus faldas o sus pantalones, luego, luego dicen ";Ay! mira que loca”, o “;Ay! mira esto".

(EST 112 Carapan 4:56)

H. Sí, es que muchas se creen así las bonitas, pues están bonitas, y andan con muchos.

H. Y aqui hablan mucho de ellas, que es... una "dejada” y así.

(EST 112 Carapan 4:4)

M. Yo tenía unas compañeras, que... cuando yo iba en la primaria, cuando yo siempre me juntaba con ellas y un día una amiga de nosotros, su mamá, había escuchado yo algo de que trabajaba en la prostitución, y que a ella una vez su mamá la llevó a donde trabajaba ella ... y que... la niña tuvo relaciones sexuales, e invitó a que mis amigas a que fueran ahi y todas fueron... pero pues yo me alejé de ellas porque mi mamá me decía que eso no estaba bien...

M. Yo también tenía... tenía porque ahora ya no... una compañera que le gustaba tener muchos novios y pues como a mi no me gusta eso... yo se lo dije a mi mamá. mamá yo no voy a tener mi novio a temprana edad, ahorita yo lo que pienso son en mis estudios...

H. De llevada.

M. No en andar de novia o yo que sé... y pues... a mí no me gusta eso, es por eso que yo me aparté, sí sentí feo, porque yo la quería, pero así como es pues no...

(ESG 02 Apatzingán - 7:93)

En cuanto a las sanciones a las que son sometidos los chicos destacan las que hacen alusión a su falta de hombría. A continuación, mostramos los discursos que señalan los y las adolescentes respecto a cómo los hombres que no tienen experiencia en las relaciones afectivas pueden ser severamente criticados. El siguiente diálogo tiene lugar después de que un joven refiriera que una compañera de clase en primaria le ofreció tener relaciones sexuales y él salió corriendo porque le causó miedo.

M. Dicen que lo hacen, pero yo pienso que es nomás por estar jugando y que no les digan que... [su intencionalidad es decir que son "jotos"] que... no son niños o que son niñas... pero no les creo.

(ESG 02 Apatzingán - 7:48) 


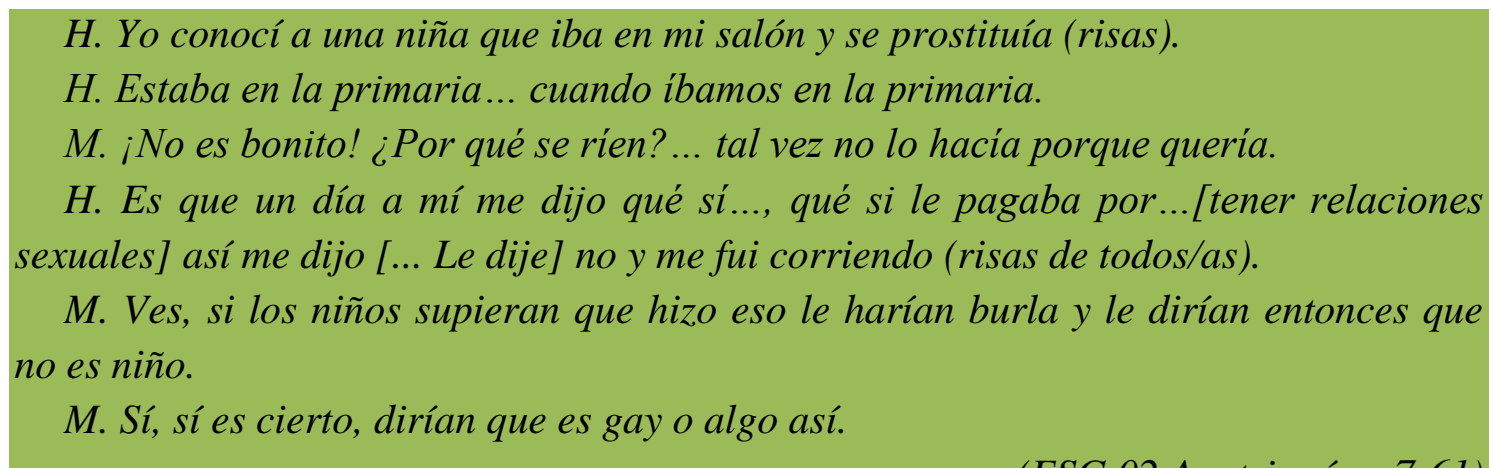

(ESG 02 Apatzingán - 7:61)

Otro aspecto que identificamos, tras el análisis de las dos categorías, es que la violencia en las relaciones amorosas no es algo ajeno para el alumnado. En los distintos entornos en los que se desenvuelven, ellos y ellas han observado e incluso experimentado situaciones de violencia en las parejas. Así pues, en varios grupos de discusión los y las adolescentes manifiestan que algunas mujeres son obligadas (bajo amenazas) a entablar relaciones amorosas (CECADEJ Internado Mixto - 10:5; 10:68; EST 23 Tangancícuaro - 3:7). También relatan que en ocasiones los hombres emprenden las relaciones afectivas con la intencionalidad de experimentar sexualmente y desprestigiar a las mujeres, por lo que ocultan sus verdaderas intenciones, conquistando a las chicas con engaños para conseguir relaciones sexuales (ESG San Felipe de los Alzatis - 9:91).

M. Hay amenazas a las mujeres: si no me quieres te voy a matar o voy a matar a alguien de tu familia.

(CECADEJ Internado Mixto - 10:5)

M. Yo conozco a una persona de aquí que anduvo con una y que la amenazó. Le dijo: si no andas conmigo golpeo a tu hermana, así que ya saben quién es.

(CECADEJ Internado Mixto - 10:68)

H. O también puede ser que el novio tiene a su novia a fuerzas, por ejemplo que la amenaza que le puede hacer algo a su familia.

(EST 23 Tangancícuaro - 3:7)

H. Que se quieren o que nada más las ocupan para un rato como un juego (risas).

(ESG San Felipe de los Alzatis - 9:91)

H. O también cuando se quieren burlar de ellas y dejarles un hijo y dejarlas ahí.

(EST 72 Patambán - 5:4) 
M. O también se metió con alguien y ya no quiso. Y él empezó a hablar mal de ella por toda la escuela y a la mejor ya no le quieren hablar porque a la mejor dijo algo que ni siquiera era.

(EST 05 Apatzingán - 6:125)

En los grupos de discusión también se alude al tema de los celos y de la posesión en las relaciones de pareja. Los y las adolescentes refieren que el hombre puede ejercer violencia hacia ellas porque la mujer "provoca" tentaciones en otros con su forma de vestir o de actuar. El amor es entendido como posesión, ya que hombres y mujeres manifiestan reiteradamente que el hecho de entablar amistad con otras personas puede desencadenar conflictos con la pareja o maltrato. En este sentido las alumnas señalan que los celos pueden darse tanto en hombres como en mujeres, aunque refieren que son únicamente ellos los que en ocasiones llegan a la violencia física:

H. Sí porque a ellos les gusta verlas con esa ropa pero nada más para ellos, pero que los demás no las vean.

(CECADEJ Internado Mixto - 10:52)

M. Si ella trabaja en la oficina o en un oficio y se encela y la golpea o está obsesionado por ella.

M. Se enojan por los chismes y las golpean y después dice el hombre que no tenía la culpa que se dejo llevar por los celos.

(CECADEJ Internado Mixto - 10:53)

M. O también el novio maltrata a la novia y le dice cosas. Y si la ve platicando con otro amigo se enoja, o ella también si ve platicando al novio con otra se enoja, piensa que está saliendo con la otra y entonces empiezan los problemas.

(ESG 02 Apatzingán - 7:1)

En la discusión que presentamos a continuación se refleja cómo el alumnado considera que algunos actos violentos hacia las mujeres pueden estar justificados. Ellos y ellas señalan que cuando las mujeres se desvían de su rol de género (respetabilidad y recato), dan pie/derecho a que ellos puedan abusar de ellas. Esta consideración es tremendamente preocupante, pues justifica que las mujeres que han decidido mostrar mayor libertad en las relaciones amorosas puedan ser violentadas sexualmente bajo la consigna de que "ella se lo buscó", eximiendo al varón de su responsabilidad ante tal falta. 


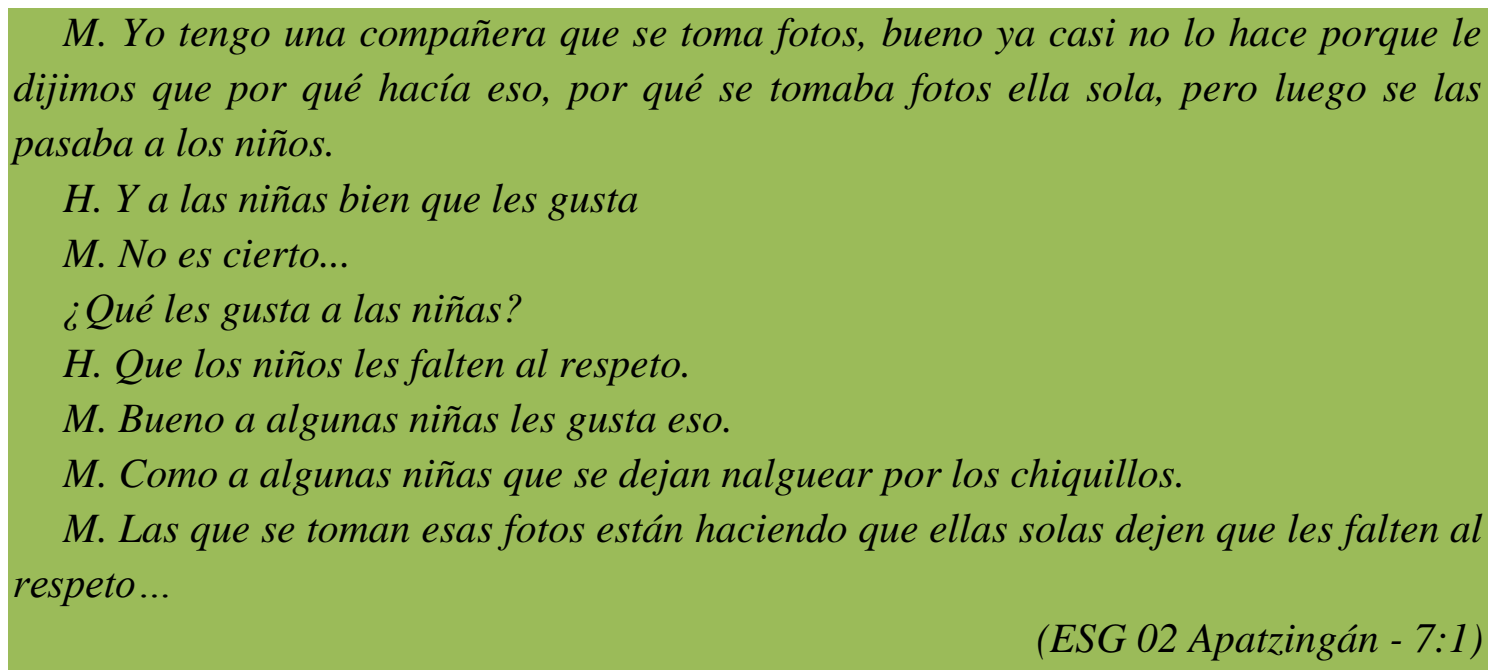

Finalmente vamos a analizar cómo las consecuencias derivadas al ejercer la sexualidad no tienen las mismas repercusiones para uno y otro sexo. Como hemos venido mostrando en párrafos anteriores, el ejercicio de la sexualidad para las mujeres es un terreno prácticamente vedado. El rol que se atribuye a las mujeres les impide expresar abiertamente deseo, placer o curiosidad, puesto que se les educa para asociar el sexo a las relaciones amorosas. El hecho de mostrar una actitud más activa en las relaciones amorosas las convierte en personas menos deseadas y con menos valor y prestigio social. Consideramos, teniendo en cuenta los discursos de los y las adolescentes, que, en el terreno de las relaciones afectivo-sexuales, las presiones sociales para uno y otro sexo tienen consecuencias distintas para hombres que para mujeres.

En las mujeres, "el fugarse con el novio" (como veíamos en el apartado de sexualidad) es una de las pocas opciones que tienen para experimentar las relaciones afectivo-sexuales, ya que, según los discursos analizados, las "chicas buenas" pueden ejercer su sexualidad con aprobación social solo en el matrimonio. El iniciar este tipo de relaciones deja a las mujeres en una situación de mayor vulnerabilidad, siendo muchas de ellas relegadas al ámbito doméstico/privado, lo que limita sus posibilidades de continuar con una preparación académica que las ayude a mejorar sus condiciones de vida. Asimismo, en los comentarios examinados se refleja la evolución que ellas 
sufren: pasan de la tutela de la familia a la tutela de la pareja, o bien a la de la familia de la pareja. Está claro, ellos deciden sobre el futuro de la menor; las mujeres parecen estar condenadas a vivir bajo consignas y pautas establecidas por otros.

H. Cuando se casan muy chicos los papás dicen que el novio todavía va a ir a la escuela, y la novia pues ya se queda a hacer el quehacer. Pero hay muchos papás de la novia que dicen "no, yo quiero que mi hija también estudie" y ellos le dan el dinero para que ella estudie, y el chavo también estudia.

(EST 112 Carapan - 4:83)

H. Y también algún hombre que se lleve a la mujer y a veces sólo la mantiene un año, y bien felices un año y pasan uno o dos años y ya los muchachos ya señores pues, les pegan a sus esposas...

H. Muchos las regresan a sus casas, solamente las tienen una semana y ya después las regresan y a veces las vuelven a casar.

H.... las regresan, o las dejan, o a veces ya tienen hijos y algunos por los problemas que hay, como por decir aquí así están los problemas, que uno ya se lleva a la muchacha, ya la mamá del señor que se lleva a la muchacha. La muchacha que se llevó tiene que levantarse temprano al molino, hacer las tortillas, hacer la comida a tiempo y cuando la muchacha no hace eso luego, luego ahi se forma el problema...

(EST 112 Carapan - 4:88)

M. El novio las ilusiona y creen que van a tener una vida que bla, bla bla ... y a la mejor les creen y se van, pero son unos escuinchillos [significa niños].

(EST 71 Nuevo Progreso - 1:44)

Los hombres, a diferencia de las mujeres, pueden experimentar este tipo de relaciones de manera ocasional, solo por ganar experiencia y reconocimiento. La aventura de formar una pareja formal a temprana edad no supone pérdida de estatus y/o reconocimiento, incluso si se decide no continuar con la relación el prestigio y valor del hombre no se verá afectado. Los y las adolescentes manifiestan que los hombres tienen la posibilidad de decidir entre continuar su formación o buscar opciones laborales, mientras que ellas tienen que renunciar a todo para dedicarse a las tareas del hogar. Además, si no cumplen con estas funciones domésticas son fuertemente criticadas (EST 112 Carapan - 4:86).

M. Sí, se van a trabajar, los mandan a trabajar sus papás, o algunos nada más están ahí y sus mamás los cuidan, o ellos se van a la escuela y su esposa nada más ahí se queda. 
(EST 112 Carapan - 4:81)

H. Y empiezan a criticarla, que no hace nada, que es una floja.

H. [...] y la mamá del señor le dice a su hijo "¿por qué trajiste a esa niña que no sabe hacer nada?”, o “¿por qué hiciste eso?” y el señor no quiere que le digan así, y ahí se forman los problemas.

(EST 112 Carapan - 4:86)

M. Pues no sé, porque hay papás que también les pasó lo mismo y dicen: "no, pues lárgate ya no te queremos aqui por sucia”.

(EST 33 Playa Azul - 8:9)

Otra consecuencia al ejercer la sexualidad a edad temprana es el embarazo. Esta problemática, sobre todo en las zonas indígena y rural, es vista como algo bueno y positivo. Ellos y ellas manifiestan que es lo mejor que le puede pasar a una persona. Esta connotación del embarazo como un regalo enviado por "Dios" supone una oportunidad para las mujeres, en la medida en que pueden redimir sus culpas al encauzar sus "malos pasos" y asumir la responsabilidad de salir adelante con el "nuevo ser".

H. Que no se ponga triste, que salga adelante con su hijo, que un hijo es lo más sagrado que tiene uno en la casa.

(EST 33 Playa Azul - 8:28)

H. Darles palabra de inspiración a las personas embarazadas, decirle si ella tiene la idea de abortar decirle lo contrario, es algo que le da Dios, algo que él quiere que tenga la persona.

(ESG San Felipe de los Alzatis - 9:186)

Así pues, estos discursos muestran cómo las mujeres que deciden continuar con el embarazo y asumir su rol de madres tienen la posibilidad de ser reconocidas y valoradas socialmente. No obstante, el hecho de continuar con el embarazo conlleva para las adolescentes diversas problemáticas: dependencia económica y emocional, postergación o renuncia de la formación académica y menos oportunidades laborales, entre otras.

H. O sea, en ese momento pierden todo tipo de oportunidades en el estudio y de superación, también en el trabajo porque con un hijo es casi imposible estar trabajando y cuidando a los niños, es una responsabilidad muy grande.

(ESG San Felipe De Los Alzatis - 9:81)

$H$. Ahora perderían sus estudios porque tienen que trabajar para poder mantener a su hijo o para formar una familia. 
(ESG San Felipe De Los Alzatis - 9:155)

M. Embarazos a temprana a edad, porque hay señoritas que tienen sexo y luego su novio no se hace responsable, por su esposa, las embarazan y las dejan y en ocasiones la familia no las apoya. Debemos tener la información nosotros, antes.

(EST 71 Nuevo Progreso - 1:14)

H. Para prevenir embarazos no deseados, porque después su familia se enoja con él y luego las rechazan.

(EST 71 Nuevo Progreso - 1:42)

M. Hay veces que las chavas cuando tienen un novio y lo quieren mucho se embarazan y así piensan que lo van a amarrar y así van a conseguir que el novio se case con ellas, pero hay veces que no es así, de hecho cuando salen embarazadas más se alejan $[\ldots]$

(EST 05 Apatzingán - 6:3)

H. Estoy recordando, era de aquí de la escuela y pues ella ya no estudió y este ya siempre está en su casa y ella antes siempre salía y pues ya no puede salir.

$M$. Que a veces el novio no acepta la responsabilidad y se sienten solas, los papás a veces las corren de su casa y a veces ellas se suicidan.

(EST 23 Tangancícuaro - 3:79)

H. Podría ser que la muchacha se sienta mal porque no va a poder seguir estudiando y va a tener que mantener a su hijo y puede ser que luego no lo quiera o que lo vaya a abortar o que cuando nazca lo maltrate.

(EST 23 Tangancícuaro - 3:80)

M. No es conveniente, te tienes que salir de estudiar.

M. Nos platicaron de una chica. Que se quedó embarazada y se tuvo que salir de la escuela.

(EST 65 Morelia - 2:30)

La problemática del embarazo no es relatada por los y las adolescentes como un compromiso compartido: en sus discursos se refleja que son las mujeres las que tienen que asumir las consecuencias. Además, en sus comentarios se puede observar que la responsabilidad de evitar los embarazos es una cuestión que corresponde exclusivamente a las mujeres. Así se ilustra en los comentarios que se muestran a continuación, donde se relata que las "compañeras se embarazaron", como si el hombre no hubiese intervenido en esta situación.

H. Hubo una compañera que iba con nosotros y ella no quiso medir las consecuencias y quedó embarazada.

H. En mi salón también hubo una que se tuvo que salir en el tercer bimestre porque se quedó embarazada.

(EST 05 Apatzingán - 6:3) 
H. También en Patamban, tres o cuatro muchachas tuvieron que salirse de ahí porque salieron embarazadas.

(EST 23 Tangancicuaro - 3:82)

M. También sería lo mismo que si no tienen información se pueden quedar embarazadas [...]

(EST 05 Apatzingán - 6:3)

H. Yo tengo una compañera que se embarazó... (murmullos, no se entiende).

M. Yo conozco una muchacha que ella, sus papás siempre la cuidaron mucho, [...] tiempo después ya ella tenía como 16 años y mi tío ya no la veía, pero "ella salió embarazada" de un señor mucho más grande que mi tío y este... Luego tuvo a su bebé y yo no la conozco mucho, pero dicen que su mamá no la ayuda a cuidar a la bebé y ella está en casa de su mamá y todo, pero no ayuda a cuidar a la bebé y dicen que ella llora mucho, porque el bebé no la deja dormir [...] y ya no puede salir con sus amigas ni nada...

(ESG 02 Apatzingán - 7:9)

Únicamente en tres grupos de discusión los adolescentes manifestaron que el embarazo era una cuestión que implicaba corresponsabilidad entre hombres y mujeres. Ahora bien, las consecuencias que ellos refirieron en caso de asumir su paternidad son la imposibilidad de disfrutar de más experiencias amorosas y la disminución de las oportunidades laborales:

H. Que los hombres si llegan a tener relaciones sexuales puede ser el causante de que una mujer quede embarazada por no usar el condón, usar condón es una responsabilidad.

(EST 72 Patambán - 5:94)

H. Que no vives tu juventud y no puedes salir con alguien más porque embarazaste a otra persona.

(EST 23 Tangancícuaro - 3:80)

H. Que a lo mejor le hubiera gustado al muchacho tener su carrera pero se tiene que salir de la escuela para mantenerlos.

...Aunque no siempre resulta el embarazo, pero puede ser que se dé.

(EST 23 Tangancícuaro - 3:85)

Con relación a las ITS, es importante destacar que las y los adolescentes manifiestan, en su gran mayoría, que no han conocido casos de personas que hayan sufrido estas problemáticas derivadas de mantener relaciones sexuales sin responsabilidad. Únicamente un alumno refirió el caso de una chica que con trece años falleció por haberse contagiado de VIH. 
H. Yo tenía una amiga que se fue de su casa a los 13 años... y como al... año le llegó la noticia a su mamá que su hija se había muerto de Sida... se contagió...

(ESG 02 Apatzingán - 7:93)

El análisis que hemos elaborado refleja la interrelación existente entre los estereotipos de género, las relaciones afectivo-sexuales en los y las adolescentes y sus posibles consecuencias en términos formalización de parejas, de embarazo y de ITS.

\subsubsection{Resumen}

El análisis de este apartado refleja cómo las mujeres se encuentran en una situación clara de desigualdad. Mientras que para ellas el mostrar apertura y habilidad en las relaciones amorosas les resta valor — no solo en el terreno de pareja, sino también en el social y personal- y las convierte en "carne de cañón" ante posibles abusos, a ellos el mismo hecho les otorga mayor prestigio social. A continuación puntualizamos la información que consideramos resume el apartado siete:

- Existe un sexismo ambivalente en las relaciones afectivo-sexuales. Hombres y mujeres consideran que existe una complementariedad natural entre el hombre y la mujer, lo cual impide que las problemáticas en las relaciones amorosas sean percibidas y analizadas por el alumnado como situaciones de desigualdad.

- Los y las adolescentes tienen muy arraigados los roles y los estereotipos de género. Sus discursos desvelan claramente tanto las relaciones de desigualdad por razón de sexo, como la aceptación de las relaciones de poder/autoridad/protección que los varones ejercen sobre las mujeres en las relaciones afectivas.

- Las situaciones de violencia contra las mujeres son al menos parcialmente justificadas por las y los adolescentes, al argumentar que en algunas circunstancias las mujeres pueden provocar el 
desencadenamiento de los abusos o de la violencia, eximiendo así a los hombres de las responsabilidades de sus faltas.

- Los discursos de los y las jóvenes evidencian que, en sus contextos más próximos, son las mujeres quienes reciben sanciones sociales más severas por el hecho de no asumir el rol de género impuesto.

- El modelo de feminidad en las relaciones afectivo-sexuales aparece supeditado a los deseos de la pareja, mientras que el modelo de masculinidad está caracterizado por dar prioridad a sus deseos, independientemente de lo que tengan que hacer para conseguirlos. 



\section{Los libros de texto}

En este capítulo presentamos los resultados obtenidos del análisis de los libros de texto de primer grado de secundaria, con la finalidad es describir y reflexionar respecto a las creencias, los valores y los modelos que se trasmiten a los alumnos en función de su sexo. Describimos la presencia de hombres y mujeres, analizando la construcción simbólica de cada uno de los personajes en cuanto a la relevancia del personaje (protagonista, secundario, invisible), su relación con el ámbito social, político, familiar y profesional y las características psicosociales (roles, estereotipos de género y transgresión de los mismos si la hubiera). Por otra parte, extraemos información referente al contenido dedicado a la promoción de la igualdad.

En los cuatro libros de texto analizados, entre las denominaciones textuales y las imágenes, hemos codificado un total de 4599 personajes. Así pues, el porcentaje de aparición de los varones es significativamente superior al de las mujeres ( 34,4 y 18,1 respectivamente). El 47,5 por ciento restante se distribuye entre la alusión a genéricos, masculinos genéricos y los grupos o colectivos. El análisis de estos personajes se va a realizar siguiendo el orden que presentamos a continuación.

En primer lugar llevamos a cabo el estudio de los personajes que se presentan al alumnado a través de las imágenes e ilustraciones contenidas en los libros de texto. Realizamos un análisis descriptivo (recuento del número de imágenes y personajes que aparecen en el texto) y cualitativo de los datos (selección de imágenes que trasmiten o rompen con los estereotipos y roles de género).

En el segundo apartado hacemos un recuento de la aparición de los personajes en el texto, para comprobar si lo hacen en situación y condiciones de igualdad, o si por el contrario tiene lugar un uso sexista. 
En el tercer punto abordamos la presencia de mujeres y hombres con relación a las labores que desarrollan en la sociedad. Se presentarán las citas textuales que hacen alusión tanto a los modelos estereotipados de hombres y de mujeres, como a los contenidos que promueven la cultura de igualdad.

\subsection{Los personajes en las imágenes}

En este apartado mostramos el análisis de las imágenes contenidas en los cuatro libros de texto que sirvieron como muestra para este estudio. En un primer momento vamos a describir los datos únicamente atendiendo a criterios cuantitativos. Así pues, se han contabilizado un total de 258 imágenes, y 468 personajes, ${ }^{157}$ esto supone el 10,2 por ciento del total de datos analizados.

Por su parte, la presentación y el análisis de los resultados lo vamos a organizar en cuatro puntos. En el primero haremos referencia a la presencia y distribución de los personajes de manera global y por asignaturas. En el segundo presentaremos los resultados respecto a las imágenes que contienen personajes que han contribuido al desarrollo social, económico, científicoacadémico y cultural. Además, analizamos el total de las imágenes con la finalidad de revelar de manera más detallada las características y aspectos de los personajes que aparecen en ellas. En tercer lugar estudiaremos los estereotipos y roles de género. Para ello se realizó, por un lado, el recuento de las actividades u ocupaciones y características psicosociales que desempeñan los personajes y, por otro lado, la selección iconográfica que se presenta en los libros de texto. Finalmente, seleccionamos algunas imágenes que a nuestro entender son positivas para promover la cultura de igualdad entre hombres y mujeres.

\footnotetext{
${ }^{157}$ Recordemos que en las imágenes en las que aparecían hasta cinco personas se contabilizaban de manera individual, mientras que en las iconografías en las que se excedía este número era contabilizado como colectivo.
} 


\subsubsection{Presencia de los personajes en los libros de texto}

La presencia de los personajes que aparecen representados en las imágenes analizadas se muestra en la tabla 8.1. En ella, destaca que la presencia de los hombres con relación a las mujeres continúa siendo superior $(48,1 \%$ frente a $36,8 \%$ ). Con relación a los grupos/colectivos vemos que el de mujeres es prácticamente inexistente: $0,4 \%$ frente al $2,4 \%$ de colectivos de varones. No obstante, comprobamos que las imágenes en las que aparecen mezclados hombres y mujeres (colectivos mixtos) es mayoritario $11,1 \%$.

Tabla 8.1. Distribución de la presencia de personajes en las imágenes

\begin{tabular}{lrrr}
\hline \hline \multicolumn{1}{c}{ PRESENCIA } & FRECUENCIA & PORCENTAJE & TOTAL \\
\hline VARONES & 225 & 48,1 & \multirow{2}{*}{50,5} \\
\cline { 2 - 4 } COLECTIVO DE VARONES & 11 & 2,4 & \\
\hline MUJERES & 172 & 36,8 & \multirow{2}{*}{37,2} \\
COLECTIVO DE MUJERES & 2 & 0,4 & \\
\hline INDETERMINADO & 6 & 1,3 & \multirow{2}{*}{12,4} \\
COLECTIVOS MIXTOS & 52 & 11,1 & \\
\hline TOTAL & 468 & 100 & 100 \\
\hline \hline
\end{tabular}

Según los datos analizados, la presencia de la mujer continúa estando en una esfera social inferior a la de los hombres. Así se refleja en la gráfica 8.1, en la que presentamos los datos únicamente de las imágenes en las que aparecen hombres y mujeres tanto individual como colectivamente (410 personajes). En esta gráfica podemos observar que los resultados resultan favorables para los varones, con un $57,6 \%$, estando presentes 15,2 puntos porcentuales más que las mujeres.

Gráfica 8.1. Distribución de la presencia de varones y mujeres en las imágenes

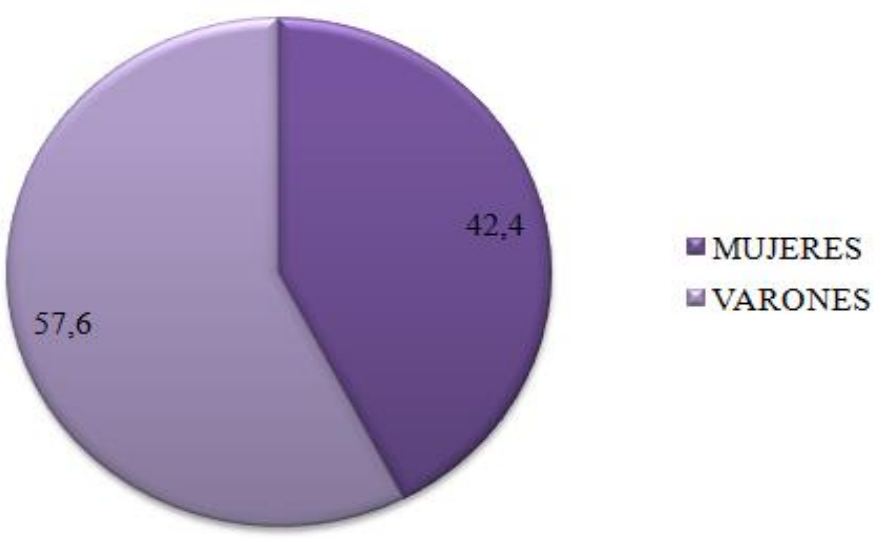

Nota: Integración de personajes tanto individuales como colectivos. 
$\mathrm{Si}$ analizamos los datos teniendo en cuenta las áreas de conocimiento que corresponden a cada libro de texto, se pueden constatar algunas diferencias entre ellos. Así pues, el libro de texto que tiene un mayor porcentaje de imágenes con personajes representando a los seres humanos es el libro de Ciencias 42,3\%, seguido del manual de Geografía con un 32,7\%. Por otra parte, el libro de Español contiene un 19,4\% y finalmente se encuentra el libro de Matemáticas con un 5,6\%.

Los libros que muestran unas cifras más cercanas al equilibrio en cuanto a la distribución de personajes (varones y mujeres), son los correspondientes a Ciencias y Español, mientras que en los libros de texto de Geografía y Matemáticas la diferencia es mayor. En el libro de Geografía existe más de un 16 por ciento de diferencia entre los varones y las mujeres, y en él también se muestra el número más alto de imágenes que contienen colectivos mixtos. Con relación al libro de Matemáticas, podemos observar que es muy escaso el número de imágenes que representan a seres humanos y, además, la mayoría de los personajes que aparecen son varones (20) mientras que solo hay una cuarta parte de mujeres (5).

Tabla 8.2. Distribución de la presencia de hombres y mujeres en las imágenes según asignatura

\begin{tabular}{lrrrrrrrr}
\hline \hline \multirow{2}{*}{ PRESENCIA } & \multicolumn{2}{c}{ CIENCIAS } & \multicolumn{2}{c}{ ESPAÑOL } & \multicolumn{2}{c}{ GEOGRAFÍA } & \multicolumn{2}{c}{ MAT. } \\
\cline { 2 - 11 } & $f_{i}$ & $\%$ & $f_{i}$ & $\%$ & $f_{i}$ & $\%$ & $f_{i}$ & $\%$ \\
\hline HOMBRE & 91 & 46,0 & 42 & 46,2 & 72 & 47,1 & 20 & 76,9 \\
\hline MUJER & 82 & 41,4 & 38 & 41,8 & 47 & 30,7 & 5 & 19,2 \\
\hline GENÉRICO & 6 & 3,0 & 0 & 0,0 & 0 & 0,0 & 0 & 0,0 \\
\hline COLECT. VARONES & 1 & 0,5 & 3 & 3,3 & 6 & 3,9 & 1 & 3,8 \\
\hline COLECT. MUJERES & 1 & 0,5 & 1 & 1,1 & 0 & 0,0 & 0 & 0,0 \\
\hline COLECT. MIXTO & 17 & 8,6 & 7 & 7,7 & 28 & 18,3 & 0 & 0,0 \\
\hline TOTAL & 198 & 100,0 & 91 & 100,0 & 153 & 100,0 & 26 & 100,0 \\
\hline \hline
\end{tabular}

Atendiendo únicamente a los datos hasta aquí presentados, podríamos decir que se refleja un cambio en pro de la igualdad sobre todo en los libros de texto 
de Ciencias y de Español, al menos en cuanto a la distribución numérica de los personajes hombres y mujeres. En los apartados que se desarrollarán a continuación mostraremos si estas cifras, en principio cercanas al equilibrio, se corresponden con una promoción de la igualdad entre hombres y mujeres, o si por el contrario el balance es solo numérico y se continúan perpetuando el sexismo y los estereotipos de género en la información que se proporciona al alumnado a través de las imágenes.

\subsubsection{Personajes históricos o representativos}

En este apartado realizamos un recuento de la distribución por sexo de los personajes cuya presencia y protagonismo se justifica por haber contribuido al desarrollo cultural, social, científico y político, entre otros. Además analizamos los ámbitos de actividad en los que han alcanzado ese reconocimiento para perdurar en la memoria.

En los libros de texto analizados son pocas las imágenes en las que se representa a personajes célebres, tan solo se encontraron 29 ilustraciones. En la mayoría de ellas se muestran fotografías de hombres solos (89,7\%), generalmente en primer plano, y de cintura hacia arriba. El libro de texto que tiene mayor número de imágenes con personajes representativos es el libro de Ciencias $(41,4 \%)$ y es, así mismo, el único en el que aparece una mujer como referente por su contribución al ámbito científico/académico. El resto de libros analizados contienen únicamente varones.

Los ámbitos de actividad en los que aparecen mayoritariamente representados los varones célebres difieren en función de la asignatura que se trate. Así pues, en Ciencias todos los personajes que aparecen han realizado alguna contribución al campo científico y/o académico. En este sentido, en el libro de Matemáticas, aun cuando los personajes que aparecen destacan mayoritariamente en el campo científico, también aparecen personajes representativos en el ámbito político, en arte y literatura y en el deportivo. Por 
su parte, en el libro de Español los personajes destacan en el contexto político y en arte y literatura. Finalmente, en el libro de Geografía solo aparece una imagen en la que se observa a un colectivo mixto participando de un evento político y además en ella la presencia de las mujeres es menor que la de los hombres (tabla 8.3.).

Tabla 8.3. Personajes representativos en las imágenes por ámbitos de actividad según la asignatura

\begin{tabular}{|c|c|c|c|c|c|c|c|c|c|c|}
\hline \multirow{3}{*}{ ÁMBITO } & \multicolumn{8}{|c|}{ LIBRO } & \multirow{2}{*}{\multicolumn{2}{|c|}{ TOTAL }} \\
\hline & \multicolumn{2}{|c|}{ CIENCIAS } & \multicolumn{2}{|c|}{ ESPAÑOL } & \multicolumn{2}{|c|}{ GEOGRAFÍA } & \multicolumn{2}{|c|}{ MAT. } & & \\
\hline & $f_{i}$ & $\%$ & $f_{i}$ & $\%$ & $f_{i}$ & $\%$ & $f_{i}$ & $\%$ & $f_{i}$ & $\%$ \\
\hline CIENTÍFICO & 12 & 100,0 & 0 & 0,0 & 0 & 0,0 & 8 & 72,7 & 20 & 69,0 \\
\hline POLÍTICO & 0 & 0,0 & 4 & 80,0 & 1 & 100,0 & 1 & 9,1 & 6 & 20,7 \\
\hline ARTE Y LITERATURA & 0 & 0,0 & 1 & 20,0 & 0 & 0,0 & 1 & 9,1 & 2 & 6,9 \\
\hline DEPORTIVO & 0 & 0,0 & 0 & 0,0 & 0 & 0,0 & 1 & 9,1 & 1 & 3,4 \\
\hline TOTAL & 12 & 100,0 & 5 & 100,0 & 1 & 100,0 & 11 & 100,0 & 29 & 100,0 \\
\hline
\end{tabular}

Hasta aquí hemos hecho alusión a los datos de manera cuantitativa. Ahora analizaremos algunas de las imágenes que se han contabilizado con el propósito de mostrar cómo la información que se presenta al alumnado a través de las imágenes continúa perpetuando la desigualdad entre hombres y mujeres, al omitir la presencia de mujeres que han contribuido de una u otra forma al desarrollo de la humanidad.

Vamos a iniciar el análisis de los personajes representativos haciendo referencia a que en la mayor parte de las ocasiones se cita su nombre y se destaca de manera sintética su contribución a la sociedad.

A continuación se muestran las principales figuras célebres del libro de Ciencias. En la mayoría de ellas, como ya hemos referido anteriormente, se muestra a varones solos, en primer plano, y con poca expresividad emotiva. $\mathrm{Su}$ atuendos y prendas de vestir son formales, y algunos de ellos tienen objetos relacionados con su ámbito académico/intelectual (libros, bolígrafos, materiales de laboratorio). 


\section{Figura 8.1. Personajes representativos en las imágenes del libro de Ciencias}

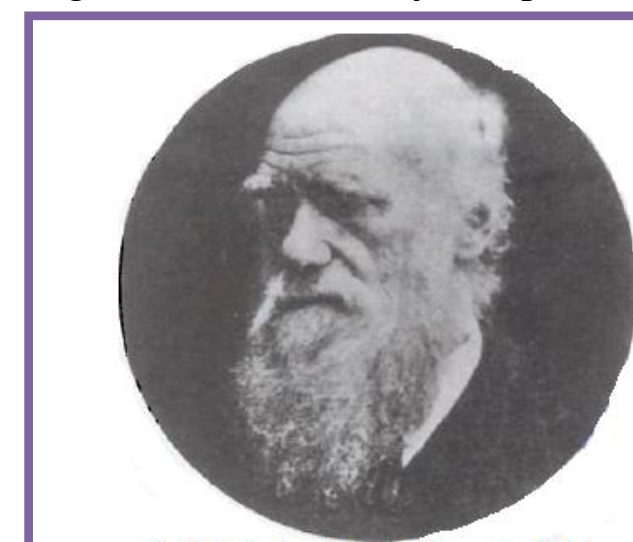

Fig. 1.54 Elaborar una teoría acerca de la evolución de las especies le llevó a Charles Darwin muchos años de estudio. p. 55

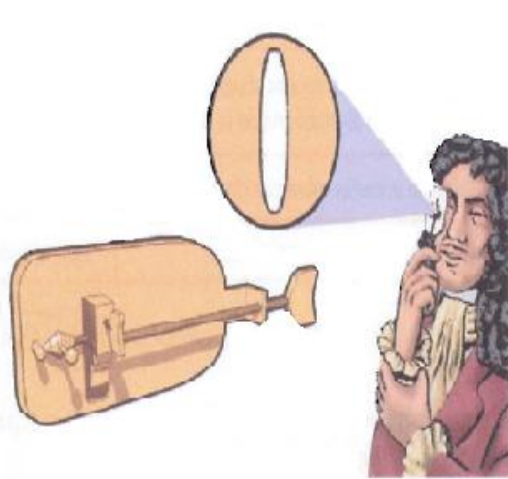

Fig. 166 El microscopio que fabricó Anton Van Leeuwenhoek le permitió conocer y describir, bacterias, glóbulos rojos, protozoarios y espermatozoides. $p$. 64

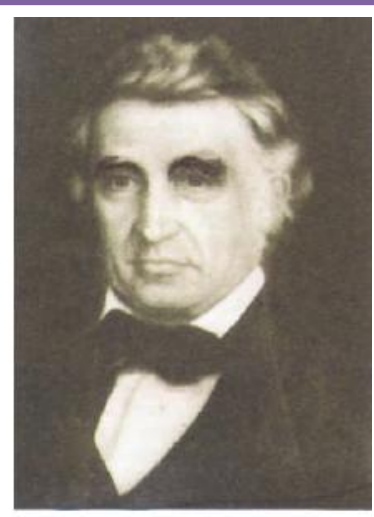

Fig. 2.5 En 1833 William Beaumar publicó sus investigaciones sobre el funcionamiento del estómago. p. 83

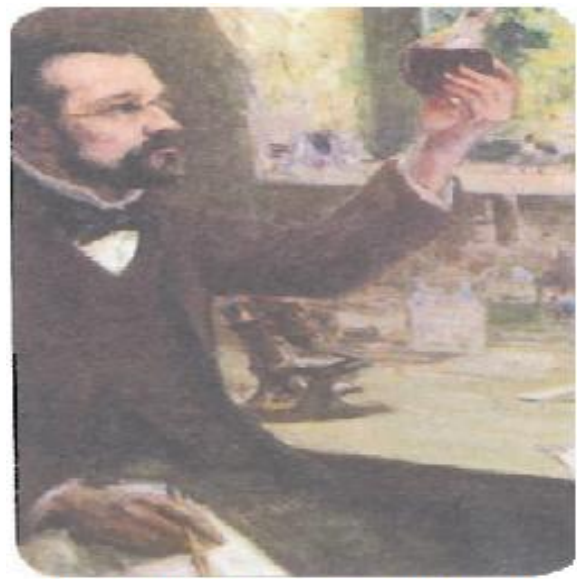

Fig. 2.57 Louis Pasteur (1822-1895), químico y biólogo frances, desarrolló la técnica de la pasteurización. p. 126.

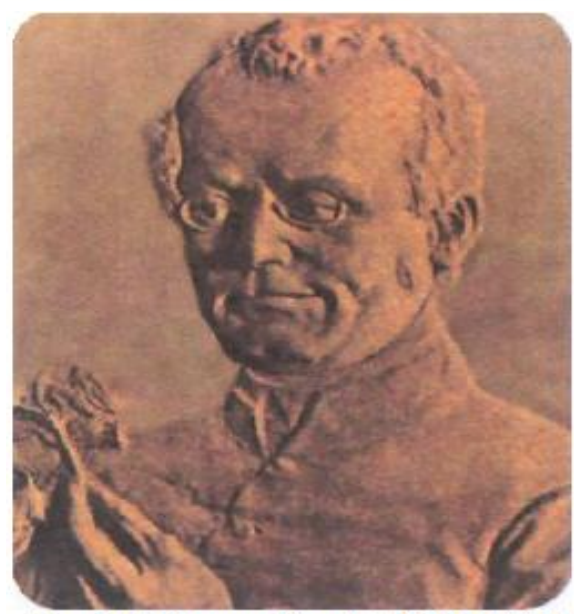

Fig. 4.45 Gregor Mendel (1822-1884) p. 234

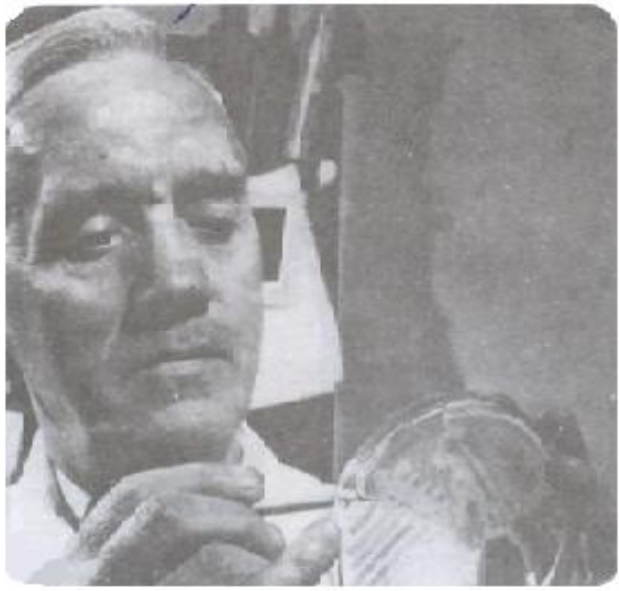

Fig. 3.51 Alexander Fleming descubrió la penicilina en el año 1928. p. 185

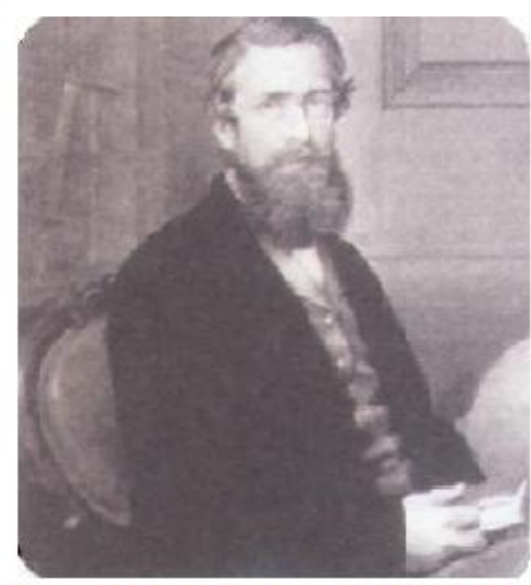

Fig. 5.5 Alfred Wallace (1823-1913). Sus investigaciones desembocaron en la fundación de una, en su tiempo, nueva ciencia: la biogeografía, o geografía zoológica. p.234 
Únicamente encontramos tres imágenes que no cumplen con las características antes descritas: en una de ellas aparece una mujer y en las dos restantes los personajes se encuentran acompañados. La Figura 8.2. Personajes representativos en las imagen en la que aparece una mujer se analizará en el apartado de promoción de la igualdad.

En una de ellas (figura 8.2.) no se incluye nota al pie de la ilustración. No obstante, la imagen se encuentra imágenes del libro de Ciencias

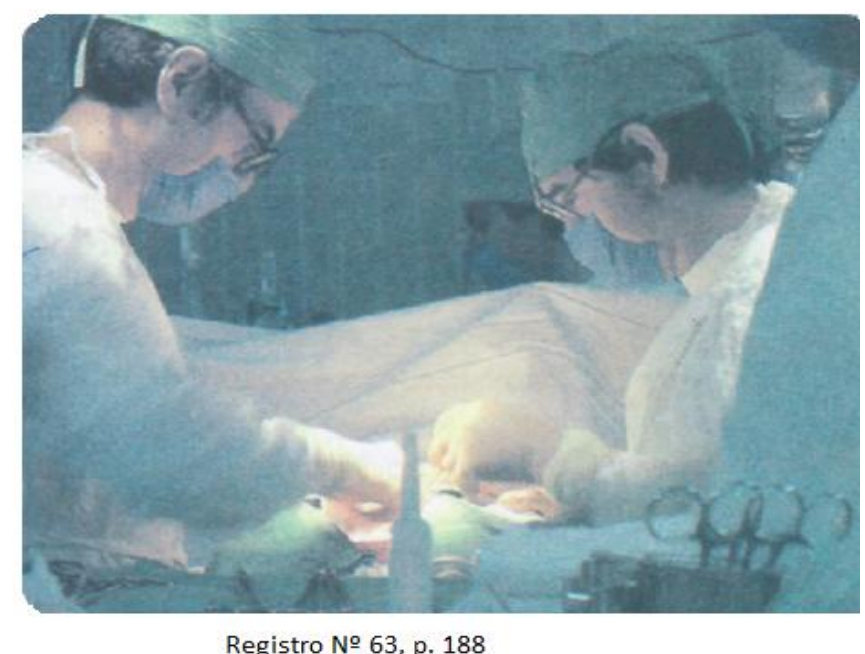
ubicada en un cuadro que se titula "Un logro tecnológico: trasplante de pulmón”, en el cual se explica la trascendencia científica que significó para la medicina este logro iniciado por dos médicos (Carre y Guthrie). Al final de la información se presenta el recurso visual de los médicos.

Figura 8.3. Personajes representativos en las imágenes del libro de Ciencias

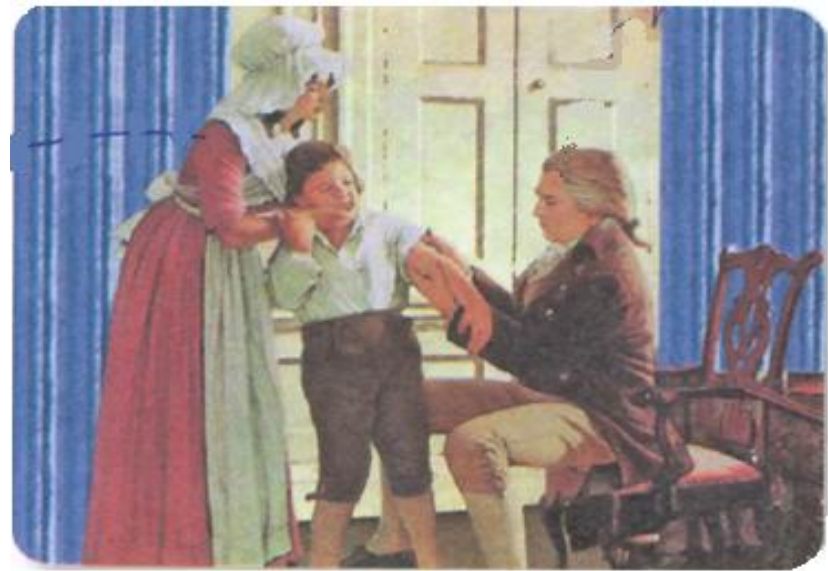

Fig. 3.14 Edword Jenner, pionero en la aplicación de vacunas. p. 154
En la otra imagen a la que hemos aludido, la 8.3, se destaca la habilidad de innovación que tuvo el científico Edward Jenner al ser el primero en aplicar la vacuna contra la viruela. Esta imagen se diferencia de las demás en que el protagonista aparece prácticamente de 
cuerpo completo y a su lado se ubica una mujer desempeñando una de las pocas profesiones que podía ejercer esa época, la de enfermera. Sin embargo no se hace ninguna mención a su participación en la fotografía.

Por otra parte, la imagen que, a nuestro parecer, es la que refleja de manera más impactante el grado de sexismo que es trasmitido al alumnado a través de las imágenes es la que presentamos a continuación. En la página 61 del libro de Ciencias se aborda la temática sobre la tecnología y su relación con el ser humano desde el inicio de la civilización hasta la actualidad. Así pues, se Figura 8.4. Personajes representativos en las imágenes del libro de Ciencias presenta al alumnado una imagen que muestra cómo el "ser humano" ha intervenido en el desarrollo social, cultural y científico. En esta imagen únicamente aparece el varón, como si la mujer no hubiese tenido ninguna participación en el desarrollo y el progreso de la humanidad.

La ocultación de la participación y la genealogía de las mujeres promueven una visión segada de la realidad. La imagen aquí presentada sintetiza cómo el sistema

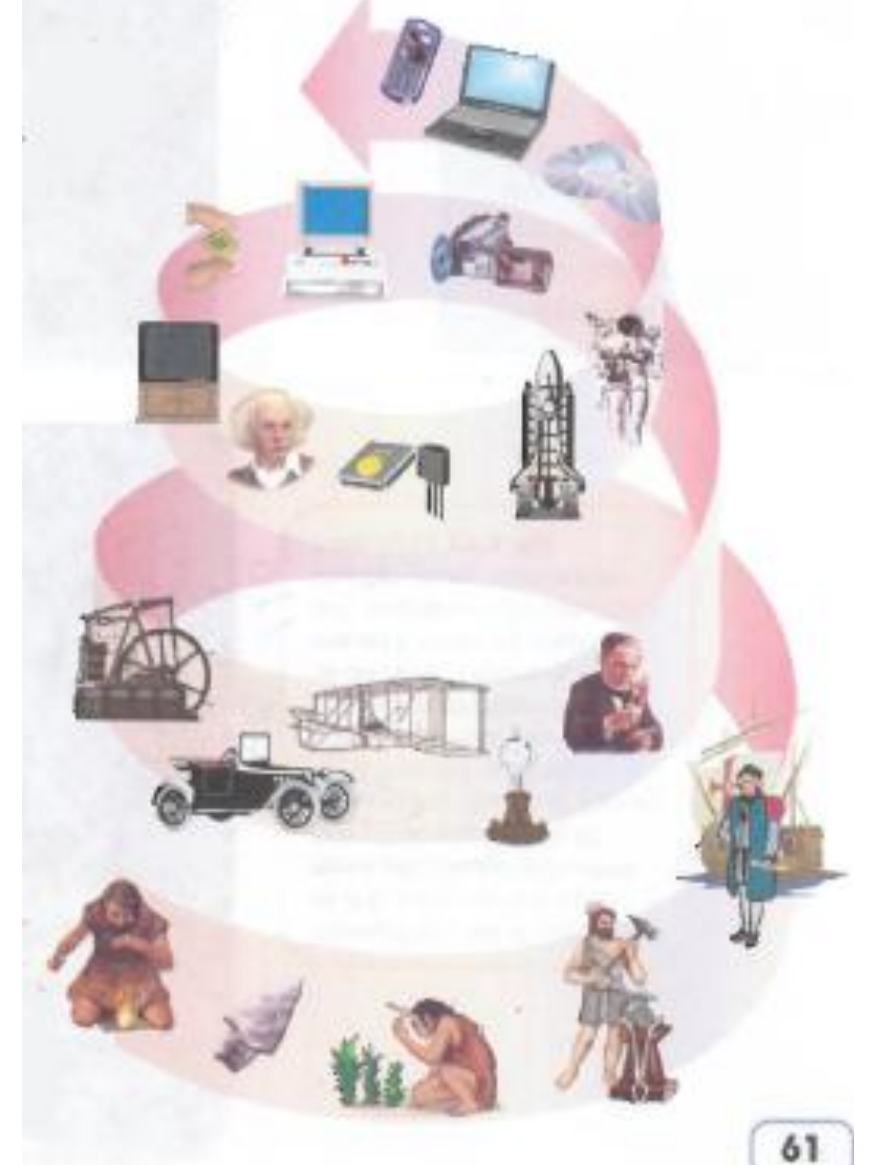

Fig. 1.62 La tecnología ha estado presente desde los inicios de la existencia del ser humano.

androcéntrico ha restado valor a las actividades, tareas y funciones que han 
desarrollado las mujeres durante siglos. Solamente se consideran dignas de perdurar en la memoria y transcender las contribuciones que han aportado los varones. Esta imagen resulta especialmente inadecuada para conseguir el objetivo de la igualdad entre hombres y mujeres, pues a través de ella se continúan perpetuando los estereotipos y roles de género.

El siguiente libro que vamos a analizar es el de Español. Los personajes representativos que aparecen en este material didáctico destacan principalmente en el ámbito político. Sin embargo, no existe una lógica para explicar el porqué de la elección de esas imágenes y no de otras que atiendan más a los principios de igualdad.

En las primeras tres ilustraciones son representados Moisés (líder liberador de su pueblo), el Rey Saúl de Israel y el líder del sionismo. Estos personajes se muestran como recurso visual para que el alumnado desarrolle una tarea de esquematización de una información que es presentada de manera textual. Posteriormente, ellos y ellas han de seleccionar la información para presentarla en una línea temporal. Resulta, entonces, llamativo que no se opte por emplear imágenes que puedan resultar más enriquecedoras para la promoción de la igualdad. Además, estas tres imágenes masculinas también se caracterizan por mostrar únicamente el rostro de los personajes que junto a los atuendos que llevan reflejan su posición de mando y de liderazgo.

Figura 8.5. Personajes representativos en las imágenes del libro de Español

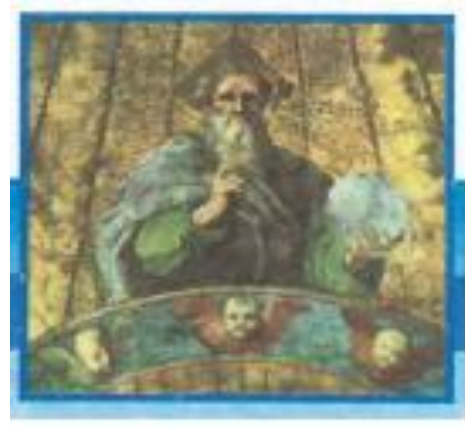

Registro № 119

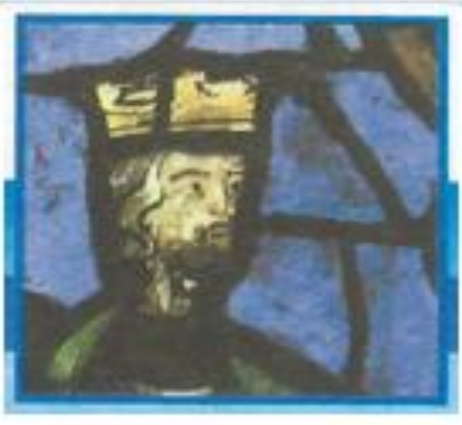

Registro № 120

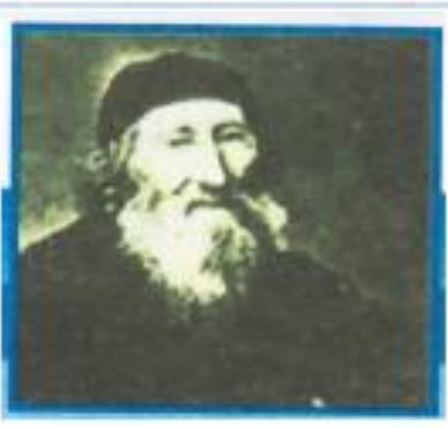

Registro № 121 
Otra imagen que se presenta al alumnado es la del Rey Figura 8.6. Personajes representativos en Moctezuma, como recurso visual de la obra de teatro "Cuauhtémoc". Se solicita al alumnado que lean la obra y la representen. No obstante, la mayor parte de personajes que aparecen son hombres.

las imágenes del libro de Español

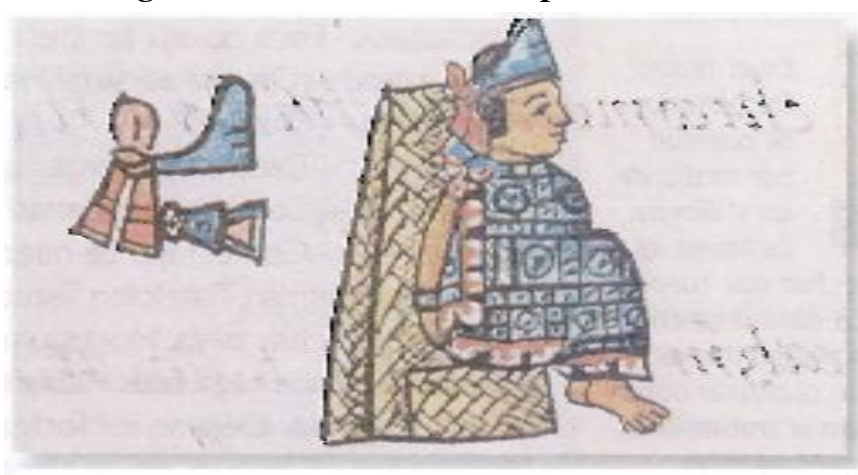

Moctezuma. Códice Florentino. Archivo editorial trillas. p. 122
Figura 8.7. Personajes representativos en las imágenes del libro de Español

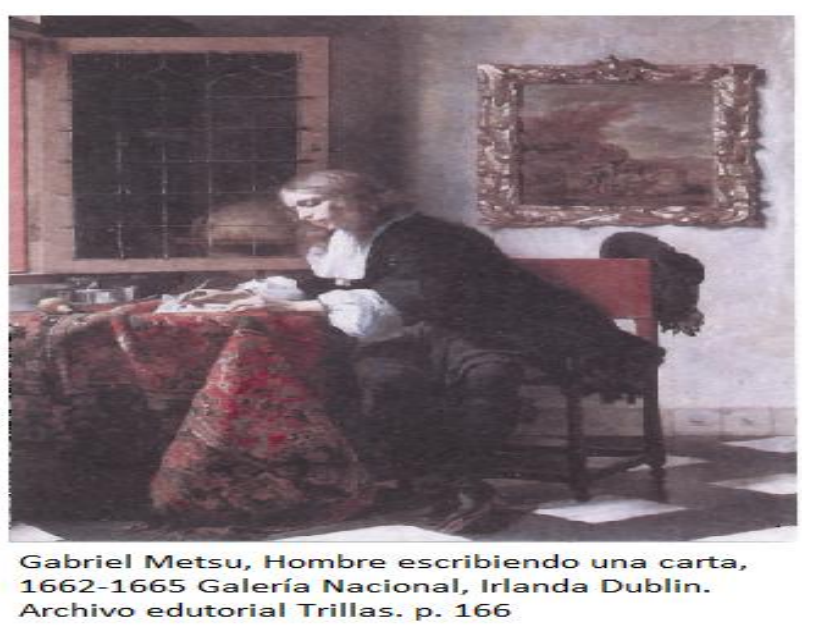

Nuevamente se muestra cómo a través de las ilustraciones y del texto se excluye a las mujeres.

La imagen que se presenta al alumnado para iniciar uno de los proyecto es la de un pintor. Nos sorprendió no haber encontrado más imágenes que mostraran referentes de personajes célebres en el ámbito

de la literatura, sobre todo en este libro de texto. Así pues, aunque son pocas las imágenes que se utilizan en este libro de texto, todas ellas muestran a varones.

Por otra parte, en el libro de Geografía únicamente encontramos una imagen que muestra a personajes representativos. La imagen ilustra una escena en la que participan dirigentes políticos de diversos países. Fue contabilizada como colectivo mixto en el ámbito político. Sin embargo, al analizar la imagen comprobamos que la presencia de las mujeres es mucho menor que la de los hombres (tres a siete) y en el atril tiene la palabra un hombre. Por todo lo 
mencionado concluimos que es escasa la aparición de las mujeres en el ámbito político.

Figura 8.8. Personajes representativos en las imágenes del libro de Geografía

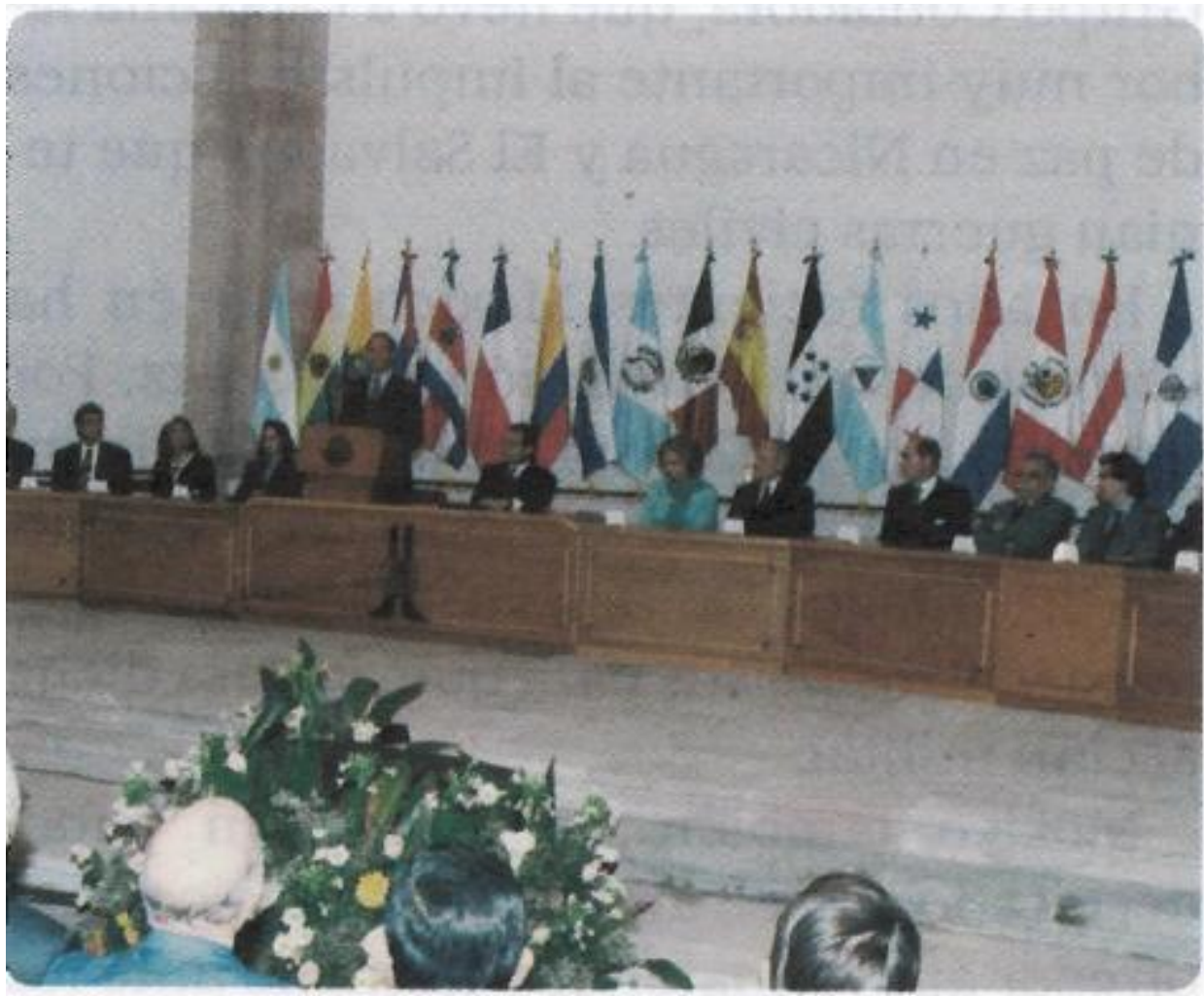

Figura 5.48 México es un actor importante en el concierto de las relaciones internacionales. p. 303

Finalmente vamos a analizar el libro de Matemáticas. En este material se encontró una mayor diversidad de ámbitos en los que aparecen los personajes célebres, todos ellos varones. En cuanto a las características de la iconografía, se diferencia del libro de Ciencias en que los personajes aparecen con mayor expresividad emotiva: aunque aparecen mayoritariamente de cintura hacia arriba, también presenta ilustraciones de cuerpo entero. En cuanto a los atuendos y vestimentas se puede observar que en su mayoría son formales, no obstante los complementos no están relacionados con el contexto científico/intelectual. El ámbito científico en el libro de Matemáticas es el que tiene mayor peso, puesto que encontramos ocho imágenes que se muestran a continuación. 


\section{Figura 8.9. Personajes representativos en las imágenes del libro de}

\section{Matemáticas}

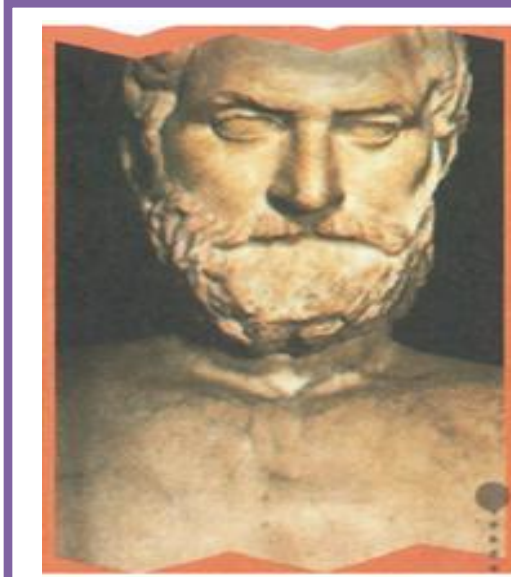

600 a. C.

En su recorrido por el mundo.

Tales de Mileto contribuyó con

el desarrollo de la geometría.

p. 55

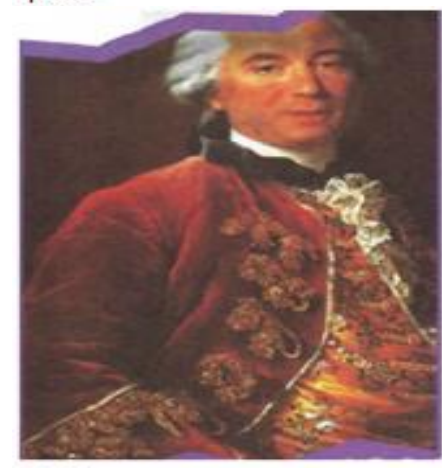

1760

El conde de Buffon

establece una conexión

entre probabilidad y $\pi$.

p. 203

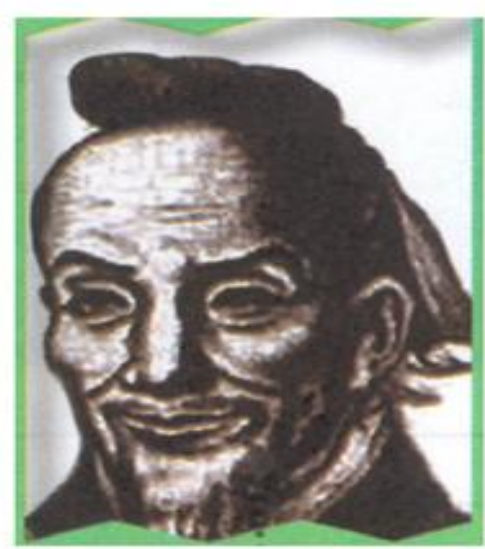

600

El chino Zu Chong-zhi y su

hijo Zu Fen-shi encuentran

que $\pi$ está entre 3.1415926 y 3.1415927. p. 127

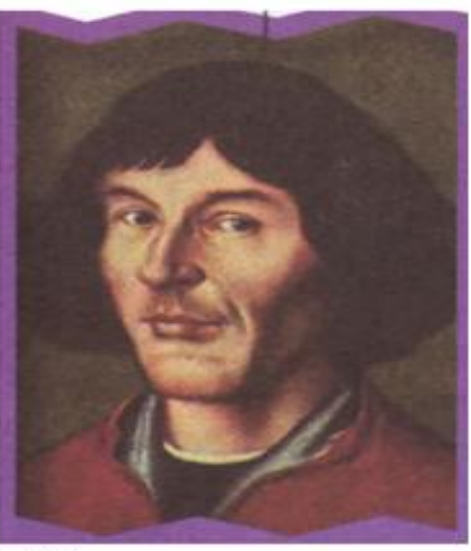

1543

La teoría de Copérnico sienta las bases de la astronomía moderna.p. 203

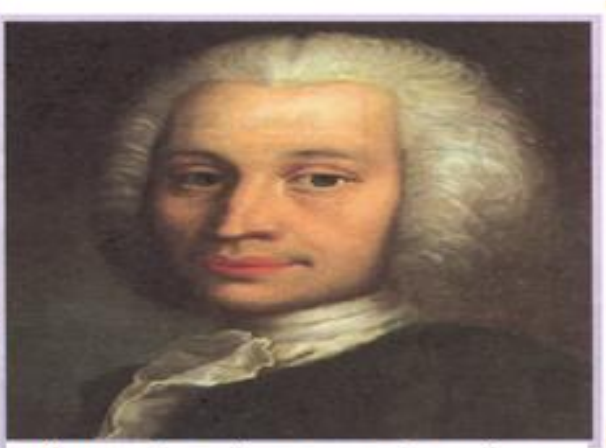

Anders Celsius (1701-1744), astrónomo sueco, fue el primero que propuso para el termómetro una escala de 100 grados que separan el punto de ebullición yel de congelación del agua. Esta escala - también conocida como

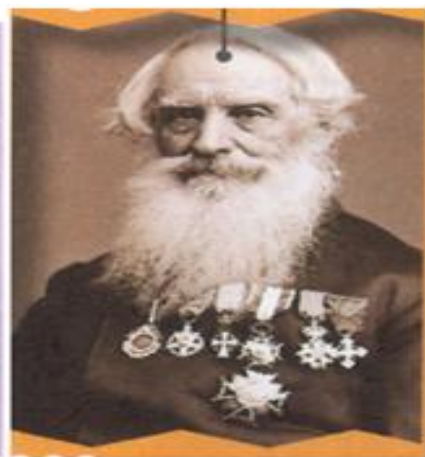
1837

Samuel Morse idea un alfabeto telegráfico conocido como clave Morse. p. 237 escala centígrada-, se utiliza en todo el mundo. p. 204

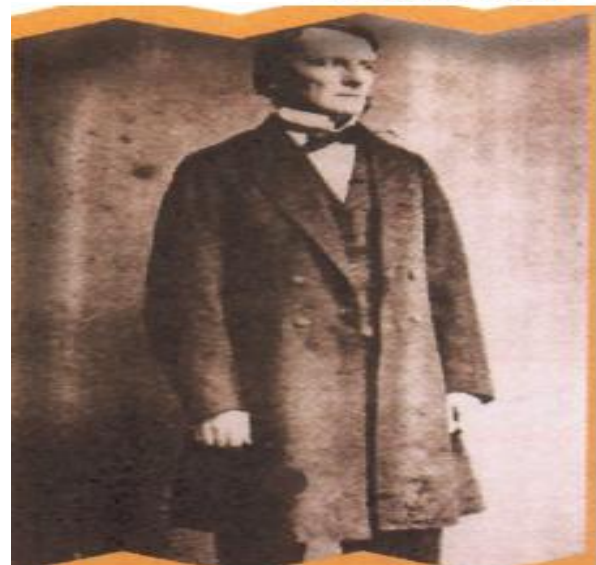

1854

George Boole desarrolla la lógica. p. 237

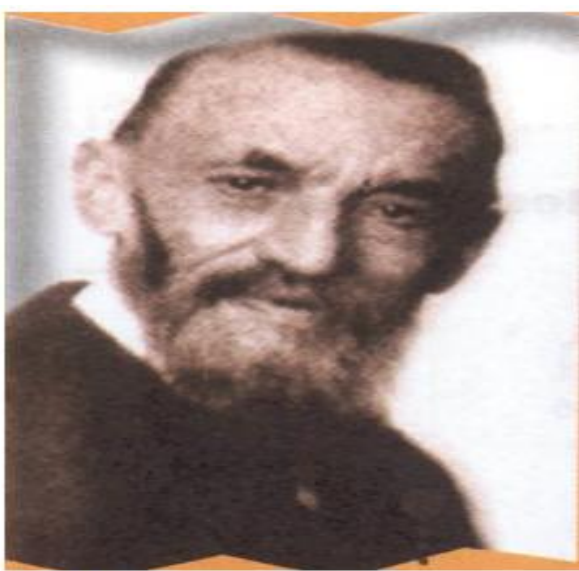

1890

Peano trata los axiomas de número naturales. p. 237 
Las imágenes que se han codificado

Figura

8.10 .

Personajes

en los ámbitos de actividad restantes, además de mostrar a los personajes de cuerpo completo, se presentan todas ellas al iniciar un bloque, con el propósito de contextualizar y asociar los hechos históricos con los avances matemáticos en una misma línea temporal.

En este sentido, la imagen con el número de registro 245 (figura 8.10.), representativos en las imágenes del libro de Matemáticas

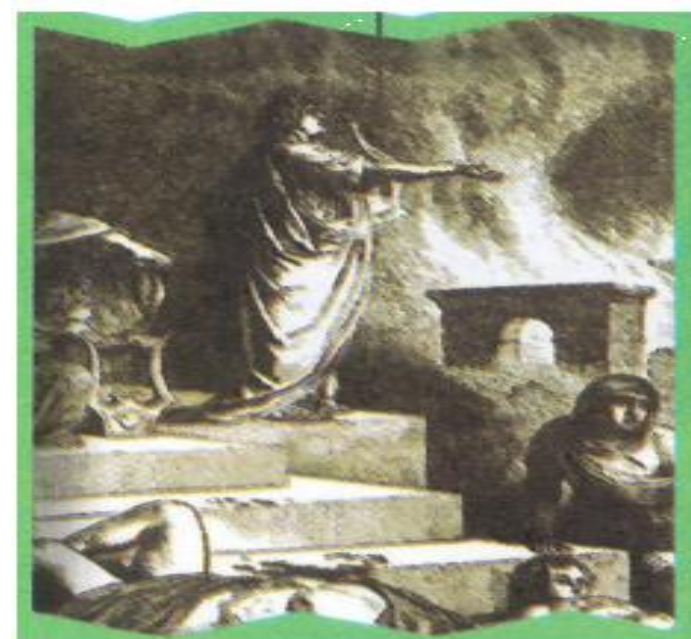

Néron incendia Roma p. 127 es la correspondiente a un emperador (ámbito político), cuya nota al pie hace referencia al hecho histórico del incendio de Roma. En esta imagen se pueden Figura 8.11. Personajes observar dos figuras. Una es la figura representativos en las imágenes del de Nerón, su posición (encima de un libro de Matemáticas

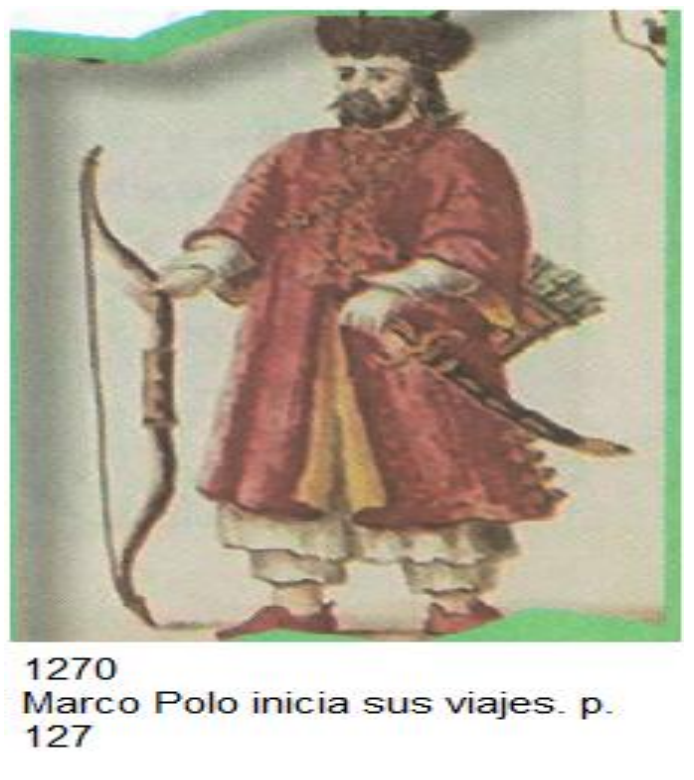
podio/tarima), su postura erguida y el brazo en alto denotan una actitud de mando y liderazgo. Mientras que la figura de una mujer aparece en una posición pasiva (bajo el podio, arrodillada), su postura corporal y su expresión facial reflejan congojo. Además, en esta imagen la mujer que aparece no es mencionada en la nota al pie.

En el registro $\mathrm{N}^{\circ} 247$ (figura 8.11.) aparece la imagen de un personaje famoso por los relatos que elabora de sus viajes (ámbito de arte y literatura). En ella se puede apreciar al personaje de cuerpo completo. Su vestimenta es informal y los 
complementos con los que aparece son armas (arco y espada) asociadas al mando, al dominio y la autoridad.

La última imagen analizada sobre personajes representativos en la asignatura de Matemáticas es la figura de una estatua de un personaje conocido por sus logros como atleta (ámbito deportivo). Si analizamos las características de la imagen, podemos observar a un varón Figura 8.12. Personajes fuerte, en posición erguida y con una representativos en las imágenes del cinta ceñida en la cabeza que representa libro de Matemáticas

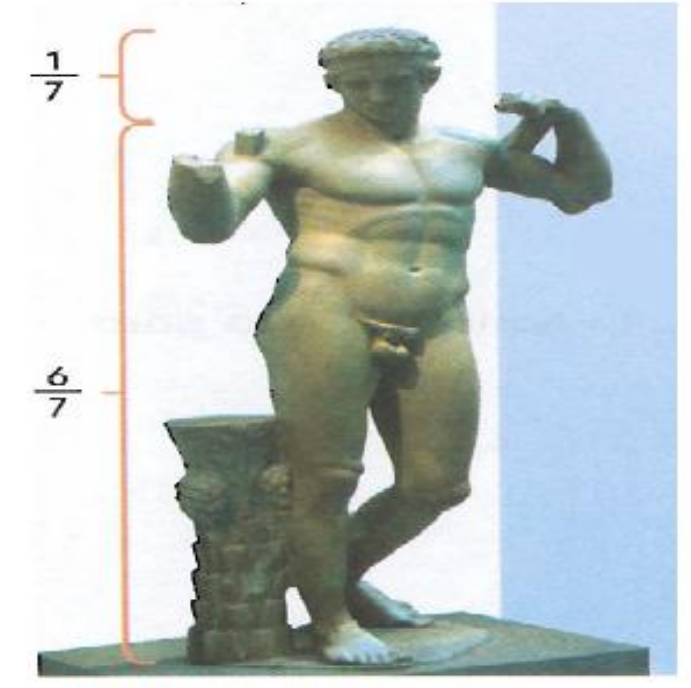

Estatua de Diadumenos, Museo

Metropolitano de Arte, Nueva York. p. 62 la victoria. Esta imagen se presenta como recurso visual para realizar una actividad sobre fracciones. En esta figura se promueven indudablemente los estereotipos de género, pues para realizar una actividad de fracciones no es necesario colocar una ilustración en la que se reproduce la imagen del varón como deportista y triunfador.

Tras el análisis cuantitativo y cualitativo de los personajes históricos y representativos que aparecen en los libros de texto, concluimos que el ámbito que ha tenido mayor peso es el científico. En todas las imágenes se promueven y destacan atributos/características asociados a los estereotipos y roles masculinos, es decir, se continúa presentando al alumnado la imagen de lo masculino como universal y tanto la presencia de la mujer como los rasgos y roles relacionados con el estereotipo femenino son excluidos de la simbología que se presenta a través de las imágenes. 


\subsubsection{Estereotipos sexistas en los modelos sociales}

En el presente apartado vamos a analizar la manera en la que se presentan los personajes. El estudio cuantitativo de las imágenes se va a realizar haciendo un recuento de las características que se observan en los personajes. Como se mencionó en el apartado de metodología (capítulo 6, p. 215), se establecieron algunos indicadores (ocupaciones o actividades públicas/privadas, características psicosociales y espacios en los que desempeñan estas actividades) que serán analizados en este orden. Estos indicadores nos permiten describir la división de los roles y los estereotipos que se atribuyen a hombres y a mujeres. Por último, analizamos algunas imágenes que consideramos reafirman los estereotipos de género tradicionales.

En cuanto a las actividades que realizan los personajes en las imágenes analizadas, encontramos que los varones aparecen desempeñado ocupaciones más diversificadas que las mujeres (hombres $=32$ ocupaciones codificadas, mujeres $=17) .{ }^{158}$

La tabla que se presenta a continuación, la 8.4., muestra que de un total de 428 imágenes, en más de la mitad de ellas aparecen hombres representados. En la tabla se comparan las imágenes que representan a hombres y a mujeres según el tipo de actividad/ocupación. En primer lugar apreciamos que del total de las imágenes encontradas en los libros de Matemáticas, Ciencias, Español y Geografía, ocho pertenecen al ámbito político y en ninguna de ellas aparece una mujer. En el ámbito militar, se encontraron únicamente dos imágenes representadas por varones. Con relación al ámbito religioso existe una cifra cercana a la equiparación entre hombres y mujeres. Por otra parte, en el ámbito político, en el cultural, en el científico, en el técnico profesional, en el económico y en el lúdico, predominan claramente las imágenes de hombres. Únicamente en las tareas domésticas y en el ámbito educativo encontramos que

\footnotetext{
${ }^{158}$ Ver anexos capítulo ocho.
} 
el porcentaje de imágenes que representan a mujeres es muy superior al de hombres.

Tabla 8.4. Presencia de hombres y mujeres en las imágenes según la actividad desarrollada

\begin{tabular}{|c|c|c|c|c|c|c|c|c|c|c|c|c|}
\hline \multirow{2}{*}{ ÁMBITо } & \multicolumn{2}{|c|}{ VARONES } & \multicolumn{2}{|c|}{$\begin{array}{l}\text { COLECT. } \\
\mathrm{V} .\end{array}$} & \multicolumn{2}{|c|}{$\begin{array}{c}\text { MUJERE } \\
\mathrm{S} \\
\end{array}$} & \multicolumn{2}{|c|}{$\begin{array}{l}\text { COLECT. } \\
\text { M. } \\
\end{array}$} & \multicolumn{2}{|c|}{$\begin{array}{l}\text { COLECT. } \\
\text { MIXTO }\end{array}$} & \multicolumn{2}{|c|}{ TOTAL } \\
\hline & $f_{i}$ & $\%$ & $f_{i}$ & $\%$ & $f_{i}$ & $\%$ & $f_{i}$ & $\%$ & $f_{i}$ & $\%$ & $f_{i}$ & $\%$ \\
\hline POLİTICO & 7 & 1,6 & 0 & 0 & 0 & 0 & 0 & 0 & 1 & 0,2 & 8 & 1,9 \\
\hline MILITAR & 2 & 0,5 & 2 & 0,5 & 0 & 0 & 0 & 0 & 0 & 0 & 4 & 0,9 \\
\hline RELIGIOSO & 10 & 2,3 & 1 & 0,2 & 8 & 1,9 & 0 & 0 & 2 & 0,5 & 21 & 4,9 \\
\hline CULTURAL & 26 & 6,1 & 3 & 0,7 & 11 & 2,6 & 0 & 0 & 5 & 1,2 & 45 & 10,5 \\
\hline CIENTÍFICO & 20 & 4,7 & 1 & 0,2 & 5 & 1,2 & 0 & 0 & 0 & 0 & 26 & 6,1 \\
\hline $\begin{array}{l}\text { TÉCNICO } \\
\text { PROFESIONAL }\end{array}$ & 21 & 4,9 & 2 & 0,5 & 4 & 0,9 & 0 & 0 & 1 & 0,2 & 28 & 6,5 \\
\hline ECONÓMICO & 14 & 3,3 & 1 & 0,2 & 11 & 2,6 & 0 & 0 & 7 & 1,6 & 33 & 7,7 \\
\hline LÚDICO & 42 & 9,8 & 0 & 0 & 19 & 4,4 & 0 & 0 & 15 & 3,5 & 76 & 17,8 \\
\hline EDUCATIVO & 29 & 6,8 & 1 & 0,2 & 64 & 14,9 & 1 & 0,2 & 17 & 4,0 & 113 & 26,2 \\
\hline SALUD & 11 & 2,6 & 0 & 0 & 11 & 2,6 & 1 & 0,2 & 0 & 0 & 23 & 5,4 \\
\hline $\begin{array}{l}\text { TAREAS } \\
\text { DOMÉSTICAS }\end{array}$ & 21 & 4,9 & 0 & 0 & 31 & 7,2 & 0 & 0 & 0 & 0 & 57 & 12,1 \\
\hline$\overline{T O T A L}$ & 203 & 47,4 & 11 & \begin{tabular}{|c|}
2,6 \\
\end{tabular} & 164 & 38,3 & 2 & 0,5 & 48 & 11,2 & 428 & 100 \\
\hline
\end{tabular}

Pasando ahora al análisis de las características psicosociales, pudimos constatar que a las mujeres se les representa asociadas con el trabajo, el amor, el cuidado al otro, la belleza, el coqueteo, la serenidad, y el trabajo. A los hombres, por el contrario, se les atribuyen características relacionadas con el trabajo, el dominio, la intelectualidad, el dinamismo, la seriedad y la fortaleza. Cabe destacar, además, que el espectro de características psicosociales con las que son representados los hombres es más amplio que el atribuido a las mujeres (ver anexos 3. tabla 7. y 8.).

Así pues, con la finalidad de mostrar los perfiles psicosociales más frecuentes en los personajes representados en las imágenes de los manuales analizados, se presenta la tabla 8.5. Los datos plasmados en ella evidencian, otra vez, diferencias entre ambos sexos. Los atributos psicosociales que más destacan en los hombres son los que están asociados al patrón de comportamiento del 
hombre como proveedor y cabeza de familia, esto es, trabajador, intelectual, dinámico y fuerte. Con respecto a las mujeres, aunque predominan atributos que antes eran considerados como masculinos (trabajo), también se encuentran rasgos relacionados con los estereotipos femeninos tradicionales, de modo que las características de personalidad que se les asignan en las imágenes examinadas están relacionadas con la crianza de niños, la timidez, la belleza y la atención a los otros.

Tabla 8.5. Características psicosociales con diez porcentajes más elevados

\begin{tabular}{lrrrrrrrc}
\hline \hline N & HOMBRES & $\%$ & MUJERES & $\%$ & $\begin{array}{c}\text { COLECT. DE } \\
\text { VARONES }\end{array}$ & $\begin{array}{c}\text { COLECT. } \\
\text { MIXTO }\end{array}$ & $\%$ \\
\hline 1. & TRABAJADOR & $21,3 \%$ & TRABAJADORA & $31,4 \%$ & DOMINIO & $27,3 \%$ & TRABAJANDO & $32,7 \%$ \\
2. & DINAMISMO & $10,2 \%$ & TIMIDEZ & $8,7 \%$ & VALENTIA & $27,3 \%$ & OCIO & $26,9 \%$ \\
3. & OCIO & $9,3 \%$ & CRIANZA & $7,0 \%$ & TRABAJANDO & $18,2 \%$ & DINAMISMO & $7,7 \%$ \\
4. & CRIANZA & $5,8 \%$ & ATENCION & $4,1 \%$ & INNOVACION & $9,1 \%$ & POBREZA & $5,8 \%$ \\
5. & FORTALEZA & $4,4 \%$ & OCIO & $4,1 \%$ & PESADUMBRE & $9,1 \%$ & COMPRA & $3,8 \%$ \\
6. & DOMINIO & $4,0 \%$ & BELLEZA & $3,5 \%$ & REZANDO & $9,1 \%$ & MIEDO & $3,8 \%$ \\
7. & TIMIDEZ & $3,6 \%$ & CUIDADO P. & $3,5 \%$ & 0 & $0 \%$ & CUIDADO & $1,9 \%$ \\
8. & JUGUETON & $3,6 \%$ & OBSERVADORA & $3,5 \%$ & 0 & $0 \%$ & DISCUSION & $1,9 \%$ \\
9. INTELECTUAL & $4,0 \%$ & DINAMISMO & $2,9 \%$ & 0 & $0 \%$ & EFICACIA & $1,9 \%$ \\
10. RACIONALIDAD & $3,1 \%$ & AMOR & $2,9 \%$ & 0 & $0 \%$ & TIMIDEZ & $1,9 \%$ \\
\hline \hline
\end{tabular}

Otro indicador que nos permite evidenciar que en las imágenes hombres y mujeres son representados de manera diferenciada es el de "conducta". A través de este indicador pudimos agrupar cinco sub-categorías: pasiva, activa, afectiva, agresiva, y triste. Esta información se codificó teniendo en cuenta la información según la vestimenta y el sentido que se da a los personajes. En la gráfica que se presenta a continuación se puede observar que hombres y mujeres aparecen mayoritariamente con actitudes que denotan actividad. No obstante, si comparamos los datos de mujeres y de hombres tenemos que ellas aparecen más frecuentemente con expresiones/actitudes pasivas (7,9 frente a 3,0 por ciento), 
al tiempo que los hombres se representan de manera más activa (45,3\% frente a $25,7 \%)$ e incluso agresiva ( 2,8 por ciento).

Gráfica 8.2. Conductas de los personajes según el sexo

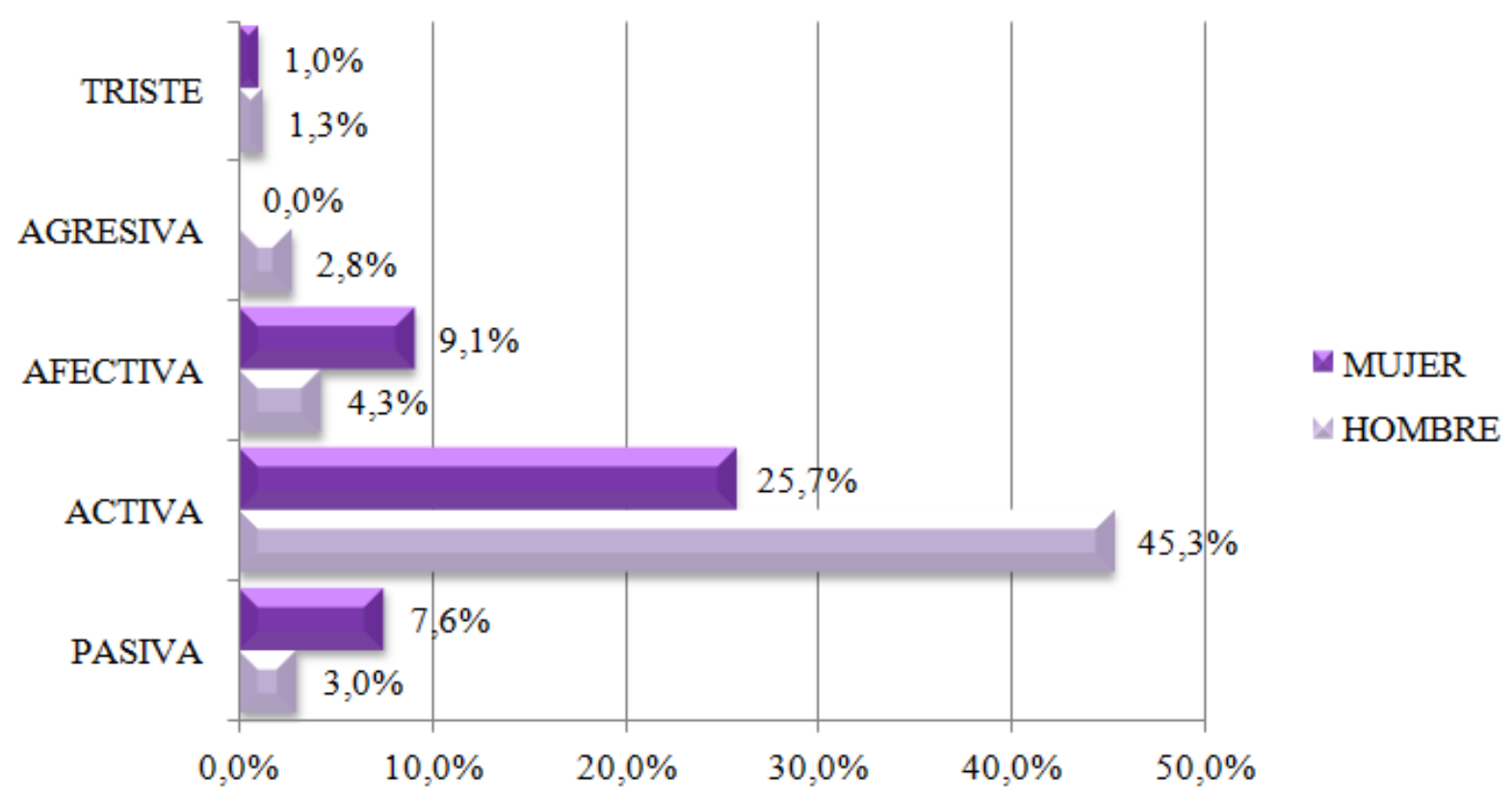

Finalmente vamos a analizar el espacio en el que se representa a los personajes. En total se analizaron 388 personajes, de los cuales 219 aparecen representando a varones y 169 a mujeres. En la gráfica que presentamos a continuación podemos observar que los espacios a los que se les da mayor prioridad son los espacios abiertos. En contraposición, los espacios privados son los que menos aparecen en las ilustraciones. El dato al que hemos aludido evidencia nuevamente el sesgo de género que trasmiten los materiales analizados, pues en ellos son pocas las referencias que tiene el alumnado para participar de manera corresponsable en las cuestiones relacionadas al ámbito doméstico.

En este sentido, pudimos comprobar que el porcentaje de las imágenes de mujeres en los espacios abiertos es muy inferior al de hombres. Todo lo contrario tiene lugar en los espacios cerrados, en los que predominan las imágenes de mujeres. En los espacios públicos hay prácticamente el doble de hombres que de mujeres. A su vez, en los espacios privados, que es en los que 
más reducida es la muestra, las cifras están equiparadas. Los datos aquí presentados constatan que se continúan promoviendo espacios diferenciados en función del sexo: los estereotipos de masculinidad trasmitidos están asociados al varón como designado para participar de la vida pública y profesional, mientras que el estereotipo de feminidad promovido es el de mujeres con escasa participación en el ámbito público/profesional.

Gráfica 8.3. Espacios en los que aparecen los personajes según el sexo

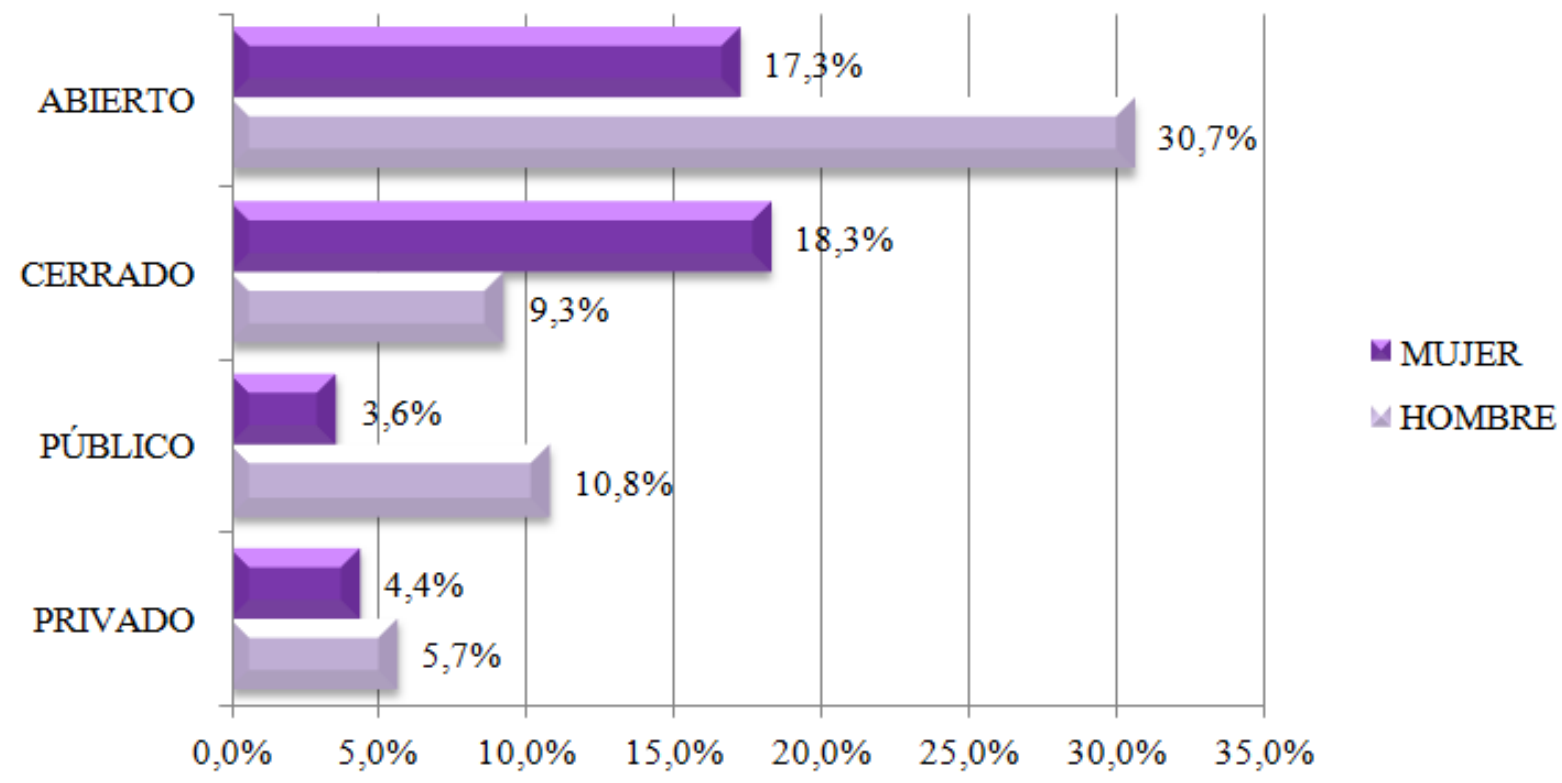

El estudio descriptivo de los datos al que hemos aludido en los párrafos anteriores evidencia que, aunque se muestra un claro intento por incorporar las normativas sobre igualdad y equidad de género, los esfuerzos no han sido suficientes. Pues, aun cuando existe mayor equilibrio entre el número de imágenes que representan a hombres y a mujeres, sobre todo en los libros de Ciencias y de Español, la gran mayoría de estas imágenes no promueve una cultura basada en la igualdad entre hombres y mujeres. Con el afán de reforzar estos argumentos, presentamos una selección de imágenes que consideramos perpetuán los estereotipos y roles de género atribuidos a uno y otro sexo.

El análisis cualitativo de las imágenes contenidas en los libros de texto nos lleva a considerar que este recurso visual ha perdido valor: son escasas las imágenes que contienen a personajes que sirven como modelos referentes para 
el alumnado. En este sentido, el libro con menos imágenes es el de Matemáticas, seguido del manual de Español. También hemos podido constatar que en los textos quienes aparecen de manera más recurrente son los personajes con características similares al alumnado, es decir, aparecen tanto fotografías como dibujos de adolescentes en contextos educativos o con uniformes.

Ahora bien, a continuación vamos a demostrar, a través del análisis de algunas imágenes, que los libros de texto trasmiten una representación diferenciada en función del sexo. Comenzaremos por mostrar las profesiones que continúan perpetuando espacios separados para hombres y para mujeres. Así, en primer lugar mostraremos las profesiones en las que aparecen los hombres y, posteriormente, las actividades laborales en las que se representa a las mujeres.

Figura 8.13. Estereotipo masculino en el ámbito profesional, libro de Matemáticas

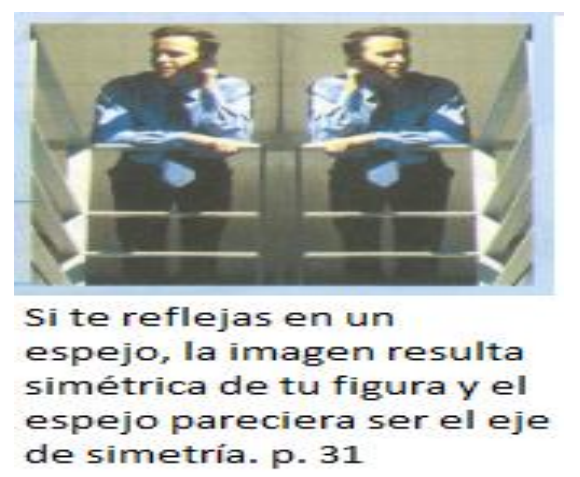

En el libro de Matemáticas, en la p. 31 se elige la figura de un varón para realizar una actividad sobre la simetría. En esta ocasión la representación del varón reproduce el estereotipo de hombre de negocios, pues su postura desenfadada, su vestimenta y el manejo del móvil denotan una actitud de control y seguridad.

Las imágenes con $\mathrm{n}^{\circ}$ de registro 123 y 124 (p. 116 del libro de Español) se utilizan como recurso didáctico para promover en el alumnado la participación en presentaciones orales. En este sentido, consideramos que la elección de estas imágenes no es adecuada, pues a través de ellas se refuerza la creencia de que los hombres son quienes han de participar en el ámbito público y que son ellos quienes poseen las habilidades para hablar en público y trasmitir sus conocimientos. En la imagen con nota al pie que dice "Presentación en mesa redonda", no solamente existe mayor presencia de 
varones, sino que su participación tiene mayor importancia, pues la vestimenta, la postura y el micrófono denotan que son ellos quienes tienen el control respecto a la presentación. En la segunda imagen se muestra igualmente a un hombre que tiene la palabra.

\section{Figura 8.14. Estereotipo masculino en el ámbito profesional, libro de Español}

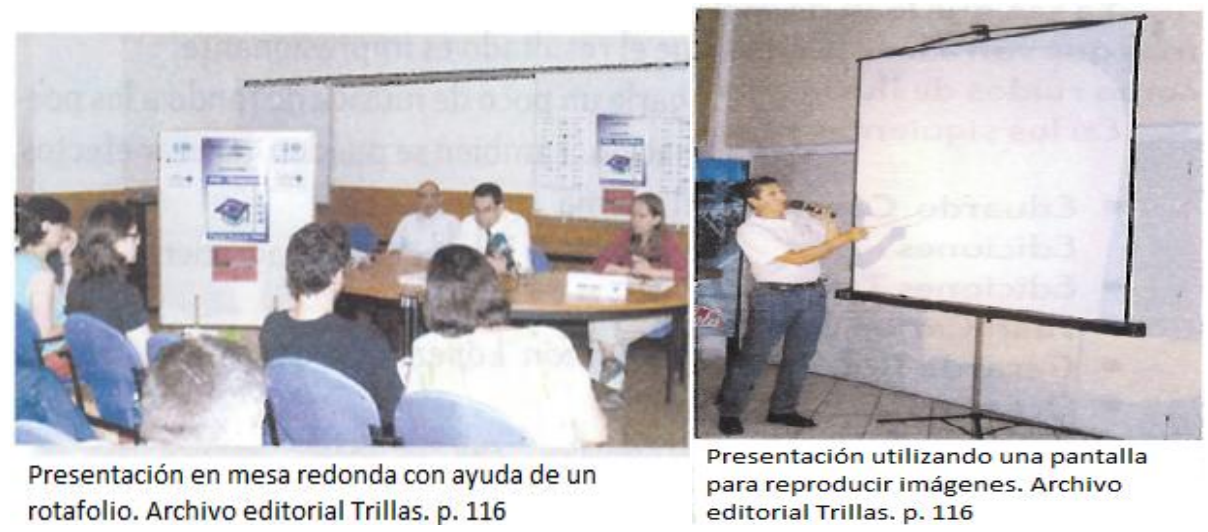

Siguiendo con el mismo manual didáctico, en la secuencia de imágenes que presentamos a continuación, figura 8.15, se puede ver nuevamente al varón participando en el ámbito profesional de los medios de comunicación y divulgación. Esta selección de imágenes se presenta al alumnado para iniciar el proyecto 10 sobre la temática antes referida (medios de comunicación y divulgación). Se muestra mayoritariamente a varones en los puestos de trabajo, mientras que la única mujer que aparece en la foto lo hace de manera invisible, pues no se le ve el rostro. Consideramos, por lo tanto, que estas imágenes no son adecuadas, dado que no reflejan la realidad de un país donde en la actualidad tanto hombres como mujeres ejercen este ámbito profesional.

Figura 8.15. Estereotipo masculino en el ámbito profesional, libro de Español

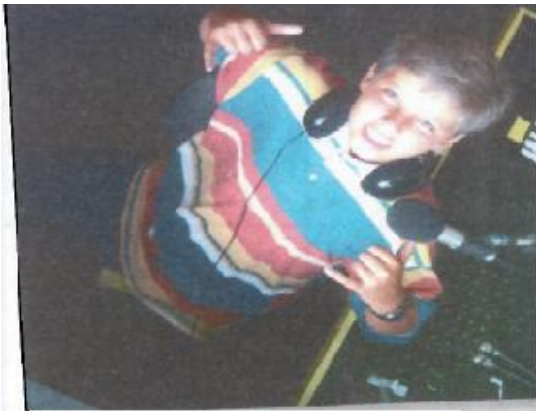

Grabación de un programa radiofónico. Archivo editoria Trillas. p. 190

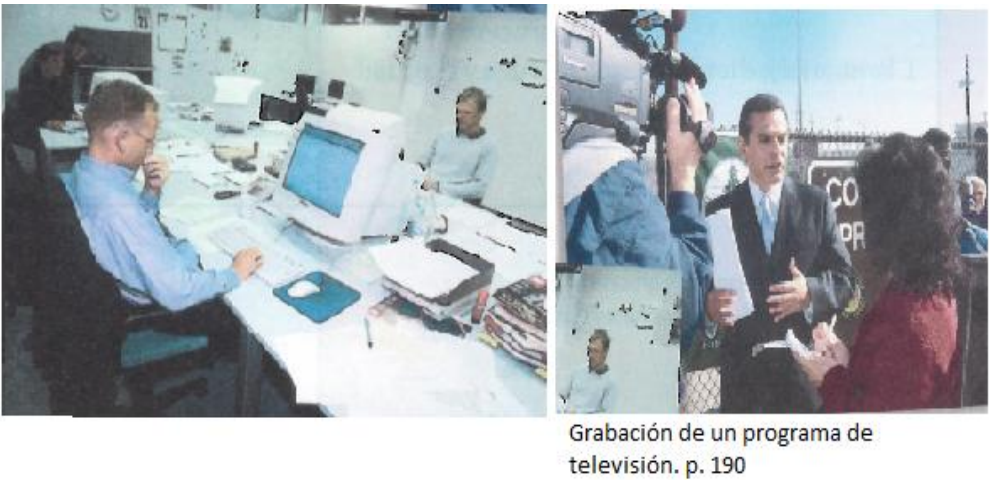


Pasando ahora al libro de Geografía, podemos observar que en la imagen 4.6, presentada al alumnado como recurso visual para explicar la Figura 8.16. Estereotipo masculino en el importancia del petróleo como principal fuente de energía en la actualidad, se representa a un colectivo de varones trabajando en una explotación de petróleo. Consideramos que la elección de esta imagen tampoco es oportuna, pues refuerza las creencias de que existen ciertos trabajos que son más apropiados para uno u otro ámbito profesional, libro de Geografía

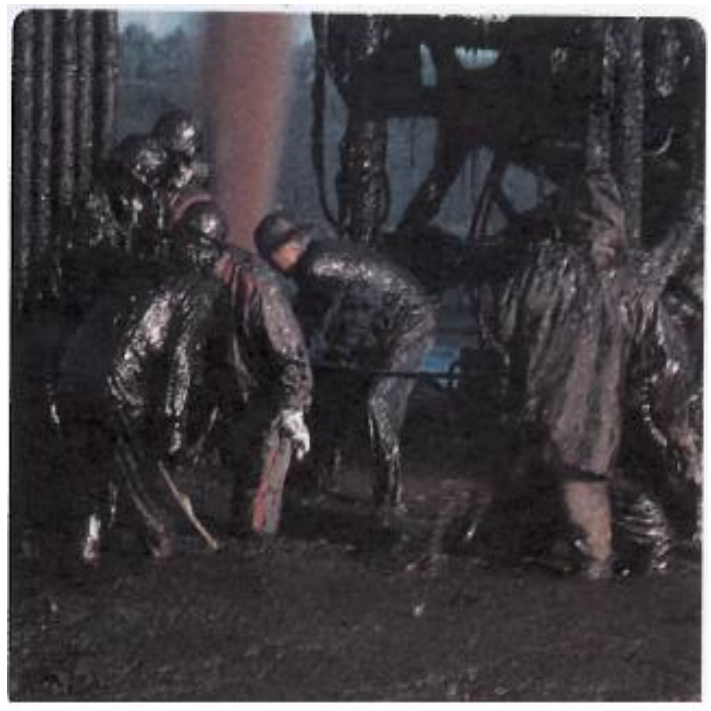

Figura 4.6 Extracción de petróleo en Burgos, España. p. 201 sexo.

$\mathrm{Al}$ abordar la temática relacionada con las migraciones, en el libro de texto de Geografía también se refuerzan algunos estereotipos masculinos asociados al espacio público. Así pues, se presentan al alumnado varias imágenes en las que los hombres aparecen como cabezas de familia, proveedores, arriesgados y trabajadores, y que, además, están dispuestos a trasgredir las leyes para ir en busca de mejores condiciones laborales que les permitan asumir su rol de sustentadores de la familia. Las actividades u ocupaciones que desempeñan estos hombres son diversas: van desde labores agrícolas, maquiladoras, hasta actividades relacionadas con el arte y la cultura (figura 8.17). Las mujeres también se embarcan en este tipo de proyectos, por lo que estas imágenes, además de no reflejar la realidad del País y del Estado, refuerzan la creencia de que los hombres han de asumir de manera exclusiva el compromiso de la manutención familiar. 
Figura 8.17. Estereotipo masculino en el ámbito profesional, libro de Geografía

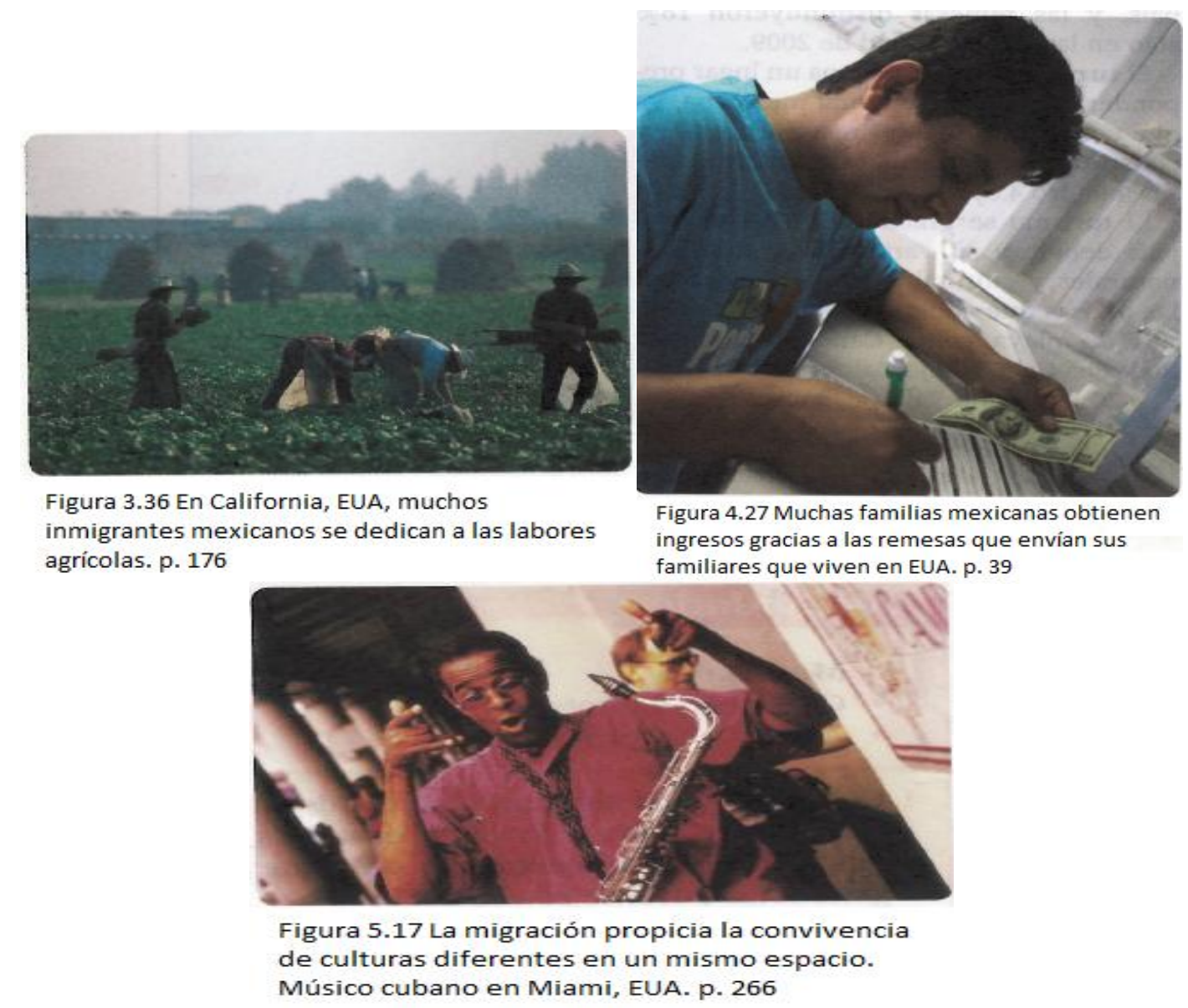

Figura 8.18. Estereotipo masculino en el ámbito profesional, libro de

\section{Ciencias}

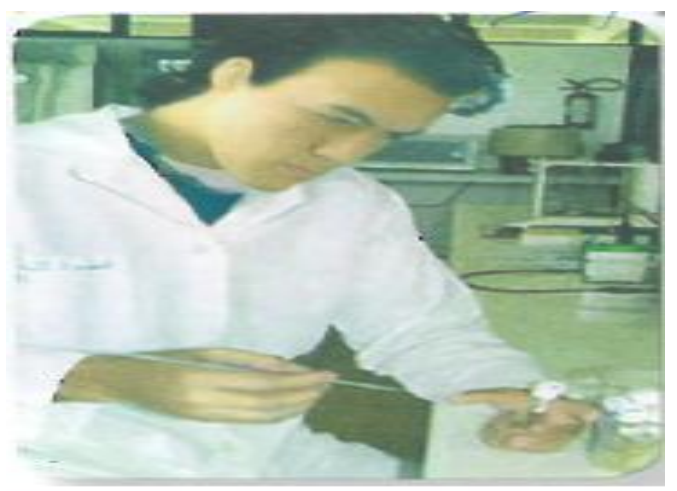

Fig. 1.75 Detrás de la mayor parte de logros científicos hay proyectos que a veces tardan muchos años en

desarrollarse. p. 70
En el libro de Ciencias hemos encontrado imágenes en las que se representa a los hombres en ocupaciones y actividades profesionales históricamente consideradas como propias de su sexo. En este ámbito científico académico se presenta la siguiente imagen (Figura 8.18.) como recurso visual para promover en el alumnado actitudes de persistencia y dedicación. Consideramos que sería más 
apropiado que se eligieran imágenes en las que tanto hombres como mujeres participasen de manera colaborativa en este tipo de profesiones.

En esta otra imagen del libro de Ciencias, (figura 8.19.) se reproducen tanto el estereotipo masculino como el femenino. Vemos al hombre desempeñando la

Figura 8.19. Estereotipo masculino en el ámbito profesional, libro de Ciencias

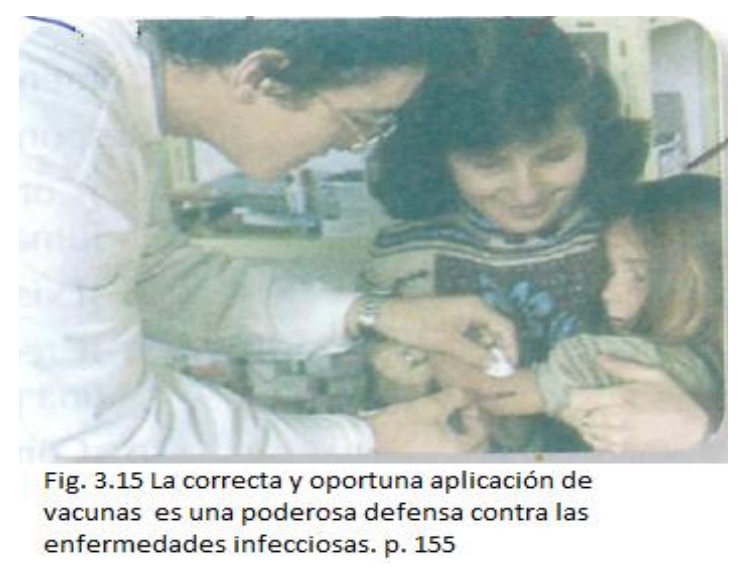
actividad profesional de "médico", que es considerada como "propia para los varones", mientras que la mujer aparece desempeñando el rol de madre cuya tarea es el cuidado y crianza de los y las hijos/as.

Las imágenes que hemos analizado respecto a las profesiones en las que aparecen las mujeres continúan reforzando el estereotipo femenino, pues se les representa en ocupaciones que históricamente han sido atribuidas a las mujeres. Asimismo, y como se veía en el análisis descriptivo, la presencia de las mujeres en el ámbito público es prácticamente inexistente. En este sentido a continuación presentamos las imágenes encontradas en el libro de Ciencias que muestran cómo a las mujeres, a pesar de que su participación laboral es cada vez más diversificada, se les continúa representando en las profesiones consideradas "propias de su sexo". Así, aparecen desempeñando funciones de cuidado, atención y enseñanza a los otros. En una de las imágenes (fig. 1.47, p. 48) se muestra a una mujer realizando una actividad que históricamente era considerada "propia de hombres", relacionada con el ámbito científico/académico, y que, además, se corresponde más con los hechos actuales del país. No obstante el texto de la nota al pie solo emplea el masculino, reflejando así una falta de conexión entre la imagen y el texto. La secuencia de imágenes que presentamos así lo demuestra: 
Figura 8.20. Estereotipo femenino en el ámbito profesional, libro de Ciencias

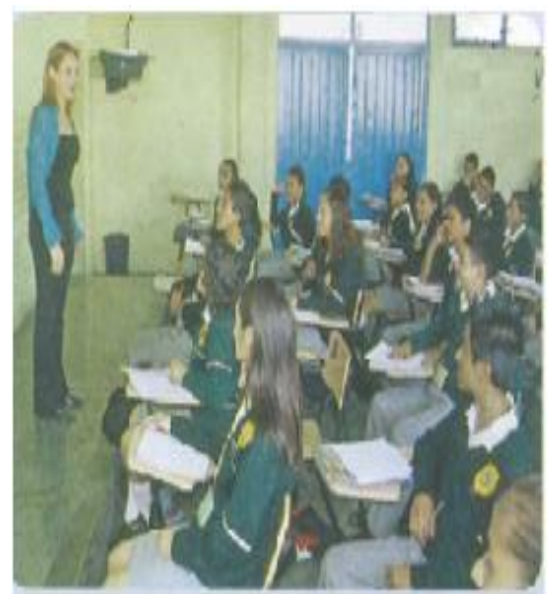

Figura 1.1. A partir de hoy todos aprenderán mucho en la clase de Ciencias. p. 14

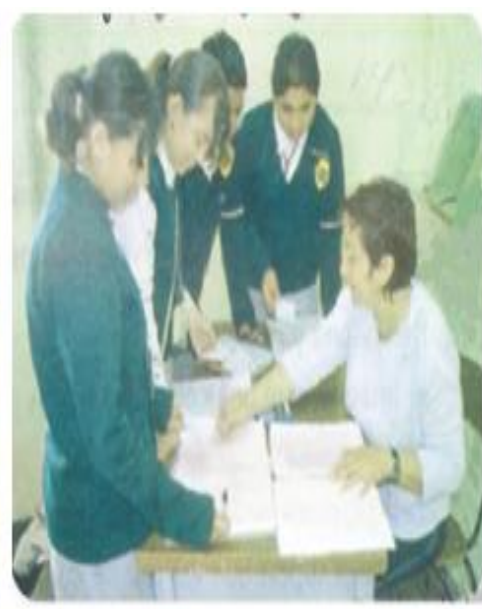

Fig. 1.80 Con tu profesor o profesora puedes compartir avances $y$ solucionar dudas. p. 75

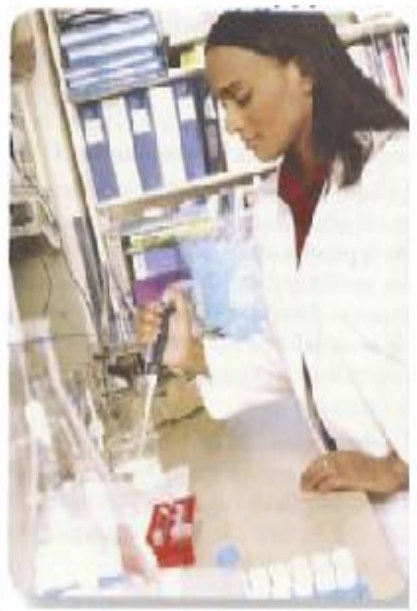

Fig. $1.47 \mathrm{El}$ cientifico se hace una pregunta, observa, elabora hipótesis, las comprueba mediante experimentos $y$ desarrolla una teoría. p. 48

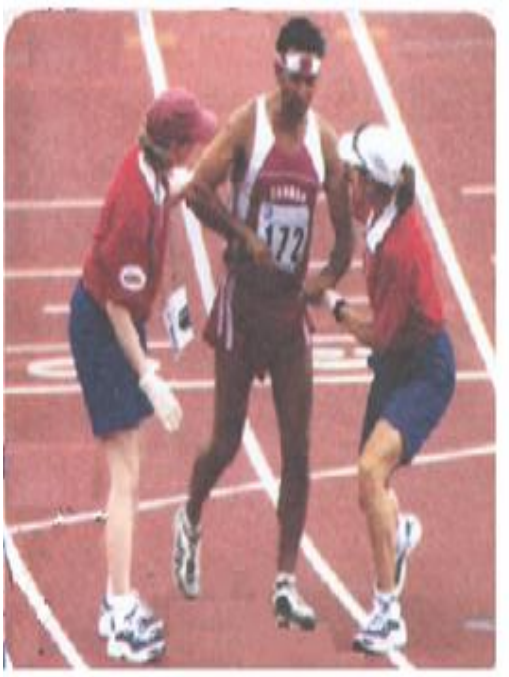

Fig. 3.5 Hacer ejercicio intenso aumenta la demanda de oxígeno, por eso las personas pueden sentirse sofocadas. p. 146

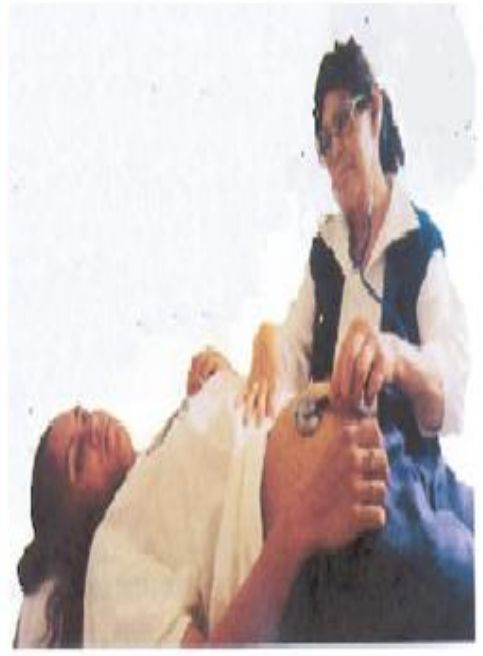

Fig. 4.14 Durante el embarazo los cambios fisicos son muy evidentes; pero los psicológicos no tanto. $p 211$

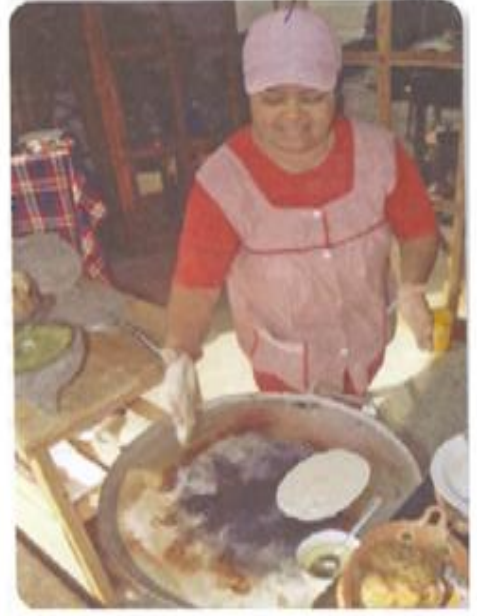

Fig. 1.46 Muchas actividades que realizamos los aprendimos empíricamente. Por ejemplo, de una generación a otra se ha transmitido la práctica de cubrir los comales con una delgada capa de cal para que las tortillas no se peguen. p. 47

Hemos evidenciado que en los libros de texto se continúan trasmitiendo, mediante las imágenes, espacios separados en función del sexo de la persona. Con ello se favorece que se perpetúen los estereotipos y las desigualdades de género, que, además no se corresponden con la actual realidad, en la que la participación de la mujer en el ámbito laboral es cada vez más diversa. 
Consideramos, pues, inapropiado que no se trasmitan al alumnado referentes y modelos que muestren que tanto hombres como mujeres pueden desarrollarse profesionalmente en cualquier disciplina, porque las habilidades y las opciones no dependen del sexo con el que se nace sino del esfuerzo, la constancia y las ganas que se tengan para ejercer una actividad u ocupación que se adecue a nuestros intereses y necesidades.

Ahora analizaremos algunas imágenes que muestran que las conductas de hombres y mujeres también son representadas de manera distinta. Mientras a los hombres se les representa de manera activa y en actitudes que destacan sus habilidades físicas y deportivas, a las mujeres se les representa desempeñando actividades relacionas con el amor y la maternidad. En la primera secuencia de imágenes (figura 8.21.) se pueden observar las figuras en las que aparecen los hombres. Si analizamos las notas al pie, nos percatamos de que estas imágenes son utilizadas como recurso visual para hablar de la alimentación y la energía (libro de Ciencias figuras 2.4 y 2.14). Es decir, no es necesaria la elección de imágenes que muestren el estereotipo
Figura 8.21. Conductas estereotipadas, libros de Ciencias y de Matemáticas

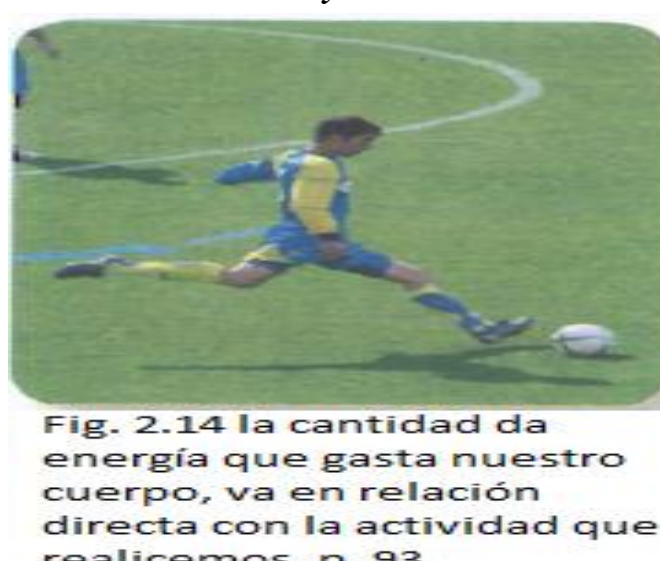
realicemos. p. 93

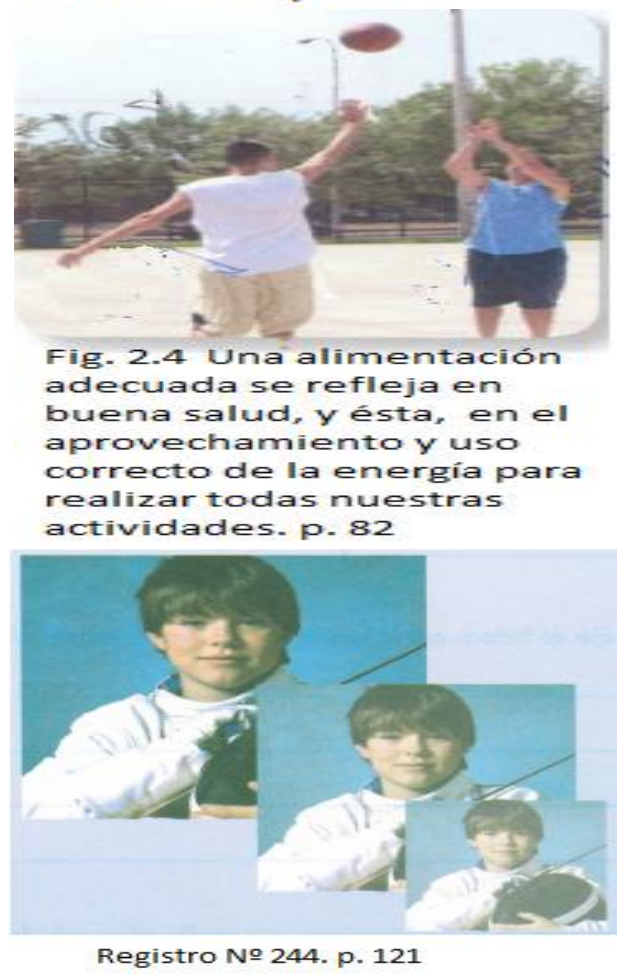


masculino del hombre como deportista, cuando se pueden elegir figuras que trasmitan una cultura de la igualdad entre hombres y mujeres. En el libro de Matemáticas, el registro $n^{\circ} 244$ es elegido como recurso visual para realizar una actividad sobre fracciones. Es decir, esta imagen tampoco guarda relación alguna con el tema en el que se encuentra inserta, y sí que refuerza el estereotipo masculino asociado a las habilidades que tienen los varones para desarrollarse en los ámbitos y competiciones deportivas (p. 121).

Las imágenes que presentamos a continuación, las de medios de comunicación y divulgación, muestran que las mujeres son representas con conductas que están relacionadas con la emotividad (alegría, amor, atención) y la maternidad. Si analizamos las notas al pie de estas imágenes, destaca que se hacen recomendaciones para protegerse de algunas enfermedades o peligros. Así, el representar a una madre con sus hijos/as evidencia que se continúa atribuyendo a las mujeres el desempeño de estas funciones y roles de género sobre el cuidado y la atención de los y las infantes. En todas las imágenes se muestran mujeres felices y amorosas desempeñando su rol de madre. Consideramos, pues, que así se refuerza en las y los adolescentes una concepción de sexismo benévolo, al promover que la maternidad es una tarea con la que las mujeres se sienten satisfechas y conformes. ${ }^{159}$

\section{Figura 8.22. Conductas estereotipadas, libros de Ciencias y de Español}

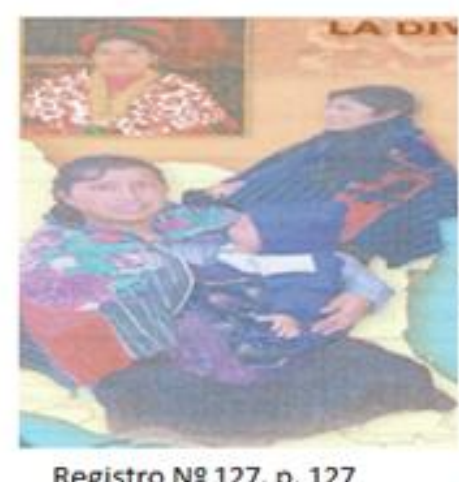

Registro No 127. p. 127

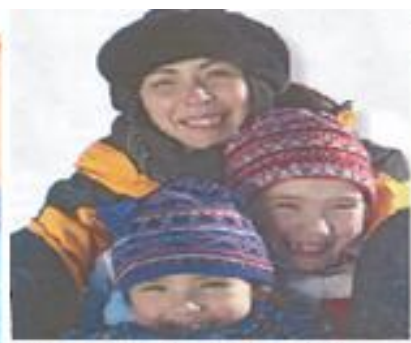

Fig. 3.11 Los cambios bruscos de temperatura son un factor que promueve las enfermedades respiratorias, así que abrigamos cuando hace frio es una manera de protegernos. p. 153

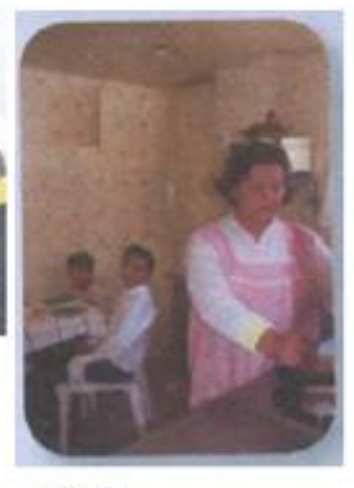

p. 253

\footnotetext{
${ }^{159}$ La imagen con número de registro 127 es retomada del libro de Español, el resto son de el libro de Ciencias.
} 

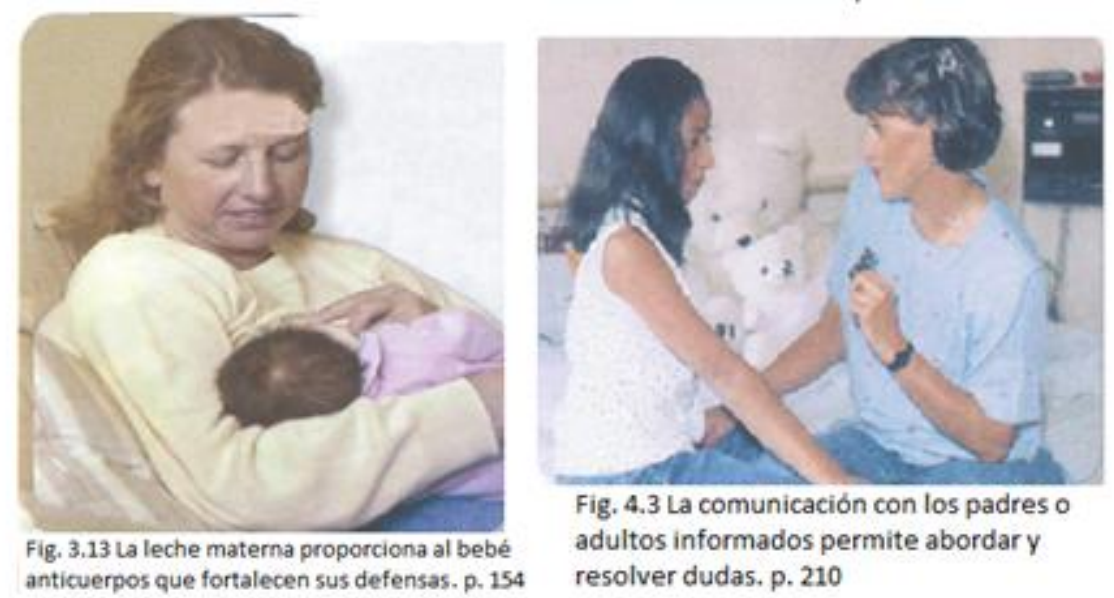

En los libros de texto de Geografía y de Ciencias, se ha incluido la temática relacionada con el medio ambiente y la ecología, este es un tema novedoso que ha sido introducido atendiendo a los compromisos jurídicos internacionales y nacionales. No obstante, constatamos que también en este ámbito se presenta a hombres y a mujeres de manera diferenciada. Así, las imágenes que se han elegido como recurso visual para reforzar la conciencia sobre el medio ambiente trasmiten roles y estereotipos de género: mientras ellos aparecen contribuyendo de manera activa a la problemática de la contaminación (Figura 2.48; 2.55; 2.57; 3.28 y 3.30 de Geografía; 1.11 del libro de biología), ellas son representadas de forma pasiva, y con actitudes que denotan angustia ante las consecuencias de los desastres naturales (figura 3.28, p. 169).

Figura 8.23. Actitudes hacia el medio ambiente, libros de Ciencias y de Geografía

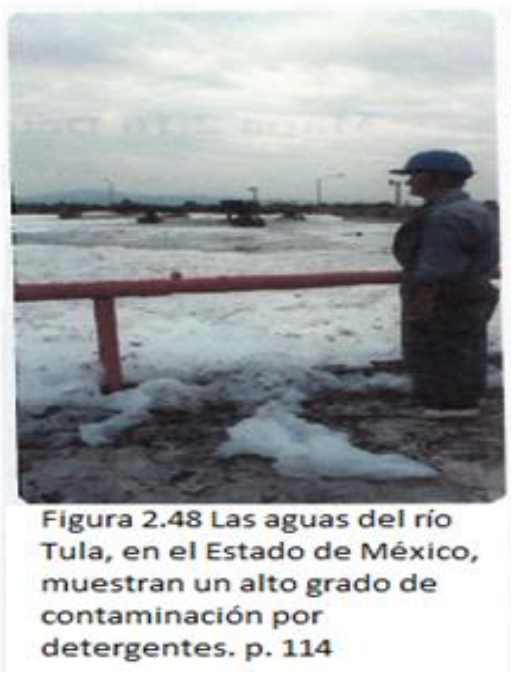

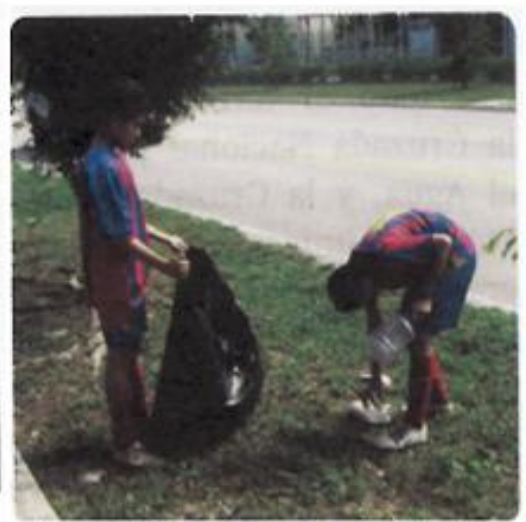

Figura 2.55 La educación ambiental nos permite asumir una actitud más responsable hacia el entorno. p. 124

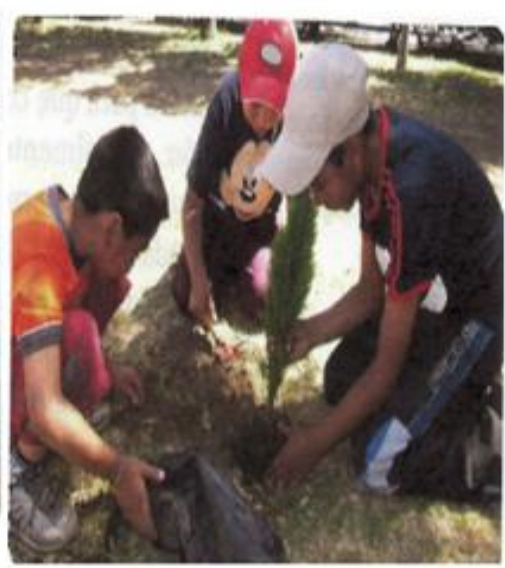

Figura 2.57 La reforestación nos compete a todos. p. 125 


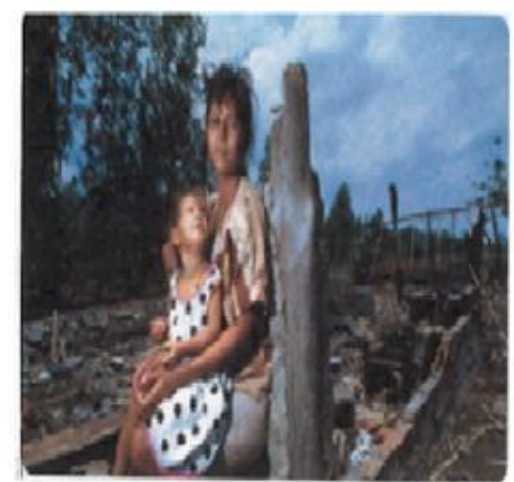

Figura 3.28 Los huracanes han provocado diversos daños ambientales en paises centroamericanos como El Salvador. p. 169

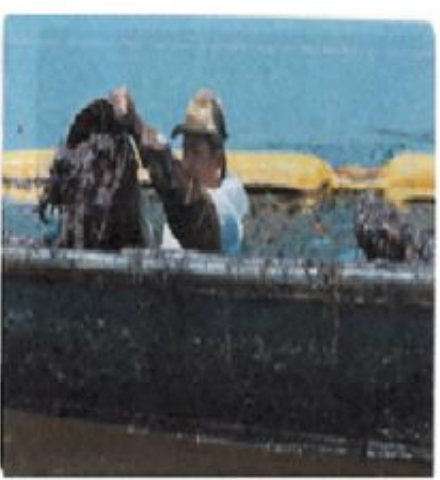

Figura 3.30 Coatzacoalcos, cruz. Los derrames petroleros el resto de la naturaleza es estrecha. p. 23 afectan principalmente a los ecosistemas y los recursos naturales. p. 169

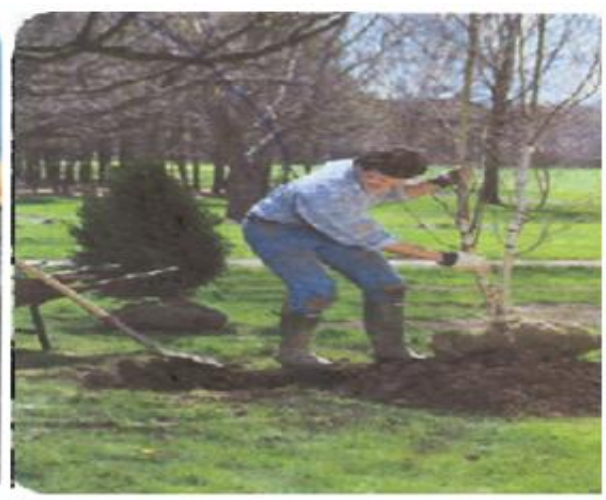

Fig. 1.11 la relación entre los seres humanos y

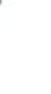

Otro aspecto que analizamos en los libros de texto es el de las relaciones Figura 8.24. La familia, libros de de pareja. Constatamos que a través de las imágenes se trasmiten a los y las adolescentes modelos de familia $y$ relaciones de pareja anclados en el pasado. No encontramos, de nuevo, iconografía que promueva una vida amorosa libre y respetuosa con las diferencias. En consecuencia, consideramos que los y las adolescentes reciben información (visual) basada en modelos de familia tradicionales, con los cuales se niega la posibilidad de formar personas comprensivas con otros tipos de familia. Estos argumentos se pueden documentar en las imágenes que presentamos en la figura 8.24. Cabe destacar que la primera imagen

Ciencias y de Geografía

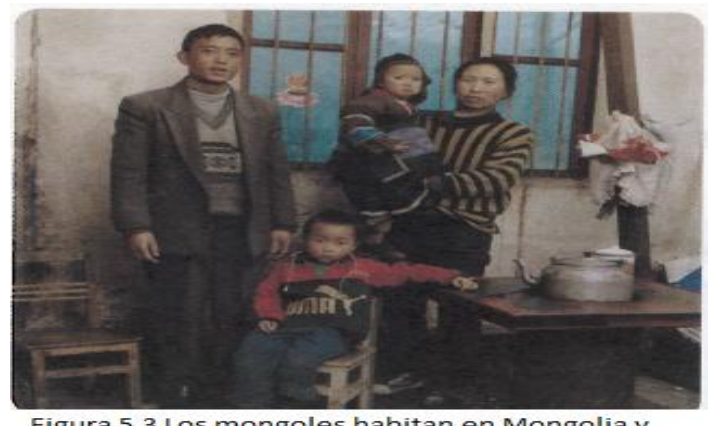

Figura 5.3 Los mongoles habitan en Mongolia y otras regiones de Asia, entre ellas el norte de China. p. 251
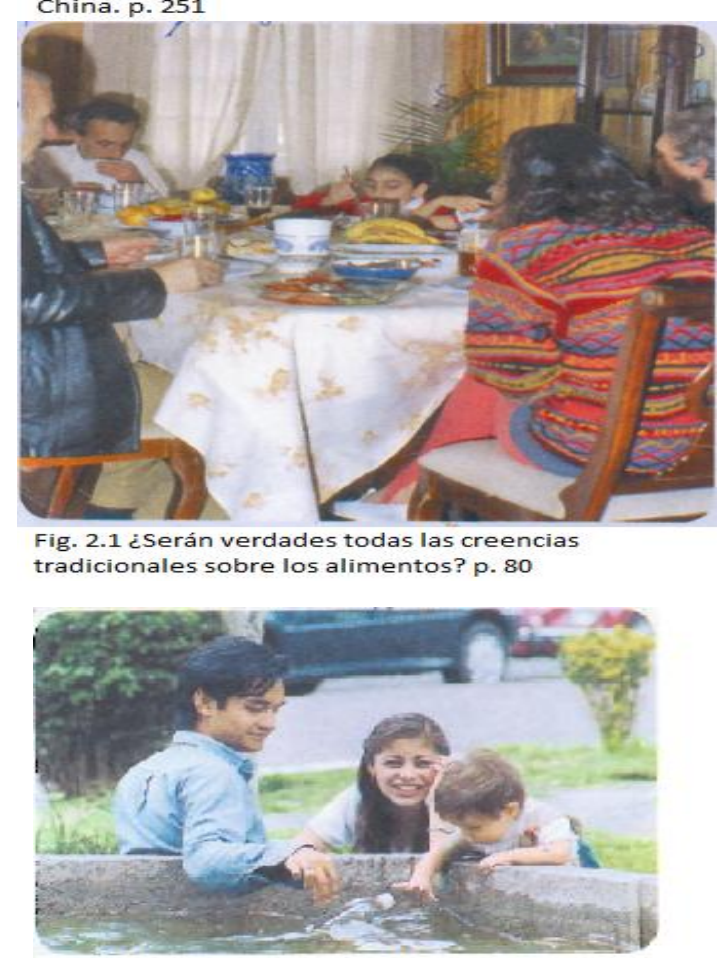

Fig. 4.17 La pareja que planea el momento de procrear hijos tiene mayor probabilidad de formar una familia exitosa. p. 215 
presentada es del manual de Geografía, mientras que el resto de imágenes fueron retomadas del libro de Ciencias.

En cuanto a las relaciones de pareja o de noviazgo, encontramos que el alumnado recibe información a través de las imágenes que promueven de manera exclusiva la sexualidad heterosexual. No aparece ninguna imagen en la que parejas de un mismo sexo tengan demostraciones afectivo-sexuales. La ocultación de otras formas de ejercer la sexualidad, a nuestro entender, trae consigo varias consecuencias. En primer lugar trasmiten al alumnado prejuicios que motivan la denigración y la falta de comprensión hacia personas que sienten atracción por otras del mismo sexo. En segundo lugar se refuerza la creencia de considerar natural y biológico que hombres y mujeres sientan atracción. En tercer lugar se crean falsas creencias, en el sentido de que todas las personas que no cumplen con estos roles en el plano afectivo tienen algún problema o desviación. Finalmente creemos que todas estas cuestiones favorecen que se continúe perpetuando un sistema patriarcal y sexista, en el que se considera que todo aquello que no sea masculino carece o tiene menor valor. A continuación mostramos las imágenes en las que se aparecen parejas de novios. Cabe destacar que la fotografía 5.38 de la p. 292 aparece en el libro de Geografía, y la temática a la que se hace referencia no guarda relación con la imagen que se muestra. Las demás imágenes son retomadas del libro de Ciencias, del bloque 4 "la reproducción", es decir, las imágenes que se muestran son empleadas como recurso visual para hablar acerca de las relaciones afectivas.

\section{Figura 8.25. Las relaciones afectivas, libros de Ciencias y de Geografía}
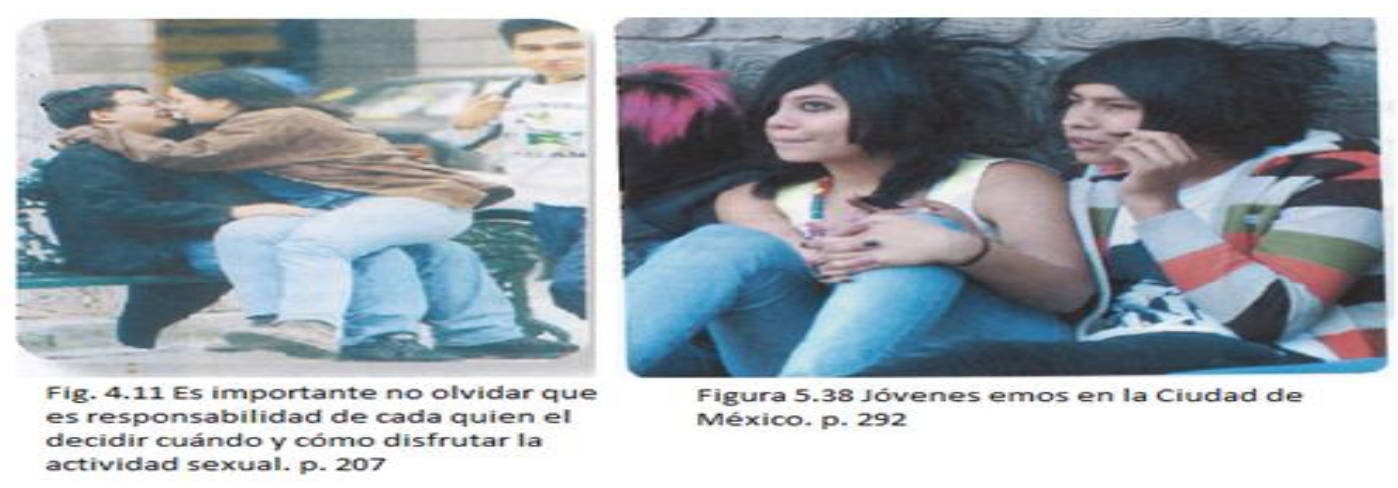

México. p. 292 


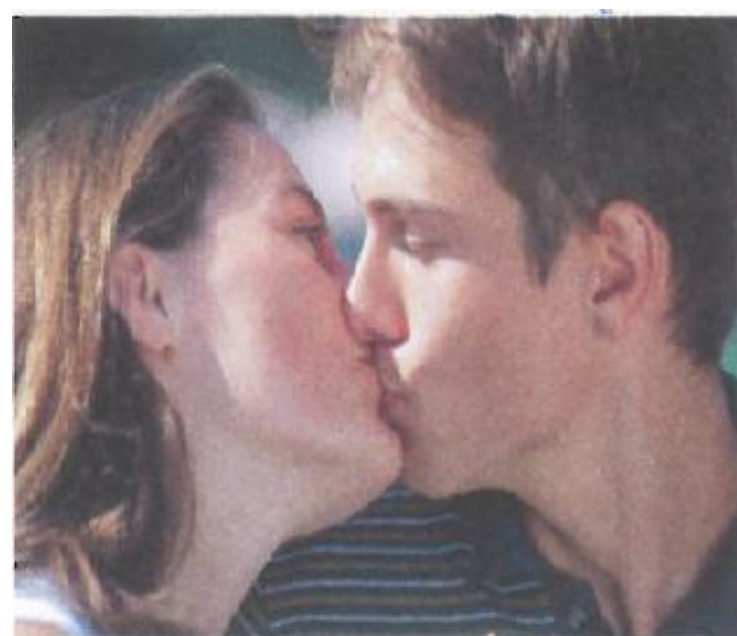

Fig. 4.6 El noviazgo contribuye al conocimiento mutuo. Al desarrollo personal compartido y a la experimentación de nuevas formas de relacionarse. p. 204

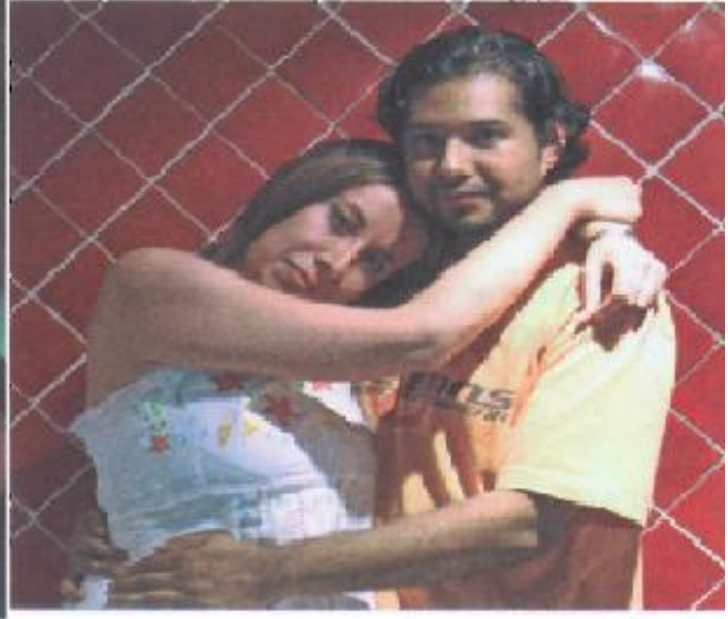

Fig. 4.7 La compañia, el contacto, la comunicación; todo esto complementa el erotismo. p. 204

Con el análisis cuantitativo y cualitativo desarrollado hasta este momento hemos intentado mostrar que - aun cuando se muestra un claro intento por incorporar una cultura de la igualdad en los libros de texto, intentando equiparar la presencia numérica de hombres y mujeres - se continúan perpetuando estereotipos y roles de género. No obstante también hemos constatado que las editoriales no han permanecido al margen de esta problemática. Por ello, en el apartado que se presenta a continuación mostramos algunas imágenes que rompen con estos estereotipos de género, con lo cual se favorecen y promueven relaciones más equitativas entre hombres y mujeres.

\subsubsection{Promoción de la igualdad/equidad de género a través de las imágenes}

En este apartado presentamos las imágenes que consideramos ofrecen al alumnado una forma alternativa de visualizar las relaciones entre hombres y mujeres. En ellas se promueve efectivamente una cultura de la igualdad, que recoge los avances y trasformaciones que se han suscitado para presentar modelos más ajustados, e incluso adelantados, en aras de construir una sociedad más justa, equitativa y digna. 
Con el propósito de organizar la información, primero vamos a presentar aquellas imágenes e ilustraciones en las que aparecen mujeres desempeñando funciones y roles que han sido considerados históricamente como "propios o aptos para hombres". Posteriormente mostraremos los recursos iconográficos en los que aparecen los hombres desarrollando actividades y/o funciones que han sido atribuidas como "propias de mujeres". Y finalmente mostraremos las imágenes que a nuestro parecer coinciden más con la realidad actual, pues se presenta a hombres y a mujeres trabajando o conviviendo de manera conjunta en actividades que eran consideradas como propias de uno $\mathrm{u}$ otro sexo.

La figura 8.26. tomada del libro de Geografía rompe con los estereotipos de género, dado que en ella aparece una mujer realizando una acción relacionada con la elaboración de un marco referencial de ubicación (croquis). Recordemos que el estereotipo de género femenino es comúnmente asociado a la falta de habilidad para la orientación espacial. Además su postura y su Figura 8.26. Promoción de la igualdad, rostro denotan características psicosociales relacionadas con la intelectualidad y el dinamismo, rasgos de personalidad que se suelen considerar como masculinos.

Nos parece muy favorable la imagen que se presenta en el

\section{libro de Geografía}

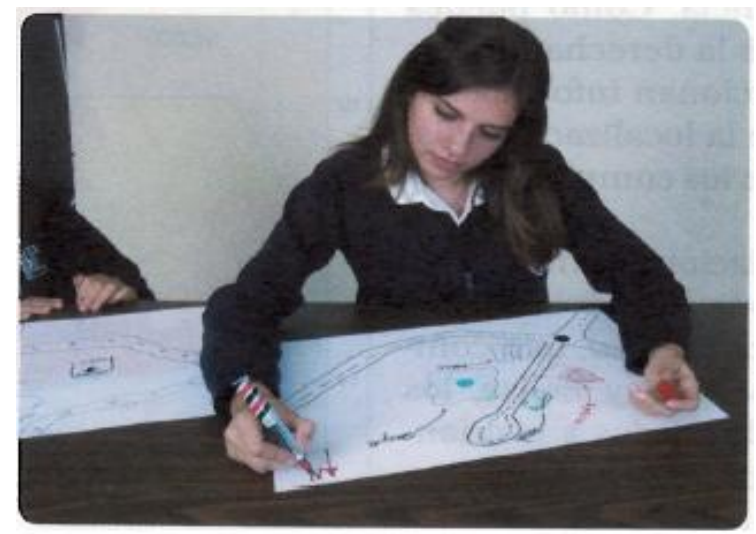

Figura 1.18 El croquis es la representación más sencilla del espacio geográfico. p. 25

bloque uno del libro de Ciencias (Fig. 1.15, p. 27), puesto que con ella se rompen varios estereotipos de género. En primer lugar se muestra que el ámbito científico es un espacio en el que pueden participar tanto hombres como mujeres. En segundo lugar, el hecho de reconocer que las mujeres también contribuyen al desarrollo del conocimiento científico, fomenta en el alumnado 
Figura 8.27. Promoción de la igualdad, libro de Ciencias

una visión más real de las

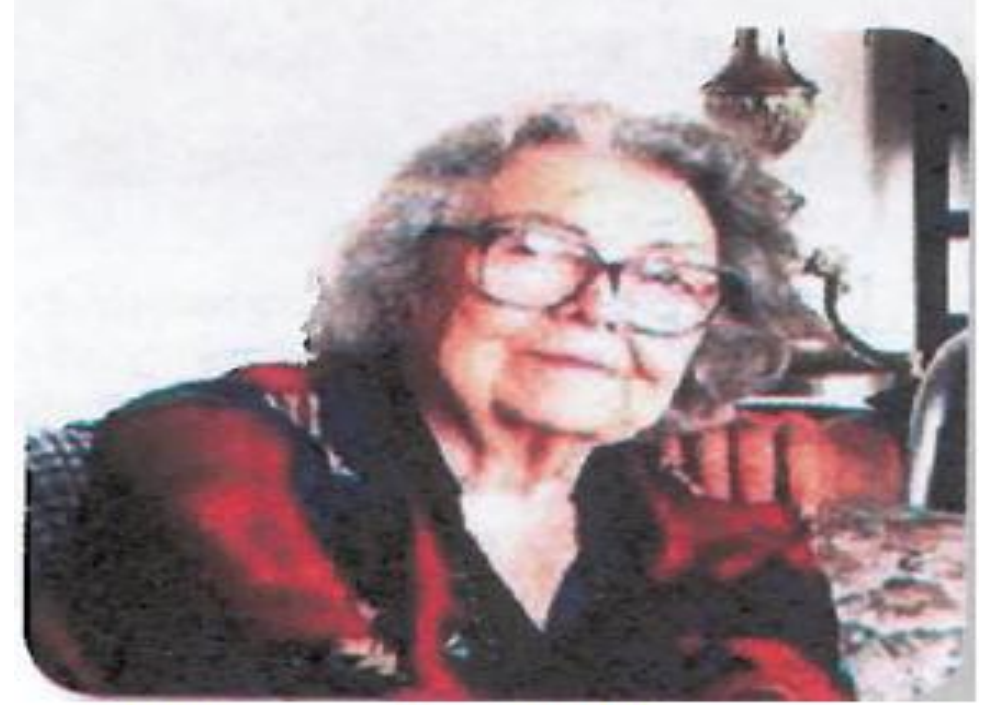

Fig. 1.15 La doctora Helia Bravo, gran científica mexicana que contribuyó al conocimiento de los cactáceos de México. p. 27 transformaciones sociales que se han producido con la incorporación de la mujer al trabajo y a la educación. En tercer lugar esta imagen promueve una cultura de la igualdad, al introducir un referente de comportamiento que no está asociado a los estereotipos de género tradicionales atribuidos a las mujeres. No obstante, de los cuatro libros analizados, únicamente en el de Ciencias se incluye a una mujer como personaje representativo, lo cual refleja la escasa presencia de modelos alternativos que puedan servir como referente para las y los adolescentes.

La imagen que se muestra en la figura 8.28., también fue considerada como positiva para la promoción de la igualdad, pues en ella aparece una mujer realizando deporte, fomentando de este modo el dejar de considerar que el ámbito deportivo es propio de hombres.
Figura 8.28. Promoción de la igualdad, libro de Ciencias

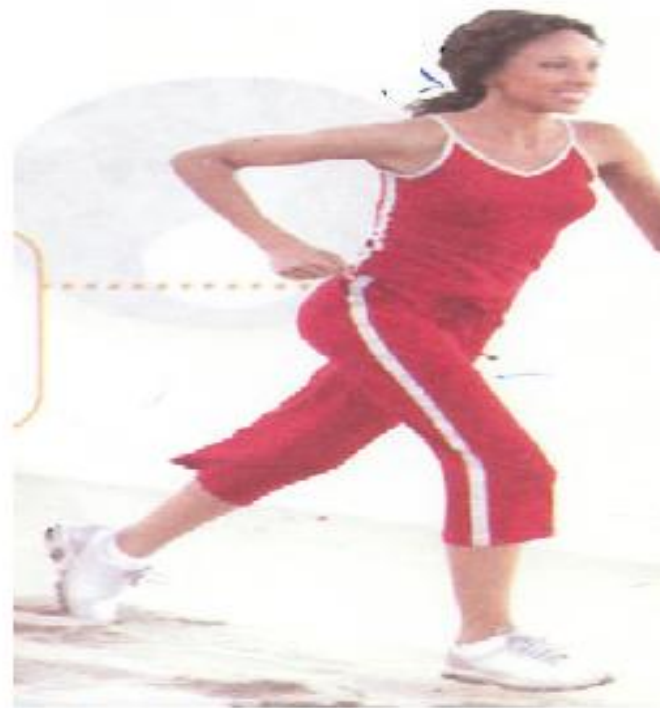

Fig. 3.2. Gracias a la respiración, en nuestro cuerpo se libera y aprovecha la energía de los alimentos. p. 142 
Con respecto a las imágenes en las que los varones aparecen representado

Figura 8.29. Promoción de la igualdad, libro de Ciencias

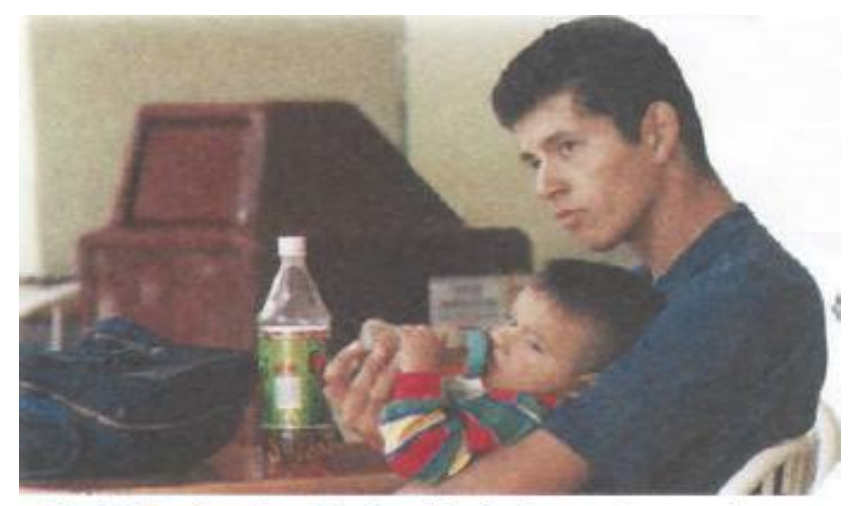

Fig. 4.5 En lo actualidad, ni todas las mujeres ni todos los hombre asumen estrictamente las conductas que tradicionalmente se les han asignado. p. 202 roles que suelen ser atribuidos a las mujeres, encontramos una que particularmente nos pareció oportuna (figura 8.29.). Además de mostrar a un hombre desempeñando funciones de crianza y cuidado, la nota al pie explica que los estereotipos de género no son estructuras que tengan que permanecer inamovibles, sino que estas

pueden variar para que hombres y mujeres puedan desarrollarse de manera libre e igualitaria.

En la figura 8.30. se puede observar una imagen positiva, dado que se muestra a un varón desempeñando una profesión (la docencia) que ha sido considerada como "propia de mujeres", pero que en la actualidad es una profesión que ejercen tanto unos como otras. En esta imagen también se refleja que niños y niñas participan de manera activa en las actividades de enseñanza-aprendizaje: en la

Figura 8.30. Promoción de la igualdad, libro de Geografía

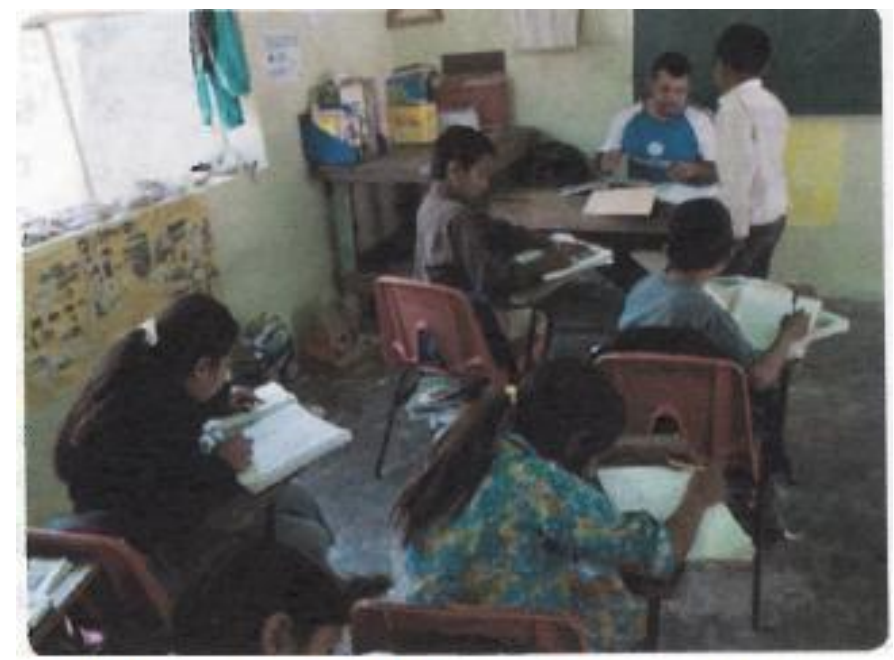

Figura 5.21 La educación bilingüe empieza a ser una realidad en diversas comunidades indígenas de México. p. 268 
imagen tanto ellas como ellos se representan realizando una actividad escolar utilizando como apoyo un libro de texto.

Finalmente vamos a mostrar dos imágenes que consideramos que promueven la igualdad entre hombres y mujeres.

Una de ellas la tomamos del libro de Geografía. En ella se puede observar a cuatro infantes. Si bien numéricamente es mayor la presencia de varones que de mujeres (tres a una), consideramos que el texto que se incluye en la nota al pie favorece la cultura de la igualdad, pues invita al alumnado a reflexionar sobre el

Figura 8.31. Promoción de la igualdad, libro de Geografía

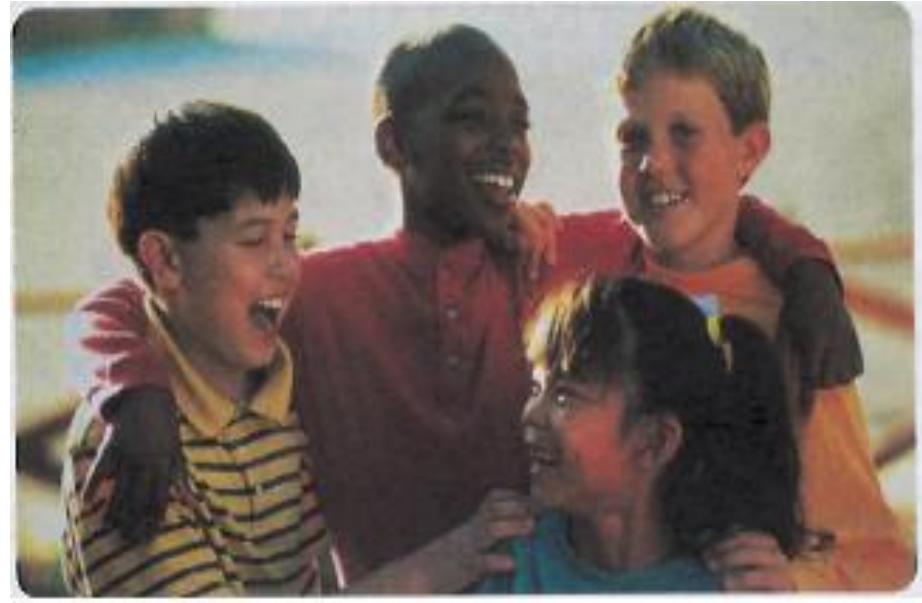

Figura 5.1 La convivencia de personas con rasgos culturales distintos enriquece la diversidad cultural del espacio geográfico. p. 250 respeto a la diferencia y se enaltece el principio de la no discriminación, invitando a convivir de manera armónica independientemente de las diferencias biológicas, culturales y/o sociales.

La otra imagen, que se presenta en la p. 130 y 131 del libro de Español, es utilizada para que el

alumnado identifique palabras de origen indígena. La elección de esta imagen para realizar esta actividad nos parece oportuna, debido a que promueve la corresponsabilidad de la familia para realizar una tarea doméstica como es la de hacer la compra en el mercado. Con esta ilustración se muestra una forma de actuación diferente a la que dicta el estereotipo de género que atribuye habitualmente a las mujeres esta tarea. Cabe destacar que es de las pocas imágenes en las que aparecen varones realizando estas funciones. Esta imagen es un ejemplo de que las imágenes, independientemente de la temática que se 
aborde, pueden ir acompañadas de modelos que favorezcan relaciones más equitativas entre hombres y mujeres.

Figura 8.32. Promoción de la igualdad, libro de Español

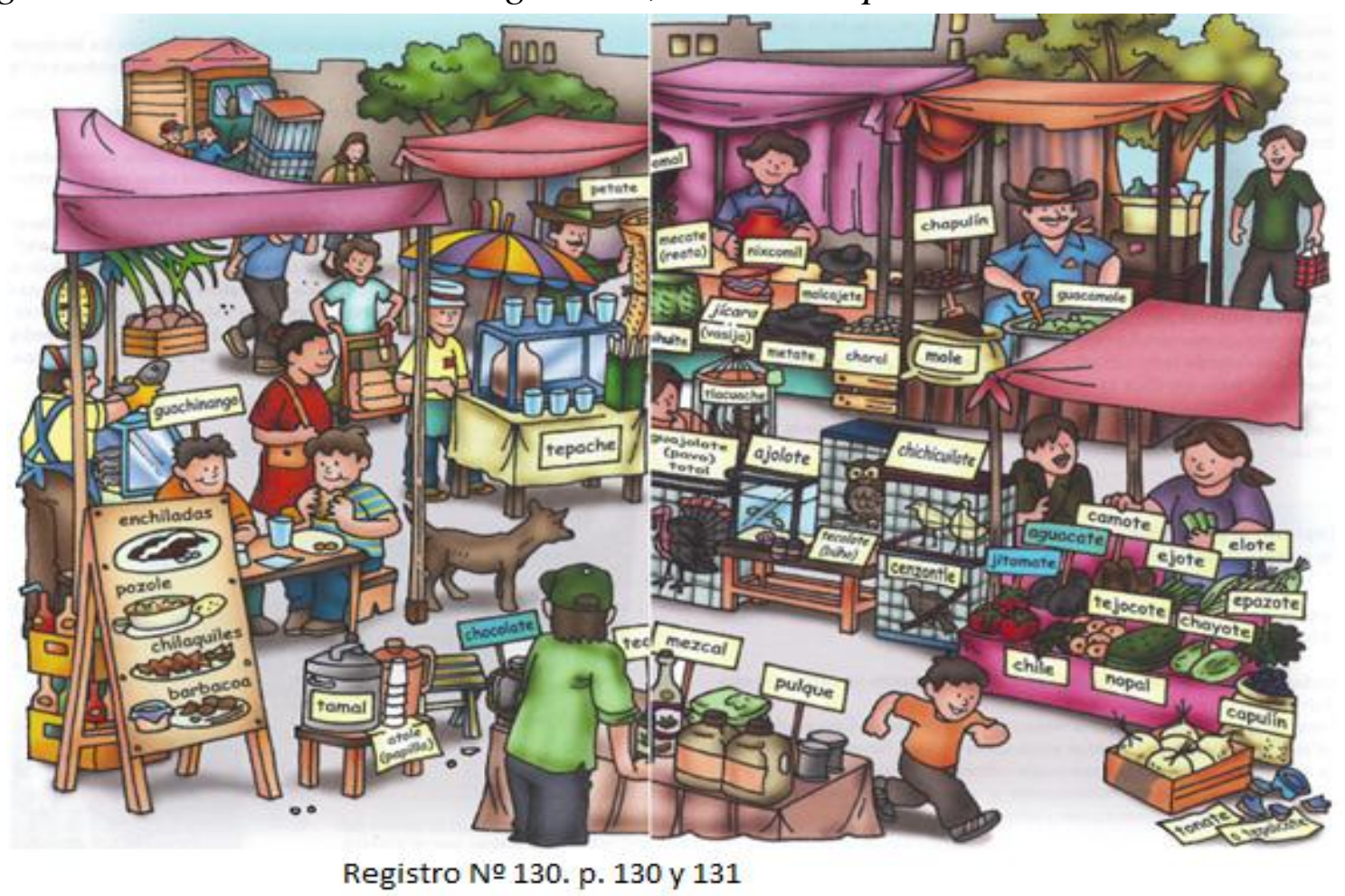

\subsubsection{Resumen}

El estudio de las imágenes de los libros de texto nos muestra que ocupan un lugar secundario, sobre todo en los materiales de Matemáticas y de Español. No obstante, tras el análisis pudimos extraer la siguiente información:

- Aunque se observa un claro intento por equiparar la presencia de hombres y mujeres — sobre todo en Ciencias y en Español-, la presencia de ellos $(48,1 \%)$ continúa siendo superior que la de las mujeres $(36,8)$.

- Se continúan trasmitiendo modelos diferenciados en función del sexo a través de las imágenes de los libros de texto analizados:

- No se recogen ni siquiera las aportaciones que a día de hoy proporcionan las mujeres para el desarrollo y progreso de la 
humanidad. Únicamente en el libro de Ciencias se muestra a una mujer célebre y se reconoce su contribución al mundo científico.

- Los personajes analizados aparecen en contextos diferenciados en función de su sexo. Los hombres aparecen con mayor frecuencia en ámbitos públicos y realizando actividades y ocupaciones más diversificadas. En cambio, las mujeres aparecen más en el ámbito privado, desempeñando actividades relacionadas con el cuidado y atención de los otros.

- Se prioriza el ámbito público sobre el privado. Es decir, se muestra con mayor frecuencia a mujeres y a hombres desempeñando actividades profesionales y $\mathrm{o}$ académico/científicas, pero no encontramos imágenes en las que se trasmita la corresponsabilidad de la familia para realizar tareas del hogar. Es decir, aquellas que muestren que tanto los hombres como las mujeres pueden limpiar, hacer la comida, lavar y planchar.

- En cuanto a la educación sobre sexualidad, pudimos constatar que se difunden relaciones de pareja únicamente heterosexuales.

Finalmente, y con relación a la promoción de la igualdad en los libros de texto, pudimos observar que se han incorporado escasas imágenes que muestran modelos alternativos de ser hombre y de ser mujer. En los hombres se promueve en alguna ocasión la corresponsabilidad en el cuidado de los hijos e hijas y el desempeño en actividades profesionales consideradas como propias de mujeres, pero no aparece ninguna imagen que tenga que ver con su participación en la limpieza o la organización del hogar. También es en pocas ocasiones en las que se promueve en las mujeres su participación en actividades consideradas como masculinas: actividades deportivas y lúdicas, actividades profesionales y académicas. 


\subsection{Los personajes en el texto}

En este epígrafe describiremos la medida en la cual son protagonizados hombres y mujeres en el texto, es decir, se elabora un recuento de los personajes que aparecen en el corpus textual de los materiales que empleamos como muestra. Para ello, primero realizaremos una descripción de los resultados de manera cuantitativa. En segundo lugar mostraremos algunos ejemplos de cómo se realiza el tratamiento de los personajes, recurriendo a citas textuales con el propósito de reforzar cualitativamente los resultados obtenidos.

Se analizaron un total de 4131 personajes, lo cual supone el 89,8 por ciento del total de datos analizados. La presentación y análisis de los resultados lo vamos a organizar siguiendo las pautas establecidas en el apartado anterior. Así pues, en el siguiente apartado haremos referencia a la presencia y distribución de los personajes de manera global y por asignaturas. En el segundo apartado, 8.2.2., describiremos la información relacionada con los personajes que han sido categorizados como representativos por haber realizado aportaciones que han contribuido al avance de la sociedad. En tercer lugar describiremos cómo se diferencia la protagonización de los personajes en función del sexo. Finalmente presentaremos de manera concisa y breve los puntos que consideremos más relevantes.

\subsubsection{La presencia de los personajes en los libros de texto}

La cuantificación de los personajes que aparecen en el texto se pueden observar en la tabla 8.6. En ella destaca que, de las 4131 denominaciones recogidas en los libros de texto analizados, el 30 por ciento son referidas a personajes masculinos. Predominio que se acentúa más si unificamos todas las referencias a personajes varones, llegando a superar el 60 por ciento. Mientras, solo el 16 por ciento de las veces se protagoniza a las mujeres. Con relación a los grupos/colectivos, vemos que tienen poco peso, ya que entre los tres colectivos analizados no se supera el cinco por ciento. También podemos 
observar que más del 20 por ciento de los personajes son nombrados en masculino genérico.

Tabla 8.6. Distribución de la presencia de los personajes en el texto

\begin{tabular}{lrrr}
\hline \hline \multicolumn{1}{c}{ PRESENCIA } & FRECUENCIA & $\mathbf{\%}$ & TOTAL \% \\
\hline VARONES & 1240 & $30,0 \%$ & \\
\hline MASCULINO GENERICO & 1197 & $29,0 \%$ & $61,5 \%$ \\
\hline COLECTIVO VARONES & 104 & $2,5 \%$ & \\
\hline MUJERES & 648 & $15,7 \%$ & \multirow{2}{*}{$16,0 \%$} \\
\hline COLECTIVO MUJERES & 12 & $0,3 \%$ & $22,5 \%$ \\
\hline GENÉRICO & 874 & $21,2 \%$ & $100,0 \%$ \\
\hline COLECTIVO MIXTO & 56 & $1,4 \%$ & \\
\hline \hline
\end{tabular}

En esta primera lectura de los datos se refleja que la presencia de las mujeres en el texto es menor que en las imágenes (15,7\% frente a 36,8\%). Si analizamos únicamente las denominaciones que se realizan en los textos a hombres y a mujeres (1888), podemos observar que es menos frecuente que se refieran a ellas (un 34,3 por ciento de las veces) (gráfica 8.4.).

Gráfica 8.4. Presencia de mujeres y hombres en el texto

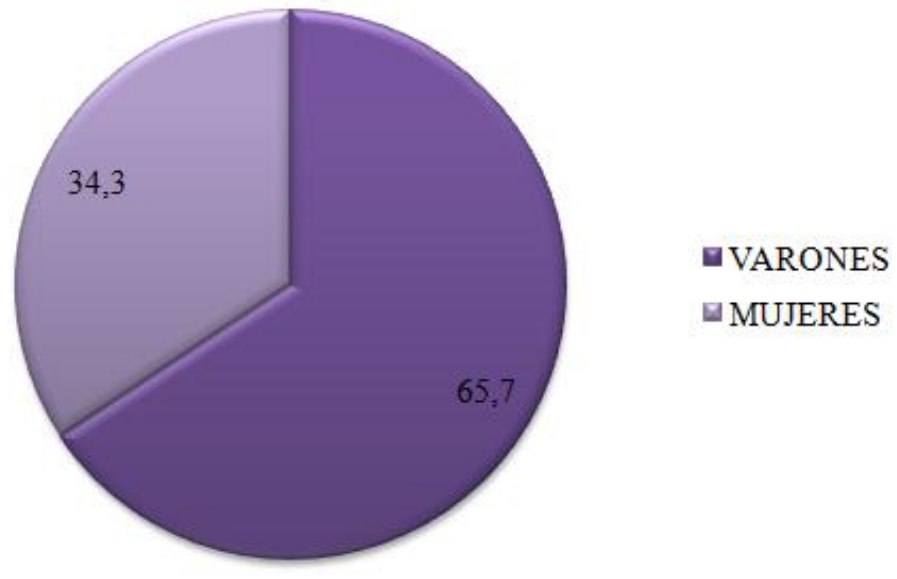

Identificados los personajes, vamos a proceder a comparar si los libros de texto analizados muestran algunas semejanzas o diferencias en cuanto a la distribución de los personajes. En la tabla que se presenta a continuación se 
recoge la información según el área de conocimiento al que pertenece cada asignatura. Es preciso mencionar que solo haremos referencia a las denominaciones de varones, mujeres y masculinos genéricos (3959). Los libros de texto en los que encontramos mayor número de referencias a seres humanos fueron el libro de Español (1302) y el libro de Ciencias (1211), habiendo entre ellos una diferencia porcentual de menos de tres puntos. Mientras, el libro con menos presencia de personajes fue el de Matemáticas (552). Los resultados obtenidos en el texto son similares a los que encontramos en las imágenes, ya que el libro de Ciencias, tanto en el texto como en la iconografía obtiene un porcentaje mayor que el resto de asignaturas. En contraposición, la asignatura de Matemáticas, tanto en el corpus textual como en las imágenes, obtiene la puntuación más baja.

En las asignaturas en las que existe mayor presencia de mujeres es en Matemáticas $(23,9 \%)$ y en Ciencias $(21,1 \%)$. Por otro lado, pudimos constatar que existe una mayor diferencia entre la presencia de unos y otras en el libro de Español $(24,6 \%)$ y en el de Matemáticas (14,9\%). El libro de texto de Geografía es el que contiene un mayor número de genéricos y el libro de texto con mayor porcentaje de genéricos es el de Español, como se puede apreciar en la siguiente tabla.

Tabla 8.7. Distribución de la presencia de hombres y de mujeres en el texto según asignatura

\begin{tabular}{lrrrrrrrrrr}
\hline \hline \multirow{2}{*}{ PRESENCIA } & \multicolumn{2}{c}{ CIENCIAS } & \multicolumn{2}{c}{ ESPAÑOL } & GEOGRAFÍA & MAT. & \multicolumn{2}{c}{ TOTAL } \\
\cline { 2 - 11 } & $f_{i}$ & $\%$ & $f_{i}$ & $\%$ & $f_{i}$ & $\%$ & $f_{i}$ & $\%$ & $f_{i}$ & $\%$ \\
\hline HOMBRES & 367 & 30,3 & 516 & 39,6 & 147 & 16,4 & 210 & 38,0 & 1240 & 31,3 \\
MUJERES & 255 & 21,1 & 195 & 15,0 & 66 & 7,4 & 132 & 23,9 & 648 & 16,4 \\
GENÉRICO & 315 & 26,0 & 143 & 11,0 & 373 & 41,7 & 43 & 7,8 & 874 & 22,1 \\
MASCULINO & 274 & 22,6 & 448 & 34,4 & 308 & 34,5 & 167 & 30,3 & 1197 & 30,2 \\
GENÉRICO & 1211 & 100,0 & 1302 & 100,0 & 894 & 100,0 & 552 & 100,0 & 3959 & 100,0 \\
\hline TOTAL & & & & & & & & & & \\
\hline \hline
\end{tabular}


Tomando en cuenta únicamente los datos aquí presentados, podríamos decir que el alto número de referencias encontradas, tanto en genérico como en masculino genérico, muestran un intento por emplear un lenguaje políticamente correcto, sobre todo en los libros de texto de Ciencias y Geografía. Menos interés por introducir estas medidas se muestra en los libros de Matemáticas y de Español. También pudimos constatar que en las imágenes, al menos con respecto a las cifras, se refleja una mayor equiparación entre hombres y mujeres.

En los epígrafes próximos analizaremos si estos intentos por incorporar un lenguaje menos sexista se han realizado basándose en las políticas de igualdad, o si por el contrario solo se ha intentado cumplir con la normativa jurídica vigente tanto a nivel nacional como internacional.

\subsubsection{Personajes históricos o representativos}

Los libros de texto son el recurso a través del cual se trasmiten los saberes y avatares que han ocurrido a través de la historia para que hoy sea tal cual la conocemos. Es decir, mediante esta herramienta didáctica se selecciona tanto aquello que es considerado necesario para que una sociedad pueda seguir avanzando, como las personas que han contribuido a ello. Así pues, al igual que en el apartado de las imágenes, en este epígrafe elaboramos una cuantificación por sexo de los personajes que aparecen en el texto por haber realizado aportaciones que han sido consideradas como destacadas en la evolución de la sociedad.

Se codificaron un total de 499 personajes, esto supone el 12,1 por ciento del total de datos analizados en el texto, de los cuales 454 eran alusiones a varones y 45 a mujeres (tabla 8.8.). De los libros analizados, en el de Español aparece una mayor referencia a personajes célebres, mientras que en el de Geografía constatamos un menor número de referencias a estos personajes. Cabe destacar, 
además, que el de Geografía es el único libro en el que no aparece ninguna referencia a personajes femeninos.

Los resultados arrojados tras el análisis reflejan que el número de personajes representativos en el texto es mayor que en las imágenes. No obstante, tanto en uno como en otro el análisis efectuado destaca la exigua mención de mujeres que han contribuido de una u otra forma al desarrollo de la humanidad.

Tabla 8.8. Personajes representativos según asignatura

\begin{tabular}{lrrrrrr}
\hline \multirow{2}{*}{ LIBRO } & \multicolumn{2}{c}{ HOMBRES } & \multicolumn{2}{c}{ MUJERES } & \multicolumn{2}{c}{ TOTAL } \\
\cline { 2 - 7 } & $f_{i}$ & $\%$ & $f_{i}$ & $\%$ & $f_{i}$ & $\%$ \\
\hline CIENCIAS & 135 & $27,1 \%$ & 6 & $1,2 \%$ & 141 & $28,3 \%$ \\
ESPAÑOL & 248 & $49,7 \%$ & 37 & $7,4 \%$ & 285 & $57,1 \%$ \\
GEOGRAFÍA & 31 & $6,2 \%$ & 0 & $0,0 \%$ & 31 & $6,2 \%$ \\
MATEMÁTICAS & 40 & $8,0 \%$ & 2 & $0,4 \%$ & 42 & $8,4 \%$ \\
TOTAL & 454 & $91,0 \%$ & 45 & $9,0 \%$ & 499 & $100,0 \%$ \\
\hline \hline
\end{tabular}

Ahora mostraremos los ámbitos en los cuales aparecen representados los personajes representativos, con la finalidad de averiguar si los personajes son nombrados en espacios distintos en función de su sexo. Así pues, en la tabla 8.9., se puede observar que en los ámbitos en los que los personajes representativos aparecen con mayor frecuencia son el científico y el ámbito de arte y literatura, con apenas 3,6 puntos porcentuales de diferencia entre uno y otro. Por otro lado, el ámbito deportivo (dptvo.) es el que tiene una menor representación, al no aparecer en las asignaturas de Español y Geografía.

Los resultados presentados en esta tabla (8.9.) muestran algunas diferencias con los encontrados en las imágenes (8.2.). En el texto aparecen personajes representativos en el ámbito religioso en las asignaturas de Español y de Geografía, mientras que en las imágenes no aparecieron. En el libro de Ciencias y de Geografía, por su parte, existe una mayor variedad de ámbitos de actividad en los que aparecen los personajes célebres. 
Tabla 8.9. Personajes representativos por asignatura según ámbitos de actividad en el texto

\begin{tabular}{|c|c|c|c|c|c|c|c|c|c|c|c|c|}
\hline \multirow[t]{2}{*}{ ASIG. } & \multicolumn{2}{|c|}{ Á. CIENT. } & \multicolumn{2}{|c|}{ Á. POLÍT. } & \multicolumn{2}{|c|}{$\begin{array}{c}\text { ARTE Y } \\
\text { LIT. }\end{array}$} & \multicolumn{2}{|c|}{ Á. DPTVO. } & \multicolumn{2}{|c|}{ Á. REL. } & \multicolumn{2}{|c|}{ TOTAL } \\
\hline & $f_{i}$ & $\%$ & $f_{i}$ & $\%$ & $f_{i}$ & $\%$ & $f_{i}$ & $\%$ & $f_{i}$ & $\%$ & $f_{i}$ & $\%$ \\
\hline CIENCIAS & 130 & 25,9 & 4 & 0,8 & 7 & 1,4 & 1 & 0,2 & 0 & 0,0 & 142 & 28,3 \\
\hline ESPAÑOL & 0 & 0,0 & 113 & 22,6 & 163 & 32,5 & 0 & 0,0 & 10 & 2,0 & 286 & 57,1 \\
\hline GEO. & 23 & 4,6 & 4 & 0,8 & 0 & 0,0 & 0 & 0,0 & 4 & 0,8 & 31 & 6,2 \\
\hline MAT. & 36 & 7,2 & 2 & 0,4 & 1 & 0,2 & 3 & 0,60 & 0 & 0,0 & 42 & 8,4 \\
\hline TOTAL & 189 & 37,7 & 123 & 24,6 & 171 & 34,1 & 4 & 0,8 & 14 & 2,8 & 501 & 100,0 \\
\hline
\end{tabular}

Como lo que nos interesa es observar las diferencias en función del sexo, a continuación presentamos una gráfica en la que se refleja que los varones aparecen mayoritariamente en el ámbito científico (40,5\%), mientras que ellas en el mismo ámbito solo obtienen el 8,7\%. En cambio, ellas obtienen un mayor porcentaje de aparición en el ámbito de arte y literatura y en el deportivo.

Gráfica 8.5. Personajes representativos según el ámbito de actividad
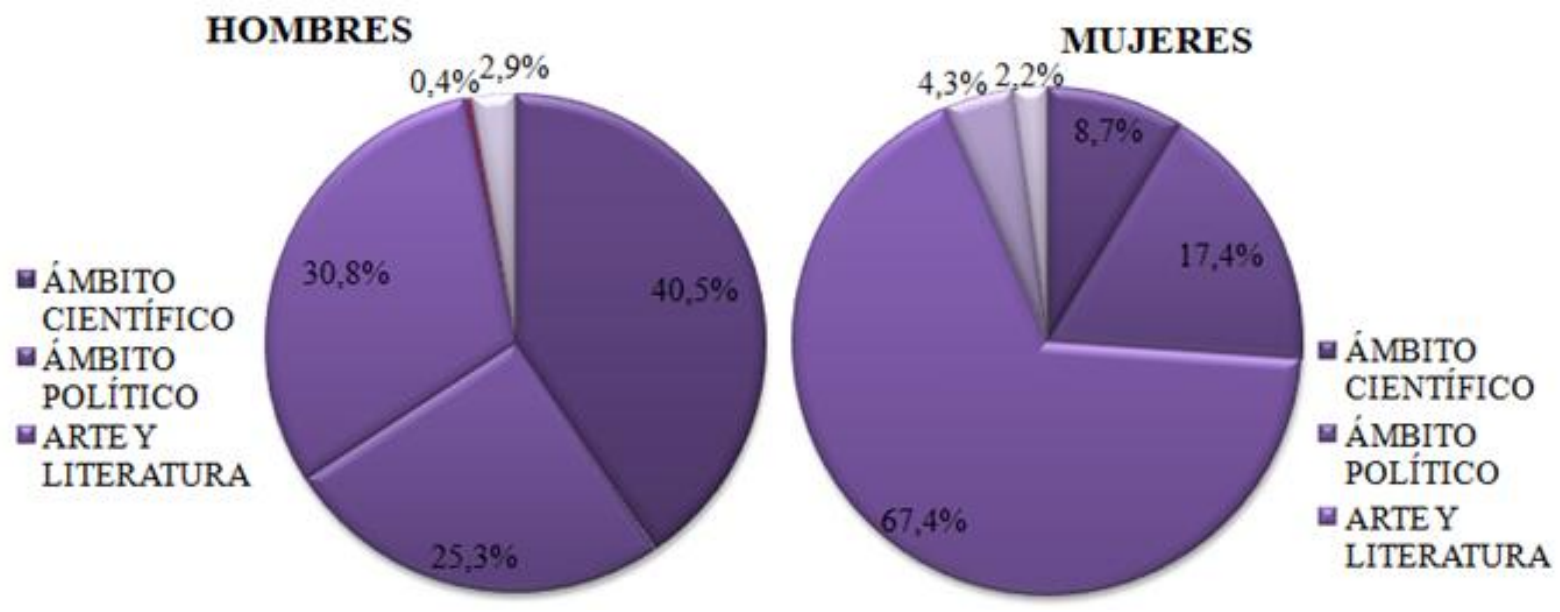

El análisis que hemos llevado a cabo en este apartado muestra los datos de manera numérica. A continuación mostramos la totalidad de personajes que contienen los libros analizados en cada una de las asignaturas, con la finalidad de ilustrar, mediante nubes de palabras, la exigua aparición de las mujeres como personas que han contribuido al desarrollo de las sociedades.

En la figura que presentamos a continuación podemos observar los nombres de los personajes representativos que aparecen en el texto, donde destacan 
principalmente las alusiones a Darwin (15), Mendel (9), Fleming (9), Urqhart (7) y Priestley (7).

Figura 8.33. Presencia de personajes históricos y representativos en el libro de Ciencias

ro ian jan von cari cruz fred funk josé juan lind watt anton antón baver bravo caire chain conde georg helia hooke james jorge keith louis waksm alfred appert cuvier 'darWin' florey garcía gloria gregor gurdon jenner joseph linneo marker martha martin ímendel' 'norman robert rubens salino selman toledo victor wilmut wright almorth badiano borlaug campell casimir erasmus 'f́leming '́francés galilei galileo georges guthrie helmont janssen marcelo nicolás pasteur posteur químico russell thomson vázquez wallace william baptista beaumont euclides gochicoa malpighi ptolomeo saavedra Urquhart alexander cervantes elizabeth hernández margarita priestley whittaker zacharias hartsoeker ingenhousz aristóteles leeuwenhoek

Todos ellos son referidos en distintas partes del libro, bien como ejemplo por sus dotes de investigadores, bien por sus contribuciones al mundo de la ciencia. A continuación mostramos algunos ejemplos.

Con base en sus observaciones, Darwin dedujo que la población ancestral de pinzones se dividió en terrestres y arbóreos. Las semillas y la pulpa de los cactus fueron la mayor fuente de alimento para los terrestres, mientras que los arbóreos se alimentaban sobre todo de insectos. Luego concluyó que las variaciones genéticas y la selección natural produjeron adaptaciones en la forma y tamaño del pico. (p. 117).

Fleming decidió dedicarse a la investigación más que a dar consultas médicas. En 1906 se unió al equipo de Almorth Wright, un médico dedicado a la investigación de bacterias. Durante ocho años trabajaron en la búsqueda de agentes que ayudaran a los leucocitos a luchar contra los microbios, investigación que resultó un éxito. En 1914, con el inicio de la primera guerra mundial, el equipo del Wright, en el que estaba, 
Fleming fue incorporado al servicio médico del ejército, donde, ayudaron a salvar a muchos heridos con la vacuna contra la tifoidea. (p. 185).

En el ámbito científico y tecnológico, los proyectos son más complejos y su éxito depende, entre otras cosas, de la planeación, la organización y el trabajo en equipo. En páginas anteriores leíste acerca de cómo Fred Urquhart desarrolló un proyecto que le llevó prácticamente toda su vida para explicar cómo y por qué se da el fenómeno migratorio de la mariposa monarca. Pueden consultar la lectura de la página 49 de este bloque. (p. 70).

De las cuatro referencias a mujeres célebres o representativas en el libro de Ciencias, solo se hace mención de ellas en un párrafo. Así pues, las referencias a Martha Cervantes y Margarita Hernández (autoras de un libro de biología) se realizan en el apartado llamado "tic tic...", — recuadro con recomendaciones para que los y las adolescentes interesados puedan investigar sobre alguna temáticas - La Doctora Helia Bravo destaca por contribuir al conocimiento de las especies de cactáceos, sobre ella se menciona lo siguiente:

En México, por ejemplo, tenemos a una de las más grandes expertas en cactáceas: la Doctora Helia Bravo, quien descubrió más de 60 géneros y especies nuevas. Además, en su honor han sido nombradas 9 especies de flora y fauna mexicanas. (p. 27).

Por su parte, la Dra. Gloria Elizabeth García se destaca en el texto como investigadora del Colegio de México, sin embargo solo se hace referencia a una opinión, no al ámbito en el que ha desarrollado sus contribuciones académicas.

Algunos factores que influyen en los embarazos en adolescentes son la falta de información y de acceso a los métodos anticonceptivos, así como todas las ideas culturales que se tienen acerca de cómo se deben comportar los hombres y las mujeres en el acto sexual. Esto último influye considerablemente para que los adolescentes decidan si usan o no algún método anticonceptivo y de protección contra infecciones de transmisión sexual. (p. 212).

La siguiente nube de palabras (figura 8.34.) ha sido extraída del libro de Español. Los personajes varones que se repiten un mayor número de veces, son destacados por sus dotes de mando y de dominio. También podemos observar que el número de referencias a mujeres es mayor que en el caso de las imágenes, como ya habíamos constatado en el análisis cuantitativo. 
En cuanto a los hombres, podemos observar que los que más veces se repiten son el Rey Moctezuma (28) y el gurrero Cuauhtémoc (27), debido a que se incluye una obra completa, iniciada en la p. 122 y terminada en la p. 124, donde el alumnado es invitado a participar interpretando a estos personajes. En cuanto a las mujeres, la mayoría de ellas son nombradas en dos ocasiones, a excepción de la ex Dip. Guadalupe Rodríguez que aparece siete veces en el texto.

Figura 8.34. Presencia de personajes históricos y representativos en el libro de Español

acevedo adolfo albert alberti alejandro alemán allan alma alvarez ana zndré antón apollinaire arreola arturo barreda bashó benito bécquer blandí blengio bodet bolívar bretón brito bustos calderón cantú carballido carlos carranza carroll casar casona cavafis cerasoli cerda chavarría constancio constantino coronado cuauhtemoc cuauhtémoc

adgar edūarđó enñiqué èrnésto escobedo estébanez euripides fabra farias federico fernando filippo flores fonseca frangois fuentes gabriel gaby galeana galindo garcilazo garcía garrido gaspar georg gerardo gloria gogh gorman gómez guadalupe) guido guillaume guillermo guillén gustavo gutiérrez hermán hernández héctor hidalgo hugo huidobro huitzilopochti ibsen ignacio jaime javier jean jesús john jordi jorge juárez landa lara leal legorreta león lewis lizalde lloyd loiseau lope lorca lozano luis luistrueba madero mahoma mariano maribelsuarez maritmo

\footnotetext{
maria marín marínetti martínez matsúo márquez metsu michel mier miguel' moliner moneada monsiváis montemayor moreno murillo nava navácenau nazaret neruda nicolás novácenau novo octavio olaff olvera orozco ortega ortiz pablo pacheco padilla parás paso paz pellicer poe porfirio quetzalcóatl rafael ramirez raúl reven rey ricardo rico robinson rod rodolfo rodrigo rodríg rodríguez roto rubẻn rufino rulfo salomón salvador saúl savater sánchez seco servando shakespeare sierra silva simón soriano soto stephens suárez tablada tamayo teodoro teresa toledo tom tomás tommaso torres tovar trakl trejo tristán tristón tzara valdès vargas vega venustiano vicente vincent victor william xv zaid zaragoza zedillo zorrilla zúñiga
}

Por otro lado, las mujeres representativas a las que se hace alusión en el libro de Español destacan en varios ámbitos de actividad. Por ejemplo, en el ámbito político se hace referencia a las ex Diputadas Guadalupe Rodríguez y Ana María Ramírez Cerda por haber trabajado con la propuesta de Ley para proteger a los no Fumadores en el Estado de Nuevo León. Esta referencia surge en el libro como parte de una actividad de análisis que han de realizar los y las adolescentes sobre una noticia. A continuación se presenta un trozo de la cita: 
Esta ley, cuya iniciativa fue planteada en diciembre de 2003 por los legisladores ecologistas Jorge Padilla Olvera y Ana María Ramírez Cerda, sería la primera que propone y emite la actual Legislatura local, pues las demás que han aprobado han sido del Ejecutivo".

"Guadalupe Rodríguez, coordinadora del PT y presidenta de esta comisión de trabajo legislativo, dijo que incluso esta ley se "suavizó" para quienes incumplan sus disposiciones (infractores), pero que aún así no lograron convencer a los albiazules de que debían votarla. (103).

Gaby Vargas (escritora), es otra de las mujeres que aparecen en este libro de texto. Se presenta al alumnado un escrito suya para que estos/as lo analicen. En este ámbito (arte y literatura) también aparece una poeta, Gloria Fuentes. A continuación presentamos un trozo de las citas que hacen alusión a estas escritoras:

Tu voz, ¿qué proyecta?

Genio y figura Por Gaby Vargas

¿Te ha pasado que al conocer a una persona sientes que hay algo en ella que te desagrada? No sabes bien qué es lo que te molesta, sin embargo, cuando lo piensas, te das cuenta de que es su manera de hablar. Por lo que te invito a analizar, ¿cómo es tu tono de voz? (p. 122).

Cuando te nombran

Gloria Fuentes

Cuando te nombran, me roban un poquito de tu nombre; parece mentira, que media docena de letras digan tanto" (p. 148).

A continuación mostramos una nube de palabras que aparece en el libro de Geografía. En ella se muestra que los personajes a los que se ha aludido un mayor número de veces son Mercator (6), Peters (7) y Kóppen (5). Estos personajes son presentados al alumnado por haber contribuido a conocer de manera más precisa y detallada nuestro planeta. También se hace referencia a las habilidades de innovación, ingenio y crítica que han empleado los personajes para realizar sus aportaciones al progreso social. 
Figura 8.35. Presencia de personajes históricos y representativos en el libro de Geografía

\section{huitzilopochtli wladimir salvador robinson pinochet}

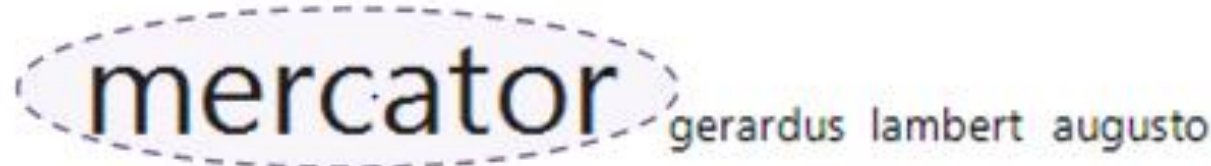

allende tláloc'

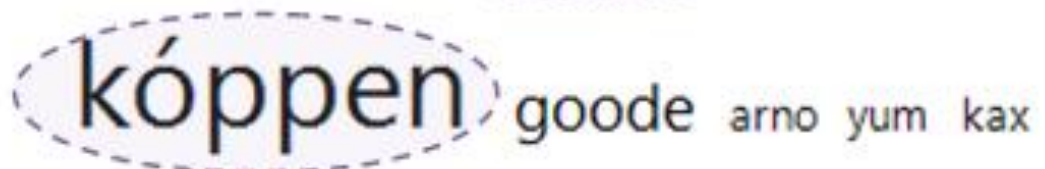

En este sentido respecto a estos autores se señala lo siguiente:

La primera proyección cilíndrica, y también la más conocida, fue desarrollada por Gerardus Mercator en el siglo XVI. Con dicha proyección es posible representar todo el planeta y observar las regiones ecuatoriales con gran exactitud; (p. 39).

La proyección de Peters, también cilíndrica, corrige matemáticamente las distorsiones en latitudes altas, por lo que muestra una proporción más exacta de los continentes. Arno Peters, su creador, consideraba que la proyección de Mercator tenía propósitos políticos, sociales y culturales al mostrar el continente europeo y América del Norte más grande de lo que son y disminuir el tamaño de las regiones menos desarrolladas del planeta. (p. 39).

A principios del siglo pasado, Wladimir Kóppen los clasificó en cinco grupos según su temperatura, régimen de lluvias y vegetación asociada. La clasificación de Kóppen, con algunas modificaciones, aún es una de las más utilizadas. (p. 90).

Finalmente mostraremos la nube de palabras del libro de Matemáticas. El personaje que más destacan en cuanto al número de veces a las que se hace alusión en el texto es Arquímedes (3), mientras que los otros personajes que aparecen redondeados solo son nombrados en dos ocasiones. 
Figura 8.36. Presencia de personajes históricos y representativos en el libro de Matemáticas

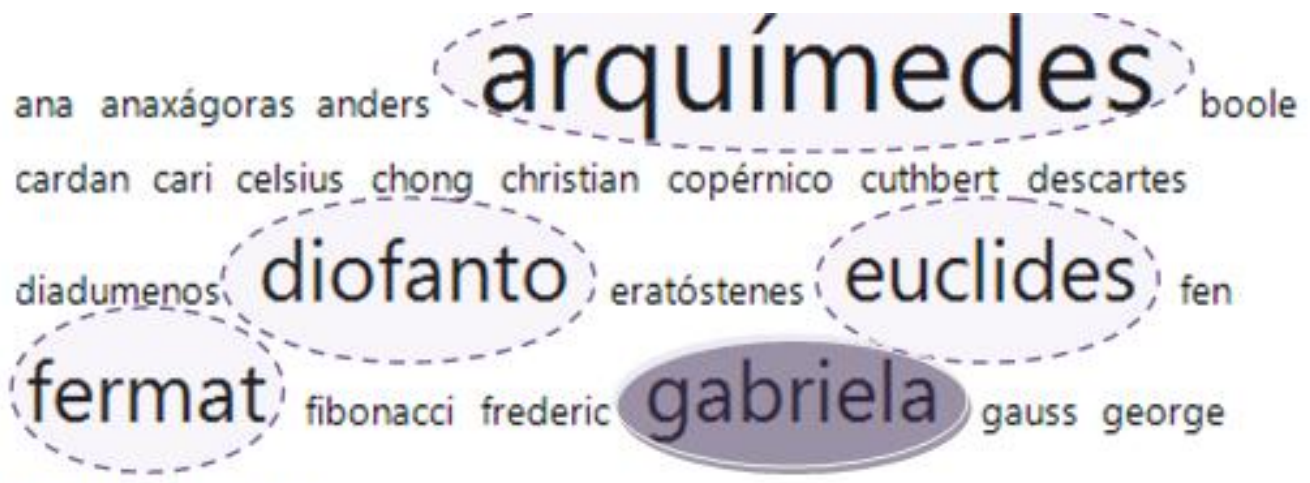

guevara hammurabi huygens jerome leibnitz leibniz louis

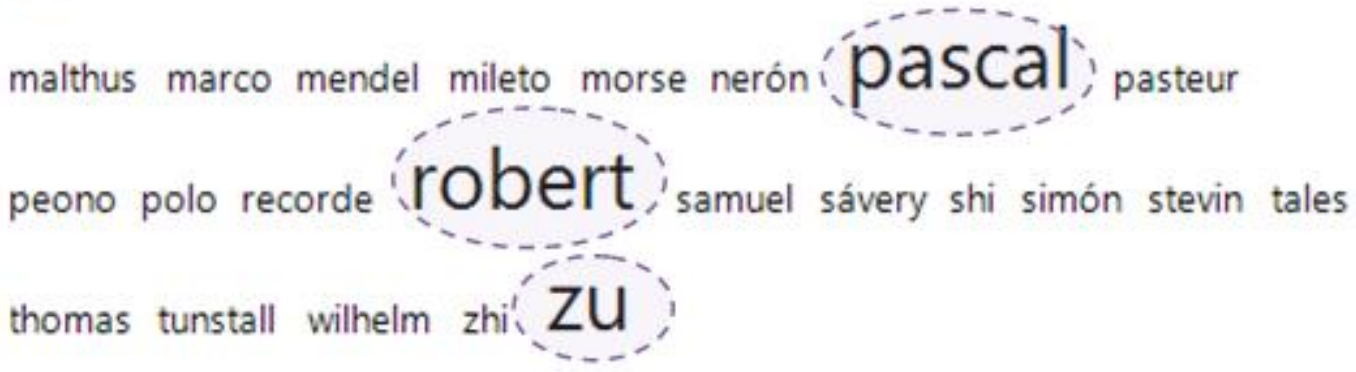

La mayoría de los personajes que aparecen redondeados son referenciados por sus contribuciones al mundo científico académico: Arquímedes, Pascal, Fermat, Euclides, Robert y Zu. Varios de estos investigadores y otros aparecen en la planeación de una actividad que se presenta al alumnado para ubicar la línea temporal a la que corresponde cada uno de ellos. A continuación mostraremos algunas de las citas en las que aparecen.

Arquímedes hizo varias contribuciones a la física y a las matemáticas. Nació en el año 287 antes de nuestra era y murió en el año 212 antes de nuestra era.

Aproximadamente en el año 240 antes de nuestra era, Arquímedes calculó el valor de $\pi$ " [...] (p. 206).

Pascal y Fermat desarrollan las leyes básicas del cálculo de probabilidades. (p. 203).

Aproximadamente en el año 300 antes de nuestra era Euclides escribió la obra Elementos de geometría. (p. 206).

En 1798, el economista y político Robert Malthus señaló: "El aumento de la población es infinitamente más grande que el poder de la Tierra para producir la subsistencia del hombre." (p. 170).

El chino Zu Chong-zhi y su hijo Zu Fen-shi encuentran que $\pi$ está entre 3.1415926 y 3.1415927 . (p. 127). 
La única mujer citada en el texto es la deportista profesional Ana Gabriela Guevara, cuyo nombre aparece en dos ocasiones. La primera de ellas, en un ejercicio donde se solicita al alumnado que escriba la expresión numérica de las cantidades a las que hacen referencia los enunciados. A continuación mostramos la cita:

Ana Gabriela Guevara es especialista en la carrera de dos quintos de kilómetro de Distancia (p. 56).

En la segunda, también se alude a esta deportista para enunciar otra actividad en el aula, cuya consigna y ejercicio son los siguientes:

Resuelve mentalmente cada uno de los siguientes ejercicios. Expresa el resultado en su forma decimal.

Gabriela Guevara le da una vuelta a la pista olímpica en 0.8 minutos (p. 74).

Los resultados arrojados tanto en el análisis cuantitativo como en el cualitativo evidencian que la presencia masculina es totalmente dominante. $\mathrm{La}$ escasa aparición de las mujeres que han contribuido al desarrollo de la humanidad, es una constante tanto en el análisis de las imágenes como en el texto. Con este análisis también se demostró que los libros analizados muestran mayores diferencias entre hombres y mujeres célebres en el texto que en las imágenes. En cuanto al ámbito de actividad en el texto, al igual que en las imágenes, predomina el científico, el de arte y literatura y el político. Los varones obtienen puntuaciones altas en estos tres ámbitos, con más de $20 \%$ en cada una de ellas, mientras que las mujeres solo en arte y literatura superan este porcentaje.

\subsubsection{Estereotipos sexistas en los modelos sociales}

En este apartado vamos a realizar un análisis de cómo y en qué contextos se hace referencia a los personajes que aparecen en el texto. Es decir, a través de los indicadores descritos en el apartado de metodología (p. 215) intentamos desvelar los sesgos sexistas que se trasmiten al alumnado mediante esta herramienta didáctica. 
En este sentido, los datos analizados en este apartado, excluyendo los datos sobre personajes representativos que ya fueron descritos, ascienden a un total de 3631 personajes, esto supone el 87,9\% de los datos.

En la gráfica que presentamos a continuación podemos observar cómo se distribuyen las menciones a los personajes analizados en el texto. En ella se destaca que los seres humanos son referidos principalmente en masculino genérico, mientras que en muy pocas ocasiones se cita a colectivos (varones, mujeres y mixtos). Por otra parte observamos que se habla de varones un cinco por ciento más que de mujeres (el 21,6\% frente al 16,6\%).

Gráfica 8.6. Distribución de los personajes en el texto

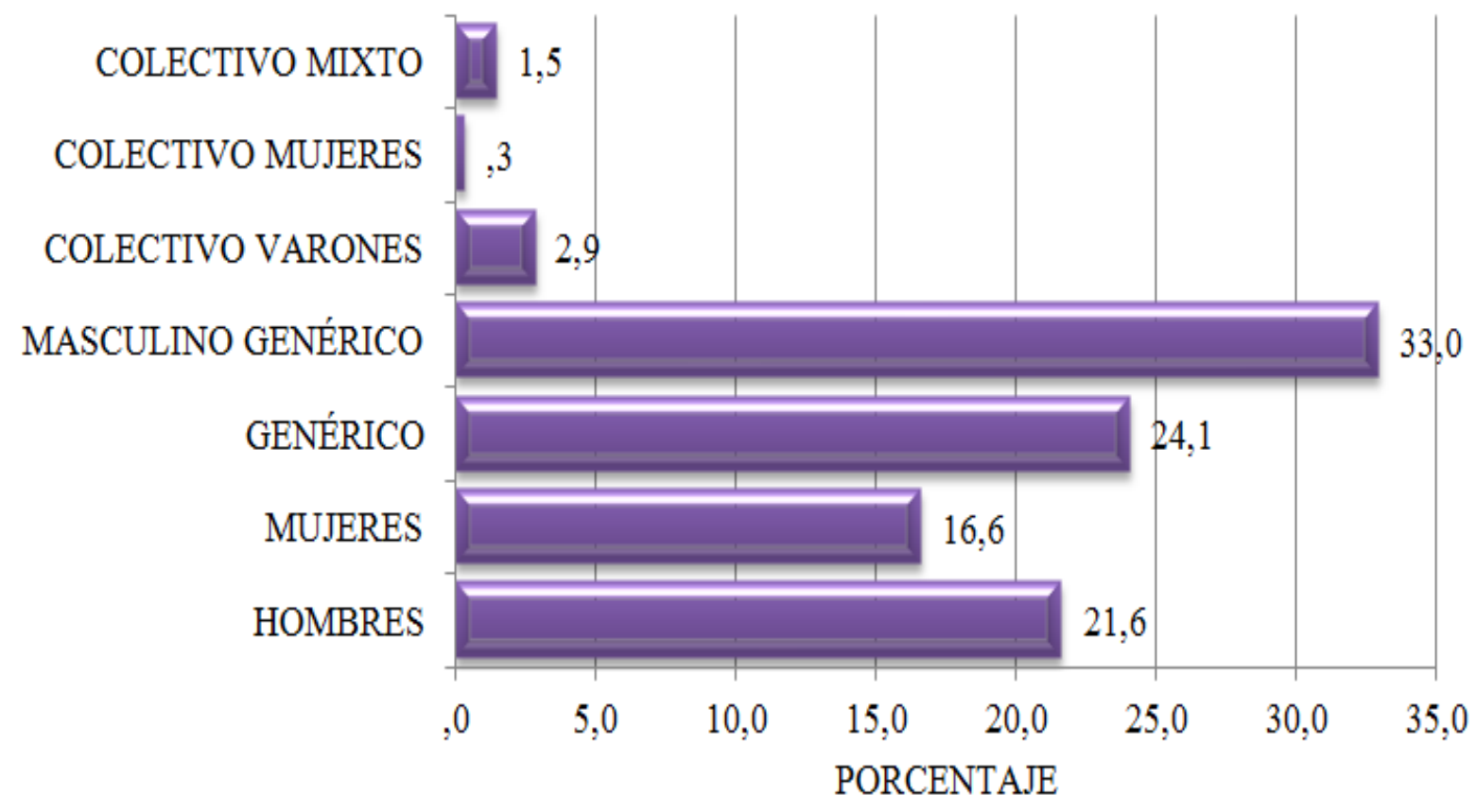

Identificados los personajes, vamos a proseguir analizando cómo se alude a ellos y ellas en el texto. Así pues, el primer indicador que utilizamos para explicar si existe una manera diferenciada de referirse a unos y otras en función de su sexo, fue analizando si los personajes son nombrados o no en el texto. Cabe destacar que existe una asociación alta y estadísticamente significativa entre las variables personajes y nombre propio ( $\mathrm{V}$ de Cramer $=0,474$, p. < $0,05)$. 
Tabla 8.10. Asociación entre la variable personajes y la variable nombre propio

\begin{tabular}{|c|c|c|c|}
\hline & VALOR & & SIG. APROXIMADA \\
\hline Phi & & ,474 &, 000 \\
\hline V de Cramer & & ,474 &, 000 \\
\hline $\mathrm{N}$ de casos válidos & & 3631 & \\
\hline
\end{tabular}

Pudimos constatar que la mayoría de las veces no se asignan nombres propios a los personajes $(88,1 \%)$. Se introducen 432 personajes en el texto de manera individualizada, es decir, por su nombre propio. No se observan diferencias con respecto al sexo de los personajes, pues tanto hombres como mujeres son nombrados el mismo número de veces (tabla 8.11.). Si analizamos los datos teniendo en cuenta las asignaturas, observamos que existen diferencias mínimas entre ellas. En este sentido, en el libro de Matemáticas se incrementa el porcentaje de nombres propios, mientras que en el de Geografía se reduce. También pudimos comprobar que en los libros de Matemáticas y de Ciencias se hace referencia a los nombres propios de mujeres en un dos por ciento más de ocasiones que a los de hombres. El caso contrario tiene lugar en las asignaturas de Español y de Geografía.

Tabla 8.11. Personajes en el texto con nombres propios por asignatura

\begin{tabular}{lrrrrrrrrrr}
\hline \hline \multirow{2}{*}{ SEXO } & \multicolumn{2}{c}{ CIENCIAS } & \multicolumn{3}{c}{ ESPAÑOL } & \multicolumn{3}{c}{ GEOGRAFÍA MATEMÁTICAS } & \multicolumn{2}{c}{ TOTAL } \\
& $f_{i}$ & $\%$ & $f_{i}$ & $\%$ & $f_{i}$ & $\%$ & $f_{i}$ & $\%$ & $f_{i}$ & $\%$ \\
\hline HOMBRES & 37 & 8,6 & 55 & 12,7 & 32 & 7,4 & 92 & 21,3 & 216 & 50,0 \\
MUJERES & 47 & 10,9 & 39 & 9,0 & 29 & 6,7 & 101 & 23,4 & 216 & 50,0 \\
\hline TOTAL & 84 & 19,4 & 94 & 21,8 & 61 & 14,1 & 193 & 44,7 & 432 & 100,0 \\
\hline \hline
\end{tabular}

El segundo indicador que vamos a analizar es el de actividades y/o ocupaciones. Se codificó tanto de manera libre como en categorías preestablecidas. Respecto a la codificación libre recogimos un total de 235 ocupaciones distintas. De estas, los varones aparecen en más del 60\% (141), mientras que las mujeres no superan el 20\% (45). Por otra parte, el masculino genérico aparece en un total de 99 ocupaciones, al tiempo que las actividades en 
las que los personajes son nombrados en genérico supone un total de 44 (ver anexos 3. tabla de la 11. a la 15.).

Los resultados de este indicador evidencian que los varones tienen un espectro mucho más amplio y diversificado en cuanto a las funciones y actividades que pueden realizar. En cambio, a las mujeres se les representa en ocupaciones mucho más acotadas y menos valoradas. Los modelos de identificación socio-laboral que recibe el alumnado, a la luz de estos resultados, son claramente desiguales.

En la siguiente gráfica que presentamos el análisis de este indicador es en la modalidad cerrada. En ella se puede apreciar que, a pesar de la alta concentración de personajes ubicados en el ámbito educativo $(27,9)$ y en el económico $(25,3 \%)$, también se muestran algunas referencias al ámbito doméstico $(12,2 \%)$ y al lúdico $(11,3 \%)$. Los ámbitos a los que se hace menor alusión en el texto son el técnico profesional $(0,7)$ y el político $(1,6 \%)$.

Gráfica 8.7. Ámbitos de actividad/ocupación en los que aparecen los personajes en el texto
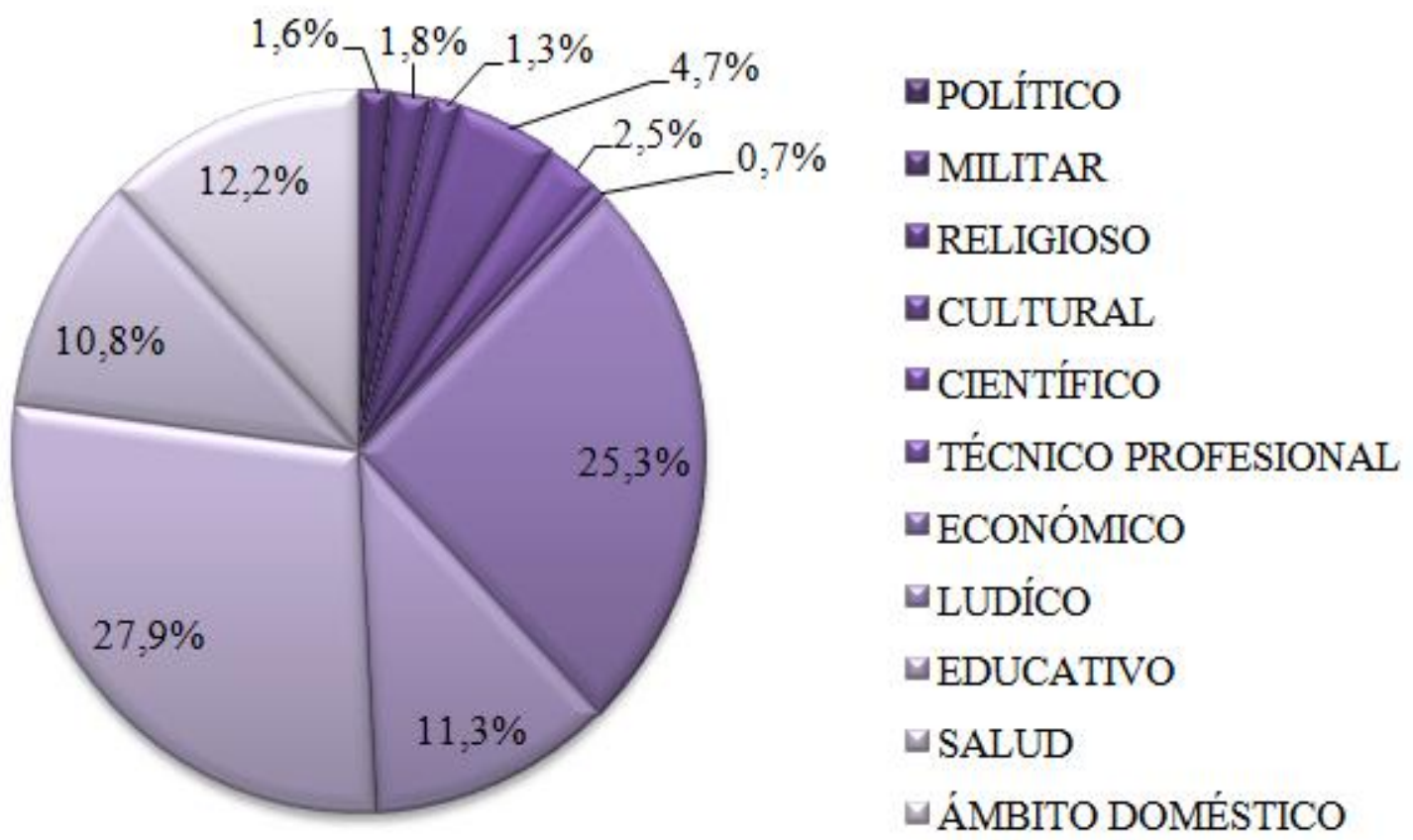

Cabe mencionar, así mismo, que las alusiones al ámbito doméstico se realizan totalmente descontextualizadas, dado que en la mayoría de las 
ocasiones se hace referencia al rol familiar como red de apoyo, pero no se reconocen ni se ponen en valor las actividades y tareas que implica este trabajo.

En la siguiente tabla podemos apreciar la distribución de las actividades y/o ocupaciones en la que aparecen los personajes. Hemos de referir que las variables analizadas muestran una asociación alta y estadísticamente significativa $(\mathrm{V}$ de Cramer $=0,329, \mathrm{p} .<0,05)$. Los datos presentados en la tabla 8.12., reflejan que existen algunas diferencias en función del sexo. Del total de personajes realizando actividades y/o ocupaciones identificadas en el texto (2764), más del 30\% corresponden a masculino genérico, y más del 25\% a los varones, mientras que las mujeres solo son referidas en un 20,2\%. Así pues, las actividades en las que más destacan ellos son las del ámbito militar, seguido del lúdico y del político, mientras que ellas aparecen en más ocasiones en el ámbito doméstico y en el lúdico. Estos resultado reflejan que en los libros de texto no solamente se transmite un mundo en el que lo masculino es predominante, sino que también se difunde una marcada división sexual en relación con las actividades y/o funciones que realizan unos y otras.

Tabla 8.12. Ámbitos de actividad y/o ocupación según personajes en el texto

\begin{tabular}{|c|c|c|c|c|c|c|c|c|c|c|}
\hline \multirow{2}{*}{ ACTIVIDADES } & \multicolumn{2}{|c|}{ HOMBRES } & \multicolumn{2}{|c|}{ MUJERES } & \multicolumn{2}{|c|}{ GENÉRICO } & \multicolumn{2}{|c|}{$\begin{array}{c}\text { MASCULINO } \\
\text { GENÉRICO } \\
\end{array}$} & \multicolumn{2}{|c|}{ TOTAL } \\
\hline & $f_{i}$ & $\%$ & $f_{i}$ & $\%$ & $f_{i}$ & $\%$ & $f_{i}$ & $\%$ & $f_{i}$ & $\%$ \\
\hline POLÍTICO & 18 & 41,9 & 1 & 2,3 & 8 & 18,6 & 16 & 37,2 & 43 & 100,0 \\
\hline MILITAR & 30 & 60,0 & 3 & 6,0 & 9 & 18,0 & 8 & 16,0 & 50 & 100,0 \\
\hline RELIGIOSO & 17 & 45,9 & 1 & 2,7 & 4 & 10,8 & 15 & 40,5 & 37 & 100,0 \\
\hline CULTURAL & 4 & 3,1 & 3 & 2,3 & 67 & 51,9 & 55 & 42,6 & 129 & 100,0 \\
\hline CIENTÍFICO & 15 & 21,7 & 5 & 7,2 & 6 & 8,7 & 43 & 62,3 & 69 & 100,0 \\
\hline $\begin{array}{l}\text { TÉCNICO } \\
\text { PROFESIONAL }\end{array}$ & 8 & 40,0 & 4 & 20,0 & 6 & 30,0 & 2 & 10,0 & 20 & 100,0 \\
\hline ECONÓMICO & 188 & 26,9 & 87 & 12,5 & 79 & 11,3 & 344 & 49,3 & 698 & 100,0 \\
\hline LÚDICO & 137 & 43,8 & 106 & 33,9 & 41 & 13,1 & 29 & 9,3 & 313 & 100,0 \\
\hline EDUCATIVO & 145 & 18,8 & 130 & 16,9 & 104 & 13,5 & 392 & 50,8 & 771 & 100,0 \\
\hline SALUD & 40 & 13,4 & 52 & 17,4 & 144 & 48,3 & 62 & 20,8 & 298 & 100,0 \\
\hline $\begin{array}{l}\text { ÁMBITO } \\
\text { DOMÉSTICO }\end{array}$ & 99 & 29,5 & 165 & 49,1 & 25 & 7,4 & 47 & 14,0 & 336 & 100,0 \\
\hline TOTAL & 701 & 25,4 & 557 & 20,2 & 493 & 17,8 & 1013 & 36,6 & 2764 & 100,0 \\
\hline
\end{tabular}




\begin{tabular}{|c|c|c|}
\hline & Valor & Sig. aproximada \\
\hline $\mathrm{Phi}$ & .570 &, 000 \\
\hline V de Cramer & 329 &, 000 \\
\hline $\mathrm{N}$ de casos válidos & & \\
\hline
\end{tabular}

Si comparamos estos resultados con los obtenidos en el apartado de imágenes observamos algunas diferencias. Mientras que en las imágenes predominaban los personajes varones en el ámbito educativo, lúdico y cultural, en el texto los varones están por encima en el ámbito técnico profesional, militar y el político. Por otra parte observamos que en el ámbito lúdico, tanto en las imágenes como en el texto se obtienen porcentajes elevados. Por otro lado, en los resultados de las mujeres vemos que tanto en el texto como en las imágenes los ámbitos con mayores puntuaciones son el doméstico, el educativo y el lúdico.

Ahora bien, continuando con el análisis del tercer indicador, el correspondiente a las características psicosociales con las que se asocia a los personajes en el texto, podemos destacar que en la modalidad abierta se codificaron un total de 193 rasgos de comportamiento. Los patrones de comportamiento que copan los ocho primeros puestos, ordenados por frecuencia de repetición, están vinculados a estereotipos masculinos: dinamismo, capacidad de trabajo, dominio y asertividad, entre otros (ver anexos 3., tabla 16.). En cambio, los estereotipos femeninos como emotividad, capacidad de mediación o timidez, aparecen solamente a partir del puesto número ocho.

En cuanto a las características psicosociales con que se hace referencia a hombres y a mujeres, vemos, al igual que en las imágenes, que ellos reciben un mayor número y más diversificado de características psicosociales 47,4\% (93) frente al 39,3\% atribuido a ellas (77) (ver anexos 3., tablas 17. y 18.).

Con la finalidad de observar si existen diferencias en función del sexo entre las características psicosociales que tienen mayor número de recurrencia, presentamos la siguiente tabla. En ella podemos observar que varias de las características que se atribuyen a hombres y a mujeres son compartidas. No 
obstante, es a ellas a quienes se les comienza a asociar con estereotipos y roles de género masculinos, mientras que a ellos no se les atribuyen los rasgos que son considerados como "propios de las mujeres". Características asociadas con la crianza y el cuidado personal continúan siendo de los rasgos de personalidad que más se atribuyen a las mujeres.

Tabla 8.13. Características psicosociales con diez porcentajes más elevados en el texto

\begin{tabular}{clrrlrr}
\hline \hline $\mathbf{N}^{\circ}$ & HOMBRES & $\boldsymbol{f}_{\boldsymbol{i}}$ & $\mathbf{\%}$ & MUJERES & $\boldsymbol{f}_{\boldsymbol{i}}$ & $\mathbf{\%}$ \\
\hline 1. & TRABAJADOR & 89 & 13,0 & DINAMICA & 70 & 12,5 \\
2. & DINAMICO & 79 & 11,5 & TRABAJADORA & 54 & 9,6 \\
3. & ASERTIVIO & 36 & 5,2 & HACENDOSA & 40 & 7,1 \\
4. & JUGUETÓN & 35 & 5,1 ASERTIVIA & 33 & 5,9 \\
5. & PROVEEDOR & 34 & 4,9 MEDIADORA & 30 & 5,3 \\
6. & DOMINIO & 30 & 4,4 & CRIANZA & 28 & 5 \\
7. & CURIOSO & 20 & 2,9 & BELLEZA & 20 & 3,6 \\
8. & DECISIVO & 16 & 2,3 & JUGUETONA & 20 & 3,6 \\
9. & OCIO & 16 & 2,3 & CURIOSA & 17 & 3 \\
10. & MEDIADOR & 15 & 2,2 & OCIO & 16 & 2,8 \\
\hline \hline
\end{tabular}

Siguiendo con el análisis de este indicador, ahora en su modalidad cerrada denominada "conducta", se elaboraron los recuentos de estas características teniendo en cuenta tanto los adjetivos con los que se hace referencia a los personajes en el texto, como el sentido que se da a los mismos. La información respecto a este indicador la presentamos a través de la gráfica 8.8. Cabe destacar que la asociación entre la variable conducta y la variable personajes es moderada, aunque significativa ( $\mathrm{V}$ de Cramer $=0,187, \mathrm{p} .<0,05)$.

Los datos reflejan que la característica psicosocial predominante en los libros de texto es la asociada a la conducta activa, seguida muy de lejos por la afectiva. En la gráfica también podemos observar que existen diferencias mínimas según el sexo de los personajes analizados. Así pues, tanto hombres como mujeres son caracterizados como activos el mayor número de veces (48,0\% frente a 33,7\%). No obstante, ellas obtienen puntuaciones un poco más elevadas en afectividad y 
en tristeza, mientras que los varones las superan en las conductas agresivas (ver gráfica 8.8.).

Gráfica 8.8. Conductas de los personajes según el sexo en el texto

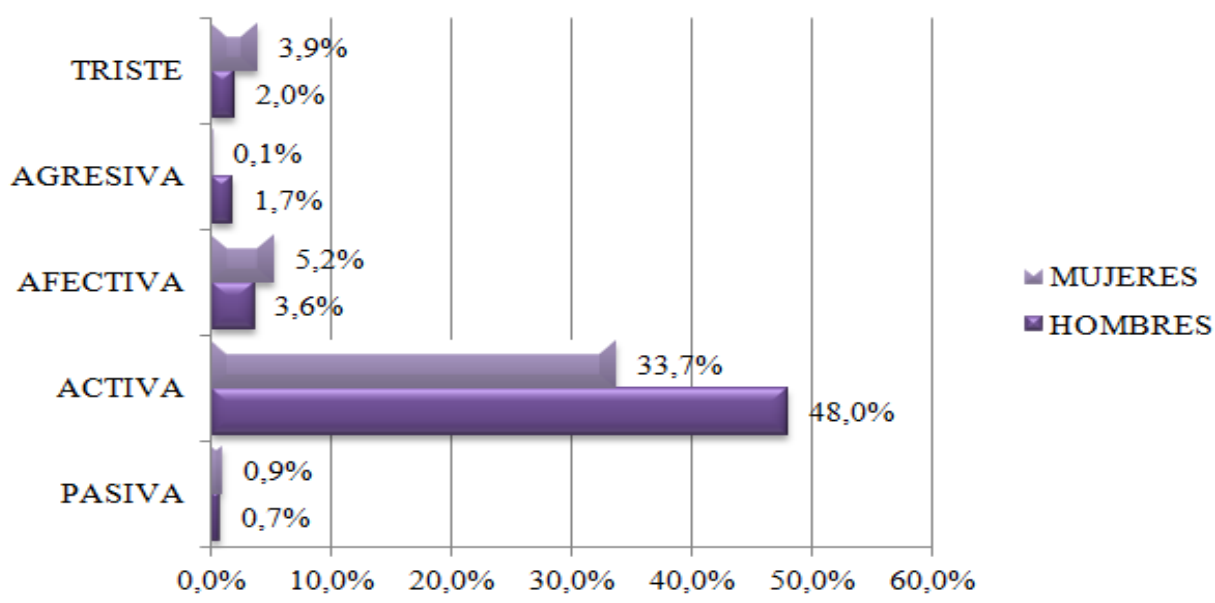

\begin{tabular}{|c|c|c|}
\hline & Valor & Sig. aproximada \\
\hline Phi & , 187 & $=000$ \\
\hline V de Cramer &, 187 & .000 \\
\hline $\mathrm{N}$ de casos válidos & 1382 & \\
\hline
\end{tabular}

Finalmente vamos a presentar el indicador correspondiente al espacio. En él se analizaron un total de 3616 personajes en el texto. Los resultados conseguidos reflejan que en los libros se priorizan los lugares abiertos (1552) y los cerrados (1144) sobre los públicos (466) y los privados (454). Por otro lado, nos sorprendió encontrar una diferencia de tan solo un 0,3\% entre el ámbito público y el privado (ver gráfica 8.9.).

Gráfica 8.9. Espacios en los que aparecen los personajes en el texto

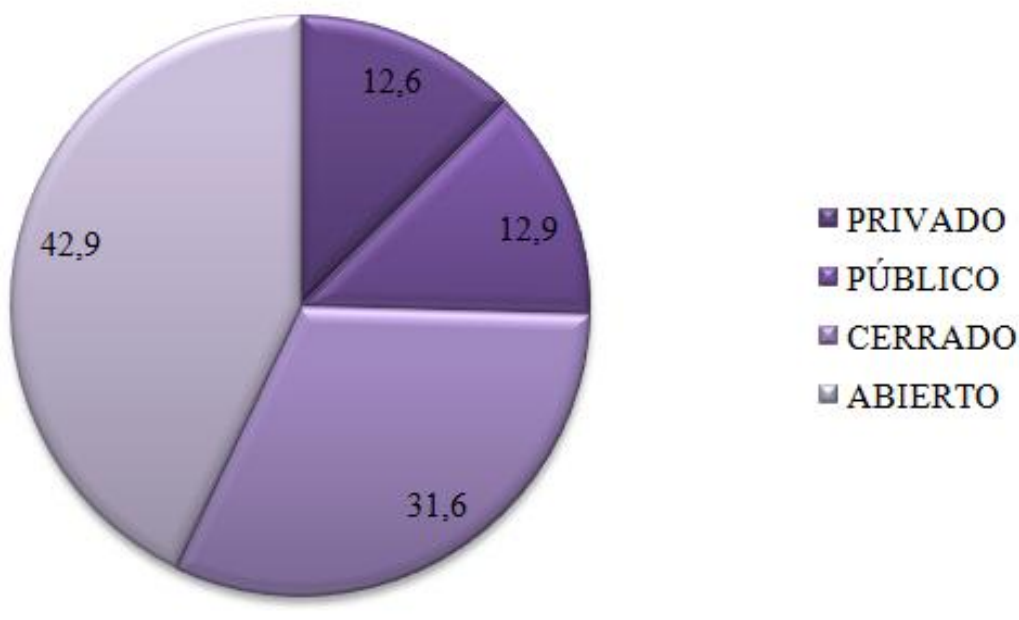


Estos resultados coinciden con los encontrados en las imágenes en las que los personajes eran representados mayoritariamente en espacios abiertos. También el ámbito de menor representación fue el privado, si bien en el análisis del texto estas diferencias son mínimas.

Con relación a las diferencias encontradas en función del sexo, pudimos comprobar que de un total de 3616 personajes, en 779 ocasiones se hace referencia a hombres y en 602 a mujeres, lo que supone el 38,0\% de los datos analizados sobre este indicador.

La investigación refleja que existen diferencias en función del sexo en cuanto a los espacios en los que aparecen unos y otras (gráfica 8.10.). Los resultados muestran un mayor equilibrio entre mujeres y hombres en los espacios cerrados, en los que tanto hombres como mujeres son referidos mayoritariamente desarrollando tareas de formación y/o aprendizaje en el contexto escolar. Las mujeres aparecen menos veces que los varones en los espacios vinculados a lo público (un diez por ciento menos). Por el contrario, en los espacios privados constatamos que las mujeres continúan superando a los varones por más de seis puntos porcentuales. Es decir, las mujeres continúan siendo representadas en más ocasiones desempeñando un rol familiar. El análisis estadístico, por otro lado, refleja que la asociación entre la variable espacio y la variable sexo es alta y estadísticamente significativa ( $\mathrm{V}$ de Cramer $=0,347, \mathrm{p} .<0,05)$.

Gráfica 8.10. Espacios en los que aparecen hombres y mujeres en el texto

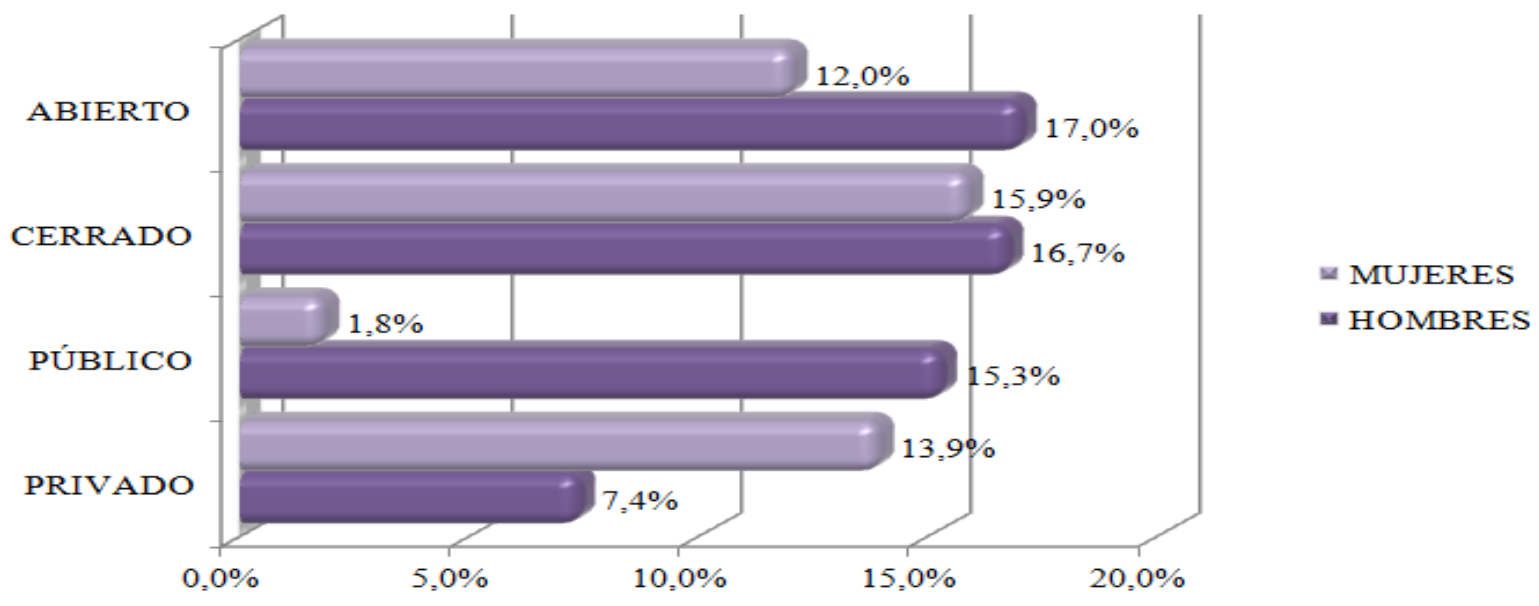




\begin{tabular}{|c|c|c|c|}
\hline Phi & $\begin{array}{l}\text { Valor } \\
, 347\end{array}$ & Sig. aproximada &, 000 \\
\hline V de Cramer &, 347 & &, 000 \\
\hline N de casos válidos & 1381 & & \\
\hline
\end{tabular}

Como veíamos reflejado en la gráfica 8.9, en el análisis del texto, el espacio privado obtiene un porcentaje de menciones muy cercano al porcentaje del espacio público. Sin embargo esta equivalencia numérica no viene acompañada de un tratamiento con base en la igualdad ya que como se aprecia en la tabla 8.10 los hombres siguen copando los espacios públicos y las mujeres los privados.

Tras el análisis descriptivo de los datos se evidencia que se han incorporado algunas medidas destinadas a cumplir con las exigencias normativas en materia de igualdad. Este hecho se puede constatar con los resultados obtenidos sobre el indicador de presencia de personajes en los textos, donde las referencias tanto a masculinos genéricos como a genéricos han obtenido porcentajes elevados. También observamos (gráfica 8.7) que la diferencia entre las referencias a hombres y a mujeres es menor (de un 5\%) que en otros epígrafes analizados. Otro indicador que nos reveló la puesta en marcha de políticas de igualdad es el hecho de que hombres y mujeres aparecen en el texto con nombre propio el mismo número de veces. No obstante, otros indicadores (actividades y/u ocupaciones, características psicosociales y espacios) constatan que continúan persistiendo los estereotipos y roles de género tradicionales.

\subsubsection{Resumen}

Con el fin de mostrar los puntos principales derivados del análisis del texto, es que presentamos este apartado:

- Se analizaron un total de 4131 personajes, lo cual supone el 89,8 por ciento del total de datos analizados. En el texto también se muestra un predominio en las denominaciones de varones (1240) sobre las de 
mujeres (648). Además, es el libro de Español en el que se encuentran las mayores diferencias entre ambos sexos (39,6\% frente a 15,0\%).

- Los personajes representativos o célebres aparecen más en el texto (499) que en las imágenes (29).

- La presencia de personajes célebres varones es muy superior. Además en ellos se destacan las contribuciones y las cualidades intelectuales y psíquicas.

- Por el contrario, las menciones a mujeres representativas en el texto es exigua (menos del 10\%). Tal y como se muestra en el análisis cualitativo de los datos, son pocas las mujeres a las que se hace referencia, y además, sus nombres aparecen repetidos en varias partes del corpus textual. Cabe destacar, por último, que en el libro de texto de Geografía no se encontró ninguna mujer célebre.

- Pudimos observar que las editoriales están intentando incorporar la normativa vigente relacionada con la igualdad, pues algunos indicadores muestran un intento, al menos en cuanto a las cifras se refiere, de promover relaciones más igualitarias.

- Existe un alto porcentaje $(50,1 \%)$ de referencias a los personajes en términos de genérico y masculino genérico. En la asignatura de Geografía se alcanza el porcentaje más alto, 76,2\% de uso de dichas formas.

- Excluyendo a los personajes célebres, obtuvimos unos resultados equitativos de personajes que aparecen como sujetos con nombre propio en el texto (216 de cada sexo).

- Los personajes analizados aparecen en contextos diferenciados en función de su sexo: 
- Los varones aparecen en un mayor porcentaje que las mujeres y además desempeñando funciones, actividades u ocupaciones más diversificadas.

- Las características psicosociales que tienen mayor incidencia en el corpus textual están vinculadas a los estereotipos de género masculinos.

- Las mujeres aparecen con menor frecuencia en ámbitos públicos, y los espacios y actividades en los que obtienen porcentajes más altos que los varones están asociados a un rol familiar.

Los resultados obtenidos, tanto en el análisis del texto como en el de las imágenes, evidencian que se continúan trasmitiendo estereotipos sexistas al alumnado a través de esta herramienta didáctica.

\subsection{Los personajes en los contenidos}

En este apartado estudiamos cómo se aborda el tema de la igualdad de género en el contenido de los libros de texto. El análisis se realizó exclusivamente con el programa estadístico ATLAS.ti versión 7.5. con el que se fueron seleccionando citas textuales que, a nuestro parecer, trasmiten tanto los estereotipos y roles sexistas, como la información que contribuye a crear una cultura de igualdad entre los y las adolescentes.

La estructura en la que vamos a presentar la información obtenida del análisis se va organizar en tres sub-apartados. En el primero, analizamos la información contenida en los libros de texto que trasmite una visión sexista y discriminatoria basada en los estereotipos y roles de género tradicionales. En el segundo, mostramos la información que promueve una cultura más igualitaria entre hombres y mujeres. Finalmente, en el tercer sub-apartado, presentamos la información obtenida de manera breve y concisa. 


\subsubsection{Estereotipos sexistas en los textos}

La redacción de los libros de texto muestra una intención de equiparar la presencia de hombres y de mujeres, sin embargo el análisis desarrollado en los apartados anteriores nos muestra que este esfuerzo ha sido insuficiente. Por ello, consideramos oportuno analizar si el lenguaje utilizado realmente contempla una perspectiva de género, o si por el contrario el objetivo de cumplir con las normativas está obligando a las editoriales únicamente a añadir referencias en términos genéricos o masculinos genéricos, sin realmente atender de manera puntual y significativa al asunto de la igualdad.

Otro aspecto que vamos a analizar es si, a través del contenido del texto, las mujeres y los hombres continúan desempeñando papeles y/o funciones que son considerados como propios de un sexo u otro con base en los estereotipos y roles atribuidos socialmente.

Con el análisis de los libros de texto pudimos constatar que se han incorporado medidas para evitar un lenguaje impropio androcéntrico. Se observa un esfuerzo por utilizar un lenguaje políticamente correcto. Es decir, se intenta ser imparcial evitando emplear términos que sean discriminatorios para uno u otro sexo. Esto se ve reflejado en varias cuestiones que hemos planteado en tres puntos que vamos a ir abordando en los próximos párrafos. El primero tiene que ver con incorporar un lenguaje directo, evitando hacer referencia al sexo. Por su parte, el segundo está relacionado con utilizar términos que engloben a ambos sexos. Finalmente, el tercero (y menos utilizado) aborda el empleo del masculino y del femenino para hacer alusión a las personas.

Con relación al primer punto, comprobamos que en los cuatro libros de texto analizados se ha incorporado un lenguaje directo para dirigirse al alumnado, sobre todo en los apartados de actividades y/o ejercicios. Se utiliza, de este modo, la segunda persona en singular o plural. A continuación presentamos algunos ejemplos: 
Hasta ahora, has resuelto diversos problemas haciendo uso de las proporciones. ¿Qué características tienen? Analiza la siguiente situación: [...]

(2:655) (Matemáticas, p. 169)

Elabora en tu cuaderno un cuadro como el siguiente, en el que incluyas los principales problemas que enfrentan las personas involucradas. Fíjate en el ejemplo.

(3:1083) (Geografía, p. 61)

Elijan de común acuerdo tres artículos que les parezcan interesantes y elaboren una paráfrasis de cada uno. Recuerden que parafrasear no es copiar, sino reescribir con sus palabras lo que consideren importante

(4:1517) (Español p. 26)

Realiza la siguiente actividad:

Consigue una lupa y acude al jardín de tu escuela o a un parque de tu localidad.

(5:1537) (Ciencias, p. 17)

En cuanto al segundo punto, el empleo de términos que engloben ambos sexos es común en los libros de texto analizados, los siguientes ejemplos lo constatan:

Para hacer un convivio, varias personas llevaron lo necesario para hacer tortas de jamón; se reunieron 3 paquetes que pesaban $1 / 2 \mathrm{~kg}, 3 / 4 \mathrm{~kg}$ y $1 / 8 \mathrm{~kg}$. ¿Cuánto jamón se reunió?

(2:643) (Matemáticas, p. 58)

En condiciones normales, la temperatura corporal del ser humano es cercana a los 37 ${ }^{\circ} \mathrm{C}$; el cuerpo mantiene cierta temperatura aun cuando el clima sea frío o caluroso. [...]

(2:656) (Matemáticas, p. 204)

En equipos de tres integrantes investiguen las características físicas y el hábitat de dos de los siguientes árboles y plantas: pino, palmera, cacto y ébano.

(3:163) (Geografía, p. 101)

Hace alrededor de 60 mil años, el ser humano comenzó a dispersarse y habitar el mundo al superar obstáculos naturales como cordilleras, pantanos y hielos eternos. Para sobrevivir, recolectaba frutos y semillas, cazaba animales, usaba el fuego y, en general, hacía todo aquello que le permitiera adaptarse al medio geográfico. [...]

(3:229) (Geografía, p. 134)

Esta diversidad se manifiesta en la originalidad y la pluralidad de las identidades que caracterizan los grupos y las sociedades que componen la humanidad.

(4:1518) (Español, p. 136)

Siempre será necesaria la ayuda o guía del docente

(5:1538) (Ciencias, p. 247)

Finalmente el último punto tiene que ver, bien con nombrar a las personas, es decir individualizarlas de manera que aparezcan con nombre propio, bien con 
nombrar en masculino y femenino. Con relación a la primera opción, es en el libro de matemáticas en el que se observa una mayor tendencia a designar con nombre propio a los personajes. No obstante, esta asignación no se realiza desde una perspectiva de género, ya que los enunciados están cargados de estereotipos sexistas, en donde las mujeres realizan actividades relacionadas con roles femeninos (atributos relacionados con la apariencia física, el hogar...) y los hombres con roles masculinos (actividades lúdicas y de ocio, capacidad de trabajo...). A continuación mostramos algunos ejemplos:

En equipo, analicen y resuelvan el siguiente problema: Israel, Eric y Mario salieron de paseo; Mario gastó \$1 500; Israel, \$3450, y Eric, \$2400. Si Israel llevaba \$4600 para el viaje; Eric, $\$ 3200$, y Mario, $\$ 2000$, iel gasto de cada uno fue proporcionalmente igual? Argumenten su respuesta.

(2:104) (Matemáticas, p. 43)

Elizabeth, Delia y Nancy ahorraron $\$ 7200, \$ 4500$ y $\$ 5200$, respectivamente, para comprar ropa de temporada. Delia gastó cuatro quintas partes de lo que ahorró; Nancy, la mitad de su ahorro, y Elizabeth, \$4800. ¿Proporcionalmente, quién gastó más dinero?

(2:112) (Matemáticas, 43)

Martha fue al mercado y compró $1 / 2$ y kg de azúcar $1 / 4$ y de kg de sal. ¿Cuánto pesa la bolsa que contiene los productos? [...]

(2:148) (Matemáticas, p. 56)

No obstante, también encontramos algunos ejemplos que muestran modelos de comportamiento alternativos, aunque en menor medida:

Javier tiene $1 \frac{1}{2} \mathrm{~kg}$ de harina y ocupa $3 / 4 \mathrm{~kg}$ Para hacer tortillas. ¿Cuánta harina le falta para preparar un pastel si se requiere $1 \mathrm{~kg}$ de harina?

(2:171) (Matemáticas, p. 61)

Doña Rosalía tiene una parcela con forma rectangular que quiere delimitar con una barda. Si el largo del terreno es $60 \mathrm{~m}$, ancho $30 \mathrm{~m}$ y desea que la barda tenga $3 \mathrm{~m}$ de altura, independientemente de la base, ¿cuántos metros cuadrados de barda colocará si deja un espacio de $4 \mathrm{~m}$ para un portón?

(2:282) (Matemáticas, p. 110)

En relación con la segunda opción (nombrar en femenino y en masculino), observamos que el libro que más hace referencia en estos términos es el de Ciencias. En los siguientes ejemplos se puede apreciar lo descrito: 
Reúnete con una compañera o un compañero, e investiguen en internet el concepto de vida.

(5:1539) (Ciencias, p. 18)

Con ayuda de tu profesor o profesora relaciona los cambios en el cuerpo de la mujer para el desarrollo de un nuevo ser y los cambios en el cuerpo del hombre para procrear.

(5:1540) (Ciencias, p. 199)

La manera en que se viven los cambios durante la adolescencia tiene gran influencia en la forma en que el ser humano se relaciona con sus padres, amigos, amigas, hermanos y hermanas. En todas estas relaciones se expresan diferentes formas de ser hombre o mujer.

(5:1068) (Ciencias 204)

Con base en el artículo de la actividad anterior, organicen una mesa redonda en la que representen el punto de vista de varios sectores de la población, por ejemplo, madre de familia, científico o científica, campesino o campesina, empresario, maestro o maestra, médico o médica, abogado o abogada.

(5:1390) (Ciencias, p 245)

Con estos ejemplos podemos constatar que el intento de incorporar en los libros de texto un lenguaje no androcéntrico está lejos de convertirse en realidad, pues la implementación de las medidas destinadas a este fin, no se realiza de manera sistemática, sino que en muchos casos es empleado de forma correcta y errónea incluso dentro de un mismo enunciado. A continuación haremos referencia a los usos sexistas del lenguaje que hemos encontrado en los libros analizados.

Por otra parte, también encontramos en los libros analizados lenguaje que muestra sesgos sexistas. El excesivo uso del masculino genérico y del genérico se convierte frecuentemente en un problema, ya que en muchas ocasiones es empleado erróneamente como sustituto de un masculino.

Así pues, con respecto a la utilización del masculino genérico como neutro, podemos encontrar el empleo del término "hombre" para hablar de los varones, y también para nombrar a todos los seres humanos en masculino genérico. Este término desvirtúa la realidad al no nombrar a la otra mitad de la humanidad. Para evitar equívocos sería más oportuno utilizar el término genérico "humanidad", o hacer referencia a hombres y a mujeres. Respecto a esto, en los 
primeros dos ejemplos $(3: 1086$ y $4: 1507)$ se muestra que la palabra "hombre" se refiere únicamente a los varones. Por su parte, en los otros tres ejemplos este término es empleado refiriéndose a la humanidad.

El Gobierno no nos respeta. Nos quita nuestras tierras, en las que vivimos desde hace muchas generaciones antes de la llegada del hombre blanco.

(3:1086) (Geografía, p. 253)

De pronto se abrió un rectángulo de madera oculto bajo la hierba rala del cerro y apareció un hombre que dijo a Rafael [...]

(4:1507) (Español, p. 86)

Muchas personas pensaban que el hombre estaba hecho de materia distinta a la de los animales y las plantas, por lo que decirles que todos estamos hechos de células muy parecidas, para muchos resultaba ofensivo

¿Puede el hombre respirar en el agua?

(5:295) (Ciencias, p. 66)

¿Los insectos tienen pulmones?

(5:833) (Ciencias, p. 64)

Cuando leen artículos o textos sobre un tema en particular, como la vida de los orangutanes, el hombre prehistórico, [...]

(4:314) (Español, p. 70)

Además, encontramos algunos saltos semánticos. Así, aunque la frase se inicia con un masculino genérico, se observa que únicamente se hace alusión a los varones. En los ejemplos que mostramos a continuación el masculino genérico en lugar de englobar a los hombres y a las mujeres integrantes de un poblado, se hace referencia exclusivamente a las tareas y funciones que desarrollan los varones. Como consecuencia de este empleo incorrecto del masculino genérico, las labores que desarrollan las mujeres quedan invisibilizadas.

Los primeros grupos nómadas desarrollaron técnicas colectivas para ser más efectivos en la caza, antes de dedicarse o la domesticación de animales.

(Ciencias, p. 123)

Pero el medio geográfico también influye de varias maneras en el ser humano. Pensemos en grupos que viven cerca del polo Norte, como los inuit, a quienes muchos conocen como esquimales (figura 1.10); ellos se han adaptado a vivir en un medio difícil para la mayoría de las personas; el clima polar los obliga a usar ropa gruesa y pieles de animales para abrigarse, y a conseguir su alimento mediante la caza y la pesca, pues las condiciones naturales impiden el desarrollo de las plantas y, por tanto, la 
actividad agrícola. [cabe destacar que esta información viene reforzada con una imagen en la que aparecen tres pescadores].

(3:1080) (Geografía, p. 17)

También sobresalen los grupos de inmigrantes mexicanos que radican en ciudades ubicadas en el noreste del territorio estadounidense [...] [viene una fotografía como refuerzo donde aparecen únicamente varones].

(3:1090) (Geografía, p. 176)

Con estos ejemplos se refleja cómo las mujeres tienen que de descifrar cuándo y qué de lo que se dice las incluye o las excluye, pues su identidad sexolingüistica no es algo que se muestre de manera explícita y clara en los libros de texto.

En los libros de texto analizados predomina el uso de términos masculinizados con relación a los sujetos y, por lo tanto, se reproduce una visión androcéntrica del mundo. En los párrafos siguientes vamos a analizar cómo tanto las profesiones como las alusiones a los y las adolescentes se realizan habitualmente empleando el masculino genérico.

Abundan las profesiones redactadas en masculino -recogimos más de 250 citas-, invisibilizando la participación laboral de las mujeres. En la figura que se presenta a continuación se puede observar que las profesiones que más se destacan están relacionadas con modelos laborales que implican una cualificación educativa superior.

Figura 8.37. Nube de palabras sobre las profesiones referidas en masculino abogado actor administrador agricultor arquitecto astronauta atteta autor autores bibliotecario biólogo biólogos caballeros campeón campesino capitán cartografo ciclista científiCO cientificos conductores detective dios dioses director doctor dueño dueños emperador empleados empresario encargado enlatadores escritor expertos exploradores fabricantes flechador fray general gobernador gobernante granjero guardia guerrero ingeniero inspector investigador investigadores jardinero jefe locutor luchador maestro maestros marinero marinos matemático mercaderes $\mathrm{MédiCO}$ médicos minero mineros ministro monje músico narrador naturalista nuevo obrero pastor pintor presidente príncipe productores 
Son muy escasas, en cambio, las alusiones a profesiones que se nombran en femenino. En total se analizaron 91 citas. Tal y como podemos observar en la siguiente nube de palabras, las profesiones más nombradas en femenino están relacionadas con los estereotipos de género. Así, la de maestra tiene vinculadas 40 citas y la de profesora 24 , mientras que el resto de alusiones no pasan de tres.

Figura 8.38. Nube de palabras sobre las profesiones referidas en femenino

\section{abogada actriz autora campesina (cientifica diosa diputada directora \\ doctora doncella dueña enfermeras jefa maestra maestras médica modelo periodista profesora secretaria}

Encontramos en este estudio que, para hacer referencia a la interacción dentro del aula entre alumnado y docente, o entre los y las adolescentes, se emplea de manera más recurrente el masculino genérico, sobre todo en los libros de Español y de Matemáticas. En este último libro no se hace ninguna alusión en femenino al alumnado. Por el contrario, en los libros de Ciencias y de Geografía, especialmente en el primero, son pocas las alusiones en términos de masculino genérico para referirse a la población estudiantil. A continuación mostramos algunos ejemplos:

Como resultado del estudio de este bloque temático, se espera que los alumnos:

1. Conozcan las características del sistema de numeración decimal (base, valor de posición, número de símbolos) y [...]

(2:641) (Matemáticas, p. 9)

Como habrás observado, algunas de las divisiones que realizaste no son exactas. Comenta con tus compañeros y con tu profesor la forma en que se manejarán estas situaciones. Anota tu conclusión.

(2:649) (Matemáticas, p. 27)

Juega con tus compañeros, de manera ordenada, a establecer una relación o regla y representarla algebraicamente, conociendo la sucesión numérica. [Esta información es reafirmada con una imagen en la que aparecen únicamente chicos].

(2:649) (Matemáticas, p. 29) 
Resuelve las siguientes situaciones. Comenta con tu profesor y con tus compañeros los procedimientos utilizados y compara, con el fin de verificar, las soluciones obtenidas.

(2:652) (Matemáticas, p. 176)

Para la realización de las actividades permanentes elige cada semana, con tus compañeros de equipo y la guía de tu profesor, alguna de las propuestas que se muestran en los rehiletes.

(4:1508) (Español, p. 20)

Con la guía de tu maestro analiza estos artículos para que comiences a identificar cómo se redactan las normas y anota en tu cuaderno las ideas centrales.

(4:1509) (Español, p. 24)

Tornando como punto de partida los resultados de su entrevista y con ayuda de su maestro, organicen una discusión grupal sobre los derechos y las obligaciones de los estudiantes; $[\ldots]$

(4:1510) (Español, p. 26)

Haz tu borrador y compártelo con un compañero para que se ayuden mutuamente a corregirlos; [...] Muestra tu escrito a tu profesor, coméntale las modificaciones que has hecho y escucha sus observaciones.

(4:1511) (Español, p. 95)

De acuerdo con tu mapa conceptual, comenta con tus compañeros cuáles son las capas atmosféricas más importantes para el ser humano y por qué.

(3:1088) (Geografía, p. 87)

Comenta tus respuestas en clase; reflexiona con tus compañeros y profesor acerca de la relación entre la pobreza y el desempleo en México y las casi siete décadas de emigración de mexicanos hacia EUA.

(3:1093) (Geografía, p. 177)

Comento con un compañero las siguientes preguntas y planteen respuestas en común:

(5:1531) (Ciencias, p. 20)

[...] Puedes consultar con tu profesor de matemáticas para que te explique este tipo de notación $[. .$.

(5:297) (Ciencias, p. 66)

Primero reúnete con aquellos compañeros y compañeras con quienes compartas intereses de investigación. Menciona tres características que buscarías en tus compañeros para decidir formar un equipo de trabajo con ellos.

(5:1533) (Ciencias, p. 72)

En este último ejemplo podemos observar el uso del doble género de forma no sistemática, ya que la alusión a hombres y a mujeres aparece y desaparece del texto de manera arbitraria. 
Pasamos ahora al estudio de los estereotipos de género promovidos por los materiales educativos. Para ello, efectuaremos un análisis del contenido de los manuales. En primer lugar, en lo referido a los contextos y a las situaciones en las que se alude a profesiones masculinas y femeninas, y posteriormente, en lo que respecta a los roles familiares que se atribuyen a hombres y a mujeres en los libros seleccionados. Este análisis nos ha permitido extraer un conjunto de referencias que ilustran la transmisión de roles y estereotipos de género a ambos niveles.

La trasmisión de modelos laborales estereotipados en función del sexo persiste en los textos escolares analizados. En ellos los hombres aparecen en el ámbito laboral o profesional en mayor medida que las mujeres. Ellos ocupan puestos en contextos públicos y desarrollan actividades laborales relacionadas con estereotipos masculinos como la fortaleza, el ingenio, el dinamismo y el prestigio. Además muchas de estas profesiones requieren de estudios superiores. A continuación se muestran algunos ejemplos encontrados en los libros analizados:

Un escritor redacta 3 páginas completas en una hora y trabaja diariamente 6.5horas. ¿Cuántos días requiere para escribir un libro de 702 páginas?

(2:287) (Matemáticas p. 112).

Los cartógrafos y otros científicos crearon una serie de círculos y puntos imaginarios llamados paralelos, meridianos y polos, que envuelven la Tierra como una red y constituyen un sistema de referencia que nos permite localizar con exactitud cualquier punto sobre la superficie terrestre.

(3:49) (p. 32 libro de Geografía)

Actualmente, gracias a la intervención de geógrafos, biólogos, ingenieros civiles y otros profesionales, se ha puesto en práctica un proyecto de recuperación del lago de Texcoco que implica adecuar el lugar para el desarrollo de bosques y pastizales para criar ganado; $[\ldots]$

(3:85) (p. 57 libro de Geografía)

Esto ha obligado a campesinos y pescadores a buscar otras alternativas de subsistencia, como la migración hacia las ciudades.

(3:1085) (p. 150 libro de Geografía)

Los antropólogos sitúan el origen del ser humano en África Central, hace alrededor de 2.5 millones de años.

(3:1087) (p. 250 libro de Geografía) 
[...] Su inefable variedad está expuesta en tiendas, mercados y galerías de arte: barro negro, alfarería, textiles, talabartería, hierro forjado; incluso se pueden adquirir pinturas o litografías de reconocidos artistas oaxaqueños como Francisco Toledo.

(4:1512) (Español, p. 53)

El Presidente, cuyas funciones son principalmente ceremoniales y formales, simboliza la unidad del Estado.

(4:1513) (Español, p. 77)

Los escritores y poetas tratan con amplitud imágenes y hechos locales, así como temas universales y reflejan la variable naturaleza de las inquietudes del país [...]

(4:1514) (Español, p. 79)

Diputados esperan que esta semana sea aprobada la ley que limita áreas para fumar

(4:1515) (Español, p. 145)

Hasta la redacción llegó la noticia de que el popular luchador La Cucaracha, famoso por la musculatura que ha desarrollado gracias al ejercicio y a una dieta especial, muy pronto va a ser padre. [...]

(5:20) (Biología p.15)

Después de las investigaciones de Priestley otros científicos continuaron estudiando sobre el proceso respiratorio en los seres humanos, hasta lograr describirlo.

(5:1534) (Biología p. 145)

Empresario: le interesa que las tierras produzcan una gran cantidad de productos, ya que con ello aumentan sus utilidades.

(5:1534) (Biología p. 244)

El contenido que hace referencia a las mujeres en este epígrafe es prácticamente inexistente. Puede decirse que cuando se habla del campo laboral, las mujeres nuevamente quedan relegadas a cumplir funciones "propias del género femenino". Esto significa que se dedican mayoritariamente a profesiones que tienen que ver con el cuidado y la atención de los otros/as, y a actividades relacionadas con la formación, tal y como muestran los siguientes párrafos:

Para festejar el Día del Niño, la directora del plantel quiere obsequiar siete bolsas de dulces a cada grupo. Cada bolsa tiene 80 piezas. Completa la tabla.

(2:653) (Matemáticas, p. 41)

Una actriz de teatro memoriza 30 líneas de su parlamento en 25 minutos. En esa misma razón, ¿cuánto tiempo necesita para memorizar 240 líneas?

(2:285) (Matemáticas, p. 112)

Marilú trabaja en una fábrica empacando chocolates en cajas que contienen 18 piezas iguales. Su jefa le pide solicitar chocolates suficientes para cumplir con los siguientes pedidos.

(2:653) (Matemáticas, p. 118) 
Mi maestra de Geografía dijo que en Soto hay pobreza porque la mayoría de los habitantes se dedican al campo o a la pesca, que ganan poco dinero y construyen sus casas donde sea y con el material más barato.

La maestra nos dijo que juntas, autoridades y población, deberían hacer simulacros, tener mapas de riesgos, definir rutas de evacuación y, sobre todo, saber cómo actuar en caso de emergencia, pero nunca la toman en cuenta.

(3:1094) (Geografía, p. 183)

Lee la siguiente carta. Después entrevista a una secretaria de la escuela, de la oficina de tus papás o de la oficina de correos, para que te ayude a contestar las preguntas "Para entender mejor."

(4:1139) (Español, p. 244)

Su esposa, la también popular modelo Rubí, luciendo su nueva y respingada nariz, dijo en una entrevista: "Sólo espero que nuestro bebé salga tan fuerte y musculoso como su papá y tan guapo como yo."

(5:20) (Biología p.15)

Maestra — dijo Lucia - mi equipo y yo sabemos ya lo que queremos hacer como proyecto final.

(5:1536) (Biología p. 253)

El análisis del contenido sobre las profesiones en las que aparecen hombres y mujeres muestra claros sesgos de género. Además de ser referidas en muchas menos profesiones que los hombres, se omiten las cualidades que poseen y que han de desarrollar en el mercado laboral. En este sentido, las profesiones en las que se hace alusión a las mujeres no requieren de la misma preparación académica que en las referidas al masculino genérico. Todo ello nos lleva a concluir que el mundo laboral que se muestra en los libros analizados está integrado mayoritariamente por hombres, existe poca promoción de la igualdad en el desarrollo profesional y además para las mujeres hay escasos referentes que requieran cualificación superior.

Por otra parte, constatamos que los libros de texto transmiten información diferenciada en cuanto al rol familiar que han de adoptar hombres y mujeres en la sociedad. Así queda demostrado con los ejemplos que presentamos a continuación:

Tuve que dejar la plática con mi abuelo porque iré con mi padre a la ciudad más poblada de nuestro país. En un par de días me llevará a las luchas en la Arena México. 
Mi papá transporta ganado vacuno a otros estados del país y a Estados Unidos de América.

(3:522) (Geografía, p. 182)

De camino a casa voy escuchando música en el mp3 que me envió mi papá desde Houston cuando cumplí 12 años, pero se le terminó la batería y no tengo con qué entretenerme; sólo me queda mirar por la ventanilla del camión hasta llegar a mi destino. Aunque todos los días uso este transporte, nunca había notado que las calles, las casas, los comercios, los coches e incluso las personas lucen distintos que años atrás. Cuando mi mamá me llevaba a la primaria, no había tanto tránsito; tampoco se llenaba el autobús; no había personas en las esquinas limpiando parabrisas ni vendedores ambulantes. Es como si la ciudad se transformara rápidamente. Además, aunque hay más bancos y centros comerciales, se observa más la pobreza. [...]

(3:659) (Geografía, p. 244)

Al llegar, platico con mi abuelo mientras sirven la comida. Comeremos pozole preparado con carne de puerco de Puebla, maíz de Guerrero y aguacate de Michoacán. Mi abuelita me cuenta de dónde viene todo lo que compra, siempre pregunta su origen porque sólo consume productos mexicanos. ¿Qué rico guisa! Debería darle a mi mamá algunas clases de cocina.

(3:666) (Geografía, p. 244)

Me levanto y lo primero que hago es buscar el nuevo huipil blanco que me hizo mi mamá. Es muy lindo, está adornado con brocados que representan flores, pájaros y otros animales. Después de vestirme, voy a desayunar, mi mamá preparó tamales de jacuane y atole de maíz. Ya extrañaba esta comida; hace mucho tiempo que mi mamá no la preparaba, debe ser porque ahora, además de tejer el ixtle, está muy ocupada ayudando a mi papá a sembrar [...]Desde entonces, todos los días me pregunto qué decisión tomará mi papá y cuántos cambios habría en nuestras vidas si nos fuéramos a la ciudad. Sólo me queda esperar... la decisión no está en mis manos.

(3:1040) (Geografía, p. 306)

En un lugar apartado de la ciudad, Luisa fue feliz, consagrada a su ciega pasión por don Ñuño, y al tierno amor por sus tres hijitos.

(4:279) (Español, 36)

Imagina que acompañas a tu mamá al mercado. Está lleno de alimentos y productos diversos, como los que aparecen en las tablas. Señala de qué reino provienen estos alimentos y productos.

(5:464) (Ciencias, p. 76)

- Mi papá me enseñó desde que era yo pequeño a tener cuidado con las herramientas por eso las mantiene guardadas en una caja. Sólo podemos tomarla con su permiso.

- Cuando hay varias personas en la cocina, mamá prefiere cocinar en las hornillas del fondo de la estufa para que los sartenes u ollas no vayan a caer por accidente y alguien se queme.

-Papá siempre supervisa que los cables; enchufes y conexiones estén en perfecto estado, además, me ha enseñado por qué no debo jugar con ellos.

(5:1467) (Ciencias, p. 253) 
El análisis de esta información evidencia que, si bien se muestra una tendencia a incorporar un lenguaje más incluyente, aún persisten sesgos sexistas que han de ser retirados de los manuales si se pretende cumplir con el objetivo de trasmitir a través de ellos una visión del mundo basada en los principios de igualdad y equidad de género. También constatamos que continúa presente la tendencia a encasillar a hombres y a mujeres en unos roles determinados. En este sentido, los varones encuentran en los libros de texto gran variedad de modelos y conductas a seguir que les dotan de mayor libertad a la hora de decidir sobre su futuro. Así, en el ámbito doméstico, se les atribuyen un rol de proveedores y otras funciones tales como fungir como persona protectora, colaborar en la casa únicamente con el arreglo de desperfectos y trabajar en tareas que requieren el empleo de herramientas.

Por el contrario, las mujeres tienen un abanico mucho más limitado. Asimismo se continúan trasmitiendo pautas de comportamiento asociadas a la dependencia y al ser para otros/as. En el ámbito doméstico sus tareas son más diversificadas: van desde la responsabilidad de atender a los hijos e hijas, hasta hacerse cargo de la organización y alimentación de la familia.

\subsubsection{Promoción de la igualdad/equidad de género}

En este apartado analizaremos los aspectos relacionados con la promoción de una cultura de la igualdad a través de los libros de texto. En este sentido, examinaremos las alusiones que de manera explícita se realizan en los textos respecto a la igualdad y a la discriminación por razón de sexo. Como demostraremos, en los libros cotejados son verdaderamente escasas las referencias encontradas que promuevan la igualdad o la equidad de género, o que al menos critiquen la desigualdad. De hecho, únicamente encontramos alusión a estas cuestiones en los manuales de Ciencias y de Geografía.

La igualdad y la dignidad entre las personas es referida en el libro de Geografía en el bloque I "Espacios geográficos y los mapas", tema tres, en 
donde se reflexiona sobre las desigualdades socioeconómicas y la diversidad cultural. A continuación presentamos la cita textual:

Al considerar el espacio geográfico como un sistema cuyo equilibrio depende de la armonía entre sus componentes, la geografía nos ayuda a reconocer que, con independencia de nuestra nacionalidad, nuestras costumbres y las dimensiones del territorio que habitamos, todas las personas somos igualmente valiosas y dignas de respeto

(3:92) (Geografía, p. 58)

En el material de Ciencias (página 27 párrafo 4), se alude tanto a la participación que ha tenido la mujer en el mundo de la ciencia, como a la poca difusión y reconocimiento que existe respecto a sus aportaciones. Además, se propone una actividad para que el alumnado reflexione sobre el papel que han desempeñado las mujeres en el ámbito de las ciencias. A continuación reproducimos la cita textual:

La participación de las mujeres en la ciencia en el mundo, en las distintas épocas de la historia, también ha sido destacada, pero realmente son pocos los casos en que se reconocen y difunden sus trabajos y aportaciones. En México, por ejemplo, tenemos a una de las más grandes expertas en cactáceas: la doctora Helia Bravo, quien descubrió más de 60 géneros y especies nuevas. Además, en su honor han sido nombradas 9 especies de flora y fauna mexicanas.

(5:81) (Ciencias, p. 27)

En equipos comenten por qué piensan que el papel de las mujeres en las ciencias ha tenido escaso reconocimiento, obtengan una conclusión y expónganla ante el grupo.

(5:84) (Ciencias, p. 27)

En el apartado de reproducción del libro de Ciencias, en el bloque IV que hace referencia a la sexualidad humana, se abordan las temáticas de género, de vínculos afectivos, de erotismo y de reproducción. En este epígrafe se realiza, así mismo, una propuesta didáctica que incluye tanto información básica, como ejercicios para reflexionar sobre la igualdad y la sexualidad.

Con relación a la igualdad de género, antes de iniciar el tema se propone una actividad en la que se solicita al alumnado que reflexione respecto a las diferencias existentes entre hombres y mujeres en diversos ámbitos. Por 
ejemplo en los juegos que realizan, en la vestimenta que utilizan, en la repartición de las tareas en el hogar y en las profesiones que desempeñan.

Respondan en equipo las siguientes preguntas:

¿Cuáles son los juegos que generalmente practican los niños y las niñas?

¿Cómo se visten las niñas y los niños?

¿Cómo se asignan las actividades en el hogar?

Tradicionalmente, ¿quién se ha hecho cargo del cuidado de los hijos?

¿Cuáles profesiones han tenido, casi siempre, los hombres y cuáles las mujeres?

Obtengan sus conclusiones y confróntenlas con los demás equipos.

(5:984) (Ciencias, p. 201)

Posteriormente, en la p. 202 se aborda la temática sobre el género como un componente primordial de la sexualidad. En el texto se le define como "una conformación sociocultural, determinada por la asignación del rol de hombre o mujer, para una sociedad determinada." Se menciona que los estereotipos de género limitan a hombres y a mujeres, al encasillarlos en el cumplimiento de ciertos roles. Finalmente se habla de la importancia de construir normas de convivencia más igualitarias. Cabe destacar que la información que se presenta en el texto es reforzada con dos imágenes que ya han sido analizadas en el apartado 8.1.4. La cita textual la presentamos en los siguientes párrafos:

A través de la sexualidad, el ser humano proyecta la imagen de sí mismo; ésta será la base para interactuar con los demás. En esta proyección de su sexualidad, un elemento fundamental es el género, el cual se va construyendo a lo largo de su vida. A partir de que nace y los padres identifican su sexo, se relacionan con el nuevo ser, asignándole una serie de roles de lo que para ellos y la sociedad es "ser, hombre" o "ser mujer". Así, a los bebés los vestirán de color azul y a las bebés de color rosa, pues son los colores que se consideran "apropiados" para cada sexo. Desde ese momento todas las experiencias, tradiciones y costumbres del nuevo ser, las vivirá de acuerdo con dichos roles. [...]

A lo largo de la historia, la asignación del género ha obligado a las mujeres y a los hombres a actuar de cierta manera, lo que en muchos casos los limita. Por ejemplo, a las mujeres se les ha dicho que deben ser dulces, coquetas, prepararse para la maternidad, aprender a guisar para atender a su marido, etc. A los hombres por el contrario, se les ha educado para ser rudos, con poca posibilidad de demostrar afecto y para mantener económicamente la casa.

Actualmente, se reconoce la importancia de favorecer el desarrollo de las personas sin que sea relevante si son mujeres u hombres. El objetivo es construir normas de 
convivencia que permitan la interacción en igualdad de condiciones y el reconocimiento de la diferencia sexual como un elemento que enriquece esta convivencia.

(5:994) (Ciencias, p. 202)

En la p. 202-203 se proponen nuevamente tareas al alumnado, con el propósito de identificar las diferencias que existen entre las actividades que realizan hombres y mujeres. En uno de los ejercicios se presenta un texto en el que se hace referencia al problema que supone para las adolescentes el hecho de participar junto a hombres en actividades deportivas como el fútbol. A continuación presentamos una fracción del texto:

Lee el siguiente texto

En el patio de la Escuela Secundaria núm. 1, Silvia, le pidió a Javier — quien es capitán del equipo de fútbol, integrado sólo por varones - entrar a formar parte del equipo.

Javier: Mira Silvia, yo sé que tú juegas bien, pero el fútbol que juegan las mujeres no es igual al fútbol que juegan los hombres.

Silvia: ¿En qué es diferente? Seguimos las mismas reglas. Yo sé que puedo jugar muy bien en el equipo.

Javier: Yo me refiero a que los hombres somos más rudos y fuertes. ¿Qué tal si en una jugada te pegamos? Tú no vas a aguantar, nosotros somos más fuertes y te podemos lastimar.

Silvia: Yo he jugado muchas veces con los chavos de mi calle y siempre he metido buenos goles como delantera. Además, tengo la capacidad para jugar fútbol, y creo que si seguimos el reglamento de juego los muchachos no tienen por qué lastimarme. [...]

(5:995) (Ciencias, p. 202)

La siguiente actividad que se les propone es la de reflexionar sobre las experiencias que han tenido como hombres y como mujeres en la realización de labores cotidianas. También se les pregunta si consideran que existen desigualdades en la asignación de tareas y, en caso de haberlas, cómo se podrían solucionar.

Realiza la siguiente actividad:

- En una hoja en blanco escribe una lista de todas las actividades que realizas desde que te levantas hasta que estás listo para dormir.

- Organicen equipos de hombres por un lado y mueres por el otro, y reúnan las actividades que anotaron. 
- Presenten sus listas de actividades en hojas de rotafolio [papelógrafo] y después en grupo contesten las siguientes preguntas:

¿Existen diferencias entre las actividades que realizan las mujeres y las que realizan los hombres? ¿a qué creen que se deba?

¿Qué cosas les gustaría a los hombres que hicieran las mujeres?

¿Qué cosas les gustaría a las mujeres que hicieran los hombres?

¿Consideras que existe inequidad en la asignación de actividades hacia las mujeres y los hombres?, ¿por qué?

¿Qué soluciones proponen a los problemas detectados?

(5:996) (Ciencias, p. 203)

De los libros analizados, únicamente dos, el de geografía y, en mayor medida, el de Ciencias, muestran una tendencia a incorporar elementos relacionados con la igualdad de género, cumpliendo así con la normativa vigente en el país, como constatan las citas mostradas en párrafos anteriores. No obstante, considerando que es un tema trasversal que debe incluirse en la estructura general de los libros de texto, el hecho de que haya elementos con sesgos de género, así como que la promoción de la igualdad se produzca en puntos aislados, demuestran que no se cuenta con un plan estructurado con base en la igualdad.

Por otra parte, en el libro de texto de Ciencias se observa un avance en el tratamiento de la temática sobre sexualidad, al advertirse una sustitución del enfoque meramente biológico/ reproductivo, por otro más integral. En su programa didáctico se incluyen elementos sociales, psicológicos y culturales de la sexualidad, como se veía en párrafos anteriores. No obstante, se continúa presentando al alumnado información que está relacionada con aspectos restrictivos y preventivos.

En este sentido, a la temática de vínculos afectivos solo se le dedica media página, donde se destaca que las relaciones afectivas y de atracción “[...] son fundamentales para el adecuado desarrollo emocional y sexual del ser humano, y las emociones que se derivan de ellas brindan placer, aceptación, bienestar, compañía y apoyo" (Ciencias, p. 204). Por su parte, el erotismo se explica únicamente en un párrafo, en el que se refiere que mediante éste las personas 
podemos experimentar sensaciones de placer, que, además, no solo se limitan a las relaciones sexuales o coitales:

[...] está relacionado con el placer sensual o de los sentidos. De esta manera, la función del erotismo no se limita al placer sexual, sino que también abarca el gusto por la compañía y en el arte.

(5:1541) (Ciencias, p. 204)

La temática de la reproducción es la que tiene mayor peso en el bloque IV. El tema relacionado con la información y la prevención de embarazos e ITS se aborda desde la p. 206 hasta la 215. Aunque se realiza una promoción de la sexualidad de manera "integral" —contemplando elementos sociales, psicológicos y culturales y haciendo referencia a que esta se construye $\mathrm{y}$ aprende a lo largo del ciclo vital—, se continúa primando una información que promueve una sexualidad exclusivamente de orientación heterosexual:

[...] La actividad sexual va desde las caricias, los abrazos y besos, hasta el acto sexual, es decir, la penetración del pene en la vagina.

(5:1109) (Ciencias, p. 206)

Por otro lado, en la información que se presenta al alumnado sobre la prevención y los métodos anticonceptivos, encontramos que se da información errónea o mal planteada, pues de su lectura se interpreta que los métodos de barrera no previenen las ITS. ${ }^{160}$

De barrera y espermicidas. Son aquéllos que impiden el paso de los espermatozoides hacia el útero o matriz, por la acción de un obstáculo físico (condón masculino o femenino, espuma, jalea o gel). Con mucha frecuencia, van acompañados de sustancias que matan a los espermatozoides (espermicidas). La ventaja de estos métodos es que no requieren receta médica y su desventaja consiste en que no previenen ITS y además, su eficacia es irregular.

(5:1220) (Ciencias, p. 213)

Tal y como hemos evidenciado, únicamente los libros de Geografía y de Ciencias abordan está temática.

\footnotetext{
${ }^{160}$ En el siguiente enlace se muestra información del ministerio de sanidad que contradice esta información en la página 52

https://www.msssi.gob.es/ciudadanos/enfLesiones/enfTransmisibles/sida/vigilancia/DocITS2011.pdf
} 
A continuación vamos a hacer referencia a la información que se presenta en los libros de texto respecto a la discriminación por razón de sexo. Así pues, siguiendo con el capítulo dedicado a la sexualidad en el libro de Ciencias, reproducimos unas citas que ponen de manifiesto la situación de vulnerabilidad de las mujeres al embarazarse en edades tempranas:

A lo anteriormente expuesto se suma el hecho de que con frecuencia el embarazo no planificado es una situación que tiene que enfrentar la mujer sola, y es bien sabido que las mujeres embarazadas constituyen un sector de la población desprotegido por la desigualdad de oportunidades.

(5:1190) (Ciencias, p. 211)

El embarazo adolescente no puede entenderse sin tomar en cuenta la estructura social y sobre todo si se piensa que los embarazos de mujeres jóvenes ocurren casi siempre en los sectores más pobres, de más baja escolaridad, lo que repercute en menos oportunidades para ellas y por lo tanto para sus hijos.

(5:1202) (Ciencias, p. 212)

En el bloque III del libro de Geografía, denominado "Dinámica de la población y riesgo", también encontramos información que hace referencia a cómo las mujeres tienen que enfrentarse a situaciones y condiciones de violencia y/o discriminación solo por el hecho de serlo. No obstante, esta problemática es representada como una situación que tiene lugar lejos de nuestras fronteras.

En Emiratos Árabes Unidos y en Qatar hay más de 200 hombres por cada 100 mujeres, debido a que por motivos religiosos ellas son objeto de discriminación y violencia, por eso viven en condiciones de desventaja respecto de los hombres (figura 3.4).

(3:283) (Geografía, p. 142)

En países musulmanes como Qatar mueren más mujeres que hombres por falta de atención médica para ellas en edades tempranas.

(3:292) (Geografía, p. 142)

Con el análisis efectuado en este apartado verificamos la escasa información contenida en los libros acerca de la temática relacionada con la igualdad entre hombres y mujeres. Únicamente en el libro de Ciencias se evidencia una voluntariedad de trasmitir la problemática a la que, como consecuencia de 
seguir los patrones culturales vigentes en nuestra sociedad, se tienen que enfrentar los hombres y en mayor medida las mujeres.

\subsubsection{Resumen}

El análisis del contenido de los libros de texto nos ha permitido constatar algunos puntos que resumiremos a continuación:

- En cuanto al lenguaje, se reflejan inconsistencias en el afán de utilizar un tratamiento equitativo de ambos géneros:

- Uso excesivo de términos genéricos y de masculinos genéricos.

- Uso del doble género de manera no sistemática, donde habitualmente las referencias a ellas aparecen y desaparecen del texto de forma totalmente injustificada.

- En lo referido a los modelos estereotipados de ser hombre y de ser mujer:

- Abundan las profesiones redactadas en masculino.

- Son escasas las alusiones a profesiones que se nombran en femenino y cuando se producen están asociadas al estereotipo en el que se enmarca a las mujeres: maestras, secretarias, enfermeras.

- En el ámbito doméstico, tanto hombres como mujeres desempeñan funciones asociadas a roles tradicionales. En este sentido, los varones aparecen en el texto desarrollando tareas de manutención familiar y su colaboración en las tareas de casa se acota al arreglo de desperfectos y al manejo de herramientas. En cambio, las mujeres aparecen en este ámbito desempeñando tareas más variadas, relacionadas con el cuidado de los/as hijos/as y con las actividades asociadas al mantenimiento del orden en el hogar. 
- Acerca de la promoción de la igualdad/equidad de género, únicamente se encontraron referencias explícitas en los libros de Geografía y de Ciencias.

- Se constata una tendencia a incorporar elementos de igualdad de género para dar cumplimiento a la normativa vigente en el país, principalmente en el libro de Ciencias. Hemos demostrado, no obstante, que tan solo se intenta equiparar la presencia de hombres y mujeres en términos numéricos, ya que no se consigue llevar a cabo un desarrollo integral de los aspectos requeridos para alcanzar una verdadera promoción de la igualdad de género. 



\section{PARTE IV. DEBATIÉNDONOS ENTRE EL SEXISMO Y LA IGUALDAD}





\section{Conclusiones y reflexiones finales}

El presente capítulo lo dividimos en cuatro apartados. En el primero recapitulamos los resultados más relevantes, tomando como hilo conductor las preguntas de investigación y los objetivos específicos formulados al inicio de este estudio. Esto nos permitirá realizar una discusión entre los resultados obtenidos, los de las investigaciones consultadas en la primera parte de este trabajo y los conceptos teóricos relacionados con la igualdad/desigualdad de género y el sexismo.

La constatación de objetivos e hipótesis se desarrolla en el segundo apartado. En el tercero presentamos las aportaciones de la investigación, así como sus posibles limitaciones. Finalmente, sugerimos algunas recomendaciones y posibles líneas de investigación.

\subsection{Discusión}

Las conclusiones que se desprenden de los resultados obtenidos en este estudio pretenden contribuir al debate sobre los desafíos educativos a los que se enfrenta nuestra sociedad. Como se ha referido en el análisis descriptivoexplicativo, el indagar respecto a los estereotipos sexuales y a los roles sociales que continúan presentes, tanto en el alumnado como en los materiales educativos, nos proporciona unas líneas actuación que podrían resultar adecuadas a la hora de reformular los planes y los programas de mejora de la convivencia dentro del contexto educativo $y$, por extensión, de toda la comunidad.

A continuación presentamos de manera concisa los principales hallazgos encontrados en este estudio, tomando como referentes las preguntas de investigación y los objetivos específicos formulados para responderlas.

¿Cuáles son las percepciones que tienen las y los adolescentes que permiten que se legitime la desigualdad entre hombres y mujeres? 
Objetivo E. 1. Describir y explicar si el alumnado del Estado de Michoacán atribuye a varones o a mujeres pautas de comportamiento "propias" de cada sexo.

En consonancia con algunas investigaciones previas consultadas (Amurrio Velez, Larrinaga, Usategui, \& Del Valle, 2012; Colás Bravo \& Villaciervos, 2007; Lameiras \& Rodríguez, 2002; Parga Romero, 2008; Quesada Jiménez \& López, 2011), tras el análisis de los resultados obtenidos pudimos constatar que prevalecen los estereotipos de género tradicionales en las percepciones de las y los adolescentes. Así, en sus discursos tanto ellas como ellos refieren rasgos y pautas de comportamiento asociadas a los roles sociales que se han atribuido históricamente a hombres y a mujeres. En este sentido, aunque las y los adolescentes identifican que tiene lugar una repartición de tareas en función del sexo - a ellos les corresponde sustentar económicamente a la familia y a ellas desempeñar las tareas del hogar-, no consideran que esto genere desigualdad.

Constatamos, también, que los y las estudiantes comienzan a asignar a las mujeres estereotipos históricamente atribuidos a los hombres, como son la realización de actividades profesionales, el consumo de alcohol, y el uso de la violencia - aunque en menor medida que los varones - para acceder al poder. Sin embargo, en ningún momento los y las adolescentes consideran que los chicos estén siendo socializados en formas culturales tradicionalmente consideradas como femeninas. Estos resultados coinciden con los encontrados por Cubillas Rodríguez et al., (2016); García Pérez et al., (2010); Osuna, (2003); y Quesada Jiménez, (2014).

Al ser cuestionados sobre las relaciones afectivo-sexuales, los y las jóvenes reproducen creencias, actitudes, valores y expectativas claramente influenciadas por los estereotipos y roles de género. Predomina el relato de un varón atrevido, conquistador, fuerte, valiente, agresivo y experimentado, sin que se documenten apenas diferencias entre las diversas zonas geográficas analizadas. Mientras, en 
ellas prevalece el discurso de una mujer dependiente, afectiva, pasiva, insegura, ingenua y seductora. Estos resultados se asemejan a los obtenidos en las investigaciones realizadas por Amurrio Velez et al., (2012); Caro Blanco, (2008); Sáez, Valor-Segura, \& Expósito, (2012); Stern, (2007).

El alumnado muestra, a través de sus testimonios, que considera que hombres y mujeres son complementarios. Únicamente da cabida a la heterosexualidad como opción sexual. Dicho pensamiento nos permite asegurar que continúa teniendo una imagen sexista de su realidad, aunque ni siquiera es consciente de ello.

Por otra parte se atribuyen a las mujeres rasgos asociados al sexismo ambivalente, que es el resultante de la unión del sexismo benévolo y del hostil. Pues, como hemos podido constatar en el estudio, por un lado el alumnado idealiza a la mujer que encarna los estereotipos basados en el rol femenino (la que es hacendosa, madre dedicada, extraordinaria cocinera...); y por otro sanciona a las que no cumplen con dichos estereotipos (la mujer que es aprovechada, que no sirve para llevar la casa, que es descuidada...). Estas conclusiones contrastan con las obtenidas en otros estudios llevados a cabo en España como el de Expósito, Moya, y Glick, (1998), en el que si bien también se aprecia la persistencia del sexismo benévolo, no ocurre lo mismo con el hostil, que no aflora en dichos resultados.

Los y las alumnos/as tienen claro el papel que han de jugar en las relaciones afectivas. Las jóvenes deben demostrar integridad, formalidad y respetabilidad, pues estos valores las diferencian del resto de chicas, que son tachadas de "fáciles", "golfas" y/o "llevadas". Por su parte, las cualidades que dan prestigio a los chicos son las que les alejan de la falta de masculinidad (el desparpajo, la experiencia, e incluso la agresividad). Estos estudios coinciden con lo señalado por Amurrio Velez et al., (2012); Ruiz Palomino et al., (2010) y Stern, (2007). 
Por otro lado, a partir de los resultados obtenidos constatamos que las percepciones que tanto las chicas como los chicos manifiestan sobre el sexo opuesto tienen una alta correspondencia con cómo se ven a sí mismos. Nuestros resultados, en este caso, divergen respecto a los obtenidos por Barberá, (2004) y Martínez Sánchez, Navarro, y Yubero, (2009).

Como apuntábamos anteriormente, nuestros resultados también evidencian que el alumnado considera que la igualdad es un hito ya alcanzado (al menos en el contexto educativo). Coincidiendo con lo referido por Amelia Valcárcel en lo que ella denominó "el espejismo de la igualdad", donde señala lo complicado que resulta, si no se cuenta con los conocimientos básicos, identificar las desigualdades, cada vez más sutiles y menos perceptibles, que sufren las mujeres (2013, p. 162). El estudio realizado por Ruiz Palomino et al. (2010) también obtiene resultados similares a los nuestros, pues con su investigación constata que, aunque se observa una actitud discriminatoria en conductas concretas, el alumnado (chicas y chicos) piensa que la igualdad se ha alcanzado.

A este respecto, los y las adolescentes refieren varias situaciones de desigualdad a las que se enfrentan en el contexto educativo. Por ejemplo, las chicas se quejan de que sus compañeros ocupan todas las pistas disponibles para jugar al fútbol y al baloncesto. No les permiten jugar con ellos, e incluso en ocasiones llegan a agredirlas para evitar que usen estos espacios deportivos. Sin embargo, los chicos consideran que esta actitud es normal. Argumentan que las canchas les corresponden a ellos y que las pocas chicas a las que les gusta el deporte deben resignarse y dedicarse "a cosas de chicas", como chismear. Coincidimos en este punto con autoras como Mirta González, (2005) y Subirats y Tomé, (2010) que también hacen referencia a la restricción de espacios en el contexto educativo como una forma de sexismo.

Las y los adolescentes manifiestan que las funciones que desarrollan hombres y mujeres están condicionadas por los roles de género. También refieren que, en 
el ámbito familiar, muchas madres, además de encargarse de todas las tareas domésticas, han comenzado a trabajar fuera de casa. Aprecian, pues, que las mujeres están empezando a desempeñar funciones tradicionalmente asociadas a roles masculinos. A partir de estas informaciones, concluimos que ellas realizan de forma habitual una doble jornada laboral, ya que los hombres no colaboran en el hogar al no llevar a cabo, en ningún momento, tareas relacionadas con los roles femeninos. Nuestros resultados están en consonancia con los obtenidos en la tesis doctoral realizada por Elisabeth Malonda (2014). Esta investigadora encuentra que una mayor aceptación de la organización desigual en el reparto de las tareas domésticas entre mujeres y varones se apoya, indudablemente, en las actitudes sexistas.

Por otra parte, los/las estudiantes manifiestan que disfrutan de diferentes derechos y libertades en función de su sexo. De forma que mientras los varones tienen total autonomía (para salir a divertirse siempre que quieran, para elegir amistades y pareja, e incluso para ponerse a trabajar en lo que ellos decidan, consiguiendo de esta forma independencia económica), las mujeres están controladas por sus familiares, con el fin de salvaguardar "sus virtudes". En consecuencia, ni tienen libertad de horarios, ni pueden relacionarse con quien ellas decidan sin el permiso de sus progenitores. Además, se les obliga a hacerse cargo, junto a sus madres, de las tareas domésticas.

¿Cuáles son las percepciones que tienen las y los adolescentes que permiten que se legitime la desigualdad entre hombres y mujeres?

Objetivo E. 2. Describir y analizar las diferencias en el contenido del discurso sobre la sexualidad y la equidad de género entre el alumnado que vive en zonas urbanas, rurales e indígenas.

En los discursos de las y los adolescentes, principalmente en los argumentos de los chicos de las zonas indígena y rural, se refleja un fuerte arraigo a los estereotipos y roles de género tradicionales. Observamos que la mayoría de las y 
los estudiantes que viven en las zonas urbanas se dedican a tareas académicas y a vivir las relaciones de pareja como un juego que les permite pasarlo bien e ir adquiriendo experiencia y seguridad en las relaciones afectivas. Mientras tanto, la adolescencia en los contextos indígena y rural tiene un significado distinto, pues ellos y ellas en esta etapa empiezan a colaborar con sus familias realizando aportaciones económicas obtenidas de trabajos remunerados, u ocupándose de las labores del hogar. Es decir, empiezan a adquirir mayor responsabilidad como hombres y mujeres. Se toman las relaciones afectivas más en serio y las emprenden con la aspiración de formar una familia. El estudio realizado por Claudio Stern, (2007) evidencia que la adolescencia en sectores marginales es más corta. Menciona que «la "adolescencia" termina entre los 15 y los 16 años» y pone de manifiesto con su investigación que los chicos empiezan a ser más independientes cuando se insertan al mercado laboral, aunque sea de manera intermitente. Su análisis parece coincidir con los resultados obtenidos en nuestro estudio, sin embargo esta analogía ameritaría mayor discusión.

Otra diferencia detectada entre los discursos de los y las adolescentes tiene que ver con las formas de violencia que experimentan. Los de zonas rurales e indígenas refieren sobre todo conflictos entre comunidades — disputas relacionadas con la propiedad del territorio-. Los de las zonas urbanas hablan de violencia escolar, de peleas entre compañeros y de casos de violencia sexual. Las chicas acusan a sus profesores de pedirles imágenes de contenido sexual o incluso sexo, a cambio de aprobarles alguna asignatura.

¿Cuáles son las percepciones que tienen las y los adolescentes que permiten que se legitime la desigualdad entre hombres y mujeres?

Objetivo E. 3. Describir las diferencias entre hombres y mujeres respecto a la percepción sobre educación sexual y equidad de género.

En este punto encontramos escasas diferencias de percepción entre uno y otro sexo. Las chicas muestran actitudes más favorables que los hombres hacia la 
igualdad, al tiempo que identifican situaciones de desigualdad por razón de sexo en los ámbitos familiar y educativo. Nuestros resultados coinciden en este aspecto con los de Cala Carrillo y Mata Benítez, (2005); Cubillas Rodríguez et al., (2016); García Pérez et al., (2010); Mosteiro García y Porto, (2016); Ruiz Palomino et al., (2010).

Por otra parte, en cuanto a la sexualidad encontramos diferencias asociadas a las prioridades o características en las que se fijan los y las adolescentes cuando se sienten atraídos por otra persona. Así pues, ellas dan prioridad a los rasgos psicosociales (que sean buenos, atentos, caballerosos, valientes...), mientras que ellos señalan aspectos más relacionados con características físicas (que sean guapas, delgadas, con buen cuerpo...). Estos resultados reflejan similitudes con los del estudio realizado por Amurrio Velez et al., (2012). En sus resultados, estas autoras relatan que en los inicios del cortejo los chicos dan prioridad a la presencia física, mientras que a las chicas les resulta muy difícil aislar los rasgos físicos de los psicosociales que conforman la personalidad.

Los chicos, cuando hacen referencia a la sexualidad, intentan mostrar dominio y conocimiento llevando la iniciativa, mostrándose atrevidos, sarcásticos y confiados. Las ITS son su principal preocupación relacionada con las prácticas sexuales. Ellas, por su parte, hablan en tono más bajo, se muestran interesadas y sobre todo más preocupadas por evitar consecuencias como el embarazo y otras problemáticas que pueden derivarse del ejercicio de la sexualidad. En este caso encontramos coincidencias con dos estudios. Uno de ellos, es el de Amurrio Velez et al., (2012), donde se evidencia que la sociedad patriarcal y androcéntrica establece sanciones para las chicas y los chicos que se desvían del rol social que les es asignado. Así, los hombres tienen que alardear de su amplia experiencia en las relaciones afectivas, mientras que ellas deben probar su escasa experiencia en el noviazgo. El otro es el desarrollado por Caro Blanco (2008). La autora señala que en las relaciones afectivas las chicas 
jóvenes consideran que han de justificar su deseo sexual mediante una concepción romántica del amor, mientras que ellos lo muestran abiertamente.

En el contexto educativo las chicas perciben actos discriminatorios en función del sexo. Así manifiestan que las adolescentes son víctimas de actos violentos (les levantan la falda, se burlan de sus cuerpos, sufren tocamientos...), tanto por parte de sus profesores como de sus compañeros.

En el ámbito doméstico perciben que sus progenitores son más permisivos a la hora de expresar emociones con las chicas que con los varones. Por el contrario, ellas se quejan de que, como explicábamos ya en objetivos anteriores, los varones tienen mayor autonomía que ellas a la hora de iniciar una relación, al salir y volver a casa, etc.

Con la discusión que hemos presentado damos respuesta a la primera pregunta de investigación $\mathrm{y}$, por tanto, cumplimos con el primer objetivo general establecido, concluyendo que las percepciones y discursos que señalan los y las adolescentes que participaron en esta investigación legitiman la desigualdad entre hombres y mujeres. Se ha constatado que las actitudes sexistas ambivalentes continúan limitando el desarrollo de las potencialidades de chicos y chicas. El sexismo ambivalente está presente en sus discursos y puede desencadenar en la justificación de conductas agresivas, así como aumentar el riesgo de sufrir violencia en el ámbito académico, especialmente en el caso de las chicas, pues se evidencia que el alumnado reproduce estereotipos de género basados en los modelos masculinidad (dominio, autoridad, dinamismo...) y feminidad (dependencia, sumisión, docilidad...) tradicionales, que en el futuro pueden desembocar en roles de agresor y víctima.

A continuación presentamos la discusión respecto al segundo interrogante.

¿La educación secundaria en el Estado promueve la igualdad de oportunidades, derechos, recursos... entre hombres y mujeres a través de los libros de texto?

Objetivo E. 4. Describir las diferencias entre hombres y mujeres respecto a la 
percepción sobre educación sexual y equidad de género.

Observamos que continúa prevaleciendo una imagen masculinizada del mundo. De los 2285 personajes codificados, 1465 corresponden a hombres, suponiendo un $64,1 \%$, mientras que únicamente 820 representan a mujeres, el $35,9 \%$ del total. Este porcentaje referido a las mujeres es equiparable a los obtenidos en los estudios de I.M.O.P. encuestas (2000) $(33,8 \%)$ y Pellejero (37,2\%). Sin embargo se aleja de los de Garreta y Carreaga (25\%), López Navajas (12\%) y Blanco (23\%).

En cuanto al estudio de las imágenes, en las que se analizaron un total de 395 personajes, el resultado arrojó un porcentaje de hombres del 56,2\% frente al $43,8 \%$ de mujeres. Aun cuando sigue habiendo diferencias a favor de los varones, son más estrechas que las obtenidas en los estudios de Luengo 2003, con un 32,95\%, Terrón Caro, con un 35,6\% y Ritter, con un 39,53\%.

Por su parte, y en lo referido al texto, se muestra también un predominio de las denominaciones de varones, con un $65,7 \%$, frente a las de mujeres que tan solo alcanzan el 34,3\%. Estas cifras resultan prácticamente coincidentes con las de I.M.O.P. encuestas (2000), en el nivel de secundaria, donde los hombres obtienen un resultado del $66 \%$.

Los resultados cualitativos reflejan que son escasas las alusiones a profesiones que se nombran en femenino y que, cuando se producen, están asociadas al estereotipo en el que se enmarca a las mujeres: maestras, secretarias, enfermeras.... Estos resultados coinciden con los arrojados hace más de veinte años por el estudio que realizó Gabriela Delgado (1994) con libros de primaria.

En el ámbito doméstico, tanto hombres como mujeres desempeñan funciones asociadas a roles tradicionales. En este sentido, los varones aparecen en el texto desarrollando tareas de manutención familiar como cabeza de familia, y su 
colaboración en las tareas de casa se acota al arreglo de desperfectos y al manejo de herramientas. En cambio, las mujeres aparecen en este ámbito desempeñando tareas más variadas, que van desde la organización hasta el cuidado de los integrantes de la familia en el hogar. Los estudios que obtienen resultados en esta misma línea son los desarrollados por Blanco (s/f); Garreta y Careaga (1987); Gómez-Carrasco y Gallego-Herrera (2016); SEP \& PUEG (2001).

¿La educación secundaria en el Estado promueve la igualdad de oportunidades, derechos, recursos... entre hombres y mujeres a través de los libros de texto?

Objetivo E. 5. Comparar el papel y la relevancia que se da a los hombres y a las mujeres en los materiales.

Con relación a la aparición en los libros de texto de los personajes célebres o representativos, codificamos 528 alusiones. En el apartado de imágenes es en el que mayor diferencia encontramos entre uno y otro sexo, puesto que de los 29 personajes célebres, 27 son varones. Las otras 499 alusiones están citadas en el texto. Aquí las mujeres únicamente representan el 9,2\% del total. Son, entonces, pocas las referencias a mujeres representativas en los materiales. Además ellas son representadas mayoritariamente en el ámbito artístico y literario, mientras que ellos predominan en los ámbitos científico y político. Nuestros resultados, de nuevo, coinciden con los de I.M.O.P. encuestas (2000), que registran una representación del 7\% de las mujeres en sus resultados referidos a la secundaria.

El análisis cualitativo de los datos constata que en los libros de texto analizados se recogen escasamente las aportaciones y contribuciones que han realizado las mujeres a la sociedad. A través de nubes de palabras logramos conocer quiénes son y las razones por las que son nombradas. Los resultados evidencian que únicamente en el libro de texto de Ciencias, se hace alusión a las razones por las cuales las mujeres no han podido estar presentes en ciertos ámbitos de actividad. El estudio elaborado por Blanco (2000) arroja resultados 
que se corresponden con los nuestros, en la medida en que se pone en evidencia que, en los libros de texto, la participación de la mujer en el desarrollo social, cultural, económico... es invisibilizada y además no se explica esta circunstancia.

¿La educación secundaria en el Estado promueve la igualdad de oportunidades, derechos, recursos... entre hombres y mujeres a través de los libros de texto?

Objetivo E. 6. Analizar las conductas y las actividades que desempeñan hombres y mujeres en los libros de texto.

Los resultados obtenidos en el análisis sobre las conductas y las actividades que realizan los personajes en los libros de texto, evidenciaron que prevalecen estereotipos socioculturales atribuidos a uno y otro sexo.

En este sentido, las características psicosociales que tienen mayor incidencia en el corpus visual y textual están más vinculadas a los estereotipos masculinos de la personalidad (las conductas que denotan actividad/dinamismo representan el $71 \%$ en las imágenes y el $81 \%$ en el texto). En el corpus visual pudimos constatar que a los varones se les representa con características relacionadas con el estereotipo masculino (proveedor, cabeza de familia, intelectual...), mientras que las mujeres aparecen en los libros de texto con rasgos de personalidad tanto femeninos (tímida, maternal, afectiva, preocupada por su físico...) como masculinos (trabajadora, dinámica, deportista...).

Los resultados del análisis del texto son similares a los encontrados en las imágenes. Así pues, se evidencia que tanto en las imágenes como en el texto aparecen características psicosociales compartidas por ambos sexos. No obstante son ellas a quienes se les empieza a asociar a estereotipos sexuales y roles sociales que históricamente habían sido considerados como masculinos, mientras que los estereotipos considerados como femeninos (afectividad, hacendosa, maternal) son representados exclusivamente por personajes 
asociados a mujeres. Las investigaciones consultadas que muestran consonancia con nuestros resultados son las de Blanco, (2000, 2003); Delgado Ballesteros, (1994); I.M.O.P. Encuestas, (2000); Luengo González y Blázquez Entonado, (2004) y Subirats, (1993).

Los resultados de nuestra investigación nos permitieron constatar que no solo hay diferencias numéricas entre hombres y mujeres, sino que además desempeñan actividades en contextos diferenciados en función de su sexo. Con relación a las imágenes, los hombres aparecen con mayor frecuencia en ámbitos públicos y realizando actividades y ocupaciones más diversificadas (32 en total). En cambio, las apariciones de las mujeres son predominantes en el ámbito privado y su abanico de actividades está más restringido (17 profesiones). Por otra parte, en lo que al texto se refiere, obtenemos unas conclusiones que siguen esta misma línea. Los varones aparecen desarrollando 141 profesiones distintas, mientras que las de las mujeres quedan limitadas a 45 . Tal y como sucedía con las imágenes, el porcentaje más elevado con relación al ámbito de ocupación para las mujeres es el doméstico con un 49,1\%. Mientras tanto, para los varones los ámbitos predominantes son los relacionados con profesiones de prestigio social (político, religioso, militar y técnico profesional), con porcentajes en todas ellos superiores al $40 \%$.

Los resultados sobre los modelos femeninos transmitidos en los libros de texto que hemos obtenido están en consonancia con lo referido por Bosch y Ferrer (2003, p. 141), "serán consideradas como naturalmente destinadas a la vida privada, a la maternidad y al cuidado de la familia, y poco interesadas por cualquier otra actividad, especialmente aquellas vinculadas al ámbito público". Además, Blanco también obtiene resultados similares, puesto que en su estudio se contabilizan más de 300 profesiones, de las cuales solo 94 aparecen asociadas a las mujeres. Otros estudios que han obtenido resultados similares son los 
siguientes: Ladrón De Guevara, (2009); Llorent-Bedmar y Cobano-Delgado, (2014); Peñalver, (2003); Ritter, Luján, Monti, y Nieto, (2011).

Con el análisis cualitativo de los datos pudimos constatar que continúan persistiendo estereotipos de género tradicionales, no obstante también encontramos información visual y textual que promueve modelos alternativos que guardan más relación con los cambios acaecidos en la sociedad. Es decir, que muestran una imagen del mundo en donde hombres y mujeres desempeñan tareas y actividades sin prejuicios sexistas. En el estudio realizado por Luengo González y Blázquez Entonado, (2004) también se hace referencia, aunque solamente en el recurso iconográfico presente en los libros de texto, a la incorporación de imágenes que ofrecen un contra estereotipo. Otro estudio que encuentra resultados en la misma línea que el nuestro, es la tesis de maestría realizada por Ladrón De Guevara, (2009), en la que se constatan avances relacionados con la inclusión de mujeres desempeñando actividades tradicionalmente consideradas como propias de varones.

Tras la discusión hemos dado cumplimiento al objetivo general número dos, al haber resuelto la segunda pregunta de investigación.

El Estado intenta, legislando al respecto, que los materiales didácticos fomenten la igualdad de género. No obstante, los avances son insuficientes como consecuencia de la falta de consistencia de las medidas adoptadas. Los libros de texto promueven y trasmiten ideas, creencias y valores cargados tanto de estereotipos sexuales (los hombres son fuertes, valientes, proveedores...; y las mujeres son maternales, afectivas, hacendosas...) como de roles sociales (los hombres son productivos, protectores...; y las mujeres son amas de casa, madres...).

\subsection{Constatación de hipótesis}

Hasta este momento se han discutido los resultados más importantes del presente estudio siguiendo las preguntas de investigación y los objetivos 
específicos. Tal y como habíamos mencionado en el capítulo 5 de cada objetivo específico se derivó una hipótesis. A continuación verificaremos si dichas hipótesis se cumplen o no y si lo hacen total o parcialmente. Además expondremos las conclusiones derivadas de tal circunstancia.

En este apartado únicamente se exponen las posibles razones por las que algunas hipótesis se rechazan o se aceptan de forma parcial o completa. Esto es importante si se toma en cuenta que las hipótesis se plantearon en consonancia con los resultados de investigaciones consultadas en la primera fase de esta investigación. La constatación de hipótesis la presentaremos a través de tablas, con la finalidad de mostrar de manera esquemática las conclusiones a las que hemos llegado con el desarrollo de este trabajo.

\section{Tabla 9.1. Conclusiones en función de las hipótesis}

Objetivo 1 Describir y explicar si el alumnado del Estado de Michoacán atribuye a varones o a mujeres pautas de comportamiento "propias" de cada sexo. Hipótesis 1 El alumnado reconoce situaciones que legitiman la desigualdad entre hombres y mujeres.

Esta hipótesis es aceptada parcialmente, pues se constata que, aun cuando el alumnado manifiesta que la igualdad entre hombres y mujeres se ha alcanzado, en sus discursos (sobre todo en los de las mujeres), cuestiona situaciones de desigualdad a las que se ve sometido en su día a día.

- Prevalecen estereotipos y roles sociales tradicionales en las personas, asociados a las funciones, cualidades y características que han de tener hombres y mujeres.

Conclusiones

- Se comienzan a atribuir rasgos comportamentales masculinos como el dinamismo y la capacidad de realizar trabajos remunerados a las mujeres. Sin embargo, todavía no se asocia a los hombres con roles considerados tradicionalmente femeninos.

- El sexismo ambivalente en los discursos de los y las adolescentes puede desencadenar en situaciones de violencia, pues se justifica como natural/biológico que los hombres sean violentos, autoritarios y dominadores. Por el contrario se considera que las mujeres son afectivas, pasivas y dependientes por naturaleza. 
Describir las percepciones del alumnado teniendo en cuenta el contexto donde se encuentra el centro educativo: zona urbana, rural e indígena.

\begin{tabular}{ll}
\hline Hipótesis 2 & $\begin{array}{l}\text { La población juvenil del contexto urbano percibe que } \\
\text { existen relaciones más equitativas entre hombres y } \\
\text { mujeres. }\end{array}$ \\
\hline $\begin{array}{l}\text { La hipótesis 2 es igualmente aceptada parcialmente. } \\
\text { - En este sentido, los discursos que proporcionaron } \\
\text { los y las adolescentes de las zonas urbanas no hacen } \\
\text { referencia explícita a relaciones equitativas entre } \\
\text { homblusiones y mujeres. No obstante, en sus } \\
\text { intervenciones aparecen en menor medida } \\
\text { argumentos en los que las actividades realizadas en } \\
\text { el ámbito académico o familiar están tan marcados } \\
\text { por los estereotipos y roles de género tradicionales } \\
\text { como lo están en la zona indígena y rural. }\end{array}$ \\
\hline
\end{tabular}

Objetivo 3 Describir las diferencias entre hombres y mujeres respecto a la percepción sobre educación sexual y equidad de género.

Hipótesis 3 El sexo del alumnado determina la percepción sobre sexualidad y equidad de género.

Esta hipótesis es totalmente aceptada, dado que hemos podido constatar que el sexo del alumnado determina su percepción sobre sexualidad y equidad de género.

- Concluimos en cuanto a la sexualidad, que hombres y mujeres asumen roles basados en estereotipos de género. Ellas se ven obligas a enmascarar sus deseos y fantasías sexuales en aras de no ser sancionadas por las personas de su entorno, mientras que ellos han de alardear de su potencia viril para alejarse de aquello que les resta valor - la homosexualidad-.

- Existe una doble moral sexual manifestada por el alumnado en sus discursos, que hace que las mujeres

Conclusiones preserven su virginidad para no ser sancionadas socialmente, mientras los varones hacen todo lo contrario para evitar ser criticados. Todo esto puede derivar en situaciones de riesgo, tanto para las mujeres como para los hombres. A ellas las encamina a emprender relaciones de pareja estables cuando todavía son demasiado jóvenes, que en muchas ocasiones provocan embarazos no deseados y relaciones de dependencia del varón, al abandonar prematuramente sus estudios. A ellos los empuja a consumir drogas y alcohol, que les ayudan a desinhibirse a la hora de tratar con las chicas con el fin de conseguir relaciones con ellas. Por otra parte, la presión de sus amigos les hace mantener 
relaciones sexuales de riesgo, con tal de preservar su hombría, en las que pueden contraer ITS.

- Por otra parte, en cuanto a la equidad, concluimos que las adolescentes tienen una actitud más crítica y reflexiva hacia la igualdad/desigualdad de género.

Objetivo 4 Describir y examinar la presencia/ausencia de mujeres y hombres en los libros de texto.

Existe mayor representación de hombres que de Hipótesis 4 mujeres en los libros de texto de primer grado de secundaria.

La hipótesis 4 es aceptada.

- Concluimos que los libros de texto analizados no solo no reflejan la realidad social, al continuar mostrando a través de las imágenes, el texto y el contenido distintos espacios (público y privado) en

Conclusiones función del sexo, sino que continúan trasmitiendo modelos hegemónicos donde el referente universal continúa siendo representado por lo masculino.

- Los resultados también demuestran que prevalecen modelos que favorecen, fomentan y/o justifican la desigualdad entre hombres y mujeres.

Objetivo 5 Comparar el papel y la relevancia que se da a los hombres y a las mujeres en los materiales.

Hipótesis 5

En los manuales los hombres aparecen desempeñando papeles más representativos que las mujeres.

La hipótesis 5 es aceptada.

- Las aportaciones de personajes representativos están monopolizadas por hombres, lo que permite concluir que existe una invisibilización/ocultación de las contribuciones que las mujeres han realizado al mundo de la ciencia, de la política, de la economía y

Conclusiones de la sociedad.

- Por tanto, consideramos que a través de los manuales analizados se trasmite de manera inconsciente violencia simbólica, al ocultar las aportaciones que han realizado las mujeres a la humanidad. Además, al no aportar información que justifique las razones por las cuales no han estado presentes, se naturaliza algo que fue impuesto.

Objetivo 6 Analizar las conductas y las actividades que desempeñan hombres y mujeres en los libros de texto. 
Los libros de texto no rompen con los estereotipos de Hipótesis 6 género tradicionalmente asignados a hombres y a mujeres.

Esta hipótesis es aceptada de manera parcial.

- Se constata que, aun cuando predominan los estereotipos y roles de género tradicionales, hay un intento por dar cumplimiento a la normativa en materia de igualdad. Esto queda reflejado en la incorporación de modelos alternativos en la información tanto visual como textual, especialmente en el libro de Ciencias.

- Concluimos que la representación psicosocial de hombres y mujeres se establece en función de los estereotipos socioculturales atribuidos a uno y otro sexo. Por un lado, las conductas y actividades de los varones están relacionadas con el ámbito laboral, deportivo, de juego y de ocio. En cambio, las mujeres, aparecen mayoritariamente destinadas a la vida privada, a la maternidad y al cuidado de la familia, y poco representadas en ocupaciones vinculadas al ámbito público.

- Los resultados reflejan que existen pocos modelos alternativos, sobre todo en cuanto al recurso iconográfico, en los que las y los adolescentes puedan encontrar opciones de convivencia más igualitarias.

- En las imágenes, el texto y el contenido analizados, es exigua la información que promueva una mayor corresponsabilidad de todos los miembros de la familia en las tareas domésticas.

- Además, en los textos analizados se favorece un modelo de pareja y de familia que ya no se corresponde con la realidad. Es decir, se promueven únicamente las relaciones de pareja heterosexuales y los modelos de familia conservadora, excluyendo a las personas que optan por otros estilos $y$ orientaciones sexuales.

- El esfuerzo que realizan las editoriales para cumplir con la normativa fijada en los planes y programas nacionales sobre igualdad de género, es insuficiente. 
- Concluimos, por tanto, que la información que se trasmite en los libros de texto en materia de igualdad de género está caracterizada por ser inconsecuente y carente de una estrategia bien definida. Dicha circunstancia queda en evidencia en multitud de descuidos que hacen que el alumnado reciba información contradictoria.

En este trabajo hemos constatado transformaciones sociales, como la ampliación de los derechos de las mujeres, impulsadas por los movimientos feministas y las políticas de igualdad que, aunque han conseguido mejorar la realidad de hombres y mujeres en el plano social, no han podido acabar con algunos elementos que perpetúan las desigualdades por razón de sexo. En el ámbito educativo, pudimos observar tímidos avances asociados a la promoción de relaciones más igualitarias entre hombres y mujeres. Este estudio pone en evidencia que, tanto en las percepciones de los y las adolescentes como en el análisis de los libros de texto, pervive un correlato en el que las relaciones se organizan de manera diferenciada y jerarquizada. Desigualdad que se justifica a partir de la diferencia sexual, limitando enormemente el desarrollo de las potencialidades de las personas y entorpeciendo las redes de convivencia basadas en la igualdad, la dignidad y la justicia social.

\subsection{Fortalezas y debilidades del estudio}

La investigación que aquí presentamos constituye, a nuestro parecer, un marco de referencia puesto que, como vimos en el apartado teórico, son escasos los estudios desarrollados en México en materia de género y educación. Así pues, en los siguientes puntos sintetizamos las aportaciones que se derivan de este estudio.

- Consideramos que tanto el análisis de los estereotipos de género en el alumnado, como el estudio del sexismo en los libros de texto, aportan información valiosa sobre la pervivencia de una imagen distorsionada, 
apoyada por un sistema androcéntrico, con la que se promueven valores y creencias sexistas.

- Estas dos líneas de investigación (percepciones sobre estereotipos de género y análisis del sexismo en los materiales) nos permiten tener un panorama general respecto a los presupuestos ideológicos latentes que favorecen la legitimación de desigualdades entre hombres y mujeres. Se considera que conocer y señalar estas diferencias y su significado, es el paso inicial e imprescindible para abordar una reflexión crítica que concluya en acciones sistemáticas dirigidas a conseguir una sociedad más justa.

- Pensamos que la información derivada de este estudio constata la necesidad de incorporar un análisis crítico de los estereotipos de género presentes en todos los manuales educativos de educación secundaria.

- Por otro lado, creemos que el abordaje metodológico (cualitativo y cuantitativo) por el que hemos optado, nos ha permitido enriquecer la descripción y explicación del sexismo presente tanto en las percepciones del alumnado como en el contenido (imágenes, texto y contenido) de los libros de texto.

- Contribuimos, también, con esta tesis doctoral al debate y a la reflexión sobre las desigualdades por razón de sexo presentes tanto en el contexto escolar como en el ámbito familiar.

- Finalmente, pensamos que la información que se deriva de este análisis puede resultar relevante para los/as interesados/as en desarrollar planes y programas en materia de políticas educativas tendientes a incluir en sus iniciativas un modelo basado en la igualdad entre hombres y mujeres. 
Consideramos oportuno mencionar algunas limitaciones observadas tras el desarrollo de esta investigación.

En primer lugar citamos las relacionadas con los grupos de discusión:

- Esta herramienta, aun cuando nos parece oportuna para describir y explicar los estereotipos y roles de género, puede complementarse con estrategias cuantitativas (inventarios ya validados) para reforzar los discursos proporcionados por el alumnado.

- Limitación en la conformación de los grupos de discusión, que fueron mixtos. Esta circunstancia pudo cohibir los discursos de unos y otras sobre los temas estudiados.

- Limitación en el tamaño de la muestra. Hubiese sido mejor ampliarla con el propósito de que fuese representativa de la población, lo que permitiría generalizar los datos a todo el Estado.

- Finalmente, pensamos que hubiese sido más enriquecedor filmar las sesiones con una videocámara en lugar de hacerlo con una grabadora de voz.

En segundo lugar exponemos las limitaciones que observamos con la técnica de recogida de información vinculada a los libros de texto:

- Limitación en el tamaño de la muestra. Consideramos oportuno analizar todos los libros de texto de secundaria que han sido autorizados por la Secretaria de Educación Pública, con la finalidad de que el/la docente tenga información sobre los materiales escolares que promueven relaciones más equitativas entre hombres y mujeres, y los que, en cambio, incumplen este aspecto. 
- Limitación administrativa. Resultó complejo que las escuelas secundarias nos proporcionaran los libros de texto, pues, al ser un material que eligen los/as docentes, no todas las escuelas secundarias trabajan con los mismo materiales.

\subsection{Recomendaciones y futuras líneas de investigación.}

Consideramos que la educación es una de las vías más oportunas para lograr la igualdad real entre hombres y mujeres. En este sentido y tras la realización de esta investigación, nos parece oportuno enunciar algunas propuestas con la finalidad de proporcionar unas directrices que puedan contribuir a la transformación de los contextos escolares mixtos en espacios tendientes a la coeducación en donde se promuevan relaciones libres de estereotipos y de discriminación por razón de sexo.

- Se vuelve necesario que las escuelas desarrollen programas de intervención en los que se implique a las familias. Es decir, que se creen proyectos y talleres formativos tendientes a promover relaciones de corresponsabilidad familiar.

- Fomentar prácticas coeducativas en las escuelas públicas, con las que se comiencen a valorar y priorizar los estereotipos positivos para mejorar la convivencia humana. Es decir, dotar de valor todos aquellos principios que estén relacionados con los afectos y los cuidados, y desechar aquellos que suponen un peligro para el desarrollo de la sociedad, como por ejemplo la agresividad y el autoritarismo.

- Fomentar en el alumnado actitudes más colaborativas en la resolución de conflictos y/o tareas.

- Promover a través de los materiales didácticos relaciones más equitativas y respetuosas con las diferencias, sean estás de tipo sexual, étnico, económico, etc. 
Antes de dar por finalizado este trabajo vamos a exponer algunas de las líneas de investigación que a nuestro juicio pueden desarrollarse en un futuro próximo:

- Resultaría interesante realizar una investigación en la que participaran todas las personas involucradas en el proceso educativo, desde los responsables de las instituciones públicas, pasando directivos y docentes, hasta el alumnado. De esta forma se podrían poner en marcha acciones conjuntas que acabaran con el problema del sexismo en la educación.

- Hacer una investigación de los procesos que se llevan a cabo en las editoriales a la hora de generar los materiales educativos, con la que podamos poner de manifiesto en qué puntos se cometen los errores que hacen que los libros de texto sigan transmitiendo modelos alejados de la igualdad de género.

Comparación de los libros de texto estudiados en este trabajo con los de los países más avanzados en materia de igualdad, con la finalidad de identificar las estrategias que promocionan las relaciones equitativas entre hombres y mujeres, y su posterior traslado a las editoriales para la redacción de materiales de calidad.

\section{Reflexões e conclusões}

Este capítulo está dividido em quatro partes. Na primeira recapitulamos os resultados mais relevantes, tendo em conta as questões de investigação e os objetivos específicos fixados no início deste estudo. Isto permitir-nos-á construir uma discussão entre os resultados, as investigações efetuadas na primeira parte deste trabalho e conceitos teóricos relacionados com a igualdade/ desigualdade de género e o sexismo.

A constatação dos objetivos e hipóteses é desenvolvida na segunda parte. $\mathrm{Na}$ terceira, apresentamos as contribuições desta investigação e as suas potenciais 
limitações. Finalmente, sugerimos algumas recomendações e possíveis futuras linhas de investigação.

\subsection{Discussão}

As conclusões extraídas dos resultados obtidos neste estudo pretendem contribuir para o debate sobre os novos desafios educativos. Tal como referido na análise descritiva e explicativa, o facto de investigar sobre os estereótipos sexuais e papéis sociais que ainda estão presentes, tanto nos alunos como nos materiais educativos, fornece linhas de ação que podem ser empregadas quando se desenham e implementam planos e programas destinados a melhorar a convivência dentro do contexto educativo e, por conseguinte, de toda a comunidade.

A seguir apresentamos as principais conclusões deste estudo, tendo como referência as questões de investigação e os objetivos específicos estabelecidos para as responder.

Quais são as perceções dos adolescentes que permitem que a desigualdade entre homens e mulheres seja legitimada?

Objetivo E. 1. Descrever e explicar se os estudantes do Estado de Michoacán atribuem aos homens ou às mulheres padrões comportamentais "próprios" de cada sexo.

De acordo com algumas investigações consultadas (Amurrio Velez, Larrinaga, Usategui, e Del Valle, 2012, Colas Bravo \& Villaciervos, de 2007; Lameiras \& Rodriguez, 2002; Parga Romero, 2008; Quesada Jiménez \& Lopez, 2011) e após a análise dos resultados, descobrimos que prevalecem estereótipos tradicionais de género nas perceções dos adolescentes. Assim, nos seus discursos, quer elas quer eles, referem traços e padrões de comportamento associados a papéis sociais que foram historicamente atribuídos a homens e mulheres. Neste sentido, e apesar dos adolescentes identificarem que existe uma divisão do trabalho em função do sexo - a eles compete-lhes apoiar 
financeiramente a família e a elas desempenhar as funções de casa -não consideram que este facto possa gerar desigualdade.

Constatamos, também, que os alunos começam a atribuir às mulheres estereótipos historicamente atribuídos aos homens, tais como a realização de atividades profissionais, consumo de álcool e o uso da violência - ainda que em menor medida que os homens - para aceder ao poder. No entanto, os adolescentes não acreditam que os rapazes estejam a ser socializados em formas culturais tradicionalmente consideradas como femininas. Estes resultados estão de acordo com aqueles encontrados por Cubillas Rodriguez et ai, (2016) .; García Pérez et al, (2010) .; Osuna, (2003); Quesada Jiménez, (2014).

Quando questionados sobre as relações afetivo-sexuais, os jovens reproduzem crenças, atitudes, valores e expetativas claramente influenciadas por estereótipos e papéis de género. Predomina o relato de um homem ousado, conquistador, forte, corajoso, agressivo e experiente, sem diferenças entre as diferentes áreas geográficas analisadas. Enquanto isso, no discurso delas prevalece a mulher dependente, emocional, passiva, insegura, ingénua e sedutora. Estes resultados apresentam semelhanças com as investigações desenvolvidas por Amurrio Velez et ai, (2012); Caro Blanco, (2008); Sáez, valor-Segura, \& Exposito (2012); Stern, (2007).

Os alunos mostram, através dos seus testemunhos, que acreditam que homens e mulheres se complementam. Apenas identificam a heterossexualidade como orientação sexual. Tal pensamento permite-nos concluir que continuam a ter uma imagem machista da sua realidade, apesar de não terem consciência disso.

Além disso, são atribuídos às mulheres traços associados com o sexismo ambivalente, que é o resultado da união do sexismo benigno e do hostil. Pois, como constatamos no estudo, por um lado os alunos idealizam a mulher que encarna os estereótipos próprios do papel feminino (trabalhadora mãe dedicada, extraordinária cozinheira...); e por outro penalizam as mulheres que não 
cumprem esses estereótipos (a mulher que é oportunista, que não serve para tomar conta da casa, que é descuidada).

Estes resultados contrastam com os obtidos noutros estudos conduzidos em Espanha, como os de Expósito, Moya e Glick (1998), que, apesar de também mostrarem a persistência do sexismo benevolente, o mesmo não acontece com o hostil, que não surge nos seus resultados.

Os/as alunos/as são claros sobre o papel que têm a desempenhar nas relações. As mulheres jovens devem demonstrar integridade, confiabilidade e respeitabilidade, uma vez que estes valores irão diferenciá-las das "outras", que são rotuladas como "simples", "vagabundas" e/ou "fáceis". Por sua vez, as qualidades que dão prestígio aos jovens rapazes são as que os afastam da falta de masculinidade (o atrevimento, a experiência, e até mesmo a agressividade). Estes estudos coincidem com os de Amurrio Velez et al., (2012); Ruiz Palomino et al., (2010) e Stern, (2007).

Por outro lado, a partir dos resultados vemos que as perceções que manifestam, tanto elas como eles, sobre o sexo oposto têm uma alta correspondência com a forma como se veem a si próprios. Os nossos resultados, neste caso, diferem daqueles obtidos por Barberá, (2004) e Martinez Sanchez, Navarro e Yubero, (2009).

Como observamos acima, os nossos resultados mostram também que os alunos consideram que a igualdade é um objetivo já alcançado (pelo menos no contexto educativo). Coincidindo com o denominado por Amelia Valcárcel como "el espejismo de la igualdad", onde indica como é complicado, se não se contar com os conhecimentos básicos (2013, p. 162), identificar as desigualdades enfrentadas pelas mulheres, ao serem cada vez mais subtis e menos percetíveis. O estudo de Ruiz Palomino et al. (2010) apresenta resultados semelhantes aos nossos, porque constata que os alunos (rapazes e raparigas) acham que a igualdade já foi alcançada. 
A este respeito, os adolescentes indicam várias situações de desigualdade que enfrentam no contexto educativo. Por exemplo, as raparigas queixam-se de que os seus colegas ocupam todos os espaços disponíveis para jogar futebol e basquetebol. Não as deixam jogar com eles e, às vezes, chegam mesmo a agredi-las para evitar que usem as instalações desportivas. No entanto, os rapazes sentem que esta atitude é normal. Eles argumentam que os espaços desportivos são para eles, e que as poucas raparigas que gostam de desporto devem resignar-se e dedicar-se a "coisas de raparigas", como coscuvilhar. Sobre este ponto, estamos de acordo com Mirta González, (2005) e Subirats e Tomé (2010), que também fazem referência à restrição de espaços no contexto educativo como uma forma de sexismo.

Os adolescentes afirmam que as funções desenvolvidas por homens e mulheres são condicionadas por papéis de género. Também referem que na família, muitas mães, para além de tratarem de todo o trabalho doméstico, começaram a trabalhar fora de casa. Reconhecem, então, que as mulheres estão a começar a desempenhar funções tradicionalmente associadas a papéis masculinos. A partir desta informação, podemos concluir que elas costumam fazer uma dupla jornada de trabalho, porque os homens não colaboram em casa, isto é, nunca realizam as tarefas relacionadas com os papéis das mulheres. Os nossos resultados concordam com os obtidos na tese de doutoramento de Elisabeth Malonda (2014). Ela conclui que uma maior aceitação da organização desigual na divisão do trabalho entre homens e mulheres, está baseada em atitudes sexistas.

Por outro lado, os/as estudantes afirmam que desfrutam dos diferentes direitos e liberdades segundo o seu sexo. Assim, enquanto os homens têm plena autonomia (para sair sempre que lhes apetece, para escolher amigos e companheira, e até mesmo para começar a trabalhar no que quiserem, alcançando assim a independência económica), as mulheres são controladas 
pela própria família, a fim de salvaguardar as suas "virtudes". Por conseguinte, elas nem têm tempo livre, nem podem relacionar-se com quem quiserem sem a permissão dos seus pais. Além disso, são forçadas a assumir, com as suas mães, o trabalho doméstico.

Quais são as perceções dos adolescentes que permitem que a desigualdade entre homens e mulheres seja legitimada?

Objetivo E. 2. Descrever e analisar as diferenças no conteúdo do discurso sobre a sexualidade e a igualdade de género entre os estudantes que vivem em áreas urbanas, rurais e indígenas.

Nos discursos dos adolescentes, principalmente nos que proveem de áreas indígenas e rurais, reflete-se uma forte ligação com os estereótipos e papéis de género tradicionais. Notamos que a maioria dos estudantes que vivem em áreas urbanas estão envolvidos em trabalho académico e vivenciam os relacionamentos como um jogo que lhes proporciona diversão, experiência e segurança nos futuros relacionamentos. Entretanto, a adolescência em contextos indígenas e rurais tem um significado diferente, pois nesta fase, elas e eles, começam a trabalhar com as suas famílias, contribuindo financeiramente ou com a realização de tarefas domésticas. Ou seja, começam a assumir uma maior responsabilidade como homens e mulheres. Levam mais a sério os relacionamentos afetivos e começam a ter a aspiração de constituir uma família. O estudo de Claudio Stern, (2007) mostra que a adolescência em setores marginais é mais curta. "Ele afirma que "la adolescencia termina entre los 15 y 16 años" e destaca que os rapazes começam a tornarem-se mais independentes quando entram no mercado de trabalho, ainda que de forma intermitente. A sua análise poderia coincidir com os resultados obtidos no nosso estudo, no entanto esta coincidência mereceria uma discussão mais aprofundada.

Outra diferença detetada entre os discursos dos adolescentes tem a ver com as formas de violência que experimentam. Os adolescentes de áreas rurais e indígenas relacionam conflitos e disputas com a propriedade da terra. Os da 
zona urbana indicam a violência escolar, brigas entre os pares e casos de violência sexual. As raparigas acusam os seus professores de lhes pedirem imagens de conteúdo sexual, ou até mesmo sexo, em troca de passarem nas suas disciplinas.

Quais são as perceções dos adolescentes que permitem que a desigualdade entre homens e mulheres seja legitimada?

Objetivo E. 3. Descrever as diferenças entre homens e mulheres quanto à perceção da educação sexual e igualdade de género.

Neste ponto encontramos pouca diferença de perceção entre ambos os sexos. As raparigas mostram atitudes mais favoráveis do que os homens sobre a igualdade, enquanto identificam situações de desigualdade de género nos contextos familiar e educativo. Os nossos resultados concordam com os de Cala Carrillo e Mata Benitez (2005); Cubillas Rodriguez et ai, (2016) .; García Pérez et al, (2010) .; Mosteiro Garcia e Porto (2016); Palomino Ruiz et al., (2010).

Além disso, em relação à sexualidade encontramos diferenças associadas às prioridades ou características sobre as quais os adolescentes reparam quando sentem atração por outra pessoa. Assim, elas dão prioridade aos traços psicossociais (que eles sejam boas pessoas, pensativos, atentos, valentes...), enquanto eles apontam aspetos relacionados com as características físicas (bonitas, magras, bom corpo...). Estes resultados refletem semelhanças com os obtidos por Amurrio Velez et al., (2012), onde se conclui que os rapazes, no início do namoro, dão maior prioridade à atração física, enquanto as raparigas acham muito difícil separar o físico do conjunto de traços que compõem a personalidade.

Os rapazes, quando se referem à sexualidade, tentam mostrar domínio e conhecimento, assumindo a liderança, mostrando-se ousados, sarcásticos e confiantes. As doenças sexualmente transmissíveis são as principais preocupações que eles exprimem relacionadas às práticas sexuais. Elas, por sua 
vez, falam num tom mais baixo, mostram-se interessadas e, acima de tudo, estão preocupadas em evitar consequências como a gravidez e outros problemas que possam surgir a partir do exercício da sexualidade. Estes resultados coincidem com os obtidos em dois estudos analisados. Um deles é o de Amurrio Velez et al., (2012). Estas autoras mostram que a sociedade patriarcal e centrada no homem e estabelece sanções para raparigas e rapazes que se afastam do papel social que lhes é atribuído. Assim, os homens têm de se gabar sobre a sua vasta experiência em relacionamentos, enquanto elas devem provar a sua falta de experiência no namoro. O outro é o desenvolvido por Caro Blanco (2008), que concluiu que, nas relações afetivas, as raparigas consideram que têm de justificar o seu desejo sexual mediante uma concepção romântica do amor, enquanto eles o mostram abertamente.

No contexto educativo, as raparigas apercebem-se de atos discriminatórios com base no sexo. Assim, afirmam que as adolescentes são vítimas de violência (levantam-lhes a saia, gozam com os seus corpos, são tocadas...), tanto pelos professores como pelos colegas.

No ambiente doméstico, eles e elas percebem que os seus pais são mais permissivos quando se trata de expressar emoções com as raparigas do que com os rapazes. Por outro lado, elas queixam-se de que, como explicamos anteriormente, os homens têm maior autonomia quando começam um relacionamento, podem entrar e sair de casa quando querem, etc.

Com a discussão que desenvolvemos, damos resposta à primeira questão de investigação e, portanto, cumprimos o objetivo geral estabelecido. Concluímos assim, que as perceções e discursos que apontam os adolescentes que participaram nesta investigação legitimam a desigualdade entre homens e mulheres. Verificou-se que as atitudes sexistas e ambivalentes continuam a limitar o potencial de desenvolvimento de rapazes e raparigas. O sexismo ambivalente está presente no discurso dos adolescentes e pode desencadear a 
justificação para comportamentos agressivos, assim como aumentar o risco de violência no âmbito académico, especialmente nas raparigas, porque é evidente que os alunos reproduzem os tradicionais estereótipos de género com base em modelos de masculinidade (autoridade de domínio, dinamismo...) e feminilidade (dependência, submissão, docilidade...) que no futuro pode levar ao desempenho dos papéis de agressor e vítima.

A seguir apresentamos a discussão acerca da segunda questão.

O ensino secundário no Estado de Michoacán promove a igualdade de oportunidades, direitos, recursos... entre homens e mulheres através dos manuais escolares?

Objetivo E. 4. Descrever as diferenças entre homens e mulheres quanto à perceção sobre educação sexual e igualdade de género.

Notamos que continua a prevalecer uma imagem masculinizada do mundo. Das 2285 personagens codificadas, 1465 são homens, ou seja, 64,1\%, enquanto que apenas 820 representam mulheres, 35,9\% do total. Esta percentagem respeitante às mulheres é comparável com a obtida nos estudos de IMOP $(33,8 \%)$ e Pellejero $(37,2 \%)$. No entanto, afasta-se dos dados obtidos por Garrett e Carreaga (25\%), López Navajas (12\%) e Blanco(23\%).

Quanto ao estudo das imagens, em que foram analisados um total de 395 personagens, os resultados mostraram uma percentagem de homens de 56,2\% contra 43,8\% de mulheres. Mesmo que ainda existam diferenças a favor dos homens, estas são mais estreitas do que aquelas obtidas nos estudos de Luengo 2003 com 32,95\%, Lump Caro com 35,6\% e 39,53\% com Ritter.

Entretanto, e no que diz respeito ao texto, também mostra uma predominância de nomes masculinos, com $65,7 \%$, em comparação com os de mulheres com apenas 34,3\%. Estes valores são praticamente coincidentes com os conseguidos pelos inquéritos IMOP (2000), no nível secundário, que obteve um resultado de $66 \%$ nos nomes de homens. 
Os resultados qualitativos mostram que há poucas alusões às profissões nomeadas no feminino e que quando elas ocorrem estão associadas com o estereótipo que se encaixa nas mulheres: professoras, secretárias, enfermeiras... Estes resultados coincidem com os lançados há mais de vinte anos pelo estudo realizado por Gabriela Delgado (1994) com manuais do ensino primário.

No âmbito domestico, tanto os homens como as mulheres desempenham funções associadas aos papéis tradicionais. A este respeito, os homens aparecem no texto desenvolvendo tarefas de apoio à família, como chefe de família, sendo que a sua colaboração nas tarefas domésticas é limitada ao concerto de coisas, ao manuseamento de ferramentas e algumas tarefas parentais. Ao invés, as mulheres aparecem nesta área desempenhando tarefas mais variadas, que vão desde a organização do lar ao cuidado de membros da família.

O ensino secundário no Estado de Michoacán promove a igualdade de oportunidades, direitos, recursos... entre homens e mulheres através dos manuais escolares?

Objetivo E. 5. Comparar o papel e a importância que é dada aos homens e mulheres nos materiais.

No que diz respeito à ocorrência nos manuais escolares de personagens famosos, foram codificadas 528 alusões. Na secção de imagens é onde se encontra a maior diferença entre ambos os sexos, já que das 29 celebridades, 27 são do sexo masculino. As outras 499 referências são citadas no texto. Aqui as mulheres representam apenas $9,2 \%$ do total. São, portanto, poucas as referências a mulheres representativas nos materiais. Além disso, são representadas, principalmente, na área artística e literária, enquanto eles dominam os campos científico e político. Os nossos resultados coincidem novamente com os dos inquéritos I.M.O.P. (2000), que registaram uma ocorrência de 7\% de mulheres nos resultados referentes ao ensino secundário. 
A análise qualitativa dos dados mostra que os manuais escolares analisados apenas referem as contribuições que as mulheres fizeram à sociedade. Através de nuvens de palavras mostramos quem elas são e as razões pelas quais são nomeadas. Os resultados evidenciam que apenas no manual e Ciências se referem às razões pelas quais as mulheres não puderam estar presentes em certas áreas de atividade. O estudo de Blanco (2000) obtém resultados que se correspondem com os nossos, na medida em que mostra que, nos manuais escolares, a participação das mulheres no desenvolvimento social, cultural, económico... é invisível e, além disso, não se explica o porquê.

O ensino secundário no Estado de Michoacán promove a igualdade de oportunidades, direitos, recursos... entre homens e mulheres através dos manuais escolares?

Objetivo E. 6. Analisar as condutas e as atividades desempenhadas por homens e mulheres nos manuais escolares.

Os resultados, obtidos na análise dos comportamentos e das atividades das personagens que aparecem nos manuais escolares, mostraram que prevalecem estereótipos socioculturais atribuídos a cada um dos sexos.

A este respeito, as características psicossociais que têm maior influência sobre o corpus visual e textual são mais relacionadas com os estereótipos masculinos de personalidade (comportamentos que denotam atividade/dinamismo representam $71 \%$ nas imagens e $81 \%$ no texto). No corpus visual descobrimos que os homens são representados por características relacionadas com o estereótipo masculino ("ganha pão", chefe de família, intelectual...), enquanto as mulheres aparecem nos manuais com traços de personalidade quer femininos (Tímida, materna, emocional, preocupada com o seu físico...) quer masculinos (trabalhadora, dinâmica, desportista...).

Os resultados da análise do texto são semelhantes aos encontrados nas imagens. Assim, evidencia-se que tanto nas imagens como no texto aparecem 
características psicossociais compartilhadas por ambos os sexos. No entanto, a elas começam a ser-lhes atribuídos a estereótipos sexuais e papéis sociais que historicamente eram considerados como masculinos, enquanto estereótipos considerados femininos (afetividade, trabalhadora, maternal) são representados exclusivamente por personagens associados a mulheres. Os estudos que apresentam correspondência com estes resultados são as de Blanco, (2000, 2003); Delgado Ballesteros, (1994); Inquéritos I.M.O.P., (2000); Luengo González y Blázquez Entonado, (2004) e Subirats, (1993).

Os resultados de nossa investigação permitem concluir que não só existem diferenças numéricas entre homens e mulheres, mas que também eles e elas desempenham atividades em contextos diferentes, dependendo do seu sexo. No que diz respeito às imagens, os homens aparecem com mais frequência nas áreas públicas e a realizar atividades e ocupações mais diversificadas (32 no total). Pelo contrário, as aparições de mulheres são predominantes no setor privado e o seu leque de atividades é mais restrito (17 profissões). Além disso, como o texto está em causa, temos conclusões que seguem este patrão.

Os homens aparecem em 141 profissões diferentes, enquanto as mulheres são limitadas a 45. Como foi o caso com as imagens, a percentagem mais elevada, em relação ao âmbito de emprego das mulheres, é o doméstico, com 49,1\%. Enquanto isso, para os homens as áreas predominantes são as relativas a profissões sociais de prestígio (político, religioso, militar e técnicoprofissional), com percentagens, em todas elas, superiores ao 40\%. Os resultados sobre os modelos femininos transmitidos nos manuais analisados são consistentes com os obtidos por Bosch e Ferrer (2003, p. 141), "serán consideradas como naturalmente destinadas a la vida privada, a la maternidad y al cuidado de la familia, y poco interesadas por cualquier otra actividad, especialmente aquellas vinculadas al ámbito público". Além disso, Blanco também obtém resultados semelhantes, uma vez que no seu estudo, das mais de 
300 profissões contabilizadas, apenas 94 aparecem associadas às mulheres. Outros estudos encontraram resultados semelhantes, são os seguintes: Ladron de Guevara (2009); Llorent-Bedmar e Cobano-Delgado, (2014); Peñalver, (2003); Ritter, Luján, Monti, e Nieto (2011).

Com a análise qualitativa dos dados, descobrimos que os estereótipos tradicionais de género continuam a persistir. No entanto, também encontramos informação visual e textual que promove modelos alternativos que estão mais relacionadas com as mudanças na sociedade. Ou seja, que apresentam uma imagem do mundo onde os homens e as mulheres desempenham tarefas e atividades sem preconceito de género. No estudo de Luengo Gonzalez e Blazquez Entonado (2004), também se refere este facto, embora apenas no recurso iconográfico presente em manuais didáticos. Outro estudo que encontrou resultados na mesma linha que a nossa é a tese de mestrado de Ladrón de Guevara (2009), na que se verificam progressos relacionados com a inclusão de mulheres envolvidas em atividades tradicionalmente consideradas masculinas.

Após a discussão, alcançamos o objetivo geral dois, dado que resolvemos a segunda questão de investigação.

O Estado tenta legislar para que os materiais de ensino promovam a igualdade de género. No entanto, os avanços conseguidos são insuficientes devido à falta de consistência das medidas tomadas. Os manuais didáticos, portanto, continuam a promover e a transmitir ideias, crenças e valores que contêm tanto estereótipos sexuais (os homens são fortes, corajosos, o "ganhapão"...; e as mulheres são maternais, afetuosas, trabalhadoras...) como papéis sociais (os homens são produtivos, protetores...; e as mulheres são donas de casa, mães...).

\subsection{Constatação de hipóteses}


Até agora temos discutido os resultados mais importantes deste estudo, de acordo com as questões de investigação e os objetivos específicos. Como mencionamos no Capítulo 5, de cada objetivo específico foi derivada uma hipótese. Em seguida analisamos se essas hipóteses são cumpridas ou não, e se é de maneira total ou parcialmente. Além disso, examinaremos as conclusões derivadas desta circunstância.

Nesta parte apenas se apresentam as possíveis razões pelas quais algumas hipóteses são rejeitadas ou aceites, completa ou parcialmente. Isto é importante quando se considera que as hipóteses correspondem aos resultados das investigações consultadas na primeira fase desta investigação. A constatação de hipóteses será apresentada através de tabelas, com o intuito de mostrar esquematicamente as conclusões a que chegámos com o desenvolvimento deste trabalho.

\section{Tabela 9.1. Conclusões de acordo com as hipóteses}

\begin{tabular}{ll}
\hline Objetivo 1 & $\begin{array}{l}\text { Descrever e explicar se os estudantes do Estado de Michoacán atribuem } \\
\text { a homens e a mulheres padrões de comportamento "próprios" de cada } \\
\text { sexo. }\end{array}$ \\
\hline Hipótesis 1 & $\begin{array}{l}\text { Os estudantes identificam as situações que legitimam a } \\
\text { desigualdade entre homens e mulheres. }\end{array}$ \\
\hline & $\begin{array}{l}\text { Esta hipótese é parcialmente aceite, dado que se } \\
\text { observa que, mesmo quando os estudantes manifestam } \\
\text { que a igualdade entre homens e mulheres foi alcançada, } \\
\text { nos seus discursos (especialmente nos das mulheres) } \\
\text { mostram que no dia-a-dia assistem a situações de } \\
\text { desigualdade. } \\
\text { Conclusões }\end{array}$ \\
$\begin{array}{l}\text { Prevalecem estereótipos e papéis sociais } \\
\text { tradicionais, associados com as características, } \\
\text { qualidades e funções que devem ter os homens e as } \\
\text { mulheres. } \\
\text { Começa-se a atribuir às mulheres características } \\
\text { comportamentais masculinas, como o dinamismo e a } \\
\text { capacidade de realizar trabalhos remunerados. No } \\
\text { entanto, ainda não se atribuem aos homens papéis } \\
\text { tradicionalmente femininos. }\end{array}$ \\
\hline
\end{tabular}


- O sexismo ambivalente nos discursos dos adolescentes pode conduzir a situações de violência, pois justifica-se como natural/biológico que os homens sejam violentos, autoritários e dominadores. Ao invés, considera-se que as mulheres são afetivas, passivas e dependentes por natureza.

Objetivo 2 Descrever as perceções dos estudantes tendo em conta o contexto em que a escola se insere: área urbana, rural e indígena.

\begin{tabular}{|c|c|c|}
\hline & Hipótese 2 & $\begin{array}{l}\text { A população jovem do contexto urbano percebe que } \\
\text { existem relações mais equitativas entre homens e } \\
\text { mulheres. }\end{array}$ \\
\hline & Conclusões & $\begin{array}{l}\text { Conclusões } \\
\text { A hipótese } 2 \text { é também parcialmente aceite. } \\
\text { - Neste sentido, os discursos que fizeram os/as } \\
\text { adolescentes das áreas urbanas não fazem referência } \\
\text { explícita às relações equitativas entre homens e } \\
\text { mulheres. No entanto, nas suas intervenções } \\
\text { aparecem, com menos frequência, argumentos nos } \\
\text { quais as atividades da área académica ou familiar } \\
\text { estejam tão marcados pelos estereótipos e papéis de } \\
\text { género tradicionais como o estão nas áreas indígenas } \\
\text { e rurais. }\end{array}$ \\
\hline Objetivo 3 & $\begin{array}{l}\text { Descrever a } \\
\text { sobre educaç }\end{array}$ & $\begin{array}{l}\text { diferenças entre homens e mulheres quanto à perceção } \\
\text { sexual e igualdade de género. }\end{array}$ \\
\hline & Hipótese 3 & $\begin{array}{l}\text { O sexo dos alunos/as determina como a sexualidade e a } \\
\text { equidade é percebida. }\end{array}$ \\
\hline & Conclusões & $\begin{array}{l}\text { Esta hipótese é totalmente aceite, verificamos que o } \\
\text { sexo do aluno/a determina a perceção que tem sobre } \\
\text { sexualidade e igualdade de género. } \\
\text { - Concluímos, em relação à sexualidade, que homens } \\
\text { e mulheres assumem funções com base em } \\
\text { estereótipos de género. Elas são obrigadas a } \\
\text { mascarar os seus desejos e fantasias sexuais para } \\
\text { não serem criticadas pelas pessoas que as rodeiam, } \\
\text { enquanto eles têm de ostentar a sua virilidade para } \\
\text { fugir do que os diminui, a homossexualidade. } \\
\text { - Há uma dupla moral a nível sexual, que se evidencia } \\
\text { nos discursos dos alunos. Isto faz com que as } \\
\text { mulheres preservem a sua virgindade, para evitarem } \\
\text { ser criticadas socialmente, enquanto os homens } \\
\text { fazem o oposto para evitar ser criticados. Tudo isto } \\
\text { pode levar a situações de risco para homens e } \\
\text { mulheres. Elas são assim encaminhadas para iniciar } \\
\text { relacionamentos estáveis quando ainda são muito } \\
\text { jovens, que muitas vezes causam gravidezes } \\
\text { indesejadas e relações de dependência do sexo }\end{array}$ \\
\hline
\end{tabular}


masculino, ao abandonar a escola prematuramente. Eles são empurrados a usar drogas e álcool para ajudá-los a desinibir-se ao lidarem com as raparigas, de modo a obter relações com elas. Além disso, a pressão dos colegas fá-los manter relações de risco para preservarem a sua masculinidade, de tal modo que podem até contrair doenças sexuais.

- Por outro lado, em termos de equidade podemos concluir que as adolescentes têm uma atitude mais crítica e reflexiva perante a igualdade/desigualdade de género.

Objetivo 4 Descrever e analisar a presença/ausência de mulheres e homens nos manuais escolares.

Hipótese 4 mulheres nos manuais escolares do primeiro ano do ensino secundário.

A hipótese 4 é aceite.

- Concluímos que os livros didáticos analisados não só não refletem a realidade social, pois continuam a mostrar, através de imagens, de textos e de conteúdos, diferentes espaços (público e privado)

Conclusões segundo o sexo, mas também porque continuam a transmitir modelos hegemónicos onde o referente universal permanece representado pelo masculino.

- Os resultados também mostram que prevalecem os modelos que favorecem, promovem e/ou justificam a desigualdade entre homens e mulheres.

Objetivo 5 Comparar o papel e a importância dada aos homens e às mulheres nos materiais.

Hipótese 5

Nos manuais os homens desempenham papéis mais representativos do que as mulheres.

A hipótese 5 é aceite.

- As contribuições de personagens representativos são monopolizadas por homens, o que leva à conclusão de que há ocultamento das contribuições que as mulheres fizeram para o mundo da ciência, da

Conclusões política, da economia e da sociedade.

- Por isso, acreditamos que através dos manuais analisados é inconscientemente transmitida violência simbólica, ao ocultar as contribuições que as mulheres fizeram à humanidade. Além disso, ao não fornecer informações que justifiquem a não referencias a elas, apresenta-se como normal algo 
que não o é.

Objetivo 6 Analisar o comportamento e as atividades desenvolvidas por homens e mulheres nos manuais escolares.

Os manuais escolares não quebram os estereótipos de Hipótese 6 género tradicionalmente atribuídos a homens e mulheres.

Esta hipótese é aceite parcialmente.

- Verifica-se que, mesmo quando os estereótipos e papéis de género tradicionais predominam, existe uma tentativa por cumprir a legislação em matéria de igualdade. Isso reflete-se na incorporação de modelos alternativos nas informações visuais e textuais, principalmente no manual de Ciências.

- Concluímos que a representação psicossocial de homens e mulheres é estabelecida com base em estereótipos socioculturais atribuídos a cada sexo. Por um lado, os comportamentos e as atividades dos homens estão relacionadas com os contextos de desporto, trabalho, jogo e lazer. Em contraste, as mulheres aparecem destinadas principalmente à vida privada, maternidade e cuidados com a família, e pouco representadas em ocupações relacionadas com o domínio público.

Conclusões

- Os resultados mostram que há poucos modelos alternativos, especialmente em relação ao recurso iconográfico, onde os/as adolescentes possam encontrar opções de coexistência mais igualitárias.

- Nas imagens, no texto e no conteúdo analisado é escassa a informação que promova uma maior responsabilidade de todos os membros da família em tarefas domésticas.

- Nos textos analisados é favorecido um modelo de casal e de família que já não corresponde à realidade. $\mathrm{Ou}$ seja, promovem-se apenas os relacionamentos de natureza heterossexual, assim como os modelos familiares conservadores, excluindo aqueles que escolhem outros estilos e orientações sexuais.

- Os esforços feitos pelas editoras para cumprir com as normas estabelecidas nos planos e programas 
nacionais sobre igualdade de género, são insuficientes.

- Concluímos, portanto, que a informação que é transmitida nos livros sobre a igualdade de género é caracterizada por ser inconsistente e carente de uma estratégia definida, coesa. Este facto é evidente em muitos descuidos, que fazem com que os alunos recebam informações contraditórias.

Neste trabalho, descobrimos mudanças sociais, como a ampliação dos direitos das mulheres, impulsionada pelos movimentos feministas e pelas políticas de igualdade que, embora tenham conseguido melhorar a realidade de homens e mulheres na esfera social, não têm sido capazes de acabar com alguns elementos que perpetuam as desigualdades de género. No contexto educativo, pudemos observar tímidos avanços associados à promoção de relações mais igualitárias entre homens e mulheres.

Este estudo mostra que, tanto nas perceções dos adolescentes como na análise dos manuais escolares, sobrevive uma correlação em que as relações são organizadas de uma maneira diferenciada e priorizada sob a justificação da diferença sexual, limitando o potencial de desenvolvimento das pessoas e travando as redes de uma convivência baseada na igualdade, dignidade e justiça social.

\subsection{Pontos fortes e fracos do estudo}

A investigação aqui apresentada constitui, ao nosso entender, um marco de referência, dado que, como vimos na parte teórica, existem poucos estudos realizados no México que englobem género e educação. Assim, os pontos seguintes resumem as contribuições derivadas desta tese de doutoramento.

- Acreditamos que tanto a análise dos estereótipos de género nos alunos, como o estudo de sexismo nos manuais didáticos, fornecem informações 
relevantes sobre a sobrevivência de uma imagem distorcida, apoiada num sistema centrado no homem, que propaga valores e crenças sexistas.

- Estas duas linhas de investigação (perceções sobre os estereótipos de género e análise de sexismo nos materiais) permitem-nos ter uma visão geral sobre os pressupostos ideológicos latentes, que favorecem a legitimação de desigualdades entre homens e mulheres. É essencial conhecer e apontar estas diferenças e o seu significado para efetuar a reflexão crítica que conduz à implementação de ações sistemáticas destinadas a conseguir uma sociedade mais justa.

- Acreditamos que a informação derivada deste estudo constata a necessidade de realizar uma análise crítica dos estereótipos de género presentes em todos os manuais do ensino secundário.

- Por outro lado, acreditamos que a abordagem metodológica escolhida (qualitativa e quantitativa) permitiu-nos enriquecer a descrição e explicação do sexismo presente tanto nas perceções dos estudantes, como no conteúdo (imagens, texto e conteúdo) dos manuais escolares.

- Podemos contribuir, também, com esta tese de doutoramento, para o debate e reflexão sobre as desigualdades de género presentes na escola e na família.

- Finalmente, pensamos que a informação derivada deste estudo pode ser relevante para os/as interessados/as no desenvolvimento e implementação de planos e de programas de políticas educativas baseadas na igualdade entre homens e mulheres.

Consideramos que é oportuno mencionar algumas limitações observadas na sequência do desenvolvimento desta investigação.

Primeiro referimos as relacionadas com os grupos de discussão: 
- Esta ferramenta de recolha de dados, mesmo que pareça apropriada para descrever e explicar os estereótipos e papéis de género, pode ser complementada com estratégias quantitativas (inventários já validados) para reforçar os discursos fornecidos pelos alunos.

- Limitação na formação de grupos de discussão, que foram mistos. Esta circunstância poderia inibir os discursos de uns e outras sobre os temas estudados.

- Limitação do tamanho da amostra. Teria sido melhor uma amostra maior, com o propósito de que fosse representativa da população, de modo a generalizar os dados para todo o Estado.

- Finalmente, teria sido mais enriquecedor filmar as sessões com câmara de vídeo em vez de um gravador de voz.

Em segundo lugar, expomos as limitações observadas com a técnica de recolha de informações relacionada com os manuais escolares:

- Limitação do tamanho da amostra. Consideramos que é apropriado analisar todos os livros escolares que foram autorizados pelo Ministério da Educação, por forma a que o/a professor/a tenha informação sobre os materiais escolares que promovem relações mais igualitárias entre homens e mulheres.

- Limitação administrativa. Foi difícil que as escolas secundárias nos fornecessem os manuais, pois, ao ser um material escolhido livremente pelos professores, nem todas as escolas secundárias trabalham com os mesmos materiais.

\subsection{Recomendações e futuras linhas de investigação}

Acreditamos que a educação é uma das medidas mais desejáveis para atingir a igualdade real entre homens e mulheres. Nesse sentido, e após a conclusão desta investigação, parece apropriado enunciar algumas propostas, de modo a 
fornecer orientações que podem contribuir para a transformação de contextos escolares mistos em espaços de coeducação, onde se divulguem relações livres, sem estereótipos nem discriminação por razão de sexo.

- Torna-se necessário que as escolas desenvolvam programas de intervenção que envolvam as famílias. Ou seja, projetos destinados a promover as relações de corresponsabilidade familiar.

- Incentivar práticas coeducativas em escolas públicas, que valorizem e deem prioridade aos estereótipos positivos para melhorar a convivência humana. Ou seja, dotar de valor todos os princípios que estejam relacionados com os afetos e o cuidado, e descartar aqueles que representam um perigo para o desenvolvimento da sociedade, tais como a agressividade e o autoritarismo.

- Fomentar nos alunos atitudes mais colaborativas na resolução de conflitos e/ou tarefas.

- Promover através dos manuais didáticos relações mais justas e respeitosas com as diferenças, sejam de natureza sexual, étnica, económica, etc.

Antes de terminar este estudo, vamos apresentar algumas das investigações que acreditamos que podem ser desenvolvidas num futuro próximo:

- Seria interessante a realização de uma investigação em que participem todas as pessoas envolvidas no processo educativo: direções, docentes, alunos, pais, responsáveis públicos... Desta forma podiam ser desenhadas e implementadas ações conjuntas que enfrentariam, com sucesso, o problema do sexismo na educação.

- Analisar os processos que ocorrem no mercado editorial, aquando da criação de materiais educativos, de maneira a identificar onde estão os 
erros que fazem com que os livros continuem a transmitir modelos afastados da promoção da igualdade de género.

Comparação dos manuais escolares estudados neste trabalho com os de países mais avançados em termos de igualdade, por forma a identificar estratégias que promovam relações equitativas entre homens e mulheres, assim como o aproveitamento na melhoria da redação de novos materiais educativos. 



\section{Referencias}

Acevedo, M. (2002). 10 de mayo. En G. Gutiérrez Castañeda (Ed.), Feminismo en México. Revisión histórico-critica del siglo que termina ( $1^{\mathrm{a}}$, pp. 3954). México: Universidad Nacional Autónoma de México-PUEG.

Alonso, J. (2004). El derecho de la mujer al voto. Revista de Estudios de Género. La ventana, (19), 152-158.

Álvarez de Morales, A. (2011). La instrucción pública y la libertad de imprenta en la Constitución de Cádiz. En L. Rodríguez-San Pedro Bezares \& J. Polo Rodríguez (Eds.), Salamanca y su universidad en el primer Renacimiento: siglo XV (1. ${ }^{\mathrm{a}}$ ed., pp. 419-430). Salamanca: Ediciones Universidad de Salamanca.

Álvarez Enríquez, L. (2004). La sociedad civil en la Ciudad de México: actores sociales, oportunidades políticas y esfera pública. UNAM.

Álvarez Lires, M. (2010). Las científicas y su historia en el aula $\left(1^{\mathrm{a}}\right)$. Madrid: Síntesis. Recuperado a partir de http://cielo.usal.es/Record/Xebook1-2490 Alvarez Nunes, M. T. (2009). O feminino e o masculino nos materiais pedagógicos:(in)visibilidades e (des)equilíbrios. Lisboa: COMISSÃO PARA A CIDADANIA E IGUALDADE DE GÉNERO.

Álvarez Olivas, V. C. (2015). Aprendizaje colaborativo mediado por TIC en la enseñanza universitaria: un acercamiento a las percepciones $y$ experiencias de profesores y alumnos de la Universidad Autónoma de Chihuahua (Tesis doctoral). Universidad de Salamanca, Salamanca.

Amorós, C. (1985). Hacia una crítica de la razón patriarcal (1a. ed). Madrid: Anthropos Editorial del hombre.

Amorós, C. (2000). Tiempo de feminismo: sobre feminismo, proyecto ilustradoy postomodernidad (2a. ed). Madrid: Cátedra.

Amorós, C. (2007). Feminismo y multiculturalismo. En Teoría feminista: de la ilustración a la globalización. De los debates sobre el género al multiculturalismo (2a , pp. 215-264). Madrid: Minerva Ediciones.

Amorós, C. (2010a). Feminismo y filosofía (1 $\left.1^{\mathrm{a}} \mathrm{ed}\right)$. Madrid: Síntesis.

Amorós, C. (2010b). Presentación. El feminismo ¿hijo no querido de la ilustración? En C. Amorós (Ed.), Feminismo y filosofía (1 $1^{\text {a }}$ ed, pp. 9-107). Madrid: Síntesis.

Amorós, C., \& Miguel Álvarez, A. de (Eds.). (2007). Teoría feminista: de la Ilustración a la globalización. 1, De la Ilustración al segundo sexo (2a. ed). Madrid: Minerva. 
Amurrio Velez, M., Larrinaga Renteria, A., Usategui Basozabal, E., \& Del Valle Loroño, A. (2012). Los estereotipos de género en los/las jóvenes y adolescentes. En XVII Congreso de Estudios Vascos: Gizarte aurrerape $n$ iraunkorrerako berrikuntza (pp. 227-248). Donostia: Eusko Ikaskuntza.

Anzures, T. (2011). El libro de texto gratuito en la actualidad: logros y retos de un programa cincuentenario. Revista mexicana de investigación educativa, 16(49), 363-388.

Aranda Friz, V. (2015). Derribando muros y techos de cristal. Las acciones afirmativas de género. Resistencia discursivas y prácticas a la ley de cuotas y paridad en Chile (1990-2010) (Doctoral). Universidad de Chile, Santiago de Chile. Recuperado a partir de http://repositorio.uchile.cl/handle/2250/137618

Arcos, E., Figueroa, V., Miranda, C., \& Ramos, C. (2007). Estado del arte y fundamentos para la construcción de indicadores de género en educación. Estudios pedagógicos (Valdivia), 33(2), 121-130.

Arizpe, L. (2002). El feinismo: del grito de los setenta a las estrategias del siglo XXI. En G. Gutiérrez Castañeda (Ed.), Feminismo en México. Revisión histórico-critica del siglo que termina ( $1^{\mathrm{a}}$, pp. 63-70). México: Universidad Nacional Autónoma de México-PUEG.

Arnot, M. (1995). Feminismo y educación democrática. En Volver a pensar la educación (Vol. I, pp. 307-325). Madrid: Fundación Paideia y Ediciones Morata. Recuperado a partir de https://books.google.es/books?id=8deIX3GtwhMC\&pg=PA307\&lpg=PA $307 \&$ dq $=$ feminismo+y+educaci $\%$ C3\%B3n+democratica\&source $=$ bl\&ots =b1hmZUlTDJ\&sig=wo7Ufp6dn3738RSheaD7y10O3hQ\&hl=es\&sa=X \&ved=0ahUKEwj6mP3yur_TAhVHHxoKHXnaDBsQ6AEIMzAC\#v=on epage $\& \mathrm{q}=$ feminismo $\% 20 \mathrm{y} \% 20$ educaci $\% \mathrm{C} 3 \% \mathrm{~B} 3 \mathrm{n} \% 20 \mathrm{democratica} \& \mathrm{f}=\mathrm{fal}$ se

Astelarra, J. (2005). Veinte años de políticas de igualdad. Madrid: Cátedra.

Auster, C. J., \& Ohm, S. C. (2000). Masculinity and femininity in contemporary American society: A reevaluation using the Bem Sex-Role Inventory. Sex roles, 43(7), 499-528.

Barberá, E. (2004). Perspectiva cognitiva-social estereotipos y esquemas de género. En E. Barberá, I. Martínez Benlloch, \& A. Bonilla Campos (Eds.), Psicología y género. Madrid: Pearson Educación.

Barberá Heredia, E. (2004). Diversidad emprendedora y perspectiva de género en la investigación psicológica. En The entrepreneur and starting up new 
$R \& D \& I$ businesses: El emprendedor innovador y la creación de empresas $I+D+I$ (pp. 921-934). Universitat de València.

Barbour, R. S., \& Amo, T. del. (2013). Los grupos de discusión en investigación cualitativa (1a. ed). Madrid: Morata.

Bardin, L. (1991). Análisis de contenido. Ediciones AKAL.

Bartra, E. (1997). Estudios de la mujer. ¿un paso adelante, dos pasos atrás? Política y Cultura, (9), 201-214.

Bartra, E. (1999). El movimiento feminista en México y su vínculo con la academia. Revista de Estudios de Género. La Ventana, 1(10), 214-233.

Bartra, E. (2010). Retos y posibilidades de la investigación feminista en México hoy. Revista de investigación y divulgación sobre los estudios de género, (6), 7-17.

Bascón Díaz, M. J. (2007). Género, adolescencia y argumentación: el discurso como acción situada en contextos de resolución de conflictos (Doctoral). Universidad de Sevilla. Recuperado a partir de https://dialnet.unirioja.es/servlet/tesis?codigo $=23372$

Becerra Ramírez, M., Carpizo, J., Corzo Sosa, E., \& López-Ayllón, S. (2000). Tratados internacionales. Se ubican Jerárquicamente por encima de las Leyes y en un segundo plano respecto a la Constitución Federal (Amparo en revisión 1475/98). Revista Mexicana de Derecho Constitucional, (3), 169-208.

Bem, S. L. (1974). The measurement of psychological androgyny. Journal of Consulting and Clin- Ical Psychology, 42, 155-162. https://doi.org/10.1037/h0077098

Bericat Alastuey, E. (1998). La integración de los métodos cuantitativo y cualitativo en la investigación social. Barcelona: Ariel.

Blanco Belver, E. (2011). Género y ética de las relaciones amorosas y conducta sexual (Máster). Universidad de Salamanca, Salamanca. Recuperado a partir de http://gredos.usal.es/jspui/handle/10366/99539

Blanco, N. (1995). El sentido del conocimiento escolar. (Notas para una agenda de trabajo). En Volver a pensar la educación (Vol. I, pp. 188-202). Madrid: Fundación Paideia y Ediciones Morata. Recuperado a partir de https://books.google.es/books?id=8deIX3GtwhMC\&pg=PA307\&lpg=PA $307 \&$ dq $=$ feminismo+y+educaci $\% \mathrm{C} 3 \% \mathrm{~B} 3 \mathrm{n}+$ democratica\&source=bl\&ots =b1hmZUlTDJ\&sig=wo7Ufp6dn3738RSheaD7y10O3hQ\&hl=es\&sa=X \&ved=0ahUKEwj6mP3yur_TAhVHHxoKHXnaDBsQ6AEIMzAC\#v=on 
epage $\& \mathrm{q}=$ feminismo $\% 20 \mathrm{y} \% 20$ educaci $\% \mathrm{C} 3 \% \mathrm{~B} 3 \mathrm{n} \% 20 \mathrm{democratica} \& \mathrm{f}=\mathrm{fal}$ se

Blanco, N. (s/f). ¿De qué mujeres y de qué hombres hablan los libros de texto? Quaderns Digitals.

Blanco, N. (2000). El sexismo en los materiales educativos de la E.S.O. Sevilla: Instituto Andaluz de la Mujer.

Blanco, N. (2003). La imagen del mundo: la representación de mujeres y varones en textos de Educación Secundaria Obligatoria. En M. D. Villuendas \& A. J. Gordo (Eds.), Relaciones de género en psicología y educación (pp. 31-46). Madrid: Consejería de Educación.

Blanco, N. (2006). Mujeres y hombres para el siglo XXI. En El harén pedagógico. Perspectiva de género en la organización escolar $\left(2^{\mathrm{a}}\right.$, pp. 119-146). Barcelona: Graó.

Blanco, N. (2007). Análisis de materiales curriculares. En A. Vega Navarro (Ed.), Mujer y educación: una perspectiva de género (pp. 105-116). Archidona: Aljibe.

Blanco, N. (2008). Los saberes de las mujeres y la transmisión cultural en los materiales curriculares. Investigación en la escuela, (65), 11-22.

Bodelón, E. (1998). La igualdad y el movimiento de mujeres: propuestas y metodología para el estudio del género. Institut de ciències polítiques i socials. Recuperado a partir de http://centreantigona.uab.cat/docs/articulos/La\%20igualdad\%20y\%20el\% 20movimiento\%20de\%20mujeres.pdf

Bosch Fiol, E., \& Ferrer Pérez, V. A. (2003a). Fragilidad y debilidad como elementos fundamentales del estereotipo tradicional femenino. Feminismo/s, 2, 139-152.

Bosch Fiol, E., \& Ferrer Pérez, V. A. (2003b). Sobre la supuesta inferioridad intelectual de las mujeres: el caso de las teorías frenológicas en el siglo XIX. Clepsydra: revista de estudios de género y teoría feminista, (2), 119-136.

Botello Lonngi, L. (2005). Identidad, masculinidad y violencia de género (Doctoral). Universidad Complutense de Madrid, Madrid. Recuperado a partir de http://www.tdx.cat/handle/10803/75205

Bourdieu, P. (2000). La dominación masculina. Barcelona: Anagrama.

Bryson, V. (1999). 'Patriarchy': A concept too useful to lose. Contemporary Politics, 5(4), 311-324. https://doi.org/10.1080/13569779908450014 
Buquet Corleto, A., \& Moreno, H. (2013). El papel de la legislación internacional en materia de género en la reforma de las instituciones de educación superior: el caso de la Universidad Nacional Autónoma de México. En J. L. Silva Méndez (Ed.), Género y educación: aportes para la discusión jurídica (pp. 83-113). Instituto Sinaloense de las MujeresFontamara. Recuperado a partir de http://ismujeres.gob.mx/genero-yeducacion-aportes-para-la-discusion-juridica/

Butler, J. (1990). El género en disputa: el feminismo y la subversión de la identidad. (M. A. Muñoz, Trad.). Barcelona: Paidós.

Cabral, B. E., \& García, C. T. (2003, Diciembre). El género. Una categoría de análisis crítico para repensar las relaciones sociales entre los sexos. Saber ULA, 13.

Cabral, B. E., \& Samudio, E. O. (2005). El género. Una categoría de análisis crítico que nos cuenta otra historia. Trocadero, 1(17), 239-247.

Cala Carrillo, M. J., \& Mata Benítez, M. (2005). Modos de discurso y actitudes en grupos de discusión. Un estudio comparativo de mujeres y hombres. Avances en psicología latinoamericana, 23(1), 155-175.

Calero, J. L., \& Santana, F. (2001). Percepciones de un grupo de adolescentes sobre iniciación sexual, embarazo y aborto. Revista Cubana de salud pública, 27(1), 50-57.

Calvo Buezas, T. (1995). La educación intercultural en una sociedad pluriétnica. En Volver a pensar la educación (Vol. I, pp. 254-267). Madrid: Fundación Paideia y Ediciones Morata. Recuperado a partir de https://books.google.es/books?id=8deIX3GtwhMC\&pg=PA307\&lpg=PA $307 \& d q=$ feminismo+y+educaci $\%$ C3\%B3n+democratica\&source=bl\&ots =b1hmZUlTDJ\&sig=wo7Ufp6dn3738RSheaD7y10O3hQ\&hl=es\&sa=X \&ved=0ahUKEwj6mP3yur_TAhVHHxoKHXnaDBsQ6AEIMzAC\#v=on epage \&q=feminismo $\% 20 \mathrm{y} \% 20$ educaci $\% \mathrm{C} 3 \% \mathrm{~B} 3 \mathrm{n} \% 20 \mathrm{democratica} \& \mathrm{f}=\mathrm{fal}$ se

Cámara de Diputados. (2012). Marco Jurídico en materia de igualdad Compilación de instrumentos en la materia (Institucional) (p. 430). México. Recuperado a partir de http://archivos.diputados.gob.mx/Centros_Estudio/ceameg/ET_2013/12_ MJMIC.pdf

Cámara de Diputados LX Legislatura. (s. f.). Seguimiento a las políticas educativas para la igualdad de género (Institucional No. DP2/IF17/2008) (p. 33). México: Centro de Estudios para el Adelanto de las Mujeres y la 
Equidad de Género. Recuperado a partir de http://archivos.diputados.gob.mx/Centros_Estudio/ceameg/Inv_Finales_0 8/DP2/2_17.pdf

Cano, G. (1992). Revolución, feminismo y ciudadanía. En Coloquio de Investigación y de Estudios de Género (p. 19). México.

Cano, G. (1996). Más de un siglo de feminismo en México. Debate feminista, $14,345-360$.

Cánovas Leonhardt, P., \& Sahuquillo Mateo, P. (2008). La influencia del medio televisivo en el proceso de socialización de la infancia. Teoría de la Educación. Educación y Cultura en la Sociedad de la Información, 9(3), 200-215.

Cantú, M. A. L. (1993). Inventario de masculinidad - femineidad: IMAFE: manual. El Manual Moderno.

Capistran, G. (2013). La desigualdad a través del libro de texto: Análisis con perspectiva de género del libro de texto lecturas tercer grado de educación primaria, obligatorio en México. Eae.

Carbonell, J. (2001). La aventura de innovar: el cambio en la escuela. Madrid: Morata.

Carbonell, M. (2012). La reforma constitucional en materia de derechos humanos: principales novedades. Instituto de Investigaciones JurídicasUNAM. Recuperado a partir de http://eprints.uanl.mx/9219/1/1080215080.pdf

Cardona Duque, D. V., Ariza-Gerena, A., Gaona-Restrepo, C., \& Medina-Pérez, Ó. A. (2015). Conocimientos sobre sexualidad en adolescentes escolares en la ciudad de Armenia, Colombia. Revista Archivo Médico de Camagüey, 19(6), 568-576.

Caro Blanco, C. (2008). Un amor a tu medida. Estereotipos y violencia en las relaciones amorosas. Revista de Estudios de Juventud, (83), 213-228.

Carpizo, J. (2012). La Constitución mexicana y el derecho internacional de los derechos humanos. Anuario Mexicano de Derecho Internacional, 1(12), 801-858.

Carrillo Prieto, I. (1981). La Ilustración. En La ideología jurídica en la Constitución del Estado mexicano, 1812-1824 (pp. 13-49). Universidad Nacional Autónoma de México, Instituto de Investigaciones Jurídicas.

Casado Aparicio, E. (1999). A vueltas con el sujeto del feminismo. Politica y sociedad, 30, 73-91. 
Castellanos Llanos, G. (2011). El Feminismo Lésbico Dentro de la Teoría Política Feminista. Crítica Contemporane. Revista de Teoría Política, (1), 127-145.

Castillo González, F., \& Viveros García, C. (2013). La igualdad entre hombres y mujeres en la Constitución de Veracruz: la garantía de ley. Cuestiones constitucionales, (29), 411-432.

Castro Sandúa, M., Duque, E., \& Villarejo Carballido, B. (2016). Socialización preventiva y nuevas masculinidades. Cuadernos de pedagogía, (468), 5153.

CEAMEG. (2007). Los materiales de apoyo al trabajo legislativo: "género, mujeres: temas selectos" (Legislativo). H. Congreso de la Unión.: H. Congreso de la Unión. Cámara de Diputados LX Legislatura.

Celis García, Z. (2011). Libros de texto gratuitos en México. Vigencia y perspectivas. En Política y Gestión (Vol. XI, pp. 1-8). México D.F.: Consejo Mexicano de Investigación Educativa, A.C. Recuperado a partir de

http://www.comie.org.mx/congreso/memoriaelectronica/v11/docs/area_1 3/2420.pdf

Cerezal, F., \& Jiménez, C. (1990). Valores genéricos discriminatorios en textos de idiomas en EGB. Recuperado a partir de http://dspace.uah.es/dspace/handle/10017/582

Chabat, J. (2010). La respuesta del gobierno de Calderón al desafío del narcotráfico: entre lo malo y lo peor. En Seguridad nacional y seguridad interior (2010. ${ }^{\mathrm{a}}$ ed., Vol. 15, pp. 21-38). México D.F.: El colegio de México.

Chapado Sánchez, J. (2012). Desarrollo ciudadano desde la perspectiva de género: estudio comparado España-México (Doctoral). Universidad de Salamanca, Salamanca. Recuperado a partir de http://gredos.usal.es/xmlui/handle/10366/121355

Chávez Carpia, J. del C. (2004). Perspectiva de género (1 ${ }^{\mathrm{a}}$ ). México D.F.: Plaza y Valdez, S. A. de C. V.

Checa, S. (2005). Implicaciones del género en la construcción de la sexualidad adolescente. Anales de la educación común, (1-2), 183-193.

Christiansen, M. L. (2014). La violencia de la Antivilencia: Una crítica a la legislación mexicana contra la violencia de género. Psicología desde el Caribe, 31(3), 495-530. https://doi.org/10.14482/psdc.31.3.5552 
Cobo Bedia, R. (2004). El sistema sexo/genero. La construcción de la agenda Setting desde los medios. En P. López Díez (Ed.), Manual de información en género (pp. 7-11). Madrid: Instituto Oficial de Radio y Televisión, RTVE.

Cobo Bedia, R. (2005). El género en las ciencias sociales. Cuadernos de trabajo social, 18, 249-258.

Cobo Bedia, R. (2007). Globalización y nuevas servidumbres de las mujeres. En Teoría feminisa: de la ilustración a la globalización. De los debates sobre el género al multiculturalismo (2a ${ }^{\mathrm{a}}$,pp. 265-300). Madrid: Minerva Ediciones.

Cobo Bedia, R. (2008). Sociología crítica y teoría feminista, 21.

Cobo Bedia, R. (2014). Aproximaciones a la teoría crítica feminista $\left(1^{\mathrm{a}}\right)$. Perú: CLADEM. Recuperado a partir de http://www.cladem.org/pdf/Aproximaciones-a-la-teoria-critica.pdf

Colás Bravo, P. (2007). La construcción de la identidad de género: Enfoques teóricos para fundamentar la investigación e intervención educativa. Revista de Investigación Educativa, 25(1), 151-166.

Colás Bravo, P., \& Villaciervos Moreno, P. (2007). La interiorización de los estereotipos de género en jóvenes y adolescentes. Revista de Investigación Educativa, 25(1), 35-58.

CONAPO. (s/f). Proyecciones de la población de México - Tasa específica de fecundidad 1990/2030 - catalogo.datos.gob.mx [Institucional]. Recuperado 24 de febrero de 2017, a partir de https://datos.gob.mx/busca/dataset/proyecciones-de-la-poblacion-demexico/resource/cc508be6-9170-4685-b42bd7f138e1817e?inner_span=True

CONAPO (Ed.). (2013). La situación demográfica en México, 2013. México, D.F: Consejo Nacional de Población. Recuperado a partir de http://www.conapo.gob.mx/work/models/CONAPO/Resource/1727/1/im ages/La_Situacion_Demografica_de_Mexico_2013_COMPLETO.pdf

CONAPO, \& UNFPA. (2009). Informe de Ejecución Programa de Acción de la Conferencia Internacional sobre la Población y el Desarrollo 1994-2009. $C I P D+15$ (Institucional) (pp. 113-132). México: Consejo Nacional de Población. Recuperado a partir de http://www.conapo.gob.mx/es/CONAPO/Informe_de_Ejecucion_Progra ma_de_Accion_de_la_Conferencia_Internacional_sobre_la_Poblacion_y _el_Desarrollo_1994-2009 
Consejo Nacional de Población. (2012). Avances y retos en materia de igualdad de género en México (Institucional) (pp. 113-132). México. Recuperado a partir

http://www.conapo.gob.mx/work/models/CONAPO/Resource/205/1/ima ges/Cap05.pdf

Cooper, J. A. (2002). Feminismo y sindicalismo en México. ¿Dos versiones compatibles? En G. Gutiérrez Castañeda (Ed.), Feminismo en México. Revisión histórico-critica del siglo que termina (1 ${ }^{\mathrm{a}}$, pp. 97-116). México: Universidad Nacional Autónoma de México-PUEG.

Cortina, A. (1998). El poder comunicativo. Una propuesta intersexual frente a la violencia. En V. Fisas Armengol (Ed.), El sexo de la violencia: género y cultura de la violencia (pp. 27-41). Barcelona: Icaria Editorial.

Costa Aguirre, A. D. (2016). Estudio sobre las percepciones de género en adolescentes de $2^{\circ}$ de bachillerato de los colegios públicos mixtos de ecuador, a través del cuestionario IMAFE (inventario masculinidadfeminidad) (Doctoral). Universidad Nacional de Educación a Distancia. Facultad de Educación, Ecuador. Recuperado a partir de http://espacio.uned.es/fez/view/tesisuned:Educacion-Adcosta

Cubillas Rodríguez, J., Abril Valdez, E., Domínguez Ibáñez, S. E., Román Pérez, R., Hernández Montaño, A., \& Zapata Salazar, J. (2016). Creencias sobre estereotipos de género de jóvenes universitarios del norte de México. Diversitas: Perspectivas en Psicología, 12(2), 217-230. https://doi.org/10.15332/s1794-9998.2016.0002.04

De Barbieri, T. (1990). Sobre la categoría género. Una introducción teóricometodológica. Debate Feminista, 145-169.

De Barbieri, T. (1998). Género, una dimensión de la desigualdad social. Pensamiento Iberoamericano, 28, 7-11.

De las Heras Aguilera, S. (2009). Una aproximación a las teorías feministas. Universitas. Revista de Filosofía, Derecho y Política, 1(9), 45-82.

De Miguel Álvarez, A. (2007a). El feminismo en clave utilitarista ilustrada: John S. Mill y Harriet Taylor Mill. En C. Amorós \& A. de Miguel Álvarez (Eds.), Teoría feminista: de la Ilustración a la globalización. 1, De la Ilustración al segundo sexo (2a. ed, Vol. 1, pp. 178-243). Madrid: Minerva.

De Miguel Álvarez, A. (2007b). La articulación del feminismo y el socialismo: el conflicto clase-género. En C. Amorós \& A. de Miguel Álvarez (Eds.), 
Teoría feminista: de la Ilustración a la globalización. 1, De la Ilustración al segundo sexo (2a. ed, Vol. 1, pp. 297-332). Madrid: Minerva.

De Silva Gutiérrez, G. (2012). Jerarquía normativa de los Tratados Internacionales en México. El Foro, Decimoctava Época, tomo XXIV, número 2, segundo semestre de 2011. Themis, 32.

Del Palacio Montiel, C. (2015). La participación femenina en la Idependencia de México (pp. 69-92). México: Secretaría de Educación Pública-Instituto Nacional de Estudios Históricos de las Revoluciones de México. Recuperado a partir de

http://repository.uaeh.edu.mx/bitstream/handle/123456789/17297

Delgado Ballesteros, G. (1994). Libros de texto de primaria de la secretaria de educación publica y la situación de los géneros. En L. E. Galván Terrazas (Ed.), Memorias del Primer Simposio de Educación (pp. 183-198). CIESAS.

Delgado Ballesteros, G. (2003a). Educación y género. En M. Berteley Busquets (Ed.), Educación, Derechos Sociales y Equidad (Tomo II, Vol. 3). México D.F.: Consejo Mexicano de Investigación Educativa, A.C.

Delgado Ballesteros, G. (2003b). Educación y género. En M. Berteley Busquets (Ed.), Educación, Derechos Sociales y Equidad (Tomo II, Vols. 1- $\mathrm{N}^{\mathrm{o}} 3$, pp. 467-573). México D.F.: Consejo Mexicano de Investigación Educativa, A.C.

Díaz Martínez, C., \& Dema Moreno, S. (2013). Metodología no sexista en la investigación y producción del conocimiento. En Sociología y género (pp. 71-95).

Dietz, M. G., \& Olivares Mansuy, C. (2005). Las discusiones actuales de la teoría feminista. Debate Feminista, 32, 179-224.

Dio Bleichmar, E. (2010). The psychoanalyst's implicit theories of gender. En L. Glocer Fiorini \& G. Abelin-Sas Rose (Eds.), On Freud's Femininity (The International Psychoanalytical Association, p. 272). London: Karnac.

DOF, [Diario Oficial de la Federación]. Ley del Instituto Nacional de Mujeres (2001). Recuperado a partir de http://www.ordenjuridico.gob.mx/Publicaciones/CDs2006/CDSegSoc/pdf /AF10.pdf

DOF. Ley General para la Igualdad entre Mujeres y Hombres, Pub. L. No. DOF 14-11-2013, 17 (2006). Recuperado a partir de http://www.ordenjuridico.gob.mx/Documentos/Federal/pdf/wo17106.pdf 
DOF. Ley Federal para Prevenir y Eliminar la Discriminación (2007).

DOF. Ley General de Acceso de las Mujeres a una Vida Libre de Violencia (2007). Recuperado a partir de http://mail.uteq.edu.ec/handle/43000/174

DOF. Acuerdo número 592 por el que se establece la Articulación de la Educación Básica, $592 \S$ (2011). Recuperado a partir de http://dof.gob.mx/nota_detalle.php?codigo $=5205518 \&$ fecha=19/08/2011

DOF. DECRETO por el que se modifica la denominación del Capítulo I del Título Primero y reforma diversos artículos de la Constitución Política de los Estados Unidos Mexicanos. (2011). Recuperado a partir de http://www.dof.gob.mx/nota_detalle.php?codigo=5194486\&fecha=10/06/ 2011

DOF. Ley General para Prevenir, Sancionar y Erradicar los Delitos en Materia de Trata de personas y para la Protección y Asistencia a las Víctimas de estos Delitos (2012). Recuperado a partir de http://sil.gobernacion.gob.mx/Archivos/Documentos/2014/02/asun_3068 549_20140218_1392747545.pdf

DOF. ACUERDO número 689 por el que se establecen los lineamientos a que se sujetará el procedimiento de evaluación para autorizar el uso de obras destinadas a servir como libros de texto en las escuelas secundarias del Sistema Educativo Nacional que se sometan a consideración de la Secretaría de Educación Pública, 689 § (2013). Recuperado a partir de http://www.dof.gob.mx/nota_detalle.php?codigo=5307044\&fecha=17/07/ 2013

DOF. (2013b). Programa Nacional para la Igualdad de Oportunidades y no Discriminación contra las Mujeres 2013-2018 (Institucional) (p. 44). México: Secretaría de Gobernación-INMUJERES. Recuperado a partir de http://www.dof.gob.mx/nota_detalle.php?codigo=5312418\&fecha=30/08/ 2013

DOF. (2015). Orden Jurídico Nacional [Institucional]. Recuperado 13 de febrero de 2015, a partir de http://www.ordenjuridico.gob.mx/Constitucion/articulos.php

Dufort, L. (2011). El feminismo de Sor Juana Inés de la Cruz. Recuperado a partir de http://www.diva-portal.org/smash/record.jsf?pid=diva2:472769

El País. (2008, septiembre 17). Ocho muertos y un centenar de heridos en un ataque narcoterrorista en México. EL PAÍS. Recuperado a partir de http://elpais.com/diario/2008/09/17/internacional/1221602407_850215.ht $\mathrm{ml}$ 
Escartí, A., Musitu, G., \& Garcia, E. (1988). Estereotipos sexuales y roles sociales. En J. Fernández (Ed.), Nuevas perspectivas en el desarrollo del sexo y el género (1988. ${ }^{a}$ ed., pp. 205-225). Madrid: Pirámides.

Espigado, G. (2004). Historia y genealogía femenina a través de los libros de texto. En C. Rodríguez (Ed.), La ausencia de las mujeres en los contenidos escolares (pp. 113-145). Argentina: Niño y Dávila.

Espín López, J. V., Marín Gracia, M. A., \& Rodríguez Lajo, M. (2004). Análisis del sexismo en la publicidad. Revista de Investigación Educativa, 22(1), 203-231.

Espinar-Ruiz, E. (2003). Violencia de género y procesos de empobrecimiento: Estudio de la violencia contra las mujeres por parte de su pareja o expareja sentimental (Doctoral). Universidad de Alicante, Alicante. Recuperado a partir de http://rua.ua.es/dspace/handle/10045/9905

Espinoza Ornelas, R., Moya, M., \& Willis, G. B. (2015). La relación entre el miedo a la violación y el sexismo benévolo en una muestra de mujeres de Ciudad Juárez (México). Suma Psicológica, 22(2), 71-77. https://doi.org/10.1016/j.sumpsi.2015.09.001

Expósito, F., Moya, M. C., \& Glick, P. (1998). Sexismo ambivalente: medición y correlatos. Revista de Psicología social, 13(2), 159-169.

Faber, J., \& Scheper, W. J. (2003). Social Scientific Explanations? On Quine's legacy and contextual fallacies. Quality and Quantity, 37(2), 135-150.

Facio, A., \& Fries, L. (2005). Feminismo, género y patriarcado. Género y Derecho, 27.

Ferguson, A. (2003). Psicoanálisis y feminismo. Anuario de psicología, $34\left(\mathrm{~N}^{\mathrm{0}} 2\right), 163-176$.

Fernández Domingo, C. (2013). Sobre el concepto de patriarcado (Máster). Universidad de Zaragoza. Recuperado a partir de https://invenio2.unizar.es/record/10957/files/TAZ-TFM-2013-169.pdf

Fernández, J. (1987). Nuevas perspectivas en el desarrollo de la tipificación sexual y de género. Estudios de Psicología, 8(32), 45-69. https://doi.org/10.1080/02109395.1987.10821506

Fernández Poncela, A. (1998). Estudios sobre las mujeres, el género y el feminismo. Nueva Antropología, XVI(54), 79-95.

Fix-Zamudio, H. (2006). La creciente internacionalización de las constituciones iberoamericanas, especialmente en la regulación y protección de los Derechos Humanos. En XI Congreso Iberoamericano de Derecho Constitucional (pp. 583-673). Curitibam, Estado de Paraná, Brasil: 
Instituto de Investigaciones Jurídicas de la UNAM. Recuperado a partir de http://biblio.juridicas.unam.mx/libros/6/2895/20.pdf

Flick, U. (2004). Introducción a la investigación cualitativa. Madrid: Ediciones Morata y Fundación Paideia Galiza.

Flores Espínola, A. (2016, febrero 23). Metodología feminista: ¿una transformación de prácticas científicas? (Doctoral). Universidad Complutense de Madrid, Madrid. Recuperado a partir de http://www.tdx.cat/handle/10803/355886

Foucault, M. (1987). Historia de la sexualidad /. 2, El uso de los placeres (3a. ed en español, (1a. ed. España)). México; España: Siglo XXI.

Fraisse, G. (2005). Los contratiempos de la emancipación de las mujeres. Condición consecuencia, medida y astucia. Pasajes, (19), 16-23.

Freedman, J. (2004a). Feminismo. ¿Unidad o conflicto? Narcea Ediciones.

Freedman, J. (2004b). Feminismo. ¿Unidad o conflicto? Madrid: Narcea Ediciones.

Freyermuth-Enciso, M. G. (2014). Mortalidad materna en México. Inequidad institucional y desigualdad entre mujeres. En Á. Sánchez Bringas (Ed.), Desigualdades en la procreación. Trayectorias reproductivas, atención obstétrica y morbimortalidad materna en México (1 $\left.{ }^{\mathrm{a}}\right)$. México: Casa abierta al tiempo Universidad Autónoma Metropolitana. Recuperado a partir de http://www.omm.org.mx/images/stories/Documentos\%20grandes/Desigu aldades_en_la_procreacion._Trayect.pdf

Freyermuth-Enciso, M. G., \& Luna, M. (2011). Observatorio de mortalidad materna en México (Institucional No. 2) (p. 52). México: Dirección General de Información en Salud, Secretaría de Salud, México. Recuperado a partir de http://www.omm.org.mx/images/stories/Documentos\%20grandes/Indicad ores2012octubre29.pdf

Freyermuth-Enciso, M. G., \& Luna, M. (2013). Observatorio de mortalidad materna en México (Institucional No. 2) (p. 66). México: Dirección General de Información en Salud, Secretaría de Salud, México. Recuperado a partir de http://www.omm.org.mx/images/stories/Documentos\%20grandes/Indicad ores2012octubre29.pdf

Freyermuth-Enciso, M. G., \& Luna, M. (2014). Indicadores 2012. Objetivo de Desarrollo del Milenio 5: Avances en México (Institucional) (p. 88). 
México: Centro de Investigaciones y Estudios Superiores en Antropología Social (CIESAS). Recuperado a partir de http://www.omm.org.mx/images/stories/Documentos\%20grandes/Indicad ores2012octubre29.pdf

Fuertes, A., Carpintero, E., Martínez, J. L., Soriano, S., \& Hernández, A. (1997). Factores predictores de la autoestima con los iguales y de la intimidad relacional en la adolescencia. Revista de Psicología Social, 12(1), 113-127. https://doi.org/10.1174/021347497320892063

Gamba, S. (2008). Feminismo: historia y corrientes. Gamba, S. Diccionario de estudios de Género y Feminismos. Editorial Biblos, 1-8.

García Alcaraz, J. G. (2016). Narrando la identificación feminista: la transición del ser para otros al ser para sí mismas (Máster). Colegio de la Forntera Norte, Tijuana, B. C. Recuperado a partir de https://colef.repositorioinstitucional.mx/jspui/handle/1014/471

García Guevara, P. (2004). Mujeres académicas: el caso de una universidad estatal mexicana (1a. ed). México, D.F: Plaza y Valdés.

García Pérez, R., Rebollo Catalán, M. A., Buzón García, O., González-Piñal, R., Barragán Sánchez, R., \& Ruíz Pinto, E. (2010). Actitudes del alumnado hacia la igualdad de género. Revista de Investigación Educativa, 28(1), 217-232.

García Vega, E., Menéndez Robledo, E., Fernández García, P., \& Cuesta Izquierdo, M. (2012). Sexualidad, anticoncepción y conducta sexual de riesgo en adolescentes. International journal of psychological research, 5(1), 79-87.

García-Vega, E., Menéndez Robledo, E., García Fernández, P., \& Rico Fernández, R. (2010). Influencia del sexo y del género en el comportamiento sexual de una población adolescente. Psicothema, 22(4), 606-612.

Garreta, N., \& Careaga, P. (1987a). Modelos masculino y femenino en los textos de E.G.B. Madrid.

Garreta, N., \& Careaga, P. (Eds.). (1987b). Modelos masculino y femenino en los textos de EGB. Madrid: Instituto de la Mujer.

Gil Flores, J. (1992). La metodología de investigación mediante grupos de discusión. Enseñanza \& Teaching: Revista interuniversitaria de didáctica, $\left(\mathrm{N}^{\mathrm{o}} 10-11\right), 199-214$.

Gil, S. L. (2013). Perspectivas teóricas feministas. Feminismos contemporáneos en la crisis del sujeto. Hacia una política de lo común. En C. Díaz 
Martínez \& S. Dema Moreno (Eds.), Sociología y género (pp. 16-43). Madrid: Tecnos.

Gil Villa, F. (2013). Discursos sobre corrupción en México. Sociedad y Equidad: Revista de Humanidades, Ciencias Sociales, Artes y Comunicaciones, (5), 259-275.

Girón, A., González Marín, M. L., \& Jiménez, A. V. (2008a). Breve historia de la participación política de las mujeres en México. En M. L. González Marín \& P. Rodríguez López (Eds.), Límites y desigualdades en el empoderamiento de las mujeres en el PAN, PRI y PRD (pp. 33-61). Distrito Federal, México: Miguel Ángel Porrúa. Recuperado a partir de http://ru.iiec.unam.mx/1774/

Girón, A., González Marín, M. L., \& Jiménez, A. V. (2008b). Breve historia de la participación política de las mujeres en México. En M. L. González Marín \& P. Rodríguez López (Eds.), Límites y desigualdades en el empoderamiento de las mujeres en el PAN, PRI y PRD (pp. 33-61). Distrito Federal, México: Miguel Ángel Porrúa. Recuperado a partir de http://ru.iiec.unam.mx/1774/

Glick, P., \& Fiske, S. T. (1996). The ambivalent sexism inventory: Differentiating hostile and benevolent sexism. Journal of personality and social psychology, 70(3), 491.

Gobierno de la República. (2013a). Decreto por el que se aprueba el Programa Nacional para la Igualdad de Oportunidades y no Discriminación contra las Mujeres (Institucional No. 22) (p. 56). Ciudad de México: Diario Oficial de la Federación. Recuperado a partir de http://dof.gob.mx/nota_detalle.php?codigo $=5312418 \&$ fecha=30/08/2013

Gobierno de la República. (2013b). Decreto por el que se aprueba el Programa sectorial de educación 2013-2018 (Institucional No. 22) (p. 56). Ciudad de México: Diario Oficial de la Federación. Recuperado a partir de http://pnd.gob.mx/

Gobierno de la República. (2013c). Plan Nacional de Desarrollo (Institucional No. 22) (p. 56). Ciudad de México: Gobierno de la Reública. Recuperado a partir de http://pnd.gob.mx/wp-content/uploads/2013/05/PND.pdf

Gobierno del Estado de Michoacán. (2015). Sistema de Justicia Penal Michoacán [Institucional]. Recuperado 1 de marzo de 2015, a partir de http://www.justiciapenalmichoacan.gob.mx/

Gobierno del Estado de Michoacán, \& INEGI. (2012). Anuario estadístico de Michoacán de Ocampo 2012 (Estadístico). Coordinación de planeación 
para el desarrollo del Gobierno del Estado y la Dirección regional occidente del INEGI. Recuperado a partir de http://www.inegi.org.mx/est/contenidos/espanol/sistemas/aee12/estatal/m ich/default.htm

Goetschel, A. M. (2007). Educación de las mujeres, maestras y esferas públicas. Quito en la primera mitad del siglo XX $\left(1^{\mathrm{a}}\right)$. Ecuador: FLACSO Ecuador- Abya-Yala. Recuperado a partir de http://digitalrepository.unm.edu/cgi/viewcontent.cgi?article=1173\&conte $\mathrm{xt}=$ abya_yala

Gómez-Carrasco, C. J., \& Gallego-Herrera, S. (2016). La pervivencia de estereotipos de género en la enseñanza de la historia. Un estudio a través de libros de texto y las percepciones del alumnado de educación secundaria en España. Revista Electrónica Educare, 20(3), 1-28. https://doi.org/10.15359/ree.20-3.1

González Astudillo, M. T., \& Sierra Vázquez, M. (2004). Metodología de análisis de libros de texto de matemáticas. Los puntos críticos en la enseñanza secundaria en la enseñanza secundaria en España durante el siglo XX. Enseñanza de las ciencias, 22(3), 389-408.

González Jiménez, R. M. (2009). Estudios de género en educación: Una rápida mirada. Revista mexicana de investigación educativa, 14(42), 681-699.

González Jiménez, R. M. (2013). Paradojas de trabajar género en educación: algunas reflexiones acerca de la formación o cómo salir del gatopardo. En J. L. Silva Méndez (Ed.), Género y educación: aportes para la discusión jurídica (pp. 1-32). Instituto Sinaloense de las Mujeres-Fontamara. Recuperado a partir de http://ismujeres.gob.mx/genero-y-educacionaportes-para-la-discusion-juridica/

González Ramírez, M. de los Á., \& Villaseñor García, M. L. (2010). La perspectiva de género en el sistema educativo de Jalisco: Bases para la acción. Revista de Educación y Desarrollo, 14, 23-29.

González Suárez, M. (2005). Del sexismo a la igualdad de oportunidades en la educación. En L. Fernández Ruis (Ed.), Género, valores y sociedad. Barcelona: Octaedro-OEI. Recuperado a partir de http://www.dgespe.sep.gob.mx/public/genero/PDF/GEN\%20O1/G_01_0

9_Del\%20sexismo\%20a\%20la\%20igualdad.pdf

Gorard, S., \& Taylor, C. (2004). Combining Methods in Educational and Social Research. Open University Press., 207. 
Grajales Valdespino, C. (2004). Sexualidad y género. En Perspectiva de género (1 ${ }^{\text {a }}$, pp. 99-109). México D.F.: Plaza y Valdez, S. A. de C. V.

Guerrero Gutiérrez, E. (2010, noviembre 1). Cómo reducir la violencia en México. Nexos. Recuperado a partir de http://www.nexos.com.mx/?p=13997

Guerrero Gutiérrez, E. (2014, julio 1). El dominio del miedo. Nexos. Recuperado a partir de http://www.nexos.com.mx/?p=21671

Guibourg García, I. (1992). La construcción de la identidad. Infancia: educar de 0 a 6 años, (16), 35-37.

Gutiérrez Castañeda, G. (2002a). Breves reflexiones sobre la historia de una incomodidad. O de las encrucijadas, retrocesos y mutaciones teóricopolíticas del feminismo en México. En G. Gutiérrez Castañeda (Ed.), Feminismo en México. Revisión histórico-critica del siglo que termina (1 ${ }^{\text {a }}$, pp. 199-215). México: Universidad Nacional Autónoma de MéxicoPUEG.

Gutiérrez Castañeda, G. (Ed.). (2002b). Feminismo en México. Revisión histórico-crítica del siglo que termina $\left(1^{\mathrm{a}}\right)$. México: Universidad Nacional Autónoma de México-PUEG.

Gutiérrez Esteban, P., \& Luengo González, M. R. (2011). Los feminismos en el siglo XXI: Pluralidad de pensamientos. Brocar: Cuadernos de investigación histórica, (35), 335-351.

Guzmán, V. (1997). La equidad de género como tema de debate y de políticas públicas. Revista Feminismo en transición, 213-230.

H. Congreso de la Unión. (2014). Necesario perfeccionar Ley General de Acceso de las Mujeres a una Vida Libre de Violencia (Boletín No. 4620). México D.F.: H. Congreso de la Unión. Cámara de Diputados. Recuperado a partir de http://www5.diputados.gob.mx/index.php/esl/Comunicacion/Boletines/20 14/Noviembre/12/4620-Necesario-perfeccionar-Ley-General-de-Accesode-las-Mujeres-a-una-Vida-Libre-de-Violencia

H. Congreso del Estado de Michoacán de Ocampo. (2012). Legislatura LXXII H. Congreso del Estado de Michoacán de Ocampo [Institucional]. Recuperado a partir de http://transparencia.congresomich.gob.mx/historial-lxxii/

Harding, S. G. (1987). Introduction: Is there a feminist method? En S. G. Harding (Ed.), Feminism and Methodology: Social Science Issues. Bloomington: Indiana University Press. Bloomington and Indianapolis. 
Harding, S., \& Norberg, K. (2005). New Feminist Approaches to Social Science Methodologies: An Introduction. Signs: Journal of Women in Culture and Society, 30(4), 2009-2015. https://doi.org/10.1086/428420

Hernández García, Y. (2006). Acerca del género como categoría analítica. Nómadas. Revista Crítica de Ciencias Sociales y Jurídicas, 13(1), 111120. https://doi.org/10.5209/NOMA.27811

Hernández Sampieri, R., Fernández Collado, C., \& Baptista Lucio, P. (2006). Metodología de la investigación (cuarta). México D.F.: McGraw-Hill.

Hierro, G. (2002). Madres simbólicas del feminismo en México. En G. Gutiérrez Castañeda (Ed.), Feminismo en México. Revisión históricocritica del siglo que termina (1 ${ }^{\mathrm{a}}$, pp. 27-38). México: Universidad Nacional Autónoma de México-PUEG.

Illades, C., \& Santiago, T. (2015). Estado de guerra: De la guerra sucia a la narcoguerra. Ediciones Era.

I.M.O.P. Encuestas (Ed.). (2000). La transmisión de los modelos femenino y masculino en los libros de la enseñanza obligatoria. Madrid: Instituto de la Mujer.

IMUJERES (2012). Políticia Nacional de Igualdad entre mujeres y hombres (Institucional No. 2007-2012) (p. 125). México: IMUJERES. Recuperado a partir de http://cedoc.inmujeres.gob.mx/documentos_download/101207.pdf

INEE (2016). La educación obligatoria en México. Informe 2016 (Institucional No. 978-607-7675-87-7) (p. 282). Ciudad de México: Instituto Nacional para la Evaluación de la Educación. Recuperado a partir de http://publicaciones.inee.edu.mx/buscadorPub/P1/I/241/P1I241.pdf

INEGI. (2008). Las mujeres en Michoacán de Ocampo. Estadísticas sobre desigualdad y violencia contra las mujeres. (Institucional) (p. 46). Michoacán de Ocampo: Instituto Nacional de Estadística y Geografía (INEGI)). Recuperado a partir de http://www.diputados.gob.mx/documentos/Congreso_Nacional_Legislati vo/delitos_estados/La_mujer_Mich.pdf

INEGI. (2011). Panorama sociodemográfico de Michoacán de Ocampo. (Censo de Población y Vivienda) (p. 247). México D.F. Recuperado a partir de https://www.google.es/?gws_rd=ssl\#q=panorama+sociodemografico+de+ michoacan

INEGI. (2012a). Estadísticas de Natalidad. Recuperado a partir de http://www3.inegi.org.mx/sistemas/sisept/Default.aspx?t=mdemo29\& 
INEGI. (s. f.). México en Cifras. Recuperado 16 de febrero de 2015, a partir de http://www3.inegi.org.mx/sistemas/mexicocifras/default.aspx?e=16

INEGI (2012b). Anuario de estadísticas por entidad federativa 2012 (Institucional No. XIII) (p. 666). México D.F.: INEGI y Gobierno del Estado de Michoacán. Recuperado a partir de http://www3.inegi.org.mx/sistemas/biblioteca/ficha.aspx?upc=702825003 406

INEGI (2013). Anuario de estadístico y geográfico por entidad federativa 2013 (Institucional) (p. 774). México D.F.: INEGI. Recuperado a partir de http://www3.inegi.org.mx/sistemas/biblioteca/ficha.aspx?upc=702825003 406

INEGI (2014). Anuario estadístico y geográfico de Michoacán de Ocampo 2014 (Institucional) (p. 657). México D.F.: INEGI y Gobierno del Estado de Michoacán. Recuperado a partir de http://www.datatur.sectur.gob.mx/ITxEF_Docs/MICH_ANUARIO_PDF. pdf

INEGI \& INMUJERES (2013). Mujeres y hombres en México 2012 (Institucional) (p. 169). México: INEGI-IMUJERES. Recuperado a partir de http://cedoc.inmujeres.gob.mx/documentos_download/101215.pdf

INMUJERES (2009). Desarrollo Local con igualdad de género (Vol. I). México: Instituto Nacional de las Mujeres.

INMUJERES, SEGOB, \& SIG (2017). Michoacán de Ocampo (Institucional) (p. 5). México: INMUJERES-SEGOB-SIG. Recuperado a partir de http://estadistica.inmujeres.gob.mx/formas/panorama_general.php?menu1 $=1 \&$ IDTema $=1 \&$ pag $=1$

Instituto de la Mujer, \& Red2Red Consultores. (2004). Estudio para conocer la situación actual de la educación para la igualdad en España (Final) (p. 205). España: Ministerio de Trabajo y Asuntos Sociales.

Instituto Nacional de las Mujeres. (2008). Compilación de los principales instrumentos internacionales sobre derechos humanos de las mujeres. INMUJERES. Recuperado a partir de http://cedoc.inmujeres.gob.mx/documentos_download/100911.pdf

Itatí, A. (1995). Socialización de género en la escuela primaria. Boletín americanista, (45), 177-187.

Izquierdo, M. J. (1998). El malestar en la desigualdad. Madrid: Cátedra. 
Izquierdo, M. J. (2013). La socialización del género. La construcción social del género. En C. Díaz Martínez \& S. Dema Moreno (Eds.), Sociología y género (pp. 96-122). Tecnos.

Jiménez Valdez, E. I. (2014). Mujeres, narco y violencia: resultados de una guerra fallida. El colegio de Sonora, 100-128.

Ladrón De Guevara Benítez, M. B. (2009). La violencia simbólica en las imágenes de los libros de texto del tercer ciclo de educación primaria en la construcción del género (Maestría en pedagogía). Universidad Nacional Autónoma de México, Estado de México. Recuperado a partir de http://132.248.9.195/ptd2009/septiembre/0649503/0649503.pdf

Lagarde, M. (1996). Género y feminismo: desarrollo humano y democracia. Madrid: Horas y Horas.

Lagarde, M. (2013). El derecho humano de las mujeres a una vida libre de violencia. En V. Maquieira (Ed.), Mujeres, globalización y derechos humanos (1a. ed, pp. 345-381). Madrid: Cátedra.

Lagarde y de los Ríos, M. (2007). Por los derechos humanos de las mujeres: la Ley General de Acceso de las Mujeres a una Vida Libre de Violencia. Revista Mexicana de Ciencias Políticas y Sociales, 49( $\left.\mathrm{N}^{\circ} 200\right), 143-165$.

Lamas, M. (1986). La antropología feminista y la categoría «género». Nueva Antropología, VIII(30), 173-198.

Lamas, M. (1995, diciembre). Perspectiva de género. Revista de Educación y Cultura de la sección 47 del SNTE, (8), 14-20.

Lamas, M. (1999). Usos, dificultades y posibilidades de la categoría género. Papeles de Población, 5( $\left.\mathrm{N}^{\mathrm{o}} 21\right), 147-178$.

Lamas, M. (2000). Diferencias de sexo, género y diferencia sexual. Cuicuilco, $7\left(\mathrm{~N}^{\mathrm{o}} 18\right), 25$.

Lamas, M. (2002). Fragmentos de una autocrítica. En G. Gutiérrez Castañeda (Ed.), Feminismo en México. Revisión histórico-critica del siglo que termina (1 ${ }^{\text {a }}$, pp. 71-82). México: Universidad Nacional Autónoma de México-PUEG.

Lamas, M. (2016). Mujeres guerrerenses: Feminismo y política. Revista Mexicana de Ciencias Politicas y Sociales, 61(226), 409-424. https://doi.org/10.1016/S0185-1918(16)30016-2

Lameiras, M., \& Rodríguez, Y. (2002). Evaluación del sexismo moderno en adolescentes. Revista de Psicología Social, 17(2), 119-127. https://doi.org/10.1174/021347402320007555 
Lapatí Escalante, P., \& González Del Pliego, E. (2015). Visibilización de las mujeres en los libros de texto gratuitos de historia: una mirada etiológica al caso de secundaria en méxico. En A. M. Hernández Carretero, C. R. García Ruiz, \& J. L. De la Montaña Conchiña (Eds.), Una enseñanza de las ciencias sociales para el futuro: Recursos para trabajar la invisibilidad de personas, lugares y temáticas (pp. 223-230). Cáceres: Universidad de Extremadura, Asociación Universitaria de Profesores de Didáctica de las Ciencias Sociales. Recuperado a partir de https://dialnet.unirioja.es/servlet/libro?codigo=570009

Lara Flores, S. M. (1991). Sexismo e identidad de género. Alteridades, 1(2), 2429.

Larrañaga, M., Jubeto, Y., \& De la Cal, M. L. (2011). Tiempos de crisis, tiempos de des-ajustes, tiempos precarios, tiempos de mujeres. Investigaciones Feministas, 2, 95-111.

Larrañaga Sarriegui, M. (s/f). Análisis teóricos de la desigualdad área temática 3. Economía feminista. Recuperado a partir de http://pendientedemigracion.ucm.es/info/ec/jec7/pdf/com3-6.pdf

Larrañaga Sarriegui, M., \& Jubeto Ruiz, Y. (2012). Reflexiones entorno a Género y Desarrollo. Boletín del Centro de Documentación Hegoa, (30), $1-6$.

Lau Jaiven, A. (1987). La nueva ola del feminismo en méxico. México: Planeta. Recuperado a partir de https://books.google.es/books/about/La_Nueva_Ola_Del_Feminismo_en_ M\%C3\%A9xico.html?hl=es\&id=wuIpAAAAYAAJ

Lau Jaiven, A. (2006). El feminismo mexicano: balances y perspectivas. En N. Lebon \& E. Maier (Eds.), De lo privado a lo público: 30 años de lucha ciudadana de las mujeres en América Latina (pp. 181-194). Siglo XXI.

Leñero Llaca, M. (2011). Equidad de género y prevención de la violencia en secundaria. (S. de E. P. SEP \& P. U. de E. de G. PUEG, Eds.). México: Secretaría de Educación Pública.

Llorca Llinares, M. (2007). Flexibilidad y rigidez en los roles de género. En A. Vega Navarro (Ed.), Mujer y educación: una perspectiva de género (pp. 79-90). Archidona: Aljibe.

Llorent-Bedmar, V., \& Cobano-Delgado Palma, V. (2014). La mujer en los libros de texto de bachillerato en España. Cadernos de Pesquisa, 44(151), 156-175. https://doi.org/10.1590/198053142752 
Lomas, C. (2002). El sexismo en los libros de texto. En C. Lomas (Ed.), Mujer y Educación. Educar para la igualdad, educar desde la diferencia (pp. 192-222). Barcelona: Grao.

Lomas, C. (2008). El otoño del patriarcado?: luces y sombras de la igualdad entre mujeres y hombres. Barcelona: Península.

López de la Vieja, M. T. (2015). Igualdad en el Tercer Sector. Revista española del tercer sector, (30), 129-142.

López, F. (1988a). Adquisición y desarrollo de la identidad sexual y de género. En J. Fernández (Ed.), Nuevas perspectivas en el desarrollo del sexo y el género (1988. ${ }^{\text {a }}$ ed., pp. 45-69). Madrid: Pirámides.

López, F. (1988b). Adquisición y desarrollo de la identidad sexual y de género. En J. Fernández (Ed.), Nuevas perspectivas en el desarrollo del sexo y el género. Madrid: Pirámides.

López Ojeda, E. (2007). Pautas de observación y análisis del sexismo. Los materiales educativos. Linterlingüística, (17), 630-639.

López Rodríguez, F. (Ed.). (2002). Género y educación: la escuela coeducativa (1a. ed). Barcelona: Graó.

López Valero, A., \& Encabo Fernández, E. (1999). El lenguaje del centro educativo, elemento impulsor de la igualdad de oportunidades entre géneros: la formación permanente de la comunidad educativa. Contextos Educativos, 2, 181-192.

López-Navajas, A. (2010). La ausencia de las mujeres en los contenidos de la ESO: una propuesta de inclusión. II Congrés Internacional de Didàctiques, Girona, 3-6 febrero. Recuperado a partir de http://dugidoc.udg.edu:8080/handle/10256/2780

López-Navajas, A. (2014). Análisis de la ausencia de las mujeres en los manuales de ESO: una genealogía de conocimiento ocultada. Revista de Educación, (363), 282-308.

López-Navajas, A. (2015). La presencia de las mujeres en los contenidos de la enseñanza secundaria obligatoria. En A. Maldonado Acevedo, L. Laureano Domínguez, \& C. Masa González (Eds.), Experiencias de género (1. a ed.). Hueva: Universidad de Hueva.

Luengo Gónzalez, M. R., \& Blázquez Entonado, F. (2004). Género y libros de texto. Un estudio de estereotipos en las imágenes (Junta de Extremadura. Instituto de la Mujer de Extremadura). Badajoz, Esp.: INEX. 
Maldonado Aranda, S. (2012). Drogas, violencia y militarización en el México rural. El caso de Michoacán. Revista Mexicana de Sociología, 2012(1), 36.

Maldonado Barahona, T. (2013a). Apuntes para una introducción a la teoría feminista. En C. Díaz Martínez \& S. Dema Moreno (Eds.), Sociología y género (pp. 16-43). Madrid: Tecnos.

Maldonado Barahona, T. (2013b). Perspectivas teóricas feministas. Apuntes para una introducción a la teoría feminista. En C. Díaz Martínez \& S. Dema Moreno (Eds.), Sociología y género (pp. 16-43). Madrid: Tecnos.

Malkin, V. (2001). Narcotráfico, migración y modernidad. En La tierra caliente de Michoacán (pp. 549-584). El Colegio de Michoacán A.C.

Malonda Vidal, E. (2014). El sexismo en la adolescencia. Factores psicosociales moduladores (Doctoral). Universitat de València, Valencia. Recuperado a partir de http://roderic.uv.es/handle/10550/36213

Manassero, M. A., \& Vázquez, Á. (2002b). Los estereotipos de género y el lenguaje en los libros de texto de ciencias. Cultura y Educación, 14(4), 415-429. https://doi.org/10.1174/113564002762700880

Maquieira, V. (2013). Género, cultura y desigualdad. En V. Maquieira (Ed.), Mujeres, globalización y derechos humanos (1a. ed, pp. 33-73). Madrid: Cátedra.

Martín Bardera, S. (2015). Concepto de género: de las teorías feministas a las políticas públicas. La universidad pública española como estudio de caso (Doctoral). Universidad de Salamanca, Salamanca. Recuperado a partir de https://dialnet.unirioja.es/servlet/tesis?codigo=54485

Martínez Benlloch, I., Bonilla Campos, A., Gómez Sánchez, L., \& Bayot, A. (2008). Identidad de género y afectividad en la adolescencia: asimetrías relacionales y violencia simbólica. Anuario de psicología/The UB Journal of psychology, 39(1), 109-118.

Martínez, R. A., \& Egido, L. T. (2009). Género, educación y formación del profesorado: retos y posibilidades. Revista interuniversitaria de Formación del profesorado, (64), 17-26.

Martínez Sánchez, I., Navarro Olivas, R., \& Yubero Jiménez, S. (2009). Estereotipos de género entre los adolescentes españoles: imagen prototípica de hombres y mujeres e imagen de uno mismo. Información psicológica, (95), 77-86. 
Matamala Sáez, M. L., \& Rodríguez Torres, M. C. (2010). Estudio exploratorio sobre la identidad de género de hombres adolescentes pertenecientes al sector barrio norte de concepción. Ultima década, 18(33), 61-84.

Mena, L., \& Murillo, S. (2006). Detectives y camaleones: el grupo de discusión: Una propuesta para la investigación cualitativa $\left(1^{\mathrm{a}}\right)$. Salamanca: Talasa.

Méndez Pérez, L. (2008). Antropología feminista. Madrid: Síntesis.

Mercado Vargas, H., \& Palmerín Cerna, M. (2012). El Estado de Michoacán y sus características. En El Estado de Michoacán y sus regiones turísticas (pp. 28-61). Fundación Universitaria Andaluza Inca Garcilaso. Recuperado a partir de http://www.eumed.net/librosgratis/2012b/1230/michoacan-caracteristicas.html

Messina, G. (2001). Estado del arte de la igualdad de género en la educación básica de América Latina (1990-2000). En G. UNESCO (Ed.), Igualdad de género en la educación básica de América Latina y el Caribe (pp. 1144). Santiago: UNESCO para América Latina y el Caribe.

Mestre Chust, J. V., \& Mayos Solsona, G. (2007). Los derechos humanos. Barcelona: Editorial UOC.

Mínguez, J. G., \& Beas, M. (1995). Análisis histórico del libro de texto. En Libro de texto y construcción de Materiales Curriculares (Proyecto Sur, pp. 13-46). Granada.

Ministerio de Educación, Cultura y Deporte. (s/f). Educación en igualdad. Diagnóstico general. (Informe previo) (p. 205). Madrid: Instituto de la Mujer y para la Igualdad de Oportunidades (Ministerio de Sanidad, Servicios Sociales e Igualdad). Recuperado a partir de http://www.inmujer.gob.es/areasTematicas/educacion/programas/docs/Di agnosticoPrevio.pdf

Minte, A. R. (2010). La imagen de las mujeres en los textos escolares de Historia de Chile. Análisis crítico. En Congreso Iberoamericano de Educación Metas 2021 (Vol. 2021, pp. 1-13). Buenos Aires, República de Argentina. Recuperado a partir de http://www.adeepra.org.ar/congresos/Congreso\%20IBEROAMERICAN O/MUJERYEDUCACION/RLE2408_Minte.pdf

Minte Münzenmayer, A. R., \& González, E. (2015). Discriminación y exclusión de las mujeres en los textos escolares chilenos y cubanos de Historia. Revista de Investigación Educativa, 33(2), 321. https://doi.org/10.6018/rie.33.2.196231 
Miranda Santana, C. (2004). Un instrumento para el análisis de los libros de texto desde una orientación sociolaboral no sesgada. REOP-Revista Española de Orientación y Psicopedagogía, 15(1), 143-153.

Miyares, A. (2007). El sufragismo. En C. Amorós \& A. de Miguel Álvarez (Eds.), Teoría feminista: de la Ilustración a la globalización. 1, De la Ilustración al segundo sexo (2a. ed, Vol. 1, pp. 247-293). Madrid: Minerva.

Molina, C. (2003). Género y poder desde sus metáforas. Apuntes para una topografía del patriarcado. En S. Tubert (Ed.), Del sexo al género. Los equívocos de un concepto ( $1^{\mathrm{a}}$, pp. 123-158). Madrid: Feminismos, Ediciones Cátedra, Universitat de Valéncia, Instituto de la Mujer.

Moloeznik, M. P. (2008). Luis Astorga, Seguridad, traficantes y militares. (El poder y la sombra.) Tiempo de Memoria. Estudios fronterizos, 9(17), 189-195.

Monroy, A. (2002). La sexualidad en la adolescencia. En Salud y sexualidad en la adolescencia y juventud (pp. 69-93). México D.F.: Pax.

Montero, J. (2006). Feminismo: un movimiento crítico. Psychosocial Intervention, 15(2), 167-180.

Montes de Oca Navas, E. (2015). Las mujeres mexicanas durante el gobierno de Lázaro Cárdenas, 1934-1940. Revista Historia de la Educación Latinoamericana, 17(24), 149-166.

Mora, L. (2006). Igualdad y equidad de género: aproximación teóricoconceptual (p. 143). Equipo de Apoyo Técnico para América Latina y Caribe Fondo de Población de Naciones Unidas (UNFPA).

Morales Garza, R. (Ed.). (2014). Plan de estudios 2011. Educación básica (3 $\left.{ }^{\mathrm{a}}\right)$. México: Secretaría de Educación Pública. Recuperado a partir de https://www.mysciencework.com/publication/show/7d32055395e4280cd 2616facdd830705

Morales Hernández, R. (2002). Violencia familiar. Revista Mexicana de Justicia, sexta época(2), 127-141.

Moreno Llaneza, M. (2016). Cómo hemos cambiado... ¿o no? Cuadernos de pedagogía, (468), 44-46.

Morgado, J. C. (2004). Manuais escolares: Contributo para uma análise. Portugal: Porto.

Morin-Messabel, C., Ferrière, S., Lainé, A., Mieyaa, Y., \& Rouyer, V. (2016). Representações das categorias de sexo em crianças no contexto escolar. 
Cadernos de Pesquisa, 46(160), 526-546. https://doi.org/10.1590/198053143624

Mosteiro García, M. J., \& Porto Castro, A. M. (2016). Análisis de los estereotipos de género en alumnado de formación profesional: diferencias según sexo, edad y grado. Revista de Investigación Educativa, 35(1), 151-165.

Muñoz Tinoco, M. V., Jiménez Lagares, I., \& Moreno Rodríguez, M. C. (2008). Reputación conductual y género en la adolescencia. Anales de Psicología/Annals of Psychology, 24(2), 334-340.

Narro Robles, J., Martuscelli Quintana, J., \& Barzana García (Eds.). (2012). Plan de diez años para desarrollar el Sistema Educativo Nacional ([En línea] $1^{\text {a }}$ ). México: Dirección General de Publicaciones y Fomento Editorial, UNAM. Recuperado a partir de http://www.planeducativonacional.unam.mx/CAP_07/Text/07_03a.html

Nava Balcázar, P., Gonález-Arraita López-Fuentes, N. I., Gurriola Peña, G. M., \& Moysén Chimal, A. (2005). Investigación cualitativa $\left(2^{\mathrm{a}}\right)$. México D.F.: Universidad Autónoma del Estado de México.

Nava Hernández, E. (1987). Cultura política y política popular en Michoacán. Notas para su estudio. El colegio de Michocán, ( $\left.\mathrm{N}^{\mathrm{o}} 31\right)$, 25-60.

Nava Saucedo, D. C., \& López Álvarez, M. G. (2010). Educación y discriminación de género. El sexismo en la escuela primaria. Un estudio de caso en Ciudad Juárez. El Cotidiano. Recuperado a partir de http://sociales.redalyc.org/articulo.oa?id=32515894007

Nehring, D. (2005). Reflexiones sobre la construcción cultural de las relaciones de género en México. Papeles de población, 11(45), 221-245.

Ochoa Avalos, M. C. (2004). El derecho al voto, un paso hacia la ciudadanía de las mujeres. Revista de Estudios de Género. La ventana, (19), 182-194.

Oikión Solano, V. (2012). Los márgenes del Estado mexicano: Territorios ilegales, desarrollo y violencia en Michoacán. Política y cultura, (37), 331-335.

Oliva Portolés, A. (2007). Debates sobre el género. En C. Amorós \& A. De Miguel (Eds.), Teoría feminista: de la Ilustración a la globalización. De los debates sobre el género al multiculturalismo (2a, Vol. 3, pp. 13-60). Madrid: Minerva Ediciones.

Orozco Henríquez, J. de J. (2011). Los derechos humanos y el nuevo artículo $1^{\circ}$ constitucional. Revista IUS, 5(28), 85-98. 
Osuna, E. (2003). Comprensión de las diferencias de género. En M. D. Villuendas \& Á. J. Gordo López (Eds.), Relaciones de género en psicología y educación (pp. 111-118). Madrid: Comunidad de Madrid, Dirección General de Promoción Educativa.

Padilla Carmona, T., Sánchez García, M., Martín Berrido, M., \& Moreno Sánchez, E. (1999). Análisis de los estereotipos sexistas en una muestra de estudiantes de $\mathrm{CC}$. de la educación. 2Revista de Investigación Educativa, 17(1), 127-147.

Paladines Escudero, C. (1996). Historia de la educación y el pensamiento pedagógico ecuatoriano. El pensamiento pedagógico ilustrado (Vol. I). Quito-Ecuador: Editorial Abya Yala.

Parga Romero, L. (2008). La construcción de los estereotipos del género femenino en la escuela secundaria. UPN. Recuperado a partir de file:///C:/Users/PC/Downloads/la-construccion-deestereotipos\%20(3).pdf

Pastor Carballo, R., \& Bonilla Campos, A. (2000). Identidades y cuerpo: el efecto de las normas genéricas. Papeles del Psicólogo, (75), 34-39.

Pateman, C. (1995). El contrato sexual. (M. L. Femenías, Trad.) (1a. ed). Barcelona : [México]: Anthropos; Universidad Autónoma Metropolitana, Unidad Iztapalapa.

Pellejero Goñi, L., \& Torres Iglesias, B. (2011). La educación de la sexualidad: el sexo y el género en los libros de texto de Educación Primaria. Revista de Educación, (354), 399-427.

Peñalver, R. (2003). ¿Qué quieres enseñar? Un libro sexista oculta a la mitad. Murcia: Instituto de la Mujer.

Pereyra, G. (2012). México: violencia criminal y "guerra contra el narcotráfico". Revista Mexicana de Sociología, 2012(3), 32.

Pérez, A. (2011). El sexismo en los manuales escolares de Ciencias Sociales de la ESO. Universidad de Almería. Recuperado a partir de http://repositorio.ual.es/jspui/bitstream/10835/1142/1/Perez_\%20Lopez_ Alicia.pdf

Pérez Prado, L. N. (1995). Sueños globales, oportunidades locales: conmoción de identidades de género en la Tierra Caliente de Michoacán, México, 201-212.

Picado Mesén, M. (2006). Un acercamiento a la evaluación cualitativa, a partir de alunas aristas metodológicas. San José: Editorial de la Universidad de Costa Rica. 
Pichardo, J. I. (2013). Mujeres lesbianas y derechos humanos. En V. Maquieira (Ed.), Mujeres, globalización y derechos humanos (1a. ed, pp. 274-312). Madrid: Cátedra.

Piedra Guillén, N. (2003). Feminismo y postmodernidad: entre el ser para sí o el ser para los otros. Revista de Ciencias Sociales, IV(102), 43-55.

Pires, M. R. G. M., Fonseca, R. M. G. S. da, \& Padilla, B. (2016). A politicidade do cuidado na crítica aos estereótipos de gênero. Revista Brasileira de Enfermagem, 69(6), 1223-1230. https://doi.org/10.1590/0034-7167-2016-0441

PNUD. (2014a). Indicadores de Desarrollo Humano y Género en México: nueva metodología (Institucional) (p. 194). México: Programa de las Naciones Unidas para el Desarrollo en México.

PNUD (2014b). Base de datos IDHyG México. Recuperado a partir de www.mx.undp.org/.../mexico/.../InformesDesarrolloHumano/PNUDMx_ Base_IDHyG_.

PO. [Periódico Oficial del Gobierno del Estado de Michoacán de Ocampo] Ley de Acceso de las Mujeres a una Vida Libre de Violencia del Estado de Michoacán de Ocampo, Pub. L. No. 70, 52 CXLV 20 (2008). Recuperado a partir de https://dialnet.unirioja.es/servlet/articulo?codigo=5563156

PO. Ley para la Igualdad entre Mujeres y Hombres del Estado de Michoacán de Ocampo, Pub. L. No. 71, 53 CXLV 12 (2009). Recuperado a partir de https://dialnet.unirioja.es/servlet/articulo?codigo $=5563156$

PO. Ley para Prevenir y Eliminar la Discriminación y la Violencia en el Estado de Michoacán de Ocampo, Pub. L. No. 72, 54 CXLV 18 (2009). Recuperado https://dialnet.unirioja.es/servlet/articulo?codigo=5563156

PO. Ley para y para Prevenir, Atender y Erradicar la Trata de Personas y para la Protección y Asistencia de las Víctimas en el Estado de Michoacán de Ocampo, Pub. L. No. 534, 79 CLXII 10 (2015). Recuperado a partir de https://dialnet.unirioja.es/servlet/articulo?codigo $=5563156$

Porta, L., \& Silva, M. (2003, octubre). El Análisis de contenido en la investigación educativa. Recuperado 19 de marzo de 2015, a partir de https://es.scribd.com/doc/192383807/Porta-y-Silva-El-Analisis-deContenido-en-La-Investigacion-Educativa

Postigo Asenjo, M. (2006). Género e igualdad de oportunidades: la teoría feminista y sus implicaciones ético-políticas (Doctoral). Universidad de 
Málaga, Servicio de Publicaciones. Recuperado a partir de http://atarazanas.sci.uma.es/docs/tesisuma/1676206x.pdf

Puleo, A. H. (1993). La Ilustración olvidada: la polémica de los sexos en el siglo XVIII (1a. ed). Barcelona: Anthropos.

Puleo, A. H. (1995). Igualdad y androcentrismo. Tabanque: Revista pedagógica, (10), 71-82.

Puleo, A. H. (2000). Filosofía, género y pensamiento crítico. Valladolid: Universidad de Valladolid. Secretariado de publicaciones e intercambio editorial.

Quesada Jiménez, J. (2014). Estereotipos de género y usos de la lengua: Un estudio descriptivo en las aulas y propuestas de Intervención didáctica (Doctoral). Universidad de Murcia, Murcia. Recuperado a partir de https://www.uclm.org/ab/educacion/ensayos/ensayos25/pdf/25_4.pdf

Quesada Jiménez, J., \& López López, A. (2011). Estereotipos de género y usos de la lengua: un estudio en Educación Secundaria. ENSAYOS, Revista de la Facultad de Educación de Albacete, (25), 41-58.

Rábago Vital, O., \& Vergara, L. (2011, agosto 10). La violencia en México y el discurso gubernamental. Recuperado 20 de marzo de 2015, a partir de http://www.animalpolitico.com/blogueros-altoparlante/2011/08/10/laviolencia-en-mexico-y-el-discurso-gubernamental/

Radl Philipp, R. (2001). Epistemología y teoría sociológica del género. En R. Radl Philipp (Ed.), Cuestiones actuales de sociología del género (1a. ed). Madrid: Centro de Investigaciones Sociológicas.

Rebollo Catalán, M. Á., García Pérez, R., Piedra, J., \& Vega, L. (2011). Diagnóstico de la cultura de género en educación: actitudes del profesorado hacia la igualdad1. Revista de Educación, 355, 521-546.

Reyes Bueno Moreno, M., \& Garrido Torres, M. Á. (2012). Relaciones intergrupales: estereotipos, prejuicios y discriminación. En M. Marín Sánchez \& R. Martínez Pecino (Eds.), Introducción a la psicología social (1a. ed. electrónica, pp. 97-124). Madrid: Pirámide.

Rifá Valls, M. (2009). Michel Foucault y el giro postestructuralista crístico feminista en la investigación educativa. Revista Educación y Pedagogía, 15(37), 69-83.

Riquer, F., \& Tepichín, A. M. (2001). Mujeres jóvenes en México. De la casa a la escuela, del trabajo a los quehaceres del hogar. En E. Pieck (Ed.), Los jóvenes y el trabajo. La educación y la exclusión social (pp. 493-525). México: UIA, IML, UNICEF, Cnterfor-OIT, RET y CONALEP. 
Recuperado

a

partir

de

http://biblioteca.uahurtado.cl/ujah/Reduc/pdf/pdf/8849.pdf\#page $=484$

Ritter, R. Á., Luján, M. S., Monti Carvalho, L. F., \& Nieto. (2011). Estereotipos de género y textos escolares. Análisis de contenido en los textos de lectura empleados en el primer ciclo de las escuelas primarias urbanas de la localidad de la cruz en el año 2010 (Conocer para incidir sobre las prácticas pedagógicas No. 1180) (p. 38). Argentina: Instituto de Formación Docente. Recuperado a partir de http://dgescorrientes.net/investigacion/wpcontent/uploads/2015/07/ALVEZ-y-otros-Estereotipos-deG\%C3\%A9nero-y-textos-escolares.-An\%C3\%A1lisis-de-contenidos-enlos-textos-de-lectura.pdf

Robalino, M., Villarruel A., M., \& Isch L, E. (1992). Mujeres invisibles: un estudio del sexismo en la docencia y en los textos escolares ecuatorianos. Ministerio de Bienestar Social-DINAMU. Recuperado a partir de http://www.explored.com.ec/noticias-ecuador/sexismo-en-docencia-ytextosescolares- 27667.html

Robles Ortega, R. (2014, 03). La construcción social de las mujeres como segundo sexo; ¿También ciudadanas de segunda clase? Recuperado a partir de http://es.slideshare.net/rosalbaro/la-construccin-social-de-lasmujeres

Rodríguez Huacuz, M. D., \& Tapia Fonllem, M. E. (2011). Elaboración de las propuestas curriculares con perspectiva de género de quinto y sexto grado de primaria (Institucional) (p. 112). San Luis Potosí: Instituto de las Mujeres del Estado de San Luis Potosí.

Rodríguez Marín, Y. (2016). La enseñanza y el aprendizaje de la coeducación en las aulas de educación infantil de la Región de Murcia (Doctoral). Universidad de Murcia, Murcia. Recuperado a partir de https://digitum.um.es/xmlui/handle/10201/50084

Rodríguez Otero, L. M., \& Mancinas Espinoza, S. E. (2016). Nivel de sexismo y estereotipos de género en estudiantes de Trabajo Social Regiomontanas. Azarbe, (5), 17-30.

Rohr, E. (1993). Feminismo y psicoanálisis. En As Mulleres e os Cambios Sociais e Económicos (pp. 149-158). Santiago de Compostela: Universidade de Santiago de Compostela. Servizo de Publicacións e Intercambio Científico. Recuperado a partir de 
https://minerva.usc.es/xmlui/bitstream/handle/10347/12538/pg_150159_cc85mulleres.pdf?sequence $=1$

Rowbotham, S. (1985). What Do Women Want? Woman Centered Values and the World As It Is. The Dalhousie Review. Recuperado a partir de https://dalspace.library.dal.ca/handle/10222/60682

Rubin, G. (1986). El tráfico de mujeres: notas sobre la «economía política» del sexo. Nueva Antropología, VIII(30), 95-145.

Ruiz Carbonell, R. (2010). La evolución histórica de la igualdad entre mujeres y hombres en méxico. En V. M. Martínez Bullé-Goyri \& C. Maqueda Abreu (Eds.), Derechos humanos: temas y problemas (1 ${ }^{\text {a }}$, pp. 69-136). México: Instituto de Investigaciones Jurídicas de la UNAM. Recuperado a partir de https://biblio.juridicas.unam.mx/bjv/detalle-libro/2758derechos-humanos-temas-y-problemas

Ruiz Cuéllar, G. (2012). La Reforma Integral de la Educación Básica en México (RIEB) en la educación primaria: desafíos para la formación docente. Revista electrónica interuniversitaria de formación del profesorado, 15(1), 51-60.

Ruiz Palomino, E., Ballester Arnal, R., Llario, G., Dolores, M., Giménez García, C., \& Salmerón Sánchez, P. (2010). ¿Cambian los estereotipos de género a lo largo de la adolescencia? Recuperado a partir de http://repositori.uji.es/xmlui/handle/10234/31616

Ruiz Pinto, E., García Pérez, R., \& Rebollo, M. Á. (2013). Relaciones de género de adolescentes en contextos educativos. Análisis de redes sociales con perspectiva de género. Profesorado, Revista de Currículum y Formación del Profesorado, 17(1), 123-140.

Sáez, G., Valor-Segura, I., \& Expósito, F. (2012). ¿Empoderamiento o subyugación de la mujer? Experiencias de cosificación sexual interpersonal. Psychosocial Intervention, 21(1), 41-52.

Saldaña, L. (2007). Poder, género y derecho: Igualdad entre mujeres y hombres en México. México: Comisión Nacional de los Derechos Humanos México.

Salinas Muñoz, M. E. (2016, octubre 4). Las tecnologías de información y comunicación -TIC- como mediación didáctica y pedagógica en los procesos de formación docente en Colombia (Doctoral). Universidad de Salamanca, Salamanca. Recuperado a partir de https://gredos.usal.es/jspui/bitstream/10366/127870/1/DTHE_SalinasMu \%c3\%b1ozM_TecnologiasComunicacionColombia.pdf 
Salinas Villanueva, D. (1996). La construcción social de la identidad sexual de la mujer, un análisis multirrepresentativo (Doctoral). Universidad Complutense de Madrid, Madrid. Recuperado a partir de http://www.tdx.cat/handle/10803/74871

Sánchez, F. L., Rouco, N. F., González, R. J. C., Kilani, A., \& Blázquez, M. I. (2010). La evolución de la sexualidad prepuberal y adolescente: diferencias en afectos y conductas entre varones y mujeres. Cuestiones de género: de la igualdad y la diferencia, (5), 165-184.

Sánchez Gómez, M. C. (2015). La dicotomía cualitativo-cuantitativo: posibilidades de integración y diseños mixtos. Campo abierto, Monográfico, 11-30.

Sánchez, J. (2012). Las mujeres en los libros de texto escolares de historia: Entre la exclusión y el (mal) disimulo. España: Achencia de noticias d Aragón. Recuperado a partir de http://arainfo.orq/2012/01/las-muieres-enlos-libros-de-texto-escolares-de-historia-entre-la-exclusion-y-elmaldisimulo/

Sau, V. (1990). Diccionario ideológico feminista (2a. ed. amp. y rev). Barcelona: Icaria.

SCJN, [Suprema Corte de Justicia Nacional] (2006). La jerarquía de normas frente a los tratados internacionales en materia de Derechos Humanos en el sistema jurídico mexicano. Suprema Corte de Justicia de la Nación. Recuperado a partir de https://www.scjn.gob.mx/Transparencia/Lists/Becarios/Attachments/41/B ecarios_041.pdf

Scott, J. W. (1986). El género: una categoría útil para el análisis histórico. Historical review, 91, 1053-1075.

Scott, J. W. (2011). Género:? Todavía una categoría útil para el análisis? Revista La Manzana de la discordia, 6(1), 95-101.

SECMUJER, [Secretaría de la Mujer] (2008). Compendio de instrumentos jurídicos para el adelanto de las mujeres (Institucional) (p. 259). Michoacán de Ocampo: Secretaría de la Mujer y Gobierno del Estado de Michoacán de Ocampo.

Secretaría de Relaciones, UNIFEM, \& PNUD (Eds.). (2005). Compilación seleccionada del marco jurídico nacional e internacional de la mujer $\left(2^{\mathrm{a}}\right.$, Vol. $2^{\circ}$ ). México. Recuperado a partir de file:///C:/Users/PC/Downloads/Marco_Jur.pdf 
SEGOB. [Secretaría de Gobernación] (s. f.). Tratados vigentes celebrados por México (1836-2012) [Institucional]. Recuperado 19 de junio de 2013, a partir de http://compilacion.ordenjuridico.gob.mx/discotratados/busquedaavanzada .php

SEGOB, (2015). Orden Jurídico Nacional - Ámbito Local y Municipal [Institucional]. Recuperado 13 de marzo de 2017, a partir de http://www.ordenjuridico.gob.mx/estatal.php?liberado=si\&edo=16

SEGOB, \& UGAJ.[Unidad General de Asuntos Jurídicos] Constitución Política de los Estados Unidos Mexicanos, Pub. L. No. $3^{\circ}, 3$ (2013). Recuperado a partir de http://ief.jalisco.gob.mx/sites/ief.jalisco.gob.mx/files/articulo_3_pedro_ve lazquez_romero.pdf

SEGOB, \& UGAJ. (2013b, septiembre 11). Ley General de Educación [Institucional]. Recuperado 14 de mayo de 2017, a partir de http://www.ordenjuridico.gob.mx/leyes.php\#

SEGOB, \& UGAJ, (2016). Orden Jurídico Nacional [Institucional]. Recuperado 20 de mayo de 2017, a partir de http://www.ordenjuridico.gob.mx/constitucion.php

SEP. [Secretaría de Educación Pública] (2012). Sistema educativo de los Estados Unidos Mexicanos. Principales cifras, ciclo escolar 2011-2012 $\left(\right.$ No. $1^{\text {a)}}$ ) (p. 258). México: Secretraria de Educación Pública. Recuperado a partir de

https://eca.state.gov/files/bureau/educational_system_in_mexico.pdf

SEP. (2016a). El modelo educativo 2016. El planteamiento pedagógico de la Reforma Educativa $\left(1^{\mathrm{a}}\right)$. Ciudad de México: Secretraria de Educación Pública. Recuperado a partir de https://www.gob.mx/cms/uploads/attachment/file/114501/Modelo_Educa tivo_2016.pdf

SEP. (2016b). Propuesta curricular para la educación obligatoria 2016. México: Secretraria de Educación Pública. Recuperado a partir de https://www.gob.mx/cms/uploads/docs/Propuesta-Curricular-baja.pdf

SEP, \& PUEG, [Programa Universitario de Estudios de Género] (2001). Metodología del análisis de los libros de texto gratuitos de telesecundaria desde la perspectiva de la equidad de género (Institucional) (p. 43). México D.F.: UNAM/SEP. 
Serrano Barquín, H., \& Serrano Barquín, C. (2006). Género y educación en México. Pharos, 13(2), 59-79.

Serret, E. (2000). El feminismo mexicano de cara al siglo XXI. El cotidiano, 16(100), 42-51.

Silva Diveiro, I. (Ed.). (2007). La adolescencia y su interrelación con el entorno. Madrid: INJUVE. Recuperado a partir de http://www.injuve.es/sites/default/files/LA\%20ADOLESCENCIA\%20y $\% 20 \% 20$ entorno_completo.pdf

Simkin, H., \& Becerra, G. (2013). El proceso de socialización: Apuntes para su exploración en el campo psicosocial. Ciencia, docencia y tecnología, (47), 00-00.

Solé, G. (2014). O manual escolar no ensino primário em portugal: Perspetiva histórica e análise do ensino da história a través deste recurso didático. Revista de la Facultad de Educación de Albacete, 29(1), 43-64.

Souto Paz, J. A. (2011). Educación y ciudadanía. Contexto histórico y cuestiones actuales. En E. Galván (Ed.), Educación, democracia y ciudadanía (pp. 11-30). Madrid: Dykinson.

SRE. (s. f.). El Estado de Michoacán. Recuperado 16 de febrero de 2015, a partir de http://20062012.sre.gob.mx/coordinacionpolitica/images/stories/documentos_gobier nos/pmichoesp.pdf

Stern, C. (2007). Estereotipos de género, relaciones sexuales y embarazo adolescente en las vidas de jóvenes de diferentes contextos socioculturales en México. Estudios sociológicos, 25(1), 105-129.

Stuven, A. M. (2013). La mujer ayer y hoy: un recorrido de incorporación social y política. Pontificia Universidad Catolica de Chile, ( $\left.\mathrm{N}^{\mathrm{o}} 61\right), 1-22$.

Suárez Ortega, M. (2005). El grupo de discusión. Una herramienta para la investigación cualitativa. Barcelona: Laertes.

Subirats M. (2007). De la escuela mixta a la coeducación. La educación de las niñas: el aprendizaje de la suboridnación. En A. Vega Navarro (Ed.), Mujer y educación: una perspectiva de género (pp. 137-148). Archidona: Aljibe.

Subirats, M., \& Tomé, A. (2010). Balones fuera. Reconstruir los espacios desde la coeducación $\left(2^{\mathrm{a}}\right)$. Barcelona: Octaedro.

Subirats, M. (1991). El sexismo en los libros de texto: análisis y propuesta de un sistema de indicadores. Madrid: Instituto de la Mujer. 
Subirats, M. (Ed.). (1993). El sexismo en los libros de texto: análisis y propuesta de un sistema de indicadores. Madrid: Instituto de la Mujer.

Subirats, M., \& González, A. T. (2010). Balones fuera: reconstruir los espacios desde la coeducación. Octaedro.

Szasz, I. (1998). Sexualidad y género: algunas experiencias de investigación en México. Debate Feminista, 18, 77-104.

Tarabini, A., \& Bonal, X. (2012). Nuevas y viejas desigualdades educativas, 19.

Tarrés, M. L. (2006). Nuevos nudos y desafíos en las prácticas feministas: los Institutos de las Mujeres en México. Revista Enfoques: Ciencia Política y Administración Pública, (5), 5-27.

Terrón Caro, M. T., \& Cobano-Delgado Palma, V. (2008). El papel de la mujer en las ilustraciones de los libros de texto de educación primaria. Foro de Educación, 6(10), 385-400.

Tomé, A. (2007). Las relaciones de género en la adolescencia. En A. Vega Navarro (Ed.), Mujer y educación: una perspectiva de género (pp. 117136). Archidona: Aljibe.

Trimiño Velásquez, C. de J. (2010). Aportaciones del feminismo liberal al desarrollo de los derechos de las mujeres (Doctoral). Universidad Carlos III de Madrid, Getafe. Recuperado a partir de http://orff.uc3m.es/handle/10016/9167

Tubert, S. (Ed.). (2003). Del sexo al género. Los equívocos de un concepto $\left(1^{\mathrm{a}}\right)$. Madrid: Feminismos, Ediciones Cátedra, Universitat de Valéncia, Instituto de la Mujer.

Tuñón Pablos, E., \& Eroza Solana, E. (2001). Género y sexualidad adolescente. La búsqueda de un conocimiento huidizo. Estudios sociológicos, XIX(1), 209-226.

Turati, M. (2011). Fuego Cruzado: Las víctimas atrapadas en la guerra del narco. Grijalbo. Recuperado a partir de http://www.goodreads.com/book/show/13326894-fuego-cruzado

Ullah, H., Ali, J., \& Naz, A. (2014). Gender Representation in Children's Books: A Critical Review of Empirical Studies. World Applied Sciences Journal, 29(1),

134-141. https://doi.org/10.5829/idosi.wasj.2014.29.01.13831

UNAM. (2013). Trayectos de género: encuentros con diversos campos de conocimiento. Guía para el estudio de la perspectiva de género como asignatura en las licenciaturas de la UNAM ( $\left.1^{\mathrm{a}}\right)$. México: Universidad Nacional Autónoma de México-PUEG. Recuperado a partir de 
file://C:/Users/PC/Documents/Tesis/1.\%20Tesis/marco\%20teorico/1.\%2 0Bibliograf\%C3\%ADa/trayectos_de_genero.pdf

UNFPA. (2006). Igualdad y equidad de género: Aproximación teóricoconceptual. Herramientas de trabajo en género para oficinas y contrapartes del UNFPA (p. 143). Equipo de Apoyo Técnico para América Latina y Caribe. Fondo de Población de Naciones Unidas. Recuperado a partir de https://dialnet.unirioja.es/servlet/articulo?codigo $=4833523$

Vaíllo Rodríguez, M. (2013). Libros de texto e igualdad: análisis y propuestas para las editoriales españolas desde la perspectiva de género (Doctoral). Universidad Complutense de Madrid, Madrid. Recuperado a partir de https://dialnet.unirioja.es/descarga/articulo/3313248.pdf

Valcárcel, A. (1991). Sexo y filosofía: sobre «mujer» y «poder». Barcelona: Anthropos.

Valcárcel, A. (2010). Las filosofías políticas en presencia del feminismo. En C. Amorós (Ed.), Feminismo y filosofía (1 ${ }^{\mathrm{a}}$ ed, pp. 115-132). Madrid: Síntesis.

Valcárcel, A. (2013). Feminismo en el mundo global (1 $\left.{ }^{\mathrm{a}}\right)$. Madrid: Madrid Cátedra.

Valdés E., T. (2013). Género en la escuela, o la porfiada desigualdad. Docencia, $\left(\mathrm{N}^{\mathrm{o}} 49\right), 46-61$.

Valdivielso Alba, R. (2015). Rasgos de personalidad y niveles de adaptación en alumnos de $3^{\circ}$ de ESO y $1^{\circ}$ de Bachillerato (Doctoral). Universidad Nacional de Educación a Distancia, España. Recuperado a partir de http://e-spacio.uned.es/fez/view/tesisuned:Educacion-Rvaldivieso

Vance, C. S. (1989). Placer y peligro. Explorando la sexualidad femenina.

Varela, N. (2008). Feminismo para principiantes. Barcelona: Ediciones B. Recuperado a partir de http://mujerfariana.org/images/pdf/Varela-Nuria--Feminismo-Para-Principiantes.pdf

Villegas Morales, G. (2001). La imagen femenina en artistas mexicanas contemporáneas: una perspectiva no androcéntrica (Doctoral). Universidad Complutense de Madrid, Madrid. Recuperado a partir de http://cdigital.uv.mx/handle/123456789/29326

Wollstonecraft, M. (1994). Vindicación de los derechos de la mujer. (I. Burdiel, Ed., C. Martínez Gimeno, Trad.). Madrid [etc.]: Cátedra [etc.].

Zambrini, L., \& Iadevito, P. (2009). Feminismo filosófico y pensamiento postestructuralista: teorías y reflexiones acerca de las nociones de sujeto e 
identidad femenina. Sexualidad, Salud y Sociedad - Revista Latinoamericana, O(2), 162-180.

Zapata, M. (2005, junio). El movimiento feminista en México. De los grupos locales de autoconciencia a las redes transnacionales. Freie Universität Berlin, 6.

Zapata-Martelo, E., \& Ayala-Carrillo, M. del R. (2014). Políticas de equidad de género: educación para una escuela libre de violencia. Ra Ximhai, 10(7), $1-21$.

Zorrilla, M. (2004). La educación secundaria en México: al filo de su reforma. REICE. Revista Iberoamericana sobre Calidad, Eficacia y Cambio en Educación, 2(1), 1-22. 



\section{Anexos 1. Parte teórica y metodológica}

\section{Legislación reformada de la Constitución Política de los Estados Unidos}

\section{Mexicanos}

\section{Artículo $1_{0}$}

En los Estados Unidos Mexicanos todas las personas gozarán de los derechos humanos reconocidos en esta Constitución y en los tratados internacionales de los que el Estado Mexicano sea parte, así como de las garantías para su protección, cuyo ejercicio no podrá restringirse ni suspenderse, salvo en los casos y bajo las condiciones que esta Constitución establece.

Las normas relativas a los derechos humanos se interpretarán en conformidad con esta Constitución y con los tratados internacionales de la materia favoreciendo en todo tiempo a las personas la protección más amplia.

Todas las autoridades, en el ámbito de sus competencias, tienen la obligación de promover, respetar, proteger y garantizar los derechos humanos de conformidad con los principios de universalidad, interdependencia, indivisibilidad y progresividad. En consecuencia, el Estado deberá prevenir, investigar, sancionar y reparar las violaciones a los derechos humanos, en los términos que establezca la ley.

Está prohibida la esclavitud en los Estados Unidos Mexicanos. Los esclavos del extranjero que entren al territorio nacional alcanzarán, por este solo hecho, su libertad y la protección de las leyes.

Queda prohibida toda discriminación motivada por origen étnico o nacional, el género, la edad, las discapacidades, la condición social, las condiciones de salud, la religión, las opiniones, las preferencias sexuales, el estado civil o cualquier otra que atente contra la dignidad humana y tenga 
por objeto anular o menoscabar los derechos y libertades de las personas. $^{161}$

\section{Artículo $2_{0}$}

La Nación tiene una composición pluricultural sustentada originalmente en sus pueblos indígenas que son aquellos que descienden de poblaciones que habitaban en el territorio actual del país al iniciarse la colonización y que conservan sus propias instituciones sociales, económicas, culturales y políticas, o parte de ellas.

La conciencia de su identidad indígena deberá ser criterio fundamental para determinar a quiénes se aplican las disposiciones sobre pueblos indígenas.

Son comunidades integrantes de un pueblo indígena, aquellas que formen una unidad social, económica y cultural, asentada en un territorio y que reconocen autoridades propias de acuerdo con sus usos y costumbres.

El derecho de los pueblos indígenas a la libre determinación se ejercerá en un marco constitucional de autonomía que asegure la unidad nacional. El reconocimiento de los pueblos y comunidades indígenas se hará en las constituciones y leyes de las entidades federativas, las que deberán tomar en cuenta, además de los principios generales establecidos en los párrafos anteriores de este artículo, criterios etnolingüísticos y de asentamiento físico.

A. Esta Constitución reconoce y garantiza el derecho de los pueblos y las comunidades indígenas a la libre determinación y, en consecuencia, a la autonomía para:

I. Decidir sus formas internas de convivencia y organización social, económica, política y cultural.

\footnotetext{
II. Aplicar sus propios sistemas normativos en la regulación y solución de sus conflictos internos, sujetándose a los principios generales de esta

${ }^{161}$ Párrafo reformado DOF 04/12/2006, 10/06/2011
} 
Constitución, respetando las garantías individuales, los derechos humanos y, de manera relevante, la dignidad e integridad de las mujeres. La ley establecerá los casos y procedimientos de validación por los jueces o tribunales correspondientes.

III. Elegir de acuerdo con sus normas, procedimientos y prácticas tradicionales, a las autoridades o representantes para el ejercicio de sus formas propias de gobierno interno, garantizando que las mujeres y los hombres indígenas disfrutarán y ejercerán su derecho de votar y ser votados en condiciones de igualdad; así como a acceder y desempeñar los cargos públicos y de elección popular para los que hayan sido electos o designados, en un marco que respete el pacto federal, la soberanía de los Estados y la autonomía de la Ciudad de México. En ningún caso las prácticas comunitarias podrán limitar los derechos político-electorales de los y las ciudadanas en la elección de sus autoridades municipales. ${ }^{162}$

B. La Federación, las entidades federativas y los Municipios, para promover la igualdad de oportunidades de los indígenas y eliminar cualquier práctica discriminatoria, establecerán las instituciones $\mathbf{y}$ determinarán las políticas necesarias para garantizar la vigencia de los derechos de los indígenas $y$ el desarrollo integral de sus pueblos $y$ comunidades, las cuales deberán ser diseñadas y operadas conjuntamente con ellos.

\section{Artículo $3_{0}$.}

Toda persona tiene derecho a recibir educación. El Estado — Federación, Estados, Ciudad de México y Municipios-, impartirá educación preescolar, primaria, secundaria y media superior. La educación preescolar, primaria y secundaria conforman la educación básica; ésta y la media superior serán obligatorias.

\footnotetext{
${ }^{162}$ Párrafo reformado DOF 22/05/2015, 29/01/2016. Este artículo se presenta de manera parcia (se omiten los puntos que van del IV al VIII), en el siguiente link se puede acceder los artículos completos: http://www.ordenjuridico.gob.mx/constitucion.php
} 
La educación que imparta el Estado tenderá a desarrollar armónicamente, todas las facultades del ser humano y fomentará en él, a la vez, el amor a la Patria, el respeto a los derechos humanos y la conciencia de la solidaridad internacional, en la independencia y en la justicia.

El Estado garantizará la calidad en la educación obligatoria de manera que los materiales y métodos educativos, la organización escolar, la infraestructura educativa y la idoneidad de los docentes y los directivos garanticen el máximo logro de aprendizaje de los educandos.

I. Garantizada por el artículo 24 la libertad de creencias, dicha educación será laica y, por tanto, se mantendrá por completo ajena a cualquier doctrina religiosa;

II. El criterio que orientará a esa educación se basará en los resultados del progreso científico, luchará contra la ignorancia y sus efectos, las servidumbres, los fanatismos y los prejuicios.

Además:

a) Será democrático, considerando a la democracia no solamente como una estructura jurídica y un régimen político, sino como un sistema de vida fundado en el constante mejoramiento económico, social y cultural del pueblo;

b) Será nacional, en cuanto - sin hostilidades ni exclusivismos- atenderá a la comprensión de nuestros problemas, al aprovechamiento de nuestros recursos, a la defensa de nuestra independencia política, al aseguramiento de nuestra independencia económica y a la continuidad y acrecentamiento de nuestra cultura;

c) Contribuirá a la mejor convivencia humana, a fin de fortalecer el aprecio y respeto por la diversidad cultural, la dignidad de la persona, la integridad de la familia, la convicción del interés general de la sociedad, los ideales de fraternidad e igualdad de derechos de todos, evitando los privilegios de razas, de religión, de grupos, de sexos o de individuos, ${ }^{163} \mathrm{y}$

${ }^{163}$ Inciso reformado DOF 09/02/2012, 26/02/2013 
d) Será de calidad, con base en el mejoramiento constante y el máximo logro académico de los educandos;

III. Para dar pleno cumplimiento a lo dispuesto en el segundo párrafo de la fracción II, el Ejecutivo Federal determinará los planes y programas de estudio de la educación preescolar, primaria, secundaria y normal para toda la República. Para tales efectos, el Ejecutivo Federal considerará la opinión de los gobiernos de las entidades federativas, así como de los diversos sectores sociales involucrados en la educación, los maestros y los padres de familia en los términos que la ley señale. Adicionalmente, el ingreso al servicio docente y la promoción a cargos con funciones de dirección o de supervisión en la educación básica y media superior que imparta el Estado, se llevarán a cabo mediante concursos de oposición que garanticen la idoneidad de los conocimientos y capacidades que correspondan. La ley reglamentaria fijará los criterios, los términos y condiciones de la evaluación obligatoria para el ingreso, la promoción, el reconocimiento y la permanencia en el servicio profesional con pleno respeto a los derechos constitucionales de los trabajadores de la educación. Serán nulos todos los ingresos y promociones que no sean otorgados conforme a la ley. Lo dispuesto en este párrafo no será aplicable a las instituciones a las que se refiere la fracción VII de este artículo;

IV. Toda la educación que el Estado imparta será gratuita;

V. Además de impartir la educación preescolar, primaria, secundaria y media superior, señaladas en el primer párrafo, el Estado promoverá y atenderá todos los tipos y modalidades educativos —incluyendo la educación inicial y a la educación superiornecesarios para el desarrollo de la nación, apoyará la investigación científica y tecnológica, y alentará el fortalecimiento y difusión de nuestra cultura; ${ }^{164}$

\footnotetext{
${ }^{164}$ Este artículo se presenta de manera parcia (se omiten los puntos que van del VI al VIII), en el siguiente link se puede acceder al artículo completo
} 
IX. Para garantizar la prestación de servicios educativos de calidad, se crea el Sistema Nacional de Evaluación Educativa. La coordinación de dicho sistema estará a cargo del Instituto Nacional para la Evaluación de la Educación. El Instituto Nacional para la Evaluación de la Educación será un organismo público autónomo, con personalidad jurídica y patrimonio propio. Corresponderá al Instituto evaluar la calidad, el desempeño y resultados del sistema educativo nacional en la educación preescolar, primaria, secundaria y media superior. Para ello deberá:

a) Diseñar y realizar las mediciones que correspondan a componentes, procesos o resultados del sistema;

b) Expedir los lineamientos a los que se sujetarán las autoridades educativas federal y locales para llevar a cabo las funciones de evaluación que les corresponden, y

c) Generar y difundir información y, con base en ésta, emitir directrices que sean relevantes para contribuir a las decisiones tendientes a mejorar la calidad de la educación y su equidad, como factor esencial en la búsqueda de la igualdad social.

La ley establecerá las reglas para la organización y funcionamiento del Instituto, el cual regirá sus actividades con apego a los principios de independencia, transparencia, objetividad, pertinencia, diversidad e inclusión.

La ley establecerá los mecanismos y acciones necesarios que permitan al Instituto y a las autoridades educativas federal y locales una eficaz colaboración y coordinación para el mejor cumplimiento de sus respectivas funciones.

\section{Artículo 4}

El varón y la mujer son iguales ante la ley. Ésta protegerá la organización y el desarrollo de la familia.

Toda persona tiene derecho a decidir de manera libre, responsable e informada sobre el número y el espaciamiento de sus hijos.

Toda persona tiene derecho a la alimentación nutritiva, suficiente y de calidad. El Estado lo garantizará.

Toda persona tiene derecho a la protección de la salud. La Ley definirá las bases y modalidades para el acceso a los servicios de salud y establecerá la 
concurrencia de la Federación y las entidades federativas en materia de salubridad general, conforme a lo que dispone la fracción XVI del artículo 73 de esta Constitución.

Toda persona tiene derecho a un medio ambiente sano para su desarrollo y bienestar. El Estado garantizará el respeto a este derecho. El daño y deterioro ambiental generará responsabilidad para quien lo provoque en términos de lo dispuesto por la ley.

Toda persona tiene derecho al acceso, disposición y saneamiento de agua para consumo personal y doméstico en forma suficiente, salubre, aceptable y asequible. El Estado garantizará este derecho y la ley definirá las bases, apoyos y modalidades para el acceso y uso equitativo y sustentable de los recursos hídricos, estableciendo la participación de la Federación, las entidades federativas y los municipios, así como la participación de la ciudadanía para la consecución de dichos fines.

Toda persona tiene derecho a la identidad y a ser registrado de manera inmediata a su nacimiento. El Estado garantizará el cumplimiento de estos derechos. La autoridad competente expedirá gratuitamente la primera copia certificada del acta de registro de nacimiento.

Toda familia tiene derecho a disfrutar de vivienda digna y decorosa. La Ley establecerá los instrumentos y apoyos necesarios a fin de alcanzar tal objetivo.

En todas las decisiones y actuaciones del Estado se velará y cumplirá con el principio del interés superior de la niñez, garantizando de manera plena sus derechos. Los niños y las niñas tienen derecho a la satisfacción de sus necesidades de alimentación, salud, educación y sano esparcimiento para su desarrollo integral. Este principio deberá guiar el diseño, ejecución, seguimiento y evaluación de las políticas públicas dirigidas a la niñez. 
Los ascendientes, tutores y custodios tienen la obligación de preservar y exigir el cumplimiento de estos derechos y principios.

El Estado otorgará facilidades a los particulares para que coadyuven al cumplimiento de los derechos de la niñez.

Toda persona tiene derecho al acceso a la cultura y al disfrute de los bienes y servicios que presta el Estado en la materia, así como el ejercicio de sus derechos culturales. El Estado promoverá los medios para la difusión y desarrollo de la cultura, atendiendo a la diversidad cultural en todas sus manifestaciones y expresiones con pleno respeto a la libertad creativa. La ley establecerá los mecanismos para el acceso y participación a cualquier manifestación cultural.

Toda persona tiene derecho a la cultura física y a la práctica del deporte. Corresponde al Estado su promoción, fomento y estímulo conforme a las leyes en la materia.

\section{Artículo 123.}

Toda persona tiene derecho al trabajo digno y socialmente útil; al efecto, se promoverán la creación de empleos y la organización social de trabajo, conforme a la ley. ${ }^{165}$

El Congreso de la Unión, sin contravenir a las bases siguientes deberá expedir leyes sobre el trabajo, las cuales regirán:

A. Entre los obreros, jornaleros, empleados domésticos, artesanos y de una manera general, todo contrato de trabajo:

I. La duración de la jornada máxima será de ocho horas.

II. La jornada máxima de trabajo nocturno será de 7 horas. Quedan prohibidas: las labores insalubres o peligrosas, el trabajo nocturno

\footnotetext{
${ }^{165}$ Este artículo se presenta de manera parcial, en el siguiente link se puede acceder al artículo completo: http://www.ordenjuridico.gob.mx/Constitucion/articulos/123.pdf
} 
industrial y todo otro trabajo después de las diez de la noche, de los menores de dieciséis años;

III. Queda prohibida la utilización del trabajo de los menores de quince años. Los mayores de esta edad y menores de dieciséis tendrán como jornada máxima la de seis horas.

IV. Por cada seis días de trabajo deberá disfrutar el operario de un día de descanso, cuando menos.

V. Las mujeres durante el embarazo no realizarán trabajos que exijan un esfuerzo considerable y signifiquen un peligro para su salud en relación con la gestación; gozarán forzosamente de un descanso de seis semanas anteriores a la fecha fijada aproximadamente para el parto y seis semanas posteriores al mismo, debiendo percibir su salario íntegro y conservar su empleo y los derechos que hubieren adquirido por la relación de trabajo. En el período de lactancia tendrán dos descansos extraordinarios por día, de media hora cada uno para alimentar a sus hijos;

VI. Los salarios mínimos que deberán disfrutar los trabajadores serán generales o profesionales. Los primeros regirán en las áreas geográficas que se determinen; los segundos se aplicarán en ramas determinadas de la actividad económica o en profesiones, oficios o trabajos especiales. El salario mínimo no podrá ser utilizado como índice, unidad, base, medida o referencia para fines ajenos a su naturaleza.

Los salarios mínimos generales deberán ser suficientes para satisfacer las necesidades normales de un jefe de familia, en el orden material, social y cultural, y para proveer a la educación obligatoria de los hijos. Los salarios mínimos profesionales se fijarán considerando, además, las condiciones de las distintas actividades económicas. 
Los salarios mínimos se fijarán por una comisión nacional integrada por representantes de los trabajadores, de los patrones y del gobierno, la que podrá auxiliarse de las comisiones especiales de carácter consultivo que considere indispensables para el mejor desempeño de sus funciones.

\section{Para trabajo igual debe corresponder salario igual, sin tener en cuenta sexo ni nacionalidad.}

Estos artículos son las únicas referencias constitucionales, a nivel federal, que hacen algún señalamiento sobre la igualdad entre hombres y mujeres. No obstante, el Plan Nacional de Desarrollo y la Ley del Instituto Nacional de las Mujeres contienen disposiciones generales establecidas para salvaguardar los objetivos y planes en materia de igualdad y equidad de género. 


\section{Guión de la guía para el trabajo con grupos de discusión}

\section{Información que vamos a solicitar al alumnado de primer grado de secundaria}

1. Qué información tienen sobre sexualidad y equidad/igualdad de género

2. Percepciones y conocimientos sobre la igualdad/equidad de género y sexualidad

3. Su interés en estas temáticas

4. Las relaciones entre pares

5. Las relaciones afectivo-sexuales en la adolescencia

6. Percepción de lo que ellos/ellas consideran consecuencias respecto a la falta de equidad y el ejercicio de la sexualidad en esta etapa del desarrollo

7. La violencia en la adolescencia

8. Análisis del entorno local y regional en cuanto a la sexualidad y la equidad de género

9. Los procesos de maduración sexual que experimentan en su desarrollo

10. Influencia de los cambios durante la adolescencia
Conocimientos e Información sobre sexualidad y género obtenida en la familia, escuela, medios de comunicación, amigos y su propia experiencia

Cómo viven:

- La igualdad

- Roles y estereotipos

- Tareas domésticas

- Derechos y oportunidades

- Permisos

- Sexualidad

- Noviazgo

- Empleo

Intereses en torno a su sexualidad Intereses relacionados con la equidad de género Importancia de las relaciones de amistad en esta etapa del desarrollo

¿Cuáles son las estrategias que emplean las y los jóvenes en el cortejo inicial?

¿Cómo deben comportarse los hombres/las mujeres en las relaciones afectivas iniciales?

¿Iniciación de las relaciones afectivo -sexuales en la adolescencia?

Dificultades en torno a su sexualidad

Dificultades relacionados con la equidad de género ¿Cuáles consideran que sean las consecuencias de la falta de equidad entre hombres y mujeres?

- En la familia

- En la escuela

- Con los/as amigos/as

- Sobre sí mismos

¿Cuáles han sido sus experiencias con relación a la violencia?

¿Qué pasa en tu localidad?

- Igualdad y desigualdad entre hombres y mujeres

- Sexualidad

¿Consideras que pasa lo mismo en otras localidades? ¿Qué cambios físicos y psicológicos has observado en el paso de la niñez a la adolescencia?

¿Cómo han influido esos cambios en sus relaciones afectivas y en la toma de decisiones?

- Dependencia-independencia en relación con los otros (padre-madre, 


\title{
Anexos 2. Parte de análisis de resultados grupos de discusión
}

\section{Transcripciones}

\author{
SECRETARÍA DE EDUCACIÓN EN EL ESTADO \\ SUBSECRETARÍA DE EDUCACIÓN BÁSICA \\ SECRETARÍA DE LA MUJER \\ DIRECCIÓN DE EDUCACIÓN SECUNDARIA
}

\section{GRUPOS DE DISCUSIÓN Nº1}

Registro de grabación. A cargo de Elva Morales.

\begin{tabular}{|c|c|c|c|c|c|c|c|c|}
\hline $\begin{array}{c}\text { Nombre } \\
\text { de la } \\
\text { escuela }\end{array}$ & Ubicación & $\begin{array}{c}\text { Zona } \\
\text { Escolar }\end{array}$ & $\begin{array}{l}\text { Grupo de } \\
\text { discusión }\end{array}$ & $\begin{array}{c}\text { Grado } \\
\mathbf{y} \\
\text { Grupo }\end{array}$ & Moderadora & Observadora & Fecha & Hora \\
\hline $\begin{array}{l}\text { EST No. } \\
71\end{array}$ & $\begin{array}{c}\text { Nuevo } \\
\text { Progreso }\end{array}$ & 04 & $\begin{array}{c}\text { Integrantes: } \\
6 \\
\text { (3 hombres, } \\
3 \text { mujeres) }\end{array}$ & 1ro. & $\begin{array}{l}\text { Ma. De Jesús } \\
\text { Soto Campos. } \\
\text { Co- } \\
\text { moderadora: } \\
\text { Georgina } \\
\text { Pérez Coeto }\end{array}$ & $\begin{array}{l}\text { Elva Morales } \\
\text { Robles }\end{array}$ & $\begin{array}{c}14-06- \\
2010\end{array}$ & $\begin{array}{c}10: 30 \\
a \\
12: 30\end{array}$ \\
\hline \multicolumn{9}{|c|}{ Contexto situacional } \\
\hline \multicolumn{9}{|c|}{$\begin{array}{l}\text { Las autoridades de la institución como fue el Jefe de enseñanza de ciencias atienden con gran disposición los } \\
\text { requerimientos de organización para la realización del trabajo, mismo que se inicia después del desayuno para } \\
\text { que no existiera interrupción por el receso. } \\
\text { Las y los alumnos que conforman el grupo de discusión manifiestan no tener claro el motivo por el cual fueron } \\
\text { convocados, lo cual se aclara con base al encuadre de la guía de entrevista. Se observa disposición para la } \\
\text { entrevista y aceptación para ser grabada por parte de los participantes. }\end{array}$} \\
\hline
\end{tabular}


SIMBOLOGÍA: $\mathrm{H}=$ Hombre $\quad \mathrm{M}=$ Mujer

\section{Pregunta/Tema: ¿Qué te gustaría que cambiara en tu escuela? Respuestas}

H. Cambiar la comida del desayunador (dan tacos de soya revuelta y dicen que es al pastor)

¿Cuál sería tu propuesta?

H. Que las mamás trajeran recetas, si se pudiera.

M. A mí me gustaría que el tiempo de receso fuera más largo, porque a veces se hace la fila muy larga y cuando apenas empezamos a desayunar tocan el timbre.

H. Más largo el receso para alcanzar entrar en clase

¿Algo más que quieran decir aparte de lo del desayuno? Es importante que sepan que ustedes sepan que esta grabación no la vamos a escuchar más que la maestra Gina y yo. Eso sólo información que va a servir para esta investigación.

H. Las instalaciones están padres, sus maestros.

H. Las chiquillas no hacen nada, en la tecnología de agricultura, que también participen.

H. Que hagan algo las chiquillas

¿Qué es lo que ustedes hacen en esta materia?

H. Nosotros sembramos

H. Cosechar

$$
\text { ¿Y ellas? }
$$

H. Nada más se la pasan jugando

H. Nada más se la pasan jugando. Y a ellas no las reprueba

M. Pero es que también él se lo busca porque casi no lleva las tareas, no hace los trabajos que le dice el maestro.

H. Lo que califica el maestro son las actividades que hacemos aquí.

H. Pero no se compara una mujer con un hombre. Las mujeres pueden hacer trabajos menos pesados y los hombres los más pesados.

H. Es que el maestro les dicen "pónganse a hacer esto" y no lo hacen. Podrían ayudar en la cosecha.

M. El maestro nos tendría que tratar a todos por igual, quizá en trabajos no tan pesados pero que sí las ponga.

Pregunta/ Tema: Experiencias en la escuela y razones para cursar la secundaria

H. Yo porque me quiero superar

\section{Respuestas}

H. Yo porque quiero llegar a ser Ingeniero

M. Para aprender, estudiar, llegar a ser alguien.

M. Ser alguien en la vida, conocer más personas

M. Para ser alguien en la vida y no ser ignorante

M. Aprender cosas que en la primaria no me enseñaron.

Estímulo visual desencadenante

FOTO ¿Qué están haciendo estos jóvenes que información estarán buscando? ¿Cuántos hombres hay? Dos (a coro) y mujeres? Dos (a coro) ¿Qué están haciendo? Leyendo Pregunta / Tema: ¿Qué información buscarán de su interés?

\section{Respuestas}

M. Información sobre la sexualidad, como preservativos y otras cosas.

H. Lo que quieren ser de grandes 
H. Lo que más les llama la atención, como sus gustos, a mí me gustan: carros, caballos. Como el otro día vi un libro de caballos y lo pedí prestado para leer y en la casa se lo enseñé a mi papá.

H. Algo de la sexualidad, preservativos, las pastillas, anticonceptivos.

M. De la sexualidad, cómo se reproducen.

¿Por qué les interesa esta información?

M. Para que no se vayan a contagiar alguna enfermedad, cuando llegue el momento de tener sexo, estén informados

H. Para que cuando tengan sexo se cuiden, usen condón

H. No.

¿Ustedes creen que buscan información por igual muchachas y muchachos?

H. Buscan por igual

M: Los más grandes buscan más información, los que están más chicos buscan menos sobre eso

H. Para prevenir embarazos no deseados, porque después su familia se enoja con él y luego las rechazan

¿Ustedes han visto que en la comunidad hay embarazos tempranos? ¿Desde qué edad?

H. Desde los 12 años, había una muchacha y que luego el novio la dejó.

¿Por qué creen que se van con el novio desde tan temprana edad?

M. El novio las ilusiona y creen que van a tener la vida que bla, bla bla... y a la mejor les creen y se van, pero son unos escuinchillos(significa niños).

¿Por qué les creerán?

M. Porque están enamoradas.

\section{Pregunta / Tema: Noviazgo. ¿Qué hace que se enamoren?}

\section{Respuestas}

H. Por interés, hay hombres que traen carros y tienen dinero.

H. O porque de verdad si los quieren

M. O porque tienen papeles y se las pueden llevar para el norte

M. Algunas en verdad sí los quieren.

M. Por detalles, los dos. (Todos dicen: si) con cariño.

M. Los dos

\section{¿Un hombre atrae a una mujer o una mujer a un hombre?}

H. Sí

¿Y qué hace que los hombres se enamoren de la mujer?

H. Por su físico, por su carácter: noble, liviana, pues activa: que haga quehacer en la casa, cuando llegue el hombre de trabajar le tenga su comida preparada.

M: Yo pienso que si te casas con una mujer va hacer tu esposa, más no tu sirvienta, para que tenga ya todo hecho.

H. Pero va ser ama de casa.

(Risas)

¿A ustedes qué les atrae un hombre? 
M: Guapos.

H: Una mujer por su escultura, su belleza, su carácter: amable, noble.

M: Las mujeres nos enamoramos de los hombres por su modo de ser, depende como sean de detallistas.

M: ¿Romántico?

\section{¿Qué más les gusta de cómo son los hombres?}

Silencio.

M. Sincero

M: Aparte que los dos nos entendamos bien.

Pregunta / Tema: ¿Cuáles son los prototipos de belleza?

\section{Respuestas}

H: Príncipe azul y la princesa rosa.

\section{Describan al príncipe azul y a la princesa rosa.}

M: Un príncipe azul debe ser guapo, caballeroso, detallista, cariñoso

M: Elegante

M: Amable

\section{¿Y la princesa rosa?}

$\mathrm{H}$ : Amable, generosa, guapa, comprensiva, guapa

H: Guapa.

H: Guapa

H: De ojos verdes.

$\mathrm{H}$ : Trabajadora, que haga todo el quehacer.

M: Las princesas no hacen quehacer.

¿De dónde obtiene más información sobre su sexualidad?

H: De los libros, internet. Papás y familiares

M: Del internet, aunque el internet ha traído cosas buenas y malas, porque no todo ha sido bueno.

\section{¿Qué es lo bueno y malo del internet?}

M. Las cosas malas serían los delitos cibernéticos porque hay personas que se hacen pasar por otras y pueden llegar a hacerte mucho daño.

$\mathrm{H}$ : los videos porno

$$
\text { ¿Los chavos los ven? }
$$

H: Sí, los ven por curiosidad.

H. Una vez unos chavos dijeron que iban a ver una película de jaripeo pero no, fue como un engaño.

\section{¿Satisface su curiosidad?}

M: Yo creo que de los videos porno no sacan nada bueno, más bien de la información, puedes platicar con tus padres.

Ustedes que los han visto, ¿qué opinan de eso? 
H: Da asco.

M: Sí les da asco, ¿por qué los miran?

H: Por curiosidad.

¿A Ustedes no les ha dado curiosidad, chicas?

M. No, qué asco

$\mathrm{H}$ : Sí los he mirado pero...No

\section{Pregunta / Tema: ¿Qué aprendieron en la asignatura de Biología, y Orientación y Tutoría relacionado con la sexualidad y la equidad de género?}

\section{Respuestas}

M: En Biología hicimos un proyecto sobre la reproducción o sexualidad, yo aprendí sobre los métodos anticonceptivos, sobre las enfermedades por contacto sexual, cómo estar preparados, porque algún día vas a tener sexo, pero no a temprana edad, porque las consecuencias van a ser fatales como un embarazo no deseado o enfermedades como $\mathrm{VH}$ sida.

H: También sobre los métodos anticonceptivos, cuáles son más efectivos, cuántos tipos son y cómo se pueden usar; que tan efectivos pueden ser si los usas correctamente.

$\mathrm{H}$ : Fume por curiosidad, mi abuelito fumaba, porque un amigo me decía.

\section{¿Por qué los consumen si hace daño?}

M: Por curiosidad por probar lo desconocido, por la edad

M: Por la moda.

M: Por los amigos.

¿Cómo hacen los amigos para encaminar?

H: Dicen no te va a pasar nada.

$\mathrm{H}$ : Porque los amigos te dicen.

M: Los amigos te dicen si ellos si lo van hacer y tú no quieres, que gallina, te da miedo, cosas por el estilo.

Carlos dijiste que fumabas porque tu abuelito fumaba, ¿era la única persona en tu familia que lo hacía?

H. Sí

¿Y por qué más?

$\mathrm{H}$ : Porque mi amigo me decía

¿Y cuál de las dos razones fue más importante?

H: Lo de mi abuelito. La curiosidad de qué sentía mi abuelito al fumar

\section{Pregunta / Tema: Temas de Interés para la asignatura estatal}

H: No hacer el sexo a temprana edad...

\section{Respuestas}

$\mathrm{H}$ : Y esperarse hasta el matrimonio, porque se puede contagiar de enfermedades.

M: A no tener relaciones sexuales.

M: También es importante, es conveniente que no te andes metiendo con uno y con otro, porque después vas a salir perjudicada, mejor, es que te esperes, nos esperemos hasta el matrimonio. 
H. Que al tener relaciones sexuales se usen anticonceptivos.

H. A los 12 y 13 años.

\section{¿Hay relaciones sexuales a temprana edad?}

H: Por qué un amigo me llevó con una mujer para tener sexo con ella, pero yo no quise porque no sé qué enfermedades pueda tener ella y con cuántos hombres se ha metido, puede tener un hijo y a mis papás no les gusta tener ..."hijos"

M: Como a nuestra edad.

\section{¿Qué es hacer el sexo a temprana edad?}

\section{¿12- 13 años?}

M: Sí, para mí al menos.

$\mathrm{H}$ : Ya hacerlo cuando tengas suficiente edad y si puedes salir embarazada con la que vas hacerlo, que lo puedas aceptar al nuevo ser que viene.

\section{amigos o es solo por curiosidad?}

¿En ocasiones se ven presionados a tener sexo a temprana edad, por los

M: A lo mejor sí

M: A lo mejor porque la mayoría de los hombres ya han tenido sexo, son más aventados. Como por ejemplo los amigos de Poncho que ya han tenido sexo pero él no y a lo mejor se siente presionado.

H. No, pero no así...

\section{¿No has tenido sexo, no así cómo?}

H. Fui a tocar y unas muchachas empezaron a tomar y luego quería que hiciera el sexo con ella, pero no quise, por cuidarme.

\section{¿Qué más?}

M. Embarazos a temprana a edad, porque hay señoritas que tienen sexo y luego su novio no se hace responsable por su esposa las embarazan y las dejan y en ocasiones la familia no las apoya. Debemos tener la información nosotros, antes.

¿Por qué creen que se embaracen a temprana edad?

M: Puede ser que su novio las presione. Porque tal vez, todas sus amigas ya han tenido relaciones y las presionan.

H. Las presionan.

H: Por atracción,

\section{¿Qué hace que tengan relaciones a temprana edad?}

H. Yo vi a un niño de 7 años con una niña...

H. Yo siento que los obligan.

M: Por la presión.

M: Porque algunos hombres con sexo se sienten más hombres, y yo creo las mujeres también.

¿O se sentirán más grandes?

H: Más altos en la sociedad, de mayor importancia.

Pregunta/ Tema: ¿Cómo adolescentes qué se les permite hacer y qué no, en la escuela, en la comunidad, en su casa, en la familia. 
M. Se me permite, lo más tarde que puedo llegar es a las 9 de la noche cuando salgo con mis amigas y cuando salgo a bailes mi mamá me trae a la 1 ó 1.30 a.m.

H. Cuando salgo con mis amigos puedo llegar a mi casa 11:30 y en los bailes 3:30 a.m.

M. Mira la diferencia tú eres hombre y a las mujeres creo que somos más puritanas.

H. Llegando de la escuela, hago mi tarea, atiendo a los animales y en la tarde me salgo a la calle a jugar con mis amigos.

M. Me permiten salir a la cancha jugar Vóley, lo más tarde que me dejan es a las 9.

M. No me gusta salir, sí me convidan mis amigas pero no me gusta salir.

\section{¿Qué dicen tus papás?}

M. Nada. A veces me invitan a las fiestas pero yo no quiero ir, porque luego se hace tarde y me regaña mi mamá.

H. Yo nomás en las tardes y en las fiestas me dejan salir.

H. A mí nada más a lazar vacas con los caballos.

H. A mí no me dejan andar con los animales porque hay una vaca brava y una vez me le metí.

H. No me dejan casi ver televisión, cuando ven que me dicen apágala y no la apago me retienen por desobediente.

M. Lo que no me permiten es jugar a game boy porque cuando juego me duele la cabeza. Porque dicen que está mal estar todo el rato pegada a la televisión y porque cuando juego me pego a la televisión y no hago caso de nada.

H. No me dejan salir porque de niño era muy peleonero y me palié con dos chiquillos y les quebré unos dientes.

\section{¿Qué les gustaría que se les permitiera hacer?}

H. Montar a caballo y andar jugando con los animales.

H. Me gustaría salir a distraerse por ahí, al corral, a la plaza.

M. Me gustaría que me dejaran pasarme todo el día de vaga, pero no puedo hacer porque tengo que arrimar la leña, hacer de comer.

M. A mí me gustaría que me dejaran salir todas las tardes.

\section{¿En la escuela que les gustaría que se les permitiera?}

H. Me gustaría que me dejaran jugar futbol en el receso.

M. Me dejaran traer el celular.

M. Que nos dejaran traer el fleco.

¿Saben por qué no les permiten traer fleco?

H. No los dejan porque es moda.

H. A veces dicen que no ponen atención por estar jugando con el fleco

Pregunta/Tema: Experiencias con los maestros, papás u otros familiares ante sus cambios que presentan como adolescentes.

Respuestas

H. A mí ya no me regañan tanto mis papás como cuando era niño.

M. Ya no me regañan porque ya no soy rebelde, le hago más caso a mi mamá.

H. Con mis papás he tenido muchas experiencias, pero con mi familia ya me regañan menos.

M. A mí me regañan menos pero porque creo que ya soy menos rebelde, antes nada más 
quería hacer mi santa voluntad.

\section{¿Y con los maestros?}

M. Me gustaría que el maestro no me dijera nada.

M. Yo creo que al maestro Humberto se ha de enfadar porque un niño que está friegue y friegue y no lo deja explicar, le dice y le dice y al niño le vale, yo si fuera maestra si lo expulsaría de mi clase.

H. Que el maestro Humberto de matemáticas no fuera tan llevado porque le dijo a un compañero que se salió de clase le dijo que se lo iba a agarrar.

M. A lo mejor es que no es verdad porque a nosotras nos dijo que si no llegábamos pronto nos iba a quemar en leña verde. Yo creo que no es verdad.

H. Es broma.

M. Yo siento que me vale, porque sigo llegando tarde.

H. Según dijo la maestra que cuando ella tocara el timbre nos iba a poner retardo si llegábamos tarde y el maestro dijo que a quien llegara tarde nos iba a quemar con leña verde pero se rio por eso digo que es broma.

\section{Estímulo visual: Fotografía con imágenes de un grupo de amigos. Pregunta ¿Qué caracteriza al grupo de amigos aquí en la secundaria? Respuestas}

H. A veces se juntan en bolita, 5-6 y andan en grupos relajeando, caminando, saludando a los demás.

M. Las mujeres a veces nos juntamos en bolitas y al chisme, de nuestras experiencias, de los niños que nos gustan. Al menos yo sí platico de eso con mis amigas, de la moda, de la ropa.

\section{¿Qué les gusta y qué no de su grupo de amigos?}

$\mathrm{H}$. Me gusta mucho jugar con ellos porque a veces me divierten.

H. Cuando no vienen los maestros yo con un primo mío nos la pasamos mirando en los salones cómo trabajan.

M. En mi grupo de amigas me gusta platicar con ellas y a veces lo que no me gusta es que cuando les vuelvo a platicar porque se enojan y me dicen "eso ya nos lo contaste!"

H. Platicamos de cuando vamos a la fiesta de sus experiencias. Cuando va a las casas de un amigo nos ponemos a platicar de una fiesta, o así.

H. Experiencias de cuando andamos en caballo.

H. De futbol, vólibol y de básquetbol.

H. Cuando se van a tocar mi primo platica sobre cosas que sucede, cuántas horas trabajan, y así...

M. De quiénes están guapos y quienes no

M. De las novelas.

Estímulo: Fotografía: imagen de Pelea entre jóvenes.

\section{Pregunta/tema ¿Por qué pelean?}

M. Yo creo que en los dos géneros se ve mal, pero en las mujeres se ven más mal.

M. Y aparte los hombres se emocionan más.

M. Las mujeres traen falda y se les alza.

H. No es bueno pelear, hay que llevarse bien con los amigos.

M. En lugar de calmarlas les dicen "peléense, peléense" 
M. Si no se pelean dicen que son una gallinita completa.

\section{¿Por qué se pelean?}

H. Porque ya se traen coraje desde antes.

M. Las mujeres se pelean y se caen mal y es pretexto para pelear.

M. Se pelean por un hombre que les gusta, pero yo no me pelearía por un hombre hay muchos como para pelearse por uno.

H. Una vez me pelee. Estábamos jugando y no me alcanzó, me aventó una pedrada y yo me le aventé para golpearlo, y yo creo que si no llega su mamá sí lo mato.

M. Es que a nadie le gusta que le hagan cosas feas y a veces con los amigos se pasan y te pegan más fuerte.

M. Y se faltan al respeto, se ponen sobrenombres a los demás.

$\mathrm{H}$. O a veces se agarran a decirse palabrotas.

M. Pero entre nosotras nos ponemos sobrenombres, no nos metemos con las mamás porque es nuestra bronca no la de las mamás.

M. En los defectos

\section{¿Y entonces en qué se basan los sobrenombres?}

\section{Por ejemplo ¿Qué sobre nombres?}

M. Cuando usan lentes les dicen 4 ojos.

M. A mi hermano también le decían así y ya no quiso ponerse lentes.

M. Como a una niña que le decían cofreña porque era de la cofradía y se salió de la escuela.

H. A mí mi abuelito una vez que lo hice enojar y me escondí y me dijo "bájate de ahí pinche cieguillo" y desde ahí me dicen el ciego.

H. A un primo como tiene su patilla larga y alguien le empezó a decir patilla del diablo y de ahí ya se le quedó.

H. Malas palabras.

¿Hay otra forma de agredirse aparte de sobrenombres?

M. Pues darle en la madre como dicen.

\section{¿Porque poner Sobre nombres?}

M. Porque se caen mal o porque se llevan, porque si no me llevo con una persona no tengo por qué decirle sobrenombres.

M. Porque me cae mal y se ponen sobrenombre.

M. Por su modo de ser.

¿Cómo qué les cae mal?

M. Pero yo creo que ponerse sobrenombres está mal poner sobrenombres porque se fijan en los defectos de las personas sin fijarse en los de ellas.

M. A mí me dicen desde la secundaria la bolsa de churros que porque estoy flaca, como a él podría ponerle el pecoso porque tiene muchas pecas, pero no tengo derecho a ponerle un sobrenombre.

M. Cada quien tiene su nombre. A una amiga le decíamos el burrito, que porque se parece al burrito que sale en Shrek, ahora ya no le digo se llama Rosa Nelly ya no le digo porque ella se enojó y ya no le digo.

Describan algunas situaciones significativas en las que puedan expresar como sienten o piensan y en qué situaciones no pueden hacerlo. 
M. Algunas situaciones con tu mejor amiga o con algunos miembros de tu familia.

H. Especialmente con tus padres.

M. Yo especialmente con mi mamá.

M. Con los hermanos.

M. Yo me expreso mejor con mi mamá.

H. Yo no me expreso.

M. ¿Nunca dices lo que piensas o sientes?

H. No.

M. Yo creo que por vergüenza.

M. Yo tampoco, a lo mejor porque no me comprenden, no les tengo confianza.

_Una alumna pregunta a otra ¿no sientes un nudo en la garganta cuando por no poderte expresar con nadie? Yo creo que tus padres siempre te van a ayudar porque son tus padres (esa es tu experiencia con tus padres) la alumna contesta que no hace nada aunque sienta necesidad de decir algo.

H. Yo casi no platico nada a nadie.

M. No le tengo la confianza a alguien (contestando la pregunta), a veces aunque quiera. A veces sí siento un nudo en la garganta.

\section{Pregunta ¿Qué hacen para cuidarse a Ustedes mismos?}

M. Yo para liberarme digo lo que pienso, lo que siento.

H. Yo voy a trabajar con mi tío y mi papá y nos da algo para comer y ahorro para comprarme zapatos y ropa.

H. Yo trabajo cuando voy a tocar pagan 200 le doy 100 a mi mama, y si nos dan 500 le doy 100 a mi mamá y 100 a mi papá.

M. Yo no sé ahorrar, a mí me gusta mucho el dinero, gastar y gastar pero no me gusta trabajar.

H. Trabajar para ganar dinero, apoyar a mi mamá.

M. Me gusta leer mucho, meterme al internet y saber más y con mis horas, nunca me traspaso porque me empieza a doler la cabeza.

¿Me llama la atención que de venir a la escuela no menciona nada?

M. Lo que pasa es que no quiero venir a la escuela porque en vacaciones me acostumbro a no venir y en ocasiones que hay fiestas no puedo ir porque tengo que venir a la escuela, pero en ocasiones pienso que bueno que hay escuela.

H. Como cuando uno no se quiere levantar temprano es cuando no quiere venir.

M. Pero cuando uno ve las buenas calificaciones es cuando se da cuenta que valió la pena todo el esfuerzo.

¿Sienten que vale la pena pero no les gusta venir?

M. A mí sí me gusta.

H. Si

Pregunta: ¿Qué piensan sobre la igualdad de hombres y mujeres?

M. Creo que debes tratar a hombres y mujeres por igual. Hay trabajos en los que prefieren a los hombres porque tienen más fuerza, pero hay trabajos en los que sí se puede emplear a una mujer, como por ejemplo de plomera. Aunque los hombres tienen más fuerza.

M. Las mujeres podemos trabajar en el campo.

H. ¿Pueden las mujeres ser albañilas?

M. Sí, pero no pueden cargar bultos.

H. Pero sí pueden pegar tabiques. 
M. Las mujeres no sólo son para estar en la casa, pueden estar en cualquier trabajo, tienen las mismas oportunidades que los hombres para estudiar y trabajar.

H. En el freeway a pizcar fresa pueden irse las mujeres para trabajar al otro lado.

H. Que pueden ser iguales, los hombres cargan bultos y la mujer pega tabique.

M. Mi mamá trabaja le ayuda a mi papá en el campo, se va con nosotros a juntar lenteja... se lleva una botella de agua para todos y para ella también.

H. Puede ser la mujer igual que el hombre.

M. Hay hombres machistas que quieren que la mujer se quede nada más en la casa, que les lave y les planche, creen que como ellos traen el dinero a la casa ellas tienen que hacerles todo lo que ellos les piden.

H. Sí

¿El hombre puede hacer igual que la mujer?

H. Sí

M. Yo opino que el hombre puede barrer, trapear, cuidar a los niños, cocinar, entre otras cosas.

H. Estaba en estados unidos y el señor se quedaba a cuidar a los hijos y la mujer iba a trabajar, y cuando ella regresaba del trabajo él ya le tenía la comida hecha.

M. A algunos hombres les gusta quedarse en la casa y que sea la mujer la que salga a trabajar y cuando llega a la casa le toca hacer todo el quehacer.

M. Yo escuché al novio de una amiga que decía que se iban al cerro para el otro día a sembrar, su mamá, su hermana... todas. Y no hacían nada en la casa. En la noche que regresaban los hombres se iban a descansar y ellas se ponían a hacer el quehacer.

H. Yo si le ayudo a mi mamá. Cuando sale me dice que espera que cuando regrese ya tenga barrido y trapeado, y sí.

H. Pero yo no entiendo cómo los hombres que se van al norte allá, no se van con su mujer, y trapean, barren, cocinan, lavan su ropa y todo lo que hacen las mujeres aquí y cuando regresan no les ayudan a hacer nada de eso aquí.

M. A lo mejor porque dicen que para eso se casaron, pero se casaron porque las querían, no para traerlas así.

H. Hay gente que viene del norte y en vez de estar con su mujer aquí se sale y se emborracha. 


\section{GRUPOS DE DISCUSIÓN N²}

\section{Registro relatoría. A cargo de Georgina Pérez Coeto Mateos}

\begin{tabular}{|c|c|c|c|c|c|c|}
\hline $\begin{array}{l}\text { Nombre de } \\
\text { la escuela }\end{array}$ & Ubicación & $\begin{array}{c}\text { Zona } \\
\text { Escolar }\end{array}$ & $\begin{array}{l}\text { Grupo de } \\
\text { discusión }\end{array}$ & Grado y Grupo & Fecha & Hora \\
\hline EST No. 65 & Morelia & & $\begin{array}{c}\text { Integrantes } 6 \\
3 \text { mujeres } \\
3 \text { hombres }\end{array}$ & $\begin{array}{c}\text { 10. "A", "B", } \\
\text { "C" }\end{array}$ & $\begin{array}{l}10-06- \\
2010\end{array}$ & 11: 15 \\
\hline \multicolumn{3}{|c|}{ MODERADORA } & \multicolumn{4}{|c|}{ OBSERVADOR } \\
\hline \multicolumn{3}{|c|}{ Ma. De Jesús Soto Campos } & \multicolumn{4}{|c|}{ Georgina Pérez Coeto Mateos / Relatoría } \\
\hline \multicolumn{7}{|c|}{ Contexto situacional } \\
\hline \multicolumn{7}{|c|}{$\begin{array}{l}\text { La selección de las/os jóvenes que eligieron para el grupo de discusión fue de la siguiente manera: Un profesor } \\
\text { llegó a los salones y dijo los nombres de algunos/as jóvenes y les pidió que levantaran la mano. Ellas/os } \\
\text { preguntaron para qué y solo se les dijo que se presentaran en la dirección a las 11:15. Solo en el caso de un } \\
\text { joven preguntaron en su salón quien era el más serio y sus compañeros lo señalaron y entonces le dijeron al } \\
\text { joven señalado, tú te presentas a la dirección. Las/os jóvenes se sentían nerviosos/as y una chica dijo sentirse } \\
\text { insegura. Se les informa sobre el objetivo de trabajo y se establece el encuadre de la entrevista. Las y los } \\
\text { participantes manifestaron su desagrado en que la sesión fuera grabada, es por ello que se elabora una relatoría } \\
\text { sobre los puntos que se pudieron rescatar de las anotaciones durante el trabajo de discusión. }\end{array}$} \\
\hline
\end{tabular}

\section{SIMBOLOGÍA:}

$\mathrm{H}=$ Hombre

\section{DISCURSO}

$\mathrm{M}=$ Mujer

\section{TEMA O PREGUNTA DESENCADENANTE}

\section{Cambios que observan}

M Cambios de humor repentinos, de repente estamos riendo y lloramos

H Carácter... nos enojamos de pronto

H Que ya creció, que le está cambiando la voz y la cara y no me lo creo.

H La fuerza

H Quisiera cambiar mi carácter enojón.

H Introvertido... quisiera ser más extrovertido. El cómo te tratan los amigos o como los tratas te cambia la vida.

H No nos atrevemos a hablar por estar con personas que no conocemos

H Cuando no estoy haciendo nada me duermo 


\section{¿Qué cosas hacen para cuidar su salud?}

M Diario hago ejercicio, tratar de correr, tratar de dormir temprano.

M Tratando de no comer chatarra

M Una dieta balanceada, no comer cosas que engordan.

\section{¿Qué cosas afectan la salud de las/los jóvenes?}

H No hacer nada

H Estresarse

M Los maestros estresan

H Dictan muy rápido y eso nos hace sentir mal

H Los exámenes porque es el $80 \%$ de las calificaciones.

M Es mucha presión porque tiene que ver con las calificaciones, algunos dicen que lo que sacas en el examen es lo que sabes.

H En cierta manera expresan lo que sabes porque es un repaso.

M Mejor estudiar... es una sugerencia.

\section{¿A qué suena Educación Sexual y Equidad de Género?}

H En biología nos han enseñado sobre eso

M Vienen los derechos de hombres y mujeres, la igualdad de género.

¿Tienen los mismos?

M En la vida real no es así, que lo que se ve que hacen los hombres las mujeres no y lo que hacen las mujeres los hombres no.

M Aquí en industria del vestido hay hombres que quieren entrar pero no lo hacen porque se burlan, y la carpintería no entran mujeres.

H En el deporte hay más equipos de hombres.

\section{¿Cómo se sienten tratados como hombres y mujeres?}

Todos/as Bien.

\section{Sobre el noviazgo}

M No lo toman en serio, es puro juego, no se enamoran.

H Un amigo le ayuda a un chavo en algunas cosas a cambio de que le lleve recados a su novia, pero es puro juego.

M Se presentan y se van conociendo y luego es como se hacen novios, es un juego.

M Solo se tiene novio por decir que se tiene novio.

M Tienen novio porque le interesa alguna persona. 
H Tener novio ha repercutido en la novia de mi amigo, tenía 10 y ahora reprueba.

M Depende, porque ella tiene novio y tiene 10 igual que antes que también tenía 10 y no tenía novio.

M Desde la primaria expresan sentimientos, emociones a los amigos.

M Conocí a mis amigos aquí, coincidimos y nos llevamos bien.

¿Con quiénes se entienden amigos/as?

M Con los que no se salan la clase, son respetuosos

M Educados

M Divertidos.

M Se divierten mojándose, saliendo a pasear, platicando, en internet (Messenger, facebook).

H Divertidos. Se divierten mojándose y en deportes.

H Algunos no son buenos estudiantes.

H Los que me caen bien.

M Es mejor hablar en persona que por el Messenger.

¿De qué platican?

M De las materias.

M De lo que pasa con los papas (mamás).

M De lo del novio.

H De deportes, de las materias.

H De todo.

\section{Papá y mamá/Cambios}

H Son estrictos

M Castigan más... no nos dejan prender la computadora, no salir con los amigos, no ver televisión.

M Sentimos que nuestros papás no nos entienden. Dicen que las amistades son malas influencias.

M Se enoja, me deja salir solo si ya hice mis cosas.

\section{¿Qué ven de los temas en su Materia de Tutoría?}

M Casi no vemos nada en Tutoría

H El maestro de Ecología utiliza la hora de Tutoría como una extensión de su materia. 
M Se la pasa regañándonos

M Porque nos gusta mucho platicar y jugar, nos regaña porque no nos portamos bien.

H Pero es su forma de carácter.

\section{Embarazo adolescente}

M No es conveniente, te tienes que salir de estudiar.

M No están preparados física y mentalmente.

M Tal vez en tercero ya tienen relaciones sexuales.

M Quizás en tercero de secundaria empiezan a tener relaciones sexuales.

M Nos platicaron de una chica. Que se quedo embarazada y se tuvo que salir de la secu.

\section{Información sobre sexualidad}

Todos/as Solo en ciencias

M Algunos obtienen información de internet

\section{Amor-Odio}

M El amor es algo que nada más sientes

H Odio, coraje. Que no seamos respetados.

M A nosotras no nos respetan diciéndonos palabras que nos ofenden como ¡zorra!.

M Con apodos, a los hombres les ofenden diciéndoles ijotos!.

\section{Trabajo}

M Algunos trabajan de cerillos en las tiendas, en negocios o con las familias.

\section{Sugerencias}

M Que los maestros cambien de salón y no nosotros porque nuestras mochilas están muy pesadas y nos distraemos entre que pasamos de un salón a otro.

\section{Sugerencias para la asignatura}

H De los cambios físicos

M De los cambios de carácter... ¿por qué pasa lo que nos pasa?

M Igualdad entre hombres y mujeres

M Que tengamos las mismas oportunidades 


\section{GRUPOS DE DISCUSIÓN N³}

Registro de grabación. A cargo de Guillermo Díaz.

\begin{tabular}{|c|c|c|c|c|c|c|}
\hline $\begin{array}{l}\text { Nombre de } \\
\text { la escuela }\end{array}$ & Ubicación & $\begin{array}{c}\text { Zona } \\
\text { Escolar }\end{array}$ & $\begin{array}{l}\text { Grupo de } \\
\text { discusión }\end{array}$ & Grado y Grupo & Fecha & Hora \\
\hline EST No. 23 & Tangancícuaro & & $\begin{array}{c}\text { Integrantes } 6 \\
3 \text { mujeres } \\
3 \text { hombres }\end{array}$ & 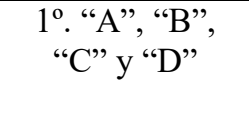 & $15-06-10$ & $9: 15$ \\
\hline \multicolumn{3}{|c|}{ MODERADORA } & \multicolumn{4}{|c|}{ OBSERVADOR } \\
\hline \multicolumn{3}{|c|}{ Ma. De Jesús Soto Campos } & \multicolumn{4}{|c|}{ Guillermo Díaz Martínez / Grabación } \\
\hline
\end{tabular}

El grupo se integra con alumnos/as de diferente grado y dos del mismo grado. Manifiestan no conocer con claridad el motivo de haber sido convocados, dos de ellos manifiestan sentirse un poco nerviosos. Se les informa sobre el objetivo de trabajo y se establece el encuadre de la entrevista. En general manifiestan disposición y agrado a participar, como apertura a la grabación de la misma en el entendido de que será confidencial. El receso está contemplado a las 10:30, razón por la cual fue necesario cuidar el tiempo de la entrevista.

\section{SIMBOLOGÍA: $\mathrm{H}=$ Hombre $\quad \mathrm{M}=$ Mujer}

Platíquenos de las experiencias de este primer año, qué les ha gustado, qué no, qué se les ha hecho fácil, qué difícil, qué han aprendido. Experiencias en la escuela:

H. Que me he sacado buenas calificaciones en este semestre.

H. Que me parece que los maestros enseñan muy bien en esta institución y me parece que todos hemos sacado buenas calificaciones.

M. Que algunos se esfuerzan por sacar buenas calificaciones y los maestros por enseñar bien. Llevamos más materias que en la primaria pero más sabiduría.

M. Que sacamos buenas calificaciones y he conocido me respetan y me dan buen trato.

M. Que sacamos buenas calificaciones y mis amigos me respetan y yo los respeto.

\section{¿Cómo ha sido la convivencia con sus amigos a diferencia de la primaria?}

H. Ha sido muy buena. Dependiendo de con quién te juntes

M. Aquí tengo más amigos que en la primaria porque allá hay más chicos que tú y aquí hay más grandes

H. Que tratas de venir a la secundaria para no perder a tus amigos porque ahora tienes más amigos. (silencio)

\section{¿Qué otras experiencias han vivido?}

H. Que a principio de año no sabes qué clases te tocan o con qué tipo de maestros te van a tocar.

Y ahora que ya terminaron en ciclo escolar ¿cómo ha sido?

H. Ya sabes cómo son los maestros, cuáles son tus amigos, cómo es el horario.

M. Que también algunos exámenes al principio se te hacen difíciles y ya luego lo vas 
superando y sacas buenas calificaciones.

¿Y qué cosas les gustaría que continuaran y qué les gustaría que cambiaran?

H. Que continuaran algunos maestros y otros los cambiaran.

H. Español o matemáticas

\section{¿De qué área?}

\section{¿Qué más?}

H. Que nos den más tiempo de receso. Tenemos 20 minutos y en la primaria eran 30 y a veces hasta $35 \mathrm{~min}$.

H. Nosotros 40'

M. Algunos maestros que no querría que cambiaran: la de geografía, matemáticas, inglés y la de estatal (historia).

H: Que no hicieran preferencias de alumnos.

\section{¿Han notado esas preferencias?, ¿cómo son, en qué consisten?}

H. Que cuando le piden ayuda al maestro más bien se va con sus preferidos y cuando uno necesita su ayuda no se la da.

H. Que cuando hay un evento siempre escogen a los mismos.

M. O que ignoran a los que sacan buenas calificaciones y a los que sacan bajas calificaciones y lo necesitan no los ayudan.

H. Que los que sacan buenas calificaciones ayuden a los que sacan bajas calificaciones para que les vaya mejor.

\section{Lo que se les permite en su adolescencia:}

H. A mí se me permite ver amigos mayores o menores que yo.

M. A mí se me permite convivir con personas que son buenas y con las malas no puedo convivir porque me traen malas ideas.

\section{¿Quiénes?}

M. Mis papás, me dejan juntarme con algunas personas siempre y cuando no nos den mal ejemplo.

H. A veces nos dejan juntar con personas que sean conocidas o sean de confianza porque a veces los papás tienen sospechas con las personas que ellos no conocen

H. Cuando una persona anda en malos pasos mejor me retiro porque mi mamá me dice que esa persona no me conviene como amistad.

H. También cuando quiero salir de viaje, una vez que invitaron no me dejó mi mamá que porque no conocía al señor y que porque era muy lejos.

H. Protección.

\section{¿Cómo se le llama a eso?}

H. También algunos alumnos no quieren dejar su amistad y se ponen rebeldes, pero los papás lo hacen por nosotros mismos, nos regañan o nos pegan para que dejemos malas amistades o andemos en malos pasos.

\section{¿Te regañan cuando alguien no es buena influencia?}

H. Sí, nada más me permiten que me saluden.

H. Antes con un amigo, un amigo mío cuando venía a la secundaria su mamá llevaba una navaja y una lámpara, son muy sobreprotectores. Lo regañaban si lo veían jugando con 
nosotros.

\section{¿En la escuela que les gustaría que se les permitiera?}

H. Como aquí en la escuela cuando alguien cumple años no se puede mojarlo y festejarlo así.

H. Como el día del niño, nos mojamos para festejar y el director nos dijo que nos iban a poner un reporte escolar.

M. Pero la bibliotecaria nos vio y no dijo nada, ya después fue el director el que nos estaba regañando por estar echando relajo.

¿Y en su casa, algo que les gustaría hacer y que no les permiten? ¿O con otros adultos?

H. Cuando visito a un primo no podemos alejarnos a más de una cuadra o dos, sólo con permiso, y si vamos a la tienda nos ve alguien desde la puerta hasta que regresamos... se siente incómodo.

Estímulo visual: Foto de adolescentes (dos hombres y dos mujeres) leyendo textos en la biblioteca.

\section{¿Qué observan en esta fotografía?}

M. Niños que están viendo libros en la biblioteca

¿Imaginen que estos libros que están leyendo se relacionan con los temas de educación sexual o sexualidad, ¿qué estarán buscando de manera específica?

H. Cómo se compone un óvulo

M. Las enfermedades de transmisión sexual

H. Que a las niñas les tiene que pasar su menstruación y a los niños los sueños húmedos.

H. Algunos anticonceptivos con los que se pueden prevenir las enfermedades de transmisión sexual.

¿Por qué creen que les puede interesar tener esta información?

H. Para cuando sean grandes saber cuidarse de esas enfermedades

H. Para poder prevenir las enfermedades

\section{¿Qué más se les ocurre chicas?}

M. Podría ser cómo actúan los adolescentes cuando pasan estas cosas

¿Cómo creen que actúan cuando pasan estas cosas?

H. Podría ser que muy desesperadamente porque no saben qué hacer a tan corta edad.

Cuando no saben qué hacer, ¿qué se preguntan?

M. Se preguntan cómo evitar, o qué hacer o a quién recurrir.

M. Lo que les pasa

¿Evitar como qué?

¿Tanto hombres como mujeres desean por igual evitar estos cambios?

H. Podría ser igual.

M. Yo pienso que algunos sí y otros no porque algunos ya quieren crecer y otros quieren seguir siendo adolescentes... 
M. Sí.

\section{O niños, ¿verdad?}

En la escuela llevan una materia que se llama Biología y otra asignatura que se llama Orientación y Tutoría, ¿en estas materias que han visto que se relacione con la educación sexual y equidad de género?

M: En Biología hemos visto la reproducción y los cambios de la adolescencia

H y M. Y las enfermedades de transmisión sexual

M. Y los genes

\section{¿Qué opinan de las enfermedades de transmisión sexual?}

M. Que son muy malas para la vida de las personas y que las personas no van a vivir su vida ni disfrutarla

H. que en la adolescencia o ya adultos se tienen que cuidar con anticonceptivos.

M. en la materia de orientación y tutoría estuvimos viendo lo del acoso escolar

M. Maltratarse

\section{¿Cómo sería eso?}

H. Unos a otros, decirse malas palabras. O decirse cosas que a los otros no les gustan, como a las niñas que no les gusta que les digan que están bien buenas y ellos les dicen.

De lo que revisan en estas materias ¿qué es lo que más les ha llamado la atención a ustedes?

H. Las enfermedades de transmisión sexual

M. Que nos dicen cómo prevenirlas

H. Cuáles se pueden curar y cuáles no

H. Cuáles pueden ser fatales

Ahora que estamos diseñando la asignatura Estatal de Educación Sexual y Equidad de Género, ¿qué les gustaría que se viera en esta asignatura?, ¿qué creen que les gustaría a los jóvenes ver?

M. Que las niñas y a los niños tenemos los mismos derechos aunque diferentes cosas, que se nos tiene que tratar igual. No me gusta que antes a las niñas les daban poquito de comer porque los niños tenían que salir a trabajar y las niñas se quedaban en la casa.

\section{¿Consideran que hay desigualdad en derechos entre hombre y mujeres aquí en la} escuela o en la comunidad?

H. Creo que sí

H. Podría ser en el taller, que dicen que es sólo para hombres aunque en realidad van dos mujeres y puede que sean mejor que yo en esa materia, no tienen que estar a fuerzas en talleres como contabilidad o... otros talleres.

*M. Yo también me metí a otro para que algo me dijera a mí, pero a mí si me dejan meterme, a otras les dicen que no van a aprender.

H. Como a mí mis amigos me dicen que contabilidad es para mujeres, pero hasta ahorita llevo buenas calificaciones y les digo que a mí me gusta y no me importa si es para mujeres o no.

O sea que a veces les gusta un taller y no entran porque les dicen que ese no es para hombres y mujeres. ¿Cómo sería? 
M. Algunas cosas son diferentes, como la vestidura. Como a veces les dan inyecciones, y a los niños les inyectan una cosa y a las niñas otras, y algunos niños que son hermanos les dicen que son iguales pero no lo son porque cuando crecen hay cambios en el cuerpo y en la mente.

\section{¿Ustedes qué piensan?}

H. Que somos diferentes en la forma de pensar y en la forma de ser porque si hay dos gemelos serán iguales por el exterior pero por el interior son diferentes.

\section{¿Creen que hay respeto a la diferencia?}

M. Algunas veces no porque luego que se meten en talleres y otros se empiezan a burlar, otras veces que se juntan a fumar se burlan de los que no quieren y les dicen que son mandilones o mujeres.

\section{¿Qué más les gustaría que se viera en esta asignatura?}

H. Torneos de futbol de mujeres.

M. Aquí una vez hicieron un torneo pero a las mujeres no las dejaron entrar.

H. Que no se haga diferencia entre los derechos del hombre y la mujer.

\section{Si lo que han dicho es lo que esperan, quiere decir que así no es en la realidad, ¿Cómo es en la realidad?}

H. Que los hombres se juntan con algunos amigos para salir, y las mujeres por no tomarse en cuenta no se ponen de acuerdo para salir con algunas amigas.

M. O que también en algunas casas las niñas nada más están para hacer quehacer y los niños se la pasan viendo tele, aunque pueden hacer las mismas cosas.

M. Niños y niñas tienen las mismas oportunidades. Antes nada más a los niños los mandaban a la escuela y a las niñas no les permitían estudiar.

H. Antes también el voto, sólo los hombres iban a votar y ahora también las mujeres pueden ir a votar.

H. Antes iban nada más los hombres a la escuela pero ahora en las escuelas hay más mujeres que hombres.

M. y también, leí en un libro que una mujer hizo una cosa para ser tratada como hombre pero la sacaron de la cárcel porque no la juzgaron como hombre y ella quería que sí lo hicieran.

H. Como Sor Juana Inés de la Cruz que también quería estudiar.

\section{¿Algo más que no ven en Orientación y Tutoría y en Biología y que les gustaría que se incluyera en la materia estatal?}

H. Que hubiera juegos y actividades al aire libre para promover la igualdad.

\section{Qué se podría hacer en esta escuela para mejorarla:}

M. Que no hubiera favoritismos entre compañeros, ni peleas, y que los maestros se pusieran las pilas para enseñar mejor y los alumnos para echarle más ganas.

H. Entre grupos

¿Cómo son las peleas que hay aquí en la escuela?

M. Algunas alumnas se pelean por algunos alumnos que les gustan.

H. Algunas niñas que se sienten más bonitas y se sienten mejores que nosotros.

H. No debe de haber un líder en el salón porque todos pueden ser un líder y todos tienen que tener su opinión.

H. En mi grupo, el jefe de grupo es muy desordenado, es muy guapo, pero porque es popular lo escogieron porque es muy popular. Yo no lo elegí porque es muy desordenado y 
presumido.

H. Sí, los criterios para escogerlos deberían ser otros, que tuviera más ideas el jefe de grupo, más listo, más responsable.

M. En mi salón la jefa de grupo es muy desordenada, ya le han sacado algunos reportes porque una vez falsificaron firmas y con otra maestra son muy groseros o no trabajan.

M. Que el jefe de grupo tuviera más comportamiento, que pusiera orden si no está el maestro.

H. Que el jefe de grupo debe poner el ejemplo.

\section{Prototipos de belleza:}

M. Algunos le ponen mensajes en las butacas y rallan los baños y eso no debe de ser porque todas las mujeres tenemos belleza por dentro y por fuera, y también de los hombres que les importan más cuáles son sus pensamientos y sus sentimientos.

H. No importa si un niño es feo y el otro guapo, pueden tener los mismos

\section{Sentimientos.}

H. Prefieren a los que son delgados o tienen una cara bonita.

H. O que sean futbolistas...

H. Podrían ser muy malas personas...

M. En mi salón hay una niña que es la más bonita del salón y siente que a todos les puede decir cosas, todo critica, pero en realidad ella no tiene amigas por cómo es.

\section{¿Cómo se da el noviazgo aquí en la secundaria?}

M: en algunos casos se da desde que se ingresa a la secundaria o en algunos casos desde antes.

H. Yo en la primaria tenía una compañera que ya tenía novio.

H. Desde que se ingresa

¿Y en esta escuela a qué edades se da el noviazgo?

H. O desde la primaria

¿Y por qué creen que se da en estas edades?

M: porque ya se sienten maduros cuando no lo están.

H. Piensan que ya pueden hacer lo que quieran, que ya están grandes.

M: algunos padres les dicen a sus hijos que no pueden tener novio porque todavía no tienen su mente madura y ellos tampoco son maduros

H. A mí mi mamá me dice que hay una edad para cada cosa.

M. Luego a algunos los aconsejan y les dicen que es muy divertido y los aconsejan para que tengan novios.

M. Que los aconsejan a otros y luego los llevan a tener problemas.

M. O también el novio maltrata a la novia y le dice cosas. Y si la ve platicando con otro amigo se enoja, o ella también si ve platicando al novio con otra se enoja, piensa que está saliendo con la otra y entonces empiezan los problemas

H. O también puede ser que el novio tiene a su novia a fuerzas, por ejemplo que la amenaza que le puede hacer algo a su familia.

\section{¿Si llega a pasar esto? ¿Ustedes que piensan de ello?}

H. Que un novio es para comunicar ideas y eso y no nada más por tener novia y creerte más.

M. A veces es por moda y por presumir.

¿Qué hacen para atraer a un hombre o una mujer?

H. Maquillarse o ponerse ropa muy corta, o blusas que no les tapen la panza.

H. También a veces hacen dieta para estar delgadas. Por decir una familia come y la niña en 
el baño se vomita.

\section{Como la anorexia o la bulimia, ¿han visto esos casos aquí?}

H. Había una señora que hacía que su hija comiera y luego vomitara a fuerzas y hasta que no vomitara no le hacía caso o no le daba comida y ahora cuando ella come ella sola se va a vomitar porque ya no puede tener la comida en el estómago, y ahora ella está muy delgada, se ve muy débil... dijeron que ya una vez estuvo a punto de morir, y se ve muy feo.

M. Antes yo iba a un programa donde hablaban del alcoholismo y las enfermedades, y nos mostraron de una niña que vomitaba porque la mamá de una amiga era muy flaca y que su mamá dijeron en el video que era gorda, pero ella hacía eso también porque quería parecerse a una Barbie, pero al final del video decía "lo malo es que voy a morir gorda", pero estaba muy delgada.

M. Que es malo para su salud.

\section{¿Y tú qué piensas de eso?}

H. Y también hay una enfermedad en la que se ven gordas ellas pero no lo están

\section{¿Cómo les gustaría que fuera su relación en su noviazgo?}

H: Normal, que no fuera celosa ni tan callada que si tuviera un problema me lo contara, que sus padres la dejen platicar.

M: Que sea respetuoso responsable, que no ande en pandillas

M. Que entre los dos se respetaran, que se permitan tener más amigos.

H: Que cada quien tenga su tiempo, porque siempre quiere que estén solo con ellas o ellos.

H. Que cada quien necesita su espacio y poder tener amigos

M; Que los papás permitan que las invitemos a viajes familiares.

M. Que no sean celosos

\section{Fotografía estímulo: de agresión / desigualdad entre hombres y mujeres. ¿En la imagen} que imaginan qué sucede?

H: Puede ser que el novio o el esposo la golpeen porque solo por tenerla a ella, que ella no quiere estar con él, porque no le gusta o por cómo es.

M. Yo vi una película en la que una muchacha tenía novio y él si era responsable, solo que él era pobre, y ella era de clase media, y había otro detrás de ella con más dinero, y ella por andar con él dejó al otro, y él una vez le disparó al otro, y a ella la trataba como cualquier cosa y la golpeaba y la amenazaba diciendo que si lo dejaba iba a matar a su mamá o a su papá y ella mejor lo dejó y regresó con el otro, y a él lo metieron a la cárcel por dispararle al otro.

\section{Eso lo viste en una película, ¿crees que en la vida real pase eso? ¿Han visto una situación así?}

H. Yo sí, con unos vecinos. Rentan una casa, antes ahí vivía un marihuana y él diario pegaba a su esposa, se alcanzaban a escuchar los gritos y tuvo que ir la policía.

M. También por mi casa vivía una familia, el papá era muy borracho, tenía dos niños. Cuando salía a la calle el niño él lo golpeaba. Y a la niña le decía que era una burra, una tonta. Su mujer le decía que les diera dinero a sus hijos para que fueran a comprarle cosas a la tienda y también la golpeaba. Cuando ella salía a la calle tenía muchos moretones. Ella una vez se atrevió y fue a demandarlo y en esa demanda le dijo que le pasara dinero para sus hijos, y ya se cambiaron de casa.

H y M. No

¿Aquí en la escuela han visto casos así? 
H. También una reflexión de Mariano Osorio (que escucha mi papá), dice que un señor se iba a la cantina y regresaba tomado y le pegaba y regresaba y le llevaba flores, y así al día siguiente... hasta que la mató. Y cuando la mató le llevó flores pero las flores no eran para ella sino para su cuñada.

\author{
H. No \\ M: no \\ H. Si \\ ¿Ni se dicen apodos? \\ H. Pero un apodo como amigo no agresiones \\ M. No un apodo que lastime o hiera sus sentimientos.
}

¿Pero aquí en la escuela ustedes han visto manifestaciones de agresión entre jóvenes?

\title{
¿Por qué hace rato hablaban ustedes de las peleas?
}

H. Si no se llevaban bien entre sí, uno le dice a otro que si se pelean a la salida y el otro le dice que sí. La primera vez que vi una, iba mucha gente y nos vio la policía y cuando los vieron corrieron.

M. También a mí hermano...

H. Podría ser por novios o por los grupos.

¿Por qué creen que pase eso?

H. Porque a un niño le gusta que le llamen por su nombre y le ponen un apodo que le moleste y se pelean.

\section{¿Y los que agreden?}

H. Porque tienen problemas familiares o no los tratan bien en la escuela.

M. Porque se sienten superiores a los demás, sienten que pueden hacer lo que quieran o porque tratan de llamar la atención de los demás.

H. Podría ser que necesitan atención, quieren llamar la atención de los demás

Fotografía de dos adolescentes pensativos. ¿Cómo ven la actitud de esta muchacha, de estos muchachos?, ¿Qué estarán pensando? ¿Qué estarán sintiendo?

H: Que están solos.

H. Que no le importan a nadie.

H. Tristeza.

H. Soledad.

M. Se sienten solos porque piensan que a nadie los toma en cuenta, ni siquiera sus padres, ni sus hermanos.

H. Que nadie los quiere ya, o que ya no tienen amigos.

H. O fueron abusados física o psicológicamente.

M. O porque los dejó su novia y ya se sienten solos.

M. Que los hayan insultado.

H. Sí

M. Sí

H. Podría ser

¿Cuándo tienen esos sentimientos que hacen? 
M: Yo tenía una amiga que se sentía muy sola y se encerraba en su cuarto y se cortaba y la llevaron a un psicólogo y se curo y le dijeron a los papás que le faltaba atención.

H: También dicen que se educa con el ejemplo, porque hay papás que maltratan a sus hijos, pero si a ellos no les pusieron atención deberían ponerles atención o no maltratarlos.

\section{¿Qué les gustaría cambiar de ustedes? Pero que lo intentan y no pueden.}

H: Mi comportamiento, porque hay veces que me enojo mucho con mi hermano o mi hermana. Me molesto y reparo con otra persona.

H: Yo también porque no me ponen atención y yo voy a maltratar a un hermano.

M. O también que yo tengo un hermano mayor que me dice cosas y yo por hacerle caso me enojo, cuando estaba chiquita hacía berrinches para que lo regañaran y ahorita cuando me dice algo quiero ignorarlo.

\section{¿Cómo entienden el amor y el odio?}

H: El amor podría ser amistad entre amigos o familiares, ser agradable, no ser malo. El odio sería que no puedes soportar a una persona que no lo entiendas y te enojes con él.

M: El amor sería tener una familia que se perdonen, te respete y el odio que no se hablen y se dirijan con malas palabras. También que se falten al respeto.

\section{Describen una situación:}

H: Cuando saqué 9.7 en la escuela y me sentía muy bien pero una compañera sacó 9.8 y yo me sentí muy mal, pero mi mamá me explicó que no me sintiera mal porque yo había hecho mi mejor esfuerzo.

M: Una vez con la familia de mi papá, mi abuelo prefieren a las más chicas que a las más grandes pero y yo he sentido amor por mi otra familia porque ellos si me consienten y me hacen sentir amada porque no les importa eso.

H. Un tío que es muy llevado, me cuentan que cuando yo estaba chico fueron a Zamora a comer, él agarró de mi comida y se ha hecho a la boca y dicen que lloré pero no recuerdo ese día.

H: Cuando saco buenas calificaciones me felicitan en mi casa y ese es el sentimiento de amor y el odio es cuando no te aceptan tus amigos o te sientes odiado o rechazado.

H. También cuando saco buenas calificaciones me felicita mi mamá, me da abrazos o me compra cosas y yo siento que mi hermano cuando no saca buenas calificaciones se siente mal y le pregunta a mi mamá qué le trajo a él.

M. Una vez a mí me compraron una muñeca porque saqué buenas calificaciones y a mi hermano para que no se sintiera mal le compraron un carrito. En algunas familias solo atienden a los que sacan buenas calificaciones y a los otros los dejan atrás, pero también debería motivar a los otros para que le echen ganas.

H: Tengo un hermano que está en prepa y dice que se quiere hacer militar para hacerse responsable y tener un buen sueldo. Dice que si saca buenas calificaciones le dan una beca de \$8000. Pero dice mi papá que estuvo ahí pero no aguantó porque son muy exigentes.

¿Qué cosas hacen por ustedes que crean que se merecen, para ustedes mismos?

M: Sacar buenas calificaciones.

M: Estudiar.

M. Comprarte tú misma algo.

H: Alguna cosa u objeto que te motive para sacar mejores calificaciones.

H. Motivarte a ser mejor que los demás.

\section{¿Describan una situación entre un hombre y una mujer donde ustedes vean que no hay equidad (igualdad)?}

M: Cuando hay una actividad se juntan los hombres y las mujeres, los hombres son más 
mandones y quieren nada más estar viendo... o al revés.

H: En el taller de carpintería me tocó con dos chavas, y como mi papá es carpintero pues yo ya sabía, era muy sencillo cortar y pegar unas tiras de madera con clavos y Resistol y como me tocó con una compañera muy tísica para hacerlo casi yo hice el trabajo solo y mi compañera solo media las tablas y con la otra que me ha tocado es una de las que más trabajo en cortar tablas y yo me llevé una, la otra se llevó la otra.

H: Los que no entienden dicen, mejor hazlo tú y yo veo cómo lo haces.

\section{¿Qué piensan acerca del embarazo a temprana edad?}

H: Podría arruinar la vida del hombre o la mujer.

M: Que a veces el novio no acepta la responsabilidad y se sienten solas, los papás a veces las corren de su casa y a veces ellas se suicidan.

H. Que no vives tu juventud y no puedes salir con alguien más porque embarazaste a otra persona.

H. Podría ser que la muchacha se siente mal porque no va a poder seguir estudiando y va a tener que mantener a su hijo y puede ser que luego no lo quiera o que lo vaya a abortar o que cuando nazca lo maltrate

\section{¿Aquí en la escuela se dan esos casos?}

H: Creo que hubo un caso o dos. Me contaron que abusaron de la muchacha, se metieron un muchacho con la muchacha en un salón y ella salió embarazada y decidió salirse de la escuela.

H. También en Patamban, tres o cuatro muchachas tuvieron que salirse de ahí porque salieron embarazadas.

\section{¿Ustedes creen que las relaciones sexuales también se dan a temprana edad? ¿O a qué edad se dan?}

H: Podría ser de secundaria en adelante, segundo o tercero.

\section{¿Qué opinan?}

M. Que no es bueno porque dejan de vivir la vida alegre como la vivían y no hacen lo que les gustaría hacer.

H. Que a lo mejor le hubiera gustado al muchacho tener su carrera pero se tiene que salir de la escuela para mantenerlos.

...Aunque no siempre resulta el embarazo, pero puede ser que se dé.

M: En la primaria nos decía la maestra que para poder tener relaciones sexuales, tenemos que tener una edad madura, casa y trabajo, para poder mantener a su familia.

H. O saber mantener a los hijos, por ejemplo una muchacha que no sabe hacer de comer tendría que ganar más dinero para comprar la comida hecha.

\section{¿Qué creen que hace que tengan relaciones sexuales a temprana edad?}

H. De que no platica con sus papás de la situación con sus hijos.

H. La curiosidad.

M: A veces los obligan a tener sexo diciéndoles que van a matar a algún familiar, como una hermana más chiquita o así.

H. Que quieren saber qué se siente.

M: También puede ser por la atracción.

¿Qué ventajas les da ser hombre o ser mujer?

H: Las ventajas de ser hombre podría ser que puedes tener un trabajo mejor pagado que las 
mujeres.

H. Que tienen más oportunidades de trabajo que las mujeres.

M. Que las mujeres también tienen oportunidades de trabajo, por ejemplo que una vecina trabaja en un camión.

M: Aquí en la escuela nos tratan por igual.

¿Y en la escuela les da una ventaja o desventaja el ser hombres o mujeres?

H: Aquí se nos trata por igual.

M: sí

¿Aquí se les trata por igual?

H. sí 


\section{GRUPOS DE DISCUSIÓN N 4}

Registro de grabación. A cargo de Guillermo Díaz.

\begin{tabular}{|c|c|c|c|c|c|c|c|c|}
\hline $\begin{array}{l}\text { Nombre } \\
\text { de la } \\
\text { escuela }\end{array}$ & Ubicación & $\begin{array}{c}\text { Zona } \\
\text { Escolar }\end{array}$ & $\begin{array}{l}\text { Grupo de } \\
\text { discusión }\end{array}$ & $\begin{array}{c}\text { Grado } \\
\text { y } \\
\text { Grupo }\end{array}$ & Moderadora & Observador & Fecha & Hora \\
\hline $\begin{array}{l}\text { EST No. } \\
112\end{array}$ & Carapan & 04 & $\begin{array}{c}\text { Integrantes: } \\
6 \\
3 \text { hombres y } \\
3 \text { mujeres }\end{array}$ & $\begin{array}{c}1^{\circ}: \\
\text { A,B y } \\
\text { C. }\end{array}$ & $\begin{array}{l}\text { Ma. De Jesús } \\
\text { Soto Campos. }\end{array}$ & $\begin{array}{l}\text { Guillermo } \\
\text { Díaz } \\
\text { Martínez }\end{array}$ & $\begin{array}{c}15-06- \\
10\end{array}$ & $12: 30$ \\
\hline \multicolumn{9}{|c|}{ Contexto situacional } \\
\hline \multicolumn{9}{|c|}{$\begin{array}{l}\text { El grupo se integra con alumnos/as de primer grado, dos por cada grupo. Manifiestan no conocer con claridad el } \\
\text { motivo de haber sido convocados. Se les informa sobre el objetivo de trabajo y se establece el encuadre de la } \\
\text { entrevista. Todos manifiestan disposición y agrado a participar, como apertura a la grabación de la misma en el } \\
\text { entendido de que será confidencial. La hora de salida de clase es a las 14:00, razón por la cual fue necesario } \\
\text { cuidar el tiempo de la entrevista, considerando el establecimiento del encuadre y la realización de la auto- } \\
\text { descripción breve. Al plantear la última pregunta de la entrevista, suena el timbre de terminación de la jornada } \\
\text { de clase, se observa inquietud en los participantes para salir por sus mochilas. Sin embargo, esperan a que se de } \\
\text { por terminada la sesión. }\end{array}$} \\
\hline
\end{tabular}

SIMBOLOGÍA: $\mathrm{H}=$ Hombre $\mathrm{M}=$ Mujer

Platíquenos de las experiencias de este primer año, qué les ha gustado, qué no, qué se les ha hecho fácil, qué difícil, qué han aprendido.

M: nos gustan cómo nos enseñan

\section{¿Cómo les enseñan?}

M. Nos explican bien, algunos maestros y otros no, para poder realizar los trabajos como ellos nos los piden y si no entendemos nos vuelven a explicar.

\section{¿Cuáles son esos maestros que sí les explican bien?}

M. Julio Catel (biología), la maestra Isabel (matemáticas)

H. Matemáticas

M. Inglés, la maestra Verónica

M. Español con la maestra Anita

H. Nada más que no todos ponen atención.

M. Estamos en diferentes talleres pero, mi maestra es la mtra. Rosalinda Velázquez

H. Y explica bien, ¿verdad?

H. Sí

H: el de nosotros es el maestro Jaime que nos da dibujo, también explica bien 
H. también el maestro Jorge de educación física

¿Qué más les ha gustado de estar aquí en la secundaria?

M: Nos han enseñado a que no tenemos que tirar tanta basura porque contaminamos el medio ambiente.

H. Y nos han enseñado a tener respeto y responsabilidad.

M: También nos han dado pláticas del alcoholismo

H. Y de la drogadicción. Yo pienso que eso es muy bueno, para todos.

\section{¿Estas pláticas que han tenido en qué les ha ayudo a ustedes?}

M. Para que no lo hagamos nosotros

H. Para un tío que anda jalando la marihuana, y ya le explico que le hace daño y ya no fuma tanto.

H: también nos enseñan el daño que nos hace el alcohol y el cigarro.

M. Para que no caigamos en ese vicio

H. Sí

¿En la escuela hay alumnos o alumnas que les guste tomar...?

M. Sí

H. En las fiestas, cuando hay y hay clases al día siguiente casi no vienen porque están crudos porque tomaron en la fiesta

M. Y se venían borrachos, todavía tomados de la fiesta

H. No todos, algunos sí

H. Es lo mismo

¿Es lo mismo es en hombres y mujeres o es diferente?

H. Por ahí, por mi casa, en las fiestas muchachas andan tomando, y se ve mal.

M: en su salón hay una compañera que toma

\section{¿Por qué creen que toma?}

M. Así como para hacerse que es chola, y sé cree la muy acá, así para que nosotros digamos que ella sí le entra a eso... ella dice que es por amor pero antes no era así.

M. No

M. Ella desde que se junta con los otros se sale y toma y se sale en las noches.

\section{¿Quiénes toman más?}

M. Los hombres.

H. Los hombres pero ya en la actualidad están emparejándose las mujeres.

¿Por qué razones consideran que toman hombres y mujeres?

M. Algunos hombres toman porque sus novias los dejan.

H. Las mujeres también toman porque sus novios las dejan.

H. Sí

M. Ajá

¿Por desilusiones de amor entonces?

H. Sí

M. Sí

H. O por problemas en su casa

H. Y en las fiestas toman mucho 
M. Porque se alegran de la fiesta

H: No

\section{¿Aquí en la comunidad se acostumbra tomar mucho?}

M, H y M: Sí

H. No tanto

M, H y M: Sí

H. Pero en las fiestas

H. En las fiestas

H. En las fiestas

H. Siempre tienen que salir borrachos

H. A los que les gusta tomar, a los que no pues no.

Pregunta/tema: Razones y motivación para estudiar en la secundaria.

H: A mí porque yo quiero ser maestro.

H. A mí porque mi papá es maestro.

M: Yo porque mi papá me dice que estudie.

H. Y a mí porque me gusta el estudio

H. A mí me gusta el trabajo y me gusta convivir con los compañeros.

H. Y me gusta ver a más personas

M. Sí

H. Y compañeros

¿Sus otros compañeros creen que tengan razones distintas a las de ustedes?

Todos. Sí

\section{¿Cómo cuales?}

H. Unos a veces dicen "no, yo voy a dejar la escuela, no me la paso nada bien".

M: "Me voy a ir a vagar por ahí".

H. $\mathrm{O}$ algunos se salen porque los molestan y ya no quieren venir.

H. $\mathrm{O}$ algunos vienen a la escuela porque no los manden a trabajar pero sale lo mismo porque no estudian.

M. Nada más a calentar la silla.

Todos. Sí

¿O sea que los que no estudian los mandan a trabajar?

M. En el cerro.

¿En qué trabajan?

H. En el cerro.

H. En el campo.

M. A traer leña.

M. Sembrar maíz.

H. Muchos, porque muchos van a ayudarles a sus papás, son albañiles, y les van a ayudar.

M. $\mathrm{O}$ campesinos.

¿Y quiénes ayudan a las tareas del campo, hombres y mujeres o sólo hombres?

H. Hombres. 
M. Hombres, a veces mujeres.

H. Hasta ahorita yo veo que ya las mujeres trabajan también en el campo.

H. Sí, ya hay muchas señoras de Carapan que van a Tangancícuaro a trabajar en la fresa.

\section{los molestan?}

¿Decían que algunos se van de la escuela porque los molestan, ¿cómo

H. Porque aquí hay muchos niños que son muy maldosos.

H: Muchos se van de la escuela porque los molestan, porque hay muchos niños maldosos, les pican o les pegan a los demás.

\section{¿Cómo qué les dicen?}

H. Como joto, es la palabra más común. Los tienen amenazados.

M. Los tienen amenazados y ellos tienen miedo que les peguen.

H. Y mejor se salen de la escuela.

H. Que saliendo de la escuela les van a pegar.

H. A una compañera se murió porque le habían pegado bien feo y...

H. Y luego se ahorcó.

H. Sí.

M. Del sentimiento.

H. Sí.

¿Por qué motivos son las peleas?

H. Las peleas se generan por muchas cosas, como por ejemplo...

H. Por los novios...

H. Que una niña le quita el novio y empiezan a alegar que "por qué me lo quitaste" y se empiezan a pelear. También se pelean por envidia.

M. Por coraje.

H. Por coraje, y también se pelean, como si alguien tiene buenas calificaciones por envidia se andan peleando.

H. Por ejemplo ella, tiene buenas calificaciones y yo le pego, le pego para que me haga mis tareas porque yo no puedo... es un ejemplo.

H. Sí

¿O sea que cuando alguien quiere algo y no lo tiene entonces agrede al otro?

M. Ajá

H. Sí

M. Sí

M. Por ejemplo hay una pelea y el otro dice "ah yo si te hago las tareas para que no me pegues".

H. Si es muy inocente, así como muy serio.

\section{¿Y pasa mucho?}

H. No mucho

H. No, no tanto

H. No tanto pero sí

Como del 0 al 10, pensando que el 10 es muchísimo ¿Cómo cuánto se da? 
H. como unos dos...

H. Cuatro

M. Cuatro

H. Cuatro

H. O cinco

¿Si dicen que se pelean por desilusiones de amor quiere decir que hay noviazgo aquí en la escuela?
H. Sí
H. sí
M. Sí
H. No aquí adentro, pero afuera sí.
H. Sí

¿Desde qué edad?

H. Desde primero

M. Desde primero

H. O desde sexto

¿Por qué creen que tienen novios o novias desde temprana edad? ¿Qué los motiva?

H. Porque quieren tener más experiencia.

M. Se creen ya las muy grandes para poder hacerse cargo de un hijo, aquí a veces se casan a los 12 años.

H. O a los 13

M: Aquí se han casado dos niñas de segundo de esta escuela.

¿Y los varones?

H. También de tercero, puro de tercero ¿verdad?

H. Sí

¿A parte de creerse o sentirse muy grandes al tener novio o novia, hay

M. No otras razones?

¿Qué les gusta a las mujeres de un hombre y a los hombres de una mujer?

M: De los hombres nos gusta cómo piensan o como es por dentro, o a algunas les gusta cómo se visten, cómo se peinan.

H: Son pocas las que se fijan en los sentimientos, las demás que porque está guapo o porque no sé qué tanto.

H. Que no se fijan ni cómo son.

H. Su forma de vestir.

H. O por el dinero.

H. No tanto en su dinero sino en que está bonita.

¿En qué se fijan los hombres?

H. En que están bonitas. 
M. Si tienen buen cuerpo.

H. Son muy pocos también que se fijan en cómo es por dentro porque siempre tienes que fijarte cómo es por dentro o cómo actúa o cómo es y sólo se fija en lo que es y cómo se viste y no se fijan de lo que es por dentro y por eso a veces cuando se casan hay problemas, que "yo no te conocía que andabas asi".

H. Sí, es que muchas se creen así las bonitas, pues están bonitas, y andan con muchos.

M. Y cuando se casan ya a veces no pueden hacer nada.

H. Y aquí hablan mucho de ellas, que es... una dejada y así.

\section{¿Ellas andan con muchos?}

H. No con muchos pero sí

\section{¿Y los muchachos?}

H. Ya hay algunos compañeros que las regañan, porque así tiene que ser que las regañan. Un compañero que regañaba a una niña, no porque era bonita o así, sino porque la quería y no quería que anduviera así, que no actuara así, y le decía "tú no vas a andar dejándote que te traten así, que te agarren en todas partes porque si andas así espera a que tengas como 18 ó 19 años y verás que ya ningún niño te va a hacer caso".

\section{¿Y tú qué piensas de eso?}

H. Pues pienso bien porque es verdad, si alguna niña se deja y ya los niños se fijan o las señoras se fijan y algunas señoras les dicen a sus hijos "¿te estás fijando en esa niña, cómo anda, cómo es de loca, cómo se lleva? Tú no vas a andar con esa niña"

H. Aquí la gente critica mucho, por ejemplo las que quieren andar a la moda, que se ponen sus faldas o sus pantalones, luego, luego dicen “¡Ay! mira que loca”, o “o ¡Ay! mira esto"

H. Cuando ven una niña con minifalda o que las ven tomar luego, luego dicen " $¡ A y$ ! mira esa niña borracha, sus papás que no le dicen nada" y empiezan critique y critique.

H. O la forma en que caminan.

H. O la forma en que caminan.

\section{¿Ustedes qué piensan de esas críticas?}

H. Que a ellos no les importa, que ellos piensen de ellos, que no les importen los demás, que no sean criticones

M. Sí, porque se necesita que primero se fije en uno

H. Porque cada quien tiene su forma de vestir y su forma de ser

M. Y su forma de actuar

H. Y hay unas que se visten así pero no andan así como las demás, y hay muchas que sí se visten así y si andan igual.

O sea que no siempre la forma de vestir quiere decir que anda de locas como ustedes dicen.

H. No

H. Y hay algunas que sólo se fijan en otras, que cómo anda y que qué sucia anda y no se fija ella cómo anda porque ande criticando a otra persona. Es como se forman los pleitos, y dicen "no, que tú no te fijas en cómo estás tú y me estás diciendo a mí, primero te debes de fijar", y así se hacen los pleitos. 
H. No.

Cuando les dicen eso, ¿la otra persona hace caso o no?

H. No.

H. De repente así nada más es cuando empiezan las pelea cuando le llegan con el chisme y dicen "ay, sí, que me dijo así'.

H. Y empiezan a palabras.

H. Y empieza, ay por qué me dijiste así y empiezan a pelear.

H. Sí

H. Sí

H. Sí

¿Hombres y mujeres?

M. Sí

H. Los hombres ya andan con cadenas y con botellas de vino y se las quiebran a los otros

H. Desde primero.

¿Desde qué edad?

H. Desde los trece años.

H. Hasta una vez hubo una pelea, y yo me salí de mi casa porque había mucho ruido, y me fijé y habían hasta niños chiquitos como de $6^{\circ}$, de $5^{\circ}$ o hasta de $4^{\circ}$ peleando y pues así se defienden, no con las manos porque no han de estar fuertes, y se defienden con palos, con botellas, con cadenas.

H. Y de repente, como aquí dicen que hay barrios, y se juntan muchos hombres, y ahí van con otra y se agarran bien feo.

H. Cuando se cruzan pues.

H. Porque aquí hay cuarteles, hay cuatro cuarteles y no se llevan. Por ejemplo, yo soy del segundo cuartel y...

\section{¿Qué son los cuarteles?}

H. El pueblo dividido en cuatro partes.

H. Cuatro partes.

H. Por ejemplo vienen las fiestas y cada cuartel saca algo. Y acá, por ejemplo yo soy del segundo cuartel y no se llevan con los del tercer cuartel.

H. Cada quien tiene nombre, nosotros somos los Cuarenta.

H. Y nosotros del segundo somos los Quésicuas.

H. Y los del tercer cuartel los 05.

H. Y los del cuarto cuartel son los Santa Cruz.

H. Sí

¿Se pelean entre un cuartel y otro?

M. Sí

\section{¿Cuál es la razón...?}

M. Que defienden su cuartel, que dicen "mi cuartel es el más grande" o "mi cuartel sí sabe pelear".

H. El cuartel de nosotros es el que sí... se cree, el cuartel de los Cuarenta son los que más problemas provocan en el pueblo. 
M. Sí, acá nosotros no porque... bueno sí también.

M. Acá los de nosotros no nos peleamos tanto, nada más cuando empiezan a decirnos, por ejemplo que van a la fiesta y empiezan a decirnos y a presumir, no que nosotros trajimos la mejor banda, no que la de ustedes no fue tan mejor, y ahí es cuando empiezan.

M. Sí

¿Se pelean por ser los mejores?

H. Sí

M. O para que no nos critiquen los cuarteles, pero aparte de los cuarteles también hay barrios chiquitos, como los Minicuarentas.

¿Qué ibas a decir tú? (dirigiéndome a otro elemento del grupo).

H. Que el otro día también se agarraron los cuarentas con los policías y bien feo se habían agarrado, tiraban piedras...

M. Y no les tenían miedo a los policías

H. Ya no respetan a la autoridad

H: Sí.

¿En la secundaria cómo es, hay pleitos, peleas, cómo es aquí?

H. Aquí en la escuela de vez en cuando.

M. Pero tampoco respetan a los maestros. La mayoría de los alumnos no respeta a los maestros porque dicen "que ese es muy exigente", "que es muy regañón", pero los maestros lo dicen por el bien de los alumnos, lo dicen porque quieren que los alumnos mejoren, o quieren que los alumnos trabajen más.

H. Pero no entendemos, no entienden.

M. Pero la mayoría de los alumnos eso que les dice el maestro...

H. Lo toman a juego.

M....lo toman a juego.

H. O cuando los regañan, lo toman a mal y no como un bien para ellos.

M. Como, a mí no me regañan, pero cuando me regañan los maestros no me enojo porque es por mi propio bien que los maestros me digan cómo ando o es por algún defecto que me regañan.

¿En las materias de Orientación y Tutoría y de Biología qué ven que está relacionado con la sexualidad o con la equidad de género, es decir la igualdad entre hombres y mujeres?

M. Que en tutoría nos explica la maestra cómo nos debemos de respetar o cómo debemos de entender bien las cosas

H. Y en Biología nos explican para que ya no tomemos tanto porque de repente hay nomás formamos las relaciones sexuales y de repente cuando algunos tienen alguna enfermedad y hacen relaciones sexuales y después rápido contagian a alguien y ya tienen enfermedades.

M. Y nos explican las enfermedades de transmisión sexual, no nos prohíben que las tengamos pero ya cuando estemos grandes.

H. A nuestra edad (interrupción)

M. No cuando estemos demasiado chicos.

H. Y tampoco hacer relaciones sexuales con una mujer que ya ha tenido con otro hombre porque qué tal si ya esa mujer tiene ya alguna enfermedad y puede causar a un hombre, o un hombre puede causarle a una mujer. 
H. Dicen que no hay que correr el riesgo de contagiarnos de alguna enfermedad.

M. De esperarnos a tener relaciones sexuales a ya cuando estemos mayores.

H. Más grandes.

M. Los hombres ya que se desarrollen bien, y yo cuando ya me desarrolle bien entonces ya voy a hacer una relación sexual.

H. O ya se las roban a sus novias.

H. Debe de ser que después del matrimonio, o de repente que todavía no se casa y que ya lo haga todavía sin saber de nada, ni nada así...

viven?

Cuando se roban a la novia ¿qué hacen ellos, la mantienen o cómo

H. Sí.

M. Sí, se van a trabajar, los mandan a trabajar sus papás, o algunos nada más están ahí y sus mamás los cuidan, o ellos se van a la escuela y su esposa nada más ahí se queda.

M. No.

¿No estudia la esposa?

H. Algunas.

M. Se queda a hacer cosas.

H. Cuando se casan muy chicos los papás dicen que el novio todavía va a ir a la escuela, y la novia pues ya se queda a hacer el quehacer. Pero hay muchos papás de la novia que dicen "no, yo quiero que mi hija también estudie" y ellos le dan el dinero para que ella estudie, y el chavo también estudia.

H. Y también algún hombre que se lleve a la mujer y a veces sólo la mantiene un año, y bien felices un año y pasan uno o dos años y ya los muchachos ya señores pues, les pegan a sus esposas...

H. Muchos las regresan a sus casas, solamente las tienen una semana y ya después las regresan y a veces las vuelven a casar.

H.... las regresan, o las dejan, o a veces ya tienen hijos y algunos por los problemas que hay, como por decir aquí así están los problemas, que uno ya se lleva a la muchacha, ya la mamá del señor que se lleva a la muchacha. La muchacha que se llevó tiene que levantarse temprano al molino, hacer las tortillas, hacer la comida a tiempo y cuando la muchacha no hace eso luego luego ahí se forma el problema...

H. Y empiezan a criticarla, que no hace nada, que es una floja.

H. ... y la mamá del señor le dice a su hijo "¿por qué trajiste a esa niña que no sabe hacer nada?”, o “¿por qué hiciste eso?” y el señor no quiere que le digan así, y ahí se forman los problemas.

H. Por los papás

¿En estas materias han visto algo sobre los derechos sexuales en hombres y mujeres? ¿O derechos de las mujeres y derechos de los hombres?, ¿o sobre los derechos humanos?

H. No

M. No

H. No

Todos. Sí

¿Ustedes consideran que las mujeres y los hombres tienen derechos?

¿Cuáles serían los derechos de la mujer para ustedes y cuáles serían los derechos del hombre? ¿Cuáles serían sus derechos a esta edad?

M. No maltratar a las mujeres. 
M. Que los hombres nos respeten.

M. Más respeto.

M. Que ahora las mujeres valemos tanto como valen los hombres.

H. Y hablarnos bien.

M. Y ahora los hombres tienen los mismos derechos de hacer cosas que las mujeres. Como antes que no permitían que el hombre lavara los trastes, a barrer, y a la mujer no le dejaba que fuera a la escuela que porque era niña y no la dejaban leñear, y ahora hay señoras que van a la leña y trabajan en el campo.

H. Y ahora las mujeres tienen derecho de estudiar y trabajar y no nada más los hombres.

H. Ahora los hombres hacen quehacer... ahora los hombres tienen los mismos derechos...

H. Y las mismas obligaciones.

H... y las mismas obligaciones.

H. Sí.

¿Y sí lo hacen?

M. Sí.

H. Sí, la mayoría ya lo están haciendo

M. No, porque los hombres ya no hacen cosas en su casa, por decir los niños, llegan de la escuela, se salen y a jugar.

H. Pero no todos

M. Y los señores se van a trabajar, llegan y comen y ya no hacen lo que las mujeres hacen.

H. Pero la mayoría lo hace, porque la mayoría trabajan tanto hombres como mujeres y descansan igual.

M. Porque dice la gente que un hombre que no tiene el mismo cuerpo que una mujer ¿qué no tiene manos o qué no tiene pies para hacer lo mismo que hace una mujer? Y a la mujer le dicen lo mismo, ¿qué no puedes tú hacer eso mismo que hacen los hombres? O que no deje que hagas tú eso.

H. O también cuando el esposo se emborracha manda a la señora a traer leña y el esposo nada más ahí se queda tomando.

H. Y deja que la muchacha haga todo en la casa y que el hombre no haga nada.

M. Que se quede acostado en la cama.

H. Eso está saliendo aquí porque también hay señores que toda la semana trabajan y trabajan y el sábado cuando les pagan hay amigos que los llaman y los deja quitarles el dinero que traiga para tomar.

H. Pero a mí no me parece eso bien, porque cualquier cosita que vean los hombres que le toca a la mujer luego, luego le dicen eso que es joto y a mí no me parece porque no porque el hombre haga algo que le pertenece a la mujer se va a morir o le va a pasar algo.

H. Sí, hay un hombre que se viste igualito que como se visten las muchachas, le dicen bolillo, y es igual, tiene el pelo largo y se pone pantalones bien apretados, y todos dicen que sí es joto.

H. Y cuando pasa por la plaza le dicen los muchachos "bolillo que acá te manda saludos este, que si no quieres con él" y le empiezan a decir cosas

H. Que a cuánto la hora.

H. Lo critican. 


\section{¿Ustedes qué piensan de eso?}

H. A mí no me parece bien porque cada quien tenemos nuestro gusto, si él decidió ser así es muy su problema.

M. Que no debería ser así.

M. Que no debe de importarnos lo que él haga, con que nosotros estemos bien.

Les decía al principio que vamos a elaborar una asignatura que va a tratar los temas de sexualidad e igualdad entre hombres y mujeres ¿qué les gustaría a alumnos como ustedes, de 12 años, que se viera en esta asignatura de manera específica?

M. Que haya más respeto.

\section{¿Eso quiere decir que no hay respeto?}

M. Más respeto hacia las mujeres, les empiezan a agarrar acá, a tocar acá y ya no hay respeto por las mujeres.

M. Ajá

Más respeto al cuerpo de las mujeres.

H. Y más respeto a los maestros.

H. Y que las mujeres no molesten a los hombres cuando estén jugando fútbol.

\section{¿Cómo los molestan?}

H. Les quitan el balón.

H. Y las niñas, cuando se llevan con los niños ya, algunas niñas, sólo algunas, les hacen algo a los niños y cuando ellos les hacen algo a las niñas a ellas ya no les parece

H. O sea, no se aguantan, porque cuando los niños ya les pegan también, luego, luego van y reportan,

H. O sea, que tengamos más respeto hacia hombres y mujeres

M. Que nos tengan más respeto y que nosotras les tengamos más respeto.

¿Por qué creen que no se respetan?

M. Y que los hombres para que no los molestemos que se vayan a la cancha de fútbol porque juegan en la de basquetbol y ahí no es para jugar fútbol las mujeres?

¿O sea que también sienten que no respetan el espacio donde pueden jugar

M. Sí

M. Sí

¿A las mujeres también les gusta el fútbol?

¿Y sí las dejan jugar?

M. Sí, pero a propósito les pegan con el balón para que le tengan miedo y se salgan.

M. O les avientan el balón por allá.

M. Que porque el fútbol sólo es de hombres.

M. Y en las dos canchas juegan los hombres y las mujeres no sabemos dónde jugar.

M. Nada más sentadotas ahí. Como ahora sí jugamos, pero nos tiraban el balón, nos pegaban bien feo.

M. Y a veces los hombres agarran el balón de nosotras y lo avientan.

M. O lo ponchan. 
¿Qué más podríamos ver en esta asignatura?

M. Que si queremos que nos respeten, nosotras también respetarlos a ellos y darse a respetar.

M. Sí, si nosotras queremos que nos respeten, nos den respeto, nosotros también debemos respetar a la persona. Nosotros debemos tenerles paciencia para que a nosotras también nos tengan mucho respeto...

Describan alguna situación en donde se den manifestaciones de amor o de odio. ¿En qué forma se sienten ustedes amadas/amados o rechazados?

M. Por medio de las cartas.

H. $\mathrm{O}$ porque platican.

\section{¿Cuándo los escuchan?}

M. Sí. Porque nos decían que según ya se sientan con el novio y empiezan a decir, no, que yo te amo, yo te quiero, y empiezan a decir cosas bonitas y así ella siente que la ama.

\section{¿De qué manera conquista un hombre a una mujer y una mujer a un} hombre?

M. Pues nomás viéndola.

H. O con una carta.

H. Diciéndole si quiere ser su novia.

M. O diciéndole, dile que le mando un saludo, que si quiere andar conmigo.

H. O por medio de una carta.

¿Y en las cartas qué se dicen, generalmente?

M. Cosas de amor.

M. Por ejemplo, "hola, cómo estás, espero que estés bien. Sólo te mando esta carta para decirte que te quiero mucho, que si quieres andar conmigo, me gustas desde el primer día que te conocí." Y así, poemas y cosas.

\section{¿Y hacen lo mismo las mujeres y los hombres?}

M. Las mujeres más, las hacen y las empiezan a mandar, porque como que las mujeres tienen más sentimientos que los hombres.

\section{¿Las mujeres buscan más al hombre o al revés?}

M. Ahorita como que las mujeres ya andan buscando más a los hombres.

H. Sí, porque aquí en Carapan hay más mujeres que hombres.

¿Qué más podrían ver en esta asignatura? Imagínense que ustedes Silencio...

tuvieron esta asignatura en primero y que dijeron "esto necesitábamos saber".
M. Sí
H. Sí
M. Sí

¿Es suficiente con lo que dijeron?

Sus maestros, sus papás o familiares ¿cómo han cambiado con ustedes a partir de los cambios que ustedes han tenido, de cuando eran niños a ahora?

M. Que nuestros papás ya nos regañan más, ya nos dan más consejos, ya no nos dejan salir tanto. 
H. Ya nos regañan más porque ahorita que es la adolescencia se revelan muchos, muy feo, se salen, toman...

H. Ya no le entienden a sus papás.

H. ... ya no le entienden a sus papás.

H. Ya no le tienen respeto a su cuerpo.

H. Y los papás también nos ponen más atención, porque así se forman las redes de que se emborrachan, porque a uno sus papás no le ponen atención, que porque no me escucha, que porque qué será que no me quiere, o por qué será que me trata así. Ya por eso los papás escuchan, les ponen más atención. Unos verdad, porque otros no. H. Y ya les explican más cosas...

\section{que ven en clase?}

¿De dónde obtienen más información sobre su sexualidad, además de lo

M. De nuestras mamás.

M. Sí, de nuestros padres.

M. Algunas, porque a muchas les da vergüenza hablar de eso.

M. A mí no me da vergüenza porque mi mamá desde la otra vez ya me dijo eso...

M. Pero no tiene que dar vergüenza porque es algo natural que a todo mundo le pasa.

M. Porque a mí lo mismo me dice mi mamá, que eso no es cochino, porque si eso fuera cochino pues no lo íbamos a tener, no nos iba a pasar eso, y muchos lo toman como si no fuera normal

H. De repente a unos todavía sus papás ni le explican y ya lo están diciendo sin saber. M. Sí, porque es mejor hablarles de eso. A nosotros el maestro de Biología nos dijo que hubo un caso de una chava que nunca le habían hablado de la menstruación y el día que le bajó se espantó mucho, pero porque no le habían hablado de eso.

H. Por eso cuando uno le pregunta a su mamá, que le dice "oye má, por qué esto, por qué aquello" y su mamá le dice, "no que eso no es así, que eso es bien cochino, eso no debes de escucharlo", ya entonces su hijo le pregunta a otra persona, y la otra persona le contesta pero le contesta algo malo, algo que no es. ....Muchas mamás tienen vergüenza de contarles pues y les dicen "no, tú no andes hablando de eso, que eso es bien cochino, a ti te trajo un avión.

M. Aquí la gente es muy penosa.

\section{¿La gente mayor?}

M. Sí, ya los más jóvenes no tanto.

Fotografía de adolescentes pensativos_, observen la siguiente fotografía, ¿Qué creen que les pasa a estas muchachas y a estos muchachos?

M. La chava yo vi como que está desilusionada del amor o algo así.

M. Y la muchacha que estaba sola se notó como que tenía algún problema en su casa o como que la regañaron.

M. Muy triste.

\section{¿Qué tipo de problemas se pueden tener en la casa?}

M. Que se peleen sus papás, que su papá le pega a su mamá.

H. O más bien su papá le pega a la muchacha.

H. Sí

¿Eso llega a pasar aquí?

M. Sí

M. O también puede que estar deprimidas porque su novio la dejó. 
H. O porque en su casa no la dejan tener novio.

H. Y las muchachas que ya estaban, casi sin nada, ya creo empezaban a pensar en suicidarse.

H. Sí

O sea, como que aquí los novios y las novias tienen mucha importancia

M. Sí

H. Sí

¿Por qué es tan importante para ustedes tener novio/ novia?

M. Para poder sacar más los sentimientos, para protección.

¿Para poder expresar sus sentimientos?

M. Sí, hacia la otra persona.

H. O conocernos.

M. Conocer muchachos.

¿Los muchachos de su edad a quienes sí pueden expresar sus emociones

H. A los amigos.

y sus sentimientos o bajo qué situaciones sí?

M. Al novio o novia.

M. Sí, porque hay papás que ni siquiera quieren conversar.

M. Que ni siquiera los quieren escuchar.

M. A la maestra.

\section{¿De qué manera se cuidan a ustedes mismos/as?}

M. De cuidar nuestro cuerpo: no tomar, no haciéndonos daño, darnos a respetar y que nos respeten. Aquí hubo un caso de una chava que se cortaba las manos, y eso no está bien porque se hacía daño.

\section{¿Por qué creen que se cortaba?}

H. A mí me había dicho una compañera que ella se cortaba por el novio, que cada vez que se enojaba el novio y se hacía una rayita aquí. (señala la pierna)

H. O cada vez que la regañaban en su casa se cortaba...

Silencio. ¿Algo más que quisieran compartirnos para esta asignatura? ¿Cómo les gustaría que se impartiera?

H. No

M. No

Silencio. Se agradece su colaboración. 


\title{
GRUPO DE DISCUSIÓN N5
}

Registro de grabación. A cargo de Elva Morales

\begin{tabular}{|c|c|c|c|c|c|c|c|c|}
\hline $\begin{array}{l}\text { Nombre } \\
\text { de la } \\
\text { escuela }\end{array}$ & Ubicación & $\begin{array}{c}\text { Zona } \\
\text { Escolar }\end{array}$ & $\begin{array}{l}\text { Grupo de } \\
\text { discusión }\end{array}$ & $\begin{array}{c}\text { Grado } \\
\mathbf{y} \\
\text { Grupo }\end{array}$ & Moderadora & Observadora & Fecha & Hora \\
\hline $\begin{array}{l}\text { EST No. } \\
\quad 72\end{array}$ & Patambán & & $\begin{array}{c}\text { Integrantes: } \\
6 \\
3 \text { hombres } \\
\text { y } 3 \text { mujeres }\end{array}$ & $\begin{array}{c}1^{\circ}: \\
\text { A,B y } \\
\text { C. }\end{array}$ & $\begin{array}{l}\text { Georgina } \\
\text { Pérez Coeto } \\
\text { Mateos }\end{array}$ & $\begin{array}{l}\text { Elva Morales } \\
\text { Robles }\end{array}$ & $\begin{array}{c}15-06- \\
10\end{array}$ & $12: 30$ \\
\hline \multicolumn{9}{|c|}{ Contexto situacional } \\
\hline \multicolumn{9}{|c|}{$\begin{array}{l}\text { La selección de las/os jóvenes que eligieron para el grupo de discusión fue de la siguiente manera: el director } \\
\text { eligió al azar a tres niños y tres niñas, sin comentar la razón para la que fueron seleccionados. El aula donde se } \\
\text { trabajó con el grupo de discusión era la sala de cómputo que parecía estar en desuso. Los/as jóvenes se sintieron } \\
\text { nerviosos en un primer momento. Todos manifiestan disposición y agrado a participar, como apertura a la } \\
\text { grabación de la misma en el entendido de que será confidencial. El trabajo transcurrió de manera positiva, sin } \\
\text { embargo la moderadora tuvo que realizar trabajo de contención con uno de los jóvenes para que la dinámica del } \\
\text { grupo no se viera afectada. El cierre da la sesión se realizó agradeciendo la participación por el trabajo. }\end{array}$} \\
\hline
\end{tabular}

\section{SIMBOLOGÍA:}

H= Hombre

$\underline{\text { DISCURSO }}$

\author{
M= Mujer
}

\section{Platíquenos de las experiencias de la escuela que quieran compartirnos}

H Pues tengo muchos amigos, algunos son muy groseros, otros muy marranos...mmm eso es que son más groseros que groseros. Tengo un primo con el que tenemos mucho en común y nos reímos mucho, él está en tercero. También tengo amigas mujeres.

\section{A ver los demás ¿Por qué están estudiando?}

M Estoy en la escuela este para seguir adelante, para seguir estudiando, para ser algo en la vida y este pues me gusta estar aquí.

M Para estudiar y ser licenciada cuando sea grande

M Estoy en la escuela para llegar a ser algo en la vida y porque me gusta 
estar aquí.

\section{¿Te gusta estar en la escuela?}

M Uhm.

H Pues para ser alguien en la vida y no andar por ahí en la calle vagando Vagando, ¿uhm?...

H Para ser alguien en la vida para ayudar a las personas

¿Esa es tu intención ayudar a las personas Jorge?

H Uhm

\section{Para que vienen ¿Tú para qué vienes?}

H A mí no me gusta venir a la secundaria, no más porque tengo amigos y si no vengo aquí me quedaría todo el día dormidote sin hacer nada de nada (risas), con mi hermano, si yo no viniera a la secundaria me la pasaría ahí todo, todo el día ahí sentado viendo tv.

\section{¿Vives nada más con tú hermano?}

H No viven mi mamá y papá y mis hermanos, pero ellos viven aparte en otra casa.

H ¿Cómo?

H Vivo en la calle (risas)

A ver cuéntanos, como dice tu compañero. ¿Cómo está eso?

H Vivo en una casa que son como tres casa, en una viven mi mamá y mi papá, en la otra mis dos hermanas, bueno nada más una porque la otra está estudiando, y mi hermano y yo nos quedamos en la última casa nada más él y yo.

A ok.

Fotografía 1: Chicos/as en biblioteca.

Bien, les voy a enseñar una foto porque quiero que me digan que ven en esa foto.

Ahorita se las voy a enseñar

Quiero que vean y me digan ¿qué ven en esta foto?

H Cuatro

M Cuatro

H Cuatro niños que hacen como que están leyendo pero no están poniendo atención, pero están poniendo atención. 


\section{Y ¿ustedes que ven?}

M Que están leyendo

M Buscando información

\section{¿Tú? Mario}

H

Buscando información

También ves niños que están ¿Cuántos niños y cuantas niñas?

H Dos niños y dos niñas

\section{Ajá, Minerva, Jorge ven algo diferente}

Están en una biblioteca buscando un libro para leerlo y no más.

\section{Que información les interesa a los/as adolescentes}

¿Algo más? Ustedes están viendo aquí a estos dos niños y dos niñas que están en la biblioteca que efectivamente seguramente están buscando información, que están leyendo o al menos eso es lo que parece, lo que podemos observar y ¿ustedes qué creen que están leyendo, que estén buscando? ¿Información de qué están buscando?

M De alguna escuela

De alguna escuela

H De alguna tarea que les dejaron de investigar

De alguna tarea, ¿De qué tema creen que estén buscando?

M De la sexualidad

H Que tienen dudas y las quieren investigar

M Libro de las ciencias

Libro de las ciencias, dudas sobre sexualidad. Qué más se les ocurre que estén buscando muchachos y muchachas como ustedes.

H Nada, nada más están así

Pero si estuvieran buscando algún tipo de información, qué estarían buscando.

H De sus cambios

H De historia, quien mato a Miguel Hidalgo, el segundo niño de matemáticas, de la raíz cuadrada, la tercera de ciencias, los cambios del medio ambiente y la cuarta niña que tuviera un libro de lo que sea como de ecología.

Los que les interesa conocer a los y las jóvenes sobre sexualidad 
Si estuvieran buscando información de sexualidad. ¿Qué creen que buscarían?

Todos No se entiende, se ríen y hablan todos a la vez.

De los cambios

M Del aparato reproductor

H Del hombres y de la mujer. Los hombres nada más de los hombres y las mujeres de las mujeres

Del hombre nada más los que son hombres, a ok

H Y qué tal si es al revés

M Si quisieran conocer las mujeres del aparato del hombre

Si tuvieran curiosidad por saber del otro sexo ¿verdad?

Todos Asienten y hay risas

Karla ¿Tú qué piensas? Sí estuvieran buscando información de sexualidad ¿Qué sería lo que estarían buscando?

M Sobre los cuidados que deben de llevar a cabo

Como obtienen información sobre sexualidad los/as adolescentes

¿De dónde ustedes adquieren información?

H De un libro

Todos No se entiende lo que dicen porque hablan todos a la vez.

H Del profesor Juan José Mares Silva

¿Él qué les enseña?

Todos Hablan todos a la vez.

M No explica

A ver, vamos pedir la palabra para hablar uno por uno/a porque después hablamos todos juntos y no nos entendemos, y yo no me quiero perder nada de lo que digan. Así que en orden para podernos escuchar. ¿Karla?

M Pues no habla más el profe José Castillo porque ahorita estamos viendo ese tema

¿De qué tema?

M Pues de los cambios que vemos en nuestro cuerpo. Como vamos sintiendo nosotros con los cambios

\section{Eso les enseña él. Y ¿cómo van sintiendo ustedes sus cambios?}


H Normal

H Normal

H Diferente de cuando éramos niños

¿En qué? ¿En qué diferente?

H En nuestro cuerpo, y...

H Ya no somos los mismos de antes

En nuestros cuerpos, en nuestros pensamientos dice pájaro, ya no son los mismos de antes

H No pues en los cambios

¿Qué piensas Minerva?, apoyas a tus compañeros

M Pues diferente a como pensaba antes, antes jugaba con las barbis, y ahorita ya otra cosa, andar con las amigas

Oigan y cuando tienen inquietudes sexuales o sobre inquietudes sobre información cómo la adquieren, de dónde sacan la información sobre sexualidad de donde la sacan

H Preguntamos al profe Juan José

H Yo le pregunto a mi papá

H Yo a mi hermano mayor

A tu hermano mayor, ajá, y ¿Ustedes chicas?

M Yo a mi mamá

H O en la clínica

También en la clínica. ¿En la clínica a quién le preguntan?

Todos A la doctora

¿Cada cuándo van a las pláticas que les dan en las clínicas?

Todos Cada mes

H Como no somos del mismo centro nos toca diferente día

Temas que les dan en las clínicas sobre sexualidad y equidad de género ¿Cuáles son los temas que abordan en la clínica?

M Enfermedades

$\begin{array}{cl}\text { H y M } & \text { Obesidad } \\ \mathbf{M} & \text { Violencia } \\ \mathbf{H} & \text { Entre familias } \\ \mathbf{M} & \text { Drogadicción }\end{array}$


Pájaro, tú también vas a las pláticas de la clínicas

H Soy el que habla más

Que temas abordan más

H Pues, voy junto con él

Que han visto en la asignatura de ciencias sobre sexualidad y género. Con Manuel, y que han aprendido sobre sexualidad y género en la asignatura que les dan de ciencias muchachos/as. ¿Viene algo en ciencias sobre sexualidad y género? ¿Qué han aprendido?, ¿Qué viene? ¿Qué se les ha quedado?

Todos Hablan varios a la vez y no se entiende

H Es que apenas estamos... no se entiende, vamos a empezar esos temas

\section{¿Qué diferencias observan entre hombres y mujeres?}

A ver, ¿qué los pensamientos de hombres y mujeres no son los mismos, qué no son iguales, qué son diferentes?

H No, no que el hombre actúa de una manera y la mujer de otra.

Ajá, ¿Qué más les han enseñado? ¿Karla?

M Pues todavía a nosotros en primero B, apenas el maestro Castillo nos empezó a hablar.

De lo que les empezó hablar ¿te acuerdas de algo?

M Pues de que tanto hombres como mujeres nos debemos tocar nuestras partes para ver si estamos bien o algo.

¿Para ver si están bien o algo? ¿Para detectar algo o alguna infección o algo así...?

M Que porque en muchas mujeres se puede detectar el cáncer de mama ¿A ustedes en ciencias qué les dicen?

H Apenas llegamos a ese tema

Qué cosas mejorarían de su escuela.

Ok, muy bien, ¿Qué harían en su escuela para mejorar? Para que pudieran hacer cosas que de pronto no pueden hacer en la escuela. ¿qué harían?

H Limpiarla

H No tirar basura

H Es lo mismo

Bueno, Jorge tiene razón si no tiramos basura ya no tendríamos que 
limpiarla

H Contesta pero no se entiende su respuesta

¿Qué más? ¿Qué más harías para mejorar?

M Correr al prefecto

H Poner computadoras

H Es bien huevón

M Es que se mete en cosas que no tiene que meterse

¿Qué no le incumben?

Todos Hablan todos a la vez y no se les entiende

A ver vamos hablar por turnos que no se entiende. ¿A ver Karla?

M La otra vez veníamos de comprar el desayuno íbamos por aquel lado y paso el prefecto y me hizo así y me pego y yo me quede así como...

¿Te pego? Y ¿qué hiciste Karla?

M Nada

¿No hiciste nada?, no fuiste con las autoridades de la escuela, nada. Y ¿tu Isela qué harías para mejorar tú escuela?

M Que corran al prefecto

\section{Los derechos fundamentales}

¿Hay algunas cosas que consideren que aquí en su escuela suceden que atenta contra sus derechos fundamentales?

¿Conocen cuáles son sus los derechos? ¿Cuáles son sus derechos?

H Derecho de venir a estudiar

Es un derecho que tenemos hombres y mujeres

H Derecho a la educación, a la vivienda

Exacto, muy bien. ¿Aquí en la escuela hay algo que suceda que atente contra sus derechos?

H Me corre el prefecto, y no me quiere explicar y me dice márchate, ve por tu mamá. Y me dijo pero no le hice caso.

M Luego también la otra vez según las del salón dijeron que los chiquillos las estaban mirando estaban, y los forzó a que trajeran dos litros de pintura.

H Es que estaban tirando en el salón de inglés, este, cintas de empaque, que a todos los chiquillos que tiraron iban a traer pintura blanca que no quería 
que estuviera ahí

M Que si no se los traían los iban a correr

H A mí no me dijo nada porque yo no tire nada

¿Cuáles son las responsabilidades de ustedes como adolescentes asumen ante todas las problemáticas que hay en la escuela?

H ¿Las responsabilidades que tomamos nosotros en la escuela?

Ajá

H Pues poner atención en las clases

M Entrar a todas las clases

H No salárnosla

E No salarnos las clases

H No estar jugando dentro del salón, o haciendo relajo

H Yo soy el más juguetón del salón

¿Hay algo en la escuela que hagan muchachas/os que más bien nos les permitan hacer y que ustedes quieran hacer?

H No creo

H No dejan usar las compus, porque no jalan

H No dejan tocar la guitarra

Fotografía 2: Una pareja. Noviazgo

A ver muchachos/as ¿Qué ven en esta foto?

M Una pareja

H Una pareja de novios

H Le está diciendo cosas al oído

Una pareja de novios y que le está diciendo que en el oído

Todos Hablan todos a la vez, risas y bromas

H Que la quiere bien arto

H Que vámonos para el rinconcito

H Para lo obscurito

¿Eso le está diciendo? ¿Y la muchacha qué hace?

H Que si, que ella también quiere

M Que ella no quiere

M Ella no lo escucha

¿Sí? A ver muchachas/os ¿Y qué hace una muchacha para traer a un 
niño?

H Se visten escotadas

H Como dijeron en la clínica que se ponen como las faldas cortas

H O las minifaldas y las pantalones bien pegaditos

H Blusas hasta aquí así

Eso que sería como bien cortitas, ombligueras. A ver que más ven en

la foto muchachas/os. A ver y ahora que hacen los muchacho para agradar o atraer a las muchachas. Ya dijeron que hacían las muchachas, ahora que hacen ellos

H Se perfuman

H Se portan decentes con ellas

¿Se portan decentes? para atraerlas ¿y luego? Ya que las atraen H Se las llevan al rinconcito

H Ya la hicieron. Y ya pueden hablar de todo. (Risas y bromas)

¿Ya que las atraen se las llevan al rinconcito? Eso es lo que dices pájaro

¿A ver las niñas que hacen los niños para atraerlos?

M Pues primero te hablan bien, se ganan tu amistad

M Se visten bien, (risas y nerviosismo)

M Se visten bien

M Se arreglan, se echan perfume

M Hablan decente, no se portan groseros en frente de nosotras.

H No toman

M Si un amigo te pide no tomar, y si la quiere pues no toma y si no la quiere pues sigue tomando.

Ajá. A ver muchachos/as en su opinión de cada una y cada uno de ustedes ¿qué es lo que lleva a los/as jóvenes a tener relaciones sexuales?

H La provocación

H La excitación (Risas y nerviosismo).

A ver chicas, ustedes que piensan

H Empezar a usar los condones

La idea de usar el condón sería una motivación ¿sí? 
Yo pienso que si

Ajá. Que piensan ustedes chicas. ¿Qué motiva a las mujeres, que motiva a las muchachas a tener relaciones sexuales? no necesariamente de ustedes, no necesitan hablar por ustedes, platique de lo que conocen de lo piensan de sus amigas

M Porque se dejan llevar

Se dejan llevar, ¿por qué se dejan llevar?

M Tal vez porque el muchacho le gusta

M Que se dejan llevar...

¿Qué piensas Minerva?, ¿qué es lo que hace que una chica, una jovencita tenga relaciones sexuales?

M Cuando se quieren

\section{Si Manuel}

H Cuando ya quieren

H Cuando ya quiere estar juntos, exacto.

H Cuando quieren pues estar juntos, cuando no quieren separarse.

Cuando ya no se quieren separar de ellas. Ajá

H O también cuando se quieren burlar de ellas y dejarles un hijo y dejarlas ahí

Ah también cuando se quiere burlar de la mujer. ¿A qué te refieres Manuel a ver platícanos?

H Cuando tienen un hijo con él y después lo regalan

M O también cuando nada más las quieren para tener relaciones sexuales y luego las dejan nada más ahí

M Cuando las muchachas tal vez por dinero tienen relaciones

¿Tal vez por dinero? Cómo es eso Karla a ver platícanos

M Pues como las de los bares, por propina se dejan

H Se prostituyen

Ajá. Si ustedes tuvieran novio/a ¿cómo les gustaría que fuera su relación? ¿Cómo les gustaría que fuera su noviazgo?

M Amistosa

H Que fuera regular

M Que fuera amable 
A ver vamos a escuchar a Isela

M Que fuera cariñoso y que si le pides alguna cosas la hiciera

H Si te dijera el novio matate ¿te matabas?

M No, entonces no te quisiera

Crees que si te quiere hace todo lo que tú le digas. ¿Qué piensas Karla de eso?

M Si todo lo que tú quieras, pero sin llegar a los extremos, no porque tú me quieras yo me voy a aprovechar de ti.

Eso es lo que piensas, ajá. ¿Tú Minerva qué piensas? A ver muchachos vamos a dejar hablar a Minerva. Todavía no empieza y ya estamos hablando y evitamos que hable. A ver

M Pues amistosa

¿Esta forma de pensar tiene que ver con sus cambios?

Todos $\quad \mathrm{Si}$

La percepción que tienen los/as adolescentes sobre las actitudes de su mamá/papá ante los cambios propios de esta etapa.

Como viven su mamá y su papá estos cambios de ustedes.

H Bien felices

Se ponen felices. ¿Por qué?

H Pues ya ni vivo con ellos

Ustedes muchachas cómo ven que su papá y su mamá toman estos cambios

Todos Normal

Como toman estos cambios su mamá y su papá.

Oigan veo que cuando les pregunto de los novios /as dicen que les gustaría que fuera amistosos y que fueran amigos, así lo dicen la niñas pero también oí que así lo dijo alguno de ustedes.

¿Es muy importante la amistad para ustedes?

Todos $\quad \mathrm{Si}$

¿En qué sentido es importante la amistad? ¿Por qué es importante la amistad para ustedes?

M Porque cuando hay amistad hay confianza

M Porque dura más una amistad que un noviazgo 
M Un amigo te cuenta todo y a un novio no le puedes contar todo.

Mmm, si cada quien su opinión y eso es lo importante de este grupo que cada quien va a dar su opinión y todas las opiniones son muy valiosas

H Yo digo que la amistad no existe porque qué tal si yo soy amigo, amigo de Emanuel y le cuento cosas y él va y las cuenta.

\section{Que creen, oigan muchachos entre amigos de que platican}

M De nuestras cosas, de lo que nos pasa

H De lo que nos pasa

A ver los niños de qué platican entre ustedes

H De las muchachas

H De que mira esa está bien bonita

¿De qué más platican los chiquillos?

H Del mundial

H De que ya va ganando México, y que va con Francia.

Y las chicas de qué platican

M De los muchachos que nos gustan

M Delos que nos pasa, de nuestros sentimiento y de los muchachos que nos gustan

De los que les pasa, de sus sentimientos, de quien les gusta. ¿De qué más platican las muchachas?

H ¿Las amigas? De los novios, ¡no! de sus amigos.

¿Tú cómo sabes Manuel?, ¿te han contado? O tú vas a las reuniones de las muchachas, te metes a las bola de las muchachas o te han contado

H He oído (Risas)

Ustedes chamacas de que más platican

H De que me voy a poner, del maquillaje, de que ropa que van a usar

A ver, es que esto es bien interesante, a ver de qué creen que hablan las muchachas, del maquillaje, de lo que van a usar, esa es la percepción que ustedes tienen de lo que hablan ellas. A ver, ahora chamacas ya que estamos en esto, ¿cuál es la percepción que tienen ustedes de lo que hablan ellos?

M De futbol

M De futbol, nada más están diciendo que la abrace, la bese. 
Tienen la idea de que ellos de pronto platican que si tienen novia platican de lo que hacen con las novias.

Ellas

M

$\mathbf{M}$

M

$\mathbf{M}$

$\mathbf{H}$

H

$\mathbf{M}$

$\mathbf{M}$

$\mathbf{M}$

$\mathbf{H}$

H

$\mathrm{Si}$

¿Qué más tienen la impresión de lo que ellos platican?, porque es bien interesante siempre ellas tienen la impresión de lo que ellos platican y ellos de lo que ustedes platican en bola, ¿no? ¿Ustedes quien les ha dicho? ¿Cómo es que saben lo que platican?

Pues a veces están platicando y nosotros oímos

Ah ok, ok. ¿Tu Minerva de que platican los niños?

Pues de las muchachas, de que ha soñado con la novia y de eso

\section{Fotografía 3: Pareja}

A ver observen esta foto chicas chicos, qué se les ocurre que hay. ¿Qué pasa aquí?

Están dos novios

Están dos novios una muchacha y un muchacho, ¿Qué estarán pensando?

La muchacha está pensando en el otro

¿En el otro?

¿Cuál otro?

¿Ahí no hay amistad?

No

\section{Venga Minerva...}

Tal vez al muchacho le paso algo y le está contando a la muchacha y la muchacha se puso triste por lo que le pasa a él.

Ok. ¿Qué piensas Karla?

El muchacho son amigos y tiene ganas de decirle lo que siente y la muchacha quiere a otro.

Que está pensando el muchacho si la quiere o no la quiere, y la muchacha está diciendo que estará pensando

Tuvieron un problema como que ella estuviera embarazada por ejemplo. $\mathrm{Si}$

\section{¿Qué piensan ustedes del embarazo adolescente?}

Que está muy mal porque es como si fuera una niña, se les dañaran no sé qué. 
H Hay en la primaria se casaron

H Ni siquiera salen de la primaria y se casan

H De más de sexto año si, luego, luego se casan o se las roban ¿Se la roba?

H No pues, se va

¿Cómo es que sucede? ¿Chicas qué piensan?

H Que como son niñas se van con cualquiera

Está bien es su opinión, acuérdense que aquí cada quien está dando su opinión. ¿ustedesqué piensas?

M Pues se dejan embarazar por descuido. Tal vez se dejan llevar y caen en la tentación

H Y se las llevan al rinconcito. (Risas y burlas).

M Que es muy mal porque si tuvo relaciones con alguien más grande que ella, le puede pegar una enfermedad que no se quita y a la mejor no más lo hace por curiosidad. (Hay interrupciones por parte de los chicos).

M Que lo hace por curiosidad

H Que tenía ganas de hembra

¿Tenían ganas de quedar embarazados? ¿Tenían ganas Manuel?

H No, de tener sexo

$$
\text { ¿Y qué paso entonces? }
$$

H Que quedó embarazada por no usar condón el hombre o la mujer

H ¿Cómo va haber condones femeninos?

H También hay condones para mujeres, ¡no sabían o qué!

Muchachas, muchachos cómo ven la responsabilidad que hay como hombre o de la mujer en esto del embarazo adolescente

H ¿Cómo que cómo ven?

¿Cuál es la responsabilidad como hombres o como mujeres en esto del embarazo adolescente?

M Pues que tanto hombres como mujeres si ya van a hacer eso que piensen y recapaciten de lo que llegue a suceder los hombres se tienen que hacer responsables, porque en muchos caso al final nada más le dejan la bronca toda a la muchacha.

Que piensan los demás ¿Pájaro qué piensas de la responsabilidad de los 
hombres o de la mujeres en este asunto del embarazo?

H Que los hombres si llegan a tener relaciones sexuales puede ser el causante de que una mujer quede embarazada por no usar el condón, usar condón es una responsabilidad

Alguna opinión más al respecto. A ver chicas/os hay alguna cosa que ustedes en la escuela o en su casa quisieran realizar y se les prohíbe por ser hombres o mujeres

Todos No

A ti nada se te prohíbe

H No

A ti Karla, por ejemplo se me ocurre ¿a qué horas llegan a la casa en la noche? ¿Llegan a la misma hora?

H A la misma hora, como a las tres y media

¿Cuándo vas de fiesta? $\mathrm{O}$ ¿Normalmente?

H Normal

¿O a esa hora llegas en el día?

H En el día llego a las tres

A las tres de la tarde. A ver cuando salen de aquí de la escuela a qué hora llegan

H у M A las 3:15

Ah ok. Y en la noche cuando salen a jugar o hacer sus actividades.

H Como a las 10 de la noche

H A las doce

A ver ¿Isela?

M A mí no me dejan salir

¿Por qué, qué sucede?

M Que porque como soy mujer no debo de salir, que solamente que los hombres

Que porque eres mujer no debes de salir. ¿Tú Karla?

H Los chicos se rién y hablan a la vez, no se entiende. Solo se escucha menos mal que soy hombre de alguno de ellos.

M Pues a mí la verdad no me llama la atención salir porque como no hay niños por mi casa y mis hermanos trabajan pues no 
Ósea no sales porque no quieres

M Porque no tengo con quien salir y me aburro

Ah ok. ¿Minerva?

M Pues me salgo me voy a casa de mi abuela, llego como antes de las nueve y media. No me regañan. Y cuando me salgo con las chiquillas por ahí si me tardo me regañan también.

¿Y a los niños de tu casa también los dejan llegar hasta las nueve y media?

M No ellos se salen en la tarde a la plaza con sus amigos y ya luego le van a ayudar a mi tía a trabajar ya llegan pasadas las doce. Y a ellos no los regañan

Pasadas las doce, ya. Y eso consideran que es equitativo? ¿Qué hay equidad entre hombres y mujeres con ese tipo de situaciones?

H $\quad \mathrm{Si}$

M No

Está bien, porque Karla

M Porque tanto hombres como mujeres tenemos los mismos derechos y si los hombres se saben cuidar y porque las mujeres no

H Porque no hay confianza en las mujeres

No hay confianza con las mujeres. ¿Por qué Manuel?

H Porque son bien chismosas, si quieres que se sepa algo cuéntenselo a las mujeres y al otro día todo el pueblo lo sabe.

¿Por qué Manuel?

H no hay confianza pues

H Una mujer no le tiene confianza al hombre y luego, luego avísale, le dice el hombre a la mujer

Cuando dicen avisar se refieren a contar ¿verdad?

H $\quad$ Si

\section{Como se sienten al ver las desigualdades por razón de sexo}

A ok. Pero por ejemplo tú Isela a ti que te dicen que no sales por ser mujer ¿Qué te hace sentir eso? ¿Qué les dices a tus papás?

M Mal, que debo salir porque si mis hermanos salen deben ser parejos con todos 
¿Pero si les dices eso a tus papás? ¿Qué te dicen ellos? ¿Qué responden?

M Que soy mujer que debo de estar en la casa. Y los hombres deben de salir

y llegar a la hora que ellos quieren.

\section{Fotografía 4: Chicas peleando. Violencia}

Vean esta foto. ¿Qué les dice esta foto?

M Se andan peleando

M Que se están peleando por una muchacha

H Son dos muchachas

No pasa nada hasta el mejor cazador se le escapa la libre, venga chicos/as qué más ven en la foto

H Que se están peleando

H Que las otras no las desapartan

Eso que las otras chicas que están ahí no las separan

H Más bien les están echando porras

M No va a avisar y son parte de...

No van avisar, no van decir que está pasando algo ¿verdad? ¿Qué pasa cuando las personas pelean? ¿Por qué están peleando?

M Por los muchachos, las chicas hablan en coro.

H Porque no se caen bien

\section{¿Cómo se sentirán las muchachas?}

M Adoloridas

Del cuero cabelludo después de esos jalones. ¿Los muchachos también se pelean?

Todos $\quad \mathrm{Si}$

$$
\text { ¿Y por qué se pelean? }
$$

M Por coraje

H Por el barrio

¿Cómo es eso?

H Es que aquí hay barrios, cada quien tiene sus nombres y aquí se pelean mucho por eso por defender al barrio

H Que porque yo soy de la izquierda y yo de la derecha, que porque soy de arriba y tú de abajo...

H Por intentar ser valientes. 


\section{¿Qué piensan de la violencia muchachas/os?}

M Que no está bien andar peleando

¿Alguna vez ustedes se han peleado?

M Yo si

M Nos estábamos peleando por un chisme que no valía la pena, igual nos hablamos (ruidos e interrupción de los chicos).

¿Te peleaste con quién?

M Con niña

H Con una amiga de ella

Con una amiga y cómo te sentiste peleando con tu amiga

M Con arto coraje y después adolorida, después me arrepentí. Porque ni valía la pena igual nos hablamos

H Yo si sentí lastima

¿Cuñando te peleaste tú Manuel? ¿Por qué?

H Yo si le pegue bien feo. Después me arrepentí de haberle pegado, no era para tanto.

Es decir que el motivo que te impulso a pelear resulto que no era tan importante. Es decir que si hay algún motivo que sea importante.

H Había quebrado una lámpara y no quería que le dijera al profe.

Creen que pelean más los hombres o las mujeres

Todos Los hombres

H Porque aquí en la escuela los primeros días se pelearon los de tercero "A" se pelearon con los de tercero "B" todos contra todos.

H Si se pelearon como una semana

H Pero también las chiquillas se estuvieron peleando

H Ah sí Norma con Selena

H Y Grecia con Brenda

Y las razones por las que pelean los muchachos son las mismas por las que pelean las muchachas.

Todos No

Porque razones pelean los muchachos

H Por el barrio

H Las mujeres pelean por chismes, porque les dicen zorras o así 
Porque se les insulta o así. ¿Y los muchachos pelean por...? Por el barrio decía Jorge

H Por creerse más chingón

H Por sentirse los valientes.

Qué más, por qué más creen que peleen los muchachos.

H Por mensos

La pelea es una de las actividades que a los adolescentes les hace sentir más hombres o así.

H No

H Si como cuando se pelean por la novia y siente que así los van a elegir más

Y a ver muchachos digan que cosas hacen los adolescentes para sentirse como más hombres. Lo que se les ocurra eh h.

H Tener novia

H Vestirse cholo

Vestirse cholo, claro, eso es muy importante. ¿Qué más...?

H Hacerse bien grosero

También eso los hace sentirse más hombres, hacerse más groseros y así. ¿Y las niñas, las adolescentes qué las hacen sentirse más mujeres?

H Vestirse más bonito, con menos ropa...

Pero desde su percepción de muchachitas, de mujeres.

H Vestirse de rosa

Vamos a dejar que ellas nos digan. Veo que ustedes dicen que es lo que a ellas las hace sentirse más mujeres, y ellas no nos pueden decir. A ver, Karla ¿desde tu percepción que es lo que a las adolescentes las hace sentirse más mujeres?

M Para mi vestirme como es mi gusto vestirme

M Tener novio

M Vestirse bien

¿Hacer cosas diferentes como actividades o deportes no las hace sentirse más mujeres o más hombres?

H No

¿Tú juegas futbol Karla? ¿Y eso te hace sentir más mujer? 
M No, pero me hace sentir bien

Bien, una penúltima pregunta la última es de las más importantes. Pero quiero hacerles una pregunta que va a cerrar lo que hemos estado hablando.

¿Qué ventajas tienen por ser hombres o por ser mujeres? A ver hazte para acá pájaro. Ahora sí que ventajas tienen como hombres o como mujeres. Que digan yo por ser hombre tengo más ventajas por esto, por esto y por esto... por ejemplo yo por ser hombre tengo estas ventajas, yo como soy mujer tengo ventajas de aquí a aquí. Cada quien desde su ser hombre o mujer, ¿Qué ventajas les da? ¿Ustedes ven alguna ventaja en ser mujeres? (hay risas y barullo)

M Que a las mujeres les compran más cosas

H Que somos más fuertes

H Que somos más inteligentes

O hay algo que les limite por ser hombres o mujeres para lograr lo que quieren.

M Alzar cosas pesadas

H Como hacer de comer

Como hacer de comer, si es cierto, ¿esa es una limitación?

H Si, que porque soy hombre

Que porque eres hombre no puedes hacer de comer ¿lo sientes como una limitante o desventaja? Manuel

H Yo si me hago de comer

H Pues estas solo

Muchachos y muchachas quieren hacernos alguna propuesta de cómo les gustaría que fuera una asignatura de educación sexual y equidad de género. ¿Qué les gustaría que viéramos en esta asignatura, ¿qué se trataran que temas?

M De la reproducción

Que otros temas les gustaría que viéramos en esta asignara a parte de la reproducción.

H De la sexualidad

H De los distintos cambios que hay en la vida del ser humano, de mujer y 
hombre

M De la violencia

H De la prostitución

M De las enfermedades y drogadicción

Enfermedades, drogadicción y anticonceptivos. ¿Qué más?

M Tener en cuenta las enfermedades que nos pueden dar al tener sexo con otra persona

M La diferencia entre ser hombre o mujer... mm... de los cambios. (Ruidos exteriores y los participantes están más inquietos).

Alguien dijo la diferencia entre ser hombre o mujer, los cambios en la diferencia de ser hombre o mujer.

H Creo que sí, si

Que más creen que podría ir en la asignatura de educación sexual y equidad de género. Algo más que quieran compartirnos que tenga que ver con el tema de la asignatura sobre todo de la igualdad y la desigualdad en las familias o entre hombres y mujeres. ¿Ustedes perciben en su familia algún trato igualdad o desigual? ¿Cómo que sí verdad Minerva?

¿Perciben en su familia, en la escuela o en alguna parte alguna situación de desigualdad?

M Por ejemplo en mi casa a mi hermana y a mí nos cuidan y nos hacen más caricias que a mis hermanos

Eso sería desigualdad, ¿No? O ¿Cómo lo ves?

M Mmm, pues como desigualdad porque a los hombres también les deben hacer cariños (se ríe y hay mucho ruido en el lugar de trabajo).

H En la escuela nos tratan igual

Vamos a tener respeto por nuestros compañeros, ¿Decías Jorge?

H Que hombre y mujeres deben ser tratados igual

¿Pero si son? ¿Aquí en la escuelas los tratan igual a los niños que a las niñas a hombres que a las mujeres?

H y M Si

¿En qué cosas los tratan diferente? ¿Los mandan hacer las mismas cosas?

H Cuando hay trabajo a nosotros nos ponen hacer todo el trabajo pesado 
M A las niñas nos ponen a barrer o a trapear

Todos Hablan todos a la vez y no se entiende

A ellas las ponían a cargar botecitos de arena y a ustedes carretillas. En ese sentido sienten que es inequitativo, y porque a ellas las ponen a barrer y a trapear y a ustedes a cargar las cosas más pesadas.

En la casa que actividades los/as ponen hacer cosas diferentes.

H Como a mis hermanas las ponen a barrer y a trapear y a mí no. Yo le ayudo a mi papá a trabajar.

$\mathrm{Y}$ eso te parece que es equitativo o inequitativo que hay igualdad o desigualdad

H Que hay igualdad

M Que hay igualdad

¿En tu familia? Te acuerdas que nos decías que a ti no te dejan salir. Eso es igualdad o desigualdad

M Si, nada más a uno. Es igualdad

Cierre Por nuestra parte es todo. Nos pueden comentar algo que no quieran que escuchen sus compañeros, o algún mensaje que nos quieran decir en privado, pueden hacerlo en esta hoja, nada más pongan si son mujer $\mathrm{u}$ hombre, la edad y como les gustaría que se impartiera la asignatura o dudas relacionadas con la sexualidad y el género.

Dudas, opiniones. Gracias. 


\title{
GRUPO DE DISCUSIÓN Nº 6
}

\author{
Registro de grabación. A cargo de Elva Morales
}

\begin{tabular}{|c|c|c|c|c|c|c|c|c|}
\hline $\begin{array}{c}\text { Nombre } \\
\text { de la } \\
\text { escuela }\end{array}$ & Ubicación & $\begin{array}{c}\text { Zona } \\
\text { Escolar }\end{array}$ & $\begin{array}{l}\text { Grupo de } \\
\text { discusión }\end{array}$ & $\begin{array}{c}\text { Grado } \\
\mathbf{y} \\
\text { Grupo }\end{array}$ & Moderadora & Observadora & Fecha & Hora \\
\hline $\begin{array}{c}\text { EST No. } \\
05\end{array}$ & Apatzingán & & $\begin{array}{c}\text { Integrantes: } \\
6 \\
3 \text { hombres } \\
\text { y } 3 \text { mujeres }\end{array}$ & $\begin{array}{c}1^{\circ}: \\
\text { A,B y } \\
\text { C. }\end{array}$ & $\begin{array}{l}\text { Ma. de Jesús } \\
\text { Soto Campos }\end{array}$ & $\begin{array}{l}\text { Elva Morales } \\
\text { Robles }\end{array}$ & $\begin{array}{c}22-06- \\
10\end{array}$ & $12: 30$ \\
\hline \multicolumn{9}{|c|}{ Contexto situacional } \\
\hline \multicolumn{9}{|c|}{$\begin{array}{l}\text { La selección de las/os jóvenes que eligieron para el grupo de discusión fue de la siguiente manera: Estuvo a } \\
\text { cargo un prefecto, al cual se le dio la instrucción que escogiera a jóvenes con disposición de participar. El } \\
\text { prefecto llego a los salones y les preguntó quiénes eran los que participaban más en clase y los que levantaron la } \\
\text { mano fueron los que participaron en el grupo de discusión. Las/os jóvenes se sentían un poco nerviosos/as pero } \\
\text { fueron adquiriendo confianza y seguridad conforme fue transcurriendo el tiempo. El aula donde se trabajó con el } \\
\text { grupo de discusión era una sala de estudio que estaba apartada de las aulas de clase. Todos manifiestan } \\
\text { disposición y agrado a participar, como apertura a la grabación de la misma en el entendido de que será } \\
\text { confidencial. El trabajo transcurrió de manera positiva. }\end{array}$} \\
\hline
\end{tabular}

\author{
SIMBOLOGÍA: \\ H= Hombre \\ M= Mujer
}

\section{DISCURSO}

Platíquenos de sus experiencias en este primer año de secundaria que está por concluir, cómo ha sido este primer año, qué les ha gustado que no les ha gustado, qué cosas cambiarían desde su experiencia como mujeres adolescentes y como hombres adolescentes.

Recuerden que cuando quieran participar pueden levantar la mano, a todos los vamos a escuchar pero con un orden.

M Pues a mí me gusto de hecho todo, aunque tuve mis roces con algunas personas, y si me gustaría pedirles disculpas a todas esas personas, porque algunas tuve la razón pero en otras me deje ir por los chismes, pero de todas manera todo es parte de eso, eso nos deja tanto cosas buenas como malas, me disgusto... nada porque todo está muy padre, me la llevo muy bien con todos los profesores, bueno no con todos, y si yo pudiera cambiar algo seria... nada porque para mí el primer año fue único y no se va a volver a repetir. (Risas)

Decías que había roces con algunas personas que te gustaría pedir disculpas. ¿De qué tipo?

Pues de hecho aquí con nosotras esta una. 


\section{Sin necesidad de decir nombres}

Ese roce fue porque yo aquí tengo una amiga que fue conmigo en la primaria y la estimo mucho ella le arrebato un collar que para ella era muy valioso porque se lo dio su abuelita y como ella es muy tímida y no se defiende, yo se lo pedí amablemente, le dije que se lo devolviera ella dijo que no, y entonces yo más enojada si le grite y le dije que se lo regresara pero no llegamos a golpes ni nada

Cómo han sido sus experiencias en la secundaria.

Por querer defender a otra compañera. Qué más, cómo fueron sus experiencias.

H Pues fue muy divertido como convivimos con los alumnos, con mis compañeros

\section{¿Cómo se divertían?}

H Aquí en la escuela nos divertimos a veces en el taller o cuando salimos a bañar algunos compañeros y platicando con algunos profesores.

¿Qué era lo que se te hacia divertido? Salir a bañar a donde aquí hay algunos balnearios

H $\quad$ Si

M A mí me gustó mucho porque aquí conocí a nuevas amigas, una que está aquí y me la paso muy a gusto porque compartimos todo lo que tenemos, y con los maestros me llevo bien platicamos y compartimos buenos momentos cuando cumplimos años, compartimos nuestras cosas. A mí me gustaría seguir así y terminar los estudios juntas las tres, junto con otra amiga que ahora no está aquí y me gustó mucho este año porque como dice ella no va haber otro igual.

M A mí también me que más me gusto fue las amigas que conocí y este como dicen también los momentos que vivimos, también compartimos muchas cosas tanto lo que nos, lo que nos pasó y lo que no me gusta es que saliendo el año muchos se van a ir muchos o se van a ir a la mañana, también me la llevo bien con casi todos los maestros y pues si me gustó mucho primer año

H A mí me gustó mucho primer año porque nos divertimos mucho con todos mis amigos, con todos los maestros me la llevo bien, y pues yo siempre todos los días me la paso bien.

Quien más. ¿Hay algo que les gustaría que cambiara en la escuela para mejorarla?

M A mi si me gustaría que los alumnos que estuvieran que no tiraran basura, que respetaran a los maestros y que correspondan con las reglas, que no se salaran las clases, brincándose al oxxo comprando bebidas que no, porque el daño se los van a hacer ellos uno no, pero uno quiere tener la escuela limpia ni modo de limpiarla nosotros mismos, para que los maestros se pongan contentos con nosotros, nos admiren y ellos estén contentos con nosotros porque tenemos unos maestros muy buenos

Ósea que aparte de no tirar basura hay otras cosas que no se respetan de las reglas de la escuela.

M Que se llevan mal con los alumnos

¿Quiénes? ¿Cómo es eso?

M Los alumnos entre ellos se golpean, por decir uno empoja a otro le dicen cosas, y ya pues empiezan a darse golpes

Porque razones se llegan a agredir los/as adolescentes 
¿Por qué creen que se dan esos golpes?

M Y pues los maestros también se portan como sangrones con los alumnos, los maestros se quedan hablando de los alumnos y hay mucha gente de aquí que saliendo van y se pelean y con eso creen que van a cambiar las cosas.

\section{Cuando dices que hay algunos maestros que son sangrones es porque} hablan más de los alumnos

M O incluso hay algunos maestros que se ponen a llevarse con los alumnos y se ponen como si fueran iguales. Nosotros también hacemos mal porque nos ponemos a decirles y ellos también no la siguen. A mí me gustaría cambiar algo de aquí seria igual seria que todos respetáramos mejor las reglas porque aunque a veces yo diga que las respeto, siempre hay alguna aunque no sea intencionalmente pero rompo alguna

Como que reglas se rompen aunque a veces no se quiera.

M Como dijera mi amiga, salarse las clases, por ejemplo en este último mes, algunos dicen yo ya la tengo pasada o yo ya la tengo reprobada entonces no entramos o nos brincamos

$\mathbf{H} \quad \mathrm{O}$ a veces les cae mal el profe y no quieren entrar

M O a veces entramos a la clase y nada más estamos escuchando, como dirían los maestros nada más calentando la banca y no hacemos nada.

Voy a continuar y espero que vayan participando los demás. Vamos a ver una fotografía. Qué ven ahí

H у M Niños y niñas leyendo

Primera foto. Chicos/as en biblioteca

Qué cosas les interesa conocer a los y las adolescentes

Como que están buscando alguna información ¿Verdad? Imagínense si son adolescentes dos hombres dos mujeres ¿qué tipo de información creen que están buscando? Que les interesa, porque aparte están buscando una información que les interesa. Qué les interesa

Qué les interesa a las/os adolescentes sobre la sexualidad

Qué sería de la sexualidad

M Sobre los anticonceptivos

M Sobre las enfermedades (risas)

H Sobre la naturaleza los cambios que tiene

M Sobre los propios cambios que tenemos en el cuerpo humano

M Las condiciones que puede llevar lo del sexo y como nos vamos desarrollando nosotros mismos.

$$
\text { ¿Qué dijiste? }
$$

M Como el sexo que ellos están buscando o las consecuencias que están buscando para no tenerlas o como se van desarrollando al tiempo

¿Cómo se van desarrollando estas consecuencias o ellos mismos?

M Pues las dos cosas casi porque cada cosa tiene su tiempo

$$
\text { ¿Qué más están investigando? }
$$

H Como llevarse entre ellos

M Los derechos

$$
\text { ¿Cómo llevarse entre ellos...? }
$$

¿Derechos qué...? 
M Los derechos que tiene el ser humano

H La igualdad

H La igualdad entre hombres y mujeres

\section{Igualdad}

Ustedes creen que hay igualdad entre hombres y mujeres aquí en la escuela. ¿Cómo es la igualdad o la desigualdad?

M Yo diría que es muy poco porque de hecho ya ni nosotras respetamos a los hombres ni mucho menos ellos nos respetan a nosotras, se ponen a decirnos cosas, nos avientan, a veces nos faltan al respeto, nos levantan la falda o así

\section{¿Cómo se faltan al respeto las/os adolescentes? \\ Digan cómo es la falta de respeto}

M Pues a mí me ha pasado que a veces voy a pasar al salón y tengo un compañero que es muy llevadito y él me quiso agarrar la pompa y yo le dije que se aplacara que porque yo no me llevo y ni le hablo casi a los hombres porque nada más andamos las tres juntas donde quiera vamos las tres y yo le dije que se fijara porque si me agarro pues la nalga y ya al último me dijo que ya no se iba a llevar conmigo pero pues se ve mal eso estando aquí en la escuela

$\mathrm{Y}$ a ti no te agrado

M A mí no

¿De qué otra forma se falta al respeto?

M Diciendo palabras

H Maldiciones

$$
\text { ¿Cómo cuáles? }
$$

Yo sé que les da pena decir maldiciones pero hay unas que son fuertes y otras no tan fuertes, ¿qué tipos de maldiciones? Va a quedar entre nosotros

H Hay de las dos de las fuertes y las no tan fuertes

H Hay unas en las que se meten con los papás

Nos las pueden decir para saber de qué tipo de maldiciones dicen ustedes

H Chinga tu puta madre

H O cuando se meten a los papás, como a tu mamá se la echo un burro

M Vete a la verga

M Hijo de tu puta madre, o no sé qué tanto empiezan a mentarse la madre y pues se ve mal.

M Y más a las mujeres

M O entre mujeres también

M Si a veces o también a las mujeres nos dicen putas o zorras, de hecho simplemente con que nos ven platicar con un hombre o al llevarnos bien, empiezan a decir que somos novios. Yo que me llevo bien con todos hace rato estaba platicando con uno de tercer y luego estaba platicando con otro y luego empiezan a decir que soy bien puta porque ando con uno y con otro.

Solo porque te llevas bien y platicas con tus compañeros

M Y eso que nos ponemos a platicar porque son compañeros de la escuela, 
no venimos a echar novio ni nada, venimos como compañeros, están más grandes pero siguen siendo compañeros de una misma escuela, y una cosas es platicar y otra es estar abrazándonos, besándonos como unos que hacen esas cosas aquí pero pues la gente ya no haya ni que decir.

\section{El respeto}

¿Qué opinan de la falta de respeto?

De hecho yo pienso que está mal

\section{¿Qué?}

H Que está mal la desigualdad, porque tanto el hombre tiene el mismo derecho que la mujer y la mujer tiene el mismo derecho que el hombre ¿Pero tú cómo notas la desigualdad?

H A veces los hombres tachan a las mujeres y las mujeres hacen lo mismo pues.

H

Las mujeres también tachan a los hombres

A veces cuando queremos estar haciendo un tipo de tarea ellas nos dicen hazte para allá y pues los hombres también hacen lo mismo con las mujeres

H Ósea las mujeres se llevan con los hombres y cuando los hombres se llevan con ellas ya es cuando no les gusta.

Eso a ustedes tampoco les gusta. Que se lleven y luego no se aguanten, ¿si te refieres a eso?

H $\quad$ Si

H Es muy raro que pase eso

H Pues también los hombres cuando ellas no se quieren llevar ni nada ellos empiezan a llevarse y a decirles cosas

\section{¿Y quiénes son más irrespetuosos o son igual?}

M No, los hombres (en coro)

H Yo también

Ellas opinan que los hombres y ustedes

\section{Consideran que los hombres son más irrespetuosos. ¿Y porque será} he?

M Porque a veces los hombres no sé dónde se la pasen y vienen aquí y creen que todas las mujeres son iguales que las que ellos conocen o no sé, y a veces se quieren pasar

Tú crees eso y ¿ustedes?

Piensan que todas las mujeres son iguales

¿Iguales? ¿Cómo quiénes?

H Cómo las que son...

H Las mujeres bellas (risas)

H Las que son homosexuales o bisexuales

$$
\text { ¿Cómo? }
$$

\section{Las que ellos tratan ¿Cómo son?}

H Con las que ellos se llevan, las que son llevadas

H Por decir en sus casas se llevan con mujeres y ellas aceptan y piensan que aquí va a ser igual

H Piensan que va a ser igual en todas las partes

Les decía en un principio que estábamos elaborando una asignatura estatal que se llama cómo, que va a tratar temas de qué 


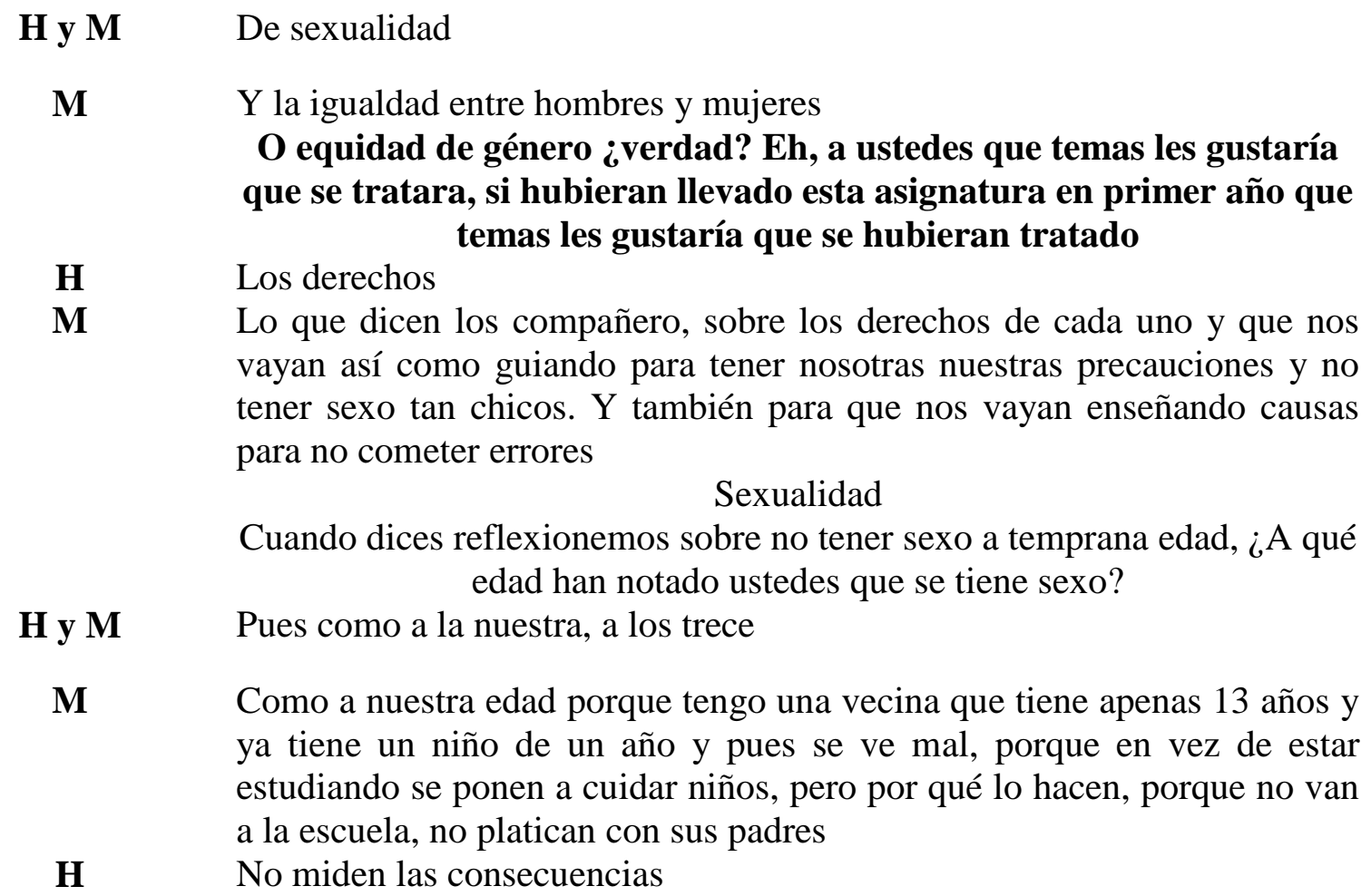

¿Y qué motivos pueden tener para tener sexo a temprana edad? Todos los motivos que puedan tener, lo que se les ocurre o que les han platicado

M Por la falta de información

H o a veces solo por curiosidad

M Pero como son tan curiosos y no se informan pues no miden las consecuencias

H O porque no tienen platicas con sus padres

H Tal vez por lo que oyen o lo que pasa en la tele

¿Cómo qué? Es que es muy interesante todo lo que están diciendo, ahorita los vamos a escuchar a todos, ¿Cómo que es lo que pasan en la tele?

H Pues todos los comerciales que pasan sobre condones y los programas que pasan en la noche

Todo esto que sacan de protección, condones o eso

M También en la noche que pasan las películas de porno los alumnos en vez de ponerse hacer tarea se ponen a ver eso y pues muchas muchachas salen embarazadas y también por falta de dinero y les dicen que vente para acá y pues ellas que saben por dinero va a hacer lo que les dicen

H O también por drogas. Las drogan y ya las llevan a eso

H O también porque algunos que ya tuvieron relaciones les dicen ¡no está bien chido! y ellos por tentación lo hacen

H Hay hombres que ya se metieron con las de las cantinas pues, y ya tienen una enfermedad como por ejemplo la gonorrea y como les gusto ya lo quieren hacer con otras mujeres y a veces no miden las precauciones pues y ya lo hacen con las mujeres y las mujeres sin darse cuenta de lo que ya había hecho.

H O lo del sida, que en venganza quieren contagiar a otras personas

H O a la mejor los hombres que ya están casados se van a las cantinas se 
meten con otras mujeres que están infectadas de alguna enfermedad, se van a su casa se meten con la mujer y le pegan la enfermedad

Y ya nacen los hijos infectados o a veces cuando ya están bien... (No se entiende) y dicen de todas formas me voy a morir se ponen una jeringa y se sacan sangre y empiezan a infectar a las otras personas, eso paso en África.

¿Qué más? ¿Aquí cómo es? ¿Aquí también pasa eso? ¿Entre muchachas y muchachos de su edad pasa eso?

H $\quad$ Si

¿De qué se infecten?

M Yo de eso la verdad no he sabido, pero de curiositos que tengan sexo a temprana edad, si

H Hubo una compañera que iba con nosotros y ella no quiso medir las consecuencias y quedo embarazada.

H En mi salón también hubo una que se tuvo que salir en el tercer bimestre porque se quedó embarazada

\section{Embarazo en adolescentes}

Bueno, cuando ustedes dicen que consideran que tienen sexo a temprana edad por varias razones por falta de información, porque no platican con sus padre, por cosas que oyen en la tele. $Y$ ¿cuáles son las razones por las que se embarazan?,

H Por no cuidarse

M no usan protección

M Por no orientarse

H Aunque me dijo un maestro que aunque usaran protección se puede pegar alguna enfermedad

H O a veces se rompe el condón

M Hay veces que las chavas cuando tienen un novio y lo quieren mucho se embarazan y así piensan que lo van a amarrar y así van a conseguir que el novio se case con ellas, pero hay veces que no es así de hecho cuando salen embarazadas más se alejan. También hay chavas que fueron violadas sexualmente y en una violación pues no se piensa nada y pues quedan embarazadas

¿Aquí ha habido casos de violación en muchachos y muchachas?

De hecho si, una de mis hermanas y ahorita el niño tiene tres años

¿Qué más les interesaría que se contemplara en esta asignatura?

Si hay casos, pocos pero si hay. ¿Qué más les gustaría que se viera en esta asignatura? Les recuerdo lo que dijeron hasta ahorita, los derechos de cada alumno, reflexionar para no tener sexo a temprana edad. ¿Qué más?

M Las formas en las que se pueden cuidar, este no sé pueden explicar para qué es y para que se utiliza porque muchos no saben y les da flojera y...

H O que los mismos maestros hablen más de esas protecciones, como deben de cuidarse porque algunos maestros les da vergüenza hablar de esos temas

H En eso son mejor las mujeres

Ósea que si les dan información pero no les dicen las formas de cómo hacerlo

H Y si no explican bien pues lo pueden usar mal

H O algunos piensan que es un juego nada más, cuando tocan ese tema , 
cuando hablan sobre eso

Sobre todo porque si hay algunos maestro que tienen la capacidad y nos explican lo de sexualidad y métodos anticonceptivos, que nos dejen en claro las responsabilidades que nos va dejar tener un acto sexual y sobre todo si queda embarazada la muchacha porque hay algunas que dicen "no pues no pasa nada" y no nos dejan en claro las causas y consecuencias y todo.

M Los abortos

$$
\text { ¿Qué más? }
$$

\section{Qué les interesa saber sobre el aborto en adolescentes ¿Qué les gustaría saber del aborto?}

M También sería lo mismo que si no tienen información pueden quedar embarazadas y se van a lo más fácil "abortan" y luego ya hay unas que como consecuencias no pueden tener más hijos y arrepienten después

\section{Las consecuencias de aborto}

H O también en el aborto pueden morir

H Por eso en el aborto en las cosas que hacen mal las mujeres no saben ya después quieren librar al bebe porque quieren seguir así y eso no está bien

H O lo llevan a un orfanato

H Los dan en un centro adopción

M Es preferible eso a uno aborto (discuten que es mejor entregar al niño en adopción que abortar).

H Algunas mujeres los venden

H Otras lo regalan a otras mujeres que no pueden tener hijos que son estériles

H Yo no

$$
\text { ¿Han visto eso también aquí? }
$$

M Aquí hubo una vez una muchacha que tiro a su bebe en el bote de basura ¿Algo más que les gustaría que se viera en esta asignatura?

M Como respetarse entre niños y niñas

M Y entre maestros

H Porque hay unos maestros malitos yo no he visto eso pero he escuchado

H y M Entre alumno y maestro

M O entre alumnas y maestros

Y alumnos, alumnas y el maestro

M Aunque hay veces que los alumnos no se toman en cuenta a ese maestro

Como es esa falta de respeto

M Bueno, un maestro de aquí le pidió a una alumna de aquí una foto de ella en trapos menores por ejemplo cuando andamos mal en esa materia nos ofrece pasarnos a cambio de otras cosas

Entonces ahí hay una gran falta de respeto y ¿qué pasa? Acceden no acceden

M Por esa misma falta de respeto muchas alumnas que las aferran pues que les den, que les den lo que les esté pidiendo y muchas que no entra o se la salan y las bajan de calificación o las reprueban y con eso tienes para reprobar la escuela y quedarte sin estudiar por lo mismo que te da miedo que te sigan molestando los maestros

M Si no hace lo que él dice te reprueban aunque cumplas con tareas y trabajos 
M Aunque uno hable con la directora o con el director, les hacen más caso a los maestros que a los alumnos. Porque eso también paso en la mañana mi tía vino hablar con el maestro y el director por lo mismo y le dijeron que lo iban a correr a él porque ese maestro si era muy malito pues decía muchas cosas a las alumnas, si se agachaba una alumna por algo y les empezaba a decir se te vio esto se te ve lo otro o les decía "desabróchate la blusa se te ve bonita la que traes abajo" y pues ellas van y se las desabrochan o les dicen algo y los maestros no les hacen caso y dicen que los alumnos ya no tienen ni que decir y les hacen más caso a los maestro que a uno.

(Interrupción de una maestra por unos minutos)

Fotografía 2 Chavo aburrido, triste

Estoy proyectando otra fotografía. ¿Qué ven ahí?

H Chavo aburridos

¿Qué más ven ahí?

M Enfadados, sin ganas de hacer nada

Fotografía 3 Chava aburrida, triste

Desganados. Ahora les voy a mostrar otra. ¿Qué ven ahí?

$\mathbf{M}$

$\mathbf{M}$

M

$\mathbf{H}$

M

H

M

$\mathbf{M}$

$\mathbf{H}$

$\mathbf{M}$

M

Depresión en adolescentes

¿Qué les pasara a estos muchachos y a esta muchacha? ¿Por qué están tristes?

Yo siento que por una enfermedad o no midieron bien el sexo y quedaron embarazados

Que le haya pasado algo malo

Que le haya pasado algo malo ¿Cómo qué?

Se refiere a algo que le haya pasado con su familiares y por eso se está sintiendo mal

Eso es lo que tú piensas, vamos a ver qué piensa estrella

Que se haya metido con otro hombre por no saber lo que ha hecho

O también se metió con alguien y ya no quiso y el empezó a hablar mal de ella por toda la escuela y a la mejor ya no le quieren hablar porque a la mejor dijo algo que ni siquiera era

\section{La discriminación}

\section{¿Tú querías decir algo de la discriminación?}

Que a la mejor lo discriminan por tener una enfermedad como el sida, piensan que se les puede pasar a ellos y ya no platican

Con la discriminación que les hacen se enfadan hasta se drogan o se quitan la vida, eso le paso a un compañero ahí por mi casa un vecino, él tenía 15 años él se drogó y salió mal con su mamá y se mató y pues ahora todos en la colonia lo extrañamos. Él se la pasaba con la muchachas bien pero se inyectaba drogas y el andaba bien pues, pero porque salió mal con su mamá él se suicidó. A veces los padres o la gente no saben y la discrimina y por lo mismo también hacen eso, por sentirse solos u mal.

Preocupada por algo que le dijeron o le prohibieron contarle a alguien o buscando la solución para ese problema 
Ósea le prohibieron contarle alguien lo que le pasa y ahora anda buscando como resolverlo

M O a la mejor que un maestro le haya hecho algo y le haya amenazado

M Haya abusado sexualmente

Con que personas las/os jóvenes pueden expresar sus sentimientos Ante quiénes las y los jóvenes pueden expresar sus sentimientos, sus ideas

Todos/as Los amigos

M Con sus amigos, no especialmente con sus amigos sino con la persona que más confianza le tienes, puede ser un amigo, una hermana, un tío, una mamá, porque no muchas veces los confidentes son los papás porque muchas veces se ocupan de darnos lo material y nunca se molestan en preguntarnos lo que nos pasa, lo que sentimos y a veces buscamos la confianza que no tengamos con ellos con otras personas.

M También platicamos cosas de nosotras de lo que nos pasa porque uno a veces confía más de los amigos y de los papás porque hay unos amigos que les cuenta algo y se lo cuentan a otros y empiezan los chismes. Al igual con ella nos platicamos todo pero como ninguna de las dos cuenta nada de la otra, pues como nos tenemos confianza nos platicamos todo, a veces estamos mal pero al ratito estamos juntas otra vez.

H Yo siento que a los que les debemos tener confianza es a los papás porque un amigo luego se pelean y anda diciendo todo y hasta lo que no y por eso empiezan a salir mal

H Pero también hay amigos a los que les tienes demasiada confianza ellos son los amigos que nunca se separan de ti, a esos son a los que debes de confiar como a los papás o alguien especial a quien le queras contar a un amigo

M Como también yo les tengo mucha confianza a mis tías y a mi mamá también. De mis hermanos son más chicos yo soy la más grande no tengo a quien contarle aunque a veces también me da pena. Y le cuento a mi tía.

H A veces da pena por el tema que le quieres contar, da pena por lo que dirá si le cuento eso.

Qué temas son difíciles de abordar para las/os adolescentes Y los temas difíciles de contar ¿Cuáles son?

M Del sexo

H La sexualidad

H Con mis amigos

¿Y eso con quienes lo comparten?

M Con mis amigas o con mi mamá porque con mi papá... yo me hallo más con una mujer que con el hombre para contarle algo de mí, porque más vale contarle a la mamá a que vaya otra gente y le cuente cosas que no, en confianza hay que platicarle a los padres

Características de las personas en las que confían los/as adolescentes

Han hablado mucho de las amigas/os, me imagino que aquí hay grupos de amigas/os, ¿qué características tiene sus grupos de amigas o amigos? ¿Cómo son, cuáles son su reglas al interior del grupo, qué hacen sea los grupos de mujeres o de hombres o mixto?

H No decir nada a nadie de lo que nosotros platicamos

H No llevarse con los mismos que estamos ahí

M A nosotras a nuestro grupo no nos gusta que de nuestras mismas amigas 
hablen cosas de nosotros a nuestras espaldas, nos gusta que si tenemos un error no los digan en cara y no lo anden diciendo en otras cosas, o que inventen cosas de uno que no son ciertas. A veces hay amigos que no son amigos que son hipócritas y pues son pocos con los que a veces se puede contar, los que si te ofrecen una amistad sincera.

Nosotros en nuestro grupo no hay reglas porque no es un juego, lo que tenemos las tres en común es que somos sinceras y si a mí me parece algo mal de ella yo vengo y se lo digo a ella, pero se lo digo a esa persona no de modo sarcástico sino de manera muy amable para hacerla reflexionar y mejore lo que no me parece, aunque si es algo que a mí no me parece y a ella le gusta hacerlo y ser así no me voy a poner a que lo mejore, simplemente nos aceptamos las tres tal y como somos

¿Y en el de los hombres?

H Pues si nos llevamos entre nosotros pues aguantarnos

Cómo se divierten los/as jóvenes

¿A qué juegan o en qué se divierten?

H Lo más común es el futbol entre nuestros compañeros.

H Entre hombres sí

¿Es lo que más juegan en su grupo?

Fotografía 4 Chicas peleando (Violencia en los/as adolescentes)

Les voy a proyectar otra foto. ¿Qué ven ahí?

H y M Se están peleando

H Y otros que les están echando porras

Todos/as Si en coro

¿Eso llega a suceder aquí en su escuela?

Razones que motivan la violencia en las/os adolescentes ¿Cómo es? ¿Por qué motivos?

H Por la novia

M Por el novio como dice el pero al revés

\section{¿Cómo que por el novio?}

M Porque dicen no que a mí me gusta el y no sé qué tanto y empieza la otra a echar más leña a la fogata y le dice no que es mi novio y que por coraje y por celos empiezan a agarrándose de la greñas y que esa no sabe pelar y va la amiga y también se mete y empieza todo ese rollo de peleas

H Por chismes

M O nada más porque alguien le cae mal esa persona

M O simplemente por molestar o porque creen que el respeto de los demás se lo van a ganar formado una imagen agresiva y ser el más fuerte dicen "yo soy la mejor en las peleas" y lo voy a demostrar por ganar esa imagen que a veces es verdadera y otras veces es solo una imagen.

H Buscan tener amigas nada más por agresividad y no por tener una amistad bien

¿Por qué creen que se da la agresividad?

H Porque todo lo quieren arreglar a golpes

M O porque tienen problemas en su casa y aquí se vienen a desahogar

M Cuando yo no me puedo desquitar de mi coraje lloro y cuando ven a alguien llorando la empiezan a criticar y cuando me pasa a mí la verdad ya no me puedo controlar si me voy a los golpes pocas veces he llegado a hacerlo pero si lo he hecho.

Consecuencias de ser violentos/as 
¿Qué consecuencias hay cuando llega a haber estos pleitos? ¿En hombres también se da o nada mas en mujeres?

H También
H у M En las mujeres
H Ya no se hablan las mujeres
¿Y cuáles son las consecuencias de esto? Ya no se hablan las mujeres
M O la suspensión por tres días
H En los hombres pueden pasar a mayores como en las mujeres pueden pasar los papás

Fotografía 5 Mujer golpeada (violencia de género)

H Una mujer golpeada

¿Y ahí que ven?

H La están violando

M Podría ser la imagen de un acoso

H Después de que la golpeo la está besando

M Hay hombres en lo que eso es una enfermedad. Los hombres golpean a sus esposas y luego lo quieren arreglar hablándoles bonito pero no se pueden controlar, a veces con enojo les pegan y después se quieren disculpar

H у M No

\section{¿Aquí se da violencia entre las parejas?}

\section{Cosas que hacen los/as adolescentes para atraerse}

¿Y cómo le hacen las mujeres y los hombres para atraer al sexo apuesto?

M Coqueteando

H Haciendo diseños, levantando pesas

H O a veces los hombres se pelean para ver quién es más fuerte y ver si así a la mujer así le gusta

H Para quedar bien con la mujer

M La mujer se empieza a arreglar para llamar la atención del hombre o también el hombre empieza a llevarle una rosa a la muchacha que le gusta y la muchacha que le gusta le empieza a mandar mensajes

M O empiezan como amigos

Ósea en los hombres es que vean su fuerza o cómo atraen a las mujeres

H A veces se pelean para que vean las mujeres, como este le gana a este, no pues este ya no me gusta, o si este ya no sabe pelear pues ya no me gusta

H O a veces nada más son novios para verlas arrepentidas, porque puede decir una mujer si este me dice algo le digo a mi novio.

Y generalmente quien tiene la iniciativa cuando se pretende alguna relación ¿Qué ven más común? ¿Quiénes toman la iniciativa las mujeres en coquetear o los hombres en mostrar su...?

M Las mujeres yo creo, porque los hombres dice el maestro Gus que todavía están en pañales

H Dicen que las mujeres reaccionan más rápido por eso que para que sea una mejor relación el hombre tiene que ser mayor que la mujer que porque los hombres no captan bien.

\footnotetext{
Cómo reaccionan las personas adultas ante los cambios de los/as adolescentes
}

¿Cómo reaccionan los adultos? Fíjense bien pueden ser maestros/as, 


\section{mamá o papá o la persona que se encargue de ustedes han presentado ahora en su inicio a la adolescencia}

Mi papá ni siquiera se da cuenta, es de los que nunca tiene el detalle ni la obligación de preguntar ni donde estoy ni en mis calificaciones, y mi mamá pues no estoy con ella y la esposa de mi papá ella si se interesa por mí y lo que hace es darme consejos y apoyarme en los problemas que tengo, porque siempre que entras en la adolescencia hay más problemas tanto entre nosotros como con los demás

¿Cómo cuáles son los conflictos que pueden presentar ustedes? O los problemas que ustedes registran

M Cuando vamos creciendo los problemas crecen con los papás por los permisos que no nos dejan salir con los amigos o por el novio

H Se vuelven más estrictos

M O el problema del novio, que no llegues tan tarde, que no nos quieren dejar salir por todo lo que sale lo que le hacen pues a las mujeres.

H $\mathrm{O}$ a veces piensan que puedes agarrar vicios se vuelven más estrictos porque pues como ya estas más grande piensan que van a agarrar cosas malas

M El papá es más celoso que la mamá, le dices "papá me dejas ir a un mandado, que no porque luego te pasa esto y esto" y a veces una mujer en bobada con el hombre y le da consejos de vámonos para mi casa y la mujer va y se mete a la casa y donde quedaron los consejos del papá y ya cuando le pasa alguna cosa o algo ahora si se acuerda del papá arrepentida.

M Como también lo más común es que creemos que siempre tenemos la razón y si alguien nos reprende o no hace ver que estamos mal empezamos a creer que no nos quieren o que están en nuestra contra o simplemente quieren manejarnos sin darnos cuenta que lo hacen por nuestro bien, especialmente con nuestros papás

M O a veces con los hermanos mayores, tu sales y el papá manda atrás de ti a los hermanos y lo que haces tú el hermano lo ve y va y le dice al papá y el papá te regañan

M Por ejemplo también a los mayores les dan más permisos y libertades obviamente porque son más mayores y más responsables, a veces no enojamos y empezamos que como a ellos sí y a nosotros no y nos ponemos celos y llegamos a lastimar a nuestros padres diciéndoles que ¡seguro a mí me adoptaste Y por eso la quieres más a ella!

Cómo reaccionan los/as docentes ante sus cambios

Y con los maestros como reaccionan con las cambios de ustedes

M Igual hay profes que te cuidan como si fueran tus papás, te ven platicando y te dicen ¡Vete a tu salón!, lo hacen por cuidarnos, hay unos que nos agarran afecto y tratan de cuidarnos para que no cometamos un error.

M Hay algunos maestros que coquetean con las alumnas y les dicen no pues tu ven has esto y quiere el maestro que lo hagas y tu no lo quieres hacer. Pues esto lo tienes que hacer

Cómo cuidan su salud los/as adolescentes

Ya vamos a acabar ya faltan dos preguntitas. De ¿qué manera ustedes cuidan su salud?

M Cuidando desde que amanece, como mis tías son enfermeras ellas me dicen que coma mucha verdura, fruta, que no ande comiendo porquerías 
como en la calle que chicharrones, comida chatarra, que chile porque luego puede hacer una enfermedad y por eso también me dice que me cuide que en la mañana me tome un vaso de leche.

Pero eso te dice tu tía, pero ¿ustedes que tanto se cuidan en lo real?

M

H

$\mathbf{M}$

$\mathbf{M}$

H

M

M

M

$\mathbf{H}$

M

$\mathbf{M}$

$\mathbf{H}$

M

$\mathbf{H}$

M

M

$\mathbf{H}$

$\mathbf{M}$

$\mathbf{M}$

Yo de comida como todo, me cuido hasta el grado de no consumir drogas y de no beber alcohol.

Hay veces que yo me enfermo de gripa o algo y me dice mi mamá que no tome cosas frías y tomo y se me quita

Pues yo también como de todo, pero si también lo único que cuido es de no tomar alcohol o drogas

¿Qué cosas implica cuidar su salud?, nada más implica el comer No, haciendo deporte, actividades físicas vitales, sociales también porque tu salud la puedes cuidar evitando llegar a golpes

La verdad yo no me cuido en nada

¿Y qué piensan de la salud emocional? ¿Creen que existan o no?

$\mathrm{Si}$, que una salud saludable emocionalmente seria que todos alguna vez estamos alegres, felices, tristes, enojados pero si estoy saludable emocionalmente no tendría que estar todo el tiempo triste, todos tenemos problemas pero si me enfoco solo en eso y me atasco todo el tiempo me la voy a pasar triste y ahí estaría enferma emocionalmente.

Qué cosas hacen cuando se sienten mal emocionalmente

¿Cuándo se sienten tristes, desolados qué hacen?

A mí me gusta estar sola

A mí me gusta escribir

Algunos se ponen a ver tv. o a escuchar música

Yo me pongo a leer, escribir o escuchar música

Me pongo a escuchar música, a pintar, cocer con mi abuelita, me enseña pues a cocer

Yo me pongo a escuchar música y a dibujar

Yo me pongo a escuchar música y de lo deprimido que estas se te salen las lagrimas

Depende

¿Y qué música escuchan?

Yo de toda, a mí lo que más me importa es la letra

¿Y qué tipo de letra es?

A mí me gusta la música romántica e idealista, como ejemplo Mana, el don de escribir es canciones es volar en la irrealidad pero mana no escribe así ellos se basan en la realidad como los temas de "Arde el cielo" o así que no se ponen a escribir por escribir, como por ejemplo a nosotros los jóvenes que se nos hace muy aburrido pensar en eso de la ecología ellos buscan la forma de hacerlo divertido. Convivan la letra con el ritmo y se encargan de hacerlo divertido, porque a nosotros no nos gusta la música para viejitos con guitarra y violín. Ellos tratan de hacerla divertida

La mayoría de las mujeres escuchan música así como de Chayanne, como de Enrique Iglesias y los hombres escuchan puro corrido como de Roberto Tapia

A mí también me gusta escuchar a Roberto Tapia y duranguense, banda

A mí también me gusta como calle trece

Decían que cuando se sienten tristes o desanimados "Pintan, dibujan, escriben, escuchan música, estar solos" ¿y les funciona? 


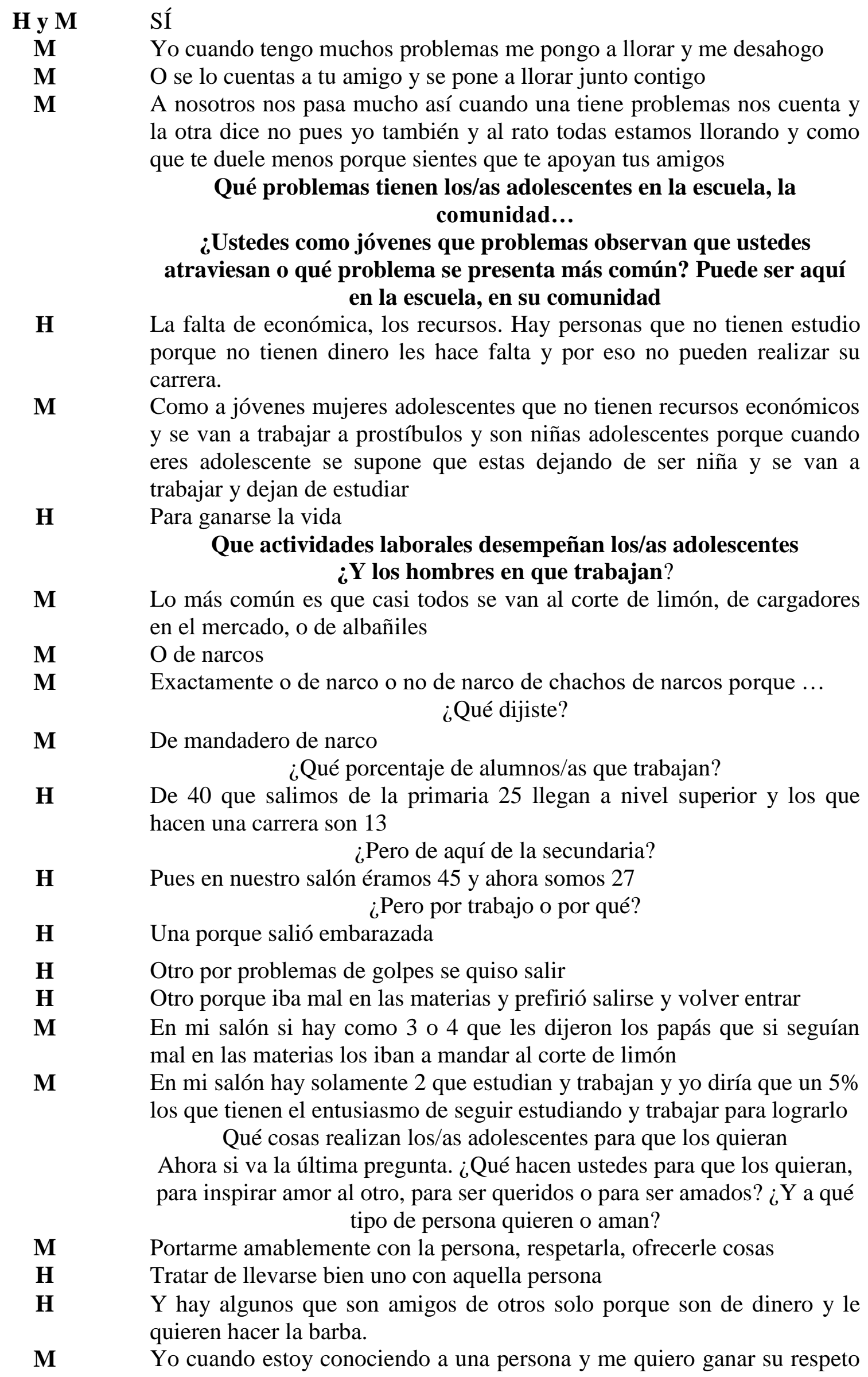


soy así como soy yo, porque a mí no me gusta si yo conozco a alguien y finge ser amable y ya con el tiempo darme cuenta de que no es así de que simplemente estaba fingiendo, es por eso que cuando yo conozco a alguien aunque sea para ligar simplemente soy como soy yo.

H Como algunas personas que en el noviazgo fingen una cosa y cuando se casan son otra

M Aquí hay unos alumnos que en su casa son unos angelitos y vienen aquí a la escuela quieren presumir que son los mejores, los más altos, los más fuertes y con el novio son otra manera al igual fuera de la escuela

H Tienen diferentes tipos de imágenes

M Aunque es cierto que hay que saberse comportar en cada ocasión

\section{Características que tienen las personas que los/as adolescentes quieren}

\section{¿De qué tipo de características tienen las personas que ustedes} quieren?

A una persona realista

Yo más que nada respeto a una persona que me respeta, porque trata como quieres que te traten. Y por ejemplo si una persona no me falta al respeto pues no le faltó al respeto, como en mi casa mi tía se comporta a veces como una niña y dice cosas que a mí no me gustan se pone a decir que mi mamá y que no sé qué, y yo le digo "tía usted me dice que la respete, si usted quiere que yo la respete usted también respéteme" y ella me dice "no pero yo te respeto" y yo le digo "hay deferentes formas de respetar, una cosa es que no se meta conmigo, pero al quererme gritar me está faltando al respeto "y de hecho hoy en la mañana salimos mal, porque yo respeto a quien me respeta

¿Y ustedes a qué tipo de personas quieren y respetan?

H También como dice ella, a las que me respetan

¿Cómo se ganan el respeto de las personas?

H Siendo amables

M Siendo respetuosos

H No echando mentiras, siendo sinceros

H No fingiendo ser otra persona

Y recuerdan que al principio decían que eso hacía falta que a veces se peleaban y discutían y se faltaban al respeto. ¿Por qué creen que se faltan al respeto?

M Porque no nos respetamos unos con otros

H Porque a veces las personas no saben cómo es y piensa que es de una forma, su apariencia lo engaña, piensa que es malo y por eso me cae mal, o si es presumido ya por eso me caer mal y por eso me quiero pelear con él.

Ósea que por que se dejan llevar por las apariencias. Los demás que dicen.

M O por decir hay unas alumnas que van aquí en la escuela y te ven y te tuercen la boca y pues las ves y ya te caen mal

M O porque le caes mal a una persona y ella les dice a sus amigas que "no les hables me cae mal" y después la otras también dicen que les cae mal 
Problemáticas que los/as adolescentes observan en su comunidad Por unirse a otro, si yo me junto con alguien es porque si tú no le hablas a tal persona pues yo tampoco. Algo más que quisieran agregar a lo que hemos platicado. ¿Aquí en Apatzingán que tipos de problemas se dan más comunes?

M La violencia

H Las drogas

¿La violencia a qué grado llega?

H A tercer grado

¿A que sería el tercer grado?

H A matar

M Andar de rateros

H Salen mal y pues le uno le dice al otro "hasta aquí llegaste" y saca la pistola y pam, pam

¿Pero en adolescentes se da eso?

H No

H у $\mathbf{M}$ Si hay casos

M O hay unos que según andan en eso de la mafia y si tienen problemas con alguien ya nada más llaman a los que ellos conocen y si los llegan a matar

H Y hay algunos que dicen "yo soy de la mafia" y cómo piensan que si es cierto, pues ya le hacen caso y va a ser como su mandadero. Para que no le hagan nada

Fíjense que hace rato hablaron de discriminación, ¿a qué se refieren?

¿Cómo se da aquí la discriminación? Aquí en la escuela que ustedes vivan

M Por la personalidad, hay una amiga mía que tiene su boca muy grande y se la pasan haciéndole burla que porque esta deforme y que esta trompuda, lo bueno es que ella no se molesta y ella dice "si y que" y no les dice nada y se calman. Hay un compañero que está mal en cuestiones de dinero y trabaja toda la mañana así que nada más llega y no se baña se cambia y se viene y a veces huele feo y los chiquillos se burlan de él también y no debería de ser así porque no saben que problemas tenga o porque lo haga depende de la vida de cada quien.

M A veces también por el promedio por ejemplo si yo tengo muy mala calificación dicen yo no me junto contigo porque eres burra y que somos el club de las fresas o las más bonitas o así, o las mas inteligentes.

En que situaciones han observado discriminación

La discriminación en que más la notan

H En que algunos maestros siempre les creen más a las mujeres

M Siempre tienen una alumna preferida y siempre la pasa a ella

Que diferencias encuentran los/as jóvenes entre hombres y mujeres Ósea que ustedes no observan mucha igualdad entre hombres y mujeres, ¿y entre ustedes?, porque dicen que observan que los maestros les creen más a las mujeres en ciertos casos. ¿Qué otras diferencias encuentran entre hombres y mujeres en esa desigualdad o discriminación? 
H Que algunas mujeres piden igualdad para ciertas cosas para las cosas que les convienen pero para otras no.

¿Como cuáles?

H Para trabajar

¿Cómo para que otras cosas no? Ándale anímate a decir porque es muy interesante, ósea piden igualdad para unas cosas, cómo para cuales

H Como para, pues...

\section{¿Cómo que cosas les convienen?}

H Para ganar dinero

¿Qué cosas no les convienen? Que dicen para eso no

H Trabajar

H Quieren dinero pero no quieren trabajar

¿Ustedes qué dicen?

M Como una maestra nos pregunta que si queremos examen o trabajo les califico, cuando ven que reprueban con el trabajo, piden mejor examen y dice la maestra "ven como son de tramposos, porque piden lo que les conviene"

Hay algo más que nos quieran compartir, les agradecemos mucho. 


\section{GRUPO DE DISCUSIÓN No 7}

\begin{tabular}{|c|c|c|c|c|c|c|c|c|}
\hline $\begin{array}{c}\text { Nombre } \\
\text { de la } \\
\text { escuela }\end{array}$ & Ubicación & $\begin{array}{l}\text { Zona } \\
\text { iscolar }\end{array}$ & $\begin{array}{l}\text { Grupo de } \\
\text { discusión }\end{array}$ & $\begin{array}{c}\text { Grado } \\
\mathbf{y} \\
\text { Grupo } \\
\end{array}$ & Moderadora & Observadora & Fecha & Hora \\
\hline ESG $N^{\circ}$ & Apatzingán & & $\begin{array}{l}\text { es: } \\
\text { s y }\end{array}$ & $\begin{array}{l}1^{\circ}: \mathrm{A}, \\
\text { B у C. }\end{array}$ & \begin{tabular}{l}
\multicolumn{2}{l}{ Georgina } \\
Pérez Coeto \\
Mateos r y \\
Mtra. Ma. de \\
Jesús Soto \\
Campos
\end{tabular} & $\begin{array}{l}\text { Elva Morales } \\
\text { Robles }\end{array}$ & $\begin{array}{l}18-06- \\
10\end{array}$ & $9: 30$ \\
\hline \multicolumn{9}{|c|}{ Contexto situacional } \\
\hline \multicolumn{9}{|c|}{$\begin{array}{l}\text { La selección de las/os jóvenes que eligieron para el grupo de discusión fue de la siguiente manera: Estuvo a } \\
\text { cargo un prefecto, al cual se le dio la instrucción que escogiera a jóvenes con disposición de participar. El } \\
\text { prefecto pregunto en diversas aulas quiénes quería apoyar en una actividad y los/as que levantaron la mano } \\
\text { fueron los que participaron en el grupo de discusión. El aula donde se trabajó con el grupo de discusión era una } \\
\text { sala ubicada en las oficinas de dirección. Todos manifiestan disposición y agrado a participar, como apertura a } \\
\text { la grabación de la misma en el entendido de que será confidencial. El trabajo transcurrió de manera positiva. Se } \\
\text { inicia la sesión con las siguientes instrucciones: } \\
\text { La dinámica sería la siguiente: La dinámica es que cada una de nosotras y digo una porque somos personas, } \\
\text { somos nosotras las personas, vamos a aportar nuestra opinión, a decir lo que queramos en el momento en que } \\
\text { queramos siempre y cuando levantemos nuestra mano, para que podamos escucharnos todos y todas. } \\
\text { Es decir que si hacemos algunas preguntas ustedes levantan la mano y rápido les damos la palabra. Y cuando } \\
\text { algo diga la compañera o el compañero, que ustedes quieran también aportar, inmediatamente levantan la mano } \\
\text { y así vamos dando la palabra ¿sí? } \\
\text { Por favor, con la mayor franqueza que puedan, a partir de su propia experiencia, a partir de lo que creen, de lo } \\
\text { que piensan, de lo que han observado isi, de acuerdo? }\end{array}$} \\
\hline
\end{tabular}

Registro de grabación. A cargo de Elva Morales

SIMBOLOGÍA:

$\mathrm{H}=$ Hombre

DISCURSO

$\mathrm{M}=$ Mujer

Bien, de acuerdo, vamos a empezar, platicando de su escuela, Platíquenme de su escuela, descríbanla... que cosa les gusta de su escuela, que cosa les gustaría que pudieran cambiar; ya saben que es con toda confianza.

\section{Las experiencias que ha representado}

H Es una nueva experiencia, una nueva etapa, conocer a nuevas personas, amigos que conoces en la escuela, este... en este mismo tiempo llegan también los cambios hormonales y emocionales, empiezas a ver las cosas de diferentes maneras, desde un punto de vista que no lo veías de chico.

Ustedes chicas, chicos... 
M Podemos contarnos cosas entre amigos llevarnos bien.

Platíquenos ¿por qué están aquí en la secundaria?, ¿cuáles son

sus razones de estar aquí?

M Yo quiero estudiar, para poder tener una profesión y trabajar. (hablan todos al la vez)

$\mathbf{H} \quad \mathrm{Si}$, para tener una profesión y ganar dinero ¿no?

H Para cuando me vaya de casa y tenga hijos los valla a tener bien

M Para saber las cosas que no sabemos... para ser alguien en la vida y si te piensas casar y tener hijos, enseñarles algo que a ti te enseñaron tus papas y que te enseñaron en la escuela.

H Para seguir estudiando y poder llegar a una carrera, para poder mantener a mi familia (cuando seas grande) ajam...

H Pues yo lo que quiero es tener un futuro estable, bien, con una economía perfecta, para eso estudio bien.

\section{¿Recuerdan cómo se iba a llamar esta asignatura chicos y chicas?}

H No más me acuerdo de equidad de género

¿Qué más?

Educación sexual y equidad de género

Y ya una vez que saben de qué trata la asignatura, que se les ocurre aparte.

Lo que pasa es que quiero que me digan sus expectativas antes que nada, ahorita les preguntaba sobre la escuela y todo, pero retomando el asunto del nombre de la asignatura, que nos dijeran que se les ocurre a partir de este nombrecito, lo que vamos a platicar aquí.

Expectativas de los/as adolescentes sobre el tema de educación sexual y equidad de género.

Chicos, ¿cuáles serían sus expectativas de esta platica, vamos a platicar de qué?

H Los derechos de la mujer y del hombre y de que somos iguales, aparte de cómo cuidarnos, las relaciones sexuales, métodos anticonceptivos, a ver que más... nuestro cuerpo. (risas y barullo)

M De la cultura general, de los derechos de los hijos

H Como debemos convivir

M Como aprender a respetarnos, a valorarnos.

M Como saberse darse a respetar

H Aprender a decir no a lo que está mal

M De si te sucede algo saber cómo resolverlo o saber pedir ayuda y saber a quien

¿De dónde obtienen la información que tienen sobre educación 
sexual y equidad de género?

Ahora que ya sabemos lo que ustedes esperan de esta plática, ahora ya van a si van a empezar a decir lo que en realidad vamos a platicar

Para empezar les vamos a preguntar ¿cómo es que ustedes saben todo esto, de dónde sacan todo esto que saben, de dónde se les ocurrió?

M De los libros de biología, de Internet y de nuestros papás.

H Exactamente de lo que dijo ella...

M Yo iba a decir de la comunicación con mi mamá

H De la sociedad

De Internet qué sacan

M De Internet a veces tus papás te dicen unas cosas y ya tú te metes a complementar o a ver que hay exactamente en Internet, si son mentiras o verdades.

\section{Mentiras de tus papás}

M No me refiero a que ves otra manera de explicación.

H Oli $i$ Te acuerdas lo que hacen nuestros compañeros con el Internet? (risas)

$$
\text { ¿Qué hacen con el Internet? }
$$

M Acercarse a videos muy feos, de pornográficos.

M Los niños siempre tienen eso en su celular (tono despectivo)

H Yo no... (Risas y barullo)

M Pero la mayoría si tiene, videos y fotos y todo eso... (Empiezan a discutir si las mujeres también tienen videos y fotos pronograficas en sus celulares).

H Ustedes también tienen (risas)

M Ay... no es cierto, claro que no

$$
\text { ¿Y tú qué piensas? }
$$

M Pues que está mal, que se ven unos niños feos.

M Acuérdate también que hay niñas que también se toman fotos mal porque lo hacen con muy poca ropa.

M Yo estoy en una red del metro blog donde subes fotos y hay unas 
páginas que tienen pornografía, que suben a las muchachas casi desnudas ahí cuando no se dan cuenta y les puede ocasionar un problema, como muchas cosas que han subido de alguien... jajaja...

H Por eso existen los secuestros

M Aparte yo creo ya solas se están haciendo saber que son... muy malas.

M Yo tengo una compañera que... bueno no ahorita si no cuando estaba con ella, ella siempre decía que quería que la manosearan y eso porque sentía (...bonito... (risas))... que ella se sentía mujer y quien sabe que otras cosas...

M Yo tengo una compañera que se toma fotos, bueno ya casi no lo hace porque le dijimos que por que hacia eso, porque se tomaba fotos ella sola, pero luego se las pasaba a los niños.

H Ya las niñas bien que les gusta

M No es cierto...

¿Qué les gusta a las niñas?

H Que los niños les falten al respeto.

M Bueno a algunas niñas les gusta eso

M Como a algunas niñas que se dejan nalguear por los chiquillos.

M Las que se toman esas fotos están haciendo que ellas solas dejen que les falten al respeto...

H O desde aquí algunas personas o compañeros ya estén teniendo relaciones sexuales

M Muchos dicen que lo hacen ...

M Ah... no les creo... jajaja...

M Los niños normalmente lo hacen... siempre... o dicen que lo hacen... (risas)

\section{¿Qué piensan de que los/as jóvenes tengan relaciones sexuales? ¿Qué piensan ustedes?}

M Dicen que lo hacen, pero yo pienso que es nomas por estar jugando y que no les digan que... que... no son niños o que son niñas... pero no les creo.

H Viendo a la comunidad de Apatzingán, deberán de comprender que hay muchas personas si se atreven. 
M Pero no sabes si si es cierto o si nada más lo digan.

¿Desde qué edad ustedes consideran que empiezan a tener relaciones sexuales?

H Las niñas desde los 10 años y los niños...

M ¡Estás loco!

H Siiii

M Si las niñas lo hacen desde los 10 años entonces como los niños empiezan a los $12 \ldots$

H Acuérdate que las niñas...

M Ella pregunta que ¿a qué edad seria la indicada no?

No... que a qué edad lo hacen

M Pues la indicada no sería a los 12

H Hay niñas que desde la primaria

¿Desde qué edad consideran ustedes que empiezan a tener relaciones?

M Yo siento que desde los 15

M $12 \ldots$

H Si yo también creo que desde los 12 o 13 años

M Yo creo que desde los 15 o algo así

M Yo pienso que no hay edad... porque hay muchos que ya han violado a una niña de 3 años, 4 años.

H Eso a veces sale en los periódicos

H Yo conocí a una niña que iba en mi salón y se prostituía (risas)

¿Cómo era Cristian... como era el asunto?

H Estaba en la primaria... cuando íbamos en la primaria

M ¡No es bonito! (por que se ríen)... tal vez no lo hacía por que quería.

H Es que un día a mí me dijo que si , que si le pagaba porque ... así me dijo

¿Y qué contestaste?

H Que no y me fui corriendo (risas de todos/as)

M Vez, si los niños supieran que hizo eso le harían burla y le dirían entonces que no es niño.

M Si si es cierto, dirían que es gay o algo así

M Antier que estábamos en nuestro salón, estábamos nosotras así platicando con un maestro y entonces llegaron los chiquillos $\mathrm{y}$ 
empezaron a hablar de que yo a esa ya me la eché, que quien sabe que cosas estaban diciendo ... (Risas)

M Si eso dicen siempre

M Y nosotras estábamos diciendo... si van a hacer eso o si van a hablar de eso mejor cállense mejor cállense por que hacen que se quemen los demás... mejor guárdenlo en secreto y ya cállense la boca, pero como que les gusta mucho presumir esas cosas...

M Si como que si fuera algo muy bonito presumir eso.

\section{Ustedes desde ser niños como ven esto}

Todos/as Mal...

Ustedes desde su ser niño

H Yo no tengo esas enseñanzas ya que a mí me educaron bien, pero viendo el lado... conociendo a los niños, este... parece que les gusta decir eso... y empiezan a decir y a platicar como están casi siempre solo eso como ya dijeron mis compañeros que es prácticamente de lo único que hablan.

¿Por qué piensan que los/as jóvenes tienen relaciones sexuales a temprana edad?

\section{¿Por qué consideran ustedes que desde esta edad empiezan a}

\section{tener relaciones sexuales?}

M Porque se quieren sentir hombres

M Porque según ellos esa es una cosa que los hace hombres, aunque no sea así...

H Y también el fumar

H De hecho también la sociedad, nuestros padres, los vemos y aprendemos desde chicos...

M Con la televisión... el Internet

H Si también.

¿Qué cosas hacen las adolescentes para sentirse mujeres?

Oigan y las niñas que cosas hacen para hacerse sentir mujeres

M Tal vez lo mismo...

M Yo no...

M Yo tampoco... 
H Se pintan, se traen su ropita chiquita.

O sea no... pero está bien porque es su percepción... o sea ustedes tiene una percepción, así como ellos tiene una percepción de cómo hacen las cosas, así también ellos tienen una percepción de cómo hacen las cosas

las muchachas, está perfecto.

Tu percepción es que ellas se siente mujeres pintándose

H Arreglándose, vistiéndose como no debería de ser a su edad, estar con personas más gran-de-sss que ellas...

Y desde ustedes chicas, que consideran que las muchachas hacen para sentirse como muy mujeres, aparte de lo que dijo Fanny que lo mismo que de las relaciones sexuales...

M No sé

M No sé

\section{Tiene razón ellos, Ustedes consideran que si, que en parte ¿sí?}

M Yo pienso que no porque hay muchas muchachas que se pintan, pero no lo hacen para sentirse mujeres, lo hacen para verse bien. Y sin pintarse saben que son mujeres

H Ok... lo admito... pero admiten que hay personas que si lo hacen desde temprana edad y andan con personas mayores...

M Si... pero pues eso ya no es igual...

M A ver... Andar a que te refieres, a ser novios o a estar con el nada mas así...

H A novios, pero acuérdense que desde empezar con una relación con un adulto mayor, quieren más...

M ¿Más qué?... ¿Quieren más qué? (risas)

H A ver, les voy a poner un ejemplo... tú tienes un novio de tercero, sabiendo que ese de tercero es... es muy así, muy exagerado en las relaciones, que les gusta... y andas con el nomás porque ves que esta guapo, sabes que te va a intrigar a hacer... a tener sexo... o ya estas desde temprana edad... si se han dado casos...

M Si, por que en mi grupo hay unas niñas que tiene13 años y dice yo no sé, que tiene un novio de 27 años... y le digo... oye, si tú tienes 13 años y tienes un novio de 27 casi puede ser tu papá no tu novio... es soldado 
y ella dice que es su amor.

M También hay una niña en mi salón, que aquí en la escuela se ha creado fama de que es... todos le dicen que es puta... este porque... (Risas) ha andado con todos los de tercero y siempre la descubren los prefectos besándose con ellos atrás de los salones de segundo, porque ya han venido muchas veces a reportarla los policías cuando se suben arriba... (No se le entiende) los prefectos la regañan y le dicen, pero nunca entiende y nosotras hemos hablado con ella y le decimos que por qué hace eso, pero nos dice que nomás porque ella quiere...

¿Qué opinan de la comunidad en la que viven?

Algo dijiste Alex... Hace rato dijiste... "vivimos en Apatzingán... tienen que comprenderlo"... tu calculas o piensas que en Apatzingán, que los apatzinguenses... ¿por qué?

H Siiii... la sociedad aquí es muy traicionera, es muy...

M No está bien educada...

H Aja... exactamente

M Tienen una mala educación

H Exacto... tienen una mala educación

Sexualidad

Y con este asunto de la sexualidad...

M También están muy mal

¿Qué pasa con los Apatzinguenses?...

M Yo siento que está bien hacerlo desde temprana edad.

$\mathrm{Y}$ a veces aunque las mamas sepan o aunque les digan a veces no, no hacen caso. Y a veces no les gusta hablar sobre sexo, porque piensan que es algo malo... o les da vergüenza y piensan "mejor ya dejarlo para después", nunca hablan sobre eso.

A veces no tienen los niños una educación sobre eso, y como los abuelitos piensan que no está bien hablar de eso pues los papás también piensan eso y los niños no tienen una mejor educación sobre eso y van y se refugian con otra persona.

M Mis papas desde que yo entre a la secundaria me hablaron de todo eso, porque dijeron que hay muchos niños malditos que... te quieren 
invitar a hacer cosas malas que no debes de hacer

M Y como no sabes tú estás buscando información o saber cosas

¿Qué piensan muchachos ustedes de eso?

M Y las personas como saben que no sabes se aprovechan de eso ... se aprovechan a lo mejor

H Yo pienso que también deberían poner de su parte los papás, que nos explicaran, que hablaran con nosotros... que no anduviéramos en mal camino, no agarremos la drogadicción y el alcohol, eh que fuéramos a la escuela...

Aquí en la escuela llevan ustedes materias, en las que tratan estos temas

H Sociología, tutoría y biología...

Aja... ustedes ya están con la reforma no... seria ciencias ¿no? y biología...

M Y biología

Aja... ciencias y biología y que ven ahí... que les enseñan ahí de estos temas

M Los cambios del cuerpo humano...

M Métodos anticonceptivos

M Como prevenir enfermedades de transmisión sexual

H Todas las enfermedades de transmisión sexual... la limpieza.

¿Y creen que con lo que abordan en estas materias es suficiente para el problema que ustedes están planteando, la problemática que habría aquí en Apatzingán?...¿ ¿cómo sería, que se podría... como se podría abordar para que hubiera una educación sexual y para que hubiera realmente equidad de género?... ¿qué se les ocurre?

H Que ambos géneros hablaran sobre esto...

M Platicar, tratar de... intentar hablar y que entiendan...

H Sin irse al lado morboso

M Porque siempre que intentamos hablar en el salón... cuando la maestra está hablando... por decir el día que vimos los aparatos reproductores, cuando nos tocó de mujer, todos los niños se la pasaban riéndose de 
nosotros. (Hablan a la vez)

M Y también cuando se vio lo de la menstruación

Es decir que se hablara de manera seria... de manera...

M Si... que los niños puedan entender que es algo serio, no es de juego.

¿Y por qué consideran ustedes que los niños se burlan?

H Prácticamente porque los niños desde muy temprano empiezan a hablar de eso, y empiezan a jugar.

M ¿Y por qué piensan que es un chiste?

M No es un juego, es algo que pasa

H Ustedes hacen que seamos así.

M Cristian tal vez solo lo hacen por seguir la corriente

H Si

¿por qué crees que los niños cuando se habla en los salones de cosas de sexualidad, del aparato reproductor de las niñas, de los niños, porque los niños se burlan, porque se ríen?

H Yo no me burlo

¿Pero por qué crees que lo hacen lo que si lo hacen?

H Por aparentar

H Que saben mucho y que ya lo hicieron, como ya dijimos.

Ok, ¿qué más?

M Tal vez porque les da pena el tema y quieren evadirlo ...

Fotografía de una pareja, Noviazgo

Ok ya que estamos entrando ... muchachas muchachos a este tema, ya el tema ya lo dejamos... ya está muy muy abordado... les voy a poner una fotografía y quiero que me digan que opinan de esta fotografía, que les dice, que parece... es una foto chiquitita, échenle una miradita... a ver qué pasa ahí...

H Yo veo...

M Alguien besando a una muchacha...

M No, le está diciendo algo al oído

H No, le está diciendo algo al oído...

A ver, qué más... ¿Qué más ven?

H Una relación estable... este... como se dice...no más... 
M Un noviazgo...

¿Qué le está diciendo al oído? ¿Quién dijo que le estaba diciendo algo al oído?

M Yo...

¿Qué le está diciendo?

H Te amo (risas)

M Cosas

¿Qué se les ocurre que le está diciendo?

M Te quiero

M Te amo

M Cosas para que ella se enamore de él...

H "chiquita"

Chiquita... ¿eso por ejemplo enamoraría a las muchachas?

M No...

M No... da risa...

¿Qué hacen los muchachos para atraer a las muchachas?

H Les dan flores...

Ándale... esa es una ¿qué más?

H Chocolates

H Se perfuman... (risas)

M Y a veces que cuando pelean, el que gana, así ya todas las niñas ya quieren con él, solamente por que gana...

H Si, se pelean dos camaradas...

Es decir que... ¿Estás diciendo si te entendí bien... que pelean para eso... para atraer chicas, para ganar chicas?

M No... bueno a veces si...

H Algunas mujeres si les interesa eso

M Pero no... es tonto...

H Algunas... pero no dije todas...

M Demasiado tonto que...

Y las chicas que hacen para atraer a los chicos?

M Yo soy como soy siempre...

H Se pintan 
H Como ya dije, se arreglan

Tú eres como eres siempre... o sea...

M Estén niños o no estén niños... no hay que cambiar de forma de ser, si alguien se enamora de ti es porque te quiere como eres

M Si con tus defectos y cualidades.

Y cuales serían las motivaciones que llevan a las chicas, a los chicos a tener relaciones sexuales

H A ser hombre

M Que si sus amigos lo hacen...

M Que si los quieren... que les den una prueba de amor

M Que si sus amigos lo hacen, ellos porque no...

Sus amigos... eso es en el caso de los chicos... ¿y de las chicas?

H La curiosidad

M También la curiosidad

H La curiosidad, de saber...

A ver... en el caso de las chicas, también cuando sus amigas lo hacen, ¿también para estar igual que las amigas?...

H Pues a veces

M Yo tenía unas compañeras, que... cuando yo iba en la primaria, cuando yo siempre me juntaba con ellas y un día una amiga de nosotros, su mamá, había escuchado yo algo de que trabajaba en el prostitución, y que a ella una vez su mamá la llevo a donde trabajaba ella ... y que... la niña tuvo relaciones sexuales, e invito a que mis amigas a que fueran ahí y todas fueron... pero pues yo me aleje de ellas porque mi mamá me decía que eso no estaba bien...

Venga, venga... vamos, ya casi terminamos... venga, venga, venga...

¿Qué más?

M Yo tenía una amiga que... ella le gustaba tener relaciones

H Oye... es que yo siento que entre las mujeres para practicar besar se besan entre si...

M Ah... Quiuuu

M Nooo

M Yo no sé pero yo nunca lo he hecho... ¡Qué te pasa! 
H De que...

E De que las niñas para practicar se besan entre si... eso lo dicen... o sea lo oyen ustedes...

H $\quad$ Si

E ¿Si?... ¿también ustedes lo han oído muchachos?

H Yo no...

M Yo tampoco...

H Yo no...

Está bien, está bien... así son las experiencias... estamos contando eso...

M Yo también tenía... tenía porque ahora ya no... una compañera que le gustaba tener muchos novios y pues como a mí no me gusta eso... yo se lo dije a mi mamá, mamá yo no voy a tener mi novio a temprana edad, ahorita yo lo que pienso son en mis estudios...

H De llevada

No en andar de novia o yo que se... y pues... a mí no me gusta eso es por eso que yo me aparte, si sentí feo, porque yo la quería, pero así como es pues no...

M Mis amigas siempre dicen que sus mamás nunca las entienden, porque por decir ellas les dicen a sus mamás que les gusta un niño y el niño ya le pidió que fuera su novia... y entonces este... las mamás les dicen... No tienes permiso de tener novio...

M Si, mis amigas les dicen a sus mamás, y sus mamás no las dejan tener novio, eso las hace que ellas tengan novio a escondidas y que cuando se enteran las regañan.

M Sí, es mejor que les den permiso, para que ella, la niña... tenga la seguridad $\ldots$

M La confianza...

H Por si las ven en la calle

M La confianza de hablar de hablar con ella...

M De hablar con su mama

¿Qué dices Adrián?

H No nada... 
Qué por si los ven en la calle...

H Aja... y si no tiene permiso, pues se enojan las mamás... y ya con permiso, ya es más fácil que se vayan los dos... que se valyan, que sepan dónde están...

M Y sepan dónde están...

H Y la mamá poder conocer al novio de ella, para tener confianza

M Para saber cómo es...

M Para ir al centro y todo...

Aquí en Apatzingán se usa, eso de irse...

M $\quad$ Si $\ldots$

H Al centro...

No de irse...

M De irse de su casa... si...

H De escaparse con el novio

¿A qué edad?

M A los quince años...

M ¡A los quince años!

H Si después de la fiesta...

M Siempre es lo que dicen aquí ...

M A veces antes de la fiesta, a los catorce o trece...

H A una amiga de nosotros se fue con el novio

H De hecho una canción esta en mi música sobre eso... el Kama Sutra y esas ondas...

M La mamá de esa muchacha es un poco... así como más recatada... y como yo siempre me la paso de a allá para acá, ahora que salgo de la escuela ya yo me voy... y pues allá, yo en el rancho nunca había escuchado eso... pero yo escuche a mi abuelita que una niña como de mi edad... si porque todavía soy niña... ya se había ido con un muchacho de 18 años... y que apenas había terminado la escuela y al entrar a la facultad y le dije... Ay mamá cómo puede ser posible que la niña no piense...

H Eso es lo que hace... no pensar...

M No piensa que una familia es una responsabilidad... 
H Yo eso siento... yo jamás haría eso, porque no me gustan las responsabilidades...

M Es que no se pone a pensar las consecuencias que puede uno tener, puede tener un embarazo no deseado, que pues un embarazo también es una responsabilidad muy grande...

M Muuuuy grande...

M Mi mamá, mi mamá no estudio la preparatoria... porque donde vivía ella... ella vivía en Coalcomán... donde vivía no había preparatoria y todas las muchachas se venían a estudiar aquí, pero siempre que regresaban ya regresaban con hijos... y mi abuelita no dejo estudiar a mi mamá por eso... porque luego decía que no iba a tener... no iba a estar ella para que le diera consejos de lo que necesitaba y por eso mi mamá no estudio...

H Yo tenía una amiga que se fue de su casa a los 13 años... y como al...

H Se la robaron...

Estamos bien Max gracias...

H Y como al año le llegó la noticia que su hija se había muerto de Sida... se contagió...

M Hay pobrecita...

\section{Embarazo en adolescentes}

Ya que tocamos este tema del embarazo... sí... Perdóname Alex... primero tú y luego vemos lo del embarazo adolescente... por qué ya que salió y vamos a seguir hablando...

H Pero... dejando de hablar de experiencias de otras personas, hablemos de las nuestras...

H No...

M Pues yo nunca he tenido una experiencia de esa así que me quedo callada...

H Estuvieron platicando nada más de otras personas...

M Pues si nosotras como hemos visto...

Esto se da de todo... de lo que hayan vivido y también de lo que hayan observado... lo que conozcan, lo que sepan, todo nos enriquece mucho... 
M Yo tengo a mis tías que también son de allá de donde es mi mamá y les digo que ellas se vinieron, porque allá se da mucho eso de que, no ya se vino con el novio y pues ya... se la trae a casa de su mamá... y yo les digo... y que saben hacer... no pues de todo... y entonces tías por que no estudiaron y pues es que me vine con tu tío, pero cuando las veo a ustedes no saben cuánto me arrepiento ... En eso no pensaban ustedes antes de venirse, es lo malo, que se están arrepintiendo y pues ya es solo otro motivo, que se arrepienten...

Así es como tú piensas... En el embarazo a qué edad se empieza a dar... M $\quad$ A los 12 o 13

H A los 10, las mujeres empiezan antes... su aparato reproductor empieza desde los 10 años,

Pero a qué edad se ven los embarazos, a qué edad ustedes lo ven aquí...

M $\quad$ A los 16

H 10

Desde los $10 \ldots$

M Yo pienso que es más común a los 16

H Yo tengo una compañera que se embarazo ...( no se entiende)

M No ves a una niña caminando diariamente de 10 años embarazadas...

Aquí en la escuela han visto casos de niñas embarazadas

H у $\mathbf{M} \quad$ No yo no...

H $\quad$ Si ...

M Yo supe de una muchacha que en otra escuela estaba en la prepa y estaba embarazada y pues obviamente la iban a correr de la escuela...pero los maestros

¿Obviamente?...

M Si porque no las dejan estar embarazadas

A si, que interesante saber... no las dejan estar embarazadas...

M No permiten embarazos porque entonces están faltando al reglamento... por que están teniendo relaciones.

¿El reglamento dice que no deben tener relaciones?

M No, pero dice que no debe... 
H No se entiende

M Ni afectos amorosos

M Pero bueno, era otra escuela en la que yo iba... y este... los maestros le ayudaban para que el director no la viera porque ella quería seguir estudiando, su novio no la había dejado y sus papas la estaban apoyando, pero pues si el director la veía, no la iba a dejar seguir en la escuela... y con el uniforme y ropa que sus papás le habían comprado, no se le notaba mucho... pero cuando el director iba a su salón sus maestros la ayudaban a no pararla o así y el maestro no se dio cuenta... y ya después se tuvo que salir porque iba a tener a su bebé ... y fue una niña... y estaba bonita...

¿Cómo viven el embarazo los/as adolescentes?

Sobre qué asunto del embarazo adolescente... dicen que aquí en la escuela no han visto casos... pero en las cosas que ustedes han visto aquí en Apatzingán, de jovencitas o jovencitos... cómo... cómo viven el embarazo adolescente así chiquillas... así chiquillos como ustedes...

M Pues yo una vez salí con mi mamá al centro y estábamos viendo que al lado mío había una niña más chica que yo... y pues yo ... yo le dije a mi mamá... "la niña está embarazada”... porque yo la veía bien quien sabe cómo... y cuando uno está embarazado... pues no estaba gordita, no... estaba flaquita...

M Panzona...

M Estaba la pancita y tenía los pies hinchados... y le dije a mi mamá que si la niña estará embarazada y me dijo (no se entiende) y le dije si... porque para estar así como ancha y gorda como que no...

M Una maestra que estaba aquí estaba chaparrita y estaba gordita y estaba embarazada y no más lo que hizo fue que la panza se le hizo para adelante

Era maestra... no pero platíquenos de chiquitas...

M Yo conozco una muchacha que ella, sus papás siempre la cuidaron mucho, cuando yo estaba chiquita ella tenía como 12 años... y andaba con un tío mío... y mi tío ya estaba grande... y este sus papás la 
regañaron y también regañaron a mi tío y este... tiempo después ya ella tenía como 16 años y mi tío ya no la veía, peor ella salió embarazada de un señor mucho más grande que mi tío y este... Luego tuvo a su bebé y yo no la conozco mucho pero mucho dicen que ella su mamá no la ayuda a cuidar a la bebé y ella está en casa de su mamá y todo, pero no ayuda a cuidar a la bebé y dicen que ella llora mucho, porque el bebé no la deja dormir...

¿Cuáles son las consecuencias del embarazo en adolescentes?

Son como las consecuencias no... Aja las consecuencias... llora, porque no la deja dormir y ya no puede salir con sus amigas ni nada...

¿Cómo perciben los cambios por los que están pasando su familia?

Oigan... estos cambios que ustedes ya perciben en las niñas, en los niños, entre los cuales está la posibilidad de estar embazadas, de embarazar, etc., y todo lo demás que han visto ustedes perciben... ¿Cómo los toman en su casa... cómo lo toman papá y mamá y toda la gente que está en su casa, cómo toman esos cambios?

H Mi papá es normal. Ellos me platicaron sobre eso... yo ya tengo una educación sexual hecha, o sea me compraron una enciclopedia...

¿Cómo reaccionan su mamá/papá, maestras/os y personas que los rodean ante sus cambios?

Y de todos tus cambios se generan, tus cambios de humor... de todos los cambios que tu percibes... ¿cómo reaccionan su mamá y su papá ante sus cambios?

M Mi mamá siempre me dice que yo le cuente todo, y que si veo algún cambio en mí que yo piense que no es normal pues que les platique... y cuando le platico algo siempre me trata de explicar bien... También de lo que pasa en la escuela me dicen que les platique

H Si igual a mi...

Te dice que lo que pienses que no es normal... es para que tú te alertes ante el cambio y le platiques... o para que tú pienses para que no son normales los cambios... 
M No, para que... yo creo que para que todo le diga y tener una buena comunicación... es que siempre me dice que no la vea solo como mamá, que a veces en ocasiones hay que verla más como mi amiga...

$$
\text { A ok... }
$$

M Y que a ella no le gusta que les tenga más confianza a otras personas que a ella...

Ustedes chicos... como los toman su mamá, su papá, sus maestras, maestros...los cambios de jovencitos... o de niñitos a adolescentes...

¿Cómo toman los cambios, ...cómo reaccionan ante sus cambios?

H Mi mamá siempre me dice... hay que grande estas...

Se sorprende de que estas creciendo mucho...

M A mí me dice mi mamá que es normal todo lo que me pase, pero que le tengo que avisar de todos los cambios que me ocurran para explicarme bien porque son...

M Como mi abuelita le dijo a mi tía... y mi tía me dijo que por qué siempre a mis primas y a mí nos preguntaban... "y ya tuviste tu menstruación"... y todo el tiempo nos lo decían... y ellas nos dijeron que es porque cuando ellas estaban chiquitas, mi abuelita no les hablaba nada sobre eso y lo único que les dijo fue que en lugar de decirles que cuando tuvieran su periodo era algo normal, les dijeron que si les pasaba eso, era porque estaban embarazadas y que cuando a mi tía le paso eso, se asustó mucho y este... y luego le paso en la escuela... y ella él dijo a su maestra le dijo que le dolía el estómago, y su maestra pues sospecho eso... y le dijo que se fuera a su casa... y cuando llego a su casa se espantó mucho y en lugar de decirle a su mamá, porque pues le iba a decir que estaba embarazada, le dijo a una prima de ella, que es mi tía y pues ya ella le explico bien, más o menos...

En la escuela no le dijeron nada...

M No... yo creo que antes hasta que tenían... 15 o 10 años...

Ah... es que esto sucedió hace mucho...

M $\quad \ldots$ si

Tu tía ya es grande... 
M Si ya tiene 2 hijas...

\section{Sexualidad}

Ok... bien algo más que nos quieran compartir de cómo sus papás, mamás, ...

¿Por qué las mujeres se dejan embarazar a esa edad y los

hombres las embarazan... ustedes a que creen que se debe...

M A las hormonas... bueno dicen todos que son las hormonas, pero yo digo que tú puedes controlar eso... tu puedes controlar los cambios que te suceden... y tú puedes controlar, pues si sabes tú que es malo hacer eso, no hacerlo, para no cometer errores y luego arrepentirse de las consecuencias...

¿Cómo consideran que eso se pudiera prevenir? Si dicen que es por las hormonas y todas estas cuestiones...

H Pues si lo van a hacer que usen métodos anticonceptivos, hay tantos...

H Que los padres, la escuela, los compañeros hablaran de eso seriamente y no como un juego y lo tomaran con moderación...

\section{Fotografía 2: mujeres peleando}

\section{Violencia}

Les voy a enseñar otra foto... chicas, chicos...

М у H $\quad$ mmm...

H Ah sí, las peleas de mujeres en Internet y YouTube... si...

¿Son muy comunes...?

H Si son muy comunes...

M Si demasiado

Estas fotos... peleas de mujeres

M $\quad$ O de niños...

Uchala, pues nos costó mucho trabajo a nosotras encontrar estas...

A ver... cuéntenme,... ¿Qué ven?

M Unas chavas de preparatoria

M A veces se pelean por cosas muy tontas

H Peleas de mujeres... muy este como se dice... muy...

Tonto, exagerado... común... 
H Es muy común que las mujeres se peleen...

Está interesante eso que nos estás compartiendo Adrián...

H No pues nada más que se pelean para quedar bien con algunos hombres más grandes... de tercero, de segundo... para no más, para ser novios y todo eso no...

M $\quad 0$ a veces... si un chavo tiene 2 novias... y una de las 2 se entera... va y se agarra... el que tiene la culpa es él y no ella...

Razones por las que pelean los/as adolescentes

Aja... ¿Qué más... por qué creen que se pelean?

H Por problemas sociales... (los y las participantes están inquietos porque sonó el timbre)

H O por que las 2 quieren a uno y se están diciendo cosas con el... una le dice una cosa, otra otra... y se dan cuenta y pues se pelean por él.

H O se can gordas...

M Se dio algo en mi salón muy chistoso, estábamos en mi salón y unas amigas mías, se pelearon, así del pelo por un shampoo, porque una le dijo a la otra... huele mi shampoo... y le dice la otra, no el mío huele mejor que el tuyo y se agarraron del pelo y se hicieron decir... dime de cuál compras... no dime tu del cuál compras... así... y luego el maestro va y les dice suéltame... y no hasta que tú me sueltes y yo de ah no te voy a soltar... a yo tampoco y se agarraron media hora de las greñas... y como una está más alta que otra, la más alta la tenía en el piso... jajaja... yo tengo el video en youtube

M Hace poquito unos niños... no diré quienes...

H Los niños...

M Hace poquito unos niño se iban a pelear y con unos niños que no son de esta escuela, son otros de ... se iban a pelear por una cosa muy tonta... un niño de nuestro salón, estaba preguntando el nombre de otro niño que no va ni siquiera en esta escuela y este... pero solo lo estaba preguntando por nomas y otros niños de nuestro salón también fueron y le dijeron que este niño que pregunto su nombre se lo iba a agarrar y no sé qué ... que quien sabe que... y este otro niño vino y dijo que se lo iba a agarrar, pero como en eso paso su papá y se lo llevo, 
luego al día siguiente el otro niño ya traía como 3 manoplas y ya se iban a agarrar... y ni siquiera se conocían en persona o sea que no sabían quién eran.. y paso por un lado, pero como le hicieron nada... porque no sabían quién era...

Alex... ahora si...

H De que las peleas de niños son muy comunes ya que siempre como ya dijeron son por mujeres o para ver quién es el más fuerte...

M Por machismo...

H Aja... exactamente... este... las peleas de los niños es muy común ver sangre...

M Y moretones feos...

H Moretones... golpes... a golpes... a veces hasta agarran piedras y cadenas... (hablan todos/as a la vez)

M $\quad$ O manoplas...

\section{Como pelean las mujeres y cómo pelean los hombres}

¿Y las niñas como pelean?

M A desgreñarse...

H A cachetadas...

M Hace poquito este... en el salón unas niñas nomas porque una quien sabe cómo se la toco y la otra se la regreso y luego terminaron así...

H Y de los hombres se agarran entre varios...

Y luego pelean para ver quién es el más fuerte ¿y que más hijo?

H Y por las mujeres...

M $\quad$ o por machismo...

\section{¿Cómo es eso del machismo...?}

M Pues piensan que el que gana es más fuerte... y el que pierde le empiezan a decir que no es hombre o así

H Y que es niña...

H Joto...

H Que es medio gay...

¿Qué pasa si los/as provocan a pelear?

¿Qué pasa si los instan o los invitan a pelear, o los provocan a pelear...?

H Si no pelean les dice que son niñas, que son collones... que son gays 
M Y que son gays... y cosas así

H Maricas...

H Maricas... jajajaja...

H $\quad 0$ ya luego a la salida se agarran y así...

\section{Experiencias que han tenido para ejercer violencia.}

\section{A ustedes les ha tocado pelear...}

H Si $\quad$...

H Si...

M Yo nunca... jamás en mi vida...

M Una niña de por mi casa este... que le decía cosas a mi mamá y un día pues... yo ya no me aguante y pues... me la agarre... y gane...

¿Es importante para ti decir... “yo gané”?

M Naaa...

H Bueno si... jejejeje

M Hay una niña por mi casa que me tiene miedo

Tú dinos tú dinos si es importante cuando dices "yo gane"

M Pues se podría decir que no

Pero y por qué dices "yo gané y yo gané” ¿Qué pasa si hubieras perdido?

M Pues igual no pasa nada

M Diría perdí

Como se han sentido al ejercer la violencia

Tú ¿Cómo te sentiste cuando peleaste...?

M Me dio mucho coraje...

Después de la pelea después de haber ganado ¿Cómo te sentiste?

M Bien pero seguía diciendo cosas,

¿Cómo te sentiste después de haber peleado con ella, que sensación te

$$
\text { deja...? }
$$

M Desahogada...

A ver... desahogada ¿cómo?

H Pues que ya no sentía coraje...

M Saque el coraje que yo sentía

Ándale... sacaste el coraje... 
M Bueno por mi casa también había una niña que me tiene miedo... porque ella dijo muchas cosas feas... dijo que yo y mi prima...

¿Tú también te peleaste?

M No, yo no me pelee... porque la niña empezó a correr

¿Quién de los muchachos se peleó?... A ver, platícanos Cristian, qué paso cuento tú te peleaste?

H Ah... les platico... se puso chido...

H A, no pues no más por defender a otros amigos...

H Estábamos ahí en mi casa... y llego uno que se llama Axel, que vivía por ahí... y empezó a dar zapes y zapes a mi hermano... y yo lo estaba dejando... y ya hasta que le di un trancazo y que le saco la sangre... vámonos... que primero le di dos en la boca, luego dos en la panza y se quedó llorando... y que "vas a ver mañana te voy a pegar"... y que se va llorando...

H Yo la primera vez o la última vez que me pelee...

H Todas...

A ver, mejor cuéntanos... cómo te sentiste Cristian... después de haberte peleado... ¿Cómo te sentiste?

H Súper héroe...

H Me sentí bien, por que traía ganas de pelear...

Ganas de pelear... ¿ ¿sabes de dónde vienen esas ganas de pelear?

H No...

M Del enojo...

H La primera vez que me pelee estaba en quinto ya estaba muy grande... pero yo siempre había sido calmado...

M Ñoño

H Calmado... nunca me había peleado

¿Cuáles son las razones por las que se da una situación de agresión? ¿Qué provoco esta situación de agresión Alex?

H Era un niño del salón y empezó a decirme cosas, durante todo el año... era nuevo me había cambiado de salón para acá... este me empezó a decir cosas y un día me empezó a decir maldiciones sobre mi mamá, o 
sea me empezó a mentar la madre... y para mí eso no era común, porque casi no conocía las tradiciones entonces, fue cuando me enoje, sentí ira, adrenalina y lo empecé a golpear, lo ahorque hasta que llegó la directora... y me separó y así me empecé a llevar a trancazos con el otro día y ya a ese niño ya lo estuvieron a punto de expulsar...

M iY a ti no?

H A mí no... porque el siempre empezaba

H Y tú le seguías...

M A mí una vez que estábamos en la primaria, una niña este... cuando yo iba en tercero ella era mi mejor amiga, pero ella, me sobornaba... me decía que si no le pasaba las tareas, me iba a dejar de hablar... y pues yo sentía feo, porque ella era la única con la que me hablaba del salón y siempre le pasaba todo... y un día le platique a mi mamá y me dijo que estaba mal, y cuando yo le dije me dijo... estás pendeja... y quien sabe que... me empezó a decir un montón de cosas... y yo aguanto que me digan a mí, pero que se metan con mi familia no... me cae mal... me prende eso... y empezó a decirme... me mentó la madre... empezó a decirme que mi papá y que mis hermanos... uy pues yo me puse bien enojada y que la agarro de las greñas, y que la boto en el piso... hasta que no me pidas perdón te voy a soltar, así que empiézale... ( risas) y no quería... hasta que la jale más que me dijo... ya ya, discúlpame... y le dije, te vuelves a meter conmigo y te va a ir peor... y ya nunca más me volvió a decir nada...

H Pero las peleas no se dan con los novios... también son por defenderse...

H A veces que se quiere agarrar uno solo y se meten los amigos a defenderlo... porque se juntan en bolita para agarrar a uno... ya lo mismos del salón van y le ayudan al que está solo, para que no lo golpeen...

¿Por qué pueden ser agredidos/as o por qué los pueden agredir?

Cuando los agreden por defenderse... ¿Porque cree en los agreden o por que los agreden?

M Porque nos tienen envidia... 
H Porque se caen mal o algo...

M Eso es lo principal, porque a mí me dicen cosas, porque siempre hablan de mi papá...

\section{Amor- odio}

Oigan chicos y chicas, cambiando abruptamente de tema porque ya se nos está acabando el tiempo, les quiero preguntar...un par de cositas más... ¿Qué piensan del amor... el odio... como lo distinguirían? ¿Qué es eso del amor... y qué es eso del odio?

H Este... el amor... (Risas) es un sentimiento de felicidad, que sientes con alguien, mientras que el odio es un sentimiento de ira, con el cual puedes experimentar que no te cae bien alguien... que lo quieres sacar de tu circulo de vida...

M Este yo pienso que el amor es cuando se siente muy bien con alguien o que estas feliz con alguien y ves todas sus cualidades... y no ves sus defectos...

M Hay una frase que dice, que cuando llega el amor se sienten mariposas...

H Hablando de eso... aquí las personas solo tienen novios por tener...

M Si, simplemente... nada más... somos novios у уа...

Por decir que tiene novio...

M Si aja...

H Si nada mas

M Si...

¿Qué cosas les pasa en la adolescencia que no se expliquen?

Hay alguna cosa que como adolescente sientan o no se expliquen... Alex... hay alguna cosa que como adolescente sientan que les suceden que no se expliquen... que sientan que les pasa y que no se expliquen... que digan... ¿Por qué me pasa esto...? ¿De qué se trata... algo?

H Los diferentes tipos de sentimientos y al día siguiente piensas otra cosa... y así...

¿Qué cambias muy rápido de manera de pensar? Eso les pasa continuamente...

M La bipolarización... 
Así crees que sería... ¿cómo bipolares?... algo más que les pase... algo que no se expliquen... A ver muchachas muchachos... ya hablamos mucho de sexualidad... pero también hay otro tema que nos ocupa aquí... equidad de género...

H Equidad de género...

Que es la igualdad entre hombres y mujeres. ¿Qué es eso de la igualdad entre hombres y mujeres? 0 bien desigualdad entre hombres y mujeres... que es eso...

M Que los hombres de creen superiores que las mujeres

H Es que físicamente somos mejores...

M Claro que no... una mujer puede ser mejor que un hombre físicamente (Varias responden a la vez)

H ¿Por qué a ver?

H Físicamente somos mejores de naturaleza...

M Pero también podemos ser mejores...

H Pueden...

M Los hombre no pueden... bueno si pueden pero no quieren o no se... barrer, trapear, hacer el aseo de la casa...

H Yo si lo hago...

M Sí, pero por que la mamá los pone...

H Pero los hombres trabajamos más que las mujeres

M También las personas mayores a veces, los hombres más que nada... dicen..."hay no pongas al niño a barrer... porque es niño... como va a hacer eso... luego se hace niña"... pues si también tienen manos, también pueden... no porque sean niños...

\section{A ver este... tu Adrián... estabas diciendo algo, pero yo no te escuche porque está hablando Fanny...}

H Que trabajamos para darles a ellas de comer y todo...

M Y que... también las mujeres trabajan...

M Las mujeres también pueden trabajar...

H Pero no igual...

M Claro que si... Y hasta más que ustedes...

M Claro que si... 
H Llegan aquí y se salen de la escuela,

M Eso que tiene que ver...

H Y $\quad$ Y andan con el novio... y el novio las mantiene...

H Aja...

M Claro que no...

M Hay mujeres también que en vez de que el hombre le invite las cosas ahorran... luego ustedes... nomás se la pasan pidiendo dinero... (discuten todos/as a la vez)

Así está bien la discusión... esta excelente pero con orden

M Los siempre se la pasan diciéndole a las mujeres que les compren cosas, que les den dinero... y que les presten dinero y nunca pagan...

M Y solo los invitan al cine cuando es gratis...

H No...

H No, pero cuando son novios... el novio tiene que guardar dinero para invitarla a una nieve ¿no?

H Y la mujer pa que la inviten...

H Pero solamente en el caso del dinero... dicen. Ya todos somos iguales...

A ver muchachas, muchachos, aquí no nos vamos a convencer de nuestras posturas, son bien importantes porque son las de cada una de nosotras y de nosotros, está perfecto, acuérdense que aquí la postura de cada uno es respetable e importante... ahora quiero que me platiquen en sus casas como es... hay equidad de género... H y $\mathbf{M}$ si ...

H Me ponen a barrer...

¿Cómo se reparten las tareas y actividades en la familia?

En sus casas la mamá, el papá, los niños... todo mundo arregla la casa... Todo se reparte por igual... la mamá y el papá...

H Lo único que no hacen las mujeres es arreglar el jardín...

¿Quién hace eso?

H Yo...

H Los hombres... al hombre le toca echarle agua, recoger la basura, cortar el sácate...

A ver eso es importante, recoger la basura... 
H Recortar el pastillo que sale pues, que no es de ahí, o que se vea feo ahí, a podar todo eso...

Muchachos muchachas... ¿en sus casas sus mamás trabajan?

H $\quad \mathrm{Si} \ldots$

M No...

M Si...

M Mi mamá si...

¿En sus casas o afuera?

M En las dos...

M En las dos...

M Mi mamá trabaja en una oficina...

Tu mamá, Cristian, ¿trabaja nada más en tu casa o afuera?

H En mi casa nada más... mi papá es el que lleva el dinero...

Ok y sus papás... ¿Trabajan en su casa o afuera?

H En mi casa y afuera...

H $\quad$ Afuera y en mi casa...

M En las dos...

¿En su familia tienen los mismos derechos las mujeres y los hombres?

Ok... aja... y cómo los enseñan a ustedes, ¿Les dan los mismo derechos cuando van a salir salen a la misma hora y regresan a la misma hora los hombres que las mujeres?

H No...

M A mi hermano no le dan permiso porque es menor que yo... pero a mi si...

M Yo no tengo hermanos hombres por eso no sé...

¿A qué hora regresas tu cuando te dan permiso de salir?

M Yo cuando voy saliendo de la escuela es antes de las dos y vamos a ir a comer o a tomar algo... es antes de las dos... y si es en la tarde, mínimo a las 8 de la noche...

H Yo siempre que voy a un baile, me dejan llegar como hasta las 3 de la mañana...

A las 3 de la mañana en un baile... ¿Y a ti Adrián? 
H A las $11 \ldots$

Y si tú vas a un baile a qué hora te dejan regresar...

M Yo nunca he ido a un baile...

Н у М uuuuu...

M Yo tampoco...

H Hasta las 10 de la noche...

H A las $12 \ldots$

¿A ti cuando te dejan ir...?

M Nunca me han dejado ir, pero cuando voy a fiestas que no vaya con mi mamá a la hora que sea... si me abre la puerta... cuando voy con mis amigas...

A cuando vas con tu familia...

H Ah... si te dejan ir a una fiesta, puedes regresar a tu casa hasta la próxima semana...

M Ay no...

M Estamos hablando de horas... no de días...

¿Qué sugerencias tienen para incorporar en la asignatura estatal?

Díganos que debería llevar la asignatura de educación sexual y equidad de género... la neta la neta la neta ¿qué debería llevar esa asignatura?

H Todo lo que ...

H Todo sobre educaciones sexuales... para que se aprendan los cambios de humor, todo lo que pasa...

Cambios de humor...

H Sí, todos los cambios que hay en la adolescencia... y en equidad de género, los derechos que tiene la mujer...

H ¡Y el hombre!

H Y el hombre... como nos debemos respetar, como nos debemos llevar... debemos vivir...

H Respetar a las mujeres

Que debe respetar las mujeres a los hombres jajaja

H Que deben ver eso como un tema normal y no como un chiste...

Eso es muy importante... si si si... eso es cierto... 
M Que se debe respetar...

Que se debe tratar como algo normal, que nos pasa a hombres y mujeres... y en el asunto de la equidad hay algo qué quiera que se trabaje... en lo que sientan que hay discriminación, algo en lo que se pueda trabajar...

H $\quad$ A los derechos...

H De mujeres y hombres...

M La discriminación entre los dos... los flaquitos, los chaparritos...

M Parejo...

M N... que no haya discriminación...

H Porque en mi salón, por decir si alguien es gordito, siempre se la pasan diciéndole... "gordo"... y eso... y si alguien es chaparrito... "chaparro", "enano"... yo cuando estaba en la primaria estaba bien chaparrita... y todos me decían que era una enana y que quien sabe que...

El trabajo en Pro de la no discriminación, eso tiene que ver con la equidad de género también, porque es parte de los derechos humanos... Cuando dices esto de que no haya discriminación, es como respetar las diferencias...

M Aja...

H Este... si violan a una mujer, a los hombres lo culpan... pero si le pegamos... pero si las mujeres nos pegan también hay una ley...

Si claro...

M Nooo...

La secretaría de la mujer, no crean que nada más atiende mujeres violentadas, lastimadas, golpeadas y todo; no, también atiende a hombres... cuando tienen un problema, pero son muchos más casos de la mujer cuando van a la secretaría, pero si... para eso es secretaría de la mujer...

M Pero siempre te dicen que los hombres son más fuertes...

Pero además si los atienden corazón, a pesar de que son más fuertes...

H Pero no todos los hombres les quieren pegar a las mujeres.

M Pero aun así lo hacen...

H Y luego andan diciendo "me pegó"... 
Pero los hombres no deben golpear a las mujeres...

A ver, ahí les va... en esa hojita, pongan algo muchachas, muchachos...

H ¿Qué ponemos...?

Que por favor no nos hayan podido decir, aunque ya nos dijeron muchas cosas fue maravillosa la entrevista... pero díganos por

favor, en esa hojita... ¿Qué secundaria es?

Ahora si... muchísimas gracias por le entrevista... no se Mara si hay algo más...

Les damos la página de Internet y si durante este tiempo quieran aportarnos algo, eso sería interesante...

Ya gracias... muchachas, muchachos, me encanto trabajar con ustedes... Adiós... 


\section{GRUPO DE DISCUSIÓN No 8}

Registro de grabación. A cargo de Elva Morales.

\begin{tabular}{|c|c|c|c|c|c|c|}
\hline $\begin{array}{l}\text { Nombre de } \\
\text { la escuela }\end{array}$ & Ubicación & $\begin{array}{c}\text { Zona } \\
\text { Escolar }\end{array}$ & $\begin{array}{l}\text { Grupo de } \\
\text { discusión }\end{array}$ & Grado y Grupo & Fecha & Hora \\
\hline EST No. 33 & Playa Azul & & $\begin{array}{c}\text { Integrantes } 6 \\
3 \text { mujeres } \\
3 \text { hombres }\end{array}$ & $\begin{array}{c}\text { 1'. "A", "B”, } \\
\text { "C", }\end{array}$ & $\begin{array}{c}21-06- \\
2010\end{array}$ & $9: 15$ \\
\hline \multicolumn{3}{|c|}{ MODERADORA } & \multicolumn{4}{|c|}{ OBSERVADOR } \\
\hline \multicolumn{3}{|c|}{ Ma. De Jesús Soto Campos } & \multicolumn{4}{|c|}{ Elva Morales / Grabación } \\
\hline
\end{tabular}

El grupo se integra con alumnos/as de diferente grado y dos del mismo grado. Manifiestan no conocer con claridad el motivo de haber sido convocados. Se les informa sobre el objetivo de trabajo y se establece el encuadre de la entrevista. Llegue tarde a la sesión no tengo conocimiento de cuál fue la dinámica de selección de los/as participantes.

SIMBOLOGÍA:

$\mathrm{H}=$ Hombre

\section{DISCURSO}

$\mathrm{M}=$ Mujer

¿Cómo afecta el trabajo en sus actividades escolares?

Influye el trabajo que realizan en su aprendizaje, que realizan en sus actividades escolares, trabajan en la tarde ¿o qué días trabajan?

M Todo el sábado

H Todo el sábado y domingo

¿Entonces no les afecta?

H No

¿Qué cosas que les gustaría que cambiaran en su escuela?

OK. ¿Qué cosas les gustaría que cambiaran aquí en la escuela? ¿Hay algo que les gustaría que cambiara para que su escuela mejorará?

H Dejaran de pelearse

M Se la pasan peleando

Y ¿Cuál sería tu propuesta? 
M Que no hubiera falta de respeto

¿Qué les pasa a los que se pelean aquí en la escuela qué hacen para evitar eso?

H Los reportamos

\section{¿Y sí ven cambios o no?}

M No, siguen igual, tienen que firmar un papel y ya.

H Siguen igual, siguen en la pelea, lo hacen a la salida

$$
\text { ¿Y a ustedes qué cambios les gustaría? }
$$

M Que tomen en cuenta el trabajo que hacemos al realizar un proyecto. Si uno le echa ganas, porque unos dicen "no me copies tanto porque casi es igual” o luego dicen "te ayudaron a hacerlo ", si uno va cambiando su letra

¿Qué más hacer? ¿Qué les gustaría también que cambiara? ò ¿Cómo podría mejorar su escuela?

H Que explicaran más, porque hay algunos que casi no explican

H Si explican

M No hay algunos a los que no les entendemos (hablan todos a la vez y no se entiende)

H Lo que pasa es que algunos no entienden porque no leen y el profe a como explica, así lo escribe y como los demás no lo leen por eso no lo entienden. Y luego quieren hacer graficas y operaciones de por y si son de más y no las pasan

¿O sea que aquí hay en algunos la dificultad para leer o entender la lectura?

H Sí la verdad. Hay algunos que no quieren leer nada son bien huevones, sólo quieren estar copiando

\section{¿Qué más cambiarían? Imagínense que tiene una lámpara maravillosa, como la lámpara maravillosa de Aladino, tienen tres deseos. ¿Qué deseos pedirían para que se sintieran mejor en la escuela?}

H Que pusieran más talleres como el de computación

M Si computadoras

H La Salud para seguir estudiando 
M Que los alumnos no sean groseros

¿Cuáles son los problemas de salud que ustedes observan? Aquí en la escuela en general

H Yo casi no me enfermo

Pero aquí en la escuela en general

H Pues de fiebre, calentura, tos, gripa

\section{¿Qué hacen para cuidarse ustedes mismos?}

H No tomar cosas frías

M No comer chatarra, dulces (risas)

M Que cambien la materia de tutoría porque nada más entramos y no hablamos de nada.

M Y que nos den otra materia en la que de verdad nos pongan a hacer algo. En geografía tampoco veo nada

H Pues tu no harás nada ¡di!

¿No han visto nada en tutoría, por ejemplo sobre los derechos?

M Nada más la de biología nos lo. Sería bueno una materia que de verdad nos de...

M Que tenemos los mismos derechos entre hombre y mujer,

H Que no porque uno esté gordo nos van a discriminar o porque este flaco. Porque a una se le empezó a caer el pelo y la empezaron a discriminar y ella se ponía cosas en la cabeza (risas) y ella se sentía mal.

\section{¿Qué si hay discriminación? ¿Nada más a las mujeres ò también a los} hombres?

H Hay unos que se ponen los pantalones hasta arriba y los empiezan a discriminar y se burlan

M También a los hombres que traen los pantalones por debajo de las nalgas (risas)

M Y hay otros que se ponen los pantalones hasta abajo.

H Sí, los que se sienten "cholos”, como esté. (risas)

H No me descubras

Foto de una persona melancólica

Su forma de vestir no la respetan. Ok ¿Algo más que les gustaría que se tomara en cuenta? Les voy a mostrar una foto, imagínense en que 


\section{ven así a un varón. ¿Cómo la varían?}

\section{Todos/as Triste}

Desganada ¿Por qué creen que pudiera estar triste? ¿Qué cosas le pudieran estar pasando?

H Termino con su novio

M A lo mejor está embarazada, que le diga a su novio

H Reprobó las materias

\section{Y si estuviera embarazada ¿Qué le aconsejarían ustedes?}

M Que platicara con sus papás para que la apoyarán, que ella no sabía lo que hacia

H Que no se ponga triste, que salga adelante con su hijo, que un hijo es lo más sagrado que tiene uno en la casa

M Pues a la mejor no se lo quiere contar porque la pueden correr de su casa. Aquí dice su compañera, que si le dice a sus papás la corren de la casa. ¿Si creen que pudiera pasar eso?

M Pues no sé, porque hay papás que también les paso lo mismo y dicen "no pues lárgate ya no te queremos aquí por sucia"

H Sí, ya no las quieren porque se les quito lo virgen (risas)

¿Y qué creen que haría esta muchacha ante eso, ante esta situación?

H Abortar

M A lo mejor querer abortar a su hijo

H Irse con otro familiar que sí la apoye.

Fotografía 2: Una persona adulta y un joven

\section{A ver y esta foto, ya nada más les voy a mostrar esta y otra.}

M De que su papá le está platicando de algo serio y él con el celular (hablan varios a la vez)

H No pone atención a lo que le está diciendo. Hay, muchos que no le ponen atención a sus papás y quieren hacer lo que él quiere y no lo que los papás le dicen

M O tal vez no le gusta de lo que le está hablando el papá.

¿Y eso cree que llegue a pasar en la vida real? 
H Sí

M Sí

¿Qué cosas quiere hacer el joven y que sus papás le dicen que no?

H Como que se junta con sus amigos para hacer cosas malas, en la calle. Su papás le dicen que está mal y él no hace caso, hace lo que él quiere (risas)

M A mí me gusta juntarme así con cholos que usan aretes pero no les gusta beber

Y cuando convives con esas personas, ¿Cómo es tu convivencia con ellas?

Te obligan o no te obligan ¿Te respetan?

M Me respetan

H Hay algunos que te dicen ¿Por qué no te pones un arete? No porque no me dejan, es malo eso si necesita la sangre un familiar no la puedes dar porque esta perforado, no te dejan donar sangre, por eso no se puede

Y por qué creen que se ponen aretes y eso.

M Para impresionar y sentirse más hombres

H Sí, para impresionar

M Y para impresionar a las chicas

¿Para sentirse más cholos y más hombres? Y ¿sí se impresionan las chicas?

M A veces sí, porque se ven más guapos (risas)

H Hay que ponernos aretes ; di!

Fotografía 3: Chicos/as en biblioteca ¿Y si se impresionan? Les muestro esta última fotografía ¿En dónde están estás muchachas?

H En la biblioteca

M En la biblioteca

$$
\text { Y ¿Qué están haciendo? }
$$

H Leyendo un libro, estudiando

M Leyendo un libro, estudiando, sacando información sobre algo importante Sacando información sobre algo importante para él ¿Qué podría ser importante para él? 
H Un trabajo, tareas de su escuela

$$
\text { O ¿Qué más? }
$$

M Proyecto para... o algo que ellos quieran saber

H Sobres sus cambios

M Sobre su sexualidad

\section{¿Qué se preguntarán sobre su sexualidad?}

M ¿Qué porque se dividieron los géneros?

H ¿Por qué a las mujeres les crece las bubis y a los hombres no? (hablan varios a la vez)

¿Qué más se preguntarán, buscarán la información?

M Por qué les duelen los cambios que han tenido

M Algunos se cambian el sexo, nacen hombres y se vuelven mujeres

H ¡No! Quién iba a hacer eso

M Sí, algunos sí, pero aquí no se han visto casos

Aquí estamos hablando de lo general y lo que ustedes han visto o experimentado ¿Qué más?

H Por qué ocurren los cambios

H O ambos quieren saber lo que no han entendido algo importante

¿Qué se les dificultara entender a esta edad?

H Las violaciones (risas)

¿De las violaciones qué será?

H ¿Por qué las golpean o por qué las...?

M Porque abusan de ellas

H Abusan pero que no quieren hacerlo

¿No sé si tú quieras preguntar algo Beto? ¿Algo más que quisieran aportar para esta asignatura? ¿Manejan ustedes el internet? ¿De dónde adquieren más información aparte de los libros?

H Internet

M Del internet

Les agradezco su participación, si tienen alguna duda o sienten que hubo cosas que les dio vergüenza discutir en el grupo pueden escribirnos a este correo electrónico aestatal_eseg@ hotmail.com 


\section{GRUPO DE DISCUSIÓN No 9}

Registro de grabación. A cargo de Elva Morales.

\begin{tabular}{|c|c|c|c|c|c|c|}
\hline $\begin{array}{c}\text { Nombre de } \\
\text { la escuela }\end{array}$ & Ubicación & Zona Escolar & $\begin{array}{l}\text { Grupo de } \\
\text { discusión }\end{array}$ & Grado y Grupo & Fecha & Hora \\
\hline ESG & $\begin{array}{c}\text { San Felipe de } \\
\text { los Alzatis }\end{array}$ & & $\begin{array}{c}\text { Integrantes } 6 \\
3 \text { mujeres } \\
3 \text { hombres }\end{array}$ & $\begin{array}{c}1^{\circ} . \text { "A", "B", } \\
\text { "C" }\end{array}$ & $\begin{array}{c}16-06- \\
2010\end{array}$ & $10: 15$ \\
\hline \multicolumn{3}{|c|}{ MODERADORA } & \multicolumn{4}{|c|}{$\begin{array}{ll}\text { OBSERVADORA } & \text { / Registro }\end{array}$} \\
\hline \multicolumn{3}{|c|}{ Georgina Pérez Coeto Mateos } & \multicolumn{4}{|c|}{ Elva Morales Robles / Grabación } \\
\hline
\end{tabular}

La selección de las/os jóvenes que se eligieron para el grupo de discusión fue de la siguiente manera: Se tuvo una reunión previa con el directo para explicar de manera breve la aplicación de los instrumentos tanto cualitativos como cuantitativos. Posteriormente el director da la instrucción a un prefecto de escoger a jóvenes con disposición de participar. El prefecto llego a los salones y les pregunto quiénes eran los que participaban más en clase y los que levantaron la mano fueron los que participaron en el grupo de discusión. Se trabajó en un cubículo pequeño aislado de ruidos en el área administrativa. Se observa disposición para la entrevista y aceptación para ser grabada por parte de los y las participantes.

\section{PARTICIPANTE}

Hombre (H)

Mujer (M)

\section{Entrevistadora}

(E)

$\mathbf{E}$

$\mathbf{H}$

H

$\mathbf{H}$

$\mathbf{H}$

\section{DISCURSO}

\section{TEMA O PREGUNTA DESENCADENANTE}

¿Cómo perciben los/as adolescentes su escuela?

Erika, Alexander, Esmeralda, Edward, Elizabeth y Diego. Bien vamos a empezar la entrevista con un tema que para todos/as es muy familiar, ¿Cierto? Aquí se la pasan la mitad de su vida, aun cuando apenas están en primero ya tienen una opinión, una idea de lo que pasa aquí en su escuela. ¿Platíquenos cómo perciben su escuela, qué pasa en su escuela, qué hay? Lo que se les ocurra

Pues aquí nos divertimos más, pasamos más de la mitad de nuestras vidas, estamos como esponjas absorbiendo todo lo que los maestros nos dicen, nos relacionamos con más personas, más amigos, más gente

¿Qué más Edward, Diego? ¿Cómo perciben su escuela?

Aquí venimos a aprender

A relacionarnos con todos los demás

También a hacer más amigos 
Aprender más cosas

Y también a no estar encerrados en la casa

Ándale eso es diferente, ¿Qué piensas Edgar, Erika? Para que se animen a platicar les voy a preguntar algo que es también de la escuela pero ya más personal. ¿Por qué están aquí en la secundaria? ¿Por qué están estudiando la secundaria? porque venimos a aprender

Tú, Erika estudias la secundaria porque vienes a aprender, ajá

Porque nos gusta

\section{A ti te gusta Esmeralda}

Sí, estamos para venir a aprender

Para tener un futuro

H Para lograr una profesión

H Para tener un reconocimiento, por decir cuando estás en el cuadro de honor

\section{¿Tú estás en el cuadro de honor Edward?}

H No

H Pues casi no pero si (risas)

Pero le estas echando muchas ganas para estar

¿Casi no pero sí?, pero si qué, ¿Si le estas echando ganas para estar en la tabla de honor?

H Pues en cierta manera si

$$
\text { ¿Por qué si y por qué no? }
$$

H Porque tendría un reconocimiento por ser aplicado, pero pues a mí no me gusta porque yo veo que los que están en la tabla de honor no se divierten tanto como los otros que no son tan aplicado.

H Que no siempre, que pueden ser muy divertidos

Eso es muy importante en este grupo que todos/as demos nuestra opinión aunque no sea la misma, eso es lo más maravilloso de estas entrevistas. Así que si no estamos de acuerdo en algo a decirlo, ok.

¿Diego para que vienes a la secundaria?

H Para aprender y conocer nuevos amigos y...

H Yo pienso que principalmente es para eso, para tener una profesión y tener un diploma

¿Qué cosas les gustaría que cambiaran en su escuela y qué cosas les gustaría que siguieran igual?

En esta escuela hay cosas que a la mejor les gustaría que cambiaran y otras que continuaran igual. ¿Cuáles serían? Primero las que les gustaría que cambiara, que acabo no les vamos a prestar la grabación a los profes.

H Los salones que tuvieran un poquito más de... Luz, ventilación De luz y ventilación...

H Que los aplanaran también

M Que arreglaran las ventanas que tuviera más seguridad

H Que en cada salón hubiera una computadora para conocer más de lo que hay

H Internet más que nada 
M Que tuvieran teléfono porque a veces algunos compañeros tienen alguna emergencia y les da vergüenza o les da pena venir aquí a la dirección

Como un teléfono público aquí afuera, ya. ¿Y el internet es muy importante para ustedes como adolescentes?

H Ahí hay una gran variedad de cosas, como en caso de que nos dejen una tarea podríamos investigar ahí

¿Qué piensas Erika? Cuéntanos corazón

M Que haya nuevos talleres,

M Cocina, carpintería

$$
\text { Como por ejemplo }
$$

H y M Para ambos

Es decir que niños y niñas podrían entrar a cocina o a carpintería. Y se permitiría en la escuela que entraran niños y niñas a cursos de cocina

M Pues solo que hubiera cursos de verano o algo así, fuera de clase

O sea que si hubiera talleres dentro de las clases que ustedes escogen ¿No los dejarían entrar o cómo sería? ¿Cuál sería tu idea Elizabeth?

que hubiera como talleres optativos para que ustedes pudieran escoger ustedes como parte de su educación. ¿Y, si les permitirían en la escuela que las niñas entraran a carpintería y los niños a cocina y al revés?

H Pues sí, yo pienso que no tiene nada de malo

\section{¿Por qué Edward?}

H Porque a veces no está mi mamá y nada más nos quedamos mi hermano y yo y cocinamos y a veces se nos quema la comida. $\mathrm{O}$ también para carpintería para arreglar algo que se nos descompuso y no llevarla con un carpintero o cuando necesitemos alguna maqueta.

Ok, esas son las cosas que no hay en la escuela y qué cosas hay en la escuela que si les gusta que les parezca que está bien.

H Las canchas

Eso está bien. ¿Qué más? Con sus clases, con sus maestros/as, con sus compañeros/as

H Con la clase a mí me gustan las clases

\section{¿Qué han aprendido sobre sexualidad y equidad de género en otras asignaturas? \\ Y en su materia de ciencias qué han aprendido sobre la sexualidad y la equidad de género}

H Pues no han dicho muchas cosas, principalmente ¿Cómo se trasmiten las enfermedades

M Que debemos cuidarnos mejor

H De métodos anticonceptivos

Perdón Esmeralda que decías:

M Que debemos cuidarnos porque se nos pueden trasmitir las enfermedades

Ok, le van pensando en esta pregunta mientras, qué les enseñan en esta clase de ciencias, y ahorita regresamos.

Continuamos con la entrevista, estábamos en su materia de ciencias. 
La pregunta era se acuerdan ¿De qué se haya hablado o platicado sobre sexualidad y equidad de género?

En la materia de ciencias nos hablan sobre todo de eso, de los métodos anticonceptivos, la prevención de enfermedades como el SIDA, el papiloma humano, así como la equidad de género entre hombres y mujeres que tenían los mismos derechos

H A no ser discriminados

$$
\text { ¿Qué sería eso? ¿A qué les suena eso? }
$$

A no ser discriminados, ¿Si Erika?

A no ser discriminados por decir si tiene una enfermedad como el SIDA no discriminar a la persona que lo tiene

¿Qué más Elizabeth?

M Tener los mismos derechos para todas las cosa, por ejemplo, los talleres de cocina que sean para hombres y mujeres porque también hay muchos hombres que pueden ser chefs

Algo más de la equidad de género que hayan hablado en su materia. ¿Y sobre la prevención de enfermedades que es lo que les cuentan? Que para prevenir algunas enfermedades hay que hacerse exámenes los dos miembros de las parejas, para que cuando tengan relaciones sexuales si están contagiados no contagien a los otros.

¿De qué más exámenes se tienen que hacer las personas para la prevención de enfermedades? ¿Les han dicho en su materia de ciencias?

H Del SIDA, del cáncer...

En el caso del cáncer ¿Cómo sería?

H Del cáncer cervicouterino en el caso de las mujeres

¿Y de los hombres? ¿No se acuerdan Elizabeth en el caso de los hombres que cáncer es el que se previene más?

H у M $\quad$ El de próstata

¿Qué entienden por la palabra equidad?

Mira que muchachos y muchachas más listos. Y en el caso de la equidad que ustedes hablan sobre la igualdad de derechos, ¿Esta palabra de equidad a qué les suena?

M A que todos somos iguales

H A que todos somos equivalentes a lo mismo

A qué equivalemos a lo mismo. ¿Qué más?

H Que nadie vale más que otro, sea porque alguien tiene más dinero, sea pobre o rico, como sea valemos lo mismo.

H Que no hay distinción de clases sociales

\section{¿Estás de acuerdo Elizabeth o piensas distinto? ¿Tú Diego a qué} te suena la palabra equidad?

H No

No te suena

H Como si en una balanza pusieran a un hombre a una mujer y estuvieran los dos igual

Primera foto. Biblioteca

Mira que linda imagen. Les voy a poner una foto, espero que

Diego la alcance a ver ¿Qué ven?

H y M Cuatro niños, dos niñas y dos niños leyendo 
Dos niños y dos niñas leyendo. ¿Qué más observan en la foto?

Están en una biblioteca

¿Qué más? ¿Qué creen que estén haciendo esos chamacos/as?

H Están investigando

¿Qué les interesa conocer a los/as adolescentes sobre sexualidad y equidad de género?

Pero de qué, suponiendo que es algo sobre la materia de sexualidad y equidad de género

M De la sexualidad

M Sobre las enfermedades

H Los métodos anticonceptivos

Y suponiendo que no están investigando sobre la materia de sexualidad y género ¿Qué se les ocurre que estén investigando?

H Pues su tarea

H Algo especial para ellos mismos, como medio ambiente.

¿Medio ambiente es algo que les preocupa a ustedes los/as jóvenes?

Porque ya en otras entrevistas hemos escuchado algo sobre el medio ambiente

H Si porque en los ríos ya no son libres

M Ya no pasan como pasaban antes, ya pasan más sucios

H También la contaminación del mundo, tanto carro

M La tala de tanto árbol

¿Eso les preocupa?

Claro también los árboles. ¿En qué les afecta a ustedes como adolescentes todo esto que han dicho?

H Pues en que esto es lo que nos van a dejar, los ríos todos contaminados, los árboles talados, todo eso es lo que nos van a dejar

H Ese es el futuro para nuestros hijos

A parte de medio ambiente qué más estarían investigando estos muchachos y muchachas

M De historia

H Estaría leyendo alguna obra literaria o un cuento

¿Cómo obtienen información los/as adolescentes?

¿Qué más se les ocurre que estén investigando? ¿Por qué esta es

una manera de conseguir información? ¿No?, pero ¿Qué otras maneras de encontrar información ustedes conocen?

M El Ciber

H El internet, la tv.

M Periódico y la tv.

M Teléfono

H Teléfono, revistas, el cine

Oigan el Ciber es algo muy importante para las y los jóvenes

¿Verdad? ¿Qué opinas Edward?

H Es algo que ahorita se está haciendo necesario para todo, porque aquí en San Felipe no hay bibliotecas.

M Son dos

¿Tienen un Ciber público? 
Y que bajan del Ciber, bajan pura información de la escuela o qué más bajan

M Música

H Imágenes, información de la escuela y de trabajo

¿Cómo resuelven sus dudas los/as adolescentes

¿Con quiénes acuden a resolver las dudas sobre sexualidad? ¿O a donde acuden?

H у $\mathbf{M} \quad$ Con nuestros padres

¿Tú acudes con tus padres, Elizabeth?

M Si porque mi mamá es doctora

Ah pues es que eso es una gran ventaja, ¿Tú Edward?

H En la clínica

H Podría ser con los maestros

M Con nuestros padres

M Yo con mi mamá

¿A dónde acudes Esmeralda?

¿Qué dudas tienen sobre la sexualidad y qué cambios han notado? ¿Cuáles son esas dudas que de repente les asaltan a ustedes los adolescentes sobre sus cambios? A ver cuéntenos, no vamos a decir nada, somos todas amigas y amigos, qué cambios

M Como la menstruación

M Lo de la voz

¿Cómo es eso de lo de la voz?

M Se va haciendo más gruesa

Cambios que los/as adolescentes han observado en su adolescencia Ustedes han notado eso, ¿Diego? ¿Cuáles son los cambios que has notado?

H Que ya soy adolescente

H Comienza la sudoración del cuerpo, sale vello axilar y púbico. En el caso de las mujeres es la menstruación el aumento de los senos

M Ensanchamiento de caderas

H Cambios de la voz

Claro, ¿Qué más cambios observan?

H La atracción por el sexo opuesto

Ese un cambio que todos/as hemos notado ¿Diego has notado este cambio en ti? Platícanos, cuando eras chiquito ya sentías esta atracción por las niñitas

H En la primaria también

Desde que edad Diego empezaste a sentir este cambio

H Desde que iba en sexto

Y ustedes cuando empezaron a sentir este cambio de la atracción por

H у M Desde sexto otra persona

Entonces, ustedes el cambio desde la perspectiva de la atracción lo sintieron desde la primaria

H El cambio seria cuando estamos cambiando de niño a joven

H De la infancia a la adolescencia

¿Cómo atraen los/as adolescentes a las personas que les gustan? 
Y cómo fue, cómo es que atraen las chicas a los chicos, los chicos a las chicas o yo no sé qué tal si una chica atrae a otra chica, cada quien sus preferencias eso es algo que no nos importa aquí.

H La química, la comunicación

H Por la belleza

H Por la apariencia física

M Por los sentimientos

H Por la higiene, pues por si llega bien bañado, perfumado, les gusta a las niñas

H Quien sabe

$$
\text { Y si andas sucio ¿No? (bromea) }
$$

Como tú siempre andas bañaditos no me sabes decir ¿Verdad? Risas ¿Edward, qué opinas?

H De la mejor manera, acercándote más a las personas

H Haciendo pequeños obsequios, regalándole rosas, chocolates

M Platicando ¿Y ustedes chicas cómo atraen?

¿De qué vas a platicar con alguien que te gusta?

H De Cómo se la pasa, qué hace

H Qué le gusta

M Qué hace en sus tiempos libres

Ó sea que la plática es lo que le interesa a la otra persona

H También apoyar a la persona pues.

¿Cuáles son los parámetros de belleza para los/as adolescentes?

Hace ratito dijeron que una de las maneras de atraer a una persona que les gusta era por medio de la belleza y es muy interesante porque aquí tenemos una preguntan que es fundamental, ¿Para ustedes que significa? ¿Cuáles son los parámetros de belleza? ¿Qué es eso de ser bello o bella?

$\mathbf{M}$

M

$\mathbf{H}$

$\mathbf{H}$

H

M

$\mathbf{H}$

M

Tener buenos sentimiento

Que no solamente sea bello por fuera sino también por dentro

Que tenga pensamientos buenos

¿A eso se refieren cuando hablan de belleza? que sea bello o que sea bella

Que sea buena persona más que nada

Y si habláramos de lo físico, ¿Cómo sería el estereotipo de belleza?

¿Cuál sería el parámetro de bello o bella?

Pues bonita cara, bonito cuerpo

En los ojos claros

La sonrisa

El cabello

¿Cómo tendría que ser el cabello para que fuera una chica bella o un chico bello?

Largo y lacio

Para ti esmeralda

A mí también me gusta lacio

A mi ondulado

¿A ustedes muchachos cómo les gusta el cabello de las muchachas?

A mi largo 
H A mí como el de ella (risas)

Alguien más que nos quiera compartir algo sobre los parámetros de la belleza tanto de los hombres como de las mujeres. ¿Algo más?

Ustedes creen que es bueno o que es malo que existan esos parámetros de belleza, o ¿Cómo sería un cuerpo bonito?

H Tener una alimentación sana, podría tener un cuerpo bien, hacer ejercicio

Pero cómo es un cuerpo bonito, o describe un cuerpo bonito.

H Alta, con cabello chino, con ojos de color o cafés, una sonrisa bonita, nada más

Ustedes chicas, cómo sería un cuerpo bonito o un chico guapo

Con músculos, ojos azules (risas)

M El color de la piel, güeros

Y cómo creen que se sientan las personas que no cumplen con ese patrón de belleza, sus amigos o ustedes mismos al no cumplir con los estereotipos de belleza que mencionaron.

H No se sentirían identificados con los demás porque es como un tipo de identificación entre un grupo de amigos o de personas

$\mathrm{Su}$ físico es una forma de identificación de hacer un grupo.

Ustedes ¿Cómo se sienten chicas en el caso de no cumplir con ese patrón?

H Sería como cuestión de mejorarlo con ejercicio o buena alimentación

M Hacer cambios con nosotros mismos

Tú ¿Cómo te sientes Elizabeth? ¿Tú crees que cumples con ese patrón de belleza?

M No sé, no me había puesto a pensar en eso.

Muchachas/os estábamos hablando hace rato de que hacíamos para atraer a las personas que nos gustan y de pronto cuando hacemos cosas para atraer a alguien nos gustan y a veces al atraerlas terminamos teniendo relaciones de noviazgo o andamos con un muchacho, una muchacha y de pronto se llega a las relaciones sexuales. ¿Qué creen que lleve a las chicas, a los chicos a tener relaciones sexuales?

H Pues una atracción entre ellos, sus sentimientos que se quieren

H La excitación

H Los vínculos afectivos, el erotismo

H Pues lo que le decía no, la excitación

¿Qué sería el erotismo?

Chicas ustedes que piensan ¿Qué lleva a las chicas a tener relaciones sexuales? De lo que hayan visto

M El quererse

M El que se quiera la pareja

H El querer tener un hijo

H Pero para eso ya tendrían que estar casados, si quieren tener un hijo

H No siempre es así, porque a veces lo quieren tener si estar casados o sin casarse

¿Qué piensan del embarazo adolescente? Qué piensan de esta parte que dice Edward que a veces se embarazan las chicas y los chicos sin 
estar casados a veces bien jovencitos/as como ustedes. ¿Han visto casos? ¿conocen casos de embarazo adolescente? ¿Tú conoces diego algún caso?

H Yo pienso que está mal porque primero deben de terminar con sus estudios, y cuando las regañan a las personas así, en la telenovelas o pasan esos casos ellos dicen que se dejaron llevar por la excitación y la pasión y pues no lo pensaron y por eso está mal.

H Yo pienso que no está bien casi, porque primero se tiene que disfrutar una vida y luego ya después será otra cosa

Chicas ustedes que piensan del asunto, nada más están comentando los chicos, apoyen a sus compañeros ¿Qué piensan del embarazo en adolescentes?

M Que si está mal porque es como desaprovechar una parte de tu vida sabiendo que puedes tener un futuro exitoso y lo desaprovechas por quedar embarazada

M Yo digo que es una edad muy temprana

¿Qué pasa con una chica que está embarazada así a los 12 años?

M Piensa en el aborto

M Porque está muy chica

H Quiere continuar con sus estudios

H Podría ser rechazada por la sociedad

M O por sus papás

¿Aquí en San Felipe ustedes han visto casos de embarazos en jovencitas? ¿No? ¿Ni en su secundaria?

H Estoy recordando, era de aquí de la escuela y pues ella ya no estudio y este ya siempre está en su casa y ella antes siempre salía y pues ya no puede salir

H Ósea en ese momento pierden todo tipo de oportunidades en el estudio y de superación, también en el trabajo porque con un hijo es casi imposible estar trabajando y cuidando a los niños, es una responsabilidad muy grande

Y con relación a una niña de 12 años que piensa en abortar ¿Cómo ven ustedes esa decisión?

M Pues es peligro porque puede llegar a perder la vida

H Pero el niño también es una vida perdida que siente también.

Fotografía 2: Pareja, Noviazgo en adolescentes

Bien, les voy a mostrar otra foto. ¿Qué ven?

H Una muchacha

H Una pareja

H Que se están dando un beso

$$
\text { ¿Qué más, Diego? }
$$

Los conocemos... Risas ¿Qué más?

H Que se quieren o que nada más las ocupa para un rato como un juego (risas) 
$\mathbf{H}$

H Que se quieren mucho (risas)

H Que es el amor de su vida

H O que nada más la está usando

¿Cómo les gustaría que fuera una relación de noviazgo?

Si tuvieran novio/a ¿cómo les gustaría que fuera su relación?

H Que fuera duradera y amistosa

M Sincera, que no hubiera mentiras

H Que confiaran en ellos mismos, que tuvieran confianza porque para eso es una pareja ¿no?

M Que confiaran

¿Qué más que les gustaría? ¿Erika?

M Que platicaran lo que sienten el uno por el otro

H Sincera que se dijeran todo

¿Quién tiene la iniciativa para iniciar un noviazgo?

¿Cuándo quieren tener novio/ quien dice la primera palabra? ¿Quién dice quieres ser mi novia o novio? O ¿cómo es?

H Pues te acercas y les dice que si quieren ser su novio

Y las chicas qué hacen ¿Qué hacen, Erika?

M No sé

No sabes porque nunca has tenido novio, si has tenido. Tú qué hiciste cuando te dijeron que si querías ser su novia

M Algunas dicen que lo van a pensar

M Bueno yo le dije que sí, pero ya luego le dije que no, duramos muy poquito

M Porque ya no me gusto

¿Qué paso para que terminaran?

¿Alexander tú has tenido novia? ¿Cómo te declaraste?

H Yo nada más le regale una caja de chocolates, y luego ya le dije y me dijo que lo iba a pensar y luego ya me dijo que si, fue muy corto el tiempo

¿Cuánto fue ese tiempo en el que lo pensó y te dijo que si?

H Fue como en dos semana

¿Quién más ha tenido novio/a que nos cuenten? ¿Cómo se sienten los chicos al tener que decir si quieren ser mi novia? ¿Se sienten bien, se sienten mal, con responsabilidad?

H Con nervios y emoción también (risas)

M También nervias

¿Y las chicas cómo se sienten? ¿Erika?

H Emoción

M Nervios

¿Cómo reacciona su familia ante los cambios que presentan en la adolescencia?

Bien. Todos estos cambios que nos están contando que sienten

Elva Morales Robles -665- Universidad de Salamanca 


\section{desde sexo de primaria y que siguen teniendo y los van a ir teniendo ¿Cómo los toman en su casa? ¿Cómo lo ven su papá y su mamá?}

H En mí caso mi familia no comprenden muy bien pero si por la edad al menos me dicen que no que primero tengo que estudiar y luego tener un tiempo de vida y ya después tener esposa

¿Cómo perciben ellos/as las actitudes de su mamá/papá ante los cambios propios de la adolescencia?

Y ¿Cómo ven a sus papás con el cambio de cuando eran de niños a ahora que ya son adolescentes, se ponen felices o se ponen nerviosos o se jalan los cabellos, o se ponen muy tranquilos. ¿Cómo ven a su mamá o a su papá?

H En algunos casos yo he visto que ni lo han notado, que ya se manifiestan de otra forma, que ya piensan de otra forma y ellos los siguen tratando igual

Han notado esto en alguna familia que no se dan cuenta de los cambios ¿Tú qué piensas Elizabeth? en tu casa si se están dando cuenta ¿quién se da cuenta?

M Mi abuelita me dice que, que grande estoy

M A mí también me dicen eso, que ya estoy creciendo

Y de sus cambios emocionales, cambios de humor ¿Qué pasa en sus casas con esos cambios?

H Pues que uno necesita más privacidad que antes

Ándale eso es importante ¿te la dan en tu casa?

H Te dan un cuarto aparte de los demás

H Que debes de tener tus cosas particulares, porque como hace rato comentaban que aumenta la sudoración y la maestra de ciencias nos platicaba que si usábamos el mismo desodorante que los hermanos si ya están más grandes pues te contagian el nivel de sudoración y el mal olor o que si agarramos el de nuestros hermanos más pequeños nosotros se los contagiamos a ellos y que el cepillo de dientes debe de tener cada quien el suyo, que todas las cosas deben ser personal

Fotografía tres: Dos jóvenes pensativos. De qué hablan los/as adolescentes cuando se reúnen

Les voy a poner otra foto ¿A ver qué les dice? ¿Qué hay en esa foto?

M El chavo está como aburrido o pensando

Dos jóvenes como aburridos o pensando. ¿De qué platicamos los chicos cuando nos juntamos, de qué platicamos las chicas cuando nos juntamos?

M De ropa, de chicos, de zapatos

De ropa, de chicos, de zapatos ¿Entre chicas?

H Entre hombres de futbol, de deporte

Digan todo no importa que las chicas se den cuenta de que platican los chicos.

H De música 
H Las chicas platican de las telenovelas

Eso perciben ustedes, que las chicas platican de telenovelas, ¿Si? Y ustedes que opinan ¿cuándo se juntan hablan de telenovelas?

A veces si, a veces no

¿Y ustedes de que perciben de qué hablan los chicos cuando se juntan? Porque también tenemos una percepción de lo que hablan ellos cuando se juntan

M De deportes o de alguna persona

M Pues de chicas

$$
\text { ¿De qué persona? }
$$

¿De qué más cosas creemos que los chicos hablan? aparte de deportes o chicas. Ellos creen que nos juntamos y hablamos de telenovelas de qué más hablamos nosotras muchacho

H De sus novios

H De cuales películas vieron

H De sus viajes y sus aventuras

M O también de sus chismes

Fotografía 4: Chicas peleando. Violencia en la adolescencia. Les voy a enseñar otra foto ¿Qué les dice esta foto?

H Se están peleando mujeres

M Que de seguro se están peleando por un chavo

H O que se caen mal

H Que les están echando porras

¿Qué más ven en la foto?

¿Qué piensan de eso? ¿Qué pasa con eso?

M Pues que está mal porque en vez de estar echando porras las deberían de separar

H Porque no está bien la violencia, la puede matar ¿A qué atribuyen la violencia?

H A más violencia, porque por decir que hoy me golpeas y ya mañana yo voy a ver la manera de regresártela

¿Alguno de ustedes ha vivido alguna situación de violencia de que se hayan peleado o así? A ver Alexander cuéntanos

H En la primaria si yo una vez me pelee, por lo regular me decían cosas ¿Cómo participaste en ese pleito? ¿Tú estabas en la bronca? O ¿Qué?

H Yo trataba de evadir al otro para que no hubiera ningún problema

¿Y los hombres y las mujeres nos peleamos igual? ¿En qué consiste la diferencia?

H Ellas pelean con las manos abiertas, a rasguñar, a agarrarse del pelo, o a veces también con los puños

$$
\text { ¿Y los chicos? }
$$

H A tirarse al piso, aunque sea gay (risas)

¿Qué motiva a los y las jóvenes a ser violentos?

La motivación para pelear es la misma de los hombres que las mujeres. ¿Pelean las chicas por las mismas razones que los chicos? O

¿Cuáles son las diferencias? ¿Por qué se pelean los chicos? 
H Porque se dicen de palabras, porque les buscan pleitos, por una mujer también

H O por apodos

H Por un hombre

M Por insultos

¿Y las chicas porque pelean?

Y ustedes chicas ¿Qué opinan?

Pues porque yo le digo algo y ella me contesta y nos empezamos a pelear (risas)

H A ver quién puede más que la otra (risas)

$¿$ Creen que se ejerza el poder al momento de agredir?

$¿$ Creen que a la hora de pelear haya ejercicio de poder? ¿Creen que se trate de poder a la hora de pelear?

H Quizás si porque si es un grupo de personas serían como los animalitos, porque tratan de ganar un lugar más alto en ese grupo ¿Quiénes ejercen más el poder?

Es como tener un lugar socialmente en su grupo. Hay entonces algo de poder en eso de la agresión y la violencia. ¿Quiénes creen que ejercen más poder las mujeres o los hombres?

H Los hombres ¿Por qué creen que los hombres ejercen más violencia, Diego?

H Porque como en el caso de los animales dicen que el león es el rey, es animal más sobresaliente de todos los demás, el más fuerte, el más agresivo

H Ellos pelean por ser el león alfa

Y las personas, los humanos ¿Por qué los hombres ejercen más el poder?

H Porque tienen más fuerza

¿Tú qué piensas, Diego?

H Porque dan con los puños cerrados y así ya no le buscan más porque saben que sabe pelear

H O para que le tengan miedo

\section{Ventajas de ser hombre/mujer}

Les voy a poner otra foto y va a ser la última. Antes de pasar ¿Ustedes lo ven como una ventaja él que sea el hombre el que tenga más poder?

H Pues eso es como quien quebró el plato, porque hombres y mujeres tienen los mismos derechos y las mujeres pueden hacer casi lo mismo que los hombres

$$
\text { ¿Casi lo mismo? }
$$

H Nada más que los hombres desarrollan más los músculos y pues los puños

H A pesar de todo los hombres tienen más fuerza

¿Hay alguna ventaja en ser mujeres? En algún aspecto de la vida

M En que son más ordenadas

H En que da vida a otra vida 
¿Hay otra ventaja en ser hombres?

H Pues que pueden hacer trabajos más duros como en el campo, que las mujeres no podrían hacer

Fotografía 5: Pareja. Embarazo en adolescentes

Vean esta foto chicas/as ¿Qué ven en esta foto?

H Ya quedó embarazada la muchacha

Si sentiste que quedó embarazada la muchacha

H Si por la prueba de embarazo

¿Qué paso con eso muchachos/as?

H Están desilusionados

M No lo esperaban

H O también no se cuidaron

H Él se fue llorando

¿Qué más?

H Ahora perderían sus estudios porque tienen que trabajar para poder mantener a su hijo o para formar una familia

H Ya se ven como personas adultas

Si se ven como un poquito más grandecitos que ustedes. ¿Y qué pasa con eso?

M Que se tienen que casar

H No es su obligación pero pues para darle mejor vida al niño si se tendrían que casar

Observan desigualdad en las parejas ¿Hay alguna cosa que vean igual o desigual en esta pareja?

H Que los dos están embarazados no nada más uno, los dos tienen la responsabilidades

H Un hombre también implica responsabilidades de amor para el niño

H Que los dos van aprender lo mismo por el niño

E Describan una situación en la que observen equidad y otra en la que no haya equidad.

Ustedes me describen una situación donde hay mucha equidad, pero descríbanme una situación donde no haya mucha equidad entre hombres y mujeres

H Donde el hombre golpea... hay casos donde en las familias el hombre golpea a su esposa

¿Aquí no habría equidad?

H Pues no porque sería como el gobernante

¿Qué piensan chicas? Algún caso de inequidad que conozcan ¿A ustedes, las dejan hacer lo mismo que a los hombres en su casa?

H No, porque un hombre cuando toma alcohol no se ve tan mal como una mujer porque el ser humano ya está acostumbrado a que las mujeres no deben de hacer eso. O sea póngale que ellas dicen que si se controlan pero pues si se ven mal con una cuba en la mano o una cerveza. 
H Por decir en el caso del quehacer de la casa hay veces que el padre no dejan a los hijos que le ayuden a su madre, por el machismo, no permiten nada porque dicen "no que te pasa esto o que te pasa lo otro"

H iO que laves los trates!, que están acostumbrados a que lo hagan las mujeres

¿Qué tareas o actividades son diferentes para mujeres y hombres en sus hogares?

Así es la costumbre, ¿Chicas quieren opinar algo, Erika? ¿Tienen hermanos hombres? ¿Las dejan hacer las mismas cosas? Salir a los mismos lugares... ¿los dejan ir a las mismas fiestas?

Pues nos dejan ir a los dos a la fiesta

$$
\text { ¿Y, los dejan salir y llegar a la misma hora? ¿Elizabeth? }
$$

No a mí me ponen hora y a mi hermano lo dejan llegar a la hora que él quiera porque ya es mayor de edad

Ah o sea que tiene que ver con una cuestión de edad

H Pero igual es más peligroso, porque entre más tarde llegue la niña ahí en la calle nunca falta que pueda pasar podrían abusar de ella o

¿Y si lo niños llegan tarde no les pasa nada?

H Pues si también

H Podrían agredirle, pero hay más riesgo en las mujeres

H Pero hay más riesgo por si hay un loco o un violador

¿Qué cosas nos gustaría hacer y no nos dejan hacer por el hecho de ser mujeres u hombres?

Ahora que vemos que hay un poco de diferencias en el trato entre hombres y mujeres ¿Qué cosas nos gustaría hacer en caso de las niñas que no nos dejan hacer o que tienen prohibido? ¿Y en el caso de los niños que cosas te gustaría hacer que tienen prohibido?

H Pues ayudarle a hacer el quehacer de la casa mi mamá

$$
\text { ¿Te gustaría hacer y no te dejan hacer? }
$$

H Si, si me dejan pero si hay amigos que son machistas, si te ven te empiezan a decir "tú que no sé qué" y te empiezan a discriminar Se burlan si te ven a ti haciendo el quehacer en la casa. Ok $¿$ Ustedes, que les gustaría?

M Llegar tarde del baile

M A mí también m gustaría poder llegar tarde

M También a mí

¿Qué más muchachas?

M Que me dejen tener novio

M Tampoco me dejan tener novio

M A mí tampoco me dejan

Y, a ustedes muchachos ¿Piden permiso de tener novia?

H Contestan todos que si pero no sé con la cabeza 


\section{¿Qué diferencias hay entre el amor y el odio? \\ Qué interesante. Una pregunta de los ochenta y cinco mil novecientos cincuenta millones $¿$ Cuál es la diferencia entre el amor y el odio?}

M Que a veces pueden llegar a ser lo mismo, por ejemplo que te diga que él me gustas y al ratito le digo te odio

H Ese es el amor y el odio

H Dicen que entre el amor y el odio hay un solo paso

¿Cómo ven esa frase? De que entre el amor y el odio hay un paso

H En casarse

H Como dicen que los que se pelean se casan

$$
\text { ¿Qué más? }
$$

H El amor es como el afecto hacia varia personas o hacia una y el odio es separación de las personas

Que es amor ¿Qué es odio? ¿Esmeralda?

M El amor es algo bonito que hay entre dos personas y el odio es un resentimiento por ella

$$
\text { ¿Amor y Odio? }
$$

H El amor es sinónimo de querer a alguien o de amarlo, es alguien que te apoya en todo, que te quiere

Siguiendo con eso del amor y del odio ¿Hay alguna relación en su vida que tenga este componente de amor y odio?

H Es una mezcla, para que sea una nivelación de lo bueno y lo malo

\section{Describan a una persona que admiren} ¿Quiere alguno/a de ustedes describan a una persona que admiren?

M Mi hermano porque es un buen padre de familia, trabaja tiene sus estudios tuvo buenas calificaciones y es una persona buena

H Yo a mi bisabuelito el ya no vive pero en un tiempo el solo fue tres meses a la escuela y a prendió a leer a escribir y sabía mucho él y todo eso se lo trasmitió a mi abuelita y hasta a mí me está alcanzando

Regresando a lo del amor y el odio muchachos/as ¿Hay alguna relación que se base en el amor o el odio?

H Su apariencia física su forma de ser

$$
\text { ¿Y qué edad tiene esta persona? }
$$

H La misma que yo

$$
\text { Por cierto no nos dijeron su edad }
$$

Todos 13

Puras coincidencias aquí. Así que esta persona tiene la misma edad que tú y existe amor y odio y hace cuanto tienes sintiendo por esa persona

H Pues desde que entre aquí.

Sugerencias para incorporar en la asignatura educación sexual y equidad de género 
H

Hay algo muchachas/as que quisieran compartirnos que sea importante y nos sirva para esta asignatura de educación sexual y equidad de género. ¿Qué ustedes consideren importante que deba de ir en esta asignatura? ¿Qué ustedes digan cuando los de primero lleven esta asignatura que vean esto, que sepan esto y qué abordan este? ¿Qué cosas?

Por mi parte seria la prevención de enfermedades de transmisión sexual y la prevención de embarazos

Como adolescentes qué les interesa saber sobre sus cambios ¿Qué más? ¿Cómo adolescentes muchachos/as qué quisieran saber sobre sus cambios que a veces no se explican ustedes mismos/as, qué

cosas quisieran que les explicaran? Piensen porque este es el momento de que sus pensamientos pueden estar en la asignatura Como cuidarte en el caso de estar embarazada, y también cuando tengas a tu hijo cómo saberlo cuidar

En el caso de que sea una madre jovencita como ustedes

Darles palabra de inspiración a las personas embarazadas, decirle si ella tiene la idea de abortar decirle lo contrario, es algo que le da dios, algo que él quiere que tenga la persona.

\section{¿Qué quieres que tenga esta asignatura?}

\section{Reconocer su cuerpo}

Que haya una explicación más amplia de esos temas

¿Que nos digan por qué suceden las cosas?

Y pues algo más avanzados de los métodos anticonceptivos, porque no nos dicen los métodos más avanzados de nuestra época pues

¿Qué sucede cuando un adolescente que está en la escuela tiene que trabajar?

Ustedes conocen a alguien, algún chico/a que trabaje, ¿Si? ¿Y qué pasa con ellos/as y la escuela?

A veces descuidan sus estudios

Pero a veces no, es al contrario porque ellos experimentan lo que es ganarse el dinero y saben que es muy trabajoso y al contrario le echan más ganas

Pero hay que reconocer que hay personas que no tienen los recursos para estudiar y necesitan trabajar los niños y pueden descuidar los estudios porque no pueden trabajar y hacer la tarea al mismo tiempo, que si les dejaran un trabajo grande no lo pueden hacer porque tienen que presentarse al trabajo

¿Quién realiza el cuidado de los otros?

Una última pregunta chicos/as ya para terminar. ¿Ustedes cuidan a alguien en su vida? ¿Cuidan a una persona de su familia? ¿A quién cuidan?

Si a mi primo

¿Qué edad tiene tu primo? ¿Lo cuidas todas las tardes?

Tiene dos años, y lo cuido todas las tardes

Yo a mi hermano, también todas las tardes 
¿Y, cuántos años tiene?

M Tres años

$$
\text { Y ¿Por qué razón los cuidan? }
$$

M Porque a veces mi mamá tiene cosas que hacer

M Porque mis tíos salen a trabajar

¿Y te pagan o lo haces así en buena onda?

M Así como ayuda

¿Qué sienten al cuidar de los otros? ¿Y qué se siente cuidar a otros? ¿Tener la responsabilidad de cuidar a otros?

M Se siente bien, y también si tu apoyas a ellos, ellos te apoyan a ti

H También sería como tipo preparación para cuando tengas tus hijos

¿Y ustedes no cuidan a nadie?

H Si a un primito chiquito

También a un primito chiquito, y cuanto tiempo lo cuidas

H Como dos horas mientras mi mamá levanta toda la casa

H Un año y medio

¿Y sientes que es una preparación para cuando tengas tus hijos?

M Si porque por un lado vas aprendiendo a como calmarlos o cuando lloran por berrinche o porque se pegaron

H Mi tía me enseñó a cambiarle los pañales, a darle de comer

¿Cómo te sientes como hombre haciendo esto Alexander?

H Pues bien porque es como una preparación para cuando tenga mis hijos

¿Y tú cómo te sientes Elizabeth haciendo esto?

M Pues bien porque es como si me estuvieran enseñando a cómo tratar a los niños

Por mi parte seria todo, agradecemos su participación. Dejamos la página por si quieren hablar o preguntar sobre algún tema que no hayan querido abordar por alguna razón en particular. 


\title{
GRUPO DE DISCUSIÓN N 10
}

\author{
Registro relatoría. A cargo de Elva Morales
}

\begin{tabular}{|c|c|c|c|c|c|c|c|c|}
\hline $\begin{array}{c}\text { Nombre } \\
\text { de la } \\
\text { escuela }\end{array}$ & Ubicación & $\begin{array}{c}\text { Zona } \\
\text { Escolar }\end{array}$ & $\begin{array}{l}\text { Grupo de } \\
\text { discusión }\end{array}$ & $\begin{array}{c}\text { Grado } \\
\mathbf{y} \\
\text { Grupo } \\
\end{array}$ & Moderadora & Observadora & Fecha & Hora \\
\hline $\begin{array}{c}\text { EST } \\
\text { CECADEJ } \\
\text { Internado } \\
\text { mixto }\end{array}$ & $\begin{array}{l}\text { San } \\
\text { Antonio } \\
\text { Corrales }\end{array}$ & & $\begin{array}{c}\text { Integrantes: } \\
6 \\
3 \text { hombres } \\
\text { y } 3 \text { mujeres }\end{array}$ & $1^{\mathrm{o}}: \mathrm{A}$. & $\begin{array}{l}\text { Ma. De Jesús } \\
\text { Soto y } \\
\text { Georgina } \\
\text { Pérez Coeto } \\
\text { Mateos }\end{array}$ & $\begin{array}{l}\text { Elva Morales } \\
\text { Robles }\end{array}$ & $\begin{array}{c}21-06- \\
10\end{array}$ & $12: 30$ \\
\hline \multicolumn{9}{|c|}{ Contexto situacional } \\
\hline \multicolumn{9}{|c|}{$\begin{array}{l}\text { La selección de las/os jóvenes que eligieron para el grupo de discusión fue de la siguiente manera: el directo } \\
\text { eligió al azar a tres niños y tres niñas, sin comentar la razón para la que fueron seleccionados. El aula donde se } \\
\text { trabajó con el grupo de discusión era un salón que parecía estar en desuso. Los/as jóvenes se sintieron nerviosos } \\
\text { en un primer momento por la grabación, sin embargo aceptaron que se realizara utilizando nombres falsos y en } \\
\text { el entendido de que sería confidencial. El trabajo transcurrió de manera positiva, sin embargo la moderadora } \\
\text { tuvo que realizar varias veces intervención para que la discusión fuera respetuosa, ya que las y los alumnos } \\
\text { hablaban a la vez y no se lograba rescatar todo la información que proporcionaban. El cierre da la sesión se } \\
\text { realizó agradeciendo la participación por el trabajo. }\end{array}$} \\
\hline
\end{tabular}

SIMBOLOGÍA:

$\mathrm{H}=$ Hombre

$\underline{\text { DISCURSO }}$

$\mathrm{M}=$ Mujer

\section{TEMA O PREGUNTA DESENCADENANTE}

\section{Cómo han sido sus experiencias esté año}

M Si me ha gustado pero a la vez es aburrido. Porque todo el día encerrados eso es lo que no me gusta de aquí

Casi por los maestros más o menos, nada más que la maestra de español nos pone a escribir con cheque (risas)

H La maestra de español escribe mucho y nosotros nos preguntamos si no le duele la mano (risas)

M Es que empieza a escribir bien arto y cuando termina lo borra y a veces no alcanzamos a copiar lo que apunta

H A mí me va a dar cáncer de mano (bromea y hay risas en el grupo) 
H Para mí es más fácil estudiar aquí que en otras secundarias, porque nos dan comida y todo

M Es más difícil en otras secundarias porque tienen que hacer proyectos

M También este internado está bien porque aquí te dan todo, te alimentan (con frijoles)

M Sí, te alimentan y te dan hospedaje

H Sí te alimentan con frijoles (risas)

H Dan diversión

M Los dormitorios están allá arriba

H También hay convivencia

H Y la diversión empieza por la tarde

\section{¿Cómo es la diversión?}

H La diversión empieza en por la tarde salimos a canchas a hacer deporte, por la noche el cine y los juegos de mesa

M De 8 a 9 es baile, o cine o juegos de mesa

H A mí eso no me interesa porque no bailo, pero si voy a escuchar música ¿Por las tarde hace convivencia? ¿Cómo son?

Todos/as No por la noche

M De 8 a 9 es baile o si quieres ir a juegos de mesa

H No, a ver se organiza por días. Los lunes y miércoles es baile o cine, el martes es baile o juegos de mesa

H Los miércoles es cine

H Y así se vuelven a repetir los días

¿Qué les gusta más de laconvivencia?

M A nosotras baile, porque aunque no bailamos damos vueltas, ¿verdad?

M A nosotras nos gusta baile porque jugamos

¿Si pudieran cambiar algo qué cambiarían?

M Los maestros

H No gracias

H No, como tú no te portas bien

M No, así están bien

H Ah que nos pongan un sustituto de la maestra de español (risas y hablan todos a la vez) 
M Que cambien el menú de la comida

¿Su convivencia con compañeros y compañeras cómo es?

M Nos separan, hombres y mujeres

H Nos separan, los lunes y los miércoles les toca ir a los hombres a la convivencia y los martes y los jueves a las mujeres

H y M Por las parejitas

H Cuando es de hombres no ponen música para bailar, porque los hombres no bailan con los hombres, solo que sean gays.

H Pero si ponen

\section{¿Por qué razón están cursando secundaria y particularmente esté internado?}

H Porque mi mamá trabaja mucho y no puede estar todo el día en la casa me aburro

M Yo me quise venir porque me gustaba pero ahora me arrepiento, pero no me quiero salir porque estoy bien a gusto y si me voy a otra secundaria tengo que caminar mucho.

M Pues para tener una vida mejor y no andar trabajando en el campo

M Para superarnos

H Así nada más trabajo en vacaciones

H A mí solo me gusta estudiar, a parte mi mamá trabaja mucho y mi papá nunca se la pasa en la casa

M A parte yo me vine porque todos mis hermanos han estado aquí

Fotografía de los jóvenes en la biblioteca. Pregunta ¿qué están haciendo?

Todos/as Están en una biblioteca

M Están buscando sobre la naturaleza humana, historia, matemáticas, geografía

Supongamos que son cuestiones que no están relacionadas con las materias

H Minerales

H Eso está relacionado con la escuela

H Sobre jardinería

M O puede investigar sobre la carrera que van a tomar después para ya tener conocimientos 
Si estuvieran investigando sobre sexualidad, ¿Qué creen que estarían buscando?

H ¿Cuántas células tiene el hombre?

H Diferencia entre hombre y mujer

M La reproducción sexual

H Las protecciones (risas)

¿Por qué están investigando sobre las diferencias entre hombres y mujeres?

H Porque se madrean (*pelean) risas

M Porque los dos empiezan de llevados y nos se aguantan

M Los niños también empiezan a llorar

H No es cierto

H A demás las mujeres se llevan con los hombres porque saben que las mujeres no se les puede pegar ni con el pétalo de una rosa

H Solo con la rosa (bromean y se ríen entre ellos)

M Si, a veces. Pero algunas veces ustedes empiezan de llevados y no les hacen nada

H Pero luego nos apedrean (risas)

\section{Por qué creen que hay esas diferencias?}

M Porque se caen gordos entre ellos

H Porque son muy creídos o muy listos

H Tienen diferentes formas de pensar

M Hay más diferencia entre las mismas mujeres

M Me cae mal que comparen o que presuman sobre la calificación como cuando dicen él saco un diez y yo un siete

M Para que aprendan a convivir hombres y mujeres

\section{Ustedes aquí en la escuela qué han aprendido sobre sexualidad y} equidad de género

M En biología hemos visto los estereotipos

H Sí, los estereotipos de hombre y de la mujer

H Como la manera de pensar de cada quien, como una señora que esta delgadita y se siente gorda porque su esposo lo dice

M También hemos visto en biología la genética y las moléculas de los átomos 
de cada personas

M También los cambios físicos y emocionales

\section{¿Cómo son esos cambios físicos y emocionales?}

M Los cambios de humor son los cambios emocionales

H Los cambios físicos es cuando están en sus días las mujeres

H Y también a las mujeres les van creciendo los senos y a los hombres le va creciendo... ya saben (risas)

M Nos salen espinillas, cambia la voz

M Los cambios de humor son como por ejemplo cuando me siento muy feliz y de repente ya estoy triste

H También puede ser como cuando antes les gustaba jugar algunas cosas y después ya no

\section{¿En qué asignatura ustedes han visto estos cambios?}

Todos Llevamos esto en un Formación Cívica y Ética en primero

\section{Si hubiera una asignatura que tratará sobre sexualidad y equidad de}

\section{género ¿qué les gustaría que se abordara sobre estos temas?}

M Reflexión sobre los cambios de humor

M ¿Cómo voy creciendo? Y lo que pasa con nuestro cuerpo, porque algunas no soportan los cambios y se andan suicidando

H Las drogas - lo que te provocan, los daños que hacen

M Los efectos que produce

H Por ejemplo chocar con el carro el poste del vecino

H Por el alcohol y les pueden poner una pastilla en la cerveza

M También sobre la violencia en el noviazgo, hay mucha violencia porque ella ya no quiere andar con él y él se enoja y la golpea corta.

M O también porque usa minifaldas o blusas escotadas y por eso las golpea

M También puede ofenderla física y emocionalmente porque ella trabaja y a él no le gusta eso

H Si porque a ellos les gusta verlas con esa ropa pero nada más para ellos pero que los demás no las vean

M Si ella trabaja en la oficina o en un oficio y se encela y la golpea o esta obsesionado por ella

M Se enojan por los chismes y golpean y después dicen el hombre que no 
tenía la culpa que se dejo llevar por los celos

H Si muchos se dejan llevar por los chismes, pero otros no

M Aquí hubo un caso de que se dejaron unos tíos por que dijeron cosas de ellos, por chismes pues.

¿Aquí en la comunidad si afecta lo que dicen sobre otros?

Todos/as Si aquí si importa mucho

¿A esta edad se dan ese tipo de casas? Por ejemplo se da el noviazgo

M Se dan noviazgos a los 12 o 13 (se ríen)

H Están muy calenturientos

M También embarazan y se van con él

H Si embarazan como a los 14

M Nombre a los 12

M Se van con ellos y al final termina hasta peleados que porque ya no se quieren

H Los ven haciendo eso y les quieren echar agua (risas)

¿Por qué creen que se den esas cuestiones a tan temprana edad?

M Por las hormonas

M Porque se quieren de verdad

M Hay amenazas a las mujeres, si no me quieres te voy a matarte o voy a matar a alguien de tu familia.

H O porque la mujeres están muy aferradas a los hombres

M Las mujeres también amenazan a los hombres, cómo cuando un hombre anda con otra mujer y su mujer está embarazada y le dice a la otra te voy a matar

H Y los chicos les dicen tu no vas a tener a ese bebé lo vas a abortar

M Ah sí, por ejemplo los muchachos les dicen a las muchas de 15 años que están embarazadas tienes que abortar este hijo

Chicos/as antes hablaban de cosas que les pasaban a ustedes ¿Esas anécdotas les han ocurrido a personas de su edad?

M Yo conozco a una persona de aquí que anduvo con una y que la amenazó le dijo: si no andas conmigo golpeo a tu hermana, así que ya saben quién es.

H Yo no soy chismoso 


\section{¿Qué hacen los hombres y las mujeres para atraer al sexo opuesto?}

M Vestirse entallada llamando la atención (risas)

M Habla mal de él para que nadie se fije en él

M Se gustan - ella o él le pide que sean novios-, más los hombres piden que sea la novia.

H Su forma de ser

H Los dos pueden pedirse ser novios

Ustedes chicas le pedirían a un niño que sea su novio

M Yo no, porque los niños son los que tienen que tener la iniciativa

M Yo tampoco se los pediría

M Yo sí, si me gusta porque no voy a poder pedírselo

Y ustedes chicos, a las chicas

H A un niño no pero a una niña sí (bromea y los participantes se ríen)

H A una niña sí, yo creo que los chicos tenemos más iniciativa para pedir ser novios, pero las chicas toman la iniciativa en otras cosas

M Pero más más los hombres

\section{¿Qué hacen los chicos para atraer a las chicas?}

M Se comportan románticos

H Se compran una camisa nueva para el verano (hablan todos a la vez)

H Les dedica canciones, como la de cielito corazón

H Les regalan anillos y de pronto le roban a su mamá para que puedan comprarlos

\section{¿Cuáles son los prototipos de belleza para las y los adolescentes?}

M Una mujer pintarse los labios, la cara, vestirse bien, perfumarse, bañarse bien. Que sea respetuoso

H Su forma de ser, amable, que respete

H Vestirse con minifalda

M También su forma de ser

M En los hombres que no sean sangrones los hombres

M Que no sean presumidos los hombres

H Pues una mujer que no se venda

M No tan cursi, que sea chistosa y que sea amable

H Que no sea materialista 
M Que no sea plástica - Hueca

\section{¿En esta foto qué observa?}

H Es una prueba de embarazo. Puede ser un embarazo no deseado

M Ajá y no saben qué hacer

H Sí, no saben si van a poder seguir estudiando o si van a tener que trabajar

M O también están dudando si abortan o se hacen cargo

H Darlo en adopción

\section{¿Qué les aconsejarían ustedes?}

M Ir con un psicólogo

H Que compren condones

M Que piensen antes de hacerlo

M Que enfrenten las consecuencias

M Que no aborte

M No se imaginaron los problemas que vendrían

\section{Vamos a ver otra imagen. Mujeres peleando}

M Peleando con el novio

M Por decirse cosas

H Por problemas que tienen entre ellas

M Pelean por envidia, celos

M La mayoría de peleas son entre mujeres

H Los hombres pelean porque les roban la novia y su novio se enoja si ella es llevada y eso provoca, porque se roban las cosas, porque les faltan cosas

M Por defender a la hermana, por ejemplo yo tengo un hermano y si me dice que si alguien me hace algo le diga. Una vez tuve un problema con un y si me dio una cachetada pero no le quise decir nada porque sabía que se lo iba a agarrar

H Las peleas se dan coraje, por envidia, por celos de las cosas

M También para lucirse y decir que yo si se pelear

M Por maldad

H Por venganza, coraje

\section{Cómo actúan los profesores, las mamás y los papás ante sus cambios}

M Los maestros dicen que vamos como cangrejos

M Mi papá me dice que apenas soy como un pajarito que están creciendo mis 
alas y yo ya quiero volar y entiendo que todavía no estoy preparada para vivir.

H Luego se cae de cabeza y está muy chica para tener novio

H Los cambios depende de con quién te juntes, por ejemplo si te juntas con personas que son buenas vas a hacer bueno. Como dice el dicho el que con lobos anda a aullar se enseña. Porque si andas con gente mala que fuma y se drogan pues eso te causa mal

\section{¿Cómo se forman los grupos?}

H La mayoría de los grupos se juntan para mal

M Uno que otro se juntan para bien

M Preguntan ¿Me puedo juntar con ustedes? Preguntan ¿Cuándo la pueden tener de enemiga, mejor se hacen amigas?

todos Para que trabajo si de cualquier manera nos vamos a morir

H Para llamar la atención

M Por la travesura, para hacer la maldad y luego le salen muchos amigos

\section{¿Qué hacen para cuidarse?}

M Darnos a respetar porque ellos tienen más fuerza y mejor no llevarse

M Casi me llevo bien con todos. Y le hablo bien a todas las personas y los que no me caen bien pues no les hablo

M Tratando bien a las personas. Porque hay personas que escriben en los baños, si quieren decir algo que lo digan a la cara.

H No juntarse con malas juntas

H Comer bien

M Hacer ejercicio

H Para que lo dicen si no lo hacen (risas)

M Estar bien en mi autoestima

\section{¿Qué hacen para que les quieran?}

H Cantarle el agua

H Hablarle bien

M Hay algunos que se aprovechan para que no les dejen de hablar

M Se aprovechan de la amistad, y luego hablan cosas de uno. Y dicen si hace esto o lo otro te dejo de hablar

\section{Qué hacen para que los papás/mamás los quieran}


M A mí de todos modos me quieren

H Portarme bien

M Sacar buenas calificaciones

\section{Ventajas de Hombres y mujeres}

H Fuerza, a veces las mujeres...

M A veces les ponen más atención a las mujeres los maestros

M Las mujeres podemos pensar en más cosas a la vez y ellos no

H Que las mujeres pasan primero, apoco no ha visto la película de titanic primero pasan a las mujeres y a los niños (risas)

M A veces tienen más oportunidades las mujeres

H Es que las mujeres siempre están bien tranquilas en el chisme y los hombres no siempre se están pegando zapes entre nosotros

M A un amigo no hizo algo y no le dieron ni una oportunidad lo dejaron externo y a las mujeres les dan cinco oportunidades y aquí las dejan

H Los maestros son más tolerantes con las niñas

Agradecemos su participación y si quieren escribir para cualquier duda que les surja les vamos a pasar la página de la asignatura. Para que nos puedan hablar de lo que les gustaría que viniera en la asignatura. 


\section{Reporte de consulta categoría de sexualidad por zona}

UH: UH SEXUALIDAD Y GÉNERO

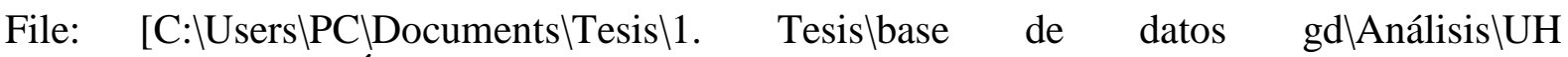
SEXUALIDAD Y GÉNERO 03.hpr7]

Edited by: $\quad$ Super

Date/Time: 2016-12-29 11:08:31

Filtro de documento: "Indígena"

20 Citas encontradas por consulta:

"1.1. SEXUALIDAD"

4:6 M. Que en tutoría nos explica .. (304:315)

$\sim 4: 56$ H. Pues pienso bien porque es .. (226:229)

Comment:

Las chicas son rechazadas y señaladas cuando ejercen su sexualidad.

4:107 M. Más respeto hacia las mujer.. (380:382)

4:127 M. Pero no tiene que dar vergü.. (461:469)

Comment:

La pregunta que se formula es de donde obtienen información.

4:155 ¿De dónde obtienen más informa.. (455:459)

5:7 ¿Qué piensan ustedes del embar.. (443:477)

5:13 M Del aparato reproductor (101:101)

5:14 H Del hombres y de la mujer. L.. (102:102)

5:37 H Se visten escotadas H Como d.. (275:278)

5:147 Los que les interesa conocer a.. (95:112)

5:149 Oigan y cuando tienen inquietu.. (146:149)

5:150 A tu hermano mayor, ajá, y ¿Us.. (151:153)

5:153 ¿Para ver si están bien o algo.. (193:197)

9:12 H Por mi parte seria la preven.. (682:696)

9:21 H Pues no han dicho muchas cos.. (111:111)

9:22 M Que debemos cuidarnos mejor (112:112)

9:25 M En la materia de ciencias no.. (120:120)

9:29 Algo más de la equidad de géne.. (131:141)

9:91 H Que se quieren o que nada má.. (384:388)

9:188 M ¿Que nos digan por qué suced.. (694:694)

28 Citas encontradas por consulta:

\section{"1.2. CAMBIOS FÍSICOS Y EMOCIONALES"}

4:44 M. Se creen ya las muy grandes.. (190:190)

4:77 M. Los hombres ya que se desar.. (313:313)

4:124 M. Que nuestros papás ya nos r.. (448:454)

4:130 M. Sí, porque es mejor hablarl.. (464:464)

4:137 ¿Qué tipo de problemas se pued.. (475:484)

5:15 H Y qué tal si es al revés (105:105)

5:16 M Si quisieran conocer las muj.. (106:106) 
5:18 M Pues de los cambios que vemo.. (129:129)

5:19 H Normal H Normal H Diferente .. (132:134)

5:20 H En nuestro cuerpo, y... H Ya n.. (137:140)

5:21 M Pues diferente a como pensab.. (144:144)

5:30 M Pues de que tanto hombres co.. (191:191)

5:147 Los que les interesa conocer a.. (95:112)

5:153 ¿Para ver si están bien o algo.. (193:197)

5:159 ¿Esta forma de pensar tiene qu.. (354:355)

5:164 M. Tener en cuenta las enferme.. (679:680)

9:5 ¿Qué dudas tienen sobre la sex.. (228:267)

9:49 M Como la menstruación M Lo de.. (230:233)

9:50 H Que ya soy adolescente H Com.. (237:238)

9:51 M Ensanchamiento de caderas (239:239)

9:52 H La atracción por el sexo opu.. (245:245)

9:53 H El cambio seria cuando estam.. (257:258)

9:103 H En mí caso mi familia no com.. (439:439)

9:104 H En algunos casos yo he visto.. (443:443)

9:105 M Mi abuelita me dice que, que.. (446:447)

9:106 H Pues que uno necesita más pr.. (450:450)

9:107 H Te dan un cuarto aparte de 1.. (453:454)

9:187 M Reconocer su cuerpo (692:692)

144 Citas encontradas por consulta:

\section{"1.3. VÍNCULOS AFECTIVOS"}

4:4 ¿Qué les gusta a las mujeres d.. (201:218)

4:14 M. Así como para hacerse que e.. (64:64)

4:17 M. Algunos hombres toman porqu.. (73:73)

4:18 H. Las mujeres también toman p.. (74:75)

4:37 H. Las peleas se generan por m.. (148:150)

4:39 ¿Desde qué edad? H. Desde prim.. (182:186)

Comment:

Estan hablando del noviazgo

4:40 H. Desde primero M. Desde prim.. (184:185)

4:43 H. Porque quieren tener más ex.. (189:189)

4:44 M. Se creen ya las muy grandes.. (190:190)

4:45 M: Aquí se han casado dos niña.. (192:192)

4:46 H. También de tercero, puro de.. (195:196)

Comment:

Hablan de si en la escuala se han casado varones. Ellos dicen que solo los de tercer año

4:47 M: De los hombres nos gusta có.. (202:202)

4:48 H: Son pocas las que se fijan .. (203:203)

4:49 H. Que no se fijan ni cómo son.. (206:209)

Comment:

Ante la pregunta en que les gusta a las mujeres de los hombres ellos contestan lo siguiente:

4:50 H. En que están bonitas. (212:212)

4:51 M. Si tienen buen cuerpo. (213:213)

4:52 H. Son muy pocos también que s.. (214:215)

4:53 M. Y cuando se casan ya a vece.. (216:216) 
4:55 H. Ya hay algunos compañeros q.. (223:223)

Comment:

Este comentario es muy ilustrador, pues muestra como el sistema patriarcal actua en las percepciones que tienen los adolescentes respecto a actuar como padres que regañan a la hija cuando no tiene un comportamiento que se adecua a los estereotipos de género.

$4: 78 \mathrm{H}$. O ya se las roban a sus nov.. (314:314)

4:79 H. Debe de ser que después del.. (315:315)

$\sim$ 4:80 Cuando se roban a la novia iqu.. (317:318)

Comment:

Los chicos hablan de la dependencia económica de las adolescentes cuando se fugan con el novio

4:81 M. Sí, se van a trabajar, los .. (319:319)

$\sim 4: 83$ H. Cuando se casan muy chicos .. $(325: 325)$

Comment:

Nuevamente con este comentario refleja cómo las mujeres continúan dependiendo de las decisiones que tomen los otros. Son los padres o las parejas las que deciden por ellas. Pareciera El hombre puede decidir que hacer, estudiar o trabajar si cuenta con el apoyo familiar en cambio la chica ha de someterese a las decisiones de los otros.

4:84 H. Y también algún hombre que .. (326:326)

4:85 H. Muchos las regresan a sus c.. (327:327)

$4: 86 \mathrm{H} . .$. las regresan, o las dejan,.. (328:331)

4:100 H. O también cuando el esposo .. (361:362)

4:115 M. Sí. Porque nos decían que s.. (420:438)

4:125 M. Que nuestros papás ya nos r.. (448:448)

4:128 M. Pero no tiene que dar vergü.. (461:462)

4:131 H. Por eso cuando uno le pregu.. (465:465)

4:138 M. O también puede que estar d.. (482:482)

4:139 H. O porque en su casa no la d.. (483:484)

4:140 ¿Por qué es tan importante par.. (491:504)

4:155 ¿De dónde obtienen más informa.. (455:459)

5:3 M Una pareja H Una pareja de n.. (259:278)

5:21 M Pues diferente a como pensab.. (144:144)

5:22 H Preguntamos al profe Juan Jo.. (147:149)

5:23 M Yo a mi mamá (152:152)

5:33 H Una pareja de novios H Le es.. (260:261)

5:34 H Que la quiere bien arto H Qu.. (265:267)

5:35 H Que si, que ella también qui.. (270:270)

5:36 M Que ella no quiere M Ella no.. (271:272)

5:37 H Se visten escotadas H Como d.. (275:278)

$\sim 5: 38 \mathrm{H}$ Se perfuman H Se portan dece.. (282:283)

Comment:

Qué hacen los hombres para atraer a las mujeres

5:39 H Se las llevan al rinconcito .. (286:287)

5:40 M Pues primero te hablan bien,.. (291:295)

5:41 H No toman (296:296)

5:42 M Si un amigo te pide no tomar.. (297:297)

$\sim<5: 46 \mathrm{M}$ Tal vez porque el muchacho 1.. (314:315)

Comment:

Ellas no hacen referencia al deseo, solo dicen que es por amor o por que se dejan llevar por la pareja. 
$>5: 47$ M Cuando se quieren (319:319)

5:48 H Cuando ya quieren H Cuando y.. (322:324)

5:54 M Amistosa H Que fuera regular.. (339:355)

5:55 M Amistosa (339:339)

5:56 H Que fuera regular (340:340)

5:57 M Que fuera amable (341:341)

5:58 M Que fuera cariñoso y que si .. (344:344)

5:59 H Si te dijera el novio matate.. (345:345)

5:60 M No, entonces no te quisiera (346:346)

5:61 M Si todo lo que tú quieras, p.. (349:349)

5:62 M Pues amistosa (352:352)

5:63 ¿En qué sentido es importante .. (372:382)

5:64 M Porque cuando hay amistad ha.. (373:375)

5:65 H Yo digo que la amistad no ex.. (378:378)

5:66 M De nuestras cosas, de lo que.. (381:381)

5:67 H De lo que nos pasa (382:382)

5:68 H De las muchachas H De que mi.. (385:386)

5:69 H Del mundial, de que ya va g.. (389:390)

5:70 M De los muchachos que nos gus.. (393:394)

$\sim 5: 71 \mathrm{H}$ ¿Las amigas? De los novios, .. (398:398)

Comment:

Hace referencia a que las chicas no tienen novio sino que tienen "amigos" en tono sarcástico.

5:72 H De que me voy a poner, del m.. (404:404)

5:73 M De futbol M De futbol, nada .. (407:408)

5:74 ellos de pronto platican que s.. (410:411)

5:76 M Pues de las muchachas, de qu.. (417:417)

5:77 Están dos novios una muchacha .. (423:424)

Comment:

La chica habla de infidelidad de la mujer y uno de los chico rápidamente interviene como si eso no fuera posible. Como si las chicas no pudieran ni siquiera pensar en la posibilidad de estar con alguien más.

5:78 M Están dos novios Están dos n.. (421:437)

5:79 H ¿Cuál otro? (427:427)

5:80 M Tal vez al muchacho le paso .. (433:433)

5:81 M El muchacho son amigos y tie.. (437:437)

5:82 M Que está pensando el muchach.. (438:438)

5:85 H Que como son niñas se van co.. (453:453)

5:115 Que se están peleando por una .. (548:548)

5:119 M Por los muchachos, las chica.. (560:560)

5:133 M Para mi vestirme como es mi .. (641:643)

Comment:

Qué hace a las mujeres reafirmar su feminidad

$\sim 5: 163 \mathrm{H}$. Las mujeres pelean por chis.. (613:613)

Comment:

Las mujeres pelean por cuestiones emocionales, por chismes, insultos.

9:8 H Una pareja ¿Qué más, Diego? .. (377:453)

9:52 H La atracción por el sexo opu.. (245:245)

9:53 H El cambio seria cuando estam.. (257:258)

9:54 H La química, la comunicación .. (262:264)

9:55 M Por los sentimientos (265:265) 
9:56 H Por la higiene, pues por si .. (266:267)

9:57 H De la mejor manera, acercánd.. (271:272)

9:58 M Platicando (275:275)

9:60 H Quién sabe Como tú siempre a.. (268:309)

9:63 M Tener buenos sentimiento M Q.. (287:288)

9:64 H Que sea buena persona más qu.. (292:292)

9:65 H Pues bonita cara, bonito cue.. (295:295)

9:66 M En los ojos claros H La sonr.. (296:298)

9:70 H A mi largo H A mí como el de.. (308:309)

9:71 H Alta, con cabello chino, con.. (315:315)

9:72 M Con músculos, ojos azules (r.. (318:319)

9:73 Muchachas/os estábamos habland.. (332:338)

$<9: 74$ H Pues una atracción entre ell.. (333:335)

9:76 Chicas ustedes que piensan ¿Qu.. (340:347)

9:77 M El quererse $\mathrm{M}$ El que se quie.. (341:342)

9:91 H Que se quieren o que nada má.. (384:388)

9:92 H. Que se quieren mucho (risas.. (391:394)

9:93 H Que fuera duradera y amistos.. (399:399)

9:94 H Que confiaran en ellos mismo.. (401:401)

9:95 M Sincera, que no hubiera ment.. (400:400)

9:96 M Que confiaran M Que platicar.. (404:405)

9:97 H Sincera que se dijeran todo (406:406)

9:98 H Pues te acercas y les dice q.. (410:410)

9:99 M Algunas dicen que lo van a p.. (416:417)

$<9: 100$ H Yo nada más le regale una ca.. (423:423)

9:103 H En mí caso mi familia no com.. (439:439)

9:104 H En algunos casos yo he visto.. (443:443)

9:105 M Mi abuelita me dice que, que.. (446:447)

9:118 H En la primaria también (248:248)

9:119 H y M Desde sexto (254:254)

9:120 M También nervias H Emoción M .. (433:435)

9:122 M De ropa, de chicos, de zapat.. (462:462)

$<9: 123 \mathrm{H}$ Entre hombres de futbol, de .. (465:465)

$>9: 124$ H De música (468:468)

9:126 M De deportes o de alguna pers.. (475:475)

Comment:

Las chicas perciben que los chicos hablan de deportes y de los ligues

9:127 H De sus novios H De cuales pe.. (481:483)

Comment:

Los chicos también piensan que las chicas hablan de cuestiones relacionadas con los novios, el cine, los viajes y las aventuras.

9:128 M O también de sus chismes (484:484)

9:139 H Porque se dicen de palabras,.. (518:518)

9:140 H Por un hombre (522:522)

Comment:

Las chicas pelean por cuestiones emocionales

9:171 M Que me dejen tener novio M T.. (634:636)

Comment:

También reclaman mayor libertad para inicar relaciones amorosas.

9:172 H Contestan todos que si (639:639) 
Comment:

A diferencia de las mujeres lo hombres de esta edad, todos confiesan que en sus hogares no les niegan la posibilidad de entablar relaciones amorosas

9:173 M Que a veces pueden llegar a .. (643:661)

9:175 H Dicen que entre el amor y el.. (645:645)

9:176 H En casarse H Como dicen que .. (648:649)

9:177 H El amor es como el afecto ha.. (652:652)

9:178 $\mathrm{M} \mathrm{El}$ amor es algo bonito que h.. (655:655)

9:179 H El amor es sinónimo de quere.. (658:658)

9:180 H Es una mezcla, para que sea .. (661:661)

9:181 Describan a una persona que ad.. (663:666)

9:182 M Mi hermano porque es un buen.. (665:665)

9:183 Yo a mi bisabuelito el ya no v.. (666:666)

9:193 M Se siente bien, y también si.. (717:717)

9:194 H También sería como tipo prep.. (718:718)

90 Citas encontradas por consulta:

"1.3.1. NOVIAZGO"

4:14 M. Así como para hacerse que e.. (64:64)

4:17 M. Algunos hombres toman porqu.. (73:73)

4:18 H. Las mujeres también toman p.. (74:75)

4:37 H. Las peleas se generan por m.. (148:150)

4:40 H. Desde primero M. Desde prim.. (184:185)

4:43 H. Porque quieren tener más ex.. (189:189)

4:44 M. Se creen ya las muy grandes.. (190:190)

4:45 M: Aquí se han casado dos niña.. (192:192)

$\sim 4: 46$ H. También de tercero, puro de.. (195:196)

Comment:

Hablan de si en la escuala se han casado varones. Ellos dicen que solo los de tercer año

4:47 M: De los hombres nos gusta có.. (202:202)

4:48 H: Son pocas las que se fijan .. (203:203)

$\sim 4: 49$ H. Que no se fijan ni cómo son.. (206:209)

Comment:

Ante la pregunta en que les gusta a las mujeres de los hombres ellos contestan lo siguiente:

4:50 H. En que están bonitas. (212:212)

4:51 M. Si tienen buen cuerpo. (213:213)

4:52 H. Son muy pocos también que s.. (214:215)

4:53 M. Y cuando se casan ya a vece.. $(216: 216)$

$4: 78 \mathrm{H}$. O ya se las roban a sus nov.. (314:314)

4:79 H. Debe de ser que después del.. (315:315)

4:81 M. Sí, se van a trabajar, los .. (319:319)

$\sim 4: 83$ H. Cuando se casan muy chicos .. (325:325)

Comment:

Nuevamente con este comentario refleja cómo las mujeres continúan dependiendo de las decisiones que tomen los otros. Son los padres o las parejas las que deciden por ellas. Pareciera El hombre puede decidir que hacer, estudiar o trabajar si cuenta con el apoyo familiar en cambio la chica ha de someterese a las decisiones de los otros.

4:84 H. Y también algún hombre que .. (326:326) 
4:85 H. Muchos las regresan a sus c.. (327:327)

$4: 86$ H.... las regresan, o las dejan,.. (328:331)

4:116 M. Sí. Porque nos decían que s.. (420:420)

4:117 M. Pues nomás viéndola. (423:423)

4:118 H. O con una carta. (424:424)

4:119 M. O diciéndole, dile que le m.. (426:426)

4:120 M. Cosas de amor. M. Por ejemp.. (430:431)

4:121 M. Las mujeres más, las hacen .. (434:434)

4:138 M. O también puede que estar d.. (482:482)

5:32 M Una pareja (259:259)

5:33 H Una pareja de novios H Le es.. (260:261)

5:34 H Que la quiere bien arto H Qu.. (265:267)

5:35 H Que si, que ella también qui.. (270:270)

5:36 M Que ella no quiere M Ella no.. (271:272)

5:37 H Se visten escotadas H Como d.. (275:278)

$\sim 5: 38 \mathrm{H}$ Se perfuman H Se portan dece.. (282:283)

Comment:

Qué hacen los hombres para atraer a las mujeres

5:39 H Se las llevan al rinconcito .. (286:287)

5:40 M Pues primero te hablan bien,.. (291:295)

5:41 H No toman (296:296)

5:42 M Si un amigo te pide no tomar.. (297:297)

$\sim 5$ :46 M Tal vez porque el muchacho 1.. (314:315)

Comment:

Ellas no hacen referencia al deseo, solo dicen que es por amor o por que se dejan llevar por la pareja.

5:48 H Cuando ya quieren H Cuando y.. (322:324)

-5:49 H O también cuando se quieren .. (327:327)

Comment:

Los alumnos hacen referencia a que la práctica sexual también se realiza con la finalidad de burlarse de las mujeres.

5:55 M Amistosa (339:339)

5:56 H Que fuera regular (340:340)

5:57 M Que fuera amable (341:341)

5:58 M Que fuera cariñoso y que si .. (344:344)

5:59 H Si te dijera el novio matate.. (345:345)

5:60 M No, entonces no te quisiera (346:346)

5:61 M Si todo lo que tú quieras, p.. (349:349)

5:62 M Pues amistosa (352:352)

5:77 Están dos novios una muchacha .. (423:424)

Comment:

La chica habla de infidelidad de la mujer y uno de los chico rapidamente interviene como si eso no fuera posible. Como si las chicas no pudieran ni siquiera pensar en la posibilidad de estar con alguien más.

5:115 Que se están peleando por una .. (548:548)

5:119 M Por los muchachos, las chica.. (560:560)

5:129 La pelea es una de las activid.. (622:624)

5:133 M Para mi vestirme como es mi .. (641:643)

Comment:

Qué hace a las mujeres reafirmar su feminidad 
9:52 H La atracción por el sexo opu.. (245:245)

9:54 H La química, la comunicación .. (262:264)

9:55 M Por los sentimientos (265:265)

9:56 H Por la higiene, pues por si .. (266:267)

9:57 H De la mejor manera, acercánd.. (271:272)

9:58 M Platicando (275:275)

9:59 H De cómo se la pasa, qué hace.. (278:279)

9:61 Qué hace en sus tiempos libres.. (280:280)

9:62 H También apoyar a la persona .. (283:283)

9:63 M Tener buenos sentimiento M Q.. (287:288)

9:64 H Que sea buena persona más qu.. (292:292)

9:65 H Pues bonita cara, bonito cue.. (295:295)

9:66 M En los ojos claros H La sonr.. (296:298)

9:70 H A mi largo H A mí como el de.. (308:309)

9:71 H Alta, con cabello chino, con.. (315:315)

9:72 M Con músculos, ojos azules (r.. (318:319)

$<9: 74$ H Pues una atracción entre ell.. (333:335)

9:77 M El quererse $\mathrm{M} \mathrm{El}$ que se quie.. (341:342)

9:91 H Que se quieren o que nada má.. (384:388)

9:92 H. Que se quieren mucho (risas.. (391:394)

9:93 H Que fuera duradera y amistos.. (399:399)

9:94 H Que confiaran en ellos mismo.. (401:401)

9:95 M Sincera, que no hubiera ment.. (400:400)

9:96 M Que confiaran M Que platicar.. (404:405)

9:97 H Sincera que se dijeran todo (406:406)

9:98 H Pues te acercas y les dice q.. (410:410)

9:99 M Algunas dicen que lo van a p.. (416:417)

$<9: 100$ H Yo nada más le regale una ca.. (423:423)

9:103 H En mí caso mi familia no com.. (439:439)

9:119 H y M Desde sexto (254:254)

9:120 M También nervias H Emoción M .. (433:435)

9:171 M Que me dejen tener novio M T.. (634:636)

Comment:

También reclaman mayor libertad para inicar relaciones amorosas.

9:172 H Contestan todos que si (639:639)

Comment:

A diferencia de las mujeres lo hombres de esta edad, todos confiesan que en sus hogares no les niegan la posibilidad de entablar relaciones amorosas.

15 Citas encontradas por consulta:

\section{"1.3.2. FAMILIA"}

4:19 H. O por problemas en su casa .. (81:82)

4:125 M. Que nuestros papás ya nos r.. (448:448)

4:126 H. Ya nos regañan más porque a.. $(449: 454)$

4:128 M. Pero no tiene que dar vergü.. (461:462)

4:131 H. Por eso cuando uno le pregu.. (465:465)

4:155 ¿De dónde obtienen más informa.. (455:459)

5:22 H Preguntamos al profe Juan Jo.. (147:149) 
5:23 M Yo a mi mamá (152:152)

9:103 H En mí caso mi familia no com.. (439:439)

9:104 H En algunos casos yo he visto.. (443:443)

9:105 M Mi abuelita me dice que, que.. (446:447)

2:171 M Que me dejen tener novio M T.. (634:636)

Comment:

También reclaman mayor libertad para inicar relaciones amorosas.

9:172 H Contestan todos que si (639:639)

Comment:

A diferencia de las mujeres lo hombres de esta edad, todos confiesan que en sus hogares no les niegan la posibilidad de entablar relaciones amorosas

9:182 M Mi hermano porque es un buen.. (665:665)

9:183 Yo a mi bisabuelito el ya no v.. (666:666)

22 Citas encontradas por consulta:

\section{"1.3.3. AMIGOS"}

4:55 H. Ya hay algunos compañeros q.. (223:223)

Comment:

Este comentario es muy ilustrador, pues muestra como el sistema patriarcal actua en las percepciones que tienen los adolescentes respecto a actuar como padres que regañan a la hija cuando no tiene un comportamiento que se adecua a los estereotipos de género.

5:21 M Pues diferente a como pensab.. (144:144)

5:64 M Porque cuando hay amistad ha.. (373:375)

5:65 H Yo digo que la amistad no ex.. (378:378)

5:66 M De nuestras cosas, de lo que.. (381:381)

5:67 H De lo que nos pasa (382:382)

5:68 H De las muchachas H De que mi.. (385:386)

5:69 H Del mundial H De que ya va g.. (389:390)

5:70 M De los muchachos que nos gus.. (393:394)

$\sim 5: 71 \mathrm{H}$ ¿Las amigas? De los novios, .. (398:398)

Comment:

Hace referencia a que las chicas no tienen novio sino que tienen "amigos" en tono sarcastico.

5:72 H De que me voy a poner, del m.. (404:404)

5:73 M De futbol M De futbol, nada .. (407:408)

5:74 ellos de pronto platican que s.. (410:411)

5:76 M Pues de las muchachas, de qu.. (417:417)

5:81 M El muchacho son amigos y tie.. (437:437)

5:82 M Que está pensando el muchach.. (438:438)

9:122 M De ropa, de chicos, de zapat.. (462:462)

$<9: 123 \mathrm{H}$ Entre hombres de futbol, de .. (465:465)

$>9: 124$ H De música (468:468)

9:126 M De deportes o de alguna pers.. (475:475)

Comment:

Las chicas perciben que los chicos hablan de deportes y de los ligues

9:127 H De sus novios H De cuales pe.. (481:483)

Comment:

Los chicos también piensan que las chicas hablan de cuestiones relacionadas con los novios, el cine, los viajes y las aventuras. 
42 Citas encontradas por consulta:

\section{"1.4. PRÁCTICAS SEXUALES"}

4:62 H. Y hay unas que se visten as.. (237:237)

4:75 H. Y tampoco hacer relaciones .. (309:310)

4:76 M. De esperarnos a tener relac.. (311:311)

4:77 M. Los hombres ya que se desar.. (313:313)

4:79 H. Debe de ser que después del.. (315:315)

5:4 Ajá. A ver muchachos/as en su .. (300:327)

5:17 M Sobre los cuidados que deben.. (112:112)

5:34 H Que la quiere bien arto H Qu.. (265:267)

5:39 H Se las llevan al rinconcito .. (286:287)

5:43 H La provocación H La excitaci.. (301:302)

Comment:

Por qué los y las adolescentes tienen relaciones sexuales

5:44 H Empezar a usar los condones (305:305)

5:45 M Porque se dejan llevar (311:311)

$\sim<5: 46 \mathrm{M}$ Tal vez porque el muchacho 1.. (314:315)

Comment:

Ellas no hacen referencia al deseo, solo dicen que es por amor o por que se dejan llevar por la pareja.

$>5: 47$ M Cuando se quieren (319:319)

5:48 H Cuando ya quieren H Cuando y.. (322:324)

5:49 H O también cuando se quieren .. (327:327)

Comment:

Los alumnos hacen referencia a que la práctica sexual también se realiza con la finalidad de burlarse de las mujeres.

5:51 M O también cuando nada más la.. (331:332)

5:52 M Pues como las de los bares, .. (335:335)

5:53 H Se prostituyen (336:336)

5:74 ellos de pronto platican que s.. (410:411)

5:76 M Pues de las muchachas, de qu.. (417:417)

5:86 M Pues se dejan embarazar por .. (456:456)

5:87 H Y se las llevan al rinconcit.. (457:457)

5:88 M Que es muy mal porque si tuv.. (458:458)

5:89 M Que lo hace por curiosidad (459:459)

$<5: 90 \mathrm{H}$ Que tenía ganas de hembra (460:460)

$>5: 91 \mathrm{H}$ No, de tener sexo (463:463)

5:92 H Que quedó embarazada por no .. (466:468)

5:93 M Pues que tanto hombres como .. (474:474)

Comment:

Esta adolescente habla que la responsabilidad en el embarazo adolescente recae en las mujeres.

5:94 H Que los hombres si llegan a .. (477:477)

Comment:

Coresponsabilidad en las prácticas sexuales. 
5:164 M. Tener en cuenta las enferme.. (679:680)

9:25 M En la materia de ciencias no.. (120:120)

9:27 M A no ser discriminados por d.. (126:126)

9:30 H Que para prevenir algunas en.. (132:132)

9:39 H Los métodos anticonceptivos (174:174)

9:73 Muchachas/os estábamos habland.. (332:338)

9:76 Chicas ustedes que piensan ¿Qu.. (340:347)

9:82 H Yo pienso que está mal porqu.. (350:350)

9:113 H De métodos anticonceptivos (113:113)

9:189 H Y pues algo más avanzados de.. (695:695)

9:203 M. Que debemos cuidarnos porqu.. (116:116)

9:205 H. O que nada más la está usan.. (395:395)

37 Citas encontradas por consulta:

\section{"1.5. PROBLEMÁTICAS Y/O CONFLICTOS AL EJERCER LA SEXUALIDAD"}

4:54 H. Y aquí hablan mucho de ella.. (217:217)

4:73 H. Y en Biología nos explican .. (305:305)

4:74 M. Y nos explican las enfermed.. (306:306)

$4: 78 \mathrm{H}$. O ya se las roban a sus nov.. (314:314)

5:5 O también cuando se quieren bu.. (327:336)

5:7 ¿Qué piensan ustedes del embar.. (443:477)

5:25 M Enfermedades (163:163)

5:50 H Cuando tienen un hijo con él.. (330:330)

5:51 M O también cuando nada más la.. (331:332)

5:52 M Pues como las de los bares, .. (335:335)

5:53 H Se prostituyen (336:336)

5:83 Tuvieron un problema como que .. (440:441)

5:84 H Que está muy mal porque es c.. (444:447)

5:85 H Que como son niñas se van co.. (453:453)

5:86 M Pues se dejan embarazar por .. (456:456)

5:87 H Y se las llevan al rinconcit.. (457:457)

5:88 M Que es muy mal porque si tuv.. (458:458)

5:92 H Que quedó embarazada por no .. (466:468)

5:94 H Que los hombres si llegan a .. (477:477)

Comment:

Coresponsabilidad en las prácticas sexuales.

5:164 M. Tener en cuenta las enferme.. (679:680)

9:10 H Ya quedó embarazada la mucha.. (569:592)

9:21 H Pues no han dicho muchas cos.. (111:111)

9:22 M Que debemos cuidarnos mejor (112:112)

9:25 M En la materia de ciencias no.. (120:120)

9:30 H Que para prevenir algunas en.. (132:132)

9:31 H Del SIDA, del cáncer... (135:135)

9:38 Sobre las enfermedades (173:173)

9:82 H Yo pienso que está mal porqu.. (350:350)

9:83 H Yo pienso que no está bien c.. (351:351)

9:84 M Que si está mal porque es co.. (354:355)

9:85 M Piensa en el aborto ¿Por qué.. (358:361) 
9:86 H Quiere continuar con sus est.. (362:363)

9:87 M O por sus papás $(364: 364)$

9:88 H Estoy recordando, era de aqu.. (367:368)

9:89 M Pues es peligro porque puede.. (371:371)

9:90 H Pero el niño también es una .. (372:372)

Comment:

El aborto no es visto como un derecho al que puedan acceder las mujeres de manera apropiada con las condiciones de higiene y seguridad. Se refleja un discurso tradicional y conservador en cuanto a los derechos y libertades sobre el cuerpo de las mujeres.

9:184 H Por mi parte seria la preven.. (682:682)

25 Citas encontradas por consulta:

"1.6. REPRODUCCIÓN"

4:44 M. Se creen ya las muy grandes.. (190:190)

5:50 H Cuando tienen un hijo con él.. (330:330)

5:83 Tuvieron un problema como que .. (440:441)

5:84 H Que está muy mal porque es c.. (444:447)

5:86 M Pues se dejan embarazar por .. (456:456)

5:92 H Que quedó embarazada por no .. (466:468)

5:93 M Pues que tanto hombres como .. (474:474)

Comment:

Esta adolescente habla que la responsabilidad en el embarazo adolescente recae en las mujeres.

9:78 H El querer tener un hijo (343:343)

9:79 H Pero para eso ya tendrían qu.. (346:346)

9:80 H No siempre es así, porque a .. (347:347)

9:81 ¿Qué piensan del embarazo adol.. (348:372)

9:84 M Que si está mal porque es co.. (354:355)

9:85 M Piensa en el aborto ¿Por qué.. (358:361)

9:86 H Quiere continuar con sus est.. (362:363)

9:87 M O por sus papás (364:364)

9:88 H Estoy recordando, era de aqu.. (367:368)

9:89 M Pues es peligro porque puede.. (371:371)

9:154 H Ya quedó embarazada la mucha.. (569:569)

9:155 H Ahora perderían sus estudios.. (581:581)

Comment:

Es interesante que varios alumnos en diversos grupos de discusión señalan que una vez que la adolescente se embaraza pierde la posibilidad de seguir con sus estudios, ya sea porque tiene que trabajar para mantener al bebé o como dice el siguiente alumno para formar una familia. $\sim<9: 156 \mathrm{M}$ Que se tienen que casar (585:585)

Comment:

Mujeres y hombres en este grupo de discusión consideran que si una pareja decide tener el bebé su "deber" es casarse para ofrecer una vida más segura a la criatra.

$>9: 157$ H No es su obligación pero pue.. (586:586)

9:158 H Que los dos están embarazado.. (590:592)

Comment:

Estos adolescentes manifiestan que ante el embarazo deberia de existir corresponsabilidad por el bien del bebé. 
9:184 H Por mi parte seria la preven.. (682:682)

9:185 M Como cuidarte en el caso de .. (686:686)

9:186 H Darles palabra de inspiració.. (689:689)

14 Citas encontradas por consulta:

"1.7. ITS"

4:73 H. Y en Biología nos explican .. (305:305)

4:74 M. Y nos explican las enfermed.. (306:306)

4:75 H. Y tampoco hacer relaciones .. (309:310)

5:25 M Enfermedades (163:163)

5:88 M Que es muy mal porque si tuv.. (458:458)

5:164 M. Tener en cuenta las enferme.. (679:680)

9:21 H Pues no han dicho muchas cos.. (111:111)

9:25 M En la materia de ciencias no.. (120:120)

9:27 M A no ser discriminados por d.. (126:126)

9:30 H Que para prevenir algunas en.. (132:132)

9:31 H Del SIDA, del cáncer... (135:135)

9:38 Sobre las enfermedades (173:173)

9:184 H Por mi parte seria la preven.. (682:682)

9:203 M. Que debemos cuidarnos porqu.. (116:116) 
UH: UH SEXUALIDAD Y GÉNERO

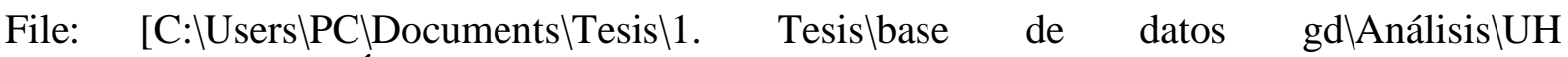
SEXUALIDAD Y GÉNERO 03.hpr7]

Edited by: Super

Date/Time: 2017-01-10 09:28:28

\section{Filtro de documento: "Rural"}

14 Citas encontradas por consulta:

"1.1. SEXUALIDAD"

1:5 H. Algo de la sexualidad, pres.. (64:68)

1:13 Pregunta / Tema: Temas de Inte.. (172:177)

1:14 ¿Hay relaciones sexuales a tem.. (179:200)

1:22 ¿De dónde obtiene más informac.. (127:152)

1:36 H. Algo de la sexualidad, pres.. (64:64)

1:37 M. De la sexualidad, cómo se r.. (65:65)

1:40 buscan información por igual m.. (69:71)

1:41 M: Los más grandes buscan más .. (72:72)

1:42 H. Para prevenir embarazos no .. $(73: 73)$

1:57 H: los videos porno ¿Los chavo.. (132:136)

1:144 M: Sí les da asco, ¿por qué lo.. (143:143)

Comment:

Las chicas preguntan las razones por las cuales los hombres ven pornografía. Ellos señalan que es por curiosidad

8:4 ¿Qué se preguntarán sobre su s.. (162:175)

8:33 H. Leyendo un libro, estudiand.. (150:151)

10:40 Ustedes aquí en la escuela ¿Qu.. (119:124)

13 Citas encontradas por consulta:

\section{"1.2. CAMBIOS FÍSICOS Y EMOCIONALES"}

1:66 M: Por curiosidad por probar 1.. (156:158)

Comment:

Justificación de las conductas de riesgo como beber alcohol o fumar.

$8: 19 \mathrm{H}$ ¿Por qué a las mujeres les c.. (164:164)

8:20 M Por qué les duelen los cambi.. (167:167)

10:3 M Los cambios de humor son los.. (127:141)

10:13 ¿Cuántas células tiene el homb.. (96:96)

10:14 Diferencia entre hombre y muje.. (97:97)

10:43 También hemos visto en biologí.. (123:124)

10:45 H Los cambios físicos es cuand.. (128:129)

10:46 M Nos salen espinillas, cambia.. (130:131)

10:47 H También puede ser como cuand.. (132:132) 
10:48 M Reflexión sobre los cambios .. (138:139)

10:61 M Por las hormonas (166:166)

10:103 ¿Cómo actúan los profesores, 1.. (241:245)

55 Citas encontradas por consulta:

\section{"1.3. VÍNCULOS AFECTIVOS"}

1:9 ¿A ustedes qué les atrae un ho.. (100:109)

1:44 ¿Por qué creen que se van con .. (76:80)

1:45 Qué hace que se enamoren? Resp.. (81:85)

Comment:

Un chico comenta que las mujeres se enamoran por interes, vuelve este discurso sexista donde las mujeres son consideradas como personas malas que se aprovechan de los hombres

1:46 M. O porque tienen papeles y s.. $(86: 88)$

1:47 ¿Y qué hace que los hombres se.. (94:95)

1:48 M: Yo pienso que si te casas c.. (96:96)

$\sim 1: 49$ H. Pero va ser ama de casa. (R.. (97:98)

Comment:

Se reafirma en su opinión de que las mujeres deben hacerse cargo de las tareas del hogar

1:50 ¿A ustedes qué les atrae un ho.. (100:101)

1:51 H: Una mujer por su escultura,.. (102:102)

Comment:

Por qué les gusta una mujer, hacen referencia al aspecto físico, ellos.

1:52 ¿Qué más les gusta de cómo son.. (105:109)

1:53 Describan al príncipe azul y a.. (114:117)

$<1: 54$ ¿Y la princesa rosa? H: Amable.. (119:124)

$>1: 55 \mathrm{M}$ : Las princesas no hacen queh.. (125:125)

$\sim$ 1:66 M: Por curiosidad por probar 1.. (156:158)

Comment:

Justificación de las conductas de riesgo como beber alcohol o fumar.

1:67 ¿Cómo hacen los amigos para en.. (159:161)

Comment:

Los amigos en ocasiones son un mecanismo de presión para que los y las adolescentes incurran en conductas de riesgo como el alcohol, las drogas, la violencia.

1:70 M: A no tener relaciones sexua.. (175:176)

Comment:

Las adolescentes mencionan que si deciden ejercer antes del matrimonio la sexualidad pueden verse afectadas socialmente.

1:91 H. A veces se juntan en bolita.. (261:261)

1:92 M. Las mujeres a veces nos jun.. (262:262)

1:93 H. Me gusta mucho jugar con el.. (265:265)

1:94 M. En mi grupo de amigas me gu.. (267:267)

1:95 H. Platicamos de cuando vamos .. (268:268)

1:96 H. Experiencias de cuando anda.. (269:271)

1:97 M. De quiénes están guapos y q.. (272:273)

$1: 102 \mathrm{M}$. Las mujeres se pelean y se .. $(285: 286)$

1:106 M. Algunas situaciones con tu .. (314:314)

1:107 H. Especialmente con tus padre.. (315:315) 
1:108 M. Yo especialmente con mi mam.. (316:316)

1:112 Describan algunas situaciones .. (313:325)

$1: 114$ esa es tu experiencia con tus .. (324:324)

1:115 H. Yo casi no platico nada a n.. $(325: 325)$

1:117 M. Yo para liberarme digo lo q.. (328:328)

$\sim 1: 143 \mathrm{M}$ : Las mujeres nos enamoramos .. (103:103)

Comment:

Por qué se enamoran las muejres. Ellas hacen referencia a cuestiones emocionales.

1:146 H: Príncipe azul y la princesa.. (113:113)

8:16 M Y para impresionar a las chi.. (138:138)

8:28 M. Que platicara con sus papás.. (103:105)

10:5 ¿A esta edad se dan ese tipo d.. (156:172)

10:52 H Si porque a ellos les gusta .. (147:147)

Comment:

Esta opinión refleja cómo la mujer es vista en las relaciones de pareja como propiedad-objeto del hombre.

10:53 M Si ella trabaja en la oficin.. (148:149)

10:59 M Nombre a los 12 M Se van con.. (161:162)

10:61 M Por las hormonas (166:166)

10:62 M Porque se quieren de verdad (167:167)

10:64 H O porque la mujeres están mu.. (169:169)

10:65 M Las mujeres también amenazan.. (170:170)

10:68 M Yo conozco a una persona de .. (175:175)

10:70 M Vestirse entallada llamando .. (179:181)

10:71 H Su forma de ser H Los dos pu.. (182:183)

10:72 M. Yo no, porque los niños son.. (186:188)

10:73 M Yo sí, si me gusta porque no.. (188:188)

10:74 H A un niño no pero a una niña.. (191:192)

10:75 M Se comportan románticos (196:196)

10:76 H Se compran una camisa nueva .. (197:199)

10:80 ¿Cuáles son los prototipos de .. (201:211)

10:97 H Los hombres pelean porque le.. (234:234)

10:98 M Por defender a la hermana, p.. $(235: 235)$

10:104 M Los maestros dicen que vamos.. (242:243)

20 Citas encontradas por consulta:

"1.3.1. NOVIAZGO"

1:9 ¿A ustedes qué les atrae un ho.. (100:109)

1:44 ¿Por qué creen que se van con .. (76:80)

1:45 Qué hace que se enamoren? Resp.. (81:85)

Comment:

Un chico comenta que las mujeres se enamoran por interes, vuelve este discurso sexista donde las mujeres son consideradas como personas malas que se aprovechan de los hombres 1:46 M. O porque tienen papeles y s.. $(86: 88)$

1:47 ¿Y qué hace que los hombres se.. (94:95)

1:48 M: Yo pienso que si te casas c.. (96:96) 
$<1: 54$ ¿Y la princesa rosa? H: Amable.. (119:124)

1:70 M: A no tener relaciones sexua.. (175:176)

Comment:

Las adolescentes mencionan que si deciden ejercer antes del matrimonio la sexualidad pueden verse afectadas socialmente.

1:146 H: Príncipe azul y la princesa.. (113:113)

8:16 M Y para impresionar a las chi.. (138:138)

10:5 ¿A esta edad se dan ese tipo d.. (156:172)

10:52 H Si porque a ellos les gusta .. (147:147)

Comment:

Esta opinión refleja cómo la mujer es vista en las relaciones de pareja como propiedad-objeto del hombre.

10:53 M Si ella trabaja en la oficin.. (148:149)

10:62 M Porque se quieren de verdad (167:167)

10:70 M Vestirse entallada llamando .. (179:181)

10:71 H Su forma de ser H Los dos pu.. (182:183)

10:74 H A un niño no pero a una niña.. (191:192)

10:75 M Se comportan románticos (196:196)

10:76 H Se compran una camisa nueva .. (197:199)

10:97 H Los hombres pelean porque le.. (234:234)

8 Citas encontradas por consulta:

"1.3.2. FAMILIA"

1:107 H. Especialmente con tus padre.. (315:315)

1:108 M. Yo especialmente con mi mam.. (316:316)

1:109 M. Yo me expreso mejor con mi .. (318:318)

1:154 Pregunta/Tema: Experiencias co.. (245:262)

8:28 M. Que platicara con sus papás.. (103:105)

8:31 ¿Qué cosas quiere hacer el jov.. (127:129)

10:98 M Por defender a la hermana, p.. (235:235)

10:104 M Los maestros dicen que vamos.. (242:243)

12 Citas encontradas por consulta:

"1.3.3. AMIGOS"

1:66 M: Por curiosidad por probar 1.. (156:158)

Comment:

Justificación de las conductas de riesgo como beber alcohol o fumar.

1:67 ¿Cómo hacen los amigos para en.. (159:161)

Comment:

Los amigos en ocasiones son un mecanismo de presión para que los y las adolescentes incurran en conductas de riesgo como el alcohol, las drogas, la violencia.

1:91 H. A veces se juntan en bolita.. (261:261)

1:92 M. Las mujeres a veces nos jun.. (262:262)

1:93 H. Me gusta mucho jugar con el.. (265:265)

1:94 M. En mi grupo de amigas me gu.. (267:267) 
1:95 H. Platicamos de cuando vamos .. (268:268)

1:96 H. Experiencias de cuando anda.. (269:271)

1:97 M. De quiénes están guapos y q.. (272:273)

1:106 M. Algunas situaciones con tu .. (314:314)

1:150 ¿Qué les gusta y qué no de su .. (264:273)

8:30 Y cuando convives con esas per.. (131:133)

38 Citas encontradas por consulta:

\section{"1.4. PRÁCTICAS SEXUALES"}

1:34 M. Información sobre la sexual.. (61:61)

1:36 H. Algo de la sexualidad, pres.. (64:64)

1:39 H. Para que cuando tengan sexo.. (68:68)

1:57 H: los videos porno ¿Los chavo.. (132:136)

1:58 M: Yo creo que de los videos p.. (139:139)

1:59 H: Da asco. (142:142)

1:60 H: Por curiosidad. (144:144)

1:61 ¿A Ustedes no les ha dado curi.. (145:146)

1:62 H: Sí los he mirado pero...No (147:147)

1:63 M: En Biología hicimos un proy.. (151:151)

1:64 H: También sobre los métodos a.. (152:152)

1:69 H: No hacer el sexo a temprana.. (173:174)

1:70 M: A no tener relaciones sexua.. (175:176)

Comment:

Las adolescentes mencionan que si deciden ejercer antes del matrimonio la sexualidad pueden verse afectadas socialmente.

1:71 H. A los 12 y 13 años. H: Por .. (180:181)

Comment:

Estos rituales para la iniciación sexual pueden representar riesgos para la salud física y psicológica de los adolescentes. Se presiona para que ellos ejerzan la sexualidad y tengan una mayor experiencia porque de ello depende tener mayor prestigio social como hombre.

$\sim 1: 72 \mathrm{M}$ : Como a nuestra edad. ¿12- 1.. (183:185)

Comment:

Iniciación sexual es a los 12-13 años.

1:73 H: Ya hacerlo cuando tengas su.. (186:186)

1:74 M: A lo mejor porque la mayorí.. (189:189)

Comment:

A los chicos les presionan para iniciar la actividad sexual

$\sim 1: 75$ H. Fui a tocar y unas muchacha.. (193:193)

Comment:

Este adolescente rompe un poco con los estereotipos de género, no cede ante las presiones y atribuciones sociales por la iniciación sexual.

1:77 ¿Por qué creen que se embarace.. (198:199)

1:78 H. Las presionan. (200:200)

1:79 M: Porque algunos hombres con .. (207:207)

Comment:

Esta adolescente habla del estereotipo de ganar más identidad por el hecho de iniciarse sexualmente, pero también hace referencia a que las mujeres tienen más identidad por tener 
prácticas sexuales, actitud que anteriormente era vista como una característica propia de hombres.

1:137 H. Que al tener relaciones sex.. (177:177)

1:144 M: Sí les da asco, ¿por qué lo.. (143:143)

Comment:

Las chicas preguntan las razones por las cuales los hombres ven pornografía. Ellos señalan que es por curiosidad

8:5 ¿Qué se les dificultara entend.. (176:182)

8:10 H Sí, ya no las quieren porque.. (110:110)

Comment:

Este adolescente manifiesta que las mujeres que no conservan la virginidad son menos valoradas afectivamente.

10:16 Las protecciones (risas) (99:99)

10:57 M También embarazan y se van c.. (159:159)

10:58 H Si embarazan como a los 14 (160:160)

10:59 M Nombre a los 12 M Se van con.. (161:162)

10:60 H Los ven haciendo eso y les q.. (163:163)

10:61 M Por las hormonas (166:166)

10:62 M Porque se quieren de verdad (167:167)

10:63 M Hay amenazas a las mujeres, .. (168:168)

10:64 H O porque la mujeres están mu.. (169:169)

10:65 M Las mujeres también amenazan.. (170:170)

10:66 H Y los chicos les dicen tu no.. (171:171)

10:67 M Ah sí, por ejemplo los mucha.. (172:172)

$\sim$ 10:81 H Pues una mujer que no se ven.. (208:208)

Comment:

Con esta expresión el adolescente hace referencia a que las chicas no hayan estado con más chicos.

22 Citas encontradas por consulta:

\section{"1.5. PROBLEMÁTICAS Y/O CONFLICTOS AL EJERCER LA SEXUALIDAD"}

1:38 M. Para que no se vayan a cont.. (67:67)

1:42 H. Para prevenir embarazos no .. (73:73)

1:43 hay embarazos tempranos? ¿Desd.. (74:75)

1:44 ¿Por qué creen que se van con .. (76:80)

1:63 M: En Biología hicimos un proy.. (151:151)

1:64 H: También sobre los métodos a.. (152:152)

1:69 H: No hacer el sexo a temprana.. (173:174)

$\sim$ 1:70 M: A no tener relaciones sexua.. (175:176)

Comment:

Las adolescentes mencionan que si deciden ejercer antes del matrimonio la sexualidad pueden verse afectadas socialmente.

1:73 H: Ya hacerlo cuando tengas su.. (186:186)

1:74 M: A lo mejor porque la mayorí.. (189:189)

Comment:

A los chicos les presionan para iniciar la actividad sexual

1:76 M. Embarazos a temprana a edad.. (196:196)

1:137 H. Que al tener relaciones sex.. (177:177)

8:2 Y si estuviera embarazada ¿Qué.. (102:114) 
8:9 M Pues no sé, porque hay papás.. (109:109)

8:11 H Abortar (113:113)

8:12 M A lo mejor querer abortar a .. (114:114)

$8: 13 \mathrm{H}$ Irse con otro familiar que s.. $(115: 115)$

10:66 H Y los chicos les dicen tu no.. (171:171)

10:67 M Ah sí, por ejemplo los mucha.. (172:172)

10:87 H Sí, no saben si van a poder .. (216:216)

10:88 M O también están dudando si a.. (217:217)

10:92 M Que piensen antes de hacerlo.. (223:226)

19 Citas encontradas por consulta:

"1.6. REPRODUCCIÓN"

1:37 M. De la sexualidad, cómo se r.. (65:65)

1:42 H. Para prevenir embarazos no .. (73:73)

1:43 hay embarazos tempranos? ¿Desd.. (74:75)

1:44 ¿Por qué creen que se van con .. (76:80)

1:63 M: En Biología hicimos un proy.. (151:151)

1:73 H: Ya hacerlo cuando tengas su.. (186:186)

1:76 M. Embarazos a temprana a edad.. (196:196)

8:6 M Que platicara con sus papás .. (103:103)

8:7 H Que no se ponga triste, que .. (104:104)

8:8 M Pues a la mejor no se lo qui.. (105:105)

8:9 M Pues no sé, porque hay papás.. (109:109)

8:11 H Abortar (113:113)

8:12 M A lo mejor querer abortar a .. (114:114)

10:15 La reproducción sexual (98:98)

10:57 M También embarazan y se van c.. (159:159)

10:58 H Si embarazan como a los 14 (160:160)

10:67 M Ah sí, por ejemplo los mucha.. (172:172)

10:85 H Es una prueba de embarazo. P.. (214:226)

10:86 M Ajá y no saben qué hacer (215:215)

4 Citas encontradas por consulta:

"1.7. ITS"

1:38 M. Para que no se vayan a cont.. (67:67)

1:63 M: En Biología hicimos un proy.. (151:151)

1:69 H: No hacer el sexo a temprana.. (173:174)

1:71 H. A los 12 y 13 años. H: Por .. (180:181)

Comment:

Estos rituales para la iniciación sexual pueden representar riesgos para la salud física y psicológica de los adolescentes. Se presiona para que ellos ejerzan la sexualidad y tengan una mayor experiencia porque de ello depende tener mayor prestigio social como hombre. 


\section{Reporte de consulta zona urbana}

\section{UH: UH SEXUALIDAD Y GÉNERO}

File: [C:IUsers\PC|Documents\Tesis $\backslash 1$. Tesis SEXUALIDAD Y GÉNERO 03.hpr7]

Edited by: Super

Date/Time: 2016-03-04 10:41:35

\section{Filtro de documento: "Urbana"}

23 Citas encontradas por consulta:

\section{"1.1. SEXUALIDAD"}

2:11 Sugerencias para la asignatura.. (124:129)

3:2 ¿Qué observan en esta fotograf.. (87:111)

3:4 M. Sí. En la escuela llevan un.. (118:133)

3:16 M. Las enfermedades de transmi.. (92:92)

6:1 ¿Qué les interesa a las/os ado.. (78:90)

6:3 Cuando dices reflexionemos sob.. (190:233)

6:4 ¿Qué más les interesaría que s.. (234:263)

6:66 M Por esa misma falta de respe.. (281:283)

6:130 ¿Qué temas son difíciles de ab.. (331:338)

7:1 H Oli ¿Te acuerdas lo que hace.. (74:103)

7:9 Así es como tú piensas... En el .. (395:439)

7:10 ¿Cómo reaccionan su mamá/papá,.. (442:470)

7:11 ¿Por qué las mujeres se dejan .. (471:476)

7:24 H Los derechos de la mujer y d.. (53:59)

7:25 H Los derechos de la mujer y d.. (53:53)

7:61 M Vez, si los niños supieran q.. (139:144)

7:77 Aja... ciencias y biología y que.. (215:219)

$\sim$ 7:81 H Sin irse al lado morboso (225:225)

Comment:

Este adolescente señala que en las clases sobre sexualidad se dan burlas y comentarios morbosos.

7:86 ¿cómo sería, que se podría... co.. (222:238)

7:89 ¿Por qué crees que los niños c.. (240:248)

7:115 H Yo eso siento... yo jamás ha.. (373:373)

7:125 H Mi papá es normal. Ellos me .. (440:440)

7:220 ¿Qué más? M. Yo tenía una amig.. (319:333) 
Filtro de documento:

"Urbana"

38 Citas encontradas por consulta:

\section{"1.2. CAMBIOS FÍSICOS Y EMOCIONALES"}

2:1 Cambios que observan M Cambios.. (22:30)

2:12 M Cambios de humor repentinos,.. (23:23)

2:14 H Carácter... nos enojamos de pr.. (24:30)

2:24 M. Depende, porque ella tiene .. (66:68)

2:33 H De los cambios físicos (125:125)

2:34 M De los cambios de carácter..... (126:128)

3:3 M. Se preguntan cómo evitar, o.. (111:117)

3:17 H. Que a las niñas les tiene q.. (93:93)

3:21 M. Se preguntan cómo evitar, o.. (111:112)

3:22 M: En Biología hemos visto la .. (121:121)

3:56 H. Había una señora que hacía .. (201:201)

3:57 M. Antes yo iba a un programa .. (202:202)

3:71 M: Yo tenía una amiga que se s.. (260:260)

3:100 M: porque ya se sienten maduro.. (187:187)

3:101 H. Piensan que ya pueden hacer.. (188:188)

6:15 H Sobre la naturaleza los camb.. (82:82)

6:16 M Sobre los propios cambios qu.. (83:83)

6:17 M Las condiciones que puede 11.. (84:84)

6:18 M Como el sexo que ellos están.. (87:87)

6:94 M. Mi papá ni siquiera se da c.. (424:428)

$<6: 95$ M Cuando vamos creciendo los p.. (427:427)

6:99 ¿Cómo reaccionan las personas .. (422:439)

6:101 M Como también lo más común es.. (432:432)

7:16 H Es una nueva experiencia, un.. (29:29)

7:78 M Los cambios del cuerpo human.. (216:216)

$<7: 82$ Porque siempre que intentamos .. (226:227)

$<7: 84$ H Prácticamente porque los niñ.. (233:233)

7:86 ¿cómo sería, que se podría... co.. (222:238)

7:91 H Por aparentar H Que saben mu.. (244:245)

7:92 M Tal vez porque les da pena e.. (248:248)

Comment:

La alumna refiere que tal vez los chicos al desconocer totalmente el tema lo que hacen es bromear para evadir su falta de conocimiento.

7:125 H Mi papá es normal. Ellos me .. (440:440)

<7:126 M Mi mamá siempre me dice que .. (444:444) 
7:129 H Mi mamá siempre me dice... hay.. (454:454)

7:130 M A mí me dice mi mamá que es .. (457:458)

7:131 M A las hormonas... bueno dicen .. (472:472)

7:178 H Los diferentes tipos de sent.. (634:634)

7:205 H Sí, todos los cambios que ha.. (746:751)

7:221 Oigan... estos cambios que usted.. (439:451)

100 Citas encontradas por consulta:

\section{"1.3. VÍNCULOS AFECTIVOS"}

2:4 Sobre el noviazgo M No lo toma.. (59:68)

$\sim 2: 20$ M No lo toman en serio, es pur.. (60:60)

Comment:

Hablan sobre el noviazgo y ellas dicen que los chicos no lo toman en serio.

2:21 H Un amigo le ayuda a un chavo.. (61:61)

2:22 M. Se presentan y se van conoc.. (62:64)

2:24 M. Depende, porque ella tiene .. (66:68)

2:25 ¿Con quiénes se entienden amig.. (70:74)

2:26 ¿Con quiénes se entienden amig.. (70:85)

2:27 H Divertidos. Se divierten moj.. (75:77)

2:28 ¿De qué platican? M De las mat.. (80:83)

2:29 H De deportes, de las materias.. (84:85)

2:37 H. Tener novio ha repercutido .. (65:65)

2:38 Papá y mamá/Cambios H. Son est.. (87:91)

3:1 Lo que se les permite en su ad.. (60:74)

3:7 M: en algunos casos se da desd.. (181:197)

3:8 ¿Cómo les gustaría que fuera s.. (206:214)

3:10 M: Yo tenía una amiga que se s.. (260:272)

3:14 H. A veces nos dejan juntar co.. (66:70)

3:15 M. Mis papás, me dejan juntarm.. (65:65)

3:44 M. Algunas alumnas se pelean p.. (165:165)

3:49 a qué edades se da el noviazgo.. (182:184)

3:50 H. A mí mi mamá me dice que ha.. (190:190)

Comment:

El alumno está hablando de iniciar una relación de noviazgo.

3:51 M. Luego a algunos los aconsej.. (191:191)

3:52 M. O también el novio maltrata.. (193:193)

3:53 H. O también puede ser que el .. (194:194)

3:54 ¿Qué hacen para atraer a un ho.. (198:199)

3:55 H. También a veces hacen dieta.. (200:200)

3:58 H: Normal, que no fuera celosa.. (209:209)

3:59 M: Que sea respetuoso responsa.. (210:211) 
3:60 H: Que cada quien tenga su tie.. (212:213)

3:61 M; Que los papás permitan que .. (214:214)

3:62 M. Que no sean celosos Fotogra.. (215:221)

3:63 H: Puede ser que el novio o el.. (218:218)

3:64 H. Yo sí, con unos vecinos. Re.. (220:220)

3:65 M. También por mi casa vivía u.. (221:221)

3:72 H: Mi comportamiento, porque h.. (262:263)

3:73 H: El amor podría ser amistad .. (265:265)

3:74 M: El amor sería tener una fam.. (266:266)

3:79 M: Que a veces el novio no ace.. (286:286)

3:80 H. Que no vives tu juventud y .. (287:288)

$<3: 98 \mathrm{H}$. Que un novio es para comuni.. (197:197)

$>3: 99$ M. A veces es por moda y por p.. (198:198)

3:100 M: porque ya se sienten maduro.. (187:187)

3:101 H. Piensan que ya pueden hacer.. (188:188)

3:107 H. Prefieren a los que son del.. (177:177)

6:19 H Cómo llevarse entre ellos (93:93)

Comment:

Hace referencia las relaciones humanas.

6:29 M Y eso que nos ponemos a plat.. (136:136)

6:46 H O también por drogas. Las dr.. (207:212)

6:53 M Hay veces que las chavas cua.. (229:229)

6:68 M Con sus amigos, no especialm.. (324:324)

6:69 M También platicamos cosas de .. (325:325)

6:70 H Yo siento que a los que les .. (326:326)

6:71 H Pero también hay amigos a lo.. (327:327)

6:72 M Como también yo les tengo mu.. (328:328)

6:73 M Con mis amigas o con mi mamá.. (338:338)

6:74 H No decir nada a nadie de lo .. (342:343)

Comment:

Los amigos han de cumplir con los códigos de lealtad y confianza.

$\sim 6: 75$ M A nosotras a nuestro grupo n.. (344:345)

Comment:

Los códigos de amistad que ellas valoran son la comunicación, el respeto, la confianza y la lealtad.

6:79 H Por la novia M Por el novio .. (367:368)

6:80 M Porque dicen no que a mí me .. (371:371)

6:86 Cosas que hacen los/as adolesc.. (405:420)

6:90 H A veces se pelean para que v.. (415:415)

$\sim 6: 91 \mathrm{H} \mathrm{O}$ a veces nada más son novio.. (416:416)

Comment:

Las mujeres se fijan en hombres fuertes para que las protejan.

6:93 H Dicen que las mujeres reacci.. (420:420) 
6:94 M. Mi papá ni siquiera se da c.. (424:428)

$<6: 95$ M Cuando vamos creciendo los p.. (427:427)

$>6: 96$ H Se vuelven más estrictos (428:428)

6:97 M O el problema del novio, que.. (429:429)

6:98 H O a veces piensan que puedes.. (430:430)

6:100 M El papá es más celoso que la.. (431:431)

6:101 M Como también lo más común es.. (432:432)

6:112 M Yo cuando tengo muchos probl.. (479:481)

6:128 ¿Con qué personas las/os jóven.. (321:329)

6:129 Todos/as. Los amigos (323:323)

$6: 131 \mathrm{H}$. Con mis amigos $(337: 337)$

6:132 Características de las persona.. (340:345)

7:71 H A novios, pero acuérdense qu.. (180:180)

7:72 H A ver, les voy a poner un ej.. (182:182)

7:73 M Si, por que en mi grupo hay .. (183:184)

7:74 M Yo siento que está bien hace.. (199:203)

Comment:

Estas adolescentes manifiestan que muchas familias no abordan los temas de sexualidad porque les da vergüenza o les parece mal. La familia advierte a las jóvenes que el ejercer la sexualidad es malo y que los hombres buscan aprovecharse de ellas.

7:93 H Una relación estable... este... .. (258:382)

7:94 H Te amo (risas) (265:265)

7:95 M Te quiero M Te amo M Cosas p.. (269:271)

7:97 ¿Qué hacen los muchachos para .. (278:283)

7:98 M Y a veces que cuando pelean,.. (284:284)

7:99 H Se pintan H Como ya dije, se.. (296:297)

7:100 M Estén niños o no estén niños.. (300:301)

7:102 M Que si sus amigos lo hacen... .. (305:307)

Comment:

Percepción de las chicas sobre que motiva a los hombres a tener relaciones sexuales.

7:110 M Mis amigas siempre dicen que.. (339:342)

7:112 H Aja... y si no tiene permiso, .. (349:349)

$>$ 7:122 Si porque no las dejan estar e.. (413:416)

7:125 H Mi papá es normal. Ellos me .. (440:440)

<7:126 M Mi mamá siempre me dice que .. (444:444)

$<7: 128$ M No, para que... yo creo que pa.. (448:448)

7:129 H Mi mamá siempre me dice... hay.. (454:454)

7:130 M A mí me dice mi mamá que es .. (457:458)

7:134 H No pues nada más que se pele.. (500:500)

Comment: 
Las mujeres se pelean para que se fijen en ellas los hombres más mayores de edad.

7:135 M O a veces... si un chavo tiene.. (501:501)

7:139 H De que las peleas de niños s.. (514:514)

7:148 H Y por las mujeres... (529:529)

7:173 H Este... el amor... (Risas) es un.. (621:640)

7:215 H. O por que las 2 quieren a u.. (506:506)

53 Citas encontradas por consulta:

\section{"1.3.1. NOVIAZGO"}

2:4 Sobre el noviazgo M No lo toma.. (59:68)

3:44 M. Algunas alumnas se pelean p.. (165:165)

3:49 a qué edades se da el noviazgo.. (182:184)

3:52 M. O también el novio maltrata.. (193:193)

3:53 H. O también puede ser que el .. (194:194)

3:54 ¿Qué hacen para atraer a un ho.. (198:199)

3:55 H. También a veces hacen dieta.. (200:200)

3:58 H: Normal, que no fuera celosa.. (209:209)

3:59 M: Que sea respetuoso responsa.. (210:211)

3:60 H: Que cada quien tenga su tie.. (212:213)

3:61 M; Que los papás permitan que .. (214:214)

3:63 H: Puede ser que el novio o el.. (218:218)

3:64 H. Yo sí, con unos vecinos. Re.. (220:220)

3:65 M. También por mi casa vivía u.. (221:221)

3:79 M: Que a veces el novio no ace.. (286:286)

3:80 H. Que no vives tu juventud y .. (287:288)

$<3: 98 \mathrm{H}$. Que un novio es para comuni.. (197:197)

$>3: 99$ M. A veces es por moda y por p.. (198:198)

3:100 M: porque ya se sienten maduro.. (187:187)

3:101 H. Piensan que ya pueden hacer.. (188:188)

6:29 M Y eso que nos ponemos a plat.. (136:136)

6:53 M Hay veces que las chavas cua.. (229:229)

6:79 H Por la novia M Por el novio .. (367:368)

6:80 M Porque dicen no que a mí me .. (371:371)

6:87 M Coqueteando (407:407)

6:88 H Haciendo diseños, levantando.. (408:410)

6:89 M La mujer se empieza a arregl.. (411:412)

6:90 H A veces se pelean para que v.. (415:415)

6:91 H O a veces nada más son novio.. (416:416)

Comment:

Las mujeres se fijan en hombres fuertes para que las protejan. 
6:93 H Dicen que las mujeres reacci.. (420:420)

6:97 M O el problema del novio, que.. (429:429)

7:71 H A novios, pero acuérdense qu.. (180:180)

7:72 H A ver, les voy a poner un ej.. (182:182)

7:73 M Si, por que en mi grupo hay .. (183:184)

7:74 M Yo siento que está bien hace.. (199:203)

Comment:

Estas adolescentes manifiestan que muchas familias no abordan los temas de sexualidad porque les da vergüenza o les parece mal. La familia advierte a las jóvenes que el ejercer la sexualidad es malo y que los hombres buscan aprovecharse de ellas.

7:94 H Te amo (risas) (265:265)

7:95 M Te quiero M Te amo M Cosas p.. (269:271)

7:97 ¿Qué hacen los muchachos para .. (278:283)

7:98 M Y a veces que cuando pelean,... (284:284)

7:99 H Se pintan H Como ya dije, se.. (296:297)

7:100 M Estén niños o no estén niños.. (300:301)

$\sim 7: 102 \mathrm{M}$ Que si sus amigos lo hacen..... (305:307)

Comment:

Percepción de las chicas sobre que motiva a los hombres a tener relaciones sexuales.

7:110 M Mis amigas siempre dicen que.. (339:342)

7:112 H Aja... y si no tiene permiso, .. (349:349)

$<7: 128$ M No, para que... yo creo que pa.. (448:448)

$\sim$ 7:134 H No pues nada más que se pele.. (500:500)

Comment:

Las mujeres se pelean para que se fijen en ellas los hombres más mayores de edad.

7:135 M O a veces... si un chavo tiene.. (501:501)

7:139 H De que las peleas de niños s.. (514:514)

7:148 H Y por las mujeres... (529:529)

7:174 M Este yo pienso que el amor e.. (622:622)

7:175 M Hay una frase que dice, que .. (623:623)

7:215 H. O por que las 2 quieren a u.. (506:506)

7:223 H. Hablando de eso... aquí las p.. (624:625)

28 Citas encontradas por consulta:

"1.3.2. FAMILIA"

2:38 Papá y mamá/Cambios H. Son est.. (87:91)

3:14 H. A veces nos dejan juntar co.. (66:70) 
3:15 M. Mis papás, me dejan juntarm.. (65:65)

3:50 H. A mí mi mamá me dice que ha.. (190:190)

Comment:

El alumno está hablando de iniciar una relación de noviazgo.

3:53 H. O también puede ser que el .. (194:194)

3:61 M; Que los papás permitan que .. (214:214)

3:65 M. También por mi casa vivía u.. (221:221)

3:72 H: Mi comportamiento, porque h.. (262:263)

3:73 H: El amor podría ser amistad .. (265:265)

3:74 M: El amor sería tener una fam.. (266:266)

6:68 M Con sus amigos, no especialm.. (324:324)

6:70 H Yo siento que a los que les .. (326:326)

6:72 M Como también yo les tengo mu.. (328:328)

6:73 M Con mis amigas o con mi mamá.. (338:338)

6:94 M. Mi papá ni siquiera se da c.. (424:428)

$<6: 95$ M Cuando vamos creciendo los p.. (427:427)

6:97 M O el problema del novio, que.. (429:429)

6:98 H O a veces piensan que puedes.. (430:430)

6:100 M El papá es más celoso que la.. (431:431)

6:101 M Como también lo más común es.. (432:432)

6:102 M O a veces con los hermanos m.. (433:434)

7:74 M Yo siento que está bien hace.. (199:203)

Comment:

Estas adolescentes manifiestan que muchas familias no abordan los temas de sexualidad porque les da vergüenza o les parece mal. La familia advierte a las jóvenes que el ejercer la sexualidad es malo y que los hombres buscan aprovecharse de ellas.

7:110 M Mis amigas siempre dicen que.. (339:342)

7:112 H Aja... y si no tiene permiso, .. (349:349)

7:125 H Mi papá es normal. Ellos me .. (440:440)

<7:126 M Mi mamá siempre me dice que .. (444:444)

7:129 H Mi mamá siempre me dice... hay.. (454:454)

7:130 M A mí me dice mi mamá que es .. (457:458)

16 Citas encontradas por consulta:

\section{"1.3.3. AMIGOS"}

2:25 ¿Con quiénes se entienden amig.. (70:74)

2:26 ¿Con quiénes se entienden amig.. (70:85)

2:27 H Divertidos. Se divierten moj.. (75:77)

2:28 ¿De qué platican? M De las mat.. (80:83) 
2:29 H De deportes, de las materias.. (84:85)

3:51 M. Luego a algunos los aconsej.. (191:191)

6:46 H O también por drogas. Las dr.. (207:212)

6:68 M Con sus amigos, no especialm.. (324:324)

6:69 M También platicamos cosas de .. (325:325)

6:71 H Pero también hay amigos a lo.. (327:327)

6:73 M Con mis amigas o con mi mamá.. (338:338)

$\sim 6: 74 \mathrm{H}$ No decir nada a nadie de lo .. (342:343)

Comment:

Los amigos han de cumplir con los códigos de lealtad y confianza.

$\sim 6: 75$ M A nosotras a nuestro grupo n.. (344:345)

Comment:

Los códigos de amistad que ellas valoran son la comunicación, el respeto, la confianza y la lealtad.

6:112 M Yo cuando tengo muchos probl.. (479:481)

6:129 Todos/as. Los amigos (323:323)

$6: 131$ H. Con mis amigos $(337: 337)$

84 Citas encontradas por consulta:

\section{"1.4. PRÁCTICAS SEXUALES"}

2:30 Embarazo adolescente M. No es .. (100:105)

3:16 M. Las enfermedades de transmi.. (92:92)

3:18 H. Algunos anticonceptivos con.. (94:98)

3:19 M. Podría ser cómo actúan los .. (101:101)

Comment:

La adolescente está hablando de tener prácticas sexuales y que surjan problemáticas como las ITS, o los embarazos.

3:20 H. Podría ser que muy desesper.. (102:102)

3:23 H y M. Y las enfermedades de t.. (122:122)

3:24 M. Que son muy malas para la v.. (124:124)

$3: 25 \mathrm{H}$. que en la adolescencia o ya.. (125:125)

3:26 M. en la materia de orientació.. (126:127)

3:28 H. Las enfermedades de transmi.. (130:130)

3:29 M. Que nos dicen cómo prevenir.. (131:131)

3:30 H. Cuáles se pueden curar y cu.. (132:133)

3:81 H: Creo que hubo un caso o dos.. (289:289)

3:82 H. También en Patamban, tres o.. (290:290)

$\sim$ 3:83 H: Podría ser de secundaria en.. (293:293)

Comment:

Estan hablando sobre la edad en la que inician las relaciones sexuales 
$\sim 3: 85$ H. Que a lo mejor le hubiera g.. (295:296)

Comment:

Este adolescente es de los pocos que hace referencia a que el varón también tiene que asumir la responsabilidad del embarazo. Los demás comentarios hacían alusión a las consecuencias para las mujeres al tener que asumir solas la responsabilidad en caso de embarazarse.

3:86 M: En la primaria nos decía la.. (297:297)

$\sim 3: 88 \mathrm{H}$. La curiosidad. (302:302)

Comment:

Por qué se inicia la sexualidad

3:89 M: A veces los obligan a tener.. (303:303)

3:90 H. Que quieren saber qué se si.. (304:304)

3:91 M: También puede ser por la at.. (305:305)

6:14 M Sobre los anticonceptivos M .. (80:81)

6:17 M Las condiciones que puede 11.. (84:84)

6:18 M Como el sexo que ellos están.. (87:87)

$\sim 6: 35 \mathrm{H}$ Piensan que todas las mujere.. (167:171)

Comment:

Se refieren a las prostitutas pero no se atreven a pronunciar la palabra. Hacen bromas sobre las mujeres que no cumplen con el estereotipo de ser una mujer casta.

6:36 H Las que son homosexuales o b.. (174:179)

6:37 M Lo que dicen los compañero, .. (187:187)

$\sim 6: 38$ H y M Pues como a la nuestra, .. (191:191)

Comment:

Iniciación de la relación sexual

6:39 M Como a nuestra edad porque t.. (192:192)

$\sim 6: 40$ M Por la falta de información (196:196)

Comment:

Que es lo que les motiva a tener relaciones sexuales.

6:41 H o a veces solo por curiosida.. (197:197)

6:42 M Pero como son tan curiosos y.. (198:198)

6:44 H Pues todos los comerciales q.. (203:203)

6:45 También en la noche que pasan .. (206:206)

6:46 H O también por drogas. Las dr.. (207:212)

6:47 H Hubo una compañera que iba c.. (219:220)

Comment:

Los chicos responsabilizan a las mujeres del embarazo, también mencionan que las experiencias que se han dado en la escuela es que sus compañeras han tenido que abandonar sus estudios.

6:48 Bueno, cuando ustedes dicen qu.. (223:229)

6:49 H Por no cuidarse (224:224)

6:50 M no usan protección (225:225) 
6:54 ¿Aquí ha habido casos de viola.. (231:232)

6:55 M Las formas en las que se pue.. (236:236)

6:56 H O que los mismos maestros ha.. (237:242)

6:57 M Sobre todo porque si hay alg.. (243:243)

6:58 M Los abortos (246:246)

6:59 M También sería lo mismo que s.. (250:250)

6:60 H O también en el aborto puede.. (253:263)

$<6: 61$ H O también en el aborto puede.. (253:256)

6:65 M Bueno, un maestro de aquí le.. (278:278)

6:67 M O a la mejor que un maestro .. (318:319)

6:104 M Hay algunos maestros que coq.. (439:439)

6:124 M. Yo de eso la verdad no he s.. (218:218)

6:125 M. O también se metió con algu.. (309:309)

Comment:

Las mujeres que ejercen su sexualidad y tienen relaciones de noviazgo con varias personas son desprestigiadas y le restan valor.

7:4 ¿Por qué piensan que los/as jó.. (152:184)

$\sim<7: 32$ Oli $i$ Te acuerdas lo que hacen .. (74:74)

Comment:

Su comentario hace alusión a los videos pornográfico que circulan por la web.

7:37 M Pues que está mal, que se ve.. (85:87)

7:41 M Aparte yo creo ya solas se e.. (89:91)

7:43 H O desde aquí algunas persona.. (100:100)

7:44 M Muchos dicen que lo hacen ..... (101:103)

7:45 M Dicen que lo hacen, pero yo .. (107:107)

Comment:

La iniciación sexual también representa para las y los adolescentes una manera de demostrar que ya son personas jóvenes que han dejado de ser niños/as.

7:46 H Viendo a la comunidad de Apa.. (108:108)

7:47 M Pero no sabes si si es ciert.. (109:109)

7:48 ¿Qué piensan de que los/as jóv.. (105:150)

7:56 H Yo conocí a una niña que iba.. (130:130)

7:61 M Vez, si los niños supieran q.. (139:144)

7:62 H Yo no tengo esas enseñanzas .. (150:150)

7:63 M Porque se quieren sentir hom.. (154:155)

7:71 H A novios, pero acuérdense qu.. (180:180)

7:72 H A ver, les voy a poner un ej.. (182:182)

7:73 M Si, por que en mi grupo hay .. (183:184)

7:74 M Yo siento que está bien hace.. (199:203)

Comment:

Estas adolescentes manifiestan que muchas familias no abordan los temas de sexualidad porque les da vergüenza o les parece mal. La familia advierte a las 
jóvenes que el ejercer la sexualidad es malo y que los hombres buscan aprovecharse de ellas.

7:75 M Y las personas como saben qu.. (206:206)

7:79 M Métodos anticonceptivos M Co.. (217:218)

7:80 H Todas las enfermedades de tr.. (219:219)

$\sim$ 7:101 H A ser hombre (304:304)

Comment:

Motivos que tienen los adoelscentes para iniciarse sexualmente.

$\sim 7: 102 \mathrm{M}$ Que si sus amigos lo hacen..... (305:307)

Comment:

Percepción de las chicas sobre que motiva a los hombres a tener relaciones sexuales.

7:103 H La curiosidad M También la c.. (310:312)

Comment:

La opinión de chicos y chicas es que lo que motiva a las mujeres a tener relaciones sexuales es la curiosidad.

7:104 M Yo tenía unas compañeras, qu.. (317:317)

7:105 M Yo tenía una amiga que... ella.. (320:320)

$>$ 7:122 Si porque no las dejan estar e.. (413:416)

7:132 H Pues si lo van a hacer que u.. (475:476)

$\sim 7: 211 \mathrm{M}$. De irse de su casa... si... (360:360)

Comment:

Establecer una pareja formal.

7:212 H. De escaparse con el novio (361:361)

7:213 M. A los quince años... M. ¡A lo.. (363:367)

7:219 ¿Desde qué edad ustedes consid.. (111:127)

Comment:

Iniciación de la sexualidad

47 Citas encontradas por consulta:

\section{"1.5. PROBLEMÁTICAS Y/O CONFLICTOS AL EJERCER LA SEXUALIDAD"}

2:30 Embarazo adolescente M. No es .. (100:105)

3:12 H: Los que no entienden dicen,.. (284:304)

3:16 M. Las enfermedades de transmi.. (92:92)

3:18 H. Algunos anticonceptivos con.. (94:98)

3:19 M. Podría ser cómo actúan los .. (101:101)

Comment:

La adolescente está hablando de tener prácticas sexuales y que surjan problemáticas como las ITS, o los embarazos. 
3:20 H. Podría ser que muy desesper.. (102:102)

3:23 H y M. Y las enfermedades de t.. (122:122)

3:24 M. Que son muy malas para la v.. (124:124)

3:28 H. Las enfermedades de transmi.. (130:130)

3:29 M. Que nos dicen cómo prevenir.. (131:131)

3:30 H. Cuáles se pueden curar y cu.. (132:133)

3:80 H. Que no vives tu juventud y .. (287:288)

3:84 M. Que no es bueno porque deja.. (294:294)

$\sim 3: 85$ H. Que a lo mejor le hubiera g.. (295:296)

Comment:

Este adolescente es de los pocos que hace referencia a que el varón también tiene que asumir la responsabilidad del embarazo. Los demás comentarios hacían alusión a las consecuencias para las mujeres al tener que asumir solas la responsabilidad en caso de embarazarse.

6:3 Cuando dices reflexionemos sob.. (190:233)

6:18 M Como el sexo que ellos están.. (87:87)

6:37 M Lo que dicen los compañero, .. (187:187)

6:39 M Como a nuestra edad porque t.. (192:192)

6:42 M Pero como son tan curiosos y.. (198:198)

6:45 También en la noche que pasan .. (206:206)

6:46 H O también por drogas. Las dr.. (207:212)

6:47 H Hubo una compañera que iba c.. (219:220)

Comment:

Los chicos responsabilizan a las mujeres del embarazo, también mencionan que las experiencias que se han dado en la escuela es que sus compañeras han tenido que abandonar sus estudios.

6:48 Bueno, cuando ustedes dicen qu.. (223:229)

6:57 M Sobre todo porque si hay alg.. (243:243)

6:58 M Los abortos (246:246)

6:59 M También sería lo mismo que s.. (250:250)

6:60 H O también en el aborto puede.. (253:263)

$<6: 61 \mathrm{H}$ O también en el aborto puede.. (253:256)

$\sim 6: 125$ M. O también se metió con algu.. (309:309)

Comment:

Las mujeres que ejercen su sexualidad y tienen relaciones de noviazgo con varias personas son desprestigiadas y le restan valor.

6:127 H. No miden las consecuencias (193:193)

7:9 Así es como tú piensas... En el .. (395:439)

7:74 M Yo siento que está bien hace.. (199:203)

Comment:

Estas adolescentes manifiestan que muchas familias no abordan los temas de sexualidad porque les da vergüenza o les parece mal. La familia advierte a las 
jóvenes que el ejercer la sexualidad es malo y que los hombres buscan aprovecharse de ellas.

7:75 M Y las personas como saben qu.. (206:206)

7:79 M Métodos anticonceptivos M Co.. (217:218)

7:80 H Todas las enfermedades de tr.. (219:219)

7:116 Es que no se pone a pensar las.. (374:375)

7:117 Mi mamá, mi mamá no estudio la.. (376:376)

$<7: 118$ H Yo tenía una amiga que se fu.. (377:378)

$>$ 7:119 H Y como al año le llegó la no.. (381:381)

7:120 M Yo tengo a mis tías que tamb.. (393:393)

$<7: 121$ M Yo supe de una muchacha que .. (410:410)

$>$ 7:122 Si porque no las dejan estar e.. (413:416)

$\sim$ 7:123 M Pero bueno, era otra escuela.. (422:422)

Comment:

El reglamento de la secundarias prohíbe a los y las adolescentes tener acercamientos amoroso, esté reglamento hace que las adolescentes que se encuentren embarazadas puedan ser expulsadas de la institución.

7:124 M Yo conozco una muchacha que .. (432:432)

7:131 M A las hormonas... bueno dicen .. (472:472)

7:132 H Pues si lo van a hacer que u.. (475:476)

7:214 H. Una amiga de nosotros se fu.. (368:369)

19 Citas encontradas por consulta:

\section{"1.6. REPRODUCCIÓN"}

2:30 Embarazo adolescente M. No es .. (100:105)

3:22 M: En Biología hemos visto la .. (121:121)

$\sim 3: 78$ H: Podría arruinar la vida del.. $(285: 285)$

Comment:

Están hablando del embarazo

3:79 M: Que a veces el novio no ace.. (286:286)

3:80 H. Que no vives tu juventud y .. (287:288)

3:81 H: Creo que hubo un caso o dos.. (289:289)

3:82 H. También en Patamban, tres o.. (290:290)

3:84 M. Que no es bueno porque deja.. (294:294)

$\sim 3: 85$ H. Que a lo mejor le hubiera g.. $(295: 296)$

Comment:

Este adolescente es de los pocos que hace referencia a que el varón también tiene que asumir la responsabilidad del embarazo. Los demás comentarios hacían alusión a las consecuencias para las mujeres al tener que asumir solas la responsabilidad en caso de embarazarse. 
3:87 H. O saber mantener a los hijo.. (298:298)

6:39 M Como a nuestra edad porque t.. (192:192)

6:45 También en la noche que pasan .. (206:206)

6:47 H Hubo una compañera que iba c.. (219:220)

Comment:

Los chicos responsabilizan a las mujeres del embarazo, también mencionan que las experiencias que se han dado en la escuela es que sus compañeras han tenido que abandonar sus estudios.

$<6: 61 \mathrm{H}$ O también en el aborto puede.. (253:256)

6:63 H Algunas mujeres los venden H.. (258:259)

7:116 Es que no se pone a pensar las.. (374:375)

$<7: 121 \mathrm{M}$ Yo supe de una muchacha que .. (410:410)

7:123 M Pero bueno, era otra escuela.. (422:422)

Comment:

El reglamento de la secundarias prohíbe a los y las adolescentes tener acercamientos amoroso, esté reglamento hace que las adolescentes que se encuentren embarazadas puedan ser expulsadas de la institución.

7:124 M Yo conozco una muchacha que .. (432:432)

13 Citas encontradas por consulta:

"1.7. ITS"

3:16 M. Las enfermedades de transmi.. (92:92)

3:18 H. Algunos anticonceptivos con.. (94:98)

3:23 H y M. Y las enfermedades de t.. (122:122)

3:24 M. Que son muy malas para la v.. (124:124)

3:28 H. Las enfermedades de transmi.. (130:130)

3:29 M. Que nos dicen cómo prevenir.. (131:131)

3:30 H. Cuáles se pueden curar y cu.. (132:133)

6:14 M Sobre los anticonceptivos M .. (80:81)

6:46 H O también por drogas. Las dr.. (207:212)

6:52 H Aunque me dijo un maestro qu.. (227:228)

7:79 M Métodos anticonceptivos M Co.. (217:218)

7:80 H Todas las enfermedades de tr.. (219:219)

$>$ 7:119 H Y como al año le llegó la no.. (381:381) 


\section{Reporte de consulta categoría género por zona}

\section{UH: UH SEXUALIDAD Y GÉNERO}

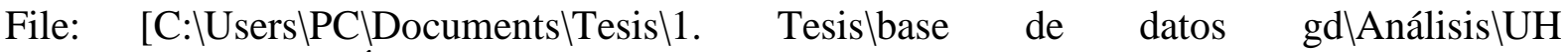
SEXUALIDAD Y GÉNERO 03.hpr7]

Edited by: Super

Date/Time: 2017-03-15 11:54:00

Filtro de documento: "Indígena"

41 Citas encontradas por consulta:

\section{"2.1. IGUALDAD Y/O DIFERENCIA"}

4:1 ¿Es lo mismo es en hombres y m.. (58:94)

4:88 Cuando se roban a la novia ¿qu.. (317:331)

4:90 ¿En estas materias han visto a.. (332:350)

$\sim 4$ :93 H. Y ahora las mujeres tienen .. (347:350)

Comment:

Ellos en cambio señalan que los hombres también colaboran en el hogar.

4:109 H. Y que las mujeres no molest.. (385:392)

5:2 ¿Qué han visto en la asignatur.. (175:185)

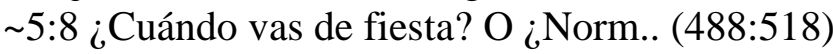

Comment:

Hombres y mujeres manifiestan que el trato que se da en las familias es igualitario, sin embargo cuando empezamos hablar de repartición de tareas en la vida cotidiana se señalan algunas cuestiones en donde se da un trato diferenciado. Las mujeres son las que lo notan más. Sin embargo están tan arraigados los estereotipos y roles de género que ellos consideran que ese trato que reciben es igualitario y es normal.

5:9 ¿Está bien, por qué Karla? M P.. (524:543)

5:16 M Si quisieran conocer las muj.. (106:106)

5:95 Alguna opinión más al respecto.. (479:483)

5:96 Todos No (480:480)

Comment:

El alumnado ante la pregunta si encuentran alguna diferencia de trato entre hombres y mujeres en la escuela. Dan un no rotundo las y los adolescentes

5:104 No, ellos se salen en la tarde.. (518:518)

5:105 Pasadas las doce, ya. ¿Y eso, .. (520:522)

$\sim 5: 106 \mathrm{Si}(521: 521)$

Comment:

Ante la pregunta consideran que estas diferencias son equitativas. Ellos responden que si y las mujeres responden que no.

$<5: 108$ Porque tanto hombres como muje.. (525:525)

$\sim 5: 112$ Mal, que debo salir porque si .. (540:540)

Comment:

El no tener los mismos derechos en su casa la hace sentir mal

5:138 M Por ejemplo, en mi casa a mi.. (687:687)

5:139 H Que hombre y mujeres deben s.. (694:694) 
$>5: 140$ ¿Pero si son? ¿Aquí en la escu.. (696:697)

5:164 M. Tener en cuenta las enferme.. (679:680)

5:165 Eso sería desigualdad, ¿No? O .. (689:691)

$\sim<5: 167$ H. En la escuela nos tratan ig.. (691:691)

Comment:

El adolescente indica que en la escuela les tratan igual y todas las personas participantes apoyan esta percepción.

9:1 Es decir que niños y niñas pod.. (94:101)

9:11 Describan una situación en la .. (594:639)

9:25 M En la materia de ciencias no.. (120:120)

9:26 H A no ser discriminados (123:123)

9:32 ¿Qué entienden por la palabra .. (143:156)

9:33 M A que todos somos iguales (145:145)

9:34 H A que todos somos equivalent.. (146:146)

9:35 H Que nadie vale más que otro,.. (149:149)

9:36 H Que no hay distinción de cla.. (150:150)

9:37 H Como si en una balanza pusie.. (156:156)

9:121 ¿De qué platicamos los chicos .. (461:484)

9:148 Ventajas de ser hombre/mujer L.. (552:565)

9:149 H Pues eso es como quien quebr.. (554:554)

9:150 H Nada más que los hombres des.. (557:558)

9:151 M En que son más ordenadas (561:561)

9:152 H En que da vida a otra vida (562:562)

9:153 H Pues que pueden hacer trabaj.. (565:565)

Comment:

Los hombres hacen referencia a que la fortaleza les da más oportunidades laborales y las mujeres no discuten está idea.

9:158 H Que los dos están embarazado.. (590:592)

Comment:

Estos adolescentes manifiestan que ante el embarazo debería de existir corresponsabilidad por el bien del bebé.

$<9: 202$ M. Que haya nuevos talleres, C.. (86:92)

155 Citas encontradas por consulta:

\section{"2.2. ROLES Y/O ESTEREOTIPOS DE GÉNERO"}

$4: 3$ ¿Por qué creen que tienen novi.. (188:198)

4:4 ¿Qué les gusta a las mujeres d.. (201:218)

4:5 ¿Y los muchachos? H. Ya hay al.. (222:241)

4:8 H. Sí, la mayoría ya lo están .. (355:365)

4:9 M. Y que los hombres para que .. (395:410)

4:13 H. Por ahí, por mi casa, en la.. (60:60)

4:15 ¿Quiénes toman más? M. Los hom.. (68:69)

4:16 H. Los hombres pero ya en la a.. (70:70)

4:28 H. Hombres. (128:128)

4:30 H. Hasta ahorita yo veo que ya.. (130:130)

4:31 H. Sí, ya hay muchas señoras d.. (131:131)

4:49 H. Que no se fijan ni cómo son.. (206:209) 
Comment:

Ante la pregunta en que les gusta a las mujeres de los hombres ellos contestan lo siguiente:

4:50 H. En que están bonitas. (212:212)

4:52 H. Son muy pocos también que s.. (214:215)

4:54 H. Y aquí hablan mucho de ella.. (217:217)

4:55 H. Ya hay algunos compañeros q.. (223:223)

Comment:

Este comentario es muy ilustrador, pues muestra como el sistema patriarcal actúa en las percepciones que tienen los adolescentes respecto a actuar como padres que regañan a la hija cuando no tiene un comportamiento que se adecua a los estereotipos de género.

$\sim 4: 56 \mathrm{H}$. Pues pienso bien porque es .. (226:229)

Comment:

Las chicas son rechazadas y señaladas cuando ejercen su sexualidad.

4:62 H. Y hay unas que se visten as.. (237:237)

4:70 M. Y no les tenían miedo a los.. (289:289)

4:82 ¿No estudia la esposa? M. No. (321:322)

$\sim 4: 83$ H. Cuando se casan muy chicos .. (325:325)

Comment:

Nuevamente con este comentario refleja cómo las mujeres continúan dependiendo de las decisiones que tomen los otros. Son los padres o las parejas las que deciden por ellas. Pareciera El hombre puede decidir que hacer, estudiar o trabajar si cuenta con el apoyo familiar en cambio la chica ha de someterse a las decisiones de los otros.

$4: 86 \mathrm{H} . .$. las regresan, o las dejan,.. (328:331)

4:88 Cuando se roban a la novia ¿qu.. (317:331)

$\sim 4: 92$ M. Y ahora los hombres tienen .. (346:346)

Comment:

El discurso de la adolescente hace referencia a cómo los roles y funciones que se consideraban propias de mujeres han evolucionado, sin embargo no refiere que los hombres hayan evolucionado en la corresponsabilidad de las tareas domésticas.

$>4: 95 \mathrm{M}$. No, porque los hombres ya n.. (356:356)

4:98 H. Pero la mayoría lo hace, po.. (359:359)

4:99 M. Porque dice la gente que un.. (360:360)

4:100 H. O también cuando el esposo .. (361:362)

4:101 M. Que se quede acostado en la.. (363:363)

$\sim 4: 102$ H. Eso está saliendo aquí porq.. (364:365)

Comment:

Este comentario también es muy ilustrador, pues el adolescente hace referencia a que cuando el hombre intenta colaborar en el hogar es fuertemente criticado. Además se refleja cómo la repartición de tareas diferenciada está totalmente asumida pues las tareas domésticas argumenta el alumno le "pertenecen" a las mujeres

$<4: 103$ H. Sí, hay un hombre que se vi.. (366:370)

4:104 H. Sí, hay un hombre que se vi.. (366:375)

$\sim 4: 108 \mathrm{H}$. Y que las mujeres no molest.. (385:385)

Comment:

Los adolescentes en el discurso reclaman los espacios de juego, porque consideran que es suyo, que las chicas han de conformarse con jugar en zonas residuales.

4:121 M. Las mujeres más, las hacen .. (434:434)

$<4: 122$ M. Ahorita como que las mujere.. (437:437)

4:155 ¿De dónde obtienen más informa.. (455:459)

5:6 A ver, los niños de qué platic.. (384:417) 
5:10 La pelea es una de las activid.. (622:650)

5:11 Qué ventajas tienen por ser ho.. (652:666)

5:14 H Del hombres y de la mujer. L.. (102:102)

5:36 M Que ella no quiere M Ella no.. (271:272)

5:37 H Se visten escotadas H Como d.. (275:278)

$\sim 5: 38 \mathrm{H}$ Se perfuman H Se portan dece.. (282:283)

Comment:

Qué hacen los hombres para atraer a las mujeres

5:39 H Se las llevan al rinconcito .. (286:287)

5:40 M Pues primero te hablan bien,.. (291:295)

5:42 M Si un amigo te pide no tomar.. (297:297)

5:68 H De las muchachas H De que mi.. (385:386)

5:69 H Del mundial H De que ya va g.. (389:390)

5:70 M De los muchachos que nos gus.. (393:394)

$\sim 5: 71 \mathrm{H}$ ¿Las amigas? De los novios, .. (398:398)

Comment:

Hace referencia a que las chicas no tienen novio sino que tienen "amigos" en tono sarcástico.

5:72 H De que me voy a poner, del m.. (404:404)

5:73 M De futbol M De futbol, nada .. (407:408)

5:74 ellos de pronto platican que s.. (410:411)

5:76 M Pues de las muchachas, de qu.. (417:417)

5:79 H ¿Cuál otro? (427:427)

5:82 M Que está pensando el muchach.. (438:438)

5:88 M Que es muy mal porque si tuv.. (458:458)

5:93 M Pues que tanto hombres como .. (474:474)

Comment:

Esta adolescente habla que la responsabilidad en el embarazo adolescente recae en las mujeres.

5:97 H Como a las 10 de la noche H .. (498:499)

5:98 M A mí no me dejan salir (502:502)

5:99 M Que porque como soy mujer no.. (505:505)

$\sim 5: 100$ menos mal que soy hombre $(508: 508)$

Comment:

Uno de los chicos refiere la ventaja que tiene al ser hombre

5:101 M Pues a mí la verdad no me 11.. (509:509)

5:103 Pues me salgo me voy a casa de.. (515:515)

5:104 No, ellos se salen en la tarde.. (518:518)

$>5: 109$ Porque no hay confianza en las.. (526:526)

$\sim 5: 110$ Porque son bien chismosas, si .. (529:529)

Comment:

Justifican la desigualdad basándose en estereotipos de género.

5:111 H no hay confianza pues H Una .. (532:533)

5:113 Que soy mujer que debo de esta.. (543:543)

5:122 H Por el barrio ¿Cómo es eso? .. (572:577)

5:123 M Yo si M Nos estábamos pelean.. (583:584)

5:126 H. Porque aquí en la escuela 1.. (602:606)

5:127 H Por el barrio H Las mujeres .. (612:613)

Comment:

Hombres y mujeres pelean por cosas distintas. 
las mujeres pelean por chicos y por que las insultan, los hombres en cambio por defender su barrio y por demostrar valentía, por ganar prestigio y por demostrar a su rival quien es el mejor.

5:128 H Por creerse más chingón H Po.. (616:617)

5:129 La pelea es una de las activid.. (622:624)

5:130 H Tener novia H Vestirse cholo.. (627:631)

Comment:

Qué les hace reafirmarse como hombres a los adolescentes

5:132 H Vestirse más bonito, con men.. (635:638)

Comment:

Qué hace a las mujeres reafirmar su feminidad los hombres responden:

5:133 M Para mi vestirme como es mi .. (641:643)

Comment:

Qué hace a las mujeres reafirmar su feminidad

5:134 M Que a las mujeres les compra.. (653:653)

Comment:

Ventajas de ser mujeres

5:135 Que somos más fuertes H Que so.. (654:655)

Comment:

Ventajas de ser hombre

5:136 M Alzar cosas pesadas (658:658)

Comment:

cosas que les limitan

5:137 H. Como hacer de comer Como ha.. (659:666)

5:138 M Por ejemplo, en mi casa a mi.. (687:687)

5:142 ¿En qué cosas los tratan difer.. (699:702)

5:144 H Como a mis hermanas las pone.. (706:706)

5:151 los pensamientos de hombres y .. (184:184)

$5: 152$ H. No, no que el hombre actúa .. (185:185)

$>5: 155$ Te pego, y ¿Qué hiciste Karla?.. (220:223)

5:161 Creen que pelean más los hombr.. (600:601)

5:166 M. Mmm, pues como desigualdad .. (690:690)

9:20 H Porque a veces no está mi ma.. (101:101)

Comment:

Este alumno señala que su madre se encarga de hacer la comida.

9:28 M Tener los mismos derechos pa.. (129:129)

9:54 H La química, la comunicación .. (262:264)

9:55 M Por los sentimientos (265:265)

9:57 H De la mejor manera, acercánd.. (271:272)

9:58 M Platicando (275:275)

9:59 H De cómo se la pasa, qué hace.. (278:279)

9:62 H También apoyar a la persona .. (283:283)

9:63 M Tener buenos sentimiento M Q.. (287:288)

9:64 H Que sea buena persona más qu.. (292:292)

9:65 H Pues bonita cara, bonito cue.. (295:295)

9:66 M En los ojos claros H La sonr.. (296:298)

9:67 M Largo y lacio (301:301)

9:68 M A mí también me gusta lacio (304:304)

9:69 M A mi ondulado (305:305)

9:70 H A mi largo H A mí como el de.. (308:309) 
9:71 H Alta, con cabello chino, con.. (315:315)

9:72 M Con músculos, ojos azules (r.. (318:319)

9:79 H Pero para eso ya tendrían qu.. (346:346)

9:80 H No siempre es así, porque a .. (347:347)

9:82 H Yo pienso que está mal porqu.. (350:350)

9:98 H Pues te acercas y les dice q.. (410:410)

9:99 M Algunas dicen que lo van a p.. (416:417)

$<9: 100$ H Yo nada más le regale una ca.. (423:423)

$<>9: 101 \mathrm{H}$ Fue como en dos semana (426:426)

$>$ 9:102 H Con nervios y emoción tambié.. (430:430)

9:103 H En mí caso mi familia no com.. (439:439)

9:112 H Las canchas (104:104)

9:120 M También nervias H Emoción M .. (433:435)

9:121 ¿De qué platicamos los chicos .. (461:484)

9:126 M De deportes o de alguna pers.. (475:475)

Comment:

Las chicas perciben que los chicos hablan de deportes y de los ligues

9:127 H De sus novios H De cuales pe.. (481:483)

Comment:

Los chicos también piensan que las chicas hablan de cuestiones relacionadas con los novios, el cine, los viajes y las aventuras.

9:129 M Que de seguro se están pelea.. (489:489)

9:137 H Ellas pelean con las manos a.. (511:511)

9:138 H A tirarse al piso, aunque se.. (514:514)

9:139 H Porque se dicen de palabras,... (518:518)

2:140 H Por un hombre (522:522)

Comment:

Las chicas pelean por cuestiones emocionales

$<9: 144 \mathrm{H}$ Los hombres (539:539)

9:150 H Nada más que los hombres des.. (557:558)

9:151 M En que son más ordenadas (561:561)

9:152 H En que da vida a otra vida (562:562)

$\sim 9: 153 \mathrm{H}$ Pues que pueden hacer trabaj.. (565:565)

Comment:

Los hombres hacen referencia a que la fortaleza les da más oportunidades laborales y las mujeres no discuten está idea.

9:154 H Ya quedó embarazada la mucha.. (569:569)

9:155 H Ahora perderían sus estudios.. (581:581)

Comment:

Es interesante que varios alumnos en diversos grupos de discusión señalan que una vez que la adolescente se embaraza pierde la posibilidad de seguir con sus estudios, ya sea porque tiene que trabajar para mantener al bebé o como dice el siguiente alumno para formar una familia. $\sim<9: 156 \mathrm{M}$ Que se tienen que casar (585:585)

Comment:

Mujeres y hombres en este grupo de discusión consideran que si una pareja decide tener el bebé su "deber" es casarse para ofrecer una vida más segura a la criatura.

$>9: 157$ H No es su obligación pero pue.. (586:586)

9:159 H Donde el hombre golpea... hay .. (596:596)

9:161 H No, porque un hombre cuando .. (602:602)

9:162 H Por decir en el caso del que.. (603:603) 
9:163 $\mathrm{H}_{\text {¡O }}$ que laves los trates!, qu.. (604:604)

9:164 M No a mí me ponen hora y a mi.. (611:611)

Comment:

Atribuyen las desigualdades de trato a una cuestión relacionada con la edad.

9:165 H Pero igual es más peligroso,.. (614:614)

9:166 H Podrían agredirle, pero hay .. (618:618)

9:167 H. Pues si también H. Podrían .. (617:619)

<9:168 H Pues ayudarle a hacer el que.. (623:623)

Comment:

Este alumno manifiesta que no le dejan colaborar en las tareas domésticas

$>9: 169 \mathrm{H} \mathrm{Si}$, si me dejan pero si hay .. (626:626)

9:170 M Llegar tarde del baile M A m.. (629:631)

Comment:

Las chicas reclaman más libertad de horarios, dicen que no las dejan salir.

9:171 M Que me dejen tener novio M T.. (634:636)

Comment:

También reclaman mayor libertad para iniciar relaciones amorosas.

9:172 H Contestan todos que si (639:639)

Comment:

A diferencia de las mujeres lo hombres de esta edad, todos confiesan que en sus hogares no les niegan la posibilidad de entablar relaciones amorosas

9:185 M Como cuidarte en el caso de .. (686:686)

9:186 H Darles palabra de inspiració.. (689:689)

9:195 H. Si a un primito chiquito, 1.. (721:721)

$\sim<9: 197$ M Si porque por un lado vas ap.. (724:724)

Comment:

Estas alumnas ven el cuidado de otros como una preparación para cuando ellas formen una familia.

9:198 H Mi tía me enseñó a cambiarle.. (725:725)

$>9: 200 \mathrm{M}$ Pues bien porque es como si .. (731:731)

38 Citas encontradas por consulta:

\section{"2.3. REPARTICIÓN DE TAREAS"}

4:8 H. Sí, la mayoría ya lo están .. (355:365)

4:22 M. En el cerro. (119:119)

4:23 H. En el cerro. H. En el campo.. (120:121)

4:24 M. A traer leña. M. Sembrar ma.. (122:123)

4:25 H. Muchos, porque muchos van a.. (124:124)

4:26 ¿En qué trabajan? M. En el cer.. (118:131)

4:27 M. O campesinos. (125:125)

4:28 H. Hombres. (128:128)

4:30 H. Hasta ahorita yo veo que ya.. (130:130)

4:31 H. Sí, ya hay muchas señoras d.. (131:131)

4:81 M. Sí, se van a trabajar, los .. (319:319)

$4: 86$ H.... las regresan, o las dejan,.. (328:331)

4:88 Cuando se roban a la novia ¿qu.. (317:331) 
$>$ 4:95 M. No, porque los hombres ya n.. (356:356)

4:97 M. Y los señores se van a trab.. (358:358)

4:98 H. Pero la mayoría lo hace, po.. (359:359)

5:23 M Yo a mi mamá (152:152)

5:97 H Como a las 10 de la noche H .. (498:499)

5:98 M A mí no me dejan salir (502:502)

5:99 M Que porque como soy mujer no.. (505:505)

5:103 Pues me salgo me voy a casa de.. (515:515)

$\sim 5: 141$ Cuando hay trabajo a nosotros .. (700:700)

Comment:

En la escuela les mandan a hacer el trabao pesado a los varones

5:142 ¿En qué cosas los tratan difer.. (699:702)

5:143 M A las niñas nos ponen a barr.. (701:701)

5:144 H Como a mis hermanas las pone.. (706:706)

$\sim 5: 145 \mathrm{Y}$ eso te parece que es equitat.. (708:710)

Comment:

Hombres y mujeres dicen que hay igualdad en la repartición de tareas diferenciadas.

9:20 H Porque a veces no está mi ma.. (101:101)

Comment:

Este alumno señala que su madre se encarga de hacer la comida.

9:158 H Que los dos están embarazado.. (590:592)

Comment:

Estos adolescentes manifiestan que ante el embarazo deberia de existir corresponsabilidad por el bien del bebé.

9:161 H No, porque un hombre cuando .. (602:602)

9:162 H Por decir en el caso del que.. (603:603)

9:163 $\mathrm{H}_{\text {¡O }} \mathrm{O}$ que laves los trates!, qu.. (604:604)

<9:168 H Pues ayudarle a hacer el que.. (623:623)

Comment:

Este alumno manifiesta que no le dejan colaborar en las tareas domésticas

$>9: 169 \mathrm{H} \mathrm{Si}$, si me dejan pero si hay .. (626:626)

9:190 ¿Quién realiza el cuidado de 1.. (703:731)

9:191 M. Si a mi primo, tiene dos añ.. (705:705)

9:192 M Porque a veces mi mamá tiene.. (709:713)

9:195 H. Si a un primito chiquito, 1.. (721:721)

9:201 M. Yo a mi hermano, también to.. (706:706)

18 Citas encontradas por consulta:

\section{"2.4. DERECHOS Y OPORTUNIDADES"}

4:72 M. Que en tutoría nos explica .. (304:304)

4:89 ¿Ustedes consideran que las mu.. (337:365)

4:90 ¿En estas materias han visto a.. (332:350)

$\sim 4: 92$ M. Y ahora los hombres tienen .. (346:346)

Comment:

El discurso de la adolescente hace referencia a cómo los roles y funciones que se consideraban propias de mujeres han evolucionado, sin embargo no refiere que los hombres hayan evolucionado en la corresponsabilidad de las tareas domésticas

$\sim<4: 93 \mathrm{H}$. Y ahora las mujeres tienen .. (347:350) 
Comment:

Ellos en cambio señalan que los hombres también colaboran en el hogar.

$>$ 4:110 H. Les quitan el balón. H. Y 1.. (388:391)

4:111 M. Que nos tengan más respeto .. (392:392)

$\sim<$ :112 M. Y que los hombres para que .. (395:395)

Comment:

Ellas argumentan que ellos ocupan las dos zonas de juego y por eso les quitan los balones

4:114 ¿Y sí las dejan jugar? M. Sí, .. (403:410)

$<5: 108$ Porque tanto hombres como muje.. (525:525)

5:112 Mal, que debo salir porque si .. (540:540)

Comment:

El no tener los mismos derechos en su casa la hace sentir mal

5:156 Los derechos fundamentales ¿Ha.. (226:232)

5:157 H. Derecho de venir a estudiar.. (229:229)

5:158 H. Derecho a la educación, a 1.. (232:232)

9:26 H A no ser discriminados (123:123)

9:27 M A no ser discriminados por d.. (126:126)

9:28 M Tener los mismos derechos pa.. (129:129)

9:149 H Pues eso es como quien quebr.. (554:554)

51 Citas encontradas por consulta:

"2.5. VIOLENCIA"

4:32 H: Muchos se van de la escuela.. (133:144)

4:33 H. Como joto, es la palabra má.. (136:136)

4:34 M. Los tienen amenazados y ell.. (137:137)

4:35 H. Y mejor se salen de la escu.. (138:142)

4:36 H. Las peleas se generan por m.. $(148: 174)$

4:37 H. Las peleas se generan por m.. (148:150)

4:38 H. Por coraje, y también se pe.. (152:153)

4:57 H. Y hay algunas que sólo se f.. (241:241)

4:63 H. Los hombres ya andan con ca.. (254:254)

4:64 H. Desde primero. H. Desde los.. (257:290)

4:66 H. El cuartel de nosotros es e.. $(278: 278)$

4:68 M. Sí, acá nosotros no porque..... (279:280)

4:84 H. Y también algún hombre que .. (326:326)

$<4: 103$ H. Sí, hay un hombre que se vi.. (366:370)

4:107 M. Más respeto hacia las mujer.. (380:382)

$>$ 4:110 H. Les quitan el balón. H. Y 1.. (388:391)

$<4: 134$ M. Que se peleen sus papás, qu.. (476:477)

4:150 H. Hasta una vez hubo una pele.. (259:259)

4:151 H. Y de repente, como aquí dic.. (260:262)

4:154 M. Sí H. Sí M. O para que no n.. (283:285)

Comment:

Las peleas son por demostrar quienes son mejores y ganar prestigio y poder.

$>4: 156$ ¿Eso llega a pasar aquí? H. Sí.. (479:481)

5:27 M Violencia (165:165)

5:28 H Entre familias (166:166) 
5:49 H O también cuando se quieren .. (327:327)

Comment:

Los alumnos hacen referencia a que la práctica sexual también se realiza con la finalidad de burlarse de las mujeres.

5:59 H Si te dijera el novio matate.. (345:345)

5:114 M Se andan peleando M Que se e.. (547:557)

5:115 Que se están peleando por una .. (548:548)

$<5: 116$ H Que se están peleando H Que .. (552:553)

5:119 M Por los muchachos, las chica.. (560:560)

5:120 No van avisar, no van decir qu.. (559:624)

5:121 M Por coraje (571:571)

Comment:

Por qué pelean los hombres las mujeres lo atribuyen a no saber controlar sus impulsos.

5:122 H Por el barrio ¿Cómo es eso? .. (572:577)

5:123 M Yo si M Nos estábamos pelean.. (583:584)

5:124 M Con arto coraje y después ad.. (591:591)

5:125 H Yo si sentí Lástima ¿Cuándo .. (592:595)

5:126 H. Porque aquí en la escuela 1.. (602:606)

5:127 H Por el barrio H Las mujeres .. (612:613)

Comment:

Hombres y mujeres pelean por cosas distintas. Las mujeres pelean por chicos y por que las insultan, los hombres en cambio por defender su barrio y por demostrar valentía, por ganar prestigio y por demostrar a su rival quien es el mejor.

5:128 H Por creerse más chingón H Po.. (616:617)

5:129 La pelea es una de las activid.. (622:624)

$\sim<5: 154$ M. La otra vez veníamos de com.. (218:218)

Comment:

Explica que intento darle una nalgada.

5:161 Creen que pelean más los hombr.. (600:601)

9:129 M Que de seguro se están pelea.. (489:489)

9:130 Fotografía 4: Chicas peleando... (486:550)

9:133 H Porque no está bien la viole.. (499:499)

9:134 H A más violencia, porque por .. (502:502)

$<9: 135 \mathrm{H}$ En la primaria si yo una vez.. (505:505)

9:137 H Ellas pelean con las manos a.. (511:511)

9:138 H A tirarse al piso, aunque se.. (514:514)

9:141 M Por insultos (525:525)

9:159 H Donde el hombre golpea... hay .. (596:596)

9:205 H. O que nada más la está usan.. (395:395)

23 Citas encontradas por consulta:

\section{"2.6. ACCESO AL PODER"}

4:38 H. Por coraje, y también se pe.. (152:153)

4:69 H. Que el otro día también se .. (288:288)

4:70 M. Y no les tenían miedo a los.. (289:289)

4:71 H. Ya no respetan a la autorid.. (290:290)

4:149 ¿O sea que cuando alguien quie.. (155:159)

4:151 H. Y de repente, como aquí dic.. (260:262) 
4:152 M. Que defienden su cuartel, q.. (277:280)

4:153 ¿Se pelean por ser los mejores.. (282:285)

5:122 H Por el barrio ¿Cómo es eso? .. (572:577)

5:125 H Yo si sentí Lástima ¿Cuándo .. (592:595)

5:126 H. Porque aquí en la escuela 1.. (602:606)

5:128 H Por creerse más chingón H Po.. (616:617)

$\sim 5: 162 \mathrm{H}$. Por el barrio $(612: 612)$

Comment:

Los hombres pelean por defender su territorio, por ganar prestigio y someter a su rival.

9:131 H O que se caen mal (490:490)

9:139 H Porque se dicen de palabras,.. (518:518)

9:142 H A ver quién puede más que la.. (529:529)

9:143 H Quizás si porque si es un gr.. (533:533)

$<9: 144$ H Los hombres (539:539)

$<>9: 145$ H Porque como en el caso de lo.. (542:543)

$<>9: 146 \mathrm{H}$ Porque tienen más fuerza (546:546)

$>9: 147$ H Porque dan con los puños cer.. (549:550)

9:159 H Donde el hombre golpea... hay .. (596:596)

9:160 H Pues no porque sería como el.. (599:599)

Comment:

Es ilustrativa esta opinión en la medida en que el alumno considera que en los hogares en los que los hombres ejercen el poder se tienen que cumplir sus reglas y el que no las acate sufrirá sanciones incluso de golpes.

25 Citas encontradas por consulta:

"2.7. DESIGUALDAD"

4:54 H. Y aquí hablan mucho de ella.. (217:217)

4:75 H. Y tampoco hacer relaciones .. (309:310)

$4: 82$ ¿No estudia la esposa? M. No. (321:322)

$\sim 4: 83$ H. Cuando se casan muy chicos .. (325:325)

Comment:

Nuevamente con este comentario refleja cómo las mujeres continúan dependiendo de las decisiones que tomen los otros. Son los padres o las parejas las que deciden por ellas. Pareciera El hombre puede decidir qué hacer, estudiar o trabajar si cuenta con el apoyo familiar en cambio la chica ha de someterse a las decisiones de los otros.

4:84 H. Y también algún hombre que .. (326:326)

4:92 M. Y ahora los hombres tienen .. (346:346)

Comment:

El discurso de la adolescente hace referencia a cómo los roles y funsiones que se consideraban propias de mujeres han evolucionado, sin embargo no refiere que los hombres haya evolucionado en la coresponsabilidad de las tareas domésticas

$>4: 95 \mathrm{M}$. No, porque los hombres ya n.. (356:356)

4:97 M. Y los señores se van a trab.. (358:358)

4:99 M. Porque dice la gente que un.. (360:360)

4:100 H. O también cuando el esposo .. (361:362)

4:101 M. Que se quede acostado en la.. (363:363)

$\sim 4: 102$ H. Eso está saliendo aquí porq.. (364:365)

Comment: 
Este comentario también es muy ilustrador, pues el adolescente hace referencia a que cuando el hombre intenta colaborar en el hogar es fuertemente criticado. Además se refleja cómo la repartición de tareas diferenciada está totalmente asumida pues las tareas domésticas argumenta el alumno le "pertenecen" a las mujeres

$\sim 4: 108 \mathrm{H}$. Y que las mujeres no molest.. (385:385)

Comment:

Los adolescentes en el discurso reclaman los espacios de juego, porque consideran que es suyo, que las chicas han de conformarse con jugar en zonas residuales.

$\sim 4$ :112 M. Y que los hombres para que .. (395:395)

Comment:

Ellas argumentan que ellos ocupan las dos zonas de juego y por eso les quitan los balones

4:114 ¿Y sí las dejan jugar? M. Sí, .. (403:410)

5:99 M Que porque como soy mujer no.. (505:505)

5:104 No, ellos se salen en la tarde.. (518:518)

$\sim 5: 107$ No (522:522)

Comment:

Las mujeres perciben más la desigualdad que los hombres

$<5: 108$ Porque tanto hombres como muje.. (525:525)

5:113 Que soy mujer que debo de esta.. (543:543)

5:138 M Por ejemplo, en mi casa a mi.. (687:687)

$\sim 5: 141$ Cuando hay trabajo a nosotros .. (700:700)

Comment:

En la escuela les mandan a hacer el trabajo pesado a los varones

5:143 M A las niñas nos ponen a barr.. (701:701)

5:144 H Como a mis hermanas las pone.. (706:706)

5:166 M. Mmm, pues como desigualdad .. (690:690) 


\section{UH: UH SEXUALIDAD Y GÉNERO 03}

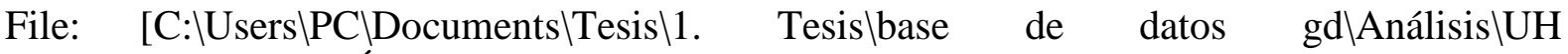
SEXUALIDAD Y GÉNERO 03.hpr7]

Edited by: Super

Date/Time: 2017-03-15 17:32:22

Filtro de documento: "Rural"

33 Citas encontradas por consulta:

\section{"2.1. IGUALDAD Y/O DIFERENCIA"}

1:15 M. Se me permite, lo más tarde.. (212:223)

1:19 H. Si Pregunta: ¿Qué piensan s.. (341:364)

1:21 H. Las chiquillas no hacen nad.. (36:48)

1:25 H. Las chiquillas no hacen nad.. (36:37)

$\sim 1: 26$ H. Nada más se la pasan jugand.. (42:43)

Comment:

Ventajas de las mujeres

1:28 H. Lo que califica el maestro .. (45:45)

1:30 H. Es que el maestro les dicen.. (47:47)

1:31 M. El maestro nos tendría que .. (48:48)

1:40 buscan información por igual m.. (69:71)

1:91 H. A veces se juntan en bolita.. (261:261)

1:92 M. Las mujeres a veces nos jun.. (262:262)

1:93 H. Me gusta mucho jugar con el.. (265:265)

1:121 M. Creo que debes tratar a hom.. (342:342)

1:122 M. Las mujeres podemos trabaja.. (343:343)

1:123 H. ¿Pueden las mujeres ser alb.. (344:344)

1:124 M. Las mujeres no sólo son par.. (347:347)

1:125 H. En el freeway a pizcar fres.. (348:348)

1:126 H. Que pueden ser iguales, los.. (349:349)

1:127 M. Mi mamá trabaja le ayuda a .. (350:350)

1:129 M. Yo opino que el hombre pued.. (357:357)

1:130 H. Estaba en estados unidos y .. (358:358)

1:131 M. A algunos hombres les gusta.. (359:359)

1:132 M. Yo escuché al novio de una .. (360:360)

1:134 H. Pero yo no entiendo cómo lo.. (362:362)

1:136 H. Hay gente que viene del nor.. (364:364)

1:145 M. Sí, pero no pueden cargar b.. (345:345)

Comment:

Un chico pregunta que si las mujeres pueden realizar tareas de albañilería y ella responde que si, sin embargo argumenta que no puede cargar bultos.

8:3 M Me respetan H Hay algunos qu.. (132:143)

10:7 H Fuerza, a veces las mujeres..... (278:285)

10:35 ¿Por qué creen que hay esas di.. (111:117)

10:39 M Hay más diferencia entre las.. (115:117) 
10:40 Ustedes aquí en la escuela ¿Qu.. (119:124)

10:71 H Su forma de ser H Los dos pu.. (182:183)

10:73 M Yo sí, si me gusta porque no.. (188:188)

114 Citas encontradas por consulta:

"2.2. ROLES Y/O ESTEREOTIPOS DE GÉNERO"

1:10 Pregunta / Tema: ¿Cuáles son 1.. (111:125)

1:16 ¿Qué les gustaría que se les p.. (230:234)

1:21 H. Las chiquillas no hacen nad.. (36:48)

1:23 Pregunta ¿Qué caracteriza al g.. (260:274)

$\sim 1: 26$ H. Nada más se la pasan jugand.. (42:43)

Comment:

Ventajas de las mujeres

1:27 M. Pero es que también él se 1.. (44:44)

Comment:

Los hombres son menos responsables con la tareas/deberes.

1:29 H. Pero no se compara una muje.. (46:46)

1:35 H. Lo que quieren ser de grand.. (62:63)

1:42 H. Para prevenir embarazos no .. (73:73)

1:43 hay embarazos tempranos? ¿Desd.. (74:75)

$\sim 1: 45$ Qué hace que se enamoren? Resp.. (81:85)

Comment:

Un chico comenta que las mujeres se enamoran por interés, vuelve este discurso sexista donde las mujeres son consideradas como personas malas que se aprovechan de los hombres

1:46 M. O porque tienen papeles y s.. (86:88)

1:47 ¿Y qué hace que los hombres se.. (94:95)

1:48 M: Yo pienso que si te casas c.. (96:96)

$\sim$ 1:49 H. Pero va ser ama de casa. (R.. (97:98)

Comment:

Se reafirma en su opinión de que las mujeres deben hacerse cargo de las tareas del hogar.

$\sim 1: 51 \mathrm{H}$ : Una mujer por su escultura,.. (102:102)

Comment:

Por qué les gusta una mujer, hacen referencia al aspecto físico, ellos.

1:52 ¿Qué más les gusta de cómo son.. (105:109)

1:53 Describan al príncipe azul y a.. (114:117)

$<1: 54$ ¿Y la princesa rosa? H: Amable.. (119:124)

$>1: 55 \mathrm{M}$ : Las princesas no hacen queh.. (125:125)

1:61 ¿A Ustedes no les ha dado curi.. (145:146)

1:67 ¿Cómo hacen los amigos para en.. (159:161)

Comment:

Los amigos en ocasiones son un mecanismo de presión para que los y las adolescentes incurran en conductas de riesgo como el alcohol, las drogas, la violencia.

1:68 M: Los amigos te dicen si ello.. (162:162)

Comment:

Para ello, los grupos de amigos emplean algunas sanciones sociales como por ejemplo poner en cuestión la hombría en un ámbito determinado como por ejemplo la escuela. 
1:69 H: No hacer el sexo a temprana.. (173:174)

1:70 M: A no tener relaciones sexua.. (175:176)

Comment:

Las adolescentes mencionan que si deciden ejercer antes del matrimonio la sexualidad pueden verse afectadas socialmente.

$\sim 1: 71$ H. A los 12 y 13 años. H: Por .. (180:181)

Comment:

Estos rituales para la iniciación sexual pueden representar riesgos para la salud física y psicológica de los adolescentes. Se presiona para que ellos ejerzan la sexualidad y tengan una mayor experiencia porque de ello depende tener mayor prestigio social como hombre.

1:73 H: Ya hacerlo cuando tengas su.. (186:186)

1:74 M: A lo mejor porque la mayorí.. (189:189)

Comment:

A los chicos les presionan para iniciar la actividad sexual

1:76 M. Embarazos a temprana a edad.. (196:196)

1:79 M: Porque algunos hombres con .. (207:207)

Comment:

Esta adolescente habla del estereotipo de ganar más identidad por el hecho de iniciarse sexualmente, pero también hace referencia a que las mujeres tienen más identidad por tener prácticas sexuales, actitud que anteriormente era vista como una característica propia de hombres.

1:80 M. Se me permite, lo más tarde.. (212:212)

1:81 H. Cuando salgo con mis amigos.. (213:213)

1:82 M. Mira la diferencia tú eres .. (214:214)

1:83 H. Llegando de la escuela, hag.. (215:215)

1:84 M. Me permiten salir a la canc.. (216:216)

1:85 M. Nada. A veces me invitan a .. (220:220)

1:86 H. Yo nomás en las tardes y en.. (222:223)

1:87 H. A mí no me dejan andar con .. (225:225)

1:88 H. No me dejan salir porque de.. (228:228)

1:89 H. Montar a caballo y andar ju.. (231:232)

1:90 M. Me gustaría que me dejaran .. (233:234)

1:91 H. A veces se juntan en bolita.. (261:261)

1:92 M. Las mujeres a veces nos jun.. (262:262)

1:94 M. En mi grupo de amigas me gu.. (267:267)

1:95 H. Platicamos de cuando vamos .. (268:268)

1:96 H. Experiencias de cuando anda.. (269:271)

1:97 M. De quiénes están guapos y q.. (272:273)

1:98 M. Yo creo que en los dos géne.. (276:278)

1:100 M. En lugar de calmarlas les d.. (280:281)

1:103 H. Una vez me pelee. Estábamos.. (287:287)

1:106 M. Algunas situaciones con tu .. (314:314)

1:108 M. Yo especialmente con mi mam.. (316:316)

1:109 M. Yo me expreso mejor con mi .. (318:318)

1:110 H. Yo no me expreso. (319:319)

1:113 Una alumna pregunta a otra ¿no.. (324:324)

1:116 M. Yo para liberarme digo lo q.. (328:333)

1:117 M. Yo para liberarme digo lo q.. (328:328)

1:118 H. Yo voy a trabajar con mi tí.. (329:330)

1:119 H. Trabajar para ganar dinero,.. (332:332) 
1:123 H. ¿Pueden las mujeres ser alb.. (344:344)

1:124 M. Las mujeres no sólo son par.. (347:347)

1:128 M. Hay hombres machistas que q.. (352:352)

1:131 M. A algunos hombres les gusta.. (359:359)

1:132 M. Yo escuché al novio de una .. (360:360)

1:133 H. Yo si le ayudo a mi mamá. C.. (361:361)

1:134 H. Pero yo no entiendo cómo lo.. (362:362)

1:135 M. A lo mejor porque dicen que.. (363:363)

1:136 H. Hay gente que viene del nor.. (364:364)

1:138 ¿En la escuela que les gustarí.. (236:237)

1:142 H. Nosotros sembramos H. Cosec.. (39:40)

1:143 M: Las mujeres nos enamoramos .. (103:103)

Comment:

Por qué se enamoran las mujeres. Ellas hacen referencia a cuestiones emocionales.

$\sim$ 1:145 M. Sí, pero no pueden cargar b.. (345:345)

Comment:

Un chico pregunta que si las mujeres pueden realizar tareas de albañilería y ella responde que si, sin embargo argumenta que no puede cargar bultos.

1:146 H: Príncipe azul y la princesa.. (113:113)

8:3 M Me respetan H Hay algunos qu.. (132:143)

8:9 M Pues no sé, porque hay papás.. (109:109)

8:10 H Sí, ya no las quieren porque.. (110:110)

Comment:

Este adolescente manifiesta que las mujeres que no conservan la virginidad son menos valoradas afectivamente.

8:14 M Para impresionar y sentirse .. (136:136)

8:15 H Sí, para impresionar (137:137)

8:16 M Y para impresionar a las chi.. (138:138)

8:17 M A veces sí, porque se ven má.. (141:141)

$<8: 21$ M Algunos se cambian el sexo, .. (168:168)

$>8: 22 \mathrm{H}$ ¡No! Quién iba a hacer eso (169:169)

8:23 M Sí, algunos sí, pero aquí no.. (170:170)

10:8 Cuando es de hombres no ponen .. (72:72)

10:14 Diferencia entre hombre y muje.. (97:97)

10:20 A demás las mujeres se llevan .. (106:107)

$\sim 10: 21 \mathrm{Si}$, a veces. Pero algunas vece.. (108:108)

Comment:

Acepta que en algunas ocasiones se aprovechan de su condición de mujeres, pero también les atribuyen a ellos la puesta en práctica de acciones violentas que luego no les son reprendidas.

10:30 H La diversión empieza en por .. (45:45)

10:31 H No, a ver se organiza por dí.. (52:52)

10:38 H Tienen diferentes formas de .. (114:114)

10:41 M En biología hemos visto los .. (120:120)

10:42 H Sí, los estereotipos de hom.. (121:122)

Comment:

Aunque refieren que han visto el tema de estereotipos en biología los chicos confunden su significado. Ellos hacen referencia a la discriminación y violencia que se ejerce sobre las mujeres por no cumplir con un estereotipo de belleza.

10:51 M También sobre la violencia e.. (144:146)

$\sim 10: 52 \mathrm{H}$ Si porque a ellos les gusta .. (147:147) 
Comment:

Esta opinión refleja cómo la mujer es vista en las relaciones de pareja como propiedad-objeto del hombre.

10:62 M Porque se quieren de verdad (167:167)

10:69 ¿Qué hacen los hombres y las m.. (178:199)

10:70 M Vestirse entallada llamando .. (179:181)

10:72 M. Yo no, porque los niños son.. (186:188)

10:75 M Se comportan románticos (196:196)

10:76 H Se compran una camisa nueva .. (197:199)

10:77 M Una mujer pintarse los labio.. (202:202)

10:80 ¿Cuáles son los prototipos de .. (201:211)

10:82 M No tan cursi, que sea chisto.. (209:209)

Comment:

Cómo deben ser las chicas para que sean atractivas para otras personas.

10:83 H Que no sea materialista (210:210)

10:84 M Que no sea plástica - Hueca (211:211)

10:92 M Que piensen antes de hacerlo.. (223:226)

10:94 M Peleando con el novio M Por .. (229:230)

10:98 M Por defender a la hermana, p.. (235:235)

10:107 M A veces les ponen más atenci.. (279:279)

10:108 M Las mujeres podemos pensar e.. (280:280)

10:109 H Que las mujeres pasan primer.. (281:281)

10:111 H Es que las mujeres siempre e.. (283:283)

10:112 M A un amigo no hizo algo y no.. (284:284)

10:113 H Los maestros son más toleran.. (285:285)

41 Citas encontradas por consulta:

\section{"2.3. REPARTICIÓN DE TAREAS"}

1:16 ¿Qué les gustaría que se les p.. (230:234)

1:21 H. Las chiquillas no hacen nad.. (36:48)

1:24 Que las mamás trajeran recetas.. (31:31)

$1: 25 \mathrm{H}$. Las chiquillas no hacen nad.. (36:37)

1:28 H. Lo que califica el maestro .. (45:45)

1:29 H. Pero no se compara una muje.. (46:46)

1:30 H. Es que el maestro les dicen.. (47:47)

1:31 M. El maestro nos tendría que .. (48:48)

1:47 ¿Y qué hace que los hombres se.. (94:95)

1:48 M: Yo pienso que si te casas c.. (96:96)

$\sim$ 1:49 H. Pero va ser ama de casa. (R.. (97:98)

Comment:

Se reafirma en su opinión de que las mujeres deben hacerse cargo de las tareas del hogar.

$<1: 54$ ¿Y la princesa rosa? H: Amable.. (119:124)

1:83 H. Llegando de la escuela, hag.. (215:215)

1:84 M. Me permiten salir a la canc.. (216:216)

1:86 H. Yo nomás en las tardes y en.. (222:223)

1:87 H. A mí no me dejan andar con .. $(225: 225)$ 
1:89 H. Montar a caballo y andar ju.. (231:232)

1:90 M. Me gustaría que me dejaran .. (233:234)

1:116 M. Yo para liberarme digo lo q.. (328:333)

1:118 H. Yo voy a trabajar con mi tí.. (329:330)

1:119 H. Trabajar para ganar dinero,.. (332:332)

1:121 M. Creo que debes tratar a hom.. (342:342)

1:122 M. Las mujeres podemos trabaja.. (343:343)

1:123 H. ¿Pueden las mujeres ser alb.. (344:344)

1:125 H. En el freeway a pizcar fres.. (348:348)

1:126 H. Que pueden ser iguales, los.. (349:349)

1:127 M. Mi mamá trabaja le ayuda a .. (350:350)

1:128 M. Hay hombres machistas que q.. (352:352)

1:129 M. Yo opino que el hombre pued.. (357:357)

1:130 H. Estaba en estados unidos y .. (358:358)

1:131 M. A algunos hombres les gusta.. (359:359)

1:132 M. Yo escuché al novio de una .. (360:360)

1:133 H. Yo si le ayudo a mi mamá. C.. (361:361)

1:134 H. Pero yo no entiendo cómo lo.. (362:362)

1:135 M. A lo mejor porque dicen que.. (363:363)

1:142 H. Nosotros sembramos H. Cosec.. (39:40)

1:145 M. Sí, pero no pueden cargar b.. (345:345)

Comment:

Un chico pregunta que si las mujeres pueden realizar tareas de albañilería y ella responde que si, sin embargo argumenta que no puede cargar bultos.

10:9 mi mamá trabaja mucho y no pue.. (76:76)

10:12 A mí solo me gusta estudiar, a.. (81:81)

10:32 M A nosotras baile, porque aun.. (57:58)

10:74 H A un niño no pero a una niña.. (191:192)

11 Citas encontradas por consulta:

\section{"2.4. DERECHOS Y OPORTUNIDADES"}

1:4 H. Yo porque me quiero superar.. (52:57)

1:80 M. Se me permite, lo más tarde.. (212:212)

1:81 H. Cuando salgo con mis amigos.. (213:213)

1:121 M. Creo que debes tratar a hom.. (342:342)

1:122 M. Las mujeres podemos trabaja.. (343:343)

1:124 M. Las mujeres no sólo son par.. (347:347)

1:126 H. Que pueden ser iguales, los.. (349:349)

1:127 M. Mi mamá trabaja le ayuda a .. (350:350)

10:10 Pues para tener una vida mejor.. (78:79)

10:11 Así nada más trabajo en vacaci.. (80:80)

10:110 M A veces tienen más oportunid.. (282:282)

Filtro de documento: 
"Rural"

29 Citas encontradas por consulta:

"2.5. VIOLENCIA"

1:77 ¿Por qué creen que se embarace.. (198:199)

1:78 H. Las presionan. (200:200)

1:88 H. No me dejan salir porque de.. (228:228)

1:98 M. Yo creo que en los dos géne.. (276:278)

1:99 H. No es bueno pelear, hay que.. (279:279)

1:100 M. En lugar de calmarlas les d.. (280:281)

1:102 M. Las mujeres se pelean y se .. $(285: 286)$

1:103 H. Una vez me pelee. Estábamos.. (287:287)

$1: 104 \mathrm{M}$. Es que a nadie le gusta que.. (288:289)

1:105 M. Pero entre nosotras nos pon.. (291:291)

1:139 Estímulo: Fotografía: imagen d.. (275:291)

1:141 H. O a veces se agarran a deci.. (290:290)

8:5 ¿Qué se les dificultara entend.. (176:182)

$8: 24 \mathrm{H}$ Las violaciones (risas) (177:177)

$8: 25 \mathrm{H}$ ¿Por qué las golpean o por q.. (180:180)

8:26 H Abusan pero que no quieren h.. (182:182)

8:27 M Porque abusan de ellas (181:181)

10:4 M También sobre la violencia e.. (144:150)

$\sim$ 10:17 Porque se madrean (*pelean) ri.. (102:102)

Comment:

Ante la pregunta que diferencias entre hombres y mujeres están leyendo se dan una serie de respuestas relacionadas con la violencia de género

10:18 Porque los dos empiezan de lle.. (103:103)

10:19 Los niños también empiezan a 1.. (104:104)

Comment:

Los hijos empiezan a llorar por las peleas de pareja.

10:53 M Si ella trabaja en la oficin.. (148:149)

10:63 M Hay amenazas a las mujeres, .. (168:168)

10:65 M Las mujeres también amenazan.. (170:170)

10:66 H Y los chicos les dicen tu no.. (171:171)

10:67 M Ah sí, por ejemplo los mucha.. (172:172)

10:68 M Yo conozco a una persona de .. (175:175)

10:93 Vamos a ver otra imagen. Mujer.. (228:239)

10:97 H Los hombres pelean porque le.. (234:234)

6 Citas encontradas por consulta:

"2.6. ACCESO AL PODER"

1:128 M. Hay hombres machistas que q.. (352:352)

10:37 H Porque son muy creídos o muy.. (113:113)

$\sim 10: 52 \mathrm{H}$ Si porque a ellos les gusta .. (147:147) 
Comment:

Esta opinión refleja cómo la mujer es vista en las relaciones de pareja como propiedad-objeto del hombre.

10:53 M Si ella trabaja en la oficin.. (148:149)

10:68 M Yo conozco a una persona de .. (175:175)

10:100 M También para lucirse y decir.. (237:237)

7 Citas encontradas por consulta:

\section{"2.7. DESIGUALDAD"}

1:82 M. Mira la diferencia tú eres .. (214:214)

1:124 M. Las mujeres no sólo son par.. (347:347)

1:128 M. Hay hombres machistas que q.. (352:352)

1:131 M. A algunos hombres les gusta.. (359:359)

1:132 M. Yo escuché al novio de una .. (360:360)

1:134 H. Pero yo no entiendo cómo lo.. (362:362)

8:18 M ¿Qué porque se dividieron lo.. (163:163) 


\section{UH: UH SEXUALIDAD Y GÉNERO 03

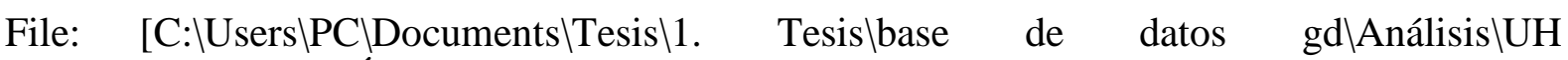 SEXUALIDAD Y GÉNERO 03.hpr7] \\ Edited by: Super \\ Date/Time: 2017-04-11 08:20:38}

Filtro de documento: "Urbana"

35 Citas encontradas por consulta:

\section{"2.1. IGUALDAD Y/O DIFERENCIA"}

2:2 ¿A qué suena Educación Sexual .. (47:54)

2:15 M Vienen los derechos de hombr.. (49:49)

2:16 M En la vida real no es así, q.. (52:52)

2:17 M Aquí en industria del vestid.. (53:53)

2:18 $\mathrm{H}$ En el deporte hay más equipo.. (54:54)

2:19 ¿Cómo se sienten tratados como.. (56:57)

Comment:

Todos/as manifiestan que ellos perciben que existe igualdad entre hombres y mujeres.

2:34 M De los cambios de carácter... .. (126:128)

3:6 ¿Algo más que no ven en Orient.. (161:172)

3:13 M: También puede ser por la at.. (305:317)

3:31 M. Que las niñas y a los niños.. (134:134)

3:32 ¿Consideran que hay desigualda.. (136:138)

3:34 M. Algunas cosas son diferente.. (143:143)

3:38 M. O que también en algunas ca.. (154:154)

3:39 M. Niños y niñas tienen las mi.. (155:155)

3:40 H. Antes también el voto, sólo.. (156:157)

3:41 M. y también, leí en un libro .. (158:158)

3:43 H. Que hubiera juegos y activi.. (162:162)

3:94 M. Que las mujeres también tie.. (310:310)

3:95 M: Aquí en la escuela nos trat.. (311:313)

Comment:

Reafirman la igualdad en la escuela cuando antes comentaron algunas diferencias según el sexo.

3:96 H: Aquí se nos trata por igual.. (314:314)

6:2 El respeto ¿Qué opinan de la f.. (138:180)

6:8 ¿En qué situaciones han observ.. (567:586)

6:20 M Los derechos ¿Derechos qué...?.. (96:99)

6:21 H La igualdad H La igualdad en.. (100:101)

6:22 Ustedes creen que hay igualdad.. (104:109)

6:122 O equidad de género ¿verdad? E.. (185:187)

7:14 ¿Qué es la igualdad entre homb.. (642:710)

7:24 H Los derechos de la mujer y d.. (53:59)

7:181 M Claro que no... una mujer pued.. (646:646) 
7:183 M Pero también podemos ser mej.. (649:649)

7:190 M Y que... también las mujeres t.. (658:659)

7:192 M Claro que si... Y hasta más qu.. (661:662)

7:197 H Pero solamente en el caso de.. (676:676)

7:206 H Este... si violan a una mujer,.. (766:766)

7:227 ¿En su familia tienen los mism.. (712:738)

109 Citas encontradas por consulta:

\section{"2.2. ROLES Y/O ESTEREOTIPOS DE GÉNERO"}

$\sim 2: 20$ M No lo toman en serio, es pur.. (60:60)

Comment:

Hablan sobre el noviazgo y ellas dicen que los chicos no lo toman en serio.

2:21 H Un amigo le ayuda a un chavo.. (61:61)

2:22 M. Se presentan y se van conoc.. (62:64)

2:28 ¿De qué platican? M De las mat.. (80:83)

2:29 H De deportes, de las materias.. (84:85)

2:30 Embarazo adolescente M. No es .. (100:105)

3:5 M. Que las niñas y a los niños.. (134:159)

3:27 H. Unos a otros, decirse malas.. (128:128)

3:33 H. Como a mí mis amigos me dic.. (140:142)

3:35 M. Algunas veces no porque lue.. (147:147)

3:38 M. O que también en algunas ca.. (154:154)

3:52 M. O también el novio maltrata.. (193:193)

3:54 ¿Qué hacen para atraer a un ho.. (198:199)

3:69 H. Podría ser que necesitan at.. (243:243)

3:75 M: Cuando hay una actividad se.. (282:284)

3:77 H: En el taller de carpintería.. (283:283)

3:87 H. O saber mantener a los hijo.. (298:298)

3:97 M. Yo también me metí a otro p.. (139:139)

Comment:

Esta alumna nos comenta que en su escuela se metió a un taller que sele ser considerado para "chicos" y a ella si le dieron permiso en su casa pero que a otras chicas no les permiten entrar porque consideran que no son disciplinas apropiadas para mujeres y los chicos les hacen burla.

$<3: 98$ H. Que un novio es para comuni.. (197:197)

$>3: 99$ M. A veces es por moda y por p.. $(198: 198)$

6:27 M Vete a la verga M Hijo de tu.. (127:129)

Comment:

Las chicas hacen referencia a que las mujeres que agreden verbalmente se ven peor que los hombres. Esto es muestra de que a los hombres se les permite realizar más trasgresiones que a las mujeres.

6:28 M Si a veces o también a las m.. (133:133)

6:29 M Y eso que nos ponemos a plat.. (136:136)

6:33 ¿Y quiénes son más irrespetuos.. (157:161)

6:34 M Porque a veces los hombres n.. (164:164)

6:39 M Como a nuestra edad porque t.. (192:192) 
6:46 H O también por drogas. Las dr.. (207:212)

$\sim 6: 47$ H Hubo una compañera que iba c.. (219:220)

Comment:

Los chicos responsabilizan a las mujeres del embarazo, también mencionan que las experiencias que se han dado en la escuela es que sus compañeras han tenido que abandonar sus estudios.

6:53 M Hay veces que las chavas cua.. (229:229)

6:56 H O que los mismos maestros ha.. (237:242)

$<6: 61 \mathrm{H}$ O también en el aborto puede.. (253:256)

6:76 Cómo se divierten los/as jóven.. (350:352)

6:77 H Entre hombres sí (355:355)

$\sim 6: 85$ M O porque tienen problemas en.. (379:380)

Comment:

Cuando muestras sentimientos se ríen, y cuando empleas violencia te ganas el respeto de los demás

6:88 H Haciendo diseños, levantando.. (408:410)

6:89 M La mujer se empieza a arregl.. (411:412)

6:90 H A veces se pelean para que v.. (415:415)

$\sim 6: 91 \mathrm{H} \mathrm{O}$ a veces nada más son novio.. (416:416)

Comment:

Las mujeres se fijan en hombres fuertes para que las protejan.

6:93 H Dicen que las mujeres reacci.. (420:420)

6:94 M. Mi papá ni siquiera se da c.. (424:428)

6:97 M O el problema del novio, que.. (429:429)

6:100 M El papá es más celoso que la.. (431:431)

6:102 M O a veces con los hermanos m.. (433:434)

6:103 M Igual hay profes que te cuid.. (438:438)

$<6: 110 \mathrm{H}$ La mayoría de las mujeres es.. (473:473)

6:112 M Yo cuando tengo muchos probl.. (479:481)

6:119 H En que algunos maestros siem.. (568:568)

6:120 M Siempre tienen una alumna pr.. (569:569)

6:125 M. O también se metió con algu.. (309:309)

Comment:

Las mujeres que ejercen su sexualidad y tienen relaciones de noviazgo con varias personas son desprestigiadas y le restan valor.

7:4 ¿Por qué piensan que los/as jó.. (152:184)

$<7: 40 \mathrm{H}$ Ya las niñas bien que les gu.. (92:96)

$\sim 7: 42$ M Bueno a algunas niñas les gu.. (97:99)

Comment:

Se justifica el abuso sexual, porque dicen que las niñas que suben fotos con poca ropa dan pie a que los hombres puedan acosarlas y manosearlas. Las percepciones que tienen los y las adolescentes a este respecto justifica la violencia de género.

$\sim$ 7:45 M Dicen que lo hacen, pero yo .. (107:107)

Comment:

La iniciación sexual también representa para las y los adolescentes una manera de demostrar que ya son personas jóvenes que han dejado de ser niños/as.

7:46 H Viendo a la comunidad de Apa.. (108:108)

7:61 M Vez, si los niños supieran q.. (139:144)

7:63 M Porque se quieren sentir hom.. (154:155)

7:64 H Y también el fumar H De hech.. (156:157) 
$\sim<7: 67$ H Se pintan, se traen su ropit.. (166:166)

Comment:

Percepción que tienen los hombres sobre como reafirman su feminidad las mujeres.

7:73 M Si, por que en mi grupo hay .. (183:184)

$<7: 82$ Porque siempre que intentamos .. (226:227)

7:97 ¿Qué hacen los muchachos para .. (278:283)

7:98 M Y a veces que cuando pelean,... (284:284)

7:99 H Se pintan H Como ya dije, se.. (296:297)

7:101 H A ser hombre (304:304)

Comment:

Motivos que tienen los adoelscentes para iniciarse sexualmente.

$\sim 7: 102 \mathrm{M}$ Que si sus amigos lo hacen..... (305:307)

Comment:

Percepción de la chicas sobre que motiva a los hombres a tener relaciones sexuales.

7:114 M La mamá de esa muchacha es u.. (370:370)

7:117 Mi mamá, mi mamá no estudio la.. (376:376)

7:120 M Yo tengo a mis tías que tamb.. (393:393)

7:124 M Yo conozco una muchacha que .. (432:432)

7:139 H De que las peleas de niños s.. (514:514)

7:144 M A desgreñarse... (523:523)

$7: 145$ H A cachetadas... (524:524)

7:147 H Y de los hombres se agarran .. (526:528)

7:148 H Y por las mujeres... (529:529)

7:149 M Pues piensan que el que gana.. (533:533)

Comment:

El perdedor es denigrado poniendo en cuestión su hombria.

7:150 H Y que es niña... H Joto... H Que.. (534:536)

7:151 H Si no pelean les dice que so.. (540:540)

7:152 M Y que son gays... y cosas así (541:541)

7:153 H Maricas... H Maricas... jajajaja.. (542:544)

$\sim 7: 164 \mathrm{H} \mathrm{Ah...} \mathrm{les} \mathrm{platico...} \mathrm{se} \mathrm{puso} \mathrm{chi..} \mathrm{(586:588)}$

Comment:

Presume que la pelea estuvo bien.

7:165 H Yo la primera vez o la últim.. (589:590)

Comment:

Los adolescentes alardean de tener varias peleas.

7:166 H Súper héroe... H Me sentí bien.. (593:594)

$<7: 167 \mathrm{H}$ La primera vez que me pelee .. (599:599)

$<>7: 168$ H Calmado... nunca me había pele.. (601:601)

> 7:169 Era un niño del salón y empezó.. (605:605)

7:170 M A mí una vez que estábamos e.. (609:609)

$<>7: 180 \mathrm{H}$ Es que físicamente somos mej.. (645:645)

$>7: 182 \mathrm{H}$ ¿Por qué a ver? H Físicament.. (647:648)

7:187 H Pero los hombres trabajamos .. (654:654)

7:188 M También las personas mayores.. (655:655)

$\sim 7: 189 \mathrm{H}$ Que trabajamos para darles a.. (657:657)

Comment:

Este adolescente justifica la desigualdad y considera que los hombres no tienen la responsabilidad de colaborar en casa porque ellos trabajan de manera remunerada.

7:191 H Pero no igual... (660:660) 
7:192 M Claro que si... Y hasta más qu.. (661:662)

7:193 H Y andan con el novio... y el n.. (665:666)

$<7: 194$ M Claro que no... M Hay mujeres .. (667:668)

$>$ 7:195 M Los siempre se la pasan dici.. (671:672)

7:196 H No... H No, pero cuando son no.. (673:675)

7:197 H Pero solamente en el caso de.. (676:676)

7:199 H Me ponen a barrer... (679:679)

7:200 H Lo único que no hacen las mu.. (683:683)

7:201 H Yo... H Los hombres... al hombre.. (686:687)

7:203 H En mi casa nada más... mi papá.. (705:705)

7:204 H En mi casa y afuera... H Afuer.. (708:709)

7:205 H Sí, todos los cambios que ha.. (746:751)

7:207 M Pero siempre te dicen que lo.. (772:772)

7:208 H Pero no todos los hombres le.. (775:775)

7:216 M. Por machismo (515:515)

$<7: 224$ M. En las dos... M. En las dos... (699:700)

7:225 M. Mi mamá en casa (701:701)

27 Citas encontradas por consulta:

\section{"2.3. REPARTICIÓN DE TAREAS"}

2:16 M En la vida real no es así, q.. (52:52)

2:17 M Aquí en industria del vestid.. (53:53)

2:18 H En el deporte hay más equipo.. (54:54)

3:32 ¿Consideran que hay desigualda.. (136:138)

3:33 H. Como a mí mis amigos me dic.. (140:142)

3:38 M. O que también en algunas ca.. (154:154)

3:87 H. O saber mantener a los hijo.. (298:298)

3:97 M. Yo también me metí a otro p.. (139:139)

Comment:

Esta alumna nos comenta que en su escuela se metió a un taller que sele ser considerado para "chicos" y a ella si le dieron permiso en su casa pero que a otras chicas no les permiten entrar porque consideran que no son disciplinas apropiadas para mujeres y los chicos les hacen burla.

6:113 M Lo más común es que casi tod.. (491:496)

7:124 M Yo conozco una muchacha que .. (432:432)

7:184 M Los hombre no pueden... bueno .. (651:651)

7:185 H Yo si lo hago... (652:652)

7:186 M Sí, pero por que la mamá los.. (653:653)

7:187 H Pero los hombres trabajamos .. (654:654)

7:188 M También las personas mayores.. (655:655)

7:189 H Que trabajamos para darles a.. (657:657)

Comment:

Este adolescente justifica la desigualdad y considera que los hombres no tienen la responsabilidad de colaborar en casa porque ellos trabajan de manera remunerada.

7:190 M Y que... también las mujeres t.. (658:659) 
7:191 H Pero no igual... (660:660)

7:192 M Claro que si... Y hasta más qu.. (661:662)

7:196 H No... H No, pero cuando son no.. (673:675)

7:199 H Me ponen a barrer... (679:679)

7:200 H Lo único que no hacen las mu.. (683:683)

7:201 H Yo... H Los hombres... al hombre.. (686:687)

7:203 H En mi casa nada más... mi papá.. (705:705)

7:204 H En mi casa y afuera... H Afuer.. (708:709)

$<7: 224$ M. En las dos... M. En las dos... (699:700)

7:225 M. Mi mamá en casa (701:701)

19 Citas encontradas por consulta:

\section{"2.4. DERECHOS Y OPORTUNIDADES"}

2:15 M Vienen los derechos de hombr.. (49:49)

2:34 M De los cambios de carácter... .. (126:128)

3:31 M. Que las niñas y a los niños.. (134:134)

3:36 M. Aquí una vez hicieron un to.. (149:149)

3:37 H. Que no se haga diferencia e.. (150:150)

3:39 M. Niños y niñas tienen las mi.. (155:155)

3:40 H. Antes también el voto, sólo.. (156:157)

3:41 M. y también, leí en un libro .. (158:158)

3:42 H. Como Sor Juana Inés de la C.. (159:159)

3:93 ¿Qué ventajas les da ser hombr.. (307:309)

3:94 M. Que las mujeres también tie.. (310:310)

6:20 M Los derechos ¿Derechos qué...?.. (96:99)

6:21 H La igualdad H La igualdad en.. (100:101)

6:30 H Que está mal la desigualdad,.. (143:143)

6:37 M Lo que dicen los compañero, ... (187:187)

6:123 H. Los derechos (186:186)

7:25 H Los derechos de la mujer y d.. (53:53)

7:26 M Como aprender a respetarnos,.. (56:57)

7:205 H Sí, todos los cambios que ha.. (746:751)

75 Citas encontradas por consulta:

\section{"2.5. VIOLENCIA"}

2:31 M A nosotras no nos respetan d.. (115:115)

2:32 M Con apodos, a los hombres le.. (116:116)

3:26 M. en la materia de orientació.. (126:127)

3:27 H. Unos a otros, decirse malas.. (128:128)

3:35 M. Algunas veces no porque lue.. (147:147)

3:44 M. Algunas alumnas se pelean p.. (165:165) 
3:47 M. Algunos le ponen mensajes e.. (174:174)

3:52 M. O también el novio maltrata.. (193:193)

3:53 H. O también puede ser que el .. (194:194)

3:55 H. También a veces hacen dieta.. (200:200)

3:62 M. Que no sean celosos Fotogra.. (215:221)

3:63 H: Puede ser que el novio o el.. (218:218)

3:64 H. Yo sí, con unos vecinos. Re.. (220:220)

3:65 M. También por mi casa vivía u.. (221:221)

3:66 H. Podría ser por novios o por.. (239:243)

3:67 H. Podría ser por novios o por.. (239:240)

3:68 H. Porque tienen problemas fam.. (241:241)

3:69 H. Podría ser que necesitan at.. (243:243)

3:70 M. Porque se sienten superiore.. (242:242)

3:72 H: Mi comportamiento, porque h.. (262:263)

3:81 H: Creo que hubo un caso o dos.. (289:289)

3:89 M: A veces los obligan a tener.. (303:303)

6:10 M Los alumnos entre ellos se g.. (55:60)

6:12 M Por los chismes, por la gent.. (59:59)

6:13 M Y pues los maestros también .. (60:60)

6:23 M Yo diría que es muy poco por.. (105:105)

6:24 M Pues a mí me ha pasado que a.. (109:109)

6:25 H Hay de las dos de las fuerte.. (121:133)

$\sim 6: 27 \mathrm{M}$ Vete a la verga M Hijo de tu.. (127:129)

Comment:

Las chicas hacen referencia a que las mujeres que agreden verbalmente se ven peor que los hombres. Esto es muestra de que a los hombres se les permite realizar más trasgresiones que a las mujeres

6:28 M Si a veces o también a las m.. (133:133)

6:32 H Pues también los hombres cua.. (155:155)

$\sim 6: 35 \mathrm{H}$ Piensan que todas las mujere.. (167:171)

Comment:

Se refieren a las prostitutas pero no se atreven a pronunciar la palabra. Hacen bromas sobre las mujeres que no cumplen con el estereotipo de ser una mujer casta.

6:53 M Hay veces que las chavas cua.. (229:229)

6:54 ¿Aquí ha habido casos de viola.. (231:232)

6:64 M Bueno, un maestro de aquí le.. (278:283)

6:65 M Bueno, un maestro de aquí le.. (278:278)

6:66 M Por esa misma falta de respe.. (281:283)

6:67 M O a la mejor que un maestro .. (318:319)

6:78 H y M Se están peleando H Y ot.. (359:380)

6:80 M Porque dicen no que a mí me .. (371:371)

6:82 M O nada más porque alguien le.. (373:374)

Comment:

Las mujeres perciben que los chicos se pelean por ganar prestigio.

6:84 H Porque todo lo quieren arreg.. (378:378)

$\sim 6: 85 \mathrm{M}$ O porque tienen problemas en.. (379:380)

Comment:

Cuando muestras sentimientos se ríen, y cuando empleas violencia te ganas el respeto de los demás

6:88 H Haciendo diseños, levantando.. (408:410) 
6:90 H A veces se pelean para que v.. (415:415)

6:100 M El papá es más celoso que la.. (431:431)

6:104 M Hay algunos maestros que coq.. (439:439)

7:12 Y luego pelean para ver quién .. (528:544)

7:15 H Este... si violan a una mujer,.. (766:779)

7:37 M Pues que está mal, que se ve.. (85:87)

7:61 M Vez, si los niños supieran q.. (139:144)

7:98 M Y a veces que cuando pelean,... (284:284)

7:133 H Peleas de mujeres... muy este .. (494:496)

7:134 H No pues nada más que se pele.. (500:500)

Comment:

Las mujeres se pelean para que se fijen en ellas los hombres más mayores de edad.

7:135 M O a veces... si un chavo tiene.. (501:501)

7:136 H Por problemas sociales... (los.. (505:507)

7:137 Se dio algo en mi salón muy ch.. (508:509)

Comment:

Las peleas de mujeres son por cosas vanales.

7:138 M Hace poquito unos niño se ib.. (511:511)

7:139 H De que las peleas de niños s.. (514:514)

7:140 H Aja... exactamente... este... las .. (516:516)

7:141 H Moretones... golpes... a golpes..... (518:518)

7:143 ¿Cómo pelean las mujeres y cóm.. (521:526)

$\sim 7: 149$ M Pues piensan que el que gana.. (533:533)

Comment:

El perdedor es denigrado poniendo en cuestión su hombría.

7:150 H Y que es niña... H Joto... H Que.. (534:536)

7:151 H Si no pelean les dice que so.. (540:540)

7:153 H Maricas... H Maricas... jajajaja.. (542:544)

7:154 Experiencias que han tenido pa.. (546:617)

7:157 M Una niña de por mi casa este.. (551:551)

7:159 M Me dio mucho coraje... Después.. (567:573)

7:162 M Bueno por mi casa también ha.. (580:580)

7:164 H Ah... les platico... se puso chi.. (586:588)

Comment:

Presume que la pelea estuvo bien.

7:165 H Yo la primera vez o la últim.. (589:590)

Comment:

Los adolescentes alardean de tener varias peleas.

$<7: 167 \mathrm{H}$ La primera vez que me pelee .. (599:599)

7:170 M A mí una vez que estábamos e.. (609:609)

7:171 H Pero las peleas no se dan co.. (610:611)

10 Citas encontradas por consulta:

\section{"2.6. ACCESO AL PODER"}

3:46 H. No debe de haber un líder e.. (167:169)

3:48 M. En mi salón hay una niña qu.. (180:180) 
3:70 M. Porque se sienten superiore.. (242:242)

6:82 M O nada más porque alguien le.. (373:374)

Comment:

Las mujeres perciben que los chicos se pelean por ganar prestigio.

6:83 H Buscan tener amigas nada más.. (375:375)

6:135 M. O hay unos que según andan .. (560:561)

7:98 M Y a veces que cuando pelean,.. (284:284)

7:147 H Y de los hombres se agarran .. (526:528)

7:157 M Una niña de por mi casa este.. (551:551)

7:165 H Yo la primera vez o la últim.. (589:590)

Comment:

Los adolescentes alardean de tener varias peleas.

21 Citas encontradas por consulta:

"2.7. DESIGUALDAD"

2:16 M En la vida real no es así, q.. (52:52)

2:17 M Aquí en industria del vestid.. (53:53)

2:18 H En el deporte hay más equipo.. (54:54)

3:31 M. Que las niñas y a los niños.. (134:134)

3:32 ¿Consideran que hay desigualda.. (136:138)

3:35 M. Algunas veces no porque lue.. (147:147)

3:36 M. Aquí una vez hicieron un to.. (149:149)

3:37 H. Que no se haga diferencia e.. (150:150)

3:38 M. O que también en algunas ca.. (154:154)

3:76 M: Cuando hay una actividad se.. (282:282)

3:77 H: En el taller de carpintería.. (283:283)

3:82 H. También en Patamban, tres o.. (290:290)

3:93 ¿Qué ventajas les da ser hombr.. (307:309)

6:23 M Yo diría que es muy poco por.. (105:105)

6:24 M Pues a mí me ha pasado que a.. (109:109)

6:30 H Que está mal la desigualdad,.. (143:143)

6:31 H A veces los hombres tachan a.. (146:150)

<7:179 M Que los hombres de creen sup.. (644:644)

7:184 M Los hombre no pueden... bueno .. (651:651)

7:188 M También las personas mayores.. (655:655)

$<7: 194$ M Claro que no... M Hay mujeres .. (667:668) 


\section{Anexos 3. Parte de análisis de resultados libros de texto}

\section{Imágenes}

Tabla 1. Personajes representativos

\begin{tabular}{|c|r|r|r|r|r|}
\hline $\begin{array}{c}\text { Personajes } \\
\text { representativos }\end{array}$ & $\begin{array}{c}\text { HOMBR } \\
\text { E }\end{array}$ & MUJER & $\begin{array}{c}\text { COLECT } \\
\text { IVO } \\
\text { VARONES }\end{array}$ & $\begin{array}{c}\text { COLECT } \\
\text { IVO MIXTO }\end{array}$ & Total \\
\hline Recuento & 26 & 1 & 1 & 1 & 29 \\
\hline$\%$ & $89,7 \%$ & $3,4 \%$ & $3,4 \%$ & $3,4 \%$ & $100,0 \%$ \\
\hline
\end{tabular}

Tabla 2. Personajes representativos según asignatura

\begin{tabular}{|c|r|r|r|r|r|}
\hline \multirow{2}{*}{$\begin{array}{r}\text { Personajes } \\
\text { representativos }\end{array}$} & \multicolumn{4}{|c|}{ LIBRO } & \multirow{2}{*}{ Total } \\
\cline { 2 - 5 } & CIECIAS & $\begin{array}{c}\text { ESPAÑO } \\
\text { L }\end{array}$ & $\begin{array}{c}\text { GEOGR } \\
\text { AFÍA }\end{array}$ & \multicolumn{1}{c|}{$\begin{array}{c}\text { MATEMÁTI } \\
\text { CAS }\end{array}$} & \\
\hline Recuento & 12 & 5 & 1 & 11 & 29 \\
\hline$\%$ & $41,4 \%$ & $17,2 \%$ & $3,4 \%$ & $37,9 \%$ & $100,0 \%$ \\
\hline
\end{tabular}

Tabla 3. Actividades y/o ocupaciones en las que aparecen varones en las imágenes

\begin{tabular}{rrr}
\hline $\begin{array}{l}\text { OCUPACIONES } \\
\text { HOMBRES }\end{array}$ & FRECUENCIA \\
\hline TOTAL & 148 & $100 \%$ \\
ESTUDIANTE & 31 & $21 \%$ \\
CIENTÍFICO & 13 & $9 \%$ \\
OBRERO & 12 & $8 \%$ \\
MIGRANTE & 10 & $7 \%$ \\
PADRE & 9 & $6 \%$ \\
HIJO/A & 7 & $5 \%$ \\
AGRICULTOR & 6 & $4 \%$ \\
REPORTERO & 6 & $4 \%$ \\
MATEMÁTICO & 5 & $3 \%$ \\
MÉDICO & 5 & $3 \%$ \\
REY & 5 & $3 \%$ \\
CAZADOR & 4 & $3 \%$ \\
DEPORTISTA & 4 & $3 \%$ \\
ENFERMERÍA & 3 & $2 \%$ \\
PESCADOR & 3 & $2 \%$ \\
SASERDOTE/RELIG & 3 & $2 \%$ \\
ASTRONOMÍA & 2 & $1 \%$ \\
DOCENCIA & 2 & $1 \%$
\end{tabular}




\begin{tabular}{rll}
\hline EMPRESARIO & 2 & $1 \%$ \\
ESCRITOR & 2 & $1 \%$ \\
MILITAR & 2 & $1 \%$ \\
MUSICO & 2 & $1 \%$ \\
ABUELO/A & 1 & $1 \%$ \\
BEBÉ & 1 & $1 \%$ \\
CURANDERO & 1 & $1 \%$ \\
DANZA & 1 & $1 \%$ \\
EMPERADOR & 1 & $1 \%$ \\
FUTBOLISTA & 1 & $1 \%$ \\
INVENTOR & 1 & $1 \%$ \\
JARDINERO & 1 & $1 \%$ \\
NIETO/A & 1 & $1 \%$ \\
POLÍTICO/A & 1 & $1 \%$ \\
\hline
\end{tabular}

Tabla 4. Actividades y/o ocupaciones en las que aparecen mujeres en las imágenes

\begin{tabular}{rrr}
\hline OCUPACIONES & FRECUENCIA & $\%$ \\
MUJERES & 122 & $100 \%$ \\
TOTAL & 63 & $52 \%$ \\
ESTUDIANTE & 16 & $13 \%$ \\
MADRE & 10 & $8 \%$ \\
HIJA & 5 & $4 \%$ \\
CIENTÍFICA & 4 & $3 \%$ \\
DOCENCIA & 4 & $3 \%$ \\
ENFERMERÍA & 3 & $2 \%$ \\
ABUELA & 3 & $2 \%$ \\
PEREGRINA & 4 & $3 \%$ \\
RELIGIOSA & 2 & $2 \%$ \\
AGRICULTORA & 2 & $2 \%$ \\
OBRERA & 1 & $1 \%$ \\
COCINERA & 1 & $1 \%$ \\
COMERCIANTE & 1 & $1 \%$ \\
BAILARINA & 1 & $1 \%$ \\
EMPRESARIA & 1 & $1 \%$ \\
MÉDICA & 1 & $1 \%$ \\
REPORTERA & &
\end{tabular}

Tabla 5. Actividades y/o ocupaciones en las que aparecen colectivos de varones en las imágenes

\begin{tabular}{crr}
\hline OCUPACIONES DE COLECTIVOS DE & FRECUENCI & $\%$ \\
VARONES & A & \\
\hline
\end{tabular}




\begin{tabular}{rrr}
\hline TOTAL & 11 & $100 \%$ \\
MIGRANTE & 4 & $36 \%$ \\
MILITAR & 2 & $18 \%$ \\
CIENTÍFICO & 1 & $9 \%$ \\
EMPRESARIO & 1 & $9 \%$ \\
ESTUDIANTE & 1 & $9 \%$ \\
OBRERO & 1 & $9 \%$ \\
SASERDOTE/RELIG & 1 & $9 \%$ \\
\hline
\end{tabular}

Tabla 6. Actividades y/o ocupaciones en las que aparecen colectivos mixtos en las imágenes

\begin{tabular}{rrr}
\hline $\begin{array}{r}\text { OCUPACIÓN COLECTIVOS } \\
\text { MIXTOS }\end{array}$ & FRECUENCIA & $\%$ \\
ESTUDIANTE & 24 & $100 \%$ \\
COMERCIANTE & 13 & $54 \%$ \\
ACTRIZ/ACTOR & 5 & $21 \%$ \\
BAILARINAS/ES & 1 & $4 \%$ \\
MIGRANTE & 1 & $4 \%$ \\
OBRERO/A & 1 & $4 \%$ \\
PEREGRINO/A & 1 & $4 \%$ \\
POLÍTICO/A & 1 & $4 \%$ \\
\hline
\end{tabular}


Tabla 7. Características psicosociales de los varones

\begin{tabular}{|c|c|c|}
\hline $\begin{array}{r}\text { CARACTERÍSTICAS PSICOSOCIALES } \\
\text { HOMBRES }\end{array}$ & FRECUENCIA & $\%$ \\
\hline TOTAL & 225 & $100,0 \%$ \\
\hline TRABAJANDO & 48 & $21,3 \%$ \\
\hline DINAMISMO & 23 & $10,2 \%$ \\
\hline $\mathrm{OClO}$ & 21 & $9,3 \%$ \\
\hline CRIANZA & 13 & $5,8 \%$ \\
\hline FORTALEZA & 10 & $4,4 \%$ \\
\hline DOMINIO & 9 & $4,0 \%$ \\
\hline INDÍGENA & 8 & $3,6 \%$ \\
\hline JUGANDO & 8 & $3,6 \%$ \\
\hline INTELECTUAL & 9 & $4,0 \%$ \\
\hline RACIONALIDAD & 7 & $3,1 \%$ \\
\hline ATENCIÓN & 6 & $2,7 \%$ \\
\hline GOBERNAR & 5 & $2,2 \%$ \\
\hline AMOR & 5 & $2,2 \%$ \\
\hline VALENTÍA & 5 & $2,2 \%$ \\
\hline DEPORTE & 3 & $1,3 \%$ \\
\hline DESDICHA & 3 & $1,3 \%$ \\
\hline EFICACIA & 3 & $1,3 \%$ \\
\hline ALEGRÍA & 2 & $0,9 \%$ \\
\hline CHARLAR & 2 & $0,9 \%$ \\
\hline CUIDADO PERSONAL & 2 & $0,9 \%$ \\
\hline DISCUTIENDO & 2 & $0,9 \%$ \\
\hline ENFADO & 2 & $0,9 \%$ \\
\hline ESTUDIANDO & 2 & $0,9 \%$ \\
\hline PASEO & 2 & $0,9 \%$ \\
\hline PASIVIDAD & 2 & $0,9 \%$ \\
\hline PENSANDO & 2 & $0,9 \%$ \\
\hline PROTECCIÓN & 2 & $0,9 \%$ \\
\hline SEGURIDAD & 2 & $0,9 \%$ \\
\hline AMOR & 1 & $0,4 \%$ \\
\hline ASERTIVIDAD & 1 & $0,4 \%$ \\
\hline BELLEZA & 1 & $0,4 \%$ \\
\hline CERTEZA & 1 & $0,4 \%$ \\
\hline COQUETEO & 1 & $0,4 \%$ \\
\hline DEBILIDAD & 1 & $0,4 \%$ \\
\hline DESCANSO & 1 & $0,4 \%$ \\
\hline DESNUTRICIÓN & 1 & $0,4 \%$ \\
\hline EMBARAZO & 1 & $0,4 \%$ \\
\hline EROTISMO & 1 & $0,4 \%$ \\
\hline INCERTIDUMBRE & 1 & $0,4 \%$ \\
\hline MANUTENCIÓN & 1 & $0,4 \%$ \\
\hline OBSERVANDO & 1 & $0,4 \%$ \\
\hline
\end{tabular}




\begin{tabular}{rrr}
\hline POBREZA & 1 & $0,4 \%$ \\
RIESGO & 1 & $0,4 \%$ \\
SERENIDAD & 1 & $0,4 \%$ \\
TRISTEZA & 1 & $0,4 \%$ \\
\hline
\end{tabular}

Tabla 8. Características psicosociales de las mujeres

\begin{tabular}{|c|c|c|}
\hline $\begin{array}{r}\text { CARACTERÍSTICAS PSICOSOCIALES } \\
\text { MUJERES }\end{array}$ & FRECUENCIA & $\%$ \\
\hline$\overline{\text { TOTAL }}$ & 172 & $100,0 \%$ \\
\hline TRABAJANDO & 54 & $31,4 \%$ \\
\hline INDÍGENA & 15 & $8,7 \%$ \\
\hline CRIANZA & 12 & $7,0 \%$ \\
\hline ATENCIÓN & 7 & $4,1 \%$ \\
\hline OClO & 7 & $4,1 \%$ \\
\hline BELLEZA & 6 & $3,5 \%$ \\
\hline CUIDADO PERSONAL & 6 & $3,5 \%$ \\
\hline OBSERVANDO & 6 & $3,5 \%$ \\
\hline DINAMISMO & 5 & $2,9 \%$ \\
\hline AMOR & 5 & $2,9 \%$ \\
\hline CHARLAR & 4 & $2,3 \%$ \\
\hline DISCUTIENDO & 4 & $2,3 \%$ \\
\hline SUMISIÓN & 4 & $2,3 \%$ \\
\hline ALEGRÍA & 3 & $1,7 \%$ \\
\hline AMOR & 3 & $1,7 \%$ \\
\hline JUGANDO & 3 & $1,7 \%$ \\
\hline PASIVIDAD & 3 & $1,7 \%$ \\
\hline SERENIDAD & 3 & $1,7 \%$ \\
\hline DEBILIDAD & 2 & $1,2 \%$ \\
\hline DEPENDENCIA & 2 & $1,2 \%$ \\
\hline ESTUDIANDO & 2 & $1,2 \%$ \\
\hline COQUETEO & 1 & $0,6 \%$ \\
\hline DELICADEZA & 1 & $0,6 \%$ \\
\hline DEPORTE & 1 & $0,6 \%$ \\
\hline DESDICHA & 1 & $0,6 \%$ \\
\hline EMBARAZO & 1 & $0,6 \%$ \\
\hline INCERTIDUMBRE & 1 & $0,6 \%$ \\
\hline INTELECTUAL & 1 & $0,6 \%$ \\
\hline INTUICIÓN & 1 & $0,6 \%$ \\
\hline PARTICIPACIÓN & 1 & $0,6 \%$ \\
\hline PASEANDO & 1 & $0,6 \%$ \\
\hline PENSANDO & 1 & $0,6 \%$ \\
\hline POBREZA & 1 & $0,6 \%$ \\
\hline RACIONALIDAD & 1 & $0,6 \%$ \\
\hline RESIGNACIÓN & 1 & $0,6 \%$ \\
\hline
\end{tabular}




\begin{tabular}{rll} 
SEGURIDAD & 1 & $0,6 \%$ \\
SOLICITA & 1 & $0,6 \%$ \\
\hline
\end{tabular}

Tabla 9. Características psicosociales del colectivo de varones

\begin{tabular}{rrr}
\hline COLECTIVO DE & FRECUENCIA \\
VARONES & 11 & $\%$ \\
\hline TOTAL & 3 & $100,0 \%$ \\
DOMINIO & 3 & $27,3 \%$ \\
VALENTÍA & 2 & $27,3 \%$ \\
TRABAJANDO & 1 & $18,2 \%$ \\
INNOVACIÓN & 1 & $9,1 \%$ \\
PESADUMBRE & 1 & $9,1 \%$ \\
RESANDO & 1 & $9,1 \%$ \\
\hline
\end{tabular}

Tabla 10. Características psicosociales del colectivo mixto

\begin{tabular}{rrr}
\hline COLECTIVO & FRECUENCIA & $\%$ \\
MIXTO & 52 & $100,0 \%$ \\
TOTAL & 17 & $32,7 \%$ \\
TRABAJANDO & 14 & $26,9 \%$ \\
OCIO & 4 & $7,7 \%$ \\
DINAMISMO & 3 & $5,8 \%$ \\
POBREZA & 2 & $3,8 \%$ \\
COMPRA & 2 & $3,8 \%$ \\
MIEDO & 1 & $1,9 \%$ \\
CUIDADO & 1 & $1,9 \%$ \\
PERSONAL & 1 & $1,9 \%$ \\
DISCUSIÓN & 1 & $1,9 \%$ \\
EFICACIA & 1 & $1,9 \%$ \\
INDIGENA & $1,9 \%$ \\
INDIÍGENA & 1 & $1,9 \%$ \\
PARTICIPACIÓ & $N$ & $1,9 \%$ \\
PASEO & 1 & $1,9 \%$ \\
REVELDÍA & 1 & $1,9 \%$ \\
SERENIDAD & 1 & $1,9 \%$ \\
VALENTÍA & 1 &
\end{tabular}




\section{Texto}

\section{OCUPACIONES}

Tabla 11. Actividades y/o ocupaciones en de los personajes en el texto

\begin{tabular}{|c|c|c|}
\hline \multicolumn{3}{|c|}{ OCUPACIONES Y/O ACTIVIDADES DE LOS PERSONAJES EN EL } \\
\hline GENERAL & Frecuencia & $\begin{array}{r}\text { Porcentaje } \\
\text { válido }\end{array}$ \\
\hline Total & 2771 & 100,0 \\
\hline ESTUDIANTE & 656 & 23,7 \\
\hline DOCENTE & 253 & 9,1 \\
\hline MIGRANTE & 90 & 3,2 \\
\hline PADRE & 82 & 3,0 \\
\hline $\mathrm{HIJO} / \mathrm{A}$ & 79 & 2,9 \\
\hline AUTOR/A & 68 & 2,5 \\
\hline CIENTÍFICO/A & 65 & 2,3 \\
\hline DEPORTISTA & 55 & 2,0 \\
\hline POETA & 54 & 1,9 \\
\hline REY & 49 & 1,8 \\
\hline ESCRITOR/A & 47 & 1,7 \\
\hline MATEMÁTICO/A & 46 & 1,7 \\
\hline PAREJA & 46 & 1,7 \\
\hline AMA DE CASA & 44 & 1,6 \\
\hline MADRE & 41 & 1,5 \\
\hline MÉDICO/A & 39 & 1,4 \\
\hline FAMILIA & 36 & 1,3 \\
\hline AGRICULTOR/A & 32 & 1,2 \\
\hline CAPITAN & 31 & 1,1 \\
\hline INVESTIGADOR/A & 31 & 1,1 \\
\hline ABUELO/A & 25 & 9 \\
\hline DIOS/A & 21 & 8 \\
\hline TÉCNICO-OBRERO & 21 & 8 \\
\hline INDÍGENA & 20 & ,7 \\
\hline NATURALISTA & 20 & ,7 \\
\hline HERMANO/A & 19 & ,7 \\
\hline CAMPESINO/A & 18 & 6 \\
\hline ESPOSO/A & 18 & 6 \\
\hline BIÓLOGO/A & 17 & 6 \\
\hline GEÓGRAFO/A & 17 & 6 \\
\hline AMIGO/A & 16 & 6 \\
\hline CONQUISTADOR & 15 &, 5 \\
\hline GUERRERO/A & 15 &, 5 \\
\hline JUGADOR/A & 15 &, 5 \\
\hline LEGISLADOR/A & 15 &, 5 \\
\hline
\end{tabular}




\begin{tabular}{|c|c|c|}
\hline COMERCIANTE & 14 &, 5 \\
\hline CONSUMIDOR/A & 14 &, 5 \\
\hline ARTISTA & 13 &, 5 \\
\hline NARRADOR/A & 13 &, 5 \\
\hline DONCELLA & 12 & ,4 \\
\hline MONJE/A & 12 & ,4 \\
\hline DIRECTOR/A & 11 & ,4 \\
\hline MATERNIDAD & 11 & ,4 \\
\hline VIAJERO/A & 11 & ,4 \\
\hline INMIGRANTE & 10 & ,4 \\
\hline DESTINATARIO/A & 9 & ,3 \\
\hline DIPUTADO/A & 9 & ,3 \\
\hline EMIGRANTE & 9 & ,3 \\
\hline GUARDIA & 9 & ,3 \\
\hline INGENIERO/A & 9 & ,3 \\
\hline QUÍMICO/A & 9 & ,3 \\
\hline EMPRESARIO/A & 8 & ,3 \\
\hline ESPECIALISTA & 8 & ,3 \\
\hline MODERADOR/A & 8 & ,3 \\
\hline REFUGIADO/A & 8 & ,3 \\
\hline TURISTA & 8 & ,3 \\
\hline CICLISTA & 7 & ,3 \\
\hline CINEASTA & 7 & ,3 \\
\hline GOBERNADOR/A & 7 & ,3 \\
\hline LECTOR/A & 7 & ,3 \\
\hline MECÁNICO & 7 & ,3 \\
\hline MODELO & 7 & ,3 \\
\hline PACIENTE & 7 & ,3 \\
\hline PRESIDENTE & 7 & ,3 \\
\hline ESCLAVO/A & 6 & ,2 \\
\hline MICROSCOPISTA & 6 & ,2 \\
\hline NIETO/A & 6 & , 2 \\
\hline NOVIO/A & 6 & ,2 \\
\hline PINTOR & 6 & ,2 \\
\hline PRÍNCIPE & 6 & ,2 \\
\hline PROPIETARIO & 6 & ,2 \\
\hline SACERDOTE & 6 & , 2 \\
\hline TRABAJANDO & 6 & ,2 \\
\hline ADMIRADOR/A & 5 & ,2 \\
\hline DOCTOR/A & 5 & ,2 \\
\hline PERIODISTA & 5 & ,2 \\
\hline PRODUCTOR/A & 5 & ,2 \\
\hline PROFETA & 5 & ,2 \\
\hline SOLDADO & 5 & ,2 \\
\hline TÉCNICO-PROFESI & 5 & ,2 \\
\hline TRANSPORTISTA & 5 & ,2 \\
\hline
\end{tabular}




\begin{tabular}{|c|c|c|}
\hline VENDEDOR/A & 5 & 2 \\
\hline ADULTO/A & 4 & 1 \\
\hline BEBÉ & 4 & 1 \\
\hline CIRUJANO & 4 & 1 \\
\hline COCINERA & 4 & 1 \\
\hline ECÓLOGO/A & 4 & 1 \\
\hline ESPECTADOR/A & 4 & 1 \\
\hline EUROPEO & 4 & 1 \\
\hline EXPOSITOR & 4 & 1 \\
\hline FRAILE & 4 & 1 \\
\hline HÉROE & 4 & 1 \\
\hline LOCUTOR & 4 & 1 \\
\hline LUCHADOR/A & 4 & 1 \\
\hline MILITAR & 4 & ,1 \\
\hline MINERO/A & 4 & ,1 \\
\hline PEREGRINOS & 4 & 1 \\
\hline PINTOR/A & 4 & ,1 \\
\hline POLICÍA & 4 & 1 \\
\hline REPORTERO/A & 4 & ,1 \\
\hline VECINO/A & 4 & 1 \\
\hline ABOGADO/A & 3 & ,1 \\
\hline ALBAÑIL & 3 & ,1 \\
\hline ARQUITECTO/A & 3 & 1 \\
\hline ASTRONOMÍA & 3 & 1 \\
\hline BIBLIOTECARIO/A & 3 & ,1 \\
\hline BISABUELO/A & 3 & 1 \\
\hline CRIANZA & 3 & 1 \\
\hline DETECTIVE & 3 & ,1 \\
\hline DONANTE & 3 & ,1 \\
\hline ENTREVISTADO/A & 3 & 1 \\
\hline EXPLORADOR/A & 3 & 1 \\
\hline GENERAL & 3 & ,1 \\
\hline MARINERO/A & 3 & 1 \\
\hline MENOR & 3 & 1 \\
\hline NUTRIÓLOGO & 3 & ,1 \\
\hline PASAJERO/A & 3 & ,1 \\
\hline PROGENITOR/A & 3 & ,1 \\
\hline QUÍMICO & 3 & 1 \\
\hline SECRETARIO & 3 & 1 \\
\hline SECRETARIO/A & 3 & ,1 \\
\hline ZOÓLOGO & 3 & ,1 \\
\hline ACOMPAÑANTE & 2 & 1 \\
\hline ANTROPÓLOGO/A & 2 & ,1 \\
\hline APICULTOR/A & 2 & ,1 \\
\hline BACTERIÓLOGO/A & 2 & 1 \\
\hline CARTERO/A & 2 & 1 \\
\hline
\end{tabular}




\begin{tabular}{|c|c|c|}
\hline CLIENTE & 2 &, 1 \\
\hline CONDUCTOR/A & 2 &, 1 \\
\hline CRISTIANO & 2 &, 1 \\
\hline DOMADOR & 2 &, 1 \\
\hline EMPACADOR/A & 2 &, 1 \\
\hline EMPLEADO/A & 2 &, 1 \\
\hline FLECHADOR & 2 &, 1 \\
\hline FUTOBOLISTA & 2 &, 1 \\
\hline INVENTOR/A & 2 &, 1 \\
\hline JARDINERO & 2 &, 1 \\
\hline JEFE/A & 2 &, 1 \\
\hline JUVENTUD & 2 &, 1 \\
\hline MERCADER & 2 &, 1 \\
\hline MINISTRO/A & 2 &, 1 \\
\hline MUSULMAN & 2 &, 1 \\
\hline OBRERO & 2 &, 1 \\
\hline PARLAMENTARIO/A & 2 &, 1 \\
\hline PASTOR & 2 &, 1 \\
\hline PESCADOR/A & 2 &, 1 \\
\hline PONENTE & 2 &, 1 \\
\hline PORTERO & 2 &, 1 \\
\hline PRESIDENTE/A & 2 &, 1 \\
\hline PRIMO/A & 2 &, 1 \\
\hline SANTO & 2 &, 1 \\
\hline TÉCNICO & 2 &, 1 \\
\hline TERRATENIENTE & 2 &, 1 \\
\hline VIGILANTE & 2 &, 1 \\
\hline ACTOR/A & 1 & ,0 \\
\hline ACTRIZ & 1 & ,0 \\
\hline ADMINISTRADOR/A & 1 & ,0 \\
\hline AGENTE & 1 & ,0 \\
\hline AMBIENTALISTA & 1 & ,0 \\
\hline ANATOMISTA & 1 & ,0 \\
\hline ARICULTOR/A & 1 & ,0 \\
\hline ARTESANO/A & 1 & ,0 \\
\hline ASTRONAUTA & 1 & ,0 \\
\hline ATLETA & 1 &, 0 \\
\hline AUSTRONAUTA & 1 & ,0 \\
\hline BAÑISTA & 1 & ,0 \\
\hline BIOGEOGRAFÍA & 1 & ,0 \\
\hline BOMBERO/A & 1 &, 0 \\
\hline BUDISTA & 1 & ,0 \\
\hline CABALLERO & 1 & ,0 \\
\hline CANTANTE & 1 & ,0 \\
\hline CARTÓGRAFO/A & 1 & ,0 \\
\hline CAZADOR & 1 &, 0 \\
\hline
\end{tabular}




\begin{tabular}{|c|c|c|}
\hline CHOFER & 1 & 0 \\
\hline COFRADE & 1 & 0 \\
\hline COLONIZADOR & 1 & 0 \\
\hline COMUNICADOR/A & 1 & 0 \\
\hline CONDE & 1 & 0 \\
\hline CONQUISTADOR/A & 1 & 0 \\
\hline CORTESANA/O & 1 & 0 \\
\hline CRIADOR/A & 1 & 0 \\
\hline CUIDADOR/A & 1 & 0 \\
\hline DOMESTICADOR/A & 1 & 0 \\
\hline ECUESTADO/A & 1 & 0 \\
\hline EJIDATARIO & 1 & 0 \\
\hline EMBRIOLÓGO & 1 & 0 \\
\hline EMPERADOR & 1 & 0 \\
\hline ENFERMERO/A & 1 & 0 \\
\hline ENLATADOR/A & 1 & 0 \\
\hline ESCULTOR & 1 & 0 \\
\hline EXPERTO/A & 1 & 0 \\
\hline FABRICANTE & 1 & 0 \\
\hline FILOLOGÍA & 1 & 0 \\
\hline Físıco & 1 & 0 \\
\hline GENETISTA & 1 & 0 \\
\hline GERENTE & 1 & 0 \\
\hline GRANJERO/A & 1 & 0 \\
\hline GUÍA TURISTICO & 1 & 0 \\
\hline INSPECTOR/A & 1 & 0 \\
\hline JUDIO/A & 1 & 0 \\
\hline JUDÍO/A & 1 & 0 \\
\hline LIMPIADOR & 1 & 0 \\
\hline MENSAJERO/A & 1 & 0 \\
\hline MEXICANO/A & 1 & 0 \\
\hline MISIONERO/A & 1 & 0 \\
\hline MúSICO & 1 & 0 \\
\hline NOMADAS & 1 & 0 \\
\hline ORGANIZADOR/A & 1 & 0 \\
\hline ORIENTADOR/A & 1 & 0 \\
\hline PARAMILITAR & 1 & 0 \\
\hline PATERNIDAD & 1 & 0 \\
\hline PEREGRINO & 1 & 0 \\
\hline PEREGRINO/A & 1 & 0 \\
\hline POLÍTICA & 1 & 0 \\
\hline POLÍTICO/A & 1 & 0 \\
\hline PRINCIPE & 1 & 0 \\
\hline PRODUCTOR & 1 & 0 \\
\hline PROVEDOR/A & 1 & 0 \\
\hline PSICÓLOGO/A & 1 & 0 \\
\hline
\end{tabular}




\begin{tabular}{rrr}
\hline PSIQUIATRA & 1 &, 0 \\
RECOLECTOR/A & 1 &, 0 \\
REPARTIDOR/A & 1 &, 0 \\
REPOSTERO/A & 1 &, 0 \\
SIRVIENTE/A & 1 &, 0 \\
SOBRINO/A & 1 &, 0 \\
SÚBDITO & 1 &, 0 \\
TALADOR/A & 1 &, 0 \\
TALLERISTA & 1 &, 0 \\
TAXISTA & 1 &, 0 \\
TÉCNICO-P & 1 &, 0 \\
TÍA & 1 &, 0 \\
TOPÓGRAFO/A & 1 &, 0 \\
TRADUCTOR/A & 1 &, 0 \\
VISITANTE & 1 &, 0 \\
VOCERO & 1 & \\
TOTAL $=$ & 1 &
\end{tabular}

Tabla 12. Actividades y/o ocupaciones en las que aparecen los varones en el texto

\begin{tabular}{rrr}
\hline $\begin{array}{r}\text { OCUPACIONES Y/O ACTIVIDADES DE LOS VARONES EN EL TEXTO } \\
\text { VARONES }\end{array}$ & $\begin{array}{r}\text { FRECUENCIA } \\
\text { POÁLIDO }\end{array}$ \\
TSOTAL & 1032 & 100,0 \\
ESTUDIANTE & 149 & 14,4 \\
REY & 49 & 4,7 \\
AUTOR/A & 46 & 4,4 \\
POETA & 44 & 4,2 \\
PADRE & 43 & 4,2 \\
ESCRITOR/A & 33 & 3,2 \\
CAPITAN & 31 & 3,0 \\
HIJO/A & 31 & 3,0 \\
MATEMÁTICO/A & 29 & 2,8 \\
CIENTÍFICO/A & 26 & 2,5 \\
DOCENTE & 26 & 2,5 \\
MÉDICO/A & 25 & 2,4 \\
AGRICULTOR/A & 23 & 2,2 \\
NATURALISTA & 20 & 1,9 \\
DIOS/A & 17 & 1,6 \\
INVESTIGADOR/A & 17 & 1,6 \\
ESPOSO/A & 16 & 1,5 \\
GEÓGRAFO/A & 16 & 1,5 \\
GUERRERO/A & 13 & 1,3 \\
DEPORTISTA & 12 & 1,2 \\
MONJE/A & 12 & 1,2 \\
\hline
\end{tabular}




\begin{tabular}{|c|c|c|}
\hline QUIIMICO/A & 12 & 1,2 \\
\hline ABUELO/A & 11 & 1,1 \\
\hline VIAJERO/A & 10 & 1,0 \\
\hline BIÓLOGO/A & 9 & ,9 \\
\hline CONQUISTADOR & 9 & ,9 \\
\hline GUARDIA & 9 & ,9 \\
\hline HERMANO/A & 9 & ,9 \\
\hline JUGADOR/A & 8 & ,8 \\
\hline CICLISTA & 7 &, 7 \\
\hline CINEASTA & 7 &, 7 \\
\hline INGENIERO/A & 7 &, 7 \\
\hline MECÁNICO & 7 &, 7 \\
\hline PRESIDENTE & 7 &, 7 \\
\hline DIRECTOR/A & 6 & ,6 \\
\hline EMPRESARIO/A & 6 & ,6 \\
\hline MICROSCOPISTA & 6 & ,6 \\
\hline PRÍNCIPE & 6 & 6 \\
\hline PROPIETARIO & 6 & 6 \\
\hline ADMIRADOR/A & 5 &, 5 \\
\hline AMIGO/A & 5 &, 5 \\
\hline ARTISTA & 5 &, 5 \\
\hline EMIGRANTE & 5 &, 5 \\
\hline GOBERNADOR/A & 5 &, 5 \\
\hline NIETO/A & 5 &, 5 \\
\hline NOVIO/A & 5 &, 5 \\
\hline PINTOR/A & 5 &, 5 \\
\hline PROFETA & 5 &, 5 \\
\hline TRANSPORTISTA & 5 &, 5 \\
\hline CIRUJANO & 4 & ,4 \\
\hline DIPUTADO/A & 4 & ,4 \\
\hline HÉROE & 4 & ,4 \\
\hline LEGISLADOR/A & 4 & ,4 \\
\hline LOCUTOR & 4 & ,4 \\
\hline LUCHADOR/A & 4 & ,4 \\
\hline SACERDOTE & 4 & ,4 \\
\hline SOLDADO & 4 &, 4 \\
\hline TÉCNICO-OBRERO & 4 & ,4 \\
\hline ARQUITECTO/A & 3 & ,3 \\
\hline ASTRONOMÍA & 3 & ,3 \\
\hline BISABUELO/A & 3 & ,3 \\
\hline DETECTIVE & 3 & ,3 \\
\hline DOCTOR/A & 3 & ,3 \\
\hline ECÓLOGO/A & 3 & ,3 \\
\hline FRAILE & 3 & ,3 \\
\hline GENERAL & 3 & ,3 \\
\hline MARINERO/A & 3 & ,3 \\
\hline
\end{tabular}




\begin{tabular}{|c|c|c|}
\hline MINERO/A & 3 & ,3 \\
\hline PACIENTE & 3 & ,3 \\
\hline PRODUCTOR/A & 3 & ,3 \\
\hline TÉCNICO-PROFESI & 3 & ,3 \\
\hline ZOÓLOGO & 3 & ,3 \\
\hline ABOGADO/A & 2 & ,2 \\
\hline BACTERIÓLOGO/A & 2 & ,2 \\
\hline CONDUCTOR/A & 2 & ,2 \\
\hline EXPLORADOR/A & 2 & ,2 \\
\hline FLECHADOR & 2 & ,2 \\
\hline FUTOBOLISTA & 2 & ,2 \\
\hline INVENTOR/A & 2 & ,2 \\
\hline OBRERO & 2 & ,2 \\
\hline PASTOR & 2 & ,2 \\
\hline PORTERO & 2 & ,2 \\
\hline PRESIDENTE/A & 2 & ,2 \\
\hline $\mathrm{PRIMO/A}$ & 2 & ,2 \\
\hline SANTO & 2 & ,2 \\
\hline SECRETARIO/A & 2 & ,2 \\
\hline TERRATENIENTE & 2 & ,2 \\
\hline TRABAJANDO & 2 & ,2 \\
\hline ADMINISTRADOR/A & 1 &, 1 \\
\hline ALBAÑIL & 1 &, 1 \\
\hline ANATOMISTA & 1 &, 1 \\
\hline APICULTOR/A & 1 &, 1 \\
\hline ASTRONAUTA & 1 &, 1 \\
\hline ATLETA & 1 &, 1 \\
\hline BIBLIOTECARIO/A & 1 &, 1 \\
\hline BIOGEOGRAFÍA & 1 &, 1 \\
\hline BUDISTA & 1 &, 1 \\
\hline CAMPESINO/A & 1 &, 1 \\
\hline CANTANTE & 1 &, 1 \\
\hline CARTÓGRAFO/A & 1 &, 1 \\
\hline CAZADOR & 1 &, 1 \\
\hline COCINERA & 1 &, 1 \\
\hline COFRADE & 1 &, 1 \\
\hline COMERCIANTE & 1 &, 1 \\
\hline CONDE & 1 &, 1 \\
\hline CORTESANA/O & 1 &, 1 \\
\hline CRIANZA & 1 &, 1 \\
\hline EMBRIOLÓGO & 1 &, 1 \\
\hline EMPERADOR & 1 &, 1 \\
\hline EMPLEADO/A & 1 &, 1 \\
\hline ENLATADOR/A & 1 &, 1 \\
\hline ESCULTOR & 1 & ,1 \\
\hline ESPECTADOR/A & 1 &, 1 \\
\hline
\end{tabular}




\begin{tabular}{|c|c|c|}
\hline EXPERTO/A & 1 & $\overline{, 1}$ \\
\hline FILOLOGÍA & 1 & 1 \\
\hline FÍsICO & 1 & 1 \\
\hline GERENTE & 1 & 1 \\
\hline GRANJERO/A & 1 & 1 \\
\hline INSPECTOR/A & 1 & 1 \\
\hline JARDINERO & 1 & 1 \\
\hline JEFE/A & 1 & 1 \\
\hline JUDÍO/A & 1 & 1 \\
\hline MERCADER & 1 & 1 \\
\hline MIGRANTE & 1 & 1 \\
\hline MILITAR & 1 & 1 \\
\hline MINISTRO/A & 1 & 1 \\
\hline MÚSICO & 1 & 1 \\
\hline PAREJA & 1 & 1 \\
\hline PERIODISTA & 1 & 1 \\
\hline POLÍTICA & 1 & 1 \\
\hline REPOSTERO/A & 1 & 1 \\
\hline SÚBDITO & 1 & 1 \\
\hline TALLERISTA & 1 & 1 \\
\hline TAXISTA & 1 & 1 \\
\hline TOPÓGRAFO/A & 1 & 1 \\
\hline TRADUCTOR/A & 1 & 1 \\
\hline VECINO/A & 1 & 1 \\
\hline VENDEDOR/A & 1 & 1 \\
\hline VIGILANTE & 1 & 1 \\
\hline VOCERO & 1 & 1 \\
\hline TOTAL= & & \\
\hline 141 & & \\
\hline
\end{tabular}

Tabla 13. Actividades y/o ocupaciones en las que aparecen las mujeres en el texto

\begin{tabular}{rrr}
\hline \multicolumn{2}{c}{$\begin{array}{r}\text { OCUPACIONES Y/O ACTIVIDADES DE LAS MUJERES EN EL TEXTO } \\
\text { MUJERES }\end{array}$} & $\begin{array}{r}\text { FRECUENCIA } \\
\text { PORCENTAJE } \\
\text { VÁLIDO }\end{array}$ \\
\hline TOTAL & 455 & 100,0 \\
ESTUDIANTE & 141 & 31,0 \\
DOCENTE & 65 & 14,3 \\
AMA DE CASA & 44 & 9,7 \\
MADRE & 41 & 9,0 \\
DEPORTISTA & 37 & 8,1 \\
DONCELLA & 12 & 2,6 \\
MATERNIDAD & 11 & 2,4 \\
HIJO/A & 10 & 2,2 \\
CONSUMIDOR/A & 9 & 2,0 \\
\hline
\end{tabular}




\begin{tabular}{|c|c|c|}
\hline ABUELO/A & 7 & 1,5 \\
\hline ESCRITOR/A & 6 & 1,3 \\
\hline HERMANO/A & 6 & 1,3 \\
\hline CIENTÍFICO/A & 5 & 1,1 \\
\hline LEGISLADOR/A & 5 & 1,1 \\
\hline AMIGO/A & 4 &, 9 \\
\hline AUTOR/A & 4 &, 9 \\
\hline COCINERA & 3 & ,7 \\
\hline MODELO & 3 & ,7 \\
\hline PADRE & 3 &, 7 \\
\hline PERIODISTA & 3 &, 7 \\
\hline ARTISTA & 2 & ,4 \\
\hline DIOS/A & 2 & ,4 \\
\hline DIPUTADO/A & 2 & , 4 \\
\hline DIRECTOR/A & 2 & , 4 \\
\hline DOCTOR/A & 2 & ,4 \\
\hline EMPACADOR/A & 2 & ,4 \\
\hline ESCLAVO/A & 2 & ,4 \\
\hline ESPOSO/A & 2 & ,4 \\
\hline INDÍGENA & 2 & ,4 \\
\hline INVESTIGADOR/A & 2 & ,4 \\
\hline ABOGADO/A & 1 & ,2 \\
\hline ACTRIZ & 1 & ,2 \\
\hline CAMPESINO/A & 1 & ,2 \\
\hline CRIANZA & 1 & ,2 \\
\hline CUIDADOR/A & 1 & ,2 \\
\hline EMPRESARIO/A & 1 & ,2 \\
\hline JEFE/A & 1 & ,2 \\
\hline MÉDICO/A & 1 & ,2 \\
\hline NOVIO/A & 1 & ,2 \\
\hline PAREJA & 1 & ,2 \\
\hline POETA & 1 & ,2 \\
\hline SECRETARIO/A & 1 & ,2 \\
\hline SOBRINO/A & 1 & ,2 \\
\hline TÉCNICO-PROFESI & 1 & ,2 \\
\hline TÍA & 1 & ,2 \\
\hline VIAJERO/A & 1 & ,2 \\
\hline $\begin{array}{r}\text { TOTAL= } \\
45\end{array}$ & & \\
\hline
\end{tabular}

Tabla 14. Actividades y/o ocupaciones en los que aparecen los genéricos en el texto

OCUPACIONES Y/O ACTIVIDADES DE LOS PERSONAJES EN EL 
VÁLIDO

\begin{tabular}{|c|c|c|}
\hline TOTAL & 246 & 100,0 \\
\hline ESTUDIANTE & 41 & 16,7 \\
\hline PAREJA & 41 & 16,7 \\
\hline MIGRANTE & 39 & 15,9 \\
\hline FAMILIA & 34 & 13,8 \\
\hline TÉCNICO-OBRERO & 10 & 4,1 \\
\hline INDÍGENA & 7 & 2,8 \\
\hline CIENTÍFICO/A & 6 & 2,4 \\
\hline DEPORTISTA & 5 & 2,0 \\
\hline COMERCIANTE & 4 & 1,6 \\
\hline HIJO/A & 4 & 1,6 \\
\hline MODELO & 4 & 1,6 \\
\hline DONANTE & 3 & 1,2 \\
\hline INMIGRANTE & 3 & 1,2 \\
\hline POLICÍA & 3 & 1,2 \\
\hline PROGENITOR/A & 3 & 1,2 \\
\hline TURISTA & 3 & 1,2 \\
\hline ACOMPAÑANTE & 2 & ,8 \\
\hline DOMADOR & 2 & , 8 \\
\hline EMIGRANTE & 2 & ,8 \\
\hline ESPECIALISTA & 2 & ,8 \\
\hline MENOR & 2 & ,8 \\
\hline PACIENTE & 2 & , 8 \\
\hline PRODUCTOR/A & 2 & ,8 \\
\hline VENDEDOR/A & 2 & ,8 \\
\hline AGRICULTOR/A & 1 & ,4 \\
\hline AMBIENTALISTA & 1 & ,4 \\
\hline ARICULTOR/A & 1 & , 4 \\
\hline BAÑISTA & 1 & ,4 \\
\hline BEBÉ & 1 & ,4 \\
\hline CONSUMIDOR/A & 1 & ,4 \\
\hline DOCENTE & 1 & ,4 \\
\hline EMPRESARIO/A & 1 & , 4 \\
\hline ENTREVISTADO/A & 1 & , 4 \\
\hline ESPECTADOR/A & 1 & ,4 \\
\hline JUGADOR/A & 1 & ,4 \\
\hline LECTOR/A & 1 & ,4 \\
\hline LIMPIADOR & 1 & ,4 \\
\hline NARRADOR/A & 1 & ,4 \\
\hline PADRE & 1 &, 4 \\
\hline PERIODISTA & 1 & ,4 \\
\hline TALADOR/A & 1 & ,4 \\
\hline TÉCNICO & 1 & ,4 \\
\hline VIGILANTE & 1 & ,4 \\
\hline VISITANTE & 1 & ,4 \\
\hline
\end{tabular}




\section{TOTAL $=$}

Tabla 15. Actividades y/o ocupaciones en las que aparecen los personajes masculino genérico en el texto

\begin{tabular}{|c|c|c|}
\hline $\begin{array}{l}\text { OCUPACIONES Y/O ACTIVID } \\
\text { MASCULINO GENÉRICO }\end{array}$ & $\begin{array}{r}\text { ES DE LOS PF } \\
\text { FRECUENCI } \\
\text { A }\end{array}$ & $\begin{array}{r}\text { ONAJES EN EL } \\
\text { TEXTO } \\
\text { PORCENTAJE } \\
\text { VÁLIDO } \\
\end{array}$ \\
\hline TOTAL & 918 & 100,0 \\
\hline ESTUDIANTE & 312 & 34,0 \\
\hline DOCENTE & 161 & 17,5 \\
\hline PADRE & 36 & 3,9 \\
\hline MIGRANTE & 35 & 3,8 \\
\hline HIJO/A & 34 & 3,7 \\
\hline CIENTÍFICO/A & 24 & 2,6 \\
\hline AUTOR/A & 18 & 2,0 \\
\hline MATEMÁTICO/A & 16 & 1,7 \\
\hline MÉDICO/A & 13 & 1,4 \\
\hline NARRADOR/A & 12 & 1,3 \\
\hline INVESTIGADOR/A & 11 & 1,2 \\
\hline DESTINATARIO/A & 9 & 1,0 \\
\hline POETA & 9 & 1,0 \\
\hline ESCRITOR/A & 8 & ,9 \\
\hline MODERADOR/A & 8 & ,9 \\
\hline REFUGIADO/A & 8 & ,9 \\
\hline ABUELO/A & 7 & , 8 \\
\hline BIÓLOGO/A & 7 & , 8 \\
\hline COMERCIANTE & 7 & , 8 \\
\hline AMIGO/A & 6 & ,7 \\
\hline ARTISTA & 6 & ,7 \\
\hline ESPECIALISTA & 6 & ,7 \\
\hline JUGADOR/A & 6 & ,7 \\
\hline LECTOR/A & 6 & ,7 \\
\hline LEGISLADOR/A & 6 & ,7 \\
\hline TÉCNICO-OBRERO & 6 & ,7 \\
\hline INDÍGENA & 5 & ,5 \\
\hline PINTOR/A & 5 & ,5 \\
\hline TURISTA & 5 &, 5 \\
\hline ADULTO/A & 4 & ,4 \\
\hline CAMPESINO/A & 4 & ,4 \\
\hline CONSUMIDOR/A & 4 & , 4 \\
\hline EXPOSITOR & 4 & , 4 \\
\hline HERMANO/A & 4 & , 4 \\
\hline
\end{tabular}




\begin{tabular}{|c|c|c|}
\hline PEREGRINOS & 4 & 4 \\
\hline REPORTERO/A & 4 & ,4 \\
\hline TRABAJANDO & 4 & ,4 \\
\hline AGRICULTOR/A & 3 & ,3 \\
\hline BEBÉ & 3 & ,3 \\
\hline DIPUTADO/A & 3 & ,3 \\
\hline DIRECTOR/A & 3 & ,3 \\
\hline NUTRIÓLOGO & 3 & ,3 \\
\hline PAREJA & 3 & ,3 \\
\hline PASAJERO/A & 3 & ,3 \\
\hline SECRETARIO & 3 & ,3 \\
\hline VECINO/A & 3 & ,3 \\
\hline BIBLIOTECARIO/A & 2 & ,2 \\
\hline CLIENTE & 2 & ,2 \\
\hline CONQUISTADOR & 2 & ,2 \\
\hline CRISTIANO & 2 & ,2 \\
\hline DIOS/A & 2 & ,2 \\
\hline EMIGRANTE & 2 & ,2 \\
\hline ENTREVISTADO/A & 2 & ,2 \\
\hline ESPECTADOR/A & 2 & ,2 \\
\hline FAMILIA & 2 & ,2 \\
\hline JUVENTUD & 2 & ,2 \\
\hline MUSULMAN & 2 & ,2 \\
\hline PACIENTE & 2 & ,2 \\
\hline PONENTE & 2 & ,2 \\
\hline VENDEDOR/A & 2 & ,2 \\
\hline ACTOR/A & 1 &, 1 \\
\hline ALBAÑIL & 1 &, 1 \\
\hline APICULTOR/A & 1 &, 1 \\
\hline ARTESANO/A & 1 &, 1 \\
\hline AUSTRONAUTA & 1 &, 1 \\
\hline CARTERO/A & 1 &, 1 \\
\hline CHOFER & 1 &, 1 \\
\hline COMUNICADOR/A & 1 &, 1 \\
\hline CRIADOR/A & 1 &, 1 \\
\hline CRIANZA & 1 &, 1 \\
\hline DEPORTISTA & 1 &, 1 \\
\hline DOMESTICADOR/A & 1 &, 1 \\
\hline ECÓLOGO/A & 1 &, 1 \\
\hline ECUESTADO/A & 1 &, 1 \\
\hline EMPLEADO/A & 1 &, 1 \\
\hline EXPLORADOR/A & 1 &, 1 \\
\hline FABRICANTE & 1 &, 1 \\
\hline GENETISTA & 1 &, 1 \\
\hline GUÍA TURISTICO & 1 &, 1 \\
\hline INGENIERO/A & 1 &, 1 \\
\hline
\end{tabular}




\begin{tabular}{rrr}
\hline INMIGRANTE & 1 &, 1 \\
JARDINERO & 1 &, 1 \\
JUDIO/A & 1 &, 1 \\
MENOR & 1 &, 1 \\
MEXICANO/A & 1 &, 1 \\
MILITAR & 1 &, 1 \\
MISIONERO/A & 1 &, 1 \\
NIETO/A & 1 &, 1 \\
ORIENTADOR/A & 1 &, 1 \\
PEREGRINO & 1 &, 1 \\
PESCADOR/A & 1 &, 1 \\
POLITICO/A & 1 &, 1 \\
PRODUCTOR & 1 &, 1 \\
PSICÓLOGO/A & 1 &, 1 \\
PSIQUIATRA & 1 &, 1 \\
RECOLECTOR/A & 1 &, 1 \\
SIRVIENTE/A & 1 &, 1 \\
SOLDADO & 1 &, 1 \\
TÉCNICO-PROFESI & 1 &, 1 \\
TOTAL= & 1 & \\
\hline
\end{tabular}




\section{CARACTERÍSTICAS PSICOSOCIALES DE LOS PERSONAJES}

Tabla 16. Características psicosociales de los personajes en el texto

\begin{tabular}{|c|c|c|}
\hline \multicolumn{3}{|c|}{$\begin{array}{l}\text { CARACTERIZACIÓN PSICOSOCIAL DE LOS PERSONAJES EN EL } \\
\text { TEXTO }\end{array}$} \\
\hline GENERAL & FRECUENCIA & $\begin{array}{r}\text { PORCENTAJE } \\
\text { VÁLIDO }\end{array}$ \\
\hline TOTAL & 3576 & 100,0 \\
\hline DINAMISMO & 499 & 14,0 \\
\hline TRABAJADOR & 333 & 9,3 \\
\hline ASERTIVIDAD & 308 & 8,6 \\
\hline DIVERSIDAD & 175 & 4,9 \\
\hline DOMINIO & 123 & 3,4 \\
\hline MEDIADOR/A & 87 & 2,4 \\
\hline INGENIO & 81 & 2,3 \\
\hline PARTICIPACIÓN & 81 & 2,3 \\
\hline RACIONALIDAD & 70 & 2,0 \\
\hline VULNERABILIDAD & 70 & 2,0 \\
\hline ENFERMEDAD & 69 & 1,9 \\
\hline JUGANDO & 62 & 1,7 \\
\hline OCIO & 58 & 1,6 \\
\hline ORIGINALIDAD & 57 & 1,6 \\
\hline CURIOSIDAD & 48 & 1,3 \\
\hline HERENICIA & 45 & 1,3 \\
\hline HACENDOSO/A & 43 & 1,2 \\
\hline CUIDADO PERSONAL & 42 & 1,2 \\
\hline CRIANZA & 41 & 1,1 \\
\hline OBJETIVIDAD & 41 & 1,1 \\
\hline ADICCIONES & 40 & 1,1 \\
\hline BIENESTAR & 40 & 1,1 \\
\hline DEPENDENCIA & 40 & 1,1 \\
\hline FORTALEZA & 40 & 1,1 \\
\hline PREVENCIÓN & 37 & 1,0 \\
\hline PROVEEDOR & 36 & 1,0 \\
\hline AMISTAD & 35 & 1,0 \\
\hline EFICACIA & 34 & 1,0 \\
\hline RESPONSABILIDAD & 33 & 9 \\
\hline BELLEZA & 32 & 9 \\
\hline CONSERVACIÓN & 32 & 9 \\
\hline INTELECTUAL & 28 & 8 \\
\hline IGUALDAD & 26 & ,7 \\
\hline PROTECCIÓN & 26 & ,7 \\
\hline DECISIÓN & 25 & 7 \\
\hline MUERTO/A & 25 & ,7 \\
\hline DEPORTISTA & 20 & 6 \\
\hline
\end{tabular}




\begin{tabular}{|c|c|c|}
\hline TIMIDEZ & 20 & 6 \\
\hline DEBILIDAD & 19 &, 5 \\
\hline PROCREACIÓN & 19 &, 5 \\
\hline VALENTÍA & 19 &, 5 \\
\hline DESIGUALDAD & 18 &, 5 \\
\hline SEXUALIDAD & 18 &, 5 \\
\hline SUBSISTENCIA & 18 &, 5 \\
\hline CONSUMISTA & 17 &, 5 \\
\hline REPRODUCCIÓN & 16 & ,4 \\
\hline SUPERACIÓN & 16 & ,4 \\
\hline COMPETENCIA & 15 & ,4 \\
\hline CONFIANZA & 14 & ,4 \\
\hline DIVINIDAD & 14 & ,4 \\
\hline FRIVOLIDAD & 14 & ,4 \\
\hline PRODUCTIVO & 13 & ,4 \\
\hline SUMISIÓN & 13 & ,4 \\
\hline AFECTIVIDAD & 12 & ,3 \\
\hline ATENCIÓN & 12 & ,3 \\
\hline POBREZA & 12 & ,3 \\
\hline AHORRADOR/A & 11 & ,3 \\
\hline SABIDURÍA & 11 & ,3 \\
\hline CUIDADO PNA & 10 & ,3 \\
\hline MIEDO & 10 & ,3 \\
\hline PROTECCIÓN/A & 10 & ,3 \\
\hline DESDICHA & 9 & ,3 \\
\hline INNOVACIÓN & 9 & ,3 \\
\hline SEGURIDAD & 9 & ,3 \\
\hline CONVERSACIÓN & 8 & ,2 \\
\hline PROGRESO & 8 & ,2 \\
\hline CREYENTE & 7 & ,2 \\
\hline DUEÑO & 7 & ,2 \\
\hline LIDERAZGO & 7 & ,2 \\
\hline RESPETABLE & 7 & ,2 \\
\hline ADAPTACIÓN & 6 & ,2 \\
\hline EXPLOTACIÓN & 6 & ,2 \\
\hline INDEPENDENCIA & 6 & ,2 \\
\hline INTERCULTURAL & 6 & ,2 \\
\hline SUPERVIVENCIA & 6 & ,2 \\
\hline CAMBIOS FÍSICOS & 5 &, 1 \\
\hline DESTRUCCIÓN & 5 &, 1 \\
\hline FAMOSO & 5 &, 1 \\
\hline MALESTAR & 5 &, 1 \\
\hline MISTERIOSO & 5 &, 1 \\
\hline PICARDÍA & 5 &, 1 \\
\hline TOLERANCIA & 5 &, 1 \\
\hline VALORACIÓN + & 5 &, 1 \\
\hline
\end{tabular}




\begin{tabular}{|c|c|c|}
\hline ATRACCIÓN & 4 &, 1 \\
\hline AUTORIDAD & 4 &, 1 \\
\hline COMUNICACIÓN & 4 &, 1 \\
\hline DISCUTIENDO & 4 &, 1 \\
\hline EMINENTE & 4 &, 1 \\
\hline INESTABILIDAD & 4 &, 1 \\
\hline LLORONA & 4 &, 1 \\
\hline PATICIPACIÓN & 4 &, 1 \\
\hline PROPIETARIO/A & 4 &, 1 \\
\hline TENACIDAD & 4 &, 1 \\
\hline ALEGRÍA & 3 &, 1 \\
\hline ATRACCIÓNDOR/A & 3 &, 1 \\
\hline AUTONOMÍA & 3 &, 1 \\
\hline CELEBRIDAD & 3 &, 1 \\
\hline EMBARAZADA & 3 &, 1 \\
\hline ENFADADO/A/O & 3 &, 1 \\
\hline EXPERTO/A & 3 &, 1 \\
\hline JOVEN & 3 &, 1 \\
\hline OPRESIÓN & 3 &, 1 \\
\hline PERSISTENCIA & 3 &, 1 \\
\hline REBELDÍA & 3 &, 1 \\
\hline SATISFACCIÓN & 3 &, 1 \\
\hline SOLEDAD & 3 &, 1 \\
\hline TRANSFORMACIÓN & 3 &, 1 \\
\hline VALORACIÓN - & 3 &, 1 \\
\hline AMANTE & 2 &, 1 \\
\hline ARRIESGADO & 2 &, 1 \\
\hline AVARICIA & 2 &, 1 \\
\hline CELOSA & 2 &, 1 \\
\hline COMPRENSIÓN & 2 &, 1 \\
\hline CONVIVENCIA & 2 &, 1 \\
\hline DESCONOCIMIENTO & 2 &, 1 \\
\hline DESCUIDADA & 2 &, 1 \\
\hline EMBARAZO & 2 &, 1 \\
\hline EMOTIVIDAD & 2 &, 1 \\
\hline ENAMORAMIENTO & 2 &, 1 \\
\hline EVALUACIÓN & 2 &, 1 \\
\hline FAMILIA & 2 &, 1 \\
\hline FORMACIÓN & 2 &, 1 \\
\hline FRUSTRACIÓN & 2 &, 1 \\
\hline GALÁN & 2 &, 1 \\
\hline IMPULSIBIDAD & 2 &, 1 \\
\hline INVERSOR/A & 2 &, 1 \\
\hline MALTRATADO/A & 2 &, 1 \\
\hline MATERNIDAD & 2 &, 1 \\
\hline NOVIAZGO & 2 &, 1 \\
\hline
\end{tabular}




\begin{tabular}{|c|c|c|}
\hline PACIENCIA & 2 &, 1 \\
\hline POSESIÓN & 2 &, 1 \\
\hline PRESTIGIOSO/A & 2 &, 1 \\
\hline RIQUEZA & 2 &, 1 \\
\hline SEXISMO & 2 &, 1 \\
\hline SUPERVISIÓN & 2 &, 1 \\
\hline VIOLENTO/A & 2 &, 1 \\
\hline VITALIDAD & 2 &, 1 \\
\hline AGRADABLE & 1 & 0 \\
\hline AGRESIVIDAD & 1 & ,0 \\
\hline ANSIEDAD & 1 & ,0 \\
\hline APOYO & 1 & ,0 \\
\hline APUESTO & 1 & ,0 \\
\hline ARROGANCIA & 1 & ,0 \\
\hline ASIEDAD & 1 & ,0 \\
\hline ASUSTADO & 1 & ,0 \\
\hline ATLETA & 1 & ,0 \\
\hline AUTOCONTROL & 1 & 0 \\
\hline BONDAD & 1 & ,0 \\
\hline COMBATIR & 1 & ,0 \\
\hline COMPARTIR & 1 & ,0 \\
\hline COMPLACIENTE & 1 & ,0 \\
\hline CONFUNDIDO & 1 & ,0 \\
\hline CREATIVIDAD & 1 & ,0 \\
\hline DEFENSA & 1 & ,0 \\
\hline DESAPARECIDA & 1 & ,0 \\
\hline DESARROLLO & 1 & 0 \\
\hline DESCUBRIDOR/A & 1 & ,0 \\
\hline DESOBEDIENCIA & 1 & ,0 \\
\hline DISCRIMINACIÓN & 1 & ,0 \\
\hline ENFADADO/A & 1 & ,0 \\
\hline ESFUERZO & 1 & ,0 \\
\hline ESTUPIDEZ & 1 & ,0 \\
\hline EXPERIMENTAR & 1 & ,0 \\
\hline FRAGILIDAD & 1 & ,0 \\
\hline FUERZA & 1 & ,0 \\
\hline GASTADOR & 1 & ,0 \\
\hline GESTIÓN & 1 & ,0 \\
\hline IGNORANCIA & 1 & ,0 \\
\hline INHUMANA & 1 & ,0 \\
\hline INICIATIVA & 1 & ,0 \\
\hline INTEGRACIÓN & 1 & ,0 \\
\hline LACTANTE & 1 & ,0 \\
\hline NECESIDAD & 1 & ,0 \\
\hline OBSERVADOR/A & 1 & 0 \\
\hline ORGANIZACIÓN & 1 & ,0 \\
\hline
\end{tabular}




\begin{tabular}{rrr}
\hline OYENTE & 1 &, 0 \\
PASAJEROS & 1 &, 0 \\
PASIVIDAD & 1 &, 0 \\
PLACER & 1 &, 0 \\
PLEBE & 1 &, 0 \\
POPULAR & 1 &, 0 \\
PREOCUPACIÓN & 1 &, 0 \\
PRESIÓN & 1 &, 0 \\
PROTAGONISTA & 1 &, 0 \\
RECLAMACIÓN & 1 &, 0 \\
RECONOCIMIENTO & 1 &, 0 \\
RELACIÓN & 1 &, 0 \\
RIESGO & 1 &, 0 \\
SENSIBILIDAD & 1 &, 0 \\
SORPRENDIDO & 1 &, 0 \\
SOSPECHOSO & 1 &, 0 \\
SUPERIOR & 1 &, 0 \\
SUPERVIVIENTE & 1 &, 0 \\
TRANQUILIDAD & 1 &, 0 \\
VECINO/A & 1 &, 0 \\
VEJEZ & 1 &, 0 \\
TOTAL= & & \\
196 & & 1
\end{tabular}

Tabla 17. Características psicosociales de los varones en el texto

CARACTERIZACIÓN PSICOSOCIAL DE LOS PERSONAJES EN EL TEXTO

\begin{tabular}{rrr} 
HOMBRES & FRECUENCIA & $\begin{array}{r}\text { PORCENTAJE } \\
\text { VÁLIDO }\end{array}$ \\
\hline TOTAL & 687 & 100 \\
TRABAJANDO & 89 & 13,0 \\
DINAMISMO & 79 & 11,5 \\
ASERTIVIDAD & 36 & 5,2 \\
JUGUETÓN & 35 & 5,1 \\
PROVEEDOR & 34 & 4,9 \\
DOMINIO & 30 & 4,4 \\
CURIOSIDAD & 20 & 2,9 \\
DECISIÓN & 16 & 2,3 \\
OCIO & 16 & 2,3 \\
MEDIADOR/A & 15 & 2,2 \\
COMPETENCIA & 13 & 1,9 \\
VALENTÍA & 13 & 1,9 \\
FORTALEZA & 12 & 1,7 \\
PARTICIPACIÓN & 12 & 1,7 \\
\hline
\end{tabular}




\begin{tabular}{|c|c|c|}
\hline ENFERMEDAD & 11 & 1,6 \\
\hline DEPENDENCIA & 10 & 1,5 \\
\hline DIVINIDAD & 10 & 1,5 \\
\hline IGUALDAD & 10 & 1,5 \\
\hline PREVENCIÓN & 10 & 1,5 \\
\hline AMISTAD & 9 & 1,3 \\
\hline DEPORTISTA & 9 & 1,3 \\
\hline DESDICHA & 9 & 1,3 \\
\hline AFECTIVIDAD & 8 & 1,2 \\
\hline HERENICIA & 8 & 1,2 \\
\hline PROTECCIÓN & 8 & 1,2 \\
\hline RACIONALIDAD & 8 & 1,2 \\
\hline ADICCIONES & 7 & 1,0 \\
\hline CUIDADO P & 7 & 1,0 \\
\hline CRIANZA & 6 & 0,9 \\
\hline DUEÑO & 6 & 0,9 \\
\hline INGENIO & 6 & 0,9 \\
\hline MUERTO/A & 6 & 0,9 \\
\hline PROCREACIÓN & 6 & 0,9 \\
\hline CUIDADO PNA & 5 & 0,7 \\
\hline MISTERIOSO & 5 & 0,7 \\
\hline PICARDÍA & 5 & 0,7 \\
\hline RESPONSABILIDAD & 5 & 0,7 \\
\hline AUTORIDAD & 4 & 0,6 \\
\hline CONFIANZA & 4 & 0,6 \\
\hline LIDERAZGO & 4 & 0,6 \\
\hline RESPETABLE & 4 & 0,6 \\
\hline ATRACCIÓNDOR/A & 3 & 0,4 \\
\hline DIVERSIDAD & 3 & 0,4 \\
\hline INDÍGENA & 3 & 0,4 \\
\hline INTELECTUAL & 3 & 0,4 \\
\hline JOVEN & 3 & 0,4 \\
\hline OBJETIVIDAD & 3 & 0,4 \\
\hline REPRODUCCIÓN & 3 & 0,4 \\
\hline AHORRADOR/A & 2 & 0,3 \\
\hline AMANTE & 2 & 0,3 \\
\hline AVARICIA & 2 & 0,3 \\
\hline CONSUMISTA & 2 & 0,3 \\
\hline CONVERSACIÓN & 2 & 0,3 \\
\hline DISCUTIENDO & 2 & 0,3 \\
\hline GALÁN & 2 & 0,3 \\
\hline INVERSOR/A & 2 & 0,3 \\
\hline PROPIETARIO/A & 2 & 0,3 \\
\hline SEXUALIDAD & 2 & 0,3 \\
\hline SUMISIÓN & 2 & 0,3 \\
\hline AGRESIVIDAD & 1 & 0,1 \\
\hline
\end{tabular}




\begin{tabular}{|c|c|c|}
\hline ALEGRÍA & 1 & 0,1 \\
\hline APUESTO & 1 & 0,1 \\
\hline ARRIESGADO & 1 & 0,1 \\
\hline ASIEDAD & 1 & 0,1 \\
\hline ASUSTADO & 1 & 0,1 \\
\hline AUTOCONTROL & 1 & 0,1 \\
\hline AUTONOMÍA & 1 & 0,1 \\
\hline BELLEZA & 1 & 0,1 \\
\hline BIENESTAR & 1 & 0,1 \\
\hline BONDAD & 1 & 0,1 \\
\hline CAMBIOS FÍSICOS & 1 & 0,1 \\
\hline DEBILIDAD & 1 & 0,1 \\
\hline EFICACIA & 1 & 0,1 \\
\hline ENFADADO/A & 1 & 0,1 \\
\hline EVALUACIÓN & 1 & 0,1 \\
\hline EXPERTO/A & 1 & 0,1 \\
\hline FRIVOLIDAD & 1 & 0,1 \\
\hline FRUSTRACIÓN & 1 & 0,1 \\
\hline GASTADOR & 1 & 0,1 \\
\hline IMPULSIBIDAD & 1 & 0,1 \\
\hline INNOVACIÓN & 1 & 0,1 \\
\hline OBSERVADOR/A & 1 & 0,1 \\
\hline ORIGINALIDAD & 1 & 0,1 \\
\hline PASIVIDAD & 1 & 0,1 \\
\hline PATICIPACIÓN & 1 & 0,1 \\
\hline PREOCUPACIÓN & 1 & 0,1 \\
\hline PRESTIGIOSO/A & 1 & 0,1 \\
\hline REBELDÍA & 1 & 0,1 \\
\hline SABIDURÍA & 1 & 0,1 \\
\hline SEXISMO & 1 & 0,1 \\
\hline SUPERVISIÓN & 1 & 0,1 \\
\hline VALORACIÓN - & 1 & 0,1 \\
\hline VITALIDAD & 1 & 0,1 \\
\hline TOTAL= & & \\
\hline 93 & & \\
\hline
\end{tabular}

Tabla 18. Características psicosociales de las mujeres en el texto

\begin{tabular}{rrr}
\hline \multicolumn{3}{c}{ CARACTERIZACIÓN PSICOSOCIAL DE LOS PERSONAJES EN } \\
EL TEXTO & A & PORCENTAJE \\
MUJERES & FRECUENCI & VÁLIDO \\
\hline TOTAL & 562 & 100 \\
DINAMISMO & 70 & 12,5 \\
TRABAJANDO & 54 & 9,6 \\
\hline
\end{tabular}




\begin{tabular}{|c|c|c|}
\hline HACENDOSA & 40 & 7,1 \\
\hline ASERTIVIDAD & 33 & 5,9 \\
\hline MEDIADOR/A & 30 & 5,3 \\
\hline CRIANZA & 28 & 5,0 \\
\hline BELLEZA & 20 & 3,6 \\
\hline JUGANDO & 20 & 3,6 \\
\hline CURIOSIDAD & 17 & 3,0 \\
\hline OClO & 16 & 2,8 \\
\hline HERENICIA & 14 & 2,5 \\
\hline PREVENCIÓN & 13 & 2,3 \\
\hline IGUALDAD & 11 & 2,0 \\
\hline PARTICIPACIÓN & 11 & 2,0 \\
\hline PROCREACIÓN & 11 & 2,0 \\
\hline AHORRADOR/A & 9 & 1,6 \\
\hline INDÍGENA & 9 & 1,6 \\
\hline DEPENDENCIA & 8 & 1,4 \\
\hline DEPORTISTA & 8 & 1,4 \\
\hline ADICCIONES & 7 & 1,2 \\
\hline CONFIANZA & 7 & 1,2 \\
\hline FRIVOLIDAD & 6 & 1,1 \\
\hline RESPONSABILIDAD & 6 & 1,1 \\
\hline ATENCIÓN & 5 & 0,9 \\
\hline CUIDADO PNA & 5 & 0,9 \\
\hline DECISIÓN & 5 & 0,9 \\
\hline ENFERMEDAD & 5 & 0,9 \\
\hline MIEDO & 5 & 0,9 \\
\hline MUERTO/A & 5 & 0,9 \\
\hline AFECTIVIDAD & 4 & 0,7 \\
\hline CONVERSACIÓN & 4 & 0,7 \\
\hline CUIDADO P & 4 & 0,7 \\
\hline DESIGUALDAD & 4 & 0,7 \\
\hline INESTABILIDAD & 4 & 0,7 \\
\hline LLORONA & 4 & 0,7 \\
\hline DEBILIDAD & 3 & 0,5 \\
\hline INGENIO & 3 & 0,5 \\
\hline TENACIDAD & 3 & 0,5 \\
\hline VALENTÍA & 3 & 0,5 \\
\hline AMISTAD & 2 & 0,4 \\
\hline DESCUIDADA & 2 & 0,4 \\
\hline DISCUTIENDO & 2 & 0,4 \\
\hline EMBARAZADA & 2 & 0,4 \\
\hline ENAMORAMIENTO & 2 & 0,4 \\
\hline LIDERAZGO & 2 & 0,4 \\
\hline MATERNIDAD & 2 & 0,4 \\
\hline REPRODUCCIÓN & 2 & 0,4 \\
\hline SEXUALIDAD & 2 & 0,4 \\
\hline
\end{tabular}




\begin{tabular}{|c|c|c|}
\hline SOLEDAD & 2 & 0,4 \\
\hline ALEGRÍA & 1 & 0,2 \\
\hline ANSIEDAD & 1 & 0,2 \\
\hline CAMBIOS FÍSICOS & 1 & 0,2 \\
\hline CELOSA & 1 & 0,2 \\
\hline COMPLACIENTE & 1 & 0,2 \\
\hline COMUNICACIÓN & 1 & 0,2 \\
\hline CONFUNDIDO & 1 & 0,2 \\
\hline CONSUMISTA & 1 & 0,2 \\
\hline DESAPARECIDA & 1 & 0,2 \\
\hline DIVERSIDAD & 1 & 0,2 \\
\hline DOMINIO & 1 & 0,2 \\
\hline ESTUPIDEZ & 1 & 0,2 \\
\hline EVALUACIÓN & 1 & 0,2 \\
\hline FRUSTRACIÓN & 1 & 0,2 \\
\hline IMPULSIBIDAD & 1 & 0,2 \\
\hline INDEPENDENCIA & 1 & 0,2 \\
\hline INHUMANA & 1 & 0,2 \\
\hline INICIATIVA & 1 & 0,2 \\
\hline MALESTAR & 1 & 0,2 \\
\hline ORIGINALIDAD & 1 & 0,2 \\
\hline PATICIPACIÓN & 1 & 0,2 \\
\hline POBREZA & 1 & 0,2 \\
\hline POPULAR & 1 & 0,2 \\
\hline RACIONALIDAD & 1 & 0,2 \\
\hline SEXISMO & 1 & 0,2 \\
\hline SORPRENDIDO & 1 & 0,2 \\
\hline SUPERVISIÓN & 1 & 0,2 \\
\hline TRANQUILIDAD & 1 & 0,2 \\
\hline 77 & & \\
\hline
\end{tabular}

